\title{
Plutarch's Science of Natural Problems
}

A Study with Commentary on Quaestiones Naturales

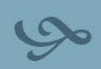

Michiel Meeusen 
PLUTARCH'S SCIENCE OF NATURAL PROBLEMS A STUDY WITH COMMENTARY ON QUAESTIONES NATURALES 


\title{
PLUTARCHEA HYPOMNEMATA
}

\author{
Editorial Board \\ Jan Opsomer (KU Leuven) \\ Geert Roskam (KU Leuven) \\ Frances Titchener (Utah State University, Logan) \\ Luc Van der Stockt (KU Leuven) \\ Advisory Board \\ F. Alesse (ILIESI-CNR, Roma) \\ M. Beck (University of South Carolina, Columbia) \\ J. Beneker (University of Wisconsin, Madison) \\ H.G. Ingenkamp (Universität Bonn) \\ A.G. Nikolaidis (University of Crete, Rethymno) \\ Chr. Pelling (Christ Church, Oxford) \\ A. Pérez Jiménez (Universidad de Málaga) \\ Th. Schmidt (Université de Fribourg)
}

P.A. Stadter (University of North Carolina, Chapel Hill) 


\section{PLUTARCH'S SCIENCE OF NATURAL PROBLEMS}

\section{A STUDY WITH COMMENTARY ON QUAESTIONES NATURALES}

By

MICHIEL MEEUSEN

Leuven University Press 
Published with support of the Universitaire Stichting van België

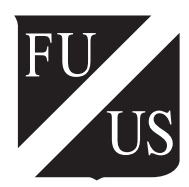

(C) 2016 by Leuven University Press / Presses Universitaires de Louvain / Universitaire Pers Leuven

Minderbroedersstraat 4, B-300o Leuven (Belgium)

All rights reserved. Except in those cases expressly determined by law, no part of this publication may be multiplied, saved in an automated datafile or made public in any way whatsoever without the express prior written consent of the publishers.

ISBN 9789462700840

$\mathrm{D} / 20 \mathrm{I} 6 / \mathrm{I} 869 / 38$

NUR $735-635$

Cover design: Joke Klaassen

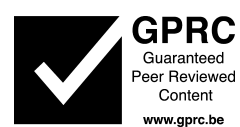




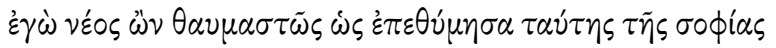

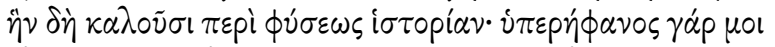

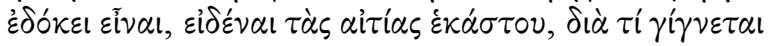

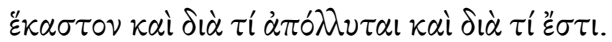

When I was young, I was tremendously eager for the kind of wisdom which they call investigation of nature. I thought it was a glorious thing to know the causes of everything, why each thing comes into being and why it perishes and why it exists.

Pl., Phd. 96a 



\section{Contents}

Acknowledgements

\section{Prologue}

Plutarch and the history of science: the case of Quaestiones naturales

I. Plato, Plutarch and scientific infancy

2. Date and chronology of Quaestiones naturales: a 'life's work'?

3. The value of Plutarch's natural problems

4. Classical philology and the petrification of science

5. Status quaestionis

6. Note on translations and abbreviations

\section{Introduction}

I. Problems, problems, problems (and Aristotelian precedents)

6I

I.I. Quaestiones naturales and the Aristotelian genre and tradition of natural problems

I. Preliminary remarks on Plutarch's Naturwissenschaft

6I

2. Quaestiones naturales: the work of a Plutarchus Aristotelicus?

3. The genre of problems and the Aristotelian tradition of natural problems

4. Internal organisation of Plutarch's natural problems (microstructure)

5. Coherent reading in Quaestiones naturales and convivales (macrostructure)

6. The title and its programmatic value

I.2. Problems related to Plutarch's scientific discourse

I. Trifles unworthy of Plutarch? Some remarks on authenticity

2. The rhetoric of scientific discourse according to Plutarch

3. The problem of style

4. The problem of morality 
5. A 'generic' solution $\quad$ I27

6. Conclusion and new questions $\quad$ I29

2. The position of Quaestiones naturales in the corpus

Plutarcheum

2.I. Scientific traits in the corpus Plutarcheum

I. Intellectual and literary interest of natural phenomena

2. Cluster analysis in Quaestiones naturales

3. Scientific digressions in the Vitae

4. Indirect references to Quaestiones naturales

2.2. A comparative study of Quaestiones naturales and Quaestiones convivales

I. The level of elocutio I5I

2. The level of dispositio $\quad{ }_{156}$

3. The level of inventio $\quad$ I59

2.3. Hypomnematic text genetics of Quaestiones naturales and Quaestiones convivales I6I

I. Historicity and fiction in Quaestiones convivales $\quad$ I62

2. Problems and personal notes $\quad 165$

3. Zetetic autonomy in Quaestiones naturales $\quad 173$

2.4. Opening up Plutarch's zetetic archive 177

I. The issue of publication: problems as functional literature

2. Classification and overlap $\quad$ I82

3. Conclusion and new questions $\quad$ I84

3. Quaestiones naturales and zetetic $\pi \alpha$ iseí $\quad$ I87

3.I. Sitz im Leben: readership and educational context $\quad$ I87

I. Natural problems and philosophical $\sigma \chi 0 \lambda \dot{\eta} \quad$ I88

2. Plutarch's academy 190

3. Digestive discussions and problematic promenades $\quad 195$

4. Quaestiones naturales as school text: technicality and complexity

5. The dialogue between author and reader: vivacity and historicity

3.2. Quaestiones naturales as a preamble to metaphysics 2 I9

I. Natural problems as a means of exercising the mind 219

2. Natural problems as a means of easing the mind 225

3. Conclusion and new questions 232

4. Plutarch's Platonic world view: the aetiological design of Quaestiones naturales and its scientific context

4.I. Science and its foes? The ancient scientific value of 
Quaestiones naturales

4.I.I. Saving popular beliefs: the wonders and paradoxes of nature

I. Natural problems and the fabric of strangeness

2. Democritus and the cucumber

3. Plutarch's popular beliefs: anti-Aristotelian and anti-Stoic dynamics

4.I.2. Plutarch's dualistic causality: rationalising the divine and the use of myth and poetry

I. Plato's scientific revolution

2. Science, religion and mythology

3. Science and poetry

4.2. Constructing scientific authority: between continuity, ingenuity and innovation

4.2.I. Character and use of the scientific tradition

I. Quotations from scientific prose authors

2. Problematisation of scientific knowledge

4.2.2. Scientific innovation and performance

I. A note on the sociology of knowledge and $\pi \alpha 1 \delta \varepsilon i \alpha$

2. The pragmatics of Plutarch's scientific ingenuity and creativity

4.3. Plutarch's scientific methodology: a rough guide to explaining natural phenomena

4.3.I. Material principles and natural processes

I. Material principles

2. Natural processes

4.3.2. Towards the limits of natural science

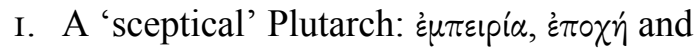
$\varepsilon \dot{\lambda} \lambda \alpha \dot{\beta} \varepsilon i \alpha$

2. Truth and probability in Quaestiones naturales

3. Sense perception and the issue of autopsy in Quaestiones naturales

4.3.3. Logical-rhetorical dynamics

I. Contradiction, non-contradiction and aetiological freedom

2. Aetiological comprehensiveness and pluricausality

3. Aetiological subtlety and sophistication

4.3.4. Uniformity and technicality of the scientific terminology

I. Let's talk science: the birth and use of technical vocabulary 
2. Big words? High-tech vs. low-tech vocabulary

3. Conclusion: Plutarch, Plato and Aristotle (again)

\section{Commentary}

o. Approach and structure

I. Salt and water (Q.N. I-I3)

2. Wheat and barley (Q.N. I4-I6)

3. Sea animals and fishing (Q.N. I7-I9)

4. Land animals and hunting (Q.N. 20-28)

5. Viniculture (Q.N. 30-3I)

6. Longolius (Q.N. 32-39)

7. Psellus (Q.N. 40-4I)

Synopsis

Bibliography

Index Locorum 


\section{Acknowledgements}

The volume at hand is a revised version of my $\mathrm{PhD}$ dissertation completed under the supervision of Luc Van der Stockt (KU Leuven, 20I3). I cannot thank him enough for the intellectual support during my years as a doctoral student and after, and for the numerous opportunities he made possible for me in Academia.

It is a pleasure to extend thanks to Geert Roskam, co-supervisor of the project in Leuven, who was and continues to be always happy to offer help and good advice whenever asked. I am much indebted also to Katerina Oikonomopoulou, Jan Opsomer, Françoise Frazier and Toon Van Hal, all of whom read an earlier draft and offered many pertinent suggestions. Special thanks are due to Sean Winkler for his corrections of the English. Any remaining inaccuracies are my own.

I would like to thank my KU Leuven colleagues, both from the Literary Studies Department and from the Institute of Classical Studies. I also gratefully acknowledge the financial support of the KU Leuven Research Council, the Research Foundation - Flanders (FWO) and the University Foundation for making this publication possible.

Finally, my heartfelt gratitude goes to my parents, my brothers, and partner for their love and caring, unsayable in words. 



\section{PROLOGUE}





\section{Plutarch and the history of science: the case of Quaestiones naturales}

Plutarch was a man of many talents as his life and writings show. Between being a political delegate and representative of his small hometown of Chaeronea, a philosophy tutor specialising in the teachings of Plato, and in his final years a priest worshipping Apollo at the oracle of Delphi, he was a full time intellectual and a true paragon of ancient learning, who found a great joy in collecting and critically transmitting many different forms of knowledge that personally caught his attention (history, literature, philosophy, science etc.). Among many other branches of ancient learning - the code word here is $\pi \circ \lambda \nu \mu \dot{\alpha} \theta \varepsilon i \alpha$-, the Chaeronean was very interested in the natural world around him in terms mainly of its underlying material principles, physical processes and its providential ordering. If Plutarch's so-called natural scientific writings can teach us one thing about his perception of physical reality, it is the fact that they are based on a very different outlook on the world than is generally promoted by scientists today. Plutarch lived in the same physical world as we do, but he saw it in a very different way and from a very different perspective. In line with his Platonic philosophy and the corresponding division between the sensible and intelligible realms in the cosmos, he ascribed a divine providence to the world, which can partly explain his interest in more fanciful beliefs regarding nature and natural phenomena, as this study will show.

In his dual role as a homo philosophicus and a homo religiosus, Plutarch did not draw a clear distinction between, what people today would call, natural science, on the one hand, and religion and mythology, on the other - that is, the traditionally ill-conceived distinction between 'reason' and 'myth'. In fact, the opposite is true, as is clear, for instance, from his De facie. In this work, Plutarch concludes an astrophysical dialogue about the substance and nature of the moon with a mythological account of the moon's purpose in the universe, explaining its importance for the life-cycle of human souls. This dualistic approach is not at all new to contemporary Plutarch scholars, but the claim that the same approach is also subtly present in Plutarch's discussions of more particular scientific topics as treated in Quaestiones naturales - a collection of $4 \mathrm{I}^{1}$ natural

1 This number (4I) includes the additional problems from Gybertus Longolius' I542 Latin translation (Q.N. 32-39) and from Michael Psellus' De omnifaria doctrina (Q.N. $40-4 \mathrm{I}=\S \S \mathrm{I} 7 \mathrm{O}$ and $\mathrm{I} 88$ Westerink). There is some controversy about the authenticity of 
problems modelled after the Ps.-Aristotelian Natural problems (from here on simply Problems) - has not yet been made, or has even been doubted. One of the goals of this study will be to resolve this issue, and to show that Plutarch's natural problems form an integral part of his wider natural philosophical project, fully consistent with the method and conceptual framework of his other scientific writings, albeit perhaps in a less obvious manner.

Plutarch discusses natural problems throughout his entire oeuvre. In Quaestiones convivales he cross-fertilises the natural problem format with the literary genre of the symposium, and in the Vitae he sporadically incorporates natural scientific digressions ( $\pi \alpha \rho \varepsilon \kappa \beta \alpha ́ \sigma \varepsilon เ \varsigma)$ in his biographical narratives [see 2.I.3.]. Plutarch uses the problem format in its traditional form only in Quaestiones naturales, where he treats such problems in an autonomous fashion. By straddling a large variety of questions (and answers) related to ancient Greek zoology, botany, meteorology and their respective subdisciplines, the collection is firmly rooted in ancient Greek physical theory ${ }^{2}$, especially as conceptualised by the Peripatetics [see I.I.3.]. A few examples of particular - and at times very peculiar - problems Plutarch tries to solve are: 'Why does seawater not provide nourishment to trees?' (Q.N. I), 'Why do the tears of boars taste sweet, while those of deer taste salty and ordinary?' (Q.N. 20), 'Why does a vine wilt if it is sprinkled with wine, and especially with wine made from its own grapes?' (Q.N.3I), 'Why is water that is drawn from wells less nutritious than water that flows from a spring or falls from the sky?' (Q.N. 33), 'Why are bees quicker to sting people who have just committed adultery?' (Q.N. 36).

Due to Plutarch's primary focus on the natural causes of such phenomena and not also on their higher, divine motivation, scholars have argued that the place of Quaestiones naturales among Plutarch's other natural philosophical writings is puzzling. However, as we will see, these scholars have often neglected the deeper philosophical-religious motivations and mythological references that discreetly accompany the collection's scientific discourse [4.I.2.2.]. The few attempts that have been made to evaluate the work's scientific character - mainly in terms of its physicalaetiological approach and referential and impersonal style - were mostly

the two chapters in Psellus' text, which may contain the remains of two lost Quaestiones naturales. The least that can be said is that there is a Plutarchan core to these two chapters. The authenticity of Longolius' additional chapters is beyond debate. See ad loc. in the commentary for further detail and literature.

${ }^{2}$ Cf. K. Ziegler, I95I, col. 857: “" physische', d.h. nach unserer heutigen Ausdrucksweise zumeist physiologisch-biologisch-medizinische Fragen". Cf. also R. Flacelière, J. Irigoin, J. Sirinelli and A. Philippon, 1987, p. lxxxii: “On voit qu'il ne s' agit pas là uniquement de "physique" proprement dite, mais aussi de biologie et de plusieurs autres matières." 
biased by modern hindsight, at the risk of neglecting the broader scientific and socio-cultural context from which the text originates. In other cases that emphasise the collection's strange and exotic character, scholars have tried to cover up their interpretative misguidance by conveniently, though often silently, siding with that lovely profundity - or scholarly fig leaf rather? - that the past is a 'foreign country', that is, a country with natural laws and scientific conventions of its own, impenetrable to modern understanding. As a result, a proper attempt to make the collection more comprehensible for the modern reader was left to others, and rightly so.

Owing to a growing awareness of the particular and, in many cases, very different intellectual-philosophical and socio-cultural background of ancient scientific texts, there are several methodological tools available now for interpreting the scientific set-up of this type of literature in conjunction with its historical context. This endeavour forms one of the basic objectives for the study at hand. Indeed, only since relatively recently scholars have started to take a more positive stance towards Plutarch's natural science, but even so Quaestiones naturales has continued to lag behind. This general reappraisal can be linked with the wider scholarly tendency in the contemporary history of science to draw a realistic and detailed picture of ancient scientific literature without in any way idealising it. Thus, it is expected that an attempt to set the game straight for Quaestiones naturales will certainly be of interest both to Plutarchists and to historians of (ancient) science. The principal aim of this prologue, therefore, is to establish a broad conceptual and methodological framework within which we can approach Plutarch's natural problems in a suitable fashion, that is, in light both of contemporary Plutarch scholarship and of the history of (ancient) science. Historians of science will be familiar with many of the points raised here, but this may not be the case for scholars working in the field of Plutarch studies. In either case, examining Plutarch's role in the history of science may offer something new to both types of readers.

The prologue at hand aims to explore how the scientific value of Quaestiones naturales can properly be assessed and what is its place in its contemporary scientific context. Through outlining a status quaestionis of the research that has already been conducted on this text, I will try to show that it is only fair to study Plutarch's scientific endeavours at face value, that is from an ancient rather than from a modern perspective. As such, the goal of this study will be of a mainly historical-antiquarian kind. It should be noted, though, that the principle of charity, which this assessment will be established on - by holding that an author's tenets and convictions be valued on the basis of his own intellectual standards and that of his time-, should not, of course, exclude a diachronic evaluation ${ }^{3}$ (see further).

\footnotetext{
${ }^{3}$ See J. Opsomer, 20I4, p. 9I: "The principle of charity, as I understand it, [...]
} 
A first important terminological question will, then, be whether the concept of 'ancient science' is actually legitimate, and, if so, why one would want to apply it here. The overarching question is whether Plutarch's scientific programme is really as 'immature', if not straightway unscientific, as it may seem to some (modern readers). This question may sound naïve, but its apologetic significance will soon become clear. In other words, what grounds do we have to take the more marginal(ised) aspects of ancient science - including Plutarch's natural problems - seriously, and why would we even care to do so? In order to provide a convincing answer to these questions, we should first take a look at the scientific programme of Plutarch's philosophical hero, Plato.

\section{Plato, Plutarch and scientific infancy}

As the attentive reader may have noticed, the quotation from Plato's Phaedo in the epigraph to this study is a rather misleading excerpt from the original Platonic dialogue. That is, it stands somewhat bare and decontextualised from the original Platonic text. This is deliberate, and it will become clear why, once we have considered the passage in greater depth.

In Phd. 95e-99d, Plato incorporates an important intermezzo, where Socrates is conversing with Cebes in an autobiographical mode about

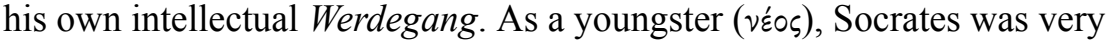

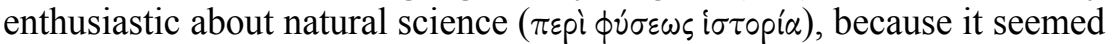
to acknowledge for the existence, coming to be and perishing of everything in the world by means of a suitable causal approach. Unfortunately, we can only guess at the real, historical extent of Socrates' interests in natural scientific matters ${ }^{4}$. From this passage in the Phaedo, however, we learn

demands that we assume, at least for the sake of a rational reconstruction of his views, that Plutarch advocated his views because he was convinced of their truth, and condemned incompatible views because he believed them to be false. (One could of course argue that his real reasons for believing certain views were opaque to him. Plutarch's psychological motives, however, are not accessible to us.)"

${ }^{4}$ It remains to be seen, after all, how much truth and how much slandering there is precisely in Meletus' attribution of Anaxagoras' physical theories to Socrates at his trial (viz. that the sun is a stone and the moon, earth), or to what precise historical extent Aristophanes' portrait of him as a mad scientist is a caricature or not. Pl., Apo. 26d (=

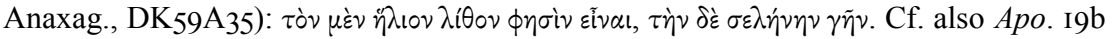
for the accusation of Socrates' excessive interest in the study of 'what is beneath the

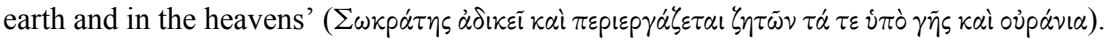

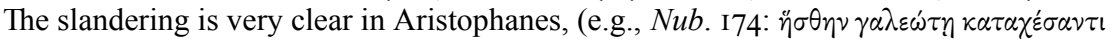

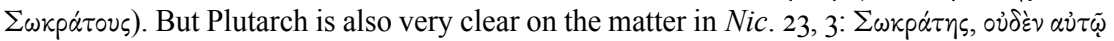

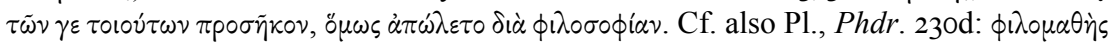

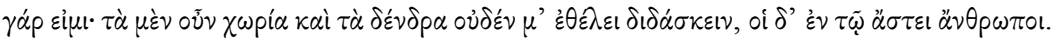


that Socrates became interested in Anaxagoras' theory of an all-embracing voús when he heard someone - perhaps Archelaus, Socrates' supposed teacher - reading from Anaxagoras' book. Socrates expected that this voṽ would arrange everything 'in such a way as it is best for it to be' ( $\tau \alpha \dot{v} \tau \eta$ ö $\pi \eta \ddot{\alpha} \nu \beta \varepsilon \lambda \tau \iota \sigma \tau \alpha$ है $\chi \eta)$. Anaxagoras' theory seemed very promising at first in this regard, but eventually - and quite ironically so, considering the kind words Socrates first had for Anaxagoras - it failed to meet Socrates' initial expectations. This disappointment is due to 'Mr. Mind's' (cf. Per. 4, 6) main focus on natural causes, a rather narrow approach in Socrates' opinion. Socrates gives the following absurd example to disprove Anaxagoras: one could say that it is due to certain positions and movements of his muscles that he sits there (in prison) with his legs bent, but when it comes to those muscles, he could just as easily have set course for Megara or Boeotia to escape the impending death penalty (the allusion is to the Crito). Therefore, the main cause for Socrates' stay in prison is his personal choice to accept the judges' verdict and not go into exile. In this sense, his muscles are only the means by which he can sit or run away, but to call them the real cause of his action is, for Socrates, most

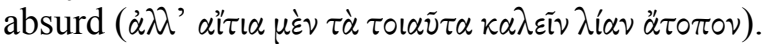

It is interesting - at least for the sake of the argument - that natural science and a person's interest in natural causality is depicted in the Phaedo passage as a puerile practice for immature intellects. Socrates is young, so his interest in natural phenomena could be pardoned as a youthful sin. Even as a youth, however, Socrates frowned at the flaws in natural science, mainly because he did not see it as shedding light on the real causes ( $\tau \dot{\alpha} \varsigma$ $\dot{\omega} \varsigma \dot{\alpha} \lambda \eta \theta \tilde{\omega} \varsigma \alpha i \tau i \alpha \varsigma)$. For Socrates, explaining natural phenomena, such as the working of the muscles, in a purely physical-aetiological way is a 'childish' and truly 'infantile' procedures. It is an oversimplified manner

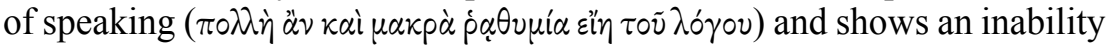

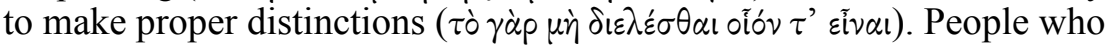
equate the natural cause with the real cause are only groping in the dark

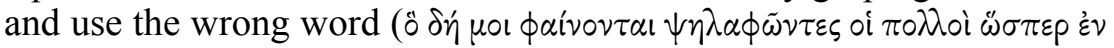

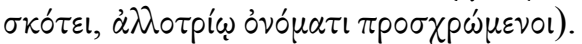

Scholars have argued that Plato is most likely projecting his own philosophical Werdegang on that of Socrates in this passage. Thus, one may wonder why Plato himself, in spite of his well-known disdain for experimental science (cf., e.g., Tht. I62e), still had an interest in biology and physical theory, as is clear from the Timaeus ${ }^{6}$. In this late work, Plato

${ }^{5}$ For more detail on the ancient belief that philosophical education can commence only after infantia, when reason sets in and logical thought starts to develop, see C. Laes, 20II, p. 84 (cf. Aët., Plac. 4, II = Ps.-Plut. 900BD and Sen, Ep. II8, I4).

${ }^{6}$ See H. Görgemanns, 1999 (with p. 75 for the theory of Plato's autobiographical writing in the Phaedo passage). 
clearly demonstrates that the contemplation of natural causes does hold great interest for a true and mature philosopher, but at the same time he makes it very clear that the study of natural phenomena should remain completely subjugated to the contemplation of a higher, intelligible cause (i.e. the idea of the beautiful and the good, the divine demiurge etc.). This intelligible and divine principle is the corner-stone of Plato's philosophical doctrine.

The point I am trying to make is different, though. To stay with Plato's Timaeus for a moment, it would be an understatement that historians of science have not always been very cheerful about its contents. Clagett, for instance, notes that "[e]ven the most apologetic Platonist will not stand behind Plato's Timaeus as a work of high scientific caliber, although it is true that some of the ideas suggested therein were not without their influence on Aristotle and later authors" "It remains to be seen, of course, whether the significance of the Timaeus for the history of science is, as Clagett here suggests, only extrinsic (viz. to be valued by its influence on later authors) and not also intrinsic (viz. to be valued in the text itself qua ancient scientific product). Plutarch, for one, can certainly be counted among these later authors: he is, indeed, an intellectual heir of Plato's science, for whom the Timaeus served as some kind of a scientific manifesto and a methodological guide to be followed when contemplating the natural world [see 4.3.2.]. From Clagett's perspective, though, this is not exactly a cause for celebration.

In fact, the problem remains, if it does not become even worse in the case of Plutarch, whose scientific project not only stems from that of Plato, but also shows a peculiar inclination to accept popular beliefs regarding nature without great concern for their reliability [see 4.I.I.]. It is not my goal in this preface to concentrate on Plutarch's own Platonically inspired focus on higher causes (this will be fleshed out later, when dealing with his dualistic view on causality [see 4.I.2.]) but to take a step downwards on the causal ladder and shed a few preliminary thoughts on the scientific value of his natural problems and their attempt to formulate plausible physical explanations for often rather peculiar natural phenomena. This question is particularly relevant in light of the physical aetiologies Plutarch provides in Quaestiones naturales, or in Greek: Aitial фuбikai [see I.I.6.].

${ }^{7}$ M. Clagett, I955, p. 64 (cf. also, e.g., B. Farrington, I96I, p. I20: "from the scientific point of view the Timaeus is an aberration"). A review of Clagett's work is found in J.T. Vallance, 1990 (esp. pp. 7I7 and 719 on the Timaeus), whose observations are of general interest for the arguments in this prologue. For a more positive reappraisal of Plato's science, see, e.g., G.E.R. Lloyd, 1968. See also J.P. Anton, I980, A.F. Ashbaugh, I988, A. Gregory, 2000, D.J. Zeyl, 2000, pp. xiii-xv, T.K. Johansen, 2004, R.D. Mohr and B. Sattler, 2010 and S. Broadie, 2012. 
Indeed, one may wonder how scientific the answer can be to a question as 'Why are bees quicker to sting people who have just committed adultery?', which is Q.N. 36 in the collection. Two basic reactions to such questions can be distinguished in modern scholarship: either eager justification of the actual occurrence of such a phenomenon in nature or outright dismissal of the problem as a bizarre, if not completely fictitious, invention. As it turns out, however, both reactions are often equally prejudiced in principle. To take the example of the bee-problem just quoted, Sandbach tried to save the phenomenon by noting that " $\mathrm{t}] \mathrm{he}$ belief that bees readily attack those who carry the odour of sexual intercourse may be true, since they appear to be provoked by other body odours." Flashar, by contrast, is less enthusiastic about this problem, which he claims to be "ausgesprochen gesucht und naturwissenschaftlich unbegründet" . Arguably, however, Sandbach is asking the wrong question while Flashar is using the wrong standard. When it comes to the scientific appeal of natural mirabilia, and of those recorded in Plutarch's natural problems more specifically, it seems only fair - and certainly much more pertinent - to evaluate these problems according to contemporary (i.e. ancient) natural philosophical standards, as opposed to Flashar's modern standards. Seeing that Plutarch makes a considerable attempt to explain these and similar phenomena in a plausible, physical way, it is only reasonable to ask why he takes such curiosa seriously. The main point of interest for us, however, should not be to find out whether Plutarch got it right or wrong (which is Sandbach's main concern): there is no use to testing the bee-problem - by any means! - in order to assess Plutarch's natural scientific inquisitiveness. What will mainly concern us in this study, then, is Plutarch's actual intention and underlying motive to account for such problems in a serious way, and what constitutes proper scientific conduct for him.

There is no denying to the fact that some of these natural questions appear to be quite playful, but the modern reader may consider Plutarch's answers to these questions even more perplexing. One might find that the physical explanations Plutarch provides contain several argumentative flaws. These can occasionally be attributed to the author's untended and careless writing, but it would certainly be too easy to ascribe each aetiological flaw solely to Plutarch's sloppy authorship ${ }^{10}$. What is probably most alarming for the modern reader is Plutarch's mainly theoretical approach to natural phenomena [see 4.3.2.]. The physical aetiologies are not infrequently based on what, for many modern readers, would seem to

${ }^{8}$ F.H. Sandbach, 1965, p. 219, n. c.

${ }^{9}$ H. Flashar, I962, p. 370 . Cf. also G. Nuzzo, I99I, p. 4IO.

${ }^{10}$ Cf., e.g., P. Donini, 20II, p. 20 (with n. 25) for the point that some errors in De facie could, in fact, already have been avoided in Plutarch's time. 
be unsound assumptions, if not absurd sophisms, about nature, many of which provoke the author's argumentative ingenuity and rhetorical talent for vindicating the untenable. This rhetorical ingenuity and aetiological sophistication on Plutarch's behalf has often been cast in a bad light by modern critics, but it should be noted that it is, in fact, an essential feature of many scientific writings from the Greco-Roman era and also of Plutarch's scientific programme in particular (think, for instance, of Galen's rhetorical debunking of rivals and predecessors). Especially the natural problems of Plutarch's Quaestiones convivales have been severely criticised in this way ${ }^{11}$, but the same criticism applies to the problems collected in Quaestiones naturales just as well ${ }^{12}$.

The physical explanations Plutarch provides often seem to end up in idiosyncratic associations (e.g., Q.N. I6, 915F: the attribution of hot and cold properties to wheat and barley, respectively), absurd value patterns (e.g., Q.N. 17, 915F: the strength of hair is gender-related), tentative speculations (e.g., Q.N. 3, 9I2E: salt literally contains sharpness,

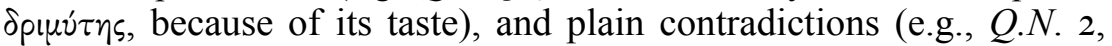
9I2BC: rainwater is suggested to be flavourless, but a little further Plutarch

${ }^{11}$ See, e.g., Z. Abramowiczówna, I962, pp. 82-83, F. Fuhrmann, I972, pp. xxiii-xxiv ("Ainsi présentées, ces recherches [scientifiques] rappellent la déclamation rhétorique qui ne constitue, elle aussi, qu' une imitation d'impression et de sentiments véritables. [...] ce ne sont que des exercices de l' esprit"), E. Teixeira, I992, p. 219 ("Mais les explications données par Plutarque sont le plus souvent assez fantaisistes, semble-t-il."). For a more positive evaluation, see, e.g., F. Frazier and J. Sirinelli, I996, p. 206 ("Ce goût du paradoxal et de l'étrange peut, à première vue, sembler un tribut payé à la rhétorique d'époque, mais il correspond aussi à une conception de la philosophie comme réflexion suscitée par l'étonnement.") and J. König, 2007, p. 5I (quoted n. 7I).

12 The same is true, moreover, for the Ps.-Aristotelian Problems, after which Plutarch's natural problems are modelled. In Antiquity, however, Aristotle's Problems were praised as being 'most delightful and filled with choice knowledge of all kinds' (Gell., NA 19, 4: lepidissimi et elegantiarum omnigenus referti). Of course, times have changed considerably since; as is well known, Aristotle's causal model of scientific research did not survive the Middle Ages. It will not come as a surprise, therefore, that modern readers have not always been positive about the scientific value of Ps.-Aristotle's Problems. For a compilation of modern disapproval (but sometimes also appreciation), see H. Flashar, 1962, pp. 377-378. A. Schopenhauer, 1976 (I85I), pp. 478-479, for instance, was very pessimistic - how could he not be? - in his evaluation: "Wer wissen will, wie unglaublich weit die Unwissenheit der Alten in der Physik und Physiologie ging, lese die 'Problemata' Aristotelis: sie sind ein wahres specimen ignorantiae veterum. Zwar sind die Probleme meistens richtig und zum Teil fein aufgefaßt: aber die Lösungen sind größtenteils erbärmlich, weil er keine

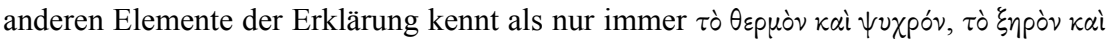
¿jpóv." R. Mayhew, 20IIa has recently produced a new English translation of Ps.-Aristotle's Problems, and the papers collected in B. Centrone, 20II and R. Mayhew 20I5a also mark a renewed scholarly interest in this peculiar branch of scientific literature. For its reception in the Middle Ages, see esp. P. De Leemans and M. Goyens, 2006. 
asserts that it nevertheless contains a sweet constituent; Q.N. 3, 9I2DE: salt can cause both an increase and a reduction in bulk). Furthermore, the aetiologies are at some points infested with non sequitur inferences, because Plutarch seems to too easily accept what he hypothesises to be true (e.g., Q.N. I8, 9I6B: the fact that the cephalopod has no body armature and is composed entirely out of soft flesh is not necessarily a cogent reason for it also being more sensitive to cold and disturbance in the sea). One may wonder, however, how fair such an evaluation of Plutarch's science really is, since many of these theories were commonly accepted by ancient natural philosophers.

Bearing in mind the passage from Plato's Phaedo, a first - somewhat introductory - point of interest for us will be whether Plutarch's Quaestiones naturales is perhaps the work of a young author, that is a youthful lapse, representative of Plutarch's juvenile enthusiasm for things natural. This is not a futile question, let alone an easy one to settle. In order to illustrate this, a link can be drawn with Plutarch's works on animal psychology (De sollertia animalium, Bruta animalia ratione uti, De esu carnium [see I.I.I.]). Many scholars have assumed the hand of a young author in these writings, mainly for reasons of their ostensibly playful and juvenile contents and rhetorical style. Such a biographical reading, traditionally based on a text's style and contents, is generally considered somewhat trite today, though ${ }^{13}$. Indeed, one may object that the link between zoology and ethics, as is present in these writings (on animal psychology), was not without precedent in ancient literature, and that the philosophical (esp. anti-Stoic and Pythagorean) overtones present therein can just as well point at a more mature authorship ${ }^{14}$. Of course, Quaestiones naturales

13 Pace, e.g., F. Krauss, I9I2, pp. 80-83 and H. Cherniss and W.C. Helmbold, I957, pp. 3I4, 490, 537. K. Ziegler, I95I, col. 732 remains hesitant when he says that Plutarch's works on animal psychology are "der rhetorischen Jugendperiode entweder noch zugehörig oder ihr doch nicht fernstehend". The belief that a highly rhetorical and literary discourse can only be ascribed to an author's youthful character, whereas a simple, unadorned style is indicative of a more settled and mature authorship is generally rejected today. Cf. C. Pelling, 20II, p. 2II, n. I4 (with further references), who objects to "the crude interference that declamatory style is a mark of immaturity". The same point was made regarding the date of De sollertia animalium by J. Bouffartigue, 20I2, p. xxi. Cf. De soll.

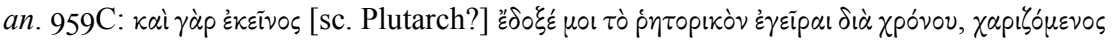

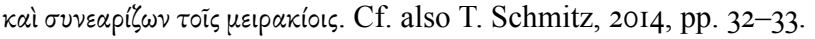

${ }^{14}$ For the anti-Stoic tendencies in these works, see D. Babut, 1969, pp. 6I ff., who assigns them "[à] l' époque de sa pleine maturité". Cf. also J. Bouffartigue, 20I2, pp. Xx-xxi. For their Pythagorean (and Orphic) tendencies, see D. Tsekourakis, 1986 (who, however, adheres to the youth theory on p. I27, n. 3). For the natural philosophical value of Plutarch's writings on animal psychology more generally, see R. French, 1994, pp. I78-I84 (esp. p. I82 for their Academic leanings) and S.T. Newmyer, 2006 and 20I4. Moreover, for the anti-Epicurean tendencies in De amore prolis, see G. Roskam, 20IIa, pp. 200-20I. 
does not belong to the category of Plutarch's writings on animal psychology, but if one considers the rhetorical dynamics and often peculiar contents of the problems collected there, the situation is worth considering more closely.

\section{Date and chronology of Quaestiones naturales: a 'life's work'?}

As stated, a first hurdle that cannot simply be avoided in this study - and that should best be cleared early on - is that of the date and chronology of Quaestiones naturales. Most scholars agree that this collection does not belong among Plutarch's early works but should be dated to a much later period of his literary career. There are no points of reference in the text to conclusively date the collection, though. The precise floruit of Laetus (presumably the Platonic philosopher Ofellius Laetus, quoted in Q.N. 2, 9IIF and 6, 9I3 E), remains uncertain, and the same is true for

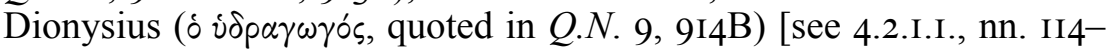
II5]. It is generally accepted that the collection was composed more or less contemporaneously with Quaestiones convivales, around IooIIO $\mathrm{AD}^{15}$ (a theory that was first formulated by Sandbach) ${ }^{16}$, but this date is, in my opinion, uncertain for Quaestiones naturales ${ }^{17}$. Scholars have

${ }^{15}$ For the late date of Quaestiones convivales, see K. Ziegler, I95I, cols. 7I3 and 888: "mindestens ins I. Jahrzehnt des 2. Jhdts., und zwar eher an sein Ende als an seinen Anfang". C.P. Jones, 1966a, pp. 72-73 dates Quaestiones convivales after 99 and before II6AD. Cf. also F. Fuhrmann, 1972, p. xxvi ("les Propos de Table ont été écrits probablement au cours de la $2^{\mathrm{e}}$ décennie du $\mathrm{II}^{\mathrm{e}}$ siècle, et $[\ldots]$ ils représentent une des dernières œuvres de Plutarque") and J. Sirinelli, 2000, p. 370 ("entre I07 et II5 et plus vraisemblablement entre I07 et IIo") and p. 380 ("Il [sc. Plutarque] touche ou vient de toucher à la soixantaine.").

${ }^{16}$ F.H. Sandbach, I965, p. I38. According to G.W.M. Harrison, 200ob, pp. 242-243 (cf. also 2000a, p. 197) both collections were composed more or less simultaneously, and, indeed, "[t]he Quaestiones in general are written in the second half of Plutarch's career". L. Senzasono, 2006, pp. 46-48 situates Quaestiones naturales at the end of the first decennium of the second century, a little earlier than Quaestiones convivales and probably after the Vitae (p. 25, n. 36; on the contemporaneous composition of Quaestiones convivales and the Vitae, see, however, C. Pelling, 20II, pp. 207-208). Problematic in Senzasono's argument is the idea that the unadorned style of Quaestiones naturales [see I.2.3.] would imply a late date, while the same late date is also presupposed for the literary vivacity of Quaestiones convivales and the Vitae, i.e. writings that are highly embellished from a stylistic perspective. According to F. Fuhrmann, I964, pp. 19, 22 and 77, Quaestiones naturales was composed after $100 \mathrm{AD}$, because it contains only one literary image (viz. in Q.N. 29, 919B: "Les météores éclatent comme des bulles"), but this is not the only case of imagery, as we will see later [I.2.3.], and, even so, this stylistic argument is not really convincing (see n. I3; it is certainly outmoded, see already F. Krauss, I9I2 and J. Kowalski, I9I8).

${ }^{17}$ In fact, only a small number of Plutarch's works allow for determining an absolute date. A study that cannot remain unmentioned here is C.P. Jones, I966a (but for a critical 
made great efforts in dating some of the sympotic discussions recorded in Quaestiones convivales by basing their argument on the historical contexts and the prosopography of the attending symposiasts ${ }^{18}$. It remains to be seen, though, whether in those cases where a precise date can be deduced (assuming that we can at least accept a certain aspect of historicity for Quaestiones convivales [see 2.3.I.]) the same date should necessarily be accepted for the parallel passages in our collection. For example, the specification है $\gamma \varepsilon \tau \tilde{\omega} \pi \alpha \rho o ́ v \tau \iota ~ \kappa \tau \lambda$. ('at least in the present discussion') in Quaest. conv. 664D is probably an implicit allusion to the parallel account about the generative property of 'lightning water' in Q.N. 4, 9I2F-9I3A (I will discuss this parallel later [see 3.I.4.]), but the sympotic discussion at issue cannot be precisely dated, since it is set at a random dinner in Elis and is hosted by the otherwise unknown Agemachus. My point is, however, that even if we had been able to date this sympotic discussion precisely, this would not necessarily have implied that the passage from Quaestiones naturales is contemporaneous with the one from Quaestiones convivales, since an earlier or later composition is at least equally plausible. This is actually true for each and every parallel between the two works (and these are numerous: cf., e.g., Q.N. I, 9IICF and Quaest. conv. 627AD; Q.N. 3, 9I2F and Quaest. conv. 685D etc. [see 2.2.3.]). Therefore, the contemporaneous composition of Quaestiones naturales and Quaestiones convivales is not a given fact. I am, in any case, inclined to be open-minded in this matter ${ }^{19}$.

It is important to draw a clear distinction between the date of a text's publication and its period of composition. This is not irrelevant, especially if one considers that some scholars argue in favour of a posthumous publication of Quaestiones naturales ${ }^{20}$ (I will come back to the issue of

review, see R. Flacelière, J. Irigoin, J. Sirinelli and A. Philippon, I987, pp. x-xi). See also G. Hein, I9I6, C. Stoltz, I929, K. Ziegler, I95I, cols. 708-719 and J. Sirinelli, 2000, pp. $476-483$.

${ }_{18}$ See esp. the commentary of S.-T. Teodorsson, 1989, I990a, I996. The main prosopographical study of Plutarch's oeuvre is B. Puech, I992.

19 Only in a few exceptional cases one can attempt to reconstruct the approximate chronological order of the text based on specific clusters of parallel passages in the corpus Plutarcheum. However, this attempt will still remain conjectural. This is the case, most notably, with Q.N. I9 (on the octopus' metachrosis): see F.H. Sandbach, I965, p. I37 and M. Meeusen, 20I2a, pp. 250-252. It is perhaps best in such cases not to claim that Plutarch worked on several works at the same time, since this is at the risk of coming to the absurd conclusion that Plutarch wrote his entire oeuvre all at once. Indeed, Plutarch's use and reuse of personal notes $(\dot{i} \pi \circ \mu \nu \eta \dot{\mu} \mu \tau \alpha)$ at different occasions offers a plausible way out [see 2.I.2.].

${ }^{20}$ See F. Fuhrmann, 1964, p. 19: "Il est évident que ces ébauches [dont il est malaisé de déterminer le but exact aux yeux de leur auteur] n' ont pas été publiées par Plutarque, mais après sa mort par les membres de sa famille, ses amis ou familiers. 
publication later [see 2.4.I.]). Whereas nothing is known about the date of publication of Quaestiones naturales, we do have some indications of its period of composition. I am inclined to accept that Plutarch may very well have worked on his natural problems over several periods throughout his life, perhaps from his years as an Athenian student onwards, adding something new or omitting (or at least reorganising) older material from time to time. These editorial interventions in the text probably involved the addition of new (sets of) problems and new answers to older problems. This is more or less the idea behind Harrison's theory of a long and intermittent composition of Quaestiones naturales ${ }^{21}$. The central point of Harrison's

De cette sorte sont les Aetia romana, les Aetia graeca, les Aetia physica." See also K. Ziegler, I95I, col. 857: "man [kann] zweifeln [...], ob sie von P. selbst oder erst aus seinem Nachlaß herausgegeben worden sind. [...] Die Möglichkeit der Herausgabe durch P. selbst muß man jedenfalls im Hinblick auf die ganz gleich gearteten Aï $\tau 1 \alpha$

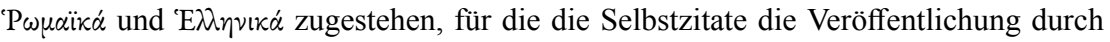
P. selbst sicher stellen." See already R.W. Emerson, I89I, pp. 309-3IO (quoted below, n. 32 ).

${ }^{21}$ See G.W.M. Harrison, 200ob, pp. 239-243 (cf. also 2000a, pp. 197-198). According to L. Van der Stockt, 20II, p. 450: "Harrison's hypothesis of the genesis of the composition (through 'intermittent composition', as he calls it) is most interesting, but [...] needs to be tested against the hypothesis of genesis through hypomnemata [...]." I will deal with this "genesis through hypomnemata" of Quaestiones naturales later [see 2.3.2.]. See already A. Gudeman, 1927, col. 2523, who argues that collections of problems (in general) are "im Laufe der Zeit aufgehäufte Kollektaneen". The same point was made more specifically for Plutarch's Quaestiones Romanae and Graecae by W.R. Halliday, I924, p. I3: "Plutarch has put together [these collections], perhaps over a fairly long period, from his miscellaneous reading". Halliday's chronological vagueness puts the stricter theories about the publication date of Plutarch's collections of problems (c.q. Quaestiones Romanae and Graecae) into perspective. According to J.-M. Pailler, I998, p. 77, for instance, "les matériaux des Questions ont été réunis en même temps que ceux des Vies", but even this is perhaps a bit too restrictive (cf. also G. Hein, I9I6, p. II: "quaestiones Romanas [...] conscripsit cum vitas parallelas componeret; quam ob rem illae in posterioribus Plutarchi scriptis numerandae sunt”; K. Ziegler, I95I, col. 862). It seems unlikely that Plutarch read and, by implication, made extractions from historical texts only while he was working on the Vitae - though, of course, the production may very well have increased at that time. It is not impossible that those specific passages in the Quaestiones Romanae which Plutarch refers to in Cam. 19, 8 and Rom. I5, 7 [see 2.I.4.] were composed shortly before their correlates in the Vitae (and are therefore late), but this is not at all certain and neither does it necessarily hold true for the collection as a whole. Nevertheless, J. Boulogne, I992, p. 4687 (with n. 30) dates Quaestiones Romanae to around the end of the first century AD: "elles profitent de la pleine maturité intellectuelle de Plutarque, qui a, alors, atteint la cinquantaine". The allusion to Domitianus in Quaest. Rom. 276E would serve as a terminus post quem, pushing the date of the collection's composition after 96 AD. One should acknowledge, though, that this date perhaps only applies to that specific chapter. Pace also K. Ziegler, I95I, col. 860, but with more nuance in col. 7I2: "die Stelle 
theory is that the collection was probably not put together in one and the same breath but at several distinct moments:

"like someone who solves cross word or jig saw puzzles over a number of days, Plutarch picked up and put down and came back to a series of questions that had begun to excite his curiosity [...]. While engaged on other projects, as he had further thoughts, Plutarch made additions to each of the quaestiones just as trains may add on cars at various stops but always in a determined sequence." 22

The possibility of smaller or larger chronological intervals, during which Plutarch let the material sink in for a while in order to revisit it afterwards, is very difficult, if not impossible, to determine within the text ${ }^{23}$. It is not unlikely that the thematic clusters of problems that are found throughout the collection hint at such an intermittent composition (see the scheme in the introduction to the commentary), but, even then, it is a hopeless task to prove exactly where and when Plutarch put his pen down or picked it up again ${ }^{24}$. On the assumption that such thematic clustering implies

[scheint] zwar nicht sicher, aber doch sehr wahrscheinlich nach seinem [sc. Domitians] Tode geschrieben" (my italics). See also H.J. Rose, I924, pp. 47-48 and C.P. Jones, I966a, p. 73 (after ca. I05 AD).

${ }^{22}$ G.W.M. Harrison, 200ob, p. 240. A similar notion of intermittent composition was entertained for Quaestiones Platonicae by H. Cherniss, 1976, pp. 4-5 (cf. J. Opsomer,

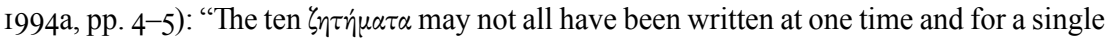
work. It is at least as likely that at some time Plutarch put together ten separate notes on Platonic passages that he had written at different times and had found no suitable occasion to incorporate into his other compositions. If this is so, any indication of the relative chronology of one of the ten would not necessarily be pertinent to that of the others." Similarly, for the intermittent composition of Plutarch's Apophthegmata Laconica, see F. Fuhrmann, 1988, p. 135 .

${ }^{23}$ See, e.g., the transition between $Q . N .23-24$, and more specifically the ghost-

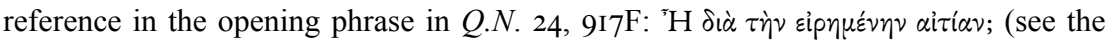
commentary ad loc. for further detail). Cf. also G.W.M. Harrison, 200ob, p. 24I.

${ }^{24}$ According to G.W.M. Harrison, 2000b, p. 242 (with a synopsis in 2000a, pp. 197I98) there is a substantial chronological rupture between the composition of Q.N. I-I8 and I9-3I, but the stylistic arguments he adduces (viz. the use of the present tense and the incorporation of literary quotations) are not very convincing, in my opinion. Harrison bases his theory on the chronology put forward by F.H. Sandbach, I965, pp. I36-I37. Sandbach does not, however, postulate a chronological rupture between Q.N. I-I8 and I9-3I as such, but focuses only on the chronology of Q.N. 19 and its parallel passages [see the scheme in 2.I.2.]. Considering the thematic clustering of problems on fishing and sea animals in Q.N. I3, I7-I9 and the parallel passages - presumably based on the same or similar hypomnematic material - in a relatively small section of De sollertia animalium (viz. $976 \mathrm{E}-977 \mathrm{~A}, 978 \mathrm{EF}, 979 \mathrm{~B}$ ), it seems rather unlikely that there is a major chronological rupture in composition between $Q . N$. I8 and 19. The inclusion of the cluster of problems 
synchronous composition, it is not impossible that the problems in each of these clusters were composed more or less contemporaneously. After all, the solution to one problem may trigger the formulation of a new one that is closely related to it. But it is just as likely that some problems were added later on to these clusters, or that the clustering itself is perhaps the result of an editorial intervention. There is no need to go into the details of this theory; it is simply the general idea behind the unspecifiable chronology of Quaestiones naturales that matters here.

The idea that Plutarch perhaps worked on his natural problems from his early years as an Athenian student onwards can be corroborated by the fact that, at several points in the discussions described in Quaestiones convivales, Plutarch stages his own literary alter ego as a young symposiast and interlocutor ${ }^{25}$. The narrated time (erzählte Zeit, temps de l'histoire) of Quaestiones convivales goes back to the time when Plutarch was an Athenian student under the tutorship of Ammonius, with whom he joins in discussion on several occasions. This is the case in the first two talks of Book three (Quaest. conv. 645D-649F), wherein two natural problems are discussed (concerning the natural properties of flower garlands and ivy) and also in Book nine, which is set at the festival of the Muses that probably took place at Ammonius' private Academy in Athens. Ammonius there (in Book nine) appears on the scene several times, and as the titles of the lost talks indicate (especially talks ten through twelve), some of the discussions originally dealt with particular natural problems (concerning solar and lunar eclipses, the body's permanent state of flux and the number of the stars respectively). Notably, Ammonius is also an interlocutor in the discussion held in De E, where Plutarch again appears as his young student (the topic of the body being in flux is treated in $D e E 392 \mathrm{AE}$ ). Jones has dated these talks in Quaestiones convivales and in De E to around 66-67AD (when Nero was visiting Greece: De E 385B), pointing out that Plutarch counts himself among the véol (Quaest. conv. 649A, 646A, cf. also De E 39IE) and that his brother Lamprias (who is also present in $D e E$ ) is still a $\pi \alpha i$ s (Quaest. conv. $747 \mathrm{~B})^{26}$. If there is any historicity to

regarding the natural properties of wheat and barley (Q.N. I4-I6) can be explained, then, in light of structural variatio [see I.I.5.]. For further detail, see the commentary ad loc. and M. Meeusen, 20I2a, p. 252, n. 75.

${ }^{25}$ For Plutarch's self-presentation as a young symposiast in Quaestiones convivales, see F. Klotz, 2007, p. 655 and J. König, 20II, p. I79. Notably, P. Louis, I99I, pp. xxviii-xxix argues, in a similar fashion, that Aristotle probably started composing his natural problems shortly after his entry in Plato's Academy. Cf. also C. Jacob, 2004, p. 44.

${ }^{26}$ C.P. Jones, I966b, pp. 206-207 (in my opinion, S.-T. Teodorsson, I989, pp. 289-290 has no convincing argument against Jones' early date; and for Book nine he argues that "[i]t is quite possible that considerable parts of the contents are student reminiscences of Plutarch": id., I996, p. 299). Talk three of Book eight (Quaest. conv. 720C-722F: "Why 
these passages [see 2.3.I.], this would imply that Plutarch was engaged in solving natural problems - and other kinds of problems just as well from a relatively early age up until his more settled years as a mature philosopher. Thus, he had a strong grasp of the genre of (natural) problems by the time he started writing Quaestiones convivales (which he did at the behest of Sossius Senecio, cf. Quaest. conv. 6I2E: $\omega_{i}^{\prime} \theta \eta \varsigma \tau \varepsilon \delta \varepsilon \tilde{\nu} \dot{\eta} \mu \tilde{\alpha} \varsigma \kappa \tau \lambda$.). So he probably already had some material on hand, and had probably already composed some or most parts of Quaestiones naturales by that time.

In conclusion, if it is true that Plutarch worked on his collection of Quaestiones naturales during several stadia of his life, there may very well have been an increase and overlap in productivity in the period that he composed Quaestiones convivales, hence their mutual influence. This is no reason, however, to restrict the chronology to that period only (nor to take Quaestiones naturales as a set of preparatory drafts for the composition of Quaestiones convivales [see 2.3.2.]). If we bear in mind Harrison's theory of intermittent composition, it is not unlikely that Plutarch's Quaestiones naturales (and his other collections of quaestiones just as well) were perhaps a 'life's work' in a chronological sense, that is, a lifelong project, representative of his relentless interest in the natural world around him. In that case, it is only likely that Plutarch sporadically made additions and adjustments to the collection after reading something noteworthy or after a discussion with his colleagues. The bottom line is that there are no certainties about the exact date and chronology of Quaestiones naturales, but everything seems to indicate that Plutarch started discussing, and presumably also composing, natural problems from a relatively early age onwards up to his more settled years as a mature philosopher.

What we learn from this, is that we cannot effectively vindicate the value of Plutarch's Quaestiones naturales as an ancient scientific product on the mere and most uncertain basis of the text's chronology. After all, it may still seem to serve a juvenile, pseudo-scientific, if not unscientific purpose. Let us, therefore, return to our initial problem.

is the night more sonorous than the day?') should probably be dated later, supposedly in $8 \mathrm{I} \mathrm{AD}$, because at that occasion Ammonius participates in the discussion with his (presumably) adult son (cf. S.-T. Teodorsson, I996, p. I8I). The difference in date is not necessarily complicated by the fact that Plutarch notes that Ammonius is in office as Athenian $\sigma \tau p \alpha \tau \eta \gamma$ ó both in Quaest. conv. $720 \mathrm{C}$ (Book eight, talk three) and in Quaest. conv. 736D (Book nine), because Ammonius held this office three times throughout his life. To complete the list: Ammonius is also an interlocutor in De defectu oraculorum (which Jones dates “in the 70's or early 80's"), and he is also mentioned in De ad. et am. $70 \mathrm{OE}$ and Them. 32, 6. For further reading on Ammonius, see K. Ziegler, I95I, cols. 65I-653, P. Donini, I986b and J. Opsomer, 2009 (esp. his conclusion at p. I77 for Ammonius' interest in Peripatetic science). 


\section{The value of Plutarch's natural problems}

If introductory companions to Plutarch's life and work or to ancient Greek literature and science more generally do not simply gloss over the Chaeronean's natural scientific achievements, they are not always very constructive in their value judgements ${ }^{27}$. The general approach of such studies is often underpinned by a certain feeling of astonishment that an author who is mainly known as a biographer and a moralist ventured to take a few humble steps in the field of natural science. Especially the humble character of Plutarch's science is underlined, in such cases, by depicting it as an often absurd, if not completely insignificant specimen of ancient thinking, or at least as the work of an amateur: that is, a trivial pursuit of inferior knowledge.

If a cursory light is shed on Quaestiones naturales (the work is mostly ignored, though), this often results in discrediting its scientific appeal. The collection's content is depicted as obscure, trivial, and only marginally scientific at best. This view is typical especially of $19^{\text {th }}$ and early $20^{\text {th }}$ century scholarship (but traces can still be found in more recent literature $)^{28}$.

${ }^{27}$ R.H. Barrow, 1967 , p. II7, for instance, notes in passing that " $[t]$ here are scientific works like the Natural Questions, or On the face on the moon. [...] But after making acquaintance with some of the better dialogues or essays a reader must not expect too much from some of those that remain unnoticed here. [...] They all contain much of interest, but Plutarch should not be judged by them." Neither Quaestiones naturales nor Quaestiones convivales are mentioned among Plutarch's natural philosophical writings by G.E. Karamanolis, 20I0. Moreover, A. and M. Croiset, I899, p. 5II (with n. I) seem to underestimate the general literary value of several of Plutarch's scientific writings: "Mais ces traités [sc. écrits relatifs aux sciences naturelles] n' ont pas un rapport assez direct à l'histoire littéraire, pour qu'il soit à propos de les étudier ici."

${ }^{28}$ Similarly, regarding the scientific value of the natural problems in Quaestiones convivales, see, e.g., R. Flacelière, J. Irigoin, J. Sirinelli and A. Philippon, 1987, p. lxxxiii: "Il faut reconnaître que beaucoup de ces questions nous paraissent aujourd' hui futiles, quelquefois absurdes, et que les explications proposées sont souvent peu convaincantes. [...] La curiosité de Plutarque, extraordinairement vaste, avait un goût marqué pour l'insolite et le paradoxal, et les arguments d'Aristote, qu'il cite si fréquemment, peuvent aujourd' hui faire sourire. Quandoque bonus dormitat ... Plutarchus." Regarding De facie and Quaestiones naturales, G. Guidorizzi, 2000, p. 559 speaks (without further specification) of Plutarch's "interesse [...] in un certo senso 'amatoriale' [...] per la scienza" (for Plutarch's ostensible dilettantism in Quaestiones naturales, see also V. Ramón Palerm, 2005, p. 398). According to P. Levi, 1985, p. 477, "[i]t would be a mistake to value Plutarch only for his Questions and Table Talks and his infinite fund of gossip." Cf. also p. 479: "Among the stranger themes that attracted Plutarch now and then - relics, I suppose, of sophistic playfulness about science - the Man in the moon [sic] (De Facie in Orbe Lunae) gives the most pleasure." A.M. Battegazzore, I992, p. 32 even connects the lack of specialisation in Plutarch's science with his 'humanism' (cf. also M. Vamvouri Ruffy, 20I2, p. 75). 
Croiset, for instance, resentfully considered the collection "un ouvrage sans valeur" 29 , which aggravates Doehner's label of "quisquilias"30, trifles, unworthy of Plutarch's authorship [see I.2.I.]. Typical in this regard is also Huit's remark:

"On éprouve quelque surprise à voir nommer dans une étude sur la philosophie de la nature le célèbre historien de Chéronée, plus connu évidemment comme biographe que comme physicien. Mais ouvrons celui de ses ouvrages qui porte le titre de Causes naturelles. Il contient la réponse (en général, il faut 1'avouer, aussi peu scientifique que possible) à trente-neuf questions, les unes assez curieuses [...] les autres singulières $[\ldots]$ d' autres enfin absurdes $[\ldots] .{ }^{\prime \prime} 31$

To claim that it really was Plutarch's goal to be as unscientific as possible in this "compilation des plus médiocres" and that its bizarre content is necessarily an indication of its lack of proper science is not the most unbiased position to take. To give another example, Emerson also underlines the curious character, rather than scientific merit, of Plutarch's natural problems:

"Except as historical curiosities, little can be said in behalf of the scientific value of the Opinions of the Philosophers, the Questions and the Symposiacs. They are, for the most part, very crude opinions; many of them so puerile that one would believe that Plutarch in his haste adopted the notes of his younger auditors, some of them jocosely misreporting the dogma of the professor, who laid them aside as memoranda for future revision, which he never gave, and they were posthumously published." 32

In what follows, Emerson adds - on the positive side - that there are some occasional "hints of superior science". These are "statements that are predictions of facts established in modern science" that can be culled (to use his wording) from Plutarch's texts (he mentions " $[\mathrm{t}]$ he explanation of the rainbow, of the floods of the Nile, and of the remora"), but in general, Plutarch's "Natural History is that of a lover and poet, and not

${ }^{29}$ A. and M. Croiset, I899, p. 5II, n. I.

${ }^{30}$ T. Doehner, I858, p. I4.

${ }^{31}$ C. Huit, I90I, pp. 479-480 (my italics). One may find it odd, moreover, that Huit considers De E 386E (regarding the Delian problem) an actual introduction to Quaestiones naturales.

32 R.W. Emerson, I89I, pp. 309-310 (part of the account also quoted by F. Klotz and K. Oikonomopoulou, 20II, p. 3I). For a more recent evaluation of Quaestiones convivales as treating "questioni minime e marginali", see A.M. Scarcella, I998, p. I33. 
of a physicist". The message is clear: Plutarch's natural problems are strange and not all that valuable in themselves, even if they contain some exceptional glints of scientific ingenuity. These exceptional glints are valuable in light of certain achievements in modern science, which they are even believed to predict, but the rest remains obscure and should be bracketed, if only to save the author's reputation. There are good reasons to discard the underlying logic of this ambiguous compliment.

Most glaringly, It goes without saying, that modern scientists are no longer concerned with the problems raised in Quaestiones naturales, or that they would at least frown at Plutarch's solutions. Take, for example, Q.N. Io, where Plutarch deals with the usefulness of adding salt (seawater) or baked gypsum to wine. He gives two alternative explanations: I) the heat of these substances is an aid against the chilling of the wine, and 2) their earthy constituents help against unpleasant odours, putrefaction, or turbidity in the wine. A modern explanation of the chemical reactions that occur in this process is provided by Sandbach in his commentary to the passage:

"Sea-water is perhaps no longer used in Greek wine-making. It would slightly increase acidity, since chlorine ions, produced by hydrolysis of sodium chloride, decrease the $\mathrm{pH}$ value. This increased acidity might improve the wine by inhibiting the growth of micro-organisms that cause cloudiness and instability. The use of gypsum, baked or unbaked, which is still practiced in some places, has the same good effect by a different means: added to the unfermented juice, the gypsum (calcium sulphate, hydrated when unbaked) reacts with potassium hydrogen tartrate contained in the juice and stalks to produce calcium tartrate, potassium sulphate, and tartaric acid: the last, being soluble in alcohol, is not precipitated (unlike the insoluble tartrate), but remains in the wine and increases its acidity. Calcium sulphate also has clarifying properties, since it causes colloidal suspended matter to settle out. Plutarch therefore correctly states the effects of adding sea-water and gypsum in wine-making, although he had no means of knowing how they are produced." 33

Presumably, Sandbach had the best of intentions by providing such information, but the conclusion he draws is rather partial. Of course, Plutarch did not know, or more precisely, "had no means of knowing" these effects the way modern scientists do. Today sulphites are added to the wine, because we know, so to say, that they eliminate unwanted bacteria and yeasts in the wine, and that they slow down the oxidation process, thus extending the wine's shelf life and increasing its tolerance

${ }^{33}$ F.H. Sandbach, 1965, pp. I74-I75, n. a (my italics). 
for changing temperatures. But the very existence of bacteria was unknown in Antiquity, and Plutarch did not have Mendeleev's periodic table at his disposal to explain such chemical reactions in, what for Sandbach would probably be, a more accurate way. Nor was he privy to an outlook of the physical world as a man like Lavoisier or, for that matter, any radical atomist was - Plato's geometric atomism not included.

The same conclusion can be drawn for Q.N. 4, where Plutarch examines why rainwater that is accompanied by thunder and lightning is said to be more fertilising for the growth of seeds. This is considered a proven fact today, but, for obvious reasons, no explanation in Plutarch's tripartite aetiology comes close to a modern chemical explanation of this phenomenon. I am told that lightning electrifies moist air in the atmosphere so that nitric acid $\left(\mathrm{HNO}_{3}\right)$ is formed, which stimulates the growth of plants (it is used today primarily to manufacture fertilisers). The electric currents of lightning flashes trigger a reaction between atmospheric nitrogen dioxide $\left(\mathrm{NO}_{2}\right)$ in the presence of water vapour $\left(\mathrm{H}_{2} \mathrm{O}\right)$. Perhaps the following chemical equation can make things clearer: $3 \mathrm{NO}_{2}+\mathrm{H}_{2} \mathrm{O} \rightarrow$ $2 \mathrm{HNO}_{3}+\mathrm{NO}$. This is what Sandbach (and probably also many modern scientists with him) would consider to be the "true reason" 34 . Plutarch, however, explains this phenomenon by referring to I) the admixture of air and breath to the rain, 2) the rainwater's concocted nature and 3) the chilling effect of spring rains. Strictly speaking, these explanations must be false, then.

Several other such examples could be added, but this is not the right place to deal with each and every one of them. After all, one may probably doubt about the scientific character of many other natural phenomena that Plutarch tries to explain, but which are less likely to be considered proven fact today. What are we to make, for instance, of the natural phenomenon at issue in Q.N. 32, where Plutarch wonders why the palm tree alone among all trees rises against a weight imposed upon it? In what sense exactly does the palm rise against an imposed weight? Is it even plausible that this phenomenon really occurs in nature? Apparently, this last question - relating to matters of empirical verification - did not really matter for Plutarch to address the phenomenon in the same aetiological way as he has been doing all along. As we will see later on, he had good epistemological motives for doing so [see 4.I.I. and 4.3.2.]. Laying bare these methodological dynamics will make Plutarch's scientific project more comprehensible to the modern reader.

${ }^{34}$ F.H. Sandbach, I965, p. I6I, n. d: "The true reason is that rain of a thunderstorm contains nitric acid, formed by the passage of electric currents through the air in the presence of water: the nitrogen is a rapid stimulant of plant growth." Cf. also S.T. Teodorsson, I990a, p. 50. 
It still remains to be seen what we actually mean by 'science', then, and how the present study aims to contribute to its history. The fact that the majority of Plutarch's natural problems are, in many ways, obsolete, worn-out, and truly ancient, explains why they are generally abandoned by modern physicists today ${ }^{35}$. This does not imply, though, that they are $u n$-scientific in principle. After all, if these ancient beliefs are to be deemed unscientific myths, they are subject to scientific inquiry for much the same reasons as those which lead to scientific knowledge today ${ }^{36}$. If they are to be considered representative of genuine science, on the other hand, we see that ancient science contains a large amount of convictions that are, in many ways, incommensurable with today's perception of it ${ }^{37}$. How to resolve this tension?

35 One of the exceptions would be "die auch heute noch ungelöste Aporie von dem Verschwinden des Salzes beim Durchgang des Meerwassers durch die Pflanzen", as reported in Q.N. 5, 9I3C (H. Diels, I905, p. 3I2). Plutarch explains that the pores, on account of their narrowness, filter the earthy and large particles of the salt, but "diese Tatsache ist, wie die moderne Forschung festgestellt hat, in dieser allgemeinen Fassung irrig" (p. 3I4). Cf. also C.F. Schnitzer, I86o, p. 2709, n. I: "Daß zum Theil die Stellung der Fragen, noch mehr aber ihre Lösung dem jetzigen Stande der Wissenschaft nicht entspricht, wird der Leser begreiflich finden; indeß ist es, abgesehen von dem historischen Interesse das diese Mittheilungen aus der Physik der Alten haben, doch bemerkenswerth wie nahe manche der gegebenen oder versuchten Erklärungen an die richtige hinstreift."

36 More universal scientific features would include the fact that Plutarch's natural science originates from a genuine wonder for the 'natural spectacle' and pursues a serious and detailed physical explanation for specific natural phenomena. To this end, Plutarch employs a scientific procedure that takes into account the intellectual tradition but, at the same time, aims to advance traditional theories by looking for innovative viewpoints [see 4.2.]. He also employs a standardised set of scientific terminologies to describe the physical processes that occur in nature in a more or less uniform way, and provides explanations that receive the necessary circumspection and prudence from a logical and epistemological perspective [see 4.3.].

${ }^{37}$ In comparison to modern scientific practice, Plutarch's approach might seem to be too theoretical (there is no interest for personal observation or experimentation) and inexact (it estimates relative qualities rather than measuring absolute quantities). Modern science, by contrast, formulates its claims in terms of universal laws and preferably in a mathematical fashion. It underpins its claims with repeatable experimentation, has a strong link with technological application and often involves an 'unnatural' manipulation of nature itself (e.g., in laboratories). It also claims to hold to 'objectivity', and - most notably - it is generally considered the counterpart of any religiously inspired discourse that is based on any 'subjective' acceptance of dogma or certain belief systems. Plutarch, however, also incorporates mythological and poetical material into his physical aetiologies, and his general outlook on the world is based on a dualistic view on causality, according to which natural phenomena are subjugated to a higher, intelligible cause and divine principle [see 4.I.]. These features are clearly incommensurable with modern science. Cf. also D.C. Lindberg, I992, pp. I-2 and T. Barton, I994b, p. xii. 
Lack of appreciation of the scientific appeal of Plutarch's natural problems mainly arose - and, in many cases, continues to arise - from a basic unfamiliarity not only with the ancient scientific paradigm to which they adhere (viz. as furnished by Ps.-Aristotle's Problems and its causal model of scientific inquiry) and from an inferior understanding of Plutarch's more general natural philosophical project (viz. as inspired by Plato's Timaeus), but also, and often primarily so, from an unfounded belief in the teleological nature of the history of scientific thought. Such a bias, which is representative of more traditional studies in the history of science, is characterised by the acceptance of a progressive and evolutionary development of scientific knowledge, where it is assumed that scientific truth becomes gradually more unveiled over time. This model draws a linear, but inherently distorted, picture of the development of science that is principally unhistorical from the very outset. Only those ancient theories that were considered relevant for contemporary scientific research or were proven to be valid by modern scientists were included in the historical framework under the label of genuine science (as is the case in Emerson's notion of Plutarch's "predictions" above) ${ }^{38}$. This approach is obviously biased by modern prejudice, which sees the results attained by contemporary science as the culmination of ages of continuous research and scientific progress. In this approach, the category of preconceived scientific 'correctness' serves as a historical measure in the evaluation of any scientific theory, without acknowledging that the category in itself is not necessarily a universal or transcultural given (see further). The great ancient Greeks were, thus, presented as having made breath-taking and even 'miraculous' advances in the field of science, for which they should be held in honour, but in the long run their discoveries remain rather immature ${ }^{39}$.

In this regard, Barton speaks of a 'genetic history' of science, according to which the teleological approach entails some kind of a historical eugenics of scientific ideas, where their individuality in the succession of

${ }^{38}$ Exemplary is the remark in R. Flacelière, J. Irigoin, J. Sirinelli and A. Philippon, I987, p. lxxxi: "[I]1 faut bien avouer que les ouvrages ou les passages isolés où Plutarque traite de physique sont généralement décevants, sans doute parce que cette science a fait $[\ldots]$ de tels progrès que beaucoup de théories antiques [...] nous paraissent aujourd' hui irrémédiablement périmées."

${ }^{39}$ Cf., e.g., W.H.S. Jones, I93I, p. xxii: "The hypotheses of early Greek thought are mere guesses, brilliant guesses no doubt, but related to the facts of experience only in the most casual way." Cf. also, e.g., P. Raingeard, I935, p. viii: "Ensuite le De facie nous est un témoin précieux de l'état de la Science vers la fin du premier siècle. Si certaines ignorances nous font sourire [...], nous éprouvons par contre quelque stupeur à découvrir 1 'antiquité de theories relativement modernes à qui il ne manqua pour figurer plus tôt parmi les acquisitions de l' esprit humain que de triompher des opinions régnantes." 
particular world systems is neglected ${ }^{40}$. It goes without saying that such an approach was bound to remain restrictive, resulting in a fragmentation, decontextualisation and, eventually, isolation of specific scientific theories by stripping them from the underlying world view that gave birth to them in the first place (think of Emerson's culling of the "hints of superior science" from Plutarch's text). As an alternative to this historical model (that is commonly referred to as 'whiggish' history $)^{41}$, contemporary history of science takes a more relativistic and contextual stance ${ }^{42}$. Notably, in Antiquity there was no term for denoting what we today call 'natural science'

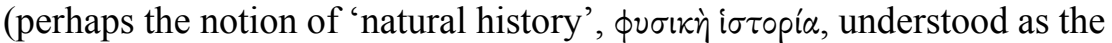
universal study of things natural, comes closest). The concept of $\dot{\varepsilon} \pi \iota \tau \dot{\eta} \mu \eta$, that is, the Latin scientia, primarily refers to 'scientific knowledge' (as opposed to $\delta \sigma^{\prime} \xi \alpha, \tau \dot{\varepsilon} \chi \nu \eta, \alpha v o l \alpha$ etc.), and it does not refer to the actual pragmatics behind scientific thinking as such (which is not per se an infallible practice, of course, science being a human enterprise $)^{43}$. In accordance with Plutarch's Platonism, for instance, no natural science could amount to the level of genuine 'science' in the philosophical-epistemic sense

${ }^{40}$ T. Barton, I994b, pp. xiv-Xvi. Barton's introduction in I994b, pp. $\mathrm{x}-\mathrm{x} x \mathrm{xiii}$ is relevant for the points made in this prologue. See also her more extensive (and at some points more abstract) introduction in I994a, pp. I-25.

${ }^{41}$ For further objections to the methods of 'whig' history, see A. Cunningham, I988, p. 387 and T. Barton, I994b, pp. xiv-xvi. The term was coined by H. Butterfield, I93I.

${ }^{42}$ E.g., for a description of Plutarch's natural science, as what stands in relation to ancient theories that explain natural phenomena, cf. J. Boulogne, 2008, p. 734 (who uses this description in demarcating the scientific digressions in the Vitae [see 2.I.3.]). Compare also, for instance, the definition of ancient science by P.J. van der Eijk, I997, p. 77, n. I: "As for 'scientific', this is used [...] in a non-sophisticated, non-evaluative manner to refer to any serious attempt at studying and understanding the nature of things (or part thereof), and - as far as texts are concerned - to any verbal expression intended to communicate about this with an audience [...]. Of course I do not wish to claim that the texts in question meet the criteria of what would count as 'scientific' in any modern sense of the word; and I am aware that there is no clear distinction between 'science' and 'philosophy' in Antiquity [...]." Similarly, regarding early Greek and Chinese scientific practices G.E.R. Lloyd, I999, p. 3 I4 (also partly in I996, p. 227) states that: "the history of early investigations in ancient civilizations is the history of the acquisition of a potential for cognitive development, not just with respect to what was believed, but also with regard to the ways of getting to believe it. Where Greece and China are concerned, to go no further afield, history shows both that the ways of acquiring that potential differed and indeed that the potential acquired did. Not that, in either case, the new potential corresponded closely to the expectations that might be generated by naive retrospection from the eventual emergence of modern science." In this sense, Plutarch's natural scientific programme (including his natural problems) certainly testifies to a certain scientific potential, how essentially different (or not) it may be from that of modern science.

${ }^{43}$ Cf. LSJ, s.v. ii, 2. 
of the word ${ }^{44}$, as it always involves a basic uncertainty towards sensible objects and the kind of knowledge that they yield [see 4.3.2.]. In this sense, scientia was not practiced but rather strived after in Antiquity.

As is well known, moreover, in Antiquity the study of natural phenomena was generally integrated in a wider philosophical programme, so that it was not considered an independent branch of research that was conducted for its own sake (as is the case rather with modern science). Also the ancient concept of 'physiology' ( interchangeably with 'natural history', cannot be separated from a wider natural philosophical framework, so that it is not an independent science. There is no denying to the fact that there is a certain convenience in speaking about 'physiology', 'natural history' or 'natural philosophy', for the simple fact that the ancient thinkers themselves would have given it that name, and this is basically what it is from an ancient perspective. This does not necessarily imply, however, that the term 'science' is wrong, or that ancient natural philosophy cannot be considered 'scientific'. In any case, the fact that ancient Greek and Roman thinkers did not, or could not, call their natural philosophy to be 'scientific' does not imply that it is, therefore, fundamentally unscientific.

For many centuries 'a science' in English denoted anything that was taught in the schools (such as grammar, logic, theology etc.). The word 'scientist' came into use not long before the middle of the nineteenth century, when the concept of 'science' began to take on its modern meaning. In this period, the 'science of natural philosophy' began to predominate the other 'sciences' and eventually acquired the monopoly of the term 'science'. The practitioners of that 'science' were called 'scientists' (and it is in this sense that 'science' existed before 'scientists'), but by that time, the 'science' itself had become very different from that of the ancients ${ }^{45}$. So, to reformulate the problem: why do we even care about 'science' in Plutarch's natural philosophical writings in the first place or in his Quaestiones naturales more specifically? Why not simply use his own terminology, thus avoiding the risk of any terminological ambiguity or of an anachronistic misconception of what Plutarch himself believed he was doing?

I believe that the connotations connected with such a reticence are undesirable. Not calling Plutarch's natural philosophy 'scientific' might raise the false impression I) that it is only of pseudo-scientific or parascientific significance ${ }^{46}$, or 2 ) that it has no scientific value at all, or

${ }^{44}$ Cf. G.E.R. Lloyd, I968, p. 92.

${ }^{45}$ I here rely (in part) on T. Barton, I994b, pp. xi-xii. Cf. also A. Cunningham, I988, p. 380 and R.W. Sharples, 2005, pp. I-3.

46 According to G. Nuzzo, I99I, p. 4IO (repeated in G. D'Ippolito and G. Nuzzo, 20I2, p. 58), Quaestiones naturales is nothing more than "un singolare 'zibaldone' di curiosità 
in any case less so in comparison to superior (viz. modern) scientific achievements. This is exactly what I intend to avoid. I) As regards the first point, Barton has correctly pointed out that "[p]seudoscience is a label that implies a deliberate falsehood on the part of its practitioners" ${ }^{47}$, but this does not apply to Plutarch, who himself took his natural philosophical programme seriously. In any case, there is no reason to assume that he did not (see n. 3 above). Even in the 'spoudogelastic' context of Plutarch's symposia we see that serious efforts are made to provide plausible explanations for natural problems. This is at least true within the conceptual scope of ancient physical theory. 2) Therefore, in light of the second point, it is only reasonable to evaluate Plutarch's natural problems according to the parameters of ancient rather than modern scientific thinking, even if there are certain points of convergence ${ }^{48}$. In the end, there are also obvious divergences between the two, meaning that it is best not to assess them in comparative terms (see nn. 36-37 above). It goes without saying, therefore, that when reference is made to ancient 'science' in the present study, this must be understood in light of Plutarch's theories and concepts about the natural world and those of his philosophical role models (unless otherwise suggested). As such, we accept that the distinction in terminology between actor's terms ('natural philosophy') and analytical terms ('natural science') is a matter of formality rather than semantics ${ }^{49}$.

pseudo- o parascientifiche, che non un' opera di impianto organico ed unitario, tanto che qualche studioso fu da ciò indotto a negarne la paternità plutarchea" (I will come back later to Plutarch's authorship of Quaestiones naturales [see I.2.I.]). The same label of pseudo-science was used by R. Flacelière, J. Irigoin, J. Sirinelli and A. Philippon, I987, p. Ixxxii and by R. Caballero Sanchez, I992, p. 9I. Z. Abramowiczówna, 1962, p. 82 speaks of the "halbwissenschaftliche Atmosphäre" in Quaestiones convivales.

${ }_{47}$ T. Barton, I994a, p. I5 (see also pp. I6-I7 on the inappropriate normativity of the concept of 'pseudo-science').

${ }^{48}$ E.g., according to A.M. Battegazzore, 1992, p. 48, Plutarch's attitude in scientific matters presupposes "un modello di ricerca vicino a quello di un 'sapiente rinascimentale' dilettante di tutto e di tutto curioso". However, linking Plutarch with a Renaissance model of science probably produces more contextual problems than it solves. See also L. Inglese, I996, p. I5I (regarding Battegazzore's remark): “Questo non può comportare, nel giudizio su Plutarco, l'adozione di parametri 'moderni' di scientificità della ricerca."

${ }^{49}$ There is much scholarly debate on this topic. A. Cunningham, 1988 prefers using the actor's terms (such as 'natural philosophy') over analytic terms and categories (such as 'science') in order to avoid the anti-historical fallacy of imposing present thinking upon the past (pp. 378-385). W.H. Stahl, I962, pp. 3-I4 also doubts the appropriateness of calling Roman science 'scientific' (or even 'Roman', for that matter). Some scholars would, indeed, prefer the actor's terminology (see also, e.g., T. Barton, I994b, pp. xiv, xxi, xxiii, n. I3), whereas others do not (see, e.g., G.E.R. Lloyd, 1983, pp. 210-2I7, who vindicates the appellation of 'science' for ancient Greek medicine and biology). Most 
Indeed, Plutarch's subordination of physics to prime philosophy is not an adequate reason to reject it as unscientific. This is significant if for no other reason than that there is a discussion among Plutarchists about the scientificity of the Chaeronean's natural philosophical works, although it is not very widespread, let alone profound. The ill-considered $I 9^{\text {th }}$ and early $20^{\text {th }}$ century claims quoted above are clear examples of this. A more recent account is found in Donini's 1994 contribution on Plutarch and the Platonic renaissance in Lo spazio letterario della Grecia antica, where the author - in a footnote - tends to adhere to this traditional view ${ }^{50}$. Donini concludes: “A mio giudizio, non c'è nessuna opera di Plutarco che meriti di essere definita semplicemente "scientifica'." ${ }^{51}$ This is intended as a frontal attack on Ziegler's designation of the category of Plutarch's "scritti di fisica e di scienza naturale" ("naturwissenschaftliche Schriften" [see I.I.I.]), but Donini in his protest employs the concept of 'science' mainly - and problematically so - from a modern perspective (in this regard, his approach does not seem to be all that different from Ziegler's). Donini demarcates Plutarch's 'science' as the attempt to explain natural phenomena solely in terms of natural causes. In my opinion, he thus too strictly divorces the Chaeronean's physical theory from its philosophical implications. It is absolutely true that Plutarch distinguishes between the physical causes of natural phenomena and their higher, divine motivation, but the distinction is not strict, since he subordinates the former category to the latter [see 4.I.2.]. As such, both categories are not, and should not be, disconnected. As Donini himself has shown in his pioneering work on Plutarch's view on causality, both modes of explanation actually go hand in hand (viz. physical and meta-physical). In the account at hand, then, Donini's restriction of "scienza" to natural causality alone might be problematic - in opposition to other, more nuanced accounts of his on the topic (see n. 54 below). In what follows, Donini successively sheds his

notably, according to E. Grant, 2007, p. 319, the difference between actor's terms and analytic terms is superficial, because actor's terms are "mere names, or labels". However, the application of "mere" is perhaps somewhat too dismissive (as E. Lao argues in her 20Io BMCR review of Grant's work). It should be noted, moreover, that a broadening of the semantic field of 'science' may risk the concept becoming meaningless, because it enables the modern historian to identify the category of 'science', or whatever it was called in the past, as always having existed. The correct procedure is probably somewhere in between, viz. in applying the concept of 'science' in historical contexts only with the necessary conceptual circumspection and qualifications (which is my aim in this study).

${ }_{50}$ P. Donini, I994a, p. 48 , n. 32 (the quotations that follow are drawn from this passage).

51 Compare the use of inverted comma's by I. Gallo, I998, p. 3527 (= I999, p. 64) in his description of Quaestiones naturales as 'une raccolta di quesiti 'scientifici' con le relative risposte". 
light on Plutarch's De facie, De primo frigido and Quaestiones naturales. As to the De facie, first of all, he seems to overdo things when he writes that the work:

"contiene certamente molta buona scienza astronomica e d'altro genere, ma non è affatto un trattato scientifico: discute un importante problema filosofico, al quale è totalmente subordinato il contenuto che i moderni [!] chiamano scientifico."

Further on, however, Donini is more at ease to underline the conceptual unity of Defacie, pointing out that the closing myth:

"vuolo ridurre, non distruggere il credito delle scienze; è lí precisamente a dirci che il discorso delle scienze fisiche e matematiche, se non è teologicamente fondato, sarà sempre inadeguato." 52

When Donini, in what follows, claims that Plutarch in De primo frigido which he interprets "a rovescio dalla maggior parte dei moderni" - actually discusses an epistemological problem, he restricts the entire treatise to the $\dot{\varepsilon} \pi \circ \chi \eta$ statement in the very last paragraph (in combination with the eighth [see 4.3.2.I.]). This seems to entirely overlook Plutarch's introductory discussion about whether heat and cold are principles of their own and also the lengthy doxography that follows on the principle of cold ${ }^{53}$. However, I see no reason to assume that both types of discourse (viz. physical and epistemological) were seen as completely distinct by Plutarch himself.

With respect to Quaestiones naturales, lastly, Donini remains pensive in making his judgements:

"A conti fatti, ho l'impressione che resti disponibile per questa classe [sc. scritti di fisica e di scienza naturale] forse (forse) la sola raccolta delle Cause naturali, che potrebbe essere soltanto un insieme di appunti da elaborare in altre opere di tutt'altro genere."

${ }^{52}$ P. Donini, I994a, p. 56. Cf. also Donini's conclusion in 1984, p. 374: “[M]i chiedo però se abbiamo con ciò stesso il diritto di dire che l'historia di Plutarco non era autentica curiosità scientifica. Era, quanto meno, la base adeguata per una scienza come quella allora possibile, così solidale con quel platonismo, con quei demoni, con quell'irrazionalità." Cf. also id., I988 and 20II, p. 2I, n. 26.

${ }^{53}$ Other scholars have interpreted the ancient scientific character of De primo frigido in terms of its allegedly playful and theoretical approach. See O. Longo, 1992, p. 229: 'Lusus di letterato? Vera e propria discussione scientifica? Un po' dell'uno e un po' dell'altro, e in ogni caso una fisica fatta a tavolino e sui libri, assai più che mettendo il naso fuori dalla finestra." 
Donini's hesitation is based on a conviction that the preceding objections (regarding the dualistic and epistemological aspects of Plutarch's science) do not, at first, seem to apply to this collection. However, as already noted at the beginning of the prologue, one of the goals of this study will be to show that the reverse is in fact true, by demonstrating that Quaestiones naturales is fundamentally in line, despite its main focus on physical causality, with Plutarch's general scientific project, including its dualistic and epistemological backdrop [see 4.I.-3. $]^{54}$.

Another point that needs to be stressed in evaluating the scientificitiy of Plutarch natural philosophical writings is the contingent nature of Plutarch's truth claims. For instance, regarding the claim in Quaest. conv. $64 \mathrm{IC}$ that there is empirical proof of the fact that a magnet rubbed with garlic loses its attractive powers, Lehoux rightly points out that:

"Any given way of framing questions of truth and falsity about the natural world is bound up in networks of relations and requires a background of standards, concepts, methods, tools, and objects against which truth and falsity can be judged." 55

As such, the ultimate scientific truth - whatever this may be - will only be a circumstantial aspect for properly evaluating the scientific character of Plutarch's theories about the natural world ${ }^{56}$. This boils down to the idea that science is - at least in a historical sense - not all that concerned with 'truth' per se.

${ }^{54}$ Donini's judgement on the scientific character of Plutarch's "scritti di fisica e di scienza naturale" (c.q. De facie) is more nuanced in 1992, pp. I06-107: "Ma, dato che noi moderni siamo abituati a pensare che sia 'scientifica' quella spiegazione che del fenomeno in discussione dice veramente tutto l'essenziale e ne chiarisce i fondamenti ultimi, è evidente che parlando della normalità dei casi di cui si occupava Plutarco non dovremmo definire 'scientifica' altra spiegazione che quella che dica entrambi gli ordini delle cause e prima di tutte, anzi, quelle 'divine': dove infatti siano coinvolte entrambi le classi, la spiegazione che si limitasse a far rilevare le sole cause materiali e strumentali sarebbe sì ancora 'fisica', ma non certamente 'scientifica'. Volendo proprio usare questo termine in riferimento al nostro autore, bisognerà adattarsi ad accettare che sia 'scientifico' l'argomento che è anche e prima di tutto teologico." Donini draws a similar conclusion for De primo frigido in 1986a, p. 2II: "il problema del de primo frigido insomma non è esclusivamente fisico, ma in ultima istanza rinvia agli agenti metafisici e divini dell'ordinamento del cosmo". See also J. Opsomer, I998, p. 2 I4.

55 D. Lehoux, 2007, p. 448, see also 2003, pp. 339-340 (cf. also, e.g., T. Barton, I994a, p. 4). For further discussion of Lehoux' account, see M. Meeusen, 20I4, 337-338.

${ }_{56}$ Contrast the concern of P. Donini, I988, pp. I26-I27 regarding De facie: "Physics, astronomy, and geometrical optics are here used to explain the nature of the moon and its spots, and the explanation proposed is the closest to scientific truth that we know from Antiquity." 
In order to clarify this, an analogy can be drawn with the revolutionary finds physicists working at CERN near Geneva, home of the Large Hadron Collider, have done in the last years. Besides from further specifying our knowledge about the basic structure of our universe (think of the discovery of the Higgs-boson or 'God particle'), these scientists have recently found clues that there may be a deeper kind of physics, a dark sector that we have not been able to reach yet, and that may even be unreachable to us. It is this deeper kind of physics that, so it is often metaphorically described, shines through the cracks of the Standard Model, which up to now served - and continues to serve - as the basic fundament of particle physics. It is not so much that the Standard Model would be wrong, of course, but one may still wonder how scientific it really is, considering the fundamental and thus far unanswered problems these discoveries raise about the existence of the universe (not to mention the potential existence of other universes). What is relevant for the history of science, then, is not so much whether any truth comes out of smashing atoms together, but what kind of truth people make of it, how it is reached, and why such research is conducted to begin with. What the study at hand aims to do, then, is to put the kind of natural problems Plutarch sought to explain in a contextual perspective, to find out what ultimate goals he had in mind in doing so, and which conceptual limits he faced. To this end, we can learn a great deal from the kind of answers he provides and from the general methodology and theoretical-conceptual framework that he employs.

Apart from revealing these intellectual mechanisms that underlie a person's or a society's world view ${ }^{57}$, contemporary studies of ancient scientific literature often also bring into consideration how specific socio-cultural factors play along in the authorisation, validation and dissemination of scientific knowledge in particular societal contexts ${ }^{58}$. A study of these features is relevant to us, as it provides a valuable perspective on how the natural world was perceived of in Antiquity and how this view became entrenched in a real-life community and

${ }^{57}$ For the concept of 'world view' as a discursive category in ancient scientific texts, cf. H. Flashar, 1962 (e.g., pp. 3I8 and 33I), who uses its German equivalent (Weltbild) to designate the general explanatory scheme that can be deduced from the problems and explanations recorded in Ps.-Aristotle's Problems. Cf. also, e.g., the title in D. Lehoux, 2012.

58 This socio-cultural contextualisation is, in fact, very central to contemporary studies in the field of the history of science: cf., e.g., T.E. Rihll, I999, p. iv. Cf. also J.T. Vallance, I990, pp. 716-717: "First, it is now generally agreed that we should not - indeed, cannot separate ancient science from its philosophical background. Ethical, metaphysical, and scientific motivations must be understood side by side. Second, some idea of the social and cultural context in which scientific ideas developed is now widely seen as essential to any generally useful appreciation." 
civilisation - the Greco-Roman civilisation, which had a seminal influence on our own. This has reflective value for our contemporary outlook on the natural world and for the place that is allotted to it in our own modern society, where science has become omnipresent.

Of course, world views can shift over time, and can be different from person to person or from society to society. Therefore, it seems useful to study scientific concepts and theories on their own terms and in view of the social and intellectual contexts from which they originate. This is especially to be understood as a caveat to the teleological approach as described above (i.e. the 'genetic history'). It does not imply that a diachronic approach should be avoided at all costs. This approach has its use, for instance, when examining the scientific or philosophical importance of a person's outlook on the world in view of a scientific or philosophical historiography ${ }^{59}$. From this perspective, the value of Plutarch's Quaestiones naturales for the history of science is reflected in the work's reception and transmission by later authors and can be examined by studying how they picked it up and adopted it to suit their specific authorial needs. In what follows, I will not discuss this in full detail but will only highlight a number of cases that were of importance for the text's later history.

The II $^{\text {th }}$ century Byzantine polymath and 'Chief of Philosophers' Michael Psellus is especially worth mentioning here, as he incorporated and adapted several of Plutarch's natural problems - both from Quaestiones naturales and convivales - in his encyclopaedic De omnifaria doctrina (two additional chapters, viz. Q.N. 40-4I, derive from this work: see the commentary ad loc.). In global, Psellus' work nicely illustrates how Pagan knowledge, thus including Plutarch's natural problems, was hesitantly accepted by the author and which intellectual restrictions were imposed on it by the religious (c.q. Christian-Orthodox) establishment of his time. Notably, Psellus did not lable his excerpts as being drawn from Plutarch (thus, perhaps, implicitly rejecting the Chaeronean's scientific authority?). On the contrary, it seems that Psellus, through Plutarch's lens, looked at, and approved of, Aristotle's scientific authority by quoting the Problems via Plutarch. The merit of Psellus' De omnifaria doctrina (or at least the work's first redaction) lies in its attempt to create a genuine Christian cosmology, which is firmly based on ancient authority. Importantly, Psellus addressed his work to the Byzantine emperor, God's regent on earth. The relationship between such encyclopaedic knowledge and

59 E.g., for the influence of Plutarch's De facie on Kepler, see H. Görgemanns, I970, pp. I57-I6I. Kepler found the text so important that he edited it with his own Latin translation and astronomical commentary. In what follows, I repeat some of the insights gained in previous publications on the reception of Plutarch's natural problems (for a short overview, see M. Meeusen, forthcoming b). 
imperial power is not of disinterest, as it provides a better understanding of what highly placed Byzantine figures were expected to know, or, at the very least, to have read ${ }^{60}$.

A similar case of religious adoption of Plutarch's natural problems is found in the Diálogos Familiares de la Agricultura Cristiana (I589) by the Spanish humanist and Jesuit Juan de Pineda. In this work, the author relies heavily on Plutarch's authority (amongst that of other Pagan authors) and, at points, incorporates several passages from Quaestiones naturales in his Christian discourse. As Ramón Palerm has shown, the author of this work "through an ongoing confrontation of the Christian and Pagan worlds, struggles to win for the Christian cause the content of the ancient traditions, to which he gives an obvious moral sense in a didactic-doctrinal tone" ${ }^{1}$. As such, the cases of Psellus and de Pineda show how later, Christian authors - both in the Orthodox East and in the Reforming West (de Pineda speaks with little respect of the Spanish Inquisition) - used Plutarch's natural problems as a basis for their own inquiries, not so much by addressing them anew, but by exploiting them as a Fundgrube of exotic materials to be assimilated into the context of a new (c.q. Christian) world system.

The situation is different in other cases, though. The scholarly interest in Plutarch's Quaestiones naturales in the Humanist era is reflected mainly in the production of new editions and Latin translations (mostly in collective volumes with other works from the corpus Plutarcheum). The I542 Latin translation by the Dutch Protestant scholar, professor and doctor Gybertus Longolius deserves specific mention here. In this Latin version, the Aldine problems (Q.N. I-3I) are followed by eight additional problems (Q.N. 32-39) that were extracted, so Longolius indicates in a marginal note, from a Milanese manuscript. Unfortunately, this manuscript has been lost ever since, and the Greek text is still missing today. Considering the numerous parallels in Plutarch's other works and the same general style and method of explanation, it is beyond doubt that these additional problems are authentic (see the commentary ad loc. $)^{62}$.

Another Latin translation of the Aldine problems was produced by Pedro Juan Núñez in I554. Interestingly, this translation served as an appendix to Theodor Gaza's version of Ps.-Aristotle's and Ps.-Alexander's

${ }^{60}$ For further discussion of the reception of Plutarch's natural problems in Psellus' De omnifaria doctrina, see M. Meeusen, 2012b (Quaestiones naturales) and forthcoming c (Quaestiones convivales).

${ }^{61}$ V. Ramón Palerm, 20II, p. 62I (see pp. 629-632 for an analysis of the Quaestiones naturales material).

${ }^{62}$ For further detail on Longolius' translation, see A. Morales Ortiz, 1999 and M. Meeusen, forthcoming a. See also R. Flacelière, J. Irigoin, J. Sirinelli and A. Philippon, I987, p. 283. 
Problems $^{63}$. This is important, as it seems to imply that Plutarch was seen as continuous with a unified and long-lasting scientific tradition that was initiated by Aristotle and his Peripatetic successors (see also Psellus' case above). The practice of solving Aristotelian natural problems lasted well until the Middle Ages and the Renaissance, when new collections of problems made their appearance and older ones were constantly copied, translated and commented upon [see I.I.3., n. 78]. As such, Plutarch's Quaestiones naturales were seen as a genuine contribution to the Aristotelian study and understanding of natural phenomena and to the development of a scientific method for approaching them. One of the goals of this study will be to nuance this view, and to show that Plutarch's natural problems are not the product of the author's Aristotelian aspirations - despite the fact that history clearly suggests otherwise [see I.I.2. and 4.3.4.3.].

In conclusion, the study at hand takes inspiration from the plea often heard in recent scholarship to study ancient scientific texts impartial to considerations of quality or centrality. Rihll, for instance, has argued:

"The primary sources for any period consist not just of the wellknown and well-ploughed texts: there are a lot of grossly underutilized 'scientific' texts too, which cast a different and sometimes brilliant light on ancient society. This incidental information is also important to the historian of science, for the society in which the science was created shapes the science itself, and neither can be properly understood in isolation from the other." ${ }^{64}$

By taking these contextual facets into consideration, the study at hand can be seen as a contribution to broadening the traditional image of ancient science and, by implication, of the history of science in genera ${ }^{65}$. Even though we are dealing with a rather obscure, non-canonical source in the case of Quaestiones naturales, this should not complicate our efforts to

${ }^{63}$ The work was printed in 1554 in Valencia by Joan Mei from Flanders as Problematum Aristotelis sectiones duae de quadraginta. Problematum Alexandri Aphrodisiei libri duo Theodoro Gaza interprete ad haec Eruditissima problemata Plutarchi. Extant apud Borbonium bibliopolam. Valentiae, Typis Ioannis Mey, Flandri. (Raya) I554. See A. Morales Ortiz, 1998 and 2000, p. 90. For further detail on the Latin translations of Plutarch's Moralia more generally dating from the $13^{\text {th }}$ to the $16^{\text {th }}$ century, see F. Becchi, 2009.

${ }^{64}$ T.E. Rihll, I999, p. 7.

${ }^{65}$ I, thus, accept Rihll's challenge (I999, p. xii): "there is a role and a need for 'ordinary' historians in the study of the history of Greek science, which is a land of opportunity for adventurous scholars." 
pull it from the margins of the corpus Plutarcheum ${ }^{66}$. In this light, Van der Stockt has recently claimed that "it are precisely the more 'irrational' and 'absurd' beliefs and practices that are most fascinating" ${ }^{67}$. His plea for a profound study of Plutarch's Quaestiones naturales more in specific is worth quoting in full:

"[I]t may have become clear that Plutarch's Causes of natural phenomena is in dire need of an interpretation that does justice to its peculiar nature. Provided that this research is conducted with philological tact as well as through a contextualising approach, the results are likely to shed light on the worldview of Plutarch as well as on the practice of authentic ancient 'science'." 68

The phrase "philological tact", especially in conjunction with "a contextualising approach", is well-put from a methodological perspective but may require some further specification, which the following section will provide.

\section{Classical philology and the petrification of science}

Historians of ancient science generally hold that there was a rapid decline of scientific creativity after its 'Golden Age' ${ }^{69}$ in the Hellenistic era, an era when several scientific disciplines, such as medicine, biology, alchemy, mathematics, geography, astronomy and mechanics, flourished more than ever before or ever after (esp. the $3^{\text {rd }}$ and $2^{\text {nd }}$ centuries BC). The Imperial Era, by contrast, is presented as a period of consolidation and transmission of received knowledge. The Zeitgeist of this era finds its incarnation in the figure of Pliny the Elder, author of the encyclopaedic Naturalis historia. Traditional Plutarchists have not resisted this view of a scientific decline in Plutarch's days, yet some nuancing is in place, at least in Plutarch's case.

In light of the period in which Plutarch lived, someone like Sambursky favoured the idea of a "petrification of science" by arguing that:

"the first century A.D. marks the beginning of the work of compilers and interpreters which went on for more than four hundred years and

${ }^{66}$ This idea is inspired by the new historicist perspective that ascribes historical value to each historical product. For problems of quality and canon in Greek literature, see T. Whitmarsh, 2004, pp. 8--10.

${ }^{67} \mathrm{~L}$. Van der Stockt, 20II, p. 447. A similar conclusion was made regarding ancient paradoxes and puzzles by G.E.R. Lloyd, 2004, pp. 5-7.

${ }^{68}$ L. Van der Stockt, 20II, p. 450.

${ }^{69}$ For this designation, see, e.g., G. Sarton, I970 and S. Sambursky, I963, p. 204. 
which is the mirror wherein we see a large part of ancient Greek science." ${ }^{\prime 70}$

Regarding the natural problems discussed in Plutarch's Quaestiones convivales, Fuhrmann bade the reader, in a rather condescending fashion, to not be too hard on Plutarch, given that his time was afflicted with "un affaib-

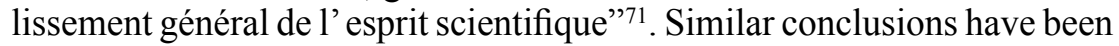

${ }^{70}$ S. Sambursky, I963, pp. 204 and 242. Cf. also the references in P. Culham, I992, p. 197, n. 30 more generally. Regarding the Greeks of the $2^{\text {nd }}$ century AD, B.A. Van Groningen, 1965, p. 56 draws the following conclusion (with what seems to be an unhealthy sense for exaggeration): "There is no real activity; nobody sets out on an exploration; everybody walks on trodden paths. Why? Because they themselves are weak, unable to display psychic energy. They are tired; they sit down comfortably in well-known surroundings, and they are waiting, waiting for something they will not find, because it is not really looked for. [...] The Greek literature of the second century is the work of a powerless community, which, on the other hand, overstrains its faculties in unhealthy exaggerations. It is a neglected one in a neglected century, and, generally speaking, it deserves this neglect." The view that all post-Classical societies are of secondary importance, non-original and non-authentic is generally abandoned in contemporary scholarship (see, e.g., T. Whitmarsh, 200I, p. 28).

${ }^{71}$ F. Fuhrmann, 1972, p. xxiii. Regarding Plutarch's method of solving natural problems, more in particular, Fuhrmann draws the following conclusion (p. xxiv): "Pour les questions d'ordre scientifique, il est particulièrement grave de ne pas discuter les problèmes dans leur fond. Or c' est ce qui se passe ici. Au lieu de chercher les causes véritables des phénomènes, Plutarque se contente en général de la vraisemblance, en citant plusieurs théories qui s'y rapportent, ou en rappelant ce que divers auteurs en ont dit. Les différentes opinions se succèdent ainsi sans aucune analyse et le plus souvent sans solution, comme si ceux qui sont chargés de les défendre s' amusaient avec elles. [...] Quand par hasard Plutarque veut faire preuve d'esprit critique, il n'y réussit guère". This view is accepted by E. Teixeira, I992, p. 22I, who concludes, however, that: "Par l' intermédiaire de renseignements scientifiques, entre autres, Plutarque a, à n' en point douter, le mérite de contribuer pour une part important à mieux nous faire connaître la pensée et la culture grecques." In a similar fashion, R.H. Barrow, I967, p. 22 claimed that "[t] he importance of the Table Talks rests not on their subject-matter, which [...] is often trivial, but upon the picture which they give of the society in which Plutarch moved, the texture of social life, and the ease and frequency of movement of people from place to place". For the inferior scientific Zeitgeist of Plutarch's time, see also K. Ziegler, I95I, col. 889: "Nicht verhehlen darf man sich, daß die Behandlung, besonders der naturwissenschaftlichen Probleme, oft recht oberflächlich und spielerisch ist; ein Vorwurf, der freilich nicht unserm P. zur Last fällt, sondern die seiner Zeit eigentümliche Erschlaffung des ernsthaften wissenschaftlichen Geistes kennzeichnet.” Cf. also R. Flacelière, J. Irigoin, J. Sirinelli and A. Philippon, I987, p. lxxxiii (quoted n. 28). For opposition against the idea of a contemporary "déclin du rationalisme", see, however, ibid., p. lxxi. See also J. König, 2007, p. 5I, who criticises Führmann's remark as "an assumption which exemplifies a common failure to understand the rhetorical idiom of so much ancient scientific writing". It was only since relatively 
reached for Pliny the Elder's Naturalis historia ${ }^{72}$. Yet, as Stahl rightly nuances, "Plutarch demonstrates greater aptitude for assimilating and reporting scientific information than Pliny, but he is no less credulous and uncritical of quaint and incongruous data." ${ }^{\prime 3}$ In light of Plutarch's allegedly derivative and compilatory authorship, Jeanneret even claimed that the Chaeronean (again in his Quaestiones convivales) could be categorised as an author who, just like Athenaeus or Macrobius, aimed for a variegated, though bloodless accumulation of knowledge, without any sense of critical evaluation. The lack of scientific creativity and ingenuity thus becomes connected with a faceless authorship that is characterised by the absence of any serious intellectual talent and ambition for personal creativity:

"What is often said of Plutarch is also true of the others: they are basically eclectic. They neither judge nor criticize, but rather put things on show [...]. The author melts into an anonymous collector and mediator; he lets the books, of which he is a mere interpreter, speak for themselves." 74

The idea that Plutarch should be ranked among other late compilers and interpreters risks grossly oversimplifying the real accomplishments of his work. Throughout his scientific writings, to go no further afield, Plutarch unambiguously aims to formulate inventive and innovative explanations for the phenomena he studies [see 4.2.2.2.]. In fact, he often explicitly marks his own, personal views (e.g., via his literary alter ego in Quaestiones convivales), thus emphasising that he does not blindly rely on received knowledge. Of course, the aspect of Plutarch's scientific innovativeness should be placed within the ancient scientific paradigm of his time: Plutarch was no scientific revolutionary. He did not leave the confines of the 'normal science' of his day. But even so, this did not stop him from contriving explanations that were certainly original within the scientific paradigm at that time ${ }^{75}$.

recently that scholars have started to recognise and revalue the argumentative style of Quaestiones convivales. See, e.g., F. Frazier and J. Sirinelli, 1996, pp. I77-207, J. König, 2008, p. 88, n. II and the contributions in F. Klotz and K. Oikonomopoulou, $201 \mathrm{II}$.

${ }_{72}$ See V. Naas, 20II, pp. 6I, and esp. 66-67.

73 W.H. Stahl, 1962, p. I33.

${ }^{74}$ M. Jeanneret, I99I, p. I67. For the alleged facelessness of Plutarch's authorship, see also R.H. Barrow, 1967, p. I5: "he [Plutarch] was a tantalisingly modest man and he effaces everything personal from his narrative". The same passage from Jeanneret was quoted and criticised by J. König, 20II, p. I89 (cf. also $i d$. ., 2007, pp. 5I-52 and J.C. Relihan, I992, p. 218).

${ }^{75}$ Cf. R. Flacelière, J. Irigoin, J. Sirinelli and A. Philippon, I987, p. lv: "Pour les sciences physiques et biologiques, par exemple, encore qu' il émette parfois des opinions qui semblent bien lui être personnelles, il suit d' ordinaire Aristote et l'école péripatéti- 
Only since relatively recently, scholars have started to recognise that Plutarch's scientific project, and his science of natural problems more in specific, is not just an impersonal echolalia of past authorities. But even so, most of the existing scholarship remains restricted to matters of source criticism. Of course, traditional Quellenforschung has great value for properly understanding the composition of a text on the basis of its specific sources and, more broadly, of the tradition in which it is anchored (this will prove a particularly useful approach in the commentary), but it also has a number of interpretive deficits. By largely restricting its scope to the analysis of the sources of a text, such an approach tends to downplay, isolate, and eventually even exclude the author from his own text ${ }^{76}$. The author is, in fact, reduced - often in a highly speculative fashion - to the sources that he is claimed to rely on, while his personal adaptations of the tradition are generally ignored ${ }^{77}$. If there is any place left for the author's personal contributions, these are pushed to the margin of the text, if for no other reason than that scholars are embarrassed not to have found any matching Quellen for them ${ }^{78}$.

On the other hand, even if Plutarch clearly pursues argumentative creativity and originality in his scientific writings, traditional authorities still play an important role in his arguments. As such, his innovativeness is perhaps not as 'adventurous' as modern critics may have expected ${ }^{79}$.

cienne. [...] Mais il ne semble pas avoir fait progresser lui-même les connaissances scientifiques de son temps. Il fut un 'honnête homme' au sens du xviie siècle [cave: see n. 48], un véritable érudit, très informé et très éclairé. Il réalisa parfaitement en lui l'idéal

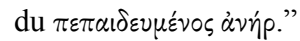

76 See the introduction "On the impoliteness of Quellenforschung" in L. Van der Stockt, 2004, pp. 33I-333. See also J. Mansfeld, I999, pp. I3-I6. For similar criticism of the presentation of Plutarch as "un simple compilateur, tout juste capable de recopier des œuvres antérieures en les démarquant”, see also R. Flacelière, J. Irigoin, J. Sirinelli and A. Philippon, I987, p. ccii (with further references). See also I. Gallo apud A.M. Battegazzore, I992, p. 37.

77 E.g., regarding the Quellenforschung tradition on Plutarch's writings on animal psychology, see S.T. Newmyer, 1992, p. 4I: "Scholars eager to detect the sources of Plutarch's arguments have paid relatively little attention to the points which he makes or to how he defends his positions." On Plutarch's adaptation of his source-material in the Vitae, cf. also C. Pelling, I980.

${ }^{78}$ See, e.g., K. Giesen, I90I, p. 448 (with the quote from F. Leo, I864). Such an approach would be sound if the text were simply a derivate of traditional sources, but things are obviously not always so simple.

79 See, e.g., R.H. Barrow, I967, p. 74: "It is not too much to say that Plutarch had at his command Hellenic and Hellenistic thought and literature. His mind was not adventurous; it did not use its accumulated knowledge as a springboard to make a leap; it may have lacked imagination." See also Barrow's strong words on p. 77: "Plutarch was a teacher, not a constructive thinker; he created no new system. Few teachers do; they may have 
Even still, to claim that his scientific programme is representative of, what Sambursky called, the "petrification of science in the period of commentators and scholastics" 80 is a one-dimensional presentation of the facts, as this study will show [see 4.2.2.2.].

An alternative way to examine how Plutarch deals with received knowledge and how he constructs his own scientific authority is by studying his 'authorial voice' - understood as an analytical concept that has recently been introduced by scholars of ancient scientific and technical writing ${ }^{81}$. This 'authorial voice' serves as an important discursive category in the text that resonates, for instance, in the explicit evaluation of the theories of predecessors but is also situated at a structural level, viz. in the development and ranking of the different arguments, and can also be seen in his method of quoting and adapting the available source material ${ }^{82}$. The concept of the author's voice proves to be a worthy analytical tool in examining the discursive construction (and deconstruction) of scientific authority and, more particularly, in detecting the author's scientific creativity that manifests itself in this process. The question of scientific authority is highly relevant in examining Plutarch's

at the back of their minds guiding principles, but they do not readily build theoretical constructions but rather make practical application. They are bound to be opportunists, availing themselves of the openings furnished by their pupils, responding to questions in answers adapted to the intelligence and experience of the questioner and then abandoned till some later time." This is in keeping with what he says earlier about Quaestiones convivales (p. 27): "table talks are interesting for their incidental matter, seldom for the original question or its answer". For the question of Plutarch's originality in the field of ancient science, see also A.M. Battegazzore, 1992, p. 32 and pp. 35-36. Pace J. Sirinelli, 2000, p. 359: "Les explications qu' il nous donne sur la patine des statues des navarques lacédémoniens à Delphes [= De Pyth. or. 395A-396C; see 2.I.I.] sont un peu naïves et ses traits Sur le froid primitif et Sur les causes physiques sont des recueils d'opinions glanées au gré de ses lectures. Le résultat n' est pas plus brillant que les considérations qui jalonnent les Propos de table. Ce sont des 'curiosités' dont, avec ses convives, il cherche l' explication, et non des démarches scientifiques. En résumé, on peut difficilement présenter Plutarque comme un savant, même à l' aune de ce temps." For further criticism of the general scholarly contempt of Plutarch's originality in the field of philosophy, see J. Opsomer, I994a, pp. I7-I9 (with further references).

${ }^{80}$ S. Sambursky, I963, p. 242.

${ }^{81}$ See the contributions in L. Taub and A. Doody, 2009 and M. Asper, 2013.

82 To employ the alternative terminology of the classical hermeneutical schema set out by W. Babilas, I96I, the 'authorial will' (voluntas auctoris) has to be taken into consideration at any point in the text. In light of the philological method employed by traditional Quellenforschung, Babilas has warned that traditional materia is only seldom simply copied by the author. It is not only commented on and criticised, but also often adapted according to the particular needs of the author. The reconciliation of the materia to the new context occurs at three distinct levels, viz. of content, arrangement and phrasing (inventio, dispositio, elocutio). 
position towards the scientific tradition, and more precisely how he tries to inscribe himself within it (or opposes it). Also the use and avoidance of a self-referential ego and alternative personal forms are relevant to us, as they can tell us something about the underlying sociology of the text $\mathrm{t}^{83}$. In particular, the addresses to the reader can inform us about the envisaged knowledge transfer from author to reader (and, thus, the text's intended reading). Analysing these discursive features in Plutarch's Quaestiones naturales will yield a much richer interpretation of the text than has been offered thus far. Let us, therefore, take a closer look at the existing scholarship and how this study aims to contribute to it.

\section{Status quaestionis}

Scholars have only relatively recently started to reappraise the actual appeal of Plutarch's scientific writings. In I976 Flacelière could still write that "Plutarque et la science de son temps' est un sujet qui a été à peine effleuré jusqu' ici, et qui mériterait, à mon avis, des recherches approfondies" 84 . However, there has been considerable progress since that time. Scholarly attention mostly goes to the more literary and essayistic treatises like De facie, De primo frigido, Quaestiones convivales and Plutarch's writings on animal psychology, whereas Quaestiones naturales often remains undiscussed ${ }^{85}$. It may well be the case that these other treatises offer a more efficient introduction into the author's scientific thought than the one at issue here, but then again Quaestiones naturales originates from the same 'genius', and, if we may assume that the much praised unity of Plutarch's works also applies to this work ${ }^{86}$, there are clear

83 On Plutarch's self-presentation in Quaestiones convivales, see F. Klotz, 2007 and J. König, $20 I I$.

${ }^{84}$ R. Flacelière, 1976, p. 195. Several editions and commentaries of Plutarch's scientific writings had already appeared by that time, but no further study of these texts had been conducted - with the important exception of H. Görgemanns, 1970. For a general introduction into 'Plutarch and the sciences', see R. Flacelière, J. Irigoin, J. Sirinelli and A. Philippon, 1987, pp. 1xix-lxxxvii, J. Sirinelli, 2000, pp. 355-366 and the contributions in I. Gallo, 1992; see also recently M. Meeusen and L. Van der Stockt, 20I5. Scholars have devoted much attention to the presence and tenets of several separate scientific disciplines and fields of technical knowledge throughout Plutarch's works, such as medicine (e.g., J. Boulogne, I996; M. Vamvouri Ruffy, 2012), astronomy (A. Pérez Jiménez, I992), mathematics (R. Seide, I98I; M. Isnardi Parente, I992), music (J.P.H.M. Smits, I970) and linguistics (O. Göldi, I920).

${ }^{85}$ Characteristic of the general scholarly neglect of Quaestiones naturales is the fact that in the proceedings of the 199I conference on "Plutarco e le scienze" (organised by the Italian section of the International Plutarch Society), there is only one reference to this work (in a footnote): see O. Longo, I992, p. 230, n. 4. The same observation was made by L. Van der Stockt, 20II, p. 449.

${ }^{86}$ See J. Barthelmess, I986, pp. 62-64 and the contributions in A.G. Nikolaidis, 2008. 
indications that it is in several respects (including contents, method and composition) fundamentally in line with his other writings. In light of this understanding, Harrison even wrote - in a lyrical vein - that Plutarch's problems "offer endless delight to the literary critic since they are so well written and so deeply infused with the warmth of Plutarch's personality". Regarding Quaestiones naturales, he asserts that they "offer a coherent and manageable collection for an investigation of Plutarch's style of composition and literary techniques within all of the quaestiones" 87 . One of the goals of this study will be to prove Harrison right, while also showing that there is even more to the collection than matters of style, composition and literary technique alone.

The situation has improved for Quaestiones naturales over the past few years. We have several thematic studies which examine specific aspects of the collection in more detail, viz. specific textual problems ${ }^{88}$, its textual history ${ }^{89}$, the relationship between Plutarch and Aristotelian science $^{90}$, Plutarch's use of scientific terminology ${ }^{91}$, the collection's literary value $^{92}$ as well as its 'encyclopaedic' appeal ${ }^{93}$. A programmatic study of Quaestiones naturales with specific attention to the cluster analysis of parallel passages was conducted by Van der Stockt ${ }^{94}$ [see 2.I.2.]. Until recently, a systematic study of the collection, which includes both an analytical and a descriptive approach, remained a scholarly desideratum. The 2006 edition, with an Italian introduction, translation and commentary by Senzasono was intended to fill in this lacuna (in the Corpus Plutarchi Moralium series). Senzasono's work offers a useful contribution especially as a scholarly instrument for consultation of the text, its translation and specific lemma's, but the general approach in the introduction is somewhat disappointing in some regards ${ }^{95}$. Senzasono's main focus is on the text and its translation, and this is certainly where the main value of his work rests. In his introduction, he is not, however, concerned with the actual place of the collection in its wider socio-cultural and intellectualphilosophical context, especially its educational goals. Senzasono does not

${ }^{87}$ G.W.M. Harrison, 200ob, p. 237.

${ }^{88}$ S.-T. Teodorsson, I990b, V. Ramón Palerm, 2005, M. Meeusen, 2015a and 2015b.

89 A. Morales Ortiz, I999, M. Meeusen, 20I2b and forthcoming a, b, c.

90 S.-T. Teodorsson, I999a, K. Oikonomopoulou, 20II, M. Meeusen, 20II and 2016.

${ }_{91}$ L. Senzasono, 1999, J. Opsomer, 1999, M. Meeusen, 2013b, L. Van der Stockt, 2013.

92 G.W.M. Harrison, 2000a and 200ob.

${ }^{93}$ K. Oikonomopoulou, 20I3a.

${ }^{94}$ L. Van der Stockt, 20II. For a preliminary study of Plutarch's science of natural problems more generally, see M. Meeusen, 20I4 and 20I5b.

95 See also the criticism by L. Van der Stockt, 20II, p. 449. The notes in Senzasono's commentary are often very extensive, but they do not always clarify the actual logic behind Plutarch's arguments and they are sometimes dizzyingly off track (moreover, for a scholarly instrument the "indici" at the end of the book are rather meagre). 
discuss Plutarch's dualistic view on causality, a remarkable interpretative inadvertence considering the collection's main aetiological concern. In general, Senzasono fails to provide a coherent and comprehensive account of the text's place among Plutarch's other (natural scientific) writings, its social and intellectual Sitz im Leben and its scientific methodology.

The more dated, though still recommendable, I965 Loeb edition by Sandbach is by no means adumbrated by this recently renewed scholarly interest in Quaestiones naturales. The relatively circumstantial introduction and clear notes have been a welcome source of inspiration for this study. Sandbach ${ }^{96}$ is obliged to Hubert's 1960 Teubner edition for the collection of parallel passages, from which he admits to "have drawn heavily" in his own clarifying notes. For my part, I owe them both a serious debt of gratitude in this regard ${ }^{97}$. Quaestiones naturales has been translated into several modern languages ${ }^{98}$, but nowhere do we find a comprehensive and monographic study of the collection as a whole, accompanied by a thorough lemmatic commentary. Therefore, the present study will attempt to restore this often marginalised and undervalued Plutarchan work by rehabilitating its significance to contemporary scholarship ${ }^{99}$. This will be done in two ways. The first part of this study contains four chapters, which successively discuss I) the collection's relation to the Aristotelian genre and tradition of natural problems and its sub-literary and a-moralistic discourse, 2) its relationship with other works in the corpus Plutarcheum (esp. Quaestiones convivales) and its alleged hypomnematic nature, 3 ) its educational and intellectual-philosophical value as a propaedeutic school text, and finally, 4) its aetiological design and scientific method. The first part will provide the preliminaries required for an informed reading and proper understanding of the text itself, which is presented in the form of a commentary in part two (see the introduction ad loc.).

\section{Note on translations and abbreviations}

Translations are borrowed from the Loeb Classical Library (with sporadic adaptations). Commonly used abbreviations are as follows.

96 F.H. Sandbach, I965, p. I47.

97 The collection has not yet been edited in the Collection des Universités de France (Budé) but will be soon by Filippomaria Pontani and myself.

98 See, e.g., D. Ricard, I844 (French), C.F. Schnitzer, I860 (German), V. Bétolaud, I870 (French), W.W. Goodwin, I878 (English), F.H. Sandbach, I965 (English), V. Ramón Palerm and J. Bergua Cavero, 2002 (Spanish), G. Janssen, 2004 (Dutch), L. Senzasono, 2006 (Italian).

99 In much the same way as J. Boulogne, I992, p. 4683 tried to revalue Quaestiones Romanae by saving it from a classification among Plutarch's "écrits secondaires, négligeables ou à jeter aux oubliettes". 


\section{General abbreviations}

DK Diels, H. and Kranz, W., Die Fragmente der Vorsokratiker, Dublin - Zurich, I966-1967.

D.L. Diogenes Laertius, Vitae philosophorum.

FGrHist Jacobi, F., Die Fragmente der griechischen Historiker, Leiden, I957-I969.

L\&S Lewis, C.T. and Short, C., A Latin Dictionary, Oxford, 1969.

LSJ Liddell, H.G. and Scott, R., A Greek-English Lexicon, $9^{\text {th }}$ ed. (rev. Jones, H.S.; with a revised supplement), Oxford, I996.

OED Trumble, W. and Brown, L., The Oxford English Dictionary, $5^{\text {th }}$ ed., Oxford, 2002.

RE Wissowa, G. et al. (eds.), Paulys Realencyclopädie der classischen Altertumswissenschaft, München - Stuttgart, I893-I980.

SVF von Arnim, H., Stoicorum Veterum Fragmenta, Leipzig, I903-1924.

TGF Snell, B., Kannicht R. and Radt, S., Tragicorum Graecorum Fragmenta, Göttingen, 1977-2004.

FHSG Fortenbaugh, W.W., Huby, P., Sharples, R.W. and Gutas, D., Theophrastus of Eresus. Sources for his Life, Writings, Thought and Influence, Leiden, I992-...

\section{Plutarch's works}

Moralia

De liberis educandis

De audiendis poetis (Quomodo adolescens poetas audire debeat)

De audiendo (De recta ratione audiendi)

De adulatore et amico (Quomodo adulator ab amico internoscatur)

De profectibus in virtute (Quomodo quis suos in virtute sentiat profectus)

De capienda ex inimicis utilitate

De amicorum multitudine

De fortuna

De virtute et vitio

Consolatio ad Apollonium

De tuenda sanitate praecepta

Coniugalia praecepta

Septem sapientium convivium

De superstitione

Regum et imperatorum apophthegmata

De lib. educ.

De aud. poet.

De aud.

De ad. et am.

De prof. in virt.

De cap. ex inim.

De am. mult.

De fortuna

De virt. et vit.

Cons. ad Apoll.

De tuenda

Coni. praec.

Sept. sap. conv.

De sup.

Reg. et imp. apophth. 
Apophthegmata Laconica - Instituta

Laconica-Lacaenarum apophthegmata

Mulierum virtutes

Quaestiones Romanae

Quaestiones Graecae

Parallela Graeca et Romana

De fortuna Romanorum

De Alexandri Magni fortuna aut virtute

Bellone an pace clariores fuerint Athenienses

(De gloria Atheniensium)

De Iside et Osiride

De E apud Delphos

De Pythiae oraculis

De defectu oraculorum

An virtus doceri possit

De virtute morali

De cohibenda ira

De tranquillitate animi

De fraterno amore

De amore prolis

An vitiositas ad infelicitatem sufficiat

Animine an corporis affectiones sint peiores

De garrulitate

De curiositate

De cupiditate divitiarum

De vitioso pudore

De invidia et odio

De se ipsum citra invidiam laudando (De laude ipsius)

De sera numinis vindicta

De fato

De genio Socratis (De Socratis daemonio)

De exilio

Consolatio ad uxorem

Quaestiones convivales

Amatorius

Amatoriae narrationes

Maxime cum principibus philosopho esse

disserendum (Maxime cum principibus philosophandum esse)

Ad principem ineruditum

An seni respublica gerenda sit

Praecepta gerendae reipublicae
Apophth. Lac.

Mul. virt.

Quaest. Rom.

Quaest. Graec.

Parall. Graec. et

Rom.

De fort. Rom.

De Al. Magn. fort.

Bellone an pace

De Is. et Os.

De E

De Pyth. or.

De def. or.

An virt. doc.

De virt. mor.

De coh. ira

De tranq. an.

De frat. am.

De am. prol.

An vitiositas

Animine an corp.

De gar.

De cur.

De cup. div.

De vit. pud.

De inv. et od.

De se ipsum laud.

De sera num.

De fato

De genio Socr.

De exilio

Cons. ad ux.

Quaest. conv.

Amatorius

Am. narr.

Maxime cum

principibus

Ad princ. iner.

An seni

Praec. ger. reip. 
De unius in republica dominatione, populari statu, et paucorum imperio

De vitando aere alieno

Decem oratorum vitae

Comparationis Aristophanis et Menandri epitome

De Herodoti malignitate

Placita philosophorum

Quaestiones naturales

De facie quae in orbe lunae apparet

De primo frigido

Aqua an ignis sit utilior

De sollertia animalium (Terrestriane an aquatilia animalia sint callidiora)

Gryllus (Bruta animalia ratione uti)

De esu carnium

Quaestiones Platonicae

De animae procreatione in Timaeo

De Stoicorum repugnantiis

Stoicos absurdiora poetis dicere

De communibus notitiis adversus Stoicos

Non posse suaviter vivi secundum Epicurum Adversus Colotem

De latenter vivendo (An recte dicendum sit latenter esse vivendum)

De vita et poesi Homeri

Parsne an facultas animi sit vita passiva

De musica

Fragments

Lamprias catalogue

Vitae

Theseus

Romulus

Comparatio Thesei et Romuli

Lycurgus

Numa

Comparatio Lycurgi et Numae

Solon

Publicola

Comparatio Solonis et Publicolae

Themistocles

Camillus
De unius

De vit. aer.

Dec. or. vit.

Comp. Ar. et Men.

De Her. mal.

Plac.

Q.N.

De facie

De prim. frig.

Aqua an ignis

De soll. an.

Gryllus

De esu

Quaest. Plat.

De an. procr.

De Stoic. rep.

Stoic. absurd. poet.

De comm. not.

Non posse

Adv. Col.

De lat. viv.

De vit. et po. Hom.

Pars an fac.

De mus.

fr. Sandbach

Lampr. cat.

Thes.

Rom.

Comp. Thes. et Rom.

Lyc.

Num.

Comp. Lyc. et Num.

Sol.

Publ.

Comp. Sol. et Publ.

Them.

Cam. 
Aristides

Cato Maior

Comparatio Aristidis et Catonis

Cimon

Lucullus

Comparatio Cimonis et Luculli

Pericles

Fabius Maximus

Comparatio Periclis et Fabii Maximi

Nicias

Crassus

Comparatio Niciae et Crassi

Alcibiades

Marcius Coriolanus

Comparatio Alcibiadis et Marcii Coriolani

Lysander

Sulla

Comparatio Lysandri et Sullae

Agesilaus

Pompeius

Comparatio Agesilai et Pompeii

Pelopidas

Marcellus

Comparatio Pelopidae et Marcelli

Dion

Brutus

Comparatio Dionis et Bruti

Timoleon

Aemilius Paulus

Comparatio Timoleontis et Aemilii Pauli

Demosthenes

Cicero

Comparatio Demosthenis et Ciceronis

Alexander

Caesar

Sertorius

Eumenes

Comparatio Sertorii et Eumenis

Phocion

Cato Minor

Demetrius

Antonius

Comparatio Demetrii et Antonii
Arist.

Ca. Ma.

Comp. Arist. et Ca.

Ma.

Cim.

Luc.

Comp. Cim. et Luc.

Per.

Fab.

Comp. Per. et Fab.

Nic.

Crass.

Comp. Nic. et Crass.

Alc.

Cor.

Comp. Alc. et Cor.

Lys.

Sull.

Comp. Lys. et Sull.

Ages.

Pomp.

Comp. Ages. et Pomp.

Pel.

Marc.

Comp. Pel. et Marc.

Dion

Brut.

Comp. Dion. et Brut.

Timol.

Aem. Paul.

Comp. Tim. et Aem.

Dem.

Cic.

Comp. Dem. et Cic.

Alex.

Caes.

Sert.

Eum.

Comp. Sert. et Eum.

Phoc.

Ca. Mi.

Demetr.

Ant.

Comp. Demetr. et Ant. 
Pyrrhus

Caius Marius

Agis

Cleomenes

Tiberius Gracchus

Caius Gracchus

Comparatio Agidis et Cleomenis cum Tiberio et Caio Graccho

Philopoemen

Titus Flamininus

Comparatio Philopoemenis et Titi Flaminini Aratus

Artaxerxes

Galba

Otho
Pyrrh.

Mar.

Agis

Cleom.

TG

$C G$

Comp. Ag., Cleom. et Gracch.

Phil.

Flam.

Comp. Phil. et Flam.

Arat.

Art.

Galba

Oth. 
INTRODUCTION 



\section{$\mathbf{I}$ \\ Problems, problems, problems (and Aristotelian precedents)}

\section{I.I. Quaestiones naturales and the Aristotelian genre and tradition of natural problems}

\section{Preliminary remarks on Plutarch's Naturwissenschaft}

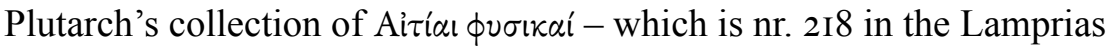
catalogue, nr. 50 in the Planudean order, nr. 67 in the 1509 Aldine edition and nr. 59 in the I572 Stephanus edition of the Moralia (9IIC-9I9E in the traditional pagination) - is commonly referred to by its Latin title,

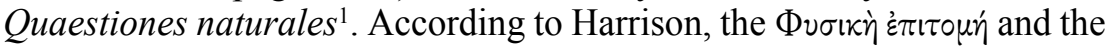

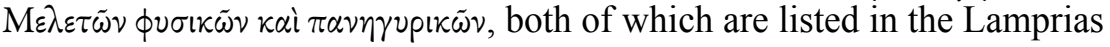
catalogue (as nrs. I83 and 200a respectively), "would surely have contained much comparative information" 2 , but since these works are no longer extant this remains uncertain. One cannot even be sure that these entries were authentic to begin with ${ }^{3}$. The $\Phi$ very similar title to Book Io of Ps.-Aristotle's Problems, the 'E $\pi$ เ $\phi v \sigma i \kappa \tilde{\omega} \nu$, which is the longest in the collection and draws heavily on Aristotle's zoological and biological writings (it often specifically deals with copulation, generation and with the number and nature of offspring in animals: cf. Q.N. 2I and 38$)^{4}$. Due to the generality of this type of

${ }^{1}$ In the traditional order of Plutarch's Moralia in the Stephanus edition, Quaestiones naturales precedes De facie (920B-945E), a work of astrophysical interest which deals with the nature of the moon and its role in the universe. It succeeds Ps.-Plutarch's (Aëtius') Placita philosophorum ( $874 \mathrm{D}-9 \mathrm{IIC})$, which is a doxography in five Books on physical and natural philosophical matters (see n. 5). Among the I23 Placita collected there, 54 are also composed in question-and-answer form (A. Gudeman, I927, col. 2525).

2 G.W.M. Harrison, 200ob, p. 237, n. 2.

${ }^{3}$ For the presence of spuria in the Lamprias catalogue, see F.H. Sandbach, 1969, p. 6. See also J. Irigoin, 1986 more generally.

${ }^{4}$ According to R. Mayhew, 20IIa, p. 280 (with n. 3) it is not improbable that this Book originates from (or is based on) an epitome by Theophrastus: perhaps the

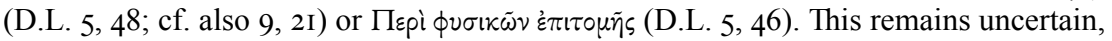

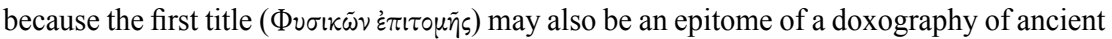
natural philosophers (in any case, it is listed after $\Phi v \sigma \kappa \kappa \tilde{\omega} \nu \delta 0 \xi \tilde{\omega} \nu$ in I6 Books in D.L. 5, 48,

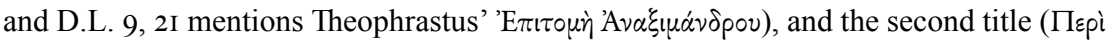

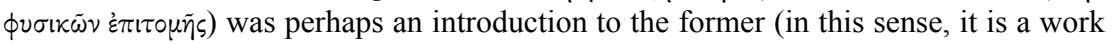

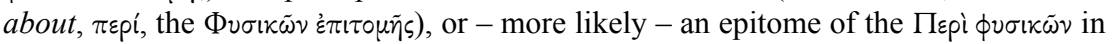


title, though, nothing can be said with any certainty about the original form or content of the entry in the Lamprias catalogue 5 . The same is

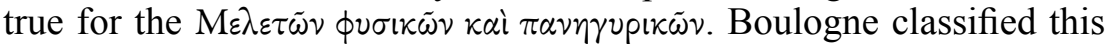
work as a collection of Plutarch's philosophical school manuals, calling it "séminaires et conférences ouvertes au grand public sur la nature". The term $\pi \alpha \nu \eta \gamma v p i \kappa \tilde{\omega} \nu$ is particularly intriguing, since it may imply that we are dealing with declamations held during festive occasions or public festivals. One may draw a link with the sympotic discussions of natural problems in Quaestiones convivales. Again, though, any further specification in this regard is speculative and inconclusive.

Ziegler classified Quaestiones naturales among Plutarch's "naturwissenschaftliche Schriften"7, a category that also includes De facie, De primo frigido, the spurious (? $)^{8}$ Aqua an ignis sit utilior and a large part -

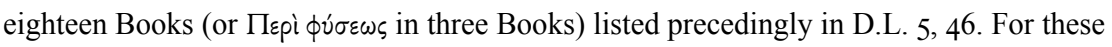
and similar titles among Theophrastus' writings, see I37 FHSG (esp. nrs. Ia, 3-7).

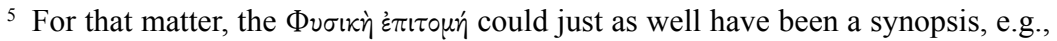
of Aristotle's Physica or of Epicurus' physical writings. Indeed, the latter introduces his

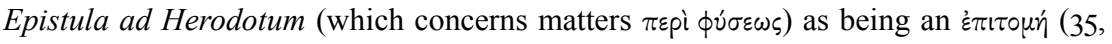

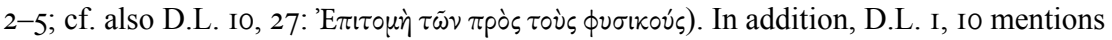

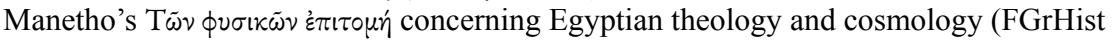
609, I7). This Manetho (from Sebennytos in Egypt) is quoted several times in Plutarch's De Iside et Osiride (see C. Froidefond, I988, p. 6i; FGrHist 609, 19-22). By contrast,

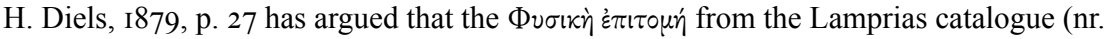

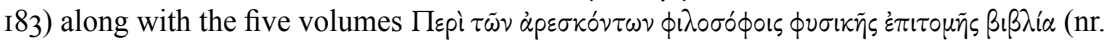

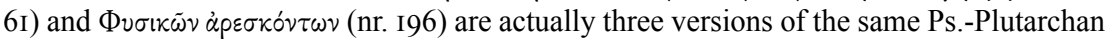
Placita (see n. I). For further detail on the complex tradition of Ps.-Plutarch's/Aëtius' doxography, see J. Mansfeld and D.T. Runia, 1997.

${ }^{6}$ J. Boulogne, 2003, p. 37, n. 98. F.H. Sandbach, 1969, p. 27 translates the entry as "A Collection of Scientific Lectures and Public Addresses". Wyttenbach separated it from nr. 200: Пврі i $\mu \varepsilon p \tilde{\omega} \nu$.

${ }^{7}$ K. Ziegler, I95I, cols. 637, 706 and 85I-858. This category also includes a number of other works that are listed in the Lamprias catalogue but which are now lost:

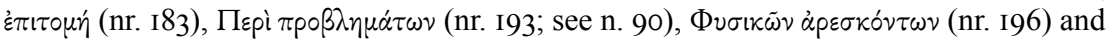

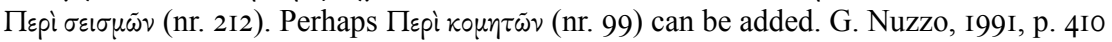
would also add De tuenda sanitate praecepta (cf. also W. von Christ, I959, p. 5I2, who uses the category of "naturwissenschaftlichen Fragen"). For protest against the Zieglerian designation ("scritti di fisica e di scienza naturale"), see P. Donini, I994a, p. 48, n. 32 [see the prologue, n. 50]. Cf. also G. D'Ippolito and G. Nuzzo, 20I2, pp. 56-59.

8 This treatise was considered "a miserable sophistical exercise" by F.H. Sandbach, 1939, p. 20I (cf. also pp. 198-202 more generally), and it was claimed to be spurious already by J. Kowalski, I9I8, pp. 258-262 (cf. also H. Cherniss and W.C. Helmbold, I957, pp. 288-289). It remains to be seen, however, if this work (disregarding whether we have it in its final version or not) is as naïve as Sandbach takes it to be. In any case, the format

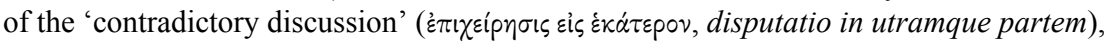
where topics are argued from both sides, is employed more often in Plutarch's writings 
roughly one third - of the table talks in Quaestiones convivales that are concerned with very similar natural problems. Ziegler was well aware, however, that there may be certain problems in categorising these works in this way. De facie, so he notes, deals with topics relating to ancient lunar science in the form of a dialogue, which culminates in the domain of religion by the integration of an eschatological myth at the end of the work. Therefore, in spite of the fact that a major part of the work relates to what Ziegler calls Plutarch's "Naturwissenschaft", the dialogue - or at least part of it - just as easily fits among his "theologische Schriften" (including De superstitione, De Iside et Osiride, the Pythian dialogues, De genio Socratis and De sera numinis vindicta). What is important here is that natural science clearly did not exclude traditional religion and mythology for Plutarch (I will come back to this later [see 4.I.2.]). Therefore, the modern attempt to dissect the Chaeronean's work into different categories probably tells us more about our own departmentalised view on science and other fields of knowledge than about Plutarch's take on the matter.

Similarly, regarding De primo frigido - where Plutarch demonstrates that cold has a principle of its own, which he tries to identify in a lengthy doxography - scholars have argued that Ziegler's classification of this essay among the "naturwissenschaftliche Schriften", as distinct from the "wissenschaftlich-philosophische Schriften"10 (including Quaestiones Platonicae, De animae procreatione in Timaeo, De Stoicorum repugnantiis, Adversus Colotem etc.), is ambiguous ${ }^{11}$. Indeed, there may again be certain difficulties in categorising this text. If one considers the epistemological implications of some of its chapters (esp. the last in combination with the eighth [see 4.3.2.I.]), this work can - again at least in part - be just as easily grouped in with the "wissenschaftlich-philosophische Schriften". However, if one considers the technical-philosophical nature of these writings, such a recategorisation would clearly result in an overly restrictive interpretation of the text. In any case, the classification of De primo frigido among the "naturwissenschaftliche Schriften" is not unsound since the

[see 4.3.3.I.], and the essay's general style of argumentation is no more 'sophistical' than that of an average Plutarchan natural problem. For the description of this treatise as a rhetorical tour de force, see R. Flacelière, J. Irigoin, J. Sirinelli and A. Philippon, I987, pp. ccvi-ccvii. The athetesis, therefore, seems to be based on doubtful grounds (cf. also C. Hubert, I959, p. I). For further discussion, see the introduction in G. D'Ippolito and G. Nuzzo, 20I2, pp. I77-I98.

${ }^{9}$ K. Ziegler, I95I, col. 85I (for Plutarch's writings on theology, see cols. 637, 705, 82585I). This feature of thematic overlap relates to the "Kreuzung der Gattungen" discussed as a typical feature of Plutarch's Moralia by I. Gallo and C. Moreschini, 2000, pp. I4-I5. Cf. also G. D'Ippolito and G. Nuzzo, 20I2, pp. 56-59.

${ }^{10} \mathrm{~K}$. Ziegler, I95I, cols. 636-637, 704-705, 744-768.

${ }_{11}$ See J. Opsomer, I998, p. 2I4. Cf. already P. Donini, I986a, p. 2II and I994a, p. 48, n. 32 [quoted in the prologue, n. 50]. 
work spends much, if not most, of its attention to specific natural phenomena and physical processes related to cold and heat. Plutarch explicitly notes that he is deliberately taking a step downwards on the ladder of epistemology, rather than upwards, turning most of his attention to the domain of sensory observation and plausible argumentation ${ }^{12}$. In fact, the more abstract discussion of what can be known about these issues remains rather peripheral (it introduces and concludes the doxographical part). What is central, in the end, is the principle of cold.

Third, Ziegler also distinguished the category of the "naturwissenschaftliche Schriften" from the "tierpsychologische Schriften"13 (including De sollertia animalium, Bruta animalia ratione uti, De esu carnium), insofar that the latter primarily deal with the topic of animal behaviour, morality and intelligence, rather than animal biology and physiology in a strict naturalist sense (as known from Aristotle's zoological writings $)^{14}$. Indeed, the ethical fundament of these writings is generally absent in Plutarch's "naturwissenschaftliche Schriften". However, even if the "naturwissenschaftliche Schriften" are far less concerned with matters pertaining to animal psychology, the distinction is not based on the traditional division between animate and inanimate nature ( $\left.\tilde{\varepsilon}^{\prime} \mu \psi v \chi \alpha-\not{\alpha} \psi v \chi \alpha\right)$. The eschatological myth at the end of De facie nicely illustrates this, speculating as it does about the purpose of the moon in the universe, more specifically by explaining its importance for the life-cycle of human souls $(94 \mathrm{OF}-945 \mathrm{D})$. Moreover, specific psychic and psychological phenomena are also discussed, sometimes at considerable length, throughout Plutarch's other natural scientific works (see, e.g., Quaest. conv. 654E, De prim. frig. 946C, Aqua an ignis 958E). In Quaestiones naturales, we find one explicit reference to a psychic process, viz. the psycho-somatic effects

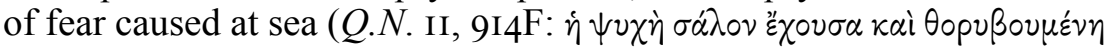

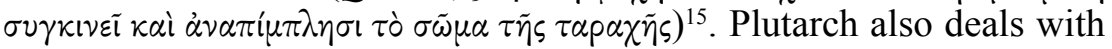

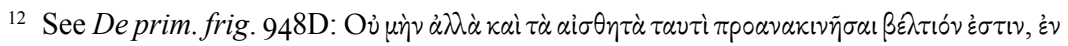

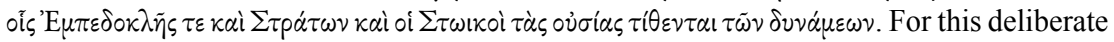
epistemological step downwards, cf. also P. Donini, I986a, p. 2II and J. Opsomer, I998, p. $216, \mathrm{n}$. II. Moreover, the category of the divine and the intelligible is still present in $D e$ primo frigido, though less central to the main argument [see 4.I.2.2.].

${ }^{13}$ K. Ziegler, 195I, cols. 636, 706, 732-744.

${ }^{14}$ Cf. R. Flacelière, J. Irigoin, J. Sirinelli and A. Philippon, I987, p. 1xxxiv: "Quand il s'agit des bêtes, que Plutarque semble avoir aimées, il s'intéresse à leur 'psychologie' plus souvent qu' à leur physiologie." See also S.T. Newmyer, 20I4, p. 223: "It has become clear to students of Plutarch's animal treatises that to dismiss him as a failed Aristotle is to misunderstand the intention of his animal philosophy, since he approaches the question of what constitutes animality and what distinguishes it from humanity not as a biologist but as a moralist.” Cf. also M. Vegetti, I979, T. Barton, I994a, p. I26 and R. French, I994, pp. $178-184$.

${ }^{15}$ Cf. L. Senzasono, 2006, p. I85, n. 73: "Del resto in esso [opuscolo] l'elemento 
psychological-pathological topics, for instance, in discussing the physiological mechanisms behind hate, courage and their opposites ${ }^{16}$. These are, in fact, the same ethical categories that structure Plutarch's arguments in the "tierpsychologische Schriften", yet they lack any obvious moralising agenda here [see I.2.4.]. In Q.N. 20, for instance, Plutarch does not explain the bravery of wild boars, as opposed to the cowardice of deer, in an ethical but a physical fashion (viz. by associating the difference in their character with their hot and cold bodily constitutions respectively). Chapters like Q.N. 26 and 37 are also particularly relevant in light of animal psychology, since they deal with animal intelligence - though specifically the lack of it. In Q.N. 37, Plutarch argues that dogs cannot understand anything by means of their intellect and have no memory, since these virtues are set aside for human beings (An quia neque cogitatione comprehendere quicquam nec reminisci (quibus solus homo virtutibus valet) potest?). Similarly, in Q.N. 26, Plutarch wonders why animals seek and pursue substances that have remedying properties when they are ill, and often restore themselves to health by using them. He points out that these animals have no previous experience or have never tried these remedies

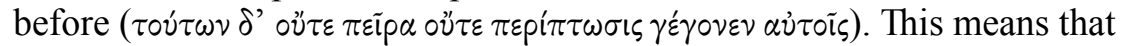
they do not act on the basis of knowledge or insight, so that there must be another, more physical, reason for it. We are very remote from the arguments in the "tierpsychologische Schriften", where Plutarch, in an overt anti-Stoic fashion, often emphasises the rational abilities of animals in combination with their moral capacities. Interestingly, the irrational nature of animals is also a common topic in Ps.-Aristotle's Problems, which served as Plutarch's model in his own natural problems ${ }^{17}$. One may presume, then, that the conceptual differences and inconsistencies in Plutarch's writings on animals are genre-related [see I.2.5.].

As these cases show, any attempt to strictly categorise Plutarch's natural scientific works runs the risk of simply being artificial or ambiguous. I will further specify this point for Quaestiones naturales later on in view of the thematic overlaps with Plutarch's other collections of quaestiones [see 2.4.2.]. I do not intend to do away with Ziegler's categories altogether,

psicologico è assai raro, sia come oggetto di problematica, sia come strumento di spiegazione dei fenomeni."

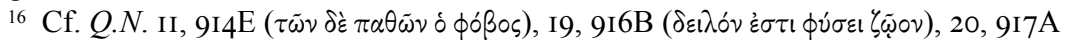

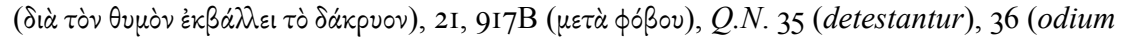
vehementius), 37 (odit).

${ }_{17}$ Cf., e.g., Ps.-Arist., Probl. $887 a$ I ( $\left.\ddot{\nu \varepsilon v ~ \lambda o ́} \gamma \circ v\right)$, Ps.-Arist./Alex. Aphr., Suppl. probl.

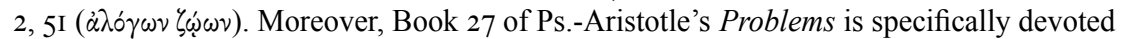
to the physical aspects of fear and courage ( $\sigma \sigma \alpha \pi \varepsilon p i \phi o ́ \beta o v ~ \kappa \alpha i ~ \alpha \nu \delta \rho \varepsilon i \alpha \nu)$, and especially to the physiological symptoms of shivering, pallor, urination etc. [see I.2.5.]. See L.M. Castelli, $20 I$. 
though. After all, the "naturwissenschafliche Schriften" do, in several regards, distinguish themselves from Plutarch's treatises on theology, philosophy and animal psychology ${ }^{18}$. As opposed to the "tierpsychologische Schriften", the "naturwissenschafliche" do not serve an overt ethical agenda, while the strictly technical-philosophical and at times dogmatic features of the "wissenschaftlich-philosophische Schriften", as well as the overtly religious-mythological approach of the "theologische Schriften", makes way for a more central focus on the tentativeness of plausible natural explanations in the "naturwissenschafliche Schriften".

If we now turn to the internal organisation of these "naturwissenschafliche Schriften", an essential observation regards their basic structure and set-up. Scholars have argued that the question-and-answer format of the genre of natural problems, as found in Quaestiones naturales, offers an epistemological matrix that lies at the basis of Plutarch's other scientific writings as well ${ }^{19}$. Each of these works is in principle concerned with supplying multiple explanations to one main problem. From a text-genetic perspective, one could even argue that these treatises are composed on the basis of actual problems, where several answers are provided to one central quaestio: as such, De primo frigido deals with the question 'Which, if any, is the active principle or substance of cold?' (cf. 945F), Aqua an ignis sit utilior investigates 'Whether fire or water is more useful?', while De facie asks 'What is the substance and purpose of the moon in the cosmos?' ${ }^{20}$. Thus, it can be argued that the problem format of Quaestiones naturales (which I will analyse in detail later on [see I.I.4.]) provides a structural mould for the orderly organisation of Plutarch's scientific writings, the development of which can vary in length depending on the degree of argumentative elaboration ${ }^{21}$.

${ }^{18}$ In addition, the distinction between the treatises on theology, philosophy and animal psychology may not be that strict either. For instance, as D. Babut, I969, p. 6I shows, De sollertia animalium belongs to Plutarch's anti-Stoic works (cf. also J. Mossman and F. Titchener, 20II, p. 278), while G. Roskam, 20IIa, pp. 200-20I, proposes to classify De amore prolis with Plutarch's anti-Epicurean works. For animals serving as instruments of the divine, on the other hand, cf., e.g., De soll. an. $975 \mathrm{~B}$ and De Is. et Os. $382 \mathrm{AB}$ [quoted I.2.4.].

19 See J. Boulogne, 2005b, p. I98, n. 6: "Il s' agit véritablement d' une matrice épistémologique qui semble être la base de l'écriture scientifique chez Plutarque, et qui, selon l' ampleur du développement rhétorique, génère des compositions plus ou moins longues."

${ }^{20}$ See also L. Senzasono, 2006, p. 9. According to H. Görgemanns, I968, p. II (cf. also I970, pp. 90-120), the central cosmological section in De facie ( $\S 6-15,922 \mathrm{~F}-928 \mathrm{D})$ was, in any case, composed on the basis of an earlier draft (perhaps a set of problems?).

21 That the format of the problem genre had its compositional advantages, is also clear from several other Plutarchan treatises, such as De sollertia animalium: 'Whether land or sea animals are more clever?', De E apud Delphos: 'What is the meaning of the enigmatic 
However, as opposed to treatises like De facie or De primo frigido, Plutarch's natural problems, as treated in Quaestiones naturales and convivales, do not explicitly portray a systematic or comprehensive vision of the object they study (i.e. the realm of natural phenomena). Instead, they deal with a range of particular questions that each concern one specific problematic issue, viz. one enigmatic natural phenomenon and its underlying causes. Plutarch clearly borrows this fragmentary and piecemeal approach from the Ps.-Aristotelian Problems, where over nine hundred such chapters are dealt with in 38 thematic Books (making it the third largest work in the corpus Aristotelicum). Therefore, Teodorsson claimed that Plutarch's "quaestiones are truly Peripatetic in character" 22. To be sure, Plutarch in solving natural problems employs a wide range of scientific concepts and theories that have a specific Aristotelian imprint (or more generally Peripatetic). In fact, Quaestiones naturales as a whole may give the impression that it was written by a Peripatetic author. However, it is not clear from this that Plutarch actually intended to compose this work with a fundamentally Aristotelian predisposition and purpose. This is, in any case, problematic in light of Plutarch's well known allegiance to Plato and Academic philosophy. In what follows, I will sketch the problem more in detail and suggest a number of explanations (a conclusive answer will only be given at the very end of chapter four [see 4.3.4.3.]).

\section{Quaestiones naturales: the work of a Plutarchus Aristotelicus?}

It goes without saying that Aristotle counted as a pre-eminent authority in the field of natural philosophy in Antiquity and that Plutarch, therefore, repeatedly quotes him in his writings on natural science (and also his acolytes, esp. Theophrastus) ${ }^{23}$. Yet, the question as to whether Plutarch

E at Delphi?', and De defectu oraculorum: 'Why have many oracles in Greece seized to function?' (cf. 4IIEF). For the link between Plutarch's philosophical dialogues and the genre of problems, see also J. Opsomer, 2005, pp. I98-I99 and 20IO, p. II5.

22 S.-T. Teodorsson, I999a, pp. 665-666. See also K. Oikonomopoulou, 20I3a, p. I52: "Thus the $Q N$ as a whole forges strong links with an ideal of encyclopaedic comprehensiveness that is specifically Peripatetic, and pays homage to the Peripatetic encyclopaedic achievement." For the Ps.-Aristotelian Problems as a model for Plutarch's natural problems, see, e.g., H. Flashar, 1962, p. 370: "So kann man im ganzen sagen: es ist sehr wahrscheinlich, daß Plutarch zur Anlage dieser Sammlung angeregt ist durch die peripatetische Problemata-Literatur." See also F.H. Sandbach, I965, p. I34, L. Senzasono, 2006, p. 7, G. Roskam, 20IIb, pp. 45-46, K. Oikonomopoulou, 20II, M. Meeusen, 20II and 2016.

${ }^{23}$ For Plutarch's quotations from Aristotle's physical and biological writings, see G. Roskam, 20Irb, pp. 45-46. For a systematic overview of Plutarch's quotations from Theophrastus, see J. Boulogne, 2005c. Strato of Lampsacus, the third in line as head of the Lyceum, is also an important Peripatetic authority for Plutarch (quoted as a фvбเкós in De 
actually tried to attain Peripatetic philosophership in his natural problems more in specific requires closer examination. This is, indeed, a relevant question in light of the reception of Aristotelian science, or at least a very specific part of it (c.q. the Ps.-Aristotelian Problems), in the Imperial $\mathrm{Era}^{24}$. Some scholars would actually claim that Plutarch, in conformity with other middle- and neo-Platonists, intended to ally Platonism with Aristotelianism in his scientific writings ${ }^{25}$. This would be of great interest for the history of Greek science in the Imperial Era, but one should be cautious in attributing Plutarch this intent, bearing in mind his primary philosophical allegiance to Plato and the Academic tradition.

The debate about the intellectual relationship between Plutarch and Aristotle, of course, is not anything new. It has been a particularly potent topic in the last few decades, giving rise to a variety of - often times irreconcilable - claims ${ }^{26}$. This discussion cannot simply be ignored here, but neither is this the place to deal with it in full detail, so I will only

tranq. an. $472 \mathrm{E}$ and De soll. an. 96IA; cf. also De prim. frig. $948 \mathrm{CD}$, De Stoic. rep. $1045 \mathrm{~F}$, Adv. Col. III5B, fr. 2I6g Sandbach).

${ }^{24}$ The relevance of this problem was already stressed by W. Capelle, I9IO, p. 328: "Doch bedürfen diese Dinge, überhaupt die Quellen der Plutarchischen Symposiaka [Quaestiones naturales can be added] sowie die Art ihrer Benutzung durch Plutarch, einer größeren Untersuchung, die für die Geschichte der nacharistotelischen Physiologie, zumal wenn man die übrigen physikalischen Schriften Plutarchs heranzieht, von besonderer Bedeutung sein wird."

${ }^{25}$ See, e.g., J. Sirinelli, 2000, pp. 36I-362: "Il y a des pans entiers des connaissances de Plutarque qui proviennent d' Aristote et de son école, notamment tout ce qui concerne ce que nous appellerions les sciences naturelles. Certes, c' est surtout dans ce courant de pensée que s'est développée la connaissance systématique de la nature et il n'y a rien d'étonnant à cela. Ce qui doit être noté est l' aisance avec laquelle Plutarque allie ses deux philosophies, sans les faire interférer et sans problèmes, chacune pour ce qu' elle lui offre, Platon apportant l' essentiel, c' est-à-dire la connaissance de la divinité du Monde et de l'Esprit, Aristote celle de la nature, de la vie et très probablement de la logique. Ce n' est pas une position aberrante et isolée. Au contraire, chez Plutarque se manifeste de façon claire et pratique cette complémentarité entre l' Académie et le Lycée qui va devenir institutionnelle dorénavant dans le platonisme." For the view that Plutarch employs Aristotelian theories in his scientific writings in order to 'save' Plato, see I. Rodríguez Alfageme, I999b, pp. 624625. For the concept of 'harmonisation' between both strands of philosophy, see also P. Donini, I992, p. I08 ("armonizzarne"). As to Plutarch's general aetiological project and its link with Aristotle, see C. Darbo-Peschanski, I998, p. 2I: "Plutarque médio-platonicien, héritier d' un mixte de philosophie académique et péripatéticienne, est, dans les Aî́tı, largement influencé par Aristote. Cette influence lui fournit le cadre dans lequel inscrire les préoccupations érudites qu'il partage avec bien des Grecs d'époque romaine".

${ }^{26}$ Seminal studies are those of G. Verbeke, I960, F.H. Sandbach, I982, P. Donini, I986a, I988, 1999, D. Babut, I996, F. Becchi, I975, I978, I999, 2014, G.E. Karamanolis, 2006, pp. 85-I26 and G. Roskam, 2008/9, 20IIb. See also more generally the contributions in A. Pérez Jiménez, J. Garciá López and R.M. Aguilar, I999. 
sketch the debate along very general lines and with a specific focus on Plutarch's natural scientific writings.

An interesting starting-point is found in Plutarch's argument in De primo frigido. The fact that the frequency of explicit (i.e. nominatim) quotations from the Stagirite is rather low in this work for some scholars marks a clear contrast with the work's generally 'Aristotelian' style of discourse. Regarding the recurrent allusion to specific natural scientific theories and concepts in this treatise, Opsomer (following Glucker) speaks of Plutarch's use of "a mock-Aristotelian style", that is, an "outward appearance of Aristotelianism [in honour of his youthful friend and/or pupil, Favorinus, which] should not be taken seriously"27. It is only at the very end of the treatise, then, that Plutarch throws off his Peripatetic mask and shows his true, Academic face, by promoting $\dot{\varepsilon} \pi \circ \chi \eta \dot{~ a s ~ a ~ s u p e r i o r ~}$ philosophical attitude in natural scientific matters (De prim. frig. $955 \mathrm{C}$ [quoted 4.3.2.I.]). This view, however, is, in my opinion, open to debate. At least some nuance seems in place.

First of all, Plutarch is nowhere explicitly making fun of Aristotle or his style of discourse in De primo frigido. In fact, the situation seems more or less similar as in Plutarch's writings on animal psychology, where Aristotelian science (c.q. biology) is also instrumentalised in a new philosophical (c.q. moralising) framework (see n. I4). In the case of De primo frigido, then, the framework is provided by Academic $\dot{\varepsilon} \pi \circ x_{\eta}$. If there is anything humoristic about this procedure, it is, indeed, very subtle. Second, to denote anything natural scientific as 'Aristotelian' would seem a gross oversimplification. Notably, De primo frigido contains some overt anti-Aristotelian and anti-Peripatetic traits, such as Plutarch's dismissal of the theory, elaborated in the first part of the treatise, that cold is a privation $(\sigma \tau \dot{\varepsilon} p \eta \sigma i \varsigma)$ of heat. This theory has clear parallels in Aristotle but is rejected at length here (De prim. frig. $945 \mathrm{~F}-948 \mathrm{~A}$; see the parallel in Q.N. 29, 919A with the commentary ad loc.). Plutarch also openly rejects Strato's theory identifying water as the principle of cold (De prim. frig. 948CD). In light of the infrequent quotes from Aristotle in De primo frigido, Helmbold concludes that "[n]o doubt it is in virtue of Favorinus' youth that his idol is treated so lightly", adding in the same breath that "Plutarch $[\ldots]$ became much more favourable to Peripatetics later in

27 J. Opsomer, I998, p. 219; see J. Glucker, I978, pp. 286-290. For Favorinus' admiration of Aristotle and his adherence to Peripatetic philosophy, see Quaest. conv. $734 \mathrm{~F}$ :

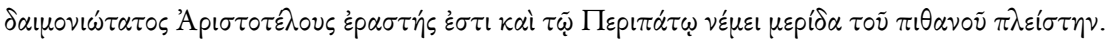
See also H. Cherniss and W.C. Helmbold, I957, p. 228, P. Donini, I986a, p. 223, n. 28, L. Holford-Strevens, 1997, p. 204 (who rightly notes that "assigning the greatest share of the $\pi \bullet \alpha \nu o$ v to the Peripatetics is not incompatible with Academic scepticism"; cf. De prim. frig. $949 \mathrm{~F}$ and $955 \mathrm{C}$ ). 
his life (e.g. in the Life of Alexander)" 28 . The latter part, based on the chronology of Plutarch's life and writings, is not further motivated, and it can, indeed, be contested on account of the fact that it is not unlikely that Plutarch was interested in discussing Aristotelian-style scientific topics from a relatively young age onwards [see the prologue]. In Plutarch's natural problems, Aristotle and his followers - with Theophrastus as the first in line - are regarded as precious authorities in the development of the arguments: Quaestiones convivales shows that personal acquaintance with their natural scientific writings is not at all a thing to scorn but rather to display, and in Quaestiones naturales Plutarch quotes Aristotle and Theophrastus by name at numerous occasions, while remaining critical in his evaluations [see 4.2.I.I. and 4.2.2.2.]. So if Plutarch had any interest in Aristotle and the Peripatetics, it is probably for the best not to conceive of it in terms of strict chronological phases in the Chaeronean's philosophical career, but to draw a more general model of intellectual allegiance - or the lack of it.

The most recent study (I know of) to provide a global account of Plutarch's reliance on Aristotelian knowledge is that of Roskam (20IIb). Roskam collects and analyses the explicit (i.e. nominatim) quotations from Aristotle throughout the entire corpus Plutarcheum, thus employing a positive method that is rigorous but safe. Roskam expresses considerable opposition to a number of Becchi's and Karamanolis' views, both of whom have defended Plutarch's Aristotelianism on the basis of more lenient readings of the available material ${ }^{29}$. There is no need to go into the details of these studies here; what matters most for us is Roskam's conclusion:

"[I]f Plutarch was prepared to embrace him [sc. Aristotle] [...] he was rather pursuing a marriage of convenience than acting out of true love. His true love was Timoxena in everyday life, and Plato in philosophy." ${ }^{30}$

It is beyond doubt that Aristotle was not Plutarch's "true love". This does not necessarily imply, however, that Aristotle did not hold a privileged rank in Plutarch's thought. Donini, for instance, has an open mind on this matter, arguing that while Aristotle did not belong to the Platonic or Academic tradition for Plutarch, one can, nevertheless, assume a certain sense of philosophical evolution, according to which, in Plutarch's mind,

${ }^{28}$ H. Cherniss and W.C. Helmbold, I957, p. 228. Helmbold finds it "odd that of the three quotations from Aristotle one is a rebuke $(95 \mathrm{OB})$, one is apparently a partial miscalculation (948A [...]), while the third is of no importance".

${ }_{29}$ Viz. as based, respectively, on Plutarch's ethical (F. Becchi, I975, p. I79 and I978, p. 264) and polemical writings (G.E. Karamanolis, 2006, pp. 92-IO0).

${ }^{30}$ G. Roskam, 20IIb, p. 6I. 
Aristotle was Plato's closest pupil not only chronologically but also intellectually ${ }^{31}$. Although Aristotle is dealt a great deal of criticism by Plutarch $^{32}$, the Chaeronean also has kind words for him, which cannot be said of representatives of other philosophical schools (esp. the Stoics and Epicureans). Aristotle was a 'prominent' ${ }^{33}$ and 'famous' ${ }^{34}$ thinker for Plutarch, and is even called 'the most famous and learned of the philosophers ${ }^{35}$. Sporadically ${ }^{36}$, Plutarch even mentions Aristotle along with his own favourite Plato - whom he considered a 'divine' ${ }^{37}$ philosopher 'pre-eminent in reputation and in influence' ${ }^{38}$, presenting both thinkers as 'the best authorities in the field of philosophy'39.

In a certain way, then, Roskam's and Donini's positions can be reconciled: Plutarch's explicit quotations in no way hint at a decisive adherence to Aristotelian philosophy but in more general utterances, Plutarch does not hide his appreciation of Aristotle and the man's philosophy, if for no other reason than that he was Plato's closest pupil. It remains to be seen, of course, to what extent Plutarch in some cases affirms Aristotle in order to support his own philosophical convictions with the authority of his predecessor (without any further implicit value judgement), whereas in other cases, where he openly criticises Aristotle, he does this in order to prove Aristotle wrong or to demonstrate his own

31 P. Donini, I986a, pp. 220-22I (see also I988, pp. I39-I40 and I44): "Ma [...] non lo considerasse affatto irrimediabilmente lontano dal platonismo: sopprattutto nel confronto con le altre scuole filosofiche l'aristotelismo rivelava a suo giudizio qualche persistente e profonda affinità con il pensiero di Platone in alcune delle questioni di maggior peso nella filosofia. [...] Se infatti Aristotele era, secondo Plutarco, colui che, senza essere precisamente platonico, o academico, rimaneva tuttavia pur sempre di tutti i filosofi non platonici il più vicino al pensiero di Platone." For Plutarch's notion of a close alliance between the philosophy of Aristotle and Plato, cf. also P.H. De Lacy, I953, p. 79. It should be noted that this view is not as such rejected by G. Roskam, 2008/9, p. 25, who argues that the Peripatetic tradition, indeed, "remains fairly close to Platonism [for Plutarch], so that it can often function as Plutarch's privileged ally in his attacks against other schools". Pace G.E. Karamanolis, 2006, p. II5, who argues that "Plutarch considers Aristotle part of the Platonist tradition".

${ }^{32}$ D. Babut, I996, pp. 23-22 points out that 'l' auteur des Moralia n' hésite pas, à l'occasion, à critiquer nommément le fondateur de l'école péripatéticienne, ce qu'il ne fait jamais, il faut le souligner, quand il s'agit de Platon" (Babut's italics).

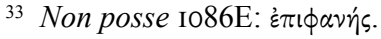

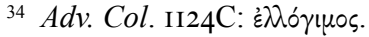

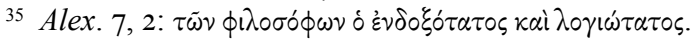

36 Viz. in De aud. poet. 26B, De Is. et Os. 382D, De E 389F, De Stoic. rep. I040A-I04IB and esp. De Is. et Os. 375C and Quaest. Plat. I006D.

37 De cap. ex inim. 90C, Per. 8, I: Өعĩos.

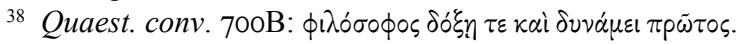

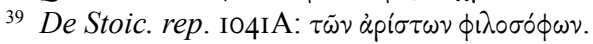


critical skills, thus trying to pass himself as even more philosophically pre-eminent than the Stagirite - a philosophical heavyweight himself.

The collection of Quaestiones naturales offers a manageable text for taking a closer look at Plutarch's reception and evaluation of Aristotle's natural scientific theories (as formulated primarily in the Problems). In some cases, Plutarch criticises specific Aristotelian accounts (Q.N. 2, 9IIF, I2, 9I4F), while on other occasions he gives a more positive evaluation (Q.N. I, 9IIE, 2I, 9I7D), even praising him for his excellent insights into natural science (Q.N. 40; cf. also Quaest. conv. 656C). It would be unwise to make generalisations on the basis of these few accounts (which I will analyse in further detail later on [see 4.2.I.I.]), unless, perhaps, by pointing out that there is not much consistency among them. Roskam is probably right, therefore, that "Plutarch's evaluation of Aristotle is always ad hoc and does not reflect a thoroughly considered general attitude towards the Stagirite" 40 . Nevertheless, Aristotle's authority holds a privileged rank in Plutarch's natural problems, which is why Roskam correctly adds that "Plutarch appears to consider Aristotle [...] a kind of "secretary of nature' [...]. For Plutarch, Aristotle is primarily a Fundgrube of erudition." ${ }^{41}$ What we learn from this is that Plutarch's intellectual marriage with Aristotle is not borne out of "true love" but of utility.

Of course, natural science is only one specific part of Aristotle's much wider philosophical project, and Aristotle himself is only one - seminal link in the tradition of ancient Greek science more generally ${ }^{42}$. It is perhaps not so remarkable, therefore, that Plutarch recurrently invokes Aristotle's authority in his natural problems, while also quoting a large number of

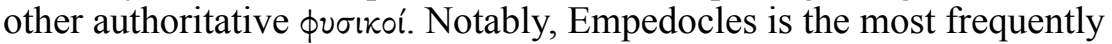
quoted authority in Quaestiones naturales with a total of seven quotations (while Aristotle and Homer share a second place with five quotations each [see 4.I.2.3. and 4.2.I.I.]), and there are also numerous references and allusions to his physical theories (e.g., of emanations $)^{43}$. It would

40 G. Roskam, 20IIb, p. 47.

41 G. Roskam, 20IIb, p. 48.

42 G. Roskam, 20IIb, p. 47 is probably right, therefore, that "Aristotle is a rather small

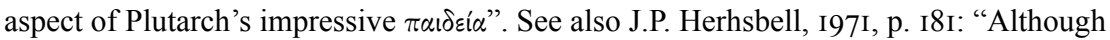
he [sc. Plutarch] was educated by Ammonius in the Academy, and considered Plato the greatest of philosophers, his own thought was somewhat eclectic. He was, for example, open to the influence of the Peripatetics and in some details to the Stoics. Although he polemicized against their principles, he rejected absolutely only the Epicurean system [...]. The influence of the Peripatetics is clear in Quaest. nat. where Plutarch discusses many of the problems propounded by Aristotle and Theophrastus, and where he also uses language employed by the Peripatetics." For Ammonius' interest in Peripatetic science, see the conclusion in J. Opsomer, 2009, p. I77.

43 According to J.P. Hershbell, I97I, pp. I72-I73 it is not implausible that some of Plutarch's citations of Empedocles derive from the works of Aristotle and Theophrastus, 
seem a bit impetuous to conclude that the Chaeronean was, therefore, an Empedoclean scientist. In any case, Empedocles' elemental and emanation theory had become common currency in ancient scientific thinking already by the time of Plato ${ }^{44}$.

Nevertheless, there is an obvious connective thread throughout Plutarch's natural problems that strikes the reader as being highly Aristotelian and obviously in line with the Stagirite's causal model of scientific research. Even if these natural problems portray a peculiar aspect of Plutarch's versatile inquisitive interests in the natural world, we do not necessarily have to rely on the nominatim quotations from Aristotle alone

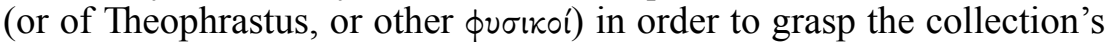
Aristotelian character. One can simply take into consideration the obvious, but often implicit, parallels in Aristotle's or Theophrastus' writings and the general scientific discourse and style of Plutarch's physical aetiologies: these are teeming with scientific terminology and physical theories that are commonly attested to in the works of the Peripatetics, and most obviously in Ps.-Aristotle's Problems ${ }^{45}$ [see 4.3.4.]. So even though Plutarch presents himself as a faithful Platonist, it might, thus, seem as though he did not see anything wrong with openly flirting with what he himself, and his contemporaries, would probably consider to be Peripatetic reasoning. One might find it remarkable, in any case, that as long as this Peripatetic affair lasts, Plato and Platonic thought seems to be pushed to the margins.

When it comes to statistics, Plato is quoted only three times in Quaestiones naturales (on a par with Theophrastus [see 4.2.I.I.]). This could imply that Plutarch's thoughts in this collection were not, or at least far less, with his "true love" in philosophy. But insofar that the number of explicit quotations does not necessarily provide conclusive proof of this, it should not be taken for granted that Quaestiones naturales exhibits Plutarch's Peripatetic aspirations in the absence of a potentially underlying

although the large quantity of quotations may also suggest that he knew the complete poems, or worked with one or more collections of fragments [see 4.I.2.3., n. 92]. See also D. Babut, I976, p. I43 (with n. 22).

${ }^{44}$ I here allude to the conclusion that was drawn for Empedocles' alleged influence on Plato's Timaeus by J.P. Hershbell, I974, pp. I65: "No doubt it can be presumed that Empedocles' views became common currency in Antiquity and that Plato was familiar with them [...], but from this it does not follow that Empedocles' influence on the Timaeus was as great as Taylor claimed." See A.E. Taylor, I928, p. II.

${ }^{45}$ Cf. G. Roskam, 20Irb, p. 39: "In his Quaestiones naturales [...] Aristotle is mentioned only four times (9IIE, 9I2A, 9I4F and 9I7C [excluding Psellus' Q.N. 40]), although Plutarch elsewhere too makes use of Aristotelian (and Peripatetic) material. Even the genre itself of the work can obviously be traced back to the Ps.-Aristotelian Про $\beta \lambda \eta \dot{\mu} \mu \tau \tau \alpha$ literature." G.W.M. Harrison, 200ob, p. 239 argues that "[o]f the thirty-one quaestiones preserved in the Planudean tradition, only nine do not have recognisable references to passages within surviving works of Aristotle and Theophrastus". 
Platonic agenda - a view that has, in any case, been suggested for the Peripatetic tendencies in the natural problems of Quaestiones convivales ${ }^{46}$. Oikonomopoulou saves the day when she notes that "Peripateticism is a key intellectual strand within Plutarch's Table Talk, second only to the position Platonism holds in its intellectual universe" ${ }^{\text {. }}$. Exemplary is the way in which Plutarch in Quaest. conv. $700 \mathrm{~B}$ tries to vindicate Plato's contested view that drink passes through the lungs. This passage (which I will discuss in detail later [see 4.3.2.I.]) clearly illustrates Plutarch's high opinion of Plato, Platonic doctrine and Platonic epistemology (c.q. his sceptical attitude towards natural phenomena and observational data). One may still wonder, though, in which precise sense Peripateticism is "second" to Platonism for Plutarch. I) Is Plutarch, perhaps, deliberately assuming a Peripatetic persona in his natural problems in order to demonstrate his all-round philosophical acumen and education, without wanting to be counted among Aristotle's ranks? 2) And/or is he perhaps trying to get a few steps closer to his "true love" in philosophy (Plato) by approaching the thought of his closest peer (Aristotle)?

I) As to the first option, Kechagia has recently made an interesting suggestion ${ }^{48}$. She argues that while the Peripatetic character of the natural problems in Quaestiones convivales is an identifying feature of the symposiasts' explanations (including those of Plutarch's literary alter ego), this most likely does not provide a strict indication of Plutarch's philosophical allegiance. After all, the symposiasts that Plutarch stages in his dialogues often adhere to different philosophical schools but they still share the very same interests and knowledge of the, in that case, more 'generic' Peripatetic tradition. This would imply that the theories and concepts of the Aristotelian tradition of natural problems (much like Empedocles' physical theories, as we saw) had become common currency by the time of Plutarch [see also 4.3.4.3.]. This argument is not necessarily incompatible with the second.

2) Plutarch most likely conducted this kind of physical-aetiological research with a basically Platonic motive in mind, through which explaining natural phenomena serves as a preamble to more metaphysical contemplations. I will elaborate this view in full detail later on, but it can already be said that the inquisitive method Plutarch employs in explaining particular phenomena - as provided by the interrogative structure and anti-dogmatic approach of the natural problem genre - is, as far as the

${ }^{46}$ For the Peripatetic influence in Quaestiones convivales, see S.-T. Teodorsson, I999a, K. Oikonomopoulou, 20II and M. Meeusen, 20I6. As to Plutarch's Platonism and "peutêtre le côté aristotélicien de sa formation" in Quaestiones convivales, cf. J. Sirinelli, 2000, p. 387. See also Z. Abramowiczówna, I962, p. 88.

${ }^{47}$ K. Oikonomopoulou, 20II, p. I05. Cf. also R. Lopes, 2009, p. $4 \mathrm{I} 9$.

${ }^{48}$ E. Kechagia, 20IIa, p. 98. 
Chaeronean is concerned, informed by the author's Platonic-Academic convictions, according to which one cannot reach definite certainty in the study of nature, so that one should hold to plausible arguments ( $\tau \dot{0}$

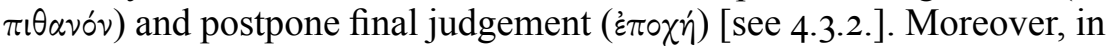
line with Plutarch's Platonic dualism, the practice of solving enigmatic natural problems is a useful exercise in looking for natural explanations for wonder-inducing phenomena [see 4.I.2.]. As such, physical aetiology trains the philosopher's mind and opens up the possibility for attaining a more stable stance towards natural 'miracles', and hence towards the working of divine providence in the world. This, in turn, enables a more intellectual devotion to the divine ( $\varepsilon \dot{v} \sigma \varepsilon \hat{\varepsilon} \varepsilon 1 \alpha)$ that does not succumb to the irrational reflex of superstition or, worse even, atheism. As such, so I will elaborate later on, Plutarch's science of natural problems is not just the product of a $\pi \varepsilon \pi \alpha i \delta \varepsilon v \mu \varepsilon$ v $v \varsigma^{\prime}$ scholarly pastime, but a lighter version of genuine philosophy [see 3.2.2.].

Clearly, this is not the right place to elaborate these theories in any detail. At this point, it is better to start from the beginning and situate Plutarch's Quaestiones naturales in the wider context of the Aristotelian tradition of natural problems - to which it, if not from a strictly intellectual, at least from a genre perspective, adheres.

\section{The genre of problems and the Aristotelian tradition of natural problems}

The genre of problems ( $\pi \rho \circ \beta \lambda \eta \dot{\mu} \mu \tau \alpha)$ has a long history that starts with early Homeric scholarship. The study of the works of the Poet raised numerous problems regarding literary quality, consistency, interpretation etc. Ancient scholars employed several approaches in order to solve these problems, ranging from purely philological (e.g., regarding problems of grammar, style and prosody) ${ }^{49}$ to allegorical (e.g., by explaining the actions of the Homeric Gods in terms of cosmic principles) and moralisingapologetic (using Homer's texts as a platform for moral education by demining - i.e. providing an 'apology' for - passages that were considered morally objectionable: cf. De aud. poet. 28E). Problems related to Homer's writings were still very popular in Plutarch's time - indeed, Plutarch himself composed a collection of 'Ounpıкаi $\mu \varepsilon \lambda \varepsilon \dot{\tau} \tau \alpha$ (from which only frs. I22-I27 Sandbach remain) $)^{50}$.

49 A. Gudeman, I927, col. 25I2 even speaks of the "Geburtstunde der philologische Wissenschaft". See also W.J. Verdenius, I966 and W. Bühler, I977 more generally.

${ }^{50}$ Notably, Aristotle also composed a series of questions related to Homer's writings (see G.L. Huxley, I979, S. Halliwell, I989 and R. Mayhew, 2015c). We also have a collection of Quaestiones Homericae (also known as the Allegoriae) by Heraclitus, the Stoic grammarian and rhetorician from the $\mathrm{I}^{\text {st }}$ century AD (see D.A. Russell, 2003 and D.A. Russell and D. Konstan, 2005). 
Relatively soon, the genre expanded to specific passages in other texts as well, and even to particular statements, opinions and realia of other sorts (e.g., cultural, historical, scientific etc.). Along with the art of philology, the genre of problems flourished during the Hellenistic era, particularly in the Museum of Alexandria ${ }^{51}$. The custom of solving problems was still prevalent during Plutarch's time, even amongst the most highly-placed authorities. For instance, it is said of Emperor Hadrian - arguably the most Hellenophilic of them all - that he posed a number of questions to the scholars at the Museum and also provided responses to those addressed to himself $f^{52}$. This clearly reveals the popularity of the question-and-answer genre and its established reputation in the highest socio-political circles at the time.

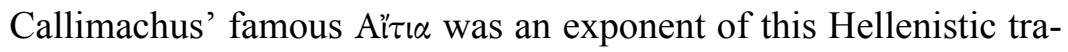
dition. In this poem, the author used elegiac form and metre to explain obscure cultural phenomena (such as cults and temple ceremonies, origin stories of cities, odd local institutions and habits throughout the Hellenic world $)^{53}$. Plutarch does not cite Callimachus' Ai i $1 \alpha$ very frequently; yet, he is well acquainted with such aetiological literature more generally ${ }^{54}$. Indeed, Plutarch's own cultural and antiquarian enthusiasm is clearly exhibited in his Quaestiones Romanae and Graecae, albeit in prose form.

As to the genre of problems, the Greek term $\pi p o ́ \beta \lambda \eta \mu \alpha$ implies in its most basic meaning "anything thrown forward or projecting"; it most likely originates from military tactics, where it refers to "anything put before one as a defence", that is, an entrenchment, a barricade or barrier, a bulwark, or an obstacle set up to guard oneself against an adversary ${ }^{55}$. The metaphorical value of this concept in light of the literary-intellectual genre of problems

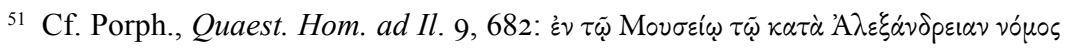

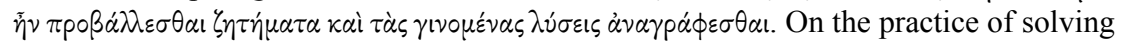
problems in the Museum, see W.J. Slater, 1982, pp. 346-349. An allusion to this Museumlike setting is perhaps found in Book 9 of Plutarch's Quaestiones convivales, which is set

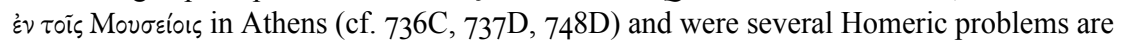
discussed. Cf. Also, e.g., Sept. sap. conv. 153E-154A.

52 See Spart. Ael., Hadr. 20, 2: apud Alexandriam in Museo multas quaestiones professoribus proposuit et propositas ipse dissolvit.

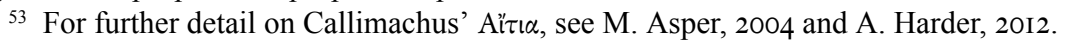

${ }^{54}$ For a collection of Callimachus passages in Plutarch, see E. Magnelli, 2005, pp. 2I8-

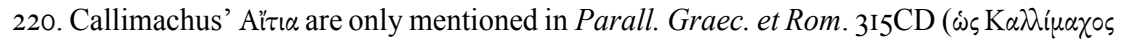
$\dot{\varepsilon} \nu \delta \varepsilon v \tau \varepsilon \dot{p} \omega$ Ai $\tau i \omega \nu)$. For Plutarch's references to other aetiological authors, see Amatorius

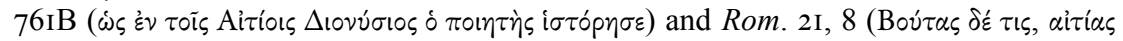

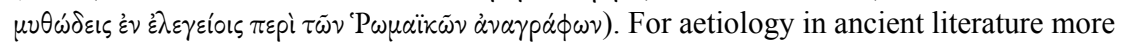
generally, see A. Harder, 20I2, pp. 24-27 (esp. p. 26) and the contributions in M. Chassignet, 2008.

${ }^{55}$ LSJ, s.v. i and ii. Cf., e.g., Comp. Arist. et Ca. Ma. 2, 4, where Cato Maior's

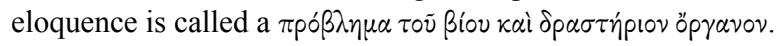


is relatively plastic: in order to reach the truth that lies within or behind the problematic stronghold or obstacle, the difficulties that surround it like walls or defend it like weapons are assailed by means of a suitable solution. The verbal pun is clear in a passage in Plato, where sophists are said to entrench themselves behind their 'problems' ( $\pi \rho \circ \beta \lambda \eta \mu \alpha \dot{\tau} \omega \nu)$. In order to catch and expose these men, so Plato writes, the adversary must first 'fight

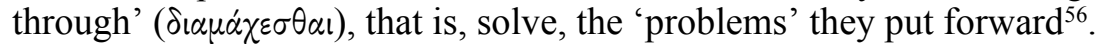

Traces of the genre of problems can already be found in the Hippocratic writings ${ }^{57}$. According to the tradition, however, Democritus was the first to

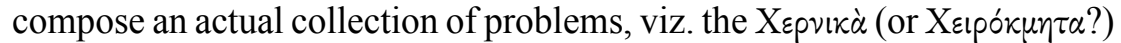
$\pi p o \beta \lambda \eta \dot{\mu} \mu \alpha \alpha$ (D.L. 9, 49 = DK68A33 and DK68B299h). Unfortunately, this collection is no longer extant ${ }^{58}$. Some scholars even saw Democritus as a precursor to Peripatetic natural science ${ }^{59}$, but Aristotle was, without a doubt, the most preeminent philosopher to attach his name to the tradition of natural problems with such authority. As we just saw, before Aristotle, Plato also used the word $\pi \rho o ́ \beta \lambda \eta \mu \alpha$ in his philosophical dialogues (and derived from it $\pi \rho \circ \beta \alpha^{\prime} \lambda \lambda_{\varepsilon v}$ : 'to propose a problem' $)^{60}$. Therefore, scholars have come to consider the Socratic elenchus - that is, the method of cross-examination by question and answer - an important precursor of the Aristotelian concept of $\pi \rho$ ó $\beta \lambda \eta \mu \alpha^{61}$. Aristotle, however, incorporated the concept of $\pi p o ́ \beta \lambda \eta \mu \alpha$ into his analytical system by attributing it with its own dialectical designation and by underlining its use in the context of scientific inquiry ${ }^{62}$.

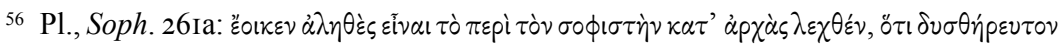

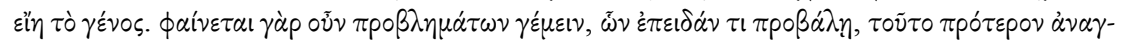

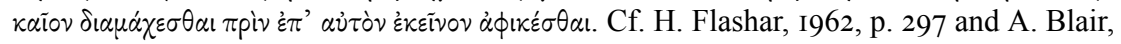
I999, p. I72.

57 See, e.g., Hipp., De diaet. in morb. ac. 7 (3, 5-I4 Littré) and Epid. 6, 2, 5 (5, 278-280 Littré). Cf. H. Diller, 1934 and H. Flashar, I962, pp. 298-299. See also n. 74 below.

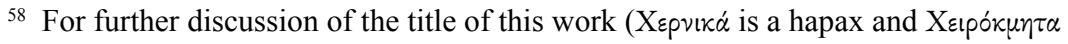
uncertain; cf. DK68B300), see H. Flashar, 1962, pp. 302-303, F. Krafft, 1969.

59 See O. Regenbogen, I93I, p. 349. For a study of Democritus' model of causal research, see P.-M. Morel, 1996. See also esp. S. Menn, 2015 for the link between Democritus' aetiological project and the Ps.-Aristotelian Problems.

${ }^{60}$ Cf., e.g., Pl., Rep. 53ob, 53Ic, Tht. I8oc, Soph. 245b, 26Ia, Pol. 285d.

${ }^{61}$ For the link between Socratic elenchus and the Aristotelian concept of $\pi p o ́ \beta \lambda \eta \mu \alpha$, see J.G. Lennox, 200I, p. 72 and 20I5, p. 36 (on Socratic elenchus itself, see G. Vlastos, 1983). However, as opposed to the style of Plato's dialogues, Ps.-Aristotle's Problems have a more monologic nature, see P. Louis, I99I, pp. xxi-xxii: "Au contraire de la dialectique platonicienne qui met en présence deux interlocuteurs, l' un qui questionne et l'autre qui répond, le problème aristotélicien ne met en scène qu' un seul personnage, l' auteur qui formule la question et qui suggère lui-même une ou plusieurs réponses. Il appartient ensuite au lecteur de se faire une opinion."

${ }^{62}$ Cf. LSJ, s.v. iv, 3. 
There are several passages in Aristotle's writings that are seminal for an analysis of his notion of $\pi p o ́ \beta \lambda \eta \mu \alpha^{63}$. According to the definition in the Topics, a $\pi p o ́ \beta \lambda \eta \mu \alpha$ is a dialectical subject of investigation $(\delta 1 \alpha \lambda \varepsilon \kappa \tau i \kappa o ̀ v$ $\theta \varepsilon \dot{\omega} p \eta \mu \alpha)$ about which people either have no opinion or one that differs among intellectuals and/or the people ${ }^{64}$. Aristotle notes that problems involve conflicting arguments, provoking doubt about whether ( $\pi$ ó $\tau$ p $о \nu$ ) something is so or not by the fact that there are plausible arguments to support both sides. They can also concern important topics about which we have no arguments at all, since we think it is difficult to give a proper reason ( $\tau \grave{\partial} \delta i \dot{\alpha} \tau i)$ : e.g., whether the universe is eternal or not ${ }^{65}$. In Top. I05bi9-2I, Aristotle makes a distinction between three kinds of problems: ethical, natural and logical. For the second category, Ps.-Aristotle's Problems come to mind, considering their mainly natural scientific content. In this work, often more than one explanation is given to a problem, and the explanations are mostly formulated in an interrogative and anti-dogmatic fashion, leaving place for further debate. This means that multiple plausible explanations can be formulated in order to solve the problem ${ }^{66}$.

Strictly speaking, however, the natural problems collected in Ps.Aristotle's Problems are no dialectical problems, because they do not

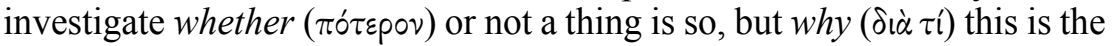
case (see n. 90). As such, it is assumed that the subject of investigation, that is, the problematic natural phenomenon at issue, is a positive fact, the legitimacy of which is not subject to debate. Arguably, the real dialectical problems are the tentative explanations provided in the aetiologies, since they are formulated interrogatively (expecting acceptance or rejection) and, thus, serve as starting-points for further discussion. As we shall see later on, the causal inquiry marked by $\delta i \dot{\alpha} \tau i$, as in the case of Ps.Aristotle's Problems, ties in more closely with the framework of Aristotle's

${ }^{63}$ Esp. Arist., Top. I04bI-28. Aristotle distinguishes a $\pi p o ́ \beta \lambda \eta \mu \alpha$ from a proposition

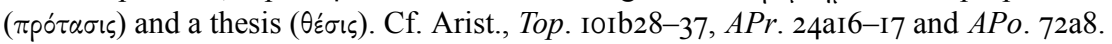
On this distinction, see P. Moraux, I95I, p. 7I and P. Louis, I99I, pp. Xx-xxi. For further study of Aristotle's types of questions concerned with problems, see J.G. Lennox, 200I (esp. pp. 77 and 87 with reference to the Ps.-Aristotelian Problems), 2015 and J. Mansfeld, 20Io, pp. 4I-49 (esp. p. 43, n. 34 with reference to the Problems).

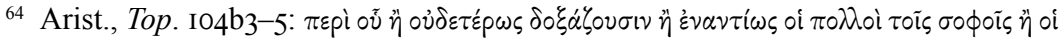

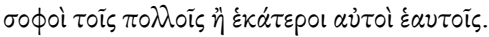

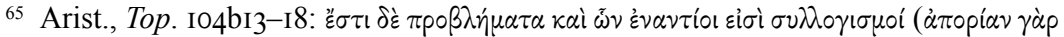

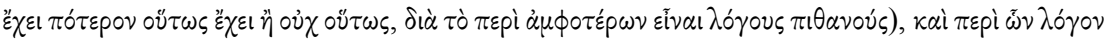

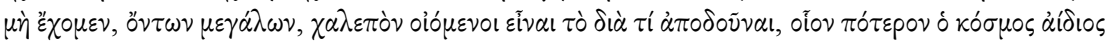
$\ddot{\eta} \circ \ddot{v}$.

${ }^{66}$ Notably, in Top. I05bi3-19 Aristotle underlines the use of drawing up thematic lists of doxographical material for the formulation of propositions and problems (cf. also Met.

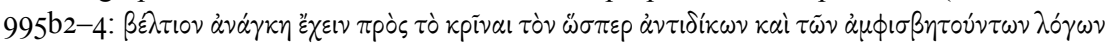
$\dot{\alpha} \kappa \eta \kappa o o ́ \tau \alpha ~ \pi \alpha ́ v \tau \omega \nu)$. See J. Mansfeld, 20IO, pp. 45-46. 
natural scientific (rather than strictly dialectical) method of investigation as expounded in the Posterior analytics and put to action in the Stagirite's writings on natural science (e.g., Parts of animals, Meteorology etc.). In these writings, the examination of the $\delta i \dot{\alpha} \tau i$ of a specific natural phenomenon introduces a second phase in the scientific inquiry, after having determined the actual, empirical veracity, that is, the ö $\tau$, of that phenomenon (see APo. 89b24-35 - I will discuss this passage later in view of Plutarch's own approach of natural problems [see 4.I.I.3.]).

There can be no doubt that the Ps.-Aristotelian Problems served as a model for Plutarch's natural problems. This is true at least for the kind of problems dealt with and for their overall structure and organisation. Scholars have pointed out that it is unlikely, however, that Plutarch relied on the same collection as we have today. The collection of Ps.-Aristotelian Problems that came down to us (in 38 Books) is the result of a complex textgenetic process, being the product of centuries of textual accumulation, contamination and reorganisation. It is generally accepted that Aristotle initiated the work by authoring an unknown number of chapters in it, but most of the content should be ascribed to his acolytes in the Lyceum. Indeed, Aristotle's students probably continued the Stagirite's original collection by adding new problems and revising older ones ${ }^{67}$. Therefore, scholars agree that only parts of the Problems, in its current form, are authentic, but it is impossible to determine with absolute certainty which are and which not. Notably, the question of authenticity does not, however, seem to have been of concern to Plutarch and his peers ${ }^{68}$ - and, indeed, the Problems do not necessarily have to be authentic to be considered 'Aristotelian'.

The formal edition of Aristotle's works by Andronicus of Rhodes in the $\mathrm{I}^{\text {st }}$ century $\mathrm{BC}$ introduced an important phase in the textual history of the Problems. It was probably Andronicus' edition that was used by Plutarch (and a wide range of other authors, such as Cicero, Strabo, Seneca, Pliny, Gellius, Apuleius, Galen and Athenaeus), but this is not the same collection of Problems as the one we have today ${ }^{69}$. The final

${ }^{67}$ For a detailed study of this compositional process, see the introductions in $\mathrm{H}$. Flashar, I962 and P. Louis, I99I, pp. xxiii-xxxv. See also R. Mayhew, 20IIa, pp. xvii-xxi. Among

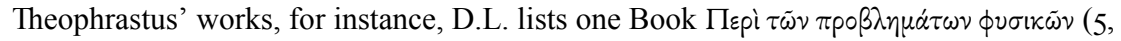

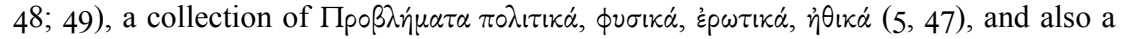

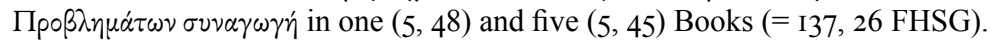

${ }^{68}$ See, e.g., K. Ziegler, I95I, col. 922, F. Fuhrmann, I972, p. xxi, P. Louis, I99I, p. xvi, K. Oikonomopoulou, 20II, p. I06, M. Meeusen, 2016.

${ }^{69}$ See H. Flashar, I962, pp. 3I2-3I4 (and 369-370) and P. Louis, I99I, pp. xxxi-xxxiii. Regarding the passage in Quaest. conv. 734CD [quoted 3.2.I.], where Florus is reading and

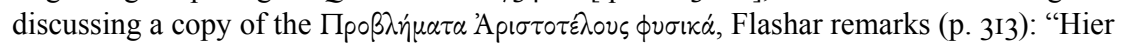
hat man den Eindruck, daß es sich um ein bestimmtes Werk 'Problemata' handelt, nicht 
redaction of the Ps.-Aristotelian Problems probably took place at the end of the $2^{\text {nd }}$ century $\mathrm{AD}^{70}$. Andronicus' new edition is generally considered a catalyst for the revival of the genre of natural problems in the early Greco-Roman Empire (esp. in the $\mathrm{I}^{\text {st }}$ and $2^{\text {nd }}$ centuries AD), a period that also witnessed the composition of several new collections of natural and medical problems by various authors. In his monumental study of the Problems, Flashar classified Plutarch's natural problems among these new collections, next to I) the Supplementary problems in three Books (formerly known as the Problemata inedita), variously attributed to Aristotle and Alexander of Aphrodisias (but considered spurious today $)^{71}$, 2) the two Books of Medical puzzles and natural problems ascribed to Alexander of Aphrodisias (but probably spurious) ${ }^{72}$, and 3) the Medical difficulties and natural problems of Cassius (Felix?), surnamed the Iatrosophist ${ }^{73}$. These collections demonstrate how the Aristotelian genre of natural problems became embedded in the medical tradition in the Imperial Era. As we saw, medical problems were already raised in the Hippocratic writings. ${ }^{74}$ In fact, the Ps.-Aristotelian Problems themselves contain a section specifically devoted to medical issues (viz. the very first

um verschiedene Schriften dieses Genus, die untereinander nur locker oder überhaupt nicht verbunden wären."

70 See P. Louis, I99I, pp. xxxiii-xxxvi. For the complex date of Ps.-Aristotle's Problems, see also H. Flashar, 1962, pp. 356-358.

71 This collection was first edited as Problemata inedita by U.C. Bussemaker in I857 (pp. 29I-334) and has recently been re-edited under the heading of Supplementa problematorum by S. Kapetanaki and R.W. Sharples, 2006. For the issue of authenticity, see $\mathrm{n} .72$ below.

${ }^{72}$ This work was first edited by J.L. Ideler, I84I, pp. 3-80 (not to be confused with

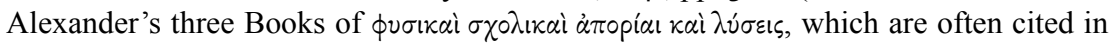
modern literature as Alexander's Quaestiones). In I859, Usener annexed the two first Books of Bussemaker's Problemata inedita to Ideler's edition, by heading them Alexandri Aphrodisiensis quae feruntur problematorum libri 3 et 4 . Thus, he believed that all four Books formed a collection of medical puzzles and physical problems circulating under the name of Alexander of Aphrodisias, but, as S. Kapetanaki and R.W. Sharples, 2006, pp. I6 and 27 have pointed out, the association of Bussemaker's first two Books (= Usener's Books three and four) with Alexander is no stronger than their connection with Aristotle. Ideler's two Books are also generally considered spurious. It is notified by Kapetanaki and Sharples (p. I, n. I) that Carl-Gustaf Lindqvist of Gothenburg university is preparing a new edition of this text, the forthcoming of which is still eagerly awaited. For an attempt to outline the complex bibliographical details on Ps.-Alexander's collection, see R.W. Sharples, I987, pp. II98-II99.

${ }_{73}$ This collection was first edited by J.L. Ideler, I84I, pp. I44-I67, and has recently been re-edited by A. Garzya and R. Masullo, 2004.

${ }^{74}$ See $\mathrm{n} .57$ above. There is also a Byzantine collection of Hippocratic problems, on which, see A. Guardasole, 2007. 
Book: ¿̊ $\sigma \alpha i \alpha \tau p ı \alpha)^{75}$. Moreover, medical question-and-answer literature was common in the Greco-Roman period. It can be found, for instance, in Soranus' Gynaecia, in Ps.-Soranus' Quaestiones medicinales ${ }^{76}$ and in a number of medical catechisms written on papyrus ${ }^{77}$. Plutarch's natural problems incorporate much medical material (e.g., by quoting renowned doctors [see 4.2.I.I., nn. IIO-III]), but they are more generally naturalist in kind, as is its Aristotelian model.

The longstanding popularity of the genre of natural problems is confirmed by the fact that it flourished well beyond the chronological and geographical boundaries of Antiquity and the Occident. Collections of natural problems were still composed during the Middle Ages and the Renaissance, and the Ps.-Aristotelian Problems were transmitted in a number of different languages such as Syriac, Arabic, Hebrew, Latin and the vernacular ${ }^{78}$. Perhaps the most important aspect of this brief outline of the history of the Problems is the idea that we are dealing with a vast corpus of ancient scientific knowledge that is open to textual evolution, reorganisation and accumulation and is deeply rooted in Aristotle's causal project of scientific research ${ }^{79}$. An important feature of Plutarch's natural problems, then, is the fact that they - at least from a genre perspective contribute to the Aristotelian tradition, to which they add new problems and from which they revise older ones by looking for new solutions ${ }^{80}$.

75 Much of the medical content in Ps.-Aristotle's Problems (not only in the first Book) is, indeed, Hippocratic in nature. Fur further detail, see F. Poschenrieder, I887, pp. 38-66, H. Flashar, I962, pp. 338-340, J. Bertier, I989, J. Jouanna, I996, C. Jacob, 2004, pp. 44-45, A. Ulacco, 20II, R. Mayhew, 20I5b, K. Oikonomopoulou, 20I5, O. Thomas 20I5. The Problems and their inquisitive method were well-known to Galen. See, e.g., SMT II, 474

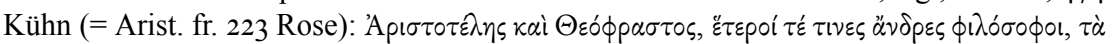

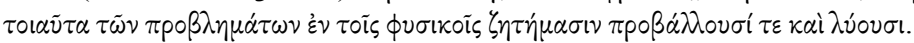

${ }^{76}$ First edited by V. Rose, I870, pp. I6I-240. A new edition of this text is being prepared by Klaus-Dietrich Fischer of Mainz university (for further detail, see K.-D. Fischer, I998).

77 These medical catechisms are doctrinal manuals organised according to a clear structural pattern, viz. by a sequence of definitions, causes, signs, characteristic features and therapies of diseases. For further literature, see D. Leith, 2009. For the questionand-answer format in medical literature more generally, see A.M. Ieraci Bio, 1995 (esp. pp. I9I-I92).

${ }^{78}$ Particularly useful here are H. Flashar, I962, pp. 370-382, A. Blair, I999 and the contributions in P. De Leemans and M. Goyens, 2006 (with a selected bibliography at pp. 295-317). See also esp. B. Lawn, 1963 and L. Filius, 1999.

${ }^{79}$ Cf., e.g., F.H. Sandbach, 1982, p. 225 and C. Jacob, 2004, p. 43. For the 'encyclopaedic' nature of problem literature (with a central focus on Plutarch's collections of quaestiones), see K. Oikonomopoulou, 20I3a.

${ }^{80}$ Cf. F.H. Sandbach, I965, p. I38: "As things are, we can say no more than that Quaestiones Naturales seem to be a compound, in unknown proportions, of traditional and newly adduced solutions." 
Notably, in several of his natural problems, Plutarch emphatically deals with phenomena that remained unexplained or were, in his opinion, explained inadequately by Aristotle. In Quaest. conv. 650A, for instance, (concerning the problem of why old men especially are susceptible to drunkenness and women least) Florus works out an explanation ( $\alpha i \tau i \alpha)$

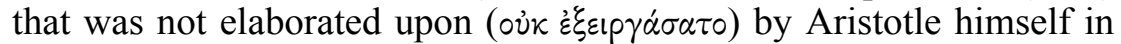

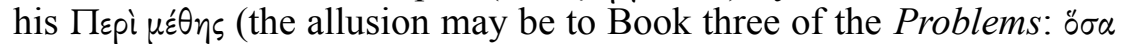

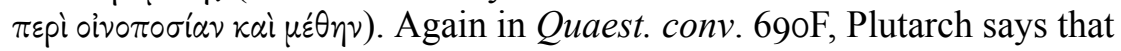
the natural phenomenon at issue (according to which pebbles or lumps of metal seem to cool and temper the water in which they are thrown) is recorded by Aristotle in his Problems but is not explained there, so

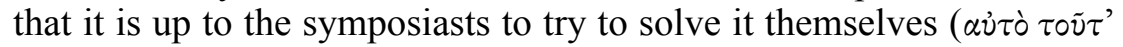

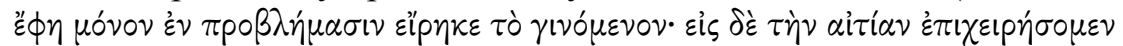
$\dot{\eta} \mu \varepsilon \tilde{\zeta})$. As we will see later on, similar passages are found in Quaestiones naturales where Aristotle's (or more broadly Peripatetic) theories often serve as a point of departure for Plutarch's physical aetiology. Arguably, then, Plutarch tried to fill in a number of gaps in the Aristotelian tradition of natural problems, and, by extension, in the contemporary scientific paradigm of his time - at several occasions he is, in any case, proud enough to have added something of his own to this $\operatorname{tradition}^{81}$ [see 4.2.2.2.].

Plutarch was well acquainted with the Aristotelian natural problem tradition (from which he not only draws in his natural scientific works, for that matter) ${ }^{82}$. Apart from the explicit (i.e. nominatim) quotations, Plutarch probably also alludes to the Problems a number of times without mentioning Aristotle's name ${ }^{83}$. In these cases, exact source passages cannot be conclusively determined. Indeed, it may well be that in these allusive accounts Plutarch was generally inspired by what Aristotle wrote, so that a clear correspondence is not only unlikely to be found but also

${ }^{81}$ For the idea that Plutarch in his natural problems progresses the science of his day one step at a time, see M. Meeusen, 20I6. The same counts, mutatis mutandis, for

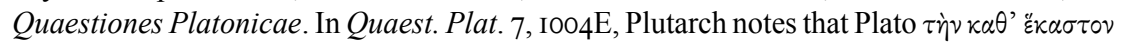

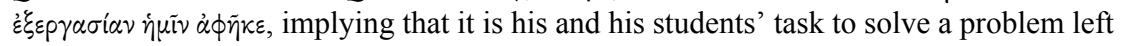
unanswered by Plato.

${ }^{82}$ E.g., in De coh. ira 458F-459A, Plutarch relies on Ps.-Arist., Probl. 875a34-35 (about Satyrus of Clazomenae stopping up his ears with wax in order not to hear the insults of his opponents).

${ }^{83}$ See W. Capelle, I9I0, pp. 329-330, n. 2: "Unzweifelhaft sind aber solche 'aristotelischen' Problemata noch an ungezählten Stellen von Plutarch, Gellius, Galen u.a. benutzt, wo der Name Aristoteles nicht genannt bzw. die Quelle verschwiegen wird." Cf. also H. Flashar, I962, pp. 308 and 3I2-3I3. For lists of Plutarch's references and allusions to the Problems, see W.C. Helmbold and E.N. O’Neil, I959, pp. 9-IO, H. Flashar, I962, pp. 369-370, F.H. Sandbach, I982, pp. 223-225, P. Louis, I99I, pp. xvi and xxxi-xxxii, E.N. O'Neil, 2004, pp. 82-83 and G. Roskam, 20II, pp. 45-46. 
unnecessary to be looked for - the Problems, thus, serving as a more abstract and flexible intertext (this is, indeed, much in line with the argumentative creativity that is so central to the genre [see 4.2.2.2.]). As to the explicit quotations, on the other hand, some are probably derived from the Problems but cannot be traced in the extant collection (or in other Aristotelian works), so that we are presumably dealing with excerpts from problems that are now lost - of course, this also remains hypothetical ${ }^{84}$. On other occasions, Plutarch's text - either in the explicit quotations or in the implicit allusions that are not labelled with Aristotle's name - contains significant parallels with Ps.-Aristotle's/Alexander's Supplementary problems and Ps.-Alexander's Medical puzzles and natural problems rather than with Ps.-Aristotle's extant Problems ${ }^{85}$. This has led scholars to assume that there must have been a common source, viz. an earlier version of the Problems that is now lost - presumably Andronicus' edition (see above) ${ }^{86}$. There are indications that Plutarch, indeed, drew on a version of Peripatetic problems that was more extensive than the one we have today. But how much more extensive this collection really was cannot be determined ${ }^{87}$. Bottom-line is that the Aristotelian genre and tradition of natural problems, with its typical content, style and organisation, had a major influence on Plutarch's own composition of natural problems ${ }^{88}$.

${ }^{84}$ See H. Flashar, 1962, p. 313. For the remains from the lost Problems, see frs. 209-245 Rose.

85 See H. Flashar, I962, pp. 360 (with n. I), 367, 369 and S. Kapetanaki and R.W. Sharples, 2006, p. I2. Cf., e.g., De Pyth. or. 395F and Ps.-Arist./Alex. Aphr., Suppl. probl. 3, 17; Quaest. conv. 689E-69oB and Ps.-Arist./Alex. Aphr., Probl. ined. 3, 5I (not recorded in the Supplementary problems; see S. Kapetanaki and R.W. Sharples, 2006, p. 7, n. 47); Q.N. 12, 914F and Ps.-Arist./Alex. Aphr., Suppl. probl. 3, 29 and 47; Q.N. 2I, 917BD and Ps.-Arist./Alex. Aphr., Suppl. probl. 2, I44, I45, I55 (=Probl. ined. 2, I4I, I42, I52 respectively); De facie 932BC and Ps.-Alex. Aphr., Probl. 2, 46 (J.L. Ideler, I84I, p. 65, I8-32) etc.

${ }^{86}$ See H. Flashar, I962, p. 369 and P. Louis, 199I, p. xxxii. For a list of parallels between Ps.-Aristotle's Problems and the Problemata inedita/Supplementa problematorum, see U.C. Bussemaker, I857, p. x and S. Kapetanaki and R.W. Sharples, 2006, p. 4 (see also the index, at p. 283). H. Flashar, I962, pp. 364-365 counts 3I parallel problems between Ps.-Aristotle's Problems and those ascribed to Alexander of Aphrodisias, and I6 in the collection of Cassius the Iatrosophist (p. 368). See also A. Garzya and R. Masullo, 2004, p. I3.

87 The lists of Aristotle's works mention a collection of Problemata (physica) in 70 Books (to which the name of the otherwise unknown Eucaerus is sometimes linked). The ancient evidence for this 70 Book version is provided by Vita Marciana 427, $8 \mathrm{R}^{3}$, index Hesychii nr. I68 and Elias' commentary on Aristotle's Categories II4, I2-I3. See P. Moraux, I95I, pp. 280-28I, H. Flashar, I962, pp. 3I2-3I4, P. Louis, I99I, pp. xxxi-xxxiii.

${ }^{88}$ For the conceptual distinction between sources and traditions, see J. Mansfeld, I999, pp. 29-30. 
In what follows, I will further explore the 'problematic' organisation of Quaestiones naturales, first at micro- and then at macrostructural level.

\section{Internal organisation of Plutarch's natural problems (microstructure)}

There can be no decisive answer as to whether Plutarch was familiar with Aristotle's definition of $\pi p o ́ \beta \lambda \eta \mu \alpha$ and its systematic integration in Aristotelian logic, as outlined above ${ }^{89}$. The Lamprias catalogue does

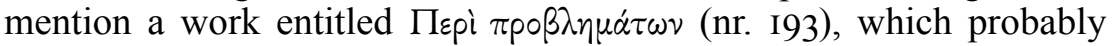
provided a great deal of useful information about the proper phrasing, structuring, method and general purpose of the genre of problems (not only natural problems for that matter), but the text is now lost ${ }^{90}$. Perhaps this work could also have shed light on the author's own appreciation of the genre. Unfortunately, though, we can only speculate about its original content. Nevertheless, we can still learn a great deal from Plutarch's collections of problems that are preserved.

The genre of problems covers a considerable share of Plutarch's entire literary production. The Lamprias catalogue lists a significant number of collections of Airía among Plutarch's writings, several of which are still extant today, while others are now lost or partially preserved in fragmentary form ${ }^{91}$. Among these collections, Quaestiones naturales

${ }^{89}$ C. Darbo-Peschanski, I998, p. 22 remains sceptical, but for the possibility of Plutarch's acquaintance with Aristotle's Topics, see F.H. Sandbach, I982, pp. 2I2-2I3 (and 230).

${ }^{90}$ It is unknown whether this work was authentic. Notably, D.L. 5, 23 mentions the

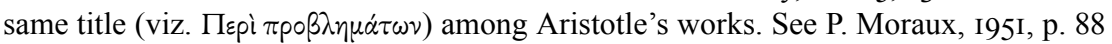
and P. Louis, I99I, p. xx, n. 50. One fragment remains from Aristotle's Пвpi $\pi \rho \circ \beta \lambda \eta \mu \alpha \dot{\tau} \omega \nu$, which concerns the conceptual distinction between natural and dialectical problems, based on their different form of inquiry (fr. II2 Rose = Alex. Aphr., In Ar. Top. 62, 30-63, I9). In short, the fragment explains that Aristotle defined a dialectical problem as a question concerning alternatives, where a positive or a negative answer is expected ('Whether a thing is so, or not?'). A natural problem, by contrast, investigates the cause or nature of a natural phenomenon ('Why is this so?', 'What is this?'), so that another type of answer is expected (viz. an explanation or a definition). Strictly speaking, then, the natural problems collected in Ps.-Aristotle's Problems are no dialectical problems. Cf. J.G. Lennox, 200I, pp. 77-78 and J. Mansfeld, 20Io, p. 43, n. 34. Aristotle also deals with problems and their

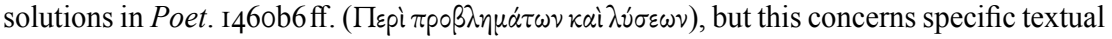
problems (viz. difficult passages or expressions in a text). D.L. 5, 48 and 49 also mentions

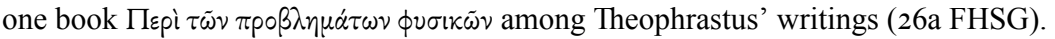

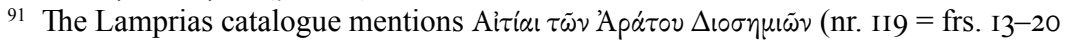

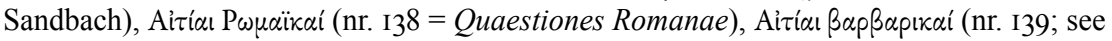

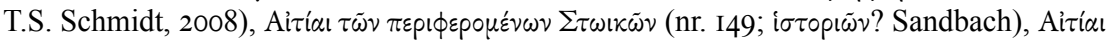

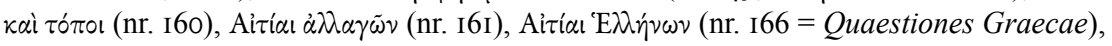

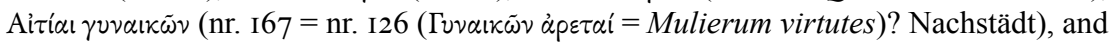


especially exhibits a remarkable degree of similarity to Ps.-Aristotle's model. This is clear especially at a structural level. The internal format of the genre of natural problem is based on a typical 'erotapocritical' scheme, where questions are raised and answered in a tight repetitive structure. The question (quaestio) remains fairly short in most cases ${ }^{92}$ and is normally introduced with $\delta \dot{\alpha} \alpha \tau^{93}$. The question is always 'Why?' and not 'What is this?' or 'Is it true that?', because it is not the author's intention to define or verify the actual existence of the natural phenomenon at hand. Rather, he is interested in finding their physical origin by formulating plausible explanations (causae) for them ${ }^{94}$. A collection like Quaestiones Graecae, by contrast, is more concerned with defining obscure Greek cultural phenomena, in the manner of an encyclopaedia or a dictionary, than with providing their aetiology or origin: therefore, 'why'-questions are far less frequent there ${ }^{95}$.

For nearly every natural problem, Plutarch provides a range of different answers (two and often more), some of which contain received knowledge, while others contain his own innovative contributions. These solutions are mostly formulated in an interrogative, anti-dogmatic fashion, implying that any criticism and new solutions can always be added ${ }^{96}$. The disjunctive

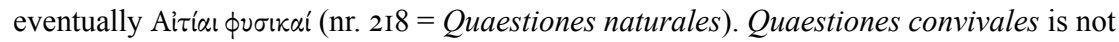
recorded in the Lamprias catalogue (perhaps to be identified with nr. I25: 'A $\pi \circ \mu \nu \eta \mu о v \varepsilon v ́ \mu \alpha \tau \alpha)$.

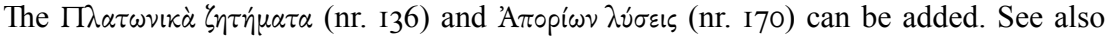
A. Gudeman, 1927, cols. 2525-2527 and G.W.M. Harrison, 2000a, p. 195 (who notes that

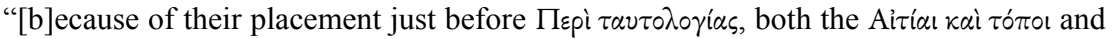

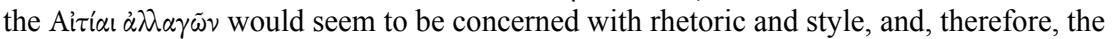
meaning of airi $\alpha$ might be quite different [sc. from that of 'explanations', viz. 'invective'; see LSJ, s.v. i, 2]").

92 Sometimes an intermediate part is incorporated to illustrate or specify a particular point in the quaestio. See Q.N. 5, 913B, 2I, 917B, 26, 918BC, 34. For intermediate pieces in the quaestiones in Ps.-Aristotle's Problems, see H. Flashar, 1962, pp. 342-343.

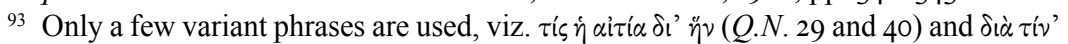
aitía (Q.N. 20), which have the same basic meaning. R. Mayhew, 20Ira, p. xiii, n. I has calculated that $98 \%$ of the Ps.-Aristotelian Problems (counting 903 in total) also begins with $\delta i \dot{\alpha} \tau i$.

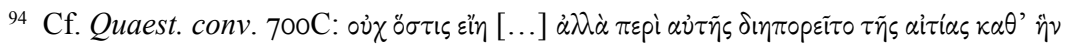
$\kappa \tau \lambda$.

95 In Quaestiones Graecae most of the questions are introduced with $\tau i$, $\tau i$ ' or $\tau i v \varepsilon \varsigma$ (cf. Quaest. Graec. I-25, 29, 30, 32, 34, 38, 40, 44). The introduction with $\delta i \dot{\alpha} \tau i$ is less frequent but not absent (see Quaest. Graec. 9b, 3I, 36, 37, 39, 45-5I, 53, 55, 58 and K. Oikonomopoulou, 20I3b); there are also alternative formulations, see the table in P. Payen, I998b, p. 4I (cf. also A. Carrano, 2007, p. 7). Moreover, each problem in this collection often receives only one clear-cut solution (or better: definition) rather than a number of successive explanations, as is the case rather in Quaestiones Romanae. See R. Preston, 200I, p. 96, J. Boulogne, 2002, pp. I79-I80 and P. Payen, 20I4, pp. 246-247.

96 The only (and therefore unintentional?) exceptions are Q.N. 20, 29, 35 (first causa) 
sequence of multiple interrogative solutions to one and the same question is ordered in accordance with the standard problem arrangement: the causae are commonly phrased as a compound question introduced with

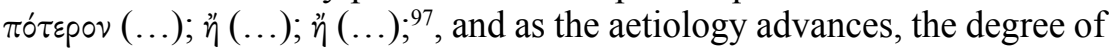
plausibility often increases. A solution most often departs from a general argument or observation, which is phrased interrogatively, and is further clarified and justified in a dogmatic fashion in the elaborative explanations, deductions, illustrations, etc., that follow - these I call the 'sub-arguments'. They are commonly introduced with a wide array of conjunctions, particles etc. (such as $\delta \iota^{\prime}, \gamma \alpha \dot{\rho} \rho, \quad 0 \varepsilon v, \mu \varepsilon^{\prime} v, \delta \varepsilon$ ), by which the author maintains an essential and coherent structure in the development of the explanations ${ }^{98}$.

and 38. Q.N. 40-4I can be neglected, since they are reformulations by Psellus (see M. Meeusen, 20I2b).

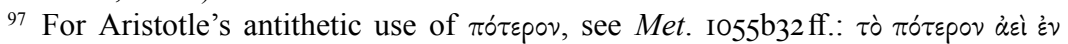
$\dot{\alpha} \nu \tau \mid \theta \dot{\varepsilon} \sigma \varepsilon \varepsilon \lambda \hat{\varepsilon} \gamma \circ \mu \varepsilon v$. As a rule, in cases where only one solution is given, the editors of Quaestiones naturales decided not to use the disjunctive $\ddot{\eta}$ (which would then have a modest affirmative, rather than interrogative nuance: cf. H. Bonitz, I870, pp. 3I2b57-3I3aI8) but the interrogative $\tilde{\eta}$ (see J.D. Denniston, I966, p. 283). Among the first 3I problems (i.e. those containing the original Greek text), I2 are without the opening $\pi$ ó $\tau$ spov causa, nine of which have only one solution: Q.N. 8, 9, II, I4, I5, I8, 22, 24, 30 (not so in Q.N. 20, 2I, 29, where the regular problem scheme is not followed; remarkably enough, Q.N. 23 has only the $\pi$ ó $\varepsilon p o v$ causa: see the commentary ad loc.). See also G.W.M. Harrison, 200ob, p. 240. Regarding such solitary solutions (in Quaestiones Romanae) J. Boulogne, I992, p. 4688 (cf. also 2002, p. 94) rightly observes that "l' unité numérique ne signifie pas unicité. Plutarque isole une cause, mais il laisse entendre qu' elle n'épuisse pas la causalité. L'investigation n' est pas fermée, il est possible de toujours l' enrichir. C'est ce à quoi invite la structure ouverte de ces interrogations qui énoncent une seule réponse." The same idea applies to Plutarch's natural problems (see below).

${ }^{98}$ In addition, Plutarch uses several standard phrases in order to indicate a specific aetiological direction to the reader. These phrases can point, for instance, to a logical

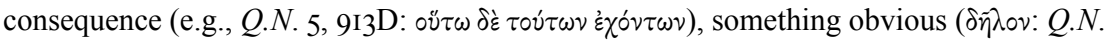

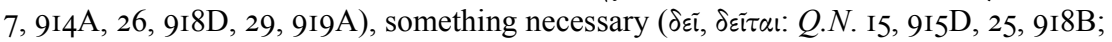

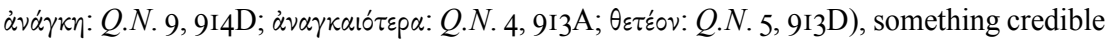

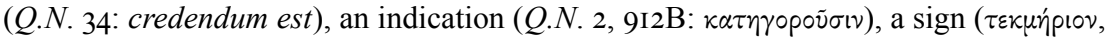

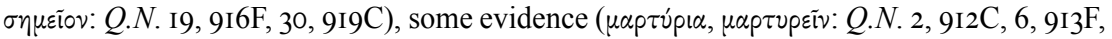

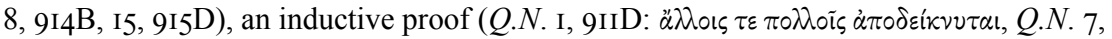
9I4A: $\dot{\omega} \varsigma \ddot{\varepsilon} \sigma \tau \imath \nu[\ldots] \kappa \alpha \tau \alpha \mu \alpha \theta \varepsilon i \nu)$ etc. These phrases clearly reflect the elementary logic of the argumentation in its most basic and transparent form. According to L. Senzasono, 2006, p. 9, this structural grid of logical connections aims at an essential and unembellished representation of the natural phenomena. As such, it would testify to the collection's scientific style: "Questi nessi collegano rilievi di fenomeni naturali in una struttura essenziale, priva di qualsiasi abbellimento, come s'addice a un'esposizione che intenda essere scientifica, nel mondo Greco come in altre epoche fino ad oggi." However, as we will see later, the embellishment-free discourse and lack of literary bravura is not an inherent feature of Plutarch's scientific discourse, nor of ancient scientific texts in general [see I.2.5.]. 
In short, the problem arrangement develops in three subsequent echelons, three layers of encapsulation, viz. question - argument - sub-argument ${ }^{99}$. The questions and arguments are mostly formulated interrogatively, the sub-arguments assertorically.

This repetitive tripartite structure permeates the entire collection and gives the problems some kind of a 'Chinese-box-effect'. The aetiological movement is upwards, viz. from the particular and atomic sub-arguments to the argument and hence further on to the quaestio itself, which is the explanandum, and serves as the heading of the chapter. This means that the smallest element in the aetiological hierarchy (the sub-argument), is in support of the higher strata and can, therefore, be considered the actual fundament of the problem construct. The concrete phrasing of the problems develops the other way round, from top to bottom: the quaestio comes first and is explained over several causae into its smallest details. The opposition between the aetiological movement (upwards) and the actual phrasing of the problem (downwards) does not remain without further interest for the actual writing process and, more in specific, for Plutarch's sophisticated use of sources (to which I will come back later [see 4.2.I.2.]).

It is not my intention to deal with every single deviation and particularity in the phrasing of the quaestiones and causae here, but special attention should be directed to the following more general observations (these points will also be relevant when dealing with Plutarch's scientific methodology later on [see 4.3.]).

I) The general interrogative and anti-dogmatic formulation of the explanations implies that the aetiological structure remains open, so that the problems do not receive final closure. In this sense, the questions are not fundamentally 'solved', and the author leaves it to the reader to make up his own mind (I will come back later to this in light of the educational interests of the collection [see 3.2.I.]). Another consequence of the interrogative formulation of the aetiologies is that the solutions do not always necessarily exclude one another, unless, of course, in those cases

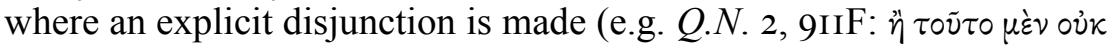

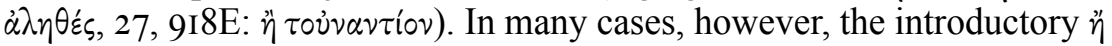
can actually indicate a sense of argumentative complementarity, rather than a disjunction, between separate causae, each solution discussing a specific facet of the complex problem at hand ${ }^{100}$. Such a notion of inclusivity can also be articulated more periphrastically with a phrase like $\ddot{\eta} \delta \varepsilon \tilde{i} \mu \eta \eta \dot{~ \mu o ́ v o v ~}$

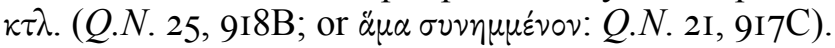

99 See also L. Senzasono, 2006, pp. 34-4I on the mutual relations between the causes in Quaestiones naturales (viz. their "griglia strutturale di relazione", p. 37).

100 J. Boulogne, I994, p. I28 speaks of a "disjonction inclusive", and he even claims (1992, p. 4690) that $\ddot{\eta}$ always has inclusive value (in Quaestiones Romanae). 
2) The solutions are primarily structured around the notion of argu-

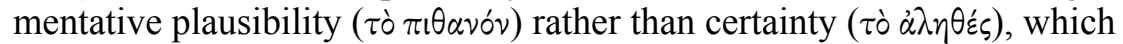
reflects a fundamental uncertainty on the author's side about what is said (the epistemic range of these concepts will be examined later [see 4.3.2.2.]). Even if each specific explanation often approaches the problem from another angle and thus has no lesser or greater claim to $\tau \dot{o} \pi \imath \theta \alpha \nu o ́ v$ than another, this is not always the case. Some solutions are explicitly suggested to be more plausible than others (e.g., Q.N. 39: an probabilius est?), and in some cases, a previous explanation is suggested to be incor-

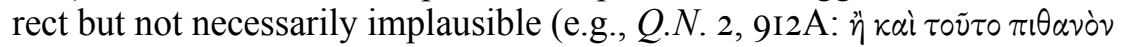

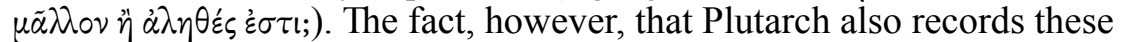
less plausible solutions seems to testify to his urge for aetiological exhaustivity, each solution attributing at least a certain aspect of plausibility to the aetiology. At the same, time this procedure may also have a heuristical motivation, as being a useful argumentative strategy in the search and development of ever new and increasingly plausible explanations (reculer pour mieux sauter $)^{101}$.

3) Even though Plutarch prefers to suggest rather than to assert in his physical aetiologies, and thus takes no responsibility in formulating a definite solution, he still has several ways of expressing his own personal preference for one explanation over another. He does this by either explicitly evaluating a certain explanation by venting his criticism or by showing his appreciation for it, mostly assessing the theory's plausibility. This is the case, for instance, in Q.N. 2, 9IIF-9I2A, where Laetus' explanation is suggested to be 'untrue' (oj $\dot{\alpha} \lambda \lambda \eta \dot{\varepsilon} \varsigma$, ranked in the first causa), whereupon Plutarch wonders whether Aristotle's solution is 'true' $(\dot{\alpha} \lambda \eta \theta \dot{\varepsilon} s$, ranked in the second causa). He concludes, however, that it is 'plausible rather than true' ( $\pi \bullet \theta \alpha \nu \dot{\nu} \nu \mu \tilde{\alpha} \lambda$ ov $\ddot{\eta} \dot{\alpha} \lambda \eta \theta \dot{\varepsilon} s)$. There are also more subtle ways of doing this. When a causa is introduced with the phrase 'or rather' ("ท $\mu \tilde{\alpha} \lambda$ ov: e.g., Q.N. 3, 9I2E, I7, 9I6A), one can presume that the solution at issue has more legitimacy towards $\tau \dot{\partial} \pi \imath \theta$ avóv than the preceding one. However, this phrase can also point to a simple, unqualified transition to another explanation. In that case, it indicates that we are simply dealing with an alternative solution that is at least equally plausible. Furthermore, the positioning of the explanations themselves often seem to imply a certain ranking by the author. In a number of cases, the explanations are not enumerated in a thoughtless order but more or less hierarchically, according to the principle of increasing plausibility ${ }^{102}$. As scholars have

101 The same conclusion was reached (for Quaestiones Romanae) by J. Boulogne, I992, p. 4689: "En définitive, l' inventaire favorise la découverte en provoquant le surgissement des idées auxquelles on n' a pas pensé, et plus il est étendu, moins la solution conservée court le risque d'être infirmée par ce qui n' est pas venu d'emblée à l' esprit."

102 For this progressive structure in Plutarch's aetiologies more generally, see also, e.g., 


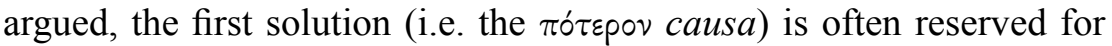
communis opinio, thus representing a first step in the direction of a correct explanation, whereas the last solution contains most progress in that direction ${ }^{103}$. In this sense, it can be presumed that Plutarch's evaluation of past authorities is often implicit in the ranking of the causae in which they are quoted (this ranking will be of interest later in the analysis of Plutarch's quotations from traditional authorities [see 4.I.2.3. and 4.2.I.I.]). This does not necessarily imply, however, that the last position is also reserved for an absolutely correct solution. At most, the last position will be an indication that the explanation expresses the author's preference ${ }^{104}$, but it is the causa palmaris only in a relative, not an absolute, sense. After all, the interrogative structure and absence of closure implies that the addition of other explanations is still possible and that the aetiological potential has not necessarily been exhausted. Also note that the same aetiological mindset is present, for instance, in Quaestiones convivales. There, Plutarch often has the courtesy to let his fellow symposiasts speak before his own sympotic character ${ }^{105}$. In this way, he can (via his sympotic alter ego) speak last and, thus, most authoritatively ${ }^{106}$. There is, indeed, a certain tendency towards authorial self-promotion in Quaestiones convivales, but as König observes, some nuancing is in place: "Even where Plutarch does speak last, or take some other prominent role in discussion, he

J. Boulogne, I992, pp. 4694-4696 and P. Donini, I992, p. III. The same gradual progression from less to more probable explanations has also been discussed for other works, such as De E and De Iside et Osiride (see P.R. Hardie, I992, p. 4755 and G. Roskam, 20IIc, p. 425).

${ }^{103}$ For the place of communis opinio in Quaestiones naturales, see G.W.M. Harrison, 200ob, pp. 238-239.

${ }^{104}$ See already C. Kahle, I9I2, pp. 63-64: "Si sententiae complures quae magni momenti sint, inter se pugnant, omnes deinceps perpetuis orationibus proferri facit, sed nulla refutatur et quae sit vera, positione fere sola quia postremo loco describitur, significatur."

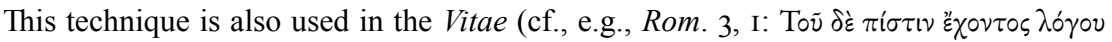

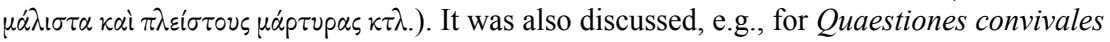
by J.C. Relihan, I992, pp. 232 and G. Roskam, 20IIc, p. 425, for Quaestiones Platonicae by J. Opsomer, I994a, p. I2 (with n. 32), I996a, p. 83 (with n. 42), and 2010 (with n. 3), and for Quaestiones Graecae, Romanae and naturales by D.A. Russell, 1973, p. 45. For the idea that Plutarch endorses his own thought at the end of the dialogue in $D e E$, see F.E. Brenk, 2005, p. 29 (with n. IO). The same technique has also been discussed for De genio Socratis and for De facie by P. Donini, 2009, p. 202 and 20II, p. 86 respectively.

${ }_{105}$ This is the case in Quaest. conv. $627 \mathrm{EF}, 635 \mathrm{CD}, 673 \mathrm{D}-674 \mathrm{C}, 674 \mathrm{E}-675 \mathrm{D}, 677 \mathrm{E}-$ 678B, 690DE, 690F-69IC, 69ID-692A. Cf. J. König, 2007, p. 5 I.

106 After all, as G. Roskam, 20Io, p. 47 has noted, Plutarch is the one who is holding the pen. On Plutarch's authorial self-presentation in Quaestiones convivales as a complex mean between self-promotion and self-effacement, see J. König, 20II. See also F. Klotz, 2007. 
sometimes stresses his own reluctance, going out of his way to avoid the impression of grandstanding." 107 Indeed, Quaestiones convivales is not an ego-document, or, at least, it is not Plutarch's intention to let his own authority prevail over that of his companions at any cost. In view of the relative plausibility of the arguments, Plutarch may have had good epistemological reasons for this, besides from purely sociological ones [see 4.3.2.].

4) Sandbach argues that the use of semi-synonymous pairs in the causae may indicate (or "provide a clue") that we are dealing with Plutarch's personal contributions to the problems ${ }^{108}$. The use of such semi-synonyms is, indeed, a typical feature of Plutarch's general style, but Sandbach's theory is not, therefore, necessarily correct. The most problematic point is that these pairs are also found in the quotations from traditional authorities

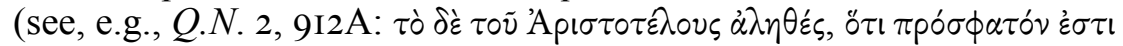

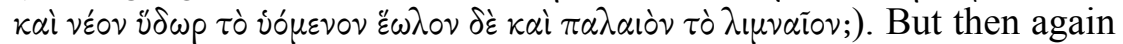
Plutarch more often paraphrases quotes by rendering them in his own words rather than by presenting them $\kappa \alpha \tau \dot{\alpha} \lambda \hat{\varepsilon}^{\xi} \xi \nu^{109}$ [see 4.2.I.I., n. II6]. Sandbach also argues that Plutarch explicitly marks his personal and innovative contributions to the problems with introductory imperatives

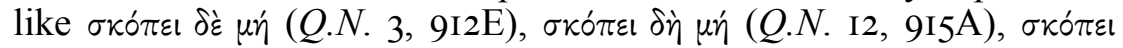
$\delta \eta^{\prime}(Q . N \text {. I9, 9I6C })^{110}$. Many scholars have shared Sandbach's opinion, supposing that these imperatives mark Plutarch's own contributions and/or highlight the greater reliability of the solutions introduced by them ${ }^{111}$. In

107 J. König, 20II, p. I95.

108 F.H. Sandbach, I965, p. I36. Sandbach refers to Q.N. 2, 6, I0, I3, I6, I9, 21, 23, 24, 26 (he omits Q.N. 3, which is misprinted as Q.N. 2 on p. I35).

109 For Plutarch's general use of semi-synonymous pairs, see U. von Wilamowitz, I902, p. 203, B.P. Hillyard, I98I, p. xxiii, T.S. Schmidt, I999, pp. I5-26, S.-T. Teodorsson, 200ob, L. Senzasono, 2006, pp. I5-17. Plutarch's use of such semi-synonyms in Quaestiones naturales has been analysed by G.W.M. Harrison, 200ob, pp. 246-249, who also puts Sandbach's theory into perspective. The following reservation was made by Sandbach himself (I965, p. I36): "The hypothesis that passages marked by these semi-synonymous pairs, many of which are drawn from a richer vocabulary than that of the bulk of the work, may be original, implies no claim of absolute priority for Plutarch, but only that he was not here abbreviating or copying a text before him, but drawing on the resources of his well-stocked mind and memory."

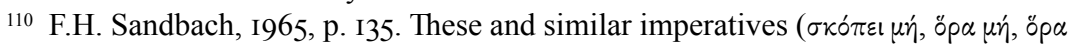
$\left.\delta \dot{\varepsilon} / \delta \dot{\eta} \mu \eta^{\prime}\right)$ occur frequently in Plutarch's other collections of problems (except for the Quaestiones Graecae), as well as in his other writings. Notably, they are also frequent in Plato, whose style of writing Plutarch perhaps imitates (cf., e.g., Apo. 27a, Phd. 74a, Tht. I62e). See also L. Senzasono, 2006, pp. 23-24.

111 Cf. F. Leo, I864, p. 6, H.J. Rose, I924, p. 49, J. Boulogne, I992, p. 4688 ("plus d'intérêt que les autres"), p. 4695 ("plus favorablement"), 2002, p. 93 ("la solution préférée"), J. Opsomer, I994a, p. II and I996a, p. 77, G.W.M Harrison, 200ob, 
De prim. frig. $952 \mathrm{C}$, for instance, Plutarch opens his (presumably) personal explanation about the essence of coldness with the phrase $\sigma$ kó $\pi \varepsilon ı$ $\delta \dot{\eta}$. His personal preference may, indeed, go to this theory, which is placed last, but at the same time the treatise's anti-dogmatic conclusion emphatically marks that it is perhaps 'neither less nor much more plausible' than other

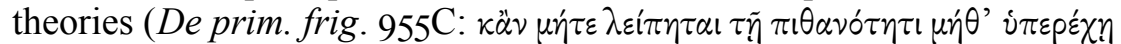
$\pi \circ \lambda v^{\kappa} \kappa \tau$.) [see 4.3.2.I.]. In the case of Quaestiones naturales, it is not always clear whether such imperatives mark Plutarch's personal theory or

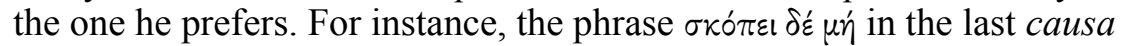
in Q.N. 3, 9I2E (about the aphrodisiac effects of salt on bitches and mice) might suggest that we are dealing with Plutarch's personal contribution. However, the same theory is formulated not by Plutarch, but by Philinus in Quaest. conv. 685DE. To give another example, in De Pyth. or. $395 \mathrm{~F}$ an explanation of Aristotle is introduced with $\sigma \kappa o ́ \pi \varepsilon ı ~ \delta '$. These theories may, of course, carry Plutarch's preference, but they are not, therefore, necessarily his. Remarkably enough, in some cases a new solution even follows after the causa that contains an imperative (as is the case in Q.N. I2, 9I5A). This can cast considerable doubt on the common assumption that these imperatives necessarily contain Plutarch's preferred contributions. The least that can be said about these imperatives, then, is that they shift the interrogative style of the causa to the affirmative - or better, to the imperative -, and, thus, draw the reader's attention to an important point that the author wishes to make ('Consider this!'; 'Attention please!'). As such, I believe the actual use of these imperatives should be explained in light of the fact that they emphatically address the intended reader (in the second person) to take something important into consideration. Plutarch, thus, makes the reading process more engaging and provokes a direct response to what is read ${ }^{112}$.

p. 243. L. Senzasono, 2006, p. 24 is probably right in pointing out that these imperatives "presentano la verità come una conquista de compiere, non come qualcosa di acquisito. [...] Si tratta, in Plutarco come in Platone [see n. IIo above], d'una concezione del sapere come ricerca ed esame, prima che come risultato."

112 Pace G.W.M. Harrison, 200ob, p. 24I, who argues that the imperative in Q.N. I2, 9I5A is an indication of intermittent composition [see the prologue, n. 2I]. He adds that "Michael Psellus was so bothered by the third causa to Quaestio I2 that he re-wrote it. The problem may not be so much the content or syntax as its mere presence. It would seem quite natural that an investigator would set up the rival theories first before concluding his own." In my opinion, however, it is highly unlikely that Psellus actually 'knew' that Plutarch introduced his own explanations with these imperatives: this is still not a matter of course today, as I have tried to show. Rather, whereas the quaestio from Q.N. I2 first mentions the $\kappa \alpha \tau \alpha \alpha_{\alpha} v \varepsilon i \alpha$ and then the $\gamma \alpha \lambda \eta^{\prime} \nu \eta$ caused by oil on seawater, Plutarch does the reverse in his aetiology, while Psellus' reorganisation of the explanations keeps more to the sequence of the quaestio. For Psellus' adaptations more generally of Plutarch's Quaestiones naturales in his De omnifaria doctrina, see M. Meeusen, 20I2b. 
It goes to show, conclusively, that from a methodological perspective, the problem format provides several structural advantages for the orderly and efficient presentation of enigmatic topics. It allows the author not only to formulate a very specific problem on its own terms, and, thus, to concentrate his full attention to it, but also to solve it in an organised fashion. It also enables the author both to summarise and, if appropriate, to criticise the scientific tradition and doxography at issue and to add his personal observations and remarks to it. Moreover, the structural open-endedness allows for further elaboration and review, either by the author himself or by his reader ${ }^{113}$. Even if, in the case of Quaestiones naturales, there are strong deviations in length, number of causae, and degree of elaboration among the problem chapters, the basic structure remains almost identical at all times. Indeed, one problem can be (much) more elaborate than another. For instance, while Q.N. I9 is more like a short essay, Q.N. 17 is nothing more than a gloss ${ }^{114}$. As such, the problem format guarantees a neat and transparent exposition of an often chaotic assortment of arguments and view-points leaving space for further insights, all of which is presented in a compendious and highly organised fashion, under the leading principle of plausibility ( $\tau \dot{o} \pi \imath \theta \alpha \nu o ́ v)$. Now that we have dealt with the internal arrangement of Quaestiones naturales, let us turn to its external macrostructure, viz. the collection's general organisation in terms of structural order and disorder of the problem chapters, and the possible impact thereof on the intended reading process.

\section{Coherent reading in Quaestiones naturales and convivales (macrostructure)}

As noted earlier on, Plutarch's natural problems do not convey a systematic or comprehensive vision of the realm of nature and its phenomena. There is no intention to capture the entire world, or entire facets of it, in a consistent and monographic study, as is rather the case in a work like Aristotle's Meteorology or Physics. When it comes to the macrostructural arrangement of the successive problem chapters in Quaestiones naturales, it is obvious that the collection is not ordered in an orderly but rather in a disorganised, haphazard fashion. Unlike the Ps.-Aristotelian Problems, Plutarch's Quaestiones naturales has not been rubricated according to

${ }^{113}$ For a similar appreciation of the genre of problems, see, e.g., R.H. Barrow, 1967, p. 67: "This method of writing has advantages; it is compendious; the point at issue is clearly defined and shortly stated; the rival solutions are put forward tentatively; there is no dogmatic answer; the writer takes no responsibility and the reader is left to make up his own mind."

114 A similar distinction was made by H. Dörrie, I959, p. 2: "Damit steht לทं was den Umfang anlangt, zwischen der einfachen Worterklärung (Glosse) und dem monographischen Exkurs". 
thematic categories that would follow the divisions in nature or the specialised sub-disciplines in science based upon them ${ }^{115}$. On the contrary, Plutarch's arrangement of the problems is considerably chaotic and ordered in a rather spontaneous, organic way, if there is, indeed, any intentional arrangement to the work at all. As we will see, some problem chapters seem to follow specific meandering lines and thematic sequences, so that they can be grouped in together, but this process remains implicit and the problem clusters are eventually interrupted by other (sets of) problems. In what follows, I will deal with these different structural dynamics in greater detail, starting with the issue of structural coherence and later dealing with that of structural variation. I will also focus on the actual reading that seems to be favoured by these dynamics, which will be further substantiated in chapter three [see 3.2.I.].

As noted, there is a certain principle of coherence and structural sophistication in Plutarch's Quaestiones naturales that binds many (but not all) of the problem chapters together. Regarding this clustering dynamic, Oikonomopoulou rightly speaks of "an incipient classificatory scheme" 116. Several such problem clusters can be detected throughout the collection (see the introduction to the commentary for a schematic representation of these clusters). This is the case most obviously in Q.N. I-I3, where Plutarch deals with problems related to salt and water, and where the recurrent opposition between salty and sweet water is at issue ${ }^{117}$. Other such clusters are found in Q.N. I4-I6 (on wheat and barley), I7-I9 (on sea animals and fishing), 20-28 (on land animals and hunting), 30-3I (on viniculture) and 35-36 (on apiculture). These associative connections between successive problem chapters guarantee a certain aspect of unity throughout the collection.

Notably, the same structuring process is present in Plutarch's other collections of quaestiones, as is the case most notably in Quaestiones Romanae (there is, for instance, an obvious "fil thématique" concerning

115 Cf. J. Boulogne, I992, p. 4684: "Rien de tel [sc. la formation de chapitres unifiés autour d' un contenu commun] dans les 'Questions d'histoire naturelle' [...] où n' est effectué aucun classement systématique." This is not, of course, to object to the claim of E.S. Forster, I928, p. I65 that "the compiler [of Ps.-Aristotle's Problems] seems to have had as his object the collection of as many problems as possible without being greatly at pains to harmonize them into a consistent and logical whole."

${ }^{116}$ K. Oikonomopoulou, 2013a, p. I52. Regarding the thematic rubrications in Ps.Aristotle's Problems, Oikonomopoulou rightly notes: "If [...] the re-organisation of this text into thematic units took place at the end of the 2 nd century $\mathrm{CE}$, the thematic clusters offered by the $Q N$ might be taken as a hint that thematic versions circulated as early as Plutarch's time".

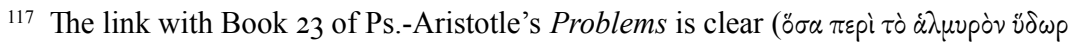

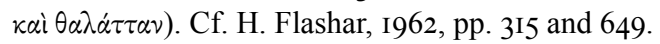


Roman nuptial rites) $)^{118}$. This process seems to be more continuous in Quaestiones naturales, though, but it still remains very implicit ${ }^{119}$. As an effect of this subtle structuring process, the separate problems are often linked to each other by means of specific thematic and verbal 'synapses'. One of the ways of tying problems together can be seen in the insertion of parallel argumentations (take, for instance, the allusion to the octopus' flesh and skin in Q.N. I8-I9, or the idea that bees hate what is harmful to them in Q.N. 35-36). At other places, the overarching principle of a coherent arrangement is more tangible. This is especially the case in those problems where we can find an explicit reference to the immediately

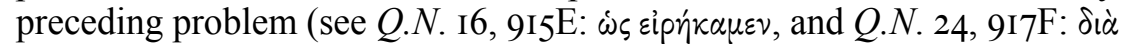

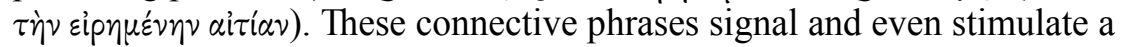
coherent, linear reading process ${ }^{120}$.

Finding my inspiration in recent scholarship on Catullus' Carmina, I will refer to this principle of structural clustering with the concept of concatenatio. The concept of a concatenatio Plutarchea will facilitate a more or less coherent approach to the problem chapters in the commentary. The notion of concatenatio was coined by Claes, who describes it as "[a] way to counteract the disintegrating force of the technique [of variation]" and as a "principle [that] interlinks consecutive poems by repeating themes and phrases"121. The connection between problems and poems is not, of course, unproblematic, since these are two completely different genres. Yet, this distinction is not necessarily strict, at least when it comes to their

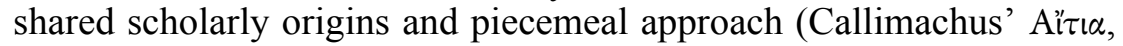
for instance, utilises poetry as a discursive medium for the aetiologies it collects) ${ }^{122}$. Indeed, the search for subtle structural unity is a typical

118 See Quaest. Rom. I-2, 29-3I, 65, 85-87, I05, I08; discussed by J. Boulogne, I998, p. 32: "Cette dispersion thématique a pour effet d' unifier l' ensemble du texte comme un fil de chaîne, un mode de composition correspondant exactement à l' importance qu' accorde Plutarque au couple dans la cohésion du tissu social romain." Similarly, for the notion of "paquet thématique", cf. L. Démarais, 2005, p. I68, n. 32. See also H.J. Rose, I924, pp. 50-5I, J. Boulogne, I994, pp. 87-88, 2002, pp. 99-I00 and J. Scheid, 20I2, pp. II-I2.

119 In fact, J. Schellens, I864, pp. I8-I9 has rightly underlined: "Naturalium denique quaestionum ordinem minus quam romanarum esse turbatum, tibi epigrammata quaestionum celeriter perlegenti patebit."

${ }^{120}$ Cf. L. Van der Stockt, 20II, p. 453.

121 P. Claes, 2002, p. 27 (see also pp. 5I-55 for concatenatio in classical poetry more generally). With this concept, Claes aims to demonstrate that Catullus calculatedly structured his Carmina as a collection of poems that fit like links in a coherent chain. He distinguishes between thematic and lexical concatenatio (with further sub-divisions). A similar structural principle has also been discussed for Martial's epigrams by N. Holzberg, 2002, pp. 37-39, who introduces the concept of "paradeepigramme", and by W. Fitzgerald, 2007, pp. I06-I38, who uses the term "juxtaposition".

${ }^{122}$ In regards to the structural set-up of Callimachus' Ait $\tau$ เ, the famous introductory 
feature of Hellenistic poetics that can be linked to the highly specialised activities of Hellenistic scholars in the Museum ${ }^{123}$. Regarding Plutarch's personal decision to employ the problem format in order to address specific case studies, rather than an all-encompassing discourse, Sirinelli rightly observes that:

"Plutarque est véritablement un intellectuel au sens où nous l'entendons aujourd' hui, c'est-à-dire un homme qui réfléchit sur les problèmes qu'il rencontre ou qui lui sont soumis. C' est sans doute cette image-là qu' il faut garder à l' esprit plutôt que celle d'un érudit parcourant méthodiquement tous les domains du savoir." 124

The piecemeal and (largely) unsystematic approach of the problem chapters explains why the concatenative line is disrupted at certain points in Quaestiones naturales. While Q.N. I-I3, for instance, deal with salt and water, Plutarch's attention in Q.N. I4-I6 abruptly shifts towards agricultural problems regarding wheat and barley. In addition, some topics that belong together thematically are broken apart, as is the case with the problems concerning wine and drinking (Q.N. I0, 27, 30-3I). From these instances, we learn that there is yet another ordering - or better, disordering - principle that disturbs the process of concatenatio, viz. the principle of variatio ( $\pi \circ \mathrm{o}_{\mathrm{c}} \lambda \mathrm{i} \alpha$, 'intricacy'), which is yet another compositional principle that is key to Hellenistic poetics.

Due to the fact that the structural unity of Quaestiones naturales remains rather implicit and is disrupted at several points, we are dealing with a digressive organisation of the problem chapters that is, perhaps, meant to encompass, or at least give an idea of, the plurality of disordered natural phenomena and the complex causality that they each involve. By the implicit interconnectedness of several natural problems, Quaestiones naturales may, thus, hint at a 'coherent diversity' in the contingent world

verses $(\mathrm{I}-5)$ of the prologue are particularly relevant. In this passage, Callimachus defends

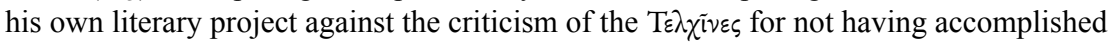

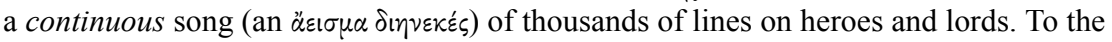

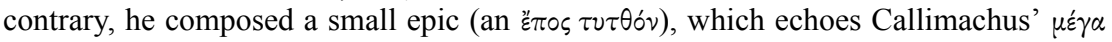

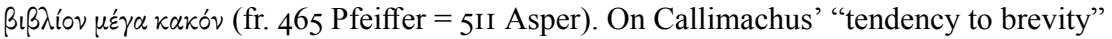
(i.e. the Hang zum kleinen) as a typically Hellenistic feature in his Aì $\tau \iota \alpha$, see A. Harder, 20I2, p. 38 (see also Harder's commentary ad loc.).

123 See n. 5I. Cf. S. Saïd, M. Trédé and A. Le Boulluec, 1997, p. 434: "la curiosité de Plutarque est universelle. A la manière d' un Callimaque et des érudits hellénistiques, il s'interroge sur les origines de tel rituel ou de telle coutume étrange chez les Grecs comme chez les Romains. Comme Aristote, il s' intéresse à des questions de physique (les Questions naturelles) ou de zoologie (Sur l'intelligence des animaux)." For the connection between Aristotle and Hellenistic scholarship, see N.J. Richardson, I994.

124 J. Sirinelli, 2000, p. 364. 
of natural phenomena and the physical processes and mechanisms that underlie them. Scholars have also detected this principle of a 'coherent diversity' in Plutarch's Quaestiones Romanae and Graecae, where the reader finds a pluralistic, but at the same time generally coherent, picture of Roman and Greek culture. In these collections, too, unity is, in a certain sense, procured through diversity, in that the text as whole reflects a general cultural identity - viz. the categories of Greekness or Romanness through a pluralism of particular cultural manifestations that build up this identity 125 .

Recent scholarship has considered Plutarch's collections of quaestiones more generally as part and parcel of ancient miscellaneous literature ${ }^{126}$. Specific attention went to the organisation and reading of Plutarch's Quaestiones convivales as representative of this literary branch ${ }^{127}$. As we will see, the results of these studies are not irrelevant in light of the literary techniques of concatenatio and variatio in Quaestiones naturales either (or in Plutarch's other collections of quaestiones) ${ }^{128}$. An interesting point of departure is Harrison's theory of a fragmented, piecemeal reading of Quaestiones convivales. According to this theory, the work's miscellaneous content and organisation allows the reader to decide for himself which specific problem chapters he would like to read and which ones he would like to leave aside:

"Beyond expanding its scope so that it could encompass all the different genres of quaestiones, Plutarch brought an episodic structure to the symposium, which allowed the reader to take up and put down his convivial reminiscences at will and browse through them rather like a collection of poems or fables instead of a work whose argument had to be followed sequentially." 129

125 See J. Boulogne, I992, pp. 4698-4707 (who for Quaestiones Romanae distinguishes between "une étiologie politique, grécisante et anthropologique") and P. Payen, I998b, pp. 49-54 (who argues for a coherent cultural landscape in both collections, based on geographical markers in the text). See also R. Preston, 200I, J. Boulogne, 2002, pp. 99-I00 and I83-184 and K. Oikonomopoulou, 2013a.

126 On miscellaneous literature from the Imperial Era more generally, see the introductions in J. König and T. Whitmarsh, 2007 and F. Klotz and K. Oikonomopoulou, 20II, pp. 22-24. See also T. Morgan, 20II, esp. pp. 70-73 for Plutarch's miscellanies in specific (see also pp. 49-54 for problems with the demarcation of the genre of ancient miscellanies).

127 See esp. J. König, 2007, pp. 62-67 and the contributions in F. Klotz and K. Oikonomopoulou, $20 \mathrm{II}$.

${ }_{128}$ Note, for instance, that among other typical titles of miscellaneous writings Gell., NA Praef. 9 specifically mentions Epistolarum Quaestionum aut Confusarum.

${ }^{129}$ G.W.M. Harrison, 2000a, p. 197. A similar piecemeal reading of Quaestiones convivales was supported by S. Goldhill, 2009, p. I09 (criticised by K. Oikonomopoulou, 20II, p. I25, with n. 59). Regarding the 'episodic' structure of Quaestiones convivales, see 
One could argue in favour of Harrison's theory that the information furnished by the problem headings (the quaestiones) of the specific sympotic discussions are very useful in informing the reader as to whether or not a specific passage is of any interest for him. However, these headings do not always entirely - let alone clearly - cover the expanse of the problem(s) dealt with (if they are authentic to begin with: e.g., Quaest. conv. 623D, 738C, 74ID). Furthermore, a table of contents at the beginning of the work listing the titles or a general description of the problem chapters would certainly have made the piecemeal reading more efficient ${ }^{130}$. However, there is none. More concrete criticism was formulated by Titchener, who objects that Harrison's theory "depends on the physical existence of the Table talk in a particular physical format, something that cannot be assumed" 131 . It is, indeed, uncertain as to whether Plutarch sent his nine $\beta$ i $\beta \lambda i \alpha$ of Quaestiones convivales to Senecio in the form of 'books', rather than 'bookrolls' - a medium that would obviously hamper a convenient browsing through the text. Finally, and most importantly perhaps, one could object that the implied reader - the all-round $\pi \varepsilon \pi \alpha i \delta \varepsilon v \mu \varepsilon v_{\nu}$ - would be interested in each of these subjects without distinction, so that a linear reading of the miscellaneous problems is not that problematic to begin with.

Bearing in mind Harrison's notion of an "episodic structure" in Quaestiones convivales, it seems that the piecemeal structure of the problem chapters and their lack of a clear overall ordering produce a certain literary effect by directing the reader's focus toward the private character of the sympotic discussions and scenes, which are time and again re-set, so that the reader finds himself invited (by means of a quaestio) to join at an ever new literary dinner table, not just as a passive witness but as an active participant in an ever new discussion (I will further ruminate on this theory later, when dealing with the text's educational goals [see 3.2.I.]). It is perhaps not unlikely that the structural aspects of concatenatio and variatio in Quaestiones convivales somehow resemble the conditions of

already A. Gudeman, 1927, col. 2526: “Auch verzichtet der Verfasser [...] fast gänzlich auf die übliche szenische Einkleidung und reiht die einzelnen Lösungen gleichsam wie Perlen an einer Schnur aneinander." Cf. also L. Senzasono, 2006, p. 8 for the "carattere frammentario, o almeno episodico" of Ps.-Aristotle's Problems.

${ }^{130}$ Such tables of contents can be found, for instance, at the beginning of each Book of Ps.-Plutarch's/Aëtius' Placita. Gellius also includes a table of contents after the preface of his miscellaneous Noctes Atticae, where he explicitly underlines its use for the reader to look up specific passages (Praef. 25: ut iam statim declaretur quid quo in libro quaeri invenirique possit). See E. Gunderson, 2009, pp. 45-47. There is also a table of contents, for instance, in Pliny's Naturalis historia, but it is not a very efficient one, since it often misleads the reader when trying to track material within the work. See T. Murphy, 2004, p. 32.

131 F. Titchener, 20II, p. 47 (cf. also 2009, p. 397). 
intellectual dialogue in real life, albeit, of course, in a dramatised form [see 2.3.I.]. It is a logical consequence of the natural development of sympotic discussions that the solution of one problem provokes the formulation of a new problem that can, but need not be, closely connected. The first three problems of Book six, for instance, concern hunger and thirst, and the following three, cold water and snow. Sometimes, the symposiasts also deal with a wide variety of themes at one occasion, as is the case, most notably, in Book nine as a whole, where Plutarch gives a report on the conversations held at Athens during the so-called festival of the Muses.

From the perspective of Plutarch's literary technique, it is not, of course, unlikely that the arrangement of Quaestiones convivales emerges spontaneously from the author's associative memory and use of personal notes. A seminal account of the miscellaneous organisation of Quaestiones convivales is found in the preface to the second Book, where Plutarch says that he simply jotted down the conversations 'without any systematic

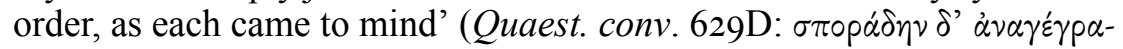

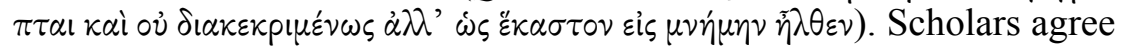
that this passage is very relevant for the work's underlying writing process and method of composition, including the structuring principles that guide it, but there is debate about its precise meaning. In light of this passage, some scholars have argued that the distribution of the questions and the transitions from one subject to another seem to be entirely capricious ${ }^{132}$. There is obviously no prepared order of subjects. Yet, regarding the first part of Plutarch's statement ('without any systematic order'), there may be more to what Plutarch actually says, as König has influentially argued in his recent study of the complex dynamics of coherence and fragmentation in the work:

"Many ancient miscellanists [...] gesture towards thematic order, drawing us into a search for patterns while also at the same time disrupting and frustrating that search. On that argument, the claim that many miscellanists make, that they are composing at random, turns out, at least in some cases, to be a matter of convention, a miscellanistic pose which can hide careful structuring beneath it [...]."133

In what follows, König argues that the reader is encouraged to navigate through the separate problems with close attention to several thematic and verbal reminiscences. This makes the reading process both more intriguing as well as more challenging (I will deal with his theory of an 'active reading' process later on [see 3.2.I.]).

${ }^{132}$ S.-T. Teodorsson, I989, p. I69 considers it "a literary device to announce unconnected disposition".

133 J. König, 2007, p. 44 (my italics). 
In regards to the second part of Plutarch's statement ('as each thing came to my mind'), König argues:

"[This] looks, on closer inspection, not like a statement of the work's randomness, but rather like an attempt to equate the ordering of the work with the retrospective patterning which memory inevitably imposes." 134

In my opinion, this is as ingenious as it may sound casuistic to some ${ }^{135}$. But the intriguing thing about it is that it enables us to kill two troublesome birds with one stone. That is, it can explain both principles of variatio and concatenatio on the basis of the author's memory and recollection, and the vagaries that they involve.

To return to the first part of Plutarch's statement now, König is absolutely right that other miscellanistic authors (like Gellius, Pamphila, Aelian and Athenaeus) ${ }^{136}$ also emphasise the artless and haphazard organisation of their writings, so that we can rightfully speak of a genuine

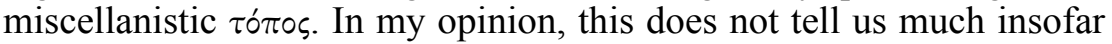
that a $\tau \dot{0} \pi \circ \varsigma$ is not necessarily a $\psi \varepsilon v \tilde{\delta} \circ \varsigma$. Plutarch may very well be playing along with this miscellanistic convention (perhaps even intentionally), but even so, it would be wrong, in my opinion, to claim that he is 'posing' (and this may also count for those other miscellanistic authors). Plutarch is no 'poser' - or otherwise, he is extremely good at it. Indeed, with

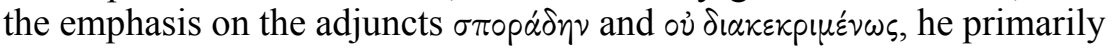

134 J. König, 2007, p. 62.

135 The germ of König's theory is present already in J.P. Small, I997, p. I80: "We might have discounted Plutarch's 'random' order of topics, if it were not for the Preface of Gellius. Instead, his explanation told the ancient reader that what was to follow fitted a well-known genre of collections of discussions on diverting topics."

136 See, e.g., Gell., NA Praef. 2 (Usi autem sumus ordine rerum fortuito, quem antea in

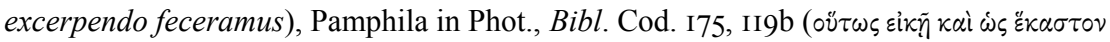

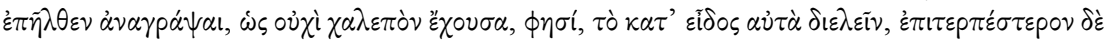

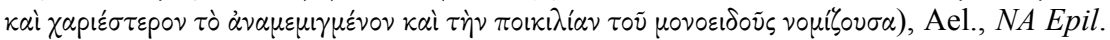

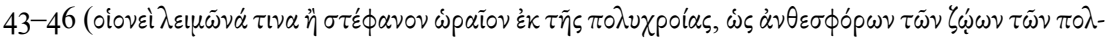

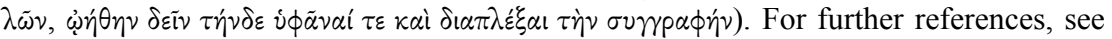
J. König, 2007, p. 44, n. 3. As to the associative style of arrangement in Plutarch's Quaestiones convivales, Athenaeus' Deipnosophistae and Gellius' Noctes Atticae, see also K. Oikonomopoulou, 20I3a, pp. I48-I49: "In texts like Plutarch's $Q C$ and Athenaeus' Deipnosophistae, this is meant to reflect the associative twists and turns of sympotic conversation. In texts like Gellius' Attic Nights, it is meant to reflect the author's own associative leaps at the moment of composition. The common denominator is the link drawn between the order of the textual product and a cognitive process (such as memory, or mental association) or work method (such as reading, excerpting) from which it emerged." See also J.P. Small, 1997, pp. I79-I8I. 
intends to capture the text's obvious lack of structural organisation, rather than to proclaim his own alleged pseudo-nonchalant writing technique ${ }^{137}$. As a matter of fact, there is no obvious general structure discernible in the succession of the questions that might indicate a clear-cut organisation of the problems, even if it would be intentionally complex or subtle. Nowhere does Plutarch explicitly formulate that intention and perhaps least of all in Quaest. conv. 629D.

To reject the question of an overt plan does not, however, eliminate the possibility of an intelligent design to the collection as a whole. Even though there is no obvious organisation of the problems, a more concealed design is, indeed, palpable and can be read somewhere in between the lines of the discussions. In this light, Titchener is convinced that:

"Plutarch goes to so much trouble to describe the well-made dinner party as something that has little obvious, but much concealed structure that it is counterintuitive to assume that there is NOT a similar structure to this work" 138 .

Let it be clear, therefore, that König is absolutely right - and this is, in my opinion, the most important and convincing point of his argument that the implied reader can detect several repeating themes, terminologies, theories and conversational turns throughout the work. Thus, there is some kind of a subtle explanatory scheme that overarches the text's chaotic surface and gives it a certain sense of unity ${ }^{139}$. This overarching explanatory scheme will be important in determining the educational value of Plutarch's collections of quaestiones later on [see 3.2.I.].

What matters here is that there is no tangible structure to miscellaneous texts like Plutarch's Quaestiones convivales. One can presume that this is deliberate, in the sense that Plutarch's $\pi \circ \lambda \nu \mu \alpha \dot{\theta} \varepsilon \varepsilon \alpha$ project not only requires a playfully digressive structure but also generates it. In view of the literary aesthetic of variatio, the associative continuum of the concatenated problem chapters breaks off at certain points only to be re-initialised later. This certainly complicates a linear reading, but it does not make such a reading impossible. Perhaps it is better, then, to speak of a staccato reading process (as an alternative for Harrison's fragmentary, piecemeal

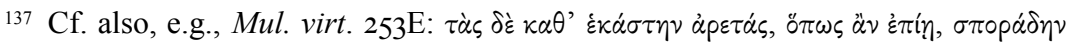

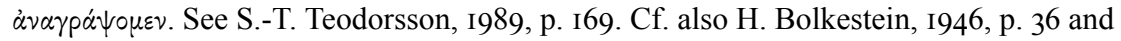
F. Fuhrmann, 1972, p. xi. A little earlier in Quaest. conv. 629D, Plutarch refers to the discussions from the first Book as $\mu \varepsilon \mu \nu \mu \varepsilon \dot{v} \alpha \delta \varepsilon \dot{\gamma} \gamma \mu \alpha \tau \alpha$. Incidentally, at the very beginning of Book one, in Quaest. conv. 612E, Plutarch notes that the discussions themselves took

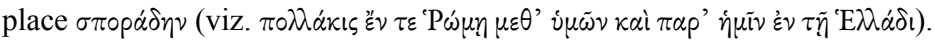

138 F. Titchener, 2009, p. 396.

139 J. König, 2007, p. 6I. See also E. Kechagia, 20IIa, pp. 97-99. 
reading process). Read in this way, Plutarch's variegated writing strategy guarantees a certain degree of structural unity and disunity, offering the reader an opportunity to focus, divert, and refocus his attention from time to time. After all, the intended reader of such miscellanies - that is, the allround $\pi \varepsilon \pi \alpha ı \delta \varepsilon \nu \mu \varepsilon v_{\nu} \varsigma_{-}$- was interested in the broad field of ancient learning. In Quaestiones convivales, one can now read something on literature, then something on science, then something on music, history, etc. It would, indeed, go against the basic prerequisites of the miscellaneous genre to expect a ready-made and fully transparent ordering of the material, and Plutarch very well knew this.

If we now transpose these ideas onto the miscellaneous macrostructure of Quaestiones naturales (while trying to avoid too much repetition), we can easily see that there is greater thematic unity in this collection than in Plutarch's Quaestiones convivales, as it exclusively deals with natural problems and their explanations. Even so, there is no clearcut macrostructure to its contents either. Plutarch does not provide a systematic survey or catalogue of nature, but a collection of very diverse natural problems that are only loosely connected with each other through specific connective phrases or repeated themes and concepts ${ }^{140}$. Despite the collection's superficial disunity, it seems that the theory of a linear, staccato reading, as has just been described for Quaestiones convivales, also applies to Quaestiones naturales. Several arguments can be adduced in favour of this type of reading (which I summarise from Morgan's article on Plutarch and the miscellany) ${ }^{141}$. I) The lack of an obvious structure complicates looking up any specific passage, and the same goes for the lack of a table of contents ${ }^{142}$. 2) Collections of problems were used in education [see 3.I.] and, by implication, were read in extenso. What was useless and could be neglected was simply left out in the first place. 3) The thematic sequences (concatenatio) are intended by the author, and they would have no use, unless the author did not expect the reader to

140 J. Boulogne, I992, p. 4699, n. III draws the same conclusion for Quaestiones Romanae: "l' ouvrage n'a pas été conçu pour être consulté à la manière d'une espèce de catalogue, qu' on peut ouvrir à n' importe quelle page. Il a été rédigé de façon liée, afin d'être parcouru dans son déroulement linéaire". When G. Nuzzo, I99I, p. 4IO regarding Quaestiones naturales speaks of the "rigida cadenza catalogica scandita dall'incipit $\delta \grave{\alpha}$ $\tau i$ ', this should not, of course, be understood as a reference to the overall structure of the collection but to the typical introduction of the quaestiones themselves. Nuzzo refers to Ps.-Aristotle's model and draws a comparison with the structure of Hesiod's ì oi $\alpha$ (i.e. the Catalogue of women). Cf. also E. Kechagia, 20Ira, p. 99 (regarding Quaestiones convivales).

141 T. Morgan, 20II, pp. 69-70.

142 Longolius' Latin translation does contain an Index Problematum de causis naturalibus Plutarchi, but this is not original, and the book-format may explain why it is included (cf. also the index in L. Senzasono, 2006, pp. 53-55). 
notice them. 4) Bridge passages between two sections would have no use if the sections were not read consecutively. As we saw, such phrases as

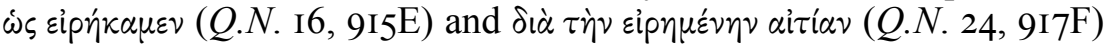
draw an explicit link with the previous problem chapter and, as such, mark and stimulate a linear reading ${ }^{143} .5$ ) An argument that can be added here, but that does not apply to Quaestiones naturales (though it does to the prefaces of Quaestiones convivales), is that the author expects the reader to have read the previous section before reading the following one by the use of introductions and digressions.

In conclusion, the fact that Plutarch's collections of quaestiones promote a linear reading does not explain why this exactly is the case. However, this is a point that I will discuss later on, when dealing with the 'active reading' process promoted by such works [see 3.2.I.]. If it is true, moreover, that Plutarch expected the reader of Quaestiones naturales to go through the collection in a systematic way and not by browsing through it at random, it seems useful to provide an interpretation of the very first words of the text as provided by the title. As is the case with most texts, there lies essential programmatic value in their title, since it creates a broad horizon of expectation on the side of the intended reader. Getting the title correct, then, will not just be a matter of scholarly pedantry but will allow a better understanding of the author's intellectual project and intentions with this work.

\section{The title and its programmatic value}

As noted earlier on, the Lamprias catalogue lists a significant number of collections of Aitial among Plutarch's writings, several of which we still have today, whereas others are now lost or partially preserved in fragmentary form (see n. 9I). Among these collections only Quaestiones Romanae (nr. 138), Quaestiones Graecae (nr. I66) and Quaestiones naturales (nr. 2I8) have been preserved at any considerable length (Quaestiones convivales is not listed and Quaestiones Platonicae belongs to the genre of $\eta_{\eta \tau} \eta_{\mu \alpha \tau \alpha}$; see further). The original title of Quaestiones Romanae and Graecae is not obvious from the manuscripts ${ }^{144}$, but

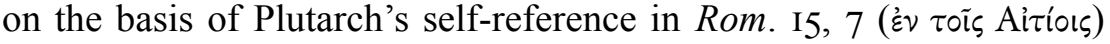
and in analogy with Callimachus' famous Ai $\tau$ i $\alpha$ scholars have inferred

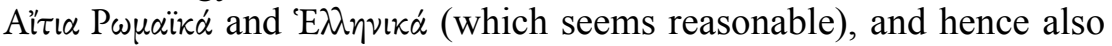

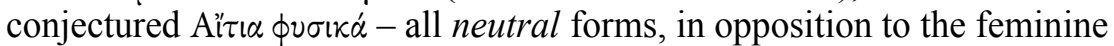
forms of the Lamprias catalogue. The latter title (Ai $\tau i \alpha \phi v \sigma i k \alpha)$ was in general use after the publication of Bernardakis' I893 Teubner edition

${ }^{143}$ Cf. also L. Van der Stockt, 20II, p. 453. For consecutive reading in Plutarch's collections of quaestiones more generally, see K. Oikonomopoulou, 20I3a, pp. I47-I52.

${ }^{144}$ See J. Boulogne, 2002, pp. 9I and I79. 
of Quaestiones naturales ${ }^{145}$, until Sandbach in his 1965 Loeb edition rejected it as a false conjecture and preferred the feminine to the

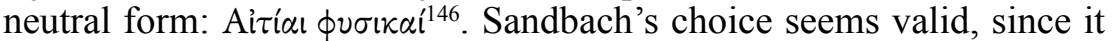
is based on the reading of (each of) the manuscripts, but, unfortunately, Plutarch does never explicitly refer to Quaestiones naturales in his other writings (or at least not by the collection's title [see 2.I.4.]). As such, except from the manuscript reading, there is no firm evidence for the title's original wording. Moreover, the evidence that is furnished by the Lamprias catalogue (which has the feminine form) has been contested by Boulogne, who pointed at the catalogue's established unreliability (see n. 3). Boulogne's guardedness may, indeed, be justifiable as far as the Lamprias catalogue is concerned, but the reading of the manuscripts still provides a sufficient argument for Sandbach's correction ${ }^{147}$. A further indication is furnished by the fact that the female noun aitia recurs more often in the collection (than the neutral form ai $\tau 10 v)$ and is even found

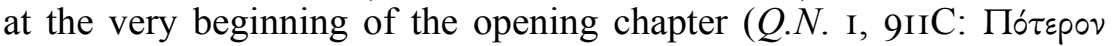

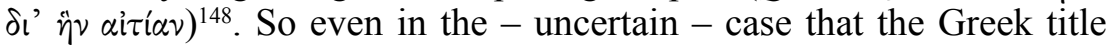
of our collection would be apocryphal (was it perhaps attributed to it posthumously on the basis of the opening in Q.N. I? [see prologue, n. 20]),

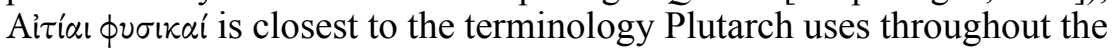

145 Bernardakis' conjecture was adopted by C. Hubert in his I960 Teubner edition. See also, e.g., H.J. Rose, I924, p. 49 and J. Boulogne, I992, pp. 4683-4684 with n. II. P. Payen, 20I4, pp. 243-244 sketches the situation in a more confused way.

146 F.H. Sandbach, I965, p. I33 (cf. also W. von Christ, I959, p. 5I2, n. 2). A. Gudeman,

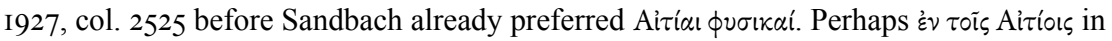

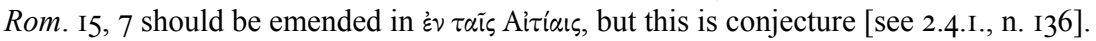

147 J. Boulogne, I992, p. 4684, n. II. Sandbach also pointed out that there is nothing

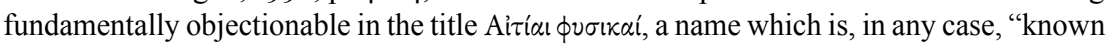
to have been used by his Greek-speaking readers" (p. 133). Notably, the feminine form

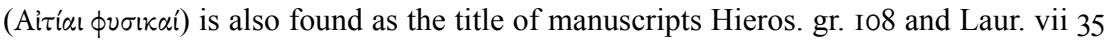
of the first redaction of Psellus' De omnifaria doctrina, of which $\S \S 92-107$ are extracted from Plutarch's Quaestiones naturales: see L.G. Westerink, 1948, p. 3. For further detail on Psellus' incorporation of Quaestiones naturales material in his De omnifaria doctrina, see M. Meeusen, 20I2b.

148 See also Q.N. 4, 913A (

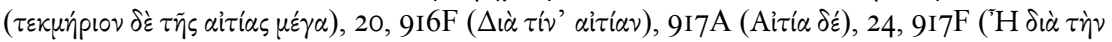

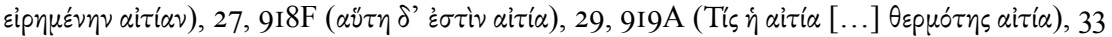

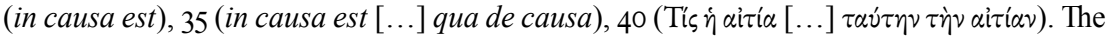

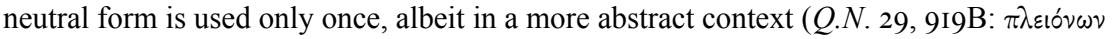

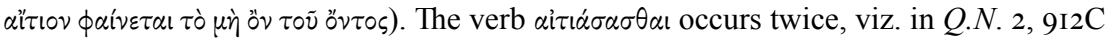
and I2, 9I5A. Cf. F.H. Sandbach, I965, p. I34 (who mentions only Q.N. 20, 916F, 29, 9I9A

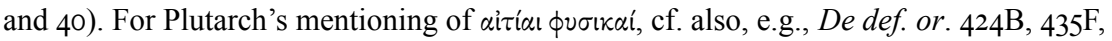
436D. The observation of G.W.M. Harrison, 200ob, p. 244 that the term aiti $\alpha$ occurs only once in the collection is inaccurate (viz. in $Q . N .20,917 \mathrm{~A}$; his assertion that this is the only causa that is formulated as a dogmatic statement is also incorrect: see n. 96). 
work, so that it at least provides an adequate description of the collection, in terms of its causal approach (see further).

As to the term Airía in the title, Harrison believes that "Plutarch's use

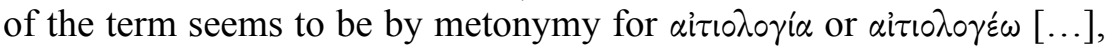
which would seem in turn to imply that Plutarch looked to one or another of Epicurus' lost works for inspiration in modifying the genre."149 The first

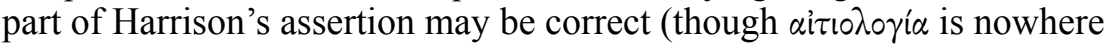

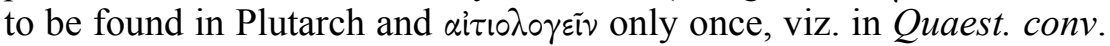
689B), but the second part (about the influence of Epicurus) seems rather unlikely. In any case, D.L. (IO, 26-28) does not list a collection of Airial among Epicurus' works (although there is a collection of $\Delta \iota \alpha \pi \circ i^{\prime} \alpha \iota$ and

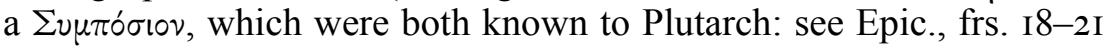
and 57-65 Usener respectively). Moreover, the argumentative strategy of providing several plausible explanations for one and the same natural phenomenon was also an important feature of Epicurus' scientific method, albeit for motives completely different than Plutarch's (as we will see later [see $4 \cdot 3 \cdot 3.2]$.$) .$

It seems more suitable, I believe, to refer to Democritus in this regard,

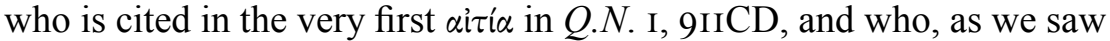
earlier, was the first to compose an actual collection of problems (see n. 58). Democritus' aetiological interests are captured in his reported saying that he would rather prefer to find a single aetiology ( $\left.\alpha i \tau i o \lambda \circ \gamma^{\prime} \alpha \nu\right)$ than to reign over the Persian empire (DK68Bir8). In fact, we know from D.L. 9, 47 that Democritus composed eight thematic sets of natural scientific Ai $\tau i \alpha \iota$ (sic), which are mentioned under the $\alpha \sigma v ́ v \tau \alpha \kappa \tau \alpha$ in Thrasyllus'

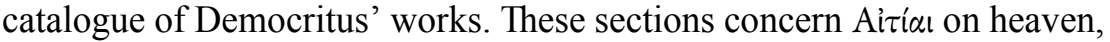
air, earth, fire, sounds, seeds, plants, fruits, animals (in three Books) and miscellanea. As we saw earlier, scholars have even considered Democritus a precursor to Peripatetic natural science, drawing a close parallel between his and Aristotle's aetiological project (see n. 59). Diels claimed that many Democritea were actually integrated in Ps.-Aristotle's Problems, so that Democritus' indirect influence on Plutarch's natural problems is not unlikely, although it is not always clearly traceable either ${ }^{150}$. Remnants of Democritus' theories about animals, plants and water can be traced, for instance, in Q.N. I, 9IICD (regarding seawater being undrinkable and bad for humans but nourishing for fish) and 5, 9I3CD (regarding the filtration

149 G.W.M. Harrison, 2000a, p. I95, n. 6.

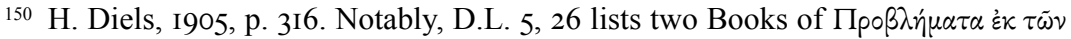
$\Delta \eta \mu о к p i \tau o v ~ a m o n g$ Aristotle's works, and the index Hesychii contains a similar title (nr.

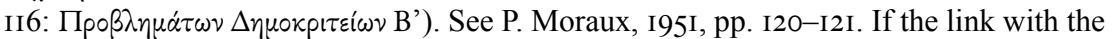
Ps.-Aristotelian Problems is real, it is not impossible that the thematic rubrications in this work was inspired by the thematic categories in Democritus' Airía. This remains uncertain, though. 
of seawater) (see the commentary ad loc. for more detail). In addition, Democritus' causal research is also relevant for interpreting Plutarch's own approach to natural problems, but this will be treated later on [see 4.I.I.2.].

To come back to the wording in the Greek title, there is no essential

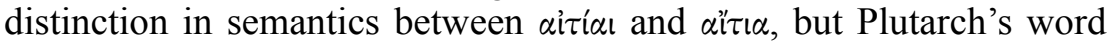
choice is not, therefore, insignificant. As Grandjean recently observed, "[c]ontrairement à Aitia, les Aitiai ne renvoient pas à une tradition littéraire. C' est un terme emprunté à la physique, à la métaphysique et au droit. Un tel titre laisse présager une réflexion philosophique plutôt qu' un récit ou une explication littéraire." 151 The Latin title, Quaestiones naturales, by contrast, which was assigned to the collection since the very first editions of Xylander etc., is clear but not really apposite, because the concept of quaestiones is too generic to map the subtle distinctions

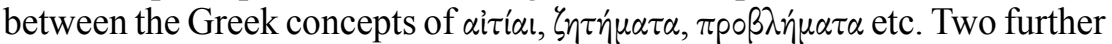
remarks should be made in this regard.

First of all, the Latin title obfuscates the distinction between the concepts of $\alpha i \tau i \alpha$ and $\zeta_{\eta} \tau \dot{\eta} \mu \alpha \tau \alpha$. Plutarch probably composed more collections

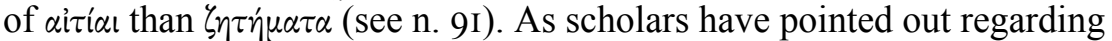
Plutarch's Quaestiones Platonicae (in Greek: $\Pi \lambda \alpha \tau \omega \nu$ ik $\dot{\zeta} \eta \eta \eta \dot{\eta} \mu \alpha \tau \alpha)$, the Chaeronean's use of ' $\eta \tau \eta \dot{\eta} \mu \alpha \tau \alpha$ often has an exegetical connotation, as it is mostly concerned with the elucidation and interpretation of particular enigmatic passages in a given philosophical or poetic text ${ }^{152}$. By contrast, Plutarch's collections of airia mostly treat more general intellectual topics, such as the origins of specific cultural traditions or the causes of natural phenomena, so that the strict connection with a text is absent ${ }^{153}$. This is not, of course, to deny that Plutarch often relies on written sources in his collections of aitial. Moreover, there is not always much consistency in Plutarch's own wording, so that at least in some cases the nuances in semantics seem artificial ${ }^{154}$. In addition, both types of inquiry do not

151 T. Grandjean, 2008, p. I47, n. 2.

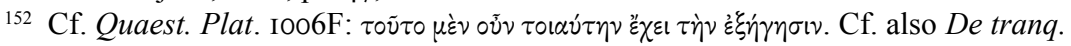

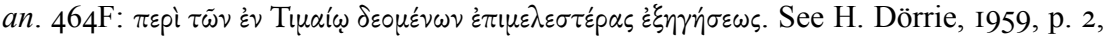
J. Opsomer, I994a, p. IO, I996a, p. 72, 20I0, p. 93 and J. Boulogne, I992, p. 4684, with n. I5: "Il [sc. Plutarque] leur [sc. les $\alpha i \tau i \alpha l$ substitue le substantif $\xi \eta \tau \eta \dot{\mu} \mu \tau \alpha$ quand il s'agit de difficultés soulevées par les assertions de poètes ou de philosophes." See also G.W.M. Harrison, 2000a, p. 195 and L. Van der Stockt, 2000b, p. 96.

153 The exegetical nature of the $\eta_{\eta} \eta^{\prime} \mu \alpha \tau \alpha$, which requires that the passage under discussion be reissued and explained more or less $\kappa \alpha \tau \dot{\alpha} \lambda \hat{\varepsilon} \xi$ lv, can perhaps explain why

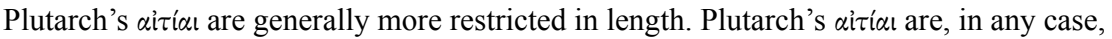
significantly shorter than an average $\zeta \dot{\eta} \tau \eta \mu \alpha . Q . N$. I, 2, 5, I9, 2I and 26, for instance, are relatively lengthy, but even so, each of them is only about half as long as an average Quaestio Platonica.

${ }^{154}$ Regarding Plutarch's terminology in Quaestiones convivales, G.W.M. Harrison, 
strictly exclude one another: for instance, the eight fragments that remain

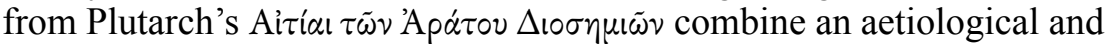
an exegetical approach (= frs. I3-20 Sandbach; cf. also the Aratus quote in Q.N. 2, 9I2D). Importantly, the more scholarly feature of $\zeta \eta \tau \eta^{\prime} \mu \alpha \tau \alpha$ does not devalue their philosophical interest for Plutarch. This is true at least for Quaestiones Platonicae, because, for Plutarch, a correct understanding of Plato's texts would enable him to grasp the philosophical truth that they contained $^{155}$.

The second point concerns the discrepancy in meaning between the concepts of $\alpha i \tau i \alpha l$ and $\pi \rho \beta \beta \lambda \eta^{\prime} \mu \alpha \tau \alpha$. Notably, the Greek title of Quaestiones naturales does not mention the word $\pi \rho \circ \lambda \eta \eta^{\mu} \alpha \tau \alpha$. Even if the 'problematic' form, style and content of Plutarch's natural problems and those collected

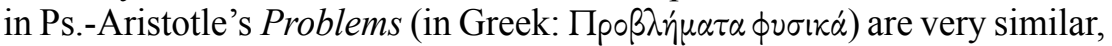
the variable terminologies in the titles may suggest a subtle difference in purpose. With the term aitial more emphasis is, then, put on the explanations - the quaerenda - of the natural phenomena under scrutiny, while the term $\pi \rho \beta \beta \lambda \eta \mu \alpha \tau \alpha$ rather stresses the enigmatic character of these phenomena themselves - as presented in the quaestiones ${ }^{156}$. As we will see later on, the distinction between quaerenda and quaestiones is very relevant in light of the scientific methodology Plutarch employs in dealing with problematic natural phenomena. In short, Plutarch's main concern is with the $\delta i \dot{\alpha} \tau i$, that is, with the natural causes and explanations of the phenomena, rather than with the ö $\tau$, that is, the aspect of empirical verification [see 4.I.I.]. In other words, Plutarch is not so much interested in the actual physical reality of the problematic natural

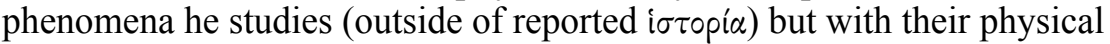
aetiology. Therefore, I agree with Boulogne when he prefers to speak of "Étiologies plutôt que [...] Questions"157. Regarding Plutarch's choice of words in the titles of his aetiological collections, Boulogne affirms that:

"les mots ne sont pas employés indifféremment, comme s'ils étaient synonymes. [...] Il semblerait, partant, que Plutarque choisisse le

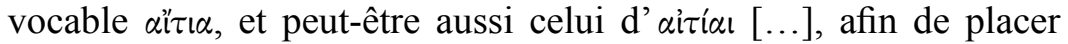
l'accent sur la détermination de l'origine des faits observés, plutôt que sur leur caractère intrigant, et par là, de signaler une étude

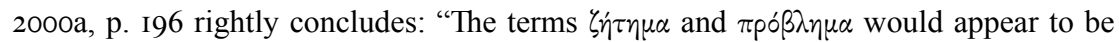
interchangeable in this work since no pattern is detectable".

155 See J. Opsomer, I996a, p. 74.

156 The distinction in semantics, again, may not be very strict: cf., e.g., De tuenda ${ }_{133} \mathrm{E}$ (

157 J. Boulogne, I998, p. 3I. F.C. Babbitt, I936a, p. 2 speaks of "The Reasons Why". G.W.M. Harrison, 2000a, p. 195 prefers "Explanations, that is, clarifying information". 
particulièrement approfondie des causes sur des objets séparés et, pour ainsi dire, isolés les uns des autres, comme s'il voulait limiter le plus étroitement possible le champ de son examen et rendre, de la sorte, son investigation plus pointue, sans que vienne s' ajouter d' autre préoccupation." 158

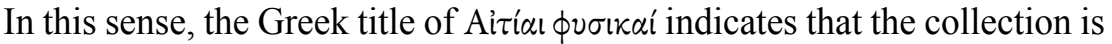
meant to be a set of profound physical aetiologies, that is, a thorough study of the natural causes of the particular enigmatic phenomena that drew the author's attention. I am not so sure, however, whether Ps.-Aristotle's model lacks this aetiological profundity, as Boulogne claims (subsequently to the given quote), or, a fortiori, that the aetiological openness of the problems there has become a purpose in itself so that the Problems remain immanently 'problematic', in opposition to Plutarch's natural problems, where the explanations would be more 'conclusive' 159 . It is, indeed, true that the average number of explanations for each problem is higher in Plutarch's Quaestiones naturales than in Ps.-Aristotle's Problems, where often only one explanation is given for a problem, but even so, the natural problems remain fundamentally unsolved also in Plutarch's case, since they are formulated anti-dogmatically and, thus, invite for further research. The only thing that is fundamentally different is the epistemological basis on which this research was grounded, Plutarch postponing final judgement, since he, in opposition to Aristotle, refused to put much confidence in knowledge derived from sensory data [see 4.3.2.I.]. By contrast, Aristotle's avoidance of argumentative conclusiveness was more practically motivated, aiming to foster further research in the Lyceum

\footnotetext{
158 J. Boulogne, I992, p. 4684.

159 Regarding the difference between Plutarch's ai $\tau\llcorner\alpha / \alpha i \tau i \alpha \iota$ and Ps.-Aristotle's Problems, J. Boulogne, I992, p. 4684 (see also C. Darbo-Peschanski, I998, p. 22) argues that "l' exploration de la causalité y [sc. dans les 'Questions d' histoire naturelle' et les Q.R. de Plutarque] est poussée bien plus loin et l'on n'éprouve pas l'impression d'être en présence d'un répertoire d'énigmes ou de mystères, pour l'éclaircissement desquels est chaque fois consignée une ébauche de solution, comme pour mémoire, dans l'attente d' enquêtes ultérieures". It should be noted, however, that the interrogative structure of the explanations is a common feature of both Plutarch's $\alpha i \tau i \alpha / \alpha i \tau i \alpha \iota$ and Ps.-Aristotle's $\pi \rho \beta \beta \lambda \eta \mu \alpha \tau \alpha$, so that it is problematic to maintain that the genre of $\pi \rho \beta \beta \lambda \eta \dot{\mu} \mu \alpha \alpha$ is more

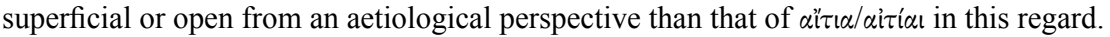
Pace also J. Boulogne, I994, p. 76 (regarding Quaestiones Romanae): "Toutefois, loin de se contenter de recenser les sujets énigmatiques et de suggérer des solutions possibles qui restent à explorer, il pretend fournir des réponses et apporter le résultat de la recherché, au lieu d'inviter à l'investigation" (my italics). As a matter of fact, both Plutarch's and Ps.-Aristotle's natural problems invite for further investigation, as they both follow an anti-dogmatic approach. What is different is the epistemological basis for this approach (see below).
} 
context. In the end, Aristotle put much more trust in the feasibility of natural scientific research than Plutarch and with him any Platonist ever did.

The bottom line is that, as the Greek title suggests, Plutarch's main attention clearly goes to the causes and not so much to the problems themselves in Quaestiones naturales. As such, the problematic natural phenomena formulated in the quaestiones are considered as given facts that do not so much require verification but rather explanation. In this sense, the Greek title captures the scope of the collection rather well, but the same cannot be said of the unlucky Latin rephrasing: Causae naturales would be a more accurate rendering than Quaestiones naturales ${ }^{160}$.

In order to now make Plutarch's primary focus on the physical causes in his natural problems more concrete, a short comparison with Seneca's Naturales quaestiones is in place. First of all, there is no reason to assume that Plutarch had actually read Seneca's work or that he was even acquainted with its existence. Apart from a few inevitable parallels in subject matter ${ }^{161}$, Seneca's work is completely different in several regards from Plutarch's, so that the significance of their resembling Latin title should not be exaggerated. This is true not only from the perspective of I) structural arrangement but also 2) of their scientific purpose ${ }^{162}$.

I) Seneca's Naturales quaestiones does not belong to the tradition of Aristotelian natural problems from a formal perspective. Hine rightly suggests that "[i]f $\mathrm{S}$. himself chose the present title of the $N Q$, it was not because he was adhering to that genre [sc. of the problemata and zetemata] as we know it. A possible reason is that such a title allowed him to treat a miscellany of such subjects as took his fancy, without committing him to a systematic and comprehensive treatise, such as a title like De rerum natura might have suggested."163 In this work, Seneca does, however, name two authorities that are of potential relevance for the tradition of natural problems: viz. Asclepiodotus and Papirius Fabianus. Asclepiodotus lived in the $\mathrm{I}^{\text {st }}$ century BC. He was one of Posidonius'

160 The same point was made by H.M. Hine, I984, p. 29. Sandbach's Causes of Natural Phenomena is periphrastic but closer to the Greek original. Longolius translates as Causarum naturalium liber unus. Flacelière speaks of "Causes physiques [...] et peut-être ferait-on mieux de parler de Questions de physique" (in R. Flacelière, J. Irigoin, J. Sirinelli and A. Philippon, 1987, pp. 1xxxi-lxxxii). K. Ziegler, 195I, col. 857 has Quaestiones physicae. And so the list can go on (see F. Tanga, 20I5, pp. II4-II5, n. 2I).

161 Cf., e.g., Q.N. 5, 913C and $N Q 3,5 ;$ Q.N. 6, 913 $\mathrm{E}$ and $N Q 3,25$, II; Q.N. 13, 915B and $N Q 6, \mathrm{I} 3,2 ; Q . N .29,919 \mathrm{~B}$ and $N Q 7, \mathrm{I}-4$. There are also obvious divergences, though: cf., e.g., Q.N. 4, 9I3A vs. $N Q 2,57,2 ; Q . N .40$ vs. $N Q 2$, 3I, 2.

162 See H.M. Hine, I984, pp. 28-29 (esp. at p. 29 on Plutarch's Quaestiones naturales).

${ }_{163}$ H.M. Hine, I984, pp. 28-29. See also A. Blair, I999, p. I92, n. I4: "[t]he most famous Natural Questions, by Seneca [...], are never called problemata [in Renaissance editions] and take a somewhat different form, with longer discursive answers within a dialogue". 
students and composed a collection of Quaestionum naturalium causae (?). He is quoted several times by Seneca. The title of his work is mentioned in $N Q 6,17,3$ - though possibly in a corrupt gloss ${ }^{164}$. Papirius Fabianus, on the other hand, lived at the beginning of our era and composed a collection of Causae naturales. This work may have had more in common, from a formal perspective at least, with Plutarch's Quaestiones naturales than with Seneca's Naturales quaestiones. In the end, Fabianus is mentioned only once by Seneca $(N Q 3,27,3)$, so that it is unlikely that his work served as Seneca's model ${ }^{165}$. There is a clear link between Seneca's Naturales quaestiones and Aristotle's natural science, but an important intermediate source of inspiration for Seneca may have been Posidonius (perhaps precisely via Asclepiodotus $)^{166}$, whom Strabo denounces as a would-be Peripatetic in light of his interests in causal research ${ }^{167}$.

2) Seneca presents his Naturales quaestiones as a thoroughly wrought piece of literature in dialogue form, which, as Hine has argued, meets the stylistic level of Plutarch's Quaestiones convivales, rather than Quaestiones naturales ${ }^{168}$. Of course, the comparison does not hold up to further analysis: in Seneca's work, there is obviously not much dialogue, where several characters are put on scene. Seneca only addresses the dedicatee, Lucilius, directly, and at times an imaginary interlocutor falls in, but even so, a monologic discourse clearly prevails ${ }^{169}$. The questionand-answer format, which is so typical of the structural organisation of the genre of problems, yields to a more essayistic and prosaic discourse in Seneca. Seneca only formulates questions on occasion, but the explanations are phrased dogmatically and there is not much place for an enumeration of several plausible explanations ${ }^{170}$. Notably, in Ben. $7, \mathrm{I}, 5$, Seneca actually agrees with the Cynic Demetrius in rejecting the practice of solving natural problems (e.g., concerning the ocean tides and optical illusions), since they provide only useless knowledge ${ }^{171}$. This

${ }^{164}$ See H.M. Hine, I984, pp. 24-25. See also K.K. Müller, I896 and P.T. Keyser and G.L. Irby-Massie, 2008b, p. 172.

${ }^{165}$ Cf. H.M. Hine, 1984, p. 29. Pliny, by contrast, names him several times and calls him 'most experienced in natural scientific affairs' ( $\mathrm{NH}_{3} 6$, 125 : rerum naturae peritissimus). See W. Kroll, 1949 and A. Zucker, 2008, pp. 6Io-6II.

166 See P. Oltramare, I96I, p. xvii. For Seneca's reliance in Naturales quaestiones on Greek science, see P. Parroni, 2002, pp. xxii-xxvi.

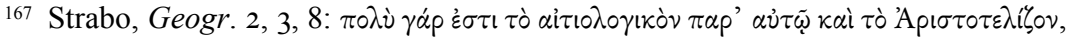

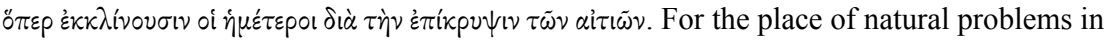
Stoic scientific thinking more generally, cf. D.L. 7, I32-I33.

168 H.M. Hine, I984, p. 28.

169 F.H. Sandbach, I965, p. 134 is right in saying that "[u]nlike Seneca's Naturales quaestiones, it [sc. Plutarch's Quaestiones naturales] is not a literary work."

${ }^{170}$ See, e.g., $N Q$ 2, 58; 3, II; I6; 20.

171 Seneca also includes natural problems among the 'leisurely delights' in Ben. 7, I, 7 
criticism should be put in perspective by the fact that the right study of natural phenomena has significant moral implications for Seneca, in that it aims to provide, what Williams has recently called, a "cosmic viewpoint" for his ethical philosophy ${ }^{172}$. As opposed to what Plutarch does in his natural problems, Seneca frequently incorporates a strand of ethical paraenesis in his scientific discourse, so that the text is lifted to a moralising echelon. By issuing imperatives of traditional social mores, there is a direct relation between the science of nature and that of life in Seneca's Naturales quaestiones ${ }^{173}$. This trait-d'union is - quite notably, considering his otherwise well-known moralising inclinations - absent in Plutarch's natural problems, as is the feature of literary stylistics.

In the following section, I will, therefore, draw further attention to the central focus in Plutarch's Quaestiones naturales on the physical causes of natural phenomena. I will do this specifically by analysing its 'problematic' discourse at two levels, viz. by examining its sub-literary style and its lack of moralising dynamics. I conclude here that it seems imprudent to include Seneca's Naturales quaestiones in the wider tradition of Aristotelian natural problem literature, and that it has only little in common with Plutarch's alleged Greek counterpart - except perhaps from its Latin title, but even this is not so unproblematic, as we saw.

\subsection{Problems related to Plutarch's scientific discourse}

\section{Trifles unworthy of Plutarch? Some remarks on authenticity}

In contemporary scholarship, Plutarch's Quaestiones naturales has come to be accepted as authentic without reservation, but this has not always been the case. Among $19^{\text {th }}$ century scholars in particular, the collection's spuriousness was commonly accepted. This changed, however, around 1900. Doehner, for instance, severely rejected the work's authenticity by disparaging it as "miseras Plutarchi imitatorum quisquilias"174, and

(oblectamenta otii). In fact, he considers the genre of problems more generally as 'useless furniture of learning' (Ep. 88, 36: supervacua litterarum supellectile). Cf. also Brev. vit. I3, I-3. See W. Bühler, I977, p. 44 and M. Beagon, 20II, p. 73.

172 G.D. Williams, 20I2. Cf., e.g., $N Q$ 3, Praef. I8. Notably, Chrysippus composed

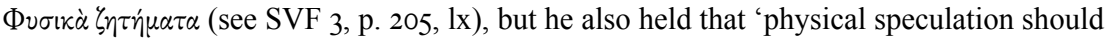
be undertaken for no other purpose than for the distinction of good and evil' (De Stoic.

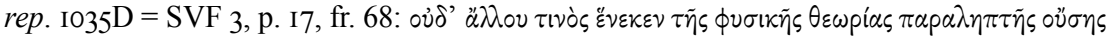

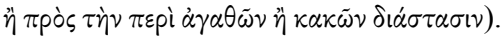

173 See esp. $N Q$ 6, 32, I: alterum sine altero non fit. G. Stahl, I964, p. 426 distinguishes three thematic categories in Seneca's Naturales quaestiones: "exakt-wissenschaftliche Naturuntersuchungen, mirabilia-Geschichten und natur- bzw. moralphilosophische Paränese". Only the first two categories are also present in Plutarch's natural problems.

${ }^{174}$ T. Doehner, I858, p. I4 (cf. also I864, p. 6I: "Plutarchum, vel quicunque quaestionum naturalium auctor est"). 
scholars like Volkmann ${ }^{175}$ followed suit. Weiss claimed in a similar vein that "quaestiones naturales non a Plutarcho profectas esse inter omnes constat" 176 . Croiset's evaluation was also negative: "Les Questions naturelles sont un ouvrage sans valeur, qui ne peut être attribué à Plutarque." 177 The authenticity of the collection was vindicated, however, on linguistic and stylistic grounds by Weissenberger ${ }^{178}$. Diels ${ }^{179}$ rejected Doehner's false evaluation of the unpretentious "Schriftchen", while Hartman ${ }^{180}$ could find no reason to reject its authenticity. Ziegler ${ }^{181}$ was also convinced of its authenticity, as was Hubert ${ }^{182}$. Eventually, Sandbach ${ }^{183}$ did not even mention the problem of authenticity, and, as Senzasono pointed out ${ }^{184}$, this problem has simply been superseded today.

It seems that the initial doubt about the work's authenticity was fed by the scholarly prejudice that Plutarch is first and foremost a moralist and eloquent story-teller, author of popular-philosophical speeches and of dramatised dialogues. Still today, the Chaeronean is seen as a flamboyant litterateur and lecturer with a balanced enthusiasm for moral instruction and stylistic embellishment. Clearly, this image does not apply to his more technical writings and to his collections of quaestiones more in specific (with the exception of Quaestiones convivales), where the text's aesthetic is restrained by a rather simple and rudimentary style of discourse. We will see that there are some glints of literary ornatus in Quaestiones naturales, though, but even so Plutarch is clearly preoccupied with the discursive concerns of brevity and clarity, thus making it absolutely clear that his main concern is with the argument rather than with the form $^{185}$.

175 R. Volkmann, I869, p. I88 (in footnote).

176 D. Weiss, I888, p. I8.

177 A. and M. Croiset, I899, p. 5II, n. I.

178 B. Weissenberger, I895, pp. 8I-82.

179 H. Diels, 1905, p. 315, n. I.

180 J.J. Hartman, I9I6, p. 556: “Aetia vero Physica cur Plutarcho abiudicemus nullam causam video. Haud pauca in eo libro admodum lepida leguntur quaeque Plutarcho cordi fuisse minime mirum sit [...]."

${ }^{181}$ K. Ziegler, I95I, col. 857: "Keinesfalls besteht ein Grund, die Schrift [...] dem P. abzusprechen".

${ }^{182}$ C. Hubert, I960, p. v: "quin genuinae sint dubitare non licet".

183 F.H. Sandbach, I965, p. I33.

184 L. Senzasono, 2006, p. 44.

185 As Plutarch notes himself, philosophical discourse is concerned with 'the lucid and

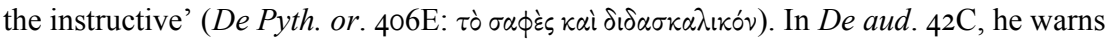
his students that they should first and foremost focus on the content of what is said during

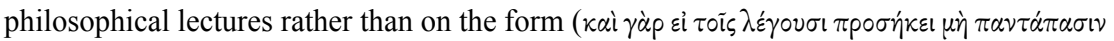

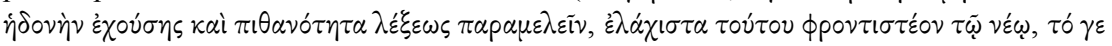
$\pi \rho \tilde{\omega} \tau \circ)$. 
Even if Plutarch's literary and moralising flair are not exactly on display in Quaestiones naturales, the text's authenticity can be confirmed on a number of grounds. First of all, several typical features of Plutarch's basic style are clearly evident in the collection. I have already mentioned the use of semi-synonymous pairs (see n. I09 above); to this the general avoidance of hiatus and (less evidently) the use and avoidance of certain rhythms at sentence endings can be added ${ }^{186}$. Furthermore, a large amount of parallel passages can be found throughout Plutarch's other works. The similarities between these parallels are so prominent that they cannot be treated as coincidental. The fact, moreover, that the collection is recorded in the Lamprias catalogue could further support the text's authenticity but this does not serve as any definitive proof (see n. 3). In short, it goes without saying that even if the text is less alluring from a stylistic or moralising perspective, this is no stable ground for denying its authenticity ${ }^{187}$. Therefore, before dealing with the problems of style and morality in Quaestiones naturales, let us first take a closer look at how Plutarch himself conceives of what constitues natural scientific discourse proper.

\section{The rhetoric of scientific discourse according to Plutarch}

Several passages in the corpus Plutarcheum indicate that Plutarch mostly identifies the rhetoric of ancient scientific discourses, and especially that of ancient meteorology, in terms of the rhetorical category of 'the sublime' ( $\tau \dot{0}$ Ư ${ }^{\circ}$ ). In De prof. in virt. $78 \mathrm{E}$, for instance, Plutarch notes that practically all young, haughty philosophers pursue those forms of discourse that strive for repute $\left(\delta \delta^{\prime} \xi \alpha\right)$, and that some of them 'like birds, are led by their flightiness and ambition to alight on the resplendent heights of the natural

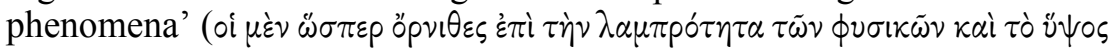

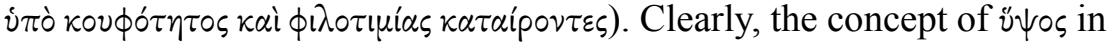
this passage refers both to the style and content of the meteorological

${ }^{186}$ On the general stylistics of Quaestiones naturales, see K. Ziegler, I95I, col. 857, F.H. Sandbach, I965, pp. I34-I36, G.W.M. Harrison, 200ob and L. Senzasono, 2006, pp. 8-I8. Regarding Plutarch's avoidance of hiatus, see J. Schellens, I864, R. Flacelière, J. Irigoin, J. Sirinelli and A. Philippon, 1987, pp. ccxii-ccxiv, S.-T. Teodorsson, I989, p. I28 (Plutarch did not avoid hiatus systematically, though: cf. De vit. pud. $534 \mathrm{~F}$ and Bellone an pace 350DE). On Plutarch's use and avoidance of certain rhythmical clauses, see F.H. Sandbach, 1939, pp. I94-203 and M. Baldassari, 2000. On Plutarch's style and language more generally, see, e.g., K. Ziegler, I95I, cols. 93I-938, S. Yaginuma, 1992 and L. Torraca, I998.

${ }^{187}$ Let alone for doing away with it altogether. The same point was made for the modest literary merits of Plutarch's Apophthegmata by F. Fuhrmann, I988, p. 4: "Mais peut-on ainsi rejeter tout ce qui, dans le corpus des oeuvres de Plutarque, n' est pas de haute tenue? A quel niveau situera-t-on la limite?" 
type of discourse, which is, indeed, concerned with things of an elevated nature (viz. the sublime realm of $\tau \dot{\alpha} \mu \varepsilon \tau \dot{\varepsilon} \omega \rho \alpha$ or $\mu \varepsilon \tau \dot{\alpha} \rho \sigma i \alpha)$. A similar idea is present in Plutarch's account of Pericles' mode of speech in Per. 8, I-2, where we read about Pericles' habit of adopting the style of Anaxagoras' natural scientific discourse in his own rhetorical speeches:

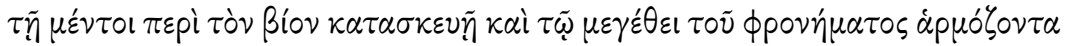

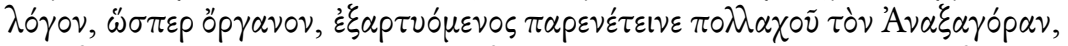

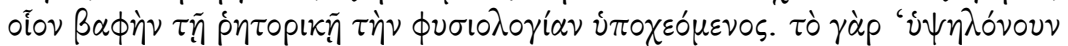

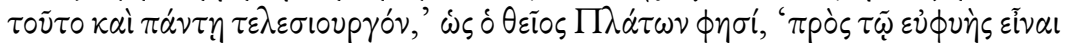

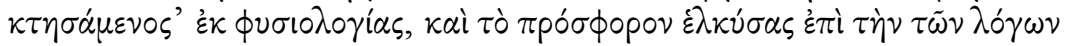
$\tau \dot{\varepsilon} \chi \nu \eta \nu, \pi \circ \lambda \dot{\nu} \pi \dot{\alpha} \nu \tau \omega \nu \delta$ in่ $\varepsilon \varepsilon \kappa \varepsilon$.

Moreover, by way of providing himself with a style of discourse which was adapted, like a musical instrument, to his mode of life and the grandeur of his sentiments, he often made an auxiliary string of Anaxagoras, subtly mingling, as it were, with his rhetoric the dye of natural science. It was from natural science, as the divine Plato says (Phdr. 270a; cf. also Them., Or. 26, 329c), that he 'acquired his loftiness of thought and perfectness of execution, in addition to his natural gifts', and by applying what he learned to the art of speaking, he far excelled all other speakers.

There is a clear moralising, ethopoietic implication to this passage, according to which the rhetorical-scientific mode and grandeur of Pericles' speech is considered to be in conformity with his way of living ${ }^{188}$ (contrast the haughtiness of young philosophers in De prof. in virt. $78 \mathrm{E}$ above). As such, Plutarch implies that the high ethical standard of Pericles' life is reflected in his stately and 'sublime' manner of speaking. Anaxagoras' influence on Pericles' character is also discussed a little earlier in Per.

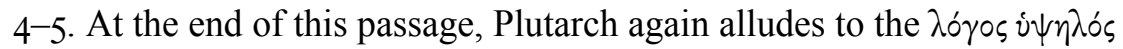
of Anaxagoras' discourses, as reflected in Pericles' own character and speech $($ Per. 5, I):

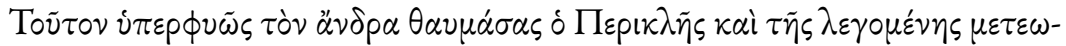

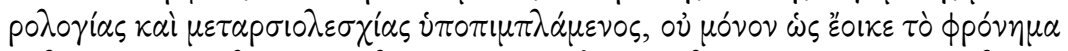

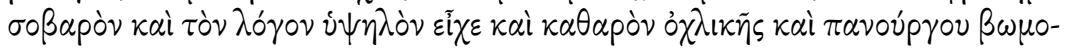

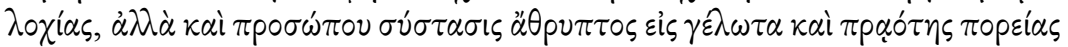

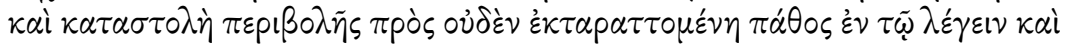

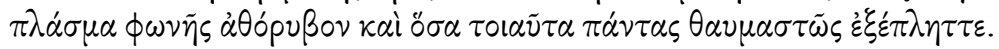

188 On the influence of Anaxagoras' discourse on Pericles' rhetorical style, see P.A. Stadter, I99I, pp. I20-I2I. 
This man (sc. Anaxagoras) Pericles extravagantly admired, and being gradually filled full of the so-called meteorology, he not only had, as it seems, a spirit that was solemn and a discourse that was lofty and free from plebeian and reckless effrontery, but also a composure of countenance that never relaxed into laughter, a gentleness of carriage and cast of attire that suffered no emotion to disturb it while he was speaking, a modulation of voice that was far from boisterous, and many similar characteristics which struck all his hearers with wondering amazement.

Arguably, Pericles' character and, connected with it, his manner of speaking elicited the same kind of wonder and amazement in its listeners as the meteorological phenomena would do of themselves. In any case, the main idea is again that Pericles' spiritual elevation, as engendered by Anaxagoras' meteorology, found its natural expression in his exalted speech $^{189}$.

What can we say about Quaestiones naturales in this regard, then? We can hardly speak of a $\lambda$ ó yos í $\psi \lambda \lambda o ́ s$ here, considering the collection's general lack of stylistic embellishment. Neither is it representative of Plutarch's own ethical persona and moralising ambitions as demonstrated elsewhere. The question is particularly intriguing, since several of the problems raised in this collection have specific meteorological interests (Q.N. 4, 24, 40). Senzasono has recently taken up a remarkable position, arguing that the general absence of stylistic embellishment in Quaestiones naturales is, in fact, an essential marker of the collection's scientific character. He argues that "l'adesione ai fenomeni fisici condiziona lo stile essenziale e sobriamente descrittivo del tratato naturalistico [...]." point of view, however, tends to be biased by our modern conceptual standards of a sober and unembellished scientific discourse, which prescribes a type of phrasing that is clear and strives for a referential

189 For a faint parallel to these two Pericles passages, see Them. 2, where Plutarch corrects Stesimbrotus' incorrect report that Themistocles was a student of Anaxagoras and a disciple of Melissus, the physicist (FGrHist I07, I). Plutarch points out that Pericles, rather than Themistocles, was a pupil of Anaxagoras and that Melissus opposed him at the siege of Samos (in 440 BC). Themistocles, on the other hand, was a disciple of Mnesiphilus the Phrearrhian, who was a sophist, that is, 'neither a rhetorician nor one of the so-called

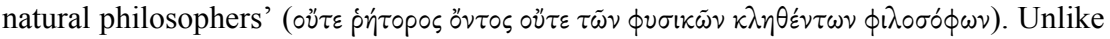
Pericles, Themistocles only relied on his natural gifts $(\tau \tilde{\eta} \phi v ́ \sigma \varepsilon เ \pi เ \sigma \tau \varepsilon \dot{v} \omega \nu)$ - not also on a philosophical education -, which may explain why his youth essays were of a deplorable

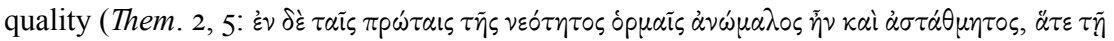

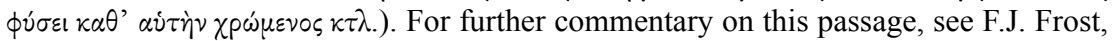
I980, pp. 65-7I.

${ }^{190}$ L. Senzasono, 2006, pp. IO-II. 
description of the physical reality that is studied ${ }^{191}$. From a modern point of view one might, indeed, argue that the general discourse and register of Quaestiones naturales complies with the ethos of scientific objectivity, by demanding a purely descriptive, unembellished discourse and, in addition, also a depersonalisation of the authorial voice. It goes without saying, though, that such a view is anachronistic, at the least. In any case, as the passages above have shown, meteorological texts were rather marked by a highly rhetorical type of discourse.

The assumption, therefore, that any scientific discourse requires a type of diction that is equally objective and depersonalised as the object of study itself is assumed to be (i.e. nature), does not add up for a large number of ancient scientific texts, including those of Plutarch. In Antiquity, the focus on natural phenomena did not necessarily entail I) a simple, unadorned style of discourse, let alone 2) an impersonal approach of the object studied.

I) As to the first point, problems rise regarding ancient scientific texts using poetry as a discursive medium, such as the didactic poems of Empedocles and Lucretius ${ }^{192}$. As we will see later on, Plutarch himself quotes again and again from the poets in his natural problems, not only from the didactic but also from the mimetic ones. Is this, then, some kind of an unscientific stain on his text? Plutarch's general attitude towards poetry is heavily influenced by his Platonism, but this does not, of course, imply that a poetical form automatically shrouds false content [see 4.I.2.3., n. 97]. Notably, regarding Empedocles' use of poetical epithets, Plutarch makes it clear in Quaest. conv. $683 \mathrm{E}$ that they do not complicate a suitably scientific approach to natural phenomena (DK3IB80):

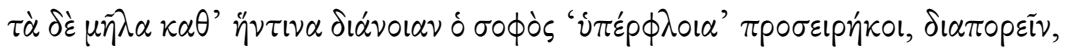

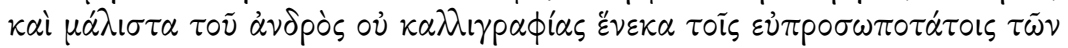

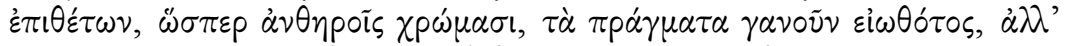

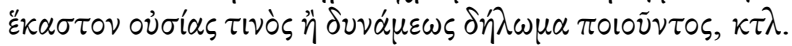

But what puzzled me, I confessed, was what the philosopher meant by calling apples "succulent" (hyperphloia); especially since he was not in the habit of tricking out facts for the sake of elegant writing by

191 The bias is obvious, for instance, in L. Senzasono, 2006, p. 9: "Questi nessi [c.q. structural markers in the text, such as $\gamma \dot{\alpha} \rho$, "̈ $\theta \varepsilon v$ etc.] collegano rilievi di fenomeni naturali in una struttura essenziale, priva di qualsiasi abbellimento, come s'addice a un'esposizione che intenda essere scientifica, nel mondo Greco come in altre epoche fino ad oggi." For similar criticism of Senzasono's position, see L. Van der Stockt, 20II, p. 449.

192 For the cases of Empedocles and Lucretius, see L. Taub, 2008 (see also id., 2009 more generally). 
using grandiose epithets, as if he were laying on gaudy colours, but in every case aimed at simple description of an essential fact or property. Etc.

As this passage shows, the scientificity of ancient scientific discourses cannot be properly evaluated on the basis of their form or register ${ }^{193}$. It rather illustrates that science was practiced in a wide range of literary genres, some, indeed, more literary than others.

2) The same conclusion can be drawn for the issue of depersonalisation in ancient scientific discourses. A comparison of Quaestiones naturales with Quaestiones convivales [see 2.2.] shows that the same kind of natural problems can be treated against the backdrop of 'real-life' table discussions, where each symposiast tries to defend his own personal theory

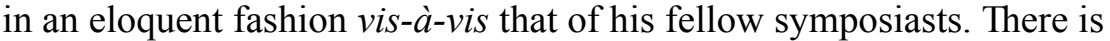
not much authorial depersonalisation in Quaestiones convivales - to the contrary, Plutarch puts his closest friends in the scene along with his own literary alter ego, thus constructing scientific authority in a very personal way (see nn. I05-I06). So even if Plutarch does not use the first person singular in Quaestiones naturales, this is not necessarily an indication of the collection's 'scientificity'. Indeed, as we will see later on, other personal forms, such as the second person singular and the first person plural, are still present, which is to be interpreted more likely in relation to the work's educational context and purpose ${ }^{194}$ [see 3.I.4.]. Another point that is very important in view of the alleged objectivity of Plutarch's natural problems is the fact that ancient natural science did not necessarily complicate the author's attempt to assume a certain ethical persona and to communicate a moralising message through his text. Morality is, in fact, a relatively common aspect of ancient Greco-Roman scientific writing, as we saw in the case of Seneca's Naturales quaestiones ${ }^{195}$ [see I.I.6.]. Similarly, in Plutarch's writings on animal psychology, the scientific discourse serves as a means of promoting the author's moral agenda (see n. I4). It remains to be seen, then, why no such agenda is found in Quaestiones naturales.

${ }^{193}$ Cf. also, e.g., Quaest. conv. 658B for the idea that the poet Archilochus writes 'in accordance with nature' ( $\phi \nu \sigma i k \tilde{\omega} \varsigma)$. For the 'very simple and antiquated' style of Solon's

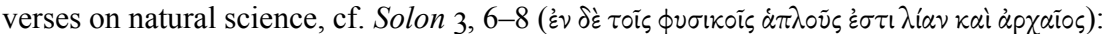
see D. Leão, 20I5. For the relation between science and poetry in Plutarch's De sollertia animalium, see also J. Bouffartigue, 20I2, p. xii, n. 7.

${ }^{194}$ For the aspects of objectivity and subjectivity in ancient scientific and technical writing more generally, as conveyed respectively by an impersonal or personal discourse, see, e.g., G.E.R. Lloyd, 1987, pp. 56-70, H. von Staden, I994, P. van der Eijk, I997, pp. II5-II9, H.M. Hine, 2009, V. Nutton, 2009, J. König, 201 I.

${ }^{195}$ For the relation between science and ethics in Antiquity more generally, see G.E.R. Lloyd, 1985 and R.W. Sharples, 2000, pp. I4-22 and 2005, p. 2. 
Before I will provide an alternative explanation for the problems of style and morality in Quaestiones naturales, let us first take a more detailed look at how, and to which extent, these problems precisely manifest themselves in our collection.

\section{The problem of style}

Although there are some notable exceptions, there is not much rhetorical liveliness in Quaestiones naturales and literary imagery is scarce. The collection's elliptical style renders the text obscure at times, and the mechanical structure of the problem chapters makes the whole collection relatively bloodless from a literary-aesthetic standpoint. Scholars speak of a 'matter-of-fact' 196 or 'referential' 197 style to denote the collection's descriptive approach. Generally speaking, the sentence structure remains simple throughout and contains a profusion of directive conjunctions and particles that mark the organisation and logic of the explanations in their most basic form. Furthermore, the explanations teem with a monotonous, but conveniently uniform, scientific vocabulary (which I will examine later on [see 4.3.4.]). In short, a clear and swift development of the explanations prevails: the aetiology is always ad rem, but conciseness often leads to obscurity ${ }^{198}$ (as is the case, for instance, in the comparative $\alpha \nu \alpha \gamma \kappa \alpha 10$ ' $\varepsilon \varepsilon p \alpha$, said of spring rains falling before the summer in Q.N. 4, 913A: see the commentary ad loc.). As a rule, the information amassed is processed in an epitomic fashion, by which each and every recorded element plays a well-determined role in the development of the causa (as is the case,

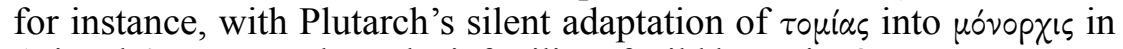
Aristotle's account about the infertility of wild boars in Q.N. 2I, 9I7D: see the commentary ad loc.). Extensive details are generally avoided in this no-nonsense discourse, and what might seem to be a fait divers at first, will often end up playing a relevant role in the argumentation after a closer reading (as is the case, for instance, with the digression on magnetism in Q.N. 19, 9I6D: see the commentary ad loc.).

Even though the discourse of Quaestiones naturales is only seldom embellished, there are a few instances where we find exceptional glints of Plutarch's literary flair. The application of tropes and stylistic devices, such as metonymy and metaphor, is rather exceptional ${ }^{199}$, but where they

196 S.-T. Teodorsson, I999a, p. 666. Cf. also J. Sirinelli, 2000, p. 365: "le caractère purement factuel de ses recueils".

197 L. Senzasono, 2006, p. IO, n. II (with a reference to Jakobson's linguistic theory). The term is synonymous with 'denotative' or 'cognitive'.

198 Cf. F.H. Sandbach, I965, p. 135 and L Senzasono, 2006, pp. II-I2. G.W.M. Harrison, 2000 b, p. 24I sees the positive side of it: "One of the great joys of Plutarch is his incisiveness and concision [...]."

199 See also L. Senzasono, 2006, pp. I2-I5. 
are used they make the argument more vivid. In Q.N. 2, 9I $2 \mathrm{~A}$, rainwater

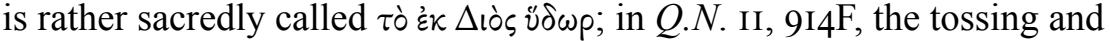

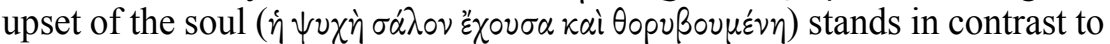
the calm of the sea; in $Q . N .34$, the heat of the sun is compared to an enemy in battle chasing off the wind (veluti hoste superatum); and in Q.N. 39, the depth is called the mother of blackness (mater nigritudinis). Notably, in his study of Plutarch's general use of literary imagery, Fuhrmann marked only one instance in Quaestiones naturales, viz. in Q.N. 29, 9I9B: "Les météores éclatent comme des bulles" $\delta(\kappa \eta \nu)$.

It is, indeed, true that an exceptional chapter is found in Q.N. 29, 9I9AB as a whole. Plutarch therein discusses the wondrous nature of hot springs vis-à-vis cold ones. His argument exhibits a remarkably vibrant case of rhetorical embellishment. Not so much the natural phenomenon of hot springs is at stake but rather the short-sighted marvelling for them by the common people ${ }^{201}$. Plutarch seems to be disillusioned by the fact that the common people's wonder for marvelous natural phenomena -

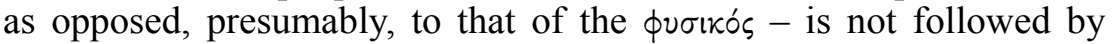
an actual investigation into their 'nature', that is the natural causes of

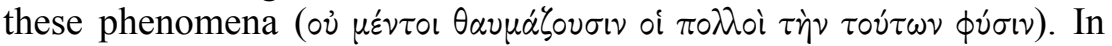
order to emphasise his disillusion, Plutarch confronts the reader with a rhetorically substantiated invective against the common people for

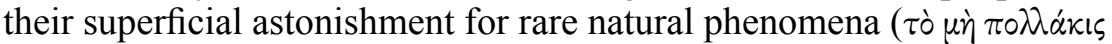
$\gamma\llcorner\nu o ́ \mu \varepsilon v o v)$. Plutarch emphatically declares his own marvel for cosmic spectacles and the wonders of nature by scanning an evocative verse from Euripides (TGF 94I: 'You see this infinite heaven up high / surrounding earth in a damp embrace') and by adding a two-part rhetorical question ('What a multitude of spectacles does it bring at night, how great is the beauty it exhibits by day?'). As we will see later on, the quotations from the poets are usually incorporated in Plutarch's natural problems primarily in order to fulfil a specific argumentative and illustrative function in the aetiologies [see 4.I.2.3.]. That is, they are not included for purely literary purposes. While they certainly add a literary accent to the text, this seems to be at the service of the main argument itself. Then again, the opposite seems to be the case for the Euripides quotation here in Q.N. 29, 919B, since it mainly contributes to Plutarch's rhetorical expression of wonder for nature rather than to a scientific theory about hot springs (these verses do, of course, have illustrative value in underlining Plutarch's sense of wonder, but they have no substantial argumentative significance). This is important for the rather exceptional character of this chapter in the

${ }^{200}$ F. Fuhrmann, I964, p. 77.

201 Unfortunately the ending of this chapter is lacunary (see the commentary ad loc. for further detail). For a separate discussion, see M. Meeusen, 20I5b. 
collection, which is why I will return to its significance for the intellectual agenda of Quaestiones naturales in further detail later on [see 3.2.2. and 4.I.I.I.].

What matters here is the fact that the general texture of Q.N. 29 differs considerably from that of the rest of the problem chapters in the collection. The exclamatory utterances and the overall style are clearly more rhetorical. As Oikonomopoulou suggests (in personal correspondence), "we may surmise a context of intellectual performance for this problem (perhaps sympotic?) - the question is whether this could be surmised for the collection as a whole". This is not unlikely if we bear in mind the link with the natural problems discussed in Quaestiones convivales $^{202}$ [see 2.2.]. As we will see later on, Plutarch's natural problems were also useful as philosophical exercises in the context of his own school in Chaeronea [see 3.I.]. But whether this means that the problems of Quaestiones naturales are the textual condensation or imitation of such 'performances' or were even intended to be 'performed' at a certain point remains uncertain. This is not, however, to reject the more generally 'performative' character of Plutarch's natural problems, at least in the sense that there are certain principles at work in them that strive for argumentative originality and for a creative refashioning of received knowledge [see 4.2.2.].

\section{The problem of morality}

The general absence and suppression of moralising dynamics in Quaestiones naturales is very prominent compared to many of Plutarch's other writings ${ }^{203}$. However, even if Plutarch does not provide any explicit moral advice here, there are still a few faint allusions to the field of ethics and moral conduct. These allusions are only made in light of a particular zetetic requirement, though, that is, for the further development or illustration of the physical aetiology at hand. A good example can be found in Q.N. 19, where the octopus' ability to change its colour is attributed, in the first causa, to the animal's cowardice. It is compared with the change of colour in cowardly persons (as is illustrated with a line from Homer, Il. I3, 279: 'the coward's complexion alters'). In the second causa, the

${ }^{202}$ Scholars have more often stressed the 'performative' character of the genre of quaestiones. In regards to Heraclitus' Quaestiones Homericae, cf., e.g., D.A. Russell and D. Konstan, 2005, p. xxix: "It may have been a showpiece, or, given its length, an earnest defense of Homer's piety. Anything more precise is guesswork". Cf. also D.A. Russell, 2003. See also K. Oikonomopoulou, 20I3a, p. I47 (with n. 7I for further references).

${ }^{203}$ Notably, in De tuenda I33E, Plutarch draws a clear conceptual distinction between problems of natural science and stories that contain ethical considerations $(\dot{\alpha} \lambda \lambda \dot{\alpha} \pi 0 \lambda \lambda \dot{\alpha} \mu \dot{\varepsilon} v$

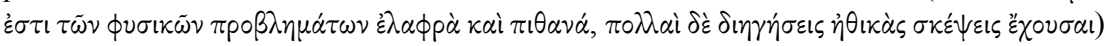
[see 3.I.3.]. 
context is again ethical: Plutarch quotes Pindar (fr. 43 Snell) and Theognis (2I5-2I6 West), who compare the octopus' ability to change its colour with the changeable character of human beings. Plutarch pokes fun at both poets by wondering whether they believe that the octopus treats its colour like a garment that can be easily changed whenever the animal

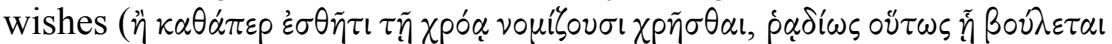
$\mu \varepsilon \tau \varepsilon v \delta v o ́ \mu \varepsilon v o v ;)^{204}$. Thus, Plutarch suggests that both poets, with their exclusively moralising approach, do not actually have a correct insight into the physical mechanism behind the phenomenon at issue, and for this reason they make themselves into easy targets for derision. The underlying idea is that the octopus' colour change is not the effect of a deliberate choice but of deeper physical causes. This is why Plutarch at the beginning of the third causa points out that it is the octopus itself that initiates the effect by feeling fright, but that the determining factors of the cause lie elsewhere, viz. in the pores in its skin taking up the emanations that settle in them

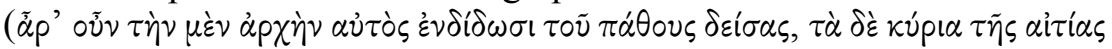

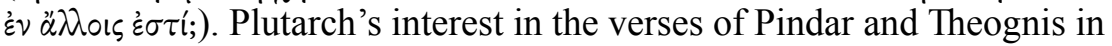
the second causa, thus, lies in the fact that they add something to the first causa. They do not only concern the change but also the adaptation of the octopus' colour to its surroundings. Eventually, the determining factor in the causation lies in the third and last causa, which is the most elaborate. It is introduced with the imperative $\sigma$ Kó $\pi \varepsilon 1$ ón, and - most importantly focuses on the physical mechanism behind the adaptation of the octopus' colour $^{205}$.

From a cluster of parallel passages in Plutarch's other works, we learn that the Chaeronean is prepared to exploit the topic of the octopus' metachrosis as a moral exemplum for people's changeable character, especially in the context of the opportunism of flatterers and politicians who adapt their character to always new situations (for a schematic presentation of this cluster [see 2.I.2.] ${ }^{206}$. The most relevant parallel in this regard is in De am. mult. 96F, where Plutarch advises against having

204 The irony in this rhetorical question is obvious - a style of register that is very exceptional to the collection's discourse. For irony in Plutarch, see the appendix in J. Opsomer, 2000, pp. 328-329.

${ }^{205}$ However, Plutarch still considers the emotion of fear as an important factor for a

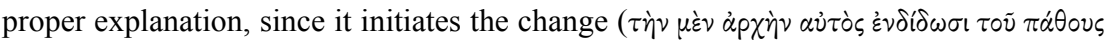
$\delta \varepsilon i \sigma \alpha \varsigma)$. L. Senzasono, 2006, p. 20I, n. I06 is correct that in this third causa "non si ha nemmeno un cenno al comportamento umano". Regarding the quotes from Pindar and Theognis, he notes (p. I98, n. IOI): "Anche in questo tratto il mutamento di colore del polipo assume la connotazione d' un paradigma morale nonostante il contesto naturalistico di un opuscolo che tratta di fenomeni fisici: Plutarco è condizionato dai due testi poetici citati, che lo inducono a questa considerazione perché entrambi contengono un'esortazione a una certa condotta."

${ }^{206}$ For a separate study of this cluster, see M. Meeusen, 20I2a, pp. 247-250. 
many friends ( $\pi \circ \lambda v \phi i \lambda i \alpha)$ by criticising the habit of certain individuals, who have no firmly grounded character of their own, to assimilate themselves to others. Plutarch compares this with the octopus' ability to change and adapt its colour to its surroundings, noting that these 'changes have no depth (i.e. they have nothing to do with the animal's character) but are generated entirely on the octopus' surface (i.e. the

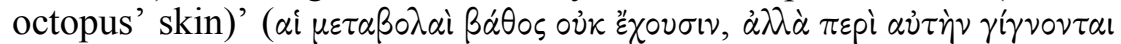
$\tau \grave{\eta} \nu \dot{\varepsilon} \pi \iota \phi \dot{\alpha} v \varepsilon(\alpha \nu)$. I take this to imply that Plutarch saw the opportunistic adaptability of flatterers, as opposed to that of the octopus, not as superficial but as in keeping with their very personality (or rather the absence thereof). Plutarch further explains that the octopus' metachrosis is caused by the fact that emanations from nearby objects are taken up by its skin due to its alternate denseness and looseness of texture, which is, in fact, a synopsis of Plutarch's third causa in Q.N. I9, 9I6CF.

Even though Plutarch incorporates the natural phenomenon of the octopus' metachrosis in a moralising context in De am. mult. 96F, by providing it with a metaphorical connotation so that it is universally adaptable in the field of ethics (c.q. as a rejection of $\pi 0 \lambda v \phi i \lambda i \alpha$ ), he makes it very clear that the phenomenon in itself is in fact free from any ethical connotation or 'depth' ( $\beta \dot{\alpha} \theta \circ \varsigma)$. This, in turn, explains why the aetiology in

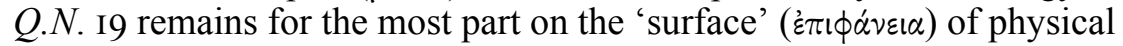
aetiology. The lines from both Pindar and Theognis (as well as from Homer) do oblige Plutarch to include a certain degree of ethical 'depth' in quoting their verses, but he complies to this zetetic requirement only in view of a refutation of their accounts. After all, as Plutarch suggests in the third causa, the determining factors of the explanation lie elsewhere

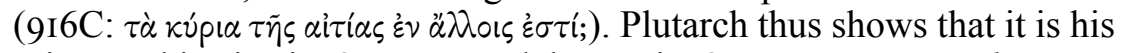
primary objective in Q.N. I9 - and, hence, in Quaestiones naturales more generally - to scrutinise, what he calls, $\tau \dot{\alpha}$ kúpia: these are clearly the most fundamental underlying physical principles. Therefore, any moral preoccupation is circumstantial or, at least, only of secondary importance to this work.

Plutarch avoids plunging into the 'depths' of morality again on several other occasions in Quaestiones naturales. In De cap. ex inim. 92B, for instance, he compares the improvement of roses and violets by planting garlic and onions beside them to the use of enemies and the joining of opposites. The same phenomenon is explained in Q.N. 4I, but therein Plutarch remains on the 'surface' of physical aetiology (referring to the theories of emanation, attraction and motion). The best example by far is provided by Q.N. 36, where Plutarch manifestly passes over an opportunity for a moral digression. The natural problem at issue concerns the popular belief that bees are quicker to sting people who have just committed adultery (stuprum). The ethical depravation of this "immoral sexual act" 
(to use Sandbach's periphrastic translation) ${ }^{207}$ turns out to be entirely subordinated to the physical aspect of the phenomenon itself (bees are cleanly insects, unable to endure the bad smell of adulterers). This becomes clear especially when confronted with the parallel account in Coni. praec. I44D, where Plutarch offers some 'moral support' to the groom. There is no need to treat this parallel in full detail here ${ }^{208}$. In short, Plutarch's advice to the groom would be to avoid adultery before (sic!) approaching his own wife, since the wife might react in the same way as a bee would react. Remarkably enough, there is a certain impulse towards a moralising diversion in Q.N. 36 (viz. in the words adulteria and perfidia), but this becomes far more explicit in Coni. praec. I44D. Passages like these show that Plutarch does not refrain from incorporating the same material from Quaestiones naturales in overtly moralising contexts elsewhere, but that in the collection itself there is a significant ethical disinterest.

Since elsewhere Plutarch would certainly approve of an ethicallyladen view of the physical world, it is worthwhile to examine the relation between his natural and moral philosophy more closely ${ }^{209}$. Several key passages that deserve attention here concern Plutarch's general cosmology and theology (these are often related to the context of his theodicy, that is, his theological vindication of God's justice in respect of existing evil $)^{210}$. In De lat. viv. II29B, for instance, Plutarch objects to Epicurus' maxim $\lambda \alpha \dot{\theta} \varepsilon \beta \iota \dot{\omega} \sigma \alpha \varsigma$ ('live unknown') by arguing that persons should not at all remain unknown to the outer world if they carry out their practice in the field of physics, ethics or politics in an honourable fashion (= fr. 524 Usener).

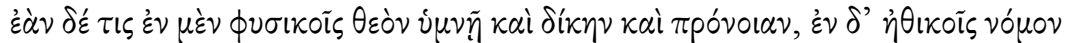

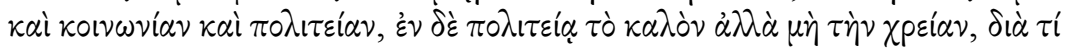

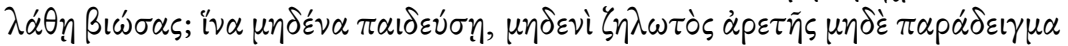
$\kappa \alpha \lambda \grave{o v} \gamma^{\varepsilon} \nu \eta \tau \alpha l$

But take one who in physics extols God and justice and providence, in ethics law and society and participation in public affairs, and in political life the upright and not the utilitarian act, what need has he to

${ }^{207}$ F.H. Sandbach, 1965, p. 219.

${ }^{208}$ For a separate study, see M. Meeusen, 20I3c. Notably, Aelian also reports that bees chase off men wearing perfume and that they also recognise and pursue adulterers, which is considered a sign of their $\sigma \omega \phi p o \sigma v i v \eta$ (NA 5, II; for further parallels see the commentary ad loc.).

${ }^{209}$ In this regard, G. Soury, I949, p. 323 speaks of "une sorte d' indifférenciation du physique et du moral, fréquente chez Plutarque".

${ }^{210}$ For further reading on Plutarch's theodicy, see, e.g., R. Del Re, I950, J. Dillon, 2002 and F. Frazier, 20I2, pp. 2I9-22I. Cf. also D. Babut, I969, pp. $287 \mathrm{ff}$. 
live unknown? In order to educate no one and become for no one an inspirer of virtuous emulation or a noble example?

What is remarkable here is that regarding the field of physics, Plutarch refers to God and providence as well as to justice $(\delta i k \eta)$ - which would rather belong to the field of ethics. As opposed to the Epicureans, whose cosmology is based on the principles of chance and atomism [see 4.3.3.2.], Plutarch firmly believes that God can intervene in the material world, which is ordered in conformity with divine providence ${ }^{211}$. Roskam highlights the central importance of the passage at hand, and more specifically the mentioning of $\delta \mathrm{i} \eta$, for the argument in De latenter vivendo as follows:

"That Plutarch also underlines the importance of justice in the domain of physics may come as a surprise, since one would a priori expect the mention of the element of $\delta i k \eta$ rather in the field of ethics. Its presence in the domain of physics could perhaps be explained by Plutarch's thoroughly Platonic theology, in which justice and the good in general are inherently and inextricably bound up with God's essence. [...] Contrary to Epicurean physical thinking, which is ultimately based on atomism, Plutarch's general programme of physics, with its emphasis on divine providence and justice, rests on, and is fundamentally justified by, a theological perspective." 212

Notably, in Arist. 6, 2-3, Plutarch again underlines the importance of dicn in physical matters. This passage clarifies the actual range of the phrase

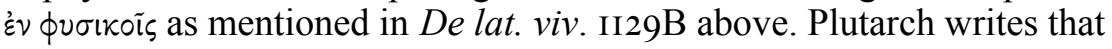
the inanimate part of nature shares its incorruptibility and power with the divine, but, in opposition to animate nature, it does not partake in virtue $\left(\dot{\alpha} \rho \varepsilon \tau \eta^{\prime}\right)$, and hence does not participate in justice ( $\delta^{\prime}\left(\kappa \eta \kappa \alpha i \dot{\theta} \varepsilon^{\prime} \mu \iota \varsigma\right)$, precisely because it is irrational.

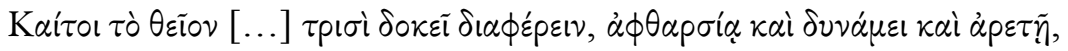

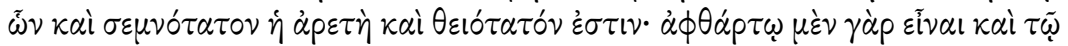

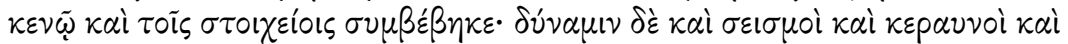

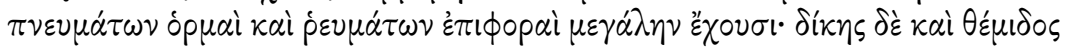

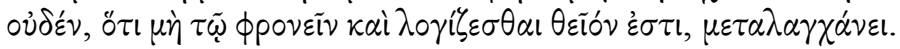

And yet divinity $[\ldots]$ is believed to have three elements of superiority, incorruption, power, and virtue; and the most reverend, the divinest

211 Cf., e.g., De def. or. 426DE. See G.E. Karamanolis, 2006, p. Io6.

212 G. Roskam, 2007, pp. I22-I23. See also F. Frazier, 20I2, p. 22I. On the role of providence and chance in Plutarch's philosophical thinking, see the contributions in F. Frazier and D.F. Leão, 2010. 
of these, is virtue. For vacuum and the ultimate elements partake of incorruption; and great power is exhibited by earthquakes and thunderbolts, and rushing tornadoes, and invading floods; but in fundamental justice nothing participates except through the exercise of intelligent reasoning powers.

Inanimate nature shares its incorruptibility and power with the divine, but it does not also partake in virtue because it is of a purely irrational and material order. Animate nature, by contrast, is constituted by more than just material components: it does have rational powers and, by implication, partakes in virtue. In the passage following the one just quoted, Plutarch notes that 'virtue is the only form of divine excellence within our grasp,

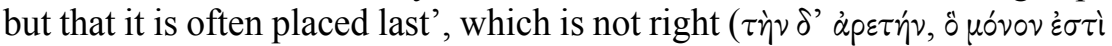

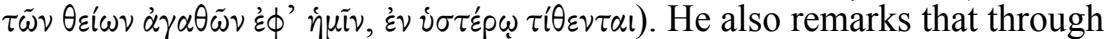

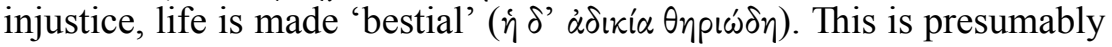
metaphorical, because in his writings on animal psychology, Plutarch emphatically marks the rational and, by implication, virtuous qualities of animals, which belong to the same animate realm in nature as human beings.

Context is important here: the general ethical purport of Plutarch's writings on animal psychology is very obvious ${ }^{213}$. The argument is of a polemical nature, aiming at undermining the Stoic tenet that animals have no rational abilities at all. In short, it seems that Plutarch is trying to show that animals actually live more in conformity with nature - another Stoic tenet - than human beings do, since the latter are often lead by vice rather than virtue. Arguably, Plutarch's works on animal psychology were intended to provide a 'noble example' for his readers to follow (i.e.

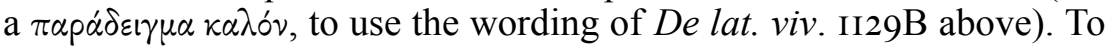
this end, Plutarch employs a moralising strategy by which he compares the ethics of human beings to the behavior of animals, often preferring the habits and attitudes of animals over those of humans ${ }^{214}$. In a highly rhetorical and moralising vein, he emphasises the unnatural behaviour of human beings (their $\dot{\alpha} \theta p \omega \pi i v \eta \kappa \alpha \kappa i \alpha$ : cf. De am. prol. 493B), as opposed to the natural incorruptibility of animals. As noted, this view strongly relativises the Stoic concern of living $\kappa \alpha \tau \dot{\alpha} \phi v \dot{\sigma} v$, showing that animals live more in accord with nature than humans do.

It is commonly accepted among scholars that Plutarch's sympathy for animals actually arises from his deep sense of humanity and $\phi i \lambda \alpha \nu \theta \rho \omega \pi i \alpha^{215}$.

${ }^{213}$ For further discussion and reading, see S.T. Newmyer, 20I4. The study of zoological phenomena more often served an ethical goal in Antiquity. Cf., e.g., H. Cherniss and W.C. Helmbold, I957, p. 322, n. a.

${ }^{214}$ See, e.g., De am. prol. 493A-495A and Gryllus 989Cff.

${ }^{215}$ See, e.g., A. Barigazzi, I992, p. 300, F. Becchi, 2002, p. I70, E. Lelli, 20I0, p. 849, 
In De soll. an. 966B, for instance, Aristotimus, one of Plutarch's students, remarks that the intelligence of animals is measured by philosophers according to several human ethical categories, such as purposefulness, memory, emotions, care for their offspring, courage, sociability, continence and magnanimity ${ }^{216}$. However, it seems only reasonable that the reduction from animal to human nature had a deeper motivation for Plutarch, although this is easily overlooked. If it is true that Plutarch 'loved' animals almost as much as he 'loved' humans, then he 'loved' what was rational and virtuous in them and, by implication, could be considered divine ${ }^{217}$.

This last aspect is important in light of the role the animal kingdom plays in Plutarch's view on religion. In relation to the cosmological connection between the divine and the animate realms in nature (and more precisely in the context of divination), Aristotimus in De soll. an. $975 \mathrm{~B}$ rather hyperbolically claims that he can produce thousands of signs and portents manifested by the gods through creatures of land and air $(\dot{\alpha} \lambda \dot{\alpha}$

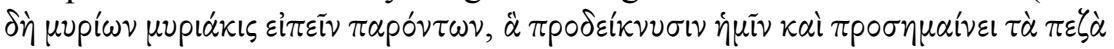
кai $\pi \tau \eta \nu \dot{\alpha} \pi \alpha \rho \dot{\alpha} \tau \tilde{\omega} \nu \theta \varepsilon \tilde{\omega} \nu)$. Plutarch's association between a rational, divine principle and the animal kingdom is also found, for instance, in De Is. et Os. 382AB, where we read that animals that are held in honour in Egyptian cults are actually the mirrors of the divine ${ }^{218}$. They are a natural instrument or medium for the God who orders all things: we should not honour these animals in themselves, but the divine through them (ov $\tau \alpha \tilde{\nu} \tau \alpha \tau \mu \tilde{\omega} \nu \tau \alpha \varsigma$,

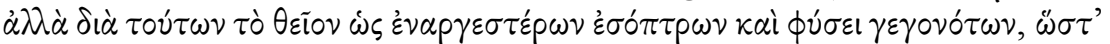

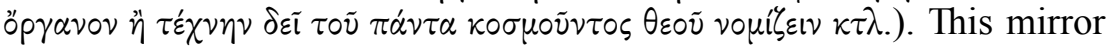
metaphor ties in closely with Plutarch's Platonic world view, where nature

S.T. Newmyer, 2009, p. 50I, J. Mossman and F. Titchener, 20II, p. 273 ("It is no surprise to us that a humane, compassionate, tolerant, and wise human like Plutarch wrote several essays specifically about animals"), J. Bouffartigue, 20I2, p. xxxvi.

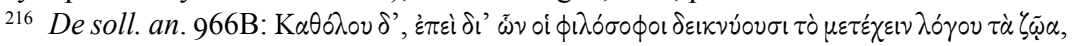

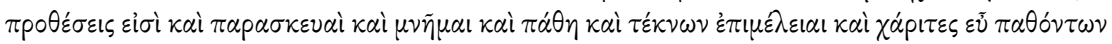

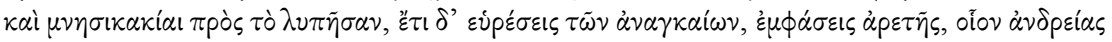

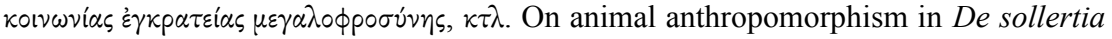
animalium, see J. Mossman and F. Titchener, 20II, pp. 280-282. Cf. also, e.g., De am. prol.

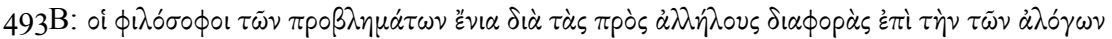

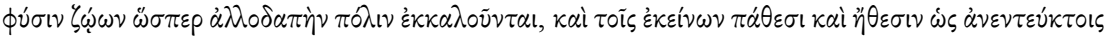

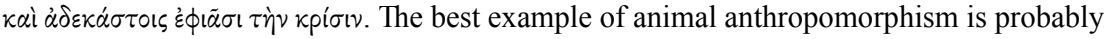
provided in Bruta animalia ratione uti (Gryllus), where we find a lively discussion between Odysseus and Gryllus, the speaking boar (who has the last and most authoritative word in the discussion).

217 See M. Meeusen, 20I3c. See also L. Van der Stockt, 2005, p. I9 (who sees animals as "part of a world in which god, man and animals take care of each other"; pace S.T. Newmyer, 2009, p. 50I). For further discussion see also S.T. Newmyer, 2006, pp. I7ff. ${ }^{218}$ See R. Hirsch-Luipold, 2002, pp. 2II-222 and J. Boulogne, 2005b. 
is considered an inferior reflection of the intelligible realm ${ }^{219}$. Again in Sept. sap. conv. I63EF, Anacharsis shares his belief that God, insofar that he governs the inanimate world, uses the animate world to carry out his goals ${ }^{220}$ :

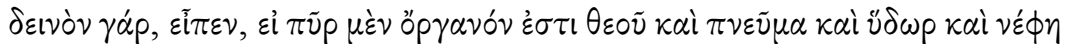

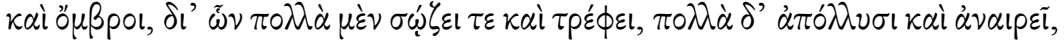

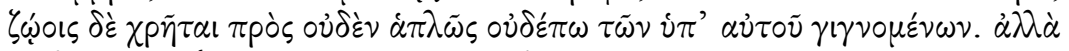

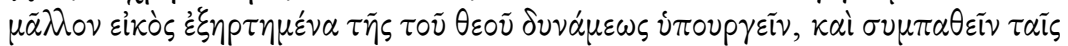

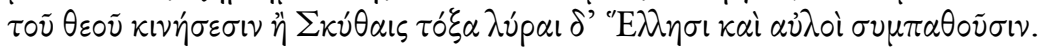

For it is a dreadful mistake to assume that, on the one hand, fire is God's instrument, and breath and water also, and clouds and rain, by means of which He preserves and fosters many a thing, and ruins and destroys many another, but that, on the other hand, He never as yet makes any use whatever of living creatures to accomplish any one of His purposes. Nay, it is far more likely that the living, being dependent on God's power, serve Him and are responsive to His movements even more than bows are responsive to the Scythians or lyres and flutes to the Greeks.

If we return to Quaestiones naturales now, we already saw that Plutarch remains rather critical towards the rational abilities of animal beings (see n. I7). The link between natural phenomena (either animate or inanimate) and divine principles is generally absent. As outlined at the beginning of this chapter, Ziegler classified Quaestiones naturales alongside other specialised "naturwissenschaftliche Schriften". If ethics seems to figure into these writings, this is far less explicit or outspoken than is the case in the "tierpsychologische Schriften"221.

In conclusion, ethical matters are never thematised in Quaestiones naturales $^{222}$. They are only present insofar as they contribute to the central

${ }^{219}$ Cf. R. Hirsch-Luipold, 2002, p. 285: "Im sinnlichen wahrnehmbaren Kosmos hat die ewige, reine Gottheit sich selbst den Menschen als Leitschnur an die Hand gegeben. [...] Als Spiegel der göttlichen Wahrheit und Ordnung gewinnt der Kosmos Anteil am Göttlichen selbst. Auch untereinander haben die Phänomene der Welt diesen Verweischarakter, weil sie alle der einen Quelle entstammen."

${ }^{220}$ This does not imply, however, that there is no place at all for free will. Cf. also, e.g., De Pyth. or. 404B-405A.

${ }^{221}$ Cf. L. Senzasono, 2006, p. 33: "Ma mentre in opere come De soll. an. l'osservazione naturalistica è subordinate a una certa tesi che lo scrittore vuol dimostrare, nelle Quaest. nat. essa è fine a se stessa $\mathrm{o}$, piú esattamente, è intesa a indagare le cause dei fenomeni in se stesse."

${ }^{222}$ I am loosely alluding here to the distinction between Plutarch's treatment of ethical topics as 'rhema' and as 'thema' made by L. Van Hoof, 20IO, p. 39 (with n. 7I). Ethics 
focus on the natural explanations of the phenomena under discussion. Nevertheless, Plutarch is well aware of the fact that some of the problems treated in Quaestiones naturales can be reused in ethical discourses. So, to reformulate the initial problem: why does some kind of a sub-moralistic essentialism prevail in Quaestiones naturales? This question also relates to the sub-literary aspect of the work. Why does the aspect of physical aetiology fold back entirely on itself in order to be treated on its own terms, as the title of the collection clearly marks?

\section{A 'generic' solution}

I can briefly provide a solution to the problems of style and morality in Quaestiones naturales, which, as I will argue here, is probably dictated by the genre to which this text belongs. This means that a closer link should be drawn with the discourse of the Ps.-Aristotelian Problems, which served as a model for Plutarch's natural problems.

In regards to style, first of all, Ps.-Aristotle's model displays a very similar 'referential' discourse as found in Quaestiones naturales, and the same is true for Plutarch's other collections of quaestiones - with the exception of Quaestiones convivales. Fuhrmann, for instance, opposed "la forme rudimentaire des Questions Naturelles, Romaines, Grecques, et la froideur stéréotypée des recueils de cette espèce"223 to the more literary and lively discourse of Quaestiones convivales. In the latter work, however, Plutarch is hybridising the genre of problems with that of the symposium, which explains the literary and dramatic elaboration of the content there [see 2.2.I.]. The genre of problems does display, at least, a minimal degree of formal elaboration (as will be further substantiated later on [see 2.3.2.]). Therefore, Senzasono is right that Fuhrmann "è giusto in generale, ma è inesatto parlare di "forma rudimentale": in realtà lo stile delle Quaest. nat. è elaborata nel senso dell'essenzialità denotativa." 224 Notably, Plutarch's

treated as 'rhema' is typical of Plutarch's works on practical ethics, where the author is concerned with a specific moral practice, whereas ethics is treated as a 'thema' in the technical treatises on philosophy. In these works, the consideration of ethical principles is related to the instruction and study of philosophical theory itself (i.e. the $\lambda$ ó $\gamma o$ rather than the $\ddot{\alpha} \sigma \kappa \eta \sigma \iota \zeta)$. In Quaestiones naturales, then, there is a certain impulse towards ethics as 'rhema', for instance, in the case of Q.N.36, (viz. in the words adulteria and perfidia), but it is not further developed when compared to the parallel account in Coni. praec. I44D. Notably, the concept of iniuria, mentioned in Q.N. 33 and 37, has no ethical implications but refers to the physical damage or 'injury' done to waters by becoming stagnant (Q.N. $33)$, or to dogs by stones flung at them (Q.N. 37).

${ }^{223}$ F. Fuhrmann, I972, p. xix, n. 2.

${ }^{224}$ L. Senzasono, 2006, p. Io. Senzasono adds (pp. IO-II and p. 46, n. 70) that there is, nevertheless, a difference in style between Quaestiones naturales, on the one hand, and Quaestiones Romanae and Graecae, on the other (on the assumption that the style of 
incorporation of literary (c.q. poetical and mythograpical) material in his natural problems lies significantly higher than in Ps.-Aristotle's Problems [see 4.I.2.2.-3.]. A plausible explanation is provided by the fact that Plutarch's natural problems, as opposed to those of Ps.-Aristotle, are part of the author's broader $\pi \circ \lambda \nu \mu \alpha \dot{\theta} \theta \varepsilon \alpha$ project. Even when dealing with matters pertaining to natural science, Plutarch aims to display and combine his all-round knowledge of several branches of Greek literature and learning, thus showing that he was a true $\pi \varepsilon \pi \alpha i \delta \varepsilon v \mu \varepsilon \dot{v}$ os.

Second, in regards to the lack of morality in Quaestiones naturales, a link can again be drawn with Ps.-Aristotle's model, where overt moralising dynamics are also absent. A few sections in Ps.-Aristotle's Problems, however, are generally related to the field of moral philosophy, viz. Books 27-30, which concern the topics of fear, courage, moderation, justice and intellectual virtue. The questions raised in these Books are never treated in a

the two latter collections is really the same). He bases his conviction on the idea that the discourse of Quaestiones Romanae and Graecae is more extensive, fluid and narrative than that of Quaestiones naturales, which he explains on the basis of the historical interest of the first two, whereas the essential and descriptive discourse of Quaestiones naturales would be conditioned by its natural scientific interests (but see above [I.2.2.]): "l'adesione ai fenomeni fisici condiziona lo stile essenziale e sobriamente descrittivo del trattato naturalistico, mentre lo stile dei due opuscoli d'argomento storico è talvolta piú disposto a un dettato esteso, fluido e sobriamente narrativo." As we will see later on, however, Plutarch reserves some space for natural science in the latter two collections as well, and also - the other way around - a cultural-antiquarian type of discourse in the former [see 2.4.2.]. In light of Plutarch's interest in natural scientific matters in Quaestiones Romanae and Graecae, C. Darbo-Peschanski, I998, p. 27 has made the following conclusion: "Plutarque penserait donc une "cosmologie de l' histoire" comme prolongement et achèvement, sur le mode du redoublement analogique, de la cosmologie physique. [...] La conséquence en est qu' on peut s' interroger sur les causes ( $\alpha i \tau 1 \alpha)$ de ce que font et de ce que produisent historiquement les hommes comme on s' interroge sur les causes des phénomènes physiques." One should not, therefore, underestimate the 'historical' character of Quaestiones naturales, at least in

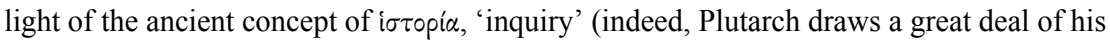
material from natural history, and also uses concepts related to the notion of i $\sigma \tau$ i see Q.N. I, 9IIE, 7, 9I4A, 9, 9I4B, 26, 9I8D, 34: vulgo fertur). It follows that at least from an ancient perspective, Quaestiones naturales is not more or less 'historical' than Quaestiones Romanae and Graecae, since the concept of i $\sigma \tau$ and natural scientific types of inquiry (cf. LSJ, s.v.). See, e.g., Plu., Cons. ad Apoll. II9D

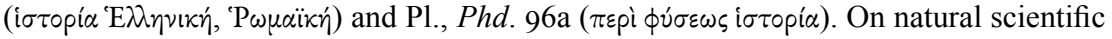
i $\sigma \tau$ opí in Plutarch, see M. Battegazore, 1992, pp. 19-35, P. Donini, 1984, pp. 374 and J. Bouffartigue, 20I2, pp. X-xii. See also L. Van der Stockt, I987, p. 289 (for Quaestiones Romanae) and P. Payen, 20I3 and 20I4 (on Plutarch's antiquarianism, esp. in Quaestiones Romanae and Graecae). On Plutarch's general use of i $\sigma \tau$ трí (esp. concerning historical narrative), see T. Duff, 1999a, pp. I7-2I. For the relation between Herodotus' Historiae and natural history, see also R. Thomas, 2000, pp. I35-167 (esp. pp. I64-I66 with nn. 93 and 99 for further literature). 
strictly moralising way, though. In fact, they are often solved in a physical, if not in a more generally technical or specialised, fashion ${ }^{225}$. Most notably, the symptoms of fear and courage are generally explained in Book 27 in relation to a person's physical properties, esp. bodily coldness and heat ${ }^{226}$. The same explanatory scheme is found in Quaestiones naturales. For instance, in Q.N. 20, Plutarch explains the courageous character of the boar vis-à-vis the cowardly character of deer in terms of the hot (fiery) vis$\grave{a}$-vis the cold (watery) constitution of their bodies respectively. Similarly, in Q.N. II, the emotion of fear is implicitly connected with coldness, since when people imagine some danger at sea, they tremble and shiver.

Now that we have analysed the close relationship between Plutarch's Quaestiones naturales and Ps.-Aristotle's Problems, it still remains to be seen, precisely why Plutarch opted for the genre of natural problems and not for another genre of writing. This, however, will be treated in the following chapters.

\section{Conclusion and new questions}

I conclude that it would prove of a doubtful insight in Plutarch's natural scientific project to claim that his study of natural phenomena concerns the examination of their physical causes alone. The fact, however, that it are precisely the $\alpha i \tau i \alpha \iota \phi v \sigma \iota \alpha$ i that receive central focus in Quaestiones naturales (as is marked by the title) does eventually define the collection's scientific outlook (as modelled after Ps.-Aristotle's Problems). However, Plutarch does incorporate the same or similar physical material in his other works, where he becomes the flamboyant moralist and litterateur we know so well. This raises questions about the position of Quaestiones naturales in the corpus Plutarcheum more generally. What kind of text is this, then, and which purpose did it serve? How does it relate to Plutarch's

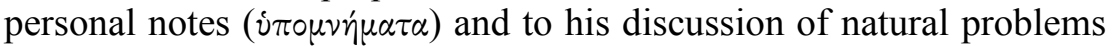
elsewhere (esp. in Quaestiones convivales)? These and related questions will be subject to debate in the following chapter.

225 Book 29, most notably, deals with legal justice for the most part, which H. Flashar, I962, p. 3I7 aptly describes as a "Fachwissenschaft" ("Wollte man den Titel "Problemata Physica" mit der Überlegung rechtfertigen, daß Ethik nicht an sich unbedingt den Bereich der Physis überschreitet, so ist zu bedenken, daß in den Probl. von Ethik im engeren Sinne kaum die Rede ist. Fast überall herrscht nämlich eine praktische Tendenz vor, die dazu führt, daß sich die behandelten Phänomene in den Zusammenhang einer Fachwissenschaft einordnen lassen."). For further reading and discussion, see R. Mayhew, 20IIb. For the place of Books 27-30 in the Problems more generally (to be identified perhaps with the

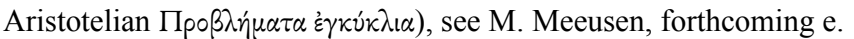

226 See L.M. Castelli, 20II. There is a precedent for the mind-body relationship already in Plato, who writes that the diseases of the soul are due to the condition ( $\varepsilon_{\xi} \xi$ เ $)$ of the body (Tim. 86b). 



\section{2 \\ The position of Quaestiones naturales in the corpus Plutarcheum}

This chapter aims to fine-tune the position of Quaestiones naturales in Plutarch's oeuvre by studying which role the genre of natural problems more generally plays throughout his writings. I will argue that in Quaestiones naturales Plutarch creates an independent problematic framework for recording his aetiological speculations about particular natural phenomena in an autonomous way (i.e. free from other concerns such as stylistic embellishment and moralising dynamics [see I.2.]). In an attempt to reject the traditional view that Plutarch's collections of quaestiones more generally were useful only as sets of notes ( $i \pi \circ \mu \nu \eta \dot{\eta} \mu \tau \alpha)$ Plutarch drafted for personal use, I will try to demonstrate that they rather provide a medium for thematically sorting out, amassing and discussing all kinds of issues that struck Plutarch as being particularly problematic.

In examining how Plutarch incorporates the genre of natural problems, including specific Quaestiones naturales material, in his other writings, I will focus especially on the discursive effects procured by this technique. How does a parallel passage or a scientific digression function in the narrative or argumentative line of a particular text? Which methods are used to incorporate it in that specific discourse? And what are the similarities and differences with Quaestiones naturales? Once these and related questions have been clarified, I will zoom in on the compository relationship between Quaestiones naturales and Quaestiones convivales more in specific ${ }^{1}$. The results of these inquiries will form the basis for further research about the intellectual purpose of Quaestiones naturales. To this end, I will consider the likelihood of the work's publication, which I will further develop in chapter three.

\section{I. Scientific traits in the corpus Plutarcheum}

As an intellectual, a teacher, and a true paragon of ancient learning, Plutarch collected and reused any form of knowledge that attracted his personal attention. Any bit of information that interested him was jotted down in the form of personal notes (i $\pi \circ \mu \nu \eta \dot{\mu} \mu \alpha \alpha)$ [see 2.3.2.]. These would surely serve him well one day, as is, indeed, suggested by the numerous parallel passages and clusters throughout his writings. In his reproduction

${ }^{1}$ A problem that, according to F.H. Sandbach, 1965, p. I38, however, "hardly admits of an answer". 
of these materials, Plutarch often tried to iron out what, in his opinion, were the most problematic difficulties. He, therefore, sought explanations for many kinds of topics (e.g., cultural, antiquarian, literary, linguistic, philosophical, scientific etc.), but he also wanted his readers to acquaint themselves with these explanations and, thus, share in the richness of manifold learning $(\pi \circ \lambda \nu \mu \dot{\alpha} \theta \varepsilon ı)$.

Even outside of his collections of quaestiones Plutarch often confronts his readers with discussions of numerous kinds of problems ${ }^{2}$. However, Plutarch's treatment of these topics is not always very closely related to the central narrative or argumentative line of the treatises at hand. On the contrary, they often divert the reader from what is really at issue. This does not imply, however, that Plutarch was just 'massing together useless material of research' in these passages, as he states himself (cf. Nic. I, 5:

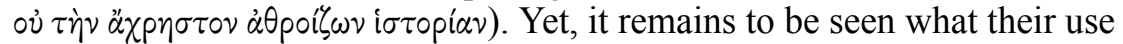
really was, then. In the Vitae, he refers to these kinds of digressions with the notion of $\pi \alpha \rho \varepsilon \kappa \beta \dot{\alpha} \sigma \varepsilon \varepsilon^{3}$; these are, in fact, abundant throughout his entire oeuvre, and are not restricted to the Vitae only [see 2.I.3.]. The length of these digressions varies from a single sentence to an entire paragraph, and they often display an 'aetiological climate'4 that strongly reminds the reader of the genre of problems and its typical organisation of knowledge [see I.I.4.].

The section at hand will mainly be concerned with Plutarch's natural scientific digressions, but I will also deal with his use of natural scientific exempla (i.e. metaphorical reinterpretations of natural phenomena). We have already briefly dealt with such exempla in the previous chapter (c.q. with their moralising intentions [see I.2.4.]), but it will become clear here that this use of imagery was an intergral aspect of Plutarch's literary style.

\section{Intellectual and literary interest of natural phenomena}

As the examples below will show, Plutarch's scientific digressions concern very similar natural scientific topics as treated in Quaestiones naturales. By incorporating such problems in the narrative or argumentative line of several of his writings Plutarch clearly intended to promote his own research to the outer world and, thus, to demonstrate his own argumentative talent. This is not necessarily incompatible with the idea that by sharing this knowledge with his readers he intended to offer some kind

${ }^{2}$ Cf. R. Hirzel, I9I2, p. 40: "Überall wird den Problemen nachgespürt, die sich in Wissenschaft und Leben darbieten, nicht bloß alten Problemen, sondern auch neuen, die der Augenblick, auch wohl nur der gesellige Scherz erfindet."

${ }^{3}$ See Alex. 35, I6 (regarding the scientific digression on naphtha; see further) and Dion 2I, 9 (regarding the historical digression on Theste).

${ }^{4}$ This concept was coined by J.-M. Pailler, I998, p. 80, who used it in light of the parallel material between the Quaestiones Romanae and the Vitae. 
of learned diversion (as fellow $\pi \varepsilon \pi \alpha \iota \delta \varepsilon \nu \mu \varepsilon v o$, they would surely appreciate such digressions). Yet, as we will see, apart from having an obvious intellectual interest, these scientific digressions often also serve a specific literary purpose in the organisation and development of Plutarch's text.

In order to illustrate this, I refer to the particularly intriguing digressions in the introductions to De Pythiae oraculis and De defectu oraculorum, which by their natural scientific interests deserve specific consideration here. The introduction to De Pythiae oraculis (395A-396C) is concerned with the patina of the bronze statues of Lysander and his admirals located near the entrance of the holy precinct in Delphi (cf. also Lys. I8, I). In connection with this topic, the interlocutors discuss the problem of why oil covers bronze with rust ${ }^{5}$. In the introduction to De defectu oraculorum (4IOB-4IID), on the other hand, the interlocutors deal with the everburning lamp at the shrine of Ammon in Egypt, which, so the local priests report, consumes less and less oil each year: does this imply that the years grow shorter and shorter ${ }^{6}$ ? I will not deal with these problems in detail here. What matters is that owing to the fact that these discussions are located at the very beginning of the treatises and are not emphatically connected with the main topic at issue (viz. that the oracles at Delphi are no longer given in verse and that many oracles in Greece have passed into disuse respectively) ${ }^{7}$, I believe that this technique provides some kind of an introductory framework, some kind of a Natureingang perhaps, for the narrative (I will come back to this) ${ }^{8}$.

The discursive value of these introductions lies in the fact that they at least for a while postpone the central issue that the author intends to treat in these writings by first providing a discussion of a completely different matter. As such, we can rightly speak of a literary and intellectual 'appetiser' in view of the intellectual $\sigma \times 0 \lambda \eta$ ' that is required for the author to produce and for the reader to consume this kind of literature. This $\sigma \times 0 \lambda \eta^{\prime}$ necessitates that the author and reader can take time to divert their attention a bit before getting to business. Starting off immediately with the central argument would not suit the decorum of this kind of literature, nor would it improve the literary verisimilitude that the author is trying to attain 9 .

${ }^{5}$ Cf. Ps.-Arist./Alex. Aphr., Suppl. probl. 3, I7. For further detail, see J. Jouanna, I975 and W.A. Franke and M. Mircea, 2005 (with an attempt towards a modern scientific explanation).

${ }^{6}$ For further discussion, see J. Hani, I976, pp. 267-268 and E.G. Simonetti, forthcoming.

7 See E. Valgiglio, I992, p. I9 and A. Rescigno, I995, p. 8, n. I. Cf. also C. Kahle, I9I2, pp. 93-95 and I03-IO4.

8 Flacelière aptly speaks of a "lever de rideau" (in R. Flacelière, J. Irigoin, J. Sirinelli and A. Philippon, 1987, pp. ccxx and ccxxii).

${ }^{9}$ Cf. E. Valgiglio, I992, p. 22: “abbiamo qui la scenografia, lo sfondo dell'azione 
We are dealing here with dramatic dialogues between real-life persons (rather than with strictly systematic treatises), in the manner of Plutarch's Quaestiones convivales and generally inspired by Plato's dialogues.

Notably, the discussion about the bronze statues in De Pyth. or. $395 \mathrm{~A}-396 \mathrm{C}$ begins and ends with a reference to the prearranged sightseeing programme of the guides at Delphi. This does not seem to be of great interest to the interlocutors, who ask the guides to cut short their lengthy stories and readings of every single inscription (395A: 'E $\pi \varepsilon$ palvov

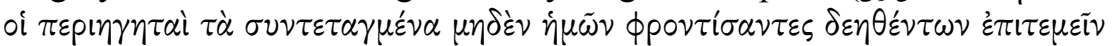
$\tau \dot{\alpha} \varsigma \dot{p} \eta \dot{\sigma \varepsilon l \varsigma} \kappa \alpha i \mathrm{i} \tau \dot{\alpha} \pi \circ \lambda \lambda \dot{\alpha} \tau \tilde{\omega} \nu \dot{\varepsilon} \pi \iota \gamma p \alpha \mu \mu \alpha \dot{\tau} \tau \nu)$. Since no heed is given to their inquiries, the interlocutors start to discuss matters of greater personal interest (viz. the patina of the bronze statues of Lysander and his admirals), while the guides are left twiddling their thumbs. When afterwards there is a short moment of silence, the guides pursue their routine speeches (396C:

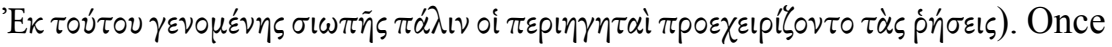
they mention a certain oracle given in verse, the interlocutors interrupt again and start discussing the common quality of the verse in which oracles are delivered in their days - which is the main topic of the dialogue ${ }^{10}$.

By the repeated interruption of the Delphic guides, Plutarch seems to suggest from the start that the treatise at hand will not just be a systematic, prearranged tour through the precinct of Delphi, but rather a more improvisatory, digressive promenade that leads the reader offtrack - that is, off the trodden paths of the subject treated. As such, the purpose of the treatise is to look for new, original ways of approaching the very essence of the prophetic art, gradually unveiling the philosophicalreligious power of the Delphic precinct. Indeed, the introductory scene of De Pythiae oraculis is literally set at the entrance of the holy precinct, where the very symbolic walk towards the Apollo-temple on the hill begins (cf. De Pyth. or. 394E, 402BC). The fact that a starting-point for the discussion is found in the genre of natural problems may be significant for the 'pre-philosophical' interest of this type of debate ${ }^{11}$ [see 3.2.].

drammatica". A link can be drawn, for instance, with the introduction in De gen. Socr.

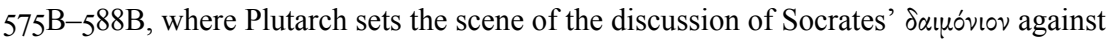
the historical background of the Theban conspiracy against the Spartan tyrants.

10 The guides cut a foolish figure again in De Pyth. or. $397 \mathrm{DE}, 400 \mathrm{DE}, 400 \mathrm{~F}-40 \mathrm{AA}$, 40IE. Cf. also De E $386 \mathrm{~B}$ and the reactions to the accounts of the guide (o $\pi \varepsilon p i \eta \gamma \eta \tau \dot{\eta}$ ) Praxiteles, in Quaest. conv. 675EF and esp. $723 \mathrm{E}-724 \mathrm{D}$.

11 The aetiology - which ends in aporetic silence - seems to suggest that the air at the precinct has unusual properties: it is at the same time dense and compact and tenuous and keen (De Pyth. or. 396AC). This may highlight the peculiar character of the precinct's natural environment (cf. Q.N. 23, 9I7 EF) and may perhaps contain an implicit allusion to the prophetic exhalations released at the Delphic shrine (a topic treated at the very end of De def. or. $437 \mathrm{C}-438 \mathrm{D})$. 
The same can probably be presumed, then, for the problem of the lamp at the shrine of Ammon, which Plutarch treats in De def. or. 4IOB-4IID in a very similar religious framework (viz. at the Delphic precinct, a short time before the Pythian games). Notably, this problem is put forward to the group by the travelling Cleombrotus of Sparta, 'a man fond of spectacles

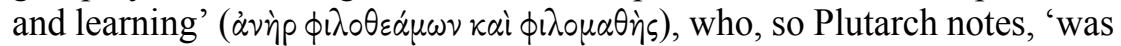
getting together a history to serve as a basis for a philosophy that had as its

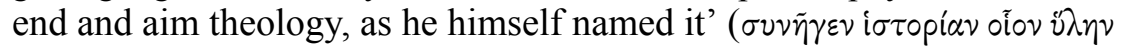

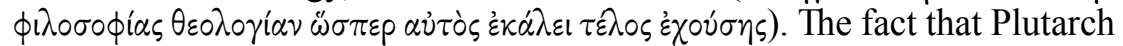
mentions Cleombrotus' literary project seems very significant, since in a very similar way, natural history, and more precisely the discussion of a specific natural problem, serves as a preamble to the philosophicalreligious discussion also in his own dialogue. This seems very significant in light of Plutarch's "effort to reconcile science and religion" in De defectu oraculorum $^{12}$.

Another suggestive means to provide some literary-intellectual diversion to the reader is found in Plutarch's frequent reinterpretation of natural phenomena in an expressive, rhetorical way as metaphorical exempla. In Q.N. 32, for example, Plutarch deals with the natural phenomenon of palm wood that rises against weight imposed upon it. This problem is explained in a purely physical way in Q.N. 32, whereas in a parallel passage in Quaest. conv. 724E, it is used as an exemplum for the athlete's well trained body and mind (notably, the palm tree's natural resilience remained a popular topic well beyond Antiquity in the form of a moral 'emblem': see the commentary ad loc.). In Maxime cum principibus $776 \mathrm{~F}-777 \mathrm{~A}$, to give another example, Plutarch compares the teachings of philosophy with the natural powers of the sea-holly (eryngium):

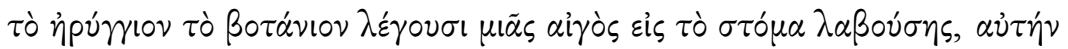

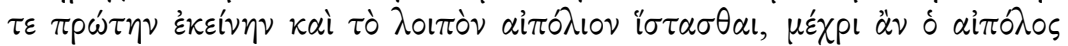

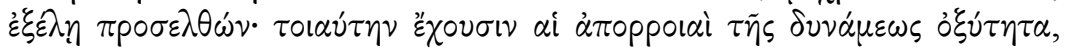

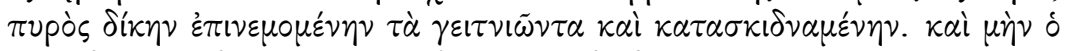

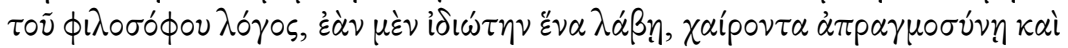

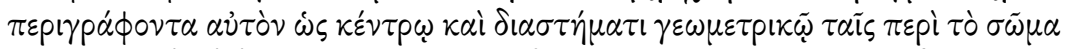

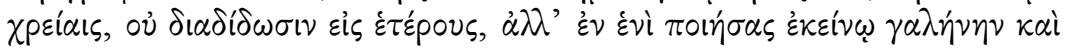

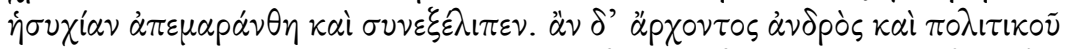

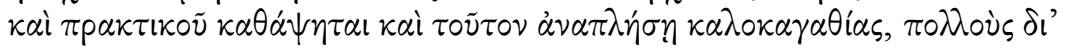

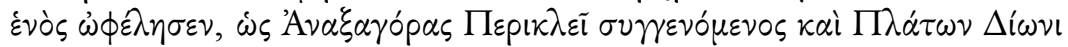

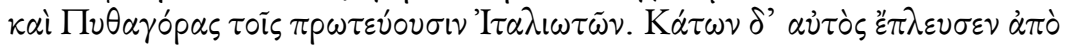

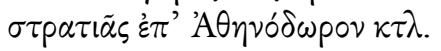

12 F.C. Babbitt, I936b p. 349. For an excellent study of the passage in light of Plutarch's main argument, see E.G. Simonetti, forthcoming. 
Of the plant eryngium they say that if one goat take it in its mouth, first that goat itself and then the entire herd stands still until the herdsman comes and takes the plant out, such pungency, like a fire which spreads over everything near it and scatters itself abroad, is possessed by the emanations of its potency. Certainly the teachings of the philosopher, if they take hold of one person in private station who enjoys abstention from affairs and circumscribes himself by his bodily comforts, as by a circle drawn with geometrical compasses, do not spread out to others, but merely create calmness and quiet in that one man, then dry up and disappear. But if these teachings take possession of a ruler, a statesman, and a man of action and fill him with love of honour, through one he benefits many, as Anaxagoras did by associating with Pericles, Plato with Dion, and Pythagoras with the chief men of the Italiote Greeks.

The popular belief about the goat and the sea-holly (which recurs in $D e$ sera num. 558E and Quaest. conv. $700 \mathrm{D}$ and probably originates from Arist., HA 6Iob29) clearly foregrounds the natural scientific subtext in this passage, and the same is true for the image of the spreading fire and the drawing of geometrical circles (as well as Plutarch's use of such technical

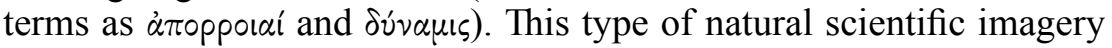
is meant to serve a literary purpose in rendering Plutarch's argument more palatable to the reader, pointing out, in this case, that not only the philosopher but also the political ruler and, through him, the people can in fact benefit from philosophical teachings.

As already noted in the previous chapter, natural phenomena are often subject to a moralising type of exemplification in Plutarch's writings [see I.2.4.]. A good example can be seen in Phoc. 3, I-3, where Plutarch compares Cato the Younger's old-fashioned virtue in times of moral decay with fruits that grow out of season: these fruits are admired but not used. In the previous paragraph (Phoc. 2, 6-9), the non-rectilinear motion of the sun, which is said to provide an ideal temperature for all things on earth, is reinterpreted in light of a political precept, in order to suggest that a moderate government is best. This aspect of cosmic balance and harmony is considered to be in line with how the Platonic God rules the universe that is, by means of reason and persuasion rather than by necessity (cf. Tim. $48 \mathrm{a})^{13}$ :

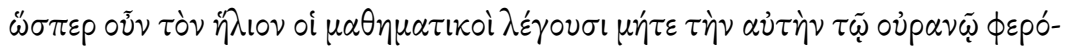

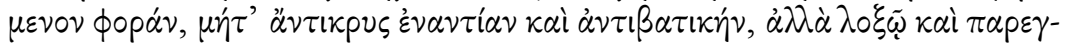

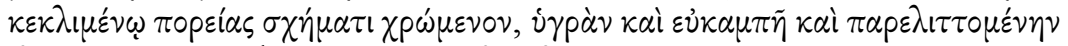

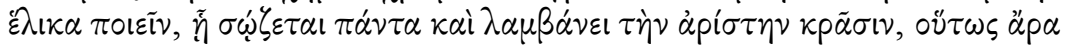

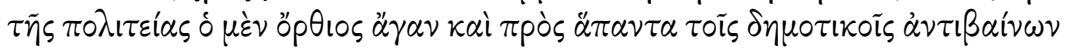

${ }^{13}$ For further discussion of this topic, see L. Van der Stockt, 2012. 


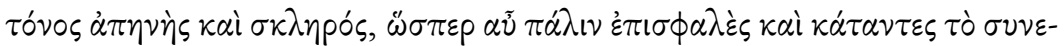

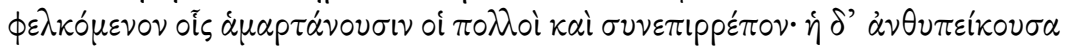

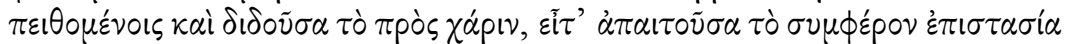

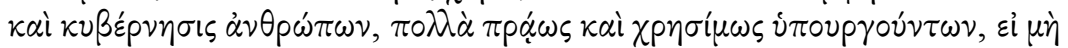

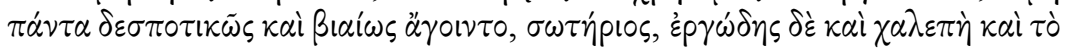

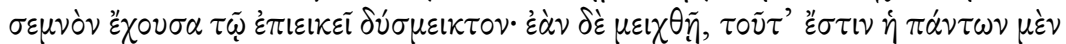

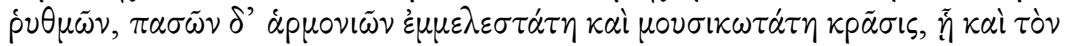

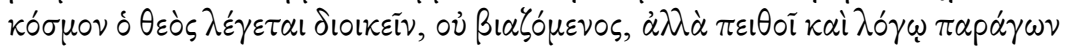
$\tau \grave{\eta} \nu \dot{\alpha} \nu \alpha \dot{\gamma} \kappa \eta \eta$.

Now, the sun, as mathematicians tell us, has neither the same motion as the heavens, nor one that is directly opposite and contrary, but takes a slanting course with a slight inclination, and describes a winding spiral of soft and gentle curves, thus preserving all things and giving them the best temperature. And so in the administration of a city, the course which is too straight, and opposed in all things to the popular desires, is harsh and cruel, just as, on the other hand, it is highly dangerous to tolerate or yield perforce to the mistakes of the populace. But that wise guidance and government of men which yields to them in return for their obedience and grants them what will please them, and then demands from them in payment what will advantage the state, - and men will give docile and profitable service in many ways, provided they are not treated despotically and harshly all the time, - conduces to safety, although it is laborious and difficult and must have that mixture of austerity and reasonableness which is so hard to attain. But if the mixture be attained, that is the most concordant and musical blending of all rhythms and all harmonies; and this is the way, we are told in which God regulates the universe, not using compulsion, but making persuasion and reason introduce that which must be.

A myriad of such examples could be adduced to illustrate Plutarch's frequent reinterpretation of natural phenomena as rhetorical exempla ${ }^{14}$. What matters for us here is that this technique of comparing and unifying human affairs with natural phenomena is intelligent and often renders Plutarch's personal comments and criticism more enjoyable to read. As such, by using these images, Plutarch offers both a literary and an instructive, if not more philosophical and contemplative pleasure to his readers (as in the last case).

In Quaestiones naturales, by contrast, Plutarch's primary concern is to provide natural explanations for problematic phenomena. Therefore, he generally avoids referring to their metaphorical implications. Never-

${ }^{14}$ For more on Plutarch's natural metaphors, see A.I. Dronkers, I892, pp. I02-I42, F. Fuhrmann, 1964 (passim) and J. García López, I99I. 
theless, several of these phenomena are exploited as rhetorical exempla elsewhere, viz. as images of fear (cf. Q.N. II $\sim$ De tranq. an. 475F-476A), the lack of steadfast character (cf. Q.N. I9 De ad. et am. $5 \mathrm{ID}-53 \mathrm{D}$, De am. mult. 96F-97A, Alc. 23, 4-5), democratic elections (cf. Q.N. 26, 9I8D $\sim$ Praec. ger. reip. 80IA), athletic strength (cf. Q.N. $32 \sim$ Quaest. conv. $724 \mathrm{E}$ ), marital infidelity (cf. Q.N. $36 \sim$ Coni. praec. I44D), hostility (cf. Q.N. $37 \sim$ De gar. 5I4D), the joining of opposites (cf. Q.N. 4I $\sim$ De cap. ex inim. 92B). Parallel passages of this sort nicely illustrate how Plutarch constantly refashions his scientific ideas in different literary contexts. The sheer amount of these parallels demonstrates that such physical themes play an important unifying role throughout the Chaeronean's oeuvre. As we will see in what follows, they are also very relevant for Plutarch's general writing method.

\section{Cluster analysis in Quaestiones naturales}

The most intriguing case in terms of parallel passages between Quaestiones naturales and Plutarch's other works is Q.N. I9, which concerns the octopus' change of colour. I have already partly discussed this problem in the previous chapter [see I.2.4.], but will return to it here in light of Plutarch's writing technique.

What is important is that several key elements relating to Plutarch's discussion of the octopus' metachrosis as found in Q.N. I9 are repeated in a number of parallel passages, where the aspect of physical aetiology is not as central. The natural phenomenon is compared with the adaptable character of flatterers in De ad. et am. 5ID-53D and De am. mult. 96F$97 \mathrm{~A}$, and with the opportunistic politics of Alcibiades in Alc. 23, 4-5. There is also a parallel concerning the animal's psychology in De soll. an. 978EF. Considering the topic's frequent recurrence, we can speak of a genuine 'cluster' of parallel passages here, which Van der Stockt has defined (in light of his method of 'cluster analysis') as "a repeated and structured collection of heterogeneous materials"15. Depending on the number of textual parallels, Van der Stockt makes a distinction between 'parallel passages' (two parallels) and 'clusters' (three or more parallels). Such parallels and clusters are often identified by a set of recurrent quotations, anecdotes, similes, concepts etc. In the case of the octopus cluster, these are found - as schematised below - in I) the quotations from Pindar and Theognis, 2) a more ethical vis-à-vis more physical orientation, and 3) the reference to specific physical concepts (viz. emanations and breath) ${ }^{16}$.

${ }^{15}$ L. Van der Stockt, I999a, p. 580.

${ }^{16}$ For a separate analysis of this octopus cluster, see M. Meeusen, 20I2a, pp. 247-250. There are several other such clusters with parallels in our collection, but it would bring us much too far to discuss each and every one of them in detail here. I will briefly discuss the 
Octopus cluster

\section{Quotations Orientation Concepts \\ Pind. Theo. Eth. Phys. Eman. Breath}

\begin{tabular}{|c|c|c|c|c|c|}
\hline Alc. $23,4^{-5}$ & & & $\mathrm{X}$ & $\mathrm{x}$ & \\
\hline De ad. et am. 5IDff. & & & $\mathrm{X}$ & $\mathrm{x}$ & \\
\hline De am. mult. 96Ff. & & $\mathrm{X}$ & $\mathrm{X}$ & $\mathrm{x}$ & $\mathrm{X}$ \\
\hline Q.N. I9, 9I6BF & $X$ & $\mathrm{X}$ & $\mathrm{X}$ & $\mathrm{X}$ & $\mathrm{X}$ \\
\hline De soll. an. $978 \mathrm{EF}$ & $\mathrm{X}$ & $\mathrm{X}$ & $\mathrm{x}$ & $\mathrm{X}$ & \\
\hline
\end{tabular}

Key: $\mathrm{X}=$ clearly present; $\mathrm{x}=$ clearly present, but less strongly articulated than in Q.N. I9; $\mathrm{X}=$ clearly present, but ruled out by Plutarch.

One of the most important advantages of Van der Stockt's method of cluster-analysis is that it, besides from being highly efficient and orderly, offers detailed insight into Plutarch's argumentative tactics and his writing and rewriting process, with a particular interest for his use of personal notes $\left(\dot{v} \pi \circ \mu \nu \eta^{\prime} \mu \alpha \tau \alpha\right)^{17}$ (I will deal with the specific nature of Plutarch's notes below [see 2.3.2.]). In the octopus cluster, then, it is not unlikely that Plutarch reuses and remodels the same material, drawing from (one or more of his personal notes on zoological topics, and adapting this hypomnematic material to various contexts. Van der Stockt is well aware of the possibility, however, that one writing can be inspired by another, or that the parallelism in subject matter derives from mental, rather than textual, processes ${ }^{18}$. Indeed, also in the case of Q.N. I9 one cannot simply dismiss that the hypomnematic material at some point became an idée fixe in Plutarch's mind, such that the textual intermediation of a $i \pi \delta$ ó $\nu \mu \alpha$ in each and every case must eventually remain hypothetical.

Another important aspect regarding the parallel passages between Quaestiones naturales and Plutarch's other writings is that there are considerably few such parallels in the Vitae ${ }^{19}$. This is not at all the case

contents of these clusters in the commentary ad loc. (with specific attention also for the parallels in other authors). Cf. Q.N. I Quaest. conv. 627AD, 695E; Q.N. 2-4 Quaest. conv. $66 \mathrm{IBC}, 663 \mathrm{~F}, 664 \mathrm{D}-665 \mathrm{C}, 666 \mathrm{~A}, 684 \mathrm{E}, 685 \mathrm{BD} ; Q . N$. I2 and $39 \sim$ De prim. frig. 950B; Q.N. $24 \sim$ Quaest. conv. 657F-659D, De facie 940A (see further); Q.N. $26 \sim D e$ soll. an. 974BD, Gryllus 99IE. The second cluster was analysed separately by L. Van der Stockt, 20II (with a schematic representation on p. 45I).

${ }_{17}$ For concrete applications of this method, see, e.g., L. Van der Stockt, I999a, I999b, 2004, 20II, B. Van Meirvenne, I999, 200I, S.A. Xenophontos, 2012 and M. Meeusen, 20I2a.

18 Therefore, each case should be considered individually. See L. Van der Stockt, I999a, p. 597 and 2004, p. 335, n. Io. See also S.A. Xenophontos, 20I2, p. 87 and M. Meeusen, 20I2a.

${ }^{19}$ Cf. Q.N. I9 Alc. 23, 4-5; Q.N. II and I9 Arat. 29, 6; Q.N. II $\sim$ Demetr. 38, 4 and Per. 33, 5. These parallels are also rather weak in comparison to those in the Moralia. 
with the Moralia, where we find an abundance of parallel material. The same material can be found especially in the more specialised natural scientific works (De primo frigido, De facie, De sollertia animalium and esp. Quaestiones convivales), but parallel passages are also present in Plutarch's non-scientific works. These parallels are not always entirely identical in form or content but often involve specific textual adaptations and rearrangements to suit the new context. A detailed analysis of each of these parallel accounts cannot be achieved here ${ }^{20}$. Instead, I will enumerate the most important procedures discernible in their incorporation.

First of all, a number of rather loose allusions to and weak reformulations of the same Quaestiones naturales material can be found throughout the Moralia, where the argumentation often relies on generally accepted scientific concepts and theories (e.g., the idea that salty seawater is naturally hot). The parallelism, however, is far more prominent in other cases, as can be seen, for instance, in the cluster of parallels passages concerning the production of dew by the moon (discussed in Q.N. 24, Quaest. conv. 659B and De facie 940A). In this cluster Plutarch repeats the same quotation from Alcman, where Dew is called the daughter of Zeus and Moon

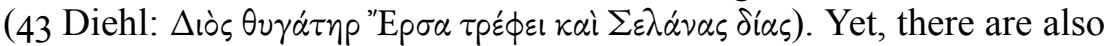
subtle differences in the arguments at hand. The most significant difference is that in Q.N. 24, Plutarch refers to the mechanism of attraction ( $\left.\delta \lambda \kappa \eta^{\prime}\right)$ in explaining how dew comes to be, while in Quaest. conv. 659B and De facie 940A, he refers to the process of change ( $\left.\mu \varepsilon \tau \alpha \beta 0 \lambda \eta \eta^{\prime}\right)$. This can be explained in light of the different aetiological contexts. In the latter two passages, Plutarch argues that the moon has a liquefying effect, and that the air (Zev́s in Alcman's line) is liquefied by the moon into dew. The context of lunar liquefaction is absent, however, in Q.N. 24, where Plutarch argues (regarding the problem of why hunters are least successful in following animal tracks during full moons) that the moon draws the dew, which is a weak and impotent kind of rain, up from the earth like the sun does, but being unable to lift it to a height and to raise it, drops it again. Considering the clear Stoic overtones in this cluster (as attested in the allegorical reading of Alcman's verse and the allusion to exhalations as fuel for the moon and sun: see the commentary ad loc.), it is only likely that a certain compositional interference must have occured when Plutarch wrote down these passages (did he perhaps draw from his notes on a Stoic commentary on Alcman?). The slight differences in argumentative detail can be ascribed, then, to the different argumentative contexts in which the material was incorporated.

${ }^{20}$ For a list of the most obvious parallels between Quaestiones naturales and the Moralia, see the index (s.v. "Plutarch"), in F.H. Sandbach, 1965, pp. 239-240 (where Quaestiones naturales covers pp. 133-229). Sandbach's index records no parallels with the Vitae (see n. 19). 
Second, when it comes to the number and detail of the explanations Plutarch provides in his natural problems, it seems that the aetiologies are far more systematic in Quaestiones naturales than in the parallel accounts. Indeed, one has the impression that Plutarch in this work aims to amass all of his knowledge on the natural phenomena at issue, while elsewhere he is more concerned with adapting only fractions of this material, often, indeed, in different contexts, so that an elaborate aetiology is not necessary. This is seen, for instance, in the octopus cluster, where the most exhaustive account is given in Q.N. I9 (see the scheme above). Only in one exceptional case does a specific argument take on greater rigor elsewhere than in Quaestiones naturales. This is the case in Q.N. 29, 919AB, where Plutarch

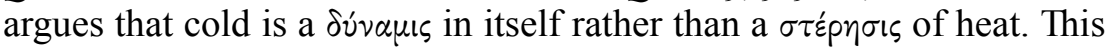
theory is elaborated in far greater detail in De primo frigido (946A-948A), a treatise in which the principle of cold is the main subject of inquiry. In Q.N. 29, however, the same theory is formulated in a very condensed fashion to serve as a starting-point for Plutarch's discussion of why we marvel at hot springs but not at cold ones.

What these clusters and parallels show is that the widely accepted unity and consisteny in the corpus Plutarcheum is considerably strengthened by the use of specific natural scientific topics, often identical or similar to those of Quaestiones naturales ${ }^{21}$. No wonder that Flacelière regarding Plutarch's digression on drinking water in Aem. Paul. I4 (discussed below) notes: "On croirait vraiment lire un paragraphe des Causes physiques." 22 In the following section, I will deal with the recurrent incorporation of scientific digressions in the Vitae more specifically and with the discursive role these digressions play in the biographical narratives at hand. Getting a clearer view of Plutarch's technique of incorporating such scientific digressions into the Vitae will be valuable to further study the position of Quaestiones naturales in the corpus Plutarcheum.

\section{Scientific digressions in the Vitae}

Plutarch's digressive writing method spans a wide range of topics in the Vitae. Most digressions in these writings deal with topics related to Greek

${ }^{21}$ For more on the unity between the Vitae and the Moralia, based on the scientific digressions in the former, see J. Boulogne, 2008, p. 748 (regarding the parallel on $\beta$ ov $\lambda_{1} \mu i^{\alpha} \alpha$ between Quaest. conv. 693E-695E and Brut. 25, 4-6; see further). Regarding the unity in the corpus Plutarcheum more generally, see J. Barthelmess, I986, pp. 62-64 and the contributions in A.G. Nikolaidis, 2008.

${ }_{22}$ In R. Flacelière, J. Irigoin, J. Sirinelli and A. Philippon, I987, p. 1xxxii (see also p. xi, n. 2). Cf. also S. Saïd, M. Trédé and A. Le Boulluec, I997, p. 444: "On retrouve partout la même érudition (la longue digression sur les eaux potables dans la Vie de Paul-Émile serait tout à fait à sa place dans les Questions naturelles) [...].” 
and Roman history and culture (viz. names, places and customs ${ }^{23}$. This is only a logical consequence of Plutarch's basic intention with these writings, which is to portray the lives of illustrious Greek and Roman political figures. To this end, many cultural and historical realia require a detailed explanation for the reader to acquire an optimal understanding of the story-line and its broader context. Plutarch also incorporates more reflective digressions, in order to add a specific philosophical-theological layer - the $i \lambda \eta \phi i \lambda \circ \sigma \circ \phi i \alpha s$ - to his biographical discourses, pointing out, for instance, that God is capable only of doing good (Per. 39, 2-3), or that demons try to lead virtuous people astray (Dion 2, 4-7). As noted, there is often also a physical specification of the narratives by the incorporation of numerous scientific digressions. In the end, the physical world - or at least Plutarch's Platonic view of it - is the ultimate background against which these biographies are set.

These scientific digressions testify to Plutarch's intellectual concerns and desire to look for explanations. From a narratological perspective, however, the digressions do not always seem to have much relevance for the main story-lines, to which they often only bear indirect relevance. Barrow may well be right, therefore, that such digressions come in handy "as a means of suspending the interest of the reader" - after all, "Plutarch should not be read in a hurry"24. These digressions add a specific physical dimension to the text. Van der Stockt has convincingly argued, in this regard, that "some of Plutarch's scientific 'digressions' are no mere display of scholarship, but are quite functional: they explain the world in which the heroes are operating" 25 . Indeed, Plutarch's Vitae are often set against a specific geographical decor that plays a direct role in the development of the narrative ${ }^{26}$. Many historical events are, in fact, directly related to specific natural phenomena and their causes. At some points, nature

23 J.-M. Pailler, I998, p. 82, for instance, distinguishes three aetiological categories in the Romulus: aetio-etymology, aetio-toponymy, aetio-ethnology. On the digressions in the Coriolanus, see G. Roskam and S. Verdegem, forthcoming.

${ }^{24}$ R.H. Barrow, I967, p. 65 (see also pp. 63-64). See Plutarch's own remark in Timol.

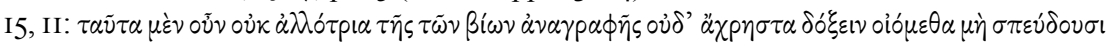

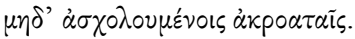

${ }^{25}$ L. Van der Stockt, 20I3, p. 445. He also points at "Plutarch's endeavour to explore more or less virtuous human conduct in the world such as it is according to the Platonist Plutarch" (p. 438).

${ }^{26}$ Cf. J. Sirinelli, 2000, p. 363: "Dans les Vies il parle souvent des particularités géographiques des pays concernés. Il suffit de consulter la Vie d'Alexandre ou celle d'Antoine pour se rendre compte qu'il s' est beaucoup informé sur les régions traversées et avec beaucoup de discernement. On ne peut affirmer qu'il a une connaissance très poussée de toute la géographie de son temps, mais il semble clair que, chaque fois qu'il traite d' un sujet qui appelle des connaissances dans ce domaine, il fait le nécessaire pour se renseigner et sait où puiser ses informations." 
even conditions human action ${ }^{27}$ (solar or lunar eclipses, for instance, can engender fear in generals, thus causing military defeat ${ }^{28}$. Moreover, the heroes of Plutarch's stories are, in a certain sense, presented as human

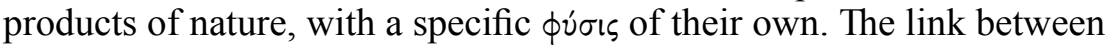
a person's character and his bodily disposition becomes concrete, for instance, in Plutarch's reference to Lysander's melancholy in Lys. 2, 3. Plutarch there quotes Aristotle, who writes that 'great natures', like those of Socrates and Plato and Heracles, have a tendency to melancholy ( $\tau \dot{\alpha} \varsigma$ $\mu \varepsilon \gamma \dot{\alpha} \lambda \alpha \varsigma \phi \dot{\sigma} \sigma \varepsilon \iota \varsigma \dot{\alpha} \pi \circ \phi \alpha i \nu \omega \nu \mu \varepsilon \lambda \alpha \gamma \chi \omega \lambda \iota \kappa \dot{\alpha} \varsigma)$, and that Lysander, not immediately, but when well on in years, was a prey to this affliction - this is a clear allusion to the famous chapter on melancholy in Ps.-Aristotle's Problems (953aro-955a40). Another likely allusion to the Problems is found in Arat. 29, 6 [quoted 3.I.I.], where Plutarch discusses Aratus' cowardice and its bodily manifestations (viz. heart palpitations, change in colour and looseness of the bowels), noting that such topics are popular points of

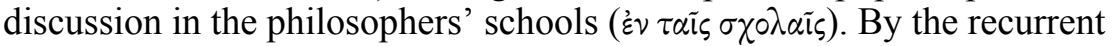
link between ethics and physics in the Vitae, Plutarch's heroes can be considered the microcosmic pawns on the macrocosmic chessboard that is the world ${ }^{29}$.

As the examples below will show, Plutarch knows very well that his natural scientific digressions might seem to contain rather redundant and heterogeneous materials in the context of the biographies of political figures. However, it turns out that these digressions, besides from serving as intellectual diversions, often also fulfil a specific literary function in the text, such as characterising the hero's personality or illustrating an important historical event (often in the context of divine intervention).

27 See P. Desideri, 1992, pp. 77-8I and A. Ferreira, 2015.

${ }^{28}$ Cf. Per. 35, 2, Nic. 23 (with De sup. I69AB), Aem. Paul. I7, 7-13 (with P. Desideri, I992, p. 83: "la conoscenza della causa scientifica del fenomeno naturale non esclude la possibilità di riconoscere in esso un segno divino"). On eclipses in Plutarch, see F.E. Brenk, 1977, pp. 4I-45, A. Pérez Jiménez, 1992, L. Torraca, 1992, pp. 240-243, L. Lesage Gárriga, 2015.

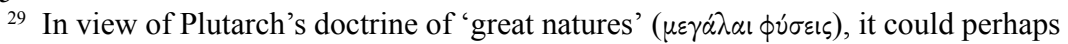
even be argued that the souls of Plutarch's heroes link up with the higher realm of the cosmos. For the relation between the world soul and the human soul in Plutarch, see P. Thévenaz, 1938, J. Opsomer, I994b, and F. Ferrari and L. Baldi, 2002, pp. 52-54. On the

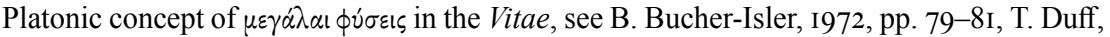
1999a, pp. 47-49, I999b (p. 323 on Lys. 2, 3), F. Frazier, 20I4, pp. 498-50I. Cf. Pl., Rep. 49Ib-492a, 495b. For Platonic psychology in Plutarch's Vitae, see T. Duff, I999a, pp. 72-98, esp. p. 9I. At another level, the conceptual link between microcosmos and macrocosmos also figures, for instance, in De facie, where several cosmological principles are explained by means of concepts related to the human body (e.g., 928AC). See H. Görgemanns, 1970, pp. I07-III and A. Pérez Jiménez, 1992, pp. 273-274. See also more generally L. Roig Lanzillotta, 2015. 
Indeed, they are often cleverly woven into the overall narrative in such a way that they do not tip the work's unity out of balance. If a digression tends to deviate too far from the central story-line, Plutarch breaks it off in time (see the formulations of closure below) ${ }^{30}$. Apparently, he is well aware of the fact that a complete treatment of natural scientific topics is impossible in the Vitae, and that this should be reserved for a more specialised genre of writing.

Desideri was the first to devote a separate study to the natural scientific digressions in the Vitae ${ }^{31}$, and there is also a more recent one by Boulogne ${ }^{32}$. Their overviews show that these digressions concern matters of physics, astronomy, geography, geometry, zoology, medicine, psychology and music. The aetiological structure and approach in these digressions, where Plutarch often provides several plausible explanations for a specific natural phenomenon, reminds the reader of the 'problematic' set-up of Quaestiones naturales [see I.I.4.]. There is not enough space to analyse each and every one of the scientific digressions in the Vitae here even Desideri notes that running through all the scientific passages in the Vitae may be a "cosa che probabilmente non avrebbe molto senso" 33 -, but the following examples may suffice to make things more concrete.

One of the most well-known scientific digressions is probably the one on the nature and origin of naphtha in Alex. $35^{34}$. Sansone has interpreted this passage in light of Alexander's character and physiognomy, arguing that "the volatile and flammable nature of naphtha is remarkably like the nature of Alexander as portrayed by Plutarch" ${ }^{35}$. As such, the digression is actually key to Plutarch's ethical portrait of Alexander. I will not provide an analysis of the entire passage here. It is worth mentioning that several parallels can be traced in Quaestiones convivales (viz. the marvellous phenomena of naphtha in $68 \mathrm{IC}$, the use of 'waterbeds' in $649 \mathrm{EF}$, and Harpalus' failure to plant ivy in Babylonian soil in 648CD and $649 \mathrm{E})^{36}$. The fact that some of these issues are treated in greater detail in

${ }^{30}$ Eight of the approximately 40 scientific digressions collected by J. Boulogne, 2008 contain a formulation of closure, meaning that Plutarch terminates these passages explicitly (see, p. 746, with n. 36).

31 P. Desideri, 1992.

32 J. Boulogne, 2008 (who on pp. 746-747 distinguishes four functions of these scientific digressions: "plaire", "instruire", "spécifier", "jugement personnel"). See also A. Ferreira, 2015.

${ }_{33}$ P. Desideri, 1992, pp. 73-74.

${ }^{34}$ Cf., e.g., J.R. Hamilton, I969, p. 94: "The former passage is a good example of Plutarch's interest in science."

${ }^{35}$ D. Sansone, I980, p. 63. Cf. also T. Whitmarsh, 2002, p. 190: "the heat of the East is inflaming Alexander, whose nature is already higly flammable". See also R. Caballero Sanchez, I992, pp. 92-95, J. Mossman, 2006, pp. 290-29I and J. Boulogne, 2008, p. 737.

${ }^{36}$ According to J. Boulogne, 2008, p. 737, in this digression, Plutarch reuses pieces of 
Quaestiones convivales is important, because at the end of the Alexander passage, Plutarch notes that if such digressions are kept within bounds, the impatient readers will perhaps complain about them less (Alex. 35, I6:

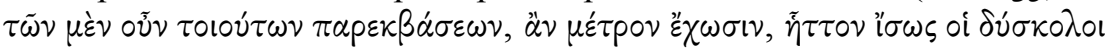

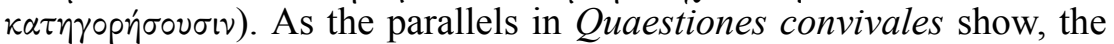
potential impatience on behalf of the reader does not so much involve the scientific contents of such digressions, but rather the fact that they tend to disrupt the fluency and coherence of the main story-line. Then again, Plutarch warned his reader in the introduction in Alex. I, 2 that

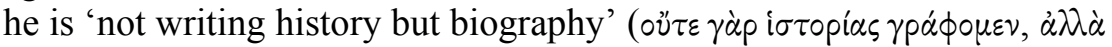
Bious). Plutarch's digression on the fiery soil of Babylon, thus, turns out to be an important motive for the biographical narrative in that it, at least implicitly, illustrates Alexander's fiery character and physiognomy.

Another example can be found in Lys. I2, where Plutarch, after having mentioned that some people thought that Lysander's swift ending of the Peloponnesian war was the result of divine intervention ( $\theta$ हióv

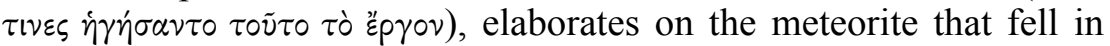
Aegospotami in $468-467 \mathrm{BC}$. Plutarch reports that this phenomenon was considered a divine portent in those days. He does not intend to reject this idea, but he gives a more physical motivation for it in the form of five explanations, including popular opinions, the theories of Anaxagoras and Daimachus, as well as his own criticisms and comments. The aetiology is relatively elaborate and occupies an entire paragraph. Importantly, Plutarch again abruptly concludes the aetiology with the remark that a more minute discussion of this subject belongs to 'another kind of writing'

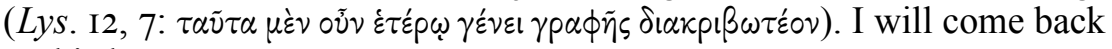
to this later.

The ending is even more abrupt in Aem. Paul. I4, where Plutarch illustrates Aemilius Paulus' superb leadership with a digression on drinking water. The story goes that Aemilius Paulus' troops were greatly overcome by thirst as there was no drinking water available. Aemilius Paulus saw green trees growing on the slopes of Mt. Olympus and inferred that drinking water must be present there. So he started digging at the foot of the mountain, yielding gallons of water for his soldiers to drink. As if intending to match Aemilius Paulus' practical ingenuity in these matters, albeit at a more theoretical level, Plutarch posits two theories in opposition to each other in order to explain where this drinking water exactly came from. The first theory is that water is generated when moist vapour and air under the earth are liquefied through compression and cooling. When the

\footnotetext{
“un dossier constitué autour de l' autorité de Théophraste et qu'il expose plus longuement dans les Propos de Table, où le nom du philosophe botaniste est cité, et il suggère d'induire que la Babylonie possède un sous-sol générateur de feu ( $\pi v p$ próvov)". See Theophr., HP 4 , 4, I (and $C P 2,3,3 ; 2,7,3$ ).
} 
soil is manipulated by digging, in response, the water flows more freely. The same counts, by analogy, for women's breasts: it is only when a baby starts sucking them that they produce milk by converting the nourishment within them (this implies that the breasts are not like vessels filled with milk). Plutarch objects, however, that those who support this doctrine give the sceptical philosophers occasion to argue (oi $\delta \dot{\varepsilon} \tau \alpha \tilde{\nu} \tau \alpha \lambda \dot{\varepsilon} \gamma \circ \nu \tau \varepsilon \zeta \varepsilon \dot{\varepsilon} \pi \mid \chi \varepsilon \varepsilon p \varepsilon \bar{\imath} \nu$

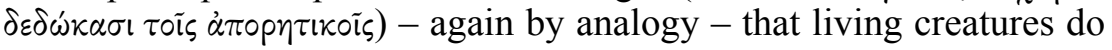
not have blood until the moment they are wounded, the blood then being generated through a transformation of some vapour or flesh, which causes its liquefaction. The alternative (and preferred) theory is that there are subterranean reservoirs and streams of water at hand, which under the weight and impulse of the pressure upon them (exerted by the mass of Mt. Olympus) discharge themselves into the vacuum afforded by the vents and wells. Plutarch closes the discussion rather inelegantly with the words

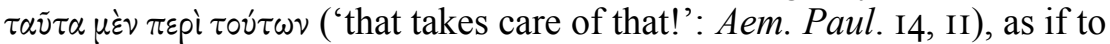
excuse himself for his somewhat schoolmasterly diligence ${ }^{37}$.

A last example is in Flam. Io, 6, where Plutarch reports that during the Isthmian games, a flock of ravens fell from the sky due to very loud cheers from the crowd. Indeed, the Greeks must have been extremely cheerful the moment that Titus Flamininus declared them to be free. In this passage, Plutarch clearly builds towards a narrative climax, yet at the same time it seems that he is trying to keep his authorial cool (this may, indeed, have specific political dimensions in view of the altered political situation in his own days). Plutarch slows down the narrative pace by the repetition of Flamininus' proclamation - at first, the Greeks could not believe their ears. This is reinforced by the incorporation of three explanations for the natural anomaly of ravens falling from the sky:

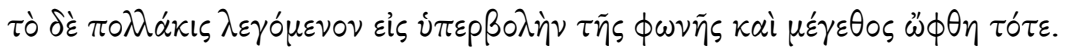

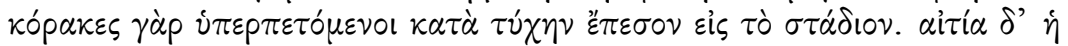

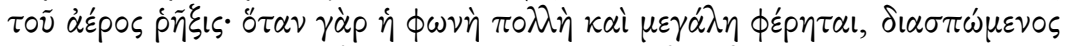

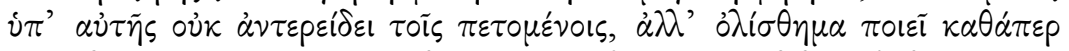

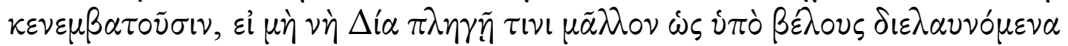

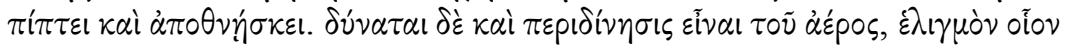

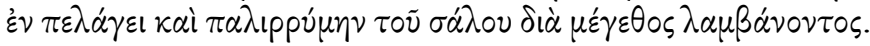

And that which is often said of the volume and power of the human voice was then apparent to the eye. For ravens which chanced to be flying overhead fell down into the stadium. The cause of this was (I) the rupture of the air; for when the voice is borne aloft loud and strong, the air is rent asunder by it and will not support flying creatures, but lets them fall, as if they were over a vacuum, unless, indeed, (2) they

${ }^{37}$ For further commentary on this digression, see C. Liedmeier, 1935, pp. I62-I67. 
are transfixed by a sort of blow, as of a weapon, and fall down dead. It is possible, too, (3) that in such cases there is a whirling motion of the air, which becomes like a waterspout at sea with a refluent flow of the surges caused by their very volume.

The same phenomenon is mentioned in Caes. 63, 2 among several other bad omens witnessed the night before the Ides of March. It also recurs in Pomp. 25, 6-7 in greater detail, in the context of the rogatio Gabinia in the Roman senate and the people's impatient cry at the forum. In the latter passage Plutarch lists the same explanations and uses the same terminology as in the Flamininus passage, but the first solution is explicitly rejected and the third is less clearly distinguished from the second:

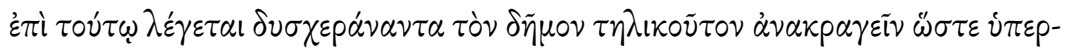

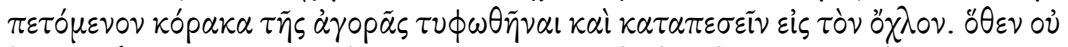

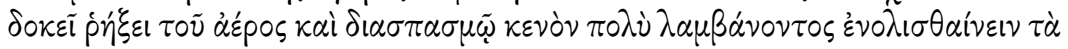

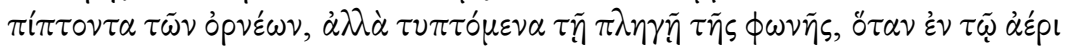

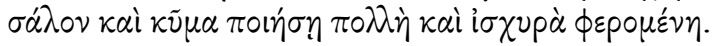

At this, we are told, the people were incensed and gave forth such a shout that a raven flying over the forum was stunned by it and fell down into the throng. From this it appears (I) that such falling of birds is not due to a rupture and division of the air wherein a great vacuum is produced, but (2) that they are struck by the blow of the voice, which raises a surge and billow in the air when it is borne aloft loud and strong.

What these passages show is that Plutarch speaks of the same natural phenomenon on several occasions and in different contexts, where it always plays a specific discursive role. In the case of falling ravens it underlines the key-importance and extra-ordinary character of specific historical events. Even if the aetiology is not simply copy-pasted in these parallel accounts, specific conceptual and verbal reminiscences can still be detected, so that we may presume a certain intermediation in composition.

Notably, Plutarch had several such fixed theoretical and terminological schemes in the back of his mind that he could easily apply to different natural phenomena. An allusion, for instance, to the $i \pi \varepsilon p \beta 0 \lambda \dot{\eta} \tau \tilde{\eta} s \phi \omega \nu \tilde{\eta} s \kappa \alpha i$ $\mu \varepsilon \dot{\gamma \varepsilon \theta}$ s at the beginning of the Flamininus passage (and more precisely the physical impact of sounds on bodies) is found in Quaest. conv. 72IEF, where Plutarch - in explaining a different problem, viz. why sounds carry better at night than during the daytime - defines sound as an impact on a sound-conducting body $(\dot{\eta} \delta \dot{\varepsilon} \phi \omega \nu \eta \grave{\eta} \pi \lambda \eta \gamma \dot{\eta} \sigma \omega \dot{\omega} \mu \tau \tau \varsigma)^{38}$. Similarly, the concept

${ }^{38}$ Cf. also De fortuna 98BC, De genio Socr. 588E, Pl., Tim. 67b and Arist., DA $420 \mathrm{~b} 29$. 
of impact $(\pi \lambda \eta \gamma \eta$ ), in combination with that of surge $(\sigma \dot{\alpha} \lambda \circ \nu)$, is once again introduced, for instance, in the first causa in Q.N. I2, 9I4F, where Plutarch - in examining how sprinkling oil on the surface of the sea clears and calms the waters - gives Aristotle's explanation, according to which the wind, by its slipping off the smoothness so caused by the oil, makes

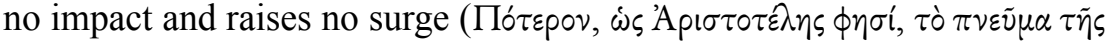

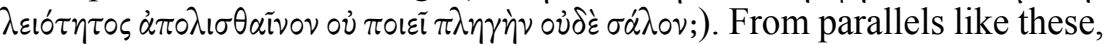
we learn that Plutarch's natural problems, as known from Quaestiones naturales, do not hold an isolated position in the corpus Plutarcheum but actually stand in close dialogue with Plutarch's other works, where physical aetiology is concerned. Remarkably enough, though, Plutarch never refers to Quaestiones naturales in his other works in a direct way, which may suggest that the collection does not hold a very central position $^{39}$. Even still, as the following section will show, several passages may qualify as indirect references.

\section{Indirect references to Quaestiones naturales}

Plutarch never directly refers to Quaestiones naturales throughout his writings, as he famously does to Quaestiones Romanae in Cam. 19, 8

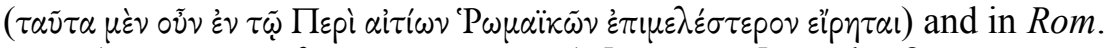

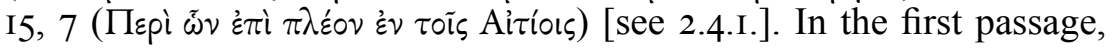
Plutarch deals with the dies Alliensis, a topic treated in Quaest. Rom. 25, $269 \mathrm{~F}$, while in the second passage, he explains three Roman customs that originated from the abduction of the Sabine women, viz. the exclamation of Talassio, the groom carrying the bride over the doorstep, and parting her hair with the head of a spear. These topics are treated in Quaest. Rom. 3I, 27IF-272B, 29, 27ID and 87, 285BC, respectively. Clearly, a precise reference to one or more specific problem chapters in Quaestiones Romanae was not necessary and probably not possible either, considering the lack of any systematic organisation in the collection.

Even if there are no such direct references to Quaestiones naturales, several passages may still qualify as indirect references. It is not unrea-

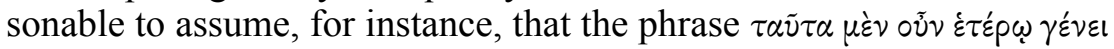

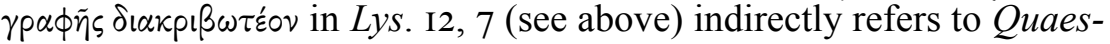
tiones naturales, or at least to this 'kind of writing' - that is, to the genre of natural problem literature. As we saw, with this phrase Plutarch admits that the present discussion (of the meteorite that fell in Aegospotami) may seem somewhat out of context in the biographical narrative at hand. It is unclear, however, whether he is implying that this matter should (- $\left.\tau \varepsilon^{\prime} \circ v\right)$ either literally or figuratively be treated elsewhere, making it unclear

39 See F.H. Sandbach, 1965, p. I33: “Quaestiones Naturales, however, are never cited by him". 
whether the reference is to an existing work or not. However, seeing as this reference is not to one specific text but to an entire $\gamma^{\varepsilon} v_{\nu} \circ \varsigma_{\gamma} \gamma a \phi \tilde{n} s$, this does not really seem to matter anyway. My point is that this $\gamma \dot{\varepsilon} v 0 s \gamma p a \phi \tilde{n} s$ would, indeed, comprise the basic characteristics of the genre of natural problems as known from Quaestiones naturales (that is, a formal disposition and enumeration of several plausible explanations for a specific natural problem, where the traditional doxography is critically evaluated). If one considers, moreover, that the problem of the meteorite should be

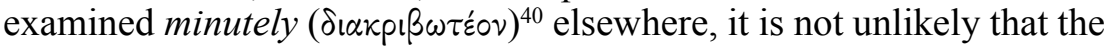
reference is in fact to Quaestiones naturales, where Plutarch's aim is to collect his knowledge on several natural problems in order to provide an aetiology that is as exhaustive as possible in each case [see 2.I.2.], but this remains uncertain. The specific problem of the meteorite in Lys. I2 cannot be retraced in our collection, but what is probably more important is that Quaestiones naturales would certainly have provided the right place for treating this problem. Due to its generality, though, the reference to 'another kind of writing' does not guarantee with absolute certainty that Plutarch is referring to Quaestiones naturales. It at least points out that the $\gamma \dot{\varepsilon}$ vos $\gamma p a \phi \tilde{n} s$ of Quaestiones naturales is worth referring to as a distinct genre of natural scientific writing.

Other indirect references to Quaestiones naturales may be found elsewhere, for instance, in De Is. et Os. $352 \mathrm{~F}$, in the context of, what seems to be, a Quaestio barbarica about Egyptian priests. The problem can be reconstructed as follows: 'Why do Egyptian priests remove their hair, and why do they wear linen garments?' ${ }^{41}$. Plutarch explains that flax, as opposed to wool, is pure, and he also mentions that it is least apt to breed lice. At the end of this passage, Plutarch refers to his treatment of

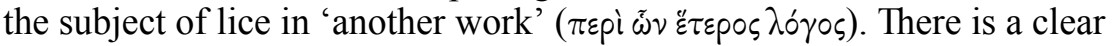
parallel in Quaest. conv. 642BC, where Plutarch deals with the problem of why sheep bitten by wolves tend to have sweeter flesh but wool that breeds lice. Clearly, this topic could just as easily have been dealt with in Quaestiones naturales. The same is true for Brut. 25, 6, where Plutarch

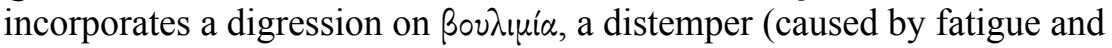
cold) from which Brutus suffered when he was near the city of Epidamnus. At the end of this digression Plutarch notes that the issue 'is discussed at

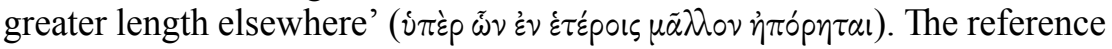
is to Quaest. conv. 693E-695E, but given Plutarch's reference to Aristotle there (cf. Ps.-Arist., Probl. 887b38-888a23) and the subsequent criticism of the Stagirite's account by the symposiasts, one can imagine that the

${ }^{40}$ Cf. J. Boulogne, 2008, p. 746: "il [sc. Plutarque] pense qu'il s' agit d' un sujet important, qui mérite un traitement complet".

${ }^{41}$ Cf. J. Boulogne, 2005b, pp. I97-I98. See T.S. Schmidt, 2008. 
reference could just as well have been to our collection - or at least, again, to this 'kind of writing'.

Importantly, regarding the latter parallel and in light of the 'crossfertilisation' between the Vitae and Quaestiones convivales more generally, Pelling is right that "we can rarely be sure that this "Table Talkmaterial' in the Lives is really informed by researches done 'for' the Table Talk, rather than drawn from material Plutarch had known for years"42. The issue is, indeed, intriguing, but as the problem about the Egyptian priests demonstrates it is not only relevant in light of the 'cross-fertilisation' between Quaestiones convivales and the Vitae but also the Moralia. One may wonder whether the whole of Quaestiones naturales (and Plutarch's other collection of quaestiones just as well) would perhaps count as "researches done 'for' the Quaestiones convivales", or if it is part of the "material Plutarch had known for years" (which I take to refer to his personal notes, his i $\pi \circ \mu \nu \eta \dot{\mu} \mu \tau \alpha)$. These two options are not necessarily incommensurable, if we may assume that the collection of Quaestiones naturales is itself a set of $i \pi \circ \mu \nu \eta \dot{\mu} \alpha \tau \alpha$ drafted for the composition of Quaestiones convivales. The belief that Quaestiones naturales (and Plutarch's other collections of quaestiones just as well) were, indeed, composed as rough drafts was commonly accepted by traditional scholarship, but in what follows I will try to demonstrate that this assumption is untenable by showing that there is still an alternative explanation for the mutual correspondences with Quaestiones convivales.

In order to shed more light on the close relationship between the natural problems discussed in Quaestiones naturales and in Quaestiones convivales, then, the following section will provide a detailed comparison of the two works. On the basis of this comparison I will argue that the composition of these works must have been closely related. This, in turn, will provide further information for our study of the actual position of Quaestiones naturales in the corpus Plutarcheum.

\subsection{A comparative study of Quaestiones naturales and Quaestiones convivales}

Scholars have often argued, and rightly so, that the composition of the natural problems collected in Quaestiones naturales and in Quaestiones convivales must have been closely interrelated ${ }^{43}$. As I will try to demon-

${ }^{42}$ C. Pelling, 20II, p. 222. Regarding 'cross-fertilisation' as a central feature of Plutarch's method of composition in the Roman Vitae, see also C. Pelling, 1979, pp. 82-83.

${ }^{43}$ Cf. F. Klotz and K. Oikonomopoulou, 20II, p. 20. This is true perhaps also from a chronological perspective, see F.H. Sandbach, 1965, p. 138 [see the prologue]. Pace I. Gallo, I998, p. 3527: "il confronto [sc. of Quaestiones naturales] con le 'quaestiones convivales', dove pure sono trattati problemi di vario genere, è solo apparente, perché diversa è la forma e l'elaborazione letteraria, quasi del tutto assente in questo [...]." 
strate here, both of these works are, indeed, tightly interwoven in several regards, even if there are also important divergences between the two. Regarding the style, organisation and content of the natural problems in Quaestiones naturales compared to those in Quaestiones convivales, Ziegler observes that:

"Die Problemen [sc. in Quaestiones naturales] sind ganz in der Art derer, die in den Symposiaka zwischen P. und seinen Tischgenossen diskutiert werden, hier aber nicht literarisch-dialogisch ausgestaltet, sondern in der einfachen Kollektaneenform zusammengestellt"44.

The three categories that Ziegler implicitly distinguishes in this short comparison are related to aspects of elocutio ("literarisch-dialogisch ausgestaltet"), dispositio ("in der einfachen Kollektaneenform zusammengestellt"), and inventio ("[die] Art [der Problemen]"). These are the three categories that I will also use in providing a more detailed comparison in the sections below ${ }^{45}$.

As noted, some scholars have argued that we are dealing in Quaestiones naturales (and in Plutarch's other sets of quaestiones) with collections of personal notes, which Plutarch produced as the inferior textual substratum for composing his other writings (c.q. Quaestiones convivales). I will try to demonstrate that such a hypothesis not only tends to downplay the zetetic autonomy of Plutarch's collections of quaestiones, but also neglects the fact that these collections do not necessarily have the same didactic purpose as Quaestiones convivales. My first objection will be discussed further on in this chapter [see 2.3.3.], the second, in the following [see 3.I.4.]. Let us first consider where the $i \pi \circ \mu \nu \eta \dot{\mu} \alpha \tau \alpha$ hypothesis precisely originates, so that the subsequent elaboration of my alternative theory, vindicating the independent status of Quaestiones naturales, gains in credibility.

\section{The level of elocutio}

From its early beginnings on, the symposium aimed at promoting social, political and cultural unity and interaction between (male) members of elite communities. Its main goal was to engender and strengthen the coherence of these communities, by means of both serious and more frivolous

${ }^{44}$ K. Ziegler, I95I, col. 857.

45 I borrow these concepts (elocutio, dispositio, inventio) from the classical hermeneutical scheme set out by W. Babilas, I96I [see the prologue, n. 82]. These categories are often closely interrelated to each other, so that they will not be analysed in strict separation from each other. Furthermore, some topics that will be dealt with here have already been examined earlier or will be later in further detail. 
activities, ranging from discussing politics to deliberating over the wine, enjoying artistic performances, jointly singing skolia, solving riddles, etc. As a late representative of the literary genre of the symposium (the

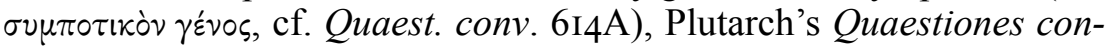
vivales serves as a lively source for much of our knowledge about how such symposia were organised in elite milieus in the early Greco-Roman Empire and what was their binding function, in both social and intellectual terms.

With the Symposia of Xenophon and Plato the age-old sympotic institution poached on the preserves of the literary-philosophical tradition. Plutarch is proud to signal that he modelled his own Quaestiones convivales after these and related philosophical texts (cf. Quaest. conv. 6I2DE, 686D: see n. 80). This, of course, plays a determining role for the eventual outlook of Plutarch's own sympotic discussions and for their philosophical purpose. At the same time, the influence of Alexandrian scholarship is undeniable in Plutarch's Quaestiones convivales. There is proof that from the Hellenistic period on, the genre of the symposium was specifically associated with aetiological research. Some fragments that remain from Callimachus' Ai $\tau \iota \alpha$ are presumably set against a sympotic background ${ }^{46}$. The same scholarly approach lies at the basis of many, if not most, of the sympotic discussions recorded in Quaestiones convivales. The work as a whole can, thus, be seen as the product of a literary experiment, in which the Chaeronean tries to crossbreed the genre of problems with that of the dramatised, philosophical symposium. Therefore, Plutarch's ambition with this work was not only of a scholarly but also, and more primarily, of a philosophical kind.

The reader finds in Quaestiones convivales a fully-fledged work of literature, where Plutarch describes the lively discussions held at the table in his company. It is generally accepted that Plutarch in this work intended to elevate the somewhat profane genre of problems to a higher literary level by fusing it with that of the symposium (or, vice versa, to implant the problem format on the symposium genre). The lively mise-en-scène of the discussions aims to intensify the sense of dramatic and literary realism in the work. From a literary perspective, it is clear that Plutarch evokes a highly rhetorical discourse that echoes (and probably idealises [see 2.3.I.]) the real-life table discussions he held with his fellow symposiasts. The characters that Plutarch puts on stage - thus including his own literary alter ego - are mostly well-read and eloquent $\pi \varepsilon \pi \alpha \iota \delta \varepsilon \nu \mu \varepsilon v_{\nu}$, eager to deliver

46 See frs. 43, I2-I7 and I78 with A. Harder, 20I2, p. 35 (in vol. I) and pp. 30I-302 and 955 (in vol. 2). See also A. Cameron, 1995, pp. 7I-I03. The pinnacle of this scholarlysympotic tradition is reached in Athenaeus' Deipnosophistae. 
on the spot deliberations on puzzling topics and capable of reproducing countless quotations by heart (from the poets, historians, philosophers etc.).

As we saw in the previous chapter, the general style of Quaestiones naturales, by contrast, remains at a rather sub-literary level [I.2.3.]. But even if the questions and answers are not dramatised so as to represent lively discussions, they still share the same learned and scholarly appeal of Quaestiones convivales ${ }^{47}$. Fuhrmann is exaggerating, then, when he writes:

"Il faut signaler ici [sc. regarding Quaestiones convivales], en outre, l' extraordinaire foisonnement des citations, des récits, fables, apophtegmes, proverbes et images, qui fournissaient à eux seuls à Plutarque un moyen facile de dépasser à coup sûr la forme rudimentaire des Questions Naturelles, Romaines, Grecques, et la froideur stéréotypée des recueils de cette espèce." 48

In fact, Plutarch does incorporate several citations, myths, stories, proverbs, and images in Quaestiones naturales, even if they appear in a more condensed form and are less numerous ${ }^{49}$. What is also important is the fact that these elements eventually serve the same discursive purpose as those recorded in Quaestiones convivales. They primarily contribute to a proper development of the problems and arguments themselves, so that their use in literary embellishment is only of secondary importance [see I.2.3.].

To come back to Fuhrmann's account, and more precisely to what he adds directly after the passage just quoted, he is absolutely right that the

47 Moreover, as scholars have effectively shown, at least a certain degree of elaboration went into the composition of Quaestiones naturales (see further). See G.W.M. Harrison, 200ob, esp. pp. 247-249 and L. Senzasono, 2006, p. IO: "è inesatto parlare di "forma rudimentale",".

48 F. Fuhrmann, I972, p. xix, n. 2.

49 I have already dealt with the presence of literary images in Quaestions naturales [see I.2.3.], and I will deal with the incorporation of myths and citations from both poets and prose authors later [see 4.I.2.2.-3. and 4.2.I.I. respectively]. There are also two proverbs (viz. in Q.N. I6, 9I5E and 2I, 9I7B). In Q.N. I0, 9I4D, Plutarch refers to a story about the people of Halieis, who received an oracle ordering them to dip Dionysus in the sea. Regarding the style of Plutarch's "books of problemata on antiquarian and scientific subjects, and the more technical philosophical treatises", see D.A. Russell, I973, p. 34, who correctly observes that "[i]n all these, there is less scope for brilliant play of exempla or quotations: [but] the richness and the metaphorical style remain pervasive". Russell concludes that "Plutarch [...] has l'âme de la naïvité; but in style, he has a sophistication and cunning which make interpretation a continuously exacting task'. On Plutarch's method of citing in Quaestiones convivales, see J. König, 20I0, esp. pp. 339-345 - we will later see that a similar method is applied in Quaestiones naturales [see 4.2.I.I.]. 
level of dramatic liveliness is not the same for each and every sympotic discussion in Quaestiones convivales (but that this is no reason to doubt the unity of the work altogether $)^{50}$. It is not unimaginable, in this regard, that if Quaestiones convivales were stripped from its dramatic context, it would have the same 'matter-of-fact' style as Quaestiones naturales. Yet, it is not, therefore, a given fact that Quaestiones naturales was still awaiting a final veneer of literary polish, viz. by pouring it into the literary mould of the symposium ${ }^{51}$. In any case, the scientific parts are obviously not incorporated in an artless fashion in Quaestiones convivales, as if they are simply patched on the sympotic framework ${ }^{52}$. Therefore, it would be incorrect to speak of a genuine caesura between the more dramatic and the more aetiological types of discourse in Quaestiones convivales.

A nice way to illustrate this is by comparing the final explanation provided in Q.N. 3, 9I2EF with its parallel in Quaest. conv. 685DE: both passages concern the aphrodisiac properties of salt. In Q.N. 3, Plutarch examines why herdsmen put salt down for their cattle. He provides three explanations, arguing successively I) that salt produces a bulk of food and fattens the cattle, 2) that it makes the cattle healthy and reduces their bulk, and 3) that it has generative and aphrodisiac properties. The formulation of the last causa is as clear as it is concise:

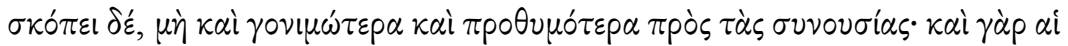

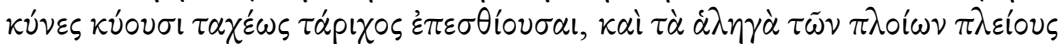

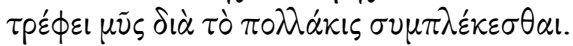

Consider, however, whether animals do not become more fertile and readier towards coition. Certainly, bitches conceive quickly when they eat salted meat after mating, and ships transporting salt harbour a larger number of mice, because they frequently copulate.

In Quaest. conv. 685DF, the same argument recurs at greater length, where it is attributed to Philinus, but the context is different. The problem at

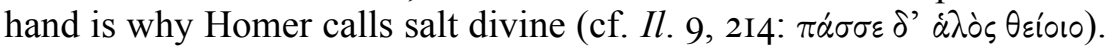
The argument again closes off the discussion. Several new elements are added by Philinus, but the basic idea remains the same. Most notably, the account about bitches and mice recurs, albeit in a less abridged form.

50 F. Fuhrmann, I972, p. xix.

51 For this theory, see K. Ziegler, I95I, col. 857, F.H. Sandbach, I965, p. I35 (but more hesitative on p. I38), F. Fuhrmann, I972, p. xiii, S.-T. Teodorsson, 2009, pp. I4-I5.

52 Cf. the so-called $\Sigma \tau \rho \omega \mu \alpha \tau \varepsilon i \varsigma_{\varsigma}$ (Patchwork), a doxographical miscellany attributed to Plutarch by Eus., PE I, 7, I6 (= fr. I79 Sandbach; Lamprias catalogue nr. 62). Cf. also, e.g., Gell., NA Praef. 7. For the athetesis of this "puerile compilation", see F.H. Sandbach, I969, pp. 324-327. 
Philinus specifies regarding the popular belief that female mice become pregnant simply by licking salt that it is more likely that the saltiness serves as a kind of aphrodisiac (this is, indeed, closer to what Plutarch writes in Q.N. 3, 9I2EF).

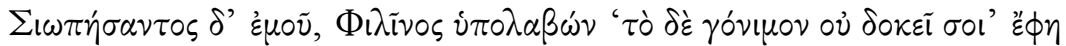

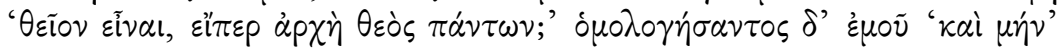

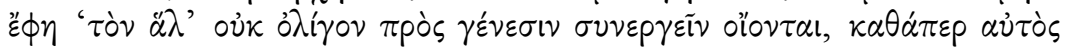

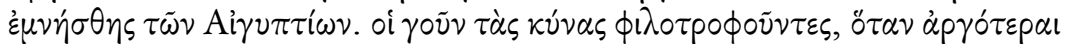

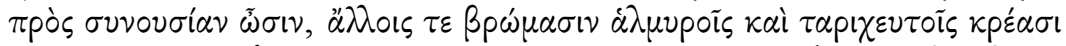

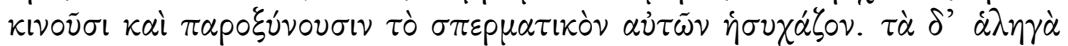

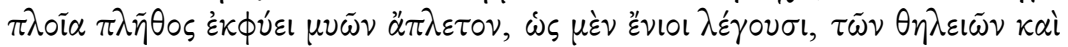

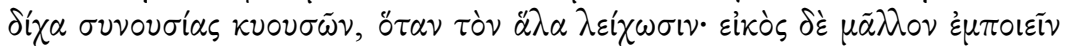

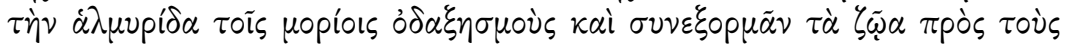

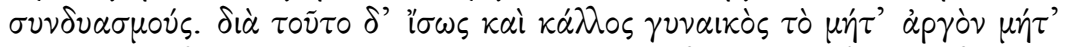

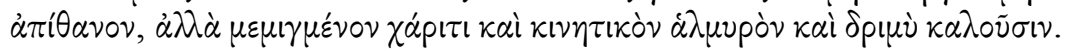

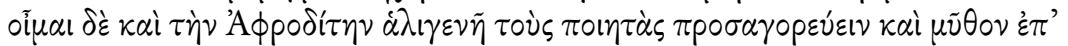

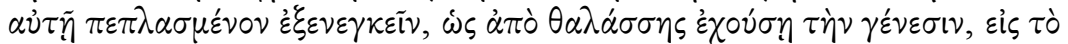

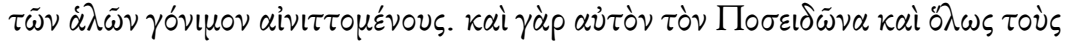

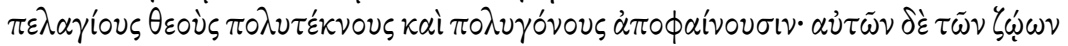

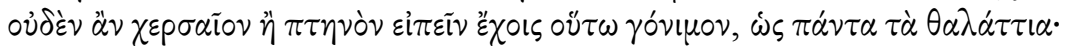

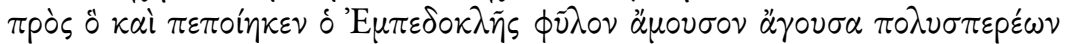

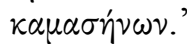

When I (sc. Plutarch) stopped speaking, Philinus took up the thread: "Don't you think that generation is divine, since the beginning of anything is always a god?" I said yes, and he went on: "Well, people hold that salt contributes not a little to generation, even as you yourself have said in talking about the Egyptians. Dog-fanciers, at any rate, whenever their dogs are sluggish towards copulation stimulate and intensify the seminal power dormant in the animals by feeding them salty meat and other briny food. Ships carrying salt breed an infinite number of mice, because, according to some authorities, the females conceive without coition by licking the salt. But it is more likely that the saltiness imparts a sting to the sexual members and serves to stimulate copulation. For this reason, perhaps, womanly beauty is called 'salty' and 'piquant' when it is not passive nor unyielding, but has charm and provocativeness. I imagine that the poets called Aphrodite "born out of the brine" and have spread the myth of her origin in the sea by way of alluding to the generative property of salt. For they also represent Poseidon himself and the sea gods in general as fertile and prolific. Even among the animals you cannot find one species of land or air that is so proliferous as are all the creatures of the sea. This is the point of Empedocles's line: Leading the mute tribe of fruitful fish (DK3IB74)." 
If we compare the two accounts, we see that a great deal of dramatic and rhetorical detail goes into the scientific argument in Quaest. conv. 685 EF. Indeed, Plutarch does not incorporate any poetical quotations in Q.N. 3, 9I2EF. However, the poetical material from Quaest. conv. $685 \mathrm{EF}$ has the same basic purpose as it would have in Quaestiones naturales. It is not merely incorporated to embellish the discourse, but to serve as an illustration of the main argument itself (viz. that salt has a generative, and therefore divine, property). The divine character of salt is central to the debate in Quaest. conv. $684 \mathrm{E}-685 \mathrm{~F}$ as a whole, but this really comes to a climax in Philinus' final explanation, where the divine

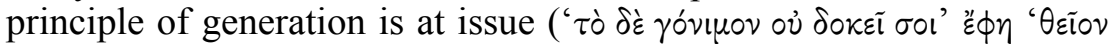

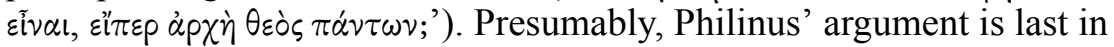
the aetiology, so as to provide some kind of theological closure to the physical aetiology. This aspect of theological closure is strengthened by the incorporation of mythological material (about Aphrodite, Poseidon and other sea gods) at the very end of the argument ( $\mu \tilde{v} \theta 0 \nu \dot{\varepsilon} \pi^{\prime} \alpha \dot{v} \tau \tilde{\eta} \pi \varepsilon \pi \lambda \alpha \sigma \mu \varepsilon^{\prime} v \circ \nu$ $\dot{\varepsilon} \xi \varepsilon v \varepsilon \gamma \kappa \varepsilon i v)$. In addition to the allegorical value of these myths - understood as riddled allusions to the generative property of salt ( $\varepsilon \grave{\zeta} \tau \tau \dot{\partial} \tau \tilde{\omega} \nu \dot{\alpha} \lambda \tilde{\omega} \nu$

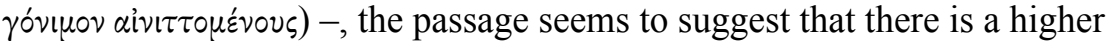
dimension of philosophical truth that lies beyond the purely physical realm.

By contrast, in Q.N. 3, 912EF, Plutarch makes no allusion to the

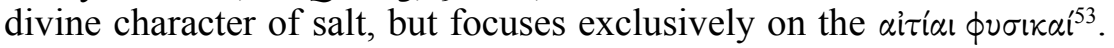
The introductory $\sigma$ кó $\pi \varepsilon 1$ $\delta \varepsilon$ does, however, draw specific attention to this explanation. Perhaps, Philinus' more elaborate account in Quaest. conv. 685 EF may explain why this is the case, as it draws a link with divine generation. The absence of mythological references here in Q.N. 3 does not imply, moreover, that Plutarch refrains from incorporating such material altogether in Quaestiones naturales, let alone that these myths do not provide a similar feature of closure to the physical aetiologies. In fact, these accounts are often placed at the very end of the aetiology in both Quaestiones naturales and Quaestiones convivales (as we will see later on [see 4.I.2.]). This is not only relevant for the issue of elocutio but also of dispositio.

\section{The level of dispositio}

The most basic ordering principle in Quaestiones convivales is the wellknown organisation of the content into nine Books, each containing ten problem chapters each, with the deliberate exception of the last Book, which contains fifteen (see n. II 8$)^{54}$. With this considered limitation of

53 The same observation was made by L. Van der Stockt, 20II, pp. 453-454.

${ }^{54}$ For the explicit formulation of this decimal system, see Quaest. conv. 612E, 629E, 660D, 697E, 736C. See G.W.M. Harrison, 2000a, p. 197, n. 21. 
the content matter, Plutarch makes it absolutely clear that the work was not intended as an indefinite and boundless literary $\ddot{\alpha} \pi \varepsilon i p o \nu$. No such restrictions, though, are made for Plutarch's other collections of quaestiones ${ }^{55}$, which highlights the open-ended character of the research projects at issue therein ${ }^{56}$.

Regarding the macrostructural arrangement of Plutarch's collections of quaestiones in general and of Quaestiones convivales more specifically, I have argued earlier that the often chaotic and unpredictable surface of these texts can be explained from the perspective of variatio (as a basic feature of ancient miscellaneous literature more generally), while the at times close interconnection of the problem chapters and the recurrent themes and theories therein are the result of the principle of concatenatio [see I.I.5. ${ }^{57}$. Indeed, the grouping together of different problems during one sympotic event is a relatively common feature in Quaestiones convivales, and the same structuring principle clearly recurs in Plutarch's other collections of quaestiones, especially in Quaestiones naturales (see the introduction to the commentary for a schematic overview). As to the internal arrangement of the problem chapters themselves, moreover, we see that the symposiasts in Quaestiones convivales put forth a variety of arguments and explanations to solve the problems, while the debate as a whole is guided by the principle of increasing plausibility ( $\tau \dot{\partial} \pi \bullet \theta \alpha$ ó $v$ ). Each symposiast personifies a specific position in the debate, leading to a combination of contending arguments. This organisation of the explanations is reminiscent of the development of the aetiologies in Quaestiones naturales and in Plutarch's other collections of quaestiones just as well.

In order to illustrate this, let us again turn to Quaest. conv. $684 \mathrm{E}-$ $685 \mathrm{~F}$ : two interconnected problems are treated there during one and the

55 According to J. Opsomer, I994a, p. I2, the collection of ten Quaestiones Platonicae may have been modelled on the same decimal system as found in Quaestiones convivales. Cf. also S.-T. Teodorsson, I989, p. 38.

56 This has led K. Oikonomopoulou, 20I3a, p. I52 to conclude that quaestiones literature is, in fact, an integral part of the history and legacy of ancient encyclopaedic writing: "The quaestiones [...] are not collections of Plutarch's notes, but self-consciously fashion themselves as texts-in-progress for reasons in fact intrinsic to the kind of encyclopaedic function they envisage for themselves." She argues that there is "an underlying desire for encyclopaedic completeness, whose fulfilment can only be guaranteed through the continuation of research, perhaps ad infinitum" (p. I50). See also esp. pp. I52-I53 for Oikonomopoulou's nuancing of the concept of 'encyclopaedism' in the context of quaestiones literature.

57 On the aspect of structural order and disorder in Quaestiones convivales, see the introduction in F. Klotz and K. Oikonomopoulou, 20II, pp. 24-27. J. König, 2008, p. 97 describes "the symposium as an institution for sanctioned flirtation with disorder". 
same sympotic event, viz. what is meant with the proverbial salt and bean friends and, connected with it, why Homer calls salt divine. Several of the explanations provided throughout the discussion recur in Quaestiones naturales, albeit in different forms and in different places. Florus is the

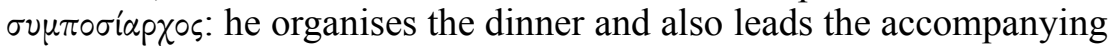
discussion. He proposes the first problem and his interference and guidance recurs throughout the discussion as a structuring feature ${ }^{58}$. The only answer to the first problem is brought up by the scholar Apollophanes, who provides the obvious explanation ( $\dot{\varepsilon} \kappa \pi p \circ \chi \varepsilon \dot{p}$ ov $\delta i \varepsilon \lambda \nu \sigma \varepsilon v$ ) that the proverb of salt and bean friends - refers to friends who are on very close terms, because they are prepared to have meals together. The symposiasts then raise the second problem ( $\delta$ in $\pi \circ p \circ \tilde{\nu} \mu \varepsilon v)$, which is closely connected to the preceding one via the topic of salt, by asking, more precisely, why it is considered divine. After an intermediate account which attests to the divine character of salt in the literature (viz. in Homer and Plato), and on the remarkable abstinence of Egyptian priests from salt, Florus urges his companions to leave the Egyptians out of the question and find a properly Greek explanation. The Egyptians do, indeed, complicate the problem ( $\left.\dot{\varepsilon} \pi \dot{\varepsilon} \tau \varepsilon I v \varepsilon \delta \dot{\varepsilon} \tau \dot{\eta} \nu \dot{\alpha} \pi \circ \rho^{\prime} \alpha \nu\right)$, since if salt is divine, why then do Egyptian priests abstain from it on religious grounds? This kind of complication may not be appropriate in light of sympotic decorum, which demands that topics of discussion not become too complex [see 3.I.4.]. Plutarch (by means of his own character in the discussion) objects, however, that the Egyptians

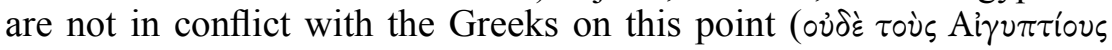
$\left.\mu \alpha^{\prime} \chi \varepsilon \sigma \theta \alpha \iota \tau \sigma \varsigma^{\prime \prime} \mathrm{E} \lambda \eta \sigma \nu\right)^{59}$. He explains that Egyptian priests abstain from salt either for reasons of purity (because it has aphrodisiac properties owing to its heat - a point Philinus will elaborate upon later), or because it is delicious as a seasoning (making needful food enjoyable - this point is introduced with eikòs $\delta \dot{\varepsilon}$ k $\alpha i$ ). Florus then asks whether this is the reason why salt is considered divine. Plutarch affirms this and explains that salt is a basic need like water, daylight, the seasons and the earth (which is even generally considered to be a goddess) and that it is very useful for adapting food to our body and appetite (this point is paralleled in the first causa in Q.N. 3, 9I2DE). He also draws specific attention ( $\sigma \kappa o ́ \pi \varepsilon l$ $\mu \eta$ ) to the fact that salt preserves bodies from decay (much like the soul preserves life in our body), as does the fire of lightning (these theories can be found also in Q.N. I, 9IID, IO, 9I4DE, 40 and Quaest. conv. 665C $)^{60}$.

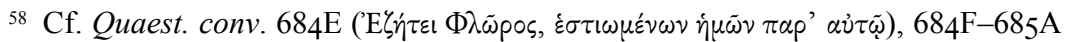

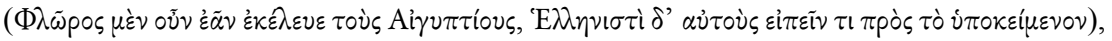

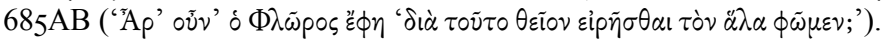

59 For a separate study of Egyptian accounts in Quaestiones convivales, see M. Meeusen, forthcoming d.

${ }^{60}$ The imperative $\sigma$ кó $\pi \varepsilon \iota$ ú may suggest that we are dealing here with Plutarch's 


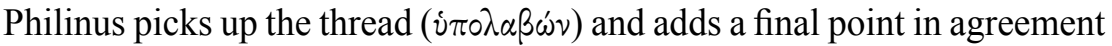
with Plutarch's previous position, by arguing that it seems likely ( that generation is divine and that salt has a generative property (see above).

What this example nicely illustrates, then, is how two problems spontaneously cluster together in one and the same sympotic context. The principle of concatenatio is expressed by the prefix in $\delta i \eta \pi \circ p \circ \tilde{v} \mu \varepsilon \nu$, which is a stronger form of $\dot{\alpha} \pi \circ \rho^{\varepsilon} \omega$ and implies a notion of continuity, as it connects the second to the first problem ${ }^{61}$. The principle of probability, which functions as the main ordering principle in the development of the

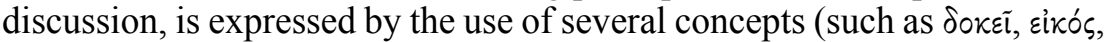
" $\sigma \omega \varsigma$, oi $\alpha_{\alpha \iota}$ etc.). Plutarch also recycles the same and similar material that he incorporates in Quaestiones naturales, albeit in a re-ordered fashion and in a new context. By the fact that these theories transgress the inter-textual boundaries of both collections, they testify to the adaptable and versatile nature of such scientific knowledge, as being applicable to very different problem contexts. This, in turn, is also relevant for the inventio of the scientific material in Plutarch's natural problems.

\section{The level of inventio}

The practice of solving natural problems allows for the efficient reuse, reordering and reinventing of numerous more or less fixed aetiological schemes in a multitude of always new problem contexts. When compared to the natural problems discussed in Quaestiones convivales, those collected in Quaestiones naturales would also make suitable topics for discussion during symposia. Even though the connection with a sympotic framework remains implicit at all times, most of the questions that Plutarch raises therein can be generally related to the thematic category of sympotic appetite (as is especially the case with the problems on wine) ${ }^{62}$ and hence to more general sympotic themes. Oikonomopoulou makes the following conclusion in this regard:

personal theories [see I.I.4., n. IIO], but, then again, in Quaest. conv. $665 \mathrm{C}$ it is the rhetor Dorotheus who refers to the theory about lightning leaving corpses undecayed. As to Plutarch's source, see S.-T. Teodorsson, I990a, p. 23I: "Presumably the connection was first made in a Peripatetic work." Perhaps a Stoic tradition is not unlikely either, considering Plutarch's reference to the Stoic belief that the sow is dead flesh at birth but that the soul is implanted in it later, like salt, in order to preserve it (SVF I, p. II6, fr. 5I6; 2, p. 206, frs. $722-723$ and p. 333, II54).

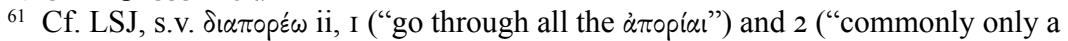
stronger form of $\dot{\alpha} \pi \circ \rho^{\prime} \omega$, raise an $\dot{\alpha} \pi \circ p^{\prime} \alpha$, start a difficulty").

${ }_{62}$ Cf. Q.N. I0, 27, 30-3I Quaest. conv. I, 6-7; 3, 3, 5, 7-9; 5, 3-4; 6, 7; 7, 3, 9-Iо.

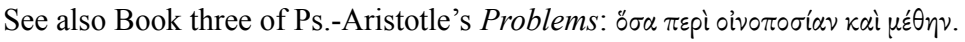


"Inspired by the physical reality of consumption at the symposium, they [i.e. the problems collected in Quaestiones naturales] prompted the exploration of topics such as the origin, nutritional benefits, and cultural value of sympotic staples such as wine, bread, water, fish, meat and vegetables (which could then ramify into the investigation of broader natural phenomena). They were also the result of curiosity about the material dimension of objects used at the symposium, or seen in religious locations such as Delphi: vessels, musical instruments, statues or sculptures." ${ }^{63}$

The relation with sympotic reality is, of course, much more palpable in the problems collected in Quaestiones convivales, where the discussions often directly arise from the circumstantial setting of the symposium (e.g., recent festivals, served meals or beverages, the place of the guests at the table, proper table talk itself etc.). As such, the wide variety of themes and subjects in this work is directly related to the miscellaneous organisation of the symposium itself ${ }^{64}$ [see I.I.5.].

Natural problems prove to be a popular topic of conversation in Plutarch's intellectual milieu. In fact, some of Plutarch's fellow symposiasts were well acquainted with the Ps.-Aristotelian Problems. In Quaest. conv. $734 \mathrm{CD}$, most notably, Plutarch writes that a copy of the work was brought to Thermopylae, where Florus discussed it with his friends [quoted 3.2.I.]. The total amount of chapters in Quaestiones convivales that deal with natural scientific topics after the manner of Quaestiones naturales

${ }^{63}$ K. Oikonomopoulou, 20I3a, pp. I46-I47.

${ }^{64}$ Notably, in Quaest. conv. 629D, Plutarch makes a basic distinction between two types of problems: viz. $\sigma \nu \mu \pi \circ \tau \iota \kappa \dot{\alpha}$ and $\sigma \nu \mu \pi \circ \sigma \iota \alpha \kappa \dot{\alpha}$. The category of $\sigma \nu \mu \pi \circ \tau \iota \kappa \dot{\alpha}$ covers problems concerning the symposium, whereas $\sigma \nu \mu \pi \circ \sigma \alpha \alpha \alpha \dot{\alpha}$ are problems generally treated at the symposium. The first category is a subcategory of the latter, because it consists of meta-symposiac debates about the proper course and pragmatics of a symposium, which were also discussed at the symposium, such as whether philosophy is a fitting topic for conversation at a drinking party (Quaest. conv. 612E), or whether the host should arrange the placing of his guests or leave it to the guests themselves (Quaest. conv. 615C). Plutarch notes that both categories can be discussed at the symposium and can, therefore, be considered $\sigma v \mu \pi \circ \sigma \alpha \alpha \alpha \dot{\alpha}$ (Quaest. conv. 629D). This probably explains the

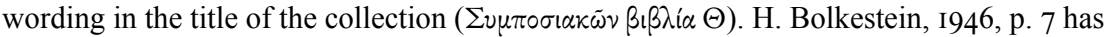
shown, however, that Plutarch is not always very conscientious in following the distinction between $\sigma v \mu \pi \circ \tau \iota k \alpha ́$ and $\sigma \nu \mu \pi \circ \sigma \iota \alpha \alpha \dot{~(c f ., ~ e . g ., ~ Q u a e s t . ~ c o n v . ~} 645 \mathrm{C}, 660 \mathrm{D}$ vs. $686 \mathrm{E}, 7 \mathrm{I} 7 \mathrm{~A}$, $736 \mathrm{C}$ ). He adds that the distinction may be of Stoic origin, because these philosophers were very fond of grammatical issues and specifically of making subtle terminological distinctions. The Stoic Persaeus of Citium may have been the first to draw this distinction

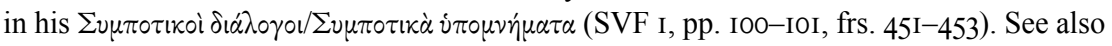
F. Fuhrmann, 1972, p. xv, with n. 3 and J. König, 2007, p. 6I. 
covers approximately one third of the entire work $^{65}$ : the reader comes across problems that are related to ancient medicine ${ }^{66}$, human physiology ${ }^{67}$ (including sensations and affections) ${ }^{68}$, zoology ${ }^{69}$, botany ${ }^{70}$, meteorology ${ }^{71}$ etc. ${ }^{72}$ By the fact that these natural problems are not concerned with highly complex issues in the field of natural philosophy, but, rather, deal with very concrete, 'everyday' phenomena ${ }^{73}$, they bear a marked similarity in manner and style to the Ps.-Aristotelian Problems. The solutions that are provided have no direct practical use, but only serve the satisfaction of intellectual curiosity, which in itself, as we will see later on, has specific philosophical relevance for Plutarch ${ }^{74}$ [see 4.I.I.].

\subsection{Hypomnematic text genetics of Quaestiones naturales and Quaestiones convivales}

From our previous comparison of the natural problems treated in Quaestiones naturales and Quaestiones convivales, we can safely conclude that there must be some text genetic tie between both collections, which deserves further study here. A study of the genesis of Quaestiones convivales in relation to that of Quaestiones naturales should clarify their relative compositional lineage. An initial problem that should be settled in this regard is the vexata quaestio of the historicity in the sympotic discussions recorded there, a controversial issue that still causes debate today ${ }^{75}$.

${ }^{65}$ Cf. R. Flacelière, J. Irigoin, J. Sirinelli and A. Philippon, I987, p. lxxxii and F.H. Sandbach, 1965, p. I38.

${ }^{66}$ Cf., e.g., Q.N. $26 \sim$ Quaest. conv. 6, 8; 8, 9.

${ }^{67}$ Cf., e.g., Q.N. 6, $36 \sim$ Quaest. conv. 2, 2; 3, 6; 4, I, Iо; 6, 8; 7, I; 8, Іо; 9, II.

${ }^{68}$ Cf., e.g., Q.N. 8, 9, II, 20, 22, $29 \sim$ Quaest. conv. I, 8; 3, 3-4, 8; 5, 7; 6, I-3.

${ }^{69}$ Cf., e.g., Q.N. 3, I7-22, 26, 28, 35-38 Quaest. conv. 2, 3, 7-9; 4, 4; 8, 8.

${ }^{70}$ Cf., e.g., Q.N. I, 2, 4-6, I4-I6, 30-32, 4I Quaest. conv. 2, 6; 3, I-2; 4, 2, I0; 5, 3, 8,$9 ; 6$, I0; 7,$2 ; 8,4$.

${ }^{71}$ Cf., e.g., Q.N. 2, 4, 7, I3, I8, 23-25, 34, $40 \sim$ Quaest. conv. 3, I0; 4, 2.

${ }_{72}$ For a similar categorisation, see R. Lopes, 2009, p. $4 \mathrm{I} 9$.

73 See K. Oikonomopoulou, 20I3a, p. I46: "the $Q N$ 's investigations do not emanate from a scientist's ivory tower, but are anchored in the economic and cultural parameters of practical life: agriculture, animal husbandry, hunting, fishing, sea-faring, swimming, feasting and drinking."

${ }^{74}$ See M. Meeusen, 20I4. Similarly, for the aspect of intellectual curiosity in the Supplementa problematorum ascribed to Aristotle and Alexander of Aphrodisias, cf. S. Kapetanaki and R.W. Sharples, 2006, p. I.

${ }^{75}$ For recent debate about the historicity of Quaestiones convivales, see esp. F. Titchener, 2009 (also 20II), G. Roskam, 20I0, pp. 46-47 (with nn. 8 and 9 for further reading) and the introduction in F. Klotz and K. Oikonomopoulou, 20II, pp. 3-7. 


\section{Historicity and fiction in Quaestiones convivales}

In the preface to the first Book of Quaestiones convivales, Plutarch addresses the dedicatee, Sossius Senecio, by declaring that the first three volumes that he sends to him present a set of conversations held at table in Rome and Greece ${ }^{76}$. In the preface to the second Book, he notes that he simply jotted down the conversations as each came to his mind ${ }^{77}$. On the basis of these accounts, scholars have accepted that we are dealing with genuine recollections in this work, and that the sympotic conversations that Plutarch records there are historical ${ }^{78}$. The discussions described in Quaestiones convivales would, thus, represent a development of personal notes that Plutarch took after the conversations in which he himself either actively or passively participated. The argument is further substantiated by the fact that many of the dinners recorded in Quaestiones convivales may very well have taken place at certain locations and during specific festive events, as they are often described in minute detail. The symposiasts that are put on stage are mostly close relatives, friends, students and acquaintances of Plutarch, rather than entirely fictitious characters ${ }^{79}$. The historicity of these settings and characters may, indeed, imply that the treatise is no complete literary fiction. However, this does not mean that the literary character of Quaestiones convivales should, therefore, be underestimated. Again in the preface to the first Book (Quaest. conv. 6I2DE, cf. also 686D), Plutarch places his work in the wider tradition of philosophical symposium literature, thus joining the line of several coryphaei in the genre (Plato, Xenophon, Aristotle, Speusippus, Epicurus, Prytanis, Hieronymus, and Dio from the Academy). The fact that Plutarch emphatically presents his work as a sample of this literary-philosophical tradition has cast considerable doubt on the historical character of its contents $^{80}$. The view, however, that Plutarch is merely instrumentalising

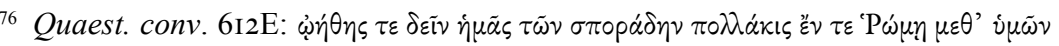

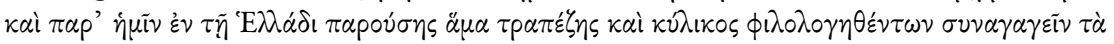

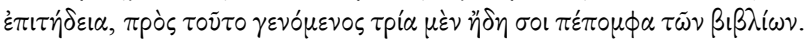

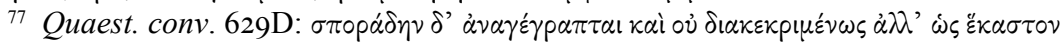
$\varepsilon i \varsigma \mu \nu \eta \dot{\eta} \mu \eta \nu \tilde{\eta} \lambda \theta \varepsilon \nu$. This passage has already been discussed in light of the miscellaneous structure of Quaestiones convivales [see I.I.5.].

${ }^{78}$ See, e.g., E. Graf, I888, p. 59, H. Bolkestein, 1946, pp. 20-26, Z. Abramowiczówna, I962, pp. 84-88. Cf. also the rather nonchalant ending of Book nine, Quaest. conv. 748D:

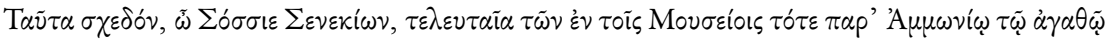
$\phi і \lambda 0 \lambda \circ \gamma \eta \theta \dot{\varepsilon} v \tau \omega \nu$ (see F. Klotz, 20I4, p. 2I0).

${ }^{79}$ Quaestiones convivales provides a great deal of prosopographical information about the symposiasts put on scene. See K. Ziegler, I95I, cols. 64I-653 and 665-696 and B. Puech, I992.

${ }^{80}$ For the Socratic symposia of Plato and Xenophon as literary models for Plutarch's Quaestiones convivales, see G. Roskam, 20I0. For Plutarch and the genre of the symposium 
the sympotic genre to disseminate his own variegated investigations to a wider public - that is, by using it as a purely literary fiction - does not hold against serious criticism either ${ }^{81}$. It remains to be seen, therefore, to what extent the lively descriptions of the sympotic discussions are faithful renderings or rather literary replicas of historic, real-life events.

Scholars have tried to reconcile both viewpoints ${ }^{82}$, by arguing that in Quaestiones convivales, Plutarch intertwines sympotic authenticity with literary allusions. One can imagine that most of the talks are rooted in discussions that actually took place on a given occasion. Perhaps at certain points, they even contain the core positions defended by each of Plutarch's fellow symposiasts, but this is uncertain, and does not necessarily rule out the author's own interventions. Indeed, the sympotic discussions may very well contain a certain degree of additional aetiological elaboration and reorganisation of the arguments based on Plutarch's own research and reading. The following indications may support this theory.

First of all, Plutarch does not partake as a sympotic character in the discussion in 28 chapters. This has led many scholars to the suspicion that a considerable part of the work is fictional ${ }^{83}$. While this certainly casts doubt on the historicity of these chapters, however, from a narratological perspective perhaps Plutarch is making a certain Platonic gesture, viz. by stressing the authorial role of reportage in the recording of these sympotic discussions ${ }^{84}$. Indeed, Plato himself is also absent in his Symposium, and his absence in the Phaedo is illustrious.

Second, the attempt to maintain an aspect of historical verisimilitude does not seem to be equally successful in each and every sympotic discussion. Some of the chapters are less circumstantial when it comes to historical detail and sympotic liveliness (see n. 50). In these cases, the description of the sympotic setting does not receive a great deal of dramatic substantiation. In some cases, the portraits of the symposiasts, who are normally characterised by their personal interests, occupations and idiosyncrasies, remain rather vague (Plutarch there simply uses such

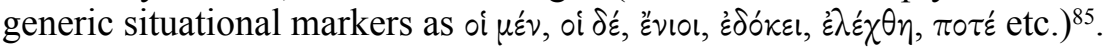
In some chapters, Plutarch does not mention the name of any of the

more generally, see, e.g., J. Martin, I93I, M. Vetta, 2000, S.-T. Teodorsson, 2009, F. Klotz, 20I4. For the place of the symposium in Plato's philosophy, See M. Tecuşan, I990.

${ }^{81}$ Cf., e.g., K. Hubert, I9II, p. I87 ("die Symposiaca [sind] ein durch und durch literarischen Werk"), J. Martin, I93I, pp. I73-I79 (p. I73: "immer unter Beibehaltung der Fiktion").

${ }^{82}$ See, e.g., K. Ziegler, I95I, cols. 886-887, F. Fuhrmann, I972, pp. vii-xix, S.T. Teodorsson, I989, pp. I2-I5, J. Opsomer, I994a, p. 8.

${ }^{83}$ See, e.g., A. Gudeman, I927, col. 2526.

${ }^{84}$ Thanks are due to K. Oikonomopoulou for this suggestion.

${ }^{85}$ See, e.g., E.L. Minar, F.H. Sandach and W.C. Helmbold, I96I, p. 2. 
symposiasts, but simply lines up a number of arguments anonymously without attributing them to specific persons (e.g., Quaest. conv. 6I9BF, $625 \mathrm{AC}$ ). By putting the main focus on the development of the arguments, these chapters give the impression of being short expositions, rather than the condensation of real-life discussions ${ }^{86}$ (even if the author attempts to maintain the illusion of reality by creating an artificial setting and evoking "un air de vérité" ${ }^{87}$ ). However, it may well be that these artificial table talks are simply rendered in summary or paraphrase due to selective or faulty recollection of the author ${ }^{88}$.

Third, the use of lengthy monologues in the argumentations in Quaestiones convivales seem to betray the author's intervention, since it is unlikely that we are dealing in these cases with the symposiasts' verba ipsissima exactly as they were uttered (e.g., Quaest. conv. $629 \mathrm{E}-634 \mathrm{~F}$; the same is true for the use of indirect speech: e.g., Quaest. conv. 620A). If it is true, moreover, that these passages do contain at least a certain nucleus of authenticity ${ }^{89}$, Plutarch may very well have made further elaborations and revisions to them. Since Plutarch may in some cases simply be using the literary characters of his fellow symposiasts as porte-paroles to voice his own opinions - a literary strategy with which he was not at all unfamiliar ${ }^{90}-$, it is not unimaginable that he intended to bring some kind of an intellectual tribute to his sympotic colleagues by labelling the explanations to the questions with their proper names and by staging them in, what, thus, turns out to be, a sympotic liber amicorum. In a way he, thus, immortalised his friends in this learned Festschrift.

Since the question of historicity and fiction in Quaestiones convivales, cannot be settled with any certainty or precision, it is safe to conclude with Titchener that "the $Q C$ do not need to be authentic to be real and true" ${ }^{\circ 1}$ :

${ }^{86}$ A comparison with the fictitious Septem sapientium convivium is never far away in these cases. Cf. A. Gudeman, 1927, col. 2526 and F. Fuhrmann, 1972, p. ix. On the place of Plutarch's Septem sapientium convivium in the tradition of symposium literature, see J. Mossman, I997b.

${ }^{87}$ F. Fuhrmann, I972, p. xvii. Cf. also pp. ix-x and xviii: "nous pouvons au moins accepter comme historiques ceux auxquels se rapporte la relation la plus circonstanciée".

${ }^{88}$ Some symposia perhaps do have that effect on a person's memory. Thanks are again due to K. Oikonomopoulou for this suggestion.

${ }^{89}$ Cf. G. Roskam, 20IO, p. 47.

90 Plutarch's brother Lamprias, for instance, is often considered the literary delegate and mouthpiece of the Chaeronean's own opinions. For the role of Lamprias as narrator in De defectu oraculorum, see, e.g., F.C. Babbitt, I936b, p. 349: "some have thought that Plutarch has used the person of Lamprias to represent himself, possibly because of the official position held by Plutarch at Delphi." Cf. also F. Ferrari, 1995, pp. 30-3I. For Lamprias' role in De facie, see P. Donini, 20II, p. 36.

${ }^{91}$ F. Titchener, 2009, pp. 398-399 and 20II, p. 39. 
"What the $Q C$ present us with is something a little in between: what at least conveys the texture of what MIGHT have happened, COULD have happened, and periodically HAD in fact happened. For Plutarch's purposes, this is really all the same thing [...]." ${ }^{92}$

As such, Quaestiones convivales vividly portrays the intellectual practice of sympotic debate as held in Plutarch's milieu, albeit in a dramatised and idealised fashion, with the goal of making these discussions accessible to posterity, much like Plato, Xenophon and other authors had done before (cf. Quaest. conv. 6I2DE, 686D). Scholars generally agree that a complex embroidery and reorganisation of hypomnematic material lies beneath the surface of the text in Quaestiones convivales ${ }^{93}$. This hypomnematic material was composed by the author on the basis of his own recollections, reading and research. As stated, this hypomnematic material has often been associated, and in some imprudent cases even identified, with Plutarch's collections of quaestiones, but this seems unlikely for several reasons, as will be set out in the following section $^{94}$.

\section{Problems and personal notes}

Contemporary Plutarch scholarship has devoted a great deal of its attention to the Chaeronean's use of personal notes ( $(\pi \circ \mu \nu \eta \dot{\mu} \mu \tau \alpha)$ both in composing the Moralia and the Vitae ${ }^{95}$. In this section, I will examine the nature and function of these notes more closely with the goal of distinguishing them from Plutarch's collections of problems. A locus classicus is the i $\pi \circ \mu \nu \eta \dot{\mu} \mu \alpha \tau$ statement in the introduction to De tranquillitate animi $(464 \mathrm{E}-$ $465 \mathrm{~A})^{96}$. Close analysis of this passage will yield important information

92 Ibid. A similar conclusion was made, e.g., for the discussion recorded in De sollertia animalium by J. Bouffartigue, 20I2, p. xix: "On retiendra l'idée de "forme idéalisée”, en ne perdant pas de vue que Plutarque n'écrit pas un reportage."

${ }_{93}$ See, e.g., J. Sirinelli, 2000, pp. 380-385 and p. 386: "On est tenté de donner comme

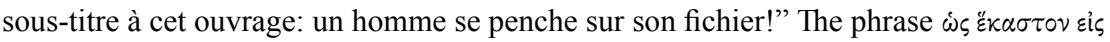
$\mu \nu \eta \dot{\mu \eta \nu} \tilde{\eta} \lambda \theta \varepsilon v$ in Quaest. conv. 629D (discussed earlier [I.I.5.]) should perhaps be taken as an implicit allusion to Plutarch's reliance on his i $\pi \circ \mu \nu \eta \dot{\eta} \mu \tau \alpha$.

${ }^{94}$ See, e.g., K. Hubert, I9II, pp. I74-I76, I80, H. Bolkestein, I946, p. 27 and F. Fuhrmann, 1972, p. xiii (quoted below).

${ }^{5}$ For the Moralia, see esp. L. Van der Stockt, 1999a, 2004, B. Van Meirvenne, I999, 200I, M. Beck, 20I0; for the Vitae, C. Pelling, I979, pp. 94-95. See also, e.g., K. Mittelhaus, I9II, p. 23 and H. Martin, I969, pp. 69-70. On the use of notes as a standard practice of literary composition in Antiquity, see J.P. Small, I997, pp. I69-176, T. Dorandi, I99I, pp. I2-I4 and 2000, pp. 28-50.

${ }^{96}$ For a detailed analysis of this passage, see esp. L. Van der Stockt, I999a, pp. 577-580 (see also I996, pp. 265-266 and 2004, p. 333). 
about Plutarch's general writing technique and his use of personal notes more specifically.

The introduction to De tranquillitate animi $(464 \mathrm{E}-465 \mathrm{~A})$ highlights the efficiency with which Plutarch accessed and used his personal notebooks, by highlighting the short period of time in which he completed the treatise on the basis of his $i \pi \circ \mu \nu \eta \dot{\eta} \mu \tau \alpha$. Plutarch apologises to his correspondent Paccius for the haste with which the work was put together - 'I did not

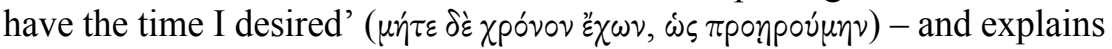
that he only recently ( $\partial \psi \dot{\varepsilon}$, being the very first word of the treatise) received Paccius' petition urging him to write 'something on tranquility of mind, and also something on those subjects in the Timaeus which require more

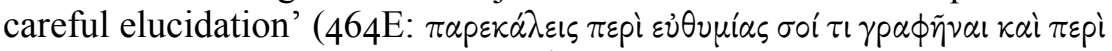

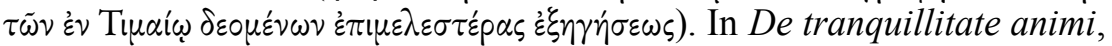
Plutarch grants only the first part of Paccius' request (I will come back later to the second part about the subjects in the Timaeus [see 2.4.I.]). Plutarch adds that their beloved friend Eros, with whom he could send the treatise to Paccius, was in a hurry ( $\dot{\varepsilon} \pi \tau \alpha \chi \dot{v} v o v \tau \alpha)$ to get back to Rome. In the same breath, he admits that the hasty composition had a strong effect on the composition of the treatise, and that Paccius, therefore, should not expect to find a fully embellished literary work, but rather an edited sequence of rough material. Most importantly, Plutarch states that he 'extracted the topic of tranquility from the notes that I took for myself'

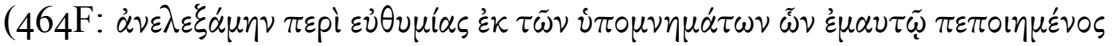
$\dot{\varepsilon} \tau \dot{\gamma} \gamma \chi \alpha \nu \circ v)$. As Van der Stockt notes, the translation of the phrase $\pi \varepsilon p i$

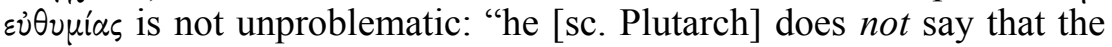
actual theme of these hypomnemata was 'tranquility'! [...] On the other hand, neither does Plutarch deny that he consulted 'hypomnemata on

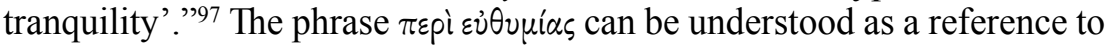

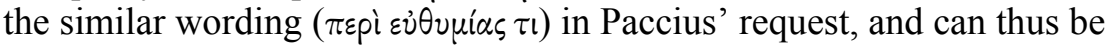
interpreted as a periphrasis of the direct object ('I extracted <something> on tranquility from my notes'). It remains uncertain, therefore, whether Plutarch's notes were ordered thematically or not, but if his use of these notes was a standard practice for the composition of most of his writings which is commonly accepted today -, this would certainly have facilitated the job ${ }^{98}$.

In regards to the actual composition of De tranquillitate animi, one can vividly imagine Plutarch sitting at his writing desk, browsing through the personal notes that he amassed, perhaps over a fairly long period of time, from his own reading and research, and selecting the material that he found fit for transfer to his peer in Rome. When it comes to the precise purpose of

97 L. Van der Stockt, I999a, pp. 578-579.

98 As for the bulk and systematisation of Plutarch's notebooks, cf. R.H. Barrow, I967, p. I53. 
drawing up notes, Plutarch indicates that he does this for personal reasons,

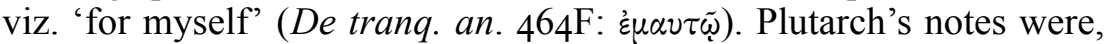

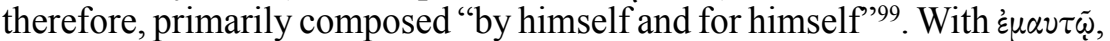
Plutarch, thus, indicates that the notes were intended to serve his own memory. In this sense, they preserve material and thoughts that were dear to him, that is, in which he was personally interested. It was not Plutarch's intention to keep this knowledge to himself, though. On the contrary, they served a more practical goal in securing knowledge and personal reflections that could later be revisited. These notes are made accessible to Paccius in such a way as to, first and foremost, cater to his practical ethical needs. Paccius' main concern is, so Plutarch assumes, not one of literary 'calligraphy': he expects practical information and instruction

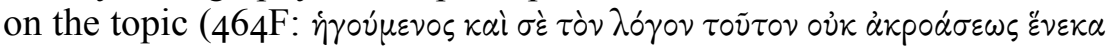

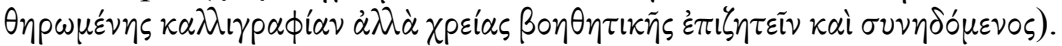

Van der Stockt is probably correct in suggesting that Plutarch is not

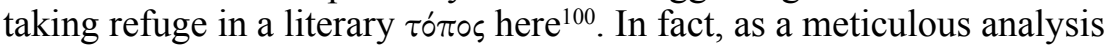
of De tranquillitate animi would suggest, Plutarch's re-editing of his rudimentary notes does not so much aim at an upgrade of the literary stylistics, but rather at a reorganisation of that material by presenting it as a more or less continuous line of thought (with some inevitable defects

99 L. Van der Stockt, I999a, p. 579. Therefore, when speaking of Plutarch's i $\pi \circ \mu \nu \eta \dot{\mu} \mu \alpha \tau \alpha$ in this study, I do this in reference to his 'personal notes', as understood by Van der Stockt and the Leuven school of Plutarchists. I am well aware, however, that Plutarch - and with him many other ancient authors - used the term $i \pi \circ \mu \nu \eta \dot{\mu} \mu \tau \alpha$ (and other concepts derived from it, e.g. i $\pi \circ \mu \nu \eta \mu \alpha \tau \iota \sigma \mu o i ́)$ not only for private documents, but also for published works: e.g., the journals of Sulla (Sull. 5, 5) or Caesar (Comp. Dem. et Cic. 3, I, Ant. 15, 5). Some treatises on ethical matters are also designated as being i $\pi \circ \mu \nu \eta \dot{\eta} \mu \alpha \alpha$ by Plutarch (De Al. Magn. fort. 328A). In Adv. Col. III5B, Plutarch refers more specifically to Aristotle's physical and ethical $\dot{\tau} \pi \circ \mu \nu \eta \dot{\mu} \alpha \alpha$. The term is also used for other public records (e.g., Sol. II, 2 and De fort. Rom. 326A). It is even used for certain institutions, like festivals (e.g., Cam. 33, 7). See L. Van der Stockt, I999a, p. 576, with n. I8. See already A. von Premerstein, I900, cols. 726-757 and F. Bömer, 1953, esp. pp. 215-226. Seeing that these are mostly published works, scholars speak of a genuine hypomnematic genre in ancient literature (A. von Premerstein, 1900, cols. 757-759, esp. col. 757 for scientific and technical commentarii, F. Bömer, 1953 and D. Amboglio, 1990, p. 503, esp. p. 506 for Plutarch's notion of $\dot{v} \pi \circ \mu \nu \eta \dot{\eta} \mu \alpha \tau)$. The concept of $\dot{v} \pi \circ \mu \nu \eta \dot{\eta} \mu \alpha \tau \alpha$ was also used, e.g., for technical commentaries on philosophical texts (see, e.g., F. Ferrari and L. Baldi, 2002, pp. I2-I6).

${ }^{100}$ L. Van der Stockt, I999a, p. 577, n. 9 and I996b, p. 265, n. 3 (pace R. Flacelière, J. Irigoin, J. Sirinelli and A. Philippon, 1987, p. xxxv, n. 3: "coquetterie littéraire"). For similar formulations of Plutarch's intentional lack of literary embellishment, cf. Reg. et imp. apophth. I72BE and Mul. virt. 243A (with L. Van der Stockt, I996b, pp. 266-272). See also M. Beck, 20I0, p. 349: "Plutarch often was working under time constraints. His multiple duties as Delphic priest and town official in Chaeronea placed some limitations on the amount of time he could devote to literary pursuits." 
in form and structure, though). As a consequence, the reader should not expect to find a highly embellished discourse, but rather one that remains relatively simple, concise, and contains information that is pertinent for direct instruction.

We do not know what Plutarch's personal notes looked like in terms of their level of composition and elaboration. Van der Stockt is inclined to conceive of a Plutarchan $i \pi \delta ́ \mu \nu \eta \mu \alpha$ "as a more or less elaborate train of thought, involving material previously gathered and certainly written in full syntactical sentences: we are beyond the stage of heuristics" 101 . Regarding its level of composition, he believes that a i $\pi \delta$ ́r $\nu \eta \mu \alpha$ "does not yet display literary finish" but "probably took the form of a rough draft" 102 . This brings us very close to the compositional level of the genre of problems, as described in the previous chapter [see I.2.3.], but it remains to be seen whether the genre of problems can actually be considered hypomnematic, and, if so, to what extent.

In order to answer this question, let us return for a moment to the earlier mention of the complex embroidery and reorganisation of hypomnematic material in Quaestiones convivales, particularly in light of what Fuhrmann says:

"Les Propos de Table sont, en grande partie, des développements [...] de notes prises par Plutarque sur ses lectures, notes tout à fait

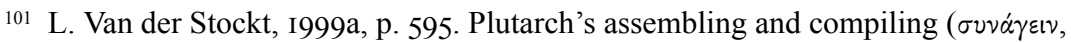
$\sigma \nu \nu \tau \dot{\alpha} \tau \tau \varepsilon \nu$ ) of material as a preparatory phase for the composition of his texts is explicitly marked, e.g., in Cons. ad Apoll. I2IE, Coni. praec. I38C, De coh. ira 457D, and Nic. I, 5.

102 Ibid. Similarly, K. Ziegler, 195I, col. 787 argues that the term $\dot{\tau} \pi \circ \mu \nu \eta \dot{\mu} \alpha \alpha$ in De tranq. an. $464 \mathrm{~F}$ "ja nicht nur Auszüge aus Quellenschriften, sondern mindestens in gleichem Maße auch Niederschriften eigener Gedankengange bezeichnet". Cf. L. Van der Stockt, I999a, p. 576: "we are not entitled to view hypomnemata as sources". Cf. also, e.g., R.H. Barrow, I967, pp. 66-76, I09-IIO and esp. p. I53: "Plutarch's notebooks contained not only quotations which seemed to him of appeal or of use, no doubt classified, but also summaries and abstracts, some at length, some little more than main headings, and no doubt the innumerable miscellaneous jottings which so assiduous a collector could not resist." This is not, of course, to reject the basic doxographical interests of Plutarch's notes. In De coh. ira $457 \mathrm{DE}$, Fundanus (who is considered Plutarch's spokesman: see H. Martin, I969, p. 69, with n. 30) states that he "collects and peruses sayings and deeds of both

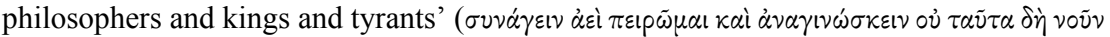

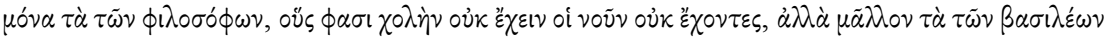

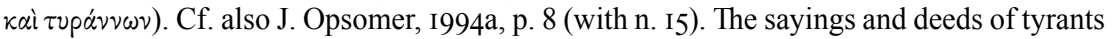
are collected in Plutarch's collections of Apophthegmata; those of philosophers are no longer extant. For further discussion on the use and status of Plutarch's collections of Apophthegmata, see P.A. Stadter, 2008 and M. Beck, 2010 (who distinguish the Regum et imperatorum apophthegmata, as opposed to the Apophthegmata Laconica, from Plutarch's 'primary' i $\pi \circ \mu \nu \eta \dot{\mu} \alpha \tau \alpha)$. 
semblables à ses Questions Grecques, Romaines, Physiques et aux Problèmes attribués à Aristote. Comme dans ces recueils, plusieurs réponses étaient données à chaque question, avec quelquefois une explication propre à l' auteur lui-même." 103

Other scholars would not care as much to make any distinction between Plutarch's notes and problems as Fuhrmann does here (he writes "tout à fait semblables") $)^{104}$. It remains unclear, however, how much Fuhrmann himself would actually distance Plutarch's problems from his notes, since he agrees with Bolkestein (in what immediately follows after the quoted passage)

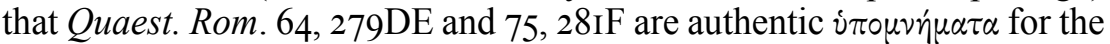
parallel accounts in Quaest. conv. 702Dff. (on the ancient Roman custom of not allowing a table to be removed empty after eating, nor to let a lamp be extinguished $)^{105}$. Elsewhere, Fuhrmann describes these "notes" as "ces ébauches" or "recueils inférieurs" 106 , presumably in light of the absence of $\kappa \alpha \lambda$ ı $\gamma$ pa $\phi i \alpha$ mentioned in De tranq. an. $464 \mathrm{~F}$.

One may wonder, however, why Fuhrmann leaves the Quaestiones Platonicae unmentioned. Is it because these are $\zeta \eta \tau \eta \dot{\mu} \mu \tau \alpha \alpha$ rather than aitiaı and display a higher degree of elaboration, as can be inferred from their average length [see I.I.6., n. I53]? Even then, other scholars include this collection among Plutarch's preparatory notes just as well, by arguing that it represents the raw material waiting to be incorporated in other writings, including Quaestiones convivales ${ }^{107}$. According

${ }^{103}$ F. Fuhrmann, I972, p. xiii. Cf. also K. Hubert, I9II, pp. I74-176 and H. Bolkestein, 1946, p. 27. According to S.-T. Teodorsson, 2009, pp. I4-15, Quaestiones convivales is "based in part on his own [sc. Plutarch's] remembrances and notes and in addition on collections of Problemata and Zetemata and a great number of other sources".

104 According to H.J. Rose, I924, p. 5I, Quaestiones Romanae is, in fact, "a series of selections from reading-notes" (cf. also pp. 48-49). Regarding Quaestiones Romanae, Graecae and barbaricae, R.H. Barrow, 1967, p. 66 argues in a similar way that these are drawn from Plutarch's reading-notes (cf. also p. 69). See also W.R. Halliday, I928, p. I3: "The matter of both [sc. Quaestiones Romanae and Graecae] is derived from literary sources, and they consist essentially of a collection of notes, which Plutarch has put together, perhaps over a fairly long period, from his miscellaneous reading." Cf. also A. Carrano, 2007, p. 9.

105 F. Fuhrmann, I972, p. xiii and H. Bolkestein, I946, pp. 27-35.

106 F. Fuhrmann, I964, p. 19 (cf. also 1972, p. xix, n. 2).

107 Cf. H. Cherniss, 1976, p. 2. He believes that we are dealing in Quaestiones Platonicae with what we today would call 'collected notes', which he distinguishes from their literary equivalent, the symposium (alluding to Quaestiones convivales). He does not deny, however, that these collected notes and symposia could both be made available to interested readers [see 2.4.I.]. Cherniss notes, moreover (p. 3) that "Plutarch himself in his Symposiacs uses the term $\eta_{\eta} \eta_{\eta} \mu \alpha \tau \alpha$ of the questions or problems there propounded and discussed, of which several without their literary embellishment could appropriately 
to Opsomer, however, there can be absolutely no doubt that these are not rudimentary or simple notes:

"Les Questions Platoniciennes ont une structure bien organisée et élaborée et il serait incorrect de penser qu' elles ne contiennent que le matériel brut. En outre, elles sont plus que de simples notes personnelles (i $\pi \circ \mu \nu \eta \dot{\mu} \mu \alpha \tau)$. La structuration et la construction méticuleuses des différentes Questions nous indiquent qu' elles ont été préparées pour être publiées." 108

The same seems to be the case for Plutarch's Quaestiones naturales. In this work, the aspect of elaboration is confirmed by the author's ample collection of content matter and also by such formal characteristics as, for instance, the use of full syntactical sentences with hypotactic structures, the presence of rhetorical elements, including emphatic addresses to the reader, the global structuring of the aetiologies along the principle of increasing plausibility, and the thematic clustering of problem chapters around specific topics.

I will come back to the issue of the publication of Plutarch's collections of quaestiones later on [see 2.4.I.]. What is important here is the idea that Plutarch's simple notes only contain the rough and unfinished material (these are the $i \pi \circ \mu \nu \eta \dot{\mu} \alpha \tau \alpha$ mentioned in De tranq. an. $464 \mathrm{~F}$ ), whereas Plutarch's collections of quaestiones display a higher level of elaboration. As a result, the level of composition of Plutarch's quaestiones is not situated at the primary level of the simple notes, but at a higher, secondary level of elaboration, where remnants of the original hypomnematic material are incorporated at certain points and further elaborated upon to fit the arguments at hand ${ }^{109}$. The same conclusion was made by Senzasono:

have been included in the Platonic Questions, just as all the latter could have been used as material for the Symposiacs." Such Platonic questions are raised in Quaest. conv. 697F, $700 \mathrm{C}, 7 \mathrm{I} 8 \mathrm{~B}$ and $739 \mathrm{E}$. He also argues (p. 4, n. b) that De def. or. 42IE-43IA is perhaps an elaboration of a Platonic $\zeta_{\eta} \tau \eta \mu \alpha$ devoted to a passage in Tim. 55 $\mathrm{cd}$ (on the number of worlds). Cf. also K. Ziegler, I95I, col. 834.

108 J. Opsomer, I996a, p. 83 (see also I994a, p. I2 and 20I0, p. 95).

109 Opsomer (ibid.) does not explicitly deny the idea that we may be dealing with more complex notes in Plutarch's Quaestiones Platonicae, as opposed to more simple ones, but he does not explicitly assert this either (in 20I0, p. II5 he notes, however, that the $i \pi \sigma_{\mu \nu \eta \mu \alpha}$ Plutarch possibly used in composing the fifth Quaestio Platonica may have had a specific 'problematic' organisation itself). This distinction may be relevant here, as there may be some ground for assuming a substantial difference in gradation between rudimentary, simple notes and more elaborate, complex ones without further terminological discrimination being made by Plutarch himself (cf. also n. 99). The distinction between simple and complex notes may have some concrete basis in other, more or less, contemporary miscellanistic authors. For instance, Gellius' conception 
"Cosí, nel complesso, le Quaest. nat., nate forse come raccolta di appunti, presentano un ordine e una struttura stilistica che hanno le caratteristiche che abbiamo indicato, frutta d' indubia elaborazione formale." "Plutarcho ha rifinito lo stile, forse partendo da appunti [...]. Lo stile induce a supporre che Plutarco abbia formalizzato degli appunti presi per interesse scientifico [...]." 110

Seeing that the level of elaboration of Quaestiones naturales oscillates between simple notes and a fully elaborated treatise ${ }^{111}$, it is not so remarkable that some hypomnematic features are still noticeable in the collection. Even though there is a certain degree of elaboration of the content and structure in Plutarch's quaestiones, a specific element of, what can be labelled, 'hypomnematic negligence' has not been eliminated ${ }^{112}$. This negligence involves a compositional sloppiness at times that takes effect on several levels of the discourse. In the case of Quaestiones naturales, Plutarch's desire to be both precise and concise in his rendering of the arguments often ends up in obscurity (e.g., Q.N. 4, 913A: the comparative $\dot{\alpha} \nu \alpha \gamma \alpha \alpha$ ló $\varepsilon p \alpha$ is confusing). At times, he is also rather careless in using sources (e.g., Q.N. I, 9IIE: Aristotle does not vindicate but, rather, reject the popular belief that seawater contains burnt earth) and is sometimes inaccurate and inexact in his claims (e.g., Q.N. 5, 913AB: Plutarch says that there are eight generic flavourings but sums up nine). Likewise, his cross-references between successive problems are not always successful (e.g., Q.N. 24, 917F contains a ghost-reference to what was previously said but cannot be clearly retraced). Sometimes, Plutarch does not answer a question in its entirety (e.g., Q.N. 21, 917B: he does not explain why all of the wild sows farrow at the same time, nor why

of 'notes' in his preface to the Noctes Atticae is confused or at least confusing. In NA Praef. 2-4 Gellius designates Noctes Atticae as being commentarii, commentationes or a commentarius in itself, but he also refers to the annotationes (ad subsidium memoriae) that provided the primary material for that work. See T. Dorandi, 2000, pp. 39-42 and L. Holford-Strevens, 2003, p. 33. There are four instances, moreover, where Gellius draws from Plutarch's Quaestiones convivales. In each of these passages, Gellius simply ignores the sympotic setting, so that the style of the commentatio comes close to that of a relatively unembellished problem. These passages are discussed by F. Klotz and K. Oikonomopoulou, 20II, pp. 235-236. See also L. Holford-Strevens, 2003, pp. 283-285. The passages at issue (with their parallel in Quaestiones convivales) are NA 3, $5(\sim$ Quaest. conv. 705E); 3, $6(\sim$ Quaest. conv. 724EF); 4, II, I3 ( Quaest. conv. 730B); I7, II ( Quaest. conv. 697F-700B).

110 L. Senzasono, 2006, pp. I8 and 45.

111 L. Van der Stockt, 20II, p. 452, n. 30 reached a similar conclusion: "The relative lack of embellishment [...] of $Q N$ may reflect the intermediary stage between hypomnema and formal edition."

112 For the aspect of compositional negligence in Plutarch's $\dot{\pi} \pi \propto \mu \nu \eta \dot{\eta} \alpha \tau \alpha$, cf. also L. Van der Stockt, 1987, p. 287. 
domesticated ones farrow at various moments), or the question itself is formulated badly (e.g., Q.N. 19, 9I6B: Plutarch criticises Theophrastus for explaining only the octopus' change of colour and not also its adaptation, but in the quaestio he himself mentions only the change). Arguably, these aspects of hypomnematic negligence can be attributed to the speed with which Plutarch composed his quaestiones. Signs of hasty composition have also been detected, for instance, in Quaestiones convivales ${ }^{113}$, and the haste with which Plutarch made extractions from his personal notes is known from the $i \pi \circ \mu \nu \eta \dot{\mu} \mu \tau \alpha$ statement itself, discussed above (De tranq. an. $464 \mathrm{E}-465 \mathrm{~A})$.

From reading Quaestiones naturales one gets the impression that Plutarch not only tries to maintain the clarity but also the momentum of his streams of thought. The hypomnematic character of this work can be connected with the style of discourse of the Ps.-Aristotelian Problems (which underlines the relevance of the genre again [see I.2.5.]). Indeed, scholars have argued that the Problems also have a specific hypomnematic disposition, to be explained in light of its educational origins ${ }^{114}$. In fact, already in the $6^{\text {th }}$ century AD the hypomnematic character of the Aristotelian Problems was recognised on the basis of the collection's form and presentation. In the preface to his Commentary on Aristotle's Categories, the commentator Elias (David) draws up a classification of Aristotle's writings by distinguishing the so-called hypomnematic from the syntagmatic works ${ }^{115}$. As opposed to the syntagmatic works, the hypomnematic ones record only the gist of the matter (II4, 2: i $\pi$ o $\mu \nu \eta \mu \alpha \tau$ ik $\alpha$

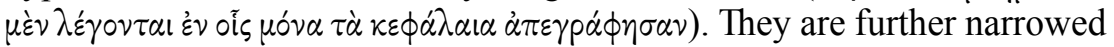

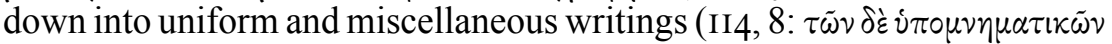
$\tau \grave{\alpha} \mu \dot{\varepsilon} \nu \mu \circ \nu \circ \varepsilon \delta \delta \tilde{\eta} \tau \dot{\alpha} \delta \dot{\varepsilon} \pi \circ \kappa \kappa(\lambda \alpha)$. Among the miscellaneous hypomnematic

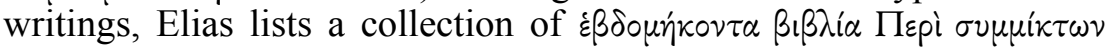

113 See F. Fuhrmann, 1972, pp. ix-x and J. Sirinelli, 2000, p. 369. Notably, in Quaest. conv. 6I2E, Plutarch promises to Sossius Senecio to send the rest of the work quickly $\left(\tau \alpha \chi^{\prime} \omega \varsigma\right)$. On signs of hasty composition also in the Vitae (attributed to the same Sossius Senecio), see C.T. Michaëlis, I875, pp. 8-9 and C. Pelling, I979, pp. 95-96.

114 According to C. Jacob, 2004, pp. 43-44, for instance, Ps.-Aristotle's Problems are not as such "hypomnémata désordonnés et hétérogènes" but still "ébauches rédactionnelles": "On y trouverait non seulement un recueil de phénomènes, mais aussi les premières versions d' explications qui seront reprises, complétées ou remplacées dans les textes plus systématiques." Cf. also P. Louis, I99I, pp. xx, xxv and xxix: "Le style est révélateur de ce genre d'écrits. Les phrases sont souvent mal construites. Certaines sont incomplètes. Elles sont tantôt très courtes, tantôt exagérément longues, avec parfois plusieurs incises qui les rendent difficiles à comprendre. Il arrive même qu' elles se contredisent. N'est-ce pas là la marque de phrases rédigées ou copiées à la hôte? Mais ce qui fait justement l'intérêt de la plupart de ces problèmes, c' est la spontanéité du premier jet."

115 For further discussion of Elias' account (and similar accounts in the works of other Aristotle commentators), see T. Dorandi, 2000, p. 85. 


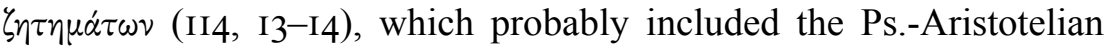
Problems [see I.I.3., n. 87]. Similar to the educational context in which Ps.-Aristotle's Problems were composed (c.q. Aristotle's Lyceum), the composition of Quaestiones naturales can be interpreted in light of the author's activities in his philosophical school (I will deal with Plutarch's school activity in the next chapter [see 3.I.4.]). Full elaboration of the style of the natural problems was not necessary, at least if the basic line of thought was sufficiently elucidated for a good understanding by the implied readership. It turns out that mainly for educational purposes, then, Plutarch, much like Ps.-Aristotle, was mainly concerned with the gist of the matter rather than the form. The fact that Quaestiones naturales still has certain hypomnematic traits should not necessarily come at the cost of the work's autonomous position in the corpus Plutarcheum, but should rather be explained in light of the eventual purpose of the collection as a school text ${ }^{116}$. As such, Plutarch's collections of quaestiones more generally created an independent space for the author to collect his personal research and findings in a thematic fashion, a point that will be further substantiated for Quaestiones naturales in the following section.

\section{Zetetic autonomy in Quaestiones naturales}

As argued previously, Plutarch did not compose Quaestiones naturales (or his other collections of quaestiones) as a hypomnematic Fundgrube of materials to be exploited for the redaction of his other writings. It is not just a collection of residual problems that Plutarch simply had no room for in Quaestiones convivales (or elsewhere) ${ }^{117}$. It may very well be the case, however, that, as a consequence of his decision to restrict each Book of Quaestiones convivales to ten chapters only, Plutarch ran out of space at certain points in the process of composing this work (see n. 54) $)^{118}$.

116 Cf. L. Senzasono, 2006, p. 47: "Può darsi che egli abbia scritto l'opera coll'intento di servirsene in seguito, ma concependola come fatto letterario autonomo e compiuto, oppure, com'è piú probabile, che abbia concepito il proposito di servirsene dopo la stesura ben elaborata dell'opera."

117 Therefore, K. Ziegler, I95I, col. 857 (cf. also col. 887) rightly remains uncertain when he wonders: "Ist es [sc. Quaestiones naturales] vielleicht ein Rest von Materialien, die in die Symposiaka nicht mehr Aufnahme fanden?". In my opinion, the answer is negative. Notably, Ziegler vindicates the autonomy of Quaestiones Romanae (vis-à-vis the Vitae) with less doubt (col. 860).

118 Plutarch's own established rule of a fixed number of ten chapters for each Book is in itself a severe restriction of the work's scope, but at the same time it is also a realistic decision on the side of the author not to chase encyclopaedic comprehensiveness. There are some ways to create extra space, though. Two problems can, for instance, merge under one heading (e.g., Quaest. conv. 664A, 684E, 700BC, 706E, 7I7A, 723A, 725F, 727A, $740 F)$. Moreover, in Book nine Plutarch makes an explicit exception to his own rule of a 
Remarkably enough, some of the problems that are only mentioned in passing in Quaestiones convivales, receive detailed elaboration in Quaestiones naturales. These I will discuss below in order to illustrate that the separate and meticulous treatment of these problems speaks to the autonomous character of Quaestiones naturales, rather than to their status of zetetic leftovers.

In Quaest. conv. 724EF, first of all, Plutarch compares the palm tree with a well-trained athlete, who possesses an unbendable vigour both in body and mind. A piece of palm wood is said to curve upward as though resisting a weight imposed upon it. It is only in Q.N. 32 that Plutarch provides an extensive aetiology for this natural phenomenon (amounting to three explanations in total). Similarly, in Quaest. conv. 700F, no one of the symposiasts ventures upon an explanation of the sweet tears of wild boars as opposed to the salty tears of deer, a detailed inquiry of which is offered in $Q . N .2 \mathrm{O}^{119}$ (which contains two explanations). The natural phenomenon of wild figs preventing domesticated figs from dropping their fruit, and thereby promoting their ripening, is mentioned in the same passage. This phenomenon is explained in the course of Q.N.4I (containing one extensive explanation), but remains without an explanation in Quaest. conv. $700 \mathrm{~F}$.

Both phenomena of tears and figs (among others) serve as paradoxographical examples that Euthydemus and Patrocleas cite from their

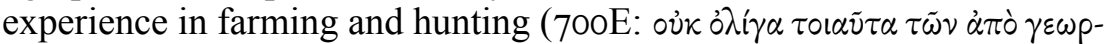

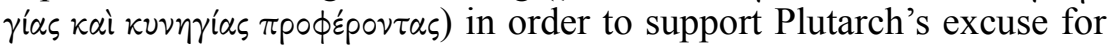
not accounting for the central problem of the so-called horncast seeds ${ }^{120}$.

fixed number of ten chapters for each Book under the pretext of bringing an appropriate tribute to the nine Muses on their own festival (this is the setting of the fifteen chapters that

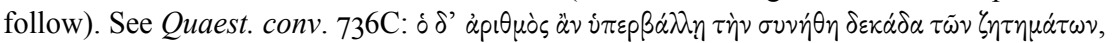

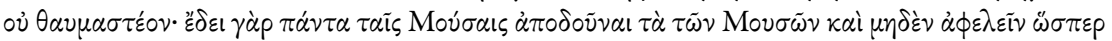

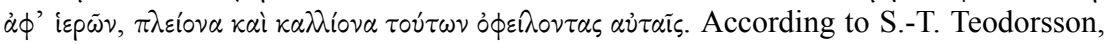
1996, p. 300, "[p]erhaps we may suppose that Plutarch, when setting out to write book IX, happened to see that he had a number of interesting questions left which he could not refrain from including." However, in this last Book no natural problems are discussed after the manner of Quaestiones naturales. Chapters Io through I2 concerned natural problems in a more general sense, though, as we can learn from the titles of the lost chapters (talks IO and I2 deal with more astronomical issues, and talk II with an ontological rather than a physical problem).

119 The same observation was made by F.H. Sandbach, 1965, pp. 138 and I93, n. b. He adds that Q.N. 20 may, therefore, be composed subsequently to Quaest. conv. 700F, or that they are at least contemporaneous, but this is uncertain. Cf. S.-T. Teodorsson, I996, pp. 40-4I (see also further).

120 According to S.-T. Teodorsson, I996, p. 4I the phenomena mentioned in Quaest. conv. $700 \mathrm{~F}$ are only enumerated as examples here, because there existed well-known explanations for them (as Q.N. 20 and 4I show). Cf. also L. Senzasono, 2006, p. 202 , n. I08. 
In what follows, Florus asserts that these (and similar) problems are not childish nonsense, and that they should not be given up as insoluble (70IA:

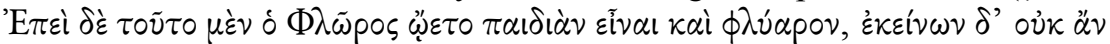

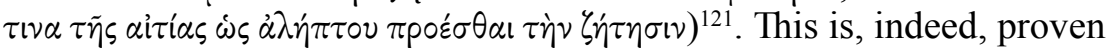
by the aetiologies in Q.N. 20 and 4I, where extensive explanations are found. The fact, then, that the two problems at issue are only mentioned in passing and remain "notoriously unsolved" 122 in Quaestiones convivales, whereas they do receive a detailed aetiology in Quaestiones naturales, is very significant, since it suggests that Quaestiones naturales does not necessarily 'need' the sympotic framework of Quaestiones convivales to accomplish its own zetetic goal. Or in other words: Plutarch does not necessarily require a boost of wine to solve these problems (cf. Quaest.

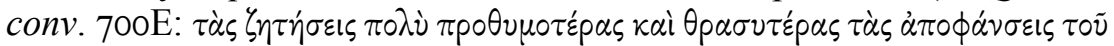

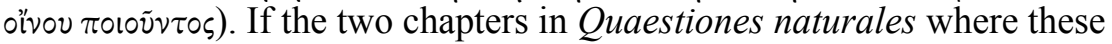
problems are solved (i.e. Q.N. 20 and 4I) are to be considered editorial remains - on the uncertain assumption, nota bene, that their composition is chronologically prior to or contemporary with that of the discussions in Quaestiones convivales -, why are they worked up in such aetiological detail? Why did Plutarch not simply delete them altogether? If it is because they were composed subsequently to Quaestiones convivales, we cannot speak of them as leftovers at all, but rather as a continuation of the same zetetic project (but then again, matters of chronology remain unclear [see the prologue]).

Rather than assuming that the research conducted in Quaestiones naturales is actually done 'for' Quaestiones convivales, I firmly believe that it is at least equally plausible that Plutarch relies on, incorporates and elaborates the same or similar hypomnematic material into the problematic framework of Quaestiones naturales as well as into the more dramatised and literary context of Quaestiones convivales ${ }^{123}$. This explains why there are numerous parallel passages between the two works, including their

${ }^{121}$ What Florus presumably does consider to be $\pi \alpha \iota \delta \dot{\alpha}^{\prime}$ (if $\dot{\varepsilon} \kappa \varepsilon i \nu \omega \nu$ in his reply, indeed, refers back to $\tau \alpha \tilde{\tau} \tau^{\prime}$ in Euthydemus' account - as it does in the translation of E.L. Minar, F.H. Sandach and W.C. Helmbold, I96I, p. 25) is what Euthydemus adds: these are the popular beliefs that celery grows better if it is trampled and crushed as it grows, and that the same is true for cumin if it is sown with curses and maledictions.

${ }^{122}$ F.H. Sandbach, 1965, p. 193, n. b (Sandbach does not, however, mention the second parallel on fig trees). Solving these and similar problems is not considered a sinecure,

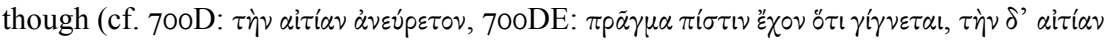

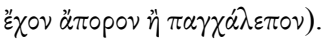

${ }^{123}$ Cf. F.H. Sandbach, 1965, p. 138: "A priori it might be guessed that the former [sc. Quaestiones naturales] provided raw material that was worked up into a literary form in the latter [sc. Quaestiones convivales]. [...] The facts in general do not [however] seem to exclude the possibility that material found for the Symposiacs was used in composing the Quaestiones Naturales and vice versa." 
slight divergences in argument at times. It would also account for the fact that certain topics, as the cases above have shown, are touched upon only superficially in Quaestiones convivales, while they receive a separate and circumstantial aetiology in Quaestiones naturales. It is only reasonable, then, that Quaestiones naturales is not a zetetic appendix to Quaestiones convivales. In fact, one could turn the tables and argue, the other way round, as Harrison did, that:

"[Quaestiones convivales] allowed Plutarch to examine customs and phenomena that might not have found comfortable places within other of his Aitial and the exegesis of which did not warrant a separate essay." 124

Whatever may be the case, Quaestiones naturales clearly has a high degree of zetetic autonomy, offering to its author plenty of space for the treatment of natural problems mostly on their own terms (i.e. in view of their physical causality without much further consideration of matters regarding style, morality etc.). The same aspect of zetetic autonomy can also be presumed, then, for Plutarch's other collections of quaestiones (viz. Quaestiones Romanae, Graecae and Platonicae), which, in this logic, portray several specialised fields of interest that reflect the author's versatile research occupations ${ }^{125}$. Let it be absolutely clear, however, that the notion of compository autonomy does not, of course, imply that Plutarch's collections of quaestiones were composed in complete intellectual isolation from each other. As we will see in the following section, sometimes there are clear thematic overlaps between these works, meaning that they are part and parcel of a larger, overarching research project, a project inspired by Plutarch's quest for all-round $\pi \partial \lambda \nu \mu \alpha \dot{\theta} \theta \varepsilon i \alpha$ [see 2.4.2.].

Another point is that the differences in form between Plutarch's Quaestiones convivales and his other collections of quaestiones involves a difference in implied reading and readership. I will argue in the next chapter that there are, indeed, good reasons to believe that there is a difference in authorial intention in these works [see 3.I.4.]. Before this is

124 G.W.M. Harrison, 2000a, p. 197. In a similar vein, F. Klotz and K. Oikonomopoulou, 20II, p. 20 have pointed out that "the Table Talk's inquiries are, in the overwhelming majority of cases, similar or approximate, but never identical to those of the other collections, suggesting that Plutarch self-consciously avoided close replication of material across the corpus. And, whereas its answers often employ scientific theories and arguments that are encountered in the other collections as well, they never do so with the same ends in view."

125 As G.W.M. Harrison, 2000a, p. 198 has argued, therefore, "[o]ne hardly feels constrained any more to state that these essays were meant to stand on their own [...]." 
possible, however, we must first focus on the issue of publication itself of Plutarch's quaestiones.

\subsection{Opening up Plutarch's zetetic archive}

The aim of this section is to investigate the possibility of a publication of Plutarch's collections of quaestiones, and of Quaestiones naturales more specifically. What indications do we have that these works were published or were at least intended to be made public one way or another? A detailed answer to this question will, in turn, provide further food for thought in the next chapter about the educational context in which these collections were useful.

\section{The issue of publication: problems as functional literature}

When it comes to the issue of publication of Plutarch's collections of quaestiones, only little is known with any certainty, leaving much room for conjecture. We will see here that there is reason to assume that Plutarch probably disclosed his collections of quaestiones to his students and close peers who presumably shared his interest for their different strands of inquiry. Plutarch's philosophical school was, in all likelihood, situated in his own house in Chaeronea [see 3.I.2.]. Perhaps his students even took up residence there. Considering that Plutarch complains about the lamentable availability of books in small towns like his own ${ }^{126}$, one can very well imagine that he, in his role as a helpful teacher, not only allowed them access to his own library, but also to his thematically ordered collections of quaestiones that he had composed on the basis of his own readings and discussions. But of course, it is only likely that he also granted requests made by friends living abroad (as the i $\tau \circ \mu \nu \eta \dot{\mu} \alpha \tau \alpha$ statement nicely illustrates; see above). Plutarch's intellectual repute, although centered in Chaeronea, must have radiated throughout the entire Mediterranean region. As we will see in what follows, there are several indications to make these points more concrete.

Regarding Plutarch's Quaestiones Platonicae, first of all, scholars have argued that they "might be made available to interested readers"127. Notably, in Quaest. Plat. I003A, Plutarch reports that a specific issue 'has

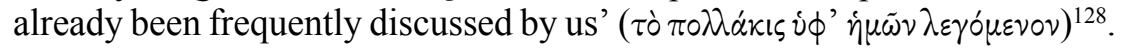
This phrase, and especially the use of the first person plural, would not have much sense unless a certain audience, presumably situated in the context

${ }^{126}$ Cf. De E 384E (quoted n. I33) and Quaest. conv. 675B. See D.A. Russell, I973, pp. 42-43 (with J. Sirinelli, 2000, p. 365). On the smallness of Chaeronea, see Dem. 2, 2 (with R. Flacelière, J. Irigoin, J. Sirinelli and A. Philippon, I987, pp. lix-lx).

127 H. Cherniss, I976, p. 2.

${ }^{128}$ See J. Opsomer, I994a, p. I2 (see also I996a, p. 83). 
of Plutarch's classroom, is implicitly being addressed by it ${ }^{129}$ (as we will see later on, similar personal forms can be found throughout Quaestiones naturales [see 3.I.4.]). Another indication of the publishable character of Quaestiones Platonicae is found in the $i \pi \circ \mu \nu \eta \dot{\mu} \mu \tau \alpha$ statement in De tranq. an. 464E [see 2.3.2.]. As seen previously, this passage speaks of

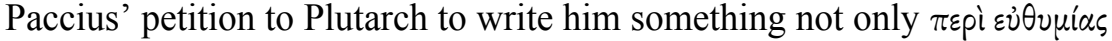

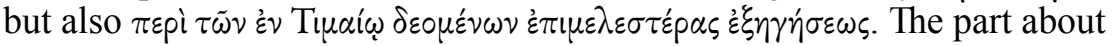
the 'passages in Timaeus that require futher elucidation' can, and has, been linked to the exegetical chapters on the Timaeus in Quaestiones Platonicae ${ }^{130}$. Cherniss argued, in this regard, that the $i \pi \circ \mu \nu \eta \dot{\eta} \alpha \tau \alpha$ that Plutarch mentions in De tranq. an. $464 \mathrm{~F}$ probably contained "such things as our $\zeta_{\eta \tau} \eta_{\mu \alpha \tau \alpha \alpha}$ [sc. Quaestiones Platonicae] or the material for them"131. The second seems more plausible, though ${ }^{132}$. What is particularly unlikely, however, is that Plutarch eventally sent this Timaeus exegesis to Paccius in its rough hypomnematic form (after all, De tranquillitate animi are no rough $i \pi \circ \mu \nu \eta \dot{\mu} \alpha \tau \alpha$ either). Therefore, Plutarch probably elaborated this exegetical material, presumably in the form of one or more quaestiones, before handing it over to his friend Eros. If this is true, the passage at hand implies a transfer of one or more chapters from Quaestiones Platonicae to Rome. It would be absurd to claim, of course, that the geographical distance is a prerogative for the disclosure of such quaestiones. If Plutarch was prepared to disclose this knowledge to acquaintances living abroad, why would he not do the same for those living closer to home, viz. to his close students and friends ${ }^{133}$ ?

129 J. Glucker, I978, p. 264, n. 27 notes, moreover, that "[f]rom De An. Procr. I0I2B, with its obvious reference to Plat. Quaest. it appears that it is his students in this particular lecture who demand an exposition of this problem. It thus seems that Plat. Quaest. owe

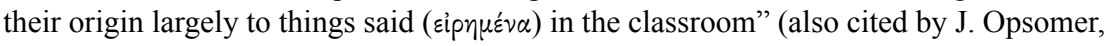
I994a, p. 13).

${ }_{130}$ Quaest. Plat. 2, I000E-I00IC, 4, I002E-I003B, 5, I003B-I004C, 7, I004D-I006B, $8,1006 \mathrm{~B}-\mathrm{I007E}$. Scholars have considered it unlikely that Paccius is referring here to De animae procreatione in Timaeo, because this treatise is composed (much like De tranquillitate animi itself) in the form of an open letter to the author's sons Autobulus and Plutarch (IOI2A). However, De animae procreatione in Timaeo may in itself be based on one or more Quaestiones Platonicae, or rather on similar underlying notes. See H. Cherniss, I976, p. I33 and F. Ferrari and L. Baldi, 2002, p. 9.

131 H. Cherniss, I976, p. 4, n. b.

132 See J. Opsomer, 20I0, pp. 94-95. Notably, Plutarch only mentions that he extracted

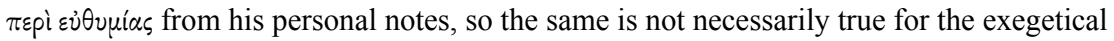
material of the Timaeus also, although this is not unlikely, of course. Paccius' twofold petition can perhaps be taken to imply, then, that he asks Plutarch to send him something on tranquility and - since he presumably has to browse through his personal archive anyway - to attach some exegetical material regarding the Timaeus as well.

133 J. Glucker, I978, p. 264 even argues that "it is not unlikely that his [sc. Plutarch's] 
Another indication of the publishable character of Plutarch's collections of quaestiones is found in Plutarch's aforementioned self-references

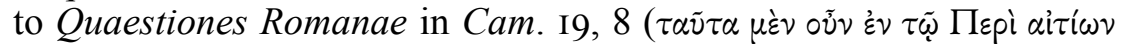

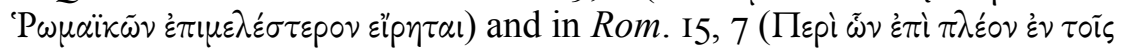
Airioıs) [see 2.I.4.]. These references would be meaningless if the collection was meant for personal use only, that is, as a private set of inquiries into Roman antiquities that was not made accessible to the intended reader of the Vitae. Therefore, scholars have accepted that Quaestiones Romanae was published by Plutarch himself and made accessible to a broader circle of readers who were interested in such antiquarian matters ${ }^{134}$. In this regard, it is important to note that these self-references explicitly indicate the aetiology to be more detailed in Quaestiones Romanae than

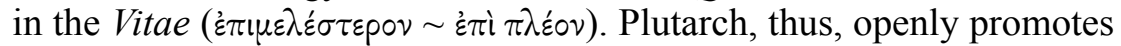
the antiquarian research from Quaestiones Romanae to the reader in these passages, by declaring that he has collected this kind of knowledge in a separate and more specialised way there. Arguably, due to the fact that the

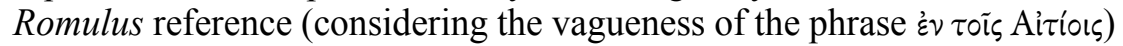
is less precise than the Camillus reference (which specifically refers to Quaestiones Romanae), it is not unlikely that by the former, Plutarch is referring to his aetiological works in general, rather than to one specific collection of quaestiones. There is debate among scholars as to whether the Romulus reference refers specifically to Quaestiones Romanae or, more generally, to the entire triptych collection of Quaestiones Romanae,

\footnotetext{
Platonicae Quaestiones were written among other things, in response to such [c.q. Paccius'] inquiries", but it is just as likely that Plutarch already had the material on hand before such requests came to his address. Scholars have argued, moreover, that Plutarch himself also had access to other people's archives and libraries. See J. Sirinelli, 2000, p. 283: "Plutarque a sans doute beaucoup travaillé sur des notes ou des documents qu' on lui avait préparés." According to R.H. Barrow, 1967, p. I52, Plutarch perhaps even contacted his Roman friends for information via letters, just as Paccius does in the introduction to De tranquillitate animi. Such a request is, indeed, found in the introduction to $D e E$, albeit

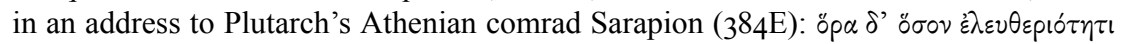

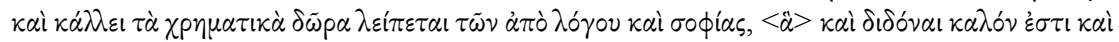

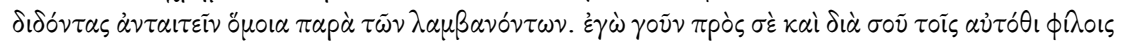

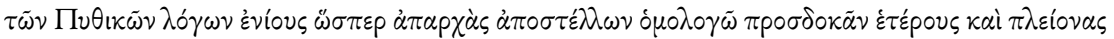

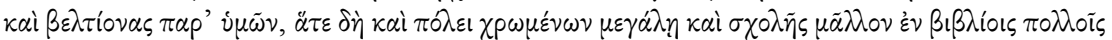

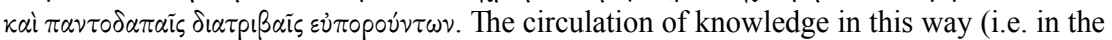
form of problems, notes, excerpts etc.), was in fact very customary among intellectuals in Plutarch's time, which certainly testifies to a high degree of intellectual freedom and promiscuity. See, e.g., E. Lao, 2008, p. 36 (with a discussion of Pliny, Ep. 3, 5, I7).

134 See, e.g., H.J. Rose, I924, pp. 47-48, K. Ziegler, I95I, cols. 857 and 860, R.H. Barrow, I967, p. 66, J. Boulogne, I992, p. 4687, I994, p. I26, I998, p. 31, J.-M. Pailler, I998, p. 77 (pace W.R. Halliday, I924, p. I3 with W. Nachstädt, W. Sieveking and J.B. Titchener, I935, p. 274).
} 
Graecae and the lost barbaricae ${ }^{135}$. If it is true, however, that Plutarch is referring to his aetiological writings in a more generic way, it is not unlikely that the reference also covers his other collections of Aitial, thus including Quaestiones naturales ${ }^{136}$ [see I.I.4., n. 9I].

Interestingly, on the basis of these two self-references in the Vitae Boulogne designated Plutarch's Quaestiones Romanae to be an autonomous 'work of reference' 137 , that is, so I take it, a depository of specialised antiquarian inquiries that is worth referring to whenever suitable. In line with Boulogne, I believe that Quaestiones naturales can be considered a 'work of reference' also. Indeed, the aetiologies in Quaestiones naturales are often more detailed than in their parallel accounts [see 2.I.2.]. Moreover, in Lys. I2, 7, Plutarch concludes the digression on the meteorite that fell in Aegospotami by referring the interested reader to the $\gamma^{\varepsilon}$ vos

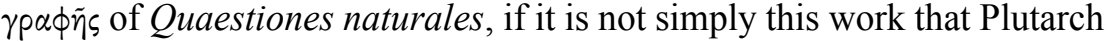
had in mind [see 2.I.4.]. Of course, Boulogne's designation of collections of quaestiones as 'reference works' should not be understood in a modern sense (i.e. as systematic encyclopaedias, handbooks, manuals or the like). In the end, there is no clear structure to these collections nor a table of contents, by the use of which material can be easily traced in the collection. By contrast, it seems that these collections provide a more general 'frame of reference', that is, a general explanatory framework in accordance with which problems could be properly solved.

As we will see in the next chapter, this 'referential framework' proves specifically useful for didactic purposes [see 3.2.I.]. Plutarch's collections of quaestiones could be consulted and used by the reader to retrieve clearly shaped but roughly finished information whenever this was needed. It is perhaps not inappropriate, therefore, to consider the genre of problems as an integral part of ancient 'functional literature' (Gebrauchsliteratur, letteratura di consumo $)^{138}$. The aspect of utilisation and consumption

135 See R.H. Barrow, I967, pp. 66-67, esp. n. I (on p. I84) and J. Boulogne, I998, p. 3I and 2002, p. 9I. Cf. also T.S. Schmidt, I999, p. IO, n. 38 and R. Preston, 200I, p. 95 (with n. 44).

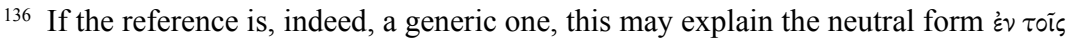

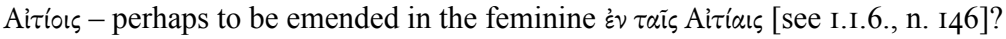

137 J. Boulogne, I992, p. 4686 and I998, p. 3I ("un ouvrage de référence"); cf. also 2002, p. 92 ("un livre de référence sur Rome"). K. Oikonomopoulou, 20I3a, pp. I44I47 has recently suggested that each of Plutarch's collections of quaestiones function as encyclopaedic-style reference works. Note, moreover, that Aristotle also explicitly refers to his Problems on several occasions throughout his writings: see Mete. $363 \mathrm{a} 24$ (cf. also 38rbi3), Somn. vig. 456a29, Iuv. 470aI8, PA 676aI8, GA 747b5, 772bir, 775b37. See P. Louis, I99I, pp. xxv-xxvii.

138 See the contributions in O. Pecere and A. Stramaglia, I996. J. Opsomer, 20I0, p. 95 suggests (somewhat hesitantly) to speak of the implied reader in Plutarch's quaestiones as "un 'utilisateur', en présupposant un contexte didactique". Cf. also p. II5: "Le lecteur- 
of ancient problem literature can, indeed, be illustrated from several papyri that were edited in the question-and-answer format, some of which contain extracts from Plutarch's quaestiones ${ }^{139}$. The existence of these papyrological sources, the origin of which is generally linked to the context of schooling, at least testifies to the importance of question-and-answer literature in ancient education. Arguably, the kind of theories, concepts and argumentative turns Plutarch uses in his collections of quaestiones could be reused and remoulded in new discussions concerning similar problems in any given situation (for instance during symposia, as described in Quaestiones convivales). As such, one could even compare these collections of quaestiones to, say, instruction manuals, atlases, books of recipes, or other kinds of 'open source' literature, that is, literature that is 'open' for free use and re-use by the reader. By its interrogative structure, the content of this kind of literature is, indeed, very dynamic, and the response triggered by it will differ from reader to reader in a considerably idiosyncratic fashion.

In conclusion, it is not unlikely that Quaestiones naturales did not remain locked up in Plutarch's office, but that it was made accessible to interested readers, or that the Chaeronean at least envisaged to prepare it for publication at some point, presumably in an educational context. In light of the idea that Plutarch's collections of quaestiones were probably made accessible to a group of interested readers that stood in close contact with Plutarch himself, Sirinelli has appropriately called the Chaeronean "un homme-ressource" (rather than that he was "un esprit véritablement encyclopédique") ${ }^{140}$. Regarding Plutarch's transfer of knowledge in the problem format, Sirinelli's conclusion is worth quoting in full:

"Plutarque a pu céder aux sollicitations de ses amis qui ont fait valoir l'intérêt que présenteraient ces collections [de problèmes] pour un

ou utilisateur - idéal devait être familier avec les règles du genre, qui n'incluent pas seulement l'usage idiomatique de certaines particules et phrases, mais aussi l'usage de certaines stratégies textuelles et argumentatives."

139 Some papyrus fragments remain from Quaestiones convivales (PSI inv. 2055, PL III 543 A; see G. Messeri Savorelli and R. Pintaudi, 1997, pp. I74-177) and also (possibly) from Quaestiones Graecae (P. Oxy. 2688 and 2689; see W. Morel, 1969, p. 219). P. Oxy. $2744\left(2^{\text {nd }}\right.$ century AD) contains Ps.-Arist./Alex. Aphr., Suppl. probl. 2, I56 (= Probl. ined. 2, I53) and attributes it to Aristotle's $\dot{\alpha} \pi \circ \eta^{\prime} \mu \alpha \tau \alpha$. See S. Kapetanaki and R.W. Sharples, 2006, p. 23I, n. 466. In addition, several fragments from a papyrus codex of Books two to five from Ps.-Plutarch's/Aëtius' Placita have also survived (P. Antinoopolis 85 and 213). See also more generally R. Cribiore, 200I, pp. 208-209 and 2I2. In addition, there is a Greek papyrus from the $\mathrm{I}^{\text {st }}$ century $\mathrm{AD}$ (P. Berol. inv. 9764), which mentions the

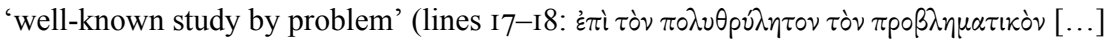
$\lambda$ 'ó 0 ). See M.-H. Marganne, I998, pp. 13-34.

140 J. Sirinelli, 2000, pp. 365-366. 
public intéressé par les questions traitées; c'était du reste la mode des collections de citations, de pensées ou de faits marquants. [...] Ce n'était pas une tâche mineure et indigne d'un écrivain de qualité mais même, à une époque où les bibliothèques demeuraient rares, un instrument intellectuel très prisé. [...] Cette pratique prouve seulement une conception différente du métier et des devoirs d'écrivain et, dans le cas de Plutarque, nous éclaire un peu mieux sur ce qu' on attendait de lui, sur les sources du savoir à cette époque et ce qu' on entendait alors par la fonction de communication et d'information." 141

Now that we have considered the publishable character of Plutarch's collections of quaestiones and their general usability as school texts, I will shortly reflect on their actual method of storage, with specific attention to aspects of thematic classification and overlap. Further indications of Plutarch's school context in Quaestiones naturales will be discussed in the next chapter [see 3.I.].

\section{Classification and overlap}

Jacob identified the genre of problems with sets of index cards ("fiches"), which are further categorised into thematic folders ("dossiers de travail") ${ }^{142}$. Even though, nothing is known with any certainty about the actual form and organisation of Plutarch's archive, scholars have often also conceived of it in a very concrete, physical way, imagining it as some sort of a systematised card-index box ${ }^{143}$. In a very similar way, Plutarch's collections of quaestiones serve as a discursive medium for the storage of several kinds of inquiries. They provide an accumulative textual format for the author's progressive research, where new problems and answers could always be added or older ones revised. The thematic categorisation of Plutarch's collections of quaestiones, by distinguishing several subsections (viz. antiquarian, scientific, literary, philosophical etc.), certainly improved their efficient usability, even if they are not catalogued in a fully

141 J. Sirinelli, 2000, p. 365.

${ }^{142}$ C. Jacob, 2004, pp. 43-44 (with K. Oikonomopoulou, 20I3a, p. I34). Jacob also points out that these problems are no simple notes because of their coherent language and style. Furthermore, in regards to the composition of Quaestiones convivales, J. Sirinelli, 2000, p. 386, n. I notes: "Il serait passionnant de pouvoir déceler dans les Propos de table tels qu'ils se présentent aujourd' hui les traces d' un classement des archives de Plutarque. On sent parfois dans telle ou telle séquence de plusieurs dîners, enjambant même la division en livres [...], un air de parenté qui suppose une classification originelle par thèmes et non par convives."

${ }_{143}$ See already A. Gudeman, I927, col. 2526, who speaks of "Zettelkasten". See also T. Dorandi, 2000 more generally. On ancient conceptions of memory in itself as an 'archive', see J.P. Small, I997, pp. 8I-I37, 224-239. 
systematic fashion [see I.I.4.]. Yet, at the same time, the technique of thematic categorisation seems to have had specific disadvantages, since on certain occasions, there may have been difficulties in classification.

Take, for instance, Quaest. Plat. 7, 1004D-I006B, which deals with the mechanism of $\dot{\alpha} \nu \tau i \pi \varepsilon$ í $\sigma \tau \alpha \sigma \varsigma$ and its operation in several natural phenomena as discussed in Tim. $79 \mathrm{e}-8 \mathrm{oc}^{144}$. Plutarch chose to classify this problem with Quaestiones Platonicae, considering the close link with Plato's text. But because of its focus on physics and natural phenomena, it would perhaps not have been out of place in Quaestiones naturales either ${ }^{145}$. There is, in fact, a close parallel on magnetism between Quaest.

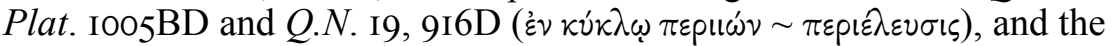
theory of $\dot{\alpha} \tau \tau i \pi \varepsilon p i \sigma \tau \alpha \sigma i s$ also recurs in $Q . N$. $13,915 \mathrm{~B}$ (moreover, Plato is quoted in Q.N. I, 9IID and 5, 9I3CD [see 4.2.I.I.]). I believe that this type of thematic overlap contributes to a sense of mutual coherence between Plutarch's collections of quaestiones more generally, which is also seen at work elsewhere.

Notably, there is also room for physical aetiology in Quaestiones

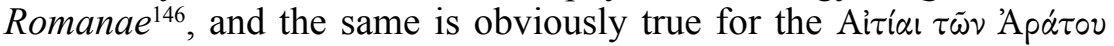
$\Delta ı \sigma \eta \mu i \tilde{\nu}$ (frs. 13-20 Sandbach). Another interesting example can be found in Quaest. Graec. 7, 292CD, which deals with the so-called floating clouds. The link with Greek culture is not very clear in this chapter. In fact, it is rather problematic. Perhaps this chapter ended up in the wrong folder in Plutarch's archive by mistake. According to Halliday, "Plutarch would more tidily have placed [this 'alien'] among his Aetia Physica"147. This is certainly supported by the fact that Plutarch quotes from the fourth Book of Theophrastus' Meteorology (I92 FHSG). The wrong (re?)location of this problem can perhaps speak to the practical, but at times, indeed, hasty and messy, use and consultation of Plutarch's collections of quaestiones (perhaps by his students?). However, at a more conceptual level, it is not unlikely that these examples rather demonstrate how physical aetiology is an important unifying factor that effectively contributes to the general coherence of Plutarch's corpus of quaestiones, and hence of his oeuvre more generally ${ }^{148}$ [see 2.I.2.].

144 See J. Opsomer, 1999 [see 4.3.I.2., n. 176].

145 Cf. K. Oikonomopoulou, 20I3a, p. I44.

146 Cf. Quaest. Rom. I, 263E, 2, 264B, 19, 268CD, 24, 269CD, 38, 273E, 77, 282CD,

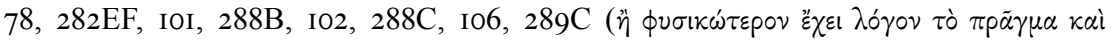

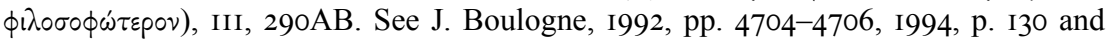
2002, p. 98.

147 W.R. Halliday, 1928, p. I4. Other physical material is found in Quaest. Graec. Io, 293A (on the small plant called 'sheep-escaper') and to a lesser degree 9, 292E (on the

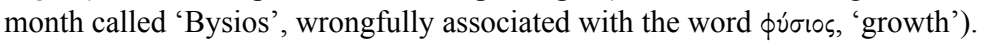

${ }^{148}$ Cf., e.g., C. Darbo-Peschanski, I998, p. 28 for the 'cosmological' connection 
Of course, physical aetiology is not the only unifying factor. Also the other way around, a number of chapters treated in Quaestiones naturales express a sensitivity for cultural-antiquarian inquiry, which reminds the reader of the problems treated in Quaestiones Graecae. This is the case, for instance, in Q.N. I0, 9I4D, where Plutarch refers in parenthesis to a story told about the people of Halieis, who received an oracle instructing them to dip Dionysus in the sea. Similarly, in Q.N. I4, 915C, Plutarch wonders why the people of Doris pray for a bad harvest of hay. And in $Q . N .23,9 \mathrm{I} 7 \mathrm{~F}$, he explains why people do not hunt in the vicinity of Mt. Etna in Sicily. Moreover, the method of incorporation of quotations from the poets, such as Homer or Aratus, is reminiscent of the exegetical-aetiological approach

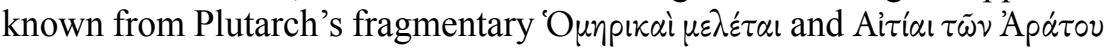
$\Delta \iota \sigma \eta \mu \tilde{\omega} \nu$ (Homer is quoted in Q.N. 5, 913D, 19, 916B, 20, 917 A, 2I, 917D, 34 and Aratus in Q.N. 2, 9I2D [see 4.I.2.3.]) $)^{149}$. Arguably, these overlaps do not only testify to the, at times, very close affiliation between the different research projects in Plutarch's collections of quaestiones, but also reveal the openness and all-round applicability of many kinds of knowledge to different contexts - a dynamic that lies at the heart of Plutarch's $\pi 0 \lambda \nu \mu \alpha \dot{\theta} \theta \varepsilon \alpha$ project $^{150}$.

\section{Conclusion and new questions}

In conclusion, Plutarch's interest in natural problems is an important unifying factor throughout his entire oeuvre, both in the Vitae and the Moralia. The collection of Quaestiones naturales holds an important position in this regard, because Plutarch there aims to treat such problems mostly on their own terms. As such, the collection provides an independent textual medium that allows for Plutarch to autonomously store and retrieve the results of his research on specific natural scientific topics. He could refer the interested reader to this work whenever necessary, making it a work that was certainly publishable. From the perspective of composition, Quaestiones naturales oscillates between simple notes and

between Quaestiones Romanae/Graecae and the Vitae: "Les Aiآı ne seraient donc pas un simple recueil de curiosités sur lesquelles un esprit érudit s' exercerait à des tentatives d'explication pour le plaisir de spéculer. Ils semblent s' inscrire dans la logique des oeuvres jugées les plus importantes de Plutarque et, comme les Vies ou les traités physiques, mettre au centre de leur propos la rationalité du devenir et du cosmos ainsi que les limites de la connaissance qu' on peut avoir de celle-ci."

149 Notably, Plutarch's collection of 'O $\mu$ p Sandbach remain) also had specific physical interests: fr. I27 Sandbach concerns the atmospheric influence on the consistency of the shoots of plants.

${ }^{150}$ Indeed, the aspect of diversity ( $\pi \supset \lambda v \varepsilon 1 \delta(\alpha)$ ), as a typical feature of Hellenistic poetics, is brought to a climax in the miscellaneous Quaestiones convivales. See I. Gallo and C. Moreschini, 2000, pp. I4-I5. 
a fully elaborated treatise. The relationship with Quaestiones convivales is important, because both works are closely related from a text genetic perspective, probably being based on the same and similar hypomnematic material. It remains to be seen, however, to which degree Plutarch's intentions with these two works coincide in terms of their educational goals. New questions emerge, especially concerning the concrete reading of Quaestiones naturales (vis-à-vis Quaestiones convivales). Who are the intended readers of Plutarch's natural problems? What is their function and how do they relate to Plutarch's overarching educational project? These questions will demand a closer examination of the socio-cultural and intellectual-philosophical context from which Plutarch's natural problems emerge. These and related issues will be treated in the following chapter. 



\section{3 \\ Quaestiones naturales and zetetic $\pi \alpha \iota \delta \varepsilon i \alpha$}

Throughout the corpus Plutarcheum, we find important information about the intellectual value of Plutarch's natural problems and their popularity in the author's social milieu. The aim of this chapter will be to focus on the socio-cultural and intellectual-philosophical backdrop of Quaestiones naturales. I will start by discussing the collection's social Sitz im Leben by reconstructing its implied readership and educational context. Afterwards, I will zoom in on the work's educational interests, arguing that the search for physical causes is inspired not only by generally scholarly but also genuine philosophical motives. Plutarch's natural problems, thus, promote some kind of 'intellectual gymnastics' and serve as a preamble to higher, meta-physical speculations.

\section{I. Sitz im Leben: readership and educational context}

Even though there is no proof that Plutarch self-handedly published Quaestiones naturales, we have seen in the previous chapter that the work is, in any case, publishable and that Plutarch presumably also prepared it for publication [see 2.4.I.]. There is debate, however, as to what kind of readership the collection is meant to address ${ }^{1}$. According to Sandbach, the work was intended "for circulation among interested friends, but not for a general public" de notes [sc. Questions Grecques, Romaines, Physiques] étaient destinés à l'usage privé, peut-être à des exercices d'école, mais non promis à l'édition publique" 3 . Senzasono, by contrast, has argued that Plutarch prepared the publication of Quaestiones naturales not for a select group of friends but for a large readership ${ }^{4}$. For most ancient works, however,

${ }^{1}$ C. Hubert, 1960, p. v left this question open: "Has quaestiones, [...] utrum Plutarchus ipse in volgus ediderit an tantum in suum usum conscripserit, ut materiam praeberent qua in futuris libris condendis (velut Quaestionibus Convivalibus) uteretur, litigari potest [...]."

2 F.H. Sandbach, 1965, p. 135.

${ }^{3}$ F. Fuhrmann, 1972, p. xiii. Cf. already H. Bolkestein, 1946, p. 27: "ad privatum usum conscripta esse videntur [sc. "[i]psa haec quaestionum corpuscula Problematis illis non dissimilia [...] quae sub Aristotelis nomine circumferuntur"] aut ut scholas habenti fortasse ad manum essent, certe non ut ab omnibus legerentur, tamquamsi elegantium litterarum essent monumenta".

${ }^{4}$ L. Senzasono, 2006, pp. 45-46: "Se Plutarco ha elaborato lo stile, come appare 
the standard avenue of publication was to first circulate a text among peers, who, in their turn, made copies and spread them among their own peers, thus causing an exponential growth of the text's readership ${ }^{5}$. One may wonder, therefore, who the initial, intended readers of Quaestiones naturales were and what we can learn about the collection as "exercises d'école".

Unfortunately, there is no formal guide, no preface to Quaestiones naturales which could shed a light on the collection's aetiological organisation and programme. In any case, Q.N. I does not have any programmatic value (though it may contain a subtle Platonic $\sigma \phi p \alpha \gamma i s$, as we will see later on [see 4.2.I.I.]). One seminal passage that attests to the intellectual agenda of Quaestiones naturales as a whole can be found in Q.N. 29, 919AB. Here, Plutarch's vituperation of people's superficial marvel for rare natural phenomena (as discussed earlier on [see I.2.3.]) can be seen as an appeal to a serious and mature study of nature. Plutarch's tirade against the common people, of course, does not imply that he is writing for the common people - they would, in any case, draw little benefit from it -, but rather, for people who have already begun their studies in (natural) philosophy or are, in any case, informed about its basic principles, concepts and procedures. The implied reader, then, is invited to carry out his physical inquiries, in order to distinguish himself from the common plebs who are unfamiliar with the finer elements of physical aetiology. Bearing in mind that Plutarch's intended reader was probably an informed reader, in what follows, I will try to clarify in what precise contexts such natural problems were useful, then.

\section{Natural problems and philosophical $\sigma \chi 0 \lambda \eta \dot{~}$}

In regards to the exemplary cowardice of Aratus (the famous Greek general and statesman) in the presence of seeming peril, Plutarch notes (Arat. 29,6 ) that the physiological symptoms of heart palpitation, change in the colour of one's skin, and looseness of the bowels, are popular questions

chiaro, l'ipotesi della destinazione a un circolo di amici cade o almeno appare improbabile: agli amici egli poteva dare degli appunti inconditi ma chiari o tutt'al piú una serie di problemi non elaborati stilisticamente ad uso pratico. L'elaborazione induce senz'altro a propendere per l'ipotesi della pubblicazione destinata al grande pubblico. [...] [S]i può ritenere altamente probabile che Plutarco, una volta portato a termine l'opuscolo, lo affidasse, subito o qualche tempo dopo, ai copisti per una pubblicazione destinata al grande pubblico."

${ }^{5}$ See R. Starr, 1987, who discusses the circulation of (literary) texts in the Roman world on the basis of widening concentric circles depending on the varying degrees of friendship (he distinguishes circles of friends from those of strangers, i.e. friends of friends etc.). Thanks are due to K. Oikonomopoulou for this reference. 


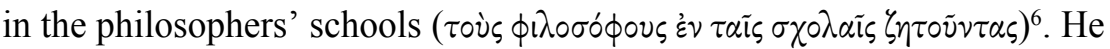
explains that these topics are generally accounted for in a twofold manner, viz. by reference to Aratus' cowardice (i.e. in an ethical sense) and some defective disposition and coldness in the body (i.e. in a physical sense):

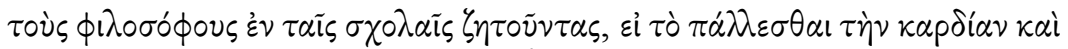

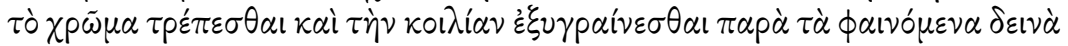

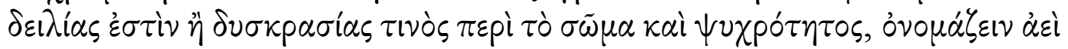

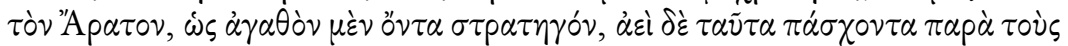
$\dot{\alpha} \gamma \tilde{\omega} v \alpha \varsigma$.

In the schools of philosophy, when the query arises whether palpitation of the heart and change of colour and looseness of the bowels, in the presence of seeming peril, are the mark of cowardice, or of some faulty temperament and chilliness in the body, Aratus is always mentioned by name as one who was a good general, but always had these symptoms when a contest was impending.

Parallels can be found for this in Book 27 of Ps.-Aristotle's Problems

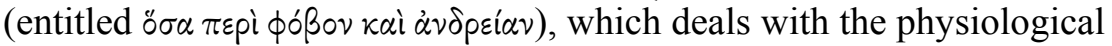
manifestation of fear and courage in the human body more generally ${ }^{7}$. Notably, some of the symptoms that are mentioned in the Aratus passage are also recorded or alluded to in Quaestiones naturales. In Q.N. II, 9I4EF, for instance, the natural phenomenon of people's bowels turning to water

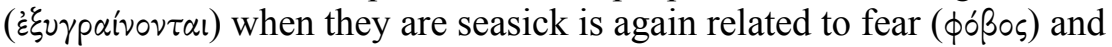
implicitly also to cold, as the persons suffering from this condition tremble

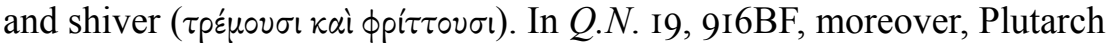
deals with the change of colour in the octopus' skin colour, arguing that

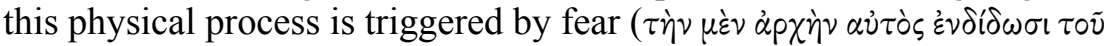
$\pi \dot{\alpha} \theta$ ous $\delta \varepsilon i \sigma \alpha \varsigma)$. What we can learn from the Aratus passage, then, is that the kind of natural problems treated in Quaestiones naturales must have been particularly useful for discussions in Plutarch's philosophical school context also ( $\dot{\varepsilon} \nu \tau \alpha i \bar{\zeta} \sigma \times 0 \lambda \alpha i \bar{i} s)$.

As seen before, the practice of solving natural problems goes back on Aristotle's teaching in the Lyceum [see I.I.3.]. It is interesting to see, then, how the genre became well-entrenched also in Plutarch's own

${ }^{6}$ A similar passage is found in Per. 35, 2, where Plutarch refers to the story that is

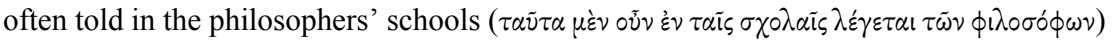
about Pericles' attempt to overcome the fear of his skipper for an eclipse of the sun by keeping his cloak before the man's eyes, thus drawing an analogy with the sun's obscuration by the moon.

7 See L.M. Castelli, 20II. As to fear turning people's bowels to water, cf. Ps.-Arist., Probl. 948b35-949a8 (with Gell., NA i9, 4). 
philosophical school ${ }^{8}$. Arguably, the Ps.-Aristotelian Problems themselves were actually read, studied, and discussed in Plutarch's philosophical school, thus, serving as some kind of a text-book model by which Plutarch and his peers were inspired to perform similar research ${ }^{9}$. There is no direct evidence for this, but it may be relevant that L. Mestrius Florus is found discussing a copy of the Problems with his friends - including Plutarch in Quaest. conv. 734CD [quoted 3.2.I.]. Similarly, we also have evidence from Gellius that the Problems were read and discussed in another Platonic school context, viz. in the school of his teacher L. Calvenus Taurus, who was a Platonist and may have even been one of Plutarch's students ${ }^{10}$. How does Plutarch's own research into natural problems fit in with his educational programme, then, and what can we learn, in this regard, about his industriousness as a philosophy tutor?

\section{Plutarch's academy}

Plato's Academy had ceased to exist as a philosophical institution for more than two centuries by the time of Plutarch's death (it closed with the sack of Athens by Sulla in 86BC). In his home town of Chaeronea, however, and presumably in his own house, Plutarch directed "eine Art Filiale der

${ }^{8}$ Cf. M. Schuster, I9I7, p. 37: "Mit gutem Grunde dürfen wir die aetia physica als eine Sammlung von Problemen ansprechen, die in Plutarchs Schule zur Erörterung gekommen sind; es sind die alten bekannten Probleme, an denen die philosophischen Schulen seit Aristoteles gearbeitet haben und die den Schülern reichen Stoff zu Disputierübungen boten." See also K. Ziegler, I95I, col. 664 (quoted below). On the use of Ps.-Aristotle's Problems as a school handbook in the Lyceum, see, e.g., H. Flashar, 1962, pp. 34I-346. On the use of problems more generally in pedagogical contexts, see already A. Gudeman, 1927, col. 2529: "Weit lebenskräftiger erwies sich diese Methode [sc. of $\lambda \dot{\sigma} \sigma \varepsilon ı$ ] sowohl in der Praxis der Schule wie in der Literatur, insofern sie dazu diente, allerlei Kenntnisse zu vermitteln [...]." See also, e.g., C. Jacob, 2004.

${ }^{9}$ Cf., e.g., F. Fuhrmann, 1972, p. xxi: "Plutarque s' inspire surtout [...] du Corpus aristotélicien, particulièrement des Problèmes, qu'il croyait authentiques et qui représentaient un manuel de prédilection pour les gens cultivés”.

${ }^{10}$ In $N A$ 19, 6, Gellius reports that when he was a student in Athens he read and discussed a passage from the Problems (fr. 243 Rose) together with his teacher L. Calvenus Taurus. K. Oikonomopoulou, 20I3a, p. 137 connects this with the school practice of

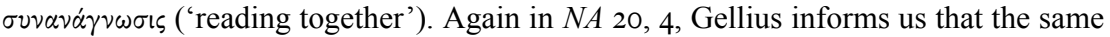

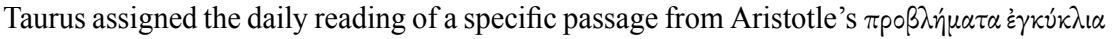
to a student to divert him from his company with actors (see M. Meeusen, forthcoming e). On Taurus' role in the Noctes Atticae more generally, see M.L. Lakmann, 1995 (esp. pp. 2I6-220 on his "Schulpraxis"); see also pp. 227-228 for Taurus' relationship with Plutarch (Lakmann remains sceptical about Taurus being a student of Plutarch, though). On Taurus' sympotic teaching methods, see also G. Roskam, 2009, pp. 377-379 (with n. 30 for further reading). 
athenischen Akademie"11, where he, after the manner of his own teacher in Athens, Ammonius ${ }^{12}$, taught philosophy with a particular interest and specialisation in the writings of Plato and the Academic tradition ${ }^{13}$. Apart from the existence of this school under the directorship of Plutarch, not much is known about its actual organisation and daily routines. Most scholars agree that it was not a very official institution ${ }^{14}$. We do not, in any case, have any account of Plutarch's school practices. There aren't any course schedules nor are there any lists of students who attended Plutarch's classes. Thus, we simply do not know how many students Plutarch tutored, where they came from, or what social or intellectual background they may have had. Nevertheless, we are not entirely bereft of information, because throughout his oeuvre, Plutarch hints at the general school-protocols in his academy and informs us about his teaching methods, the subjects of his courses, and, most notably, how students should behave during lectures.

In his I9I7 study of De sollertia animalium, Schuster goes into the details of Plutarch's tutorship often with a great amount of imagination (at times, perhaps, even too much) ${ }^{15}$. From Plutarch's texts, we can deduce only more general institutional customs and educational practices. We learn that Plutarch's method of instruction entails a number of different approaches. Thus, Schuster distinguishes between Plutarch's acroamatic and erotematic teaching ${ }^{16}$. Among Plutarch's writings, we come across $e x$ cathedra course-lectures, such as Adversus Colotem and De communibus

${ }^{11}$ K. Ziegler, I95I, col. 663. Cf. F. Fuhrmann, I972, p. xviii: "une manière de petite

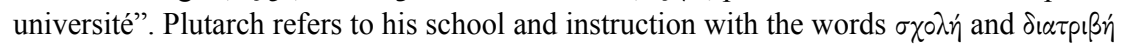
(cf., e.g., De aud. 42A, De E 385A, Quaest. conv. 613C, 613F, 702A, 705B, 713C, De facie 929B, 942C). See M. Schuster, I9I7, p. 2 and J. Opsomer, I998, p. 25 (with n. 6I).

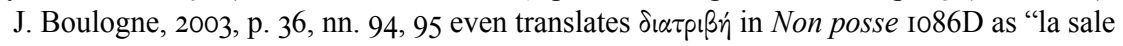
de conférences".

12 For a philosophical profile of Ammonius, see J. Opsomer, 2009. See also P. Donini, I986b.

${ }^{13}$ In De soll. an. 964D, Plutarch's father Autobulus says that his son, under the direction of Plato, instructs inquisitive persons who have no love of wrangling ( $\Pi \lambda \dot{\alpha} \tau \omega \nu \circ \varsigma$

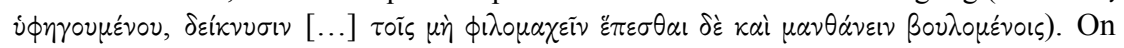
Plutarch's school pragmatics, see, e.g., J. Boulogne, 2003, pp. 34-37. For further reading on the Academy and Plutarch's school, see J. Opsomer, I998, pp. 2I-26.

${ }^{14}$ For the informal character of Plutarch's academy, cf., e.g., K. Ziegler, I95I, cols. 662-663, R.H. Barrow, I967, pp. I8-19, D.A. Russell, I973, p. I3, J. Glucker, 1978, pp. 257280, J. Boulogne, 2003, p. 34 and J. Bouffartigue, 20I2, p. xix. Pace M. Schuster, I9I7, pp. I9-2I.

15 Take, for instance, his argument that the lessons took place at fixed hours and that the ancient Greeks were early risers (M. Schuster, I9I7, pp. 20-2I). Did Plutarch use a school bell, by the way (cf. Cic., De or. 2, 5, 2I)?

${ }_{16}$ M. Schuster, I9I7, p. 27. 
notitiis adversus Stoicos ${ }^{17}$, where the students play a rather passive role and just have to listen to what is said. However, there are also philosophical discussions that require much more active input from the students in formulating their own well-reasoned opinions on certain subjects, as can be seen in Non posse $e^{18}$.

Interestingly, Plutarch at times reports from his own years as a student under Ammonius. In Quaest. conv. 645D-646A, for instance, we read that after a dinner party in Athens flower garlands were offered to the symposiasts. Ammonius ridicules the custom of wearing such garlands and considers it a girlish habit, so the young men who were present at the event took them off out of shame. Plutarch, still a pupil himself at the time (and a diligent one), knew, however, that Ammonius actually threw this problem in the middle of the group not so much to offend the young men

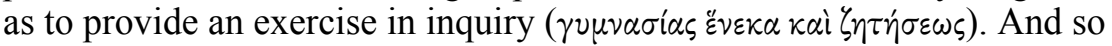
the sympotic discussion about the natural properties of flower garlands and ivy begins.

A similar passage to illustrate how the students' own zetetic skills are put to the test in a mostly competitive situation, when prompted to answer to a problem put forward by the teacher, is seen in De sollertia animalium. The second part of this work is presented as a school discussion about the intelligence of animals. In the preceding discussion between Autobulus and Soclarus, we read that a symposium took place the other day, during which someone read an encomium of hunting. The symposiasts declared that all animals are, to some extent, rational and partake in $\delta \alpha^{\alpha} v o l \alpha$ and $\lambda \circ \gamma ı \sigma \mu o ́ s$. In light of this understanding, Aristotimus and Phaedimus, two of Plutarch's students ${ }^{19}$, received their formal assignment for their discussion $(\dot{\alpha} \gamma \omega \dot{\omega} v)$, viz. to determine whether land or sea animals are more clever. In the discussion that follows, each of them defends the opposite case. The use of such contradictory discussions, in which topics are argued

${ }^{17}$ In Adversus Colotem Plutarch gives the course himself (cf. IIo8Bff.), but in De communibus notitiis adversus Stoicos (cf. I060Bff.) this task is allotted to Diadumenus (presumably Plutarch's double: cf. D. Babut, 1969, p. 38).

${ }_{18}$ In a recent study of Plutarch's conceptualisation of teacher-student communication, G. Roskam, 2004 has analysed the level of independence that students were allowed. He thus distinguishes between a propaedeutic stadium (under the guidance of the $\pi \alpha 1 \delta \alpha \gamma \omega \gamma o$ s, the $\delta i \delta \dot{\alpha} \sigma \kappa \alpha \lambda \circ \varsigma$, and the $\gamma p \alpha \mu \mu \alpha \tau \leqslant \kappa o ́ s$ ) and the actual philosophical $\pi \alpha i \delta \varepsilon i \alpha$ (under the guidance of a $k a \theta \eta \gamma \eta \tau \dot{\eta}$ ). The first stadium is generally passive-receptive for the student and monologic for the teacher, and the second stadium more active and dialogic. More generally useful in the context of ancient education are H.-I. Marrou, I948 (esp. pp. 252-255 and 289-299 regarding to the use of problems), T. Morgan, I998, R. Cribiore, 200I and the contributions in Y.L. Too, 200I.

${ }_{19}$ See M. Schuster, I9I7, pp. 57 ff. and H. Cherniss and W.C. Helmbold, I957, p. 3I2, n. b. 
from both sides, was a common practice in philosophical schools (i.e. the

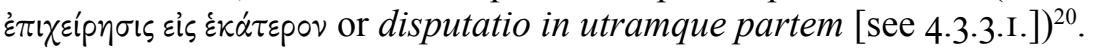

In most of Plutarch's dialogical writings, however, more than two persons participate in the discussion, so that a multiplicity of answers is given, each of which illuminates a specific aspect of the complex problem at hand. It is the task of the teacher or the presiding moderator of the debate to steer the discussion in the right direction, then ${ }^{21}$. He can do this by adducing a range of questions and problems (as marked with the

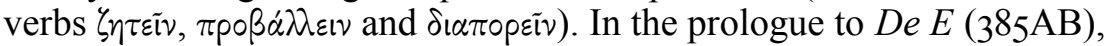
for instance, we read that the problem of the enigmatic $E$ at Delphi had been brought up many times in school discussions ( $\dot{\varepsilon} \nu \tau \tilde{\eta} \sigma \chi 0 \lambda \tilde{\eta})$, but that thus far, Plutarch had avoided it. Now that he is confronted with the same problem in the presence of his sons and some strangers who are about to leave Delphi, he feels embarrassed to divert the discussion any longer. Plutarch then creates a schoolish setting by finding a place for himself and his audience to sit near the temple and by looking for answers himself

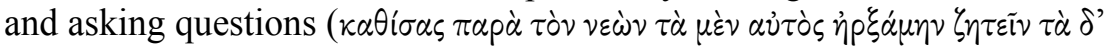

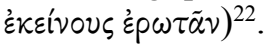

Of course, the student was also allowed to ask questions himself, often after the lectures ${ }^{23}$. However, Plutarch writes in De aud. 42E-44A that the student should follow certain rules in doing so. We read, for instance, that those individuals who lead the speaker to digress to other topics, interject questions or raise new difficulties are not pleasant or agreeable

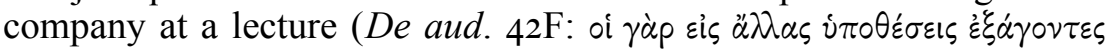

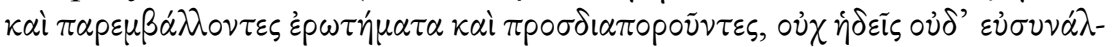

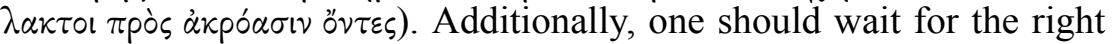
time to ask a question and only ask questions that are useful and relevant. The questions should also be adapted to the speaker's competence and

20 The same format also lies at the basis, e.g., of Plutarch's Aqua an ignis sit utilior, which may originate from a similar school exercise (for the issue of authenticity [see I.I.I., n. 8]).

21 For Plutarch's i $\gamma \varepsilon \mu o v i ́ \alpha$, e.g., in Adversus Colotem and Non posse, cf. H. Adam, I974, p. 6. The debates often take place under the guidance of the teacher, but another leading figure can also fulfil this task, e.g. the $\sigma u \mu \pi$ ríapxos in case of a symposium (see Quaest.

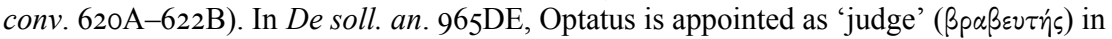
the discussion, because he is considered to be an expert on Aristotle's writings ( $\Delta \varepsilon \tilde{\nu} p \circ \delta \dot{\eta}$

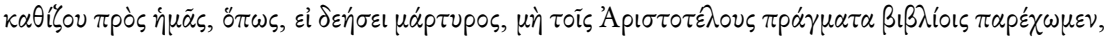

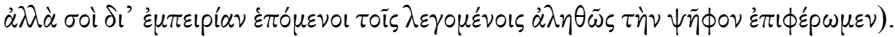

22 Indeed, sometimes the teacher gives the solution himself. Therefore, he should develop personal insights (cf. De virt. mor. 440E, De an. procr. Iог2B).

23 Gellius also reports that his Platonic teacher L. Calvenus Taurus often held question time style debates after his lectures (NA I, 26: dabat enim saepe post cotidianas lectiones quaerendi, quod quis uellet, potestatem). Cf. C. Jacob, 2004, p. 30. On the practice of

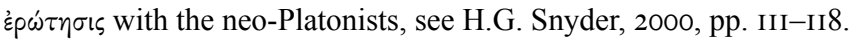


should not be too high in number. Therefore, one should not ask natural scientific or mathematical questions to those who are more concerned with the ethical side of philosophy or problems related to logic to natural

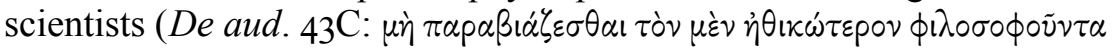

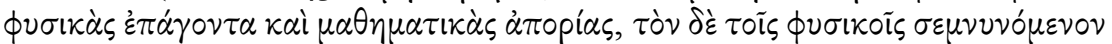

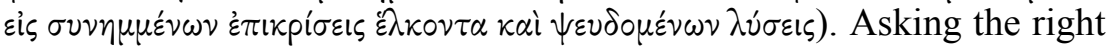
question, thus, turns out to be some kind of a regulated art in itself with which the student should acquaint himself.

Clearly, the method of questioning and answering obliges the participants to actively partake in the discussion. As to the right way to obtain an answer to a question, Plutarch often insists on providing a personal response, which he considers a useful means for sharpening a person's zetetic skills ${ }^{24}$. A relevant passage for this insistence on providing personal responses to problems can be found in the finale of De audiendo (48BC). Herein, Plutarch encourages lazy people to do some thinking of their own instead of continually asking questions about the same things to the lecturer:

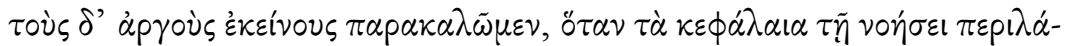

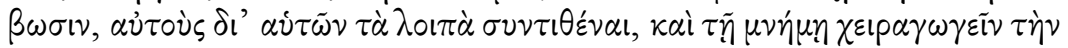

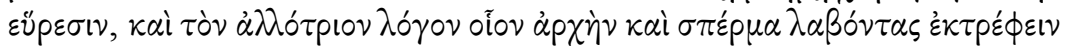

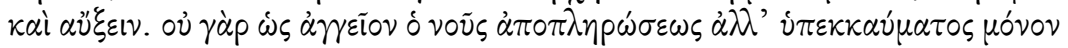

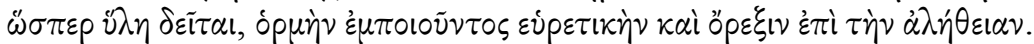

But as for those lazy persons whom we have mentioned, let us urge them that, when their intelligence has comprehended the main points, they put the rest together by their own efforts, and use their memory as a guide in thinking for themselves, and, taking the discourse of another as a germ and seed, develop and expand it. For the mind does not require filling like a bottle, but rather, like wood, it only requires kindling to create in it an impulse to think independently and an ardent desire for the truth.

A zetetic agenda is implied in the 'stimulus and desire for the truth'

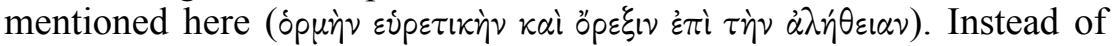
implanting knowledge from without, an appeal is made to activate the knowledge already present in a person's memory in his search for answers $(\tau \tilde{\eta} \mu \nu \eta \dot{\eta} \mu \eta \chi \varepsilon i \rho \alpha \gamma \omega \gamma \varepsilon \tilde{\nu} \tau \tilde{\eta} \nu \varepsilon \tilde{\nu} \rho \varepsilon \sigma \nu)^{25}$. This emphasis on activating independent

${ }^{24}$ On the stimulation of the zetetic attitude of Plutarch's students, see G. Roskam, 2004, p. I03.

25 A parallel can be drawn with Socrates' maieutical method in philosophy, cf. Quaest.

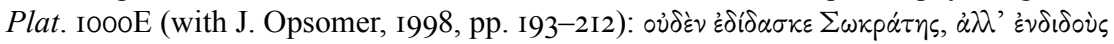

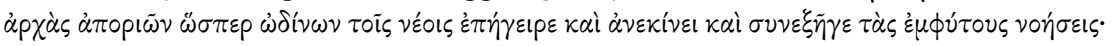


thought ties in closely with Plutarch's more general conceptualisation of personal ingenuity in intellectual debate [see 4.2.2.2.].

\section{Digestive discussions and problematic promenades}

Zetetic education is not restricted to the discussions in Plutarch's school context but extends to other social settings that have a less schoolish character ( $\sigma \chi 0 \lambda \eta \dot{~ b e i n g ~ a n ~ e l a s t i c ~ c o n c e p t) . ~ S u c h ~ a ~ s e t t i n g ~ i s ~ f o u n d ~ i n ~ t h e ~}$ discussions at sympotic events ${ }^{26}$, where for Plutarch a healthy balance between seriousness and play is even required by protocol ${ }^{27}$. Another occasion is the spontaneous discussion that arises during the so-called 'peripatos' ${ }^{28}$, that is, a stroll often after dinner or after a lecture (as it was

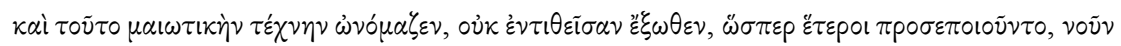

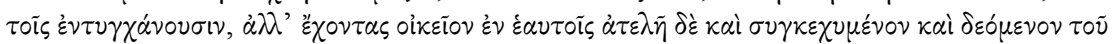

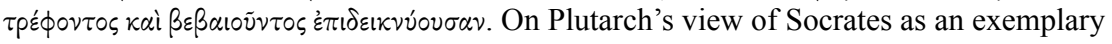
teacher, see G. Roskam, 2004, pp. I04-I05, I08 and 20IIc, pp. 42I-425. See also C. Pelling, 2005 .

${ }^{26}$ On the educational agenda of the symposia described in Quaestiones convivales and on convivial teaching more generally, see, e.g., M. Schuster, I9I7, pp. 5I-52, J. König, 2007, G. Roskam, 2009, E. Kechagia, 20IIa, L. Van der Stockt, 200ob and 20II.

27 Intellectual entertainment and instruction were important aspects of the symposium (see, e.g., G. Roskam, 2009). Even if the notion of $\sigma \pi \circ \nu \delta \circ \gamma \varepsilon \lambda \circ เ$ with this precise term, its basic idea can be found throughout Quaestiones convivales. Cf.,

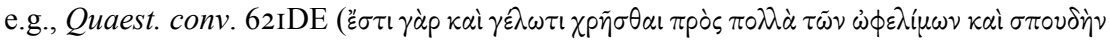

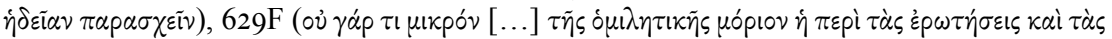

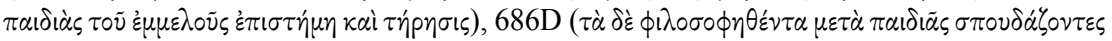

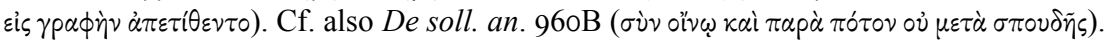
On the aspect of play in Quaestiones convivales, see F. Frazier, I998. For the notion of $\sigma \pi \circ \nu \delta \circ \gamma \varepsilon \lambda$ oเov in ancient Greek literature more generally, see D. Arnould, I990, pp. II3-I22.

28 For the connection between the peripatos and the discussion of problems, see, e.g., R. Hirzel, I895, vol. I, p. 364 (with notes for further references), M. Schuster, I9I7, pp. 485I, A. Gudeman, I927, col. 2522, K. Ziegler, I95I, col. 664 (quoted below). In several of Plutarch's writings, the peripatos serves as some kind of a hodological framework for the dialogue's development. In Non posse, for instance, Plutarch records the discussions that spontaneously arose during the customary peripatos after school hours (IO86D: $\dot{\varepsilon} \pi \varepsilon \dot{\delta} \delta \dot{\varepsilon}$

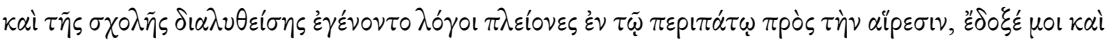

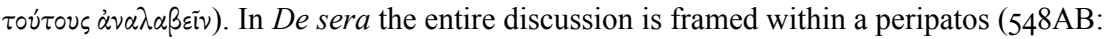

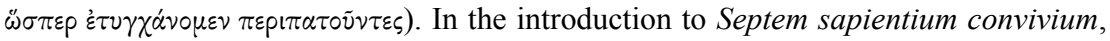
Plutarch describes the walk on the way to Periander's banquet, offering the participants the opportunity for free, leisurely conversation and discussion of several problems, as it

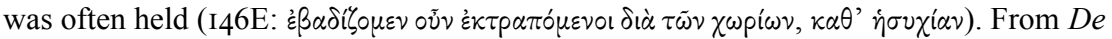
facie $937 \mathrm{CD}$, we learn that the interlocutors had, until thus far, been walking, but they now sit down upon the steps, where they remain seated until the end of the discussion

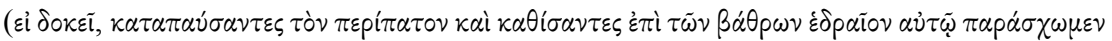

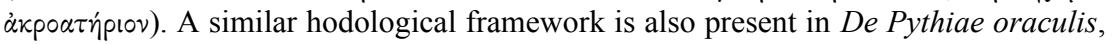
where the discussion is set against the background of the Delphic sanctuary [see 2.I.I.]. 
traditionally made in the Lyceum $)^{29}$. In spite of their less formal character, the symposium and the peripatos can be considered a supplement to Plutarch's school education ${ }^{30}$.

Interestingly, several passages from Plutarch's De tuenda sanitate praecepta show that there lies not just an intellectual but also a specific physiological agenda behind these sympotic and peripatetic discussions. De tuenda comes in the form of a dialogue between the physician Moschion and his friend Zeuxippus (but surely many of the author's own ideas and convictions on this topic must be present as well) ${ }^{31}$. Although there are clear reminiscenses to medical literature in this work, Plutarch is not highly concerned with the technical side of medicine as such ${ }^{32}$. Rather, the work is about the practical side of intellectual living. At some point, we read that the discussions during the symposium and peripatos have a direct impact not only on the mind, but also on the body of its participants, and that they, thus, contribute to a person's mental and physical well-being at the same time.

Regarding the 'exercises suitable for scholars' (De tuenda § I6, I30A:

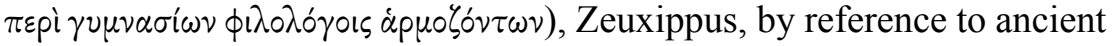

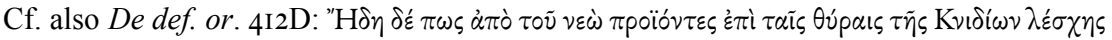

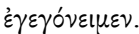

${ }^{29}$ For the peripatos as an emblematic occupation of Peripatetic philosophers, cf.

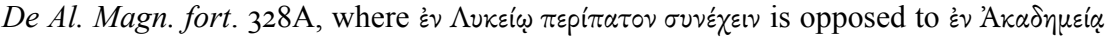

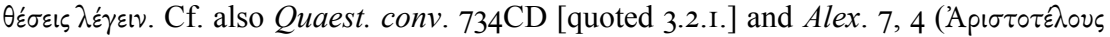
i $\pi \circ \sigma k i o v \varsigma \pi \varepsilon p\left(\pi \dot{\alpha} \tau \circ v_{\varsigma}\right)$. According to Cic., Ep. ad Attic. 7, I, I the slow ambulatio is typical for philosophers. For more on walking in Roman culture, see T.M. O'Sullivan, 20II. Cf. also E. Lao, 2008, pp. I79-I80 and J. Scheid, 20I2, p. I47.

${ }^{30}$ See K. Ziegler, I95I, col. 664: "Die diskussion wurde öfters, gemäß peripatetischer Tradition, im Umhergehen geführt, und die Symposien, von denen natürlich die schwierigeren, volle Konzentration erfordernden Themen ausgeschlossen wurden, bildeten eine Ergänzung des eigentlichen Unterrichts und so gewissermaßen einen Teil der Schule. [...] [A] uch Fragen aus der Physik - in dem weiten antiken Sinne, wonach sie auch Biologie und Medizin umfaßt - [wurden] nicht selten behandelt [...]." For the distinction between the symposium and a more strict school context, cf., e.g., Quaest. conv. 712A

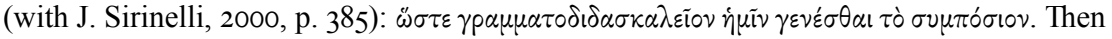
again, it was not at all inappropriate to bring along students to the symposium in order to introduce them as novices in the intellectual milieu (cf., e.g., Quaest. conv. 66oD). The other way round, a certain degree of informality in the private milieu of Plutarch's academy, cannot be excluded either, as we saw earlier on (see n. I4).

${ }^{31}$ In fact, the $\dot{\varepsilon} \alpha$ ĩpos from De tuenda $\mathrm{I} 22 \mathrm{~F}$ has been identified with Plutarch himself. See F.C. Babbitt, 1928, pp. 215 and 220, n. a.

32 As F.C. Babbitt, I928, p. 2I4 points out, Plutarch's "advice is meant for men whose work is done with their heads rather than their hands". For an interpretation of De tuenda sanitate praecepta in light of Plutarch's practical ethics (or 'diet-ethics'), see L. Van Hoof, 20IO, pp. 2II-254 (with further useful literature). For the influence of Plutarch's Platonism on this treatise, see L. Senzasono, 1992, pp. 19-25. 
$\pi \nu \varepsilon \tilde{v} \mu \alpha$-theory, recommends the daily use of the voice by conversing, reading aloud or declaiming (De tuenda $\mathrm{I} 3 \mathrm{OBD}$ ). He asserts that speaking during the peripatos (after rubbing oneself with oil, thus equalising the bodily breath) is an appropriate exercise enabling one to 'simultaneously instruct, question, learn, and use one's memory' (De tuenda I30F: ä $\mu \alpha \delta \delta \delta$ '́-

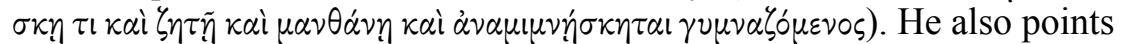
out that rhetorical and sophistical debates, by contrast, are unhealthy, due to

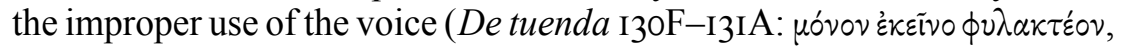

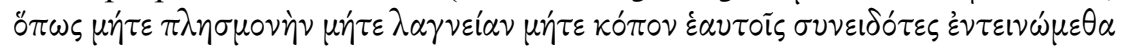

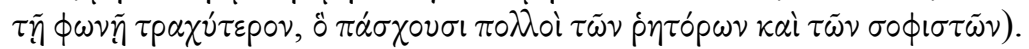

A little later, Zeuxippus indicates a number of remarkable physiological advantages and disadvantages provided by the peripatos after dinner ${ }^{33}$. He opposes two theories on this topic (including Aristotle's) and concludes that pleasant discussion in itself may suffice for the proper digestion of food (De tuenda § 2I, $\mathrm{I} 33 \mathrm{~F}-\mathrm{I} 34 \mathrm{~A})$ :

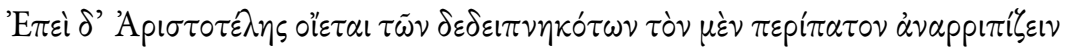

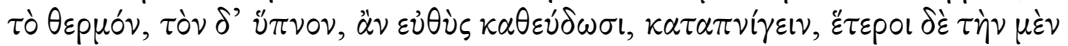

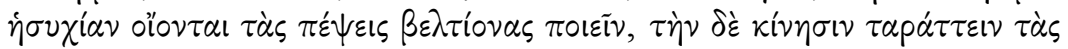

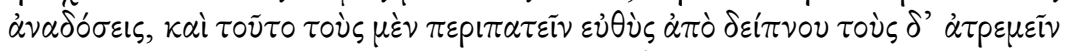

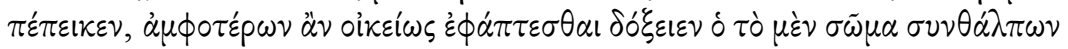

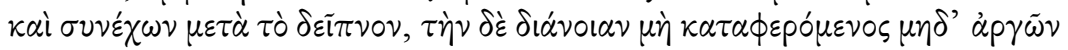

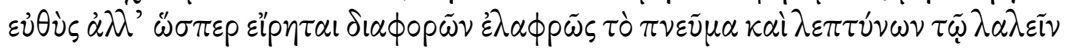

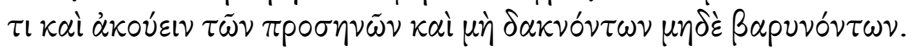

Aristotle (fr. 233 Rose) holds that walking about on the part of those who have just dined revives the bodily warmth, while sleep, if they go to sleep at once, smothers it; but others hold that quiet improves the digestive faculties, while movement disturbs the processes of assimilation; and this has persuaded some to walk about immediately after dinner, and others to remain quiet. In view of the two opinions a man might appear properly to attain both results who after dinner keeps his body warm and quiet, and does not let his mind sink at once into sleep and idleness, but, as has been previously suggested, lightly diverts and enlivens his spirits by talking himself and listening to another on one of the numerous topics which are agreeable and not acrimonious or depressing.

The reference to what 'has been previously suggested' ( $\check{\sigma \pi \tau \varepsilon p ~ \varepsilon i p \eta \tau \alpha)}$ in this passage is to the preceding paragraph (De tuenda $\S 20,133 \mathrm{BF}$ ),

${ }^{33}$ For the connection between the peripatos and the digestion of food, cf. also De

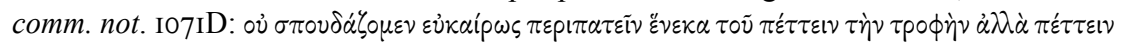

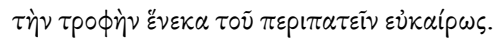


which deals with the topics that are fit and agreeable for discussion. There, Zeuxippus first attacks the athletic trainers and teachers of gymnastics, who state that scholarly conversation at dinner spoils the food and makes the head heavy. He admits that problems in the field of dialectics are not very pleasant because "they bring on a headache and are extremely

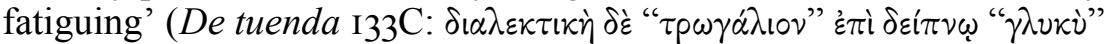

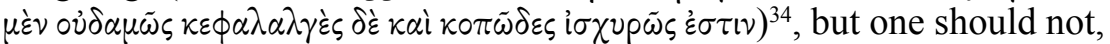
therefore, do away with the discussion of problems after dinner altogether. The rest is worth quoting in full (De tuenda $\mathrm{I33DF}$ ):

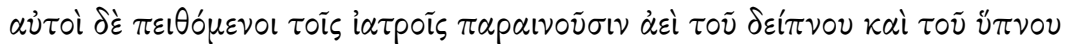

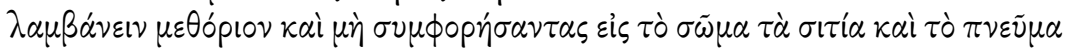

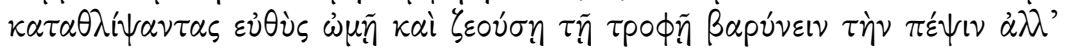

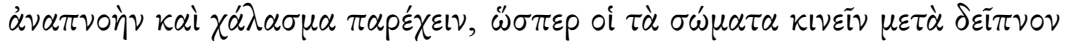

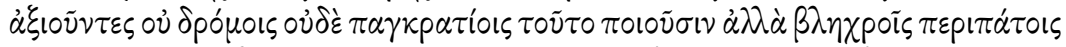

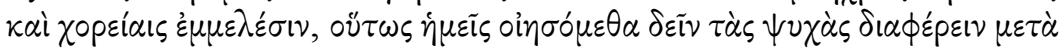

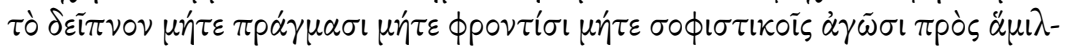

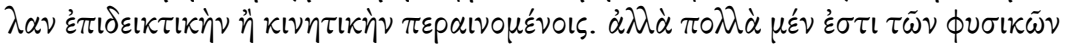

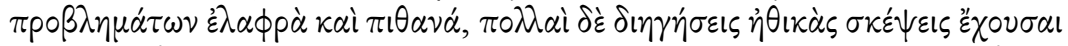

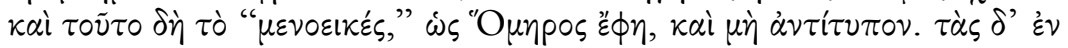

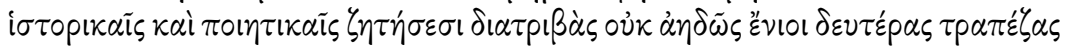

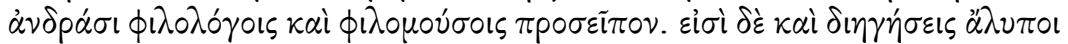

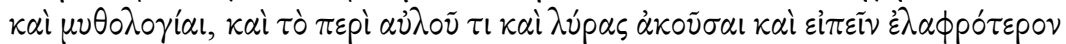

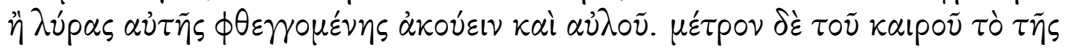

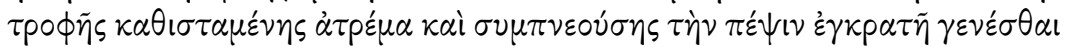

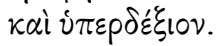

But as for ourselves, we shall follow the advice of the physicians who recommend always to let some time intervene between dinner and sleep, and not, after jumbling our victuals into our body and oppressing our spirit, to hinder our digestion at once with the food that is still unassimilated and fermenting, but rather to provide for it some respite and relaxation; just as those who think it is the right thing to keep their bodies moving after dinner do not do this by means of foot-races and strenuous boxing and wrestling, but by gentle walking and decorous dancing, so we shall hold that we ought not to distract our minds after dinner either with business or cares or pseudo-learned disputations, which have as their goal an ostentatious or stirring rivalry. But many of the problems of natural science are light and enticing, and there are many stories which contain ethical considerations and the "soul's

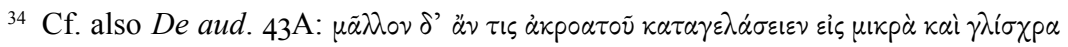

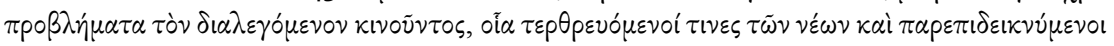

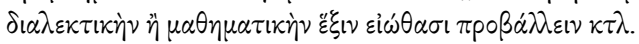


satisfaction," as Homer has phrased this, and nothing repellent. The spending of time over questions of history and poetry some persons, not unpleasingly, have called a second repast for men of scholarship and culture. There are also inoffensive stories and fables, and it is less onerous to exchange opinions about a flute and a lyre than to listen to the sound of the lyre and the flute itself. The length of time for this is such as the digestion needs to assert itself and gain the upper hand over the food as it is gradually absorbed and begins to agree with us.

The idea that 'many of the problems of natural science are light and entic-

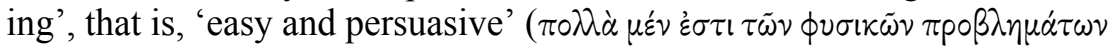
$\dot{\varepsilon} \lambda \alpha \phi \dot{\alpha} \alpha \alpha \dot{\imath} \pi(\theta \alpha \nu \alpha)$, is very significant for the type of problems collected in Quaestiones naturales and for their intellectual appeal. Also, the fact that this type of problems is placed next to other topics that are considered 'satisfactory to the soul' ( $\mu \varepsilon v o \varepsilon ı \varepsilon \varepsilon ́ s$, cf. also Phoc. 2, 3), 'not repellent'

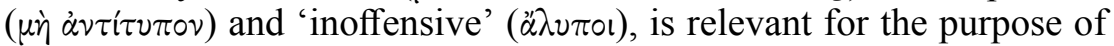
Plutarch's own natural problems. Indeed, even if the words $\dot{\lambda} \lambda \alpha \phi \rho \dot{\alpha} ~ \kappa \alpha i$ $\pi \imath \theta \alpha \nu \dot{\alpha}$ qualify $\pi \circ \lambda \lambda \dot{\alpha}$ - rather than $\pi \dot{\alpha} \nu \tau \alpha-\tau \tilde{\omega} \nu \phi v \sigma \kappa \kappa \tilde{\omega} \nu \pi \rho \circ \beta \lambda \eta \mu \dot{\alpha} \tau \omega \nu$, it is not implausible that this qualification applies to the genre of natural problems more generally, as known from the Ps.-Aristotelian Problems. Gellius, for one, confirms that these problems are 'most delightful and filled with choice knowledge of all kinds' (NA I9, 4: Aristotelis libri sunt, qui Problemata Physica inscribuntur, lepidissimi et elegantiarum omnigenus referti). Plutarch's qualification, then, seems to imply that natural problems are not very complex but relatively easy ( $\dot{\varepsilon} \lambda \alpha \phi \rho \alpha ́)$, because anyone can solve them: learned men and lesser intellectuals alike (cf. Quaest. conv. 613E, quoted below). Their persuasiveness $(\pi i \theta \alpha \nu \alpha)$, on the other hand, probably has a deeper philosophical implication, because in light of Plutarch's Platonic epistemology, solving natural problems is a conjectural science, where the plausibility of the arguments is of the utmost importance [see 4.3.2.2.].

The opposition with complex, dialectical problems cannot be any more obvious. These should be avoided for physiological reasons, because, as we saw, 'they induce headaches and are very fatiguing' (De tuenda

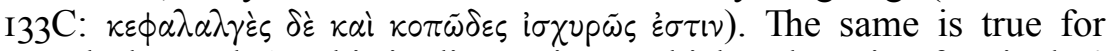
pseudo-learned, 'sophistic disputations, which only strive for rivalry'

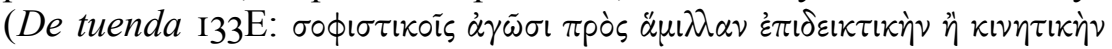

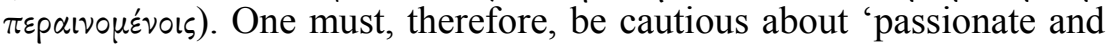
convulsive vociferations, because spasmodic expulsion and straining of the breath produces ruptures and sprains' (De tuenda I30D: ai $\gamma \dot{\alpha} \rho \dot{\alpha} \nu \omega \dot{\alpha} \mu \alpha \lambda \circ \mathrm{o}$

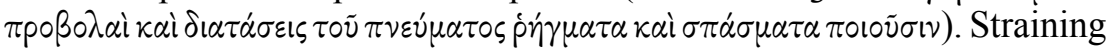
the voice too hard is, in fact, an experience 'of rhetoricians and sophists'

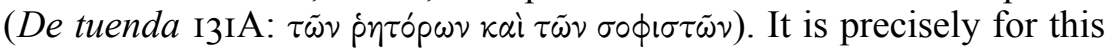


reason that excessive rivalry and sophistic arguments are excluded from the decorum of sympotic discussions.

This is not to say, of course, that there is no place for rhetorical manoeuvres at all at Plutarch's table - quite to the contrary -, but it does clearly imply that sympotic discussions should be more philosophical in nature, albeit not overtly philosophical either (as we will see in a moment). It is presumably in this sense, then, that the topics that Zeuxippus recommends for discussion, including natural problems, are not only 'beautiful and useful but also contain an element of plea-

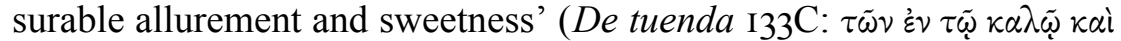

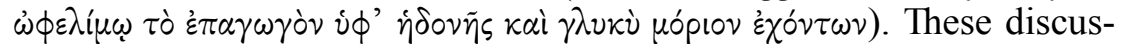
sions have immediate psychosomatic effects and function as a kind of intellectual digestif that takes as long as the assimilation of the food requires.

In Quaestiones convivales, many topics such as these are treated by Plutarch and his fellow symposiasts, and the general sympotic protocols from this work are very similar, if not identical, to those described in De tuenda (and vice versa). For instance, in the preface to the fifth Book (Quaest. conv. 672D-673A), Plutarch considers sympotic topics to be

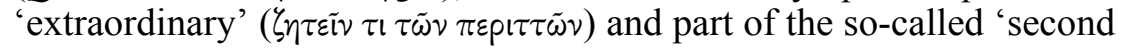
repast' ( $\delta \varepsilon v ं \tau p \alpha \tau p \alpha \pi \varepsilon \zeta \alpha$ ), which consists of 'delights set aside for the soul' ( $\tau \tilde{\eta} \psi \nu \chi \tilde{n} \tau \alpha \mu \varepsilon \varepsilon \tilde{\imath} \nu \nu \varepsilon \dot{\tau} \pi \alpha \theta \varepsilon เ \tilde{\omega} \nu)^{35}$. Regarding the easy and persuasive character of natural problems - these are $\dot{\varepsilon} \lambda \alpha \phi \rho \dot{\alpha} \kappa \alpha i ~ \pi \imath \theta \alpha \nu \dot{\alpha}$, as we just saw (De tuenda $\mathrm{I} 33 \mathrm{E}$ ) - a great deal of relevant information can be found in the very first chapter of the first Book. There, Plutarch and his fellow symposiasts discuss the programmatic problem of "whether philosophy is a fitting topic for conversation at a drinking party' (Quaest. conv. 6I2E: Ei $\left.\delta \varepsilon \tilde{\imath} \phi і \lambda \circ \sigma \circ \phi \varepsilon \tilde{\imath} \nu \pi \alpha \rho \dot{\alpha} \pi \sigma^{\prime} \tau \nu\right)$. In approving this, Plutarch insists that the topics of inquiry at the symposium should be 'easy to handle' (Quaest. conv. 6I4E: '̇ $\lambda \alpha \phi p \alpha i \zeta \eta \tau \eta \dot{\sigma} \sigma \mathrm{\varepsilon} \zeta)$. Indeed, 'the matter of inquiry should remain rather facile, the topics familiar and the subjects suitable and not complex, since, in this way, the less intellectual guests may neither be stifled nor turned

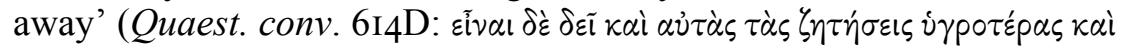

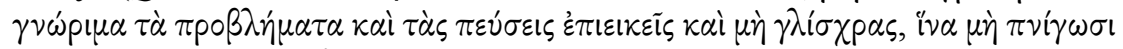

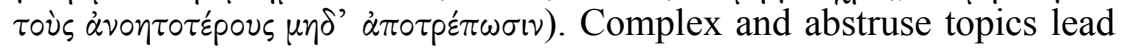

${ }^{35}$ Cf. also Gell., NA 7, I3, where 'sympotic questions' (quaestiunculae sympoticae) are considered 'ingenious' (argutiae), 'neither weighty nor serious' (non gravia nec reverenda), but 'pleasant and neat' (lepida et minuta); they are no 'pointless or idle sophisms' (captiones [...] futtiles atque inanes), no 'trifling amusements' (nugarum aliquem ludum), but the 'sweetmeats of the desserts' (mensarum secundarum [...] $\tau p \alpha \gamma \eta \mu \dot{\alpha} \tau i \alpha)$. Cf. also Macrob., Sat. 7, 3, 23: quod genus [sc. quaestiones convivales] veteres ita ludicrum non putarunt ut et Aristoteles de ipsis aliqua conscripserit et Plutarchus et vester Apuleius, nec contemnendum sit quod tot philosophantium curam meruit. 


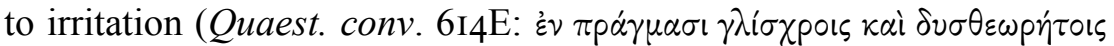
$\tau \circ \cup ́ \varsigma \tau \varepsilon \pi \alpha p \alpha \tau \nu \gamma \chi \alpha \dot{\alpha} \nu \circ \nu \tau \alpha \varsigma \alpha \dot{\alpha}(\tilde{\omega} \sigma \nu)$ ). Engaging in complex argumentation over one's wine is a 'sophistical' thing to do, and should therefore be

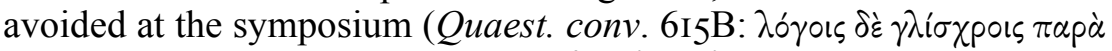

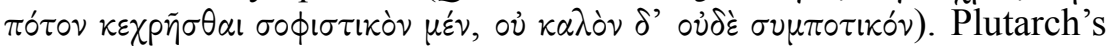
main concern is that everyone be able to participate in the discussion, learned men and men without erudition alike (Quaest. conv. 6r3E: $\ddot{\alpha} v$

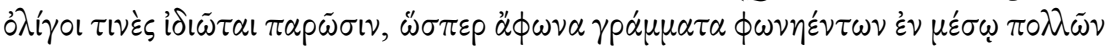

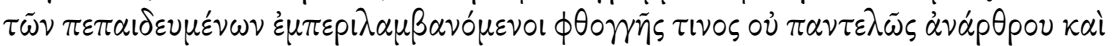

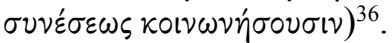

This clearly reflects on the level of complexity of sympotic discussions, among which natural problems take a prominent place (they make up approximately one third of Quaestiones convivales). Still in the first chapter of the first Book, Plutarch says that the dilemma, of course, is that philosophy is mostly concerned with 'subtle and disputatious

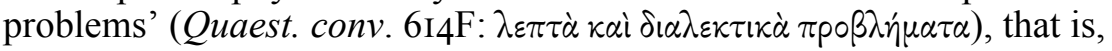
problems that are annoying for guests who are not philosophers. Thus, 'the height of sagacity is to talk philosophy without seeming to do so'

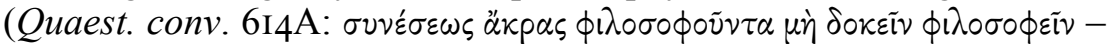
I will come back to this later). Furthermore, it is not so much the 'compulsion of the arguments', but rather their 'persuasiveness', that

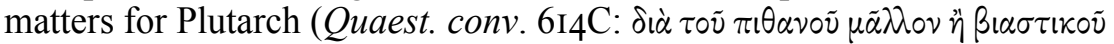
$\left.\tau \tilde{\omega} \nu \dot{\alpha} \pi \circ \delta \varepsilon \varepsilon^{\prime} \xi \varepsilon \omega \nu\right)$. The emphasis on the persuasiveness of the arguments recurs throughout Quaestiones convivales and can be linked not only with the social dimension of sympotic debates but also with Plutarch's

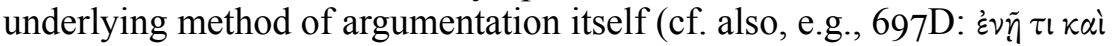
$\pi(\theta \alpha \nu o ́ v)$ [see 4.3.2.2.].

The social dynamics of Plutarch's convivial milieu are very important for gaining a better insight into his sympotic protocols. Considering the proliferation of secondary literature on this topic, I will limit myself to outlining this topic only in general terms here ${ }^{37}$. We can see, then, that for Plutarch, the intellectual satisfaction provided by the discussion after dinner is inextricably bound with the social function of the symposium itself. In the preface to the seventh Book, Plutarch writes that subjects of

36 Cf., e.g., P. Donini, I992, p. IIo.

37 For a socio-political analysis of Plutarch's symposia, see, e.g., the contributions in J.R. Ferreira, D. Leão, M. Tröster and P. Barata Dias, 2009 (sub "Section 2: The Symposion as a Space for Social and Political Gatherings"), J.G. Montes Cala, M. Sanchez Ortiz de Landaluce and R. Gallé Cejudo, I999, F. Klotz and K. Oikonomopoulou, 20I I and also M. Vamvouri Ruffy, 20I2. Cf. F. Fuhrmann, I972, p. xix, for the view that Quaestiones convivales evokes "tout un tableau de la vie sociale sous l'Empire romain". On the realities of public banqueting in Quaestiones convivales, see, e.g., J.C. Relihan, I992, pp. 232, P. Schmitt-Pantel, I992, pp. 47I-482 and F. Pordomingo Pardo, I999. 
discourse, like friends, should be admitted to dinner only if they are of proven quality. If not, they should be refused entrance to the select group

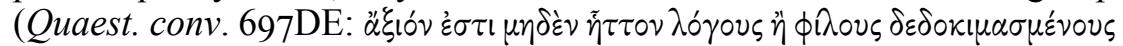
$\pi \alpha \rho \alpha \lambda \alpha \mu \beta \dot{\alpha} \nu \varepsilon \nu \nu \dot{\varepsilon} \pi i \tau \dot{\alpha} \delta \varepsilon i \pi \nu \alpha)$. Guests are invited to the symposium for the sake of drinking together rather than for drinking per $\mathrm{se}^{38}$. This means that drinking is only a means of gathering people who are mostly of a distinguished social standing, in order to foster learned discussions and social networking. Plutarch's attitude towards drinking and inebriation is, indeed, heavily influenced by the intellectual practices of his social milieu. He strongly disapproves of a symposium that ends up in 'a lascivious carousal and drunken jabber' (Quaest. conv. 7I6F), but sympotic conversation in itself is important, since it 'steadies' those who drink (Quaest. conv. 66oC, 643AB) ${ }^{39}$. Personal participation in the sympotic conversations is, therefore, essential: every symposiast should contribute to the discussion and share his own - preferably original - opinion to the debate.

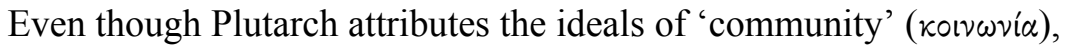

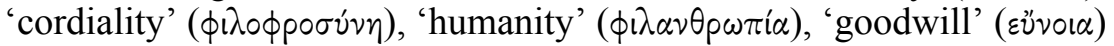
and 'mildness' ( $\pi \rho \alpha o ́ \tau \eta \xi)$ to sympotic companionship ${ }^{40}$, and even stresses its 'democratic' nature ${ }^{41}$, its aristocratic character should not, of course, be underestimated. In any case, Plutarch's discourse tends to exhibit a bias of elitist exclusivity. This is not, however, a goal in itself for Plutarch. As seen above, less intellectual people were also allowed at his table

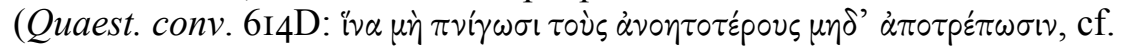
also 613E: $i \delta(\omega \tau \alpha \iota)$. Moreover, when Plutarch says that he shuns 'banquets

${ }^{38}$ On heavy drinking and alcoholism in Antiquity, see J.D. Rolleston, 1927 and J.H. D'Arms, I995.

39 For a discussion of Plutarch's approval of a moderate consumption of wine and for its capacity to encourage friendly interaction, see H.G. Ingenkamp, 1999, A.G. Nikolaidis, I999, P.A. Stadter, I999 and S.-T. Teodorsson, I999b. On Plato and wine, see P. Boyancé, I95I.

${ }^{40}$ See L. Van der Stockt, 200ob, p. 94 and F. Frazier and J. Sirinelli, I996, pp. I80 ff. Cf. Also A.M. Scarcella, I998, pp. I4-20.

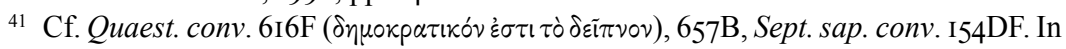
Quaest. conv. 62 IB the democratic character is placed in a negative light ( $\nu \tilde{\nu} \nu \mu \dot{\varepsilon} \nu \varepsilon \dot{\varepsilon} \kappa \lambda \eta \sigma^{\prime} \alpha \nu$

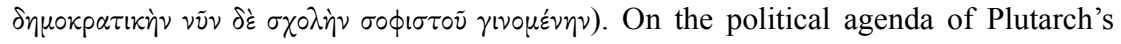
Quaestiones convivales, see also P. Schmitt-Pantel, 1992, pp. 47I-482 and M. Vamvouri

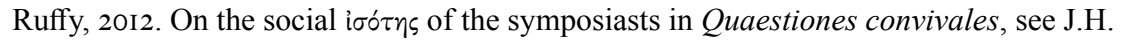
D'Arms, I990, p. 313. At the same time, the guests preserve their aviovó $\mu$ i, because they have their personal interests and idiosyncrasies (cf. Quaest. conv. 643A). The good

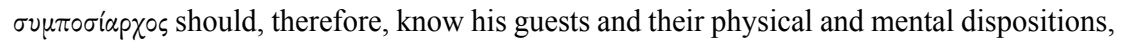
viz. how much they can drink, their character, and - most of all - their particular field of expertise (cf. Quaest. conv. 613D, 613 E, 621A, 643C, 644D). 
for citizens and foreigners', he does so not because he is a snob or a xenophobe of any kind, but because he prefers to be among 'intellectuals' $(\phi i \lambda \hat{\lambda} \lambda \circ \gamma \circ)^{42}$.

For Plutarch, social elitism is intrinsically bound with intellectual pre-eminence rather than parvenu arrogance ${ }^{43}$. It is more specifically distinguished from regular, more popular, symposia by the introduction of philosophy - as recurrently opposed to egotistic, self-absorbed sophistry as the primary concern of the age-old institution of the symposium ${ }^{44}$. Plutarch finds his examples for this in authors like Plato and Xenophon [see 2.3.I., n. 80]. At times, his adherence to the philosophical symposium receives a polemical, anti-Epicurean dimension, as is the case, for instance, in Non posse I095CD, where he blames Epicurus for allowing no place, not even over wine, for 'scholarly enquiries' ( $\left.\phi \lambda \lambda \lambda_{\lambda} \circ \gamma \alpha \zeta \eta \tau \dot{\eta} \mu \alpha \tau \alpha\right)$ or 'problems' $(\pi \rho \beta \lambda \eta \dot{\eta} \mu \alpha \alpha)$ concerning music and poetry. In fact, Plutarch sees the Epicureans as finding no pleasure in the contemplative part of the soul whatsoever but only in the pleasure of the belly ${ }^{45}$.

There is a tendency in recent scholarship to connect the sociointellectual dynamic of Plutarch's symposia with the Second Sophistic's culture of $\pi \alpha i \delta \varepsilon i \alpha$ - that is, a culture were overt demonstration of personal

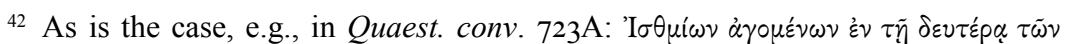

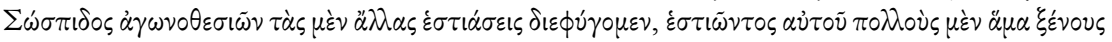

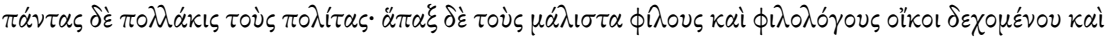

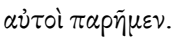

${ }^{43}$ In Quaest. conv. 6I5CD, for instance, Plutarch draws a bead on the sympotic protocol of placing guests at fixed places at the table in relation to their social status. We read that when his brother Timon once hosted a symposium and decided that the guests could choose their place themselves, an ostentatious stranger turned up at the door and immediately

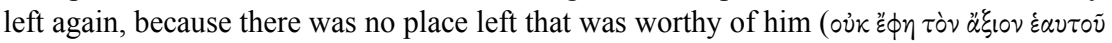
$\tau o ́ \pi \circ \nu$ ó $\left.\tilde{\alpha} \nu \lambda \varepsilon i \pi o_{\mu} \mu \varepsilon \vee \nu\right)$. As a result, the symposiasts were indignant about the stranger's arrogance and bid him goodbye.

${ }^{44}$ See especially the programmatic opening problem in the first Book of Quaestiones

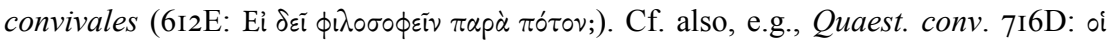

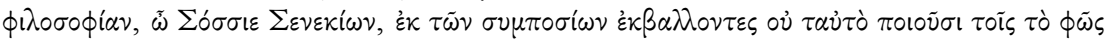
$\dot{\alpha} \nu \alpha \iota p \circ \tilde{v} \sigma \nu, \dot{\alpha} \lambda \dot{\alpha} \chi \varepsilon \tilde{\varepsilon} \rho \circ \nu$. In addition, Plutarch's distinction between philosophical problems and (popular) trivial riddles (cf., e.g., Quaest. conv. 673A) also has specific sociointellectual implications (see S. Beta, 2009). On the omnipresence of philosophy in Quaestiones convivales, see R. Lopes, 2009.

${ }^{45}$ For Plutarch, on the contrary, the discovery of solutions to entangled problems provides a genuine intellectual pleasure. See Non posse I096BC: $\lambda \dot{\sigma} \sigma \varepsilon เ \varsigma \dot{\alpha} \pi \circ p$

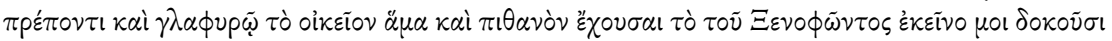

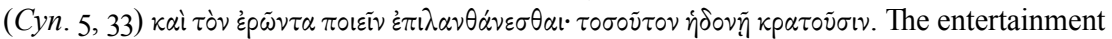
value and joy ( $\left.\dot{\eta} \delta \circ \eta^{\prime}\right)$ that is provided by solving problems is also appreciated by Plutarch

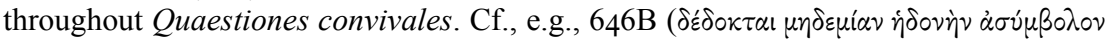

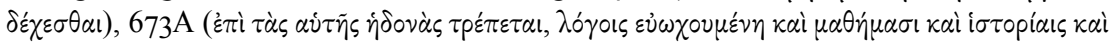
$\tau \tilde{\omega} \zeta \eta \tau \varepsilon \tilde{\varepsilon} \nu \tau \iota \tau \tilde{\omega} \nu \pi \varepsilon \rho i \tau \tau \tilde{\omega} \nu)$. 
knowledge and learning serves as a means to confirm and sharpen elite identity, especially by distinction from the common, un(der)educated plebs $^{46}$. However, this elitist ambition for intellectual distinction from the

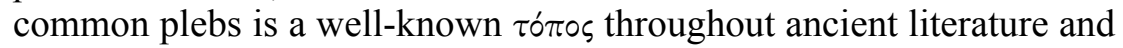
is not restricted to Second Sophistic literature only (as we will see, its presence in Q.N. 29, 919AB serves an underlying philosophical programme [see 3.2.2.]). Moreover, Plutarch's emphasis on the centrality of philosophy as a collective search for the truth clearly distinguishes his symposia from those recorded in a work like Athenaeus' Deipnosophistae, where the link between the sympotic genre and the Second Sophistic adoration of $\pi \alpha 1 \delta \varepsilon i \alpha$ is far more discomforting. In Plutarch's case, moreover, the consolidation of elite identity is reinforced by the friend-making ( $\phi i \lambda \circ \pi \circ \circ o^{\circ}$ ) character of the dinner-table, which requires a friendly sociability on behalf of the symposiasts at all times, rather than an continuous self-promotion of one's own education ${ }^{47}$. The unification of the intellectual upper-class is realised at these occasions by the emphasis on social networking between people who enjoyed the same education and can, therefore, call themselves 'welleducated' (Quaest. conv. 634F: $\pi \varepsilon \pi \alpha i \delta \varepsilon v \mu \varepsilon ́ v o l ~ k \alpha \lambda \omega \tilde{\omega}$ ). One may wonder, then, how high this degree of $\pi \alpha$ id $\varepsilon^{\prime} \alpha$ actually is in the case of Plutarch's natural problems and what is their level of technicality and complexity.

\section{Quaestiones naturales as school text: technicality and complexity}

As seen in the previous section, Plutarch's golden rule at the symposium is to 'discuss philosophy without seeming to do so' (Quaest. conv. 6I4A:

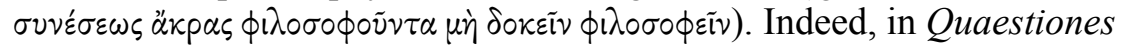

${ }^{46}$ For the connection between Quaestiones convivales and the Second Sophistic, see, e.g., J. König, 2008, p. 88, F. Klotz and K. Oikonomopolou, 20II, p. 3 and M. Vamvouri Ruffy, 20I2, pp. 2I8-220. Cf. also S. Goldhill, 2009, pp. I09-IIO. Regarding $\pi \alpha \iota \delta \varepsilon^{\prime} \alpha$ as a key concept in scholarship on the Second Sophistic, see M. Gleason, I995, T. Schmitz, 1997 and T. Whitmarsh, 2005. Regarding the symposium as providing a framework for consolidation of elites already in Archaic and Classical Greece, see O. Murray, I99ob and M. Griffith, 200I, pp. 56-59. G.W.M. Bowersock, I985, p. 665 doubts about the connection between Plutarch and the Second Sophistic. For a more systematic analysis of Plutarch's conceptualisation of sophists and sophistry, see T. Schmitz, 20I4. I side with his conclusion that "Plutarch's world is not the world of the Second Sophistic" (pp. 32, 40), neither in a chronological nor in a geographical sense. Yet, even if Plutarch, much like Plato, depicts sophistic argumentation in a negative fashion, as being diametrically opposed to proper philosophical conduct, he was well acquainted with the agonistic debates of the sophists, and at times even employs overt rhetorical strategies in his own arguments - albeit never, so it should be added, for purely sophistical but for higher, philosophical reasons.

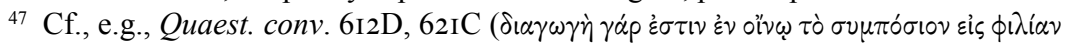

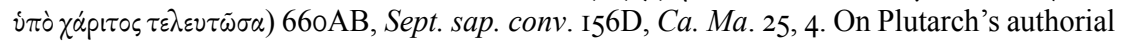
self-presentation in Quaestiones convivales as a complex mean between self-promotion and self-effacement, see J. König, 20II. See also F. Klotz, 2007. 
convivales Plutarch at several points shows to his reader how the discussion of seemingly futile topics can eventually evolve into more, albeit much concealed, philosophical inquiries. This higher, philosophical layer is generally absent from Quaestiones naturales, where the main focus is on the natural causes of the phenomena under discussion (think of the parallel, discussed earlier on, about the generative property of salt and its divine nature in Quaest. conv. 685DE vis-à-vis Q.N. 3, 9I2EF [see 2.2.I.]). As such, the natural problems collected in Quaestiones naturales are more 'technical' in kind than those treated in Quaestiones convivales, that is, they are more concerned with the type of knowledge and terminology that belongs to the $\tau \varepsilon \chi \nu \tilde{i} \tau \alpha$ l, such as doctors, farmers etc., rather than to

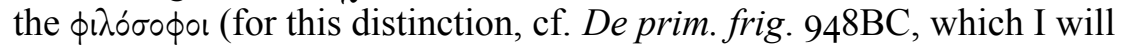
discuss later on [see 4.3.2.I.]). Scholars have differentiated the intended reading of the two works accordingly.

It is generally accepted that in Quaestiones convivales Plutarch aims to portray how intellectual discussions should be held in real-life situations. Therefore, the educational value of Quaestiones convivales is to offer some kind of a manual for proper socio-philosophical conduct ${ }^{48}$. Quaestiones naturales, on the other hand, by its primary focus on the physical aetiologies rather than on the form and dialogical set-up of the arguments, represents the actual 'theory' for such discussions. This, in turn, reflects the different educational purposes of the two texts, representing the argumentative dynamics of intellectual discussion of natural problems 'in practice' and 'in theory', respectively. In this sense, Quaestiones convivales adds a social dimension to the discussion of problems: it not only shows how they should be solved, but how they should be solved in a real-life situation among friends and strangers (or potentially new friends). Van der Stockt is right in writing:

"The $Q N$, then, are an introduction to the art of philosophical conversation about causes in the $Q C$ : to its required 'zetetic' attitude, and to the 'polite' conversation at a symposium. As a result, the $Q C$ offer us a more clear sight on the criteria applied for the scientific validation of opinions, explanations, and assertions [...]." 49

${ }^{48}$ Cf. L. Van der Stockt, 200ob, pp. 93-98. See also S. Goldhill, 2009, pp. I09IIO, J. König, 2007, p. 62, 20I0, p. 332 and F. Klotz, 20I4, p. 209. On savoir-vivre and conviviality in Quaestiones convivales, cf. also, e.g., J. Sirinelli, 2000, pp. 376-379. For the revival of the conversational ethics and etiquettes of Quaestiones convivales during the Renaissance, see M. Jeanneret, I99I, pp. 65-68.

${ }^{49}$ L. Van der Stockt, 20II, p. 453. In the same way, C. Jacob, 2004, p. 46 considers Plutarch's Quaestiones convivales as "l' un des modes d'emploi" of Ps.-Aristotle's Problems. 
In a following step, one may wonder how the aspect of technicality relates to that of complexity in Plutarch's natural problems. As seen before, the sympotic decorum of Quaestiones convivales prescribes that discussions at the table may not become too complex or sophisticated. One of the key-words here is that of $\gamma \lambda i \sigma$ xpov, which literally means 'sticky' but is often used by Plutarch in a metaphorical sense to qualify an idea that is 'complex', 'all too subtle' or 'far-fetched' ${ }^{50}$. It remains to be seen, then, whether a higher degree of complexity and sophistication is allowed perhaps in the more 'technical' Quaestiones naturales. I believe that this is rather unlikely, though, and that for Plutarch, natural problems are

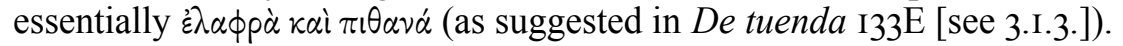

A close analysis of the parallel passage between $Q . N .4,912 \mathrm{~F}-913 \mathrm{~A}$ and Plutarch's $\lambda$ ó ${ }^{\circ}$ s in the second chapter of Book four (Quaest. conv. $664 \mathrm{D}-$ $665 \mathrm{~A}$ ) will allow us to further substantiate these points. Both passages deal with the generative property of rainwaters that are accompanied by thunder and lightning (these are called $\dot{\alpha} \sigma \tau p \alpha \pi \alpha i \alpha$, 'lightning waters', by farmers $)^{51}$. In the passage from Quaestiones convivales $(664 \mathrm{~A}-665 \mathrm{~A})$, Plutarch and his fellow symposiasts deal with the popular belief that truffles are produced by thunder. Agemachus, who hosts the dinner in Elis,

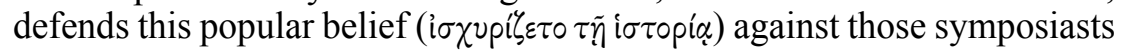
who remain sceptical and reject it. The latter argue that thunder does not

${ }^{50}$ For the metaphorical implications of Plutarch's concept of $\gamma \lambda i \sigma \chi x \rho \varsigma$ and its medical overtones, see M. Vamvouri Ruffy, 20I2, pp. 67-75. The notion of $\gamma \lambda i \sigma \chi p \circ \nu$ has several meanings: viz. 'sticky', 'tough', 'importunate', 'penurious', 'niggardly', 'mean', 'shabby', 'poor', 'carefully', 'detailed' or 'difficult to see' (see LSJ, s.v.). It is closely connected to the notion of $\sigma \circ \phi i \sigma \tau i o^{\prime}$ in Plutarch's writings (cf. Quaest. conv. 615B; quoted above). The adjective $\gamma \lambda i \sigma \chi p \circ \varsigma$ is used synonymously with $\delta v \sigma \theta \varepsilon \omega \dot{\rho} \eta \tau \circ \varsigma$, meaning 'abstruse' or 'hard to understand' (cf. Quaest. conv. 6I4E, quoted above; cf. also Quaest. conv. 73IA). In Quaest. conv. ${ }_{14} \mathrm{D}$ (quoted above), Plutarch says that the matter of sympotic inquiry should remain

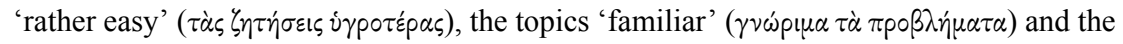

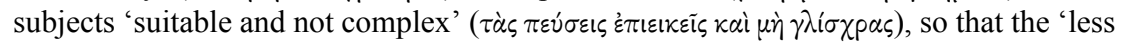

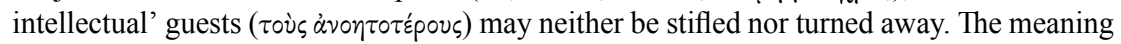
of 'abstruse' or 'hard to understand' is clearly present in the concept of $\gamma \lambda$ i $\sigma$ xpas here. The pejorative connotation of 'petty' or 'frivolous' may also be implied, but not in the sense of 'easy' (cf. De aud. 43A, where problems in the field of dialectics and mathematics are considered $\mu$ kp $\dot{\alpha} \kappa \alpha \grave{i} \gamma \lambda i \sigma \chi p \alpha)$. It can also be used in connection with philosophical issues

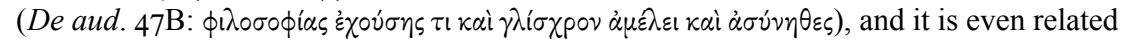
to play and unconvincing inventiveness (De aud. poet. $3 \mathrm{IE}: \gamma \lambda \hat{i} \sigma \chi \chi_{p \circ s} \dot{\varepsilon} \sigma \tau i \nu$, ov $\pi \alpha i \zeta \omega \nu \dot{\alpha} \lambda \lambda^{\prime}$

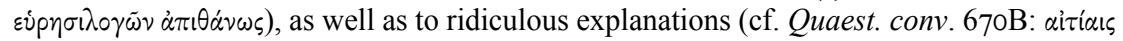

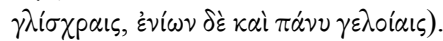

51 This same parallel is discussed by F. Klotz and K. Oikonompoulou, 20II, pp. 20-2I, albeit not in light of what is $\gamma \lambda$ í $x$ pov for Plutarch, nor of the subtle philosophical agenda in Quaestiones convivales, but in view of Plutarch's flexible reuse of specific bits of knowledge in different contexts. Cf. also L. Van der Stockt, 20II, pp. 450-454. 
actually generate truffles but simply makes them visible in the cracks in the earth. Agemachus, by contrast, lists several other natural mirabilia that are related to thunder and lightning, which, so he says, are 'difficult if not completely impossible to solve' but are not, therefore, unworthy

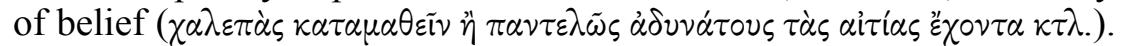
Among these mirabilia he mentions the farmers' account of the generative

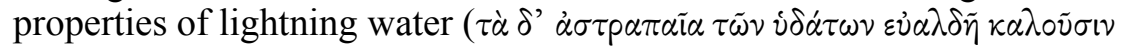

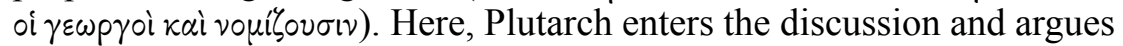
that 'at least at the time' he cannot provide 'a more plausible explanation' ( water than that the heat of the rain, so produced by the fire of lightning, enriches the soil. This explanation runs parallel to the second causa in Q.N. 4, 9I3A, where Plutarch, regarding the same problem of lightning water, argues that the heat of lightning concocts the moisture of rainwater and makes it agreeable and useful to the growth of things.

Notably, at the end of his explanation in Quaest. conv. 665A (after adding a number of other sub-arguments), Plutarch says that his fellow symposiasts may find his $\lambda$ ó $о \varsigma_{s}$ somewhat $\gamma \lambda i \sigma \chi p \circ \varsigma^{52}$. He assures them, however, - and this is the very essence of his $\lambda$ ó $\gamma \circ \varsigma_{-}$- that most of the effects of thunder and lightning are like that, that is, they have a generative property ( $\gamma$ óvıov), and this testifies to their ostensibly divine character

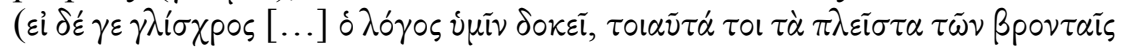

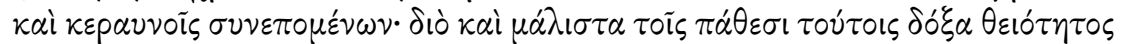
$\pi$ pó $\sigma \varepsilon \sigma \tau l)$. This is followed by an account of the divine character of thunder and lightning by the rhetorician Dorotheus, which closes off the problem at hand (and opens up the discussion of a new and closely related popular belief, viz. that sleepers are never struck by thunderbolts). In the parallel account in Q.N. 4, however, Plutarch adds yet another natural explanation (in the third and final causa) that can also be considered $\gamma \lambda i \sigma \chi p o s$. He argues that it is not so much the thunder and lightning, which particularly occur in spring due to uneven temperature in the air, that make the rain more fertile. Rather, the rainwater itself is useful to plants, because it comes 'before

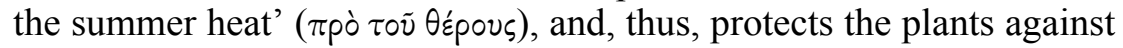
this heat. Now, if the second causa can already be considered $\gamma \lambda i \sigma^{\circ}$ pos to a certain degree - as Plutarch suggests in Quaest. conv. $665 \mathrm{~A}-$, this is perhaps even more the case in this third causa in $Q . N .4$, since a subtle

52 The adjective $\gamma \lambda i \sigma$ xpos qualifies Plutarch's entire $\lambda$ ó ${ }^{\circ}$ s here. This means that it does not only refer to Plutarch's sub-arguments about the special charateristics and flavour imparted by such rains on vegetation (e.g., the belief that dew makes grass sweeter and that rainbows fill trees with fragrances); nor is it restricted to the theory that a truffle is a

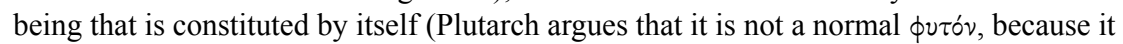
bears no fruit and has no roots and is made entirely of earth that is slightly altered by the rain). 
aetiological distinction is made there. Plutarch suggests that the influence of lightning and thunder on the increase in fertility is an incidental adjunct rather than the main cause of this phenomenon. In other words, thunder and lightning are rather circumstantial phenomena that have nothing to do with the generative properties of rainwater as such (compare the initial, sceptical argument of the symposiasts who reject the popular belief about the generation of truffles by lightning). As we will see later on, there is often, indeed, an increase in specificity and detail in the development of Plutarch's aetiologies [see 4.3.3.3.]. One should not, therefore, jump to conclusions, though, and claim that, in light of the aforementioned technical character of Quaestiones naturales, our collection admits, or is even reserved for $\gamma \lambda i \sigma \chi p o v$ argumentations.

Those who would, nevertheless, stick to such a belief might come

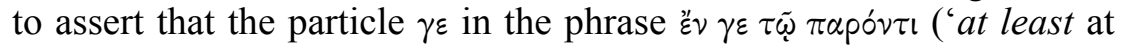
this moment'; see above) implies that Plutarch would be able on other occasions - c.q. in the more technical discussion in Q.N. 4 (where the specific natural phenomenon of the lightning water is discussed separately and on its own physical terms) - to provide another explanation that is not only $\pi \bullet \alpha \nu \omega \dot{\tau} \tau$ pov but also even more $\gamma \lambda i \sigma$ xpov (viz. the third and final causa with its subtle aetiological distinction). Such a claim would run the risk of neglecting the different argumentative contexts of the two discussions, though. The main problem at hand in Quaest. conv. 664B-665A is not why lightning water is fertile for plants but why truffles are thought to

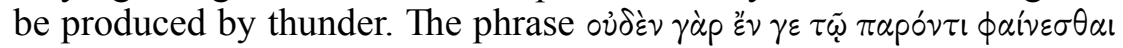
$\pi \bullet \theta \alpha \nu \omega \tau \tau \varepsilon \rho \nu$ should be interpreted in this specific context: Plutarch cannot find an explanation that is more probable at this very moment, that is, in the current discussion - as opposed to other discussions, such as Q.N. 4 , where the main problem is not that of the generation of truffles, though. It

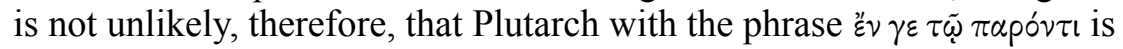
subtly alluding to Q.N. 4 [see 2.I.4.]. He must have been aware of the fact, then, that the contexts were very different. Plutarch would probably have acknowledged that other explanations for the problem about the lightning water are possible, as the third causa in Q.N. 4 proves. Arguably, then, his explanation in the discussion at issue in Quaest. conv. $664 \mathrm{~B}-665 \mathrm{~A}$ is very ad hoc, since it is, indeed, the most probable one, at least in the present context.

If Plutarch had made the same subtle aetiological distinction in his $\lambda$ ó yos in Quaest. conv. 664 D-665A as he does in the third causa in Q.N. 4, he would actually have sided with the camp of the sceptical non-believers (who reject the popular belief that thunder is really generative of itself and argue that it merely brings the truffles to light). In that case, there would have been no opportunity for further discussion but only an awkward silence (notably, in Quaest. conv. 64ICE and also in 642 AB, similar subtle aetiological distinctions are made, which close off the discussions at 
hand [see 4.3.3.3.]). Therefore, we should probably cut Plutarch some argumentative slack in his physical aetiologies, especially since, from his Platonic epistemological perspective, nothing in nature can be captured in terms of certainty [see 4.3.3.I.]. It is presumably for this reason, then, that he considers natural problems to be essentially $\pi \imath \theta \alpha \alpha \dot{\alpha}$ (De tuenda $\mathrm{I} 33 \mathrm{E}$; quoted above). If Plutarch had also added the third causa from Q.N. 4 in

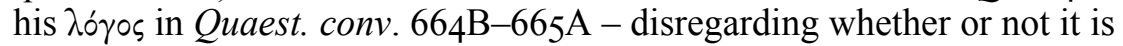
even $\pi i \theta \alpha \nu \omega \tau \tau \varepsilon p o \nu$ - this would have entirely disrupted the rationale of his own argument. It is precisely for this reason that Plutarch says that in this specific context, nothing seems more plausible than the explanation that he provides ${ }^{53}$.

Another important - if not the most important - point that should be added is that at the very end of his $\lambda$ ó 0 s in Quaest. conv. 665A, Plutarch shifts from speaking of the physical properties of lightning towards its

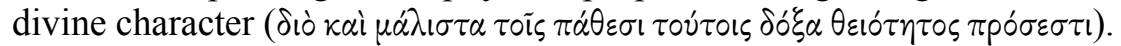
This point is further elaborated upon in the subsequent argument by the rhetorician Dorotheus, who notes that the divine theory is accepted 'not only by ordinary people but also by some philosophers' (oủ yàp róvov oi

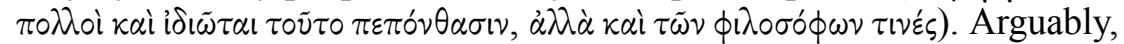
the incorporation of such religious-theological topics in Quaestiones convivales is indicative of the philosophical goal of the sympotic discussions at hand. It nicely elucidates Plutarch's golden rule, as stated above, that philosophy should be discussed in guarded terms during symposia, viz. 'without seeming to do so' (Quaest. conv. 6I4A). No such divine interpretation is found in the parallel passage in Q.N. 4, though, which, in turn, illustrates the more 'technical' approach of Quaestiones naturales as a

${ }^{53}$ As F. Klotz and K. Oikonomopoulou, 20II, p. 2I have rightly concluded, therefore: "Seen together then, the two chapters vividly showcase the remarkable flexibility with which Plutarch can engage with a core of factual knowledge, adapting it to different contexts and objectives: what the fictional Plutarch in the Table Talk cites as a selfsufficient explanation (rain following from thunder is highly nourishing for plants, because of the admixture of heat) in the Natural Questions features as a partial answer to an open question (what is it that makes the rain following from thunder nourishing?), which admits different scientific explanations - all of which are exhaustively explored. The difference is not just of focus, but also concerns context and register. What the Table Talk especially underscores is the way such knowledge can naturally spring up in the relaxed context of learned conversation, blending in with folk wisdom, oscillating between seriousness and play (chapter 4.2's main topic of discussion is after all truffles!), and serving the needs of a speaker's selected argumentative strategy. It thus brings before us the fact that scientific inquiry is never a value-free exercise, but one influenced by situations and objectives often extraneous to a search for scientific 'truth'. Moreover, it allows us to place scientific knowledge in a wider cultural framework, by drawing attention to the kinds of cultural preoccupation - in this instance, the marvellous - which it can address." Cf. also L. Van der Stockt, 20II, pp. 450-454. 
whole. As seen previously, Plutarch in this work primarily focuses on the physical causes of the phenomena studied therein without much further $\operatorname{ado}^{54}$ [see I.I.6.].

This does not necessarily speak to the complexity of the natural problems as such, though, but rather to their different intellectual dispositions. So the key question still remains about the actual level of $\pi \alpha i \delta \varepsilon i \alpha$ that is required on behalf of the reader. How much knowledge is actually needed beforehand for a proper understanding of these problems? In order to answer this question, an analogy can be drawn with Quaestiones Platonicae.

For an 'esoteric' school text (see n. 73), the aetiologies in Quaestiones naturales never seem to become too complex. If the text is in any way obscure, this is a matter of style rather than content [see 2.3.2.]. In fact, a minimal acquaintance with the theoretical and terminological apparatus seems to suffice for an adequate understanding of the text [see 4.3.4.]. It is only likely, then, that the implied reader did not necessarily have to consider himself a specialist in ancient physics to be able to follow the general lines of argumentation. Dörrie reached a similar conclusion regarding Quaestiones Platonicae, by arguing, mutatis mutandis, that no profound philosophical foreknowledge was required for a good understanding of the problems collected therein. Thus, it should not be considered specialist literature, but rather the work of an author aiming to popularise specific debates in the Platonic tradition ${ }^{55}$. Opsomer, however, refuted this theory by arguing that a serious and profound degree of philosophical foreknowledge actually was required for a proper understanding of the text ${ }^{56}$. This obviously tells us something about its implied readership, but what holds true for Quaestiones Platonicae does not necessarily hold true for Quaestiones naturales just as well.

If we bear in mind the opposition between the notions of aitial and $\zeta_{\eta \tau} \eta \dot{\mu} \alpha \tau \alpha$ [see I.I.6.], it is clear that the kind of research conducted in Quaestiones naturales is less specialised than in Quaestiones Platonicae, in that it is not exegetical (at least in a strict sense). Our collection is

54 This was also observed by L. Van der Stockt, 20II, p. 454: “QN offers no leg up here. But that doesn't mean Plutarch's physical world is without god! It only means that we have to look for Plutarch's philosophia prima elsewhere in his oeuvre."

${ }^{55}$ H. Dörrie, I959, p. 4: "Auch in anderer Hinsicht fand der Leser, was er erwarten durfte: er durfte erwarten, daß die Fragen von vielfältiger Thematik - eben vermischter Art waren; er durfte erwarten, sich nicht in dornige Spezialuntersuchungen, die Vorkenntnisse erfordern, verstrickt zu sehen, sondern ein auch dem Laien übersehbarer Beweisgang mußte zu plausiblen Ergebniße führen." According to some scholars, Plutarch's De facie, for instance, was also destined for a readership of non-specialists (see $\mathrm{H}$. Cherniss and W.C. Helmbold, I957, p. I9; cf. also P. Donini, I984, p. 369). See, e.g., De facie 938C.

${ }_{56}$ J. Opsomer, I994a, pp. I2-I3 (see also I996a, pp. 82-83). 
not concerned with the clarification of specific enigmatic passages in a text or with the tradition of that text with which the reader had to be acquainted first. Rather, it deals with explanations of more general, everyday problems, that are, in a certain sense, universal and common to everyone's experience. As Oikonomopoulou rightly states:

"[T]he $Q N$ 's investigations do not emanate from a scientist's ivory tower, but are anchored in the economic and cultural parameters of practical life: agriculture, animal husbandry, hunting, fishing, seafaring, swimming, feasting and drinking." 57

In some way, 'nature', understood as a conglomerate of countless natural phenomena and the current beliefs about them, is the 'text' being examined here - though, of course, Plutarch himself generally relies on the scientific literature at hand to make sense of it. Bearing in mind, however, that Plutarch's collections of quaestiones are all set in the educational context of his philosophical school ${ }^{58}$, it is not unimaginable that the actual readerships of Quaestiones naturales and Quaestiones Platonicae were identical. Thus, we should think of Plutarch's readers here as philosophers, not only experts, but also students who are advancing in their philosophical $\pi \alpha i \delta \varepsilon i \alpha$, and also well-educated $\pi \varepsilon \pi \alpha \iota \delta \varepsilon v \mu \varepsilon \dot{v} \circ$ เ with an informed notion of the philosophical tradition in general. The bottom-line, then, is that Quaestiones naturales is more generally comprehensible than Quaestiones Platonicae, but that both texts originate from the very same school context. In the end, natural problems remain essentially

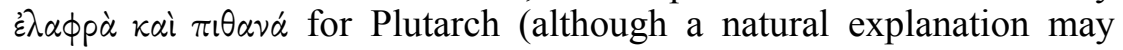
sometimes become somewhat - albeit never excessively - complex or sophisticated). This is not necessarily irreconcilable, then, with the view that Quaestiones naturales presents the 'theory' of scientific discussions, whereas Quaestiones convivales presents such discussions 'in action'.

In order to receive a more concrete idea of Plutarch's readership and of the kind of audience that was interested and actually participated in such inquiries, we can think of the types and characters put on stage in Quaestiones convivales. These are Plutarch's intimi and belong to his more or less direct intellectual milieu: viz. his students, family-members, friends, but also friends of friends, both $\pi \alpha \iota \delta \varepsilon v o ́ \mu \varepsilon v o เ$ and $\pi \varepsilon \pi \alpha \iota \delta \varepsilon v \mu \varepsilon$ vol, young and old, philosophers and all-round intellectuals, specialists and laymen alike, all of whom had their personal interest and occupations

${ }^{57}$ K. Oikonomopoulou, 20I3a, p. I46.

58 Also historical-antiquarian problems, as those treated in Quaestiones Romanae

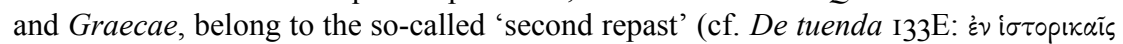
$\zeta \eta \tau \eta^{\prime} \sigma \varepsilon \sigma \mathrm{l}$ ), and this is also the case with the more philosophical-exegetical ones (cf., e.g.,

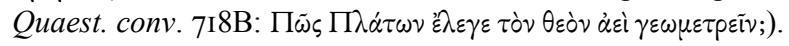


in day to day life (either politics, rhetoric, poetry, literature, medicine, agriculture, philosophy etc.), but shared a general interest in a broad array of intellectual matters, thus by no means despising the lower strata of natural philosophy ${ }^{59}$.

\section{The dialogue between author and reader: vivacity and historicity}

Even if Quaestiones naturales represents only the 'theory' of natural scientific discussions, there is still some degree of argumentative vivacity to it, as can be seen in its dialogical organisation (albeit to a far lesser degree than is the case in Quaestiones convivales, of course). This is not so exceptional to the genre of problems more generally. Regarding Ps.-Aristotle's Problems, some scholars have argued that the questionand-answer format is, in fact, all about argumentative liveliness, and that the problems are actually based on genuine philosophical debates (in the Lyceum), or at least resemble the conditions of such debates. At the same time, however, it is generally acknowledged that the problem format had become a standard method of composition in dealing with scientific topics already by the time of Aristotle, which underlines the 'literary' character

59 According to L. Van der Stockt, 20II, p. 453, " $Q N$ offers philosophical fuel for the philosophical discussion and is destined to people in need of that fuel, namely all those who are not philosophers [cave], who uphold only popular opinion, but want to take part in philosophical discussion. These are the young students in Chaeronea and older friends of Plutarch: people who controlled their agenda and had had some training in rhetoric and grammar (poetry)." Cf. also K. Ziegler, I95I, cols. 662-665, esp. col. 663: "Der Schülerkreis besteht teils aus älteren Leuten, die zu dem Leiter mehr in einem

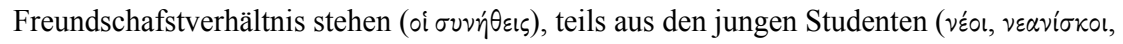
$\mu \varepsilon ı \alpha \dot{\alpha} \ltimes \alpha)$, von denen uns eine Anzahl namentlich vorgestellt wird". For the diversity of the interlocutors in Quaestiones convivales, cf., e.g., F. Klotz, 2007, p. 653 and G. Roskam, 2009, p. 376. See also J. Sirinelli, 2000, p. 380: "En somme, ainsi que Plutarque le précisera, il s'agit de banquets de personnes cultivées et non pas de spécialistes, qu'ils soient hommes d' affaires, politiciens ou sophistes, ou même philosophes, ou plus exactement, les conversations (car ce sont les conversations qui sont ainsi qualifiées) ne doivent pas être des conversations de spécialistes. Chacun, [...] et mêmes les philosophes, doit abandonner les questions techniques pour ne discuter que de questions intéressant des hommes simplement cultivés." If required by some social protocol, specialists can, of course, discuss non-specialist matters, or at least converse in a non-specialist way. On the intended readership of Quaestiones convivales, see also F. Klotz and K. Oikonomopoulou, 20II, pp. 27-29. Moreover, regarding the readers of Plutarch's Vitae, P.A. Stadter, I988, pp. 292-293 argues that they were "male, upper class, and leisured. [...] Plutarch's audience were also intellectuals, well-read and familiar with the science of their day". According to D.A. Russell, I973, p. 43, Plutarch addresses himself in his entire oeuvre to "the highlytrained, the imaginative, the leisured", but H.G. Ingenkamp, I976, p. 547 has put this into perspective: "Sicher war P. ein solcher Leser besonders willkommen, aber seine Gelehrsamkeit hindert den durchschnittlich Gebildeten nicht am Zugang." 
of the problem genre ${ }^{60}$. It is not unimaginable, therefore, that some parts of Plutarch's Quaestiones naturales may originate from actual dialogues in his school, or that Plutarch at least composed this collection with a specific school context in mind. It would not be unrealistic to assume that Plutarch, as the head of his own school, participated in the school discussions and actually took notes on what was said ${ }^{61}$. These notes he later incorporated and remodelled in his quaestiones, adding his own views and comments, based on his own reading and research. If this is correct, Quaestiones naturales represents the proceedings of Plutarch's school seminars on natural scientific topics, providing a status quaestionis of the discussions held, after a thorough review by Plutarch himself. However, except from a few indications, presented below, there is no solid proof for the historicity of Quaestiones naturales (as is also the case for Quaestiones convivales, as we saw earlier on [2.3.I.]).

Scholars have identified the enigmatic figure of $\Lambda$ ai $\tau \circ$, whose answers to two specific meteorological problems are recorded in Q.N. 2, 9IIF and 6, 9I3E, with Ofellius Laetus, a contemporary Platonic philosopher with whom Plutarch perhaps had a real-life discussion on specific meteorological phenomena once [see 4.2.I.I., n. II5]. This has been inferred from the imperfect ' $\varepsilon \lambda \varepsilon \gamma \varepsilon$ which introduces Laetus' two accounts, and which, according to scholars, may suggest a personal encounter with Plutarch ${ }^{62}$. Notably, Plutarch again uses $\dot{\varepsilon} \lambda \varepsilon \gamma \varepsilon$ to introduce the opinion of another contemporary Platonic philosopher, the Lacedaemonian Tyndares, in Quaest. conv. 728E. This man also makes his appearance in Quaest. conv. 7I7E and 7I8C, where his accounts are introduced differently, though, with है $\phi \eta$ and हाँ $\tau \varepsilon \nu$ respectively. The evidence is, indeed, uncertain, since Plutarch uses $\dot{\varepsilon} \lambda \varepsilon \gamma \varepsilon$ not only of contemporaries but also of past authorities,

${ }^{60}$ Cf. H. Flashar, 1962, p. 34I, C. Jacob, 2004 and K. Oikonomopoulou, 20I3b. For some aspects of counter-liveliness in Ps.-Aristotle's Problems, see, however, H. Flashar, I962, p. 345: "Nicht immer sind die Problemata der unmittelbare Reflex der lebendige Diskussion, denn in zahlreichen Fällen können wir nachweisen, daß das Frage- und Antwortschema erst nachträglich einem in Aussageform bereits fixierten Gedanken aufgesetzt ist. Dieser Umsetzungsprozeß ist überhaupt ein wesentlicher Bestandteil der Quellenverarbeitung. Immerhin braucht sich die Tatsache eines in einer Quelle vorgegebenen Gedankens und die Möglichkeit einer Schuldiskussion nicht unbedingt auszuschließen [...]. Bei der Beurteilung der Entwicklung der Problemata-Form, die von der lebendigen Diskussion zum Handbuchschema führt, muß man auch berücksichtigen, daß die für die Probl. charakterische Frage- und Antwortform schon bei Ar. in starkem maße 'literarisch' geworden ist".

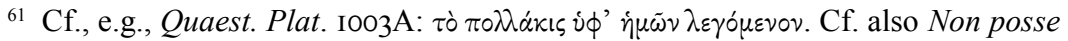

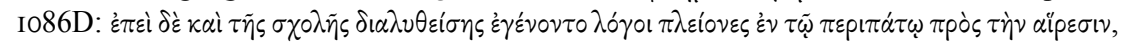

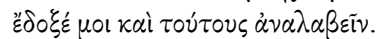

${ }_{62}$ Cf. J. Opsomer, 2008, p. 586. For further reading, see also G.W.M. Bowersock, I982 and M. Meeusen, 20I3a. 
such as Plato (Cor. I5, 4; Non posse I09ID), Euripides (Alc. I, 5), and Cleanthes $(A l c .6,2)$. It remains to be seen, then, whether any aspect of historicity can be deduced from the two Laetus quotes, a problem that hardly admits of an answer. This is not, of course, to reject that some parts of Quaestiones naturales may contain the argumentative nucleus of the responses that Plutarch's fellow discussants gave to the problems at hand and which he then recorded in a primarily anonymous fashion (perhaps, indeed, with the exception of Laetus). In Q.N. 3, 9I2EF, to give just one example, Plutarch anonymously records a solution that is ascribed to Philinus in Quaest. conv. 685D, albeit in a different context [see 2.2.I.].

The issue of historicity is very difficult, if not impossible, to settle, since we should always bear in mind Plutarch's potential editorial interferences in the text. What is perhaps more important, therefore, is that Plutarch's general school context has clearly left its marks on the collection's discourse, disregarding whether this influence occured directly or not. In the end, the possibility that Quaestiones naturales is simply exploiting the question-and-answer format, precisely because of the latter's roots in school practice, cannot be excluded ${ }^{63}$. The bottom line would, then, be that Quaestiones naturales does not necessarily have to originate from historical school discussions to have a basic educational intention. In either case, the question-and-answer format operates as a useful educational tool for the systematisation and communication of scientific knowledge between the author and his readership. It is also an efficient tool in Plutarch's attempt to convince the reader that certain physical explanation are plausible and deserve specific consideration. As such, in each natural problem, we find the condensation of some kind of a virtual dialogue, where the author poses a question and, at the same time, suggests several answers to the reader in an interrogative way. A dramatised version of such dialogues is found in Quaestiones convivales, where Plutarch shows how these problems provided popular topics of conversation during the social event of the symposium. This is not, however, to claim that the

${ }^{63}$ According to K. Oikonomopoulou (in personal correspondence), readers of Quaestiones naturales of a more advanced age would have perhaps enjoyed learning from a text written in a format familiar to them from the years of their school instruction. This may, indeed, be the case, but whether this implies that discussing natural problems is normally a practice suitable for young students only is not a given fact. In any case, both younger and older symposiasts are found discussing natural problems in Quaestiones convivales. In fact, the fictional Plutarch himself makes his appearance both as a young student and as a more mature philosopher [see the prologue, n. 25]. Therefore, the philosophical value of Plutarch's natural problems is not necessarily age-related. In fact, they provide a useful intellectual exercise for more mature philosophers just as well, as we will see further on [3.2.2.]. 
genre of problems mimics that of the dialogue: at the very least there are similar structural principles at work in both genres.

On closer inspection, the problem format has several structural similarities with that of the (philosophical) dialogue ${ }^{64}$. It allows for critical discussion, refutation and correction of traditional view-points and for a tentative proposition of personal theories in a generally zetetic fashion. Moreover, the solution to one question may give rise to another question that is closely related. This may account for the concatenative process that has been noted for the development of many problem chapters in our collection at a macrostructural level ${ }^{65}$ [see I.I.5.]. But then again, this concatenated structure is not necessarily caused by the dynamics of real-life discussions; it can also be explained on the basis of the author's editorial interventions, or of the coherence of the content in the source text on which the chapters are sometimes based [see 4.2.I.2.].

At a microstructural level [see I.I.4.], the profusion of question marks and the absence of aetiological closure, testify to the author's awareness that the explanations he provides do not necessarily fully exhaust the entire aetiological potential of a specific problem. As such, the almost incessant formulation of explanations in an interrogative and anti-dogmatic fashion in the aetiologies is not so much a rhetorical technique inspired by feigned uncertainty (analogous to rhetorical questions), but a sign of scientific caution, both on the side of the teacher and the student ${ }^{66}$. In fact, it is one of Plutarch's firm epistemic convictions that it is impossible to formulate natural explanations that are certain and definite ( $\left.\dot{\varepsilon} \pi \circ \chi_{\eta}^{\prime}\right)$. As a consequence, the фuбikós has to manage with probable arguments and leave space for the potential addition of new solutions, corrections and criticisms [see 4.3.2.]. When it comes to the interrogative and open-ended structure of the explanations, one could even argue that the role of the reader, in a certain sense, merges with that of the author. The reader is invited, then, to evaluate the positions the author proposes and, if possible, to formulate his own explanations. This certainly makes the reading process more active and engaging, and for that matter, more attractive from a didactic perspective.

Closely connected to this point is the idea that, from an epistemological perspective, Plutarch, as a teacher, actually places himself on par with his students, since they are both looking for what are essentially plausible

${ }^{64}$ See, e.g., C. Jacob, 2004, J. Opsomer, 2005, pp. I98-I99, 20IO, p. II5 (“une forme rudimentaire de dialogue") and K. Oikonomopoulou, 2013b. For a study of Plutarch's general use of the dialogue format, see L. Van der Stockt, $2000 \mathrm{~b}$ (with further references).

65 The same argument was made for Ps.-Aristotle's Problems by H. Flashar, I962, p. 30I.

${ }^{66}$ A similar conclusion was made for Ps.-Aristotle's Problems by H. Flashar, I962, p. 34I. 
natural explanations. Therefore, obvious authorial self-promotion in providing such arguments is unnecessary. This probably explains why Plutarch's personal statements and remarks are not formulated in an authorial fashion in Quaestiones naturales ${ }^{67}$. In fact, Plutarch effaces everything personal by avoiding the use of the first person singular ('I') in favour of the less emphatic first person plural ('we'). In some cases ${ }^{68}$, though, the first person plural may function as a substitute for the first person singular (scholars call this the "authorial we") ${ }^{69}$. Yet, this is rather unlikely, if not impossible, in other cases ${ }^{70}$. The use of the first person plural can be considered a suggestive means, then, of involving the student in a joint search for physical causes (scholars call this the "sociative we") ${ }^{71}$. It

${ }^{67}$ Cf. G.W.M. Bowersock, I985, p. 666: "But spread throughout his [sc. Plutarch's] works is a genuine and irresistible humanity, unfettered by egotism or pretence. In this respect too he is highly unusual." The rather impersonal authorship is also typical of Ps.-Aristotle's Problems (see C. Jacob, 2004, p. 4I, V. Nutton, 2009, pp. 58-59, K. Oikonomopoulou, 20I3b). Similarly, in regards to Quaestiones Platonicae, J. Opsomer, 20Io, p. 93 notes that "l' intervention de l' auteur est minimale". This general impersonal authorship can perhaps be connected, in the case of Plutarch, with the $\dot{\alpha} \phi \alpha \sigma^{\prime} \alpha$ of the Academic Sceptics [see 4.3.2.I.], that is, the avoidance of formulating theories of one's own, a practice that goes back on Socrates' aporetic attitude in philosophical dialogues

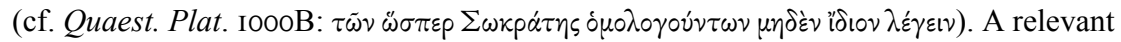
passage for this $\alpha \phi \alpha \sigma i \alpha$ is found in De facie $922 \mathrm{E}-923 \mathrm{~A}$, where the Stoic Pharnaces

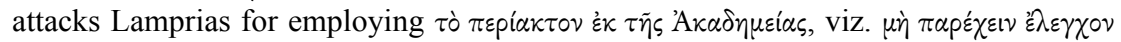

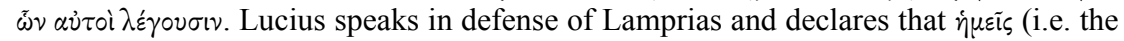

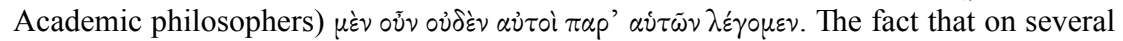
occasions, they do employ the first person, might complicate the consistency of this sceptical feature in De facie (cf. H. Görgemanns, I970, p. 86), but P. Donini, 20II, pp. $38-39$ is probably right that "semplicemente, in quelle occasioni i suoi personaggi si identificano con la teoria che difendono non perché improvvisamente se ne siano fatti conquistare e abbiano abbondonato ogni riserva a proposito della sua veridicità definitiva così tradendo le premesse dell'epistemologia 'academica' e del Timeo, ma soltanto in quanto la considerano la migliore delle spiegazioni disponibili”. Arguably, then, the same counts, mutatis mutandis, for Plutarch's personal statements (by means of his own literary alter ego) in Quaestiones convivales (see further). Note, moreover, that the aspect of $\dot{\alpha} \phi \alpha \sigma^{\prime} \alpha$ or avoidance to beget personal doctrines does not withhold Plutarch from proposing his own original contributions to the problems, again, at least within the limits of his Platonic-Academic epistemology [see 4.2.2.2.].

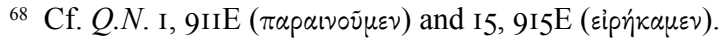

${ }^{69}$ See H. von Staden I994, p. I08 and H. Hine, 2009, p. 2I.

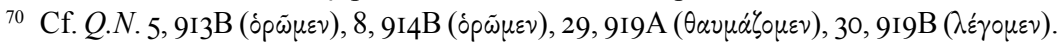

${ }^{71} \mathrm{~F}$. Slotty, 1928. Regarding the most common uses of the first person plural in ancient scientific writing, see H. von Staden, 1994, pp. I08-I09 and H. Hine, 2009, pp. 2I-22. For the didactic relationship expressed by the first person plural in Quaestiones convivales, see J. König, 20II, p. I85. On Plutarch's use of the first person plural in Quaestiones Romanae, 
evokes a certain sense of zetetic community ( cov $\left.\omega \nu v^{\prime} \alpha\right)^{72}$ and, in most cases, hints at some kind of didactic pact between the teacher and the student by invoking, and at times even insisting on, shared believes, customs and experience. For instance, in Q.N. 8, 9I4B, Plutarch wonders why we observe that the sea grows warmer when it is agitated, whereas all other liquids - paradoxically - become colder when disturbed $(\Delta i \dot{\alpha} \tau \dot{i}, \tau \tilde{\omega} \nu \dot{\alpha} \lambda \lambda \omega \nu$

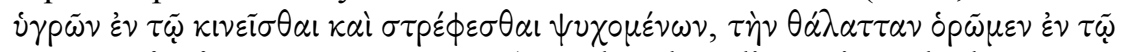
$\kappa \nu \mu \alpha \tau \circ \tilde{\nu} \sigma \theta \alpha \iota \theta \varepsilon \rho \mu \tau \varepsilon \dot{\varepsilon} \alpha \nu \gamma \iota \gamma \nu \circ \mu \varepsilon \dot{\nu} \eta \nu ;)$. Rather than discussing whether or not this is really true, Plutarch, by use of the first person plural in ó $\tilde{\omega} \mu \varepsilon v$, insists on assuming that this is the case, if only for the sake of argument [see 4.I.I.2.]. It can be inferred from this aspect of authorial self-effacement that Plutarch deliberately aims to temper his authorial voice, so that the text never becomes too obtrusive or self-promoting.

This is far less the case in Quaestiones convivales, presumably for reasons of 'exotericism' - vis-à-vis the 'esotericism' of Quaestiones naturales $^{73}$. Arguably, in Quaestiones convivales, Plutarch aims to pro-

cf. also R. Preston, 200I, p. II4 ("[Plutarch's] use of the first person plural [...] suggests the possibility of a unified, undifferentiated humanity") and P. Payen, 20I4, pp. 245. For the Vitae, see also C. Pelling, 2004, pp. 4II-4I2: "It is indeed often unclear exactly how that category of 'us' is envisaged: 'we Greeks', 'we cultured beings', 'we people of humane sensibility', 'we who are interested in the past'? Does it include real readers in subsequent generations as well as those 'in our day', i.e. Plutarch's own? But in any case, it is evidently a category that includes narratee as well as narrator. [...] The blurring is important in insinuating that of course narrator and narratee are people who think along similar lines." Cf. also id., 20II, p. 208: "that characteristic Plutarchan 'we' and 'us' [...] contrives to suggest a large happy family of readers”. See also T. Duff, 20I4, pp. 340-342.

${ }^{72}$ In Praec. ger. reip. 8I6DE, Plutarch reports his father's advice that it is more polite and unambitious to use the first person plural instead of the first person singular as a way of

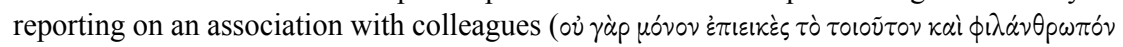

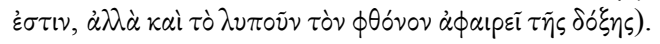

${ }^{73}$ If Quaestiones naturales can rightly be considered an 'esoteric' text, which Plutarch presumably composed for the inner circle in his own school, Quaestiones convivales can be considered a more 'exoteric' work, promoting Plutarch's own research activities and that of his intellectual milieu to the outer world (the work was dedicated to Sossius Senecio). The esoteric nature of Quaestiones naturales can be generally linked, then, with its theoretical character, and the exoteric nature of Quaestiones convivales with the social pragmatics that it promotes by describing the discussion of problems 'in action'. This distinction may not remain unproblematic, though. In any case, scholars have also treated the issue of exotericism vis-à-vis esotericism with regard to Ps.-Aristotle's Problems, but at first sight, their claims seem irreconciliable. This incongruity mainly rests in a different perspective of interpretation. Some scholars especially focus on the form and organisation of the Problems in considering them esoteric, whereas others consider them exoteric on the basis of their content. According to C. Jacob, 2004, p. 44, n. 32, for instance, Ps.Aristotle's collection of Problems is an esoteric work to be situated in the Lyceum: "[L]es Problèmes seraient un exemple parmi d' autres des différentes formes d'écriture à l' oeuvre 
mote the practices and achievements of his research to a wider audience by placing his own literary alter ego in the sympotic spotlights at several points in the discussions (often allowing him the final and, thus, most authoritative word on a given topic [see I.I.4., n. I04]). To this end, Plutarch often presents his literary alter ego as some kind of primus inter pares in the discussions with his peers ${ }^{74}$. This is not to say, however, that Quaestiones convivales is an ego-document, since the views of Plutarch's sympotic peers often have even more weight in the discussion. What is perhaps more important, however, is that a certain aspect of argumentative caution and undecidedness is never abandoned (cf. n. 67).

Another discursive means of involving the reader in a joint search for physical causes is found in the use of the second person singular in

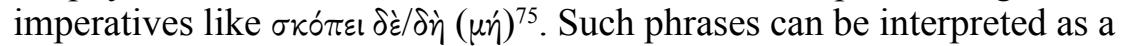
"metadirective" $" 76$ address to the reader, meant to emphatically encourage

dans la partie ésotérique du corpus aristotélicien, qui nous est parvenue: 'textes d'école' comprenant des notes de cours, des textes de conférences, des brouillons, mais aussi des instruments de travail partagés par les membres de la communauté, pouvant faire l' objet de révisions et d' enrichissements." Cf. also W.S. Hett, 1936, p. viii ("The form of the book suggests that it originated as a lecture notebook containing problems for discussion.") and H. Flashar, 1962, p. 34I. On the contrary, P. Louis, I99I, pp. xix-xx has argued that the Problems are exoteric, because they are sometimes labelled $\dot{\varepsilon} \gamma \kappa \dot{\kappa} \kappa \lambda \iota \alpha$ (see M. Meeusen, forthcoming e), implying that they are 'in the hands of everyone', making it a work of philosophical vulgarisation (see also A. Garzya and R. Masullo, 2004, p. I2). Louis does not as such reject the school context for the Problems, though, since he describes them as "des notes prises au cours de lectures ou à la suite d'observations personnelles" (p. xxix). If we now transpose this problem on Plutarch, we see that the natural problems treated in Quaestiones naturales and Quaestiones convivales are very similar from the perspective of content to those treated in Ps.-Aristotle's Problems, so that they can be considered exoteric [see 2.2.3.]. From a formal perspective, though, Quaestiones naturales is closer to Ps.-Aristotle's Problems than is Quaestiones convivales, so that the former can be considered more esoteric, at least according to these standards [see 2.2.2.]. For Plutarch's acquaintance with the distinction between Aristotle's exoteric and esoteric writings, cf. Adv. Col. III5B and Alex. 7, 2.

${ }^{74}$ On the intricacy of Plutarch's authorial self-promotion and self-effacement in Quaestiones convivales, see J. König, 20II and F. Klotz, 2007. As J. König, 20II, p. I88 observes, Plutarch "was on the whole [...] uninterested in confrontational Galenic debunking of intellectual rivals and predecessors". Cf. also J. König, 2008, p. 97.

${ }^{75}$ Cf. Q.N. 3, 912E, 12, 915A, I9, 916C. The use of the second person singular is also

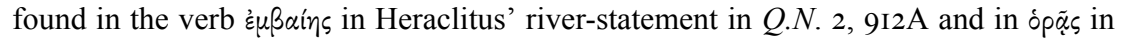
Euripides' quote in Q.N. 29, 919B.

${ }^{76}$ See R. Risselada, I993, pp. 258-278 and H. Hine, 2009, p. I9: "[The] point is that it is part of the unspoken contract between writer and reader that the reader normally pays attention, believes statements the writer makes, considers arguments presented by the writer, and so on; so 'listen to this', 'believe me' and the like are foregrounding and making explicit what is normally implicit." 
him to take a specific point that has been made into consideration and to be attentive and thoughtful towards what has been said ('Consider this!', 'Attention please!'). As such, these imperatives certainly make the zetetic process more engaging for the reader, as seen before [see I.I.4., n. IIO].

Bearing in mind that we are dealing in Quaestiones naturales with a 'functional' type of literature, as we saw [2.4.I.], there is much reason to assume that Plutarch composed the work as some sort of a technical manual, setting an example that could be followed by the reader when discussing natural problems himself ${ }^{77}$. As such, the collection provides a general aetiological framework or frame of reference to be followed and reactivated when confronted with similar natural problems, a point that deserves further consideration in the following section.

\subsection{Quaestiones naturales as a preamble to metaphysics}

For Plutarch, physics, as the causal study of natural phenomena, has no practical use in itself (contrary to, say, politics) ${ }^{78}$, but has a more intellectual goal, in as far as the search for natural explanations provides an efficient means of making sense of the immediate world around us. In contrast to Plutarch's other natural philosophical writings, the research conducted in Quaestiones naturales is, as we saw, of a mainly 'technical' kind, meaning that not much place is left in it for a 'higher' type of causality. Van der Stockt is probably right, therefore, that the collection is "a leg up for philosophy at its best" ". In what follows, I intend to explore precisely how we should read Quaestiones naturales as a prephilosophical text, then, and what is the intellectual and propaedeutic function of physical aetiology more generally according to Plutarch.

\section{Natural problems as a means of exercising the mind}

As suggested before, the discussion of natural problems is intrinsically bound up with Plutarch's intellectual $\pi \circ \lambda \nu \mu \alpha \dot{\theta} \varepsilon$ s $\alpha$ project [see 2.4.2.]. An important passage illustrating this is found in Quaest. conv. $734 \mathrm{CD}$, where L. Mestrius Florus is reading a copy of Aristotle's Problems, which he shared ( $\mu \varepsilon \tau \varepsilon \delta i \delta \circ v)$ with his friends for pleasant conversation (oủk ä $\chi \alpha p \nu$

${ }^{77}$ For Plutarch's Moralia more generally as an exponent of the $2^{\text {nd }}$ century Greek handbook movement, cf. W.H. Stahl, I962, p. I33.

${ }^{78}$ Cf., e.g., Plutarch's account in Per. I6, 7 of Anaxagoras' theoretical way of living

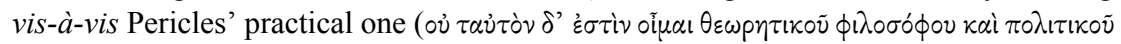

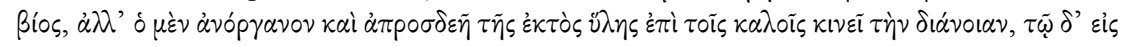

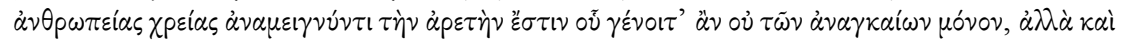

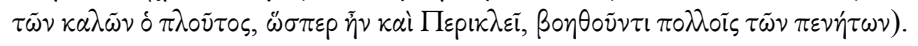

${ }^{79}$ L. Van der Stockt, 20II, p. 452. 
$\delta(\alpha \tau p) \beta \dot{\eta} \nu)$ during the daytime strolls ${ }^{80}$. We read that Florus was full of questions, as is natural for a philosopher ${ }^{81}$, thus confirming Aristotle's saying that great learning $(\pi \circ \lambda \nu \mu \dot{\alpha} \theta \varepsilon ı)$ provides many starting-points:

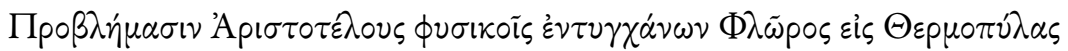

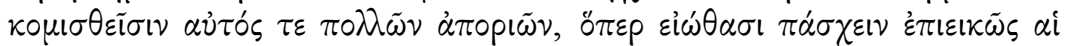

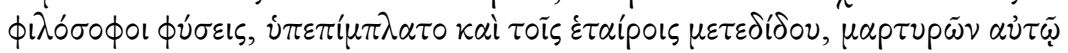

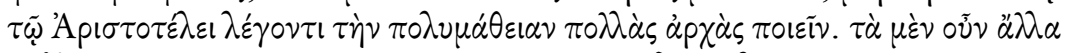

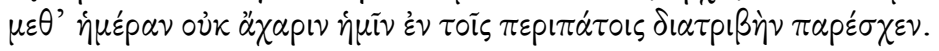

Florus, who was engaged in reading a copy of Aristotle's Problems that had been brought to Thermopylae, was himself full of questions, as is natural for a philosophical spirit, and shared them with his friends too, proving Aristotle's own statement that "great learning gives many starting-points." Most of the questions raised provided us with a pleasant pastime during our daytime walks.

Aristotle's quote, according to which 'great learning provides many starting-points' (fr. 62 Rose: $\pi \circ \lambda v \mu \dot{\alpha} \theta \varepsilon 1 \alpha \pi 0 \lambda \lambda \dot{\alpha} \varsigma \dot{\alpha} p x \dot{\alpha} \varsigma \pi \circ \varepsilon \tilde{)}$ ), originates from his lost Пвpi $\pi \alpha i \delta \varepsilon i \alpha$ s. In light of Plutarch's description of Florus as a philosopher full of questions who shares the Problems with his friends for discussion, the quote does, indeed, seem to have specific educational meaning. I take it to imply that great learning $(\pi \circ \lambda \nu \mu \alpha \dot{\theta} \theta \varepsilon)$ functions as a useful starting-point for philosophical research (notably, the chapter at hand inquires into the nature of dreams and ends with a reference to divination). If great learning provides many starting-points, it is obviously not a $\tau \varepsilon \lambda \circ \varsigma$ in itself. The ultimate $\tau \varepsilon \lambda \circ \varsigma$ for Plutarch, as a philosopher, is to look for philosophical knowledge - however unattainable this may

${ }^{80}$ The pleasant character of natural problems is also acknowledged, e.g., in De tuenda I33B, where they are included among many pleasant scholarly diversions at table ( $\kappa \alpha \lambda \dot{\alpha} \varsigma \kappa \alpha \grave{\imath}$

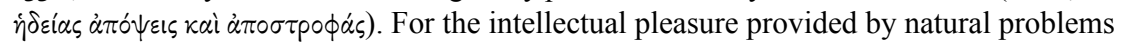
in Quaestiones convivales, cf. also F. Fuhrmann, 1972, p. xxiv: "Pour les questions d' ordre scientifique, il est particulièrement grave de ne pas discuter les problèmes dans leur fond. Or c' est ce qui se passe ici. Au lieu de chercher les causes véritables [quid?] des phénomènes, Plutarque se contente en général de la vraisemblance, en citant plusieurs théories qui s'y rapportent, ou en rappelant ce que divers auteurs en ont dit. Les différentes opinions se succèdent ainsi sans aucune analyse et le plus souvent sans solution, comme si ceux qui sont chargés de les défendre s' amusaient avec elles." For a more positive evaluation, see F. Frazier and J. Sirinelli, 1996, p. 206: "Sans jamais tourner à la leçon de philosophie - ce qui serait un manquement inacceptable à l'atmosphère détendue du banquet -, celui-ci témoigne donc d'un esprit curieux et toujours en éveil chez ses participants et d' un véritable plaisir d' exercer ensemble son esprit." See also F. Frazier, 1998.

${ }^{81}$ Elsewhere, Florus is called a 'lover of antiquities' (Quaest. conv. 702D: $\left.\phi 1 \lambda \alpha ́ p \chi \alpha 10 \varsigma\right)$. 
be. It remains to be seen, then, how natural problems can serve as useful starting-points to achieve this more philosophical goal. Before we can do this, we should first look into their more basic intellectual appeal, as distinct from their higher, philosophical purpose.

In regards to the basic intellectual appeal of Plutarch's natural problems, we learn from several passages throughout his oeuvre that they provide a virtual training court for mental exercise $\left(\gamma v \mu \nu \alpha \sigma^{\prime} \alpha\right)^{82}$. This is generally interpreted in light of their function as scholarly-rhetorical exercises, that is, a training in natural scientific $\zeta \dot{\eta} \eta \eta \sigma i \varsigma$, to be situated in the wider context of the Chaeronean's philosophical school. As scholars have argued in light of the natural problems discussed in Quaestiones convivales, the practice of solving such problems by means of looking for plausible natural explanations is a scholarly endeavour, suitable for all-round $\pi \varepsilon \pi \alpha 1 \delta \varepsilon \nu \mu \varepsilon \dot{v}$ ol, to whom it offers an incentive for rhetorical-argumentative creativity. When read in this way, the problem-format offers an agonistic (but amusing and friendly) framework for rhetorical demonstration and the ingenious display of multifarious $\pi \alpha i \delta \varepsilon i \alpha$. Indeed, the symposiasts generally try to show off their knowledge of traditional authorities in combination with their proficiency to remodel this knowledge in an original fashion to ever new problem contexts. However, further nuance is necessary, insofar that the eventual utility and purpose of such exercises remains unexplained. Were they merely scholarly, but for the rest entirely noncommittal, games played by learned people, or is there more to them? I will deal with this in the next section [3.2.2.].

When it comes to the implied reading of Plutarch's natural problems and their role as scientific literature, scholars agree that they intend to activate the reader's attentiveness for the kind of theories and terminologies used in solving such problems. As such, they promote, what has been called, an 'active reading' 83 , meaning that they provide some kind of theoretical model that presents a general aetiological method and design for the reader to follow when dealing with natural problems himself.

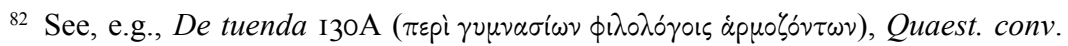

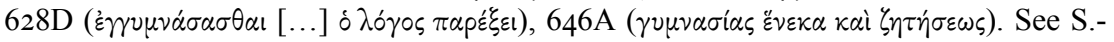
T. Teodorsson, 1989, p. 290: "The discussions at the drinking-parties were pursued as a sport and training in $\varepsilon \dot{v} p \eta \sigma i \lambda \circ \gamma_{i} \alpha[\ldots]$. ." The idea that natural inquiry is an opportunity for intellectual exercise is a widespread tótos in ancient literature. For the conception of natural science as an intellectual exercise (mostly with an ethical finality), see P. Hadot, 2002, pp. 207-2II.

${ }^{83}$ This hypothesis has especially been discussed in view of the problems treated in Quaestiones convivales. See J. König, 2007 and E. Kechagia, 20IIa. See also C. Jacob, 2004 and K. Oikonomopoulou, 20I3a more generally. I have argued elsewhere that the same idea also applies to Ps.-Alexander's Medical puzzles and natural problems, where the situation seems far less hypothetical (see M. Meeusen forthcoming f). 
These scientific concepts and theories - in short, the general aetiological framework - could be reused and remoulded in new discussions concerning similar problems, for instance, during symposia ${ }^{84}$. This does not necessarily imply, however, that the intended reader should simply learn these problems by heart in order to reproduce or 'perform' them during discussions. Extemporisation and on the spot ingenuity was, after all, a much valued intellectual virtue by Plutarch and his peers [see 4.2.2.2.]. If the main educational purpose of this branch of research is not so much achieved by the exact reproduction and 'performance' of the problems that have been recorded ${ }^{85}$, then, it is presumably found in the implicit and indirect acquisition of a more general aetiological sensitivity, some kind of an aetiological Fingerspitzengefühl for explaining natural phenomena. By means of solving specific case studies in his problems, Plutarch, thus, intends to outline a general aetiological modus operandi for the implied reader to absorb and to reactivate whenever suitable. A similar notion of the reader's acquisition of a general "explanatory schema for natural philosophy" has recently been discussed by Kechagia for the natural problems treated in Quaestiones convivales ${ }^{86}$ :

${ }^{84}$ Interestingly, Plutarch does, indeed, inform us that there is a certain sympotic protocol that guests should prepare themselves intellectually to participate in the discussion

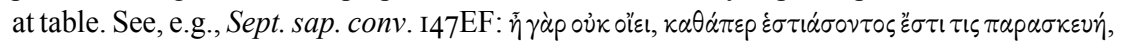

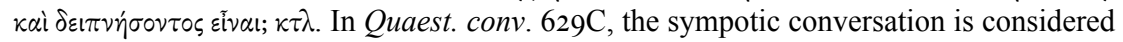

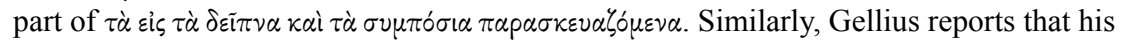
teacher L. Calvenus Taurus often invited some of his students (viz. the iunctiores) to dinner at his house and that each diner was obliged to prepare a light and entertaining topic for discussion, 'suitable for a mind enlivened with wine' (NA 7, I3: Quaerebantur autem non grauia nec reuerenda, sed $\dot{\imath} \theta \nu \nu \eta \eta \alpha \dot{\alpha} \tau \alpha$ quaedam lepida et minuta et florentem uino animum lacessentia). This contribution to the discussion is considered the 'tax' or $\sigma u \mu \beta 0 \lambda \eta$, that is, some kind of an intellectual entrance-fee to the dinner (cf. LSJ, s.v. iv). The same imagery recurs passim throughout Quaestiones convivales (cf. 664D, 668D, 682A, 694B, 719EF).

${ }_{85}$ This cannot be refuted with full certainty either, though. The bite-size format of such problems would, in any case, facilitate memorisation. On the memorability and reusability of miscellaneous knowledge (as collected in Plutarch's Quaestions convivales), see S. Goldhill, 2009, p. I09. See also F. Klotz and K. Oikonomopoulou, 20II, p. I6 and K. Oikonomopoulou, 20I3a, pp. I44-I45. For further reading on ancient mnemotechnics and its importance in ancient education, see J.P. Small, I997, R. Cribiore, 200I, T. Morgan, 1998. For the link between compilation literature and teaching practices more generally, see M. Horster and C. Reitz, 20I0, p. II.

${ }^{86}$ E. Kechagia, 20IIa, pp. 97-99. Cf. also J. Sirinelli, 2000, pp. 382-383: "Ce [sc. Quaestiones convivales] ne sont pas les plus anodines. Elles représentent assez exactement le niveau moyen des problèmes posés mais ce n' est pas à cette aune que se mesure pour Plutarque leur intérêt: c' est à la nature et à la diversité des réponses. Il convient que l'on puisse, pour répondre, invoquer l' autorité d' auteurs connus, la discuter, confronter les réponses et, éventuellement, en retenir une pour des raisons plausibles. Ce n' est donc pas l'importance du sujet traité qui fait l'importance de la question, mais c' est plutôt 
"In other words, what the reader effectively gets to learn through reading the zeteseis one after another are not specific (and firm) explanations of a certain phenomenon; he rather learns how to use the basic tools available, with the help of which he can embark on an inquiry into nature. Just as philosophy can be employed in every question needing an answer, so this particular explanatory schema can be tried out in search of an answer to almost any question relevant to natural philosophy." 87

If the main objective of the active reading process is, indeed, found in the reader's mastery of this explanatory scheme and in his ability to remodel and reactivate this scheme in other problem contexts, the active reading in itself sharpens the zetetic potential of the reader, who is challenged not only to remain critical and attentive in reading the aetiologies and mining them for useful insights but also to be inventive in constructing his own solutions to the problems that are raised. As such, Plutarch's natural problems not only appeal to a good understanding by the reader, but also demand a critical response from him in return. This appeal is found both at the micro- and at the macrostructural level of the discourse in Quaestiones naturales.

At the microstructural level, an appeal is done to the reader by means of the interrogative and open-ended formulation of the explanations, as well as by the metadirective addresses in the text that closely engage the reader

l'ingéniosité et la force de la démonstration. Il s' agit d' une sorte de rituel: évoquer les avis des poètes et des savants, les discuter, discuter des raisonnements présentés ou sousentendus. Le ressort de ce jeu de société est la question posée (problèma) et la recherche de la solution (zetema), autrement dit c' est une question de méthode et non pas un jeu de devinettes qui fait l'intérêt de ces discussions. Sous cet angle il n'y a pas de petits sujets, mais une activité de l'esprit et du jugement qui satisfait les philologoi présents, lesquels en retirent non seulement des informations mais surtout des travaux pratiques et des confrontations de procédure." See also p. 387: “C' est bien là que réside l'intérêt de l' ouvrage aujourd' hui encore: il nous livre beaucoup de renseignements sur la manière dont un contemporain cultivé de Trajan se représentait le monde, mais surtout il nous fait connaître les mécanismes intellectuels de cet homme, ce qui lui paraissait constituer les règles d'un raisonnement scientifique et le "critère" de la vérité."

${ }^{87}$ E. Kechagia, 20IIa, p. 99. The same conclusion has also been made for Ps.-Aristotle's Problems. See, e.g., C. Jacob, 2004, pp. 40-48 (sub "Les Problèmes aristotéliciens: savoir ou pratique?"). Cf. also, e.g., A. Blair, 1999, p. I74: “The resolution of problemata involves the manipulation of the common pool of Aristotelian and Hippocratic notions about nature and human physiology: humors and qualities, phenomena of antiperistasis (or opposition), concoction, sympathy, and the like." Cf. also p. I75: "Problemata are best understood as exercises in manipulating concepts of physics and medicine, using methods of argumentation acquired earlier. The goal is perhaps less to reach a single, "true" answer than to display mastery and ingenuity in the use of fundamental principles." 
in the zetetic process (see n. 76). By formulating the physical aetiologies in this way, Plutarch, in a certain sense, breaches the fiction of his own text and taps into the reader's reality. He extends a hand to the reader and invites him to actively participate in the virtual discussion, in order to evaluate the proposed solutions and to formulate personal answers to the problems that have been raised ${ }^{88}$. In the end, Plutarch leaves it up to the reader to decide which explanation he considers most convincing, and, if possible, to formulate his own solution to the problem so as to challenge the author's own problem solving ability. Of course, the author tries to convince the reader by formulating plausible explanations to the problems himself, but at the same time, on the side of the intended reader, there is also a certain willingness to be convinced (cf. Quaest. conv. $665 \mathrm{E}$ : $\left.\varepsilon \dot{v} \pi \varepsilon^{\prime} \theta \varepsilon 1 \alpha\right)$.

At the macrostructural level, on the other hand, we have seen before that the mostly chaotic and disorganised line-up of the problem chapters also stimulates active reading [see I.I.5.]. In regards to the generally unstructured variation of themes and topics in Quaestiones convivales, König argues that "Plutarch embeds the requirement for personal response in the very form of his writing, forcing us to take up the provocative challenges of interpretation precisely through his arrangement of material." 89 This means that the implied reader should remain attentive to the repetition of specific recurring themes and theories in the text, in order to deduce a certain sense of structural unity for himself in spite of the work's thematic diversity and miscellaneous arrangement. As such, the collection's chaotic organisation challenges the implied reader to "read things disjointedly and out of context or not" and at the same time "to experience the way in which disparate material can begin to resolve itself into unity if only we read carefully enough" 90 . These claims also apply to Plutarch's Quaestiones

${ }^{88}$ In this sense, the function of the reader resembles that of an umbra accompanying someone to a symposium, without being directly invited by the host, but who is nevertheless welcome to join in (cf. Quaest. conv. 706E). Regarding the concrete reading of Quaestions convivales, G.W.M. Harrison, 2000a, p. 196, n. I9 also notes that "as self-aware as selfeffacing, Plutarch certainly had to know that we are his grateful umbrae".

89 J. König, 2007, p. 50. See also pp. 45-46: "The Sympotic questions prompts us to read actively - in other words to respond creatively and philosophically for ourselves to the many different questions under discussion, and to stay alert to the recurring themes and patterns of the texts. Plutarch also shows us his fellow dinner-guests learning that style of active response for themselves, using the topics they discuss as springboards for personal response, as stepping-stones in their philosophical lives. The work demonstrates, in other words, how processes of universally relevant philosophical enquiry can start from frivolous snatches of conversation."

90 J. König, 2007, p. 6I. Scholars have, indeed, argued that a similar overarching scheme lies behind the disordered problems in Quaestiones Romanae (see, e.g., J. Boulogne, I992, pp. 4698-4707, who analysed it in terms of politics, Greekness and 
naturales. In this work too, subtle continuities of thematic and theoretic leitmotifs stimulate the reader's response to the text (this is the principle of concatenatio). As such, the author encourages and challenges the reader to form a coherent picture of the text and, by implication, also of the physical world behind it, in terms of the natural processes and powers that operate in it.

Clearly, the reader's direct involvement in the zetetic process underlines the intellectual appeal of this kind of literature. However, as noted before, a deeper, philosophical motive still lies at the heart of Plutarch's interest in natural problems, a feature that has been neglected by scholars thus far and that can put the hypothesis about the active reading in a broader perspective ${ }^{91}$.

\section{Natural problems as a means of easing the mind}

The aim of this section is to demonstrate that the eventual goal of Plutarch's natural problems was not just of a generally scholarly-intellectual but of a more elevated and philosophical kind. These two features do not necessarily exclude one another, but even so the second seems to outstrip the first. This will be very seminal in determining how Plutarch's natural problems relate to his overarching natural philosophical programme, an issue that will be further examined in the next chapter.

An important passage to start with is Q.N. 29, perhaps the most significant chapter to interpret the eventual goal of Quaestiones naturales (it has already partly been discussed earlier on [see I.2.3. and 3.I.]). Initially, the reader of Q.N. 29 might expect Plutarch to simply treat yet another natural problem here, but the tone of the discourse rapidly changes. Plutarch wonders why we marvel at hot springs but not at cold ones, while it is clear that heat is the cause of the former and cold of the latter (Tis $\dot{\eta} \alpha i \tau i \alpha, \delta i$

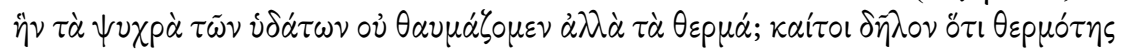

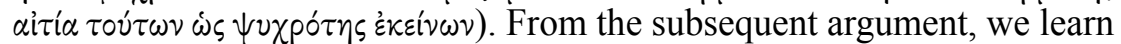
that it is not so much the natural phenomenon of hot or cold springs

anthropology), Quaestiones Graecae (see, e.g., P. Payen, 1998b, pp. 49-55, who analysed it in terms of geographical categories) and Quaestiones naturales (K. Oikonomopoulou, 2013a, p. I52 [see I.I.5.]).

91 J. König, 2007, p. 47 has actually considered Plutarch's "insistence on personal response [in Quaestiones convivales] as a central part of philosophy". He argues that "the frivolous joys of ingenious speculation are shown to embody the most important principles of philosophical education" (p. 56). He also says (p. 6I) that "Plutarch thus repeatedly emphasises the requirement that the philosopher should be able to use any conversation as a starting point for philosophy, by applying his or her own distinctive skills of reading." Unfortunately, König does not specify how this leap towards philosophy - which I take to be philosophia prima and not a generally scholarly-intellectual mode of conversation can be made then. 
as such, but rather the aspect of marvelling itself that is at issue here ${ }^{92}$. Plutarch explains that it appears that nature attributes marvellousness to rarity and stimulates the research of how a phenomenon comes to be only

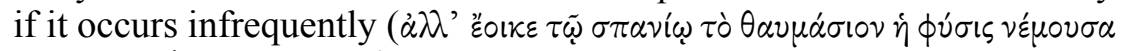

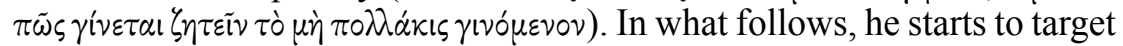
the common people, whom he accuses of not feeling any wonder for the nature of celestial phenomena that can be seen during night and day ( $\circ \dot{v}$

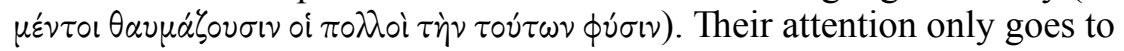
rare phenomena such as rainbows, the variety of clouds by day, meteors bursting like bubbles, and comets ...- and then the text breaks off (ip $1 \delta \varepsilon \varsigma \delta \dot{\varepsilon}$

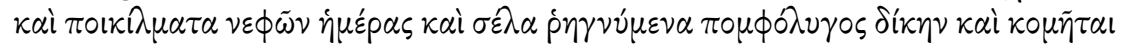
****). I take this to imply that the wonder of the common people remains superficial, not only because they are not interested in 'less marvellous' phenomena, but also - and more importantly so - because they do not look into the nature ( $\phi \dot{v} \sigma \mathrm{s}$ ) of these phenomena. Unlike a genuine $\phi v \sigma i k o ́ s$, who would also be astonished about these phenomena, albeit not in the same superficial way, the common people have no intention towards natural philosophical insight, so that they do not really wonder about the actual nature of wonder-inducing phenomena. In other words, the kind of wonder they experience does not lead on to natural philosophical contemplation. As I will try to show in what follows, Plutarch considers this lack of a rational, physical approach a fertile ground for superstition ( $\delta \varepsilon เ \sigma i \delta \alpha \mu o v i \alpha)$.

As just indicated, the end of Q.N. 29 is lacunary and open to conjecture. Notably, a similar polysyndetic enumeration of wonder-inducing celestial spectacles can be found in the conclusion of De Pyth. or. 409CD (in the context of the prophetic art). Plutarch there reprimands children's selective amazement at marvellous phenomena in the heavens: 'It is a fact that children take more delight and satisfaction in seeing rainbows,

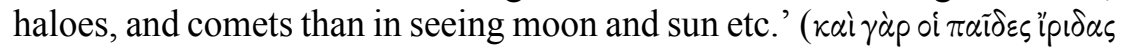

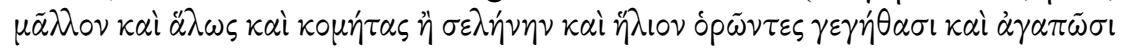
$\kappa \tau \lambda$.). Another parallel for this childish marvelling is found in Amatorius 766A (in the context of love): 'It is like the eagerness of children to catch the rainbow in their hands, attracted by its mere appearance' ( $\ddot{\sigma} \sigma \varepsilon p$ oi

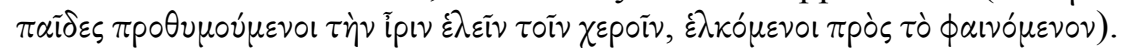
From these parallels, one can induce that Plutarch originally concluded his invective in Q.N. 29 with the same topic, namely that the childish astonishment of the ignorant plebs for such celestial phenomena - and hence also for other astonishing phenomena, such as the hot springs is motivated on irrational grounds ${ }^{93}$. As we learn from Per. 6, I, these

${ }^{92}$ If wonder is the beginning of philosophy, why not wonder about wonder itself [see 4.I.I.I., n. 23]?

93 P.R. Hardie, I992, pp. 4747-4748 also highlights people's "foolish wonder at meteorological marvels" in Q.N. 29 (n. 2I), and he correctly interprets the parallels in 
irrational grounds can be identified with superstition ( $\delta \varepsilon \_\sigma \delta \alpha \iota \mu \nu$ í $\left.^{\prime}\right)$, which Plutarch describes as a 'feeling which is produced by amazement at what happens in regions above us':

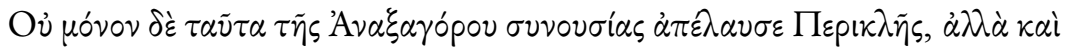

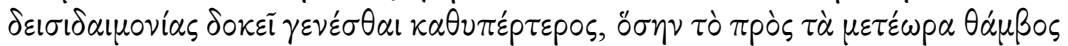

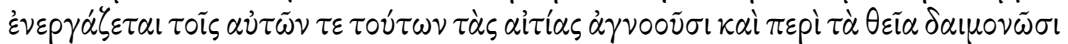

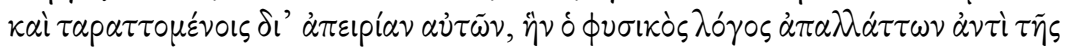

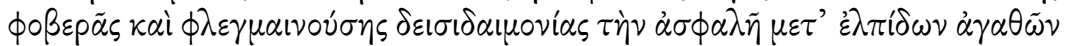

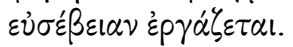

These were not the only advantages Pericles had of his association with Anaxagoras. It appears that he was also lifted by him above superstition, that feeling which is produced by amazement at what happens in regions above us. It affects those who are ignorant of the causes of such things, and are crazed about divine intervention, and confounded through their inexperience in this domain; whereas the doctrines of natural philosophy remove such ignorance and inexperience, and substitute for timorous and inflamed superstition that unshaken reverence which is attended by a good hope.

If my conjecture is correct, Plutarch's message in Q.N. 29 seems to be

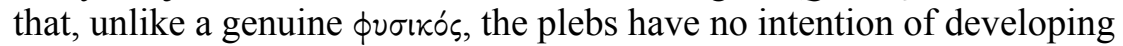
natural philosophical insight, meaning that they do not really wonder about the actual nature ( $\phi \dot{v} \sigma \varsigma \varsigma)$ of these phenomena. They only focus on the miraculous and supernatural character of some rare phenomena without any serious attempt at understanding even these in a proper physical way, being 'attracted by their mere appearance' (cf. Amatorius $766 \mathrm{~A}$ above). By contrast, the more everyday phenomena, such as the positions of the sun, the movement of the stars and the phases

De Pyth. or. 409CD and Amatorius 766A in their broader Platonic context, where the childish people do not aim to reach the ultimate intelligible truth. In the present context

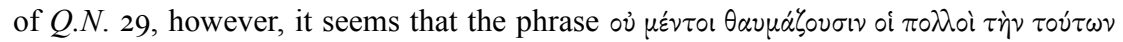
$\phi v \sigma \leftarrow \nu$ primarily implies that the people do not feel any wonder for the nature - i.e. for the natural causes - of these phenomena. Then again, in light of Plutarch's dualistic causality, the higher, intelligible causes are always closely related to the natural ones [see 4.I.2.], and in this sense, the meteorological phenomena dealt with here presumably also have a divine motivation for Plutarch - which he perhaps mentioned in the lost part of Q.N.

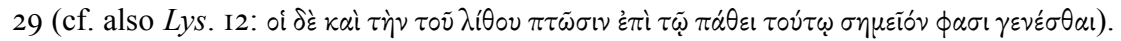
But even so, the central focus is clearly on natural causes in Quaestiones naturales, so that a divine motivation may only be implied. Cf. also, e.g., Quaest. conv. $720 \mathrm{E}$ with S.-T. Teodorsson, I996, p. I83: "The causes that should be investigated are those of the physical processes which are the objects of the scientist, in contrast to the ultimate cause, the will of Providence, which lies beyond his competence." Cf. Pl., Tim. 68e. 
of the moon, are much more 'regular' phenomena, and, thus, deserve attention also. Notably, Plutarch elsewhere emphasises that contemplation of astronomical phenomena has actually empowered us to acquire philosophical knowledge, an idea that ties in closely with Platonic epoptics [see 4.I.2.2., n. 65].

A similar idea recurs on several occasions in Quaestiones convivales, especially at those points where one or more symposiasts are reprimanded because they do not look for physical explanations of natural mirabilia but simply remain perplexed about their wondrous character (they often relate these phenomena to the cosmic antipathy or sympathy of the Stoics, without further aetiological specification or detail [see 4.I.I.3., n. 45]). This does not mean, of course, that Plutarch sides with the other type of symposiasts who do not believe in such natural marvels or popular beliefs altogether but simply reject them. His position seems to be more moderate, giving wonderful popular beliefs the benefit of the doubt (see, for instance, the discussion of the belief that thunder generates truffles in Quaest. conv. $664 \mathrm{~A}-665 \mathrm{~A}^{94}$ [see 3.I.4. and 4.I.I.I.]). This benefit of the doubt, in turn, ties in closely, as we will see in the following chapter, with Plutarch's scientific method, and more precisely with his Platonic-Academic caution

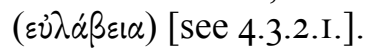

As we saw at the beginning of this chapter, Plutarch's vituperation of people's short-sighted marvel at natural phenomena may be considered an actual appeal towards a more serious and mature study of nature. To this end, Plutarch aims to lure the reader into an intellectual contemplation of natural causes, as it allows him to distinguish himself from the common, superstitious plebs, that are unfamiliar with the subtleties of such a study. In this sense, physical aetiology serves as a means for achieving intellectual distinction and can be considered a first step towards genuine philosophy. It is a weapon against superstition and a useful instrument in attaining an intelligent devotedness to the gods, that is, $\varepsilon \dot{v} \sigma \varepsilon \hat{\varepsilon} \beta \varepsilon 1 \alpha$ - being a means between the religious extremes of atheism and superstition ${ }^{95}$ [see 4.I.3.].

An interesting passage for the underlying philosophical-religious motivation of Plutarch's natural scientific project is found in the conclusion of De tranquillitate animi $(477 \mathrm{CD})$. Plutarch there says that 'tranquillity

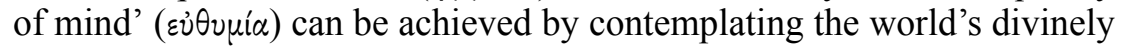
inspired spectacles. The Chaeronean here takes position as a Platonic

${ }^{94}$ Plutarch here actually aims to save a traditional belief in a physical way. See the discussion by A. Setaioli, 2009.

${ }^{95}$ Cf. D. Babut, I969, p. 517: "Son idéal est de trouver le juste milieu entre la crédulité naïve, qui fait prendre le moindre fait insolite pour un signe, et a vite fait de sombrer dans la superstition, et, de l' autre côté, l' étroitesse rationaliste, qui récuse tout ce dont elle ne peut rendre compte." See also M. Meeusen, 20I4 and 2015b. 
contemplator mundi, portraying human beings as spectators of a divinely governed universe:

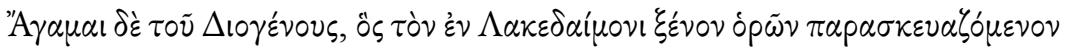

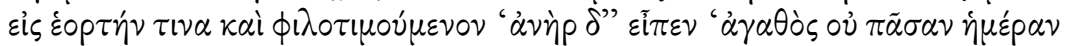

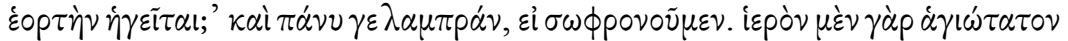

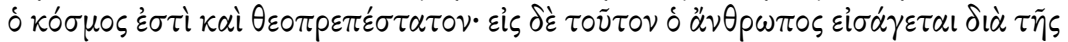

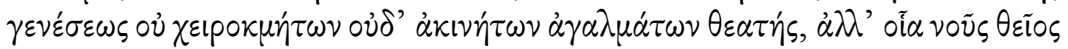

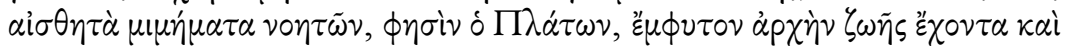

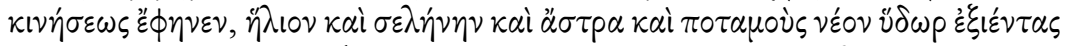

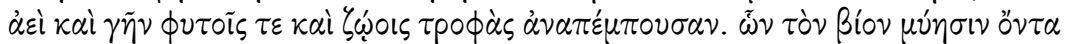

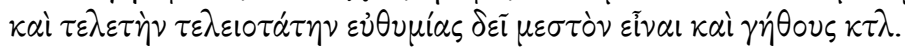

And I am delighted with Diogenes, who, when he saw his host in Sparta preparing with much ado for a certain festival, said, "Does not a good man consider every day a festival?" And a very splendid one, to be sure, if we are sound of mind. For the universe is a most holy temple and most worthy of a god; into it man is introduced through birth as a spectator, not of hand-made or immovable images, but of those sensible representations of intelligible things that the divine mind, says Plato (Tim. 92c, Epinom. 984a), has revealed, representations which have innate within themselves the beginnings of life and motion, sun and moon and stars, rivers which ever discharge fresh water, and earth which sends forth nourishment for plants and animals. Since life is a most perfect initiation into these things and a ritual celebration of them, it should be full of tranquillity and joy etc.

As Hirsch-Luipold argues, this passage is very relevant for Plutarch's view on religion: "With this statement the cult is transferred into daily life, as a quotidian form of divine service" ${ }^{96}$. At a natural philosophical level, the contemplation of the intelligible things ( $\nu \circ \eta \tau \dot{\alpha})$ exposes the meta-physical and divine aspect behind material reality, that is, what lies behind the face of nature, which in itself is only a sensible representation thereof ( $\alpha i \sigma \theta \eta \tau \dot{\alpha} \mu \mu \eta \dot{\eta} \mu \alpha \tau \alpha)$. In this sense, the study of nature paves the way for more abstract, philosophical contemplations, and as such, Plutarch's physics dovetails with his higher Platonic philosophy ${ }^{97}$. The

${ }^{96}$ R. Hirsch-Luipold, 20I4, p. I70. He adds: "as humans we are supposed to celebrate every day of our lives as a festival of the gods. Plutarch, in connecting the traditional religious world of symbols with philosophical interpretation, renders religion the basis of striving for understanding and personal happiness."

97 The distinction between $\alpha i \sigma \theta \eta \tau \dot{\alpha}$ and $\nu 0 \eta \tau \dot{\alpha}$ can be taken as a reference to the

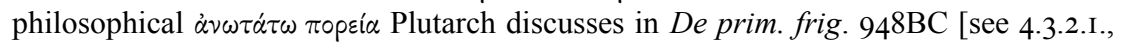
n. 195]. Cf. also, e.g., Quaest. conv. 7I8DE (in the context of geometry). 
natural phenomena that Plutarch is dealing with in his natural problems belong to the lowest regions of the universe (c.q. 'the rivers which ever discharge fresh water, and earth which sends forth nourishment for plants and animals'), but they are equally subject to 'the innate

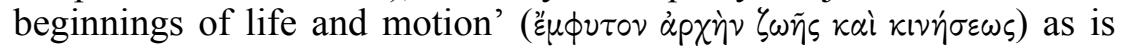
the case for the higher, celestial phenomena (c.q. "sun and moon and stars'). This means that there is no strict conceptual distinction for Plutarch between natural phenomena here on earth or at a distance in the heavens. In the end, they are all sensible representations of intelligible things.

An interesting parallel for this can be found in De cur. $5 \mathrm{I} 7 \mathrm{CE}$, where Plutarch advises the 'busybody' ( $\pi \circ \lambda \nu \pi \rho \alpha \dot{\gamma} \mu \omega \nu)$ to turn his soul to 'better and more pleasant subjects' than those suitable for baser forms of curiosity

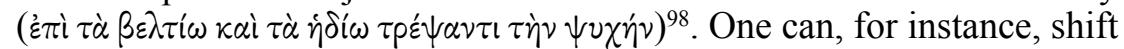
and divert one's inquisitiveness towards natural phenomena, either great or small.

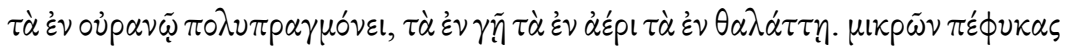

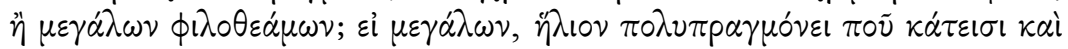

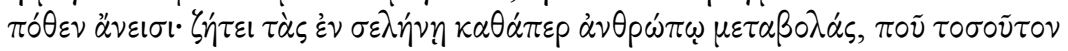

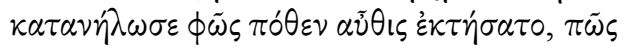

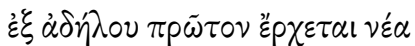

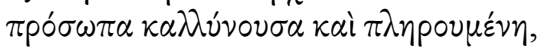

$$
\begin{aligned}
& \chi \ddot{\omega} \tau \alpha \nu \pi \varepsilon \rho \alpha \dot{\tau} \tau \tilde{\eta} s \varepsilon \dot{\nu} \gamma \varepsilon v \varepsilon \sigma \tau \dot{\alpha} \tau \eta \emptyset \alpha \nu \tilde{\eta},
\end{aligned}
$$

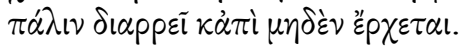

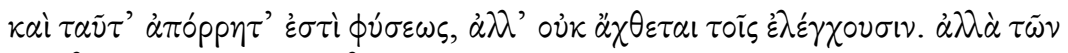

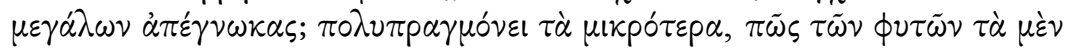

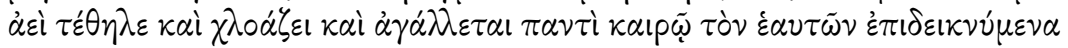

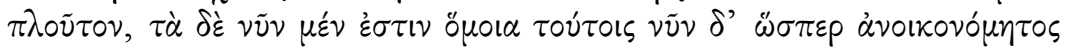

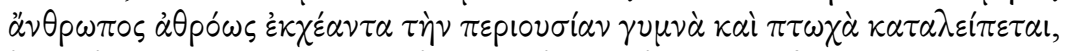

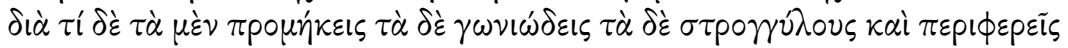

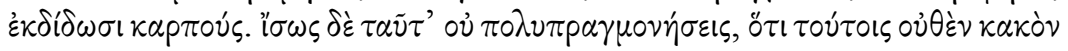

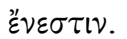

Direct your curiosity to heavenly things and things on earth, in the air, in the sea. Are you by nature fond of small or of great spectacles? If of great ones, apply your curiosity to the sun: where does it set and whence does it rise? Inquire into the changes in the moon, as you

98 For a study on ancient curiositas, see A. Labhardt, I960 (esp. pp. 210-2I6 on natural scientific curiosity). For the passage at issue, cf. A.M. Battegazzore, I992, pp. 48-49. 
would into those of a human being: what becomes of all the light she has spent and from what source did she regain it, how does it happen that

When out of darkness first she comes anew, She shows her face increasing fair and full; And when she reaches once her brightest sheen, Again she wastes away and comes to naught? (Soph., fr. 787)

And these are secrets of nature, yet nature is not vexed with those who try to find them out. Or suppose you have renounced great things. Then turn your curiosity to smaller ones: how are some plants always blooming and green and rejoicing in the display of their wealth at every season, while others are sometimes like these, but at other times, like a human spendthrift, they squander all at once their abundance and are left bare and beggared? Why, again, do some plants produce elongated fruits, others angular, and still others round and globular?

In what follows, Plutarch even attaches a moral advantage to this type of scientific curiosity by noting that physical inquiry diverts the busybody's curiosity from malicious subjects towards relatively innocent ones. But he is well aware that the busybody might not be interested in these natural scientific matters precisely because there is nothing morally depraved (kakóv) in them ${ }^{99}$.

As suggested in the previous passage (De tranq. an. $477 \mathrm{CD}$ ), Plutarch's distinction between grandiose, heavenly phenomena (c.q. the rising of the sun and the stages of the moon) and the rather small, profane ones (c.q. those on the earth, in the air and in the sea) is not strict. Moreover, as appears from the examples that Plutarch gives of the latter phenomena (viz. the loss of leaves in plants and the shapes of different fruits), these clearly belong to the category of 'everyday' natural phenomena studied in Quaestiones naturales. The fact that these problems evoke the same sense of intellectual curiosity as the grandiose phenomena do is very significant for their shared intellectual appeal.

The idea that nature is not vexed with those who try to find out its 'secrets' ( $\dot{\alpha} \pi \dot{\rho} p p \eta \tau \alpha)$ is very important. Nature is represented here as an oracle, whose mysterious 'utterances' should be investigated and interpreted in order to properly understand their underlying meaning. Plutarch makes it very clear that natural philosophical inquisitiveness is not an act of sacrilegious profanation. After all, in line with his dualistic view on causality, the search for physical causes in explaining marvellous

${ }^{99}$ For the ethical influence of natural philosophy on the character and intellect of its practitioners, cf. also Per. 5, I and 8, I-2 [quoted I.2.2.]. 
natural phenomena, either great or small, is not an alternative to a more religious-philosophical interpretation [see 4.I.2.I.]. Rather, the concept of $\alpha \pi$ ópp $\tau \tau$ implies a feature of philosophical-religious caution towards the divine here ( $\varepsilon \dot{\nu} \lambda \dot{\alpha} \beta \varepsilon ı)$, the workings of which we are unable to fathom with our human intellect [see 4.3.2.I.].

The bottom line is that Plutarch's world is constituted in such a way that there is no rigid border between the natural and intelligible realms in the cosmos. Natural phenomena are firmly rooted in the category of the divine, so that their natural causes go firmly hand in hand with the final ones [see 4.I.2.]. As such, Plutarch's search for physical causes is not intended as an alternative but rather as a confirmation of his religious outlook on the world. Therefore, the contemplation of the world's divinely inspired spectacles provides $\varepsilon \dot{v} \theta u \mu i \alpha$. And it is in this sense that natural science not only challenges but also eases Plutarch's mind.

\section{Conclusion and new questions}

I conclude that Quaestiones naturales, as a school text, conveys only the theory of scientific discussions, whereas in Quaestiones convivales Plutarch adds a supplementary social and philosophical dimension to the problems, showing how such problems could be solved in real-life situations. Notwithstanding the 'technical' nature of Quaestiones naturales, Plutarch does not consider the genre of natural problems highly complex. On the contrary, they are 'easy and persuasive', which implies that we are not dealing with specialist literature (De tuenda $\mathrm{I} 33 \mathrm{E}$ : $\dot{\varepsilon} \lambda \alpha \phi \rho \dot{\alpha}$ кai $\pi \imath \theta \alpha \nu \alpha)$. I have argued that the genre of natural problems provides a scholarly-rhetorical exercise in argumentative creativity ('mental gymnastics'), presenting an aetiological framework for the reader to absorb by an 'active reading', but that its eventual goal is of a more philosophical and even religious kind for Plutarch. Physical aetiology offers a useful instrument for doing away with superstition $(\delta \varepsilon 1 \sigma i \delta \alpha \mu o v i \alpha)$ and for attaining a well-reasoned devotion towards the divine $(\varepsilon \dot{v} \sigma \varepsilon \beta \varepsilon \varepsilon 1 \alpha)^{100}$. Needless to say that both options are fully commensurable with one another, in that the practice of physical aetiology can, thus, be considered an intellectual exercise in eradicating superstitious beliefs. As such, the genre of natural problems provides some kind of a preamble to more meta-physical speculations, and, thus, can be considered a light version of philosophy.

A detailed analysis of the aetiological design and scientific context of Quaestiones naturales in the following chapter will yield valuable insights into Plutarch's scientific modus operandi. This will help us to conjure the physical world system that is silently propagated in it. Such a study

100 Cf. P. Desideri, I992, p. 8I: “è a quest'ultima [sc. alla superstizione], e non alla religiosità, che la scienza si contrappone". See also M. Meeusen, 2015b. 
embraces questions related to Plutarch's Platonic view on causality, his reliance on traditional sources and his urge for argumentative creativity, and the general explanatory scheme employed by him. These issues will be treated in the following chapter. 



\section{4 \\ Plutarch's Platonic world view: the aetiological design of Quaestiones naturales and its scientific context}

\section{I. Science and its foes? The ancient scientific value of Quaestiones naturales}

In order to interpret Quaestiones naturales in light of Plutarch's overarching natural philosophical programme and Platonist convictions, this final chapter will focus on the peculiarities of the method the Chaeronean applies both in raising and solving natural problems. To this end, I will first examine the wonder-inducing nature of the phenomena that receive Plutarch's attention and how he approaches them [4.I.I.]. A more overarching question will then concern Plutarch's well-known dualistic view on causality. In this regard, I will also examine the presence of a more mythological and poetic type of discourse in Plutarch's scientific writings [4.I.2.]. This will provide us with the necessary background information for further inquiry into the issues of scientific authority and its discursive construction in Plutarch's natural problems [4.2.], and also into more specific aspects related to Plutarch's scientific methodology in the sections to follow [4.3.].

\section{I.I. Saving popular beliefs: the wonders and paradoxes of nature}

I will start by examining the often paradoxographical and truly 'enigmatic' nature of the natural phenomena that Plutarch investigates in his natural problems. As regards Plutarch's custom of solving natural problems, it is clear that their main purpose is to satisfy intellectual curiosity ${ }^{1}$. At several points in Quaestiones naturales, the reader finds himself confronted with rather bizarre natural problems, such as the sweet taste of the tears of wild boars as opposed to the salty and ordinary ones of deer (Q.N. 20), or the palm tree's ability to rise against a weight imposed upon it (Q.N. 32). The kind of scientific research conducted in such problems might seem to be rather playful if not absurd, and as such might remind one

1 The same conclusion was reached by S. Kapetanaki and R.W. Sharples, 2006, p. I for the Supplementary problems ascribed to Aristotle and Alexander of Aphrodisias, in which even the medical problem chapters have no immediate practical use. 
of the sympotic $\sigma \pi \circ v \delta \circ \gamma \varepsilon \lambda \circ{ }^{\circ} \mathrm{v}$ described in Quaestiones convivales ${ }^{2}$ [see 3.I.3., n. 27]. Teodorsson has, in fact, distinguished these "examples of fanciful beliefs in Quaestiones naturales which Plutarch accepts without hesitation" from other problems that are of a more "respectable, scientific kind"3. This distinction, however, seems unnecessary, since Plutarch does not make it himself. Seeing that Plutarch makes a considerable attempt to explain these and similar fanciful phenomena in an intelligent, physical way, the question is legitimate as to why he takes such curiosa seriously and how this ties in with his Platonic philosophy. In other words, what is Plutarch's actual intention for accounting for such problems in a serious way, and what does he see as constituting proper scientific conduct, then ${ }^{4}$ ?

The philosophical-educational context of Plutarch's school has clearly left its mark on the scientific outlook of his natural problems, to the effect that they are for a great part detached from nature itself. For Plutarch, scientific demonstration ( $\left.\dot{\alpha} \pi \delta^{\delta} \varepsilon \varepsilon \xi \xi l \varsigma\right)$ remains, to a considerable extent, a theoretical practice, that is, a rhetorical-argumentative exercise fuelled by scholarly $\pi \Delta \lambda \nu \mu \dot{\alpha} \theta \varepsilon i \alpha$ (viz. his acquaintance with the scientific tradition and literature). In order to balance this view, we saw that these problems are not merely trivial Spielereien, which Plutarch did not attach any philosophical relevance to. Indeed, Plutarch did not believe or at least ascribe credibility to such phenomena only for reasons of rhetorical exercise ${ }^{5}$ [see 3.2.2.]. Of

2 See, e.g., the evaluation by J. Sirinelli, 2000, p. 382: "Cet ouvrage, dont les sujets sont pour nous souvent déconcertants et parfois fastidieux, a été paradoxalement composé avec allégresse. Plutarque trouve du plaisir à nous rapporter ces propos que le lecteur d' aujourd' hui se laisse aller à juger comme des "curiosités" parfois puériles, dignes plutôt d'Élien ou d'Athénée."

3 S.-T. Teodorsson, I999a, p. 666.

${ }^{4}$ Pliny the Elder's predilection for natural mirabilia serves as a nice parallel. See, e.g., V. Naas, 20II, pp. 66-67, who first negatively remarks that "Pliny's attitude, between rationality and mirabilia, is also typical of the evolution of science at his time. The rise of the paradox goes with a decline of the sciences." A little further on, though, she draws a more reasonable conclusion: "We must not seek in the mirabilia a proof of the decline of knowledge. They simply reflect a different kind of knowledge [...]."

${ }^{5}$ Solving natural problems is more than simply a matter of sophistic bravura for Plutarch. But even so, there are certainly links with contemporary suasoriae, where it was a common rhetorical practice and strategy to defend the most absurd cases first. Cf. De aud. $44 \mathrm{~F}$, where Plutarch mentions a panegyric on vomiting, on fever and on the kitchen-pot, and says that they actually have a certain degree of plausibility (see R. Flacelière, J. Irigoin, J. Sirinelli and A. Philippon, I987, pp. ccvi-ccvii). Sophists

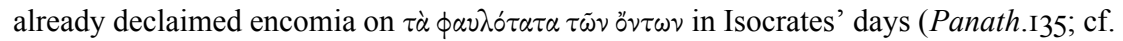
Paneg. I88). Isocrates mentions a praise of the fly and one of salt (Hel. I2). The encomium on salt is also mentioned in P1., Symp. I77b, and Lucian's comic Praise of the Fly shows that this type of declamatory pyrotechnics was still very alive after Plutarch's death. Cf. also, e.g., the pieces by Favorinus (frs. I-2 Barigazzi and L. Holford-Strevens, I997, 
course, it is only likely that some element of intellectual entertainment and rhetorical persuasion was intrinsically bound up with Plutarch's science of natural problems, but this should not necessarily interfere with the claim that it can be taken seriously as an intrinsic part of his natural philosophical programme (or of ancient science more generally) ${ }^{6}$. Similarly, in regards to the discussion in De facie of the problem of the face appearing in the moon, Gianakaris argues that:

"Man always seems to accept strange phenomena more easily when seen as part of a system intelligible to human experience. [...] Plutarch's age, like our own, apparently was willing to contemplate science-fiction possibilities in the universe but not to pursue all theories indiscriminately." 7

The border between 'science' and 'fiction' was probably less fixed for Plutarch than it is for us today. This is presumably due to the fact that Plutarch had a different, more religious, outlook on the world. He obviously lived in the same physical reality as we do, but he looked at it in a different way and, therefore, saw different things. Because of his religious devotion, Plutarch was inclined to accept more fanciful phenomena and popular beliefs. He primarily did this in order to explain the world he lived in on a theological basis and in view of his Platonic-Academic philosophy. The following sections are intended to further subtantiate this point.

\section{Natural problems and the fabric of strangeness}

The strangeness and paradox of Plutarch's natural problems are central to the wider genre of natural history that embraces paradoxology and mirabilia literature. Scholars have shown that a great deal of ancient natural scientific writing actually relies on pre-scientific data, including bizarre and unreliable popular beliefs ${ }^{8}$. Plutarch's discussion of natural

p. 200). For further reading on this type of 'adoxographical' literature, see A.S. Pease, 1926. For its relation wih the $2^{\text {nd }}$ century culture of the Second Sophistic, see G. Anderson, I993, pp. I7I-I99 (sub “Adoxa paradoxa: the pepaideumenos at play").

${ }^{6}$ For a similar discussion, see M. Sassi, I993, pp. 465-468 (sub "Credevano gli antichi ai loro mirabilia?" - with the allusion to the classic work of P. Veyne, I983, pp. I26-I37).

${ }^{7}$ C.J. Gianakaris, I970, p. I04.

${ }^{8}$ For the role of mirabilia and the marvellous in ancient scientific literature, see, e.g., G.E.R. Lloyd, I983, M. Sassi, I993 (esp. pp. 454 ff. regarding Peripatetic natural history), J.F. Healy, I999, pp. 63-70, T. Murphy, 2004, pp. 87 ff., V. Naas, 20II, M. Beagon, 20II (esp. p. 85 regarding Quaest. conv. 680D; see further). For more background and further literature on ancient paradoxography, see G. Schepens and K. Delcroix, 1996 and C. Jacob, I983. For the role of $\theta \tilde{\omega} \mu \alpha$ already in Herodotus' work, see G.E.R. Lloyd, I979, pp. 29-32 and R. Thomas, 2000, pp. I35-I67. Cf. De Her. mal. 855EF. 
problems ties in well with the more common intellectual endeavour from Hellenistic and Roman times of saving such popular beliefs through scientific and philosophical interpretations ${ }^{9}$. In this sense, the study of nature is designed, not so much to deny common-sense beliefs but to vindicate them as being an intrinsic aspect of natural scientific research. At the beginning of his work on Science, Folklore and Ideology, Lloyd writes that many Greek scientists "often remain deeply influenced by such [popular] beliefs" ${ }^{10}$. Although they try to understand the physical world according to a safe, rational basis, they still incorporate these beliefs into their scientific treatises on a large scale. This does not mean, of course, that their inquiries remain unsubstantiated from an intellectual perspective. On the contrary, in their attempts to rationalise such popular beliefs, ancient scientists mostly try to assimilate them with a critical analysis, just as can be seen in Plutarch's natural problems. There, Plutarch records many folk traditions concerning fauna, flora and meteorology, albeit never without any sense of aetiological thoroughness and detail. After all, he is prepared to deal with these popular beliefs in an intelligent way - at least within the conceptual scope and limits of ancient physics - and indistinctly from the other, perhaps to modern readers, more serious problems (see above).

Plutarch's interest in natural mirabilia is based on a belief that what is contrary to expectation ( $\pi \alpha \rho \alpha \dot{\delta} \delta \xi \circ v)$ is not necessarily beyond reason ( $\pi \alpha \rho \dot{\lambda} \lambda \circ \gamma \circ v)$. This idea is formulated in Sept. sap. conv. I63D by Pittacus in the context of the wondrous myth of Enalus:

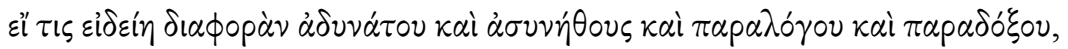

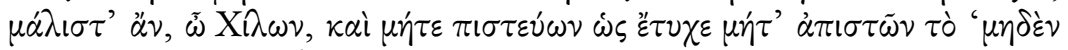

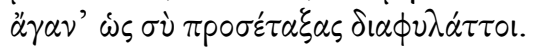

${ }^{9}$ For the notion of 'saving' popular beliefs through physical explanation, see, for instance, the conclusion in Ammonius' account of the ever-burning lamp at Ammon's

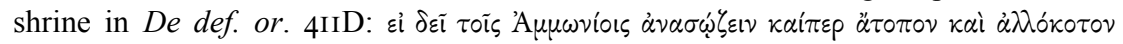

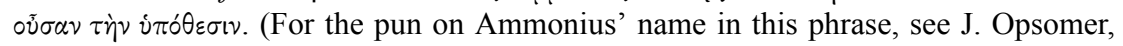
2009, p. I43, n. 97.) In a similar way, in De def. or. $420 \mathrm{C}$, the same Ammonius quotes Theophrastus (fr. 263 FHSG) regarding the contested existence of demigods: óp $\theta \tilde{\omega} \varsigma$ है $\phi \eta$

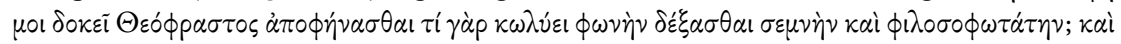

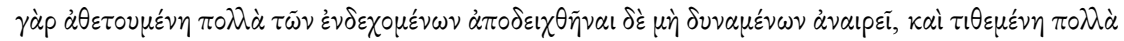

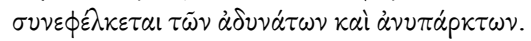

${ }^{10}$ G.E.R. Lloyd, I983, p. I. This is the case, e.g., with Aristotle's biological writings [see 4.I.I.3.]. See also, for instance, Lloyd's account on the informants of Theophrastus, pp. II9-I35, esp. I33: "He [sc. Theophrastus] does not merely record many folk traditions concerning the use of plants, but is prepared to take some of them seriously. But his admirable openness occasionally tips over into uncritical or naïve acceptance, and his reserving judgement becomes the expression of a bafflement that he was unlikely to be able to resolve." 
If a man realises a difference between the impossible and the unfamiliar, and between what is beyond reason and what is contrary to expectation, such a man, Chilon, who would neither believe nor disbelieve at haphazard, would be most observant of the precept, 'Avoid extremes,' as you have enjoined.

The epistemological value of this $\mu \eta \delta \dot{\varepsilon} \nu$ aै $\gamma \alpha \nu$ is seminal also for Plutarch's sceptical, Academic attitude towards natural mirabilia, mediating between belief and disbelief, as we will see [4.3.2.I.]. The paradox in itself, as something 'contrary to expectation', can be considered a subcategory of the mirabilia, because it just as well arouses a certain sense of wonder for what is said and responds to a sentiment of initial disbelief (I will deal with the actual phrasing of natural paradoxes in Quaestiones naturales later on [see 4.3.3.I.]).

The often surprising character of the natural phenomena under discussion in Plutarch's natural problems can be explained by the fact that a great amount of traditional, and often, indeed, bizarre and unreliable lore (i $\left.\sigma \tau \tau^{\prime} i^{\prime} \alpha, \delta o^{\prime} \xi \alpha, \phi \eta^{\prime} \mu \eta\right)$ was incorporated from an early stage into the scientific tradition. In the case of Quaestiones naturales, Plutarch's sources can be identified, either directly or indirectly ${ }^{11}$, with un(der)educated informants like travellers or merchants (e.g., Q.N. I, 9IIE on plants growing in the Indian Ocean) ${ }^{12}$, women (e.g., Q.N. 6, 913F on dew making overweight women thinner, and Q.N. 26, 9I8D on pregnant women eating stones and dirt), sponge-divers (e.g., Q.N. I2, 9I5A on oil producing illumination and transparency in the depths of the sea), farmers (e.g., Q.N. 4I on better flowering in plants), shepherds (e.g., Q.N. 3, 9I2DF on the aphrodisiac effects of salt on cattle and other animals), hunters (e.g., Q.N. 20, 9I6F on the taste of the tears of boars and deer, and Q.N. 22, 917D on the taste of the bear's fore-paws), fishermen (e.g., Q.N. I7, 915F on the fabrication of fishing lines from the hair of horses), bee-keepers (e.g., Q.N. 35-36 on the behaviour of bees towards pungent smells) etc.

Clearly, Plutarch did not reject these popular beliefs ${ }^{13}$. In fact, wonders and miracles more generally are an inherent aspect of his world view.

${ }^{11}$ For instance, the paradoxographical account about she-wolves in Q.N. 38 is borrowed from the De animalibus of Antipater (presumably the Stoic philosopher of Tarsus: see n. II3), who probably relies on traditional hunter lore himself.

${ }_{12}$ F.H. Sandbach, $\mathrm{I} 965$, p. I5I, $\mathrm{n}$. $\mathrm{g}$ is probably correct in pointing out that " $[\mathrm{t}]$ ravellers tales, both of mangroves and of seaweed, seem to lie behind these reports". Cf., e.g., Theophr., $H P$ 4, 7, 3 (which mentions an expedition of those returning from India sent out by Alexander).

13 Perhaps, his sympathy for popular beliefs can even be linked with his devotion towards traditional belief more generally, that is, the $\pi \dot{\alpha} \tau p \operatorname{lo\varsigma } \pi i \sigma \tau \iota \varsigma$, which, as Flacelière notes, is one of the two "constantes de sa pensée" - the other one being philosophy. See 
In Q.N. 29, 9I9B, as we saw, Plutarch notes that 'it appears that nature attributes marvellousness to rarity and stimulates the research of how a phenomenon comes to be only if it occurs infrequently' ( $\dot{\alpha} \lambda{ }^{\prime}$ '

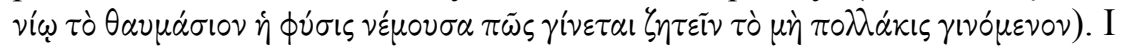
have taken Plutarch's subsequent complaint against the common people for not feeling any wonder for the nature of more 'everyday' celestial phenom-

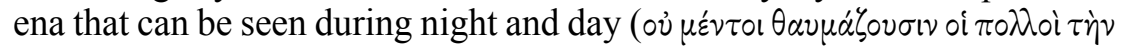

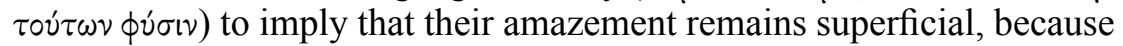
they do not look into the actual causes of natural phenomena [see 3.2.2.]. In other words, the kind of wonder they experience does not lead on to natural philosophical contemplation. As Oikonomopoulou rightly notes, this passage "may well be a reference to the genre of paradoxography, which flourished in the period of the empire"14. It is indeed remarkable that the paradoxographical genre is not, or not at least greatly, concerned with formulating explanations for the natural mirabilia that it collects. By contrast, this genre of writing is mostly preoccupied with simply listing wonderinducing phenomena and with preserving their wondrous nature by intentionally abandoning any attempts of formulating a reasonable explanation for them ${ }^{15}$. In many cases, the paradoxographer even omits the explanations that have already been provided for the mirabilia in the scientific literature, from which they are mostly drawn. Therefore, if the link with

R. Flacelière, J. Irigoin, J. Sirinelli and A. Philippon, I987, pp. cli-clii: "Les deux constantes de sa pensée, depuis sa jeuneusse jusqu' à sa mort, à savoir un double attachement, une double fidélité à la $\pi \dot{\alpha} \tau p ı \varsigma \pi i \sigma \tau \iota \varsigma$, d' une part, et de l' autre à la philosophie, [...] ont toujours été les mêmes. Jamais sa conception de la vie et du monde ne s'écarta sensiblement de ces deux pôles." For Plutarch's notion of $\pi i \sigma \tau \iota \varsigma$, see D. Babut, I969, p. 517 ("la foi ne supprime pas la raison, elle la dépasse et l' intègre") and 1994, pp. 580-58I. F. Frazier, 2008, p. 6I does not believe, however, that there is an "émergence d' un concept de 'foi' dans la pensée de Plutarque, qui servirait de terme alternatif au logos: la patrios pistis pose davantage le problème de la place de la tradition, si importante dans la philosophie impériale". As M. Bonazzi, 20I4, p. I29 has argued, moreover, "Plutarch does not anticipate the fideism of modern times". See also J. Opsomer, I996b, p. I87, I998, pp. I78-I79 (see also pp. I3I-I32 on Plutarch's $\sigma \varepsilon \mu \nu o ́ \tau \eta \varsigma) ~ a n d ~ G . ~ V a n ~ K o o t e n, ~ 2012 . ~ C f ., ~ e . g ., ~ D e ~ P y t h . ~ o r . ~ 402 E: ~ \delta \varepsilon \tilde{~} \gamma \grave{\alpha} \rho \mu \grave{\eta}$

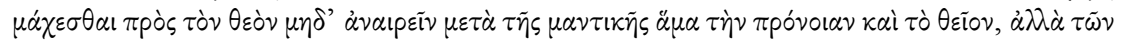

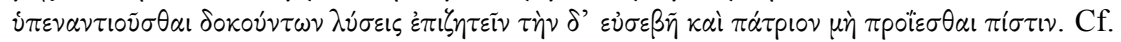

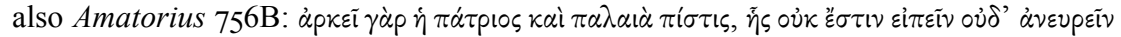

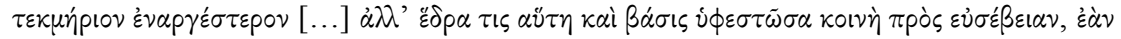

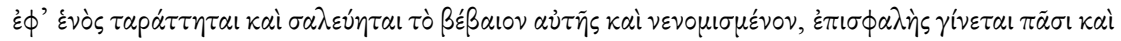
ï $\pi \circ \pi \tau \circ$.

${ }^{14}$ K. Oikonomopoulou, 20I3a, p. I46, n. 69. In personal correspondence, she rightly adds that "[i]n a way, Plutarch re-claims the notion of $\theta \alpha \tilde{\nu} \mu \alpha$ from the paradoxographers".

${ }_{15}$ Cf. G. Schepens and K. Delcroix, I996, pp. 390-394. C. Jacob, 1983 appropriately speaks of "la fabrication du merveilleux" as a main preoccupation of the genre (see esp. p. I33, sub "Le privilège du fait brut. La disparition des causes"). 
the genre of paradoxography is, indeed, legitimate in Q.N. 29, Plutarch's acclamation is not so much to the paradoxographical kind of natural phenomena recorded by this tradition, but rather to the fact that the common people - much like the paradoxographers themselves - make no attempt to explain and understand such phenomena in a proper physical way.

As an intellectual and a philosopher, Plutarch has no objections against the use of natural mirabilia and paradoxes as starting-points for learned and philosophical discussion, at least if the explanations applied to them remain plausible. For instance, regarding the popular belief that lightning produces truffles (Quaest. conv. 664A-666D [see 3.I.4.]), Agemachus argues against the non-believers (who object that lightning is not generative of itself but merely brings the truffles to light) that 'the miraculous should not be regarded as unworthy of belief, even if it is very difficult if not impossible to find the causes ${ }^{16}$. Plutarch (as a character in the discussion) follows Agemachus in not rejecting the popular belief and makes an attempt to explain it in a physical way (by arguing that lightning water is fertile owing to its heat), thus implying that it is incorrect to dismiss popular, pre-scientific beliefs without at least trying to find suitable theories for explaining them.

Démarais has conducted a more general study of the mirabilia discussed in Quaestiones convivales ${ }^{17}$. She has demonstrated that many of these discussions concern an apparent contradiction or an unusual report, and that the symposiasts are repeatedly confronted with something

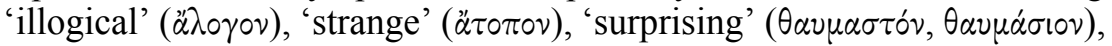

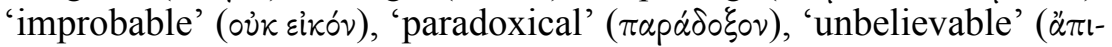
$\sigma \tau \circ v)$, if not 'impossible' ( $\left.\dot{\alpha} \delta v^{2} \alpha \tau o v\right){ }^{18}$. Thus, she shows that the genre of problems has a clear preference for extraordinary topics and in fact supposes a "fabrique de l'étrange"19. By highlighting the enigmatic aspect

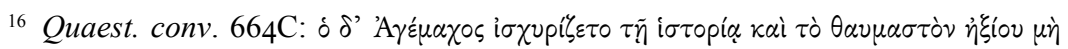

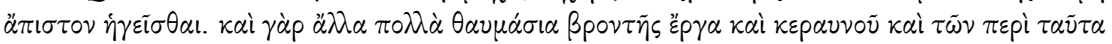

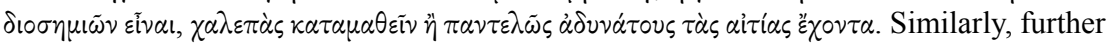
on in Quaest. conv. 665C, Dorotheus regarding the natural phenomenon of lightning never striking people who are asleep (and related phenomena) remarks that such mirabilia can be

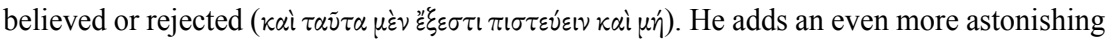
phenomenon ( $\left.\pi \dot{\alpha} \nu \tau \omega \nu \delta \dot{\varepsilon} \theta \alpha \nu \mu \alpha \sigma i \omega^{\prime} \tau \alpha \tau \sigma\right)$ ), noting that 'we all know, so to say, that the bodies

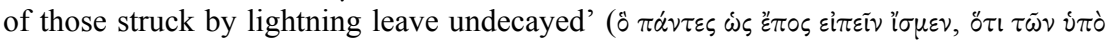

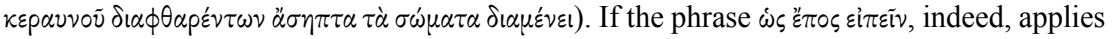
to " $\sigma \mu \varepsilon v$, rather than to $\pi \dot{\alpha} v \tau \varepsilon \varsigma$ here ( pace P.A. Clement and H.B. Hoffleit, 1969, p. 325), it may have a certain relativising (perhaps even humoristic) effect, implying as if this is a commonly known fact.

17 L. Démarais, 2005.

18 See L. Démarais, 2005, p. I6I (with references).

19 L. Démarais, 2005, p. I6I: "La présentation du problème, comme celle des mirabilia, suppose une 'fabrique de l'étrange'." 
of the mirabilia and their ability to be reformulated as problems, Plutarch stresses the aetiological challenge that they give rise to ${ }^{20}$. To push these mirabilia into the realm of the $\ddot{\alpha} \pi \_\tau \tau$ (without further ado) would, in fact, be an intellectual refusal of turning them into problems for debate ${ }^{21}$.

Plutarch did not dismiss such mirabilia, nor should his custom of turning them into natural problems necessarily be taken as an attempt to extricate their wondrous character altogether. In fact, Plutarch approaches the mirabilia in the exact sense as they are recorded in the tradition, so that an important aspect of the initial wonder remains when reformulating them as problems. Moreover, the aetiological preoccupation of natural problems does not necessarily undermine the wondrous character of these phenomena. As can be inferred from Plutarch's inquisitive and antidogmatic approach in his physical aetiologies and from his custom of postponing final judgement ( $\left.\dot{\varepsilon} \pi \circ \chi_{\eta}\right)$, wonder is, in fact, key to his natural scientific method [see 4.3.2.]. A relevant passage in this regard can be found in Quaest. conv. 680CD, which discusses the problem of those who are said to cast an evil eye. Some symposiasts consider this matter to be completely silly and laugh at it, but L. Mestrius Florus does not see it this way $^{22}$ :

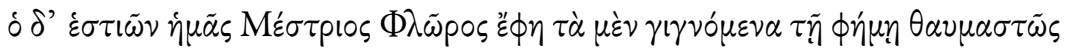

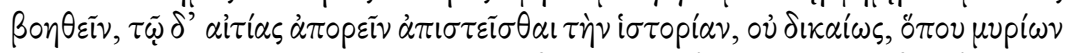

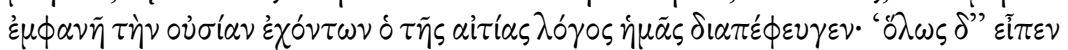

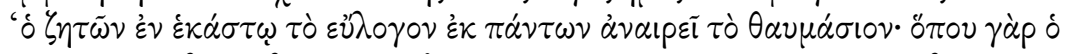

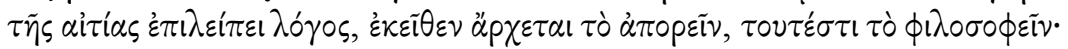

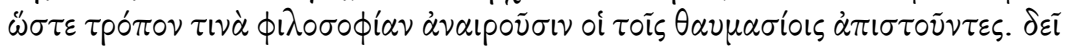

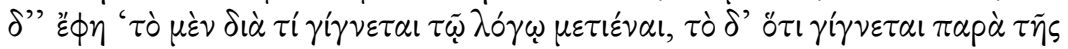

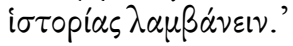

Mestrius Florus, our host, declared that actual facts lend astonishing support to the common belief. Yet the reports of such facts are commonly rejected because of the want of an explanation; but this is not right, in view of the thousands of other cases of indisputable

${ }^{20}$ L. Démarais, 2005, p. I63: "Défi pour l'étiologie, les mirabilia représentent une forme de quintessence du questionnement 'problématique', c' est-à-dire formulé (ou formulable) en problema."

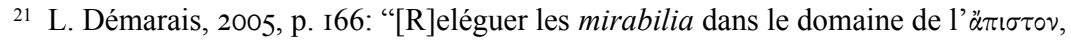
c' est renoncer à en faire des problemata."

${ }^{22}$ Later on in Quaest. conv. 70IA, Florus shares a similar opinion regarding other

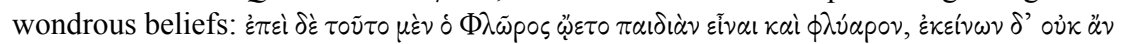

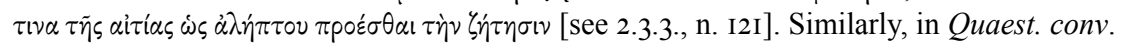
$698 \mathrm{E}$, he calls for a vindication of Plato's contested theory that drink passes through the

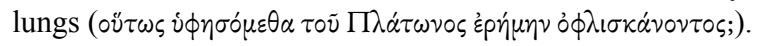


fact in which the logical explanation escapes us. "In general," he went on, "the man who demands to see the logic of each and every thing destroys the wonder in all things. Whenever the logical explanation for anything eludes us, we begin to be puzzled, and therefore to be philosophers. Consequently, in a way, those who reject marvels destroy philosophy. The right method," he maintained, "is to search out the reason for facts by means of logic, but to take the facts themselves as they are recorded."

This is meant not so much as an incentive to accept the phenomenon without further ado, but to look for plausible explanations while maintaining an inquisitive attitude in the debate. Two points are important here for Plutarch's method of raising and solving problems (as voiced in this passage through the figure of Florus).

As to Plutarch's method of raising natural problems, first of all, the last sentence of Florus' account, where he promotes the aetiological study of popular beliefs exactly as they are put on record, is very important: 'the right method is to search out the reason for facts by means of logic, but

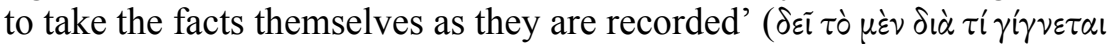

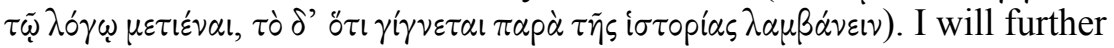
examine this point in the next section.

Second, as to Plutarch's method of solving natural problems, the passage nicely illustrates his aporetic attitude in (natural) philosophy. Its formulation may, however, seem somewhat paradoxical in itself. The point is that by explaining the logic behind mirabilia, wonder disappears, and similarly, but the other way around, by rejecting these mirabilia, there is no wonder to begin with, so that in both cases there can, in fact, be no philosophy. After all, wonder is the beginning of philosophy, but a logical explanation is the end of wonder and, thus, of philosophy ${ }^{23}$. As Opsomer indicates in this regard, "[ $[\dot{\alpha}] \pi \circ p^{\prime} \alpha$ is $[\ldots]$ vital to philosophy" for Plutarch ${ }^{24}$. This means that his philosophy is an essentially zetetic search for the truth which attempts to, but cannot eventually

${ }^{23}$ For the ancient $\tau$ ó ${ }^{\circ}$ s that wonder triggers philosophy, cf. also, e.g., De E $385 \mathrm{C}$ with Pl., Tht. I55d and Arist., Met. 982bII-I5. For the opposite idea that philosophy is the end of wonder, cf., e.g., De aud. 44BC, with the interpretation of G. Roskam, 2005, p. 352, who holds (in his italics) that: "Whereas Plato considers wonder to be the beginning of philosophy, Plutarch considers philosophy to be the end of wonder." However, considering Plutarch's aporetic attitude in philosophy, other scholars (see n. 24) are more inclined to underline the harmony between Plato and Plutarch in this regard - at least in the context of natural philosophy. The ambiguity related to the concept of wonder either as an impetus or an obstruction to attaining knowledge (in Antiquity and later) is outlined by M. Beagon, 20II, pp. 80-88.

${ }^{24}$ J. Opsomer, I998, p. 80. See also M. Meeusen, 20I4, p. 325. 
culminate in genuine 'science' $(\dot{\varepsilon} \pi\llcorner\sigma \tau \dot{\eta} \mu \eta)$. When it comes to natural philosophy, we will see further on that from Plutarch's epistemological perspective, it is impossible to acquire steadfast knowledge in the study of natural phenomena, so that an aspect of uncertainty and wonder will always remain in physical research [see 4.3.2.I.]. So even if this is Florus speaking, Plutarch's own approach is much in line with this account.

\section{Democritus and the cucumber}

As is to be expected in light of Plutarch's Platonism, the stipulation of empirical verification - which is a premise in Aristotelian science - is of secondary importance for the Chaeronean's scientific project. This is not to say, though, that the role of $\alpha i \sigma \theta \eta \sigma \iota s$ is absent or of no significance at all in Plutarch's natural problems [see 4.3.2.I.], but even so he is not only interested in those natural phenomena that have been positively proven to occur in nature. A relevant passage is found in Quaest. conv. 628BD, which illustrates Plutarch's choice of a more theoretical model of natural scientific research. Here, in regards to the veracity of an antiquarian problem (viz. 'Why is the chorus of the phylè Aiantis at Athens never judged last?'), Philopappus tells the following story about Democritus (DK68AI7a):

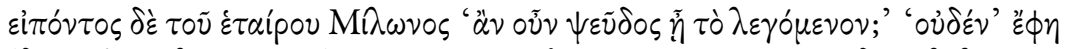

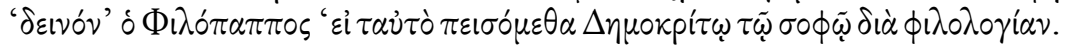

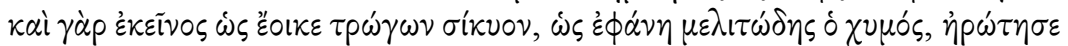

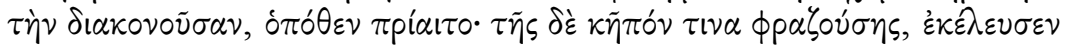

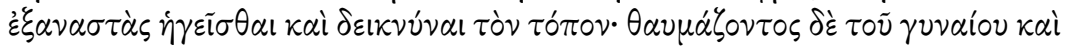

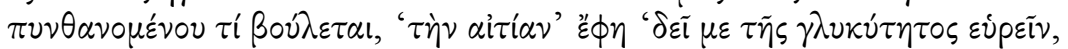

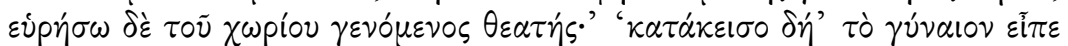

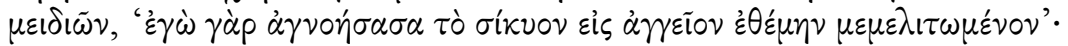

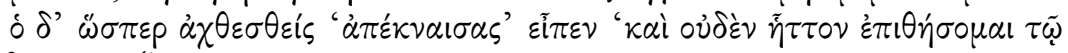

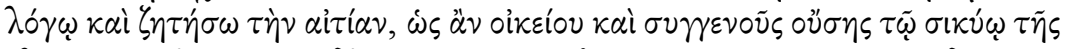

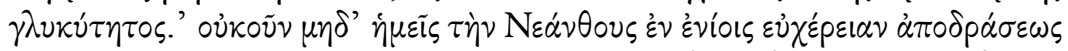

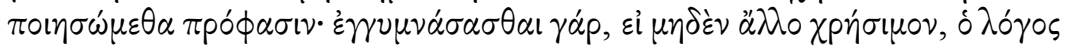
$\pi \alpha p \varepsilon \hat{\xi} \varepsilon l . '$

His companion Milo said, "What if actually the information is false?" "No matter!" said Philopappus. "It is not bad if the same thing does happen to us that happened to the wise Democritus because of love for learning. It seems that the juice of a cucumber he was eating appeared to have a honeylike taste, and he questioned his serving-woman about where she had bought it. When she indicated a certain garden, he got up and told her to take him and show him the place. The woman was 
astonished and asked what he had in mind. 'I must find,' he replied, 'the explanation for the sweetness, and I shall find it if I see the place.' 'Sit down,' said the woman with a smile, 'the fact is I accidentally put the cucumber in a honey-jar.' 'That was very annoying of you,' said Democritus with pretended anger, 'and I shall apply myself not the less to the problem and seek the explanation as if sweetness were proper and natural to this cucumber.' Let us not, then, make Neanthes's indifference in some items a pretext for running away, for this discussion will be a good exercise, if nothing else useful."

It is said of Democritus that he wrote about 'the most wondrous and paradoxical things of nature ${ }^{25}$. The passage at hand subscribes to this idea. According to Abramowiczówna ${ }^{26}$, the irony of this anecdote aims to subvert the zetetic attitude of philosophers in general towards fictitious problems. She finds it remarkable, however, that the symposiasts are not affected by the irony of the story, but consider it as encouragement to simply go on explaining the problem. It remains to be seen, however, whether the anecdote is really ironic to begin with. Of course, a certain humorous effect cannot be denied in it, but the actual moral of the story is, I take it, that, for Plutarch (and for Democritus in the story), explaining natural scientific problems should not so much be concerned with the ö $\tau \iota$ of the phenomenon at hand but with the $\delta i \dot{\alpha} \tau i$ (to allude to Florus' conclusion in Quaest. conv. $68 \mathrm{oD}$, quoted above $)^{27}$. In other words, not the reality of natural phenomena as such is the main topic of inquiry but their causes. A phenomenon that can lay a hypothetical claim to being real or empirically verifiable, disregarding whether it also actually does, requires an appropriate explanation ${ }^{28}$. Indeed, in his natural problems, Plurach does

${ }^{25}$ DK68A99a: $\tau \grave{\alpha} \theta \alpha \nu \mu \alpha \sigma \tau \grave{\alpha} \kappa \alpha \grave{~} \tau \grave{\alpha} \pi \alpha p \alpha \lambda \circ \gamma \omega \dot{\tau} \tau \alpha \tau \alpha \tau \tilde{\eta} \varsigma \phi v ́ \sigma \varepsilon \omega \varsigma$. Cf. also M. Sassi, I993, p. 449. I have discussed Democritus' aetiological activities earlier on [see I.I.6.]. For a study of Democritus' model of causal research, see P.-M. Morel, I996.

${ }_{26}$ Z. Abramowiczówna, I960, pp. II3-II4 (passage also discussed in I962, p. 83). Cf. also S.-T. Teodorsson, I989, pp. I58-I59.

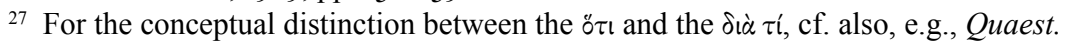

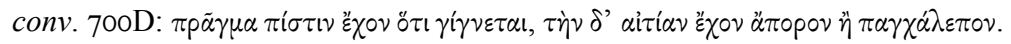

${ }^{28}$ The concept of 'indifference' ( $\varepsilon \dot{\chi} \chi \varepsilon \dot{\rho} \varepsilon \varepsilon$ ) in the passage at hand refers to the irresponsibility of historians to falsify historical facts (cf. LSJ, s.v.), but it also applies to the field of natural history, as is the case in the Democritus anecdote [see I.2.5., n. 224]. For the issue of historical accuracy in the Vitae, Plutarch's account in Alex. I is well-known (cf. also Galba 2, 5 and Fab. I6, 6). The conclusion reached for this passage by C. Pelling, I980, p. I35 is relevant in light of Plutarch's natural science also: "It is simply that the boundary between truth and falsehood was less important than that between acceptable and unacceptable fabrication, between things which were "true enough" and things which were not. Acceptable rewriting will not mislead the reader seriously; indeed readers will grasp more of the important reality if they accept what Plutarch writes than if they do not. 
not so much emphasise the 'actuality' of the natural phenomena but their 'potency'. 'Potential phenomena' can and should be studied - these are phenomena that possibly exist in principle (since they are recorded in the tradition), but are not, therefore, empirically proven to occur in nature and may, thus, remain without a parallel in actual physical reality ${ }^{29}$. The notion of 'what can and might be' is formulated explicitly in De facie 938C (regarding the possibility of habitation on the moon):

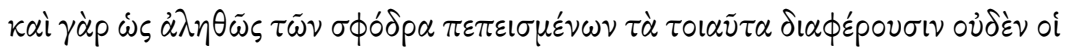

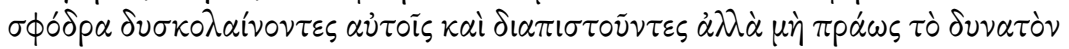

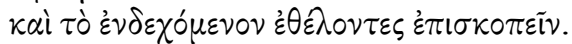

It is, moreover, a fact that there really is no difference between those who in such matters are firm believers and those who are violently annoyed by them and firmly disbelieve and refuse to examine calmly what can be and what might $b^{30}$.

The fact that Plutarch firmly opposes those who either blindly reject or blindly accept such possibilities is very significant for his own attitude towards natural mirabilia. Even though for Plutarch there is no strong commitment to what actually occurs in physical reality in order to explain natural phenomena, a certain degree of scientific caution ( $\varepsilon \dot{u} \lambda \alpha \dot{\beta} \varepsilon \varepsilon \alpha)$ towards the actual existence of these mirabilia obviously remains. It seems that Plutarch often gives such phenomena the benefit of the doubt. This is, I believe, seminal for the theoretical and sceptical character of Plutarch's

Truth matters; but it can sometimes be bent a little." Cf. also, e.g., Adv. Col. III5C for

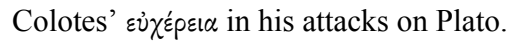

29 The Aristotelian view of 'actualisation', where potential phenomena become actual one way or another, is not at issue here. Rather, I am alluding to the wording of S. Sambursky, 1963, pp. 234-235, who argues, by contrast, that the Greeks in general were only able to study natural phenomena in their actuality (i.e. as they occur directly in nature), and that they were, therefore, unable to execute laboratory-like experiments (viz. regarding artificially recreated phenomena in an unnatural environment, i.e. phenomena that are isolated and extracted from their direct natural context). See p. 235: "The latter [sc. potential phenomena] become actual only in the laboratory. In such a sense we may call an experiment unnatural. This, no doubt, is how it seemed to the Greeks, who would have thought it paradoxical to study natural phenomena by unnatural methods." However, Plutarch's theoretical and non-experimental model in explaining natural phenomena (and that of many other ancient scientific authors) can also be called 'unnatural' according to Sambursky's standards (see also n. 244).

30 It seems that Plutarch does not intend to make a technical distinction here between

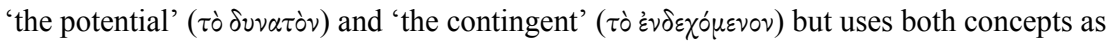
synonyms, basically denoting 'what is possible'. See H. Cherniss and W.C. Helmbold, I957, p. I63, n. e and P. Donini, 20II, p. 329, n. 306. 
science of natural problems. Plutarch does not necessarily intend to study nature as it is (empirically), but as it could be (theoretically), that is, if the postulated premises are accepted $a$ priori as they are formulated in the quaestiones. In his natural problems, Plutarch, much like Democritus in the story (though perhaps to a lesser degree), does not ascribe much value to empirical verification (or falsification) of the natural phenomena, but, indifferent to their claim to being real or not, intends to provide a more or less reasonable explanation of the problem, if only for the sake

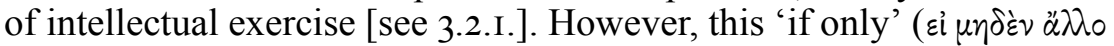

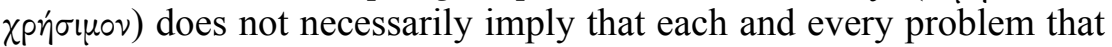
Plutarch deals with would simply be false, or, a fortiori, that Plutarch does not really believe them, or does not at least ascribe some credibility to them. In any case, it puts the often absurd character of the phenomena discussed into perspective, which, at the very least, appear to be worthy of a plausible explanation.

As we saw earlier, the Greek title of Quaestiones naturales - viz. Airial $\phi v \sigma i k \alpha i$ - hints at a distinction between quaerenda and quaestiones, that is, between explanations and problems respectively ${ }^{31}$ [I.I.6.]. From this title it is clear that the primary focus of the collection is on the physical causes of the problems, that is, the $\delta i \dot{\alpha} \tau i$, rather than the natural phenomena themselves that are questioned, that is, the ö $\tau{ }^{32}$. The formulation of each quaestio is motivated on the basis of a conviction that the natural phenomenon functions as a manifestation, a in nature - these are the quaerenda that are decipherable and fathomable by means of physical aetiology ${ }^{33}$. However difficult or even impossible it may sometimes seem, it is a priori assumed that the natural problems are explicable and that there are plausible physical $\alpha i \tau i \alpha$ to support them ${ }^{34}$. The

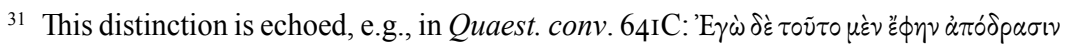

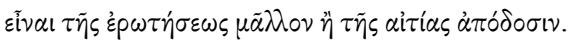

32 The $\delta i \dot{\alpha} \tau i$ in the quaestiones inquires specifically into the material, not the higher, type of causes of the natural phenomena at hand. Moreover, the recurrent use of the preposition $\delta \iota^{\prime} / \delta \iota^{\prime}$ in the explanations links up closely with this interrogative $\delta \iota \dot{\alpha} \tau i$ in the

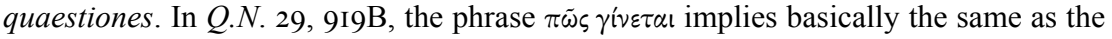

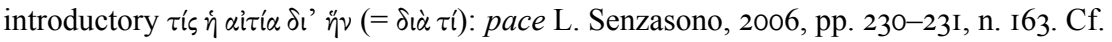
P. Donini, 1992, p. I07: "Ben lontano dal preoccuparsi di ricordare sempre anche le cause "divine", quando si domanda il perché di un fatto del mondo sensibile o di un fenomeno fisico Plutarco si limita per lo più nelle Questioni [conviviali] a parlare delle sole cause che altrove chiama subordinate, meno importanti, naturali o necessarie [...]."

${ }_{33}$ For the conceptualisation of natural $\sigma \eta \mu \varepsilon i \alpha$ in Quaestiones naturales, cf. Q.N. 2, 9I2D, I8, 9I6A, 30, 9I9C (25, 9I8A).

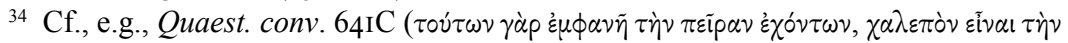

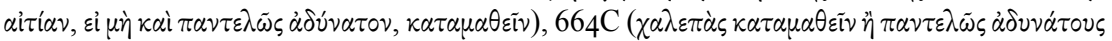

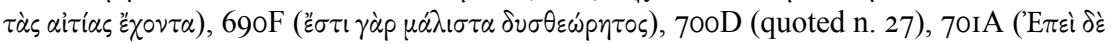

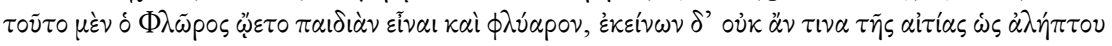


quaestio itself is not questioned: it actually has a rationale, a raison d'être, of itself, and the problematic natural phenomenon is, by implication, a virtual given only in the guise of a problem.

It is incorrect, therefore, to identify the quaestiones with 'hypotheses', for the simple fact that the latter need to be verified by further research: hypotheses are accepted until the opposite has been proven to be true (by falsification), whereas the quaestiones in Quaestiones naturales are accepted without further ado, so that a certain aspect of objectivity and credibility is ascribed to them. The concept of hypotheses more appropriately applies to the arguments in the aetiologies, which are tentative by their anti-dogmatic and interrogative formulation. There is no urge to fully prove or demonstrate things in Plutarch's physical aetiologies (this is, in fact, considered impossible from his Platonic-Academic point of view [see 4.3.2.I.]). In other words, the quaestio is not only an 'unknown factor' in the development of the problem, but also an 'invariable' or a 'given' in itself, the validity of which is not generally put to question. The quaestio functions as a stepping-stone on which the entire aetiology is founded. In a certain sense, the explanations to these problems are the real 'variables' in the problems. They are not formulated dogmatically and are, therefore, always a potential subject for criticism and revision.

\section{Plutarch's popular beliefs: anti-Aristotelian and anti-Stoic dynamics}

As seen in the previous section, empirical verification in dealing with natural problems was not of great concern to Plutarch's scientific methodology, and, as we will see later on, he had good epistemological reasons for it [see 4.3.2.3.]. What is important, and what has also been flagged before, is the anti-Aristotelian position Plutarch is implicitly taking. It is worth digging a bit deeper regarding Plutarch's subordination of the veracity of the natural phenomena to their physical causes in light of Aristotle's concept of science, which famously departs from what is positively given in nature. Afterwards, I will also confront Plutarch's approach with that of the Stoics.

Indeed, judging from his recurrent statement that natural science should progress from a consideration of what actually appears to the senses (see below), Aristotle has often been hailed by historians of science as the first empiricist. However, on closer inspection, much of the material gathered in his biological writings derives from popular hearsay rather than from personal observations. Even though Aristotle probably sought empirical verification for at least some of his assertions in these writings

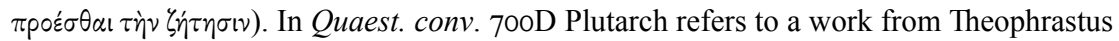

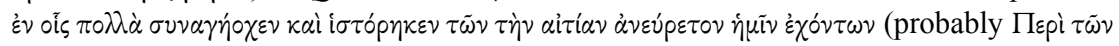

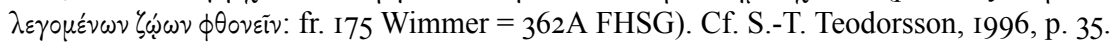


(he mentions dissections, for instance), scholars have convincingly shown that, to a great extent, his approach relies on reported observation rather than on autopsy ${ }^{35}$. In a famous passage concerning his scientific method in biology, Aristotle states that 'first the phenomena should be grasped

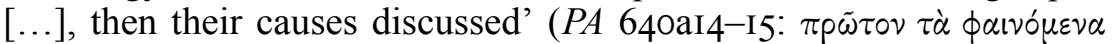

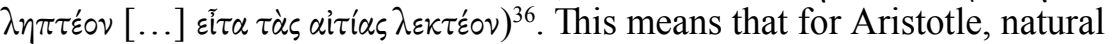
science should start from a consideration of what actually appears to the senses, and that examining the reasons of a reported phenomenon without knowing whether it actually exists or not leads to bad science (in principle). Aristotle's injunction to first grasp the observable phenomena ( $\left.\tau \dot{\alpha} \phi \alpha \iota \sigma^{\prime} \mu \varepsilon v \alpha\right)$ and to discuss their causes afterwards ( $\left.\tau \dot{\alpha} \varsigma \alpha i \tau i \alpha \varsigma\right)$ is a genuine appeal towards empirical verification. However, as just noted, Aristotle's actual scientific practice is often at odds with this injunction. Despite his official empiricist concern, Aristotle often violates his own methodological rule by basing his inquiry on popular hearsay and on doubtful assumptions rather than on empirical observations.

Even though it is uncertain as to whether Plutarch was acquainted with the empirical injunction from $P A$ 640aI4-I5 just quoted, he is clearly not following Aristotle's advice. In fact, a clear anti-Aristotelian attitude speaks from Plutarch's explicit subordination of the reality of the natural

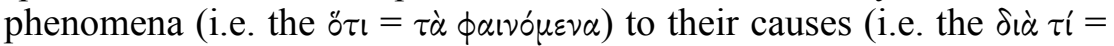

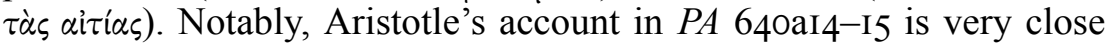
from a formal perspective $(\lambda \varepsilon \dot{\gamma \varepsilon \iota \nu}-\lambda \alpha \mu \beta \alpha \dot{v} \varepsilon \varepsilon v)$ to Quaest. conv. $68 \mathrm{oD}$, quoted above, where Florus argues, on the contrary, that 'the right method is to search out the reason for facts by means of logic, but to take the

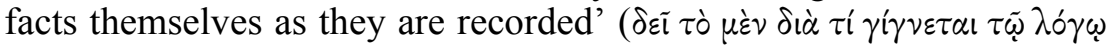

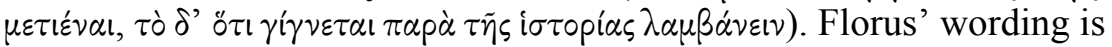

35 E.g., I. Düring, 196I, pp. 2I8-22I was right that: "we should be careful not to overemphasize Aristotle's own rôle as a pioneer of the empirical sciences. [...] [H]e was, perhaps to a far greater extent than we sometimes are inclined to believe, a desk-work

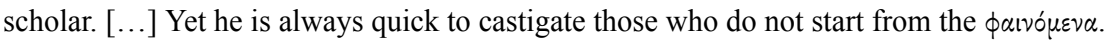
'Facts', 'data', did not mean the same for him as for us; practically every statement in which he himself believed was classed as a 'fact', or as 'true'." Cf. also H. von Staden, I989, p. II8. For a general outline of the aspect of empirical research in Aristotle's science, see G.E.R. Lloyd, 1979, pp. 200-225.

${ }^{36}$ A similar empiricist concern is found, e.g., in Herophilus, fr. 50a (and b) von Staden:

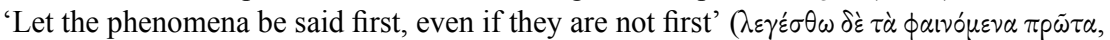

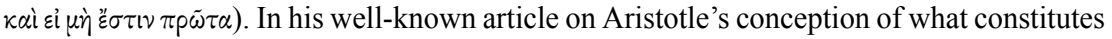
the фaเvó $\varepsilon \varepsilon v a$, G.E.L. Owen, I96I argued that Aristotle used this concept not in the sense of

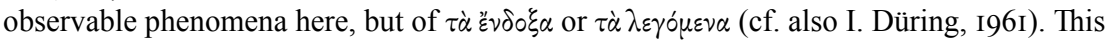
was rejected by H. von Staden, I989, pp. II7-II9, who argued, more convincingly, that the concept of фаıvó $\mu \varepsilon \nu \alpha$ really denotes the observable phenomena in Aristotle's biological writings, but that this does not eventually preclude the incorporation of $\tau \dot{\alpha} \tilde{\varepsilon} v \delta \circ \xi \alpha$ or $\tau \grave{\alpha}$ $\lambda \varepsilon \gamma o ́ \mu \varepsilon v \alpha$ in these writings (see also the review by R.J. Hankinson, I990, pp. 213-215). 
very close also to another Aristotelian account about the proper method of scientific inquiry: 'when we know the fact, we seek the reason why' ( $A P O$.

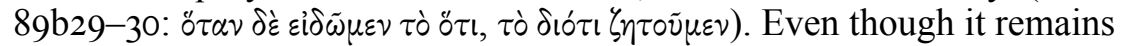
unclear as to whether Plutarch is intentionally alluding to these Aristotelian accounts (Aristotle's name and authority remain unmentioned), it is clear that Aristotle's appeal towards an empirical science did not greatly affect him in his natural problems. However, when push comes to shove, it turns out that the actual scientific practice of both philosophers was not always that different after all.

Plutarch's interest in explaining marvellous natural phenomena is more generally germane to the genre of natural problems. A large amount of paradoxes and mirabilia found their way into the Ps.-Aristotelian Problems $^{37}$ (we know that Florus owned a copy of this work: cf. Quaest. conv. 734CD [quoted 3.2.I.] ). As such, the scientific outlook of Plutarch's natural problems is not that different from those attributed to Ps.-Aristotle, which served as his model. Notably, the explanations $(\delta i \dot{\alpha} \tau i)$ in the Ps.-Aristotelian Problems also receive priority to the veracity of the phenomena themselves (ö $\tau$ ). As Mayhew observes, the Problems "never ask whether something exists or whether some proposition is true." 38

37 The Problems have a clear predilection for explaining popular beliefs $(\xi \nu \delta \circ \xi \alpha)$. See H. Flashar, 1962, p. 299 and pp. 342-343, M. Sassi, I993, p. 455, A. Blair, I999, p. I73, R. Mayhew, 20IIa, pp. xxi-xxii. See, for instance, the compilation by O. Thomas in his BMCR review (2I august 20I2) of R. Mayhew's 20II Loeb edition of Ps.-Aristotle's Problems: "Why do warthogs find each other attractive? Why do certain noises send a chill down the spine? Why do we get more enjoyment from tunes that we already know? Why do you yawn if I yawn? And why, while we yawn, do we lose our hearing? Why do children get more nits (and runny noses, and nosebleeds) than adults? Why does holding one's breath cure hiccups? Why can't one tickle oneself? Why is sex the highest pleasure? Why do drunks see double, or see the room spinning? Why does cutting an onion make you cry? Why does fear loosen the bowels? Why is it more shocking to kill a woman than a man? Why are most professional performers odious? Why do we count in base ten? (Is it because of the Pythagorean tetraktys? Or because we have ten fingers?) Why do some people feel sleepy the moment they open a book?" Ps.-Aristotle's De mirabilibus auscultationibus is an exponent of the genre of ancient paradoxography, but this work is generally considered spurious. This is not the case for Ps.-Aristotle's Problems, which contains at least a certain, albeit undefinable, nucleus of authentic Aristotelian problems [see I.I.3.].

${ }^{38}$ R. Mayhew, 20Ira, p. xxii. Cf. also, e.g., A. Blair, 1999, p. I73 (and pp. I87-I88): "The question, in $\delta i \dot{\alpha} \tau i$, asks not about the existence or nature of a fact, but about the cause of a fact that is presumed so well known that it is not even stated before it is explained. However bizarre the 'fact' may seem to us, the problema never includes discussion of its veracity but only of its cause." Cf. also J. Mansfeld, 20I0, p. 44: "Aristotle is quite clear that one need not always put all the questions. As to the "ö $\tau$ and the $\delta$ เó $\tau$, he says [...] that when you already know the 'that' you immediately ask for the 'why'." Cf. also C. Jacob, 2004, p. 45: "Ces questions donnent une réalité objective aux phénomènes 
This may explain, then, why Plutarch did not bother to verify the popular beliefs in his own natural problems but simply took them for granted, perhaps even considering this procedure a characteristic feature of the Aristotelian genre of natural problems. This would, in turn, put Plutarch's alleged anti-Aristotelianism into perspective.

A good example is found in Q.N. 38 , where Plutarch examines why she-wolves give birth to their young at a fixed time of the year within twelve days. As to the belief that they do this within the timespan of twelve days, Plutarch in the second causa mentions the story about Leto, 'to which certain people refer' (Quidam ad fabulam Latonae referunt). When Leto became pregnant from Zeus, she could not find a safe haven from Hera anywhere. Thus, Zeus transformed her into a wolf for a period of twelve days, during which she travelled to Delos. In this way, she procured that all wolves should be able to litter in that same period from then on. Among the quidam mentioned at the beginning of the causa, Aristotle certainly comes first, since the same mythological account is also recorded in HA 580aI4-I9. The Stagirite remains sceptical, however, about the popular belief that she-wolves (and dogs) mate and litter within twelve days. He writes: 'whether this really is the time for their pregnancy or not, has not yet been definitely established by observation; that is merely

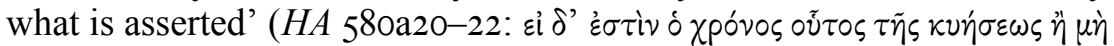

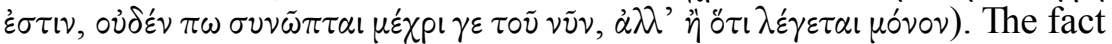

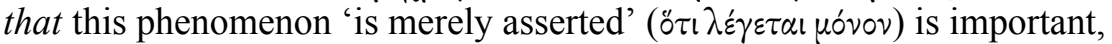
since it does not withhold Plutarch from addressing the problem anyhow. He may be relying directly on Aristotle or on an intermediary source, perhaps a lost natural problem, where this very assertion was supported and explained (see the commentary ad loc.).

As such, the fundamental difference between Aristotle's and Plutarch's scientific projects does not so much lie in the authority they ascribe to popular hear-say - in fact, they seem to be relatively convergent at this point -, but rather in the epistemological relevance they attribute to empirical observation. Aristotle openly vindicates an empirical approach in natural scientific research, while Plutarch does not see observational data as procuring reliable knowledge. In other words, while the Stagirite neglects to empirically double-check what is put on record in popular natural i $\sigma \tau$ opí $\alpha$, the Chaeronean is not primarily concerned with verifying (or falsifying) these popular beliefs in the first place, since he is convinced, as a faithful Platonist, that data pertaining to sense perception are

qu' elles problématisent: loin d'être des faits aléatoires, ils sont présentés comme des phénomènes généralisables et récurrents dont il est légitime de chercher les causes. Ces dernières peuvent relever de principes physiques ou de principes psychologiques, de schémas scientifiques ou de la sagesse populaire, non dénués parfois d'une certaine forme d' humour, du moins aux yeux du lecteur moderne [...]." 
essentially deceitful in kind [see 4.3.2.I.]. This does not imply that Plutarch ascribes no value whatsoever to empirical knowledge, but it is quite clear that his main concern lies elsewhere. Considering their authoritative statute, Plutarch assumes that popular beliefs must contain at least a certain aspect of reliability. Perhaps more important even, he believes that these often marvellous beliefs hint at the workings of a higher type of causality.

A relevant passage to illustrate this is found in Cor. 38 which speaks of the popular belief that statues of deities can cry, sweat, bleed or even speak, or at least give the appearance of doing so (the context is the story of the goddess Fortuna expressing words of thanks to Coriolanus' mother and wife via her newly erected statue). Plutarch points out that this is not, in fact, impossible for both natural and super-natural reasons:

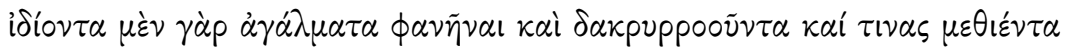

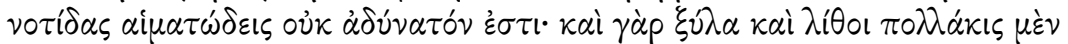

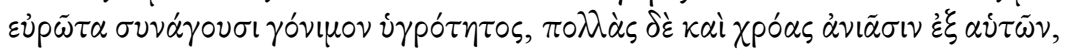

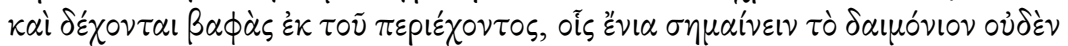

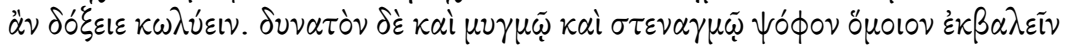

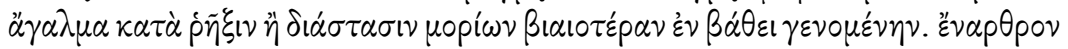

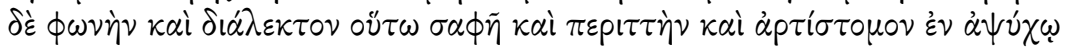

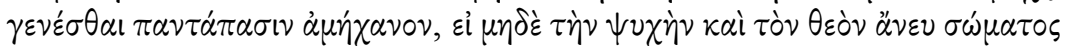

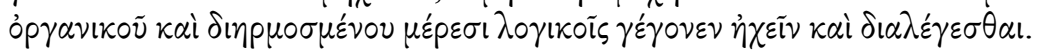

For that statues have appeared to sweat, and shed tears, and exude something like drops of blood, is not impossible; since wood and stone often contract a mould which is productive of moisture, and cover themselves with many colours, and receive tints from the atmosphere; and there is nothing in the way of believing that the Deity uses these phenomena sometimes as signs and portents. It is possible also that statues may emit a noise like a moan or a groan, by reason of a fracture or a rupture, which is more violent if it takes place in the interior. But that articulate speech, and language so clear and abundant and precise, should proceed from a lifeless thing, is altogether impossible; since not even the soul of man, or the Deity, without a body duly organised and fitted with vocal parts, has ever spoken and conversed.

Plutarch, in what follows, notes that 'history forces our ascent with

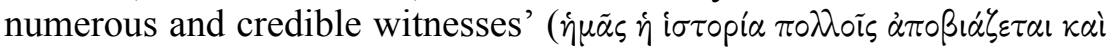
$\pi \iota \theta$ ขois $\mu \alpha \dot{\rho} \tau \nu \sigma \iota v)$. He does not, however, accept these beliefs blindly but tries to save them by providing a natural explanation (see the parallel in Cam. 6, 5-6 below). Even so, Plutarch is clear that it is 'altogether impossible' ( $\left.\pi \alpha \nu \tau \alpha \dot{\alpha} \pi \alpha \sigma \nu \alpha \mu \eta^{\prime} \chi \alpha \nu \circ \nu\right)$ for these statues to really produce articulate speech. He concludes that 'an experience different from that of sensation arises in the imaginative part of the soul, and persuades men to 


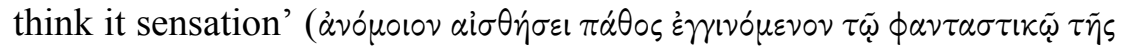

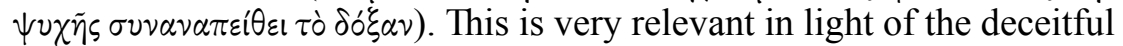
nature of data pertaining to sense perception more generally, underlining how this deceit works exactly in the context of natural mirabilia.

In what follows, Plutarch explains that too eager acceptance of such miracles is a sign of superstition. He formulates this in rather shrouded and euphemistic terms, calling superstitious people 'those who cherish strong feelings of good-will and affection for the deity, and are therefore

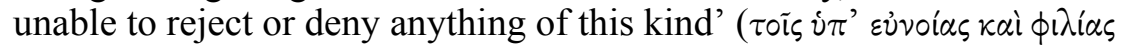

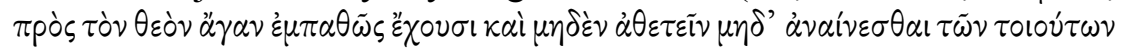

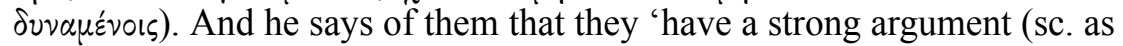
provided by their belief in talking statues) for their faith in the wonderful

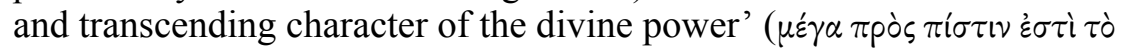

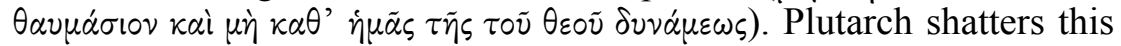
illusion by pointing out that 'the deity has no resemblance whatever

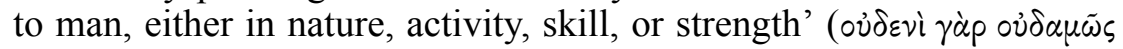

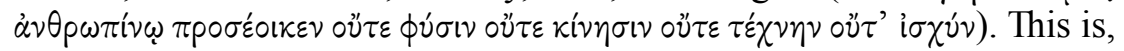
of course, no cause to resort to radical atheism. On the contrary, so Plutarch concludes, 'most of the deity's powers, as Heraclitus says, "escape our knowledge through incredulity" (DK22B86)' ( $\tau \tilde{\omega} \nu \mu \dot{\varepsilon} \nu \theta \varepsilon i \omega \nu \tau \dot{\alpha} \pi \circ \lambda \lambda \dot{\alpha}, k \alpha \theta$ '

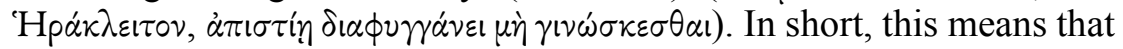
God is able to communicate with us, albeit not by employing human speech but by other means strange to us (e.g., via dreams: cf. Per. 13, 7-8). What the passage shows, then, is not that natural mirabilia (as recorded

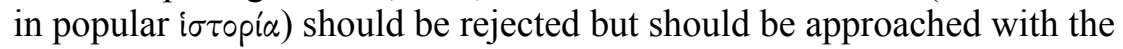
necessary circumspection and caution.

As we know from a work like De superstitione, Plutarch more often invites his reader to avoid religious immoderation by following a 'middle course' between atheism ( $\dot{\theta} \theta \varepsilon o ́ \tau \eta \zeta)$ and superstition $(\delta \varepsilon เ \sigma \delta \delta \alpha \mu o v i ́ \alpha)$ - these he considers the extreme antipodes in the spectrum of impiety $(\dot{\alpha} \sigma \varepsilon \hat{\varepsilon} \beta \varepsilon)^{39}$. Plutarch at times connects the concept of a 'middle course' with the Delphic imperative to 'avoid extremes' ( $\mu \eta \delta \dot{\varepsilon} \nu \alpha$ ' $\gamma \alpha \nu)$. This is the case, for instance, in Cam. 6, 5-6, where a parallel account is found about the marvellous phenomena connected to divine statues (the broader context is that of the statue of Juno assenting to its transfer from Veii to Rome after the sack by Camillus). Again with a reference to traditional i $\sigma \tau$ i Plutarch reports that "not a few historians wrote that statues of gods could talk, drip with sweat, utter audible groans, turn away their faces and close

${ }^{39}$ Cf. De sup. I69F. For the opposition between atheism and superstition, cf., e.g., De

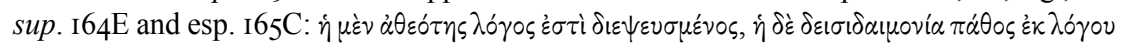

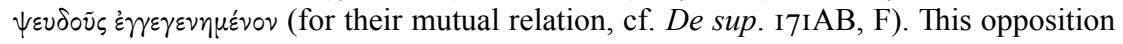
recurs passim throughout Plutarch's writings: cf., e.g., De ad. et am. 66CD, De Is. et Os. $355 \mathrm{D}, 378 \mathrm{~A}, 379 \mathrm{E}$ etc. 


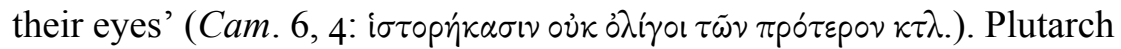
warns, however, that certainty is unattainable in such cases for the human intellect:

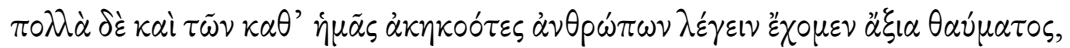

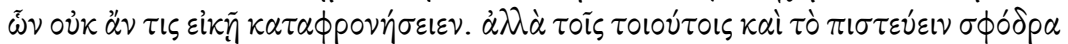

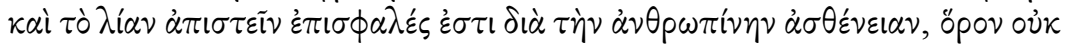

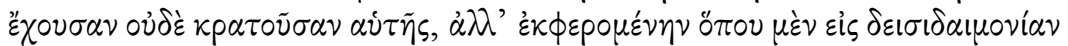

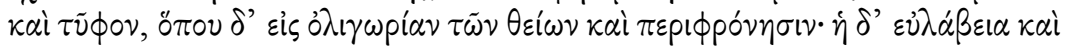

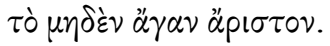

And we ourselves might make mention of many astonishing things which we have heard from men of our own time, - things not lightly to be despised. But in such matters eager credulity and excessive incredulity are alike dangerous, because of the weakness of our human nature, which sets no limits and has no mastery over itself, but is carried away now into vain superstition, and now into contemptuous neglect of the divine. Caution is best, and to go to no extremes.

For Plutarch, an unreasoned rejection of the possibility of divine intervention through miraculous natural phenomena allows for radical disbelief and atheism, much in the same way as unreasoned acceptance thereof does for credulity and superstition. In order to avoid the religious extremes of atheism and superstition, Plutarch adheres to some kind of rational devotion to the gods $(\varepsilon \dot{v} \sigma \varepsilon \varepsilon \varepsilon 1 \alpha)^{40}$, which, as we learn from De sup. I7 IF,

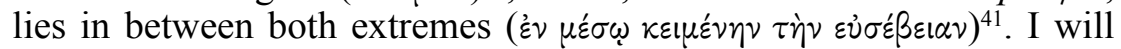
later return to the epistemological value of the $\mu \eta \delta \dot{\varepsilon} \nu \dot{\alpha} \gamma \alpha \nu$ and $\varepsilon \dot{\nu} \lambda \dot{\alpha} \beta \varepsilon 1 \alpha$ at the end of this passage in light of Plutarch's penchant for Academic philosophy in more detail [see 4.3.2.I.]. Important for the argument at hand is that Plutarch's attempt to save popular mirabilia relates to issues of theology and world view. For Plutarch each natural phenomenon can be considered a sign not only of the working of physical forces in nature, but also of a higher entity that orders the world in a providential way [see 4.I.2.]. This allows Plutarch to draw a close affiliation between the natural and the divine realms in nature, which, in turn, closely alines his world system with Plato's and distinguishes it from Aristotle's.

40 See R. Flacelière, J. Irigoin, J. Sirinelli and A. Philippon, I987, p. clxii: "Mais sa foi, certes, n'était pas celle du charbonnier; elle était raisonnée, réfléchie, 'éclairée' comme il sied à un philosophe fermement convaincu du primat de la raison."

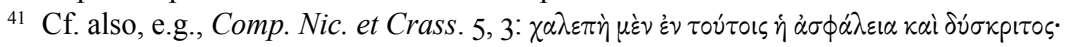

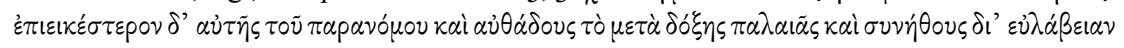

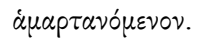


Aristotle's God, as perceived by Plutarch, is more divorced from the world that we live in. He has only set the world in motion (in his capacity

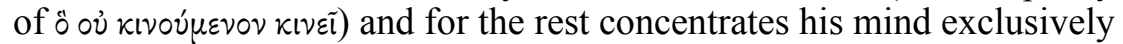

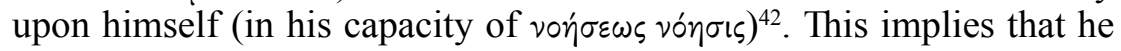
does not intervene in nature in a providential way and does not care about the animate world that we, human beings, belong to. By consequence, the incorporation of popular and wonderful beliefs in the Stagirite's natural scientific writings is not motivated on religious grounds, but is rather symptomatic of the author's urge for scholarly-encyclopaedic comprehensiveness. If Aristotle is interested in collecting 'raw data' from traditional natural history, it is not because they hint at the existence of a higher level of reality, but because they require further scientific investigation. In the case of Plutarch, by contrast, a deeper religiousphilosophical motive does play an important role in his interest in natural mirabilia.

Notably, the Stoics also had this custom of saving natural mirabilia in their attempt to support a providential ordering of the world ${ }^{43}$. Again, however, their motives are fundamentally different from Plutarch's. Stoic cosmology is based on the assumption of a universally predetermined fate

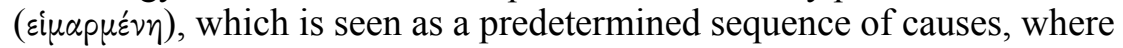
every cause is considered the predetermined effect of a previous cause, which in turn is the effect of yet another previous cause, and so on. It follows that the world's natural ordering, from its very outset until its very end, is predetermined from a causal perspective (which also enables us to make predictions about the future by means of divination). Importantly, for the Stoics the world's providential ordering is essentially linked to a physical interpretation of all causality, whereas in the case of Plutarch there is room also for a higher type of causality, which transcends physical reality (but still stands in close contact with it). According to the Stoics, a divine fire steers the cosmos, and the world's providence is based on this material-logical principle. As such, the providential ordering of nature is founded on an essentially material basis, since the divine principle is immanent in the natural world. Plutarch's God, by contrast, has a more transcendental nature, although his influence can still be felt in the natural world (this means that God is not simply detached from the lower natural realm as is the case rather in Aristotle's theology $)^{44}$.

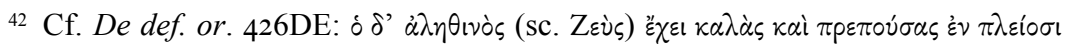

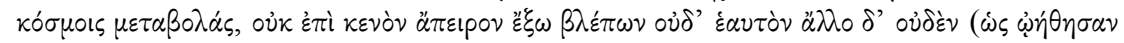

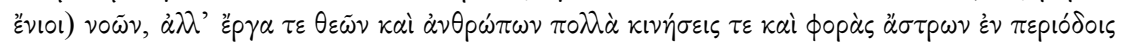
$\kappa \alpha \tau \alpha \theta \varepsilon \omega \dot{\mu \varepsilon \nu} \circ \kappa^{\prime} \tau \lambda$.

${ }^{43}$ See, e.g., Sen., De prov. I, 2-4.

${ }_{44}$ Plutarch's Platonic God arranges nature in a providential fashion, but his essence is located in the intelligible realm. For the difference between Plutarch's concept of divine 
As a consequence, the religious motivation for Plutarch's attempt to save natural mirabilia is very different from that of the Stoics. Whereas Plutarch does not reject the relevance of physical aetiology in interpreting what are essentially divinely inspired phenomena, the Stoics attribute everything in nature to a predetermined chain of material causes. In so doing, they invoke the concepts of natural sympathy and antipathy, by which they assume a permanent interaction of every phenomenon in the cosmos, in a positive or negative way respectively ${ }^{45}$. Plutarch does not seem to be a great enthusiast of these theories. In fact, it seems that for him the sympathy/antipathy argument is a non-explanation. At least, it is presented as not being very plausible or convincing from an aetiological perspective. Presumably by its lack of explanatory detail and elaboration the sympathy/antipathy argument remains rather close to the realm of fable and superstition, for Plutarch, and cannot, therefore, be considered an adequate physical explanation. This may explain why it is not mentioned in Quaestiones naturales ${ }^{46}$, and why on several occasions in Quaestiones convivales, Plutarch even objects to it openly ${ }^{47}$. In Quaest. conv. $64 \mathrm{IB}$, for

providence vis-à-vis that of the Stoics, see G.E. Karamanolis, 2006, p. I08: "Against the Stoic view that providence is immanent in Nature in particular, Plutarch argues that nature has been arranged in a certain way, and it is in this arrangement that the essence of divine providence lies (De facie 927C-D)." See also p. I06: "Plutarch regards God as being constantly involved with the world, exercising providence over everything in it." For further reading, see also J. Opsomer, 20I4. For the place of divine $\pi$ póvola in Plato's cosmos, cf., e.g., Tim. 30c. On Plutarch's view of the workings of providence and chance in the development of history, see S. Swain, 1989 (his appendix of terms on pp. 298-302 is useful in light of Plutarch's conceptualisation of providence). Cf. also F. Titchener, 20 I4.

${ }^{45}$ For the strong Stoic connotation of the cosmological theories of antipathy and sympathy, see, e.g., T. Weidlich, I894, pp. 4-II, K. Reinhardt, I926, pp. I78-I86 and G. Soury, 1949, pp. 322-323. Bolus of Mendes (Ps.-Democritus), a contemporary of

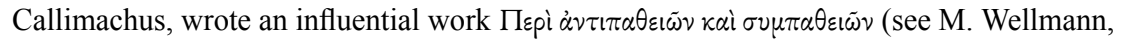
I897). See also S.-T. Teodorsson, I989, pp. 255-256 and I999a, pp. 667-668. In addition, Book seven of Ps.-Aristotle's Problems is entitled ö $\sigma \alpha \dot{\xi} \kappa \sigma v \mu \pi \alpha \theta \varepsilon i \alpha \varsigma$, but this type of sympathy concerns medical contagions (in a broad sense). See R. Mayhew, 20IIa, pp. 228229. The theme of Q.N. 6 perhaps goes back on this topic (see the commentary ad loc.).

${ }^{46}$ However, there may be an implicit allusion to this Stoic theory in the sympathetic account about she-wolves that Plutarch borrows from Antipater in the first causa of Q.N. 38 (presumably the Stoic philosopher of Tarsus: see n. II3). There are also a number of instances where the theories of attraction and motion ( $\delta \lambda \kappa \eta^{\prime}$ and $\left.\phi o p \alpha \dot{)}\right)$ are mentioned, often in combination with that of emanation, but this is not necessarily an allusion to the Stoic theory of natural sympathy/antipathy in a strict sense, bur rather to a more general mechanical theory of natural movements. Cf. Q.N. 7, 9I4A, 19, 9I6D, 24, 9I8A, 26, 918C, 4I. Notably, Plato rejected the theory of $\delta \lambda \kappa \eta$ for the working of several natural phenomena (including magnetism) in Tim. 80c (cf. Quaest. Plat. I005BD and Q.N. 19, 9I6D).

${ }^{47}$ For a list of problems pertaining to sympathy and antipathy in Quaestiones 


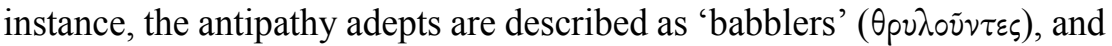
in Quaest. conv. 664CD such antipathies are considered mere 'chatter' significantly, this is meant as an emphatic invitation to search for a theory that will explain such phenomena ( $\dot{\alpha} \delta 0 \lambda \varepsilon \sigma \chi \tilde{\omega} \pi \alpha p \alpha \kappa \alpha \lambda \tilde{\omega} \nu \dot{\nu} \mu \tilde{\alpha} \varsigma \dot{\varepsilon} \pi \dot{i} \tau \dot{\eta} \nu \zeta \dot{\eta} \tau \eta \sigma \omega$ $\tau \tilde{\eta} \varsigma \alpha i \tau i \alpha \varsigma)^{48}$. Arguably, then, Plutarch in his natural problems aims to take an anti-Stoic position by further investigating and providing detailed physical aetiologies of the natural mirabilia at hand, that is, by suggesting more plausible natural explanations for them (than simply assuming the workings of natural sympathy and antipathy), without moreover forsaking a higher type of causality ${ }^{49}$.

We can safely conclude that Plutarch's positive attitude towards natural mirabilia ties in closely with his philosophical-religious convictions about the natural world and its providential ordering. When Plutarch carefully attaches credence to natural mirabilia - giving them the benefit of the doubt - , he does this with necessary epistemic caution $(\varepsilon \dot{\lambda} \lambda \dot{\alpha} \beta \varepsilon 1 \alpha)$ and with an underlying philosophical-religious motive in the back of his mind ( $\varepsilon \dot{\nu} \sigma \varepsilon \hat{\varepsilon} \varepsilon \varepsilon \alpha$ ), according to which divine providence is active and permanent in the natural world. I will further specify this in the next section in light of Plutarch's dualistic view on causality, which lies at the very basis of his Platonic world view.

conviales and in other works by Plutarch, see M. Wellmann, I928, pp. 25-26 and T. Weidlich, I894, pp. 53-58.

${ }^{48}$ I take this to imply that according to the Stoic approach of mirabilia the natural causality of these phenomena should be accepted without further aetiological specification (presumably they were seen as the factual consequences of universal faith, understood as a predetermined sequence of natural causes). Regarding the popular belief that thunder produces truffles, for instance (as discussed in Quaest. conv. 664A-665A [see 3.I.4.]), A. Setaioli, 2009, pp. 442-443 draws a link with Stoic divination theory and argues that "the area in which the Stoics tried hardest to reconcile popular traditions with their own philosophy was of course divination. This form of prediction of the future was theoretically founded on the doctrine of $\sigma \nu \mu \pi \dot{\alpha} \theta \varepsilon 1 \alpha$, the mutual connection and reciprocal influence of all

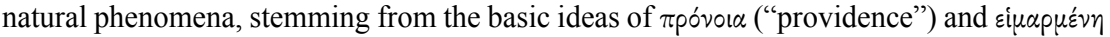
("fate", conceived as an uninterrupted chain of causes), but the need to save the prephilosophical folkloric traditions connected with divination forced the Stoics to assume a link between the facts traditionally considered as signs and the ensuing phenomena considered to be announced by them - which restricted them to an empirical observation admitting of no experimental test or rational ascertainment of causal sequences" (my Italics). On the role of divination in Plutarch's own philosophical thinking, see J. Opsomer, I996b.

49 For Stoic aversion to Aristotelian-style aetiology (more precisely that of Posidonius), cf. Strabo, Geogr. 2, 3, 8 [quoted I.I.6., n. I67]. For Plutarch's general anti-Stoic attitude, see D. Babut, I969, pp. 22-69. See also J. Opsomer, 20I4, pp. 92-93. 


\section{I.2. Plutarch's dualistic causality: rationalising the divine and the use of myth and poetry}

Plutarch's outlook on the world prescribes that natural phenomena are not fathomable in terms of physical causes alone, since they also allow for an alternative interpretation based on their deeper and underlying significance. Thus, Plutarch firmly believes that the order of nature has a divine basis ${ }^{50}$. In light of this understanding, the section at hand aims to discuss Plutarch's dualistic view on causality and how this was influenced by Plato's philosophy ${ }^{51}$.

\section{Plato's scientific revolution}

For Plutarch, as a Platonist, the world of contingent natural phenomena is an image of a higher, intelligible model. He believes that the natural world of becoming mirrors the divine reality and provides a faint reflection of it in a material form ${ }^{52}$. By consequence, Plutarch's world system is constituted in such a way that there is no rigid border between physical and meta-physical causes ${ }^{53}$. From numerous passages throughout the corpus Plutarcheum, we learn, rather, that the reverse is true.

The locus classicus is Per. 6, where Plutarch describes Pericles'

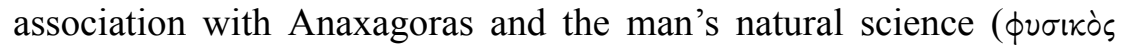
$\lambda$ ó$_{0 \varsigma}$ ). As we saw earlier on, this acquaintance provided Pericles with the advantage of rising above superstition $\left(\delta \varepsilon เ \sigma i \delta \alpha \iota \mu \circ v_{i} \alpha\right)$ and paved the way for genuine devotion to the gods $(\varepsilon \dot{v} \sigma \varepsilon \varepsilon \varepsilon i \alpha)^{54}$ [quoted 3.2.2.]. In what follows, Plutarch does not specify how this occurred precisely but tells a legendary story instead about a one-horned ram whose head was brought to Pericles from his farm. Plutarch's attempt to reconcile the diametrically opposed interpretations of this marvellous natural phenomenon by the

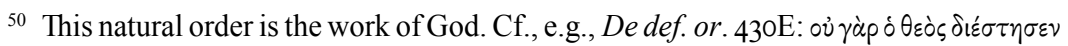

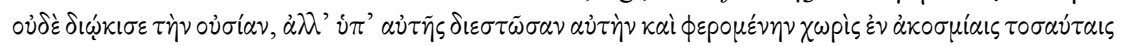

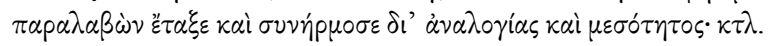

${ }^{51}$ For a seminal study of Plutarch's view on causality, see P. Donini, I992. See also, e.g., F. Ferrari, I995, p. 79 and J. Opsomer, I998, pp. I8I-I84.

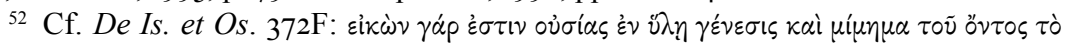
$\gamma(v o ́ \mu \varepsilon v o v$. This conception ties in closely with Plutarch's Platonic cosmology. For Plutarch's view of the physical world as an image of the divine, see R. Hirsch-Luipold, 2002, esp. pp. I74-222 (and pp. 284-285 for a general synopsis).

${ }^{53}$ G.E.R. Lloyd, I979, pp. 32, 5I, 57 would speak of "double determination", where it is believed that natural phenomena are brought about both by the gods and by natural causes.

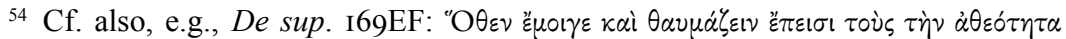

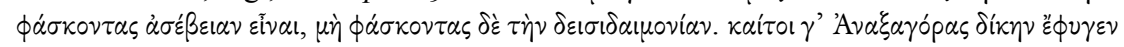

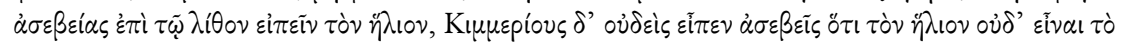

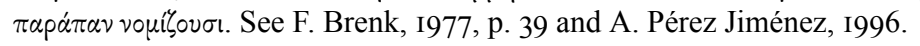


seer Lampon, on one side, and the natural philosopher Anaxagoras, on the other, is revealing for his own understanding of causality in general (Per. 6, 2-4):

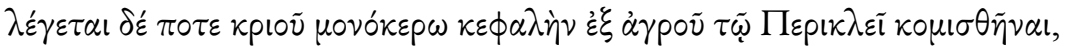

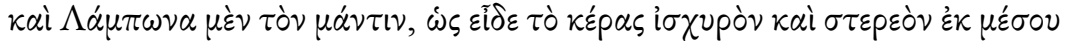

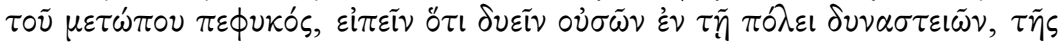

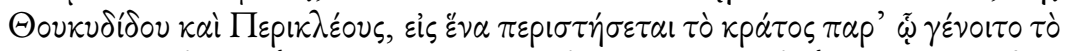

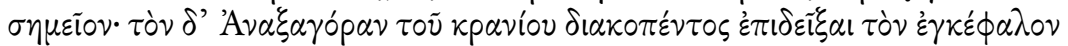

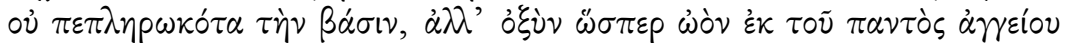

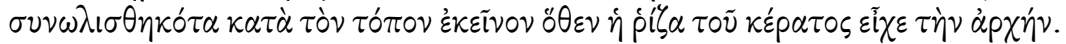

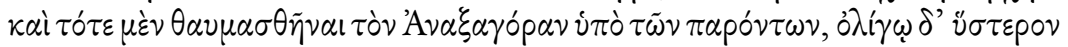

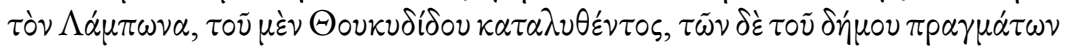

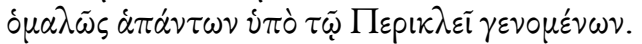

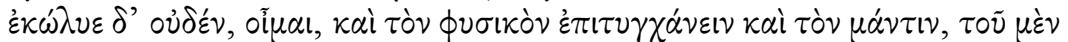

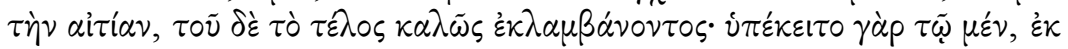

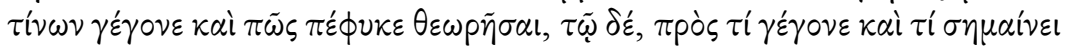

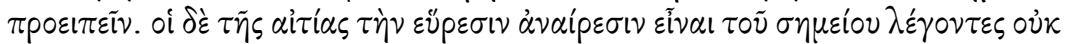

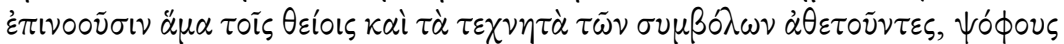

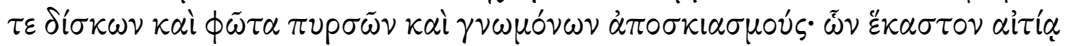

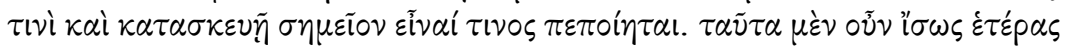

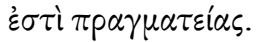

A story is told that once upon a time the head of a one-horned ram was brought to Pericles from his country-place, and that Lampon the seer, when he saw how the horn grew strong and solid from the middle of the forehead, declared that, whereas there were two powerful parties in the city, that of Thucydides and that of Pericles, the mastery would finally devolve upon one man, - the man to whom this sign had been given. Anaxagoras, however, had the skull cut in two, and showed that the brain had not filled out its position, but had drawn together to a point, like an egg, at that particular spot in the entire cavity where the root of the horn began. At that time, the story says, it was Anaxagoras who won the plaudits of the bystanders; but a little while after it was Lampon, for Thucydides was overthrown, and Pericles was entrusted with the entire control of all the interests of the people.

Now there was nothing, in my opinion, to prevent both of them, the naturalist and the seer, from being in the right of the matter; the one correctly divined the cause, the other the object or purpose. It was the proper province of the one to observe why anything happens, and how it comes to be what it is; of the other to declare for what purpose anything happens, and what it means. And those who declare that the discovery of the cause, in any phenomenon, does away with the meaning, do not perceive that they are doing away not only with divine portents, but 
also with artificial tokens, such as the ringing of gongs, the language of fire-signals, and the shadows of the pointers on sundials. Each of these has been made, through some causal adaptation, to have some meaning. However, perhaps this is a matter for a different treatise.

Stadter rightly argues that: "By introducing examples of signals made by men, P. implies by analogy that the gods make natural phenomena function as signs also" 55 . As seen in the previous section, a natural phenomenon is some kind of a $\sigma \eta \mu \varepsilon i \sigma_{0}$ for Plutarch, albeit not only of the manifestation of physical causes, but also of a deeper meaning ${ }^{56}$ (see n. 33). The distinction in the explanation between these two aspects, viz. between the physical

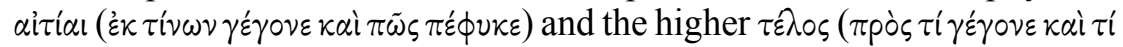
$\sigma \eta \mu \alpha(v \varepsilon)$, is not absolute for Plutarch but of a complementary kind, because they form a tight explanatory unity. An adequate scientific explanation of natural phenomena should, therefore, take into account both of these aspects.

Plutarch's dualistic causality ties in closely with his Platonic philosophy, as can be deduced, for instance, from Nic. 23, 2-4, where Plutarch reports on Nicias' superstitious reaction when witnessing a lunar eclipse. In this passage, Plutarch outlines some kind of a micro-development in the history of ancient Greek science, where Anaxagorean physics became subjected $\left(\dot{\nu} \pi \dot{\varepsilon} \tau \alpha \xi_{\varepsilon}\right)$ to divine and meta-physical principles in Plato's cosmology ${ }^{57}$ :

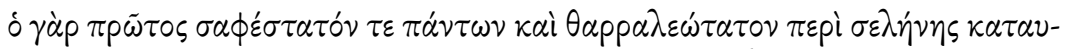

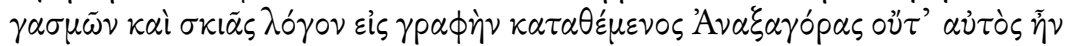

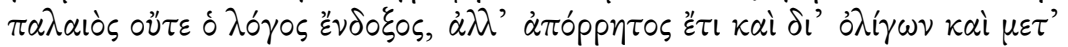

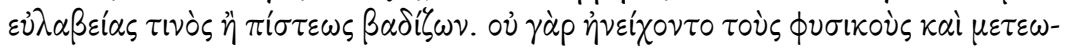

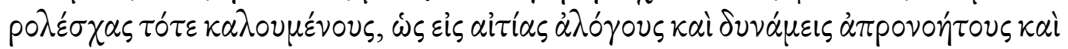

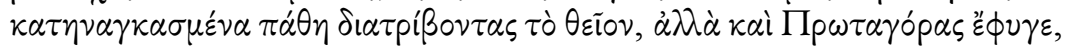

55 P.A. Stadter, 1989 , p. 87. He interprets the concluding phrase ( $\tau \alpha \tilde{\tau} \tau \alpha \mu \dot{\varepsilon} \nu$ oป̃v l゙ $\sigma \omega \varsigma$

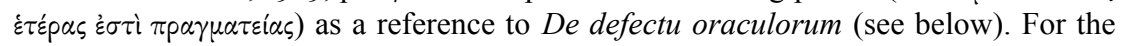
influence of Anaxagoras' philosophy on Pericles' statesmanship, see id., I99I, pp. I20-I22. For further commentary on this passage, see also J.P. Hershbell, I982, pp. I4I-I42.

${ }^{56}$ For the idea that natural phenomena contain a deeper, divine significance, cf. also, e.g., Sept. sap. conv. I49CE (on the monster brought to Periander) and Cor. 38, 2 (regarding talking statues; quoted above).

${ }^{57}$ Plutarch also considers Plato's philosophy to be a turning point in other, more exact scientific disciplines. It initiated a theoretical distinction $(\delta$ เккpi $\theta \eta)$ between abstract geometry and technical mechanics, as practiced by Archimedes, Eudoxus, Archytas and Menaechmus (cf. Marc. I4; I7 and Quaest. conv. 7I8EF, with G.E.R. Lloyd, I973, pp. 9395, A. Georgiadou, I992, P. Culham, I992, J. Sirinelli, 2000, pp. 356-357). In addition, for Plutarch's idea of historical progress in the field of astronomy, cf. Arist. 19, 7 (with J. Boulogne, 2008, p. 74I). 


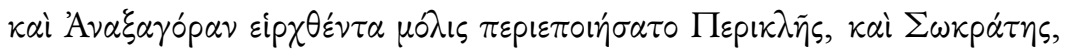

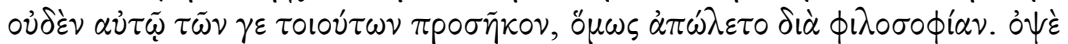

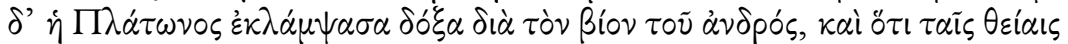

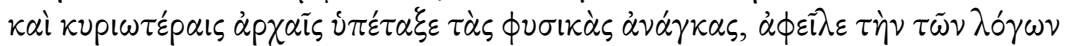

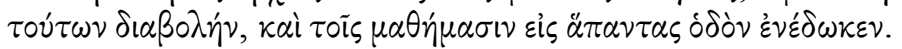

The first man to put in writing the clearest and boldest of all doctrines about the changing phases of the moon was Anaxagoras. But he was no ancient authority, nor was his doctrine in high repute. It was still under seal of secrecy, and made its way slowly among a few only, who received it with a certain caution rather than with implicit confidence. Men could not abide the natural philosophers and "visionaries," as they were then called, for the reason that they reduced the divine agency down to irrational causes, blind forces, and necessary incidents. Even Protagoras had to go into exile, Anaxagoras was with difficulty rescued from imprisonment by Pericles, and Socrates, though he had nothing whatever to do with such matters, nevertheless lost his life because of philosophy. It was not until later times that the radiant repute of Plato, because of the life the man led, and because he subjected the compulsions of the physical world to divine and more sovereign principles, took away the obloquy of such doctrines as these, and gave their science free course among all men.

The same notion of a scientific revolution avant la lettre that arose from Plato's criticism of Anaxagorean natural science is found in De def. or. $435 \mathrm{~F}-436 \mathrm{~A}$, where Plutarch describes the final and the efficient causes ( $\tau \dot{0}$

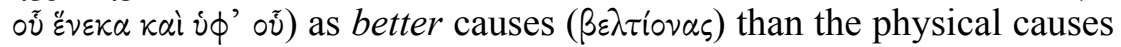
and the law of necessity ( still speaks of them as being closely interrelated:

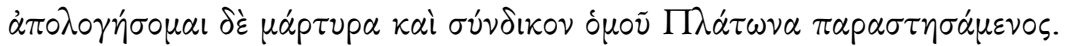

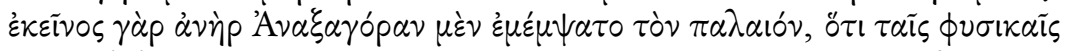

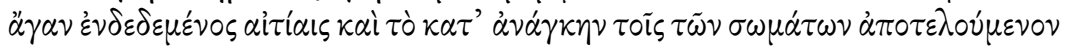

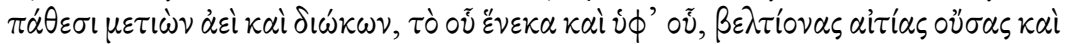

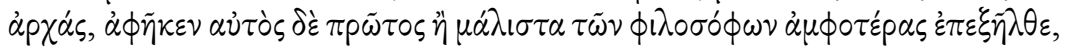

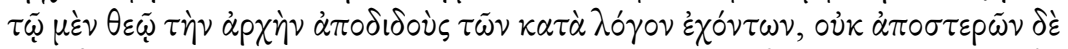

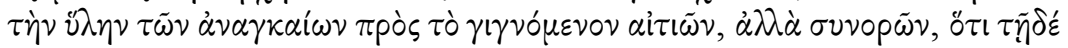

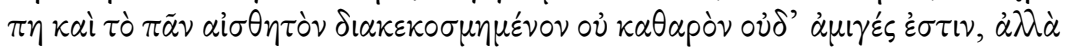

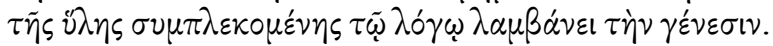

I shall defend myself by citing Plato as my witness and advocate in one. That philosopher found fault with Anaxagoras, the one of early times, because he was too much wrapped up in the physical causes and was always following up and pursuing the law of necessity as it 
was worked out in the behaviour of bodies, and left out of account the purpose and the agent, which are better causes and origins. Plato himself was the first of the philosophers, or the one most prominently engaged in prosecuting investigations of both sorts, to assign to God, on the one hand, the origin of all things that are in keeping with reason, and on the other hand, not to divest matter of the causes necessary for whatever comes into being, but to realise that the perceptible universe, even when arranged in some such orderly way as this, is not pure and unalloyed, but that it takes its origin from matter when matter comes into conjunction with reason.

The reference is probably to $\mathrm{Pl}$., $P h d .97 \mathrm{~b}-99 \mathrm{~d}$, where Socrates vents his disappointment about Anaxagoras' almost exclusive focus on physical causes. At first, Anaxagoras' mention of the all-embracing voṽs seemed promising to Socrates, because he assumed that it would arrange every-

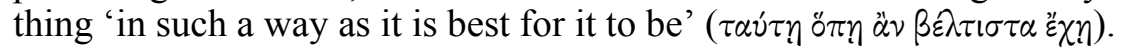
Eventually, though, Anaxagoras' theory did not meet up to Socrates' initial expectations (I have discussed this passage in further detail in the prologue). For a clearer account of causality in Plato we must turn to the Timaeus, where a basic distinction is drawn between necessary and divine causes (68e). Plato here describes natural causes as 'contributory causes' (46ce, $76 \mathrm{~d}$ : $\sigma v v \alpha i \tau i \alpha l)$ and natural necessity as the 'wandering cause' (48a: $\left.\pi \lambda \alpha \nu \omega \mu \varepsilon^{\prime} \nu \eta \alpha i \tau^{\prime} \alpha\right)$ : these are auxiliary or secondary to the primary cause ${ }^{58}$, which Plato varyingly calls 'the best cause' (29a, cf. Quaest. conv. 720B), 'the maker and father of the universe' (28c), 'demiurge' (29a), 'mind' (47e), 'God' (30a, 53b) etc.

Accordingly, a little bit further in De def. or. 436DE, Plutarch returns to the issue of causality. Even though his preference clearly goes to the

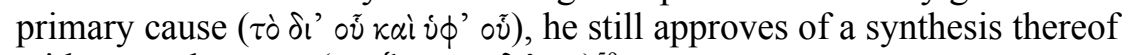
with natural causes $\left(\tau \dot{\partial} \xi^{\xi} \xi \tilde{\omega} \nu \text { Kal } \delta \iota^{\prime} \tilde{\omega} v\right)^{59}$ :

${ }^{58} \mathrm{Cf}$. also Tim. 29e, 68e. For the distinction between primary and secondary causes in Plato's Timaeus, see, e.g., W. Scheffel, I976, pp. II8-I39. For the influence of this dichotomy on Plutarch's philosopy, see, e.g., P. Donini, I984, p. 374, I992a and J. Opsomer, 1998, p. 183 .

${ }^{59}$ In an attempt to bring Plutarch's terminology in this passage more in line with the traditional (Aristotelian) scheme of causes, P. Donini, I992a, p. Ior proposed to emend $\delta$ ' ov (= instrumental cause) in $\delta l^{\prime}$ ' (= final cause). This is clever, because it is only reasonable

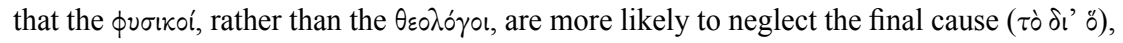
but, then again, all the manuscripts read $\delta l^{\prime}$ ov (cf. also Quaest. conv. 698B: $\tau \dot{\text { ò } ~ o v ̃ ~ ह ै v \varepsilon k \alpha ~[. . .] ~}$

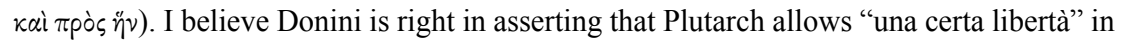
his formulation of the different causes. Therefore, it is not unlikely that he is generally alluding to the traditional scheme of causes without having the intention of becoming too technical or precise. It remains to be seen, then, whether $\tau \dot{\partial} \delta l^{\prime}$ o ṽ is really simply equal to $\tau \grave{o} \delta \iota^{\prime}$ ' $\omega \nu$ for Plutarch in this passage ( $\tau \dot{\partial} \delta l^{\prime}$ + gen. of the relative pronoun being the 


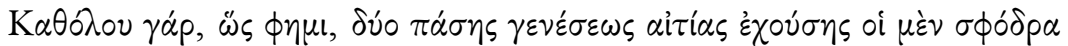

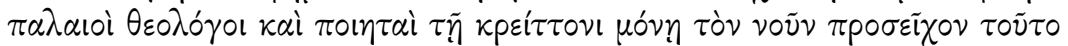

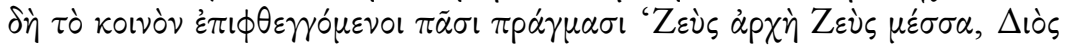

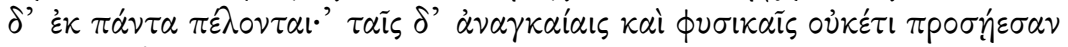

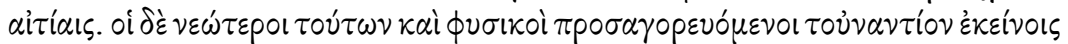

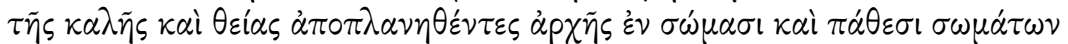

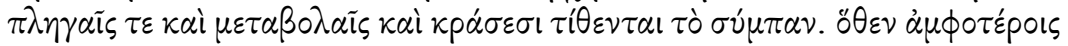

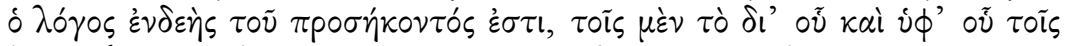

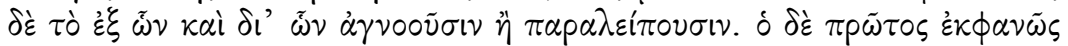

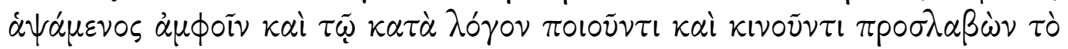

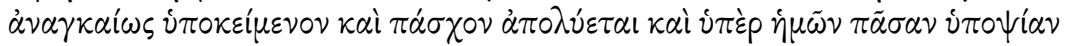

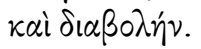

To sum up, then: while every form of creation has, as I say, two causes, the very earliest theological writers and poets (Orph. fr. I68) chose to heed only the superior one, uttering over all things that come to pass this common generality: "Zeus the beginning, Zeus in the midst, and from Zeus comes all being"; but as yet they made no approach towards the compelling and natural causes. On the other hand the younger generation which followed them, and are called physicists or natural philosophers, reverse the procedure of the older school in their aberration from the beautiful and divine origin, and ascribe everything to bodies and their behaviour, to clashes, transmutations, and combinations. Hence the reasoning of both parties is deficient in what is essential to it, since the one ignores or omits the intermediate and the agent, the other the source and the means. He who was the first to comprehend clearly both these points and to take, as a necessary adjunct to the agent that creates and actuates, the underlying matter, which is acted upon, clears us also of all suspicion of wilful misstatement.

The first person to have done this, that is, to endorse both aetiological approaches towards natural phenomena, is obviously Plato. As such, Plato's reconciliation of both types of causality is depicted as a real turning point in the history of ancient Greek philosophy.

instrumental cause). In my opinion, the most important aspect of Plutarch's formulation of the different types of causes is the shift in number in the relative pronouns $\circ \tilde{v}-\tilde{\omega} v$ : viz. $\tau$ co

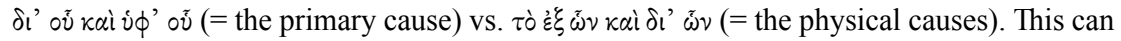
be taken to imply, then, that whereas nature is subject to a plurality of lower causes (cf. De def. or. $435 \mathrm{~F}-436 \mathrm{~A}$; quoted above), the higher cause is essentially a singularity, viz. God (or synonymous concepts, which basically imply one and the same divine entity or principle). Whatever may be the case, Plutarch's main point is clear and comprehensible with or without Donini's emendation. 
Plutarch is clearly self-fashioning himself in these passages as a faithful son of the Platonic revolution. For him, as for Plato, natural phenomena are grounded in divine principles. Therefore, one's devotedness to the gods does not necessarily result in bad science. At the same time, one's attempt to save the phenomena by means of natural explanations is not an act of impiety, since natural causality does not provide an alternative to religion ${ }^{60}$. This raises questions about how to precisely trace these two approaches - viz. the physical and the theological - in Plutarch's own natural scientific works ${ }^{61}$. To this end, in what follows, I will focus on how

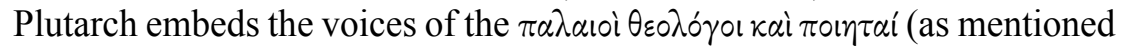
in De def. or. 436DE) in his scientific works. Afterwards, I will turn to the

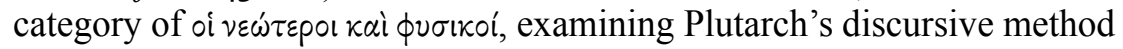
of incorporating the authority of authors of scientific prose into his natural problems [see 4.2.I.I.]. In the next two sections, I will start by analysing the categories of the $\theta \varepsilon \circ \lambda \sigma_{\gamma o l}$ and the $\pi \circ \eta \eta \tau \alpha$ successively.

\section{Science, religion and mythology}

As seen in the previous section, the demarcation line between what belongs to the realms of physics and religion is not rigid for Plutarch, but osmotic. There is, in fact, a clear preeminence of theology over physics in Plutarch's natural philosophy ${ }^{62}$, since his God is the cornerstone and culmination point of his world system ${ }^{63}$. As we will see in the section at hand, this

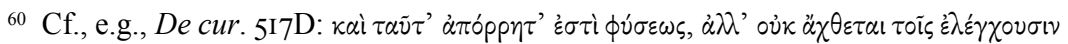
[quoted 3.2.2.]. Cf. also, e.g., De facie 923A, where Lucius' sarcasm in his reference to Cleanthes' past accusation of Aristarchus' attempt to save the phenomena as an act of

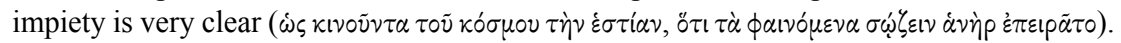
See, e.g., J. Opsomer, I998, p. I8I: "For Plutarch there is no conflict between 'rationalism' and faith." Pace E. Teixeira, 1992, p. 2 I4.

${ }^{61}$ I make this distinction - viz. myth/poetry vs. prose - mainly for practical reasons. Seeing that Plutarch makes this distinction himself (in De def. or. 436DE just quoted), it seems useful to do the same, if only for the sake of a transparent development of the analysis in what follows. This is not to claim, however, that these distinctions are entirely water-tight, let alone that for Plutarch the poets and mythographers have no authority in the field of natural science. Empedocles, for instance, belongs to both categories of $\pi \circ i \eta \tau$ i and $\phi v \sigma i k o i ́$ strictly speaking (see n. 92). Nevertheless, a fundamental difference between these categories is found in the fact that the poetical and mythographical accounts in Plutarch's natural problems not only have argumentative value in the aetiologies, but also add an extra layer to the technical-physical discourse (e.g., by providing a literary illustration of a specific argument [see I.2.3.]).

${ }^{62}$ Cf. P. Donini, I986a, p. 210: "ma la fisica non è la scienza suprema per Plutarco: c'è ovviamente un' altra e superiore dimensione della filosofia teoretica".

${ }^{63}$ See P. Donini, I986a, p. 2II (cf. also id., I994a, p. 48, n. 32, 20II, p. 96) and J. Opsomer, I998, p. 2 I4. 
theological preeminence recurs throughout Plutarch's natural scientific writings, even if it is not always strongly emphasised.

The Platonic endnote in Aqua an ignis 958E is particularly worth quoting in order to illustrate this, if only because it is often neglected (presumably for reasons of the work's controversial authorship [see I.I.I., n. 8]). The passage deals with the function of water and fire in sensory perception and argues for the pre-emincence of sight over the other senses $^{64}$ :

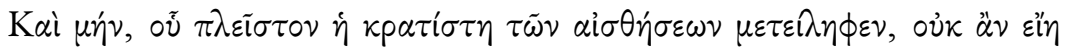

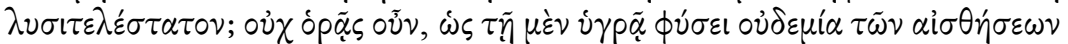

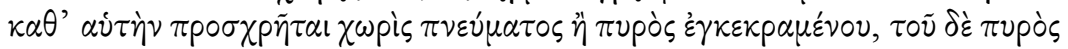

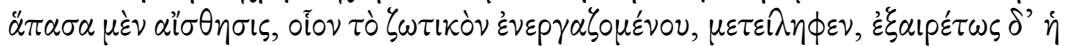

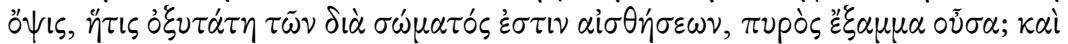

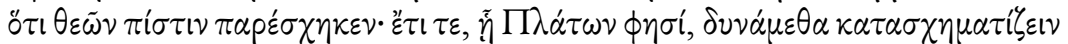

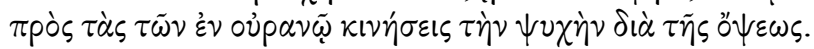

And, to be sure, will not that (sc. substance, i.e. either water or fire) be the most advantageous of which each of the senses has the greatest proportion? Do you not perceive, then, that there is no one of the senses which uses moisture by itself without an admixture of air or fire; and that every sense partakes of fire inasmuch as it supplies the vital energy; and especially that sight, the keenest of the physical senses, is an ignited mass of fire and is that which has made us believe in the gods? And further, through sight, as Plato says (Tim. 47ab), we are able to conform our souls to the movements of the celestial bodies.

In this passage, Plutarch portrays human beings as spectators of a divinely governed universe ${ }^{65}$. According to Plato, quoted here (Tim. 47ab), the divine gift of sight has led us to inquire into astronomical phenomena, which in turn has empowered us to acquire philosophical knowledge, an idea that lies at the very basis of Platonic epoptics. From a parallel account in De sera num. 550DE, we learn that the contemplation of the heavenly motions and cosmic ordering is a useful means of doing away

${ }^{64}$ On the pre-eminence of sight over the other senses, cf. also, e.g., Quaest. conv. 654D, Pl., Phdr. 250d, Arist., Met. 980a26-27, Cic., De or. 2, 86-87, SVF 2, pp. 232-233, frs. 863 and 866 .

${ }^{65}$ Cf., e.g., Quaest. conv. 7I8D (in the context of geometry enabling us to see the

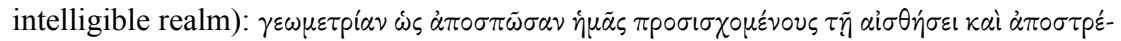

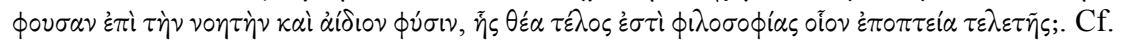
E.L. Minar, F.H. Sandach and W.C. Helmbold, I96I, p. I20: "the philosopher passes, with the help of geometry, from study of physical objects to the vision of the ideas." 
with errant passions and allows us to assimilate our soul to God's beauty and goodness. What we should try to attain, then, from contemplating the ordered universe is 'likeness to God' ( $\delta \mu o i \omega \sigma ı s \theta \varepsilon \tilde{\omega}$, cf. De Is. et Os. 35ICD). This is the eventual $\tau \varepsilon \lambda_{0} \circ$ for Plutarch as a middle-Platonic philosopher ${ }^{66}$. And it is probably to this idea that Plutarch is alluding in the above passage when he writes that sight enabled us to believe in the gods $(\theta \varepsilon \tilde{\omega} \nu \pi i \sigma \tau \imath \nu$ $\pi \alpha \rho \varepsilon ́ \sigma \chi \eta \kappa \varepsilon v)$.

The idea of a divine ordering of the cosmos, as perceived in the cosmic balance of opposite forces at work in nature, is most clearly formulated in De prim. frig. $946 \mathrm{EF}$, where Plutarch explains why God is called a cosmic harmoniser and musician:

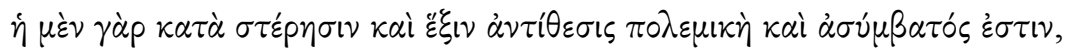

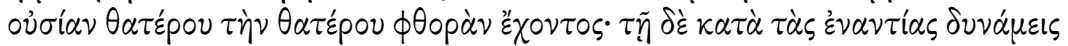

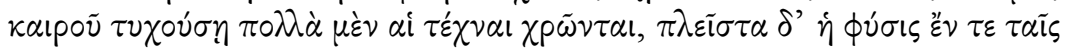

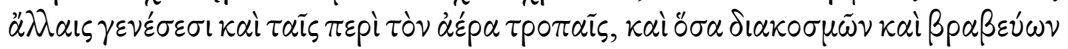

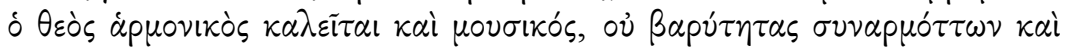

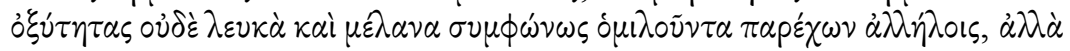

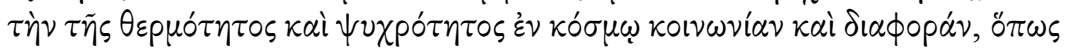

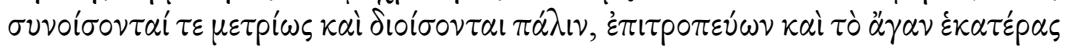

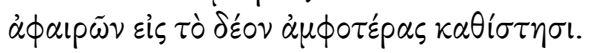

For the opposition of a negation to a positive quality is an irreconcilable hostility, since the existence of the one is the annihilation of the other. The other opposition, however, of positive forces, if it occurs in due measure, is often operative in the arts, and very often indeed in various phenomena of nature, especially in connexion with the weather and the seasons and those matters from which the God derives his title of harmoniser and musician, because he organises and regulates them. He does not receive these names merely for bringing sounds of high and low pitch, or black and white colours, into harmonious fellowship, but because he has authority over the association and disunion of heat

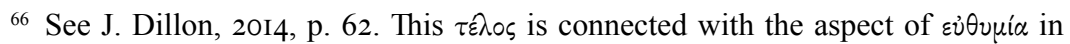
De tranq. an. $477 \mathrm{CD}$, where the sense of sight is again very central, viz. in the word $\theta \varepsilon \alpha \tau \dot{n} s$ (passage discussed earlier on [see 3.2.2.]). P. Donini, I988, p. I32 argues that everything in Plutarch's world "is at the god's service and designed for his worship" (cf. also M. Battegazzore, I992, p. 25). However, as J. Opsomer has objected (in personal correspondence), it seems useful to make an Aristotelian distinction here between two forms of teleology, viz. between that which is strived after, and the instance to whose

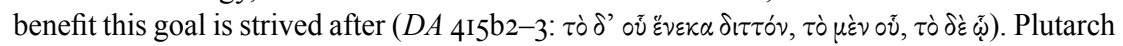
emphasises that providence is executed in the interest of human beings and the world. Cf. J. Opsomer, 20I4, p. 9I: "the gods exercise providence for our benefit (and not just to our benefit)". 
and cold in the universe, to see that they observe due measure in their combination and separation, and because, by eliminating the excess of either, he brings both into proper order.

The idea that there is a divine agent and ruler who procures cosmic order is made somewhat in passing here. Yet, its mere presence clearly indicates that De primo frigido, in dealing with a specific natural problem (viz. 'Which, if any, is the active principle or substance of cold?': cf. 945F), not only relies on physical causality but is ultimately based on theological principles ${ }^{67}$.

The idea that natural phenomena have a divine motivation to which their physical causality is ultimately subordinated is not very emphatically argued for in Plutarch's natural problems collected in Quaestiones naturales and Quaestiones convivales. According to Van der Stockt, there are in fact no divine causes in Quaestiones naturales: "This is strange because physics should end in philosophia prima, supreme philosophy"68. In several discussions in Quaestiones convivales, by contrast, we saw earlier on that there are several allusions to the divine aspect of natural phenomena (such as the generative properties of salt or lightning in Quaest. conv. $665 \mathrm{~A}, 684 \mathrm{E}-685 \mathrm{~F})$. One may presume that the sympotic decorum would probably not allow more overt philosophical ruminations, which explains why these divine aspects are only seldom elaborated upon (cf. Quaest. conv. 6I4A [quoted 3.I.4.]).

An important passage where Plutarch alludes to the higher causal motivation of natural phenomena is found in Quaest. conv. 699B (concerning Plato's contested view that drink passes through the lungs). Here, Plutarch says that 'the ingenious organisation of nature's activities is beyond the range of words, and it is impossible to explain adequately the exact work-

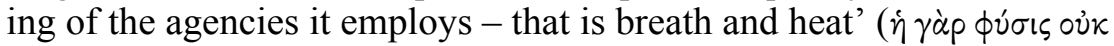

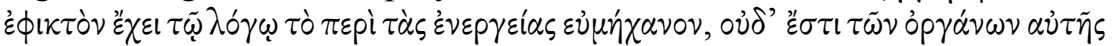

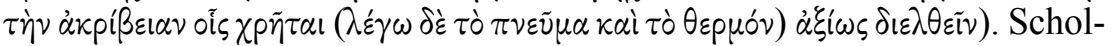
ars have taken this to imply that the exact way in which nature actually works cannot be captured in physical terms or by the use of any human discourse, considering the divine powers at work in it ${ }^{69}$. There seems to be a concrete Platonic background to this idea in Tim. 28c, where Plato writes that it is not as such impossible ( $\dot{\alpha} \delta \dot{v} v \tau \tau \circ v)$ to personally discover

${ }^{67}$ Similar references to a divinely governed cosmology can be found, e.g., in $D e$ def. or. 430E-43IA and Aqua an ignis 957B. For further study, see P. Donini, I986a, pp. 207-208.

${ }^{68}$ L. Van der Stockt, 20II, pp. 453-454. For the general absence of higher causes also in the natural problems treated in Quaestiones convivales, cf. P. Donini, 20II, p. 96, n. 203.

69 As P. Donini, I986a, pp. 208-209 argues, "sono infatti implicite le operazioni della demiurgia che non sono però completamente esplicabili dal discorso umano". 


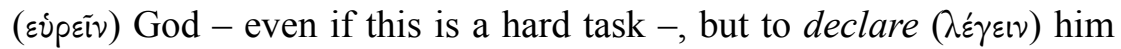
unto all men $^{70}$. Plutarch knows very well that divine, intelligible truth is, indeed, extremely hard, if not altogether impossible, to reach, considering the epistemological weakness and limits of our human understanding ${ }^{71}$. To capture his essence in words is simply impossible.

As the natural problems discussed in Quaestiones convivales, thus, show, a deeper philosophical-theological style of discourse is not absent in them, although it is only seldom foregrounded. It remains to be seen, then, whether similar implicit allusions to the category of the divine are also present in Quaestiones naturales despite the work's main attention for natural explanations [see I.I.6.]. Indeed, in line with Ps.-Aristotle's Problems, Plutarch's Quaestiones naturales is primarily concerned with material-mechanical causes. But even so, I believe that there still are some hints in the work towards a higher type of causality ${ }^{72}$. I will try to corroborate this view by examining the passages, I) where Plutarch hints at a providential ordering of nature, and 2) where he incorporates mythological material in his physical discourse.

I) First of all, there are a couple of instances in Quaestiones naturales where nature's providential ordering is central to the physical aetiologies. This is the case most notably for two passages, where Plutarch relies on meteorological lore. In Q.N. 2, 912CD, Plutarch argues that when frogs

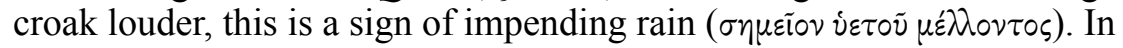
Q.N. I8, 9I6AB, he explains that when the calamary leaps out of the sea or when the octopus hurries back to the shore and grasps small rocks, this

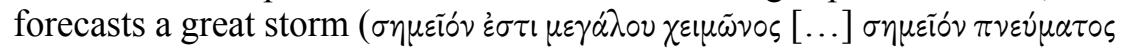

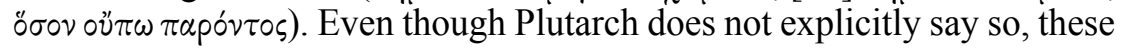
meteorological signs imply that there is a providential ordering in nature which makes weather predictions possible. Indeed, elsewhere, Plutarch openly refers to the divine inspiration and the mantic powers of animals ${ }^{73}$ (as well as of other things in nature), by which the gods transmit a message

70 The same Platonic idea is formulated at several places in Plutarch's oeuvre. Cf.,

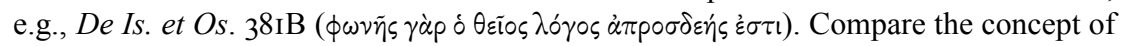
$\dot{\alpha} \pi \dot{\rho} p p \eta \tau \alpha$ (natural science as some kind of a 'mystery cult') in De cur. $5 \mathrm{I} 7 \mathrm{D}$ [quoted 3.2.2.].

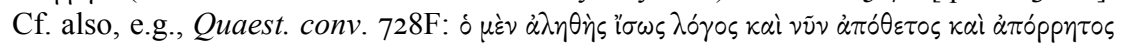

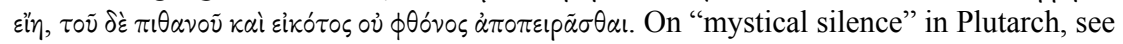
P. Van Nuffelen, 2007.

${ }^{71}$ Cf. also De aud. poet. I7DF. At times, Plutarch says that the human intellect cannot attain the divine truth (cf. De Is. et Os. 35IC) but only a share of it (cf. Ad princ. iner. 78IA).

72 Notably, in Ps.-Aristotle's Problems there is an "occasional interest in teleological explanation", but this is very exceptional and not of the order of Plutarch's divine causes (see R. Mayhew, 20IIa, p. xxiii, who notes only two cases). See also B.J. Stoyles, 2015.

${ }^{73}$ Cf., e.g., De soll. an. 975AC, 976C, De Is. et Os. 382AB, Sept. sap. conv. I63EF [see I.2.4.]. 
to the world ${ }^{74}$. Moreover, the account about frogs is illustrated at the end of Q.N. 2 with a quotation from Aratus, the poet of meteorological signs. As to Plutarch's interest in Aratus' Phaenomena, the conclusion of Negri is very significant:

"[I]l Plutarco fedele sacerdote dell'Apollo delfico, cioè del dio che per eccellenza comunica con gli uomini attraverso 'segni', dovette sentirsi particolarmente in sintonia con il poeta dei 'segni' benevolmente offerti

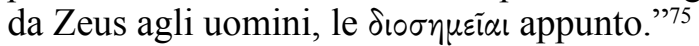

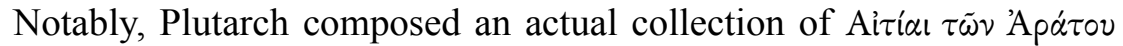
$\Delta\llcorner 0 \sigma \eta \mu i \omega \nu$ of which some fragments remain (frs. I3-20 Sandbach; Lamprias catalogue nr. II9). Plutarch's aetiological-exegetical approach of Aratus' verses in this work - and also at the end of Q.N. 2 - seems to indicate that these verses require further physical explanation in order to reveal their full causal extent, Aratus adducing only the higher cause (c.q. divine providence).

2) Even if Plutarch's primary concern in Quaestiones naturales is with the physical causes of natural phenomena, the Olympic pantheon is not dispelled from the physical scene. There are seven references to mythological figures and gods in our collection (see the scheme below). The mention of their names may appear to be somewhat casual in some cases (Q.N. 2, 9I2A, I0, 9I4D, 2I, 9I7 B), while in other cases, we find a short allusion to a more extended myth $(Q . N .24,918 \mathrm{~A}, 36)$ or a short paraphrase of it $(Q . N .23,917 \mathrm{~F}, 38)$. As Hardie has argued in regards to the mythographical material Plutarch incorporates in Quaestiones convivales, "[t]he interpretation of myth is often handled as an exercise in solving

${ }^{74}$ Similarly, the two mythological accounts recorded at the very end of the aetiology in Q.N. 36 open up onto the broader context of divine punishment (c.q. by means of bee-stings). The first one is recorded by Theocritus and concerns the infidelity of Anchises and Aphrodite, the second by Pindar concerning Rhoecus' unfaithfulness (or insult?) to a nymph. Cf. $\mathrm{n} .85$ below. See also M. Meeusen, 2013c.

${ }^{75}$ M. Negri, 2004, p. 288. Plutarch quotes Aratus only here in Q.N. 2, 912D (Arat.,

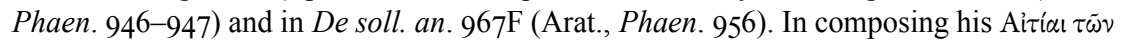

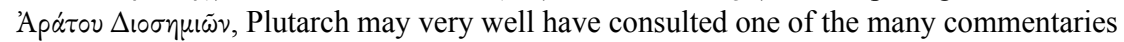
that existed on Aratus' work (cf. W.C. Helmbold, 1957, pp. 370-37I, n. c and F.H. Sandbach, I969, p. 89; for the overlap between his aetiological and exegetical approach, see [2.4.2., n. I49]). It is worth mentioning, in this regard, that the Stoics Boethus of Sidon and

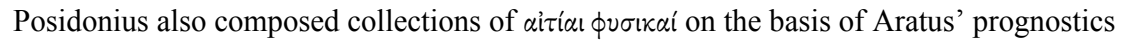

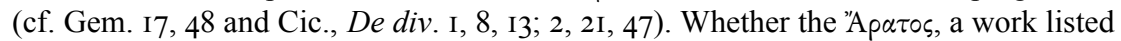

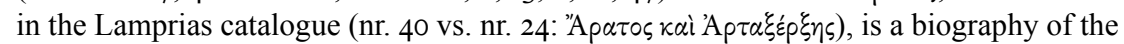
Greek didactic poet or of the Greek statesman is unclear, but the second seems more likely (pace K. Ziegler, I95I, col. 698). 
problems." ${ }^{76}$ Myths often directly contribute to the arguments at hand and, as such, demonstrate the symposiast's argumentative ingenuity in activating his scholarly $\pi \circ \lambda \nu \mu \alpha \dot{\theta} \varepsilon \varepsilon \alpha$ in an original way. However, as I will try to show, there may be more to these mythological accounts, in that they may hint at a higher level of causality.

Clearly, such mythographical accounts in Plutarch's natural problems provide an important alternative for the purely physical discourse. If myths, indeed, hint at higher philosophical truth ${ }^{77}$, it is not unlikely that those recorded in Quaestiones naturales contribute to the physical aetiologies in a meta-physical way. In fact, rather than reducing the myths to a purely physical explanation (after the manner of the allegorical interpretations of the Stoics), they more often confirm and corroborate the main argument at hand or even serve as an explanation in their own right. This means that Plutarch does not incorporate mythological tales in his natural problems so as to reduce the gods and their actions to physical principles. It seems that the exact opposite dynamic is at work here (though he does not, therefore, shun such allegorical interpretations altogether: see below).

At several points, Plutarch seems to incorporate mythological material so as to provide some kind of a 'mystifying' extension to the physical aetiology, in much the same way as this is the case, for instance, with the closing myth in De facie $e^{78}$. In this work, the astrophysical inquiry into the substance and nature of the moon, does not as such insist on a denial of the moon's divine and spirited nature. In fact, the opposite is true, since an

${ }^{76}$ P.R. Hardie, I992, p. 475I. He notes, moreover, that "[s]ome of the physical allegorizations in the 'Qu. conv.' have the air of ad hoc improvisations, examples of

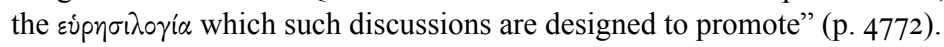

77 For Plutarch, myth is not, of course, an explicit record of the truth as such, but contains a deeper meaning. P.R. Hardie, 1992, p. 4754 notes that in many passages, Plutarch, indeed, "describes myth as a faint reflection of a transcendental truth. [...] Myths act as ladders to the truth, which may then be kicked away." See also pp. 4746-4749 for the relationship between myth and truth in Plutarch more generally. In De Iside et Osiride, for instance, Plutarch interprets the Isis myth in light of Plato's philosophy in the Timaeus (see R.M. Jones, I980, p. 25). Cf. also F. Ferrari, 1995, p. I74: "si può dire che il mito fornisce il quadro filosofico-metafisico entro il quale contestualizzare le argomentazioni 'scientifiche'". For Plutarch's ambivalent attitude towards myths in general, see L. Van der Stockt, I992a, pp. 88-97.

${ }^{78}$ The same conclusion was made for the scientific-mythological account about lunar eclipses in De genio Socr. 59IC by R. Flacelière, I95I, esp. pp. 2I3-2I4: "Il me semble que Plutarque s' est complu à entretenir dans ses mythes une atmosphère de vague, de pénombre, de mystère, par différents moyens qui vaudraient la peine d'être étudiés [...]." For the relation between "science et mystique" in the light of Plutarch's eschatology, see also Y. Vernière, I977, pp. I64-I78. In fr. I56 Sandbach, Plutarch calls myths a 'mystic

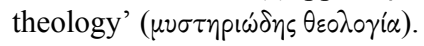


eschatological, Platonic myth is appended to the treatise about the purpose of the moon in the universe, explaining its importance for the life-cycle of human souls (De facie 940F-945D). I see no reason why Plutarch's motivation for incorporating such Platonic type of eschatological myth should essentially differ from the more traditional type - in any case, Plutarch does not make a clear conceptual distinction between the two. Clearly, the annexation of such mythological material does not remain without consequences for the eventual outlook and scope of Plutarch's natural scientific discourse ${ }^{79}$.

Notably, in Plutarch's natural problems, the mythographical accounts are never disparaged or even hinted at as being dispensible faits divers. What may perhaps arrest the reader's attention the most is the fact that these accounts tend to be located at the very end of the aetiology, which, as we saw earlier on [I.I.4., n. I04], is the most significant locus in Plutarch's aetiologies (Q.N. 23, 24, 36, 38 - at the end of Q.N. 23, Plutarch may have actually re-edited the text in order to obtain a mythological finale to the problem: see the commentary ad loc.). This can be taken to imply, then, that Plutarch incorporated these myths in order to hint at some kind of a causa finalis, in the sense of a higher, divine cause. In any case, numerous discussions in Quaestiones convivales also contain such a mythological ending ${ }^{80}$, and the same is true for De facie as we just saw. Yet, as Donini argues in regards to the closing myth of De facie, "the explanations of the myth are not literally true: they are only an example and a suggestion of how matters could otherwise stand"; therefore, they must "simply be understood as a hint of another truth, different from physical truth" "1. If Senzasono is right, then, that the myth about Kore and Pluto at the end of Q.N. 23 "non aveva

${ }^{79}$ H. Görgemanns, I968, pp. IO-II (cf. also id., I970, p. 85) rightly connects this in the case of De facie with Plutarch's human aim towards Sinngebung: "Für Plutarch ist das übergreifende Thema offenbar [...] die kosmische Theologie. Das "Wozu?" der so fremd und fern erschienenden Himmelshelft bewegt ihm, und er versucht in verschiedener Weise, wissenschaftlich und mythisch, darauf zu antworten. Er folgt damit eine menschliche Bedürfnis nach Sinngebung, das von der strengen Wissenschaft nicht befriedigt wird. [...] Mechanistisches Funktionieren wird ausgeschlossen; statt dessen wird eine sinvolle Ordnung durch einen göttlichen "Werkmeister" angenommen." Cf. also F. Ferrari, 1995, pp. I73-I75. L. Van der Stockt, 20II, pp. 454-455 adds that "[i]f that kind of science was able, to quote Görgemanns, 'to make people feel at home in the cosmos', it remains to be seen if modern science is equally successful in that respect." Plutarch's science is, indeed, incommensurable with modern science in this regard. For a study of the philosophical myth of Thespesius in De sera num. 563B-568A, see F. Frazier, 2010.

${ }^{80}$ See Quaest. conv. 657 E, 67IBC, 679DE, 685EF, 7I4C, 7I6BC, $718 \mathrm{AB}, 720 \mathrm{C}, 739 \mathrm{D}$, $743 \mathrm{BC}, 747 \mathrm{~A}$. On the telling of tales as an essential passtime at the symposium, see M.V. Ruffy, 20II, pp. I40-I42.

${ }^{81}$ P. Donini, I988, pp. I38-I39. On the relation between myth and reason ( $\mu \tilde{v} \theta_{\circ} \varsigma_{-}$

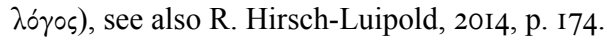


per Plutarco lo stesso peso delle osservazioni naturalistiche" $" 82$, it should be added that Plutarch does not explicitly prefer one mode of explanation to the other. This can be explained, then, by the fact that for him there is no rigid border between the natural and higher causes.

Hardie has also paid attention to the structural use of myth in Plutarch's writings: he notes that "Plutarch uses myth to highlight the structure of an essay or dialogue, especially at the beginning and the end"83. It remains to be seen, however, whether such mythological material is, as Hardie believes, "used essentially as ornament" ${ }^{4}$. If my hypothesis is correct, it is not unlikely that Plutarch incorporates mythological material into his physical aetiologies in order to hint, in a very concealed way, at the higher level of causality behind natural phenomena. After all, for Plutarch, the world we live in is the work of a divine cosmic ruler who organises nature in a providential way, so that natural causes do not exclude a higher, divine principle. In this sense, Zeus, is responsible for fixing the period during which she-wolves litter (Q.N. 38). The cosmic ruler also cares about a proper punishment for improper behaviour as can be implied by the myths recorded in Q.N. 36 (he punishes adulterers - and even the lower gods for their stuprum by means of bee-stings) ${ }^{85}$. There are also divine precincts in nature (Q.N. 23, 917F: 2ँ $\sigma 0 \lambda \circ v$, 'sanctuary'), where nature behaves in a somewhat unnatural (read: super-natural) fashion, since once upon a time, some mythological event took place there (Q.N. 23, 917F: Pluto's abduction of Kore near Mt. Etna). Additionally, Plutarch mentions several gods in a more allegorical fashion in relation to the physical attributes over which they preside, that is, over which they are kúplos $\varsigma^{86}$ viz. Zeus and heaven (Q.N. 2, 9I2A and 24, 9I8A), Dionysus and wine (Q.N. IO, 9I4D) and Cypris and love (Q.N. 2I, 9I7B).

As previously noted, Plutarch exercises considerable restraint in endorsing allegorical interpretations of myths, probably because this reduces the gods to natural phenomena and material categories, an interpretative strategy that was common to the Stoics due to their monistic view of the world [see 4.I.I.3.]. This interpretive strategy is not, however, entirely absent from Plutarch's writings, and is also seen at work in Quaestiones naturales ${ }^{87}$. In Q.N. 24, 9I8A, he quotes Alcman's line where

${ }^{82}$ L. Senzasono, 2006, p. 215, n. 135.

${ }^{83}$ P.R. Hardie, I992, p. 4783.

${ }^{84}$ Ibid.

${ }^{85}$ For fabulous stories about (late) divine punishment, cf. De sera num. $556 \mathrm{~F}-557 \mathrm{~F}$.

${ }^{86}$ Cf. P.R. Hardie, I992, p. 4768.

${ }^{87}$ For the Stoic practice of allegorising myths and its influence on Plutarch, see D. Babut, I969, pp. 367-440 and J. Opsomer, 20I4, p. 92. For physical allegory in Plutarch's mythological accounts, see W. Bernard, I990, pp. 2I8-222 (and pp. I83-275 more generally) and P.R. Hardie, I992, pp. 4766-4772. Notably, Plutarch reports (in fr. I57 Sandbach) that 
Dew (Ersa) is allegorically called the daughter of Zeus (air) and Moon (Selene). In general, however, Plutarch's physical aetiologies are not concerned with rationalising the myth in such an allegorical way, where the mythological packaging and imaginative content is done away with once the myth's metaphorical value has been brought to light by a physical interpretation ${ }^{88}$. In many cases, it seems that Plutarch actually tries to save these traditional myths in the form in which they are recorded ${ }^{89}$, much in the same way as he does with many other popular beliefs about the natural world, as we saw [4.I.I.].

The following table shows where the mythological material is located in Quaestiones naturales and in which cases we can speak of a causa finalis $(C F)$, in the meaning attributed to it above. In the remaining cases where there is no causa finalis, we are dealing with more casual references to deities in connection with the physical attribute over which they reside (i.e. over which they are kúplos).

\begin{tabular}{llll}
\hline No. & Q.N. & Mythological god/figure & $\boldsymbol{C F}$ \\
\hline I & $2,912 \mathrm{~A}$ & Zeus & \\
$\mathbf{2}$ & I0, 9I4D & Dionysus & \\
$\mathbf{3}$ & $21,917 \mathrm{~B}$ & Cypris & \\
$\mathbf{4}$ & $23,917 \mathrm{~F}$ & Kore, Pluto & $\mathrm{X}$ \\
$\mathbf{5}$ & $24,918 \mathrm{~A}$ & Zeus, Ersa, Selene & $\mathrm{X}$ \\
$\mathbf{6}$ & 36 & Anchises, Aphrodite, Rhoecus & $\mathrm{X}$ \\
$\mathbf{7}$ & 38 & Leto, Hera, Zeus & $\mathrm{X}$ \\
\hline
\end{tabular}

\footnotetext{
'ancient physics among both Greeks and barbarians took the form of a scientific account

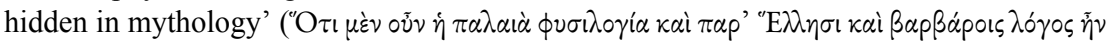

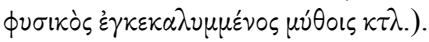

${ }^{88}$ Elsewehere, Plutarch sometimes does vindicate such a process of Entmythologizierung, though, by removing the fictitious parts of myths. Cf., e.g., Thes. I, 3. See L. Van der Stockt, I992a, pp. I40-I4I and C. Pelling, 2002, pp. I7I-I95.

${ }^{89}$ For a general study of how ancient philosophers (including Plutarch) 'saved' myths, see L. Brisson, 2004. The notion of 'saving' myths can be seen, for instance, in the digression on naphtha in Alex. 35, I0-I2, where Plutarch refers to the tragic story of Medea and says that 'some people reasonably wish to bring fables into conformity with truth'

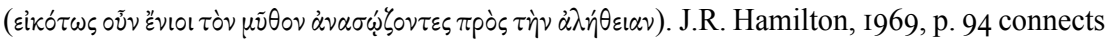
this with the Stoic allegorical interpretation of myths and argues that "Plutarch doubtless came across the reference to Medea in one of the many Stoic works he read". According to J. Boulogne, 2008, p. 737, however, in this digression, Plutarch reuses pieces of "un dossier constitué autour de l' autorité de Théophraste" [see 2.I.3., n. 36]. Both theories do not necessarily exclude one another, if we may assume that both traditions were already combined, or that Plutarch did this himself.
} 
I conclude that Plutarch's incorporation of mythological elements in his scientific discourse forms an inherent, if not essential, aspect of it. If my hypothesis is correct, these elements not only illustrate Plutarch's scholarly approach in explaining natural problems but are also fundamentally in line with his dualistic view on causality, in that they may indicate that there are divine forces at work in nature. As such, they hint at an intrinsic consistency in Plutarch's general scientific project and its underlying world view. Arguably, these mythographical elements articulate what remains 'beyond words' in a purely physical discourse (by which I allude to Quaest. conv. 699B, quoted above). Indeed, they somehow enliven the mainly physical approach of the natural problems and thus also their sub-literary style [see I.2.3.]. Notably, the mythographical accounts in Q.N. 24, 9I8A and 36 are in verse, which sharpens the contrast with the purely physical discourse even more. It will be useful to further consider the relationship between physics and poetry in Plutarch's natural scientific discourses in the following section, by taking a closer look at Plutarch's incorporation of poetic material in Quaestiones naturales.

\section{Science and poetry}

Apart from relying on the $\theta \varepsilon \circ \lambda o^{\prime}$ or and their myths, Plutarch also recurrently calls on the authority of the $\pi \circ \eta \tau \alpha i$ in explaining natural problems. The relatively high number of poetical quotations in Quaestiones naturales -22 in total - makes it clear that the poets play a significant role in Plutarch's scientific discourse. As the scheme below will show, several poets are cited by name (apart from two anonymous metrical proverbs). Empedocles is the most frequently quoted authority in the entire collection (seven times) and is closely followed by Homer (five times) ${ }^{90}$. Pindar and Euripides are each quoted twice, and Alcman, Aratus, Theocritus and Theognis once.

A first important observation is that the link between physics and poetry

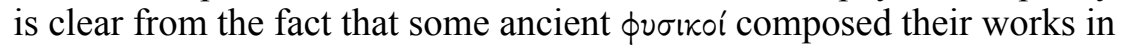
verse (see n. 6I) ) $^{91}$. This is the case with Empedocles (whom Plutarch calls

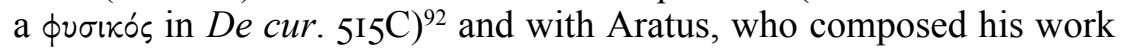

${ }^{90}$ In De facie, Homer and Empedocles are also the most frequently cited poets (see P. Raingeard, 1935, p. xxviii).

${ }_{91}$ For a more general account of ancient natural science treated in verse, see L. Taub, 2008 and 2009.

${ }_{92}$ In Quaest. conv. 683E, Plutarch writes that Empedocles (described as a бoфós) did

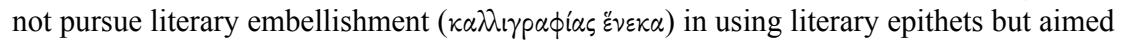
at a referential description of essential facts or properties [quoted I.2.2.]. For Plutarch's evaluation of Empedocles' verses, see also De aud. poet. I6C. Notably, Hippol., Haer. 5, 20, 5 mentions Plutarch as a composer of ten Books of 'E $\mu \pi \varepsilon \delta \circ \kappa \lambda \varepsilon \dot{\varepsilon}$ (= fr. 24 Sandbach), which is nr. 43 in the Lamprias catalogue (Plutarch's authorship remains uncertain for this 
on astronomical and meteorological matters in verse ${ }^{93}$. But Alcman also wrote cosmogonic poetry, and the Poet (Homer) is even considered 'a sensitive observer' of natural phenomena in Quaest. conv. 627E (i $\pi \varepsilon p \phi v \tilde{\omega} s$

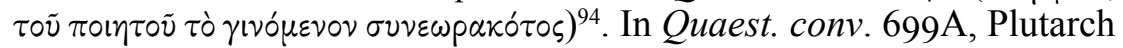
also says of Euripides that he 'has keener eyes' than Erasistratus, the

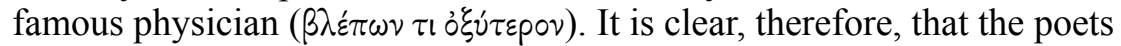
have a great deal of authority in the field of natural science, or that Plutarch at least ascribes it to them. In this respect, it is important to note that in Plutarch's scientific writings, we cannot make a clear distinction between the quotations from the didactic and the mimetic poets, since they are all treated in the same way by him. It seems unlikely, then, that this distinction really mattered to Plutarch himself, who indiscriminately interprets the poets in a physicalist fashion, thus often ingeniously stripping their verses from their original contexts (I will come back to this point later).

Another seminal issue, which has already been highlighted earlier on [see I.2.3.], is that the poetical accounts clearly enliven the referential style of the purely physical discourse, but that this is not necessarily their primary objective. Plutarch mostly incorporates this poetical material in order to contribute to the main arguments themselves or to illustrate them in the sub-arguments, meaning that they do not fulfil a simply aesthetic function in the text. Therefore, Barrow's "rough and ready rule" according to which citations in Plutarch's Moralia are only recorded for the purpose of superfluous illustration - in the sense that they do not contribute to the main arguments themselves - does not seem to be apposite ${ }^{95}$.

When it comes to Plutarch's heuristical method, it remains uncertain as to whether he extracted the poetical material directly from the works of the poets or relied on intermediary sources (e.g., commentaries or florilegia). Some of the quotations may suggest first-hand extraction, as is the case with the one from Aratus in Q.N. 2, 9I2D, but Plutarch may just as well rely on an intermediary source here (e.g., a commentary: see n. 75). It goes without saying, moreover, that Plutarch must have been

lost work, though: see F.H. Sandbach, I969, p. I03). The discussion of the poetical value of Empedocles' verses is also found in Aristotle (cf. Poet. I447bi8 and fr. 70 Rose).

${ }_{93}$ On Plutarch's acquaintance with Aratus' oeuvre, see n. 75.

${ }^{94}$ Cf. also, e.g., Quaest. conv. 698EF, 684F. Plutarch composed a set of 'Ounpixai $\mu \varepsilon \lambda \varepsilon \tau \alpha i_{1}$ in four Books (Lamprias catalogue nr. 42), of which six fragments remain (frs. I22-I27 Sandbach). We learn from fr. I27 Sandbach that physical aetiology was an inherent aspect of Plutarch's Homer exegesis [see 2.4.2., n. I49]. A genuine Homeric question is found in Q.N. 34, which concerns Il. I9, 4I5-4I6 (on the swiftness of the west wind). On physical allegory and scientific explanations in Heraclitus' Quaestiones Homericae, see D.A. Russell and D. Konstan, 2005, pp. xxi-xxii [see I.I.3., n. 50].

95 R.H. Barrow, 1967, p. 156. The same conclusion was reached for Quaestiones Romanae by L. Van der Stockt, 1987, p. 29I. On Plutarch's general method of citing poets, see C. Bréchet, 2007. 
well acquainted with Homer's works, but even so, this does not guarantee that he went directly to the source text (Homer is quoted via Aristotle in $Q . N .2 \mathrm{I}, 9 \mathrm{I} 7 \mathrm{D})$. In addition, there may be reason to assume that the quotation from Alcman in Q.N. 24, 9I8A originates from a Stoic tradition, considering the allegorical context in which it is situated. It would not be an easy undertaking, if not an impossible one, to make an attempt towards generalisation here. But what is perhaps more important is the fact that Plutarch's interpretive strategy implies that the accounts of the poets disregarding whether the poets themselves were aware of it or not - are in conformity with the natural problem at hand, or are at least bent to fit in the new context. As a rule, Plutarch simply extracts the poetical material from its original context and adapts it to the new one (some of these contexts were originally physical, others not). In this way, it often receives the necessary syntactic adaptations, and more importantly, a new semantic appropriation [see 4.2.I.I.].

Plutarch does not always simply accept what he reads, though. He knows very well, after all, that the poets tell many lies, sometimes even intentionally, for the purpose of giving 'pleasure and gratification to the

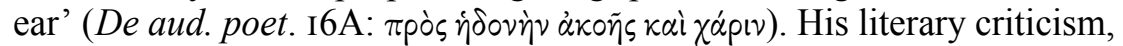
which becomes explicit (only) in Q.N. I9, 9I6BC, involves the idea that while the poets (c.q. Pindar and Theognis) certainly do have authority in the field of natural science, they do not always have good insight into the mechanism that lies behind the natural phenomena they mention (which makes them an easy target of derision $)^{96}$. As the accounts of Pindar and Theognis in Q.N. I9, 9I6BC show, the octopus has the ability to adapt and assimilate its colour to its surroundings, much like certain people do by imitating their neighbours. Plutarch, however, ridicules the poets and asks whether 'they believe that the octopus treats its colour like a garment

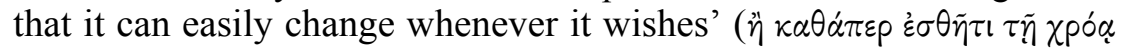

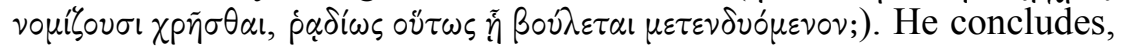
to the contrary, that the octopus' change in colour is not the effect of a deliberate choice but of underlying physical causes [see I.2.4.].

The scheme below sets out all the poetical quotations from Quaestiones naturales with special attention to their place and ranking in the aetiologies. No steadfast rules can be detected in this ranking, though, which seems to suggest that Plutarch is simply quoting the poets whenever he finds the proper occasion for it. Homer, for instance, is quoted once in the quaestio, twice in the first causa and again twice in the final causa of several problems. As to the poetical quotes that are recorded in the final causa, it is not unlikely that they, at least in some cases - viz. where they

96 There is some disdain towards the poets (c.q. Alcaeus) also, e.g., in Quaest. conv.

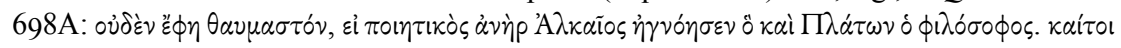

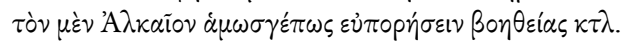


actually conclude the causa -, allude to a higher level of causality. This is the case most clearly in Q.N. 2, 912D, with the quote from Aratus, and in Q.N. 36, with the mythological accounts of Theocritus and Pindar [see 4.I.2.2.]. This remains hypothetical, of course, but it is not, in any case, unlikely, since, for Plutarch, "poetry is the bridesmade of philosophy", as Gianakaris puts it, insofar that it is often considered to shroud an essential part of the intelligible truth ${ }^{97}$.

\begin{tabular}{|c|c|c|c|}
\hline No. & Q.N. & Poetical source & Rank \\
\hline 1 & $2,912 \mathrm{C}$ & Emp., DK31B81 & c. 4( \\
\hline 2 & $2,912 \mathrm{D}$ & Arat., Phaen. 946-947 & c. $5 \odot \dagger$ \\
\hline 3 & $5,913 \mathrm{D}$ & Hom., Od. 5, 322-323 & c. $4^{\circ} \dagger$ \\
\hline 4 & $16,915 \mathrm{E}$ & Proverb & \\
\hline 5 & $19,916 \mathrm{~B}$ & Hom., Il. 13, 279 & c. 1 C \\
\hline 6 & $19,916 \mathrm{BC}$ & Pind., 43 Snell & c. 2 \\
\hline $\begin{array}{l}7 \\
8\end{array}$ & $19916 \mathrm{CD}$ & $\begin{array}{l}\text { Theog., 215-216 West } \\
\text { Emn DK } 31 \text { B89 }\end{array}$ & c. 2 \\
\hline $\begin{array}{l}8 \\
9\end{array}$ & $\begin{array}{l}19,916 \mathrm{CD} \\
20,917 \mathrm{~A}\end{array}$ & $\begin{array}{l}\text { Emp., DK31B89 } \\
\text { Hom., Od. 19, } 446\end{array}$ & $\begin{array}{l}\text { c. } 3 \\
\text { c. } 1\end{array}$ \\
\hline 10 & $20,917 \mathrm{~A}$ & $\begin{array}{l}\text { Emp., DK31A78 } \\
\text { Emom }\end{array}$ & c. 2 \\
\hline 11 & $21,917 \mathrm{~B}$ & Proverb & $q$. (C) \\
\hline 12 & $21,917 \mathrm{~B}$ & Eur., TGF 895 & c. $1^{\circ}$ \\
\hline 13 & $21,917 \mathrm{C}$ & Emp., DK31B64 & c. $3^{\circ}$ \\
\hline 14 & $21,917 \mathrm{D}$ & Hom., Il. 9, 539 & c. $4^{\circ} \dagger$ \\
\hline 15 & $23,917 \mathrm{E}$ & Emp., DK31B101 & c. $1^{\circ}$ \\
\hline 16 & $24,918 \mathrm{~A}$ & Alcm., 43 Diehl & c. $1^{\circ} \dagger ?$ \\
\hline 17 & $29,919 \mathrm{~B}$ & Eur., TGF 941 & c. 1 \\
\hline
\end{tabular}

${ }^{97}$ C.J. Gianakaris, I970, p. I28. Plutarch's attitude towards poetry is ambivalent. As a

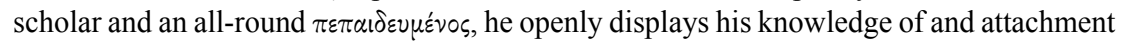
to the poets, arguing for the didactic function of their verses. But as a Platonist, he takes a more polemical position (see L. Van der Stockt, I992a, p. 85, see also pp. 88-97 for the relation between myth and poetry). This explains why Plutarch writes in De aud. poet. ${ }_{17} \mathrm{DE}$ that 'the art of poetry is not greatly concerned with the truth' ( $\pi \circ \eta \eta \tau \kappa \tilde{\eta} \mu \dot{\varepsilon} \nu$ ov $\pi \dot{\alpha} v v$ $\mu \dot{\varepsilon} \lambda$ ov $\dot{\varepsilon} \sigma \tau i \tau \tilde{\eta} \varsigma \dot{\alpha} \lambda \eta \theta \varepsilon i \alpha \varsigma)$. In De aud. poet. I6C, he says that Socrates - the philosopher par excellence - was 'the champion of truth all his life rather than a plausible or naturally

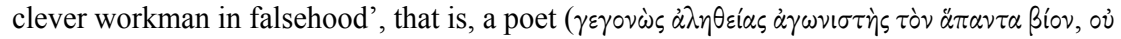

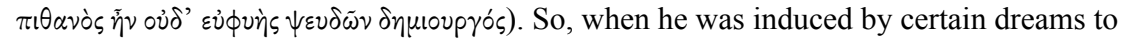
take up poetry, he only put Aesop's fables into verse instead of writing poetry of his own,

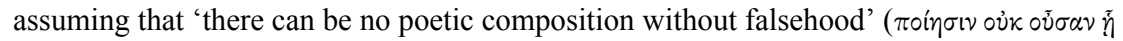

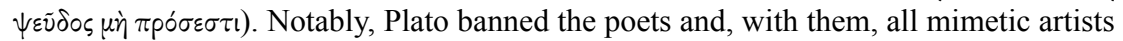
from his ideal state (Rep. 603ab), but morally uplifting art was still very welcome (Rep. 40Icd, 607be). See A.G. Nikolaidis, 20I3, pp. I70 and I76-I78. 


\begin{tabular}{llll}
\hline No. & Q.N. & Poetical source & Rank \\
\hline $\mathbf{1 8}$ & $31,919 \mathrm{CD}$ & Emp., DK31B81 & c. $2^{\circ}$ \\
$\mathbf{1 9}$ & 34 & Hom., Il. 19,415 & q. $\odot$ \\
$\mathbf{2 0}$ & 36 & Theocr. 1, 105-107 & c. $1 \odot \dagger$ \\
$\mathbf{2 1}$ & 39 & Pind., 252 Snell & c. $1 \odot$ \\
$\mathbf{2 2}$ & Emp., DK31B94 & . \\
\hline
\end{tabular}

Key for rank: $c .=$ causa; $q .=$ quaestio ${ }^{\circ}=$ part of the argument; $\mathbb{C}=$ concludes $c . / q . ; \dagger=$ final $c$.

\subsection{Constructing scientific authority: between continuity, ingenuity and innovation}

As seen in the previous section, Plutarch's approach to natural problems is for the most part of a scholarly and literate kind. The Chaeronean mostly extracts scientific knowledge from books: folklore, mythology and poetry proclaim aspects of the 'truth', and it is precisely therein that their authority lies ${ }^{98}$. In order to gain further insight into the intellectual traditions to which Quaestiones naturales adheres, the section at hand will offer an analysis of Plutarch's scientific prose sources. Specific attention will also be directed toward Plutarch's method of composing and solving natural problems on the basis of his source material [4.2.I.]. Afterwards, I will try to balance this analysis by studying the underlying dynamics of argumentative creativity and ingenuity in Plutarch's physical aetiologies, showing that Quaestiones naturales is no mere accumulation of purely doxographical material [4.2.2.]. By taking these issues into consideration, the section at hand can be seen as a companion to the previous one on the popular, mythological and poetical traditions on which Plutarch relies, since each of these traditions were dealt a great deal of authority in the field of natural science by him (see n. 6I).

${ }^{98}$ Cf. the observation of A. Gudeman, I927, col. 2523 that we are dealing in collections of problems more generally "mit am Schreibtisch entstandenen Werken". However, the oral context of the discussion of problems should not be neglected. Considering the educational background of Quaestiones naturales, we should remain cautious in assuming Plutarch's direct acquaintance with the sources he apparently relies on, because in many cases, we may just as well be dealing with the (argumentative core of the) explanations that his fellow interlocutors gave to the problems at hand, and which Plutarch then incorporated into his own text [see 3.I.4.]. 


\subsection{Character and use of the scientific tradition}

In what follows, I will provide an analysis of Plutarch's scientific prose sources $^{99}$. To this end, I will mainly focus on the explicit, that is, the nominatim quotations from prose authors. Arguably, an analysis of these quotations is representative of Plutarch's more general knowledge and use of the scientific tradition, as well as of his appreciation of the authorities on which he relies. Therefore, it will provide a great deal of useful information for a subsequent study of Plutarch's method of composition in his natural problems on the basis of his source material. This is not, however, the place for an all-embracing analysis of Plutarch's incorporation of traditional material in Quaestiones naturales, that is, an analysis that would also include Plutarch's countless allusions and implicit references to the scientific literature more generally (occasion for this will be provided in the commentary). Nevertheless, I will start by stressing more general aspects of Plutarch's reliance on the ancient scientific tradition, shedding a few ideas on this topic also.

\section{Quotations from scientific prose authors}

First of all, as just noted, many of Plutarch's references and allusions to the scientific literature remain vague and implicit. As seen before, Plutarch probably alludes to the Ps.-Aristotelian Problems a number of times without mentioning Aristotle's name [see I.I.3., n. 83]. For instance, several of the accounts on animal diseases in Q.N. 26, 9I8BC can be retraced to Aristotle's Historia animalium, but this is not the case for each

99 As K. Ziegler, I95I, cols. 857-858 noted, Plutarch relies on the following authorities (“Gewährsmänner") in Quaestiones naturales: Heraclitus, Empedocles, Plato, Aristotle, Theophrastus, the physicians Apollonius and Mnesitheus, Dionysius $\delta \dot{\delta} \delta \rho \alpha \gamma \omega \gamma o ́ \varsigma$, Antipater (author of De animalibus), a number of poets and the obscure Laetus. Cf. also R. Flacelière, J. Irigoin, J. Sirinelli and A. Philippon, I987, p. 1xxxii. For a concise analysis of Plutarch's "fonti letterarie", see also L. Senzasono, 2006, pp. 24-25. Notably, Senzasono argues (p. 25) that in those cases where a parallel can be found in a Latin author, this is probably due to the use of a common source that is now lost, but he does not exclude Plutarch's direct knowledge of those Latin authors either: "In questo opuscolo le concordanze sono probabilmente frutto in massima parte di dipendenze da una fonte comune, spesso perduta; in qualche caso non è da escludere una conoscenza diretta, come nel caso delle Nat. quaest. di Seneca e, soprattutto, date le frequenti concordanze, di Plinio il Vecchio." It is true that Plutarch had a notion of Latin later on in his life (as he notes himself in Dem. 2, 2-4; cf. A. De Rosalia, I99I and J. Scheid, 20I2, p. 7), but it seems rather unlikely that his limited knowledge enabled him to read technical scientific works in Latin (by which I leave unmentioned the clear inconsistencies with these authors at points), which is why I will leave Seneca and Pliny the Elder aside here. The latter is not explicitly quoted throughout Plutarch's entire œuvre, the former only once (in De coh. ira $46 \mathrm{IF}-462 \mathrm{~A}$; cf. also Galba 20, I). 
and every one of them, and Aristotle is not explicitly quoted by name. It is not always clear in such cases whether Plutarch directly relies on a specific source text where a parallel is found, which he then perhaps connected with material from other sources, or on an intermediary tradition, such as lost natural problems, where they were already combined. The same uncertainty counts, for instance, for the material that can be related to Theophrastus' lost De aquis (see Q.N. I, 9IID, 5, 9I3CD, 7, 9I4A, I3, 9I5B). It is not unlikely that some accounts in Quaestiones naturales and especially a number of the explicit quotations from Theophrastus originate from this work, but the intermediation of lost natural problems cannot be excluded, especially if one considers that much Theophrastean material is still present in the Ps.-Aristotelian Problems that came down to us.

Additionally, the potential influence of a largely anonymous tradition, either popular or more specialised, should not be underestimated. In regards to the incorporation of ancient medical knowledge, most notably, we see that Plutarch not only cites 'accomplished physicians' (Q.N. 26,

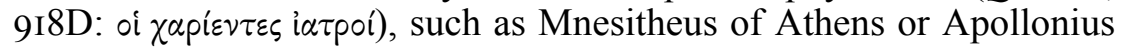
the Herophilean, but also mentions several more popular beliefs in an anonymous fashion. He reports, for instance, that dew makes fat people thinner by imbibing it or by soaking it up on their cloths $(Q . N .6,913 \mathrm{~F}$; cf. Cael. Aur., Tard. pass. 5, 139), or that pregnant women eat stones and $\operatorname{dirt}($ Q.N. 26, 9I8D; cf. Hipp., De superfetat. I8).

As to the parallels with the Hippocratic writings, these remain rather vague, and at some points there are also obvious divergences ${ }^{100}$. This does not imply, however, that these parallels are merely coincidental, since the Hippocratic tradition, including its general theoretical and terminological framework, was incorporated into the Ps.-Aristotelian Problems from an

100 For the parallels between Quaestiones naturales and the corpus Hippocraticum (esp. Aer. 7-8 Q.N. 2, 9I2A; 3, 9I2E; 5, 9I3C; 9, 9I4C; 33), see R.M. Aguilar, I994, pp. 42-43 and V. Andò, 2004, pp. I77-I78 (who, however, assume Plutarch's direct reliance on the Hippocratic writings). The same problem applies to Plutarch's De tuenda sanitate praecepta. F.C. Babbitt, 1928, p. 214, believes that the "body of Hippocratic medical writings, along with others, was in circulation, and had undoubtedly been read by Plutarch". Also according to L. Senzasono, I992, p. II, the Hippocratic writings were "piú o meno conosciuti da Plutarco". He notes (n. 9) that "la presenza latente degli scritti ippocratici è probabilmente diffusa, piú o meno, in tutto l'opuscolo [c.q. De tuenda]". I remain hesitant towards Plutarch's firm acquaintance with the Hippocratic tradition, though. Cf. also K. Ziegler, I95I, col. 925: "Bei dem ziemlich breiten Raum, den medizinische Dinge bei P. einnehmen, möchte man glauben, daß er allerlei medizinische Literatur gelesen hat. Aber Zitate daraus sind nich zahlreich [...]. Für sonstige naturwissenschaftliche Frage sind Aristoteles und Theophrastos P.s Hauptquellen gewesen." For Plutarch's quotes from the Hippocratic writings, see W. Helmbold and E.N. O’Neil, I959, p. I9. See also the general study on "Plutarque et la médecine" by J. Boulogne, I996. 
early stage onwards ${ }^{101}$. It seems rather unlikely, therefore, that Plutarch is relying on the Hippocratic writings directly. In any case, Hippocrates is not cited explicitly in Quaestiones naturales. The idea, for instance, that fever turns moisture into bile in Q.N. I, 9IIE can be generally related to the humoral theory of the Hippocratics. However, seeing that this idea illustrates a quote from Aristotle that cannot be retraced in the extant Aristotelian writings, it perhaps more likely originates from a lost problem, so that the context is more generally Peripatetic (see the commentary ad loc.).

The following scheme sets out the explicit quotations from scientific prose authors in Quaestiones naturales with special attention to their place and ranking in the aetiologies. In what follows, I will zoom in on individual (groups of) intellectuals, viz. the Presocratics, Plato, Aristotle etc., and more specifically on the ranking of their authority in Plutarch's explanations.

\begin{tabular}{|c|c|c|c|}
\hline No. & Q.N. & Authority & Rank \\
\hline 1 & & Pl., Tim. 90a; Rep. 491d, 546a & \\
\hline 2 & $1,911 \mathrm{D}$ & Anaxag., DK59A116 & c. $1^{\circ}$ \\
\hline 3 & & Democritus $^{102}$ & \\
\hline 4 & $1,911 \mathrm{E}$ & Arist., Mete. $358 \mathrm{a} ?$ & c. $4^{\circ} \dagger$ \\
\hline 5 & $2,911 \mathrm{~F}$ & Laetus & c. $1^{\circ}$ \\
\hline 6 & $2,912 \mathrm{~A}$ & Arist., fr. 215 Rose & c. $2^{\circ}$ \\
\hline 7 & $2,912 \mathrm{~A}$ & Heracl., DK22B12 & c. 2 \\
\hline 8 & $3,912 \mathrm{DE}$ & Apollonius, fr. 33 von Staden & c. 1 \\
\hline 9 & $5,913 \mathrm{C}$ & Pl., Tim. 59e & c. $3^{\circ}$ \\
\hline 10 & $5,913 \mathrm{D}$ & P1., Tim. 65de & c. $4 \dagger$ \\
\hline 11 & $6,913 \mathrm{E}$ & Laetus & c. $1^{\circ}$ \\
\hline 12 & $7,914 \mathrm{~A}$ & Theophr., $161 \mathrm{~W} .=214 \mathrm{C}$ FHSG & c. $2 \dagger$ \\
\hline 13 & $9,914 \mathrm{~B}$ & Dionysius & q. (C) \\
\hline 14 & $12,914 \mathrm{~F}$ & Arist., Pr. 935b? & c. $1^{\circ}$ \\
\hline 15 & $13,915 \mathrm{~B}$ & Theophr., $163 \mathrm{~W} .=173$ FHSG & c. $1^{\circ}$ \\
\hline 16 & $19,916 \mathrm{~B}$ & Theophr., $188 \mathrm{~W} .=365 \mathrm{C}$ FHSG & c. $1^{\circ}$ \\
\hline 17 & $21,917 \mathrm{D}$ & Arist., HA 578a? & c. $4^{\circ} \dagger$ \\
\hline
\end{tabular}

101 The Ps.-Aristotelian Problems contain a great deal of Hippocratic theories and concepts [see I.I.3., n. 75]. For the sources of the Problems in general, see H. Flashar, I962, pp. 333-34I.

102 This fragment is not recorded among the Democritus fragments collected by DK (nor is it mentioned in the list of Plutarch's quotations by W.C. Helmbold and E.N. O'Neil, I959, p. 22). Cf. also J.P. Hershbell, I982b, p. 8I, n. 2. 


\begin{tabular}{llll}
\hline No. & Q.N. & Authority & Rank \\
\hline $\mathbf{1 8}$ & $26,918 \mathrm{DE}$ & Mnesith., fr. 16 Bertier & c. $2 \dagger$ \\
$\mathbf{1 9}$ & 38 & Antip., SVF 3, p. 251, fr. 48 & c. $1^{\circ}$ \\
$\mathbf{2 0}$ & 40 & Arist., fr. 218 Rose & c. $1 \bigcirc \dagger$ \\
\hline
\end{tabular}

Key for rank: $c .=$ causa; $q .=$ quaestio $;^{\circ}=$ part of the argument; $(C)=$ concludes $c . / q . ; \dagger=$ final $c$.

For Plutarch, the Presocratics were essentially masters in natural scientific matters (in their capacity of $\phi v \sigma(k \circ)^{\prime}$ ), which explains why he recurrently relies on their authority in his natural problems. In Quaestiones naturales, Heraclitus, Anaxagoras and Democritus are cited only once each, but this number rises sensitively with Empedocles, who is quoted no less than seven times, making him the most frequently quoted authority in the collection. In regards to Plutarch's reliance on the Presocratics (throughout his entire oeuvre), Sambursky claimed that it "is not only typical of the eclectic spirit of Plutarch's time, but demonstrates the closeness of its intellectual viewpoint to the scientific approach of the great pre-Socratic philosophers" 103 . The issue of eclecticism has, of course, led to much debate among historians of philosophy and has long been abandoned by Plutarchists today ${ }^{104}$. Also the second part of Sambursky's claim is problematic: it is somewhat dubious for the contemporary value of Plutarch's scientific writings, as it implies an intellectual setback. Plutarch does, indeed, show great interest in Presocratic natural philosophy and in the Presocratics themselves (e.g., underlining Anaxagoras' importance as Pericles' philosophy tutor). Yet, the role that he attributes to them in the history of science remains inferior to the intellectual agenda of Plato and the scientific revolution lead by him (outlined above [see 4.I.2.I.]).

Interestingly, Aristotle also frequently engages with Presocratic physics (e.g., in the doxographical sections of De generatione et corruptione or the Parva naturalia), albeit often in such a way that his own scientific theories come out best ${ }^{105}$. Such self-promoting dynamics, though, are generally absent from Plutarch's treatment of the Presocratics in his natural problems. Instead of engaging in a polemic with the Presocratics, Plutarch generally appeals to their authority in order to underpin and illustrate his

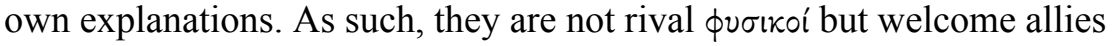

103 S. Sambursky, I963, pp. 2II-2I2. For Plutarch's acquaintance with the Presocratics in general, see A. Fairbanks, I897, A.M. Battegazzore, 1992, p. 54, n. 50, C. Santaniello, 2004 and S.-T. Teodorsson, 20II. See also the separate case studies by J.P. Hershbell.

104 See J.M. Dillon, I988.

105 For further detail on Aristotle's review of the Presocratics, see C. Collobert, 2002. 
in Plutarch's scientific project. In Q.N. 19, for instance, Plutarch refers to Empedocles' theory of emanations in order to back up his (presumably) personal explanation of the octopus' metachrosis [see 4.2.2.2.].

However, seeing that Plato - in defiance of a correct chronology is mentioned before Anaxagoras and Democritus in the very first causa of Q.N. I, 9IID, it is clear where Plutarch's heart eventually lies. This point should not go unnoticed here. Arguably, this chronological inversion has implicit programmatic value for Quaestiones naturales, as it reveals Plutarch's personal preference for Plato - who, thus, carries of the privilege of being quoted as the very first authority at the very beginning of the collection, before the Presocratics. This does not imply, of course, that Plutarch does not esteem the Presocratics at all, since Plato is mentioned along with two Presocratic eminencies (viz. Anaxagoras and Democritus). Therefore, the chronological inversion does not strictly separate Plato

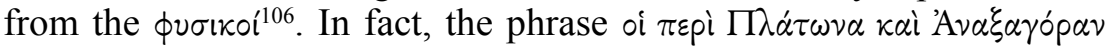

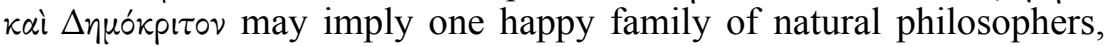
thus including Plato. However, if it is true that Plutarch does, indeed, show himself to prefer Plato (or more periphrastically, oi $\pi \varepsilon p i ~ \Pi \lambda \dot{\alpha} \tau \omega \nu \alpha$ ) at the beginning of Quaestiones naturales, it is not unlikely that we are dealing with Plutarch's philosophical signature here, that is, some kind of a subtle Platonic $\sigma \phi p \alpha \gamma$ is ('seal', 'signet'), for the entire collection. Plutarch's philosophical loyalty to Plato does not require illustration, nor does a subtle intellectual signature seem to be out of place at the beginning of a collection of natural problems, particularly considering the strong Peripatetic tradition in which it stands [see I.I.3.]. We know from elsewhere that Plutarch does not as such aim to reject the approach of the $\phi v \sigma$ ikoi and their search for natural causes but aims to complete it with a teleological perspective, after the model of Plato [see 4.I.2.I.]. Perhaps the chronological inversion is, thus, meant as a subtle reminder or a silent

106 A similar conclusion was reached by D. Babut, I994, pp. 574-475 (with n. I38) for De prim. frig. 948C, where Plato is also mentioned along with Democritus: "Platon n' est pas entièrement dissocié ici des autres physiciens"; n. I38: “[l]e passage n' oppose pas, en effet, Platon en tant que métaphysicien à tous les autres en tant que physiciens". Democritus is named again in association with Plato (and with other philosophers) in De tranq. an. 472D, Adv. Col. IIO8BC and II24C (cf. J.P. Hershbell, I982b, p. 96 with n. 5I). In regards to the reference to Anaxagoras and Democritus here in Q.N. I, 9IID, J.P. Hershbell, I982a, pp. I46-I47 notes: "In itself, the report is of little value, but the mention of Anaxagoras (also Democritus) together with Plato, suggests Plutarch's esteem for Anaxagoras as a student of the natural world." See also p. I53: "Because of Plutarch's own personal interest in the workings of nature, it is not surprising that he has regard for Anaxagoras' views [...]. In Plutarch's eyes, Anaxagoras was also a precursor of his own fight against superstitious explanations of the world's happenings. But however sympathetic Plutarch may have been to Anaxagoras' beliefs, the latter's views did not really explain the purposive activity of nature, a doctrine dear to both Plutarch and to his master Plato." 
invitation to read the work in the spirit of Plato's natural philosophical project and in light of the scientific revolution that it caused according to

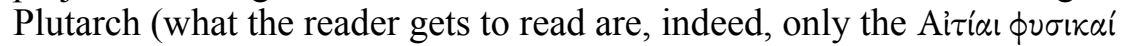
[see I.I.6.]). In that case, the rough rule that the first causa is usually reserved for communis opinio may be less operative here (at the very least, this passage may reveal the elasticity in such a theory). Plato is quoted two more times, viz. in Q.N. 5, 9I3 CD, where he closes off the aetiology. There can be little doubt, moreover, that Plutarch was able to quote Plato by heart, but he may just as well have consulted the Platonic text directly, or indirectly via an intermediary source (e.g., a commentary). In any case - and this is perhaps not so remarkable -, the three Platonic quotations can be retraced to the Timaeus (among several other parallel passages in Plato's oeuvre).

While the intellectual signature may be Platonic, the general atmosphere of the collection is clearly Peripatetic [see I.I.2.]. There are five quotes from Aristotle, which make him a very important authority in the collection (on a par with Homer, and only surpassed by Empedocles) ${ }^{107}$. This can be further illustrated by the fact that if Aristotle's account is not explicitly considered to be 'plausible' (cf. Q.N. 2, 9I2A, I2, 9I4F), it closes off the aetiology (cf. Q.N. I, 9IIE, 2I, 9I7D, 40). In Q.N. 40, Aristotle is

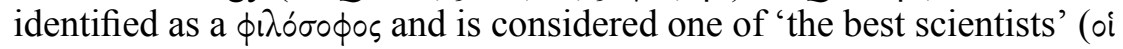

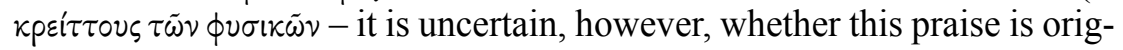
inal or part of the reformulation of the chapter by Psellus). Moreover, as would appear from the ranking of the quotes, Plutarch seems to appreciate Aristotle more than his successor, Theophrastus, whom he quotes three times. Theophrastus kicks off the aetiology in Q.N. 13, 915B and 19, 916B, and is ranked in the second causa in $Q . N .7,914 \mathrm{~A}^{108}$. Plutarch considers

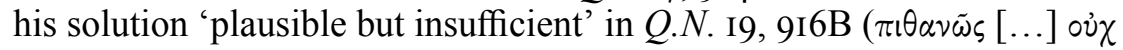
$i \kappa \alpha \nu \tilde{\omega} s)$. In many cases, though, a more attractive alternative follows upon the accounts of Aristotle and Theophrastus, but they are never openly rejected, since their explanations are not altogether implausible according to Plutarch ${ }^{109}$.

A small group of authorities remains, among which only the Greek doctors Apollonius the Herophilean (Q.N. 3, 9I2DE) $)^{110}$ and Mnesitheus

${ }^{107}$ For a separate analysis of Aristotelian quotes in Plutarch's natural problems, see M. Meeusen, 20II and 20I6.

${ }^{108}$ For a general study of Plutarch as a reader of Theophrastus, see J. Boulogne, 2005c. Boulogne rightly notes that the first causa in the Chaeronean's aetiological system is not "synonyme de rang préférentiel, mais de premier pas vers la vérité" (pp. 292-293, with further references).

109 Pace F.H. Sandbach, I965, p. I34.

110 Surnamed 'Mys', presumably because he wrote a treatise $\Pi \varepsilon p i \mu \nu \tilde{\omega} \nu$ (ca. 6o BC). Herophilus of Chalcedon, the leader of the school to which Apollonius belonged, worked 
of Athens (Q.N. 26, 9I8DE) ${ }^{111}$ can be identified with certainty ${ }^{112}$. These doctors are not quoted anywhere else by Plutarch, which makes a direct consultation of their works implausible. While Plutarch quotes Apollonius in the first causa on a par with oi $\pi$ oldoí, he references Mnesitheus in the last

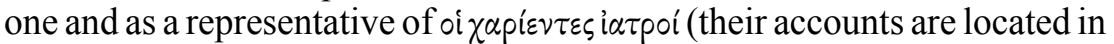
the sub-argument). Furthermore, in the first causa of Q.N. 38 (concerning the period of twelve days during which she-wolves litter), Plutarch quotes a passage from Antipater's De animalibus, probably the Stoic philosopher of Tarsus ${ }^{113}$. We do not know who the Dionysius from Q.N. 9, 9I4B is,

as an anatomist in Alexandria around $300 \mathrm{BC}$ (cf. also De cur. 5I8D). For further reading on Herophilus and his followers, see H. von Staden, I989, with pp. 540-554 on Apollonius (esp. p. 544 regarding the quote in Q.N. 3, 912DE).

${ }_{111}$ Mnesitheus of Athens (ca. 350BC) wrote several works on dietetics (Пвpi $\tau \tilde{\omega} \nu$

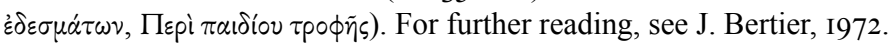

112 For Plutarch's acquaintance with Hellenistic medicine, see S. Grimaudo, 2004, R.M. Aguilar, 2005 and I. Rodríguez Alfageme, 2005. The literature on Plutarch and medicine mostly concerns specific case studies. On popular medicine in Plutarch, see I. Rodríguez Alfageme, I999a. For a more general overview, see J. Boulogne, I996 (esp. p. 2766, with n. 3I for Plutarch's treatment of medical topics in Quaestiones naturales).

$113=$ SVF 3, p. 25I, fr. 48 (von Arnim refers to Cic., De div. 2, 33 and notes: "possunt haec Stoico Antipatro vindicari de $\sigma \nu \mu \pi \alpha \theta \varepsilon i ́ \alpha$ disserenti, sed certi nihil affirmare licet"). For Plutarch's quotations from Antipater of Tarsus, see W.C. Helmbold and E.N. O'Neil, I959, p. 5. In De soll. an. 962F (= SVF 3, p. 25I, fr. 47), Plutarch probably relies on Antipater's $\Pi \varepsilon p i \zeta \omega \omega \nu$ again (concerning asses and sheep and their lack of cleanliness). The scholiast on Apoll. Rh., Arg. 2, 88-89a refers to a similar phenomenon as in Q.N. 38 (concerning

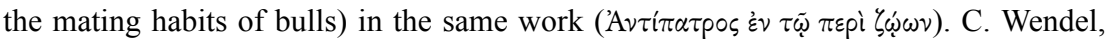
1942, pp. 216-217 dismisses the hypothesis that the Antipater from this passage can be identified with a doctor from the time of Augustus. This was considered uncertain already by M. Wellmann, I894, but no longer by G. Lachenaud, 20I0, p. 213, n. 27. According to A. Dyroff, I897, p. 403, however, the work should be attributed to Antipater of Tyre and was mainly directed against Antipater of Tarsus. This was shown to be unlikely by G. Tappe, I9I2, pp. I9, I and 52, I (cf. also M. Schuster, I9I7, p. 77 and D. Babut, I969, pp. 2II-2I4). C. Wendel, I942, pp. 2I6-2I7, by contrast, remains sceptical, and argues that we are dealing in $Q . N .38$ with an unknown chronicler of animal $\sigma \nu \mu \pi \alpha \dot{\theta} \theta \varepsilon 1 \alpha$ and $\pi \alpha \rho \alpha \dot{\delta} \delta \xi \xi \alpha$ (cf. also L. Senzasono, 2006, pp. 247-248, n. 208). The Stoic predilection for paradoxes and mirabilia is well-known [see 4.I.I.3.]. Cf. also J. Schmidt, 1949 and F.H. Sandbach, 1965, pp. 222-223, n. b: "Yet marvels did not come amiss to Stoics, as being evidence of the workings of Providence or of the unity of all things in the universe." Cf., e.g., Cleanthes' story about ants in De soll. an. $967 \mathrm{E}$ (= SVF I, p. II6, fr. 515). Another relevant passage is found in Quaest. conv. 626EF, where Theon the critic asks why Chrysippus never gave an explanation for any of the strange and extraordinary things he frequently mentions (SVF 3,

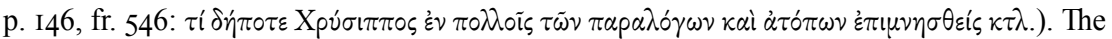
Stoic Themistocles answers that Chrysippus does so by way of example, because people are easily and irrationally trapped by what appears likely, and contrariwise disbelieve

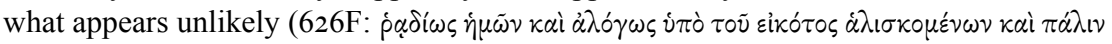

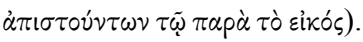


quoted in oratio obliqua in the quaestio, where he is surnamed $\delta \dot{\delta} \delta \alpha \gamma \omega \gamma$ ós ('the designer of aqueducts', 'the hydraulic engineer') ${ }^{114}$. Lastly, a certain $\Lambda$ airos is quoted twice, viz. in Q.N. 2, 9IIF and 6,9I3E, both times in the first causa and regarding specific meteorological phenomena related to precipitation (viz. rain and dew respectively). Plutarch's references to the man's explanations are kept fairly short, and in Q.N. 2, 9IIF, he

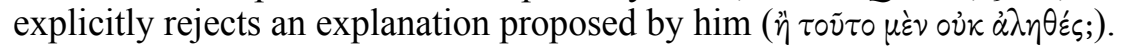
Scholars have identified this $\Lambda$ aĩos with Ofellius Laetus, a contemporary Platonic philosopher and author of a meteorological hymn (a $\mu \varepsilon \tau \dot{\alpha} \rho \sigma ı \varsigma$ v $\mu \nu \circ \varsigma$ ), whom we know from two inscriptions: one from Athens (I.G. $\mathrm{II}^{2}, 38 \mathrm{I} 6$ ), the other from Ephesus (I.Eph. VII, 2, 390I). It is not unlikely that Plutarch personally knew this man as a fellow (or perhaps rival?) Platonist, but this remains uncertain ${ }^{115}$ [see 3.I.5., n. 62].

As to Plutarch's general method of citing, it is his habit to keep the quotations fairly brief, but even so, he does not seem to show tremendous concern for precision, as he often renders the original text in his own words ${ }^{116}$. The adaptation of the traditional material is often

114 Throughout the corpus Plutarcheum, several persons are named Dionysius, which is a commonly used Greek name (cf. De def. or. 42IE). The Dionysius from Q.N. 9, 9I4B remains obscure, though. Notably, in Amatorius 76rB, Dionysius of Corinth is mentioned as a poet and author of a collection of Ai $\tau 1 \alpha$. In Quaest. conv. $744 \mathrm{~F}$, a certain farmer ( $\dot{\eta} \mu \varepsilon i \bar{\varsigma}$ oi $\gamma \varepsilon \omega \rho \gamma \circ i$ ) called Dionysius of Melitè participates in one of the discussions during the festival of the Muses in the Academy (S.-T. Teodorsson, I996, p. 356 notes that "[t]his Attic farmer is the only representative of his profession appearing in the Talks"). This Dionysius was perhaps a close friend or acquaintance of Plutarch's, but even so it remains uncertain whether he can be identified with the Dionysius from Q.N. 9, 9I4B. The same can be said of Dionysius of Delphi, named in De soll. an. $965 \mathrm{C}$, who was the father of Aeacides and Aristotimus. According to L. Senzasono, 2006, p. I79, n. 64, the Dionysius from Q.N. 9, 9I4B must have been a sufficiently known person (like Laetus; see n. II5), even if Plutarch cites him indirectly, but this seems unlikely precisely for that reason. In addition, the epitheton í $\rho \alpha \gamma \omega \gamma$ ós may perhaps refer to Dionysius' local (?) nickname (rather than to his profession): 'the waterdrinker', 'the sufferer of dropsy' (cf. LSJ, s.v.). This remains speculative but is not, in any case, implausible in the context of the question at issue in

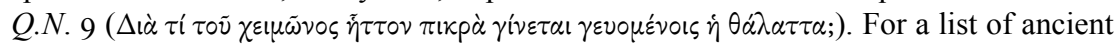
scientists named Dionysius, see P.T. Keyser and G.L. Irby-Massie, 2008a, pp. 258-265.

115 For further reading on Ofellius Laetus, see G.W.M. Bowersock, 1982, J. Opsomer, 2008 and M. Meeusen, 2013a.

116 See already A. Fairbanks, I897, pp. 78-79 and also D.A. Russell, I980, p. I4: "Plutarch's quotations and allusions are often loose and inexact". Whether this happens on purpose or not is not always clear. It remains to be seen, moreover, whether precision in

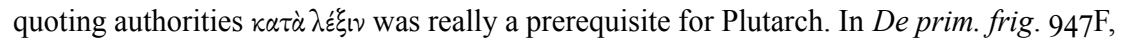
for instance, Plutarch notes that his paraphrase of Anaximenes (DKI3 $\mathrm{BI}$ ) comes close to the original wording, which, apparently, was good enough for him to make his point (ovi $\tau \omega$

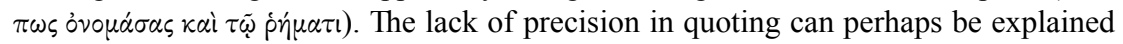
by the vagaries of Plutarch's memory or by the inexactness of his personal notes. See, 
more conspicuous, though, especially when Plutarch changes the specific wording of the citation to fit the context (as is the case, for instance, with the adaptation of $\tau o \mu i \alpha$ into róvopxis in the quote from Aristotle in Q.N. 2I, 9I7D; see the commentary ad loc.). Moreover, Plutarch often extracts material from a very specific context, so that it needs to be adapted in several ways to the new context, that is, not only by syntactic or verbal but also by semantic modifications (as is the case, for instance, with Plutarch's claim in Q.N. 5, 913B that salt is 'not generated', whereas Theophrastus, who is his probable source, implies that it 'does not generate'; see the commentary ad loc.). Plutarch's custom of lifting specific accounts from their original context is widely observed throughout his entire oeuvre and testifies to his desire and ability to use the available sources in an original fashion, so that a simple reproduction is deliberately avoided. This is especially the case with the quotations from the poets, since they are often reinterpreted in a somewhat exegetic fashion, thus receiving a new physical appropriation, as we saw [4.I.2.3.]. Plutarch also applies this interpretive strategy, for instance, to Heraclitus' famous river statement in Q.N. 2, 912A: 'you could not step into the same rivers twice, because other waters flow upon you'. Plutarch reinterprets this in a very literal, physical fashion in order to support the theory that river water has a fresh and new-born property. As such, the deeper and original pan-cosmic meaning of Heraclitus' saying is no longer relevant. Such a literal interpretation, which is, indeed, much in keeping with the general referential stylistics of the collection [see I.2.3.], illustrates how Plutarch freely and often very playfully processes received knowledge and traditional authority in his natural problems, twisting it where he personally finds possible and fit $^{117}$.

e.g., W.C. Helmbold and E.N. O’Neil, I959, p. ix (“[h]is memory was prodigious, and his confidence in it no less so") and R. Flacelière, J. Irigoin, J. Sirinelli and A. Philippon, I987, p. lix. In some cases, though, the adaptation seems deliberate, which can be explained, then, in light of Plutarch's urge to process traditional authority in an original way, even if this means that the original text should be bent a little. In Quaest. conv. 718C, for instance, the 'misquotation' from Plato is certainly deliberate: Plutarch is very well aware that Plato nowhere literaly says that 'the demiurge is always practicing geometry', but the saying is

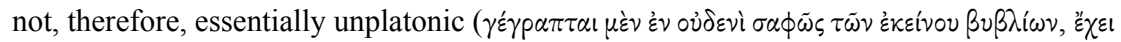

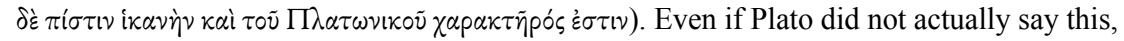
it is not, therefore, an 'unorthodox' saying, and that is what really matters for Plutarch. Or formulated more negatively, in the words of S.-T. Teodorsson, I996, pp. I62-I63: "Plut. clearly indicates that he is aware of the fact that the subject to be discussed goes beyond Plato's doctrine, and he implicitly warns that the opinions are not entirely orthodox."

117 For Plutarch's similar method of citing in Quaestiones convivales, see J. König, 20Io, esp. pp. 339-345 (see also id., 20II for an account of how the symposiasts stage and re-enact the voices of past authorities by quoting them). On Plutarch's general method of citing the poets, see C. Bréchet, 2007. See also E. Bowie, 2008. 


\section{Problematisation of scientific knowledge}

One of the central aims of the genre of natural problems, besides from raising questions about problematic passages in the scientific literature, is to communicate received knowledge in, what can be called, a 'problematised' fashion, meaning that the author often adapts and remoulds certain passages from a specific source text into the problem format, in order to reframe the source text and/or to reopen it for discussion, a procedure seen at work throughout Ps.-Aristotle's Problems ${ }^{118}$. In doing so, the author often adds his own criticisms and further remarks, suggestions, specifications, so as to advance or review traditional theories. The same procedure is clearly present also in Plutarch's natural problems, as we will see here. Despite the sophisticated use of source material, the result comes across quite organically, because the borrowed material ties in neatly with the development of the problem chapters ${ }^{119}$. As such, the transformation of traditional material into the problem format - both in the quaestiones and in the causae - testifies to the author's attempt at a problematisation of a wide array of ancient Greek scientific learning. Nature and, by implication, the field of natural scientific knowledge, is cut up into small problem units and is transmitted in a piecemeal fashion. Each of these problem units usually focuses on one specific natural phenomenon. Therefore, as Blair argues in light of Ps.-Aristotle's Problems, "Problemata are one of the ways of attaching particulars to the universals of scientia developed in systematic treatises, through commonsensical but often sophisticated reasoning." 120

118 In some cases, not the subject for the quaestio is found in a specific source text, but one or more of the explanations themselves. For more detail on this technique in Ps.-Aristotle's Problems, see H. Flashar, I962, p. 334: “Aber es handelt sich keineswegs um mechanische Exzerpte, vielmehr ist die Art der Quellenbenutzung im einzelnen gans verschieden: teils geht nur die Frage, nicht aber die Antwort, teils nur die Antwort, nicht aber die Fragestellung aus Ar. zurück." For a general account on the problematisation of source material into the problem format, see C. Jacob, 2004, pp. 48-53.

119 The same technique can be found in Plutarch's other collections of quaestiones, esp. Quaestiones Romanae and Graecae. For Quaestiones Graecae, see K. Giesen, I90I, p. 449 and W.R. Halliday, 1928, pp. I4-15; for Quaestiones Romanae, see L. Van der Stockt, I987, pp. 287-288 and J. Boulogne, I992, p. 4686, n. 27: "Il est peu vraisemblable que Plutarque ait commencé par dresser une liste de problèmes à résoudre, pour ensuite procéder aux recherches nécessaire. L'ordre des opérations a dû être inverse."

120 A. Blair, I999, p. I75. Cf. also R. Mayhew, 20IIa, pp. xxi-xxii: "In the broadest terms, the purpose of the chapters of the Problems is to raise questions - about passages in the works of Aristotle or Theophrastus or other Peripatetic philosophers and scientists, about passages in the works of medical writers (and especially the Hippocratic treatises), and in general about endoxa (the reputable opinions in the air at the time, on any number of subjects)." 
A manageable case for illustrating this procedure in Plutarch's Quaestiones naturales is the cluster of problems on hunting in Q.N. 23-25, which discusses the influence of the meteorological conditions of spring, winter, dew and full moons on tracks and trails left behind by animals. There is a dense cluster of parallel passages with Xen., Cyn. 5, I-5, as set out in the following table:

Xen., $C y n .5$, I-5

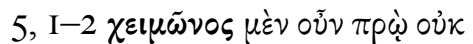

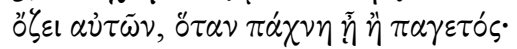

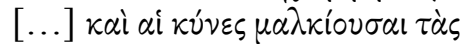

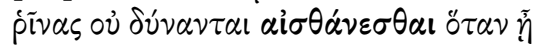

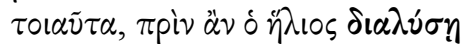

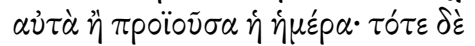

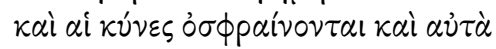

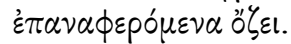

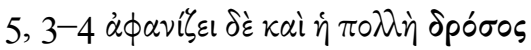

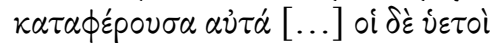

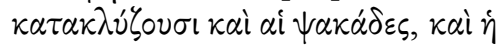
$\sigma \varepsilon \lambda \hat{\eta} \nu \eta \dot{\alpha} \mu \alpha v p o i \tilde{\tau} \tilde{\omega} \theta \varepsilon p \mu \tilde{\omega}, \mu \alpha \dot{\lambda} \iota \sigma \tau \alpha \delta \dot{\varepsilon}$

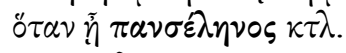

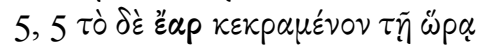

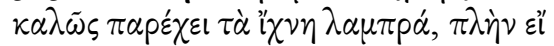

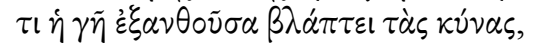

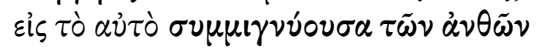

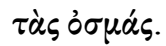

Plut., Q.N. 23-25, 917E-918B

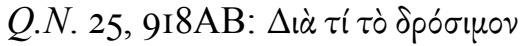

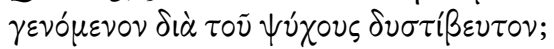

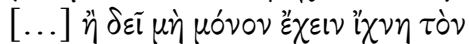

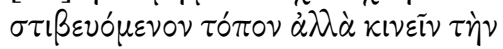

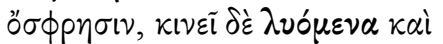
$\chi \alpha \lambda \omega \mu \varepsilon v \alpha \mu \alpha \lambda \alpha \kappa \tilde{\omega} \varsigma$ vंสò $\theta \varepsilon p \mu o ́ \tau \eta \tau o \varsigma, \dot{\eta}$

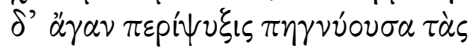

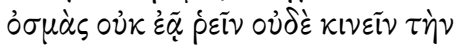

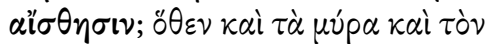

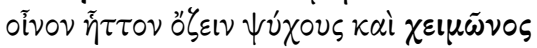

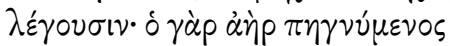

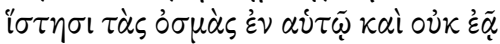
$\dot{\alpha} \nu \alpha \delta i ́ \delta \circ \sigma \theta \alpha$.

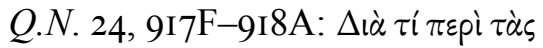

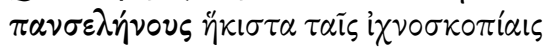

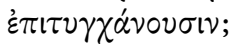

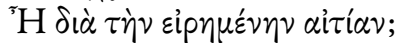

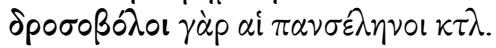

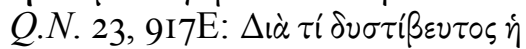

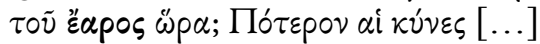
$\tau \dot{\alpha} s \dot{\alpha} \pi \circ \rho p o i ́ \alpha s \dot{\alpha} \nu \alpha \lambda \alpha \mu \beta \dot{\alpha} \nu 0 v \sigma v, \ddot{\alpha} s$

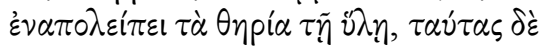

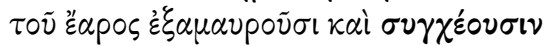

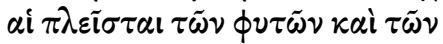

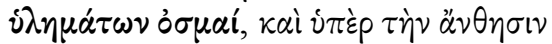

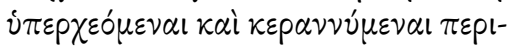

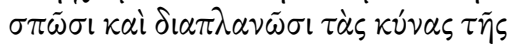

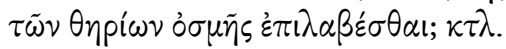

Two further remarks should be made here. First of all, the parallel passages in Xenophon are very relevant for the concatenative clustering of the distinct problem chapters around the same topic in Plutarch. Indeed, this problem cluster nicely illustrates how the obvious connective threads 
between two or more chapters can sometimes be explained on the basis of the coherent structure of the source text which they problematise [see I.I.5.]. Second, even though there may be reason to assume that Plutarch was acquainted with Xenophon's Cynegeticus ${ }^{121}$, it is not clear that this text served as a direct subtext for the three problem chapters at hand. After all, the intermediation of another text (e.g., one or more lost natural problems) and/or an oral report cannot be excluded (e.g., during a sympotic dicussion: cf. the encomium on hunting mentioned in De soll. an. 959B). Hardie correctly states that "[b]y Plutarch's time much scholarly and philosophical discussion had been reduced to the status of the $\pi p \circ \beta \lambda \eta \dot{\eta} \mu \alpha \alpha$ " 122 . But this is not, of course, to underestimate Plutarch's own authorial intermediation in composing such problems. In any case, each of the chapters in Q.N. 23-25 contains more than one demonstrable source, since Plutarch also relies on communis opinio, incorporates mythological material, and quotes Empedocles and Alcman by name (these are located in the passages that are bracketed in the table above). It is only likely, then, that Plutarch draws on a mixture of sources for each problem chapter and, in doing so, adds his own findings and comments by developing or adding new material or by nuancing older material (cf., e.g., the allegorical interpretation of Alcman's line in Q.N. 24, 9I8A, where the moon's ability to draw up moisture from the earth is emphasised, vis-à-vis the parallels in Quaest. conv. 658B and De facie 929A, where the moon's liquefying ability is at issue; see the commentary ad loc.).

Sandbach is probably correct, then, in concluding that it is unlikely that Plutarch drew all of his information from one and the same book in Quaestiones naturales ${ }^{123}$. Even if Plutarch incorporates a great deal of received knowledge in his natural problems, we should not lose track of his personal intuition for scientific speculation and zetetic ingenuity.

${ }^{121}$ See J. Mossman and F. Titchener, 20II, p. 277. Cf. Non posse I096C with the quote from Cyn. 5, 33 .

122 P.R. Hardie, I992, p. 475I. He adds that "the form is characterized by the massive deployment of argument and learning on questions which are selected for their inherent trickiness rather than by any externally determined standard of importance; by a corresponding obsession with detail at the expense of wider connections; and, not so obviously, by the readiness to let go of the question once a number of plausible explanations have been found, which may be ranked in order of likelihood but need not be".

${ }^{123}$ F.H. Sandbach, 1965, p. 135: "Notes of this sort [sc. Quaestiones naturales, Romanae and Graecae] can arise from summarizing and abstracting from a single book, but they may be drawn from diverse sources, and include suggestions and criticisms made by the note-taker himself. Any contention that Plutarch took all his questions from a single source [...], does not admit of profitable discussion. If the questions referred to Aristotle, Theophrastus, and the unknown Laetus implied first-hand consultation of these authors, the contention would be untenable; but there is no better reason for asserting than for denying that Plutarch went directly to them." 
Quaestiones naturales is not a mere doxography of traditional authorities, since, as Teodorsson remarks, Plutarch in this work "did not follow his sources slavishly but developed the material further in his own way" 124 . This leads the way to a further examination of the actual innovative dynamics in Plutarch's natural problems in the following section.

\subsubsection{Scientific innovation and performance}

\section{A note on the sociology of knowledge and $\pi \alpha i \delta \varepsilon i \alpha$}

Plutarch's eagerness to examine and reprocess received knowledge can be regarded as one of the unifying factors throughout his entire oeuvre ${ }^{125}$. Regarding Plutarch's scholarly and literate approach in scientific matters, Sirinelli observes that: "Le nombre des citations qu' il propose et leur diversité sont destinés souvent, plus qu' à fortifier son argumentation, à faire admirer la force de sa culture et l'étendue de sa documentation." 126 From a sociological perspective, one can, indeed, argue that profound knowledge of the tradition testifies to a person's degree of $\pi 0 \lambda \nu \mu \alpha \dot{\theta} \theta \varepsilon \alpha$ and $\pi \alpha i \delta \varepsilon i \alpha$ in a specific field of expertise (therefore, presumably, Plutarch's quotations are mostly nominatim $)^{127}$. However, restricting things to matters of intellectual ostentation - to be measured only in terms of Bourdieu's

124 S.-T. Teodorsson, I999a, p. 666. Pace E. Lelli, 20I0, p. 849: “Ancora di taglio dossografico sono gli Aitia physica, elenco di dottrine su disparati argomenti di scienza naturale."

125 Cf. G. Roskam, 20IIc, p. 420. On the unity in Plutarch's work more generally, see J. Barthelmess, I986, pp. 62-64 and the contributions in A.G. Nikolaidis, 2008.

126 J. Sirinelli, 2000, p. 363 . He adds: "Il est dans toute l' extension du terme un philologos. Il suffit de le comparer à cet égard à Sénèque, Épictète et Dion Chrysostome pour discerner clairement où il veut situer son originalité et sa supériorité." Cf. also F. Klotz, 20I4, p. 208. For fierce criticism of an exclusively sociological reading of (serious) philosophical texts, see J. Opsomer, 20I4, pp. 90-9I: "It is true that knowledge and power are often closely intertwined. Yet it would be a vast exaggeration to claim - as some theorists in their awe for Foucault do - that it would invariably be illicit to study philosophical ideas without looking at their relation to cultural power structures. Just as the history of philosophy is not eliminatively reducible to rhetoric, social and cultural contexts alone cannot account for why persons hold certain views. Intellectual traditions, philosophical argument, hermeneutics, and theoretical constraints linking various ideas across philosophical sub-domains are much more important in accounting for the views of serious philosophers."

127 In a sympotic context, the $\pi \varepsilon \pi \alpha 1 \delta \varepsilon \nu \mu \varepsilon v{ }^{\prime}$ s should be able to flag his sources by name, and if he fails, this is at the risk of becoming an object of ridicule (cf. Quaest. conv. 675DC). Then again, as C. Pelling, 20II, pp. 216-217 remarks (regarding De se ipsum laud. $544 \mathrm{~A}$ ), forgetfulness is "one of the engaging weaknesses one can readily admit to" (cf. also D.A. Russell, 1993, p. 43I and F. Klotz, 2007, p. 66I). On the aspect of memory and its vagaries in Quaestiones convivales more generally, see K. Oikonomopoulou, 20II, pp. I08-I23. 
cultural capitalism - would clearly impoverish the actual historical value of Plutarch's scientific project, as it would fail to appropriately account for its higher philosophical goals (discussed earlier on [see 3.2.2.]). Nevertheless, recent studies have especially highlighted the importance of rhetorical display $(\dot{\varepsilon} \pi \hat{i} \delta \varepsilon \xi \xi \zeta)$ in scientific works produced in the early Roman Empire, often drawing links with the Second Sophistic's culture of $\pi \alpha i \delta \varepsilon i \alpha$, and this feature has often - and increasingly so - also been discussed for Plutarch's Quaestiones convivales, as we saw ${ }^{128}$ [see 3.I.3., n. 46]. However, with respect to the sympotic discussions described in this work, one may wonder what there really is to gain in terms of socio-cultural prestige, when - not just from a social, but also from an underlying epistemological perspective - the symposiasts are, in fact, each other's intellectual peers and equals [see 4.3.2.]. The relative plausibility of the arguments is, indeed, an important criterion in the participants' personal investments in the discussion, but the only common currency that is really at stake, in the end, is the philosophical truth ( $\pi \circ \lambda \nu \mu \alpha \dot{\theta} \theta \varepsilon \alpha$ being just a means to an end for Plutarch). So why should we doubt Plutarch's sincere and honest interest in the subject matter if at the heart of his research project lies a higher philosophical motive? In this light, a person's acquaintance with traditional knowledge is important to the more introvert development, rather than extravert ostentation, of personal research and reflection, in that it underpins any personal arguments or theories that sprout from it, and in which the author personally believes, or to which he at least ascribes a certain measure of plausibility (bearing in mind the principle of charity [see the prologue, n. 3]).

Let it be clear, moreover, that close familiarity with the tradition was a quintessential predisposition for an eager scholar and intellectual in Plutarch's time. However, the ability to handle this knowledge in a personal and original way, by assessing it critically or by adapting it where possible and where necessary to the new context, is even more important than the mere reproduction or 'performance' of received knowledge tel quel [see I.2.3., n. 202]. In this sense, a person's acquaintance with the tradition plays an essential role in the search for plausible explanations ${ }^{129}$. If it is true, moreover, that one can only be original and be fully aware of it if one 'knows' the tradition, then it is equally true that great learning is not a $\tau \dot{\varepsilon} \lambda_{\circ}$ in itself, but provides many 'starting-points' (cf. the notion of apxaí in Quaest. conv. 734D [quoted 3.2.I.]). Accordingly, Plutarch is well aware that firm acquaintance with the tradition only provides a

128 See, e.g., M. Gleason, 2009 for the performative dimension of Galen's anatomy demonstrations $(\dot{\varepsilon} \pi \mid \delta \varepsilon \dot{\xi} \xi 1 \zeta)$. Notably, in De ad. et am. 7IA, Plutarch vituperates the shamelessness of physicians to conduct operations in theatres in order to gain new clients.

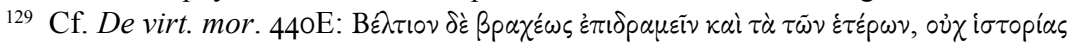

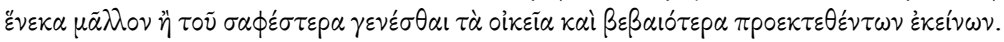


stable foothold for his research, because inventiveness requires knowledge to be 'performative', that is, open to rhetorical-argumentative reuse and adaptation. In De prim. frig. $952 \mathrm{C}-955 \mathrm{C}$, for instance, the theory that earth is the principle of cold is commonly understood as Plutarch's "original contribution to theoretical physics" 130 . Nevertheless, it is clear from the preceding doxography that Plutarch only managed to formulate this theory by critically assessing several other traditional opinions (viz. of Aristotle, the Stoics, Empedocles and Strato). Therefore, Plutarch's inventiveness and originality does not arise ex nihilo, but from a thorough acquaintance with the tradition. The following section will examine this point in further detail for Plutarch's natural problems.

\section{The pragmatics of Plutarch's scientific ingenuity and creativity}

Throughout the corpus Plutarcheum, improvised ingenuity is designated

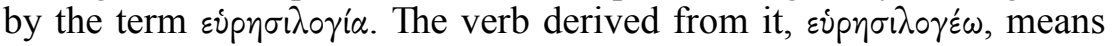
"to invent ingenious arguments, explanations or pretexts"131, but it often has a pejorative connotation, as it often applies to rhetorical and slightly sophistical practices. Plutarch considers it a most valuable asset when used in the right proportion, but if an explanation becomes too ingenious or rhetorical, he criticises it as constituting bad philosophy ${ }^{132}$.

We learn a great deal from Quaestiones convivales regarding the pragmatics of Plutarch's conception of ingenuity and originality in solving problems. As we saw earlier on, for Plutarch, sympotic events provide an occasion for social and intellectual interaction, where each symposiast tries to contribute and bring his own share to the debate [see 3.I.3.]. Notably, even if a solution has already been deemed adequate, this is no reason to stop looking for new arguments. In Quaest. conv. 656D,

${ }^{130}$ H. Cherniss and W.C. Helmbold, I957, p. 227. The originality of Plutarch's theory was also acknowledged by O. Longo, I992, p. 228, but G. D'Ippolito and G. Nuzzo, 20I2, p. 64 remain uncertain.

131 LSJ, s.v.

132 Plutarch places the term in a good light in De def. or. 4I4A and in Quaest. conv. $642 \mathrm{~A}$ and $656 \mathrm{~A}$, but it more often receives a negative connotation (it is even related to inebriety in Quaest. conv. 682BC; cf. also 700E). Plutarch notes that verbal ingenuity in poetic texts can corrupt the young (De aud. poet. 28A), and that it tends to constitute bad

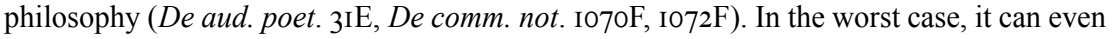
be directly opposed to serious philosophy, being synonymous rather with vainglorious $\pi \alpha i \delta 1 \alpha$ (De Stoic. rep. I033B). From Quaest. Rom. 283C and Quaest. conv. 625C, 656A, $682 \mathrm{~B}$, we also learn that even though the author considers a causa to be an unsound conjecture, he may still write it down in a collection of problems, albeit simply to disprove it or to provide an alternative explanation for it. G. Roskam, 2009, p. 373 has argued that Stoic philosophers, in particular, are blamed for their sophistical ingenuities. See also the

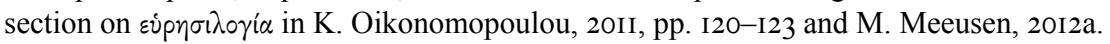


for instance, Plutarch's father reproduces Aristotle's explanation for the problem of why the so-called tipsy are more deranged than very drunk people. Aristotle argued that tipsy people judge badly because they follow illusory appearances. Plutarch's father is not very enthusiastic about the explanation, though, and invites his fellow symposiasts to say 'something

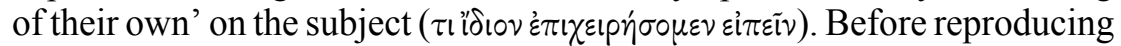
Aristotle's explanation, he notes that, 'even though Aristotle is normally very sharp in such investigations, he does not seem to have sufficiently

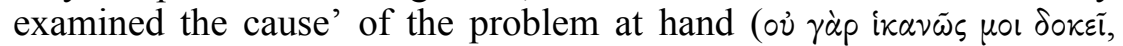

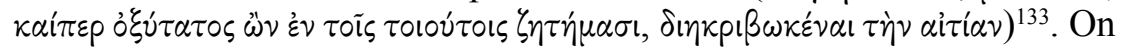
his father's request, Plutarch then examines Aristotle's explanation and concludes that 'it is sufficient as far as causality is concerned' ( $\dot{\alpha} \pi \circ \chi_{\rho} \tilde{\omega} \nu$

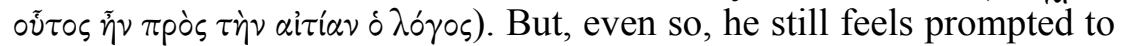
add 'something of his own' ("ióo $v \tau)$, which he does by arguing that the power of wine is variable in proportion to its quantity. Apparently, Aristotle's explanation attains a certain level of sufficiency ( $\dot{\alpha} \pi \circ \times \rho \tilde{\omega} v)$ from a causal perspective, but this does not preclude the formulation of yet other explanations, presumably because for Plutarch (both as author and as sympotic character) the aspect of plausibility is the only criterion that matters in these discussions, rather than the singling out of one ultimately correct explanation ${ }^{134}$.

Another relevant passage, where Aristotle's authority is again central, is found in the previous talk from Quaest. conv. $655 \mathrm{D}-656 \mathrm{~B}$, which is set in the same sympotic context. The problem at hand is why $\gamma \lambda \varepsilon \tilde{v}$ kos ('must'; i.e. sweet, new wine) is least intoxicating. Two young philosophers make their own attempt at an explanation: Hagias argues that the excessive sweetness of the wine prevents people from drinking a quantity that is sufficient for intoxication, and Aristaenetus of Nicaea argues that the sweetness blunts the intoxicating effects of the wine ${ }^{135}$. Their ingenuity is heartily approved by the group, because, so Plutarch writes, 'they did not fall upon the evident arguments but attained their personal explanations'

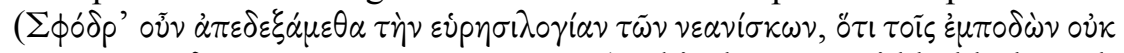

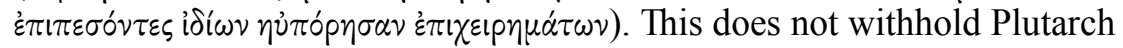
from also adding some arguments which he describes as 'at hand and easy

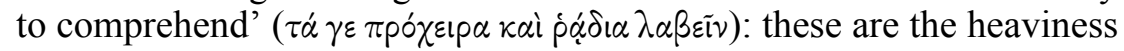

${ }^{133}$ Parallels are found for this problem in Ps.-Arist., Probl. 871a8-16 and 875a29-40.

${ }^{134}$ Cf. F. Frazier and J. Sirinelli, I996, p. 200 (see also pp. 197-200 more generally): “l'originalité n' est pas imagination débridée, mais élaboration d' une théorie plausible".

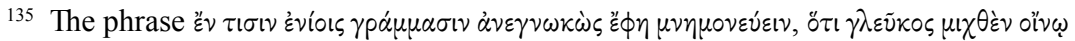
$\pi \alpha v^{\varepsilon} \varepsilon \mu_{\varepsilon}^{\prime} \theta \eta \nu$ in Aristaenetus' account is an implicit reference to Ps.-Arist., Probl. 872b32873 a4 (see S.-T. Teodorsson, 1989, p. 370). Perhaps, Aristotle is not named explicitly as Aristaenetus' source, in order to (falsely) underline the aspect of personal ingenuity in his argument (see below). 
of the wine, which, as Aristotle - presumably in one of his lost natural problems - says, breaks through the stomach ${ }^{136}$, and the large quantity of pneumatic and watery substances that are mixed with the wine $(=$ fr. 220 Rose). Plutarch thus shows that the formulation of personal ingenuities should not necessarily go at the cost of mentioning also the more obvious, traditional (c.q. Aristotelian) explanations, seeing that these also bear direct relevance to the discussion at hand and to its search for plausible arguments. It is precisely herein, then, that Plutarch's subtle criticism of the young philosophers presumably lies.

A most relevant passage to illustrate the importance of received knowledge as a starting-point for personal creativity is found in Quaest. conv. $694 \mathrm{D}$, where the symposiasts are looking for the cause of 'oxhunger' (Bov $\left.\lambda_{1 \mu i} \alpha\right)$. This problem is treated in Ps.-Arist., Probl. 887b38888a23, where the same processes are central as described in Plutarch's explanation. After an introduction of the problem, Plutarch in an interior monologue reflects on the importance of argumentative creativity in the context of intellectual inquiry. Notably, Plutarch very seldom uses this technique of interior monologue, as attested here, which only highlights the importance of the passage at issue ${ }^{137}$.

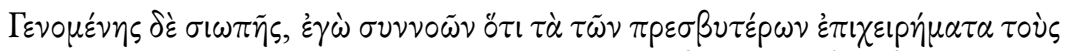

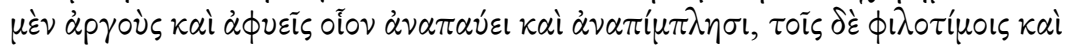

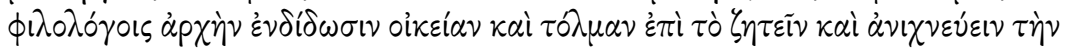
$\dot{\alpha} \lambda \eta^{\prime} \theta \varepsilon ı \alpha$

There was a silence during which I reflected that it suits the dull and unschooled to accept and be full of the solutions provided by our predecessors, whereas to the ambitious and learned it provides a familiar beginning and an encouragement to search and track down the truth.

The idea that traditional knowledge provides a beginning $\left(\dot{\alpha} p \times \eta_{\eta}\right)$ for zetetic discussions may very well be an echo of Aristotle's quote in Quaest. conv. $734 \mathrm{D}$, according to which 'great learning provides many startingpoints' (ápxaí [quoted 3.2.I.]) $)^{138}$. In what follows, Plutarch suits the action

136 See S.-T. Teodorsson, I989, p. 37I. R. Mayhew, 20IIa, p. III, n. 23 draws a parallel with Ps.-Arist., Probl. 872b25-32 and 874bi3-2I.

137 See S.-T. Teodorsson, I990a, p. 289: "This example of inner soliloquy is unique in the Talks and rare in Ancient literature on the whole." (With the well-known exception, of

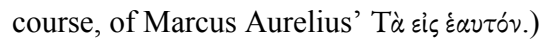

${ }^{138}$ See J. König, 2007, p. 57: "This passage [i.e. Quaest. conv. 734D] is typical of patterns which are repeated over and over again throughout the Sympotic questions: the use of past authority to provide a stimulus for present discussion; explicit recommendation 
to the word. He first brings Aristotle's account to mind ( $\dot{\varepsilon} \mu \nu \eta \dot{\sigma} \sigma \eta \nu \tau \tilde{\omega} \nu$

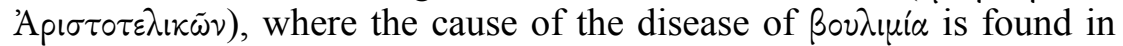
the processes of heating and colliquation. The discussion then proceeds, some persons attacking Aristotle's theory, others advocating it, and

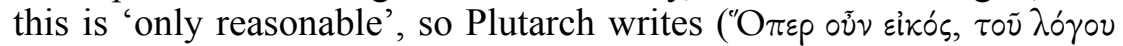

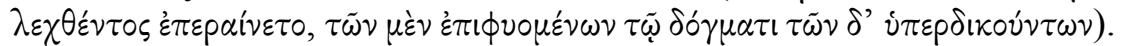
The emphasis on sixós here, implies that the continuation of the discussion by the formation of two camps is a logical consequence in the context of the debate, since those symposiasts advocating Aristotle will have to come up with new arguments against those attacking him. This clearly indicates that received (c.q. Aristotelian) knowledge only provides an incentive $\left(\dot{\alpha} p \times \eta^{\prime}\right)$ for discussion and should not simply be taken for granted, as was, indeed, highlighted in the interior monologue.

What we learn from these passages, then, is that traditional authority often functions as a starting-shot in the race for the truth ${ }^{139}$. It provides an $\dot{\alpha} p x \dot{y}$ for zetetic ingenuity, that is, a first step in the direction of an innovative explanation. However, originality and creative, improvised speculation are valued more than a person's mere acquaintance with past authorities. Therefore, a true intellectual should by no means be content with the tradition, but when he eventually ventures upon original speculation, it will often be in a progression and advancement of received knowledge ${ }^{140}$.

The same ambivalence can be seen throughout Quaestiones naturales, especially in those passages where Plutarch relies on traditional authorities and at the same time displays a strong sense for aetiological originality. In these cases, Plutarch neatly balances past authorities with personal speculations. To this end, he sometimes marks his criticism of traditional authorities in a very explicit way. This is the case, for instance, in Q.N. I2, $9 \mathrm{I} 4 \mathrm{~F}$ regarding the problem of why oil that is sprinkled on sea-water causes

of independent thought [...]; and use of the language of contribution to describe individual

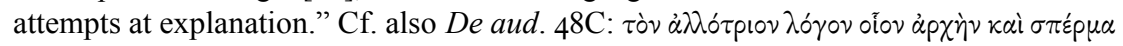
$\lambda \alpha \beta \delta^{\prime} \tau \alpha \varsigma \kappa \tau \lambda$. [quoted 3.I.2.].

${ }^{139}$ For a more inclusive analysis of the construction and deconstruction of Aristotle's authority in Plutarch's natural problems, see M. Meeusen, 2016.

140 As J. König, 20II, p. 190 observes, "[p]ast and present speak with each other particularly within the all-embracing framework of the symposium." Plutarch recurrently deploys the metaphor of "entering into conversation with the past" (id., 2008, p. 90, with n. I8): cf., e.g., Quaest. conv. 65IF, 653B, 718C. The imagery used in staging traditional authorities often becomes very plastic, so that we come across "vivid metaphors which depict the quoted text as an object in its own right, to be controlled and mastered by the symposiasts" (id., 20II, pp. 200-20I). In Quaest. conv. 734F-735A, most notably, Democritus' theory of the 'spectral films' $\left(\varepsilon^{\prime} \delta \omega \lambda \lambda \alpha\right)$ is compared with an old weapon Florus brushes up in his own argument, and in ${ }_{735} \mathrm{C}$ the language from the world of boxing and wrestling is used. 
clearness and calm ( $\left.\kappa \alpha \tau \alpha \phi \alpha \dot{\nu \varepsilon 1 \alpha ~ \kappa \alpha i ~} \gamma \alpha \lambda \eta^{\prime} \nu \eta\right)$. According to Aristotle, so Plutarch writes in the first causa, the wind, slipping off the smoothness (so caused by the oil), makes no impact and raises no surge. Plutarch criticises this view in the second causa, where he highlights the incompleteness of Aristotle's theory: the explanation is plausible, but only so regarding

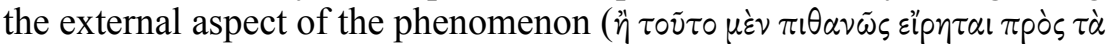
$\dot{\varepsilon} \kappa \tau$ ós). He then draws attention to the internal (c.q. submarine) aspect of the problem by referring to diver lore: divers take oil into their mouth and blow it out in the depths, so that they may have light and transparency when under water. As Plutarch notes, it is impossible to adduce the cause

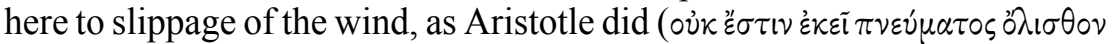
$\alpha i \tau i \alpha \dot{\sigma} \alpha \sigma \theta \alpha \iota)$. By reason of its denseness, so Plutarch further explains, the oil (in its movement out of the divers' mouth), pushes and forces the sea aside, which is earthy and irregular (and thus cannot mix with the oil). Afterwards, when the sea flows back to itself and draws together, intermediate passages are left, which provide transparency and clearness to the eyes. What this argument nicely illustrates is how Plutarch aims to criticise Aristotle's theory not necessarily by rejecting it (he considers it a plausible point of departure, after all), but by further elaborating upon it. Aristotle only explained the external aspect of calm $\left(\gamma \alpha \lambda \eta^{\prime} \nu \eta\right)$, as mentioned in the quaestio, whereas Plutarch's second causa deals with the internal

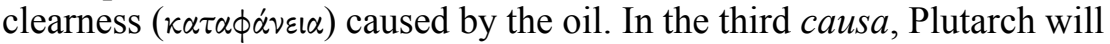
eventually try to combine these two aspects (viz. of $\kappa \alpha \tau \alpha \phi^{\alpha} \alpha \varepsilon \varepsilon \alpha \kappa \alpha i \gamma \alpha \lambda \eta^{\prime} \nu \eta$ ) in an attempt to formulate a complete solution to the problem (I will come back to this argument later [see 4.3.3.I.]).

Another good example where Plutarch makes a genuine attempt at a hybridisation of traditional material with his own innovative insights is found in Q.N. I9, where the octopus' change of colour is central ${ }^{141}$. In the first causa, Plutarch writes that Theophrastus ascribes this change to the octopus' cowardice: fear triggers a physiological process in the body under the influence of the animal's breath. Plutarch considers this

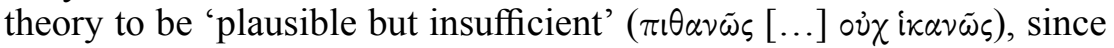
Theophrastus only explains the change of the colour but not its adaptation to the animal's surroundings (this was not, however, mentioned in the quaestio). The incompleteness of Theophrastus' account is illustrated in the second causa, where Plutarch provides two poetical quotations. Pindar and Theognis mention the adaptation of the octopus' colour in their verses, but they do not provide an apposite explanation for the physical mechanism behind this phenomenon. This is not the effect of a deliberate choice, after all, but of underlying physical causes. Plutarch's own theory, which follows in the third causa, sets out on explaining what Theophrastus

${ }^{141}$ For a separate case study of Q.N. I9 in light of Plutarch's argumentative creativity in his natural problems, See M. Meeusen, 20I2a. 
left unsolved (that is the aspect of the colour's adaptation). In so doing, Plutarch refers to Empedocles' theory of emanations and argues that the emanations from nearby objects interlock in the pores of the octopus' skin. The pores contract when the animal feels fear, and, thus, change and adapt the animal's colour. Importantly, at the beginning of his (in all likelihood) personal explanation in the third causa, Plutarch alludes back to Theophrastus' initial theory (viz. fear triggers a pneumatic process in the body) and suggests that it contains 'the starting-point but not the most

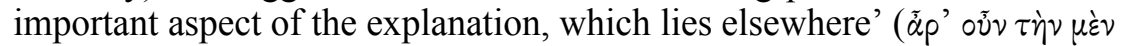

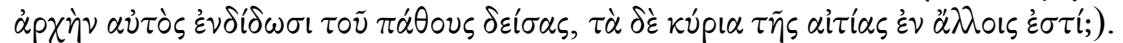
This clearly indicates how a traditional (c.q. Theophrastean) theory again provides an $\dot{\alpha} p x \eta$ for Plutarch's own original contribution to the problem. Plutarch, thus, shows that he aims to complete what Theophrastus left unsolved. To this end, he creatively calls on the authority of the poets and of Empedocles to introduce his own original contribution to the problem.

I conclude that by remodelling traditional theories in a problematised fashion in his natural problems (viz. by remoulding them in the problem format) and simultaneously by looking for original viewpoints, Plutarch, somehow advanced the science of his day one problem at a time. It is at least so that by underlining the innovativeness of some of his explanations he clearly shows that what is to be avoided in solving natural problems is intellectual lazyness (his insistence on providing personal responses to problems more generally is also stressed in De aud. $48 \mathrm{BC}$, as we saw previously [quoted 3.I.2.]). Plutarch's concept of originality may not, however, be as adventurous as some modern scholars may have hoped [see prologue, $\mathrm{n}$. 79]. In fact, his idea of zetetic originality is rather ambivalent: it departs from the tradition, to which it permanently looks back, and at the same time looks forward to new, innovative perspectives ${ }^{142}$. As such, the innovative dynamic in Plutarch's zetetic project is strongly intertwined with the incorporation of traditional material and authority. In almost half of the natural problems collected in Quaestiones naturales, and often more than once in the same problem chapter, Plutarch quotes a wide variety of authorities by name. However, the quotations not only testify to the author's scholarly acumen and $\pi \circ \lambda \nu \mu \alpha \dot{\theta} \theta \varepsilon \alpha$, but they also come in handy for the sake of heuristics itself, in that they provide a useful 'starting-point' $\left(\dot{\alpha} p \times \eta^{\prime}\right)$ for further discussion.

We can now return to where we started from, by stressing Plutarch's scholarly and literate approach in his natural problems. As we have already seen before, the Chaeronean's study of natural phenomena remains situated on a theoretical level, so that it is for a great part detached from what is

${ }^{142}$ For the close relationship between tradition and innovation as a common feature of ancient Greek scientific literature more generally, see, e.g., G.E.R. Lloyd, I987, pp. 50-I08, T.S. Barton, I994a, pp. I49-I52 and J. König, 20II, p. I82. 
positively given in nature itself. As we will see in the following section, this has great repercussions for Plutarch's scientific methodology, and also for a proper understanding of it in light of contemporary philosophical debates. The remainder of this chapter will, therefore, be devoted to an analysis of several aspects of Plutarch's scientific method in solving natural problems in relation to his other natural scientific writings. This will further reveal the world view that Plutarch is promoting in these writings.

\subsection{Plutarch's scientific methodology: a rough guide to explaining natural phenomena}

The main goal of this section is to demonstrate that there are significant correspondences between the aetiological design of Quaestiones naturales and the overall method Plutarch employs in his other natural scientific writings. In analysing Plutarch's scientific approach in his natural problems, I will pay special attention to the following topics: his main attention for the material side of natural phenomena [4.3.I.], the epistemological limits of this type of inquiry [4.3.2.], its logical and rhetorical dynamics [4.3.3.], and the scientific terminology that Plutarch employs in his aetiologies [4.3.4.]. It seems appropriate to treat these more 'technical' aspects of Plutarch's scientific methodology under a separate heading. Nevertheless, the two preceding sections in this chapter are still very relevant for the analysis at hand. After all, a good understanding of Plutarch's dualistic view on causality is seminal for a proper demarcation of the ontological and epistemological backdrop of Plutarch's scientific project. Likewise, the aspect of scientific authority is important for examining the intellectual backdrop of the physical theories and concepts Plutarch employs in his aetiologies. The question as to whether he really envisages a reconciliation between the Aristotelian/Peripatetic and the Platonic/Academic tradition in his natural problems by blending both traditions into his general explanatory scheme will be revisited at the end of this chapter as a means to conclude the first part of this study (the question itself was already raised at the beginning of the first chapter [see I.I.2.]).

\subsection{Material principles and natural processes}

In his natural problems, Plutarch has no ambition to be very precise or 'exact', at least in the sense that his approach is not of a quantitative but of a qualitative kind. He is mainly concerned with theoretical speculations regarding natural substances, their properties and the processes to which they are subject ${ }^{143}$. These substances are often described without any

${ }^{143}$ For an account of the "carattere prevalentemente qualitativo delle relazioni strutturali" in Quaestiones naturales, cf. also L. Senzasono, 2006, pp. 4I-44, esp. pp. 4I-42: 
consideration of what lies at the very heart of them, in terms, for instance, of geometrical solids, atoms or other principles. Moreover, some things in nature simply are 'by nature', which probably hints at an aspect of natural necessity and in most cases does not appear to require any further explanation ${ }^{144}$.

In his natural problems, Plutarch does not carry out any mathematical measurements in order to abstract quantifiable data from physical reality. This modus operandi of taking mathematical measurements was common in other, more exact ancient scientific disciplines, such as geometry, astronomy, acoustics, harmonics, optics, catoptrics, statics, hydrostatics, mechanics, but not in ancient physics, meteorology biology and medicine. In De E $387 \mathrm{~F}$, Plutarch famously states that he was enthusiastically devoted to mathematics during his youth but began to hold to the adage

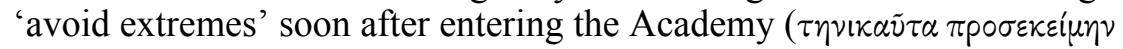

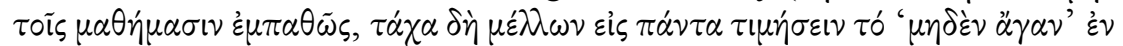

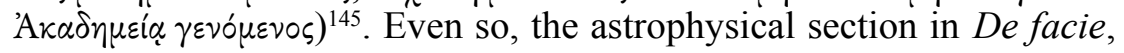
with its references to astronomical theory and calculation (e.g., De facie 935DE), shows that Plutarch's interest in mathematical matters was not completely doused by his conversion to the Academy. Nevertheless, the physical-aetiological parts of his scientific writings clearly outweigh the exact mathematical ones ${ }^{146}$. Notably, in Quaest. conv. $720 \mathrm{E}$, Plutarch's

\footnotetext{
"Si tratta infatti soprattutto di problemi che oggi chiameremmo biologici o fisio-patologici e nel mondo antico in tale ambito di ricerca scientifica non interessavano le relazioni quantitative, diversamente da quanto accadeva in campo astronomico e geografico o comunque dove fosse ritenuta possible una geometrizzazione o matematizzazione della realtà fisica." Senzasono is primarily concerned with the opposition between the qualitative and the, at times, indeed, more quantitative approach of the phenomena in Quaestiones naturales, but unfortunately the former category is not greatly substantiated in his analysis, and the accounts he considers to be exceptions to the qualitative approach may not be that exceptional, as we will see further on. Senzasono does not, moreover, explain Plutarch's qualitative approach in light of his more general scientific method.

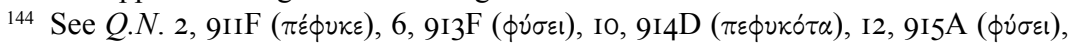
I8, 9I6A ( translation of F.H. Sandbach, I965, p. 227 is rather pregnant: "by a law of nature"). The phrase $\pi \alpha \rho \dot{\alpha} \phi v \dot{\sigma} \nu$ occurs only once (Q.N. 3I, 9I9D). Naturally, such phrases are very

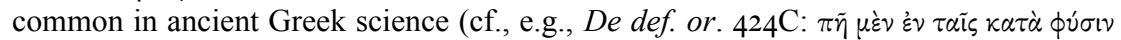

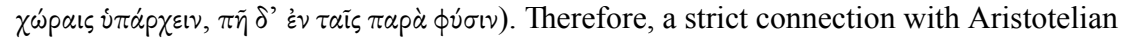
terminology seems unlikely (pace L. Senzasono, 2006, pp. 236-237, n. I82).

145 For discussion of this passage in light of Plutarch's philosophical career, see D. Babut, I994, pp. 556-558 (cf. also J. Opsomer, I998, p. I30). For Plutarch's attitude towards Platonic mathematics more generally, see M. Isnardi Parente, I992. Cf. also L. Senzasono, 2006, p. 42 (with n. 63).

146 The distinction between the mathematical sciences and knowledge related to the sensible world is, indeed, very Platonic. Cf., e.g., Quaest. conv. 7I8DE and 744D.
} 


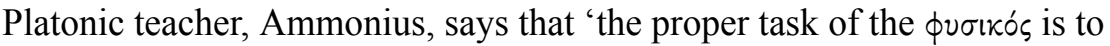

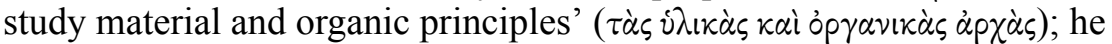
also calls for an investigation of 'the causes which operate by the inevitable

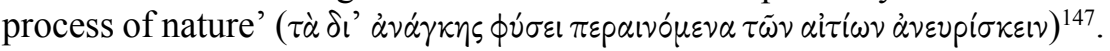
This allows us to analyse in more detail how these aetiological categories figure in Plutarch's Quaestiones naturales.

\section{Material principles}

As to the material principles, which concern the constitutive organisation of physical bodies and their attributes, Plutarch in his natural problems traces all of physical matter to the well-known Empedoclean scheme of the four primary elements (fr. $\mathrm{DK}_{3} \mathrm{IBI}_{\mathrm{I}}$ ), viz. earth, water, air and fire, to which breath $(\pi \nu \varepsilon \tilde{\nu} \mu \alpha)$ is added ${ }^{148}$. These primary elements are pure and

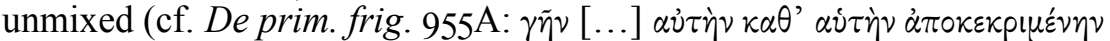
$\tau \tilde{\omega} \nu \ddot{\alpha} \lambda \omega \omega \nu$ ). As such, they function as the elementary building blocks for all composite material bodies that appear in nature (such as blood, seawater, wood etc.). As always, $\pi \nu \varepsilon \tilde{\nu} \mu \alpha$ is a special case. Being the basic result of $\pi \nu \varepsilon \tilde{\nu}$ ('to blow', or 'breathe'), $\pi \nu \varepsilon \tilde{\nu} \mu \alpha$ is essentially air containing a specific motive force (i.e. air in motion) $)^{149}$, but it is also related to fire (Q.N. 32: ignea et spirabilis facultas $)^{150}$. Considering its motive force, $\pi \nu \varepsilon \tilde{\nu} \mu \alpha$ has a lot in common with wind (Q.N. I2, 9I4F-9I5A, I4, 9I5D, I8, 9I6A) and is

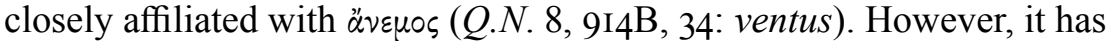
a more 'elementary' value, as it retains its motive force ad infinitum ${ }^{151}$. Therefore, rainwater falling from the sky is imparted not just with air, but with 'air in motion', that is, $\pi v \varepsilon v \tilde{\mu} \alpha(Q . N .2,9 \mathrm{I} 2 \mathrm{AC}, 4,9 \mathrm{I} 2 \mathrm{~F})$. Similarly, in wine, the pneumatic (and the watery) substances are considerably unstable and, thus, inclined to suffer change (Q.N. I0, 9I4D). Plutarch mainly uses

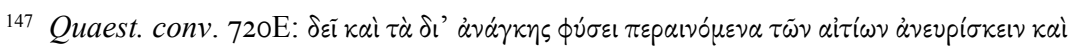

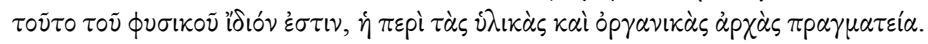

148 The lack of a fully adequate English equivalent for the Greek $\pi \nu \varepsilon \tilde{\nu} \mu \alpha$ is well-known (see F.H. Sandbach, I965, p. I4I and p. I87, n. f, who at times prefers to transliterate the concept). For the scheme of the four traditional elements, cf., e.g., De prim. frig. $947 \mathrm{E}$ and Aqua an ignis 957A. For the five worlds theory and the scheme of the five primary bodies related to it, see $D e E_{3} 89 \mathrm{~F}-390 \mathrm{~A}$ and De def. or. 430A-43IA (with $\alpha i \theta \dot{p} \rho$ instead of $\pi \nu \varepsilon \tilde{u} \mu \alpha$ as the fifth primary body). See G.E. Karamanolis, 2006, pp. I04-I05.

149 Cf. F.H. Sandbach, I965, pp. I40-I4I and L. Senzasono, 2006, pp. I5I-I52, n. I8.

150 Notably, Aristotle describes $\pi \nu \varepsilon \tilde{\nu} \mu \alpha$ as being 'analogous to the element of the stars',

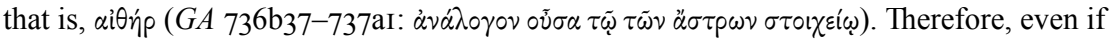
$\alpha i \theta \eta_{\rho}$ is also a fiery substance, it is not simply identical to $\pi \nu \varepsilon \tilde{u} \mu \alpha$ (cf., e.g., De prim. frig. 95ID and Pl., Epin. 98Ic).

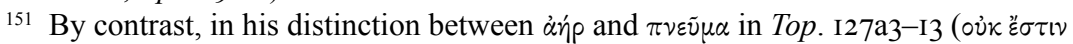

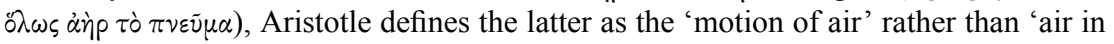
motion' (which has a more elementary value). 
the concept in a material sense in his natural problems ${ }^{152}$. Therefore, the 'breath of life' in the lungs, probably has the same properties as regular $\pi \nu \varepsilon \tilde{\nu} \mu \alpha$ (Q.N. 36: spiritus vitalis). In Q.N. I9, 916BE, the $\pi v \varepsilon \tilde{v} \mu \alpha$ acts as a connector between the octopus' soul and body: the passive impulse of fear in the animal's $\psi v \times y^{\prime}$ triggers an active movement and change in the body by the intermediation of the $\pi \nu \varepsilon \tilde{v} \mu \alpha^{153}$. In this case, Plutarch refers to Peripatetic pneumatology (he quotes Theophr., fr. I88 Wimmer $=365 \mathrm{C} \mathrm{FHSG}$ ), but $\pi \nu \varepsilon \tilde{v} \mu \alpha$ theory had become very common in ancient Greek physics and medicine by Plutarch's time. The pneumatic school of medicine ( $\mathrm{I}^{\text {st }}$ century $\mathrm{AD}$ ) deserves specific mention here; the doctrines of this school (if we may call it that) were congenial to the $\pi \nu \varepsilon \tilde{\mu} \mu \alpha$ theory of the Stoics. The same connection can perhaps also be drawn for the concept of 'transpiration', which implies an active passage of air through an object

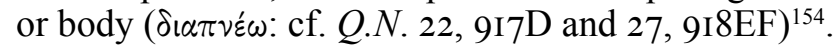

In line with traditional physical theory, Plutarch further specifies the four primary elements (earth, water, air and fire) by the four primary qualities (cf. De prim. frig. $947 \mathrm{E}$ : $\pi$ oló $\eta \tau \varepsilon \varsigma ~ \pi \rho \omega \tilde{\omega} \tau \iota)$, viz. heat, cold, dryness and moistness. Some of these qualities are specifically linked to a physical substance: heat, for instance, is 'innate' to seawater (Q.N. 8, 9I4B: $\sigma \dot{u} \mu \phi v \tau \circ v)^{155}$. To these primary qualities, Plutarch adds a vast number

152 Yet, in other contexts, $\pi \nu \varepsilon \tilde{\mu} \mu \alpha$ has a more 'super-natural' implication, as being "something midway between the material and the spiritual" (H.W. Parke and D.E.W. Wormell, 1956, p. 23). Notably, in De def. or. $437 \mathrm{C}-438 \mathrm{D}$, we read that the $\delta$ v́vaus of the hallucinogenic $\pi v \varepsilon \tilde{\nu} \mu \alpha$ that is released in the vicinity of the Delphic oracle 'comes from the gods and demigods, but, for all that, it is not unfailing nor imperishable nor ageless, lasting into that infinite time by which all things between earth and moon become wearied out,

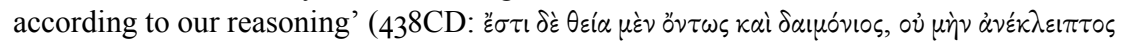

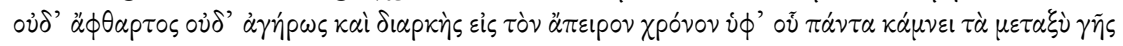

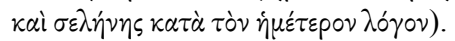

${ }^{153}$ Cf. G. Verbeke, 1945, p. 266: "Cette explication [sc. the third causa in Q.N. I9] est intéressante à notre point de vue parce qu' elle révèle le pneuma comme principe de la vie et du mouvement." Cf. also L. Senzasono, 2006, p. I96, n. 96. Aristotle famously describes $\pi \nu \varepsilon \tilde{\mu} \mu \alpha$ as an öpyavov of the soul, by which movement is imparted to the body (DA 433bir, GA 789b8-9; cf. also esp. $M A$ 703a3-bi). Cf. F.H. Sandbach, I965, p. I4I: "a living being contains air in motion that performs some of the functions that our physiology gives to the nervous system and the hormones".

${ }^{154}$ On Plutarch's conceptualisation of $\pi \nu \varepsilon \tilde{u} \mu \alpha$ more generally, see G. Verbeke, I945, pp. 260-287 (esp. p. 267 for the link with Stoic and medical theory). On pneumatic processes in Ps.-Aristotle's Problems, see M. Meeusen, forthcoming g.

${ }^{155}$ This idea recurs several times in the first section of problems on salt and water in Quaestiones naturales (cf. Q.N. I, 7-IO, I3). Cf. also, e.g., Arist., Mete. 358b6-9. The

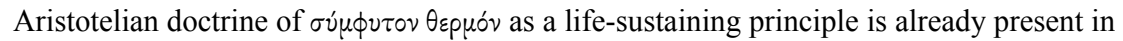
the Hippocratic writings. Cf. also, e.g., Quaest. conv. 635C (with S.-T. Teodorsson, I989, p. 208). 
of secondary qualities ${ }^{156}$ : physical substances can be heavy, light, large, small, transparent, obscure, smooth, rough, firm, loose etc. Moreover, from the primary elements, specific elementary qualities are derived, viz. earthy, watery, airy, fiery and pneumatic. If one or more of these elementary qualities is ascribed to a certain substance, this means that the substance not only contains the qualities of that specific element (either

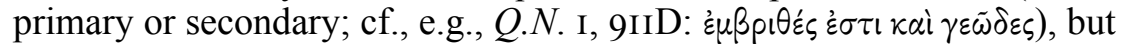
also a share of that element itself. This means that physical qualities have a specific material value for Plutarch.

The elements and qualities are the material fundaments on which Plutarch's natural world, as depicted in his natural problems, is built. They provide a terminological arsenal of concepts that can be freely used in explaining all different kinds of natural phenomena. One issue that deserves special attention here (and that has just been highlighted) concerns the direct association between physical matter and its qualities in Plutarch's natural science. In this regard, Sandbach rightly points out that Plutarch "tends to think of a quality as specifically linked to a substance"157. The opening sentence of De primo frigido illustrates this nicely. Here, Plutarch wonders whether there is a principle of cold, just as fire is of what is hot: nothing has the quality of heat without containing fire, just as nothing can become cold without containing the principle of cold ( $D e$

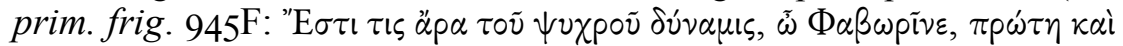

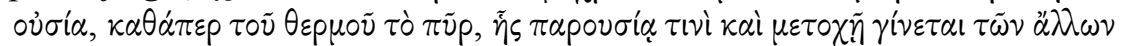

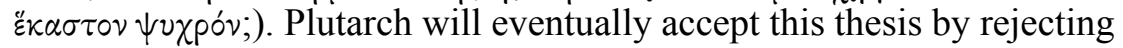
the opposite (Aristotelian) theory that cold is a 'privation' ( $\sigma \tau \varepsilon p \eta \sigma \varsigma)$ of heat, and by arguing that earth is the principle of cold (as opposed to what the Stoics, Empedocles and Strato believed). This is not just a metonymical ingenuity, but a genuine physical scheme that pervades Plutarch's natural scientific writings.

There are numerous instances in Quaestiones naturales where the same link between physical matter and its qualities is clearly present. Plutarch does not, however, apply it to the primary elements and qualities only but also to the compound material bodies constituted by them. In Q.N. I7, $915 \mathrm{~F}$, for instance, the hairs of male horses are considered stronger than those of female horses, by analogy with the general strength in the horses' other body parts: the idea is that the male animal is 'essentially' strong so that it must also have strong hairs, whereas the female is 'essentially' weak so that its hairs must be weak. Similarly, in Q.N. 32, it is argued that the great strength of the palm tree as a whole is also present in its

${ }^{156}$ For the distinction between primary and secondary qualities, cf., e.g., Arist., $P A$ 646ai5.

${ }^{157}$ F.H. Sandbach, 1965, pp. I39-I40. Cf. also L. Senzasono, 2006, p. 38: "la causa materiale o proprietà potenziale deviene termine di una relazione unitaria". 
separate parts, that is, in its trunk but also even in its soft and tender branches and twigs. Seeing that there is no clear distinction between physical matter and its qualities in Plutarch's natural problems, the difference between the particular phrasing of material substances and the qualities is not always crystal-clear either. The ancient Greek language

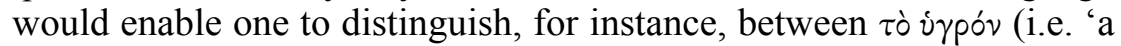
substance characterised by moistness', 'moisture': e.g., Q.N. I, 9IIE) and

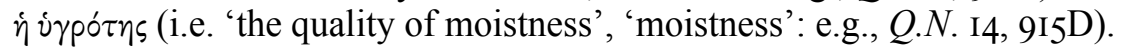
In general, Plutarch complies with this distinction, but his phrasing is not always consistent, because the adjectival phrase ( $\tau$ ò ípóv) occasionally

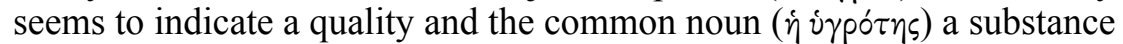
(e.g., Q.N. 4, 9I2F, 3I, 9I9D).

Sandbach made the same observation regarding the notions of $\tau \dot{\partial} \gamma \lambda \nu \kappa u$ (i.e. "a substance characterized by sweetness") and $\dot{\eta} \gamma \lambda \nu \kappa v i \tau s$ (i.e. "the quality of sweetness") ${ }^{158}$. In fact, Plutarch's general concept of the $\chi v \mu o$ í ('flavours') is also illustrative of his tendency to conceive of matter and its qualities in close connection to each other. A flavour can be seen as some kind of liquid (matter) that possesses an intrinsic taste (quality).

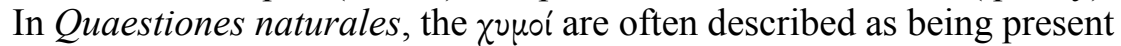
in living beings (not so much in animal beings, though, but in plants: cf. Q.N. 5, 9I3A, C, D, 27, 9I8E) ${ }^{159}$. Despite the fact that rainwater is counted among the $\ddot{\alpha} \chi v \mu \alpha$ in $Q . N .2,9 \mathrm{I} 2 \mathrm{~B}$, it is considered sweet, since it contains water with an inherent sweet taste (Q.N. 2, 9I2C, 9, 9I4C). Sandbach understands from Q.N. 2, 9I2C that 'the 'sweetness' of rainwater is a separable constituent, though doubtless far the largest, which can be caused to leave it and enter into a plant"160. Sandbach presumably puts sweetness in inverted commas to hint at the material-in-combination-withthe-qualitative aspect of the sweet flavour present in rainwater (indeed, Plutarch speaks of $\tau \dot{\partial} \gamma \lambda \nu x \dot{v} \tau \tilde{\omega} \nu$ ó $\mu \beta p i \omega \nu)$. However, rainwater also contains several other material elements and qualities, so it is not 'pure' (i.e. it is not simply identical to a sweet flavour, but just contains it). A little bit

158 F.H. Sandbach, I965, pp. I39-I40.

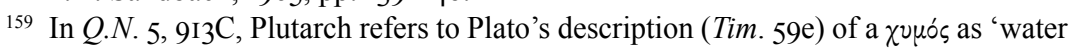

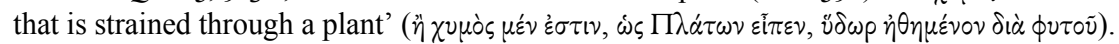
See LSJ, s.v. i: "juice of plants". Notably, in Quaestiones naturales, Plutarch does not use this concept in relation to Hippocratic humoral theory, that is, in relation to the presence of 'humours' in animal bodies (cf. W.H.S. Jones, I923, pp. xlvi-li). This does not imply, however, that he has no notion of humoral theory whatsoever (in Q.N. I, 9IIE, for instance, he reports that fever turns moisture into bile). F.H. Sandbach, I965, p. I40 translates $\chi v \mu o$ í not simply as 'flavours', but as 'flavourings', by which he presumably refers to liquids giving off a certain taste (rather than to actual spices or aromas; pace L. Senzasono, 2006, pp. I68-I69, n. 40 and p. I72, n. 45).

160 F.H. Sandbach, I965, p. I40. 
earlier in Q.N. 2, 912A, for instance, Plutarch argues that 'rainwater is

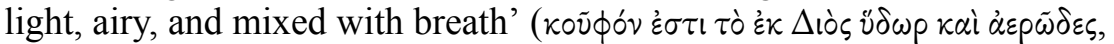

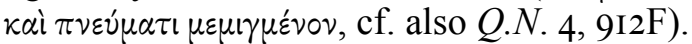

Similar to sweet rainwater, salty seawater, is not 'pure' either. In Q.N. I, 9IICF, Plutarch draws attention to several material aspects of seawater in an attempt to explain why it does not provide nourishment to trees: he argues that seawater is thick, heavy and earthy (causa I), that it has a drying effect (causa 2), contains a fatty, oily content (causa 3 ) and is undrinkable and bitter by an admixture of burnt earth (causa 4 ). From other accounts in Quaestiones naturales we learn that seawater has numerous other attributes. It contains not only bitter but also sweet drinkable water, because many rivers empty out into the sea, but the sweet water, which is light and lies at the surface, evaporates by the heat of the sun (Q.N. 9 , 9I4C). Likewise, when a thunderbolt strikes seawater, the sweet water is expelled immediately, leaving only salt crystals behind (Q.N. 40). Seawater also contains innate heat (see n. I55), it is transparent, earthy and heavy (Q.N. 8, 9I4B), and a certain amount of air is also mixed with it (Q.N. I2, 9I5A).

Clearly, for Plutarch, there is no material purity in the natural phenomena we perceive around us, since physical bodies contain more than only one element or quality. The material substances that appear in nature are rather conceived of as being complex compounds of different primary elements and a multitude of primary and secondary qualities connected to them. This idea has direct repercussions for the aetiological design of Plutarch's physical aetiologies. It allows him to apply a variegated focus in the explanations that he provides and to freely differentiate between a myriad of physical attributes and properties, with the feature of argumentative plausibility being the only criterion to be taken into account. There is at some points, however, also a certain aspect of regularity in Plutarch's explanations of natural phenomena, insofar that specific elements and qualities are more or less consequently and repetitively attributed to specific material bodies. Seawater, for instance, contains a heavy, earthy component and is hot, as we saw (cf. Q.N. I, 9IID, 5, 9I3C, 7, 9I4AB, $8,9 \mathrm{I} 4 \mathrm{~B}, \mathrm{IO}, 9 \mathrm{I} 4 \mathrm{D})$. The air in the atmosphere is also hot and transparent because it is full of sunlight and fire (cf. Q.N. I2, 915A, 39, De facie 930F). Yet, despite there being fixed concepts of this sort, Plutarch still allows a degree of aetiological flexibility in applying them in his explanations (I will come back to this later [see 4.3.3.I.]). For instance, in Quaest. conv. $652 \mathrm{~B}$, he is found extemporising ( $\left.\alpha \dot{\tau} \tau \circ \sigma \chi \varepsilon \delta \iota^{\prime} \sigma \alpha \iota\right)$ that the $\delta \dot{v} v \alpha \mu \iota s$ of wine is actually cold, whereas, normally a hot $\delta \dot{v} v a \mu$ s is attributed to $\mathrm{it}^{161}$.

${ }^{161}$ Cf. Q.N. I0, 9I4D, 3I, 9I9C, Quaest. conv. 70IF. Cf. also, e.g., Ps.-Arist., Probl. 87ra2. The argument in Quaest. conv. 652B is inspired by Pyrrhonic scepticism. 
Another important point is that Plutarch often draws specific attention in his explanations to opposite elements and qualities in a material body or natural process. Not infrequently, he focuses on specific binary oppositions in the natural phenomena that he tries to explain. In Q.N. 20, for instance, he deals with the sweet taste of the tears of wild boars as opposed to the salty and ordinary ones of those of deer. In the first causa, Plutarch explains this on the basis of the hot and cold character of both animals respectively: the natural heat in wild boars melts the salty particles in their tears so that they become sweet, whereas no such process takes place in deer, due to their natural coldness. The second causa focuses on the composition of the blood of both animals, from which the tears (according to Empedocles) are discharged: the blood of wild boars is rough and black owing to their heat, whereas that of deer is thin and watery, and the taste of the tears, which are secreted from the blood, depends on these opposite qualities. The focus on such binary oppositions is a relatively common explanatory strategy in ancient science more generally ${ }^{162}$. In Plutarch's case, it can be related to his belief that there are opposite forces at work in natural bodies ${ }^{163}$. This polarity of natural forces does not, of course, fragment Plutarch's world view. By contrast, he accepts that the order of nature is actually based on such oppositions, which are themselves kept in check by the demiurgic ordering of the universe ${ }^{164}$.

\section{Natural processes}

While the material principles are concerned with the constitutive organisation of physical bodies in terms of elements and qualities, natural processes, on the other hand, concern the changes and movements to which these bodies are subject. The process of change is expressed in Quaestiones naturales with such terms as $\mu \varepsilon \tau \alpha \beta \alpha \dot{\lambda} \lambda \omega$ ( $\mu \varepsilon \tau \alpha \beta 0 \lambda \eta \dot{)}), \dot{\varepsilon} \xi i \sigma \tau \eta \mu$ or $\tau \rho \varepsilon \dot{\pi} \omega \omega$. The terminology, of course, tends to be more specific in many cases. Apart from the basic alterations and phase transitions of material bodies (as expressed with a range of concepts, such as $\chi \nu \lambda o^{\prime} \omega, \tau \eta^{\prime} \kappa \omega, \psi \dot{\gamma} \chi \omega, \pi \varepsilon p i \psi \psi v-$

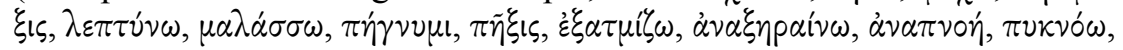
$\pi \dot{v} \kappa \nu \omega \sigma l \varsigma)^{165}$, the processes of generation $\left(\gamma^{\prime}(\gamma \nu \sigma \mu \alpha \mathrm{l}, \gamma \varepsilon \nu \nu \tilde{\alpha} \omega, \gamma \varepsilon v \varepsilon \sigma \iota \zeta)\right.$, corrup-

162 See G.E.R. Lloyd, 1964 and I966, pp. I5-I7I.

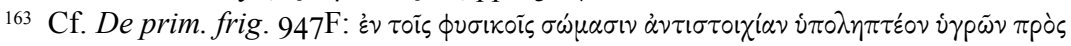

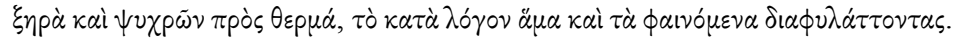

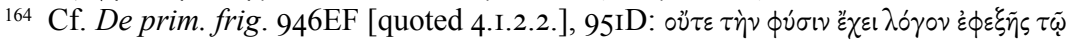

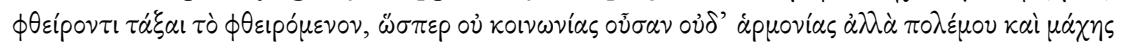

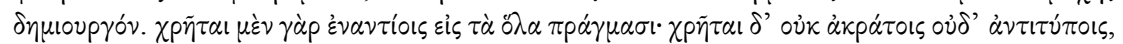

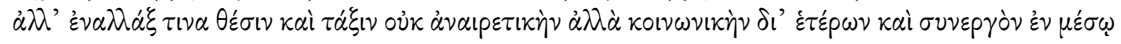

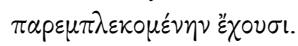

165 Some material substances appear in nature in several physical states: the substance 


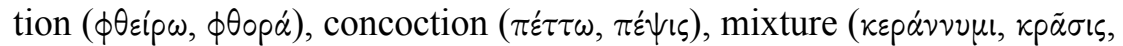
$\dot{\alpha} \nu \alpha \dot{\mu} \mu \xi \xi \zeta)$ and concentration of opposites $(\dot{\alpha} \nu \tau i \pi \varepsilon p i \sigma \tau \alpha \sigma i \varsigma)$ are also relevant here. The latter three concepts may require some further elucidation.

Generally speaking, concoction $(\pi \dot{\varepsilon} \psi(\zeta)$ is a physical process by which a material substance is generated out of another substance by means of heat. In the case of plants or animals (Q.N. 33: stirpibus et animantibus [...] concoquatur $)^{166}$, it is often the nourishing subtance that is concocted into an assimilate substance by means of natural heat (but external heat can also trigger this process: Q.N. 4, 913A, 27, 918E). Concoction does not only refer to the digestion of food (Q.N. 2, 9I2B, 22, 9I7D), but also, for instance, to the conversion of grape juice into wine (Q.N. 27, 9I8E). It is identified with the process of putrefaction (in Q.N. 2, 9I2C: $\sigma \tilde{\eta} \psi(\varsigma)$ ), but this last point is, as Sandbach points out, "contrary to the standard Aristotelian opinion that distinguishes these two processes, the former $\left[\pi \varepsilon^{\prime} \psi(\varsigma]\right.$ being the formation of a substance, effected by natural internal heat, the latter $[\sigma \tilde{\eta} \psi(\varsigma)$ its destruction, due to alien external heat"167. Even so, there are obvious parallels between Plutarch's and Aristotle's notion of concoction (and, similarly, also that of non-concoction, $\dot{\alpha} \pi \varepsilon \psi i \alpha: Q . N$. 2, 9I2B). Yet, the concept is not, therefore, specifically Aristotelian in kind, since concoction is a standard process in ancient Greek physical theory more generally (in fact, Aristotle himself borrowed this concept from medical literature) $)^{168}$.

The same is true for the notion of $k p \tilde{a} \sigma \varsigma^{169}$, which basically refers to a process of mixture or blending (Q.N. $23,917 \mathrm{E}, 27,9 \mathrm{I} 8 \mathrm{E})$. It is often used in a more specific sense, viz. as the material result of such a process ${ }^{170}$. When

of salt, for instance, is constitutive of salt liquids (e.g., the salt flavour in seawater and in tears), but it also occurs in a solid state (e.g., salt licking stones and salt crystals).

${ }^{166}$ Cf. L. Senzasono, 2006, p. 240, n. I9I: "Il verbo concoquere, dato il suo uso tecnico, del quale il Longolio era certo cosciente [he was a physician], con ogni probabilità corrisponde a $\pi \dot{\varepsilon} \tau \tau \varepsilon \iota \nu$ del testo originale perduto."

${ }_{167}$ F.H. Sandbach, I965, p. I57, n. a. See Arist., Mete. 379bio-38ib23 for an account of concoction and non-concoction and their various species. On decay, see Mete. 379ail-b9.

168 See F.H. Sandbach, 1965, p. 138. For concoction in the Hippocratic writings, see W.H.S. Jones, I923, pp. li-lii (cf. esp. De prisc. med. I8-I9). According to L. Senzasono, 2006, p. I53, n. 20, Plutarch may rely on both Aristotle and medical authors for this concept.

169 See A.L. Peck, 1965, pp. lxxv-lxxvii. Cf. also J. Boulogne, 2006/7, pp. 3-4. The

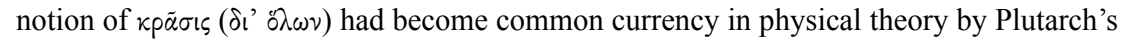

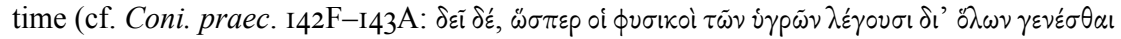

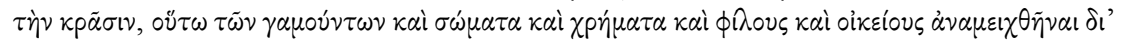
$\dot{\alpha} \lambda \hat{\eta} \lambda \omega \nu$ : cf. Antipater of Tarsus, SVF 3, p. 255, fr. 63, I5).

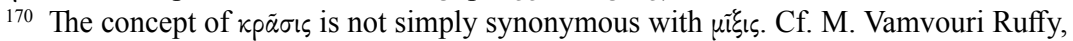
20I2, p. I25: "la mixis est le mélange des éléments, la krasis la fusion qui s' ensuit". Cf.

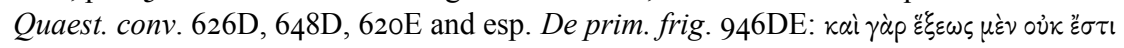

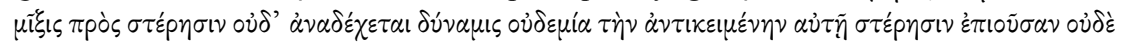


used, for instance, in reference to the soil (Q.N. $16,915 \mathrm{E}), \kappa_{p} \tilde{\alpha} \sigma \varsigma \zeta$ refers to the composition of the ground in terms of the different material elements and qualities that are blended in it (not simply earth). In regards to the mixing of the principles of heat and cold (e.g., in the air), the concept of кp $\tilde{\sigma} \sigma \varsigma$ can be translated as our modern 'temperature' or, more specifically, 'climate' (Q.N. 4, 9I3A, 3I, 9I9D) ${ }^{171}$. The notion of kp $\tilde{\sigma} \sigma \varsigma s$ is also used in regards to the bodies of animals (Q.N. 26, 9I8DE), thus referring to the blending of their bodily constituents and qualities ${ }^{172}$. In this sense, $к \rho \tilde{\alpha} \sigma \varsigma \varsigma$ is best translated as 'constitution' or 'composition', which is synonymous with 'condition' (Q.N. 26, 9I8E: $\left.\delta \imath^{\prime} \theta \varepsilon \sigma / \varsigma\right)$. This constitution is variable in living beings, and it is not the same in sickness as in health ${ }^{173}$.

The process of $\dot{\alpha} \tau \tau i \pi \varepsilon p i \sigma \tau \alpha \sigma i \varsigma$ involves the concentration of one of two opposites ( $\left.\dot{\alpha} \nu \tau i^{-}\right)$by the other, which surrounds and encloses it ( $\left.\pi \varepsilon \dot{i}^{-}\right)$. Only the nomen actionis ( $\dot{\alpha} \nu \tau i \pi \varepsilon p(i \sigma \tau \alpha \tau \alpha)$ ) is referred to in Quaestiones naturales, viz. in Q.N. 13 , 915 $\mathrm{B}^{174}$, where Plutarch relies on Theophrastus (fr. I63 Wimmer $=$ I73 FHSG) in arguing that coldness in the winter season overwhelms the heat that is present in the seawater, so that the latter is concentrated and enclosed at the bottom of the sea (the phrase $\kappa \alpha \tau \alpha \kappa \lambda \varepsilon i \varepsilon \tau \alpha l$

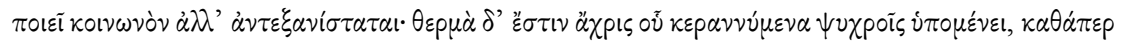

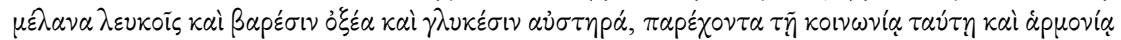

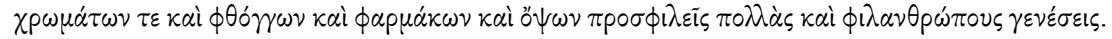

171 Notably, Book I4 of Ps.-Aristotle's Problems, entitled ö $\sigma \alpha \pi \varepsilon p \grave{~ к р \alpha ́ \sigma \varepsilon ı \varsigma, ~ m o s t l y ~ d e a l s ~}$ with problems concerning climate. As F.H. Sandbach, 1965, p. I39 notes, "whereas we do not normally remember that by etymology 'temperature' means 'blending', and regard a

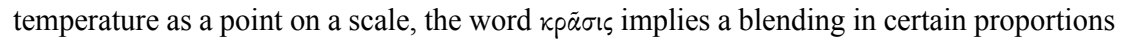
of absolute heat with absolute cold". The use of thermometers, as we know them today, did not exist in Antiquity, and temperatures were not measured in a quantitative fashion (i.e. in units of $\mathrm{K},{ }^{\circ} \mathrm{F},{ }^{\circ} \mathrm{C}$ etc.), if they were measured at all. It is not unlikely that such a quantitative approach would even have seemed outlandish to Plutarch, who himself conceives of kpã $\sigma$ ls as a blending of proportionate amounts of heat and cold (cf., e.g., Quaest. conv. 649D and De prim. frig. 946DE; quoted n. 170). For a history of the thermometer and of thermometry more generally, see W.E.K. Middleton, I966. Galen was the first to describe heat and cold in a numeric fashion. The earliest Greek writings about the expansion of air by heat were composed by Philo of Byzantium and Heron of Alexandria.

${ }^{172}$ Notably, Plutarch does not explicitly refer to the Hippocratic blending of humours ( $\left.\chi \nu \mu 0^{\prime}\right)$ in the body in Quaestiones naturales (see n. I59).

${ }^{173}$ Cf., e.g., Galen, Temp. I, 509, I-4 Kühn. P.J. van der Eijk, 20I3, p. I88 (with

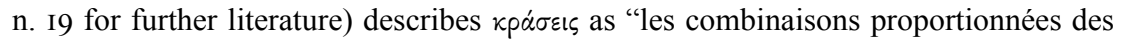
quatre qualités et les modalités de leur variation, qui déterminent les différences dans la constitution physique entre les corps humains et les corps des animaux et les variations entre les individus humains".

174 See L. Senzasono, 2006, pp. I87-I88, n. 78 (this term is not recorded under the heading of "scientific vocabulary" by F.H. Sandbach, I965, pp. I38-I4I, probably because it is not "recurrent" in our collection). It seems that the physical process of $\alpha \nu \tau i \pi \varepsilon p i \sigma \tau \alpha \sigma i \varsigma$ is not always mentioned by name (cf., e.g., Q.N. 27, 9I8EF and Quaest. conv. 694DE). 


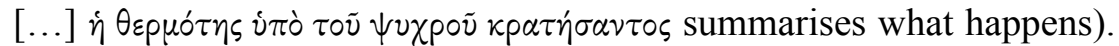
The concept of $\dot{\alpha} \nu \tau i \pi \varepsilon p i \sigma \tau \alpha \sigma ı \zeta$ has a strong Peripatetic connotation (it is also attested in Ps.-Aristotle's Problems) ${ }^{175}$, but has its roots, as Opsomer has shown, in the Platonic theory of $\pi \varepsilon$ i $^{\omega} \omega{ }^{1 \zeta^{176}}$. Additionally, the concept of $\pi \varepsilon p i \psi v \xi_{i \varsigma}$ is closely related to that of $\dot{\alpha} \nu \tau i \pi \varepsilon p i \sigma \tau \alpha \sigma \iota \zeta$, by the notion of enclosure or surrounding ( $\pi \varepsilon p i-)$. By this process, a substance is solidified by the influence of cold around it $(Q . N .7,913 \mathrm{~F}, \mathrm{I0}, 9 \mathrm{I} 4 \mathrm{D}, 25,9 \mathrm{I} 8 \mathrm{~B}$; cf. $D e$ prim. frig. 949B).

Apart from the natural processes that involve material change, Plutarch also mentions an abundance of processes that involve an aspect of spatiality and are often mechanical in kind. These again embrace a multitude

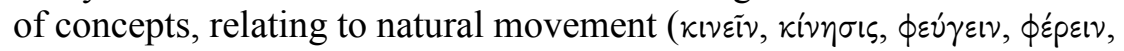

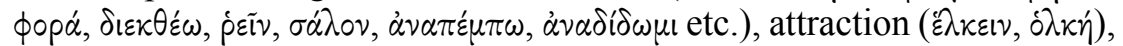
contraction ( $\left.\sigma \nu \gamma \kappa \circ \pi \eta^{\prime}\right)$, dilatation $(\delta 1 \alpha \sigma \tau \dot{\varepsilon} \lambda \omega \omega)$, collision $\left(\pi \lambda \eta \gamma \eta^{\prime}\right)$, dissipation

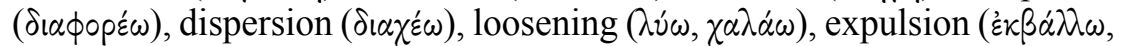
$\dot{\varepsilon} \kappa \pi \dot{\varepsilon} \mu \pi \omega, \dot{\varepsilon} \xi \omega \theta \dot{\varepsilon} \omega)$, insertion ( $\dot{\varepsilon} \mu \beta \dot{\alpha} \lambda \lambda \omega)$ etc. The theories of emanations and

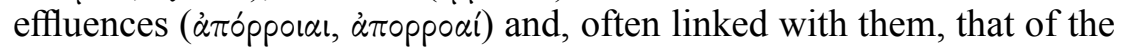
pores ( $\pi$ ópol), deserve specific consideration here. These concepts have an Empedoclean touch but had become more generally used in physical theory by Plutarch's time ${ }^{177}$ (also especially via the atomist movement) ${ }^{178}$.

175 See H. Flashar, I962, pp. 328-329. Cf. also, e.g., Arist., Mete. 348 b2 (with H.D.P. Lee, 1952, pp. 82-83, n. b).

176 J. Opsomer, 1999. Aristotle in De respir. 472b6-473aI4 comments on the Platonic theory of breathing as formulated in Tim. 79a-8oc, where the process of $\pi \varepsilon p i \omega \sigma \iota$ is central. In order to remain as close as possible to the wording of his source, Aristotle mostly uses the original Platonic terminology ( $\pi \varepsilon p i \omega \sigma \iota \zeta, \pi \varepsilon p i \omega \theta \varepsilon i v)$, but in $472 b I 6$ the Aristotelian concept occurs $(\dot{\alpha} \nu \tau i \pi \varepsilon p u \sigma \tau \alpha \mu \dot{\varepsilon} v \omega \nu)$. Plutarch comments on the same Platonic passage in Quaest. Plat. 7, I004D-I006B, where we find a combination of Platonic (I004E: $\pi \varepsilon p$ and Aristotelian terminology (I004D: $\alpha \nu \tau \iota \pi \varepsilon p i \sigma \tau \alpha \sigma \iota v)$, which at times results in peculiar

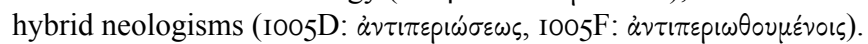

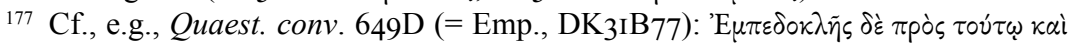

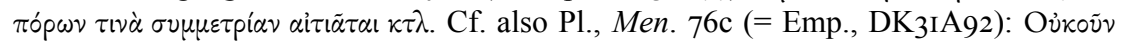

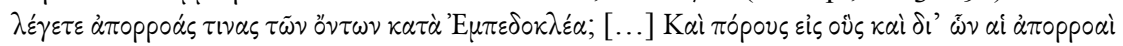

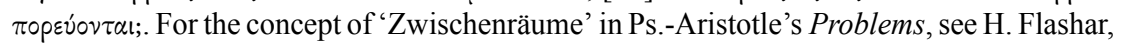
I962, p. 330. For the use of the concept of $\pi$ ópor in a medical context, cf., e.g., Quaest. conv. 687 BC (with S.-T. Teodorsson, I990a, pp. 24I-243). In Quaest. conv. 689BC, Plutarch

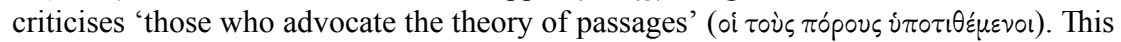
is probably an allusion to the followers of Asclepiades of Bithynia, who founded the methodic school in medicine.

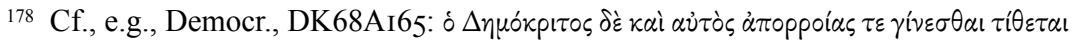

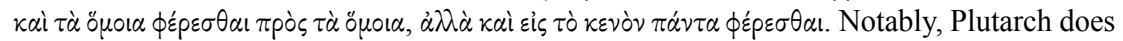
not connect the concept of pores with a notion of к'́vov (vacuum) in Quaestiones naturales. He emphatically rejects the existence of the void in Quaest. Plat. I004DE (following Plato) and in De def. or. $424 \mathrm{D}$ (following Aristotle). Its existence is not necessarily implied,

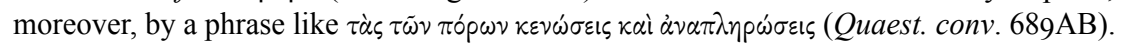


In Q.N. 19, 916D, Plutarch relies on Empedocles in arguing that there are particles emanating from all objects, either animate or inanimate

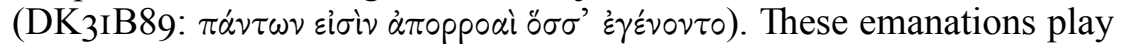
an important role, for instance, in processes related to sense perception (Q.N. 23, 9I7 E, Quaest. conv. 680F-68IA) and in bodily processes more generally, such as the octopus' metachrosis (Q.N. I9, 9I6CF). Pores, on the other hand, are empty interstices in animate or inanimate bodies through which matter can pass. In the case of animals and plants they refer to the pores in the skin $(Q . N$. 19, 9I6EF) or in the body $(Q . N .3,912 \mathrm{DE}, 5$, 9I3D, 3I, 9I9D). When they are mentioned in relation to the earth (Q.N. 2, 9IIF) or seawater (Q.N. I2, 9I5A), they are more naturally translated as 'passages', 'ducts' or 'channels'.

The emanations hover freely and can pass trough the pores of certain substances or lodge themselves in the ones with which they are commen-

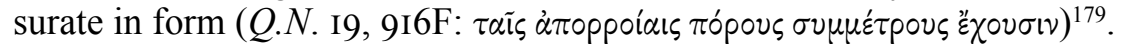
If there is no commensuration, the emanations are blocked off or slip off the surface of the substance. There is a more abstract, geometrical motivation here, which takes into account the form of both the emanations and the pores. It is important to add, however, that Plutarch phrases this in approximate rather than in exact mathematical terms. For instance, in regards to the octopus' metachrosis (Q.N. I9, 9I6BF), he argues that the skin of the creature contains many pores in which many minute particles ( $\mu \varepsilon \dot{p} \eta \kappa \alpha i \theta p \alpha v \dot{\sigma} \mu \alpha \tau \alpha \pi 0 \lambda \lambda \dot{\alpha} \kappa \alpha i \lambda \varepsilon \pi \tau \dot{\alpha})$ that are continually detached from the rocks by the seashore can settle. These fragments slip off the surface of animals that have narrower pores or pass quickly through those that have

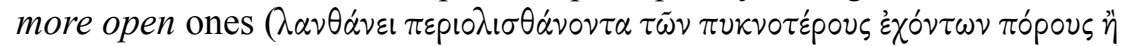
$\delta 1 \varepsilon k \theta \varepsilon \dot{\varepsilon} \circ \tau \tau \tau \tau \tilde{\omega} \nu \mu \alpha \nu \circ \tau \varepsilon$ p $0 \nu \varsigma)$, but the octopus has a flesh which is obviously honeycombed ( $\alpha \nu \theta p \eta \nu i \omega \delta \delta \zeta)$, so that it offers places for these particles to

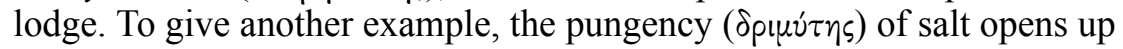
the passages in the bodies of animals and thus better prepares the way for the food to be distributed (Q.N. 3, 9I2D). By contrast, such passages

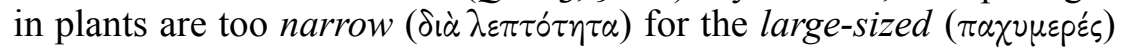
earthy constituents of salt to pass through $(Q . N .5,913 \mathrm{D})$. In the same way, unmixed wine penetrates the roots of vines that are sprinkled with it, con-

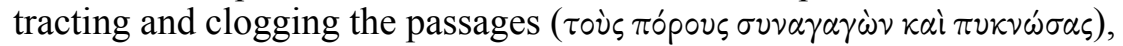
so that water cannot enter into the plant (Q.N.3I, 919D). Thus, we see that the basic geometrical motivation of the emanations and the pores never becomes very exact. This ties in closely with Plutarch's more generally qualitative rather than quantitative approach in his natural problems, as highlighted earlier on.

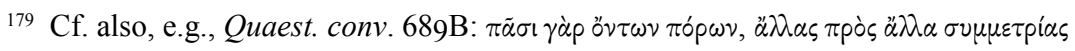
$\dot{\varepsilon} \chi o ́ v \tau \omega \nu \kappa \tau \lambda$. 
Indeed, when the description of natural processes involves a variable amount ( $\pi \circ \sigma o ́ \tau \eta s)$ of material qualities, Plutarch mostly formulates this in relative terms (c.q. by means of comparatives). In Q.N. 9, 9I4 BC, for instance, he connects the relative bitterness and sweetness of seawater with the variable effect of the sun's heat in the summer and in the winter, respectively. He explains that seawater is more bitter in the summer, insofar that the heat of the sun removes the sweet parts of the seawater. Likewise, it is less bitter (and thus sweeter) in the winter, when the sun has a gentler effect. To give another example, in Q.N. 8, 914B, Plutarch argues that seawater becomes warmer when agitated insofar that heat is innate to it, but that this is not true of all other liquids, which grow colder. As Senzasono notes, there is no attempt to mathematise this proportion in terms of numerical quantities ${ }^{180}$. Only in an exceptional case does Plutarch refer to a physical change in an absolute fashion, that is, in terms of numeric quantities. This is the case in Q.N. 7, 9I4A, where Plutarch records a hydrostatic account from Theophrastus (fr. I6I Wimmer $=2 \mathrm{I} 4 \mathrm{C}$ FHSG). He writes that the weight ratio of a vessel filled with water from a certain source on Mt. Pangaeum in Thrace depends on the season: the vessel weighs twice as much in the winter as it does in the summer ( $\dot{\varepsilon} \nu \delta \dot{\varepsilon} \Theta p \dot{\alpha} k n$

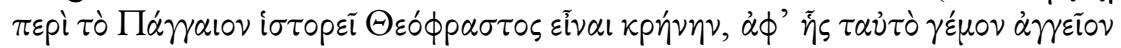

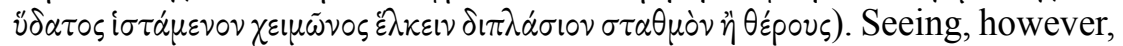
that Plutarch simplifies the numbers from Theophrastus' account - the original weight ratio would be 96 to 46 (cf. Ath., Deipn. 2, 42b = fr. I59, I5-2I Wimmer $=2 \mathrm{I} 4 \mathrm{~A}, \mathrm{I} 3-\mathrm{I} 7 \mathrm{FHSG}$ ) - , it is clear that he is primarily referring to the water's relative quality of heaviness vis-à-vis lightness in relation to the seasonal temperature rather than to its exact mass density. Therefore, this account should not be seen as an exception to Plutarch's qualitative approach ${ }^{181}$.

In conclusion, for Plutarch, natural science as the causal study of natural phenomena is not an exact, but rather a conjectural science ${ }^{182}$. Explaining natural phenomena in the immediate world around us - that is, in the sublunary region, as opposed to those situated in the astronomical realm - is a matter of estimation rather than calculation, and of gentle persuasion rather than rigorous proof and demonstration. Therefore, the exact mathematisation of physical reality was not a common procedure in Plutarch's physical aetiologies, and the same is true for the Ps.-Aristotelian

${ }^{180}$ L. Senzasono, 2006, p. 43: "non c'è tentativo di matematizzare in termini numerici il rapporto".

181 Pace L. Senzasono, 2006, p. 44.

${ }_{182}$ It is comparable, at least from a methodological perspective, to the $\sigma \tau \circ \chi \alpha \sigma \tau$ ik $\alpha i$

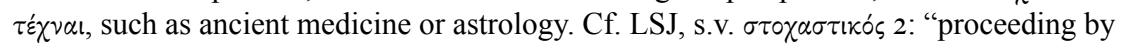
guesswork" (e.g., Pl., Philebus 55e). Cf. T. Barton, I994a, p. I6 (with n. 57) and I994b, p. 7. For medicine as a 'stochastic art', see K. Ierodiakonou, 1995. 
Problems, in which he found his model ${ }^{183}$. Plutarch does not carry out any exact measurement of physical data in his natural problems ${ }^{184}$. Even in those cases in Quaestiones naturales which tend toward mathematical quantification, the quality of the material substances and natural processes remains central. Notably, there are no references in Plutarch's natural problems to Plato's solids and their geometric formations ${ }^{185}$. Presumably, no further abstraction of the natural elements and their qualities was necessary in order to properly explain what is happening in the immediate world around us. In the end, a speculative consideration of the working of natural processes in the world suffices to attain a certain level of plausibility in the aetiologies. The idea that natural science provides a conjectural body of knowledge is very seminal for Plutarch's scientific method and will be further substantiated in the following section in light of his adherence to Platonic natural philosophy. In line with Plato, Plutarch did not consider the object itself that was being studied - that is, nature to be ontologically stable. In this way, it could not provide indisputable and steadfast knowledge from an epistemological perspective either.

\subsubsection{Towards the limits of natural science}

As is well-known, the study of natural phenomena is for Plutarch intrinsically bound with his Platonic world view ${ }^{186}$. Accordingly, the ontological distinction Plutarch makes between the sensible and intelligible realms

${ }^{183}$ Book I5 of Ps.-Aristotle's Problems does concern mathematical topics, albeit in a

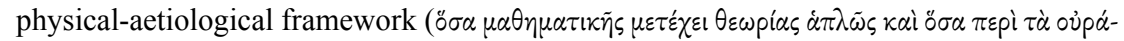
$v(\alpha)$. For the distinction between natural and mathematical problems, cf., e.g., De aud. ${ }_{43} \mathrm{C}$.

${ }^{184}$ For the natural philosopher's (Platonic) disdain for the use of geometrical instru-

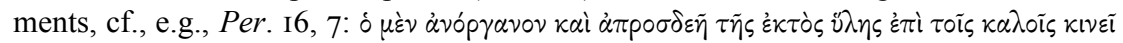

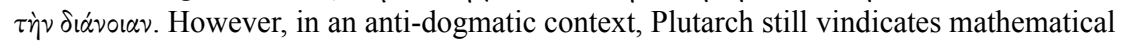
calculation by means of geometrical instruments, because he prefers this approach to plain

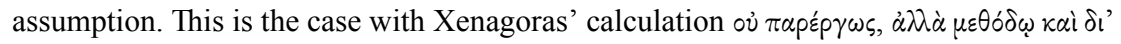
op $\gamma \dot{\alpha} \nu \omega \nu$ of the height of Mt. Olympus as opposed to the dogmatic attitude of the geometers, who believe that no mountain or sea can be higher or deeper than ten stadia (Aem. Paul. I5, 9-II). See J. Boulogne, 2008, p. 748: “Ce rationalisme pondéré d' un scepticisme de méthode dénote une méfiance indiscutable à l'égard de la raison et de ses spéculations théoriques, susceptibles à la fois d' errements et de progrès. C'est pourquoi Plutarque incline à accorder, de façon pragmatique, plus volontiers sa confiance à l' expérience qu'à la spéculation pure [...]". For Plato's influence on Plutarch in this regard, see R. Flacelière, J. Irigoin, J. Sirinelli and A. Philippon, I987, pp. 1xx-lxxiii and M. Isnardi Parente, 1992.

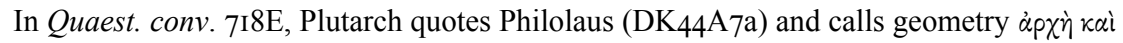
$\mu \eta \tau p o ́ \pi 0 \lambda ı \varsigma$ of the other scientific disciplines.

${ }_{185}$ On Plutarch's concept of geometric atomism, see J. Opsomer, 2015.

186 The literature on this topic is vast and has accumulated exponentially in the last decades. Generally useful are J. Opsomer, 1998 and 2005. For a recent overview with further literature, see also G.E. Karamanolis, 2010 and P. Donini, 20II, pp. 27-40. 
has an immediate epistemological implication, taking effect in an analogous distinction of corresponding levels of explanation [see 4.I.2.]. In Plato's cosmology, the sensible world we live in is seen as a world of becoming that is never truly existent (Tim. 27d-28a). Sensible objects are created, perpetually in motion, subject to the processes of generation and corruption, and they are only apprehensible by 'opinion in addition

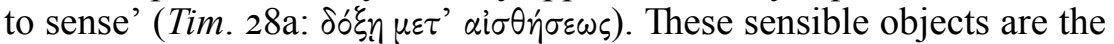
second-rate likenesses or images of the real, intelligible world of the forms, which, themselves, are self-identical, ungenerated, indestructible, and perceived by mind alone (vónбıs: Tim. 52a, 92c). In the Timaeus, Plato famously gives probabilistic reasoning an important place within the field of natural philosophy. Timaeus describes his own account as a

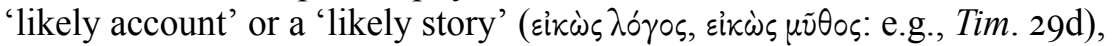
which is often interpreted as being programmatic for Plato's own study of natural phenomena ${ }^{187}$. In order to foreground the same epistemological backdrop in Plutarch's natural problems, this section will draw a closer link between Plutarch's 'sceptical' approach in natural science and what influence it draws from Plato and the Platonic tradition. This will also bring into consideration Plutarch's evaluation and use of data pertaining to sense perception and the role of autopsy.

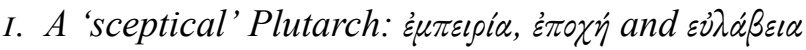

In accordance with Plutarch's dualistic view on causality [see 4.I.2.], the world of natural phenomena is subordinated to a higher realm of intelligibles, and the same holds true for the kind of knowledge that the study of these different realms yields. Even though Plutarch occasionally highlights the importance of $\dot{\varepsilon} \mu \pi \varepsilon i i^{\prime} \alpha$ and $\alpha i \sigma \theta \eta \sigma \iota s$ in studying natural phenomena and even prefers serious observation to theoretical speculation, this can by no means be generalised ${ }^{188}$. Plutarch's problem with data pertaining to sense perception is that they often procure unreliable knowledge. This idea shines through on several occasions in the natural

187 According to F.M. Cornford, I937, pp. 28-29 (see also pp. 28-32 more generally) this implies "that there can be no exact, or even self-consistent, science of Nature. [...] There is $[\ldots]$ no exact truth to which our account of physical things can ever hope to approximate". See also more recently D.J. Zeyl, 2000, pp. xxxii-xxxiii (p. xxxii: "Probably what Plato means is that within the constraints in which the story must be told something like this account is the most plausible one can hope for."), T.K. Johansen, 2004, M.F. Burnyeat, 2009 and L. Brisson, 2012.

${ }_{188}$ Cf., e.g., Quaest. conv. 64IC (with D. Lehoux, 2003), 699D, 725C, De facie 933A, C, De soll. an. $975 \mathrm{DE}$. For the idea that theory should be squared with fact according to

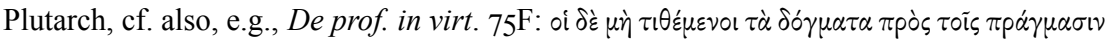

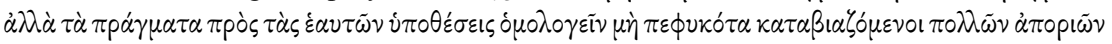
$\dot{\varepsilon} \mu \pi \varepsilon \pi \lambda \dot{\eta} \kappa \alpha \sigma \mathrm{\tau} \tau \dot{\eta} \nu \phi i \lambda \circ \sigma \circ \phi i \alpha \nu$. 
problems treated in Quaestiones convivales ${ }^{189}$. For instance, in regards to Chaeremonianus' report that he actually saw a tiny fish, the remora,

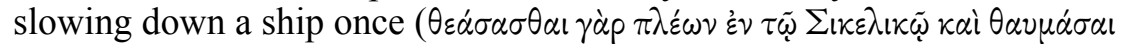

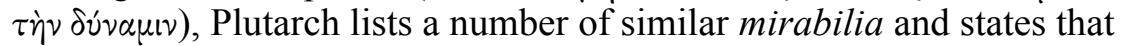
'these phenomena are, indeed, obvious to the senses but it is not easy, if not entirely impossible to explain them' (Quaest. conv. 64IC: $\tau 0 v$ $\tau \omega \nu$

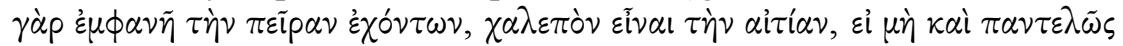
$\dot{\alpha} \delta \dot{v} v \alpha \tau o v, \kappa \alpha \tau \alpha \mu \alpha \theta \varepsilon i v)$. In what follows, he explains that we should not mistake the effect for the cause in this case: it is not so much the remora that slows down the ship, but rather the seaweed that sticks to the hull of the ship and that attracts this tiny fish. This reflects on the value of Chaeremonianus' initial report (i.e. his autopsy claim), revealing its basic unreliability. What the passage shows, then, is that sensory data are very valuable for scientific research, but that they are at least equally unreliable.

Another relevant passage is found at the end of Quaest. conv. $697 \mathrm{~F}-$ $700 B$, where Plutarch personally defends Plato's contested view that drink passes through the lungs (Tim. 70c, 9Ia) ${ }^{190}$. Plutarch ascribes great probability to a set of arguments that he draws from sense perception (Quaest. conv. 699D: $\dot{\varepsilon} \kappa \tau \tilde{\eta} s \alpha i \sigma \theta \dot{\eta} \sigma \varepsilon \omega \varsigma$ ), among which he especially emphasises the bodily function of the lungs and bladder in processing liquids. He remains cautious, though, and adds that such knowledge is uncertain, especially because the subject itself is obscure (Quaest. conv. 700B):

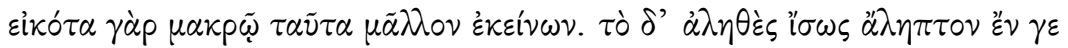

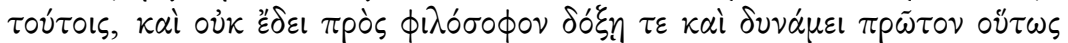

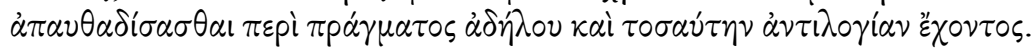

This (sc. corroboration from sense perception) is far more probable than the other accounts. Certainty, however, is doubtless ${ }^{191}$ unattainable in questions of this sort; and it was wrong to make such a rash attack, in a matter which is obscure and admits of so many contrary arguments, against a philosopher pre-eminent in reputation and in influence (i.e. Plato).

This passage clearly illustrates Plutarch's high opinion of Plato, Platonic doctrine and Platonic epistemology (c.q. his sceptical attitude towards natural phenomena and observational data). The idea that natural phenom-

\footnotetext{
189 See, e.g., Z. Abramowiczówna, I962, pp. 83-84.

190 Cf. the parallel in De Stoic. rep. I047CD.

${ }_{191}$ F. Frazier and J. Sirinelli, I996, p. 22 translate ' $\sigma \omega \varsigma$ as "peut-être", but the "sans doute" of D. Babut, I994, p. 573 is stronger.
} 


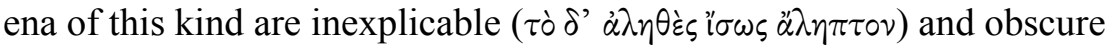
$(\alpha \delta \eta \lambda \alpha)$ is of great significance, since Plutarch makes a very similar conclusion at the end of his argumentation in De prim. frig. 955C. Here we find the famous $\dot{\varepsilon} \pi \circ \chi_{\eta}$ statement, which is a locus classicus in the debate on Plutarch's epistemological framework ${ }^{192}$.

In De primo frigido, Plutarch discusses the problem of whether cold is a privation of heat or has a principle of its own, and prefers the second option (cf. also Q.N. 29, 9I9AB). After criticising several theories on the principle and primary element of cold in a doxographical fashion, he expounds his own view according to which the element of earth is the most likely candidate. Plutarch concludes his study with an exhortation to Favorinus, to whom the treatise is dedicated ${ }^{193}$. In order to anticipate Favorinus' evaluation of the new theory, he declares that suspension of judgement ( $\left.\dot{\varepsilon} \pi \circ \gamma_{\eta}\right)$ is the right philosophical position in such matter $(D e$ prim. frig. 955C):

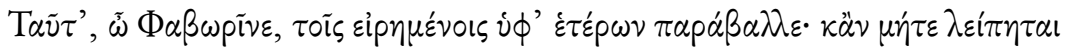

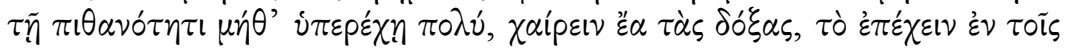

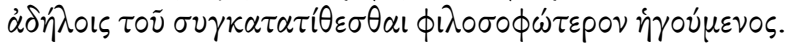

Compare these statements, Favorinus, with the pronouncements of others; and if these notions of mine are neither less probable nor much more plausible, say farewell to opinion, in the belief that it is more philosophic to suspend judgement when the truth is obscure than to take sides.

A very fundamental, philosophical dynamic lies at the basis of the finale of De primo frigido, which originates from Plutarch's sincere epistemological conviction that inferior knowledge ( $\left.\delta \sigma^{\xi} \xi \alpha\right)$ springs from an ontologically inferior object $(\phi \dot{\sigma} \sigma \varsigma)^{194}$. Plutarch aims to demonstrate that firm knowledge cannot be attained from natural phenomena, because they pertain to the

192 See, e.g., J. Opsomer, I998, pp. 2I3-22I, and more recently P. Donini, 20II, pp. 3I-35, esp. p. 32 (with further references) and G. D'Ippolito and G. Nuzzo, 20I2, pp. 65-68.

193 Favorinus, the famous philosopher of Arelate, dedicated a work to the Chaeronean,

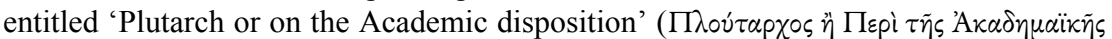

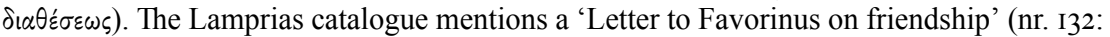

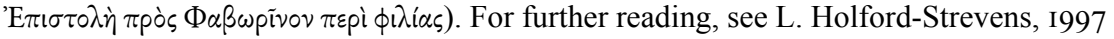
and J. Opsomer, 1997 and I998, pp. 213-240.

${ }^{194}$ It is unlikely that in the finale of De primo frigido Plutarch is playing along with

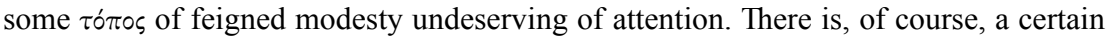
feature of modesty at play here, but this is not just a rhetorical strategy that Plutarch is deploying $a d$ hoc in an attempt to render his own theory more digestible for Favorinus. Cf., e.g., the ending of De defectu oraculorum, where the author suggests to postpone the discussion to another time (438D: $\left.\tau \alpha \tilde{v} \theta^{\prime} \dot{v} \pi \varepsilon p \kappa \varepsilon i \sigma \theta \omega\right)$. 
level of sense perception, and are, therefore, essentially obscure and uncertain. Thus, they cannot grant any evident comprehension.

For a better understanding of the concept of $\dot{\varepsilon} \pi \dot{\varepsilon} \chi \varepsilon \varepsilon \nu$ in this closing comment, we should take a closer look at De prim. frig. 948BC earlier on. In this passage, Plutarch (after leaving the question of whether cold has a principle of its own, and before starting to inquire which principle this may be) incorporates a seminal paragraph, where he demarcates the domain of natural philosophy from that of the crafts on the basis of the different procedures followed by their practitioners. The passage is worth quoting in full:

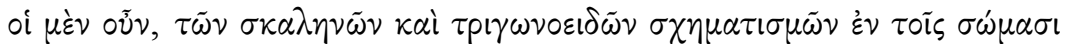

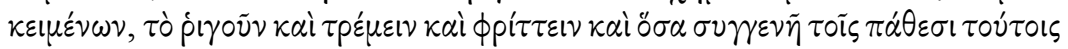

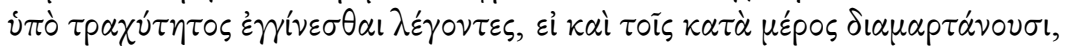

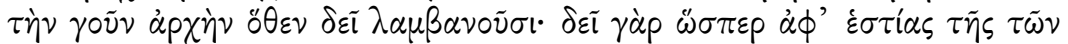

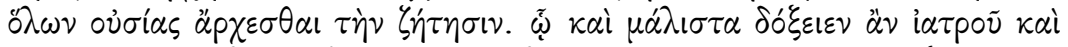

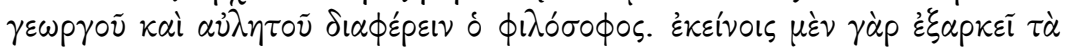

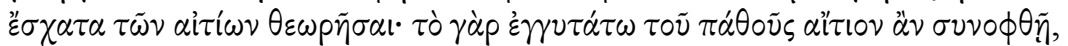

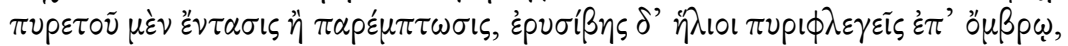

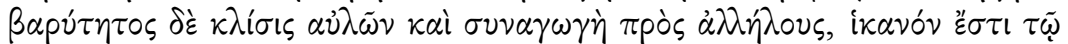

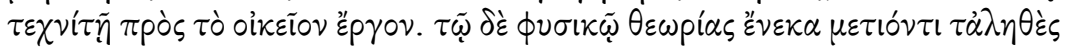

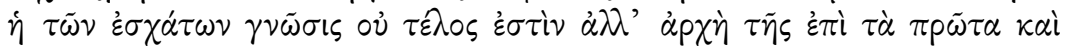

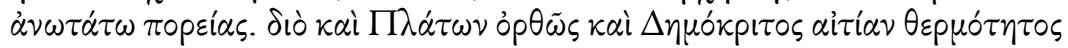

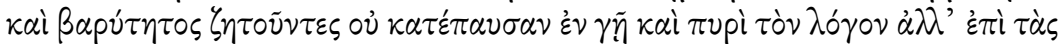

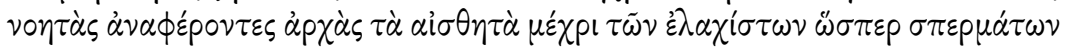
$\pi p \circ \tilde{\eta} \lambda \theta 0 v$.

Now those who affirm that there are certain uneven, triangular formations in our bodies and that shivering and trembling, shuddering and the like manifestations, proceed from this rough irregularity, even if they are wrong in the particulars, at least derive the first principle from the proper place; for the investigation should begin as it were from the very hearth, from the substance of all things. This is, it would seem, the great difference between a philosopher and a physician or a farmer or a flute-player; for the latter are content to examine the causes most remote from the first cause, since as soon as the most immediate cause of an effect is grasped - that fever is brought about by exertion or an overflow of blood, that rusting of grain is caused by days of blazing sun after a rain, that a low note is produced by the angle and construction of the pipes - that is enough to enable a technician to do his proper job. But when the natural philosopher sets out to find the truth as a matter of speculative knowledge, the discovery of immediate causes is not the end, but the beginning of his journey to the first and highest causes. This is the reason why Plato and Democritus, when they were inquiring into the causes of heat and heaviness, were right 
not to stop their investigation with earth and fire, but to go on carrying back sensible phenomena to rational origins until they reached, as it were, the minimum number of seeds.

The study of natural phenomena, as conducted either by the natural philoso-

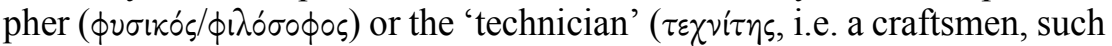
as a doctor, farmer or musician), departs from the material object. But while the 'technician' limits his research to the immediate, natural causes, the natural philosopher continues his intellectual pursuit further upwards

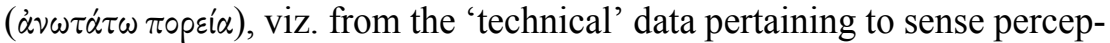

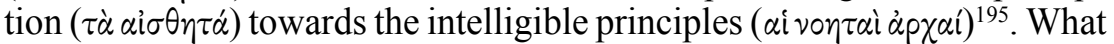
this passage makes clear, then, is that the discovery of the natural causes provides only the beginning ( $\left.\dot{\alpha} p \times \eta^{\prime}\right)$ for an investigation into the higher, intelligible causes ${ }^{196}$. Therefore, 'technical' knowledge can be considered a first step towards natural philosophical contemplation $\left(\theta \varepsilon \omega \text { pí }^{\prime}\right)^{197}$ [see 3.2.2.]. This is, of course, seminal in light of Plutarch's 'technical' inquiry into the natural causes in his natural problems. Even though each type

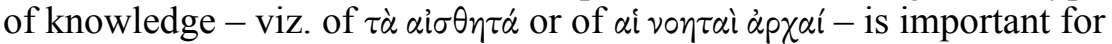
natural philosophical contemplation $(\theta \varepsilon \omega p i \alpha)$, the former category remains subordinated to the latter. Even the use of a more abstract and theoretical approach - viz. by invoking Democritus' atoms and Plato's triangles ${ }^{198}$

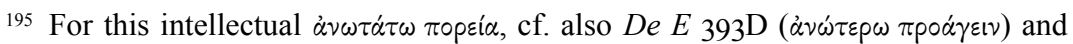
$A d v$. Col. ${ }_{11}{ }_{5} \mathrm{E}$ ( $\dot{\alpha} \nu \omega \tau \dot{\varepsilon} \rho \omega \delta$ ' o $\pi p \circ \tilde{\eta} \lambda \theta 0 \nu$ ). These passages are rightly interpreted in light of Plutarch's adherence to Plato by G. Roskam, 20IIb, p. 60 (see also G.E. Karamanolis,

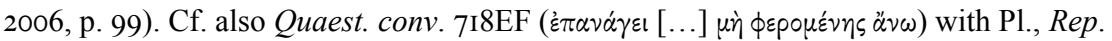

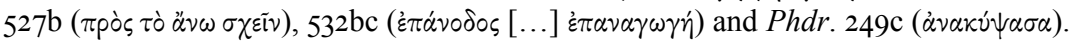

196 See P. Donini, I986a, pp. 2I0-2II, J. Opsomer, 1998, pp. 2I5-2I6. For the distinction between $\tau \dot{\varepsilon} \chi v \alpha \iota$ and $\dot{\varepsilon} \pi\llcorner\sigma \tau \tilde{\eta} \mu \alpha \iota$ in this passage and its importance for Plutarch's philosophical thinking, see L. Van der Stockt, I992b, pp. 29I-293, esp. p. 292: "It seems that all that is needed here is a further distinction between what we call science and ... philosophy!" In

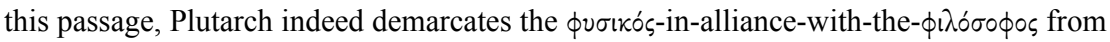

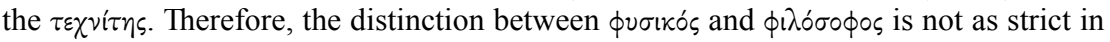
this passage as G.E. Karamanolis, 20I0 suggests: "This is what, for Plutarch, demarcates the philosopher from the mere natural scientist [...], a distinction much exploited by later Platonists [...]."

${ }^{197}$ For Plutarch's use of $\theta \varepsilon \omega$ pí $\alpha$ in the sense of theoretical contemplation, with specific applications in the fields of physics, mathematics, geometry, theology and psychology, cf. E. Kechagia, 20IIa, p. 87, n. 22. For Aristotle's ruminations on the relation between $\dot{\varepsilon} \mu \pi \varepsilon ı p^{\prime} \alpha, \tau \dot{\varepsilon} \chi \nu \eta$ and $\dot{\varepsilon} \pi \imath \tau \eta^{\prime} \mu \eta$, see, e.g., Met. 981aff.

198 The reference is, indeed, to Plato's geometric atomism (see n. I85), not to his intelligible forms (see G. Boys-Stones, I997a, p. 227, n. 2, whose attack on Donini was countered by D. Babut, 2007, p. 79, n. 49). It may seem to some that Plato's theory of triangular formations is implicitly criticised in De prim. frig. 948B (Plutarch initially writes oi $\mu \dot{\varepsilon} \nu$, but Plato's name eventually appears in 948C). In any case, this strategy of 
will not eventually suffice, in Plutarch's opinion, to get at the bottom of things, because he knows that there still is a higher, primary, and, by implication, divine seed: this is 'the godly harmoniser and musician', who, as we saw earlier on, orders all things in the universe (De prim. frig.

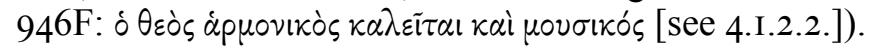

Notably, in the doxography on the principle of cold that immediately follows, Plutarch takes a deliberate step downwards on the ladder of ontology/epistemology, by arguing that 'it is better to first attack things perceptible to the senses in which Empedocles, Strato and the Stoics locate

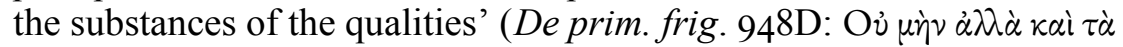

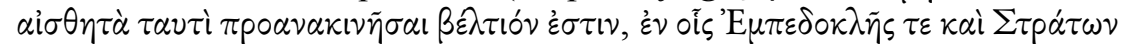

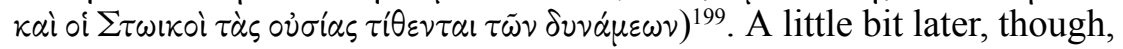
Plutarch reminds us that the senses are unreliable, because 'they often

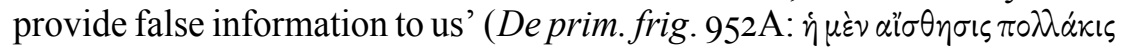
$\dot{\eta} \mu \tilde{\alpha} \varsigma \dot{\varepsilon} \xi \alpha \pi \alpha \tau \tilde{\alpha})^{200}$. What Plutarch is implying in the finale of De primo frigido (955C), then, is that one should remain cautious when confronted with physical $\delta \delta^{\prime} \xi_{l}$ - including the one he puts forward on his own personal account -, because these concern a sensible object that is essentially obscure ( $\ddot{\delta} \delta \lambda\rangle \nu)$. Natural phenomena are inherently obscure $(\ddot{\alpha} \delta \eta \lambda \alpha)$, because they are ever-changing. As we can learn from several passages, for instance, throughout De E apud Delphos, only God is in the full meaning of the word. Everything else in this world is subject to a continuous

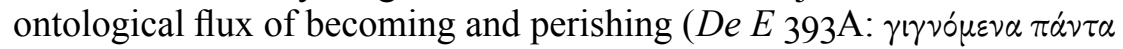

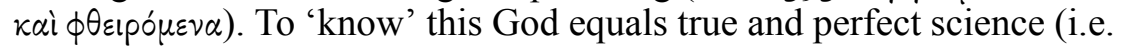
$\dot{\varepsilon} \pi\left\llcorner\sigma \eta^{\prime} \mu \eta\right)$, which is, however, unattainable by the human intellect, or at least not in this life. True philosophy is primarily concerned with genuine knowledge ( $\left.\dot{\varepsilon} \pi \iota \tau \eta^{\prime} \mu \eta\right)$ and not with mere opinion $\left(\delta \delta^{\prime} \xi \alpha\right)$, which is

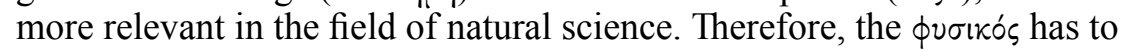
manage with probable accounts and explanations, but what is plausible from one perspective, may seem less plausible, or even implausible from another. This probably explains why Plutarch presents his own personal theory about the principle of cold (identifying it with the element of earth) from the very outset as being persuasive and plausible, while Chrysippus

implicit criticism occurs on several other occasions in the Moralia (see D. Babut, 1994, p. 574, with n. I37, and 1969, p. 95, with nn. 5-6; cf. also 2007, p. 79). However, Plutarch's criticism of Plato is not fundamental. After all, what matters most for Plutarch's argument is that Plato (and Democritus with him), as opposed to the technicians, who simply settle for an examination of the immediately perceptible natural causes, sets a good example by pursuing a higher mode of explanation. This is an issue of scientific method rather than orthodoxy. Cf. J. Opsomer, I998, pp. 217 and 22I, with n. 26.

199 For this deliberate 'step downwards', see also P. Donini, I986a, p. 2II and J. Opsomer, I998, p. 2I6, n. II.

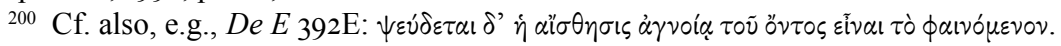


rejected it as being utterly unadmissable and absurd (De prim. frig. 952D:

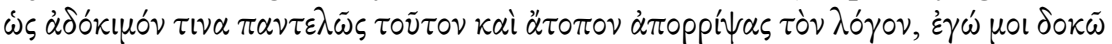

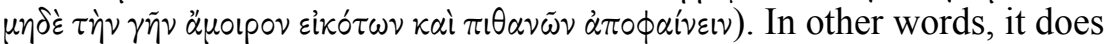
not really matter whether Favorinus considers Plutarch's $\delta o^{\prime} \xi \alpha$ 'neither less probable nor much more plausible than that of others' ( $\kappa \ddot{\nu} \nu \mu \eta^{\prime} \tau \varepsilon \lambda \varepsilon i$ in $\eta \tau$ l

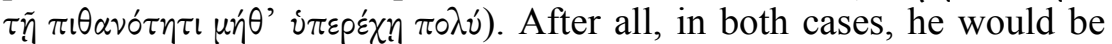
dealing with an inferior category of relative probability, and not with the absolute category of steadfast knowledge suitable for a true philosopher. Therefore, in matters pertaining to natural science, that is, in matters that are essentially unclear and conjectural, suspension of judgement ( $\left.\dot{\varepsilon} \pi \circ \gamma_{\eta}\right)$ is a more philosophical attitude than taking sides.

Plutarch's notion of suspension of judgement in natural scientific matters $\left(\dot{\varepsilon} \pi \circ \chi \eta^{\prime}\right)$ ties in closely with his intellectual caution in divine matters $(\varepsilon \dot{u} \lambda \dot{\alpha} \beta \varepsilon ı \alpha, \dot{\alpha} \sigma \phi \dot{\alpha} \lambda \varepsilon 1 \alpha)^{201}$. These concepts are closely affiliated with each other in that they both originate from an aporetic awareness that the philosopher cannot eventually attain certain or true knowledge in physical or divine matters respectively ${ }^{202}$. Plutarch often relates this cautious attitude to the Delphic imperatives to I) 'avoid extremes' ( $\mu \eta \delta$ 'े $\nu$

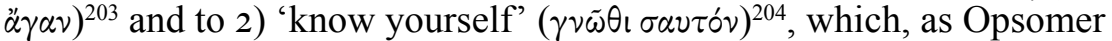
has shown, have both an Academic and a religious connotation for $\operatorname{him}^{205}$. I) As we saw earlier on, the extremes that should be avoided

201 J. Glucker, I978, p. 268 argued (pace P.H. De Lacy, I953, pp. 83-84) that the concept

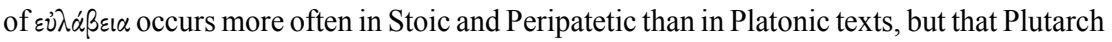
may have "lifted" the word and some of its meanings from the Stoic terminology in order to use it in a Platonic context.

202 P. Donini, I986a, pp. 205 (with n. II), 209 and 2I2-2I3 (cf. also 20IIb, pp. 34-35) has argued that there is a strict difference in meaning between $\varepsilon \dot{\nu} \lambda \dot{\alpha} \beta \varepsilon 1 \alpha(\dot{\alpha} \sigma \phi \dot{\alpha} \lambda \varepsilon เ \alpha)$ and $\dot{\varepsilon} \pi \circ \chi \dot{\eta}^{\prime}$. He distinguishes I) $\dot{\varepsilon} \pi \circ \chi \dot{\eta}$, which concerns opinions based on evidence from the senses, from 2) caution in the domain of the sciences and 3) $\varepsilon \dot{\nu} \lambda \dot{\alpha} \beta \varepsilon i \alpha$, which implies a cautious attitude towards divine matters. The distinction between I) and 2) was later rejected by D. Babut, 1994, p. 573 and J. Opsomer, 1998, p. 218 (cf. also pp. 178-I86). Donini remarks, moreover,

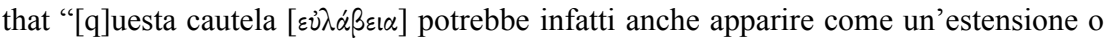

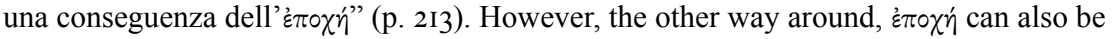

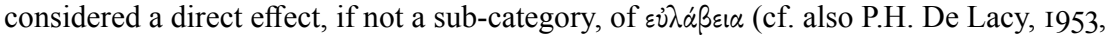
p. 83). Either way, Donini was the first to show that both concepts are closely connected in Plutarch's epistemology and that they have seminal importance for his philosophical method.

${ }^{203}$ See Cam. 6, 6 [quoted 4.I.I.3.], Sept. sap. conv. I63D [quoted 4.I.I.I.], I64B, De E 387F, De Pyth. or. 408E, De def. or. 43IA, De gar. 5IIB.

${ }^{204}$ See De ad. et am. 49AB, 65E, De cap. ex inim. 89A, Cons. ad Apoll. II6D, Sept. sap. conv. I64B, De E 385D, 392A, 394C, De Pyth. or. 408E, De gar. 5IIB, Adv. Col. III8C, Lamprias catalogue nr. I77.

${ }^{205}$ J. Opsomer, I998, p. I85. For the proverbial value of these Delphic maxims, see also J.A. Fernández Delgado, I99I, pp. 207-208. 
are those of eager credulity and incredulity in the context of things that are unclear (mostly divinely inspired mirabilia [see 4.I.I.3.]). 2) Selfknowledge, on the other hand, should lead a true philosopher to maintain an aporetic attitude in his inquiries, much like Socrates did in Plato's dialogues ${ }^{206}$. Philosophy is, after all, a continuous zetetic pursuit of the truth, for Plutarch, whose only philosophical dogma is the infallibility of Platonic doctrine. Accordingly, there are obvious sceptical overtones in Plutarch's writings, but, as recent scholarship has shown, this does not necessarily imply that Plutarch considered himself a full-blooded Academic Sceptic, rather than a true-hearted Platonist ${ }^{207}$. Plutarch certainly appreciated the Academic Sceptics' anti-dogmatic attitude in philosophy, but at the same time he still uncritically valued Plato's doctrines as well.

Plutarch's attitude towards the Academic Sceptics and their scientific method is, indeed, positive: he is well affiliated, for instance, with their notions of $\dot{\varepsilon} \pi \circ \times \dot{\eta}$ (suspension of judgement), $\dot{\alpha} \kappa \alpha \tau \alpha \lambda \eta \psi \dot{\alpha} \alpha$ (impossibility of infallible apprehension) and $\dot{\alpha} \phi \alpha \sigma^{\prime} \alpha$ (abstention from expressing a personal opinion $)^{208}$. He even personally defends the Academic Sceptics and the method that they employ against the Epicureans and the Stoics, which is not a mere polemical strategy to assail his personal adversaries ${ }^{209}$. On the contrary, he actually considers the Academic Sceptics important authorities in the wider Platonic tradition, to which he himself adheres ${ }^{210}$. Furthermore, there is an obvious sceptical undertone in Plutarch's own writings, as the $\dot{\varepsilon} \pi \circ \chi_{\eta}$ statement in De prim. frig. $955 \mathrm{C}$ clearly illustrates.

\footnotetext{
${ }^{206}$ Cf., e.g., De ad. et am. 72A, Adv. Col. III7D with P1., Phdr. 229e, Charm. I64eI65a.

207 Some scholars have seen an Academic Sceptic in Plutarch, or at least noted a great influence of the New Academy on his thinking (especially so on the basis of the $\dot{\varepsilon} \pi \circ \chi \eta \dot{~ s t a t e m e n t ~ i n ~ D e ~ p r i m . ~ f r i g . ~ 955 C) . ~ S e e, ~ e . g ., ~ J . ~ S c h r o e t e r, ~ I 9 I I, ~ J . J . ~ H a r t m a n, ~ I 9 I 6, ~}$ pp. 253-254, K. Ziegler, I95I, col. 856, H. Cherniss and W.C. Helmbold, I957, p. 227, H. Görgemanns, I970, pp. 86-89, J. Glucker, I978, pp. 287-288, J. Dillon, I988, p. I07, n. 9, D. Babut, 1994. More recent scholarship emphasises that Plutarch's debt towards the Academic Sceptics should not be exaggerated in favour of a more basic Platonic stance. See, e.g., P.H. De Lacy, I953, pp. 83-84, R.M. Jones, I980, pp. I8-I9, P.R. Hardie, I992, p. 4754, A.M. Ioppolo, 2004, p. 3IO, F. Ferrari, 2005, p. 384, J. Opsomer, I998, 2009, p. I69, P. Donini, 2002, pp. 250-25I, 27I-272, 20II, pp. 3I-35, M. Bonazzi, 20I4, J. Dillon 2014.

${ }^{208}$ For $\dot{\pi} \pi \circ \chi^{\prime}$, see Sext. Emp., $H P$ I, 3I ff.; for $\dot{\alpha} \kappa \alpha \tau \alpha \lambda \eta \psi \dot{i} \alpha, H P$ I, 200-20I; for $\alpha \dot{\phi} \alpha \sigma^{\prime} \alpha$, $H P$ I, I92-I93.

${ }^{209}$ Cf., e.g., $A d v$. Col. II24B. See, e.g., D. Babut, I969, pp. 276-284, G. Boys-Stones, I997b, J. Opsomer, I998, pp. 84-I05, 2005, p. I75, E. Kechagia, 20IIb, pp. 305-3II.

${ }^{210}$ Plutarch vindicated the unity of the Platonic Academy in a lost treatise listed in

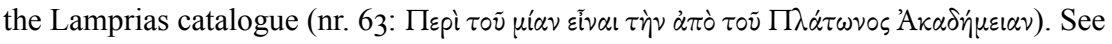
P. Donini, I994b, pp. 5064-5073, D. Babut, 1994, p. 550, n. 9, 2007, J. Opsomer, I998, pp. 59-60, I7I ff., 2005, p. I69.
} 
In the following section, I will examine this in further detail for the natural problems treated in Quaestiones naturales by focusing on how Plutarch's (generally) sceptical attitude features in the aetiologies at hand. To this end, I will first analyse the categories of $\tau \dot{o} \pi \imath \theta \alpha \nu$ ó and $\tau \dot{o} \dot{\alpha} \lambda \eta \theta \dot{\varepsilon} \varsigma$. Afterwards, I will also take into consideration the argumentative role he ascribes to knowledge pertaining to sense perception and also the issue of autopsy.

\section{Truth and probability in Quaestiones naturales}

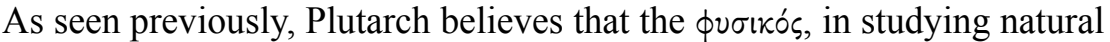
phenomena, can only formulate plausible opinions and should, therefore, suspend his judgement on things that are essentially uncertain ( $\left.\dot{\varepsilon} \pi \circ \eta^{\prime}\right)$. He should remain cautious and acknowledge that the ultimate truth

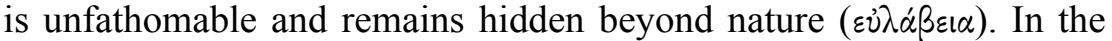
natural problems treated in Quaestiones convivales, Plutarch shows how this approach takes effect in the context of sympotic deliberations ${ }^{211}$. In these discussions, Plutarch and his fellow symposiasts are in search of a correct physical explanation without ever explicitly claiming to have reached it. The symposiasts formulate only plausible explanations, and they remain cautious not to show too much confidence in their own contributions to the discussion. This aspect of plausibility is not only an essential feature of the social decorum of sympotic table talk, as we saw, where argumentative egotism is considered a practice suitable for sophists rather than philosophers ${ }^{212}$. It also reveals Plutarch's underlying methodological concerns and is more fundamentally bound with the genre of natural problems itself, which is essentially concerned with

${ }^{211}$ E. Kechagia, 20IIa, p. IOI is absolutely right that in his natural problems in Quaestiones convivales "Plutarch is no outright sceptic; he is, rather, a dedicated Platonist for whom the workings of the physical world can never be fully apprehended unless one appealed to a higher level of explanations [...]". In a similar vein, A.H. Armstrong, 1967, p. 6I notes that "Plutarch [...] has kind words for the scepticism of the New Academy, though, for himself, scepticism means simply cautiousness in committing oneself to a definite solution of a difficult matter." Cf. also, e.g., J. Boulogne, I992, pp. 4695-4696 (regarding Quaestiones Romanae): “Un tel aveu d' impuissance n' est pas, ici, à confondre avec le doute des sceptiques. La perspective de Plutarque relève plutôt du probabilisme. [...] Par sa terminologie, il ne cesse de rappeler que nous sommes dans le royaume de la doxa et non pas de l'épistèmè."

${ }^{212}$ See, e.g., L. Van der Stockt, 200ob, p. 94 (with n. 9 for references). See also J. König, 2007, pp. 57-58: "The requirement of being an entertaining conversationalist, and to be generous with one's own interventions, seem to outweigh any requirement to aim for a single correct answer." Cf. also, e.g., J. Opsomer, 2009, pp. I3I and I33. For

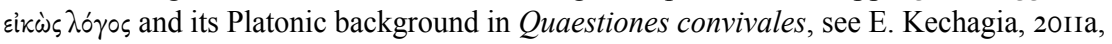
99-IO4. 


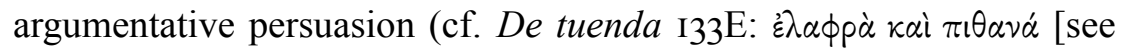
3.I.3.]). It is only likely, then, that the notion of plausibility in Plutarch's natural problems has a deeper, epistemological motivation for him, which is also foregrounded in the problems collected in Quaestiones naturales, as we will see.

Indeed, genre bears concrete meaning: it represents a certain attitude toward reality and the world, and does not come into existence by hazard, as a merely artificial game played by learned authors ${ }^{213}$. In the case of Quaestiones naturales, the fundamental motivation behind Plutarch's choice for the genre of natural problems relies on his aporetic awareness that it is hard, if not altogether impossible, to attain the highest measure of accuracy and certainty in matters pertaining to natural science. The genre of natural problems provides a convenient format in which a given natural phenomenon is explained in a variety of more or less plausible explanations [see I.I.4.]. These explanations are phrased interrogatively, and none of the physical aetiologies receive any closure, that is, a response that removes all possible doubt ${ }^{214}$. In this way, place is always left for potential criticism and further investigation, and final judgement is ultimately suspended $\left(\dot{\varepsilon} \pi \circ \chi \dot{\eta}^{2}\right)^{215}$. Also the use of the categories of $\tau \dot{0}$ $\pi \imath \theta \alpha o^{\prime} v$ and $\tau \dot{\partial} \dot{\alpha} \lambda \eta \theta \varepsilon \dot{s}$ in the aetiologies tell us much about Plutarch's argumentative strategies. The Chaeronean has a tendency to resort to correct explanations ( $\tau \dot{\partial} \dot{\alpha} \lambda \eta \theta \dot{\varepsilon} \varsigma)$, but this never becomes a strict aetiological compulsion. In the end, the explanations are mainly concerned with an

${ }^{213}$ Cf., e.g., G.B. Conte, I992, p. I20: "Genre functions as a mediator, permitting certain models of reality to be selected and to enter into the language of literature; it gives them the possibility of being 'represented'." Cf. also id., I994, p. I32: "genre must be thought of as a discursive form capable of constructing a coherent model of the world in its own image".

${ }^{214}$ Cf. already J. Schroeter, I9II, pp. 23-24: "Die praktische Anwendung dieser Lehre [sc. of $\dot{\varepsilon} \pi \circ \gamma_{\eta}$ ] bieten die Abhandlungen: quaest. nat. und aqua an ign. util. In diesen Schriften tritt Plutarch keiner von den vorgetragenen Ansichten bei, sondern überlässt es dem Leser, die wahrscheinlichste zu wählen.”

${ }^{215}$ H. Görgemanns, I970, p. 87 also connected Plutarch's sceptical attitude with the “zetematische Form der Aet. phys. und der Quaest. conv.”. Cf. also R.M. Jones, I980, p. I9 and P. Donini, I986a, p. 205. For a similar aporetic approach in Quaestiones Romanae, see J. Boulogne, 2002, p. 94. Notably, R. Preston, 200I, p. II2 opposed the tentative explanations of Quaestiones Romanae with the dogmatic ones of Quaestiones Graecae, arguing that for Plutarch, "Roman culture will elude definitive explanation". It is not unreasonable that Greek culture was, indeed, better known or, in any case, more familiar to Plutarch than the more exotic Roman one. Perhaps, it is not so remarkable, therefore, that interpretative pluralism is scarce in Quaestiones Graecae, where we are mostly dealing with an attempt at defining, rather than explaining, specific Greek cultural phenomena [see I.I.4., n. 95]. Nevertheless, Preston's theory was rejected by T. Morgan, 20II, p. 72, n. 77 . 


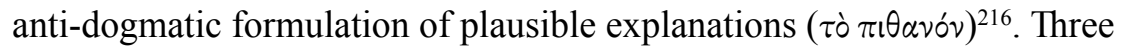
further observations can be made in this regard.

I) First of all, several passages show that the feature of aetiological sufficiency plays an important role in Plutarch's search for plausible explanations. In Q.N. I2, for instance, Plutarch examines why oil sprinkled on seawater causes clearness and calm. The aetiology opens with Aristotle's explanation, according to which the wind, slipping off the smoothness (so caused by the oil), makes no impact and raises no surge. In the second causa, Plutarch considers Aristotle's explanation to be plausible with

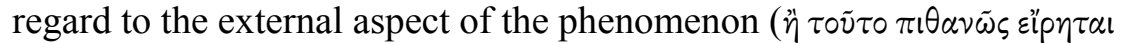
$\pi p o ̀ s \tau \dot{\alpha} \dot{\varepsilon} \kappa \tau \dot{o}^{\prime}$;), but he adds that it gives no internal explanation of how this phenomenon works in the sea $(\dot{\varepsilon} \nu \tau \tilde{\omega} \beta \nu \theta \tilde{\omega})$, where it is of course impossible

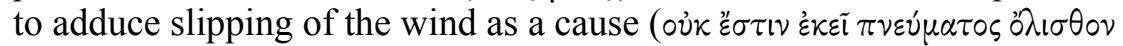

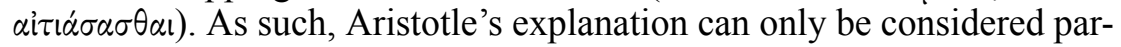
tially correct at best, but this does not, of course, make it implausible in principle, so that it is still worth mentioning. The association between the aspects of aetiological plausibility and sufficiency is rendered more explicit in Q.N. I9, where Plutarch examines the octopus' colour-changing ability. In the first causa, Plutarch provides Theophrastus' explanation, according to which the change of colour is due to the octopus' natural cowardly nature ( $\left.\delta \varepsilon 1 \lambda \delta^{\prime} \nu \dot{\varepsilon} \sigma \tau \iota \phi \dot{v} \sigma \varepsilon l \zeta \tilde{\omega} \circ \nu\right)$ and the working of its $\pi \nu \varepsilon \tilde{v} \mu \alpha$. This explanation is considered plausible but insufficient in the second causa, because it only accounts for the change of the octopus' colour and not also for its adaptation to its surroundings ( $\ddot{\eta} \tau 0 \tilde{v} \tau 0 \pi p o ̀ s \tau \dot{\eta} \nu \mu \varepsilon \tau \alpha \beta 0 \lambda \dot{\eta} \nu \pi \imath \theta \alpha \omega \tilde{\omega} s$

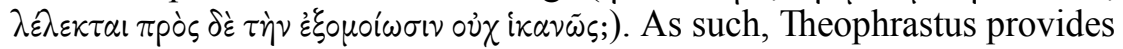
only a partial explanation of the problem (as was also the case with Aristotle's explanation in Q.N. I2). Nevertheless, it is still considered to be a plausible account, since, so Plutarch adds in the third causa, it adduces an important 'starting-point' in the aetiology ( $\left.\dot{\alpha} p \times \eta^{\prime} \nu[\ldots] \dot{\varepsilon} \nu \delta i \delta \omega \sigma \iota\right)$. In both of these cases, Plutarch shows that what is plausible from one perspective may turn out to be insufficient from another ${ }^{217}$.

216 The conceptualisation of $\tau \grave{o} \pi \imath$ avóv in Quaestiones naturales (see Q.N. 2, 9I2A, I2, 9I5A, I9, 9I6B, 26, 9I8E, 39) clearly outweighs that of $\tau \dot{\alpha} \dot{\alpha} \lambda \eta \theta \dot{\varepsilon} \varsigma$ (see Q.N. 2, 9IIF-9I2A and $2 \mathrm{I}, 9 \mathrm{I} 7 \mathrm{D})$.

217 Cf. L. Senzasono, 2006, p. I97, n. 98 (cf. also pp. I8-I9): "l' opposizione del persuasivo (o probabile) e del sufficiente non esclude, anzi implica la possibilità del vero." "La spiegazione sufficiente è appunto quella adeguata alla realtà di fatto del fenomeno e quindi vera dal punto di vista gnoseologico. La spiegazione probabile sotto un certo aspetto può a sua volta essere insufficiente o inadeguata sotto un altro". However, for Plutarch, the ultimately 'true' (or better: 'correct'; see n. 228) explanation cannot be attained nor formulated in a physical discourse (considering the epistemic restriction imposed by

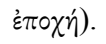




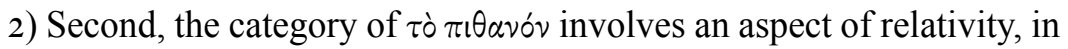
the sense that one explanation can be more or less $\pi \imath \theta \alpha \nu$ o than another (cf. Q.N. 39: probabilius $)^{218}$. One may wonder, however, what Plutarch exactly means in the last causa of Q.N. 2I (regarding the problem of the higher fertility of domesticated sows $v i s$ - $\grave{a}$-vis wild ones) when he asks whether

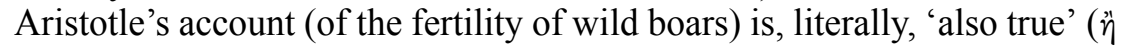

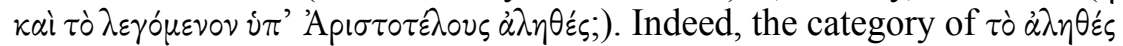
is used in an interrogative and anti-dogmatic context here and is, thus, ultimately pushed back into the region of plausibility and verisimilitude ${ }^{219}$. Thus, even if Aristotle's account has the appearance of providing a correct explanation to the problem, it does not surpass the realm of plausibility. This makes it possible for Plutarch to use the category of $\tau \dot{\partial} \alpha \lambda \eta \eta \dot{\varepsilon} \varsigma$ in a relative rather than an absolute sense here. Arguably, the use of the

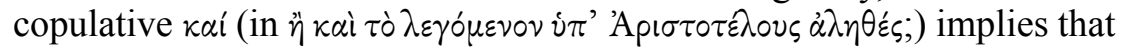
the three preceding explanations may also have the appearance of being correct $(\dot{\alpha} \lambda \eta \theta \dot{\varepsilon} \varsigma)$, and may lay an equally legitimate claim to it as the fourth (see n. 262). Alternatively, the k ai may be used adverbially, expressing "emphatic assertion or assent" (see LSJ, s.v.); the translation, then is: 'Or, indeed, is Aristotle's account true?'. This does not, of course, alter the relative value of the truth claim at hand.

3) Third, at some points, Plutarch explicitly relates the criterion of $\tau \dot{\partial} \pi \imath \theta \alpha \sigma^{\prime} \nu$ to that of $\tau \dot{\partial} \dot{\alpha} \lambda \eta \theta \dot{\varepsilon} \varsigma$, without, therefore, identifying the two as being completely equivalent. For instance, in the first causa of Q.N. 2 (regarding the problem of why trees and seeds naturally receive more nourishment from rainwater than from irrigational water), Plutarch records Laetus' explanation that focuses on the rainwater's impact. He does not consider the explanation very convincing, though, and suggests, in an

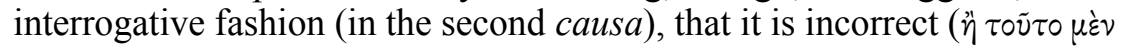

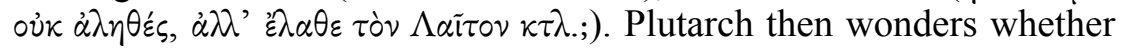
Aristotle's explanation, which draws attention to the the rainwater's

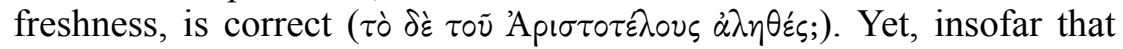

218 Cf. L. Senzasono, 2006, p. 249, n. 2I2: "probabilius è quasi certamente la traduzione

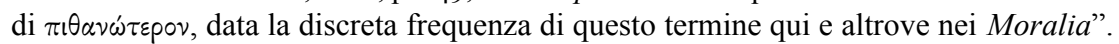
Senzasono refers to Quaest. conv. 629A, 664D, 74IC, De facie 930C, 933CD, De prim. frig. 95IF. Longolius translates $\pi \imath \alpha \nu \omega \tilde{\omega} s$ in $Q . N$. I2, 9I5A and I9, 9I6B as probabiliter. Furthermore, it is unlikely that the original Greek text read $\ddot{\eta} \mu \tilde{\alpha} \lambda \lambda_{0} \nu$, which Longolius elsewhere translates as an potius (Q.N. 3, 9I2E, 7, 9I3F, 28, 9I9A).

219 A similar conclusion was reached for Quaestiones Romanae by J. Boulogne, 1992, p. 4695: "Le mode interrogatif de la formulation des causes examinées ne tient pas, toutefois, seulement au respect de la forme traditionnelle du genre littéraire des Q.R. Il correspond surtout à une réflexion personnelle, consciente de l'impossibilité de parvenir à des certitudes. Il est, d' ailleurs, remarquable que les explications qualifiées de vraies ne le sont, pour ainsi dire, jamais que sur le mode interrogatif." 
running waters do, indeed, share their freshness with rainwater but are less nourishing, he argues that this explanation is 'also/indeed plausible rather

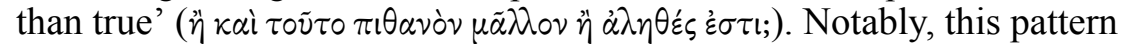

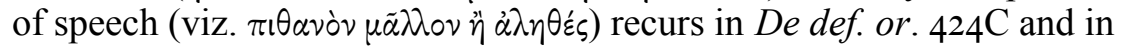
Quaest. conv. 627B, again regarding a specific Aristotelian account ${ }^{220}$. Scarcella may be right in pointing out that this phrase has a playful and ironic connotation ${ }^{221}$. In my opinion, this does not, however, make it irrelevant in light of Plutarch's underlying epistemology. What the phrase probably implies, then, is that what is at first suggested to be a correct explanation, after close examination is considered to have falsely aroused that appearance, and is, therefore, degraded as being plausible (rather than true). The basic idea here is that the relative plausibility of a physical explanation, rather than its absolute correctness, is the main criterion to be taken into consideration in evaluating this type of theories. Or as Teodorsson has put it: "These expressions seem at first sight to indicate that Plut. was a thorough researcher, eager to arrive at the truth, but in

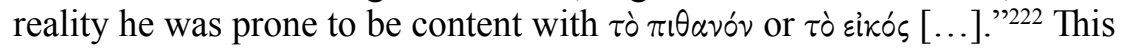
can be linked, then, with Plutarch's philosophical attitude in postponing final judgement in natural scientific matters. Moreover, the phrase also indicates that there is a clear epistemological distinction between what is plausible and what is correct for Plutarch, but that it is not always easy to draw the line in reality. Therefore, these categories are not strictly opposed to each other at a conceptual level ${ }^{223}$. After all, what is plausible is not necessarily incorrect ${ }^{224}$. Then again, at a conceptual level, presumably only one plausible explanation can be the correct one (but this cannot be said of Aristotle's explanation here in Q.N. 2). It is from this overlapping

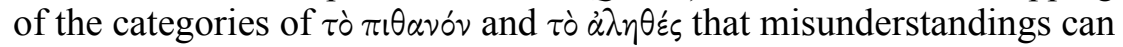
eventually arise, and this is why the фuбikós should remain pensive in his judgement ${ }^{225}$.

${ }^{220}$ It can also be seen in an adapted form in De prim. frig. 952B (cf. also Quaest. conv. 687DE). See also, e.g., Galen, SMT II, 47I, I3-I4 Kühn. A similar idea is

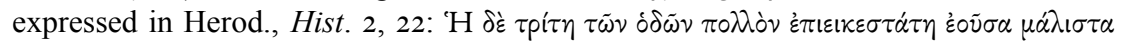
$\ddot{\varepsilon} \psi \varepsilon v \sigma \tau \alpha \iota$.

${ }^{221}$ A.M. Scarcella, 1998, p. 340, n. 352: "un gradevole tono ironico". Pace L. Senzasono, 2006, pp. 19-20, with n. 29, who seems to link Scarcella's irony too strictly with Socratic irony.

${ }^{222}$ S.-T. Teodorsson, I989, p. I50 (translated by L. Senzasono, 2006, p. 20 without reference). For the conceptualisation of the category of $\tau$ c̀ zixós in Quaestiones naturales, see Q.N. 2, 912C, 5, 913 D, 7, 914 $\mathrm{B}, 19,9 \mathrm{I} 6 \mathrm{D}, 20,917 \mathrm{~A}, 29,919 \mathrm{~B}$.

${ }^{223}$ Pace L. Senzasono, 2006, pp. I9 (“opposizione”, "distinti”, “contrapposizione”), 20 ("contrapposti") and I49, n. I5 ("opposizione").

${ }^{224}$ Cf. L. Senzasono, 2006, p. 22: "Plutarco possa attribuire al probabile una possibilità di verità".

${ }^{225}$ This also works the other way around, insofar that the categories of the 'plausible' 
In conclusion, Plutarch never claims to know what is ostensibly true or false in a natural scientific context. Nevertheless, in spite of suspending judgement, he still shows that he has a certain opinion about these aspects. If he suggests an explanation to not be true, he does not take it to be strictly implausible (Q.N. 2, 9IIF-9I2A). Conversely, what is plausible sometimes turns out to be only partially correct (Q.N. I2, 9I5A, I9, 9I6B). In this sense, the notion of plausibility can be considered a heuristic stimulus to further complete the aetiology ${ }^{226}$. It functions as a useful argumentative criterion (often, indeed, ranked in the first causa: Q.N. 2, 9IIF, I2, 9I5A, I9, 9I6B), by means of which the фuбikós is exhorted to look for an even more plausible or more comprehensive explanation. In the end, Plutarch is satisfied by formulating plausible arguments, since in some cases, what is plausible is also potentially correct (ranked in the final causa: Q.N. 26, 9I8E, 39).

We can safely assume from these observations that the natural problems collected in Quaestiones naturales comprise some kind of status quaestionis of an ongoing zetetic search for plausible arguments, thus embodying a collection of open-ended natural scientific ह̇ $\pi \iota \chi \varepsilon\llcorner p \eta \dot{\mu} \mu \alpha \tau$ (i.e. endeavours, attempts, essays $)^{227}$. In the end, the search for the 'truth' in the sensible world leads to more or less plausible opinions ( $\delta \delta^{\prime} \xi \alpha l$ ), which cannot attain the cognitive status of absolute science $(\dot{\xi} \pi\llcorner\tau \tau \dot{\eta} \mu \eta)$. The physical aetiologies Plutarch provides are only indicative of $\tau \dot{\partial} \dot{\alpha} \lambda \eta \theta \dot{\varepsilon} s$. Therefore, $\dot{\varepsilon} \pi \circ \eta_{\eta}$ is the most appropriate method in natural scientific inquiry, even if it does not offer a clear way out of the problems that nature confronts us with. When all is said and done, many blind spots will inevitably remain on the map of nature 228 . As we saw previously, from an epistemological

and the 'incorrect' do not necessarily exclude one another, as can be inferred from Plutarch's criticism of Laetus in combination with that of Aristotle here in Q.N. 2, 9IIF9I2A. Their explanations are suggested to be oủ火 $\dot{\alpha} \lambda \eta \theta \dot{\varepsilon} \varsigma$ but still $\pi \iota \theta \alpha$ óv. What is untrue may sometimes seem plausible (cf. De aud. poet. I6C: $\mu \varepsilon \mu \iota \gamma \mu \varepsilon v 0 \nu \pi \imath \theta \alpha \nu o ́ \tau \eta \tau \iota ~ \psi \varepsilon \tilde{\delta} \delta \varsigma$ ). There may even be some truth to what seems improbable (cf. Quaest. conv. 626F: $\dot{\alpha} \alpha \delta i \omega s \dot{\eta} \mu \tilde{\omega} \nu$

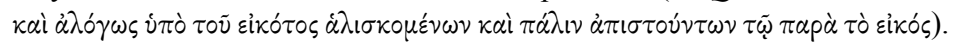

${ }^{226}$ Cf. L. Senzasono, 2006, p. 22, n. 3I: "la stessa probabilità è un criterio euristico".

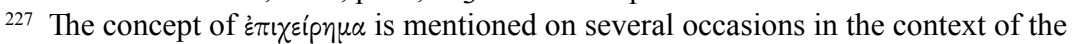
natural problems discussed in Quaestiones convivales (cf. $65 \mathrm{IC}, 656 \mathrm{~B}, 662 \mathrm{D}, 694 \mathrm{D}, 7 \mathrm{OIF}$ ). For the link between Plutarch's aetiological originality and the notion of "essai", cf. also F. Frazier and J. Sirinelli, 1996, p. I98. In Aristotelian logic, an $\dot{\pi} \pi \iota \varepsilon \dot{p} p \eta \mu \alpha$ is more technical

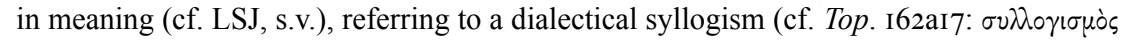
$\delta 1 \alpha \lambda \varepsilon \kappa \tau i \kappa o ́ s)$.

${ }^{228}$ I here add a critical note on Senzasono's interpretation of Plutarch's (generally) sceptical stance in Quaestiones naturales (L. Senzasono, 2006, esp. pp. 20-2I). Senzasono argues that Plutarch's scepticism is not fundamental in his natural problems but I) methodological and 2) partial or limited. I) The methodological aspect implies that "si tratta d'un atteggiamento che guida la ricerca, non d'una convizione gnoseologica che si radica 
perspective, natural phenomena are immanently unclear $(\not 2 \delta \eta \lambda \alpha)$ since they belong to the domain of sense perception, and therefore cannot grant

in una concezione scettica sistematica, sia pure probabilistica" (p. 2I, n. 3I; see also p. I49, n. 15). Senzasono therefore prefers to speak of "agnosticismo metodologico, inspirato allo scetticismo accademico" (p. I50, n. I5). There are, indeed, clear sceptical overtones in Plutarch's natural scientific method, which does not, however, imply, as we saw above, that Plutarch would consider himself to be an Academic Sceptic pur sang rather than an enthusiast of Plato. Therefore, Plutarch is not following Carneades' 'probabilism' in a strict way, as Senzasono knows (p. 2I, n. 3I): "È probabile che un intellettuale come Plutarco, antidogmatico e aperto a istanze problematiche, sia stato stimulato dalla gnoseologia di Carneade e indotto da essa all'uso frequente del termine [sc. $\pi \bullet \theta \alpha v o ́ v]$, tanto piú che aveva fatto parte dell'Accademia; ma [...] basta Platone a spiegare l'attegiamento di Plutarco e l'uso del termine è originariamente platonico." However, regarding the $\dot{\varepsilon} \pi \circ \times \dot{\eta}$ statement in De prim. frig. $955 \mathrm{C}$, Senzasono seems to overdo things a bit when he speaks of "un cauto scetticismo di convenienza, da adottarsi quando le idee non sono né inferiori né superiori alla probabilità ( $\pi \bullet$ $\theta \nu o ́ \tau \eta s)$ " (p. I50, n. I5). Plutarch's scepticism in natural scientific matters is more than simply a methodological convenience (to use Senzasono's wording), since it does not just imply an ad hoc approach, applicable only on occasion ( pace also the conclusion drawn for Quaestiones convivales by F. Fuhrmann, 1972, p. xxv: "Le scepticisme n' est jamais présenté que comme une diversion."). On the contrary, Plutarch's anti-dogmatic and aporetic approach towards natural phenomena is applied consistently all throughout his scientific writings in general, thus including his natural problems more in specific, and it is firmly rooted in his Platonic epistemological conviction

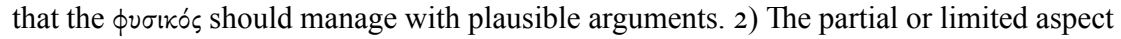
of Plutarch's scepticism, on the other hand, implies, to use Senzasono's own words again, that Plutarch examines "certi aspetti e non altri della realtà che è oggetto di conoscenza" (p. 2I), which means - if I understand Senzasono correctly - that Plutarch's approach "è limitato a ciò che non è chiaro, non investe la totalità del reale; la stessa probabilità è un criterio euristico e non esclude la conoscibilità del vero in generale" (p. 22, n. 3I); "la sua origine può essere scettica solo limitatamente all'uso del termine 'probabile', non per la concezione della verità in generale" (p. 2I). In regards to the intelligible, divine truth in itself, however, one could object that, contrary to what Senzasono writes, Plutarch believed that it cannot be reached in its full extent by the human intellect (which is why he

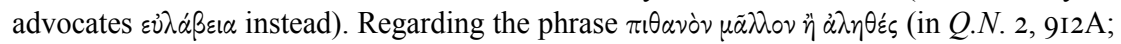
see above), Senzasono (p. 19; cf. also p. 24) argues that it actually is possible for Plutarch to attain the truth ("si ammette la possibilità di conoscere il vero"; "non esclude l'approdo alla verità"), but, then again, it is a mistake to assume that $\tau \dot{\partial} \dot{\lambda} \lambda \eta \theta \dot{\varepsilon} \varsigma$ can be attained because it is merely mentioned there. In his commentary to this passage, Senzasono, does, indeed, draw attention to the interrogative and non-assertoric formulation of the phrase, but he still seems to go too far when he adds that "in generale si ha sempre l'ammissione implicita della possibilità del vero non identificabile col probabile: dunque qui non c'è riduzione di esso [i.e. il vero] al probabile, e quindi scetticismo" (p. I49, n. I5). As we saw earlier on, however, the concept of $\tau \dot{\partial} \dot{\partial} \lambda \eta \theta \theta \dot{\varepsilon} \varsigma$ in Plutarch's physical aetiologies does not, in fact, surpass the realm of verisimilitude. Moreover, it seems that there is a category mistake in Senzasono's account, obfuscating the conceptual border between the logical category of truth and the psychological-subjective category of certainty. This idea applies specifically 
reliable knowledge ${ }^{229}$. In what follows, I will take a closer look at the use and role of sensory knowledge in Quaestiones naturales, including the controversial issue of Plutarch's personal observations.

\section{Sense perception and the issue of autopsy in Quaestiones naturales}

In accordance with Plato, Plutarch firmly believes that natural phenomena have something that we apprehend by opinion and something that we apprehend by intellect ${ }^{230}$. He, therefore, draws a sharp distinction between sensible and intelligible knowledge. Knowledge of intelligibles is superior to that of the senses, since the latter is situated at the level of opinion and conjecture ${ }^{231}$. In light of Plutarch's (generally) sceptical method in natural science, it should be noted that the Academic Sceptics themselves did not intend to do away with the working of $\alpha i \sigma \theta \eta \sigma i s$ as such but with the unstable $\delta \delta^{\prime} \xi \alpha_{1}$ that it yields ${ }^{232}$. Even though Plutarch accordingly rejects a scientific method that is entirely based on $\alpha i \sigma \theta \eta \sigma \iota$, this does not imply that sense perception is of no importance in his study of natural phenomena. On the contrary, Plutarch ascribes a great deal of argumentative value to the data pertaining to sense perception in his aetiologies. The overall function of this empirical knowledge is often restricted, though, to somewhat indecisive inductions, associations, analogies, examples etc., that help corroborate the

to Plutarch's use of the concept of $\tau \dot{\partial} \grave{\lambda} \lambda \eta \theta \varepsilon$ s in Quaestiones naturales. One should draw a functional distinction between the object language (i.e. in Plutarch's text) and the descriptive-analytical language (i.e. how we should interpret it): on the second level the opposition is not plausible-true but plausible-certain, i.e. 'with certainty true' (thanks are due to J. Opsomer for this remark). Of course, the intelligible truth does, indeed, exist for Plutarch, but certainty not, or at least not in a domain like physics. This is precisely why Plutarch's physical aetiologies are formulated in an anti-dogmatic, fashion. For further criticism of the alleged partialness of Plutarch's scepticism (as put forward by P. Donini, I986a), see also D. Babut, I994, pp. $570 \mathrm{ff}$.

${ }^{229}$ Cf., e.g., De prim. frig. 955C and Quaest. conv. 700B. The conceptual distinction between $\ddot{\alpha} \delta \eta \lambda \alpha$ and $\dot{\alpha} \kappa \alpha \tau \dot{\alpha} \lambda \eta \pi \tau \alpha$, as made by Carneades (see J. Opsomer, I998, pp. I64-I65), is not of importance here.

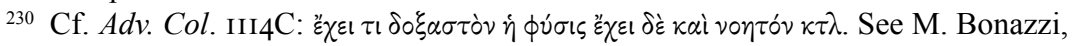
2004, pp. 67-68.

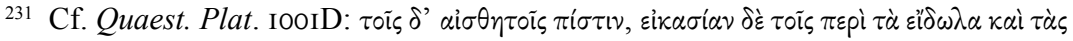
हixóvas. See J. Opsomer, 1998, p. 196.

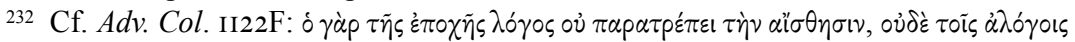

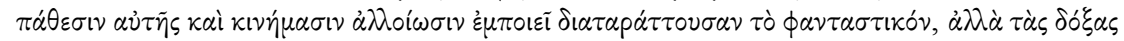

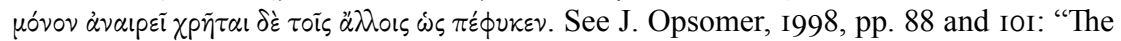
reason why we should distrust the senses is not in the first place that our sensory cognitive faculty is defective as such, but rather that the world is not the sort of place which it is possible to know with total clarity." For the idea that sight and hearing are not the result of chance but of reason, cf. De fortuna $98 \mathrm{BC}$. 
physical aetiologies in an irresolute fashion (see the examples below) ${ }^{233}$. As such, these empirical data are highly indicative and supportive of the plausibility of Plutarch's arguments, but in the end, they are only slightly compelling for producing argumentative certainty ${ }^{234}$.

For instance, in Q.N. I, 9IID, Plutarch argues that salt water supports boats and swimmers, from which he induces that it has an earthy quality. Regarding this earthy component in salt water, he argues that it cannot provide trees with nourishment, since it is unable to enter the roots and rise in the plant (on account of its thickness and heaviness). Similarly, in Q.N. 2, 9I2B, Plutarch argues that rainwater falling from the sky makes bubbles, from which he induces that it contains light air and breath. Thus, rainwater is more nutritive for plants than irrigational water, since it can be guided and transmitted more quickly into the plant by its tenuity (an attribute of air and breath). These inductions are based on the association of the quality of the water with its corresponding localities (and the primary elements situated there): if it comes from the sky ( $\left.\dot{\alpha}^{\prime} \rho\right)$, it is pure and light; if it is mingled with earth $(\gamma \tilde{\eta})$, impure and heavy. A case of analogy is found, for instance, in Q.N. I, 9IIE, where the natural phenomenon of burning heat that destroys drinkable water is compared with fever in the body, which is said to turn moisture into bile. A direct link is drawn here between processes that occur in nature and in living bodies, suggesting that these are based on the same or similar physical principles. An interesting case of exemplification is found, for instance, in Q.N. I2, 915A: in order to illustrate that oil causes transparency in the sea, Plutarch adduces a popular account, according to which divers take oil into their mouth and blow it out into the water, so that they - literally - get light and transparency in the depths of the sea (cf. De prim. frig. 950BC). Numerous other instances of inductions, associations, analogies and examples of this sort (c.q. relating to empirical knowledge) could be added. What is important, however, is that Plutarch is relying, in most of these cases, on relatively common physical schemes and received beliefs that were already current on the contemporary scientific scene. For instance, in regards to the popular account about divers and oil, the introductory verb $\phi \alpha \sigma$ เ clearly indicates that Plutarch is relying on a traditional belief, probably originating from diver lore (perhaps via the intermediation of a lost problem; see the commentary ad loc.). Plutarch incorporated and adapted such data to the new problem contexts. Considering that Plutarch elsewhere emphatically underlines the inferior epistemological value of this kind of knowledge, it seems rather unlikely

${ }^{233}$ This approach is very common in ancient physical theory. E.g., for the use of analogy, see G.E.R. Lloyd, I966, pp. I72-420. See also L. Taub, 2003, 98-IO2 (on Aristotle).

${ }^{234}$ Cf., e.g., E. Teixeira, I992, p. 213 (regarding the natural problems treated in Quaestiones convivales): "Plutarque use de comparaisons pour mieux convaincre, bien que ce qu'il avance parfois ne corresponde pas toujours à la réalité." 
that he is relying on personal experience in these cases, that is, on empirical data that he personally gathered or verified in the field.

This has not, however, discouraged some scholars from thinking otherwise with regard to a number of natural phenomena recorded in Quaestiones naturales, where Plutarch could perhaps be relying on his own personal observations. The arguments in support of this theory are not very convincing, though ${ }^{235}$. The meticulous and detailed description of some natural phenomena was seen as an important indication of Plutarch's personal observations by Senzasono. However, descriptive detail alone is not a necessary, let alone sufficient, condition for assuming personal observation 236 (think of Plato's minute description of Atlantis). Senzasono also regards the apparent lack of traditional sources in some cases as an additional indication of Plutarch's autopsy ${ }^{237}$. However, in these cases Plutarch may just as well be relying on an oral tradition, or some of his sources may have gone lost - or are we perhaps dealing with an aspect of aetiological ingenuity? Whatever may be the case, the examples that Senzasono provides are not convincing.

In regards to a number of problem chapters on hunting (viz. Q.N. 20, 22-25 and 28), Senzasono argues that Plutarch relies on personal experience. Plutarch would also have had personal knowledge of navigation and fishing (as would appear from Q.N. II and I3; see also Q.N. I7-I9). However, in these cases, we are dealing with rather weak indications of Plutarch's alleged personal observation. Notably, the natural problem at issue in Q.N. 20 about the tears of wild boars tasting sweet (as opposed to the salty and ordinary ones of deer) is cited by Euthydemus and Patrocleas from their acquaintance with farming and hunting (in Quaest. conv.

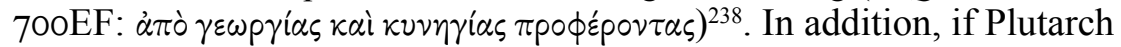
was cultivated in botany, as Senasono believes (considering the names of specific marsh plants in Q.N. 2, 9I2A ${ }^{239}$, this would have only been indirectly and not by his own experience in gardening. It seems far more reasonable to assume that in his capacity as an armchair scientist, Plutarch draws most of his information from the tradition, which he intends to

${ }^{235}$ In his study on 'Plutarch and autopsy', J. Buckler, I992 concludes "that autopsy was neither of particular nor central interest to him" (p. 4829). Regarding Plutarch's de visu observation in Quaestiones Romanae, see L. Van der Stockt, 1987, p. 287 and also J. Boulogne, 2002, p. I00: "Si la plupart des sujets paraissent fournis par l' expérience même du voyageur qu' est Plutarque, au titre de choses vues, plusieurs portent sur le passé et présentent manifestement une provenance livresque."

${ }^{236}$ L. Senzasono, 2006, pp. 25-28, esp. p. 25: "In certi casi Plutarco sembra aver osservato direttamenti i fenomeni, tanto è puntuale e minuta la notizia che li tramanda."

${ }^{237}$ L. Senzasono, 2006, p. 27.

${ }^{238}$ Pace L. Senzasono, 2006, p. 26, n. 39 and p. 203, n. IIO.

${ }^{239}$ L. Senzasono, 2006, p. I48, n. I3. 
recycle and 'problematise' for intellectual discussion (as we saw earlier on [4.2.I.2.]). Therefore, Plutarch the hunter, sailor, fisherman, gardener, but also the cattle breeder $(Q . N .3,2 \mathrm{I})$, winegrower $(Q . N .30-3 \mathrm{I})$ and bee-keeper (Q.N. 35-36) will remain the Plutarch of our imagination.

In a number of cases, the use of oratio obliqua clearly betrays Plutarch's reliance on received knowledge (I have already mentioned the use of the verb $\phi \alpha \sigma \mathrm{\iota}$ in Q.N. I2, 9I5A in the context of diver lore). Regarding the question of why the sea becomes less bitter to the taste ( winter, Plutarch in Q.N. 9, 9I4B indicates that he does not speak from his own experience but relies on what people say to be recorded by

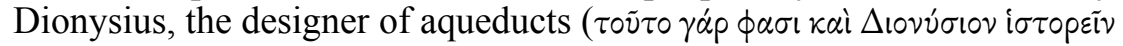

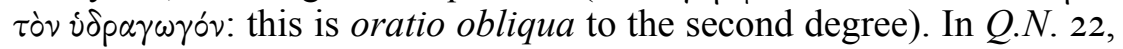
$9 \mathrm{I} 7 \mathrm{D}$, to give another example, Plutarch wonders why people say $(\phi \alpha \sigma i)$ that the bear's fore-paws have the sweetest flesh and is the most delicious to eat. This means that Plutarch, in raising the problem, has not necessarily tasted the flesh himself but can just as well be relying on the popular tradition (c.q. hunting lore ${ }^{240}$. Indeed, in regards to the observations in Q.N. 26 on animal diseases, Senzasono this time rightly underlines Plutarch's dependence on the tradition, because many parallels can be found in the literature ${ }^{241}$.

Among the 'technicians' ( $\tau \varepsilon \chi \nu i \tau \alpha l)$ mentioned in De prim. frig. 948BC [quoted 4.3.2.I.], doctors and farmers especially (not so much musicians) ${ }^{242}$ have specific authority in the context of the natural problems treated in Quaestiones naturales, since several of these problems are of specific medical or agricultural interest. Ancient doctors sought empirical verification for most of their assertions (e.g., when diagnosing their patients or when performing surgery), as did farmers (e.g., when confronted with an abnormality in the growth of their crops or in the behaviour of their cattle).

${ }^{240}$ Pace F.H. Sandbach, 1965, p. I98, n. a. As Sandbach notes, Xenophon reports that

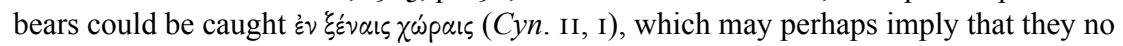
longer lived on Greek territory by Xenophon's time. The appearance of bears in Greece was again reported in the $2^{\text {nd }}$ century AD, though (cf. Paus., Graec. descr. I, 32, I; 3, 20, 4; 7, I8, I2; 8, 23, 9; cf. also L. Senzasono, 2006, pp. 2I0-2II, n. I26; see the commentary ad loc.). Bears were also used in the battles in the arena (cf., e.g., De soll. an. 977D, Pliny, NH 8, I30, Sen., Dial. 5, 30, I, Martial., Spect. 22). Considering his vegetarian leanings, one may doubt that Plutarch ever tasted bear meat himself.

${ }^{241}$ L. Senzasono, 2006, p. 28. This means that these observations "possono suscitare, se non la certezza, almeno il forte sospetto che Plutarco non abbia verificato personalmente quanto riferisce. [...] È probabile che egli [...] si sia rifatto solo a fonti letterarie che tramandavano le abitudine di certi animali, senza un controllo sperimentale." Senzasono draws the same conclusion for the observations in Q.N. 5 on the filtration of seawater (see further).

${ }^{242}$ For musical problems, see Quaest. conv. 657BE, 672C, 704C-706E, 7I0C-7IIA,

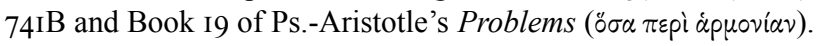


The same is true for other specialists, like hunters (e.g., when distinguishing the trails of different kinds of animals) or bee-keepers (e.g., when trying to find out ways to sedate their bees). This technical know-how must have been a welcome source of inspiration for Plutarch to rely on. It seems rather unlikely, however, that Plutarch, considering his Platonic and Academic leanings, ventured to verify his sources empirically, or $-a$ fortiori - that he even considered to do $\mathrm{so}^{243}$.

In those instances where one may be inclined to speak of 'experiments' or of 'experimental observations' (see the examples below), it turns out that Plutarch frequently relies on the scientific literature - mostly from the Peripatetics - and accepts the eventual outcome without any attempt towards verification (or falsification). Plutarch often incorporates such 'experimental' data in the sub-arguments in order to validate or support the main arguments, but the procedure of controlled experimentation, where the repeatability of the results is essential, is clearly absent in his natural

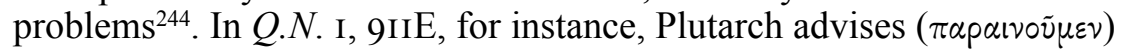
people not to throw seawater onto flames, because it contains a fatty, oily constituent that would only fan the fire. He adduces this point in order

${ }^{243}$ Cf., e.g., S.T. Newmyer, 20I4, p. 225. In fact, this lack of empirical and experimental verification was not uncommon in ancient science. The same conclusion was made, for instance, for Seneca's Naturales quaestiones by T.H. Corcoran, I97I, p. xiv: "[Seneca's] age evaluated theories by the arguments of analogy. To test a theory by controlled experiment was not a standard reflex and it would be inappropriate to expect it." See also, for instance, the account of G.E.R. Lloyd, I983, pp. II9-I35 on the informants of Theophrastus (esp. p. I33; quoted n. IO). See also more generally $i d$., I99I, pp. 70-99 and L. Taub, 2003, pp. IO2I03 (with n. I35 for further literature). On ancient empirical arguments, see G.E.R. Lloyd, I979, I26-225. Pace L. Senzasono, 2006, p. 27: “Certo, in molti casi nei quali la presenza di citazioni esplicite o di concordanza con altri testi s'impone, non si può quasi mai escludere del tutto la diretta osservazione o almeno l'esperienza del fenomeno."

${ }^{244}$ According to L. Senzasono, 2006, pp. 30-3I the aspect of empirical observation in Quaestiones naturales is, indeed, insufficient due to a lack of systematic experimentation, but he still maintains that in most cases, Plutarch relies on personal observation. Senzasono would, therefore, connect this lack of experimental repetition with Plutarch's observation of sensible phenomena in their direct natural context, that is, without any attempt towards generalisation: "Cosí qui questa mancanza di ripetizione sperimentale è connessa al fatto che Plutarco tendenzialmente, lungi dall'isolare i fenomeni di cui indaga le cause, li vede piú o meno sempre legati all'ambiente entro il quale si manifestano, quindi nella loro immediatezza." The idea that ancient Greek science in general was not concerned with a systematic experimental repetition of its findings ("carenza statistica"), and that it did not intend to artificially isolate particular natural phenomena by excerpting them from their natural environment - which is a common approach in our modern laboratories - is borrowed by Senzasono from S. Sambursky, 1963, p. 233. In my opinion, however, there is an obvious aspect of artificial isolation of these phenomena out of their direct natural context in Plutarch's natural problems in that they are approached from a theoretical rather than empirical standpoint (see also n. 29). 
to explain why seawater cannot nourish plants. Plutarch's argument is that the oil in the seawater is hostile to plants and destroys those that are smeared with it. The idea that seawater is highly combustible because it contains a fatty, oily constituent is paralleled on several occasions in Ps.-Aristotle's Problems (see the commentary ad loc.). Thus, it is unlikely that Plutarch tested or personally experienced what he dissuades others from doing here ${ }^{245}$. To give another example, in Q.N. 5, 913C, Plutarch asserts that when seawater is boiled, it loses its saltiness and tang. This would explain why the salty flavour, which is initially present, one way or another, in ripening fruits, loses its natural character by the action of heat caused by the ripening process. Clear parallels can again be drawn with Aristotle's writings for this belief (see the commentary ad loc.). A little bit further in Q.N. 5, 913CD, Plutarch argues that seawater loses it saltiness, which is earthy and has large particles, when it is filtered. We read that drinkable moisture can be reached by digging on the seashore, that sweet filtered water can be drawn from the sea by a jar made of wax, and that the passage of seawater through white clay renders it drinkable ${ }^{246}$.

${ }^{245}$ See the doubt, however, in L. Senzasono, 2006, p. I43, n. 6: "Quanto all' “esortazione" a non gettare acqua marina sulle fiamme, sembra che si riferisca, anche per l'uso della prima persona plurale ( $\pi \alpha$ paเvoṽ $\mu \varepsilon v$ ), all'esperienza diretta all'autora, o almeno a un uso di cui egli spesso ha sentito parlare."

${ }^{246}$ Modern attempts to repeat the experiment with the wax jar have failed - in spite of

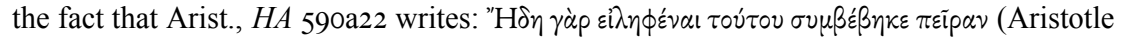
mentions this experiment also on other occasions: see the commentary ad loc.). Some scholars have tried to correct Aristotle's text: instead of knpivols they suggested to read

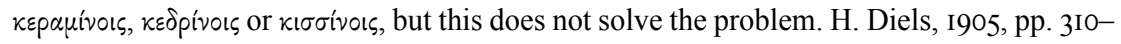
3I6, esp. 3IO-3II already considered the experiment to be false, and argued that perhaps a certain amount of seawater permeated through the cork into the vessel and obtained a sweet taste from the honey that was still sticking to the wax. He adds, p. 3I4: "Ebenso unrichtig ist die Behauptung (913CD), das Meerwasser werde, durch eine Tonschicht geleitet, seines Salzes beraubt, da diese als Filter wirke." G.E.R. Lloyd, 199I, p. 90 upholds Aristotle's experiment by arguing that water vapour perhaps condensed in the jar once it was submerged. F.H. Sandbach, I965, p. I65, n. d remains sceptical: "Salt can be extracted from seawater by filtering through certain resins, but not through clay or wax. The mistake over the origin of fresh water in a well by the sea-shore [...] is understandable, but not that over the story of the wax vessel [...]." L. Senzasono, 2006, pp. 27-28 considers this experiment "un caso limite", and on the basis of its "falsità" he argues that "l'intervento verificatore di Plutarco appare del tutto improbabile o è addirittura da escludarsi": "Sarebbe bastato un esperimento elementare mediante un recipiente di cera o d'argilla per verificare che l'acqua di mare non perde affatto la salinità in virtú di tali recipienti, perché evidentemente non viene filtrata da essi. Dunque Plutarco ha accolto da fonti letterarie, o forse da tradizione orali, questa notizia senza curarsi di verificarla." However, A. Stückelberger, I996, p. 379 made an attempt to explain the phenomenon by invoking modern chemical theory. He speaks of a specific "Ionenaustauscheffekt": "Ton hat namlich die Fahigkeit, Cl-Ionen und Na-Ionen der Salzlosung gegen andere im Ton vorkommende lonen auszutauschen und 
There are again obvious parallels to these accounts in Aristotle (see the commentary ad loc.). To give a last example, in Q.N. 7, 9I4A, Plutarch argues that the winter cold compresses the water of rivers and makes it heavy and solid. In support of this argument he refers to the phenomenon of clepsydrae drawing up water more slowly in winter than in summer, and to Theophrastus' account that a certain amount of water from a source on Mt. Pangaeum in Thrace would weigh twice as much in winter as in summer. It seems only likely that Plutarch borrowed these data from the scientific tradition and adapted them to the new problem context without verifying or falsifying them (Theophrastus' lost De aquis served as a probable source $)^{247}$. Since empirical knowledge cannot lead on to steadfast science, according to Plutarch, it does not really matter how many times these claims have been checked or re-checked [see 4.I.I.3.]. These 'experimental' data are only incorporated in view of underpinning the plausibility of the arguments at issue. As such, it is perhaps better not to speak of 'experiments' or of 'experimental observations' at all in Plutarch's natural problems. It turns out that these data are often treated on a par with other paradoxographical phenomena, which a priori receive Plutarch's benefit of the doubt, as we saw [4.I.I.2.]. Thus, they fall into the same category as traditional knowledge and idées reçues.

Even in those few instances where Plutarch employs terminology related to human sense perception, this does not necessarily imply that he directly relies on his own personal observation. When in Q.N. 5, 913 AB, for instance, he wonders why we observe (op $\tilde{\omega} \mu \varepsilon v)$ that only one of the eight generic flavours, namely the salty, is not produced by any fruit, whereas the others actually are, it is clear that he aims to evoke a sense of shared, communal experience, as is expressed by the use of the first person plural [see 3.I.4.]. But Plutarch is not necessarily speaking from his personal experience here. In any case, it seems unlikely that he collected all kinds of fruits to do the test, rather than that he just accepted this a priori. In fact, the same problem was already raised and solved by Theophrastus (CP 6, IO, I-2), so it is probably Plutarch's primary intention here to provide a few insightful theoretical speculations of his own about the old problem of flavours. This is also the case, in Q.N. 9, 9I4B, where Plutarch wonders

damit Salzwasser bis zu einem gewissen Grade zu entsalzen”. L. Taub, 2003, p. I03 (with further references) is probably right, however, that " $[\mathrm{w}]$ hile Aristotle may have done the experiment as described, it seems possible that he is reporting hearsay evidence, which literally does not hold water".

${ }^{247}$ See L. Senzasono, 2006, pp. 43-44: "È assai probabile che Plutarco non abbia eseguito alcuna verifica sperimentale [...]." F.H. Sandbach, I965, p. I69, n. b is sceptical about Theophrastus' report: "An experiment involving an exact quantitative observation is unusual in Antiquity, and this one cannot have been correctly performed, if the result is correctly reported." 
why the sea becomes less bitter to the taste ( $\gamma \varepsilon v \circ \mu \varepsilon$ voเs) in winter - this he knows indirectly from Dionysius, as we saw -, and in Q.N. 22, 9I7D, where the sweet taste ( $\phi \alpha \gamma \varepsilon \tilde{\nu} \nu \dot{\eta} \delta \dot{\sigma} \sigma \eta \eta)$ ) of the bear's fore-paws is under scrutiny - he probably knows this from popular hunter lore, as we saw.

To give another example, in Q.N. 8, 9I4B, Plutarch wonders why we

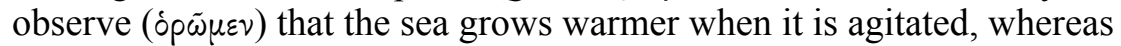
all other liquids become colder when moved and disturbed. By the use of the first person plural he is again evoking a certain sense of shared experience. According to Sandbach, this "phenomenon [is] familiar to bathers, but not registered by thermometers." He explains that "[t]he cause of the illusion is to be sought mainly in the relative temperatures of sea and air, and the chilling effect of the wind that often accompanies a rough sea." ${ }^{248}$ This may well be true, but one may still wonder why Plutarch adds that the same effect does not take place in other liquids (e.g., the fresh water in lakes or rivers, but perhaps also such liquids as oil, milk, wine, etc. - the quaestio speaks of ípóv, rather than $v \delta \omega \rho)$. Plutarch does not necessarily have to rely on personal observation to raise this problem, let alone to solve it in a plausible way. One can very well imagine that it is precisely in the paradoxical element in the quaestio that the problematic aspect of this phenomenon is situated, rather than in Plutarch's alleged personal observation, or, for that matter, in the empirical attestation of this phenomenon in the actual physical reality to begin with. If Plutarch had not denied that this particular phenomenon takes place in other liquids just as well, this would have entirely eroded the paradox and thus the problematic aspect of the quaestio at hand.

Indeed, Plutarch's explanation of the problem in Q.N. 8 is clearly based on this paradoxical element: he a priori treats the property of heat as an intrinsic feature of seawater (heat is innate to it: $\sigma \dot{u} \mu \phi v \tau o v$ ), as opposed to all other liquids (where it is considered an incidental and alien intrusion:

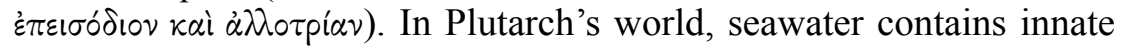
heat and other liquids do not (see n. I55). This did not require empirical verification for him, an idea that clearly highlights the theory-ladenness of empirical knowledge ${ }^{249}$. As such, the explanation that he provides is,

${ }^{248}$ F.H. Sandbach, I965, pp. I70-I7I, n. b. See also L. Senzasono, 2006, p. 29: "Plutarco quindi in questo caso assume un dato sensoriale soggettivamente reale considerandolo direttamente oggettivo, senza sottoporre a una mediazione critica la sensazione per verificare quale sia la sua origine e se essa abbia una corrispondenza nella realtà oggettiva o si tratti di un'impressione (sua o di altri). Cosí la vera causa del fenomeno gli sfugge [...]." Cf. also p. I78, n. 60: "Qui il dato sensoriale è direttamente assunto come dato sperimentale senza riflessione critica [...]."

249 On the secondary importance of empirical verification in the formation of ancient scientific theories, but also in our modern evaluation of them, see D. Lehoux, 2003. Lehoux discusses Quaest. conv. 64IC, where it is argued that there is tangible experience ( $\pi \varepsilon i \tilde{p} \alpha \nu$ ) 
indeed, plausible, albeit only in this specific context, that is, when all premises are accepted as stated. However, in Q.N. I8, 9I6B, Plutarch argues, on the contrary, that the calamary leaps out of the sea in an attempt

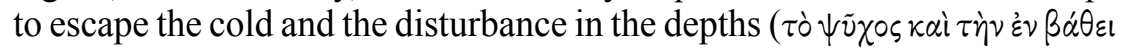
$\tau \alpha p \alpha \chi \dot{\eta} \nu \tau \tilde{\eta} s \theta \alpha \lambda \dot{\alpha} \tau \tau \eta \zeta)$. This implies that cold can, in fact, be accompanied by movement in the sea - in opposition to what Plutarch says in Q.N. 8 , 9I4B (the sea grows warmer when it is agitated). Clearly, then, Plutarch's world is not constituted such that it leaves no room for variations of such physical theories (c.q. the innate heat of seawater), at least within the broad limits of $\tau \dot{o} \pi \imath \theta \alpha \nu o ́ v$. These theories are not idées fixes in a strict sense, because nothing in the sublunary region is ontologically stable. Thus, all possibilities should also remain open at an aetiological level250. Therefore, we should probably cut Plutarch some aetiological slack in physical matters, especially in the context of sense perception (I will come back to this point later [see 4.3.3.2.]).

Similarly, close to the end of the aetiology in $Q . N .8$, Plutarch refers to the seawater's transparency in order to illustrate its innate heat (transparent water contains light, and by implication fire and heat). One may wonder, though, if this transparency does not apply to other kinds of water just as well, such as that of lakes, rivers or fountains. Plutarch does not mention this, precisely because it would disturb the logic of his argumentation.

for the antipathetic phenomenon of magnets losing their attractive force when rubbed with garlic. Who would even consider putting this ancient belief to the test today in his rejection of it? On the basis of this question, Lehoux develops his thesis according to which shifts in ontological categories can occur over time, and that the evaluative significance of empirical verification is a priori subjected to these categories. He argues (p. 334) that "the category of 'experience' is heavily intertwined with the category of 'theory'" (c.q. the ancient theory of cosmic sympathy and antipathy vis-à-vis the modern theory of magnetic attraction). He, therefore, notes that "obviousness has more to do with the [epistemological] classifications of facts than it does with the experiences of those facts. But the epistemologies on both sides [i.e. in ancient and modern evaluations of such phenomena] try to tie that obviousness of kind to obviousness of experience, by surreptitiously including classification under the rubric of experience" (p. 327). For further (critical) discussion of Lehoux' account, see the conclusion in M. Meeusen, 2014.

${ }^{250}$ Cf. J. Opsomer, 2009, p. I3I: "The very fact that opposed principles can apparently be applied at will in physical contexts show something important about what we can know about the physical world according to Plutarch [...]." "[T]he physical world is by nature such as to elude a firm epistemic grasp". The same conclusion was made for the (alleged) contradictions in De facie by P. Donini, 1988, p. I38: "The contradictions [...] have the purpose of insisting on the nondefinitive, not fully certain, nonabsolute nature of scientific explanations. The Platonic philosopher suggests that when one engages in the science of nature or of the heavens, one must always remember that in a wider vision [...] the explanations could be different, involving metaphysical forces or entitites which are not even exactly perceptible by science." 
Nevertheless, Sandbach tries to redeem Plutarch by suggesting that " $[t]$ he sea is no more transparent than fresh water, but some Greeks, perhaps as not familiar with any deep fresh waters, thought that it was" ${ }^{251}$. Sandbach's claim seems to imply that Plutarch never saw the water of a pond in his entire life - however, he is not that much of an armchair scientist either.

In Q.N. 39, Plutarch deals with the problem of why water is seen as white in its upper layer but black at the bottom. In the explanation he draws attention to the visual aspect of both colours (spectatur), but only in order to emphasise the paradoxical opposition between them. Again, we are dealing with a classic paradox. The main problem is that if water is essentially black (a physical theory that recurs, for instance, in De Is. et Os. 364B and in De prim. frig. 950A), why is it seen as white in its upper layer but black only at the bottom? Apparently, it did not really matter for Plutarch - for the sake of the argument, presumably - that if one takes a portion of the deep water, it will turn out to have the same colour as that in the upper layer ${ }^{252}$.

A similar conclusion can be drawn for Q.N. II, 9I4EF. Here, Plutarch addresses the problem of seasickness, which, according to what he says in the quaestio, occurs on the sea rather than on rivers, even if the weather is calm. Plutarch argues that of all sensations, the sense of smell induces

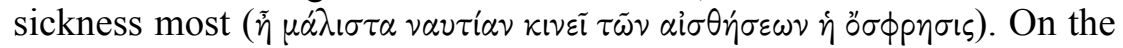
basis of this reference to human sensation $(\alpha i \sigma \theta \eta \sigma \varsigma)^{253}$ and a lack of exact sources, Senzasono suggests that we are dealing here with an instance of Plutarch's personal experience in navigation ${ }^{254}$. Surely, though, one does not necessarily have to suffer from a certain affliction (c.q. seasickness), in order to speculate about its origins - otherwise, doctors would find themselves in a most distressful situation. Of course, one cannot rule out the possibility that Plutarch personally experienced this ailment during

${ }^{251}$ F.H. Sandbach, I965, p. I7I, n. c. He refers to Ps.-Arist., Probl. 932 b8 and 935 bi 7.

${ }^{252}$ Cf. W. Capelle, I9IO, p. 333, n. 2: "Daß das Wasser von Natur weder schwarz noch weiß, sondern farblos ist, scheint man im Altertum nicht erkannt zu haben, offenbar, weil man es nicht in durchsichtigem Glase geprüft hat." One could just as well use one's hands to test this, so it is only likely that the aspect of experimentation was not that important an issue to begin with for Plutarch.

${ }^{253}$ Notably, it is only in this passage in Quaestiones naturales that Plutarch relates the concept of $\alpha$ il $\sigma \eta \eta \sigma \varsigma$ to human sense perception. In other passages, it refers to the sensation

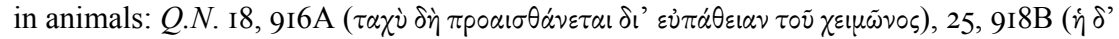

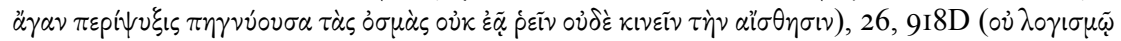
$\tau \circ \tilde{v} \sigma u \mu \phi \dot{p} p \circ \nu \tau \circ \varsigma \dot{\alpha} \gamma \circ \dot{\sigma} \sigma \eta \varsigma \tau \tilde{\eta} \varsigma \alpha i \sigma \theta \dot{\eta} \sigma \varepsilon \omega \varsigma)$.

${ }^{254}$ L. Senzasono, 2006, p. 27: “Cosí il Problema XI [...] presuppone senza dubbio l'esperienza diretta della navigazione e la riflessione personale sui malesseri che essa può comportare [...]." Cf. also p. I85, n. 73: "qui Plutarco si riferisca a sue esperienze personali e rifletta su di esse in modo originale". 
a sea voyage once, but it is just as likely that he heard or read about it. In either case, I would argue - perhaps ad nauseam at this point - that this element of sense perception is subordinated to the logical development of the aetiology itself. The quaestio is again formulated as a traditional paradox: even if the weather is calm, people are liable to suffer from seasickness, and more so when sailing on the open sea than on rivers. One may wonder whether this is really so. Modern scientists would ascribe the cause of seasickness to the rocking motion of the ship on the water over which it sails, regardless of whether it is that of the sea or of rivers. They hold that the illness originates from the conflicting signals that the eyes and the equilibrium sensors in the ears send to the brain. Plutarch, however, links this phenomenon to our perception of smell in conflict with that of sight. Once again, he conjures up a physical opposition in the aetiology, this time between the strange ( $\left.\dot{\alpha} \eta \varepsilon^{\prime} \dot{\alpha} \alpha\right)$ smell of the undrinkable seawater and the customary ( $\sigma \nu v \eta^{\prime} \theta$ s) smell of the drinkable fresh water of rivers. There is no point in putting this to the test for Plutarch, because human al $\sigma \theta \eta \sigma \varsigma s$ is fundamentally deceptive anyway (he emphatically speaks of $\phi \alpha \nu \tau \alpha \sigma i \alpha \nu \kappa \iota \nu \delta v v o v)$. In fact, this is actually what the problem in $Q . N$. II is all about, effectively illustrating how our senses (c.q. smell) trigger our base emotions (c.q. fear), which can eventually fool our souls and sicken our bodies (c.q. by causing seasickness).

In conclusion, Plutarch's relative nonchalance towards observatory knowledge and empirical verification in his natural problems can be connected not only with the intellectual context of problem solving itself, where the theoretical aspect of argumentative ingenuity is considered an important criterion in the debates, but also, and probably more fundamentally so, with his Platonically inspired depreciation of the low epistemological value of sensible data. In accordance with Platonic-Academic philosophy, Plutarch accepts that natural phenomena have a low ontological statute and, thus, yield inferior knowledge. Therefore, the logical persuasiveness of the explanations is more important for Plutarch than the actual verification or even verifiability of sensory data. The only thing that matters for Plutarch is providing a set of more or less plausible explanations for each natural problem. In the end, the logical development of the explanations takes priority, and when it is necessary, the data pertaining to sense perception are adapted to the logical development of the arguments themselves, rather than the other way around. Van der Stockt is correct, therefore, that:

"there is, in ancient science and Plutarch's practice, undeniably a certain degree of negligence in the gathering and classifying of physical data, of testing hypotheses against those data, let alone of experimentation; 
the criterion for validating scientific opinions seems to have been more the comprehensiveness of "logical" explanations and the coherence of the theory"255.

In the following section, I will examine in further detail how Plutarch organises his natural problems in a generally logical fashion, and which methodological dynamics are playing along in this process.

\subsubsection{Logical-rhetorical dynamics}

In his natural problems, Plutarch is not concerned with formulating cogent proofs but probable arguments, by means of which he tries to convince the reader of what is said ${ }^{256}$. The emphasis on argumentative persuasion has specific rhetorical overtones - rhetoric being the ability to see what is possibly persuasive in every given case (cf. Arist., $R h$. I355b26-27 and Top. I49b25) -, but it is also an intrinsic aspect of Plutarch's natural scientific method, as we saw previously. By providing several plausible explanations

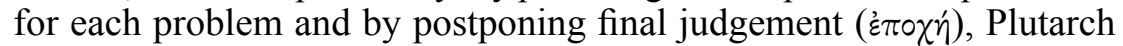
intentionally avoids taking a dogmatic position and leaves space for further examination. We know from De tuenda ${ }_{3} 3 \mathrm{CE}$ that problems in the field of dialectics are not very pleasant, according to Plutarch, because they 'bring on a headache and are extremely fatiguing', whereas natural problems are 'easy and persuasive' ( $\dot{\lambda} \alpha \phi \rho \dot{\alpha} \kappa \alpha \grave{\imath} \pi \imath \theta \nu \alpha \dot{\alpha}$ [quoted 3.I.3.]). Plutarch thus distinguishes physical aetiology from purely logical demonstration $(\dot{\alpha} \pi \delta \dot{\delta} \varepsilon \xi \xi \mid \zeta)$, that is, a type of reasoning which, in line with Aristotelian dialectics, departs from premises that are strictly true and certain ${ }^{257}$.

\footnotetext{
${ }^{255}$ L. Van der Stockt, 20II, pp. 454-455.

${ }^{256}$ For the distinction between plausible vis-à-vis cogent demonstration, see, e.g., Quaest. conv. 6I4CD, where preference goes to the former category ( $\delta \dot{\alpha} \tau \sigma \tilde{\nu} \pi \imath \theta \alpha \nu \circ \tilde{\nu} \mu \tilde{\alpha} \lambda \lambda_{0} \nu$

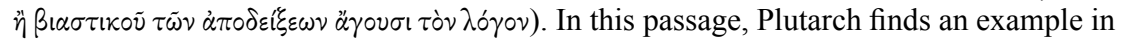
Plato, who in his Symposium, even when discussing serious philosophical matters such as

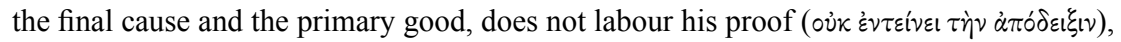

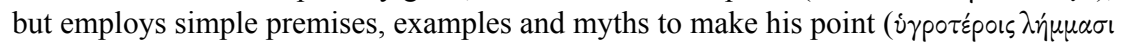
kai $\pi \alpha p \alpha \delta \varepsilon i \gamma \mu \alpha \sigma \iota$ k $\left.\alpha \iota \mu \nu \theta 0 \lambda \circ \gamma^{\prime} \alpha \iota \varsigma\right)$. The same Platonic strand of argumentation is also present throughout Quaestiones convivales, and in Plutarch's other collections of quaestiones, including Quaestiones naturales.

${ }^{257}$ In Aristotelian logic, demonstrative reasoning ( $\left.\dot{\alpha} \pi \delta ́ \delta \varepsilon \xi \xi \zeta \zeta\right)$ is deductive proof by syllogism, which is based on primary and true premises (as opposed to dialectical, contentious and false reasoning: cf. Arist., Top. Iooa25-IOIa24). It can also apply to a rhetorical demonstration, though, viz. an $\dot{\varepsilon} v \theta \dot{v} \mu \eta \mu \alpha$. See LSJ, s.vv. Cf. Arist., Rh. I355a6-

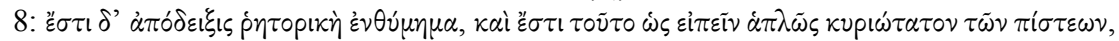

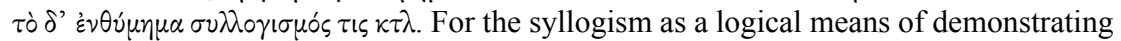

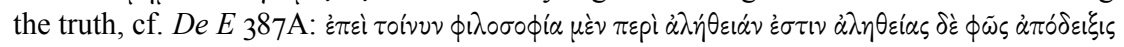

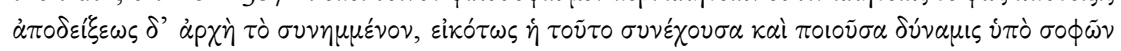

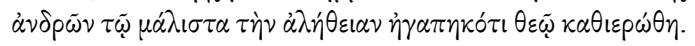


This does not imply, of course, that the arguments in Plutarch's natural problems would be strictly illogical. As I will try to show in this section, the laws of logic and dialectics remain operative in Plutarch's natural problems, albeit in a broader sense, viz. by being applied to the overall plausibility, not the veracity, of the arguments at hand ${ }^{258}$. Indeed, Plutarch's custom to argue from probabilities impedes his physical aetiologies from developing into fully logical demonstrations ( $\left.\dot{\alpha} \pi \circ \delta \varepsilon \dot{\xi} \xi \varepsilon \iota_{\zeta}\right)$. Even still, the basic principles and rules of logic and dialectics are observed throughout the entire collection, which is true at least within the epistemological confines of physical aetiology. More concretely, I will examine how Plutarch deploys several such dialectical-rhetorical strategies in order to bolster the persuasiveness of his arguments ${ }^{259}$. I will also try to explain why - that is, for which methodological motives - they are deployed in his natural problems.

\section{Contradiction, non-contradiction and aetiological freedom}

First of all, the principle of non-contradiction is operative throughout Quaestiones naturales, albeit not always in a very strict sense. At some points, Plutarch intentionally avoids logical contradictions among the different problems. This is the case, most clearly, in Q.N. 5, 913 B, where he (regarding the problem of why the salty flavour is not produced by any fruit) in the first causa notes that salt is not nutritious for animals that feed on seeds and plants (a similar point is made in the first causa of Q.N. I, $9 \mathrm{IIC}$ ). At the end, though, he adds that it still functions as a relish for some

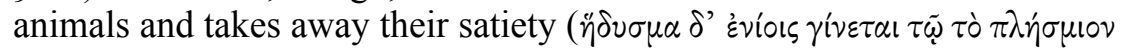
$\dot{\alpha} \phi \alpha\llcorner\rho \varepsilon \tau \tau \tau \tilde{\omega} \nu \tau \rho \varepsilon \phi o ́ v \tau \omega \nu$ ). This addition does not directly contribute to the argument at hand, but it is still useful as an allusion to Q.N.3, 912DE earlier on, where the same point was made, albeit regarding another problem (viz. why herdsmen put down salt for their cattle). Plutarch there argues in

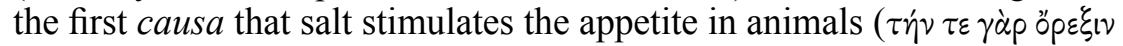

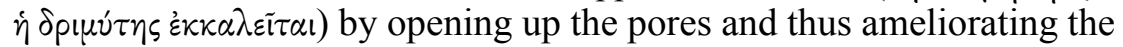
passage of the food for distribution into the body. By implicitly alluding in $Q . N .5,913 \mathrm{~B}$ to what was previously argued in Q.N. 3, 912DE Plutarch, thus, avoids contradiction.

Such back-references between different problems can also be marked

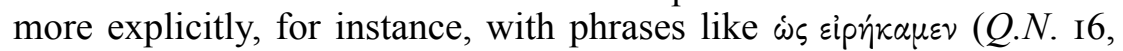

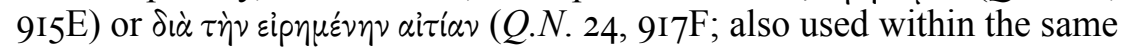

${ }^{258}$ Notably, in Q.N. 15, 915D the argument is actually called a $\lambda{ }^{\circ} \gamma \circ \varsigma$, in the sense of a logical account. Cf. also, e.g., Quaest. conv. 680CD [quoted 4.I.I.I.], De facie 932D.

${ }^{259}$ For the operation of several such logical principles also in Quaestiones Romanae, see J. Boulogne, I992, pp. 4690-4694 ("raisonnement logique") and pp. 4696-4698 ("esprit dialectique"). 
aetiology in Q.N. 4, 9I3A). The avoidance of contradiction is not, however, attested consistently throughout the entire collection (at times, not even within one and the same aetiology: see further $)^{260}$. Take, for instance, the aforementioned case concerning the relation between the motion and the temperature of seawater in Q.N. 8, 9I4B vis-à-vis Q.N. I8, 9I6B. In the former passage, Plutarch argues that motion causes warmth in the sea, but in the latter it is said to produce coldness. As noted previously regarding this type of contradiction, we should probably allow some aetiological freedom in Plutarch's natural problems, since nothing in the realm of natural phenomena and sensory data is certain from an epistemological perspective, so that all possibilities remain open also on an aetiological level (see n. 250).

The principle of non-contradiction is also operative within each problem chapter separately, where it applies to the validity of both the quaestiones and the causae. As to the quaestiones, first of all, the natural phenomena are often formulated on the basis of a specific paradox, which aims to evoke a sense of wonder for a given 'contradiction' in nature. These paradoxes are most commonly formulated (with the usual ellipses in phrasing in Quaestiones naturales) as follows: 'Why does phenomenon X have the effect Y, while phenomenon Xa does not have the effect Ya?' (e.g., Q.N. 7, 8, I3) or 'Why does phenomenon $\mathrm{X}$ have the effect $\mathrm{Y}$, while not-Y is in fact expected?' (e.g., Q.N. II, 26, 28). The paradox can be considered a subcategory of the mirabilia, because it just as well arouses a sense of wonder for what is said, and responds to a sentiment of initial disbelief [see 4.I.I.I.]. With the aetiology that follows, the author then tries to demonstrate that the contradictory aspect in this paradoxical phenomenon is only a matter of appearance and can be solved by providing pertinent explanations, thereby revealing the actual logic behind the paradox. This is usually achieved when a subtle conceptual distinction is made in the problematic natural phenomena itself. This distinction is often already hinted at in the specific phrasing of the quaestio, more precisely by the mentioning of or allusion to opposite substances, qualities, powers or processes ${ }^{261}$. Take, for instance, $Q . N$. I3, 9I4BC, where Plutarch wonders why fishermen's nets decompose more in the winter than in the summer, whereas the opposite is true for other objects. The abnormality of this paradoxical phenomenon is twofold: why does this process of decomposition occur more in the winter than in the summer and not the other way around, as could be expected

${ }^{260}$ Pace H. Flashar, 1962, p. 370, who ensures us that Quaestiones naturales is entirely free from contradictions (and doublets). On Plutarch's contradictions more generally, see A.G. Nikolaidis, I99I. On contradictions in Ps.-Aristotle's Problems, see C. Prantl, I852, pp. 358-359 (with E.S. Forster, I928, p. I65).

${ }^{261}$ For the idea that there are, indeed, opposite forces at work in nature, cf. De prim. frig. $947 \mathrm{~F}$ (quoted, n. I63). 
(since heat, which is an attribute of the summer rather than the winter season, has a putrefactive quality)? And why is the opposite true for other objects (presumably on land), but not for the nets (in the sea)? In other words: why does nature seem to make an exception for the nets? In his aetiology, Plutarch will draw specific attention to these opposite attributes in order to solve the paradox (viz. winter vs. summer, and nets vs. other objects). The first causa draws attention to the opposition between cold and heat. The heat of the seawater withdraws under the atmospheric cold in winter and is concentrated by it ( $\alpha \nu \tau i \pi \varepsilon p i \sigma \tau \alpha \sigma i \varsigma)$, so that the water in the depths of the sea becomes warmer and, by consequence, decomposes the nets more easily. It is implied that the same process ( $\alpha \nu \tau i \pi \varepsilon p i \sigma \tau \alpha \sigma i \varsigma)$ does not occur in the case of other objects on land in winter, on account of the presence of atmospheric cold. Plutarch makes a more subtle distinction in the second causa, where he argues that the nets do not actually decompose, but undergo a process similar to it (see further).

At the level of the causae, secondly, we see that within one and the same explanation no contradictions occur, probably because this would disturb the internal logic of the argument at hand. Nevertheless, such contradictions sometimes do occur among the separate causae in one and the same aetiology. It is perhaps useful for our further analysis to draw a functional distinction here between two different types of causae, based on the underlying logic they each have in the aetiologies. I) At times, the aetiology consists of a number of causae that are complementary to each other, in the sense that they complete one another. In this case, the natural phenomenon is conceived of as the result of a complex natural process, and the different explanations each mention a cause that explains part of this process (cf., e.g., Q.N. I2, 19, 26, 34). For instance, regarding the problem in Q.N. 26 of why animals seek and pursue substances that have remedying properties when they are ill, and often restore themselves to health by using them, Plutarch gives two complementary explanations. According to the first causa, it is by the attractive qualities of odours that animals find the proper cure for their disease. However, this does not explain why animals are attracted by these odours only when they are ill. Plutarch explains this point in the second causa, where he argues that the animal's

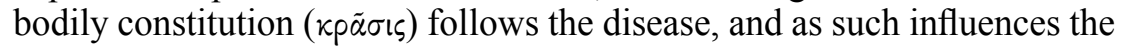
appetite. The two explanations are complementary to each other and must be read together for a proper understanding of the problem. At times, the aspect of aetiological complementarity is formulated more periphrastically

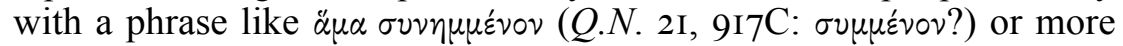

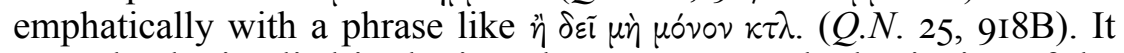
may also be implied in the introductory $\ddot{\eta} \kappa a i$ at the beginning of the causae (Q.N. 2, 9I2A, 2I, 9I7C, 28, 9I9A (?), 3I, 9I9D) 262. 2) In other

${ }^{262}$ In this sense, $\ddot{\eta}$ kai signals a connection between two or more solutions (implying 
cases, the causae provide alternative interpretations for the same problem, which are not linked to each other and can be seen as completely distinct approaches to the problem. This is the most common type of explanation. Two sub-categories deserve specific consideration here. A) Sometimes the explanations exclude each other by mentioning causes that cannot occur at the same time. B) On other occasions, Plutarch tries to cast doubt on the natural phenomenon itself, as mentioned in the quaestio (I will deal with the second sub-category later [see 4.3.3.3.]).

As regards the first sub-category (2A), apparently, Plutarch's wellreasoned undecidedness in natural science allows contrary arguments to be taken into consideration. This is the case, for instance, in Q.N. 3, 9I2 DE, concerning the problem of why herdsmen put down salt for their cattle. In the first causa, Plutarch argues that salt fattens the cattle, whereas according to the second it reduces their bulk. Plutarch here marks the contradictory value of his second argument with the introductory $\ddot{\eta}$ $\mu \tilde{\alpha} \lambda \lambda_{0}$, but on other occasions the contradiction is more explicit with a

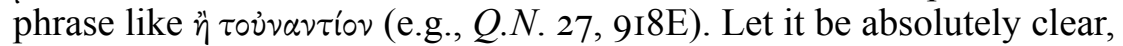
however, that these 'contradictions' are not logical errors per se. On the contrary, they aim to provide an alternative explanation that is, in all regards, opposed to the preceding one but is at least equally, if not more, plausible. It is, in fact, a well-planned rhetorical strategy and challenge for Plutarch to reverse a certain argument in order to argue in favour of its exact opposite ${ }^{263}$. This argumentative technique ties in closely with the

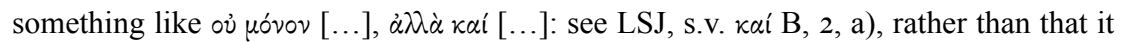
introduces an alternative explanation that must be seen as fully distinct from the other causae ('or rather', 'or indeed'). For the complementary value of $\ddot{\eta}$ kaí, see J.D. Denniston, I966, p. 299: "B is true as well as A". This is not to suggest that, in the case of Plutarch's problems, two explanations can be true for one and the same phenomenon (cf. F.C. Babbitt, I936a, p. 2: "presumably not more than one can be right"); rather, it implies that B may lay an equally legitimate claim to being 'true' as A does, the connection bearing on the underlying epistemological conviction that certainty is eventually unattainable. This very meaning is also attested in Plutarch's use of $\eta \hat{~} \kappa a$ i throughout the Quaestiones Romanae

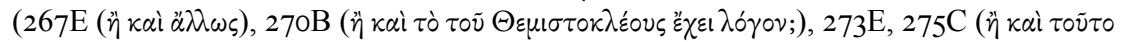

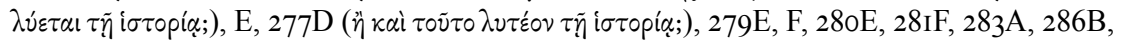
288B, 29IA).

${ }^{263}$ Cf. J.R. Hamilton, I969, p. xxx (in the context of rhetorical school exercises): "one should not rest content with refuting one's opponents, but should seek to prove the exact opposite". In regards to the reversing ( $\dot{\alpha} \nu \alpha \sigma \tau \varepsilon \dot{\phi} \phi \varepsilon \nu$ ) of arguments, compare the analogy in De Pyth. or. 396E, where the following story is told by the Epicurean Boëthus. Pauson the painter was commissioned to paint a rolling horse, but painted it galloping. The patron was displeased, but Pauson laughed and turned the painting upside down, so that the horse appeared to be rolling instead of galloping. According to Bion, this is also what happens

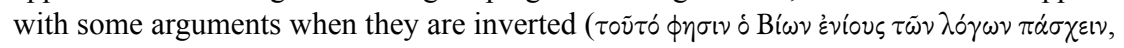
ö $\tau \alpha \nu \dot{\alpha} \nu \alpha \sigma \rho \alpha \phi \tilde{\omega} \sigma \iota)$. 


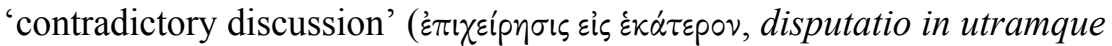
partem) that was a common educational practice in the schools of rhetoric and philosophy at the time, where topics were argued from both sides, pro and con $^{264}$. As is well-known, several of Plutarch's works are based on this antithetic scheme ${ }^{265}$. Babut has even argued that this is a typical procedure in Plutarch's scientific writings in general:

'Et c' est cette méthode de la disputatio in utramque partem que l' on voit mise en œuvre dans les écrits de l' auteur qui traitent de problèmes de physique, qu' il s' agisse d' excercices purement scolaires, comme les Aetia physica et la dissertation Aquane an ignis sit utilior, ou de travaux plus élaborés et susceptibles de refléter davantage ses propres options philosophiques, comme le De facie ou le De primo frigido $[\ldots] .{ }^{266}$

This method of contrary discussion can be connected with the concept of

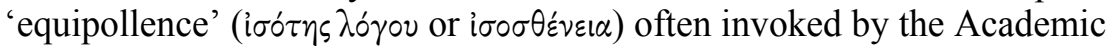
Sceptics ${ }^{267}$, that is, the argumentative strategy, where a person, in order to dispute his opponents' claims to the truth, substantiates his own theory with arguments that are equally convincing or plausible, a procedure that eventually results in $\dot{\varepsilon} \pi \circ \chi_{\eta}^{\prime}$ (as is the case, e.g., in De prim. frig. $955 \mathrm{C}$ [quoted 4.3.2.I.]). A similar dynamic is seen at work in the contradictory arguments in Plutarch's natural problems, since they each contribute an equal share of plausibility to the aetiology, often without any clear value judgement being made.

Strictly speaking, the concept of contrary discussion involves an opposition of two essentially irreconcilable explanations ${ }^{268}$. However,

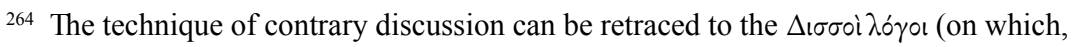
see P. O'Grady and D. Silvermintz, 2008, pp. I47-I5I). It was also well-entrenched in the philosophy of Plato, Aristotle and the Academic Sceptics (cf., e.g., De Stoic. rep. 1035FI036A, $A d v$. Col. II24A). See, e.g., J. Boulogne, I992, p. 4697 (with n. I00), D. Babut, I994, pp. 566-567, J. Opsomer, I998, pp. I86-I90, E. Kechagia, 20IIa, pp. 96-97.

${ }^{265}$ It can be seen both in Plutarch's scientific and non-scientific writings. For the contrary discussion in Quaestiones convivales, see, e.g., 667C-669E. See also esp. the contrary argumentations in De sollertia animalium and Aqua an ignis sit utilior, but also, e.g., in Animine an corporis affectiones sint peiores, De fortuna, De fortuna Romanorum, De Alexandri Magni fortuna aut virtute, Bellone an pace clariores fuerint Athenienses

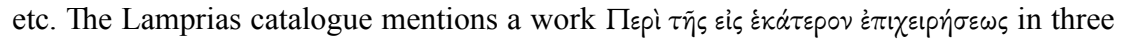
Books (nr. 45). Cf. R. Flacelière, J. Irigoin, J. Sirinelli and A. Philippon, I987, pp. ccviiccx.

266 D. Babut, 1994, p. 567.

267 Cf. Sext. Emp., HP I, 202-206. See J. Opsomer, I994a, pp. 77, 79 and I998, pp. I86, 2I4-2I6 (with n. I3 for further references).

${ }^{268}$ See, e.g., those problems where Plutarch alternately draws attention to the external 
Plutarch often opposes more than two explanations in his aetiologies, and the opposition is not always that strict either. Even though he does often employ an aetiological parting into two opposite causae, in some cases yet other alternative causae are added (see below). Moreover, in those cases where only two explanations are given, these are not always strictly opposed to each other ${ }^{269}$. There is reason to assume, therefore, that yet another, more complex, logical principle plays an important role in Plutarch's physical aetiologies. Two further observations should be made in this regard.

First of all, this 'contradictory' approach, where an argument ('thesis') and a counterargument ('antithesis') are directly opposed, can be subsumed by some kind of combinatory argument ('synthesis' - the Hegelian scheme of Aufhebung is never strictly applied, though). Such an aetiological scheme is found, for instance, in Q.N. I2, where the external and the internal effects of the phenomenon of oil poured on seawater are opposed to each other in the first two explanations, while in the third solution, both of these effects are combined. The first two causae are complementary to each other, explaining the seawater's $\gamma \alpha \lambda \eta^{\prime} \nu \eta$ and $\kappa \alpha \tau \alpha \phi \alpha$ ' $\nu \varepsilon 1 \alpha$ provided by the oil respectively, but the last one tries to comprise and combine the preceding causae by explaining both the effects of $\kappa \alpha \tau \alpha \phi \alpha$ 'vi $\alpha \alpha i$ $\gamma \alpha \lambda \eta^{\prime} \nu \eta$ at the same time (as mentioned in the quaestio), so that it is the most complete in the aetiology. The second point, which is more complex, has to do with the aspect of 'aetiological comprehensiveness' in Plutarch's natural problems ${ }^{270}$. I will deal with this issue in the following section.

\section{Aetiological comprehensiveness and pluricausality}

In Plutarch's natural problems, each causa is meant to adduce a more or less plausible element to the aetiology, without final judgement being made $\left(\dot{\varepsilon} \pi \circ \chi \eta^{\prime}\right)$. The combination of a number of plausible explanations - either as alternatives for or complementary to each other - can be considered an implicit attempt at aetiological comprehensiveness, in the sense that an

and internal explanations of a specific phenomenon (cf. Q.N. 7, I2, 2I, 26 - the alternation also occurs the other way around: cf. Q.N. I6, I7: see G. Roskam, 20IIc, pp. 424-425).

269 A similar observation was made for Quaestiones Romanae by J. Boulogne, I992, p. 4697.

${ }^{270}$ For this, I - partly - rely on a theory Boulogne has proposed in view of the logic behind Plutarch's aetiologies in Quaestiones Romanae (J. Boulogne, I992; quoted below), and which has also been applied to Plutarch's other collections of quaestiones by other scholars. For its application to Quaestiones Platonicae, Romanae, naturales, convivales, and also De E and De Iside et Osiride, see G. Roskam, 20IIc, pp. 424-425. For its application to Quaestiones convivales more in specific, see J. König, 2009, p. 88 and F. Klotz and K. Oikonomopoulou, 20II, p. 26. 
effort is made to exhaust the principle of plausibility as much as possible. Boulogne has drawn a similar conclusion for Plutarch's Quaestiones Romanae:

"Face à la complexité du monde, Plutarque applique la méthode capable, à son avis, de lui en procurer la saisie la plus totale possible. D' où une interrogation systématiquement multiforme, fondée sur la conviction que seule la pluricausalité ouvre, dans le champ d'étude parcouru, le chemin de la compréhension."271

The aspect of 'pluricausality' (to use Boulogne's wording) is not necesarily the same as 'causal overdetermination', which implies that of several explanations that are given each may be sufficient in itself to account for the problem at hand ${ }^{272}$. Rather, Plutarch's attempt towards aetiological comprehensiveness reveals an important aspect of his natural scientific

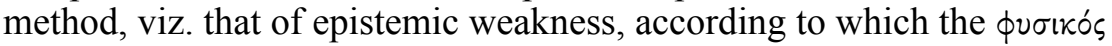
should acknowledge that the ultimately correct explanation cannot be grasped by means of physical aetiology. The formulation of several more or less plausible explanations in the aetiologies is not, of course, an obstacle in the search for a valid explanation: it rather promotes it. At the same time, it testifies to the author's impulse to put into words the diversified range of causal attributes that may be operative in a specific natural phenomenon,

271 J. Boulogne, I992, p. 4690. Boulogne adds (p. 4697): "Dans ces conditions, la multiplication des interrogations $[\ldots]$ tend $[\ldots]$ vers une espèce de démonstration du bien-fondé de la promotion d' une solution regardée comme la plus valable. Plus l'addition des disjonctions s' accroît, plus celles-ci s' enrichissent de la confrontation des origines possibles ainsi rapprochées les unes des autres, plus nombreuses, du coup, deviennent les associations et les combinaisons qu' elles provoquent et plus grande leur chance d'emprisonner la réalité dans leurs rets." I am not so sure, however, whether the ultimately correct explanation will be reached by doing the sum of the plausible elements found in the distinct causae, each containing a complementary 'part of the truth'. In the end, the aetiology as a whole will provide only a plausible account. Cf. id., I994, p. I29: "le domaine étudié n' offre aucune certitude absolue. Néanmoins, plus que le doute ou la prudence liée négativement à une impuissance intellectuelle, ce qui sous-tend cette démarche demeure principalement la conviction que la réponse la plus plausible est celle qui parvient à réunir de façon cohérente le maximum des parcelles de vérité dispersées au sein de la multiplicité des explications connues et possibles".

${ }^{272} \mathrm{Cf}$. De $E 387 \mathrm{~B}$, for the idea that, since nothing in the cosmos becomes without a

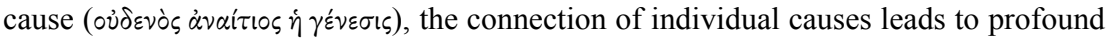

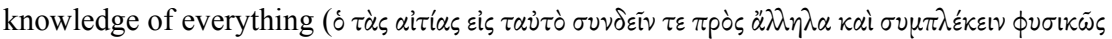

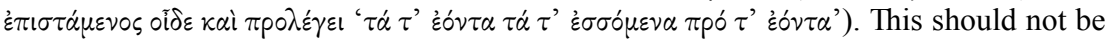
interpreted in light of 'causal overdetermination' but in light of the Stoic theory of fate

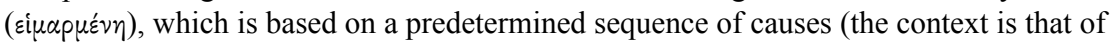
the prophetic art) [see 4.I.I.3.]. 
and thus in nature as a whole. The search for logical comprehensiveness is, thus, motivated on a firm epistemic basis.

Notably, the aspect of 'pluricausality' was a common argumentative procedure also in the scientific method of the Epicureans, especially in matters pertaining to meteorology ${ }^{273}$. However, as König has argued in light of the aetiological pluralism of the natural problems treated in Quaestiones convivales, it has a very different motivation in Plutarch:

"Epicurean theory holds that all explanations are equally valuable, the main aim of explanation being to remove superstition by showing that a number of plausible rational explanations exist; in some of his works Plutarch rejects that assumption, tending to hierarchise his alternative explanations according to plausibility [...], but the Quaest. conv. in places comes close to endorsing that Epicurean view, albeit for very different reasons, by the suggestion that all responses may be equally valid because of their equal capacity to inspire philosophical reflection." 274

In what follows, I will zoom in on I) the aspect of superstition, and 2) the value and validity of the aspect of plausibility in Plutarch's aetiologies.

I) König is absolutely right in pointing out that Plutarch's custom of listing several plausible explanations for one and the same natural phenomenon is fundamentally different from that of Epicurus. This can be explained in light of the completely different outlooks on the world these two thinkers had, and especially in light of their dissimilar views on theology. As is well-known, Epicurus did not reject the existence of the gods, but situated them in the intermundia, thus generally separating them from our world. These gods do not really care about us, but focus all of their attention on their own blissful state of being. In an attempt to attain $\dot{\alpha} \tau \alpha \rho \alpha \xi i \alpha$, we should strive to emulate their tranquil way of living, but we should not fear their wrath. By providing several equally valid natural explanations, then, for the at times very frightening natural phenomena around us, Epicurus aims to show that these can be explained by the working of natural causes alone (only one of these causes being valid in our world: cf. Lucr., De rer. nat. 5, 526-532). Although for Plutarch physical aetiology also serves as a useful tool to do away with irrational feelings of superstition, as discussed previously [see 3.2.2.], he would probably consider Epicurus' approach atheistic, at least in the sense

${ }^{273}$ See E. Asmis, I984, pp. 32I-330, F. Jürss, I994, L. Taub, 2003, pp. I27-I37, F. Bakker, 20I0, pp. 8-68.

${ }^{274}$ J. König, 2007, p. 54, n. 38. Cf. also J. Boulogne, I992, p. 4694 (with n. 77), I994, p. I29 and P.R. Hardie, I992, p. 476r: "One may compare the Epicurean attitude to meteorology; curiosity is satisfied when a number of possible materialist accounts have been given, and the danger of superstition has been removed". 
that it does not account for the providential ordering of the world. This world is based, rather, on the principles of chance and atomism instead ${ }^{275}$. Even if it seems that the eventual purpose of Epicurus' science and its search for 'pluricausality', which is to procure $\alpha \dot{\tau} \alpha \rho \xi^{\xi}$ i $\alpha$, is not so different from the $\varepsilon \dot{v} \theta v \mu i \alpha$ ('tranquillity of mind') Plutarch's science envisages, the fundamental difference is that Plutarch's concept of $\varepsilon \dot{v} \theta v \mu i \alpha$ is based on a firm belief that God's benevolent influence is very palpable in this world, whereas Epicurus' concept of $\dot{\alpha} \tau \alpha \rho \alpha \xi i \alpha$ is established rather on the absence of the gods. As opposed to Epicurus, Plutarch draws a much closer link between the material and the divine realms. Accordingly, he is convinced that only by taking into account both the natural and the intelligible aspects

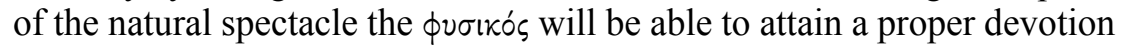
towards the divine ( $\varepsilon \dot{v} \sigma \varepsilon \varepsilon \varepsilon 1 \alpha)^{276}$ [see 4.I.I.3.]. So if this type of research is to "inspire philosophical reflection" (to use König's words), it will only be by shifting towards a higher level of explanation.

2) In regards to the value and validity of the aspect of plausibility in Plutarch's physical aetiologies, it is true that one natural explanation is often presented as being more or less plausible than another, hence the possibility of hierarchising them (cf. the finale in De prim. frig. $955 \mathrm{C}$ [quoted 4.3.2.I.]). However, eventually each of the natural explanations cannot be more than plausible - it cannot attain the level of $\tau \dot{\partial} \dot{\alpha} \lambda \eta \theta \dot{\varepsilon} s$ [see 4.3.2.2.] -, so that they are, at least from a strictly epistemological perspective, equally invalid (as opposed to König's equal

275 This is also why the exclusion of mythology from natural scientific discourse is a

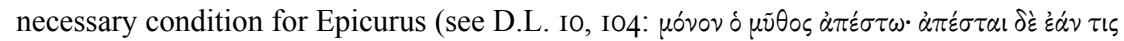

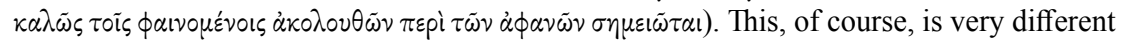
from Plutarch's approach [see 4.I.2.2.].

276 Arguably, the distinction Plutarch makes between superstitious and atheistic reactions to natural phenomena ties in closely with his (at times, indeed, somewhat misguided) representation of his sworn philosophical adversaries, viz. the Stoics and the Epicureans respectively. Superstition applies to the world view of the Stoics, in the sense that they accept the working of divine providence in nature on a rather unscientific basis (they rely on their blind faith in a universally predetermined fate, which is immanent in nature [see 4.I.I.3.]), whereas the Epicureans - always according to Plutarch - openly promote atheism in their natural scientific inquiries by rejecting divine providence. For Plutarch, however, the natural causality of our world relies on a divine order, and both of

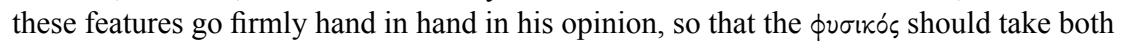
of these aspects into consideration. A similar observation was made by G.E. Karamanolis, 2006, p. I09: "Plutarch's criticism of the Epicurean and the Stoic positions on the divine providence is a clear contrast. [...] In his view, the Epicurean denial of divine providence arises from their atheism, while the Stoic view on providence rests on a materialist conception of God and their assumption of a universally pre-determined fate, since both Epicureans and Stoics are fundamentally mistaken about God's nature." See also J. Opsomer, 20I4, pp. 90 and 93. 
validity). It is this idea of equal invalidity that stimulates Plutarch's search for multiple natural explanations for one and the same natural phenomenon in an attempt to attain aetiological comprehensiveness. Several explanations are plausible in principle, so that the $\phi v \sigma t-$ кós should always leave space for the formulation of new explanations by postponing final judgement $(\dot{\varepsilon} \pi \circ \times \dot{\eta})$. As a result, Plutarch's quest for aetiological comprehensiveness is a very sophisticated process that often involves a high level of aetiological subtlety. I will further examine this in the following section in light of the logical and rhetorical strategies Plutarch employs in his physical aetiologies more generally.

\section{Aetiological subtlety and sophistication}

Each and every element that Plutarch adduces in his physical aetiologies performs a significant and meaningful function in the development of the explanations. Therefore, a careful reading is often required in order to fully seize the precise logic that lies behind an explanation. This is not only true for the specific wording Plutarch uses and their precise meaning (as is the

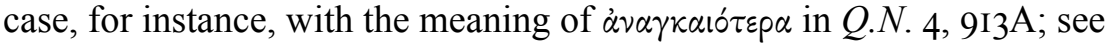
the commentary ad loc.), but also, more generally, for the formulation of the explanations themselves. These are aften formulated in a deductive fashion, where the stated premises should be accepted as stated. In Q.N. $22,917 \mathrm{D}$, for instance, the explanation develops in a syllogistic fashion. In this problem, Plutarch wonders why people say that the bear's fore-paws (or 'hands') have the sweetest flesh and are most delicious to eat. He argues that those body parts that concoct the food the most provide the most delicious meat (this is the first premise). In the sub-argument, he adds that the best concoction is by what 'transpires', being that part of the body that is most in motion and exercised. Plutarch continues that the bear makes most movements with its fore-paws, which it uses as feet when walking or running and as hands when grasping (this is the second premise). Therefore, as the reader can deduce for himself, the bear's forepaws 'transpire' most and, by implication, provide the best concoction. For this reason, they are the most delicious (this is the suggested conclusion). From a structural point of view the deductive-syllogistic development of Plutarch's argument remains implicit in the causa and the reader has to deduce the conclusion for himself. From a logical point of view, moreover, the argumentation is not strictly valid, because the first premise is formulated interrogatively - that is, as a hypothetical argument -, meaning that the deduction proceeds from an uncertain starting-point. Therefore, we are not dealing with a fully logical demonstration $(\dot{\alpha} \pi \delta \delta \delta \varepsilon \xi \xi \varsigma)$ but rather with a rhetorical one. But even so, it is clear that the explanation forms a tight and concise logical unity which is firmly captured in a 
deductive frame. This is what eventually determines its argumentative power and plausibility.

Notably, a certain increase in specificity and detail in the explanations can often be noticed as the aetiology proceeds. It would be wrong to assume, however, that the aetiological development in Plutarch's natural problems is necessarily bound up with an increase in complexity. The last causa of Q.N. 2, 9I2 C, for instance, is actually introduced as being

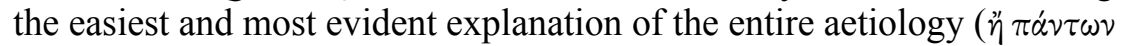

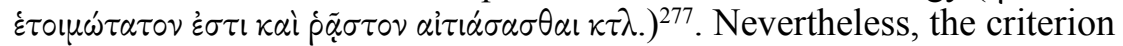
of increasing plausibility, which is the main structuring principle in the development of Plutarch's physical aetiologies [see I.I.4.], often involves an according increase in aetiological subtlety. For instance, in Q.N. I7, 915F-9i6A, Plutarch deals with the problem of people using the (tail) hairs of stallions rather than mares in order to manufacture fishing lines. He gives two explanations for this: in the first one, he draws an analogy with the relative strength in other body parts of horses in arguing that the stallion has stronger hair than the mare. In the second explanation, a more subtle distinction is made between the male vis-à-vis the female body on the basis of their anatomical dissimilarity. Plutarch argues that people believe that the mares' tail hairs become inferior because they are wetted by their urine - which discomfort is, so the reader must add for himself, strange to stallions, since their tails, as opposed to those of mares, are not located in the vicinity of the urethra. Another example is found in Q.N. 6, where Plutarch examines why persons (probably hunters) who frequently walk through bushes wet with dew contract 'leprosy' on those body parts that come into contact with the brushwood. The first explanation is attributed to Laetus, who holds that the dewy moisture scrapes off the skin by means of its fineness. This implies that dew harms the human skin directly. The second explanation is more detailed than the first, since Plutarch there also includes the role of the plants in the phenomenon, as mentioned in the quaestio. He argues that some kind of dust is discharged from plants wet with dew, and that this dust causes harm to those who come into contact with it. As such, it is implied that the erosive effect of dew damages the skin indirectly, that is, via the damage

277 Cf. also, e.g., Quaest. Plat. I004D, where the second and final explanation is

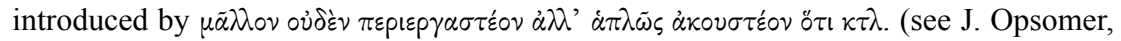
I996a, pp. 78-79, with n. 32 for the negative connotation of $\pi \varepsilon p \iota p \gamma \alpha \sigma \tau \varepsilon$ '́ ). See also E. Teixeira, 1992, p. 219 (regarding Quaest. conv. 722E): “On a l'impression, ainsi, que Plutarque adopte une démarche quelque peu surprenante, en ce sens qu' il présente une explication assez scientifique avant d' en proposer une autre, beaucoup plus simple et, pour ansi dire, terre à terre." For the idea of a "progressive structure" in Plutarch's writings (especially, but not exclusively, in his collections of quaestiones), see G. Roskam, 20IIc, pp. 424-425. 
it does to plants. Arguably, the custom of making such subtle aetiological distinctions ties in closely with the common rhetorical strategy in ancient scientific competition ( $\dot{\alpha} \gamma \dot{\omega} \nu)$ to cap an opponent's arguments with one's personal ingenuities ${ }^{278}$ (as is clear in Plutarch's criticism of Laetus here in Q.N. 6, 9I3E). This sensitivity to increasing aetiological specificity and detail also recurs in the sympotic discussions recorded in Quaestiones convivales. Excessive subtlety is avoided at all cost, though, because, as we saw previously, this suits sophistic disputations by its striving for rhetorical rivalry rather than philosophical dialogue ${ }^{279}$ [see 3.I.3.].

A similar feature of aetiological subtlety can be found in the type of explanations that aim to refute or nuance the phenomenon at issue in the quaestio by explaining a different but seemingly similar phenomenon (this is sub-category $2 \mathrm{~B}$ in the analysis of the different types of causae set out previously [see 4.3.3.I.]). This kind of explanation is usually found last in the aetiology. For instance, regarding the problem of why fishermen's nets decompose more in the winter than in the summer, whereas the opposite is true for other objects, Plutarch, in the second (and final) causa of Q.N. I3, 9I5BC, argues that these nets do not actually decompose, but undergo

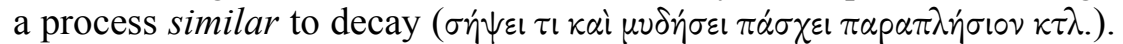
The real process is that of weathering, which is due to the fact that the nets are desiccated by the cold and violently frayed by the waves. Likewise, in the final causa of Q.N. 32, regarding the problem of why the palm tree alone rises against a weight imposed upon it, Plutarch argues that the tree raises its twigs only in appearance. The supple and tender twigs cannot sustain the impetus of the weight, but when the weight comes to rest, the twigs gradually erect themselves and give the impression of rising up against it (speciem quasi contra illud adsurgant praebent). Another example can be found in the last causa of Q.N. 4, 9I3A, regarding the problem of why rainwater accompanied by thunder and lightning is more fertile for seeds. There, Plutarch argues that lightning and thunder are not the actual cause of increasing fertility in plants but rather an incidental aspect. The (spring)rains themselves are more nutritive because they come before the summer heat and, thus, protect the crops against it. Similar instances can be found in Quaestiones convivales, especially in those cases where Plutarch emphatically draws a distinction between cause

278 See T. Barton, I994a, pp. I3-I4 (esp. p. I4, regarding "the emphasis on subtle distinctions, which seems highly unconvincing to us now"), and pp. I47-I49 (on "the agonistic arena"). For professional rivalry among ancient physicians, see, e.g., G.E.R. Lloyd, I970, pp. I42-I43, I979, pp. 97-98, I983, pp. 208-209. For the aspect of debate in the context of Galen's anatomical show-case demonstrations ( $\left.\dot{\pi} \pi \delta \varepsilon_{\varepsilon}^{\prime} \xi \varepsilon ı\right)$, see M. Gleason, 2009, pp. 88-89.

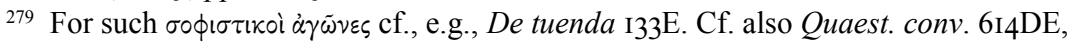
$7 \mathrm{I} 3 \mathrm{~F}$. 
and effect in a given natural phenomenon. Plutarch uses this aetiological strategy, for instance, in dealing with the problem of the remora slowing down a ship (Quaest. conv. 64IAE), and also regarding the (subsequent) problem of wolf-bitten horses being mettlesome (Quaest. conv. 64IF$642 \mathrm{~B}$ ). He argues - twice at the end of the aetiology - that we should not mistake the effect for the cause in these problems ${ }^{280}$ ( $\sigma \kappa \circ \pi \tilde{\omega} \mu \varepsilon \nu \delta^{\prime}$ हi $\pi \circ \nu$

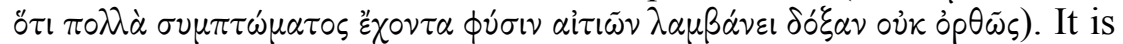
not so much the remora that slows down the ship, but rather the seaweed that sticks to the hull of the ship and that attracts this tiny fish. In the same way, the horses that are attacked by wolves do not at once become swifter, but they would not have escaped their attackers if they were not swift by nature in the first place. In each of these cases, Plutarch puts the popular belief as formulated in the quaestio somewhat in perspective, but he does not, as such, aim to reject it (nor to deny any aspect of divine providence to it). After all, he still takes the popular tradition (i $\sigma \tau \tau^{\circ} \operatorname{pi}^{\prime} \alpha$ ) as a credible starting-point for the discussion, by giving it the benefit of the doubt [see 4.I.I.2.]. Moreover, this kind of explanation, which sets out on denying the traditional view, is only a plausible one, among several other such explanations: eventually Plutarch postpones final judgement ( $\left.\dot{\varepsilon} \pi \circ \eta^{\prime}\right)$.

Another subtle aetiological strategy is the use of argumentative rings, where a specific argument is wound up or completed only at the very end of the explanation or aetiology (e.g., Q.N. I, 2, 9, I2, I8, 26). In some of these cases, we are dealing with a repetition of aformentioned elements in a conclusive fashion. In Q.N. I8, for instance, Plutarch wonders why the appearance of the calamary is a sign of a great impending storm. He opens his explanation by pointing out that all cephalopods by nature are sensitive to cold due to their bodily constitution. Their flesh is bare and naked, they are not covered with a shell, skin or scales, and their hard and bony parts are located inside, which is why they are called 'soft things' $(\mu \alpha \lambda \alpha$ 'kı $\alpha)$. At the end of the explanation Plutarch adduces the specific case of the calamary, noting that it jumps out of the water in an attempt to escape the cold and the disturbance in the depths of the sea. He says that the calamary has the most fragile and delicate flesh

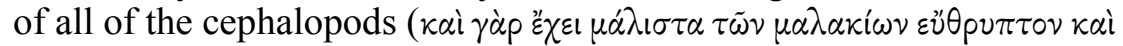
$\dot{\alpha} \pi \alpha \lambda \grave{o} \nu \tau \dot{\partial} \sigma \alpha p \kappa \tilde{\omega} \delta \varepsilon \varsigma$ ), thus closing the argumentative ring by repeating an element that was adduced at the very beginning of the explanation. In other cases, however, the closing of the argumentative ring at the very end of the aetiology enables a clearer view on an explanation that was previously given. This is the case, for instance in $Q . N$. I, regarding the

280 The parallel argument in these two problem chapters was also marked by S.T. Teodorsson, I989, p. 262. 
problem of why seawater cannot provide nourishment to trees. Here part of the first causa becomes clearer only after reading the last one. In the first causa Plutarch argues that it is not the case that seawater, for the reason that it is nutritious and potable for marine plants and fishes alike, feeds plants and trees on land just as well. The idea that marine plants feed on seawater is not further explained here, but recurs in the fourth and final causa, where Plutarch explains that such marine plants (growing in the Indian Ocean) actually receive their nourishment from rivers which deposit much silt in the sea. Plutarch, thus, suggests that the nourishment of marine plants does not essentially differ from that of terrestrial plants, since they are not fed by the seawater itself but by a specific nutritious constituent in it (c.q. silt deposits from rivers). As such, the reference to the nourishment of the marine plants (and perhaps also of fish) by seawater mentioned in the first causa is made more specific in the last one. A similar argumentative ring structures the aetiology in Q.N. 2, where an implicit connection is made between the first two explanations and the final one: the final causa suggests that the season of spring is probably the 'right season' ( $\kappa \alpha \theta$ ' $\omega$ " $\alpha \nu$ ) for the growth of plants in ponds, as mentioned, but not further clarified, in the second causa (see the commentary ad loc.). Such a careful, and at times very subtle, structuring gives the aetiology a sense of finalisation and completion, but, of course, the closing of the argumentative ring is not final or complete in the sense that it removes all possible doubt.

In conclusion, even if Plutarch's physical aetiologies are not - or better: cannot be - envisioned as fully logical demonstrations ( $\dot{\alpha} \pi \circ \delta \varepsilon i \xi \varepsilon l \zeta)$, the elementary rules and principles of logic and dialectics are still observed in them, albeit within the epistemological limits of physical aetiology. Several logical-rhetorical strategies regulate the concrete phrasing of Plutarch's problems, often in a very subtle and sophisticated way. A specific discursive feature that has remained unmentioned thus far but also contributes to the logical-rhetorical coherence of the problems is found in Plutarch's use of a more or less uniform set of scientific terms and concepts. Notably, most of the physical concepts and processes that Plutarch refers to recur among the most disparate natural phenomena. The theory of kpã $\sigma \varsigma$, for instance, applies to the air in the atmosphere, to the composition of the soil and to the constitution of the body. In a similar way, $\pi$ ópor are present in the earth, in the sea, in plants and animals. As such, these fixed terminological schemes hint at an aspect of conceptual coherence and aetiological unity in nature or at least indicate that the

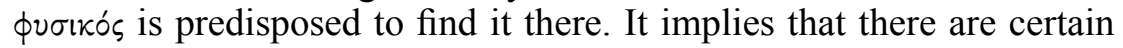
conceptual rules and laws immanent and permanent in nature, at least within the limits of the contingent and unstable ontological status of the realm of natural phenomena to which they apply. These concepts deserve 
separate analysis in the following section, where I will zoom in on the terminological uniformity of the disourse in Quaestiones naturales and also on its level of technicality ${ }^{281}$.

\subsubsection{Uniformity and technicality of the scientific terminology}

Even though Plutarch acknowledges that 'the ingenious organisation of nature's activities is beyond the range of words' (Quaest. conv. 699B [quoted 4.I.2.2.]), he is well aware of the fact that there is still a suitable scientific way to talk about the sensible world arond us. $\mathrm{He}$ also knows that in order to treat a scientific problem properly and, thus, to be regarded as a scientist, he must speak as one, that is, with the terminology that scientists most commonly employ. In De def. or. 436E, for instance, Plutarch (in the context of his dualistic view on causality [quoted 4.I.2.I.]) lists a number of concepts that the $\phi v \sigma i k o$ frequently use in formulating physical explanations: 'the younger generation of physicists [...] ascribes everything to bodies and their behaviour, to

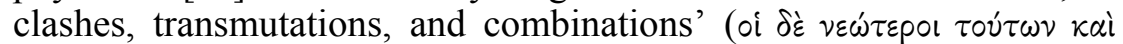

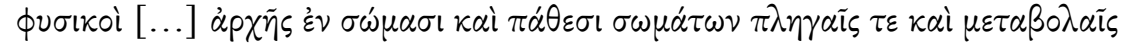

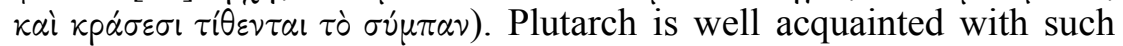
scientific concepts, which he himself also recurrently employs in his natural problems. One may wonder, though, how technical they really are.

Compare, for instance, the unsystematic enumeration of physical concepts in the short excursion into magnetism in Q.N. I9, 9I6D. Plutarch there writes that "people explain the phenomenon of attraction or jumping (in magnetism) by emanations, some assuming it to be due to entanglements, others to impacts, and still others to impulsions and

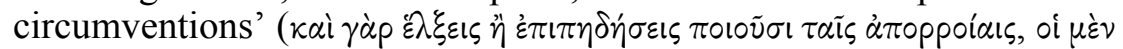

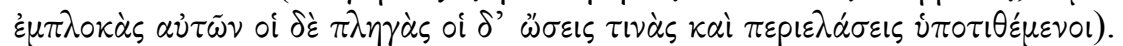
This unsystematic enumeration of technical terms contains references to the theories of Democritus/Epicurus ( $\dot{\varepsilon} \mu \pi \lambda \circ \kappa \alpha i / \pi \varepsilon p \iota \pi \lambda_{0} \alpha \alpha^{\prime}:$ interlacing

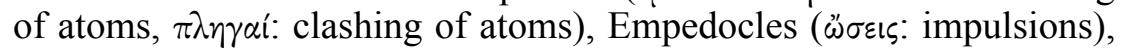
and Plato ( $\pi \varepsilon p 1 \varepsilon \lambda \varepsilon \dot{\sigma} \sigma \varepsilon ı$ : circumventions). Plutarch does not explain these technical concepts any further, but it is rather unlikely that he is simply trying to impress the reader with his mere knowledge of such concepts. On the contrary, these terms are meant to illustrate Empedocles' theory

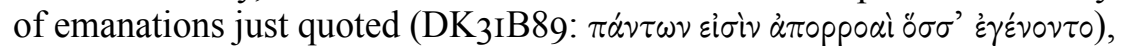
as if to suggest that there is more to them, but that this is not the proper place to deal with them in any detail. Sandbach may well be right, therefore, that Plutarch means to summarise "some account of the

${ }^{281}$ For a separate treatment of this topic, see M. Meeusen, 20I3b. See also L. Van der Stockt, 2013. 
emanation theory that had no original connexion with the problem of the octopus" at issue in Q.N. I9, but this does not necessarily imply that the digression into magnetism "contains barely intelligible and certainly irrelevant detail" 282 .

The section at hand will analyse and clarify the usage of such scientific terms in Plutarch's natural problems. Part of this analysis has already been provided earlier on (in light of the material principles and natural processes in Quaestiones naturales [see 4.3.I.]), and it will be further elaborated upon here in light of the collection's technicality. As we have already seen in chapter three, the genre of natural problems as treated in Quaestiones naturales is of an essentially 'technical' kind, being concerned with the type of knowledge that belongs to the $\tau \varepsilon \chi \nu i \tau \alpha$, but it is not therefore overly complex [see 3.I.4.]. What I will argue here, then, is that the aspect of technicality of Plutarch's scientific discourse never becomes a goal in itself but rather a means to communicate about natural phenomena in a clear and uniform way.

\section{Let's talk science: the birth and use of technical vocabulary}

A relevant passage for Plutarch's view on technical terminology can be found in Cic. 40, 2, which deals with Cicero's effort to come up with a Latin translation of several Greek terms of dialectics and natural philosophy:

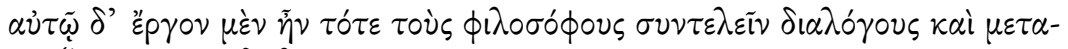

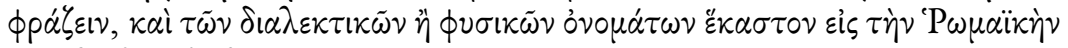

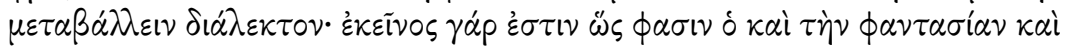

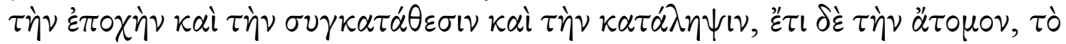

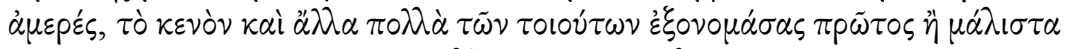

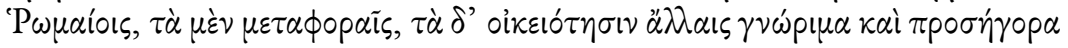
$\mu \eta \chi \alpha \nu \eta \sigma \alpha ́ \mu \varepsilon v о \varsigma$.

He made it his business also to compose and translate philosophical dialogues, and to render into Latin the several terms of dialectics and natural philosophy; for he it was, as they say, who first, or principally, provided Latin names for 'phantasia' (visum), 'synkatathesis' (assensio), 'epokhe' (retentio) and 'katalepsis' (comprehensio), as well as for 'atomon' (individuum), 'ameres', 'kenon' (vacuum), and many others like these, contriving partly by metaphors and partly by other proper senses to make them intelligible and familiar.

${ }^{282}$ Pace F.H. Sandbach, 1965, p. 137. Indeed, in a parallel passage in Quaest. Plat. I005BD, Plutarch gives an interpretation of Tim. $79 \mathrm{e}-8 \mathrm{oc}$, where he provides a more extensive account of magnetism (the context is that of the effect of amber and the loadstone on other objects: see the commentary ad loc.). 
What Plutarch is probably implying here is that Cicero's decision to translate these Greek terms into Latin is a practical one and originates from his personal experience that Latin, his native tongue, was somewhat inadequate for the task of philosophy, without the help of Greek philosophy ${ }^{283}$. It testifies to Cicero's intention to create a terminological system that is not only uniform in itself, but also uniform with the Greek philosophical tradition. These terms did not exist in Latin, or at least they did not have the extra, technical connotation that their Greek equivalents had before Cicero translated them from the Greek ${ }^{284}$.

Notably, a significant amount of the terms and concepts that ancient Greek natural scientists employed were present in popular vocabulary long before they received their more specialised meanings in scientific discourses ${ }^{285}$. Other technical terms did not originate directly from popular vocabulary, but are rather the result of a linguistic process of neology (as is the case, for instance, with the Peripatetic concept of $\dot{\alpha} \nu \tau i \pi \varepsilon p i \sigma \tau \alpha \sigma \iota \zeta$, discussed earlier on [see 4.3.I.2.]). In many cases, popular vocabulary proved to be too imprecise to communicate a very specific scientific notion or idea, so that it often received a more specific and systematic 'pregnancy' in technical contexts ${ }^{286}$. Where in an unscientific context a concept like

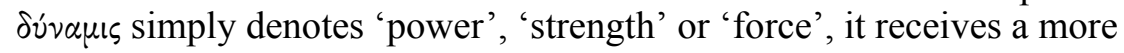

${ }^{283}$ On Cicero's translations from the Greek, see J.G.F. Powell, 1995. This passage is also discussed by L. Van der Stockt, 20I3, pp. 440-44I, who points at Plutarch's omission of the Latin equivalents for the Greek terms. He concludes (p. 44I) that the Chaeronean "is eager to explain and to suggest the high level of Cicero's intellectual activity by a selection of technical terms to be translated. [...] Plutarch's audience was hardly eager to learn some translation theory, and this learned remark probably only testifies to Plutarch's eagerness to explain and illustrate, to his didacticism. And if any pride is involved here, it is not the pride of a Plutarch parading his knowledge of translation theory, but the Greek pride to have taught philosophy to the Romans." For the use of Greek terms in Latin technical literature more generally, see T. Fögen, 2009, pp. 92-I05.

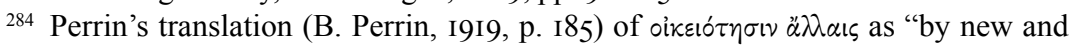

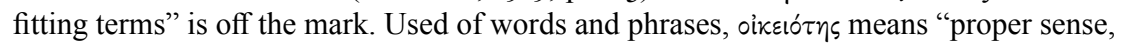
opp. $\mu \varepsilon \tau \alpha \phi o p \alpha ́$ " (LSJ, s.v. ii, with a reference to this passage). Cicero did not make 'new terms' (i.e. neologisms), but provided existing Latin words with 'other meanings' (i.e. proper senses). Cf. L. Van der Stockt, 20I3, p. 44I: "Cicero did not make new words: that would have been a verborum fictio acceptable only because of necessitas, sc. the verborum inopia of the Latin language. The $\mu \varepsilon \tau \alpha \phi о p \alpha$ Plutarch is hinting at, is probably the periphrastic metaphor (Lausberg \#563 and 594, 3)."

285 A considerable amount of the technical terminology of ancient scientific writings actually originates from the abstraction of everyday language (see B. Snell, I960). E.g., for the close relationship between Hippocratic and popular vocabulary, see G.E.R. Lloyd, I983, p. 204.

${ }^{286}$ E.g., for the development of anatomical terminology, see G.E.R. Lloyd, I983, pp. I49-I67. 
technical connotation, for instance, in medical literature, where it often refers to the therapeutic properties of foodstuffs ${ }^{287}$. The concept of $\delta$ v́vaus also has its well-known technical meaning in Aristotelian philosophy, where it is typically translated as 'potentiality' and thought of as opposed

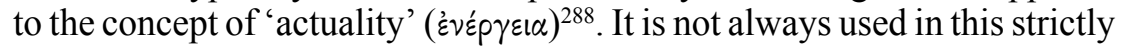
contrastive fashion by Aristotle, though. He often also uses it to speak more generally of an 'active characteristic' or 'property' of a specific substance, as does Plutarch ${ }^{289}$. According to Senzasono, Plutarch is using the concept of $\delta \dot{v} v a \mu \mathrm{s}$ in an essentially Aristotelian fashion in Quaestiones naturale $^{290}$, but this is not necessarily the case, because the concept was firmly entrenched in the ancient Greek scientific tradition more generally (it can also be found in this very meaning in earlier scientific authors, such as the Hippocratics or Plato ${ }^{291}$. Moreover, the typically Aristotelian opposition between $\delta \dot{v} v \alpha \mu \iota$ and $\dot{\varepsilon} v \dot{p} \rho \varepsilon \varepsilon \alpha$ is absent in our collection and rare in Plutarch's writings more generally ${ }^{292}$. In Q.N. 29, 919A, Plutarch

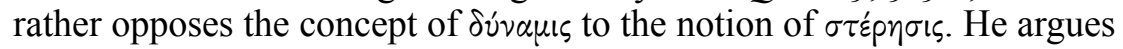
that some people believe that heat is a dúvaus (i.e. an active property), whereas cold is a $\sigma \tau \dot{\varepsilon} p \eta \sigma \iota s$ (i.e. a privation, absence or negation) of heat an Aristotelian theory with which he disagrees here and elsewhere ( $D e$ prim. frig. $945 \mathrm{~F}-948 \mathrm{~A}$; see the commentary ad loc.). Plutarch's definition of cold as a $\delta$ v́vaus is more in line, then, with the term's connotation of "elementary force, such as heat, cold, etc." ${ }^{293}$. A $\sigma \tau \dot{\tau} p \eta \sigma \mathrm{s}$, by contrast, is

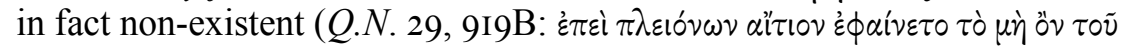

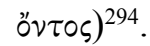

${ }^{287}$ See, e.g., passim in the Hippocratic De prisca medicina. Galen wrote three books De alimentorum facultatibus.

288 This Aristotelian opposition became popular also, e.g., in the writings of Imperial medical authors (cf. Gal., Nat.Fac. 2, 7, 2-3 Kühn).

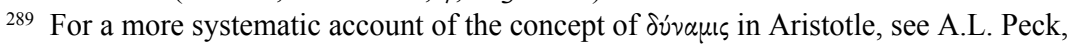
I953, pp. xlix-1v.

${ }^{290}$ L. Senzasono, 1999. Cf. also L. Senzasono, 2006, p. 36, n. 55 (with further references): "il termine in questione ha per noi senso essenzialmente aristotelico, o almeno è da considerarsi d' origine aristotelica: si tratta d'una proprietà materiale, che è potenza, $\mathrm{e}$ quindi causa materiale dei fenomeni”.

${ }^{291}$ Cf. A.L. Peck, I953, p. xlix. Cf. also G.E. Karamanolis, 2006, p. II3.

292 It is mentioned only once in Quaestiones convivales, albeit not in a strictly contrastive fashion, viz. in Quaest. conv. 637D. Cf. also Pars an fac. 2, I6-17; 6, 1517 and fr. 215 f Sandbach.

${ }^{293}$ LSJ, S.v. ii, 2.

294 According to F.H. Sandbach, I965, p. I4I, dúvaul sometimes has a specific material connotation for Plutarch, denoting a "substance of a distinctive character" (e.g., Q.N. 26, 9I8B, 29, 9I9A, 32) - a view that is much in line with Plutarch's custom to directly associate physical matter and its qualities (see n. I57). Cf., e.g., De tuenda $\mathrm{I} 29 \mathrm{~F}$ (i் $\lambda \eta \nu$

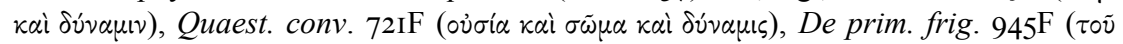


A similar case is found in the concept of $\pi \varepsilon p i \tau \tau \omega \mu \alpha$, which is basically a nominalisation of the adjective $\pi \varepsilon p i \tau \tau o ́ s(Q . N$. IO, 9I4E). In a nonscientific context, $\pi \varepsilon p i \tau \tau o ́ s ~ m e a n s ~ ' e x c e p t i o n a l$ ' or 'extraordinary', but in a natural scientific discourse it receives a metaphorical sense, implying 'superfluous'. The notion of $\pi \varepsilon p i \tau \tau \omega \mu \alpha$, derived from it, denotes a residue of a substance that is secreted or excreted after a specific physical process has taken place (e.g., digestion of food). These residues often have various additional properties, among which Plutarch in Quaestiones naturales only mentions the generative one (the generative residue produces the offspring: see Q.N. 2I, 9I7BC, 30, 9I9C). This concept occurs frequently in Aristotle's biological works, but it is not, therefore, of Aristotelian origin $^{295}$.

Due to the fact that Plutarch uses such scientific terms in a somewhat specialised sense, it is reasonable to assume that some familiarity with the scientific terminology and its use in the scientific tradition was required, or in any case helpful, for a proper understanding of the natural problems by the implied reader. It remains to be seen, however, whether we are really dealing with the kind of jargon that can only be understood by the Greek specialist ( $\phi v \sigma \kappa o ́ s)$ or not also by the generally educated layman ( $\pi \varepsilon \pi \alpha i \delta \varepsilon v \mu \varepsilon \dot{v} 0 \varsigma)$. Even if these terms received a specialised meaning at a certain point in history, their use had become relatively common by Plutarch's time ${ }^{296}$. Plutarch does use several rare Greek words and hapax

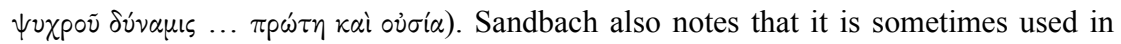
a more abstract sense, thus simply referring to a "distinctive character" or quality in itself (e.g., Q.N. I0, 9I4D, 3I, 9I9D). In regards to the use of facultas in Q.N. 32, cf. L. Senzasono, 2006, pp. 238-239, n. I86: "[i]1 termine facultas quasi certamente corrisponde a $\delta$ v́vauı nel testo originale perduto". Senzasono adds that a more adequate Latin translation would have been virtus or potentia. Perhaps, the use of facultas can be explained, then, in light of Longolius' medical expertise and knowledge of Galen (see n. 287).

${ }^{295}$ On the constitution of these residues, including the generative one, and their importance in Aristotelian biology, see A.L. Peck, I953, pp. lxv-lxvii and I965, pp. 1xxilxxii. The theory that sperm (and blood and marrow) is a $\pi \varepsilon p i \tau \tau \omega \mu \alpha \tau \tilde{\eta} s \tau p o \phi \tilde{\eta} s$ is attributed to Pythagoras in Aët., Plac. 5, 3 = Ps.-Plut. 905A. Cf. also, e.g., Arist., GA 726a26-27. Notably, the concept of $\pi \varepsilon p i \tau \tau \omega \mu \alpha$ does not occur in the corpus Hippocraticum, and it may have been introduced in the field of nosology by Aristotle or one of his students: see A. Thivel, I965 and P.J. van der Eijk, I990, p. 53. For the distinction in meaning between $\pi \varepsilon p i \tau \tau o ́ s ~ a n d ~ \pi \varepsilon p i \tau \tau \omega \mu \alpha$ in Ps.-Arist., Probl. 953aio-955a40, cf. also B. Centrone, 20IIb, p. 335 .

${ }^{296}$ An analogy can be drawn with the modern English notion of 'landscape' (see OED, s.v.). This term derives from popular Dutch vocabulary, where the concept of 'landschap' initially denoted a 'region' or a 'tract of land'. The Dutch 'landschap' received a more technical meaning in the context of Dutch landscape painting around I60o by taking on the artistic connotation of 'a picture depicting scenery on land'. The word was initially adopted 
legomena in Quaestiones naturales, but in these cases we are dealing with derivations or compounds of already existing words rather than with fully neologistic technicisms ${ }^{297}$. For instance, the word $\pi \nu \varepsilon v \mu \circ v i \alpha$ ('disease of the lungs') in the quote from Mnesitheus in Q.N. 26, 918DE is rare, while $\pi \varepsilon p i \pi v \varepsilon v \mu o v i \alpha$ or $\pi \varepsilon p l \pi \lambda \varepsilon v \mu o v i \alpha$ (also simply $\pi \lambda \varepsilon v \mu \circ v_{i} \alpha$ ) are more common. One may wonder whether Plutarch is relying on an intermediary source in this case or is perhaps paraphrasing Mnesitheus' account in his own, non-specialist words ${ }^{298}$.

\section{Big words? High-tech vs. low-tech vocabulary}

As Sandbach points out, "[i]t is an error to suppose that because a word needs explanation [for us non-native speakers] it is a 'technical' term". He argues that the scientific terms in Quaestiones naturales "are all common Greek words, and no ancient reader would have felt that they were used in an unusual or special way"299. The same and similar scientific terminology as found in Quaestiones naturales recurs in the natural problems in Quaestiones convivales. As seen before, sympotic decorum prescribes that the discussions be kept simple [see 3.I.3.]. This way, everyone can understand what learned people are saying, even those who have no erudition at all (Quaest. conv. 613 $\mathrm{E})^{300}$. In fact, the mood of the symposiasts would be affected too much if they bombarded each other with technicisms too abstruse for non-specialists (Quaest. conv. 6I4E). Plutarch even rebukes this as a practice of 'wranglers', as Democritus calls them, and of 'phrase-twisting' sophists (= DK68Bı50: 'हp

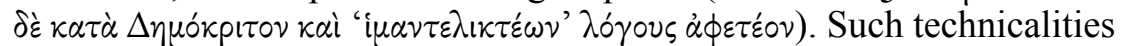
are banned from the dinner table, because they break convivial harmony: 'just as the wine must be common to all, so too the $\lambda$ ó

in English with this technical (c.q. artistic) meaning, which can still be retraced today in our modern notion of 'landscape' as an 'inland natural scenery'. The technical sense is now largely lost, though, since the word is no longer used (only) in the context of painting. This example illustrates, then, how a popular concept can become technical at a certain point in time and afterwards bleed over again into popular vocabulary, with corresponding shifts in semantics. Similarly, the concept of 'panorama' came into existence as a neologism only near the end of the $18^{\text {th }}$ century, again in the context of painting.

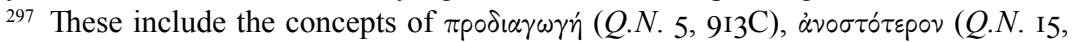

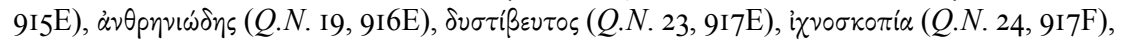

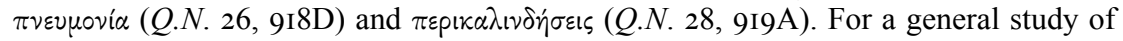
Plutarch's use of rare words and hapax legomena, see S.-T. Teodorsson, 2005.

${ }^{298}$ See J. Bertier, I972, p. I7I (with LSJ, s.vv.). Perhaps an emendation is needed (see the commentary ad loc.)?

${ }^{299}$ F.H. Sandbach, I965, p. I4I. For further discussion of the level of technicality in ancient (Latin) technical writings, see T. Fögen, 2009, pp. I9-25.

${ }^{300}$ Cf., e.g., P. Donini, I992, p. IIO. 


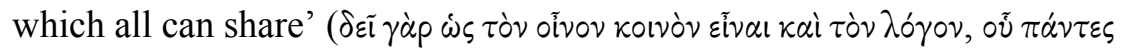
$\mu \varepsilon \theta \dot{\varepsilon} \xi o v \sigma \omega v)$. It is rather unlikely, then, that Plutarch - both as a symposiast and as an author - intended to overwhelm non-specialists with all too specialised concepts in his natural problems. He is not a sophist, after all, and does not intend to promote himself as one.

Of course, the discussion of natural problems was part of elite intellectual entertainment and education, but, even so, natural problems are essentially 'easy and persuasive' for Plutarch himself, as we saw ( $D e$

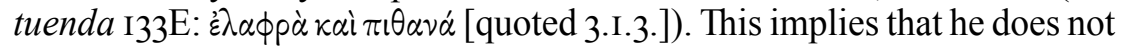
mean for this branch of inquiry to become too specialised. Consequently, when using technical scientific terms in explaining natural phenomena, Plutarch is not so much striving for verbal pretentiousness but rather for an efficient communication of scientific knowledge and ideas in a uniform way. Notably, most of the interlocutors in Quaestiones convivales have their own field of expertise, but they are still familiar - regardless of whether this may be a trick of Plutarch's literary fiction - with the basic features of the genre of natural problems. Grammarians, for instance, are also acquainted with the scientific literature, at least to such a degree that they are able to hold their ground when the discussion moves to their field of expertise. In Quaest. conv. $626 \mathrm{E}-627 \mathrm{~F}$, for instance, Theon, a grammarian and Homer specialist, contributes to the question of why fresh water washes clothes better than salt water by quoting Aristotle and

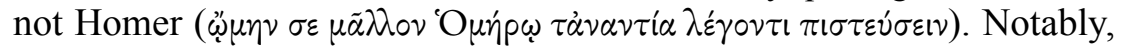
several symposiasts in Quaestiones convivales are philosophers and doctors, but they do not necessarily speak like specialists when discussing natural problems. If they had done so, this would probably not have been appreciated by their fellow symposiasts (including poets, grammarians, political figures, students etc.). As Van der Stockt rightly notes in regards to Plutarch's terminology in the scientific $\pi \alpha \rho \varepsilon \kappa \beta \alpha \dot{\alpha} \sigma i s$ in the Vitae, "that is in works not destined to experts in any $\tau^{\prime} \chi \nu \eta "$ " [see 2.I.3.]:

"it is inherent in such [technical] language that it is largely incomprehensible to those who are not familiar with the $\tau^{\prime} \chi \chi \nu$; those laymen may take offence because of what they experience as obscurity in the communication $[\ldots]$ or as boasting with erudition on the part of the author/speaker, or even as a haughty or mindless insult of the ignorance of the audience." 301

For people who are not at all acquainted with the scientific literature, such scientific terminology would probably sound too specialised. But then

${ }^{301}$ L. Van der Stockt, 20I3, p. 440. Van der Stockt argues that in these scientific

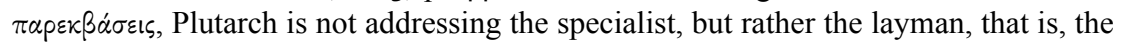

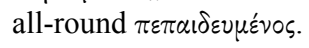


again, Plutarch is not writing for the common plebs [see 3.I.]. Nevertheless, in some passages in his natural problems, he does emphatically employ the terminology of un(der)educated laymen, especially of farmers ${ }^{302}$. Farmers call water of rains that accompany thunder and lightning 'lightning water' (Q.N. 4, 912F: $\dot{\alpha} \sigma \tau \rho \alpha \pi \alpha i \alpha \kappa \alpha \lambda \circ \tilde{v} \sigma \iota)$, and they consider it 'more fertilising'

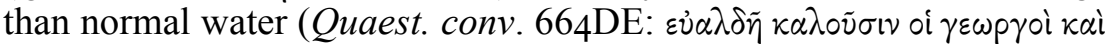

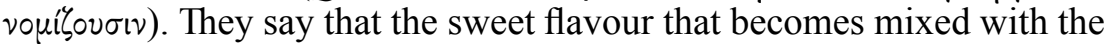
(unripe, sour) grape 'ripens' (Q.N. 27, 918E: $\left.\pi \varepsilon \pi \alpha i v \varepsilon \sigma \theta \alpha \iota \lambda \varepsilon^{\prime} \gamma \varepsilon \tau \alpha \iota\right)$, and that vines that do not fruit, but flourish luxuriously with branches and shoots,

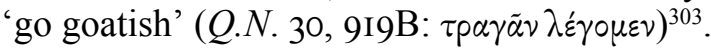

The sub-technical value of such popular colloquialisms can be inferred from the fact that Plutarch refers to them with phrases like 'this they call' ( $\kappa \alpha \lambda \circ \tilde{v} \sigma \iota)$, 'this is called' $(\lambda \varepsilon \dot{\varepsilon} \varepsilon \tau \alpha \iota)$, or even 'we call this' ( $\lambda \varepsilon \dot{\gamma} \sigma \mu \varepsilon v)$. The last phrase is particularly intriguing as it hints at an aspect of intellectual community between author and reader by the use of the first person plural [see 3.I.5.]. It denotes something like 'we Greeks - including elite men and farmers alike - call this X', 'we call this X in Greek', 'Greek people is what we are and Greek is what we speak'. It is only likely, then, that in such cases, the use of popular vocabulary should not be taken as a narcissistic attempt to parade one's personal erudition and knowledge of sub-technical jargon, but more as a candid aspiration to strengthen the sense of a shared cultural heritage, as constructed, in this case, on linguistic grounds. It may seem strange, in any case, to measure a person's elitist $\pi \alpha i \delta \varepsilon i \alpha$ in terms of his knowledge of peasant lingo. By consequence, I am not inclined to evaluate the technicality of Plutarch's scientific terminology more generally in all too strict sociological categories, where the use of such terms is primarily understood as a means of promoting the user's own person rather than facilitating the efficient communication of his ideas [see 4.2.2.I.]. This does not imply, of course, that this lust for intentional obscurity was not observed in Antiquity ${ }^{304}$, but it is rather unlikely, in my opinion, that it applies to Plutarch just as well ${ }^{305}$.

${ }^{302}$ Also, e.g., fishermen, who call cephalopods 'soft things', 'molluscs' (Q.N. I8, 9I6A: $\kappa \varepsilon ́ \kappa \lambda \eta \tau \alpha \iota \mu \alpha \lambda \alpha \dot{\alpha} \kappa \alpha)$.

${ }^{303}$ For another, but similar, etymology, see, e.g., Quaest. conv. 692E: $\tau p \nu \gamma \tilde{\alpha} \nu \lambda \varepsilon \dot{\varepsilon} \gamma 0 \mu \varepsilon \nu$.

${ }^{304}$ Cf. Quint., Inst. or. 8, 2, I2-I3.

${ }^{305}$ A similar caveat was made by L. Van der Stockt, 20I3, p. 445: "It is indeed tempting to understand his [sc. Plutarch's] use of technical terminology and his fondness of quoting ancient authorities as a means to invest his 'cultural capital', in order to secure his own authority, and to obtain a distinguished social position. Yet concerning Plutarch's practice in these matters, I would rather read him as a spectator/investigator of human drama, than as a player or actor in the drama of his society, and I would regard any possible social gain from his practice rather as a non-pursued consequence than as his purpose. There is reason enough to make this stance at least acceptable." Van der Stockt concludes that Plutarch was more likely "driven by an honest desire to teach and explain". 


\section{Conclusion: Plutarch, Plato and Aristotle (again)}

Most of the scientific terminology that Plutarch uses in his physical aetiologies has a specific Aristotelian imprint, as we saw, which is not so remarkable considering the Aristotelian origin of the tradition of natural problems. The same terminology is recurrent in the extant Ps.-Aristotelian Problems. This does not imply, however, that it is also necessarily of Aristotelian origin, or - more importantly - that Plutarch is using such terminology with the intention of being regarded as a Peripatetic natural philosopher ${ }^{306}$.

As a way to conclude the first part of this study, I will here revisit the question of Plutarch's philosophical allegiance in his natural problems [see I.I.2.]. Since Plutarch was first and foremost an enthusiastic adherent of Plato, one may wonder why he was so interested in this Aristotelian type of scientific research. Did he perhaps intend to inscribe himself in the scientific community of the Lyceum by positioning himself in the tradition of Peripatetic scholarship? Did he intend to ally Platonism with Aristotelianism, as other middle- and neo-Platonists did? Or is the answer more nuanced? The question is particularly intriguing, since it sheds a light on the influence of the Aristotelian and Peripatetic tradition - a tradition that was reinvigorated in the time of the early Roman Empire on Plutarch's own philosophical thinking ${ }^{307}$.

Regarding the natural problems treated in Quaestiones convivales, Kechagia has recently argued that while there is clearly a Peripatetic character to the general explanatory scheme employed by the symposiasts, Plutarch himself probably did not aspire any strict allegiance to this philosophical school. After all, the symposiasts that Plutarch stages in Quaestiones convivales often adhere to different, if not rivalling, philosophical schools, although they still share the very same interest and knowledge of the, in that case, more 'generic' Peripatetic tradition ${ }^{308}$.

306 See F.H. Sandbach, I965, p. I34: "the terminology used in the proffered solutions largely coincides with that employed, but not necessarily invented, by the Peripatetics". See also M. Meeusen, 2016.

307 That Plutarch was not a member of the Peripatetic tradition is emphasised by H. Flashar, I962, p. 369, who notes that "[a]ußerhalb des peripatos läßt sich eine sachliche Nähe und productive Weiterbildung der arist. Probl. nur bei Plutarch beobachten". As M. Frede, 1987 , p. 282 rightly observed, "someone who saw himself as basically a Platonist at this [sc. Imperial] time would be inclined to study Stoic or Peripatetic physics". Cf. also K. Oikonomopoulou, 20II, p. I29: "Peripatetic knowledge [is] the common property of a highly complex and diverse network of intellectual communities". On the reception of Aristotelian philosophy in the time of the Roman Empire, see most recently the contributions in Y. Lehmann, 2013.

${ }^{308}$ E. Kechagia, 20IIa, p. 98: "It is characteristic that the speakers who appeal to this schema in the Table Talk often do so independently of sect-allegiance. What matters is not 
In fact, the terminology that Plutarch employs is well-entrenched in the broader scientific tradition, and can, thus, be considered more 'universally' scientific ${ }^{309}$.

Notably, Plutarch more often uses the terminology of philosophical schools other than Plato's, albeit always in the confines of an essentially Platonic framework ${ }^{310}$. The same is probably the case, then, in his natural problems. These should be interpreted in light of Plutarch's wider natural philosophical project, which is, as this chapter has shown, radically informed by Platonic dualism and generally inspired by Academic Scepticism. In the end, as we have learned from Quaest. conv. 699B, 'the ingenious organisation of nature's activities is beyond the range of words' for Plutarch [quoted 4.I.2.2.], that is, beyond a general physical style of discourse - either Peripatetic or more generally scientific -, since

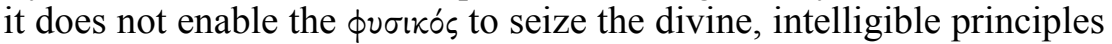
that lie behind the face of nature.

According to Teodorsson, however, Plutarch frequently draws on Aristotle's natural scientific writings and is also generally inspired by his critical scientific method, as would be attested by his sceptical attitude towards popular beliefs ${ }^{311}$. Karamanolis has objected to this view by pointing out that this alleged critical 'Aristotelian' attitude "is what one would expect from a Platonist of sceptical orientation like Plutarch anyway"312. I have tried to further nuance Teodorsson's view by showing that Plutarch actually gives these popular beliefs the benefit of the doubt before subjecting them to a thorough scrutiny. A specific anti-Aristotelian dynamic was detected in Plutarch's subordination of the actual reality of the natural phenomena (the ö $\tau \iota$ ) to their causes (the $\delta i \dot{\alpha} \tau i$ ) [see 4.I.I.3.].

the sect so much as the attempt at a plausible explanation." On philosophical allegiance in the Greco-Roman world more generally, see D. Sedley, 1997 (esp. pp. II7-II8 on the role of Aristotelianism in Imperial philosophy).

309 The concept of $\pi$ ópol, for instance, is described in Quaest. conv. $689 \mathrm{C}$ as a popular

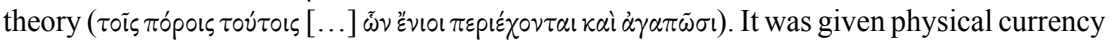
first by Empedocles, and it became very popular, indeed, later on in Peripatetic and medical writings. See n. I77.

310 See D. Babut, I969, pp. 533-534, esp. p. 533 (quoted also by R. Flacelière, J. Irigoin, J. Sirinelli and A. Philippon, 1987, p. clix): "Tandis que chez Plutarque, alors même que les mots sont les mêmes que dans les textes stoïciens, le fond, le soubassement d'idées et de croyances qu' ils traduisent se révèle inconciliable avec la vision stoïcienne du monde." See also J. Opsomer, 20I4, p. 88. For Plutarch's use of Stoic and Epicurean terms also in Quaestiones Platonicae, see J. Opsomer, 1994a, p. 620. For the use of Stoic and Aristotelian terminology by Platonists more generally, see G.E. Karamanolis, 2006, pp. 24-25, esp. p. 25: "All this merely represents a modernization of the language of philosophy; it does not imply anything about the philosophical loyalties of the Platonists."

311 S.-T. Teodorsson, 1999a, p. 674.

312 G.E. Karamanolis, 2006, p. 90, n. I9. 
Plutarch does this not just for methodological reasons but with a deeper philosophical and religious motive in mind, according to which wonderinducing phenomena reveal not only the working of natural forces in the world around us but also hint at its providential ordering.

To set the record straight, then, Quaestiones naturales is not the work of a Plutarchus Aristotelicus, and Plutarch's science of natural problems more generally should not be seen as the product of his philosophical aspiration to be counted among the rangs of the Peripatetics. Even if there is much Aristotelian twinkling in Plutarch's physical aetiologies, it is a Platonic twilight that will eventually shatter darkness in his world. 
COMMENTARY 



\section{o. Approach and structure}

The second part of this study aims to provide further detail about the content and set-up of Quaestiones naturales in the form of a commentary. In discussing each problem chapter individually a tripartite structure will be followed: first a short synopsis of the chapter as a whole with a discussion of its topic and basic structure, second a paraphrase of the aetiology with further clarification of the line of reasoning in the explanations, and third a commentary for the lemmas in the text that require further clarification (this also includes a discussion of parallel passages, cross-references and possible sources). The structural and thematic unity - and also the disruption thereof - is studied not only as a feature of the problem chapters individually (as seen in the coherence and development of the causae) but also of the collection as a whole (viz. in the concatenative and variative principles between the problem chapters themselves [see I.I.5.]). Each cluster of problems will be shortly introduced under a separate heading. The following scheme gives a tentative overview of the thematic clusters in the Greek problems (Q.N. I-3I).

\begin{tabular}{lll}
\hline Q.N. & Theme & Cluster \\
\hline $\mathbf{1 - 1 3}$ & Salt and water & 1 \\
$\mathbf{1 4 - 1 6}$ & Wheat and barley & 2 \\
$\mathbf{1 7 - 1 9}$ & Sea animals and fishing & 3 \\
$\mathbf{2 0 - 2 8}$ & Land animals and hunting & 4 \\
$\mathbf{3 0 - 3 1}$ & Viniculture & 5 \\
\hline
\end{tabular}

Two further remarks are in place. First of all, this scheme might oversimplify the more complex concatenative processes at work in the collection: for instance, problems of agriculture (2) also occur in the category on hydrology (I), and viniculture (5) can also be considered part of agriculture (2). Furthermore, the division between sea animals (3) and land animals (4) may not be as strict as this scheme suggests. Alternative schemes are, therefore, possible ${ }^{1}$.

Second, the original Greek text of a number of additional problems went lost in the manuscript tradition after the lacuna in Q.N. 3I [see the

${ }^{1}$ For instance, K. Oikonomopoulou, 20I3a, p. I52 distinguishes the following thematic categories: "matters of nourishment (I-5); the sea (8-, or perhaps 7-I2); plants and agriculture (I4-I6); animals and human activities connected with them (I8-26)". She also notes that "[t]he reader is offered hints that these categories may expand to wine and drinking (IO, 27, 30-3I)". 
prologue]. They - or at least part of them - did survive thanks to two side traditions of the text, albeit in adapted versions. Q.N. 32-39 are preserved in Longolius' I542 Latin translation of a lost manuscript from Milan (6), and Q.N. 40-4I are found in Psellus' encyclopaedic De omnifaria doctrina (7). In general, these additional problems are related to the categories demarcated in the scheme above (with the exception perhaps of Q.N. 34; see the commentary ad loc. for further detail). Additionally, there is a small cluster of two problems concerning the behaviour of bees in Q.N. 35-36 (and perhaps another less obvious one about animal instincts in Q.N. 37-38).

The work of Sandbach (1965) has been a very useful source of inspiration for this commentary (I follow his text mostly). In several cases, though, my interpretation will be radically different from his. Other editions that have certainly proven to be useful are those of Hubert (I960) and Senzasono (2006). A new edition of the text is currently being prepared by Filippomaria Pontani and myself in the Collection des Universités de France (Budé).

\section{Salt and water (Q.N. I-I3)}

The first thirteen problem chapters (with the exception perhaps of Q.N. 6) form a close thematic cluster. The most prominent subject of this cluster concerns the physical properties of salt and water, especially based on a qualitative opposition between salty seawater and sweet drinking water. This is a theme that probably draws on Book 23 of Ps.-Aristotle's

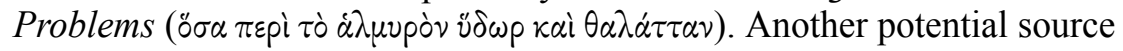
is Theophrastus' lost De aquis (who is quoted in Q.N. 7, 9I4A and I3, 9I5B; cf. also Q.N. I, 9IID and 5, 913CD).

\section{Q.N. I, 9IICF}

In Q.N. I, Plutarch wonders why seawater provides no nourishment

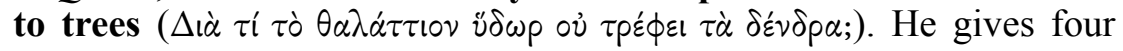
explanations, each of which is concerned with the natural constitution and properties of the salty seawater. The first causa draws attention to its heavy, earthy constituent, the second to its drying property, the third to its oily character, and the last to its admixture with burnt earth. The final causa ties in closely with the first by alluding to the earthy constituent of seawater and by referring to plants growing in the sea (this results in an implicit argumentative ring [see 4.3.3.3.]).

In the first explanation, Plutarch takes into account the heavy, earthy constituent of seawater. He starts by drawing an analogy with the animal kingdom, arguing that the reason for the inability of seawater to nourish

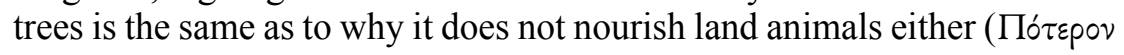




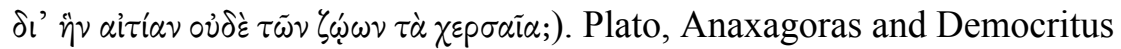

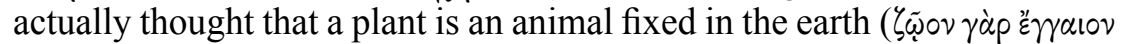

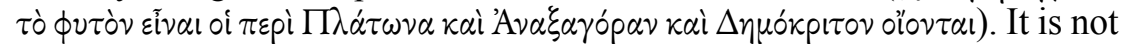
the case, so Plutarch adds, that seawater, for the reason that it is nutritious and potable for marine plants and fishes alike, feeds plants and trees on

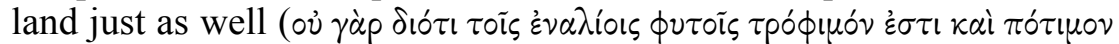

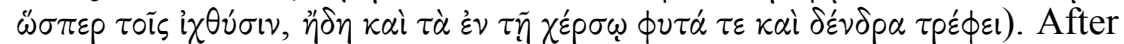
all, seawater cannot enter the roots nor rise in the plant, because of its

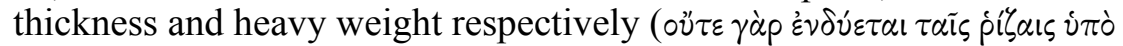

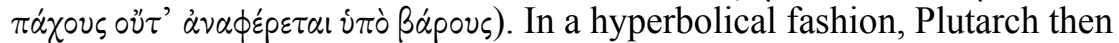
asserts that the heavy and earthy quality of seawater can be demonstrated from many other phenomena, as from the fact that it holds up and supports

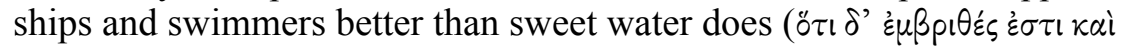

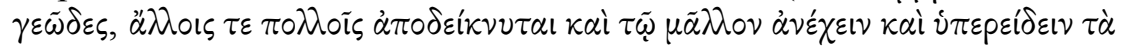

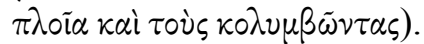

The second explanation is based on the drying property of seawater and salt. Plutarch argues that trees are especially damaged by dryness,

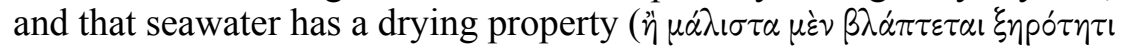
$\tau \grave{\alpha} \delta \dot{\varepsilon} \nu \delta \rho \alpha, \xi \eta p \alpha \nu \tau i k \grave{\nu} \nu \delta \dot{\varepsilon} \tau \grave{\partial} \theta \alpha \lambda \dot{\alpha} \tau \tau 10 \nu ;)$. This drying property explains why salt (which is present in seawater) is a safeguard against putrefaction, and why the bodies of people who have bathed in the sea instantly receive a

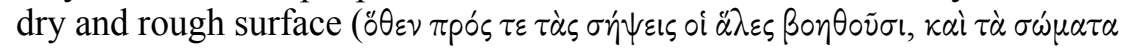

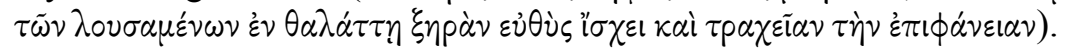

The oily and fatty character of seawater is central to the third explanation, where Plutarch argues that oil is hostile to plants and destroys

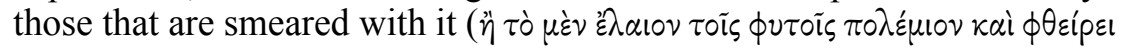
$\tau \dot{\alpha} \pi \rho \circ \sigma \alpha \lambda \varepsilon i \phi o ́ \mu \varepsilon v \alpha)$. He adds that the sea has a large fatty content, which is why it is combustible, and why we advise people not to throw seawater on

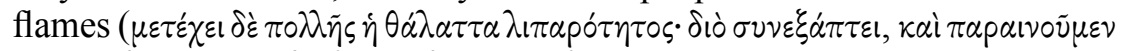

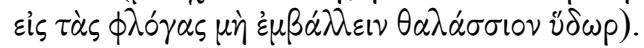

In the fourth and final explanation, Plutarch further refines the aspect of the earthy component in seawater (which was already referred to in the first explanation). On the authority of Aristotle, he argues that the (sea)water

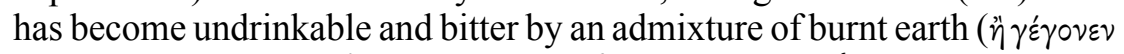

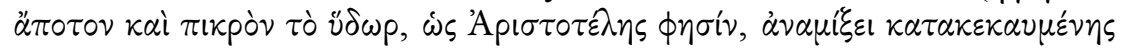
$\gamma \tilde{\eta} s ;)$. He offers further illustrations regarding I) the burnt earth and 2) the undrinkable character of (sea)water caused by heat. Plutarch explains I) that lye (which is also undrinkable and bitter) is formed when fresh water is thrown onto ashes, and 2) that burning heat changes and ruins the useful and potable constituent, similar to how in our bodies fevers turn moisture

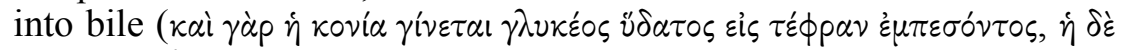

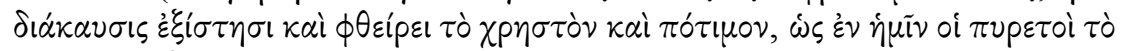

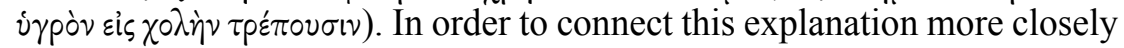
with the problem at hand, Plutarch adds that the bushes and plants that 
are reported to grow in the Indian Ocean do not bear any fruit and acquire their nourishment from rivers, which deposit a great deal of silt in the sea. Therefore, these plants do not grow far away from the shore but close to it

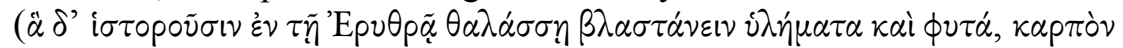

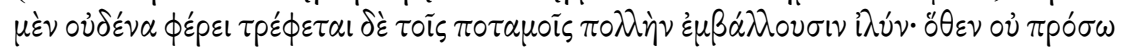

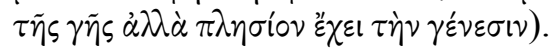

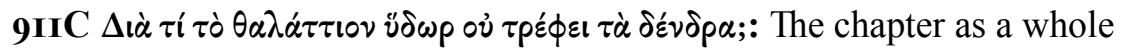
is closely paralleled in the ninth problem of the first Book of Quaestiones convivales (esp. 627 AD), albeit in the context of a different problem (viz. why clothes are washed with fresh water instead of seawater). The phenomenon itself is rejected by Theophrastus, who reports that saline waters feed land plants too (albeit worse than sweet drinking waters), and especially trees, because of their strength $(C P 2,5,3)$.

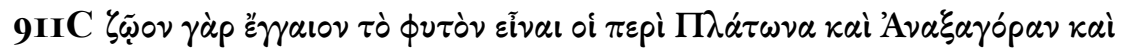

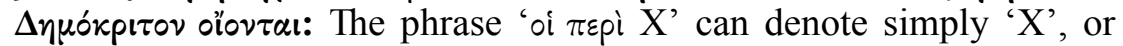
more periphrastically ' $\mathrm{X}$ and his followers', that is, 'the school of $\mathrm{X}$ ' or at least 'the school of thought of X' (for the ambiguity in phrases of this kind, see W.R. Roberts, I9I0, p. 195, J. Dillon, I977, p. 23I, L. Torraca, I998, pp. 3489-3494). The first meaning is doubtful here. In any case, these are not Plato's ipsissima verba but rather a paraphrase of what he writes on this topic - which is uncertain for the accounts of Anaxagoras (= DK59Air6) and Democritus (not recorded among the DK fragments). The allusion is to Tim. $77 \mathrm{ab}$, where Plato calls trees, plants

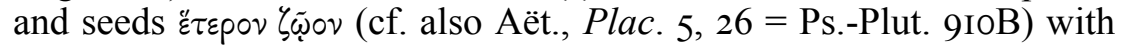

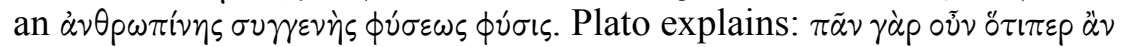

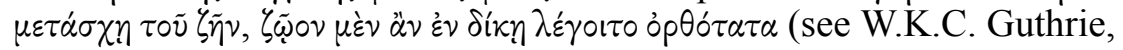
I965, p. 3I6, with n. 2). Conversely, in Tim. 90a, man is called a фuтòv

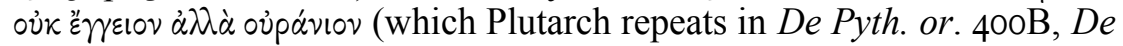
genio Socr. 59IDE, De exilio 60oF, Amatorius $757 \mathrm{E}$; cf. F. Fuhrmann, I964, pp. I20-I2I). See also Pl., Rep. 49Id, 546a and Epin. 98Id. For Anaxagoras' and Democritus' theory that plants have the power of thought, cf. Ps.-Arist., De plant. 8I5bi6 (= DK3IA70 and DK59Air7), where Empedocles (Abrucalis) is also mentioned as an authority. On the difficulty in classifying some inanimate (vegetal) and animate lifeforms, cf. Arist., HA 588bi6-I7 and PA 68IaI2-I5. Considering the different contexts, it seems unlikely that Plutarch was influenced by Aristotle here - pace L. Senzasono, 2006, p. I42, n. I, who is probably right, however, that Plutarch preferred Plato's authority in the present context, albeit not so much to that of Aristotle, as to that of Anaxagoras and Democritus. In any case, the reference to Plato is not out of place at the very beginning of this collection of natural problems, perhaps as a subtle Platonic $\sigma \phi p \alpha \gamma i s$ [see 4.2.I.I.]. 


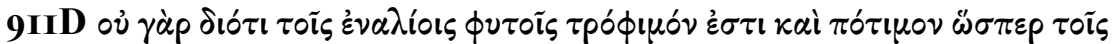

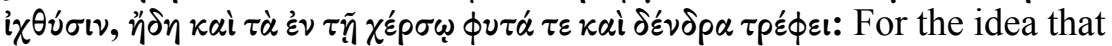
seawater is undrinkable and bad for humans but provides nourishment for fish, cf. De cap. ex inim. 86E. Democritus may be the source of this theory: see H. Diels, I905, pp. 3I4-3I5. Indeed, a similar belief, viz. that fish are not nourished by the salt water in the sea, but by the sweet water mixed with it, is recorded by Aelian on the authority of Democritus (DK68Ai55a) in combination with that of Aristotle and Theophrastus

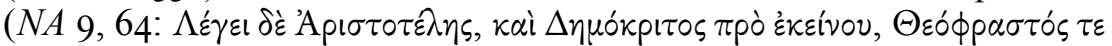

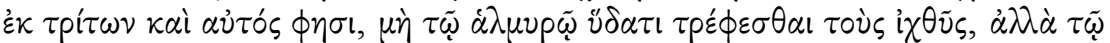
$\pi \alpha \rho \alpha \mu \varepsilon \mu \gamma \mu \varepsilon \dot{\varepsilon} \omega \tau \tilde{\eta} \theta \alpha \lambda \dot{\alpha} \tau \tau \eta \gamma \lambda \nu \kappa \varepsilon \tilde{l} \circlearrowright \delta \delta \alpha \tau)$. In this context, Aelian also refers to the Aristotelian account about the wax jar that filters seawater (which recurs in $Q . N .5,913 \mathrm{C}$ : see the commentary ad loc.). If we are to follow Diels, it is not unlikely that Plutarch knew Democritus' account (and perhaps also that of Anaxagoras) indirectly via a lost Ps.-Aristotelian problem. This lost problem, in turn, was perhaps based on an intermediary doxographical passage in one of Theophrastus' smaller natural scientific treatises, presumably his lost De aquis (cf. D.L., 5, 45). A clear parallel is

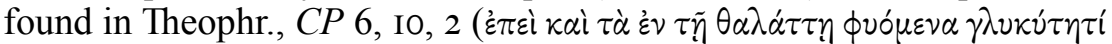

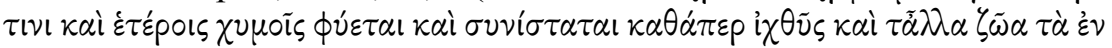
$\alpha \dot{\tau} \tau \tilde{\eta})$.

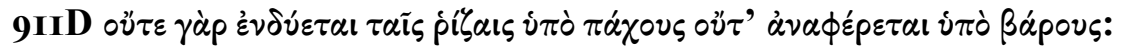
This implies that only sweet drinking water is fine enough to penetrate through the pores of the roots, due to their narrowness (cf. Q.N. 5, 9I3D: of

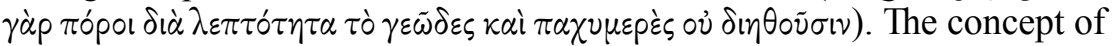

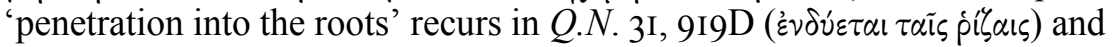

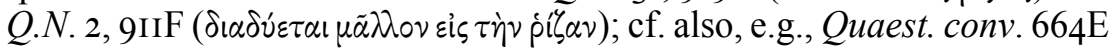

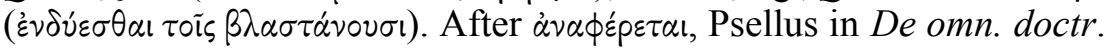

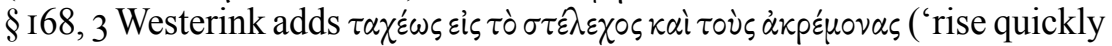
into the stem and branches'). As F.H. Sandbach, I965, p. I49, n. c notes, Psellus "may as well have invented this as found it in his text of Plutarch".

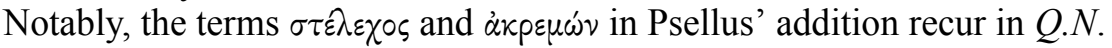
2I, 9I7D and 30, 9I9B respectively. These problems, however, are not in Psellus (see M. Meeusen, 20I2b, p. II3, n. 60). Moreover, the adverb $\tau \alpha \chi \varepsilon \dot{\varepsilon} \omega \varsigma$

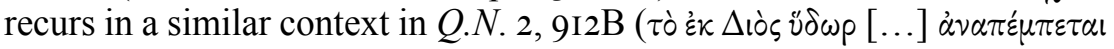

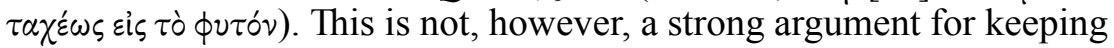
the addition from Psellus' text, which is probably an interpolation.

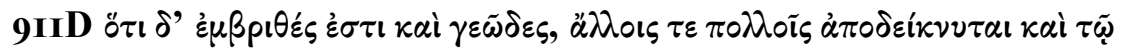

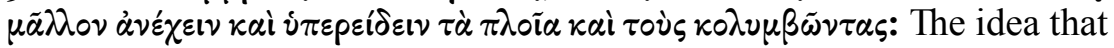
the admixture of earthy matter $(\gamma \varepsilon \tilde{\omega} \delta \varepsilon \varsigma)$ in seawater is responsible for its saltiness is ascribed to Aristotle (fr. 2I7 Rose) in Quaest. conv. 627AB, where it is also reported that this earthy constituent in seawater supports 
swimmers and makes heavy objects float better. Cf. also Arist., Mete. 359a7-2I (in the context of the experiment with the wax jar: cf. Q.N. 5, 9I3C), Ps.-Arist., Probl., 933a9-I3, Pliny, $\mathrm{NH} 2$ 2, 224. Cf. also M. Glycas,

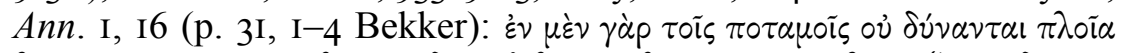

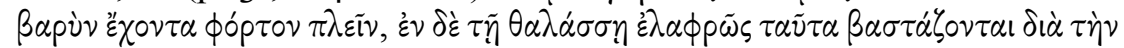

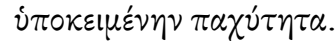

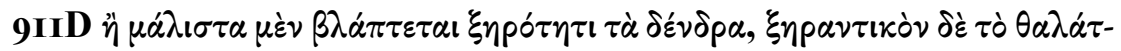
$\tau$ iov;: For the drying property of salt, cf. Q.N. 5, 913E. Cf. also Ps.-Arist., Probl. 932a40-b8.

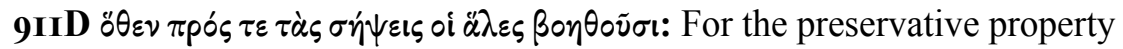
of salt, cf. Q.N. IO, 9I4DE, 40 and Quaest. conv. 685BC. Because of this property, salt is also believed to have a divine character, which is not mentioned here (cf. also Quaest. conv. 697D and 684E-685F more generally, with the scholia on Hom., Il. 9, 2I4).

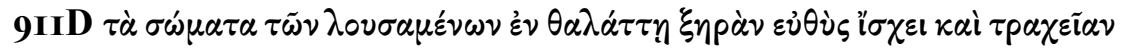

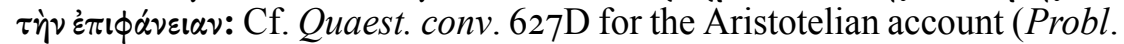
932b25-28) that people who wash themselves in the sea, if they stand in the sun, dry faster than those who use fresh water - an idea that recalls the eìv's from our passage and seems to imply that seawater, as opposed to fresh water, contains natural heat (which was, indeed, commonly accepted). In Quaest. conv. 627EF, Plutarch further elaborates this view by making a subtle distinction between the constituents of seawater. He argues that the sun does not evaporate the seawater in its full extent but only its finest and lightest parts so that a salty and rough coating, that is, a briny scum,

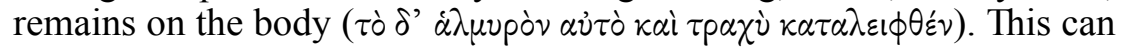
be rinsed off with fresh drinking water. The distinction between fine and rough constituents is less relevant here in Q.N. I, 9IID, where the main

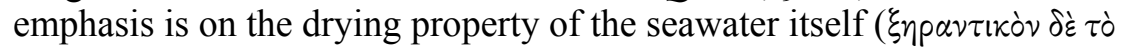
$\theta \alpha \lambda \dot{\alpha} \tau \tau 10 \gamma)$. It is not unlikely, as F.H. Sandbach, I965, p. I50, n. a points out, that Plutarch's allusion in Q.N. I, 9IID to a rough deposit on the surface of the skin is perhaps "due to an association of ideas caused by the writing of the other passage". Alternatively, it is not unlikely either, as Sandbach concludes, that the roughness may simply imply dryness here. However, in $Q . N .5,913 \mathrm{DE}$ Plutarch again mentions the drying property of salt but says that it is ou $\tau p \alpha \chi u v$.

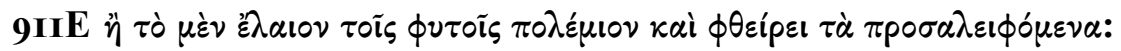
In Quaest. conv. 640C, Plutarch ascribes the belief that oil is harmful ( $\pi \circ \lambda \varepsilon \dot{\mu} 10 v)$ to plants (and bees) both to learned people ( $\left.\sigma \circ \phi \circ{ }^{\prime}\right)$ and to farmers ( Pliny, $N H$ I7, 234; I8, I52. 


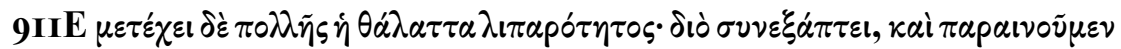

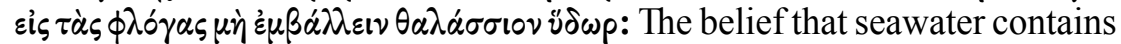

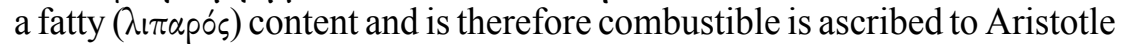
in Quaest. conv. 627C (cf. Ps.-Arist., Probl. 932b4-6, 933ar8-27, 935a5-8 and bi $8-20$ ). Plutarch there reports that seawater, when sprinkled onto flames, flashes up with them. He also says that, compared to other types of water, seawater is particularly flammable (which explains his advice here). Notably, in the historical context of the battle of Actium, Dio Cass., Hist. Rom. 50, 34 reports that Antony's seamen were unable to extinguish the burning missiles that were fired from Octavian's fleet with salty seawater

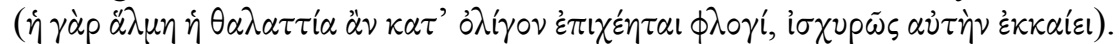
Plutarch also mentions these incendiary projectiles in Ant., 66 ( $\pi v p \circ \beta o \dot{\lambda}$ ol), albeit without reference to this peculiar natural phenomenon.

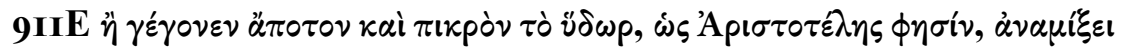

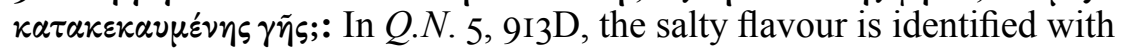
the bitter ( $\pi$ ikpóv), as seems to be the case here too. The quote from Aristotle may be a reference to Mete. 358aI4-I7, where it is reported that some people ascribe the saltiness of seawater to burnt earth $(\theta \dot{\alpha} \lambda \alpha \tau \tau \alpha \nu$ $\dot{\varepsilon} \kappa \kappa \alpha \tau \alpha \kappa \varepsilon \kappa \alpha \nu \mu \varepsilon \dot{v} \eta s \phi \alpha \sigma i \gamma \varepsilon v \varepsilon \dot{\sigma} \sigma \alpha \mathrm{l} \gamma \tilde{\eta} s)$. Aristotle himself, however, considers this ascription absurd ( $\ddot{\tau} \tau 0 \pi \circ v)$. Even still, he concludes that the admixture

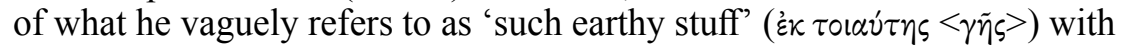
water is undoubtedly what makes the sea salty. We may be dealing here with a simplifying paraphrase by Plutarch (cf. L. Senzasono, 2006, p. I44, n. 7). Yet, the possibility cannot be excluded that Plutarch is relying on a lost Ps.-Aristotelian problem, where that precise theory was supported (cf. F.H. Sandbach, 1982, p. 227). The second possibility is not unlikely, since in the Ps.-Aristotelian Problems there is a clear tendency to restore specific theories that Aristotle explicitly rejected (see H. Flashar, I962, pp. 334-335 and M. Meeusen, forthcoming g; for instance, in Ps.-Arist., Probl. 934b34-36, an argument from the Heracliteans is restored that is considered ridiculous in Arist., Mete. 354b33.) In addition, F.H. Sandbach, I965, p. I5I, $\mathrm{n}$. $\mathrm{f}$ is probably correct in pointing out that Plutarch assumes burnt earth to be essentially burning earth, in the sense that it retains a certain amount of heat, which spoils the useful and potable constituent in seawater. This is important for the connection between the quotation from Aristotle and the natural phenomena referred to in what follows in Plutarch's explanation (viz. the formation of lye from water and ashes, heat ruining drinking water and fever turning moisture into bile: see the

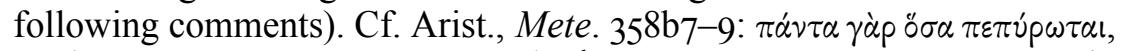

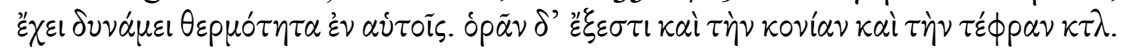

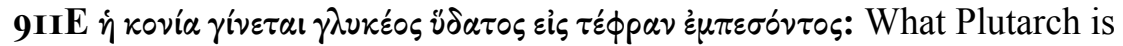
probably implying here is that the basic constitution of seawater is very 
similar to that of lye: both substances are basically a mixture of fresh water and burnt earth or ashes, which makes them both undrinkable and bitter. Another correspondence between lye (kovi $\alpha$ ) and seawater is the fact that lye is an alkaline fluid used for washing (cf. LSJ, s.v.), and that seawater, with its corrosive, earthy constituent, could also be used for this purpose, as is argued in Quaest. conv. 627 BC on the authority of Aristotle (fr. 217 Rose). In Quaest. conv. 684C and 697A, Plutarch reports that lye produced from ashes of the wood of fig trees is most purgative. For the relation between lye and seawater, cf. also Gal., SMT II, 630, 2-4 Kühn (more generally regarding lye, cf. Gal., $S M T$ I2, 35, 3-7; 222, I5-223, 5 Kühn). Cf. also Pl., Tim. 6ode and Arist., fr. 222 Rose.

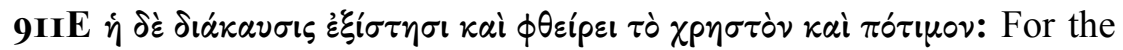
negative effects of (summer) heat on sweet drinking water, cf. Q.N. 9, $9 \mathrm{I} 4 \mathrm{C}$ (with the commentary ad loc.).

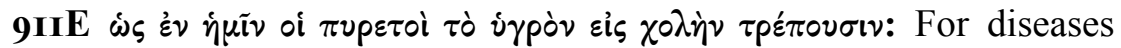

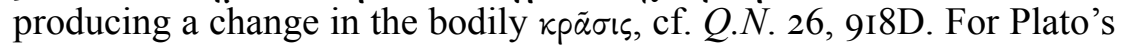
comments on bile, see Tim. 83c.

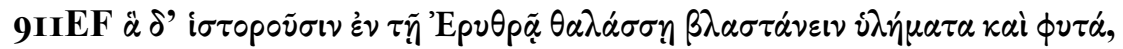

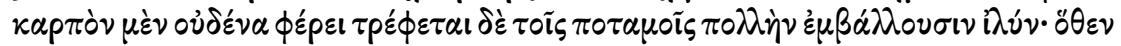

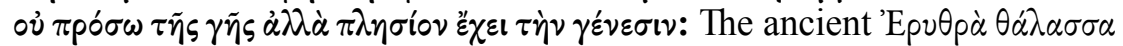
(literally 'red sea') can be identified with the Indian Ocean, which covers all known waters along the south coast of Asia, sometimes including the modern Red Sea itself, that is, the ancient 'Apáßı⿻ kó $\pi$ os (cf. LSJ, s.v.). In Quaest. conv. 733B, Plutarch quotes from Agatharchides' work on the

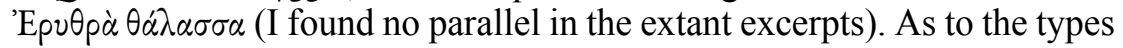

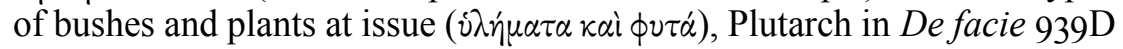
writes that plants of wondrous magnitude grow down in the deep of the (Indian) Ocean near Gedrosia and Ethiopia, some of which are called olives, some bay, and some Tresses of Isis. For the aquatic plants of the 'outer sea' (i.e. the Atlantic and Indian Ocean), see Theophr., HP 4, 7 , esp. 2, where it is reported that so-called bay and olive grow there, but that the latter - in opposition to what Plutarch suggests in Q.N. I, 9IIE does carry fruit similar to genuine olives (cf. also Pliny, $\mathrm{NH}_{2}$, 226; I3, I35; I39-I42 and Eratosthenes apud Strabo, Geogr. I6, 3, 6 (c. 766)). With respect to plants growing in the Mediterranean sea, see also Theophr., $H P$ 4, 6: some of these plants are reported to grow close to the shore ( $\pi p o ́ \sigma \gamma \varepsilon i \alpha$, $\pi \alpha \rho \dot{\alpha} \gamma \varepsilon 10, \pi \rho \dot{s} \varsigma \tilde{\eta} \gamma \tilde{\eta})$, but others do not, and some of them do bear fruit. If Plutarch's mention of the absence of fruits is his own invention (which is uncertain, though), he may be implying that these marine plants consume their entire nourishment for their own growth - De facie 939D, in any case, emphasises the amazing magnitude of these plants - so that no 
generative residue remains to form fruits (cf. Q.N. 2I, 917B, 30, 919C, Quaest. conv. 640F-64IA, 724E). In addition, there seems to be a subtle opposition in this final causa between the non-nutritive (bitter) burnt earth

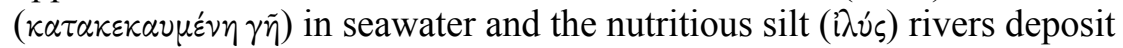
in the sea. Plutarch, thus, seems to suggest that the nourishment of marine plants does not essentially differ from that of terrestrial plants, since they are not fed by the water of the sea but by the nutritive particles (c.q. silt) deposited by sweet river water in it. This specifies the reference in the first causa to the nourishment of the $\dot{\varepsilon} v \alpha \dot{\lambda} \iota \alpha \phi v \tau \dot{\alpha}$ (and perhaps also of fish?) by seawater, which are presumably nourished in the same way (the result then is a subtle argumentative ring [see 4.3.3.3.]). The belief that marine plants are not nourished by the salty seawater, but by the fresh water (and other flavours) present in it is paralleled, e.g., in Theophr., CP 6, IO, 2 (quoted in the comment on Q.N. I, 9IID above).

\section{Q.N. 2, 9IIF-9I2D}

Q.N. 2 is closely linked to the theme of the previous problem by its hydrological and botanical interests. It again focuses on the nourishment that certain kinds of water provide to plants. Plutarch wonders why trees and seeds naturally receive more nourishment from rainwater

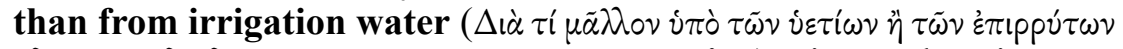

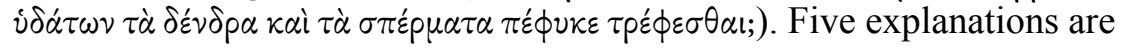
given, which - with the exception of the first - deal with the material constitution and physical characteristics of rainwater (vis-à-vis irrigation water). The first explanation is of a mechanical kind and draws attention to the rainwater's impact on the earth, the second explanation draws attention to the rainwater's freshness, the third to its airy and breathlike composition, the fourth to the ease with which it changes, and the last to its sweetness. There is again a subtle argumentative ring in the aetiology by the implicit connection of the first two causae with the final one [see 4.3.3.3.]. The connective idea is that the raining/mating season (i.e. spring), as referred to in the final causa, is probably the 'right season' ( $\kappa \alpha \theta^{\prime}$ '̈pav) for growth and procreation in plants and animals in ponds, as mentioned in the second causa (which, in turn, is closely connected to the first).

The first explanation focuses on the impact of rainwater on the earth. It is ascribed to Laetus, who said that raindrops make passages in the earth by separating it on impact, so that they better penetrate into the roots of

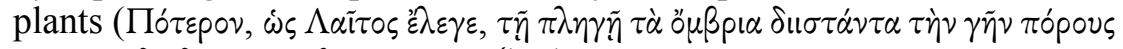

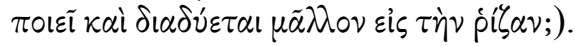


In the second explanation Plutarch criticises Laetus' theory. He argues that this theory is incorrect, Laetus failing to notice that plants that grow in ponds, such as reed mace, wool-tufted reed and rushes, also remain

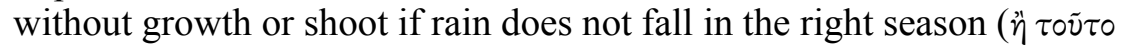

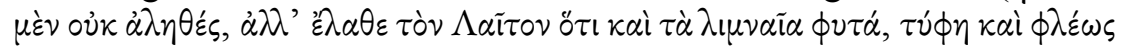

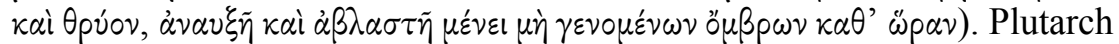
then gives Aristotle's explanation, according to which rainwater is fresh and new as opposed to that of ponds, which is stale and old ( $\tau \dot{0} \delta \dot{\varepsilon} \tau \circ \tilde{v}$

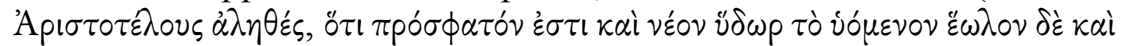
$\pi \alpha \lambda \alpha i o ̀ v \tau \dot{\partial} \lambda \mu \nu \nu \alpha i o v ;)$. He wonders, however, whether this theory is probable

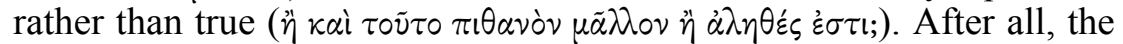
(running) waters of springs and rivers are (also) fresh and new-born, but are (still) less nourishing than rainwater ( $\tau \dot{\alpha} \gamma \gamma \dot{\alpha} \rho \pi \eta \gamma \alpha \tilde{\alpha} \alpha \kappa \alpha i$ i $\pi \circ \tau_{\alpha} \mu 1 \alpha \nu \alpha \dot{\alpha} \mu \alpha \tau \alpha$

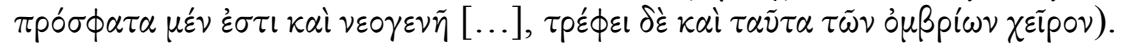
The second point (about rainwater being more nourishing than water of springs and rivers) is explained no further here (but it is in the fourth causa; see also Q.N. 33), and the first point (about water of springs and rivers being fresh and new-born) is illustrated with a literal interpretation of Heraclitus' river statement: 'you could not step into the same rivers

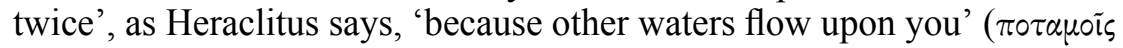

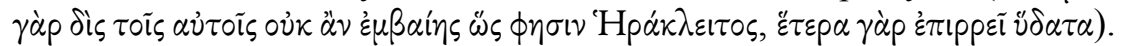

The third explanation draws attention to the airy and breathlike composition of rainwater. Plutarch argues that the water from the heavens is light and airy and, being mixed with breath, is more quickly guided and

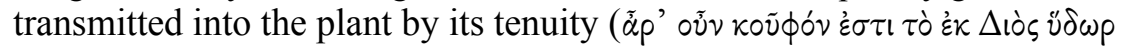

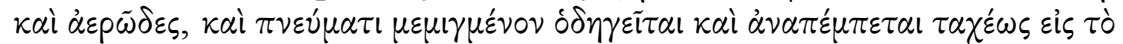

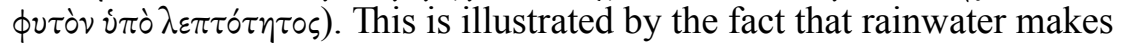

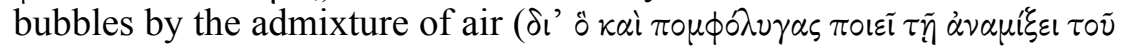
áśpos;).

The fourth explanation focuses on the ease with which rainwater changes. Plutarch's argument is relatively sophisticated and is based on two premises. He argues I) that most nourishment is provided by what is mastered most by the thing fed (Plutarch clarifies that this is the process of concoction - non-concoction being the opposite, when the food is too strong to undergo that action), and more concretely 2) that light, simple and tasteless substances, like rainwater, are more subject to change ( $\eta \tau_{p} \varepsilon \dot{\phi} \varepsilon l$

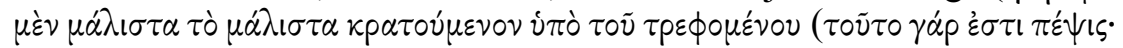

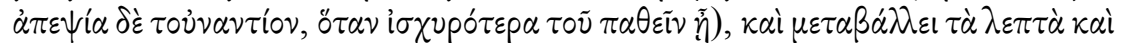

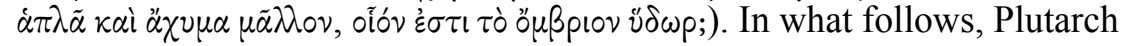
then alludes to both of these premises in reversed order in an attempt to substantiate his theory 2) that rainwater is simpler in composition (i.e. unmixed) than irrigation water, and thus more liable to change, so that I) it is more concocted, and thus provides more nourishment. 2) In regards to the simple composition of rainwater, he first explains that rain is formed in 
the air and in the wind (cf. the previous causa); it falls from the sky pure and unmixed, while springwaters, because of their assimilation both to the earth and to the places whence they emerge, become infected with many qualities, so that they change with less ease and convert more slowly by

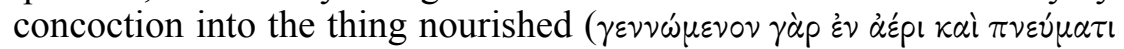

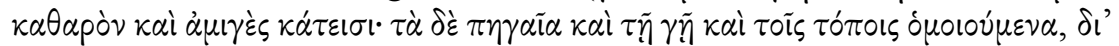

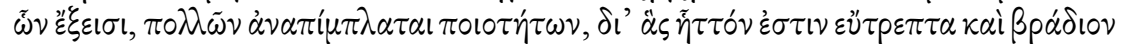

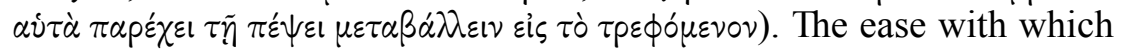
rainwater, on the other hand, changes is accounted for by its processes of putrefaction. Plutarch explains that it putrefies more easily than water

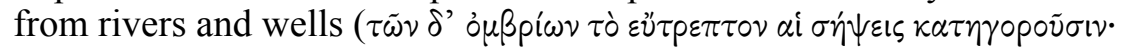

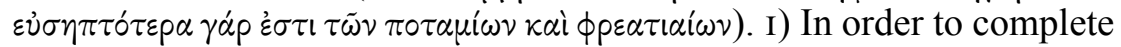
his argument, Plutarch then states that concoction appears to be a process of putrefaction. He borrows this point from Empedocles, who says that

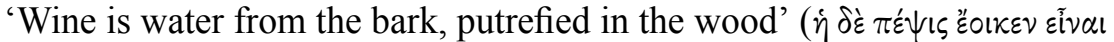

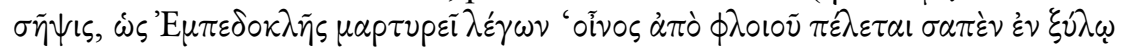
ชं $\left.\omega \rho^{\prime}\right)$.

The fifth and final explanation draws attention to the sweet constituent of rainwater and is introduced as being the most obvious and easiest of

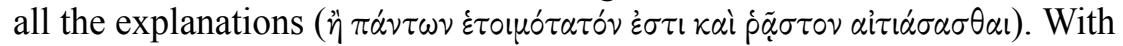
an implicit allusion to the third causa, Plutarch argues that the sweet and useful part of rainwater is immediately lifted (into the plant) by the breath

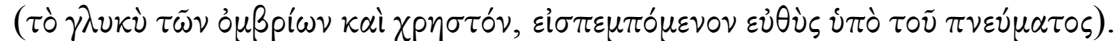
In regards to the rain's sweet constituent, Plutarch explains that domestic animals also enjoy rainwater with more pleasure, and that frogs croak louder in joyful anticipation of the rain, looking forward to accepting it as a sweetening of the water of the pond and as a seed of their (sc. the

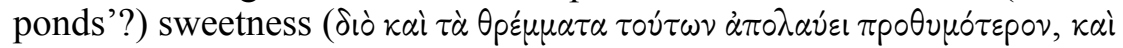

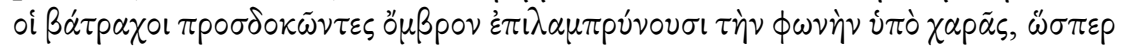

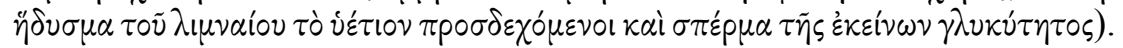
Plutarch illustrates this last point with a conclusive quotation from Aratus, who considers the croaking of frogs as a sign of coming rain. The poet says: 'straight from the pond, the tadpoles' fathers cry: truly wretched

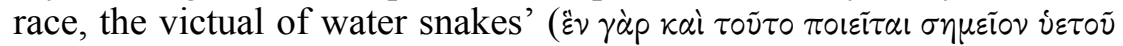

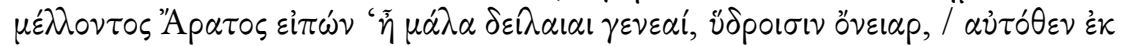

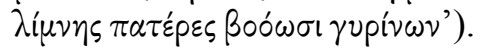

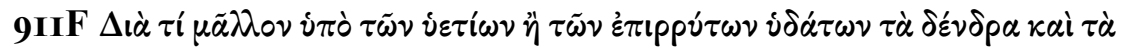

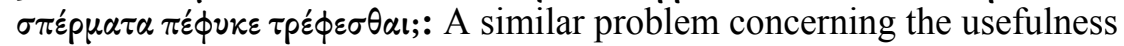
of rainwater for plants (and more specifically rain that accompanies thunder and lightning) is discussed in Q.N. 4. Notably, Theophrastus at several occasions denies that rainwater is better than irrigation water for nourishing several kinds of plants (cf. $C P$ 3, 8, 3 (ónoíws); 2, 5, 5; $H P$ 4, 7, 8; 8, 7, 3; fr. I59, 32-37 Wimmer $=214 \mathrm{~A}, 26-30 \mathrm{FHSG})$, but he 
accepts it for others (cf. HP 7, 5, 2). F.H. Sandbach, I965, p. I52 (with n. a) translates $\sigma \pi \varepsilon \dot{p} \mu \alpha \tau \alpha$ as 'seedlings', i.e. young plants shortly after the fase of germination (here and in Q.N. 4, 9I3A; he bases this translation on Theophr., $H P$ 8, 8, 2, but the concept does not seem to be used in a different sense there). It is uncertain, however, that this is really what Plutarch means (cf. also L. Senzasono, 2006, p. I46, n. II). Perhaps Plutarch is implying that the production of seeds, which is triggered by a residue of nourishment in the plant or tree ( $\pi \varepsilon p i \tau \tau \omega \mu \alpha \tau \tilde{\eta} s \tau p \circ \phi \tilde{\eta} s: \mathrm{cf}$. Q.N. 2I, 9I7 B and 30, 919C), increases when these seeds - and, by implication, the plant or tree itself from which they grow - receive more nourishment (c.q. by

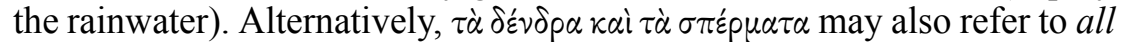
kinds of flora in a metonymical fashion, thus including trees and seeds in specific but also plants, shrubs, bushes etc. more generally (i.e. the genus of $\tau \dot{\alpha} \phi v \tau \dot{\alpha})$.

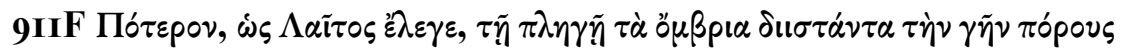

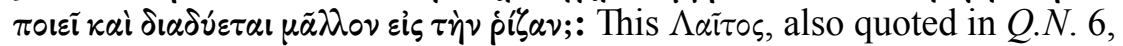
$913 \mathrm{E}$, is probably to be identified with the Platonist Ofellius Laetus [see 4.2.I.I., n. II5]. It is implied in Laetus' explanation that irrigation water, as opposed to rainwater, causes no impact on the earth, because it flows over it. The concept of penetration into the roots recurs in Q.N. I, 9IID

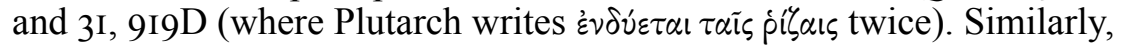
in Quaest. conv. 664B, we read that thunder also parts the earth ( $\tau \dot{\eta} \nu \gamma \tilde{\eta} \nu$ $\left.\delta \operatorname{ri}^{\sigma} \tau \alpha \sigma \theta \alpha \iota\right)$ by using the air as a spike.

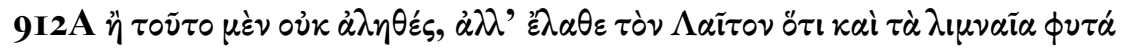

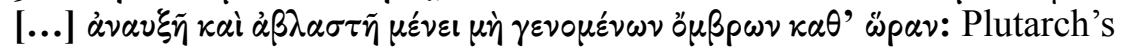
refutation of Laetus' thesis is clear (rain does not part the earth in the case of water plants), but Plutarch does not specify the phrase $\kappa \alpha \theta^{\prime}$ "̈pav any further. The meaning of this phrase will become clearer from the fifth causa, where we learn that the (raining/mating) season of spring is probably meant by the 'right season' here (see the commentary ad loc.).

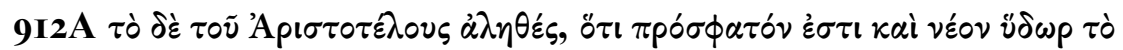

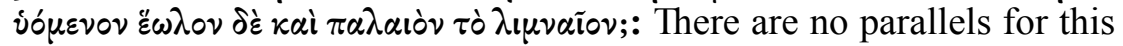
quotation in Aristotle's surviving works (= Arist., fr. 2I5 Rose). We are probably dealing with a remnant of a Ps.-Aristotelian problem that is now lost (see F.H. Sandbach, I982, pp. 224 and 227; according to L. Senzasono, 2006, pp. I48-I49, n. I4, it is not impossible that the original Aristotelian text made reference to a physical process of change, by which fresh water, including rains, turns into the water of ponds, but this is conjecture). The usefulness of running water (including rainwater) as opposed to stagnant and slow water is also mentioned by Pliny, $N H$ 3I, 3I, who invokes the authority of physicians. Considering the medical (i.e. non-agricultural) 
context there, Senzasono (ibid.) argues that Pliny possibly relies on Hipp., Aer. 7, where rain is characterised as aỉ̇ véos. He states that Plutarch possibly had Hippocrates' passage on hand as well, but this is unlikely. The intermediation of a lost problem seems more plausible: after all, Plutarch is quoting Aristotle and the link between Ps.-Aristotle's Problems and the Hippocratic writings is well-known [see 4.2.I.I., nn. IOO-IOI].

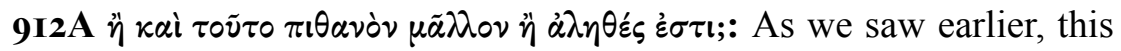
pattern of speech is relevant in light of Plutarch's search for plausible explanations in natural scientific matters and, thus, for his PlatonicAcademic method more generally [see 4.3.2.2.]. It indicates that what

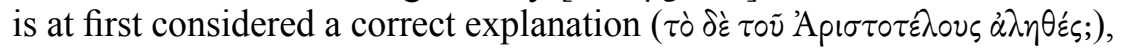
after closer examination appears to have falsely aroused that appearance, so that it is degraded from being true to just being plausible.

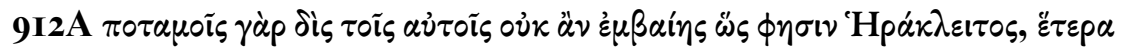

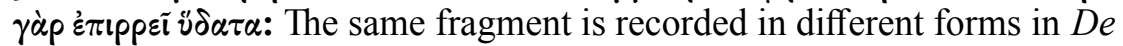
E 392B and De sera num. 559C (= Heracl., DK22BI2, 49a, 9I; A6, I5). Therefore, the introductory $\ddot{\omega} \varsigma \phi \eta \sigma \nu{ }^{\prime} \mathrm{H}^{\prime} \alpha \dot{k} k \lambda \varepsilon i \tau \circ \varsigma$ does not guarantee that Plutarch is quoting Heraclitus $\kappa \alpha \tau \dot{\alpha} \lambda \hat{\varepsilon} \xi$ lv or directly (cf. J.P. Hershbell, I977, p. I90, n. 46). According to G.S. Kirk, 2010 (= I954), pp. 366-380, Plutarch's quote in the passage at hand may be affected by Pl., Crat. $402 \mathrm{a}$ (perhaps via a sceptical source, viz. Aenesidemus, as M. Marcovich, I978,

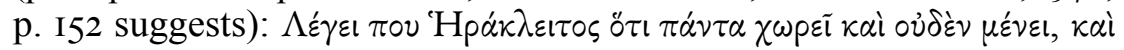

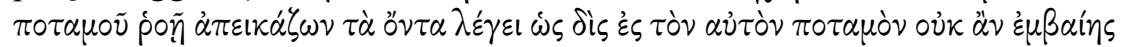
(this may explain the same potential mood in Plutarch's version: ov่k $\alpha 2$ $\dot{\varepsilon} \mu \beta a i \eta \xi)$. Moreover, Kirk argues that the original saying was that of Arius

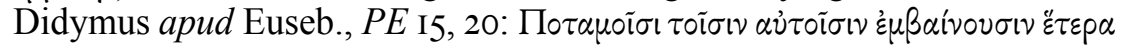

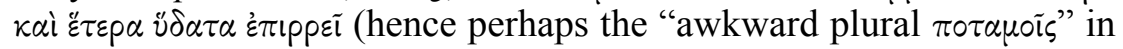
Plutarch's version, as F.H. Sandbach, I965, p. I53, n. d notes). This theory, however, was countered by G. Vlastos, I955, pp. 338-344, who argues that Plutarch's quotation in Q.N. 2 is closer to the original. According to W.K.C. Guthrie, I962, pp. 488-492 Plato's is. I do not intend to get involved in this discussion. The least that can be said is that it is typical of Plutarch's method of citing that Heraclitus' saying is playfully lifted from its original context to receive a new meaning [see 4.2.I.I.]. It is interpreted here in a literal, physical fashion and not in its original cosmological sense (cf. L. Senzasono, 2006, p. I5I, n. I6).

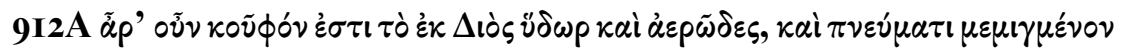

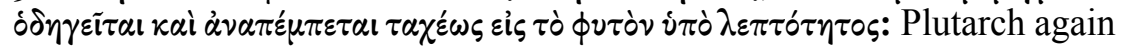
alludes to the airy and breathlike composition of rainwater in the fourth and fifth causae of Q.N. 2 and also in the first causa of Q.N. 4, 9I2F. For the lightness of rainwater, cf., e.g., Hipp., Aer. 8, Cels., De med. 2, I8, I2, 
Pliny, $N H$ 3I, 3I, Ps.-Arist./Alex. Aphr., Suppl. probl. 2, 22. The poetical formulation of the phrase $\tau \dot{\jmath} \varepsilon \kappa \Delta$ เòs vँ $\delta \omega p$ to denote rainwater falling from the sky may seem somewhat at odds with the general sub-literary style of the collection [see I.2.3.]. However, the name of Zeus is a common metaphor for all celestial phenomena (cf. L. Senzasono, 2006, p. I3), including the $\delta \iota_{0} \eta \mu_{i} \alpha$ (cf. Aratus' quote in the fifth causa). Cf., e.g., Alex. $27,2$.

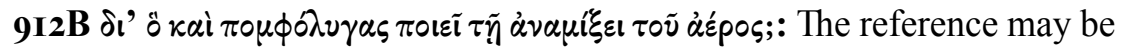
to the bubbles (filled with air) that are formed by the impact of raindrops on the surface of puddles, ponds and pools.

9I2B

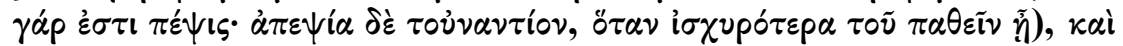

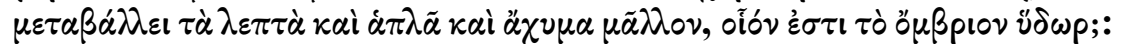
For the easy concoction of simple foodstuffs, cf. Quaest. conv. 66IBD (to the contrary, cf. Quaest. conv. 663B with Arist., DA 416a28-35; but cf. also Ps.-Arist., Probl. 86ra6-9).

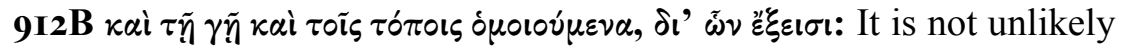

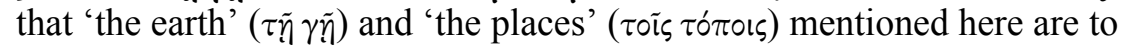
be identified with one another (despite the double use of the copulative $\kappa \alpha i$ ). In this sense, the phrase 'whence they emerge' ( $\delta \iota^{\prime} \tilde{\omega} \nu$ है $\left.\xi \varepsilon \mid \sigma \iota\right)$ implies that the springwaters emerge from $(\dot{\xi} \xi)$ certain 'locations in the earth'. According to F.H. Sandbach, I965, p. I55, however, Plutarch uses the term $\tau$ ó $\pi$ ol to imply that not only the earth, but also the air at the location where water exits a spring affects the quality of the water. A parallel passage for this is found in Sen., $N Q$ 3, 2I, 2: locus atque aer aquas inficit similesque regionibus reddit per quas et ex quibus veniunt. Cf. also Q.N. 33: iniurias quas vel ab aeris mala qualitate vel a terra accipiunt digerere nequeant (said of stagnant waters). Due to the fact, however, that Plutarch has just ascribed the purity of rainwater to the air (and breath) in which

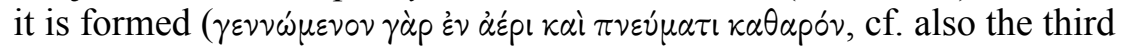
causa), it seems unlikely that the air at the localities of the spring renders the springwater impure, unless of course, this 'spring-air' is less pure (or breathlike) than that in the sky, but this seems far-fetched. In any case, Plutarch would probably have made this point more explicit if he really intended to draw a subtle distinction between both types of air (cf. also L. Senzasono, 2006, p. I56, n. 22). Sandbach also refers to M. Glycas, Ann. I, I6 (p. 3I, I2-I3 Bekker), where the 'spring-air' is not mentioned,

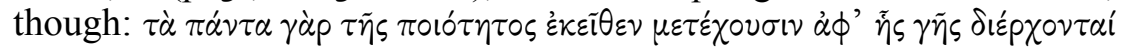

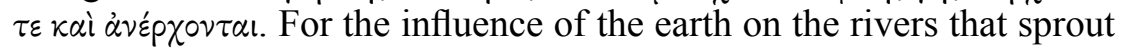
from it, see also Pl., Phd. II2ac, where it is noted, moreover, that air and breath accompany the oscillating movements of the liquid in Tartarus. 
According to L. Senzasono, p. I57, n. 22, Plutarch is actually relying on this passage in Plato so that the connection of rainwater with the air and breath just mentioned "difficilmente può essere casuale". This is very unlikely, though, because the contexts are completely different (and if we may assume that the rivers flowing out of the Tartaric liquid contain admixed air and breath themselves, this is contradictory to Plutarch's argument).

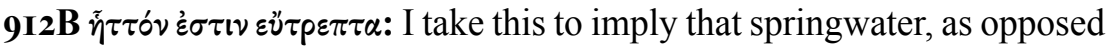
to rainwater, is in fact already a changed substance by the fact that it is assimilated to the earthy locations whence it arises (see the previous comment), so that it has great difficulty in undergoing new change.

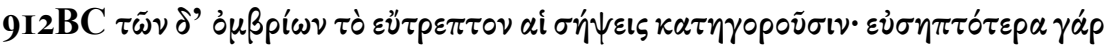

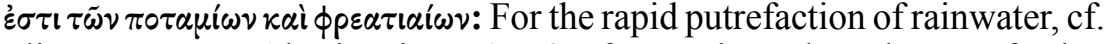
Pliny, $N H$ 3I, 34. Also in Hipp., Aer. 8 reference is made to the putrefactive quality of rainwater, albeit on the basis that it is impure and of mixed origin. In Quaest. conv. $725 \mathrm{CD}$, we read that mixing produces putrefaction and that standing waters in ponds are $\varepsilon \dot{v} \sigma \eta \pi \tau \alpha \mu \tilde{\alpha} \lambda \lambda o^{\prime} v$, because they are impure and mixed with earth (running waters, by contrast, shake off any admixed earth). On the putrefactive quality of standing waters, cf. also Aqua an ignis 957D and De lat. viv. II29D (with F. Fuhrmann, I964, p. 60).

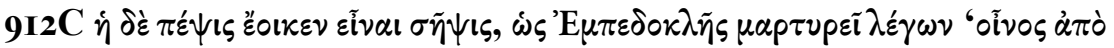

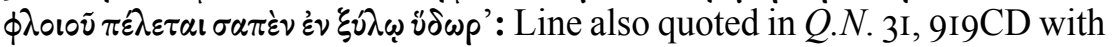
syntactical adaptations (=Emp., DK3IB8I). There is discussion among scholars about the correct interpretation of this fragment: see H. Diels, I90I, p. I37, F.H. Sandbach, I965, pp. I56-I57 (n. a), M.R. Wright, I98I, pp. 225-226, B. Inwood, 200I, p. I3I, L. Senzasono, 2006, p. I57, n. 24. I am not so sure of Sandbach's claim (approved of by Senzasono) that oivos implies grape juice here in Plutarch's account and not wine (being the resulting concoction from that grape juice). He refers to Quaest. conv. $676 \mathrm{~B}$, where we read that clay is hot, which is why it matures oivos (kept in clay vessels presumably). The formulation is, indeed, elliptic there, implying, so I take it, that heat concocts <grape juice into $>$ wine. The

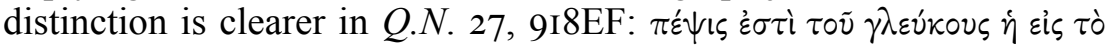

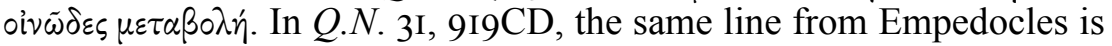
quoted regarding the putrefactive nature of, what is abstractly called, 'the vinous' liquid, which is probably identical with wine ( $\phi \dot{\sigma} \sigma \varepsilon \iota \sigma \eta \pi \tau$

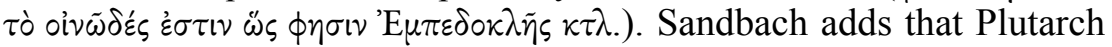
undoubtedly wrote $\dot{\alpha} \pi \dot{\partial} \phi \lambda$ เ $о \tilde{v}$ ('from the bark') in the fragment at hand, but that it is possible that Empedocles originally wrote viò $\phi \lambda$ ○เov ('under the bark', as already suggested by Xylander, but rejected by Diels). The term $\phi \lambda$ oı́s itself may refer to the bark of the vine, but also to the skin 
of the grape (cf. LSJ, s.v. I). The second option seems more plausible, albeit perhaps in a metonymical sense, as in Emp., DK3IB80 (= Quaest. conv. $683 \mathrm{D}$ ), where $\phi \lambda$ orós probably refers not just to the skin but to the edible part of the apple surrounding the seeds (see Wright). As to $\dot{\varepsilon} \nu \xi \dot{\nu} \omega \omega$, Wright argues that it refers to the wooden casks or vats containing the pressed grapes, but this was already rejected by Diels ("noli cogitare de vino in dolio condito"). It is difficult to reconstruct the original sense of the fragment (especially because Plutarch may be twisting Empedocles' original wording). What matters most for Plutarch's argument, though, is the idea that wine - being a concoction from grape juice - is essentially putrid water, which illustrates the idea that the process of concoction

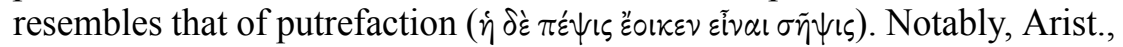
Top. I27arg dismisses Empedocles' view that wine is putrefied water, but he does this in order to illustrate a common error in predication of the

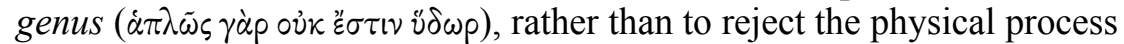
as such.

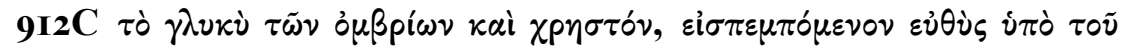
$\pi \nu \varepsilon v ́ \mu \alpha \tau o s:$ We are probably dealing here with an allusion to the third causa, as can be illustrated by two points: I) the phrase i $\pi$ ò $\tau 0 \tilde{u} \pi \nu \varepsilon v ́ \mu \alpha \tau o s$

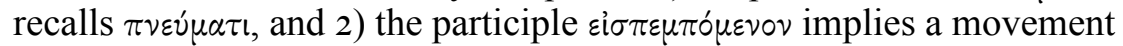
of the rainwater into the plant: as such, it recalls the phrase $\pi \nu \varepsilon v \dot{\mu} \alpha \tau$ l

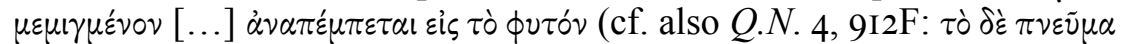

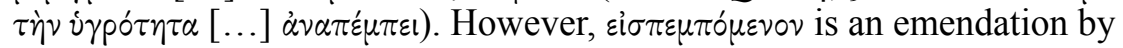

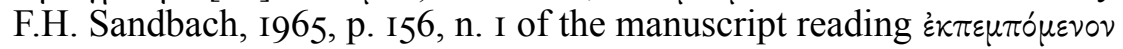
(Hubert suggests $\dot{\varepsilon} \kappa \pi \varepsilon \mu \pi \circ \mu \varepsilon \dot{\varepsilon} \omega \nu$ ). If the manuscript reading is to be

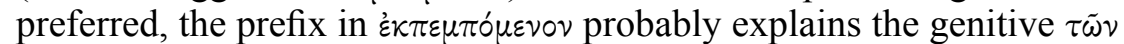
oußpi $\omega \nu$ (notion of separation). In this sense, the breath immediately exports the sweet and useful constituent from the rainwater (into the plant). Sandbach corrects the prefix $\dot{\varepsilon} \kappa$ - in $\varepsilon \dot{i} \sigma$ - by comparing Hipp., De flat. 7 (in the context of breath entering the body together with the food). The correction is plausible from a paleographical perspective, and even if one would stick to the reading of the manuscripts, the connection with causa three remains clear.

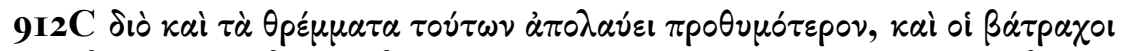

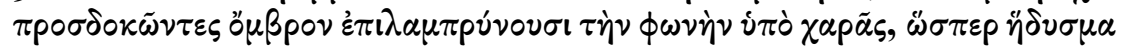

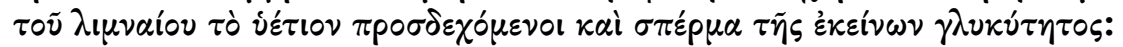
F.H. Sandbach I965, I56, n. 3 finds "[t]he text [...] suspect" and suggests

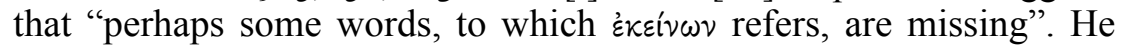
translates: "Frogs, when expecting rain, croak more loudly and clearly for joy, looking forward to the rain-water as a kind of sweetening for the water of the pond, and as a seed from which the freshness of the other waters will increase (?)." As Sandbach indicates, the "other waters" in 
his translation is unclear (he does not clarify it any further). There is no lacuna in the manuscripts, so the text is probably correct. L. Senzasono 2006 , p. I60, n. 26 may be right, therefore, that $\dot{\varepsilon} \kappa \varepsilon i v \omega \nu$ has anaphoric value, referring back to the water of the pond $(\tau \dot{\partial} \lambda \mu \nu \alpha \tilde{i} o \nu<i \delta \omega p>)$. The variation between singular and plural forms may cause confusion, but, if Senzasono is correct, for Plutarch, the singular and the plural forms imply basically the same here. In other words, 'the water of the pond' (i.e. in each pond specifically) implies the same as 'the water of the ponds' (i.e. in ponds in general). Notably, Plutarch formulates the names of different types of water in the plural in 9I2C ( $\left.{ }^{\prime} \mu \beta p i \omega \nu, \pi 0 \tau \alpha \mu i \omega \nu, \phi \rho \varepsilon \alpha \tau i \alpha i \omega \nu\right)$, yet for rainwater he uses both plural and singular forms in the fifth causa

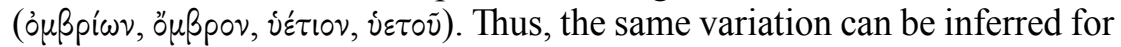
pond water(s). Furthermore, it is not improbable that Plutarch deliberately avoids using $\tau \circ v^{\tau} \tau \omega \nu$ here (instead of $\dot{\varepsilon} \kappa \varepsilon \dot{\varepsilon}(\omega \nu)$ ), because only a little bit earlier, this pronoun (in that precise form, as conjectured by Wyttenbach

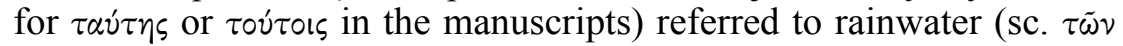
o $\mu \beta p^{\prime}(\omega \nu$ ). This, of course, cannot be the meaning of $\dot{\varepsilon} \varepsilon \varepsilon i v \omega \nu$ here (seeing that the resulting meaning would make no sense: 'rain as a seed of the rain's sweetness'?). It is not unlikely, therefore, that in his attempt to avoid misunderstanding, Plutarch unintentionally obscures things a bit. I interpret the passage as follows: 'frogs croak more loudly and out of joy when they expect rain, looking forward to accepting it as a sweetening of the water of the pond and as a seed of their (sc. the ponds') sweetness' (see also M. Meeusen, 20I5a).

Some further commentary is necessary, then, regarding the croaking of frogs. The scholiast on the Aratus passage Plutarch quotes (see the following comment) says that the croaking of frogs is a sign of storm $\left(\sigma \eta \mu \varepsilon i \sigma_{\nu} \chi \varepsilon \mu \tilde{\omega} \nu \circ \varsigma\right)$. He explains that frogs become aware in advance

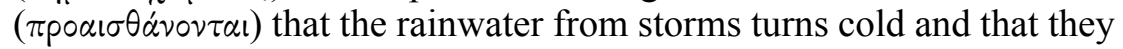

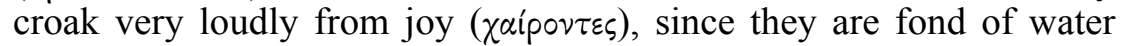
( $\phi \lambda \nu \delta \rho \circ \iota)$. Especially the fact that the rainwater is sweeter than the water of the pond gives them joy and causes them to breed more, just like

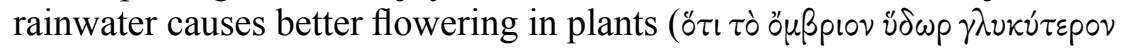

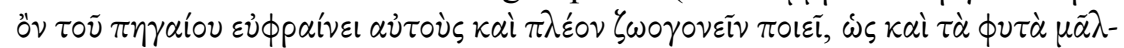

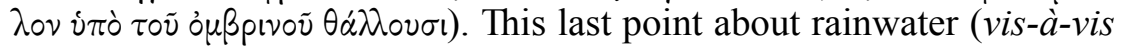
pond water) improving the flowering of plants is remarkably close to the problem at hand in Q.N. 2. C. Hattink apud F.H. Sandbach, I965, p. I57, n. c even argues that the Aratus scholiast may be relying on Plutarch's lost

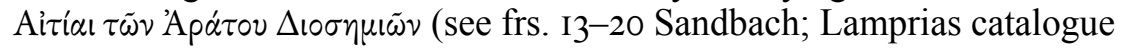
nr. II9). However, the use of a communal source is also plausible (e.g., one of the many Aratus commentaries that circulated widely in Antiquity [see 4.I.2.2., n. 75]). Regarding the croaking of frogs itself, in De soll. an. $982 \mathrm{E}$, a distinction is made between I) the erotic/nuptial call of male

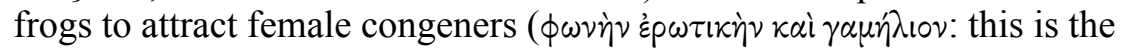


so-called ${ }^{2} \lambda 0 \lambda \nu \gamma \omega \dot{\omega} v$, which is not mentioned in Q.N. 2, 9I2C; cf. also Arist., $H A$ 536aII), and 2) the shrill cry that they make when they expect

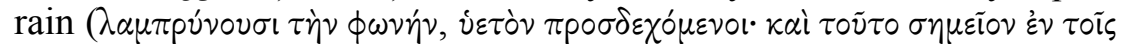
$\beta \varepsilon \beta \alpha ı \tau \dot{\alpha} \tau o\llcorner\varsigma ⿱ 宀 \varepsilon \sigma \tau i v$ : Plutarch here does use the very same terminology as in Q.N. 2, 9I2C). This distinction is rendered explicit in De soll. an. $982 \mathrm{E}$

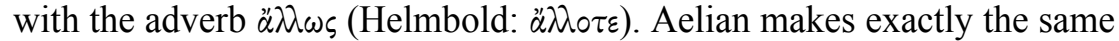
distinction in $N A$ 9, I3 (as L. Senzasono, 2006, p. I59, n. 25 points out, it is uncertain whether Aelian relies on Plutarch directly or on the same source; for the difference in pitch of the 'erotic' $\partial \lambda \partial \lambda \nu \gamma \omega \dot{ }$, see also NA 6, I9; the

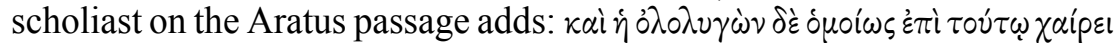

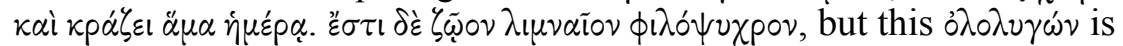
presumably the tree-frog rather than the croaking itself produced by male frogs: see LSJ, s.v. ii). It is not unlikely, however, that these two distinct explanations for the croaking of frogs are to be considered complementary, because spring is both the mating and the raining season (for frogs as a token, $\sigma \dot{v} \mu \beta 0 \lambda$ ov, of springtime, cf. De Pyth. or. $400 \mathrm{C}$; for the influence of the hot south wind on the mating of animals, including frogs, that arise $e x$ spermate, cf. also Arist., fr. 245, Io Rose). F.H. Sandbach, I965, p. I57, n. c. even believes that "it is possible [...] that the word $\sigma \pi \varepsilon p \mu \alpha$ in 912C refers to the mating of frogs, which croak particularly in the breeding season" (cf. also L. Senzasono, 2006, p. I60, n. 26). This is, indeed, what is suggested

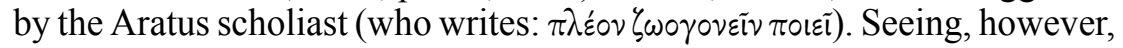
that no explicit reference is made to the 'erotic' $0 \lambda \Delta \lambda \nu \gamma \omega \dot{\omega} \nu$ in Q.N. 2 , it remains uncertain as to whether $\sigma \pi \varepsilon$ ép $\alpha$ really refers to the frog's mating here (the reference is implicit at most). The problem at hand in Q.N. 2 has a main hydrological and botanical interest, not a zoological one. It concerns the physical-meteorological circumstances connected to the rain's sweetness and its influence on plants rather than animals. In regards to the actual meaning of the concept of $\sigma \pi \varepsilon p \mu \alpha$, then, L. Senzasono, 2006, pp. I2-I3, n. I6 and p. I6o, n. 26 is probably right that it has metaphorical value, denoting a cause, germ or origin of something (cf., e.g., fr. I36

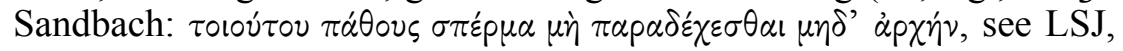
s.v. i, 2). The seed imagery may be more ingenious than that. It is from the rainwater-seed, then, that the sweet content of the ponds grows. In this sense, it is implied that pond water is initially unsweet (or, in any case, less sweet), and that it becomes sweet(er) from the rainwater-seeds that fall into it. There may be reason to connect the term $\sigma \pi \varepsilon p \mu \alpha$ with the introductory explanation of the problem by Laetus (who argues, as we saw, that the rain parts the earth by its impact and so better penetrates into the roots). The image of raindrops ( $0 \mu \beta p(\alpha)$ being planted like seeds might not be that far-fetched in the final causa at hand: like seeds, raindrops fall on a certain surface and penetrate it, so that they provide fresh and sweet nourishment to plants. Moreover, in his criticism of Laetus' theory, Plutarch refers to plants growing in ponds when rain falls in the 'right 
season' ( $\kappa \alpha \theta^{\prime}$ '̈pav), which is not further specified. One can infer from the final causa that the 'right season' probably is that of spring. The result, then, is a subtle argumentative ring composition, where Plutarch at the very end of the aetiology explains what remained unexplained initially [see 4.3.3.3.]. The (generalising) singular $\sigma \pi \dot{\varepsilon} p \mu \alpha$ (cf. also $\eta \dot{\delta} \nu \sigma \mu \alpha$ ) can be

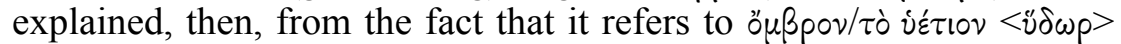
(which implies basically the same as $\tau \dot{\alpha}$ ö $u ß p ı$ in Laetus' explanation). On the 'spermatic' faculty of rain falling from the heavens on earth (where the heavens resemble the father and the earth the mother), cf. also, e.g., Aët., Plac. I, 6 = Ps.-Plut. $88 \mathrm{oB}$. In a similar vein, Ps.-Arist./Alex. Aphr., Suppl. probl. I, I7, 32-35 compares sunbeams to seeds planted in the moon's surface.

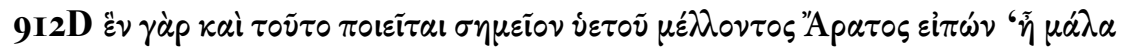

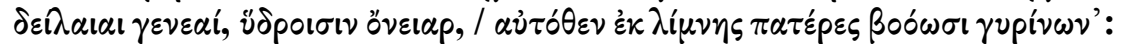
= Arat., Phaen. 946-947 (= Diosem. 2I4-215). Theophr., Sign. I5 also includes the croaking of frogs among signs of rain; cf. also Sign. 40, Cic., De div. I, I5 = Progn. 4, I-3, and Pliny, NH I8, 36I. See the previous comment for a discussion of the comments of the Aratus scholiast on this passage and their relevance for the problem at hand.

\section{Q.N. 3, 912DF}

Q.N. 3 deals with a dietetical problem concerning the nutritive effects of salt on animals (a theme that recurs in Q.N. I, 9IICD and 5, 9I3B). Plutarch examines why herdsmen put salt down for their cattle $(\Delta \dot{\alpha} \tau i \dot{i} \pi \alpha \alpha \beta \alpha \dot{\lambda} \lambda-$

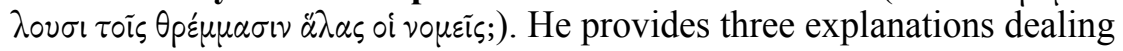
with the physical constitution and properties of salt. The first one refers to the salt's pungency, the second to its ability to dissolve fat and the third to its generative properties. The first two explanations are 'contradictory' to each other [see 4.3.3.2.].

The first explanation focuses on the pungency of salt and is of a mechanical kind. It is a popular belief, so Plutarch writes, that salt produces a bulk of

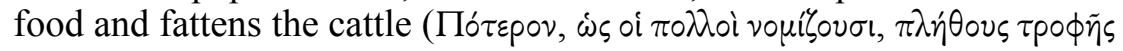

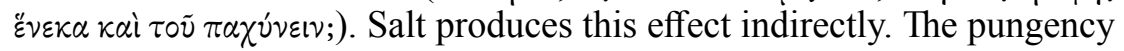
of salt, so Plutarch explains, stimulates the appetite, and by opening up the pores, it ameliorates the passage of the food for distribution in the body

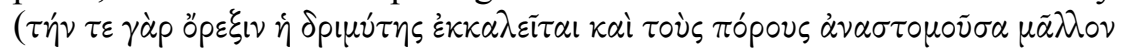

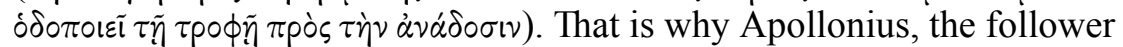
of Herophilus, recommends that weak and ill-nourished persons should not be fed on syrup or porridge but on pickled and salty foods, the fineness 
of which, having become like a hair-sieve (?), adds the nourishment to the

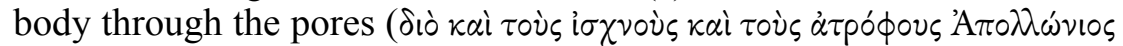

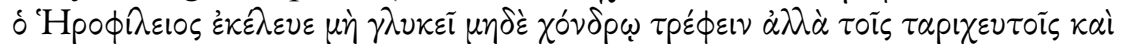

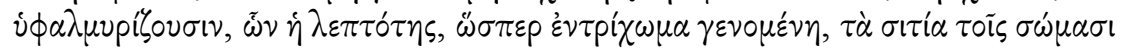

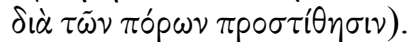

The second explanation aims to refute the first. Plutarch argues that herdsmen accustom their cattle to licking salt, rather because it makes

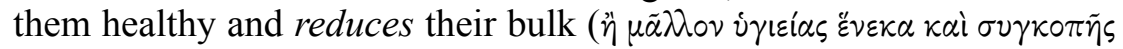

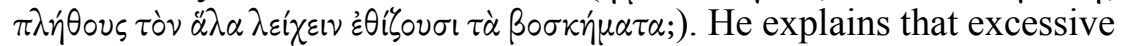

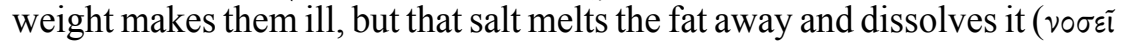

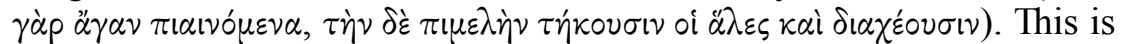
illustrated by the fact that herdsmen skin their animals easily and without difficulty after the slaughtering, because the fat that binds and fastens the skin becomes thin and weak due to the pungency of the salt $\left({ }^{\prime \prime} \theta \varepsilon v\right.$

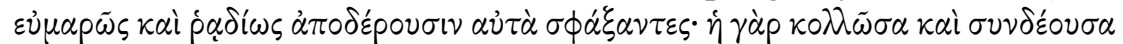
$\tau$ that the blood of animals that lick salt also grows thin, and that there is no

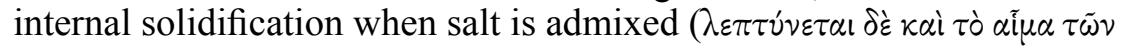

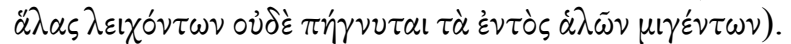

In the third explanation, Plutarch alludes to the generative and aphrodisiac property of salt. He urges the reader to consider that animals (by licking the salt) become more fertile and readier towards coition

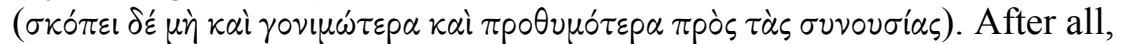
bitches also conceive quickly when they eat salted meat after mating, and ships that transport salt harbour a larger number of mice (or rats), because

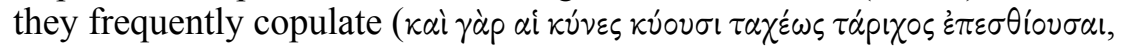

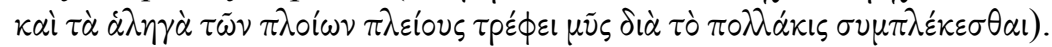

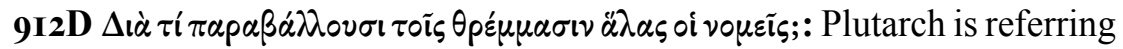
to salt stones that are licked by the animals (cf. 9I2E: $\lambda \varepsilon^{\prime} \chi_{\varepsilon \varepsilon \nu}, \lambda \varepsilon i \chi o ́ v \tau \omega \nu$ ). To this day, such salt stones are used to provide extra mineral nutrition to farm animals in order to foster their growth and overall health. According to G.W.M. Harrison, 2000b, p. 248 , the problem at hand "presumably encapsulates Peripatetic views, although a precise source has yet to be identified". A potential source is Arist., HA 596aI6-25, where it is reported that farmers put salt down for their animals so that they become thirsty. Aristotle explains that thirst fattens ( $\pi\llcorner\alpha i v \varepsilon l)$ the animals thus improving their health (for further parallels with $H A$, see also the comments below on 9I2EF). It is uncertain whether Plutarch directly relies on this account or, rather, on a lost Ps.-Aristotelian problem based on it. A clear parallel

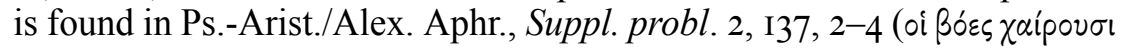

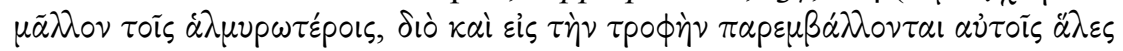

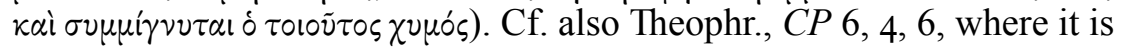
said that salt functions as a $\eta \delta \delta \sigma \mu \alpha \alpha$ (cf. $Q . N .5,913 \mathrm{~B}$ ) tempering the food 


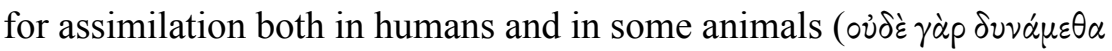

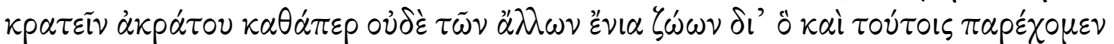
$\left.\tau \circ \dot{\alpha} \varsigma \bar{\alpha} \lambda \alpha_{\varsigma}\right)$. For the vital nutritive value of salt for cattle, cf. also Ps.-Arist.,

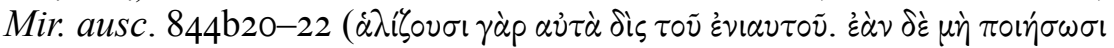

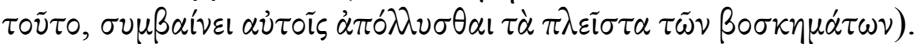

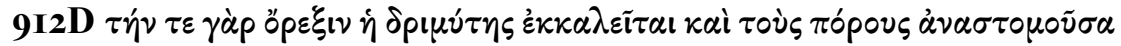

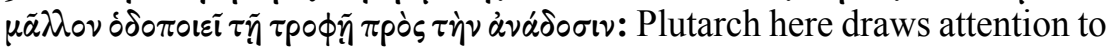
the nutritive effect of salt, but he does not try to prove that salt is nutritive in and of itself for land-animals (this would be in contradiction with what he says in Q.N. I, 9IIC). The effect is rather of a mechanical kind: the salt's pungency stimulates the appetite by opening up passages for the distribution of the food into the body. Cf. also Q.N. 5, 913B for the idea that salt acts as a relish for some animals by removing the satiety ( $\tau$ ò $\left.\pi \lambda \eta^{\prime} \sigma \mu \nu v\right)$ caused by their food, and thus stimulating appetite.

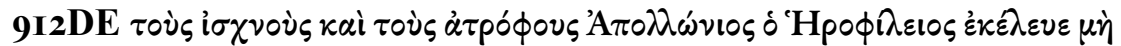

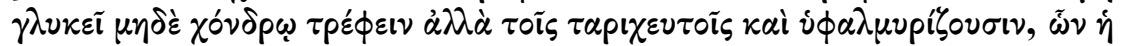

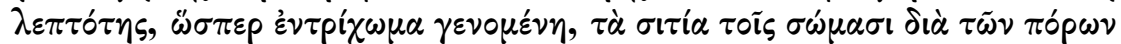
$\pi \rho \circ \sigma \tau i \theta \eta \sigma \nu$ : The manuscript reading $\chi 0 v \delta \rho \tilde{\omega}$ (perispomenon), as printed by Hubert, refers to the granular form of the food, which is not at issue here. The fragment at hand (= Apoll., fr. 33 von Staden [see 4.2.I.I., n. IIO]) possibly originates from Apollonius' Eủ tópı $\sigma \tau \alpha$ (On common remedies). The precise meaning of $\dot{\varepsilon} v \tau p^{\prime} \chi \omega \mu \alpha$ is obscure and remains problematic. LSJ, s.v. give two possible meanings for it: I) "edges of the eyelids, eyelashes" (with reference to Poll., 2, 69) and 2) "hair-sieve" (with reference to our

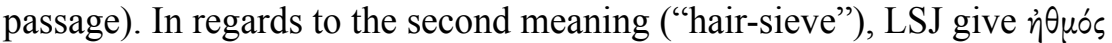
(i.e. a strainer or colander) as a synonym. The passage that comes closest to formulating this idea is Xen., Mem. I, 4, 6, where we read that eye-lashes grow from the eye-lids in order to 'filter' the winds, so that they cannot

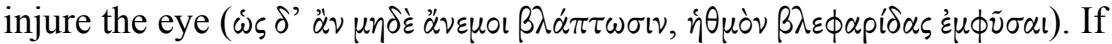
this is the correct meaning here, it remains to be seen in what precise sense the fineness of salty foods becomes 'like a hair-sieve' in our passage. According to K. Oikonomopoulou (in personal correspondence), this fineness may refer to the fine grains of the salt. She argues that the "hairsieve" "would suggest that salt acts like some kind of filter of fine hairs, which perhaps attaches itself to the pores (? the role of the pores is not clear

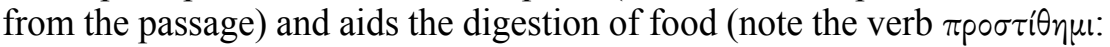
it 'adds the food to the body' [cf. also Q.N. 30, 9I9C and 3I, 9I9E]), so it acts as some sort of medium of digestion; this would fit well with the meaning of 'filter'. If this is right, the correct translation would be: 'acting like a fine sieve'." As to the role of the pores (in the flesh presumably), Plutarch previously argued that they are opened by the salty constituent in the pickled foodstuffs and that the nourishment is transmitted through them 


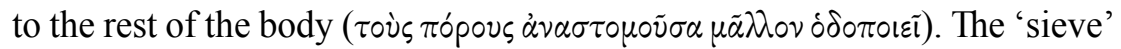
thus created may, indeed, be a very fine one, with microscopic pores having the diameter of a single hair. I agree with Oikonomopoulou when she adds that "the theory was [perhaps] idiosyncratic to Apollonius" ("though it should be noted that we cannot be sure, on the basis of Plutarch's quotation, whether the explanation is actually Apollonian: maybe the Apollonius quote ends with i $\phi a \lambda \mu v p i \zeta o v \sigma v$, the rest of the explanation supplied by Plutarch"). Moreover, the context in Q.N. 3 is very similar to that of Quaest. conv. $687 \mathrm{D}$, where we read that salt recovers the appetite in ill people by its effect on the stomach (with reference to the theory of pores) it is not unlikely that the word $\dot{\varepsilon} \tau \tau^{\prime} \chi \chi_{\omega} \omega \alpha$ fell out in the lacuna there. For similar references to the working of a sieve in relation to the transmission of nourishment in the body, cf. also Quaest. conv. 689C (where Plutarch rejects the idea that dry and liquid food are separated by the pores in the flesh, as if through a strainer, $\ddot{\omega} \sigma \pi \varepsilon p \dot{\eta} \theta \mu o i \varsigma$ ) and 699AB (where Plutarch argues that the lung is created in the pattern of a sieve and that it contains

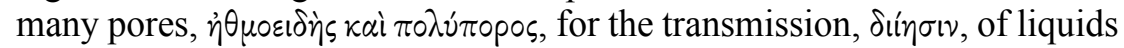
and solids).

Other interpretations of the concept of $\dot{\varepsilon} \nu \tau p$ í $\chi \mu \alpha \alpha$ have been suggested (sometimes involving textual emendations), but none as convincing as the one proposed. The translation by F.H. Sandbach, I965, p. I59 (with $\mathrm{n}$. b) as "some kind of hairy growth (?)" is accurate from an etymological perspective (cf. the first meaning in LSJ) but remains enigmatic (before him, Duebner and Bernardakis also thought of hairs). Sandbach notes that "[t]his passage awaits explanation. $\dot{\varepsilon} v \tau p i \chi \omega \mu \alpha$ might be expected to mean a growth of hairs or filaments: its only known use is of that part of the eyelid from which the lashes grow, Pollux, ii. 69. Does Plutarch mean that the 'fine' parts of salty foods form fine threads, which pass through the passages and draw the rest of the food after them?" This is odd, but in any case there is a certain relationship between the residue $(\pi \varepsilon p i \tau \tau \omega \mu \alpha)$ of nourishment and the growth of hairs (cf. Quaest. conv. 65IA, De Is. et Os. 352D; Ps.-Arist., Probl. 893a3I, 893b7; Ps.-Arist./Alex. Aphr., Suppl. probl. 2, 59, 6I, 64). There is no clear indication, however, that this is what Plutarch is hinting at here. Alternately, Xylander and Kaltwasser have connected the concept of $\dot{\varepsilon} v \tau$ í $(\omega \mu \alpha$ with an aspect of friction, and Koechly conjectures हैं $\tau$ p $\mu \mu \alpha$ ('ointment'). L. Senzasono, 2006, pp. I6I-I62, n. 29

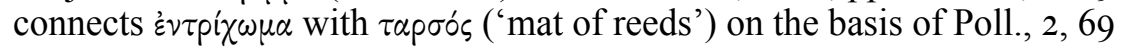

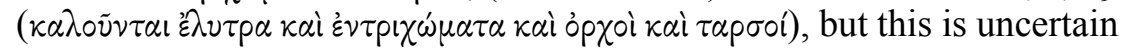
in the present context (as are the other synonyms in Pollux). Doehner, by

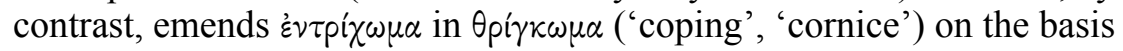
of Quaest. conv. 685B, where it is argued that salt adapts the food to our

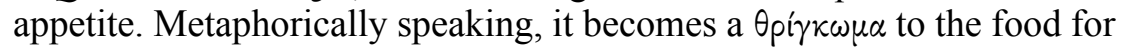
the body, implying a 'completion', or 'finishing touch' (Hoffleit), or a 'topping'. If this emendation is correct - F. Fuhrmann, I978, p. I82, n. I 
(to p. 87) speaks of $\dot{\varepsilon} v \tau p i ́ x \omega \mu \alpha$ as "une étrange paronymie" -, it perhaps contains a reference to salty desserts, which were believed to produce beneficial effects (cf. Quaest. conv. 669B: salty food improves digestion). This remains doubtful, but Doehner's emendation is not unsound from a paleographical perspective (as can be inferred from Flav. Jos., Antiq. $J u d$. I5, II, 3, where $\theta p \iota \gamma \kappa \omega ́ \mu \alpha \sigma \iota$ was also conjectured for $\tau \rho \iota \chi \omega ́ \mu \alpha \sigma \iota$, cf. LSJ, s.v.). On the contrary, S.-T. Teodorsson, I990a, pp. 228-229 (cf. also

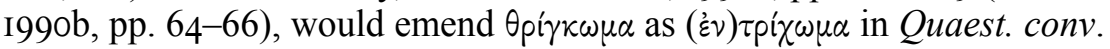
$685 \mathrm{~B}$, arguing that we are dealing with a strange anatomical practice by which strong and pliable hairs (of horses or humans) were used as a kind of a 'probe' to examine the fine bloodvessels. It is difficult to either prove or disprove this theory. Another possible theory may involve an emendation based on De Is. et Os. 352F, where salt is considered to 'sharpen' the appetite ( $\dot{\varepsilon} \pi \hat{\imath} \theta \dot{\eta} \gamma 0 \nu \tau \alpha \varsigma \tau \dot{\eta} \nu$ öp $\varepsilon \xi(\nu)$. The imagery of salt as an $\dot{\varepsilon} \pi i \theta \eta \mu \alpha$ (the head of a spear) is not implausible in the present context, but this remains conjecture. Another possibility can perhaps be adduced from Erasistratus' metaphor of water serving as an oै $\chi \eta \mu \alpha \tau \tilde{\eta} s \tau \rho \circ \phi \tilde{\eta} s$, a vehicle transporting $(\pi \rho \circ \tau i \theta \eta \mu)$ the food through the pores into the body (cf. Quaest. conv. $690 \mathrm{~A}, 698 \mathrm{D}$; probably also $687 \mathrm{E}$ ). The context is similar, but the imagery is not mentioned anywhere in regard to salt itself, only to seawater (in a different meaning, cf. De cap. ex inim. 86E) and honey (cf. Gal., MM Io, 300, II).

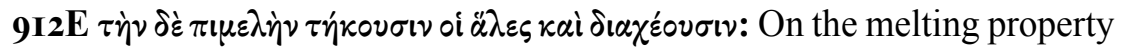

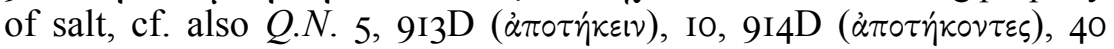

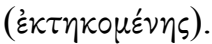

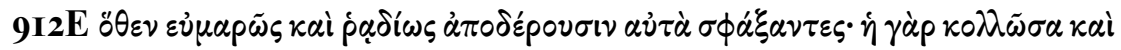

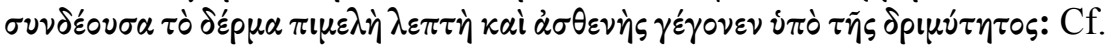
Quaest. conv. 697B, where salt is considered a powerful natural solvent owing to its heat, which counteracts the so-called interlocking and binding

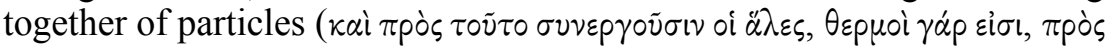

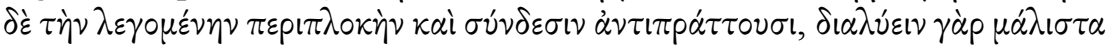
$\pi \varepsilon \phi u ́ k \alpha \sigma l)$. The property of heat in salt may also be implicitly present in our

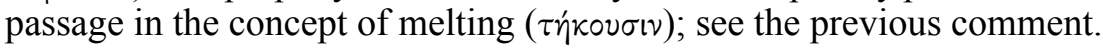

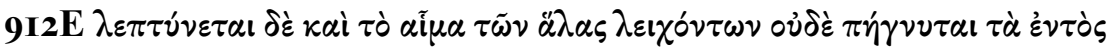
$\dot{\alpha} \lambda \tilde{\omega} \nu \mu \iota \gamma \varepsilon \tau \tau \omega \nu$ : Similarly, in Q.N. 20, 917AB, Plutarch connects the salinity in the tears of deer (as opposed to the sweet ones of boars) with the thinness $\left(\lambda \varepsilon \pi \tau \sigma^{\prime} v\right)$ of their blood, from which the tears are secreted. The reference in

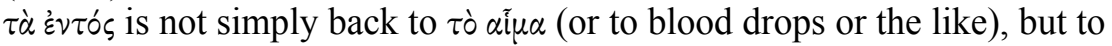
other 'internal parts', perhaps the animals' entrails. This meaning is found in Quaest. conv. 684A, where in the context of slaughtering, the 'outher pieces' ( $\tau \dot{\alpha}$ ' $\xi \xi \omega \omega$, i.e. the limbs etc.) of sacrificial animals are contrasted to 
the 'inner pieces' ( $\left.\tau \dot{\alpha} \dot{\varepsilon} \nu \tau \delta^{\prime} \varsigma\right)$. The same context of slaughtering is present in our passage (cf. Plutarch's previous mention of the skinning of animals). This may suggest that the salt not only ameliorates the skinning process but also the drainage of the blood and the removal of the organs. In this sense, there may be an implicit opposition between the 'external' skin on the one hand and the organs 'inside' of the body on the other. Alternatively, $\tau \dot{\alpha} \dot{\varepsilon} v \tau \dot{c} s$ perhaps refers to the contents of the bowels, the main point of interest being the laxative property of salt. This is, indeed, relevant in the context of the reduction of 'bulk' in cattle as mentioned in the second causa (but the formulation is obscure; cf. F.H. Sandbach, I965, p. I60, n. a). In Quaest. conv. 690A, concerning the effect of bathing on nourishment,

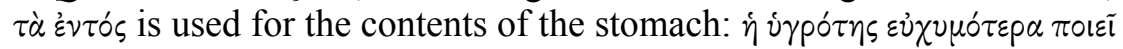

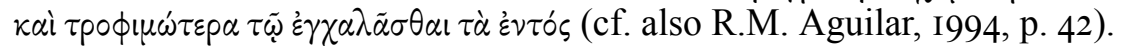
For the laxative property of salty foods, cf. also, e.g., Hipp., De victu 45, 7-Io (white chick-peas) and 56, Iff. (salty meat). Cf. also Ps.-Arist./Alex. Aphr., Suppl. probl. 2, II5-II6. In Hipp., Aer. 7, 68-72, the popular theory

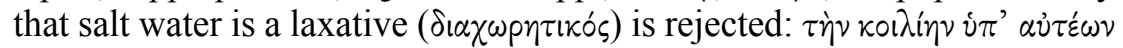
[sc. $\tau \tilde{\omega} \nu \dot{\alpha} \lambda \mu \nu \rho \tilde{\omega} \nu \dot{v} \delta \dot{\alpha} \tau \omega \nu] \sigma \tau \dot{v} \phi \varepsilon \sigma \theta \alpha \iota \mu \tilde{\alpha} \lambda\rangle \nu \nu \ddot{\eta} \tau \dot{\eta} \kappa \varepsilon \sigma \theta \alpha \mathrm{l}$. It seems far-fetched to assume that there is a subtle polemic against Hippocrates here (pace L. Senzasono, 2006, p. I63, n. 30; cf. also V. Andò, 2004, pp. I77-I78, n. 34 vs. R.M. Aguilar, I994, p. 42) [see 4.2.I.I., n. I00].

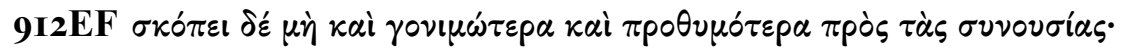

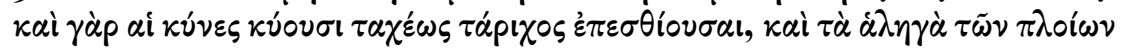

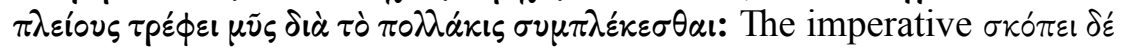
$\mu \eta$ may signal Plutarch's preference for this explanation, or that we are even dealing with Plutarch's personal contribution to the problem [see I.I.4., n. III]. In any case, it emphatically draws the reader's attention to what Plutarch is writing here. However, the same popular belief about bitches and mice is reported not by Plutarch but by Philinus (in the final explanation) in Quaest. conv. 685DE, in relation to the divine character of generation (earlier on in Quaest. conv. 685A Plutarch refers to the aphrodisiac properties of salt). Philinus argues that mice do not become pregnant simply by licking the salt, as some say, but that the salt probably stimulates copulation (as is argued here in Q.N.3). The same popular belief is also recorded in Arist., $\mathrm{HA}_{5} 8 \mathrm{0b} 3 \mathrm{I}$ and Pliny, $\mathrm{NH}$ I0, I85. Regarding the relation between salt and fertility in cattle, cf. also Arist., $H A 574 \mathrm{a} 8$.

\section{Q.N. 4, 9I2F-9I3A}

Q.N. 4 concerns a meteorological phenomenon that, especially by its focus on the effect of rainwater on seeds, ties in closely with the theme of Q.N. 
2. Plutarch wonders why rain that accompanies thunder and lightning is more fertilising for seeds. He adds that this kind of rain is called

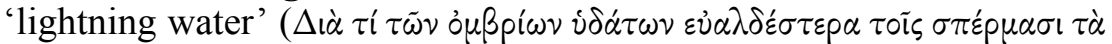

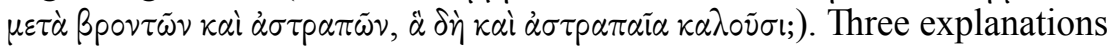
are given for this problem. The first one focuses on the mixture of rainwater with breath, the second on its concocted nature, and the third on its cooling effect. The influence of lightning and thunder on the increase in fertility is - especially in the final causa - considered an incidental aspect rather than the main cause of this phenomenon. As such, Plutarch does not aim to reject the popular belief about lightning water, but certainly puts it into a broader physical perspective in his aetiology [see 4.3.3.3.].

In the first explanation, Plutarch alludes to the breathlike constituent of lightning water. He argues that these rains become breathlike by the disturbance and admixture of air, and that the breath better transmits and

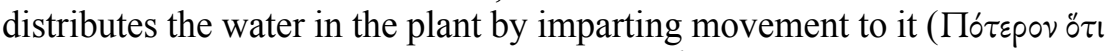

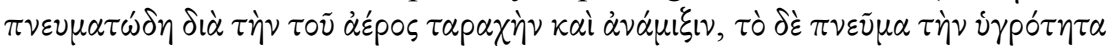

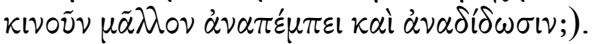

The process of concoction is central to the second causa, where Plutarch first explains how thunder and lightning are produced. This is

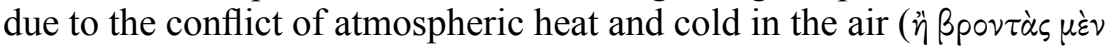

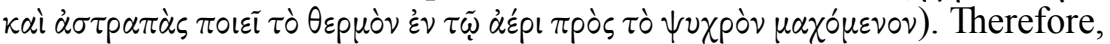
thunder occurs least in winter and most in spring and autumn, owing to the

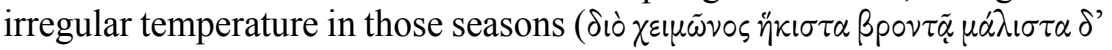

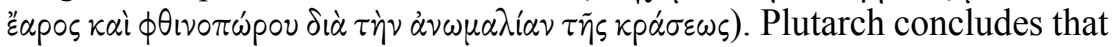
it is in fact the heat (of the lightning flashes) that concocts the moisture (c.q. rain) and makes it agreeable and useful for growing things ( $\dot{\eta} \delta \dot{\varepsilon}$

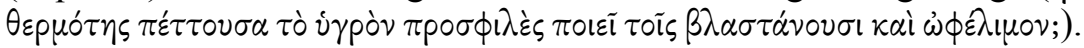

In the third and final explanation, Plutarch makes a subtle distinction by arguing that it is true that thunder and lightning especially occur in spring for the reason given (see the previous causa), but that spring rains are more essential to the seeds, because they come before the summerheat

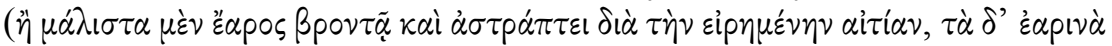

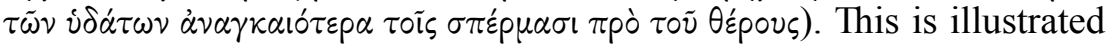
by the fact that the land that receives most rain in spring, like that in Sicily, yields crops that are abundant in quantity and good in quality ( $0 \varepsilon \varepsilon \nu$

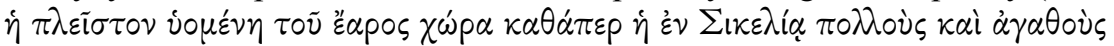

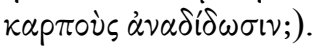

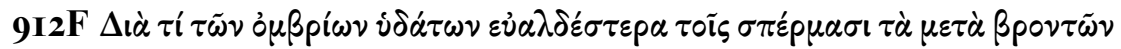

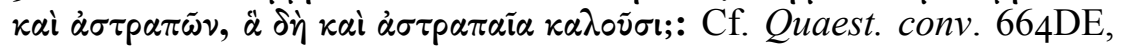
where the generative property of lightning water is mentioned among other $\delta 10 \sigma \eta i_{i} \alpha$ not unworthy of belief. We learn from that passage that the term $\varepsilon \dot{\nu} \alpha \lambda \delta \eta^{\prime}$ ('fertilising') is a farmer's word. Plutarch's explanation is 
very similar in the second causa here: he points out that the heat that is produced by the fire of lightning and that is mixed with the rain makes it fertile and enriches the soil (the idea that lightning, therefore, has a divine character is not repeated, though [see 3.I.4.]).

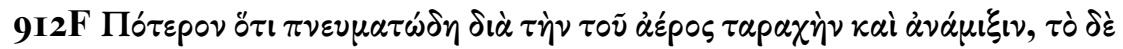

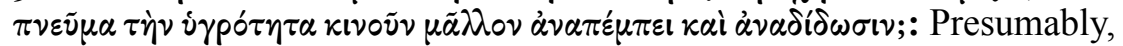
it is implied that lightning and thunder are accompanied by disturbance of the air in the sky, which in turn causes the rain's admixture with breath (for the breathlike and airy constituent of rainwater, cf. also Q.N. 2, 9I2AB).

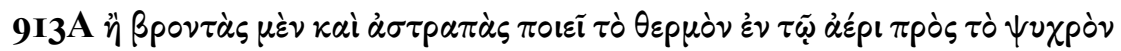

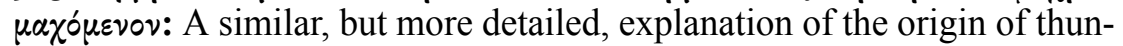
der and lightning, based on the opposite temperatures of the exhalations in the sky, is found in Arist., Mete. 369ai2-29.

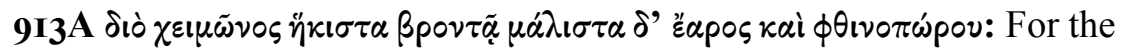
idea that thunderbolts occur most in spring and in autumn (for the reason previously given), cf. Lucr., De rer. nat. 6, 357-378. Cf. also Pliny, NH 2, I35-I36 and Arrian, Frag. Phys. 3, I90, 7-I2 Roos (= Stob., Flor. I, 29, 2). By contrast, according to Arist., fr. 245, 8, I5-I9 Rose, thunder occurs most often in the summer and in the winter. Cf. also Sen., $N Q 2$, 57, 2: lightning occurs more frequently in the summer. The reader may wonder why at this point in Plutarch's aetiology only the season of summer remains unmentioned. Presumably, there is not much conflict between atmospheric heat and cold in the hot summer to trigger lightning flashes (as is also the case in winter, which Plutarch does mention). The summer season will play an important role in the third causa, which may explain why it is not mentioned here.

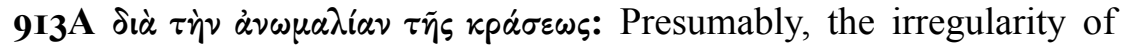
temperature refers back to the atmospheric conflict between hot and cold air. The seasons of spring and autumn are some kind of 'intermediary seasons', situated between those of winter (cold) and summer (hot), which explains their irregular temperature (cold and hot).

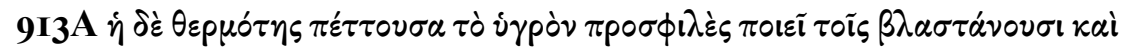

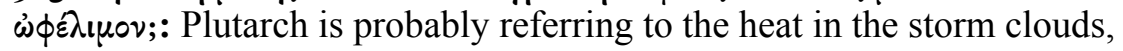
so caused by the lightning blazes (cf. Quaest. conv. 664DE). For the agreeableness of slightly warm moisture for the young crops, cf. fr. 68 Sandbach. Cf. also Quaest. conv. 676B (regarding hot soil).

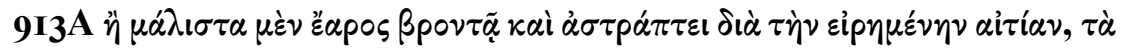
$\delta$ ' 
to F.H. Sandbach, 1965 , p. I62, n. b, the comparative $\dot{\alpha} \nu \alpha \gamma \kappa \alpha$ ió $\varepsilon \varepsilon p \alpha$ may indicate "that spring rain is more essential than winter rain" (he finds the Greek "awkward"; cf. also L. Senzasono, 2006, pp. I67-I68, n. 38, who supposes an ellipse of $\ddot{\eta} \tau \dot{\alpha} \chi \varepsilon \varepsilon \mu \varepsilon p \imath \nu \dot{\alpha}$ or $\tau \tilde{\omega} \nu \chi \varepsilon \varepsilon \mu \varepsilon p(\nu \tilde{\omega} \nu)$. His suggestion to emend it to mean "more essential than those which come just before the time of the harvest", however, is not very clear, nor plausible. The argument is probably more subtle. First of all, note that the adverb $\mu \alpha \dot{\lambda} 1 \sigma \tau \alpha$ ('especially') in the second causa (said of the occurrence of thunder in specific seasons) concerns both spring and autumn, whereas in the third causa, it only concerns spring. Indeed, autumn, does not come before

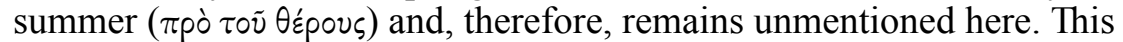
temporal specification is essential for a proper understanding of the causa at hand. I take the $\mu \varepsilon^{\prime} \nu[\ldots] \delta \dot{\varepsilon}$ construction to imply a disjunction between two (opposed) facts here, viz. thunder and lightning on the one hand and spring rain on the other. What Plutarch is probably implying, then, is that $\left(\mu \varepsilon^{\prime} \nu\right)$ thunder and lightning particularly occur in spring (for the reason given in causa two), but ( $\delta \hat{\varepsilon}$ ) that they have no actual effect on the growth of seeds, because the spring rains themselves are more essential ( $\alpha \nu \alpha \gamma \kappa \alpha$ เó $\varepsilon p \alpha)$ in that regard, that is, more essential than the effects of thunder and lightning, the reason being that they come before the summer. This last point, putting the emphasis on the temporal specification of spring

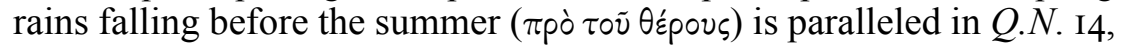
$915 \mathrm{D}$. There, Plutarch argues that spring rain is important for wheat and barley grains because it falls before the summer, soaking the earth, so that it protects the ears of the grain against the hot southerly winds (vó $\mu \varepsilon v o s \delta \dot{\varepsilon}$

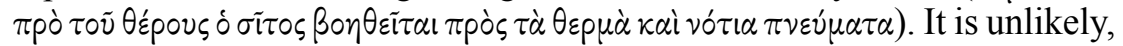
therefore, that Plutarch is referring to "some generative property of spring rains" here in Q.N. 3 (pace P.A. Clement and H.B. Hoffleit, I969, p. 32I, n. a). The reference is rather to the rain's cooling effect. With this final explanation, then, Plutarch does not, as such, aim to reject the popular belief about lightning water (as mentioned in the quaestio), but he certainly puts it in a broader physical perspective (compare the initial 'scepticism' of the symposiasts towards the belief that thunder generates truffles in Quaest. conv. 664B and Plutarch's subsequent reaction in 664DE [see 3.I.4.]).

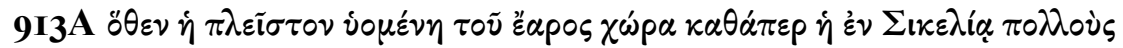

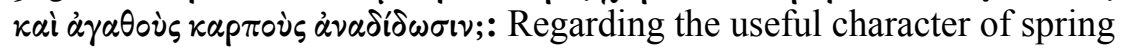
rains for plants, Plutarch in his commentary on Hes., Op. 486-489 (= fr. 68

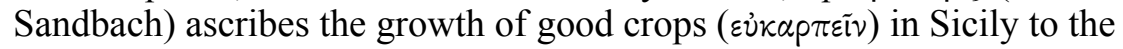
copious quantity of spring rains that the land receives ( $\dot{\alpha} \pi \dot{\partial} \tau o \tilde{v} \tau \dot{\eta} \nu \sum \ltimes \varepsilon \lambda i \alpha \nu$

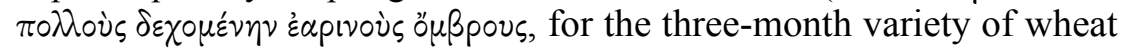
mentioned in this passage, cf. also Q.N. 15 , 915DE). Cf. also Theophr., $H P$

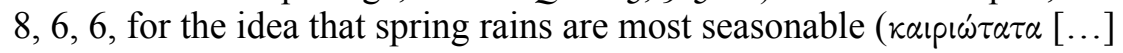




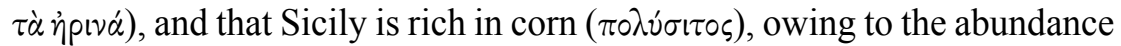
of soft rain in spring and the lack of it in winter (cf. also $C P 4,9,4-5$ and $H P 8,4,5)$. Notably, none of these parallel passages pay attention to the thunder and lightning that accompany the spring rains.

\section{Q.N. 5, 9I3AE}

In Q.N. 5, Plutarch deals with a problem concerning the generation of flavours $\left.(\chi v \mu)^{\prime}\right)$, with specific attention to the salty. He asks why we observe that only one of the eight generic flavours, namely the salty, is not produced by any fruit, whereas the others actually are

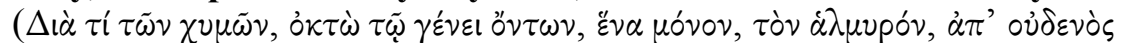

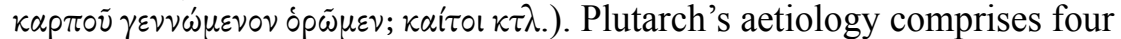
explanations in total. The first one holds that salt is not generated at all, the second that it is destroyed by the fruit's heat, the third that it cannot enter the plant's narrow pores, and the fourth that it is a kind of bitterness. Still in the quaestio Plutarch gives an account of the different types of generic flavours and their generation in several kinds of fruits.

Plutarch writes that at first, the olive produces the bitter flavour while the grape produces the acid. Afterwards, they change and become oily

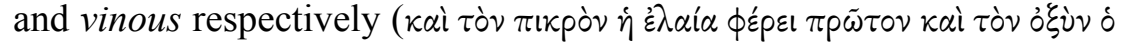

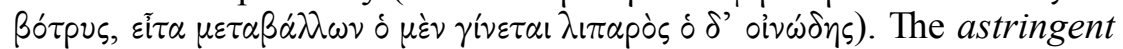
flavour in dates and the sour in pomegranates become sweet, although some pomegranates and apples only produce the acid; and, the pungent

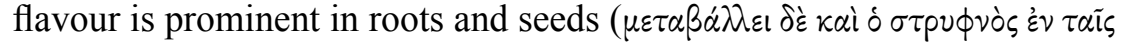

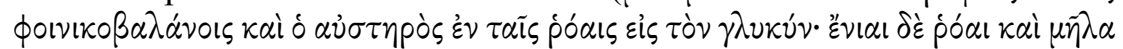

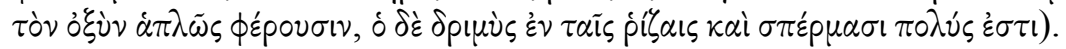

In the first explanation, Plutarch draws attention to the opposition between the processes of generation and corruption. He explains that the salty flavour is not generated by any fruit; in fact, it is not generated at all. On the contrary, it is a corruption of the other flavours (Пó $\tau \varepsilon p \circ v$ ojv ojk

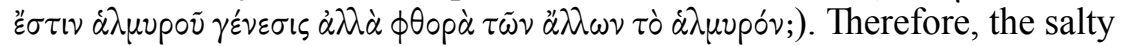
flavour is not nutritious for any animal that feeds on plants and seeds. For some, though, it acts as a relish by removing the satiety caused by their

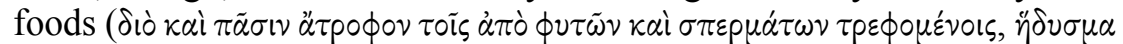

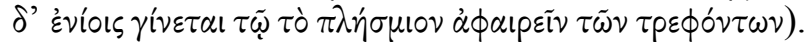

In the second explanation, Plutarch takes a step backwards by arguing that the salty flavour - initially present one way or another in fruits (as opposed to what was said in the quaestio) - loses its natural character by the action of heat, just like people remove the salty and pungent 
constituent from seawater by boiling it (

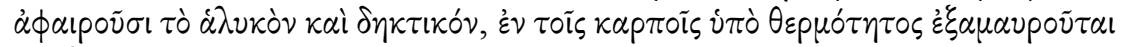
$\tau \dot{\alpha} \dot{\alpha} \lambda \mu v \rho o ́ v ;)$.

In the third explanation, Plutarch quotes Plato and argues that a flavour is basically water that has been strained through a plant ( $\ddot{x}$ xujos

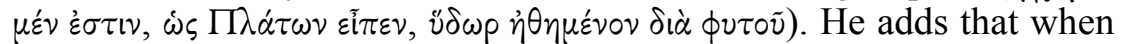
seawater is filtered, it also loses its saltiness, because this is earthy and

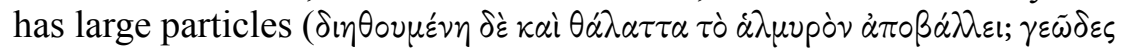

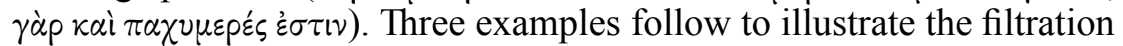
of seawater. I) Those who dig near the seashore find small drinkable

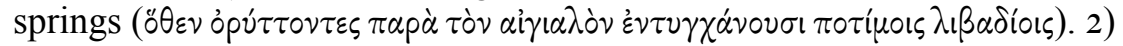
People also frequently draw up sweet filtered water from the sea in jars made of wax, because the salty and earthy constituent is separated from

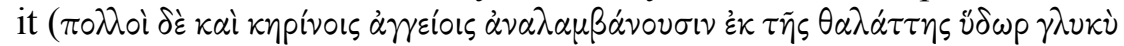

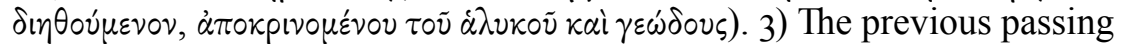
and filtering through white clay also renders the seawater completely drinkable, because the clay retains the earthy constituent and does not let

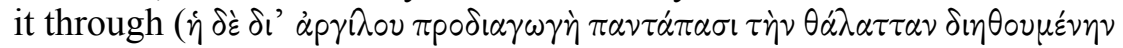

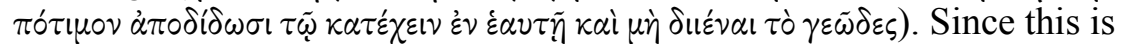
so, it is likely, according to Plutarch, that plants neither take up anything salty from their surroundings nor excrete any salty product into their fruit, should it be generated internally, because the pores, owing to their narrowness, do not strain through the earthy and large particles (oí $\tau \omega \varsigma \delta \dot{\varepsilon}$

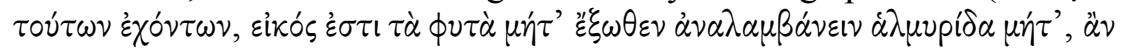

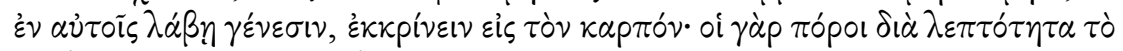

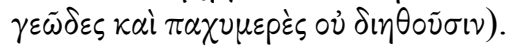

According to the fourth and final explanation, it could be posited that the salty flavour is a kind of bitterness, which Plutarch illustrates with the following Homeric lines: 'From his mouth he spat the bitter brine that

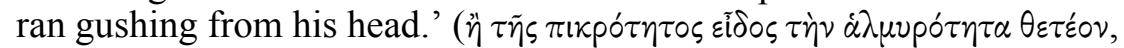

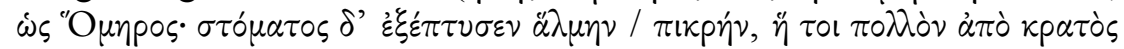
$\kappa \varepsilon \lambda \alpha$ pu $\zeta \varepsilon v)$. In what follows, Plutarch combines the authority of Homer with that of Plato, who also connects both flavours with each other. Plato says that they both cleanse and dissolve, though the salty does this to a

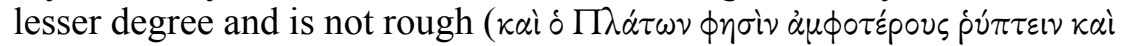

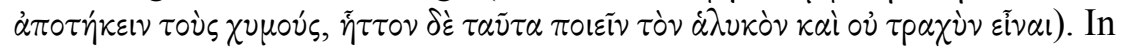
order to illustrate the last point (i.e. to specify the slight difference that Plato notes between the bitter and the salty), Plutarch adds that the bitter has a greater level of dryness, because the salty also has some drying

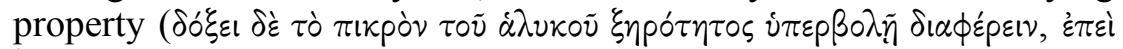

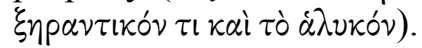

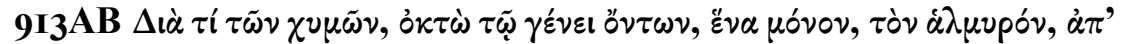

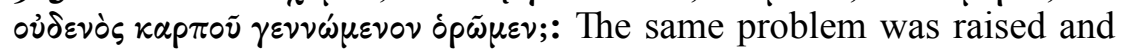


solved (see the following comments) by Theophrastus (CP 6, IO, I-2:

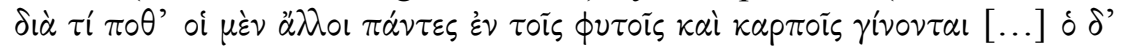

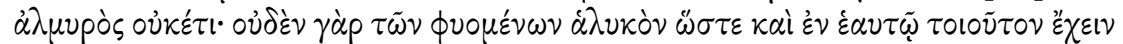

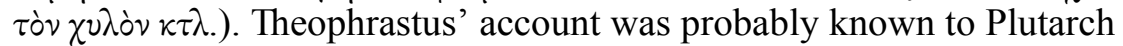
via a lost Ps.-Aristotelian problem (see already H. Diels, I905, pp. 3I53I6).

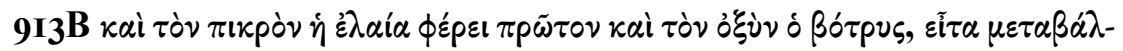

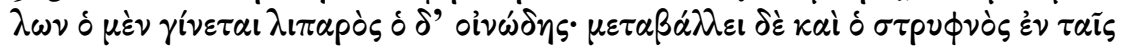

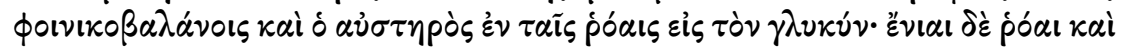

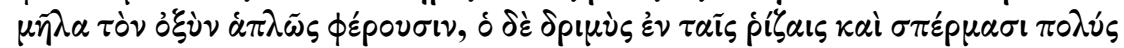
$\dot{\varepsilon} \sigma \tau \imath$ : While Plutarch maintains that there are eight different flavours, he sums up nine in total (also noticed by F.H. Sandbach, I965, p. I63, n. d). The confusion may originate from Theophrastus, who says that there are seven kinds of flavours (i $i \delta \varepsilon \dot{\alpha} \alpha \tau \tilde{\omega} \nu \chi \nu \mu \tilde{\omega} \nu$ ), on the condition that saltiness

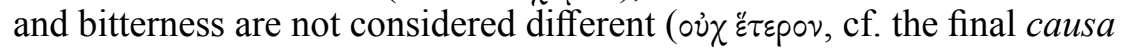
here in Q.N. 5); otherwise saltiness becomes the eighth flavour (see $C P 6$, 4, I; cf. also $C P$ 6, I, 2). After summing up the different kinds of flavours, Theophrastus concludes that some people would add the vinous - as does Plutarch here -, and rightly so, because this flavour has its own particular

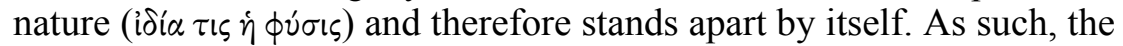
total number of flavours amounts to nine, not eight (or seven). According to L. Senzasono, 2006, p. I69, n. 4I (who believes that Plutarch makes no mistake at all), Plutarch is following Theophrastus in implicitly setting the vinous flavour apart from the others. If this is true - which I doubt -, one may wonder why Plutarch did not explicitly say so, as Theophrastus did. I take it that the fact that the vinous flavour is not mentioned separately from the other eight by Plutarch, precisely suggests that he considers it to be a generic flavour ( $\left.\tau \tilde{\omega} \gamma_{\gamma} \bar{\varepsilon} v \varepsilon\right)$ just as well. On the other hand, if there is one flavour that is clearly the odd one out, it is the salty one, because it is not generated in plants. To speak of a genuine miscalculation on Plutarch's side goes too far, since he really sees the salty as being distinct from the eight generic flavours. Plutarch's inaccuracy can perhaps be explained, then, by his untended writing (due to hypomnematic negligence [see 2.3.2.]). Alternatively, he perhaps wrote the intermediate part of the quaestio in view of his argument in the fourth causa, where the salty flavour is identified as a kind of bitterness. Whatever may be the case, this inaccuracy (if that is what it is) has no repercussions for the rest of Plutarch's argument. Theophrastus also concludes that the correct number of flavours would make no difference for the proper understanding of the rest of the subject; for him the number seven is 'most appropriate and

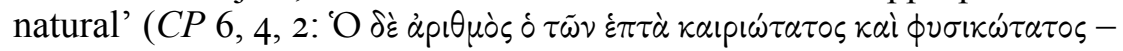
this expression may be based on Pythagorean numerology; cf. Alex. Aphr., Comm. in Ar. Met. 38, I6-20). 
Scholars have argued that Theophrastus' source for the number of flavours was probably Democritus (see already H. Diels, I905, pp. 3I23I6). In Theophrastus' doxography of Democritus' theory of the shapes of

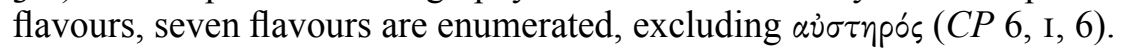
In a parallel passage (Sens. 65-67), he lists only six flavours, excluding

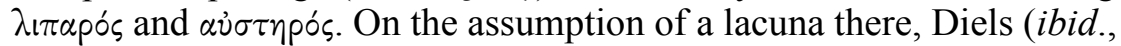
p. 3I4; cf. also I879, p. 5I8, I8) argues that Democritus' theory also originally proposed eight flavours, and he adds $\lambda ı \pi \alpha$ pós and $\alpha \dot{\sigma} \sigma \tau \eta \rho^{\prime} \varsigma$ (from $C P$ 6, 4, I), yet in his remark to Dem., DK68Ai35 (= Theophr., Sens., 67, 27), he notes that "[i]n den Hss. [...] nichts ausgefallen [ist]". There is also much speculation in the remark of L. Senzasono, 2006, pp. I69-I70, n. 4I that the Democritean origin of the eight flavours can be accepted for $C P$ 6 , 4, I on the assumption that Theophrastus - for whatever reason - left

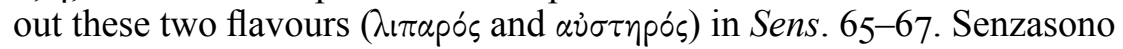
does not exclude the possibility, however, that Democritus' theory did embrace six flavours, but that Theophrastus added two more in $C P 6,4$, I.

There are also interesting accounts of the nature and number of the flavours in Aristotle and Plato (the latter is quoted by Plutarch in the third and fourth causae). Aristotle writes that there are seven flavours, excluding the vinous and identifying the salty and the bitter; he describes these flavours in terms of contraries and draws a link with the number of colours (see DA 422bio-I4 and De sensu 442aI7-2I). Plato lists seven flavours in Tim. 65b-66c, excluding the oily and the vinous; he believes that taste is brought about by certain contractions and dilatations of the surface of the tongue and that the flavours involve roughness and smoothness (cf. also Theophr., $C P$ 6, I, 4). Additionally, Pliny, $N H$ I5, I06 ff. records I3 genera saporum. For yet another account of the number of flavours, see Gal., SMT II, 450, I4ff. Kühn.

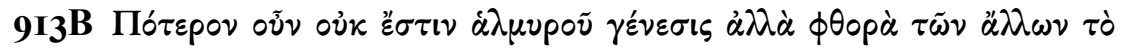
$\alpha \lambda \mu v p o ́ v ;:$ According to Theophrastus $(C P 6, \mathrm{IO}, \mathrm{I}-2)$, salt is neither

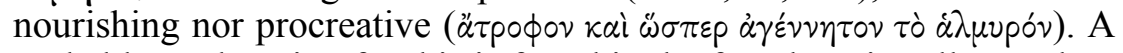
probable explanation for this is found in the fact that virtually no plant grows on salty land, because the salt would consume and take away

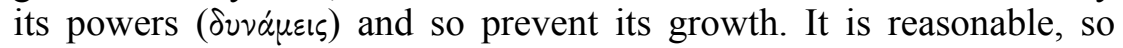
Theophrastus specifies, that what prevents other things from generating

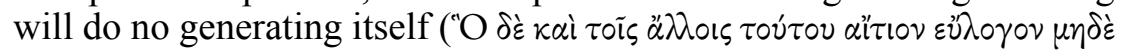
$\left.\kappa \alpha \theta^{\prime} \alpha i \tau \dot{\partial} \gamma \varepsilon v \nu \tilde{\alpha} \nu\right)$. He then refers to plants growing in the sea: they are not nourished by the salt, but by some sweet constituent and by other flavours in the seawater, as are fish and other sea animals (this is close to Plutarch's argument in Q.N. I, 9IID: see the commentary ad loc.). Importantly, unlike Plutarch, Theophrastus does not so much claim that salt is 'not generated' or 'unoriginated' (passive), but that it 'does not generate', 'is

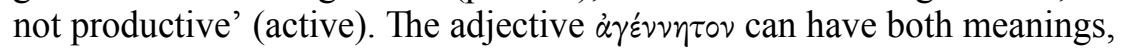


but Theophrastus clearly uses it in the second sense (cf. LSJ, s.v. iii: "not productive", with a reference to this particular passage in Theophrastus). If we may assume that Theophrastus is Plutarch's source, the adaptation to the new context, where the $\gamma^{\prime} \varepsilon \varepsilon \sigma \iota \varsigma$ - $\phi \theta \circ p \alpha$ opposition is central, may be intentional. If no adaptation had been made, that is, if Plutarch had followed Theophrastus in arguing that salt has no productive or generative property, this would be in direct contradiction with his arguments in Q.N. 3, 9I2EF and Quaest. conv. 685DE (which both concern the generative and aphrodisiac properties of salt). Moreover, by making this semantic shift, Plutarch is able to more closely connect the causa with the quaestio

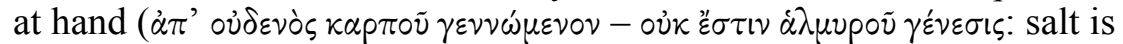
not generated in any fruit - a fortiori it is not generated at all). As to the idea that salt is a corruption of 'other things' ( $\phi \theta 0 p \dot{\alpha} \tau \tilde{\omega} \nu \alpha \partial \lambda \omega \nu)$, I take it that Plutarch means the other flavours - these are generated from the fruit and turn salty when corrupted. For the idea that generation of a thing can be caused by the corruption of something else (and vice versa), cf. Arist., GC 318b33-35 (cf. L. Senzasono, 2006, p. I7I, n. 43).

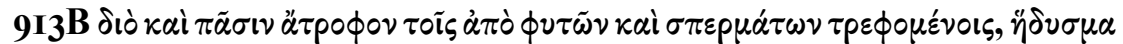

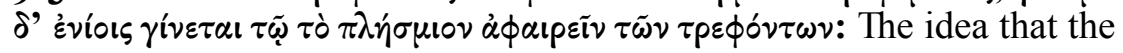
salty flavour is not nutritious for any animal that feeds on plants and seeds echoes the first causa of Q.N. I, 9IICD (where Plutarch argues that seawater is not nutritious for land animals). The second idea, that salt acts as a relish for some animals by removing the satiety caused by their foods, is presumably added to avoid contradiction (and thus to reinforce concatenatio) with the first causa of Q.N. 3, 9I2 $\mathrm{D}$ (where Plutarch argues that salt stimulates the appetite of animals by its pungency). Theophrastus $(C P 6,4,6)$ also says that salt functions as a $\ddot{\eta} \delta v \sigma \mu \alpha$, tempering the food for assimilation both in humans and in some animals (quoted in the commentary to Q.N. 3, 912D above).

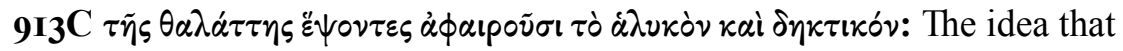
seawater becomes sweet by boiling (or more generally by heating) is paralleled in Arist., Mete. 358bi6-I8 (in the context of distillation). Cf. also Ps.-Arist., Probl. 933biı-I6, Cass. Iatrosoph., Probl. 65 and Geopon. 2, 47, II (the account of Hipp., Aer. 8, 6 is more general: the heat of the sun produces coction and, thus, sweetens the rainwater, and in addition all other boiled liquids always become sweet as well). According to F.H. Sandbach, I965, p. I64, n. a, this extraordinary idea "[p]erhaps [...] arose from a misunderstanding of some account of distillation". He refers to M. Glycas,

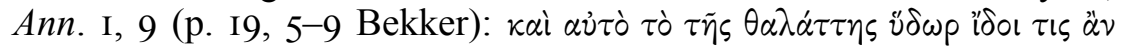

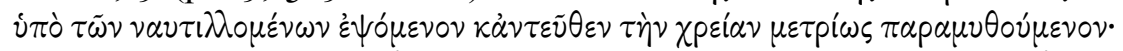

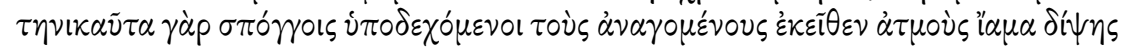

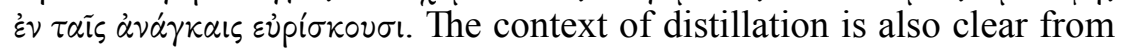


Arist., Mete. 358bi8-20, where we read that wine can be evaporated and afterwards condensed into water (on Aristotle's experiments in this passage, see G.E.R. Lloyd, I99I, pp. 90-9I and L. Taub, 2003, pp. IO2-I03).

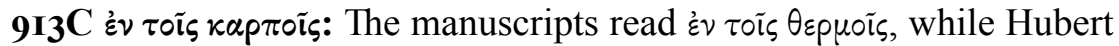
suggests $\theta$ epriols (which implies basically the same), and Sandbach conjectures kapтoĩs (cf. also V. Ramón Palerm, 2005, pp. 398-399). L. Senzasono, 2006, pp. I7I-I72, n. 44 follows the reading of the manuscripts against Sandbach's conjecture, but his stylistic argument is not convincing (I am doubtful about the alleged elegance of the phrase

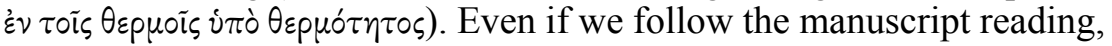

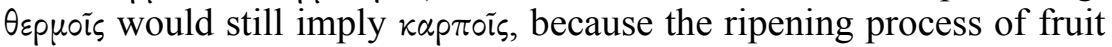
(which involves heat; see the following comment) is probably the issue here.

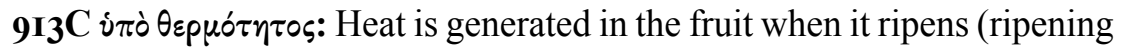
being a process of concoction), so that any salty constituent that may be a part of the fruit's nourishment is destroyed by it (cf. F.H. Sandbach, $\mathrm{I} 965$, p. I64, n. a). A parallel process is described in Q.N. $20,917 \mathrm{~A}$, where Plutarch argues that the salty tears of wild boars become sweet by the heat of their fiery temper. For the idea that the sweetness of a plant (c.q. the fig tree) is concentrated in the fruit, leaving the rest of the plant bitter and unmixed (without reference to a ripening process, though), cf. Quaest.

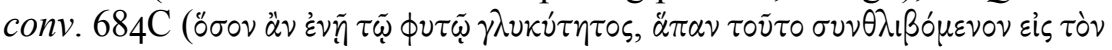

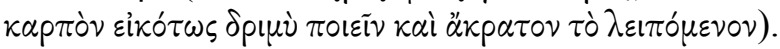

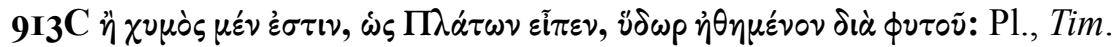
$59 \mathrm{e}$. For the relation between the flavour of a plant and the moisture that permeates its shoots, cf. Quaest. conv. 664E.

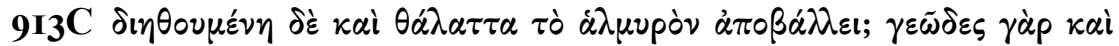

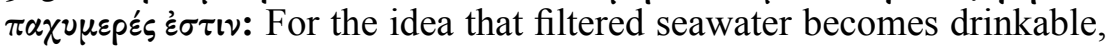

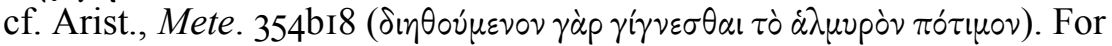
the earthy matter in seawater, cf., e.g., Q.N. I, 9IID, 8, 9I4B and Quaest.

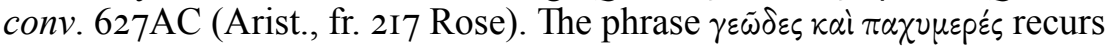
at the end of the explanation.

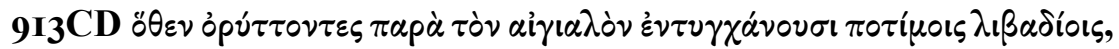

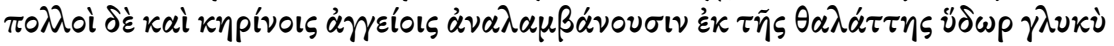

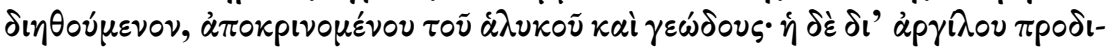

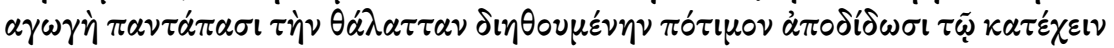

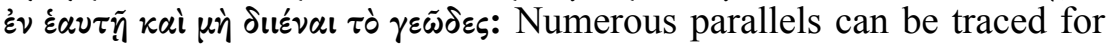
these three experiments. For the first (about digging near the seashore), cf. Ps.-Arist., Probl. 935b3-I7 and 933b33-4I (also bi7-20), Ps.-Arist./Alex. 
Aphr., Suppl. probl. 2, 34 (with S. Kapetanaki and R.W. Sharples, 2006, p. I37, n. 255), Ps.-Alex. Aphr., Probl. I, 55 (J.L. Ideler, I84I, p. I9, 22-3I), Pliny, $N H$ 2, 224, Sen., $N Q$ 3, 5, Lucr., De rer. nat. 2, 474; 5, 269 ff. and 6, $635 \mathrm{ff}$. For the second (about the wax jar [see 4.3.2.3., n. 246]), cf. Arist., Mete. 358b34-359a5 (with Olympiod., Comm in Ar. Mete. I58, 27 ff.), HA 590a22-27, GA 743a8-II, Ael., $N A$ 9, 64, Pliny, $N H$ 3I, 70. For the third (about white clay), cf. Pliny, $N H$ 3I, 70 (and 48). The noun $\pi p o \delta 1 \alpha \gamma \omega \gamma \eta$ is a hapax (cf. LSJ, s.v.: "previous passing through" with a reference to the passage at hand).

As to the experiment with the wax jar, F.H. Sandbach, I982, p. 227 argues that Plutarch possibly relies on Arist., Mete. 358b34-359a5, but that the intermediation of a lost Ps.-Aristotelian problem cannot be excluded. Arguably, in the latter case, Plutarch perhaps also relies on this intermediating problem for the other two experiments (these are not mentioned in Aristotle's Meteorology). Cf. H. Diels, I905, pp. 3IO-3I6, esp. pp. 3I5-3I6, who argues that all three experiments were given currency by Democritus, but that Democritus was hardly read in the time of the Early Empire, so that Plutarch probably became acquainted with them via a lost collection of Ps.-Aristotelian Problems. This collection, so Diels argues, contained a large amount of Democritea (Democritus was, indeed, the first to compose a collection of problems, as we saw [I.I.3., n. 58]) and Theophrastea (viz. material from Theophrastus' smaller doxographical natural scientific treatises, such as the lost De aquis: cf. D.L., 5, 45). Interestingly, in regards to the belief that fish are nourished by the sweet water mixed with salt water in the sea (see the commentary to Q.N. I, 9IID), Aelian quotes Democritus, Theophrastus and Aristotle together; yet, for the experiment with the wax jar he only calls in the authority of the son of Nicomachus, that is, Aristotle (NA 9, 64).

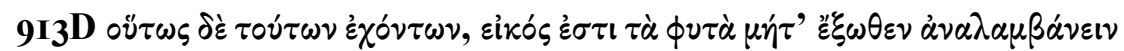

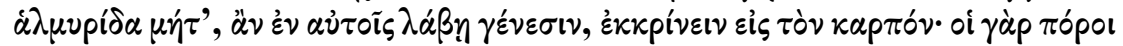

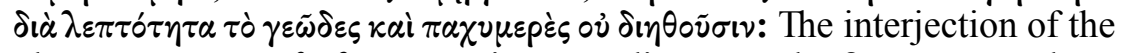

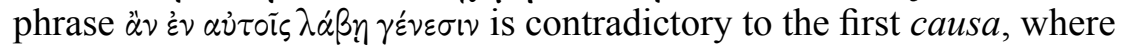

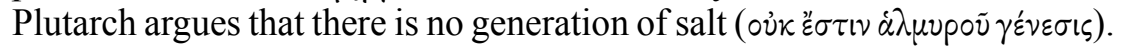
Clearly then, the element of zixós is what really matters here, suggesting that all possibilities remain open from an epistemological perspective [see 4.3.3.I.]. For the idea that the earthy and heavy quality of salt makes it impossible for seawater to enter into the roots of the plant, cf. also Q.N. I, 9IID.

913D

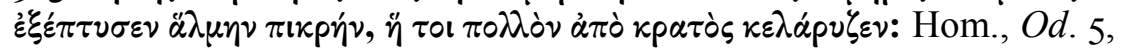
322-323. For the identification of the salty and the bitter, cf. also, e.g., Arist., De sensu 442 aI7 and Theophr., CP 6, 4, I. 


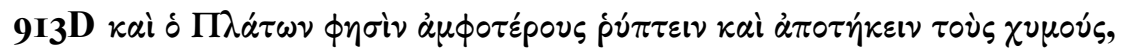

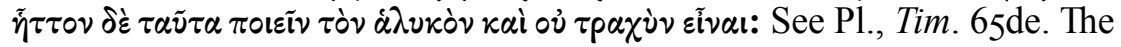
idea that salt has a dissolving property ( $\dot{\alpha} \pi \circ \tau \dot{\eta} \kappa \varepsilon \varepsilon v)$ is paralleled in Q.N.

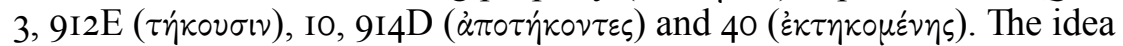

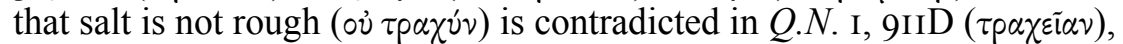
albeit in a different context.

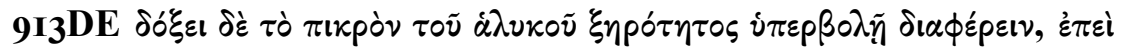

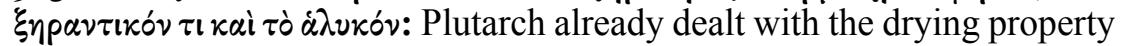
of salt (in seawater) earlier in Q.N. I, 9IID, and this point does not seem to require further detail here. Indeed, Plutarch does not further specify the greater level of dryness in the bitter flavour vis-à-vis the salty, perhaps because it is only added in order to illustrate the difference that Plato mentions (viz. that the salty flavour cleanses and dissolves less than the bitter). Thus, it supports the claim that salt is a species ( $\varepsilon \tilde{i} \delta \circ \varsigma$ ) of bitterness, showing that these flavours are not simply identical.

\section{Q.N. 6, 913EF}

Q.N. 6 does not fit in as well with the previous and the following problems that constitute the first thematic cluster of questions about salt and seawater (thus, we are dealing here with a case of thematic variatio). The focus returns to the central theme in the following problems of Q.N. 7-I3. In Q.N. 6, by contrast, no mention is made of salt or seawater, but the problem is still generally concerned with hydrology (c.q. water in the form of dew), and Plutarch agains quotes Laetus here, in the first causa, as he did in Q.N. 2, 9IIF. Plutarch wonders why persons (probably hunters) who frequently walk through bushes wet with dew contract 'leprosy' on those body parts that come into contact with the brushwood $(\Delta i \dot{\alpha} \tau i$

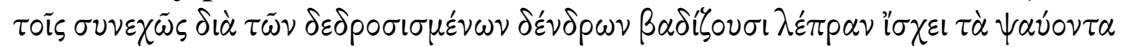
$\tau \tilde{\eta} s \tilde{\nu} \lambda \eta s \mu o ́ p ı \alpha \tau o \tilde{v} \sigma \dot{\omega} \mu \alpha \tau \circ$;). The theme of dew will return in the cluster of problems on hunting in Q.N. 23-25. A similar context can be presumed for the problem at hand, then. Two explanations are given for the detrimental effects of dew on the skin. The first focuses on the fineness of dew, the second on its erosive property. As opposed to the first causa, the second includes the role of the plants in the explanation, suggesting that dew damages the skin indirectly.

The first explanation remains very concise and is attributed to Laetus, who said that the dewy moisture scrapes off the skin by means of its

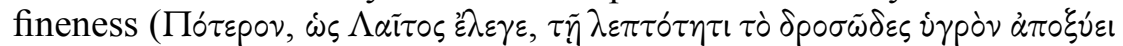
$\tau \circ \tilde{\nu}$ $\left.p \omega \tau \tau^{\prime} s\right)$. This is not further explained but implies that the dew harms the skin directly. 
In the second explanation, Plutarch further examines the harmful effects of dew, viz. its erosive property. As opposed to Laetus, Plutarch does not, however, connect this erosive property directly to the damage done to the skin, but examines more closely the role of plants in the phenomenon (as mentioned in the quaestio). By analogy with the rust that forms in wet seeds, Plutarch argues that some kind of dust is discharged from objects (c.q. from plants) that are tender and soft on the surface, but become rough and dissolved by the dew. This dust causes (contagious) harm (

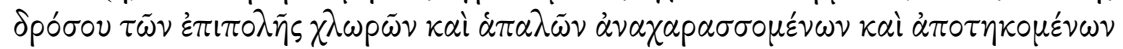

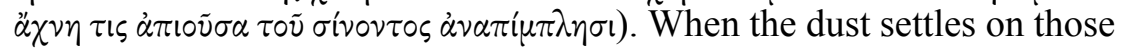
parts of the flesh that are the most bloodless, such as the lower legs and the feet (of hunters), it scratches and eats away at the surface of the skin

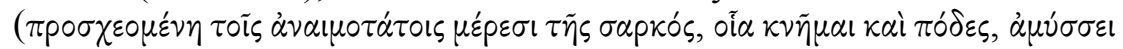

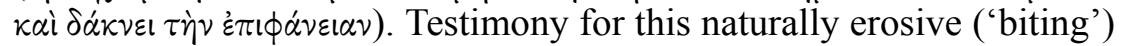
property of dew is found in the fact that it makes people who imbibe it thinner. In any case, so Plutarch says, fat women imagine that they can dissolve their excess fat by soaking up dew on cloths or soft flocks of wool

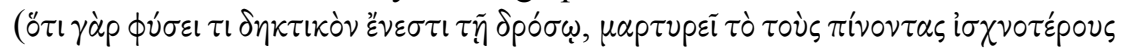

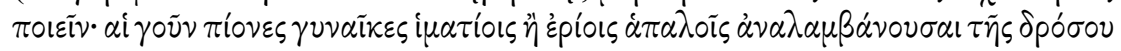

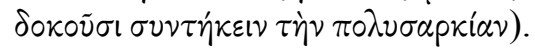

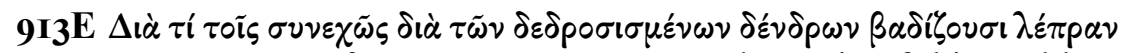

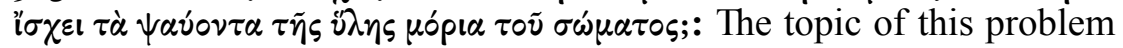
falls under the general theme of 'sympathy' (in the medical sense of 'contagions'), as treated in Book 7 of Ps.-Aristotle's Problems: ö $\sigma \alpha \dot{\varepsilon} \kappa \sigma \nu \mu \pi \alpha \theta \varepsilon i \alpha \varsigma$ (see R. Mayhew, 20IIa, pp. 228-229). On infectious diseases, cf. esp. Ps-Arist., Probl. 886b4-9 and 887a22-40. According to G.W.M. Harrison, 200ob, p. 244, "[t] he picture is of people walking through low plants shedding dew and the vocabulary fairly frolics with bouncy light syllables and assonance, particularly nouns formed in composition with $\alpha \nu \alpha$ - [three times], which is quite a feat given Plutarch's well known aversion to hiatus". There is great deal of sensitivity in Harrison's phonetic analysis, but there is only one (minor) case of hiatus in the aetiology: viz. in $\ddot{\eta}$ Epiors.

9I3E $\lambda \dot{\varepsilon} \pi p \alpha v$ : The $\lambda \dot{\varepsilon} \pi p \alpha$ in question is not the same as modern-day leprosy, but is, rather, some kind of scabby skin disease. Cf. F.H. Sandbach, 1965, p. I67: "scabbiness"; P.A. Clement and H.B. Hoffleit, I969, p. 359, n. a: "any scaly condition, cf. psoriasis". According to L. Senzasono, 2006 , p. I76, n. 53, the term is used in its Hippocratic meaning ("la scabbia, la psoriasi e l'eczema"). Senzasono identifies modern leprosy with $\dot{\varepsilon} \lambda \varepsilon \phi \alpha \nu \tau i \alpha \sigma ı$ (cf. Quaest. conv. 73IA, with S.-T. Teodorsson, I996, pp. 259-260), but $\lambda \varepsilon v ́ k \eta$ is more plausible (cf., e.g., Hipp., Prorrh. 2, 43). 


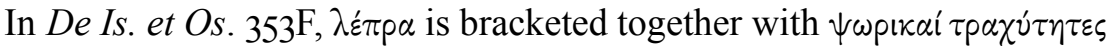

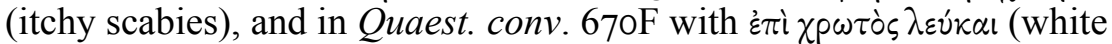
scale) and $\psi \omega \rho$ pı́ $\dot{\xi} \xi \alpha \nu \theta \dot{\eta} \mu \alpha \tau \alpha$ (scaly eruptions). For the belief that dew causes scabies, cf. also Pliny, $N H$ I7, 225; 3I, 33 and Seneca, $N Q$ 3, 25, II.

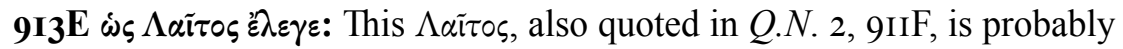
to be identified with the Platonist Ofellius Laetus [see 4.2.I.I., n. II5].

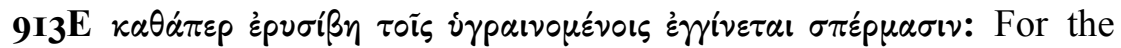
harmful effect of rust $\left(\varepsilon \rho \varepsilon^{\prime}(\beta \eta)\right.$ produced by moisture on seeds and plants, cf. Theophr., $C P$ 3, 22, I-2 and 4, I4, 3 (where it is treated as some kind of

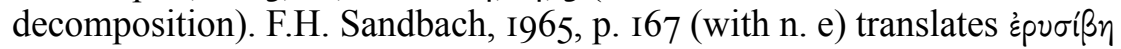
as mildew (with reference to Pliny, $N H$ I8, 9I and 275, who mentions robigo). Mildew is "a growth (typically a whitish and fluffy coating) of fungal mycelium and fructifications on the surface of a plant; plant disease characterized by this type of growth" (OED, s.v.). He notes that mildew implies honey-dew, that is, "a sweet sticky substance found on the leaves and stems of trees and plants [...] formerly imagined to be in origin akin to dew" (OED, s.v.). In addition, there is note of a rare disease called mildew-gangrene or mildew-mortification produced by diseased grain,

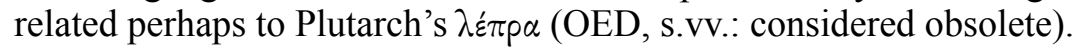

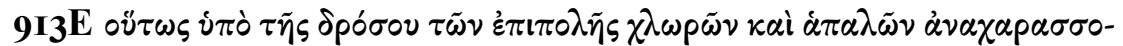

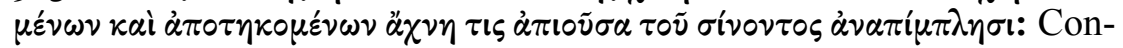
versely, for the beneficial effect of copper-ore dust ( $\alpha$ $\chi \nu \eta)$ on the eyes of miners, cf. Quaest. conv. 659C.

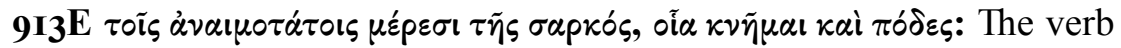

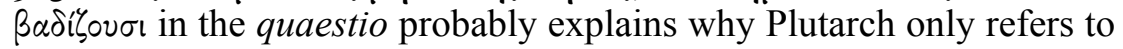
the lower legs and the feet. One may wonder, therefore, whether the dust is only harmful for these 'most bloodless' body parts, and not also, for instance, for the hands, arms, chest and face (perhaps these remain unmentioned because they are not 'most bloodless'; but what the bloodlessness of body parts has to do with the argument remains unspecified, though).

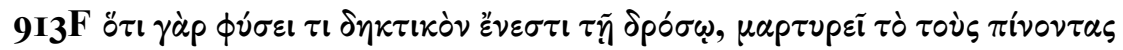

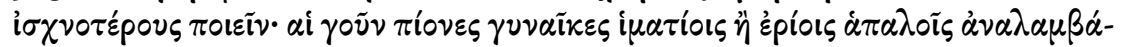

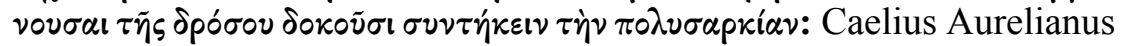
reports, in the context of losing weight ( $\left.\pi \circ \lambda \nu \sigma \alpha \rho \alpha^{\prime} \alpha\right)$, that physicians recommend imbibing the air moistened by nocturnal dew before sunrise (Tard. pass. 5, I39: nocturni roris auram ante solis ortum bibendam). Many thanks are due to C. Laes for drawing my attention to this passage. I could find no clear source for the popular belief about overweight women 
soaking up dew on their garments in order to dissolve excess fat. Plutarch may be reliant, therefore, on popular hearsay or (indirectly) on a gynaecological treatise (perhaps from the kind of Soranus' Gynaecia or the Hippocratic gynaecological writings). The belief that pregnant women eat both stones and dirt (as recorded in Q.N. 26, 9I8D: see the commentary ad loc.) may originate from the same source.

\section{Q.N. 7, 913F-9I4B}

In Q.N. 7, Plutarch returns to the thematic line of the first section of questions concerning salt and seawater. He examines why boats travel more slowly on rivers during the winter, while this is not even nearly

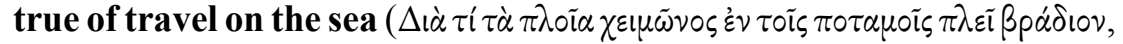

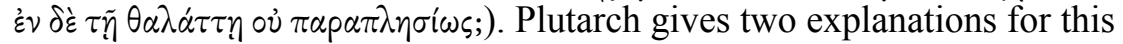
paradox, first attributing the cause to the heavy river air, and afterwards to the cold river water itself.

According to the first explanation the river air is an obstacle to shippers. It is always slow-moving and heavy, so Plutarch explains, and is further

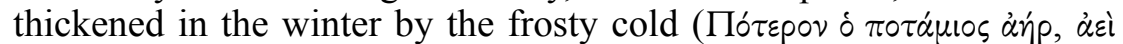

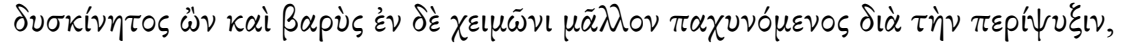

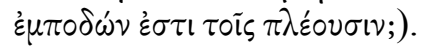

In the second explanation, the thickening of the river water itself,

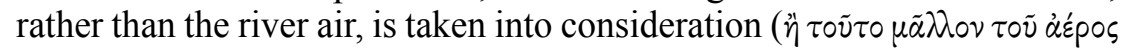
$\pi \dot{\alpha} \sigma \chi 0 v \sigma \nu$ oi $\left.\pi \circ \tau \alpha \mu o_{i}^{\prime} ;\right)$. Plutarch explains that the winter cold compresses

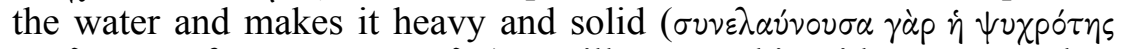

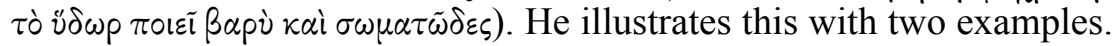
The same phenomenon can be observed in the clepsydrae, which draw

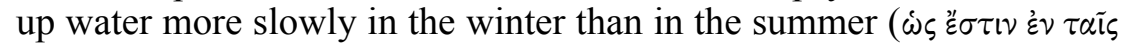

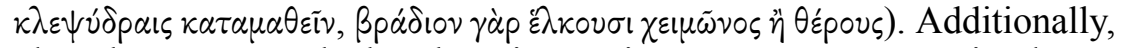
Theophrastus records that there is a spring on Mt. Pangaeum in Thrace from which the same amount of water in a full vessel, when put on the scales, weighs twice as much in the winter as in the summer ( $\dot{\varepsilon} \nu \delta \dot{\varepsilon} \Theta \rho \alpha \alpha$ $x$

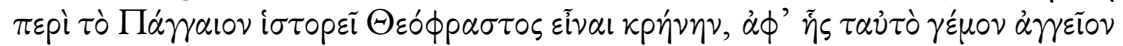

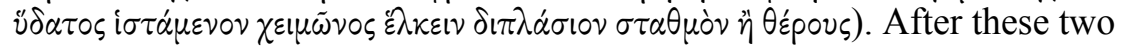
examples, Plutarch returns to the main argument and notes that the density of the water causes the ship's slow passage, which is obvious from the fact that river-ships can carry more cargo in the winter, as the water becomes

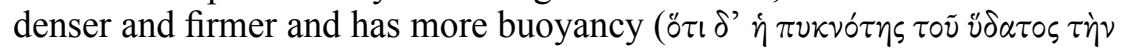

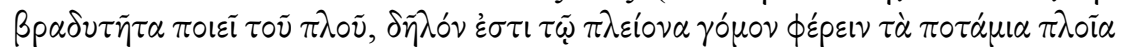

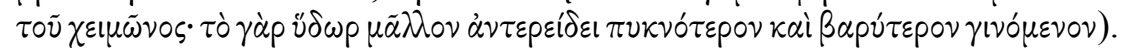
The sea, by contrast, is prevented from growing solid by its heat, and this 
explains why it does not freeze, since stiffening seems to be a process of

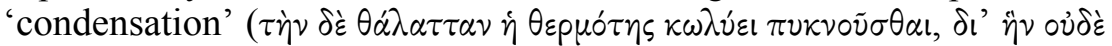

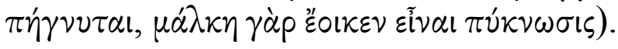

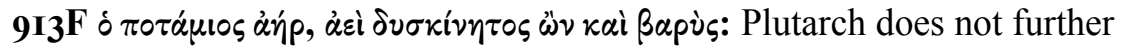
specify why river air is always slow-moving and heavy. Perhaps it is implicitly contrasted with the windy weather on the open sea, for instance, during storms (these do not occur on rivers).

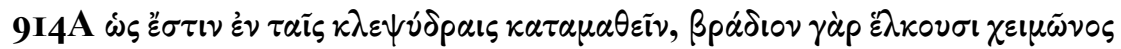

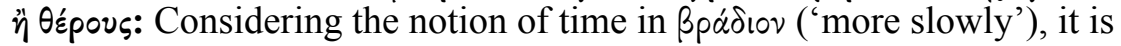

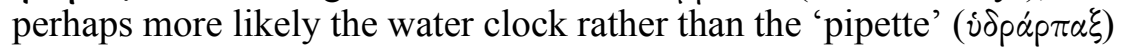
that is meant with $\kappa \lambda \varepsilon \psi v i \delta \rho \alpha$ here (cf. the following comment; pace F.H. Sandbach, I965, pp. I68-I69, n. a). The water clock was used in law-courts to measure the litigants' speaking time. It was also used for making other measurements: e.g., military (cf. Aen. Tact., 22, 24) or astronomical (cf. Procl., Hyp. 4, 74). For images, see M. Lewis, 2000, pp. 36I-369.

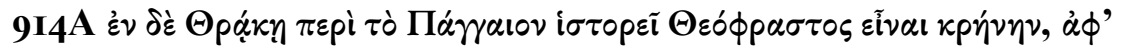

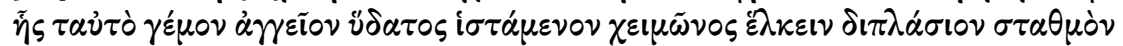

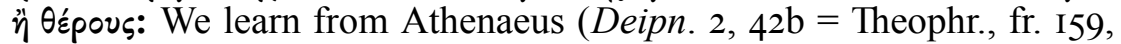
I5-2I Wimmer $=2 \mathrm{I} 4 \mathrm{~A}, \mathrm{I} 3-\mathrm{I} 7$ FHSG) that this account (= Theophr., fr. I6I Wimmer $=2 \mathrm{I} 4 \mathrm{C}$ FHSG) originates from Theophrastus' lost De aquis (cf. D.L., 5, 45), and that Plutarch simplifies the weight ratio, which is recorded in a more precise way by Athenaeus (viz. 96 to 46). Interestingly, the same fragment also mentions the $\gamma \nu \omega \mu \omega \nu$ in the-exceptional-meaning

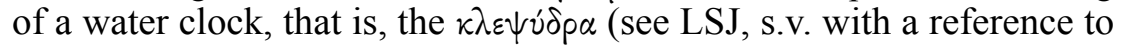
Theophrastus' fragment; cf. the previous comment). It is reported that the water that flows in these water clocks does not measure the hours correctly in the winter, but runs too long, which is attributed to the slower outflow

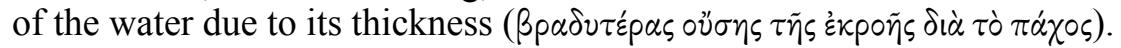
It is not unlikely that Plutarch here (and presumably also in the previous

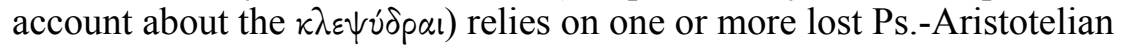
problems based on the passage in Theophrastus' De aquis.

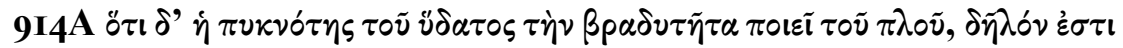

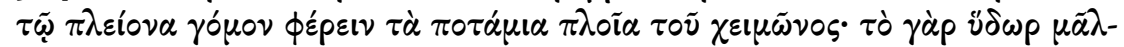

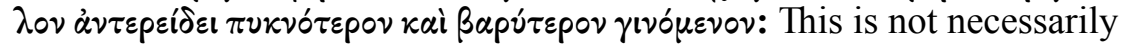
incompatible with the idea from Q.N. I, 9IID that seawater supports ships better $(\mu \tilde{\alpha} \lambda$ 시) than fresh water does, owing to its earthy constituent.

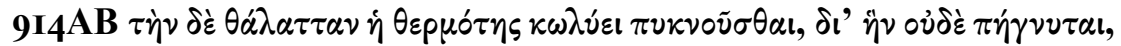

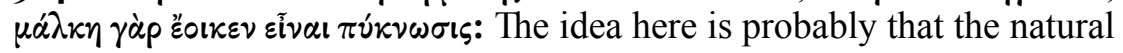


heat of seawater (present in the salt) causes liquefaction, so that no solidification or 'condensation' can occur in it during the winter by freezing cold (cf. Q.N. 8, 9I4B: $\mu \grave{\eta} \pi \dot{\eta} \gamma \nu v \sigma \theta \alpha$ ). For similar effects of winter cold on sea and riverwater, cf. Pliny, $\mathrm{NH}_{2}, 234$ (seawater freezes more slowly and boils more quickly) and 3I, 56 (riverwater becomes heavier after the winter solstice). F.H. Sandbach, I965, p. I70, n. a is probably correct that the term $\mu \dot{\alpha} \lambda \kappa \eta$ implies an analogy between the body growing numb with cold and the freezing of water (cf. LSJ, s.v., with a reference to this passage; pace L. Senzasono, 2006, p. I77, n. 59).

\section{Q.N. 8, 914B}

From a thematic perspective Q.N. 8 is closely connected with the previous problem, especially by its focus on the inability of seawater to freeze (this theory recurs at the end of the aetiology). Plutarch wonders why we see that the sea grows warmer when it is agitated, whereas all other liquids become colder when moved and disturbed $(\Delta i \dot{\alpha} \tau \dot{i}, \tau \tilde{\omega} \nu \dot{\alpha} \lambda \hat{\lambda \omega \nu}$

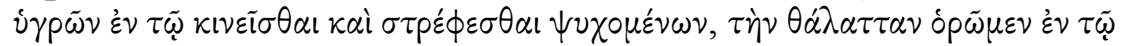

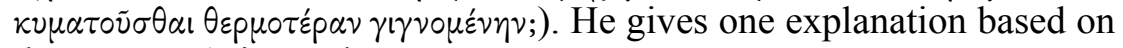
the seawater's innate heat.

Plutarch argues that motion dispels and dissipates the heat from other liquids, where it is an incidental and alien intrusion. But in seawater, to which it is innate, heat it is fanned and fed by the winds more and more

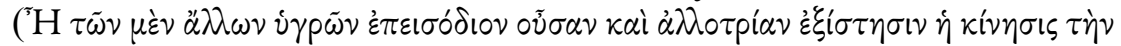

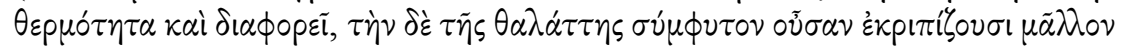

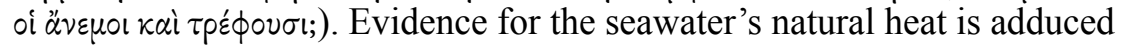
from the facts that seawater is transparent and that it does not freeze,

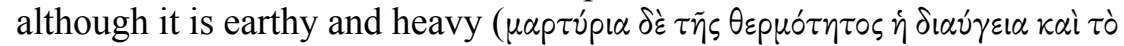

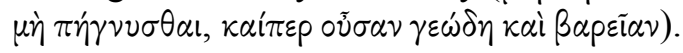

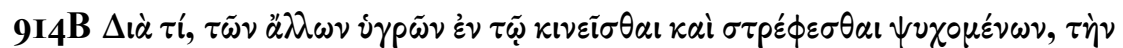

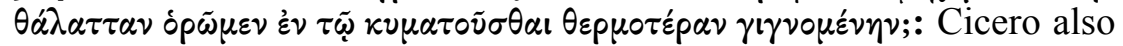
notes that the sea becomes warm when violently stirred by the wind ( $D e$ nat. deor. 2, 26). In Q.N. I8, 9I6B, however, Plutarch says that the calamary leaps out of the sea in an attempt to escape the cold and the disturbance

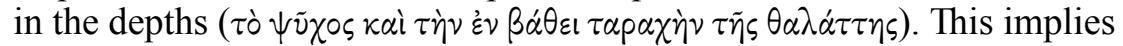
that movement and cold can still occur together in the sea.

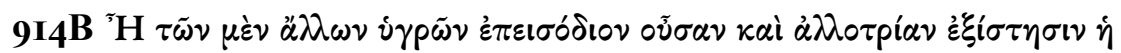

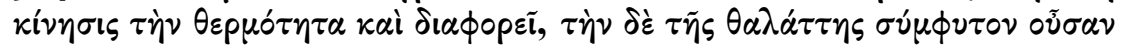

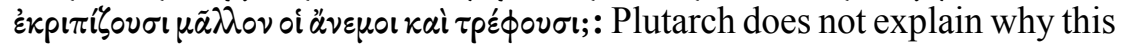


movement exactly increases the heat of the seawater (cf. also L. Senzasono, 2006 , p. 29). One may wonder if this is perhaps due to the friction of the earthy particles in it $(\gamma \varepsilon \omega \delta \eta)$. For the (Stoic?) opposition between the attributes of $\sigma \dot{\mu} \mu \phi \nu \tau o \nu$ and $\dot{\pi} \varepsilon เ \sigma o ́ \delta เ o v$, cf. also, e.g., De virt. mor. $45 \mathrm{IC}$ and De comm. not. I070C (cf. also De Stoic. rep. I04IE).

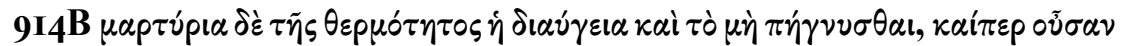
$\gamma \varepsilon \omega \delta \delta \eta$ каi $\beta \alpha \rho \varepsilon \tilde{\alpha} \alpha \nu$ : Plutarch does not further specify I) that seawater is transparent and 2) that it does not freeze, nor 3) how this relates to it being earthy and heavy. The following points, however, can be added. I) Seawater is considered to be transparent, because it contains light and, by implication, fire and heat (cf. Q.N. I2, 9I5A and 39). According to Ps.-Arist., Probl. 932b8-I6 and 935bi7-27, seawater is even more transparent than fresh water (cf. F.H. Sandbach, I965, p. I7I, n. c). 2) The

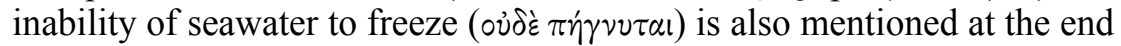
of Q.N. 7, 9I4B, in relation to its inability to solidify ( $\dot{\eta} \theta \varepsilon p \mu o ́ \tau \eta \varsigma \kappa \omega \lambda v^{2} \varepsilon \iota$ $\pi v \kappa \nu \circ \tilde{v} \sigma \theta \alpha l$ ). This process of solidification (or 'condensation': $\left.\pi v v^{\prime} \nu \omega \sigma \iota \varsigma\right)$ is more likely to occur in liquids that contain a large amount of solid matter (cf. F.H. Sandbach, I965, p. I7I, n. d). 3) The fact that sea water is earthy and heavy ( $\gamma \varepsilon \omega \delta \eta \kappa \alpha i \beta \alpha \rho \varepsilon \alpha \nu$, cf. also Q.N. I, 9IID) but at the same time transparent and unable to freeze may seem strange in this logic, but not for Plutarch. For him, it a fortiori underpins the underlying idea that the effects of the innate heat outdo those of the earthy and heavy constituents in seawater. Just like fire, the innate heat gives light (c.q. transparency) and heat (c.q. inability to freeze) to seawater.

\section{Q.N. 9, 9I4BD}

In Q.N. 9, we find yet another problem concerned with seawater and how it is perceived by our senses, viz. why the sea becomes less bitter

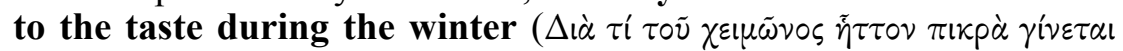
$\gamma \varepsilon \cup \circ \mu \varepsilon$ voเs $\dot{\eta} \theta \alpha \dot{\lambda} \alpha \tau \tau \alpha$;). Plutarch notes that people say that this phenomenon

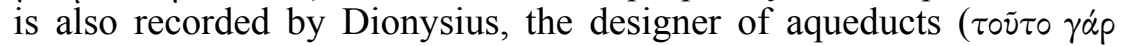

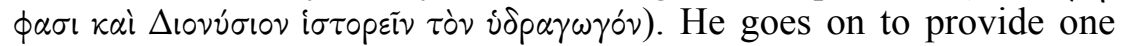
extensive explanation, in which he relates the taste of seawater to seasonal temperatures.

Plutarch argues that the sea's bitterness is not entirely destitute or devoid

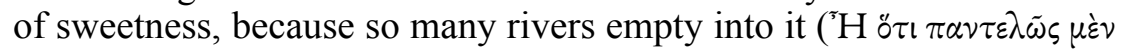

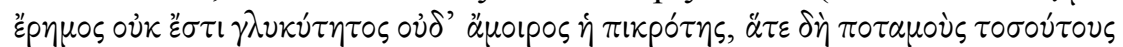

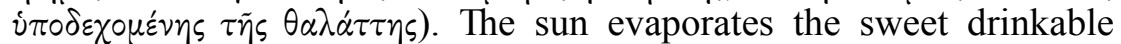

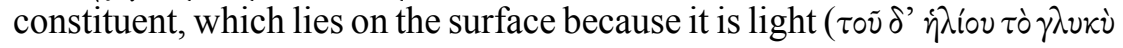




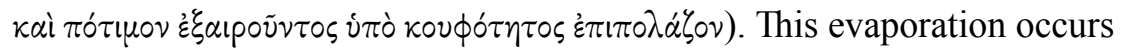
more in the summer, because the winter sun has a gentler effect, due to the weakness of its heat. As such, a large amount of sweetness is left behind (in winter) that dilutes the purely bitter and poisonous constituent ( $\kappa \alpha i \mu \tilde{\alpha} \lambda \lambda_{0} \nu$

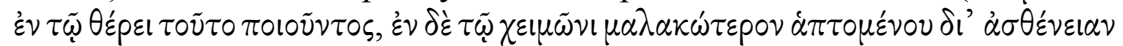

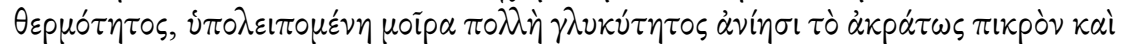
$\phi \alpha p \mu \alpha \kappa \tilde{\omega} \delta \varepsilon \varsigma)$. Plutarch adds that the same process occurs in a mild way in drinkable waters as well. In the summer they become less good, since the heat dissipates the lightest and sweetest part, while fresh new water flows

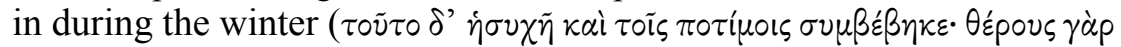

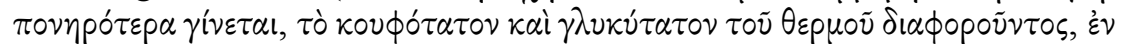

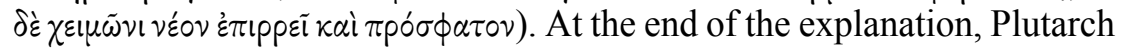
points out that seawater necessarily receives a share of this fresh new water as well, since rain falls upon it and rivers empty into it (oṽ $\mu \varepsilon \tau \varepsilon \dot{\varepsilon} \chi v$

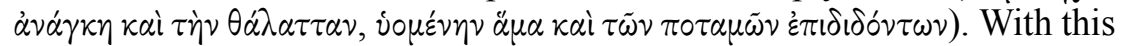
last point the argumentative ring is complete [see 4.3.3.3.].

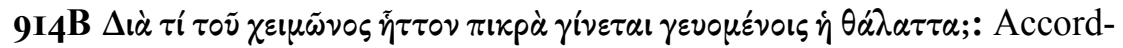
ing to Pliny, $\mathrm{NH}_{3}$ I, 52 all water is sweeter in winter and less so in summer. For the relation between the salt and the bitter flavours, cf. Q.N. $5,913 \mathrm{D}$ (with the commentary ad loc.).

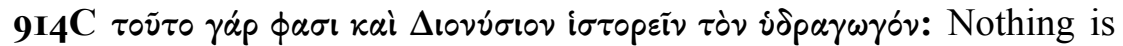
known about this Dionysius, the designer of aqueducts [see 4.2.I.I, n. II4].

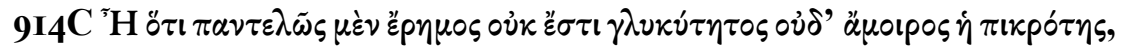

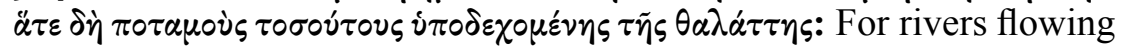
into the sea, thus rendering it more drinkable, cf. also, e.g., Pliny, $\mathrm{NH}_{4}$, 79 and 6, 5I. In Q.N. I, 9IIE, Plutarch formulates a similar idea (viz. that rivers deposit silt into the sea).

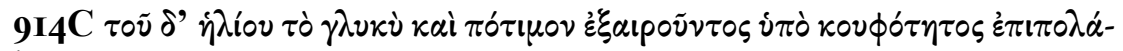
Gov: The idea that the sun evaporates the sweet drinkable constituent in seawater recurs in Q.N. 40. Cf. also Hipp., Aer. 8, Arist., Mete. $355 \mathrm{a} 32 \mathrm{ff}$., Ps.-Arist., Probl. 934b27 ff., Ps.-Alex. Aphr., Probl. I, 55 (J.L. Ideler, I84I, p. 19, 23-25), Pliny, $\mathrm{NH} 2,222$.

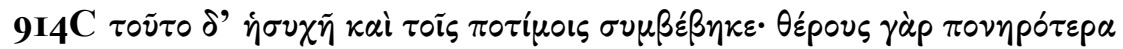

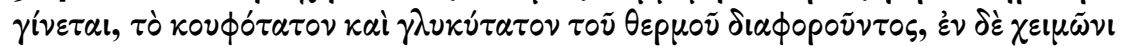

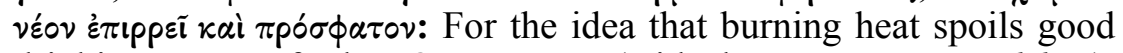
drinking water, cf. also Q.N. I, 9IIE (with the commentary ad loc.).

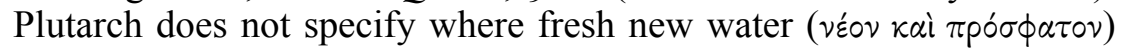
comes from in winter (perhaps from the mountains or the Northern regions?). 


\section{Q.N. I0, 9I4DE}

In Q.N. IO, Plutarch deals with yet another problem related to the topic of seawater, this time in combination with that of wine (cf. also Q.N. 27, 30-3I). He wonders why people pour seawater into wine, and why those who live far away from the sea put baked gypsum from Zacynthus

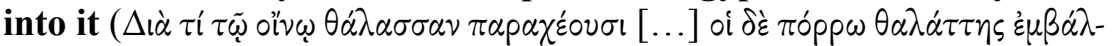

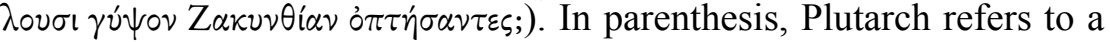
story told by the people of Halieis (or by fishermen?) who say that they received an oracle instructing them to dip Dionysus into the sea ( $\chi \rho \eta \sigma \mu o$ r

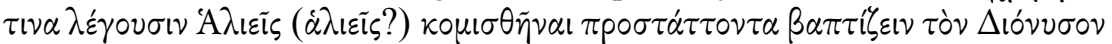
$\pi$ pòs $\tau \dot{\eta} \nu \theta \dot{\alpha} \lambda \alpha \tau \tau \alpha \nu)$. Two explanations are given: the first focuses on the heat of seawater, the second on its earthy constituent.

The first explanation is based upon an opposition between heating and cooling. Plutarch argues that heat (which is natural to seawater) is an aid against cooling, which, by itself, does more than anything to change the

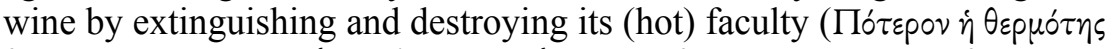

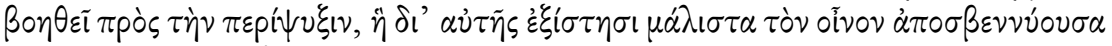

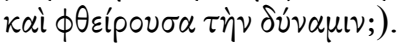

In the second explanation, the elementary composition of wine vis$a$-vis that of seawater is central. Plutarch argues that earthy substances, which naturally bring forth fixation and reduction, fasten the watery and breathlike parts of the wine, which are most inclined to suffer change ( $\eta \dot{\gamma} \tau \dot{o}$

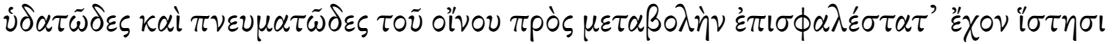

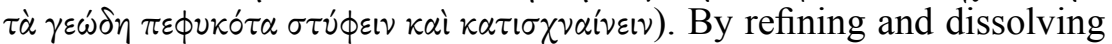
foreign and superfluous parts (c.q. in the wine), the salty (c.q. earthy) crystals in the seawater prevent the development of unpleasant odours

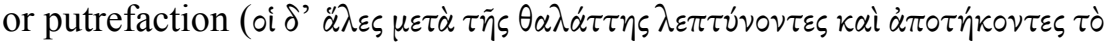

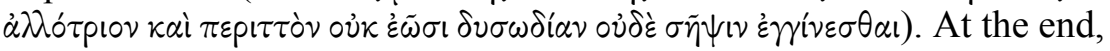
Plutarch adds that all that is thick and earthy (c.q. in wine) is entangled and dragged down along with the heavier parts (c.q. in the seawater) to

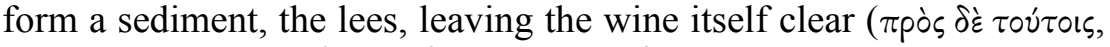

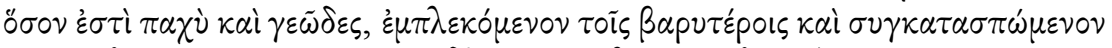
نं

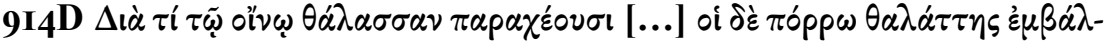

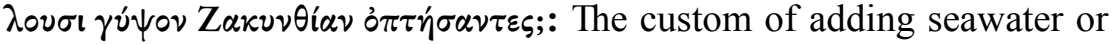
gypsum to wine, common in Antiquity, is widely attested in the literature (see, e.g., Theophr., Lap. 67, Ath., Deipn. I, 26b; 3I f.; 32de; 33b, Pliny, NH I4, 73-75; 78; I20; I26, Pallad., Op. agr. II, I4; I7; 2I). The admixture of salt or seawater was considered typical of Greek wines, but some Romans 
also adopted this custom. Cf. Cato, De agr. 24; I04-I06 (with a recipe on making seawater), Col., De re rust. I2, 2I-22; I2, 37, Plautus, Rudens 588.

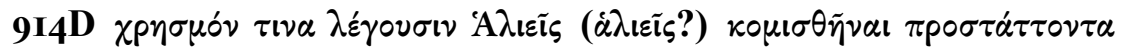

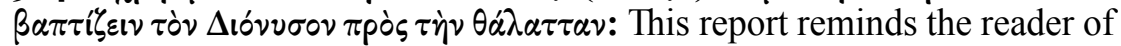
the type of cultural-antiquarian inquiry in Plutarch's Quaestiones Graecae (cf. also Q.N. I4, 9I5C and 23, 9I7F [see 2.4.2.]). We may be dealing with a reference to the ritual submerging of the statue of Dionysus into the sea (see L. Senzasono, 2006, p. I80, n. 66). In Hom., Il. 6, I36, there is the story of Dionysus finding his refuge in the bosom of the sea nymph Thetis. In Eustathius' commentary to this passage, this is interpreted allegorically as a riddle about the usefulness of seawater for preserving wine (629, 63-64; cf. also 87I, 36-38, Ath., Deipn. I, 26b, Ps.-Heracl., Quaest. Hom. 35; for a similar riddle, cf. Quaest. conv. 7I6F-717A). As to the addressees

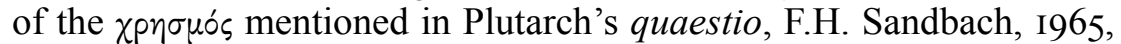
pp. ${ }^{7} 72-173$ (nn. 6 and d) corrected the reading of the manuscript $\dot{\alpha} \lambda \iota \varepsilon i s$

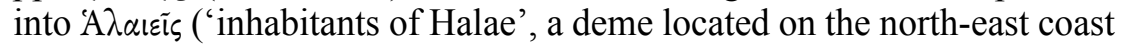
of Attica), but perhaps 'A $\lambda$ iाis is more plausible ('inhabitants of Halieis', a

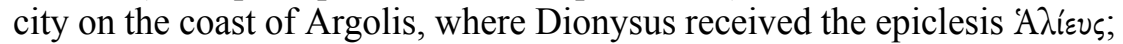
see O. Jessen, I9I2). Sandbach relies on von Wilamowitz' corrections of the T-scholium to the Homeric passage at hand (Il. 6, I36), which is ascribed to Philochorus (FGrHist 328, I9I) and may very well be Plutarch's

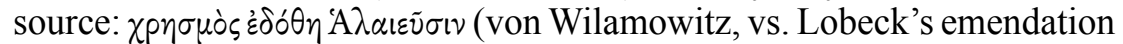

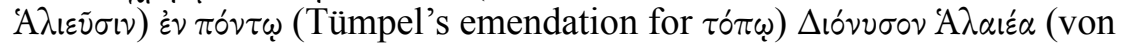

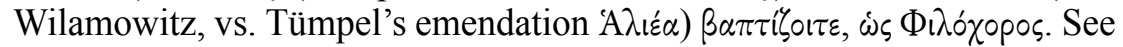
C.A. Lobeck, I829, p. I088, von Wilamowitz apud E. Maßß, I887, p. 210 and K. Tümpel, I889. Tümpel (with Lobeck) prefers the reading of 'A $A \iota \varepsilon \tilde{\sigma} \sigma \nu$ and 'A $\lambda_{\imath} \varepsilon \alpha$. Considering the manuscipt reading of Plutarch's quaestio at hand ( $\left.\dot{\alpha} \lambda i \varepsilon \tau_{\zeta}\right)$, I am inclined to follow this reading. In that case, Plutarch refers to the 'inhabitants of Halieis', rather than 'the people of Halae'

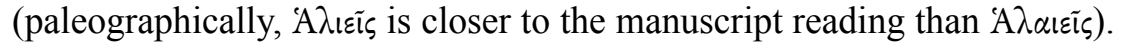
In any case, the reference is probably not just to unspecified 'fishermen', since the city or its inhabitants to which an oracle is given is commonly mentioned by name in ancient Greek literature (cf. L. Senzasono, 2006, p. I80, n. 66). Moreover, the $A \lambda ı \varepsilon i \varsigma$ were often considered fishermen from their name, which may explain the confusion here. Cf. Strabo, Geogr. 8,

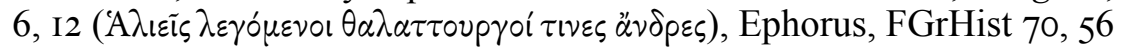

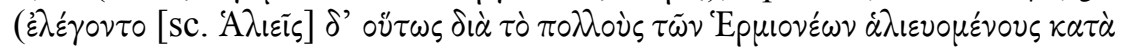

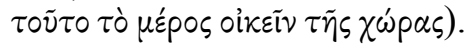

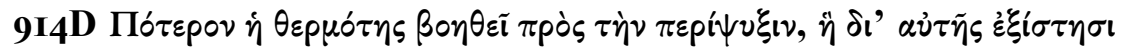

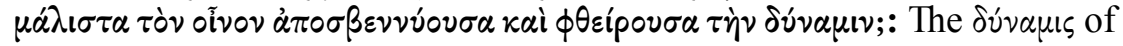
wine is in its fiery heat (cf., e.g., Q.N. 3I, 9I9CD and Quaest. conv. 70IF), which is destroyed by cooling. In Quaest. conv. $652 \mathrm{~B}-653 \mathrm{~B}$, by contrast, 
Plutarch argues ex tempore that the dv́vaus of wine is cold. According to Aristotle and Theophrastus, some wines are hot by nature while others are colder (fr. 22I Rose). They also hold that the innate heat in wine is due to putrefaction (fr. 222 Rose): this heat is, so to say, 'killed' by vinegar, because the vinous parts in wine become cold when the wine turns into vinegar, while the watery residue putrefies and receives an additional amount of heat, like all putrefied things (in this sense, vinegar is constituted by parts that are opposed by their properties, viz. from cooled and heated substances, as is also the case with all ashes of burned wood). In regards to the excessive coldness of vinegar, which is even said to be able to extinguish fire, cf. also Quaest. conv. 652F.

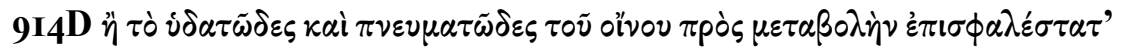

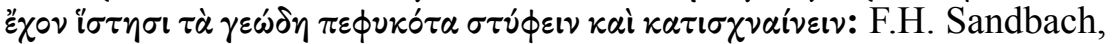
I965, p. I75, n. $d$ is probably correct in pointing out that " $[\mathrm{t}]$ he vaporous [c.q. breathlike] elements tend to evaporate, the watery ones to putrefy". An allusion to these two processes (of evaporation and putrefaction) can be found in the second part of the sentence that follows, viz. in the concepts of $\delta \nu \sigma \omega \delta \delta^{\prime} \alpha$ and $\sigma \tilde{\eta} \psi i s$ respectively. Note, moreover, that the verb $\kappa \alpha \tau i \sigma \chi v \alpha i v \varepsilon \iota \nu$ is related to the reduction and weakening of odours (see LSJ, s.v.). For the tenuity $\left(\lambda \varepsilon \pi \tau \tau^{\prime} \tau \eta \zeta\right)$ of $\pi \nu \varepsilon \tilde{\nu} \mu \alpha$ and the putrefactive quality $(\sigma \eta \dot{\psi} \psi \varepsilon \iota \varsigma)$ of (rain)water, cf. Q.N. 2, 9I2B (cf. also Q.N. 33 for the bad quality, qualitas aliquis mala, of stagnant waters).

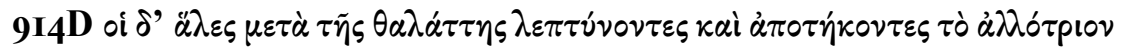

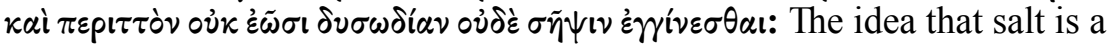
safeguard against putrefaction is paralleled in Q.N. I, 9IID and 40; cf. also Quaest. conv. 685BC. For the melting ( $\left.\tau \eta^{\prime} \kappa \varepsilon เ \nu\right)$ and thinning $\left(\lambda \varepsilon \pi \tau v^{\prime} v \varepsilon เ \nu\right)$ property of salt, cf. Q.N. 3, 9I2E (with the commentary ad loc.).

\section{Q.N. II, 9I4EF}

Q.N. II deals with the pathological condition of seasickness caused by navigation, which, so Plutarch writes, occurs on the sea rather than

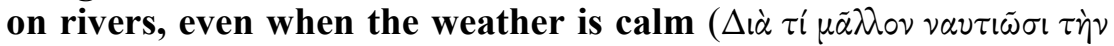

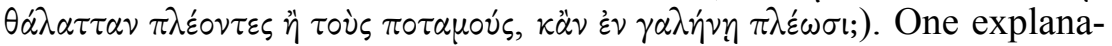
tion is given, which is based on the opposition between strange and familiar smells. The aetiology draws on a close relation between human physiology and psychology showing how our senses (c.q. of smell) stir our soul into an erroneous emotion (c.q. of fear of things to come), and how the body reacts on this erroneous impulse, thereby leading to sickness. 
Plutarch explains that of all the sensations, that of smell, and of all emotions, that of fear, is the most conducive to seasickness ( $\tilde{\eta} \mu \dot{\alpha} \lambda \iota \sigma \tau \alpha$

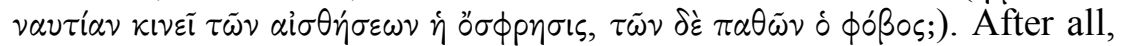
when people imagine some danger, they tremble and shiver, and their

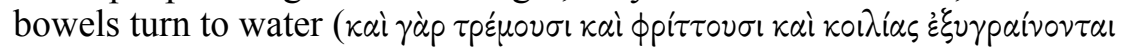

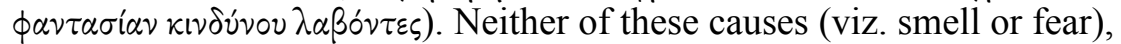
though, worries those who travel by river, because everyone's smell is accustomed to the drinkable and fresh river water, and the passage is

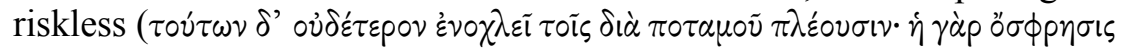

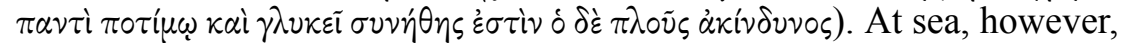
people feel uncomfortable by the strange smell, and they are afraid of what may become, since they distrust the present situation $\left(\dot{\varepsilon} \nu \delta \dot{\varepsilon} \tau \tilde{\eta} \theta \alpha \lambda \alpha \dot{\alpha} \tau \eta \eta \eta^{\prime} \nu\right.$

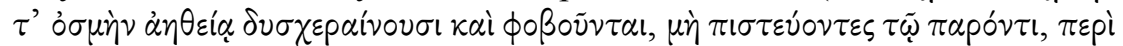

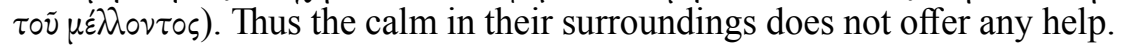
On the contrary, the disturbance and wavering of the soul stirs up the body

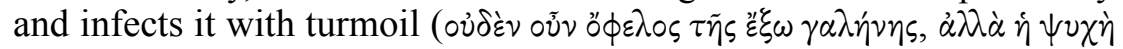

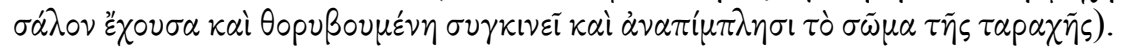

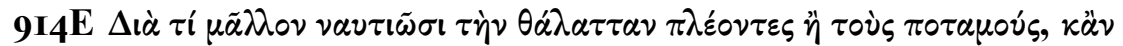

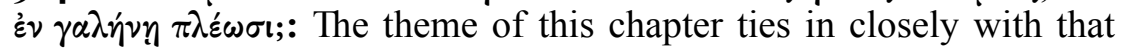
of Book 27 of Ps.-Aristotle's Problems, where the emotions of fear and courage are treated in terms of physiological processes in the body (

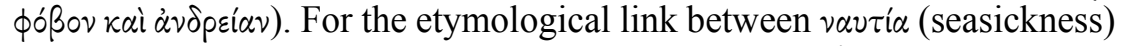
and the world of navigation, see Quaest. conv. 694B ( $\dot{\omega} s \delta \dot{\varepsilon} v \alpha v \tau i \tilde{\alpha} \nu \dot{\omega} v o \mu \alpha \dot{\sigma} \sigma \eta \eta$

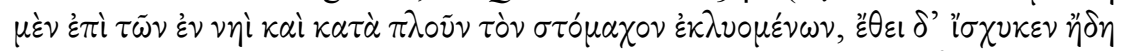

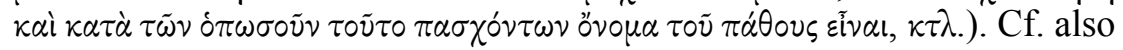
P1., Leg. 639b.

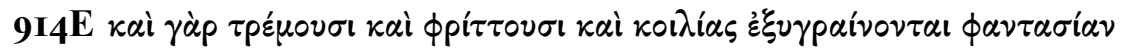

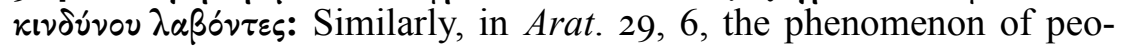

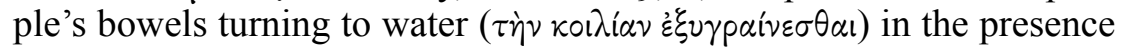
of seeming peril, is ascribed to cowardice or some faulty temperament and chilliness in the body (this last point recalls the phrase $\tau p \varepsilon ́ \mu o v \sigma \iota k \alpha i$ $\phi p i \tau \tau 0 v \sigma \mathrm{l}$ here) [quoted 3.I.I.]. For the connection between seasickness and fear, cf. also Ps.-Arist./Alex. Aphr., Suppl. probl. 2, Io6 (S. Kapetanaki and R.W. Sharples, 2006, p. 2 report a lack of parallels in the medical literature for this problem, but Q.N. II may provide an exception).

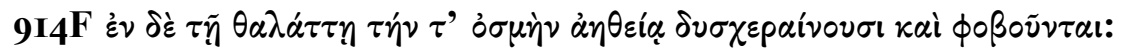
By contrast, in De prim. frig. $954 \mathrm{C}$, Plutarch argues that living by the sea in the winter provides a welcome refuge from living on land, because we can wrap ourselves in the comfortable and warm salty sea air there. 


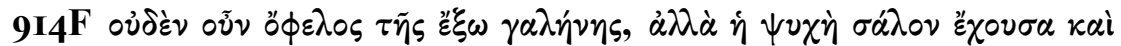

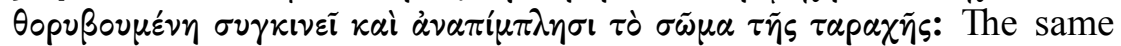
imagery, where the upset in the human soul is compared with that of the sea, recurs in De tranq. an. $475 \mathrm{EF}$, Demetr. 38, 4 and Per. 33, 5 (see F. Fuhrmann, I964, p. 50). For the physiological implications of psychological $\theta$ ópußos and its metaphorical value in light of the decorum of the symposium, see M. Vamvouri Ruffy, 20II, pp. I35-I39 (with a reference to the problem at hand).

\section{Q.N. I2, 9I4F-9I5B}

In Q.N. I2, Plutarch examines why oil that is sprinkled on seawater

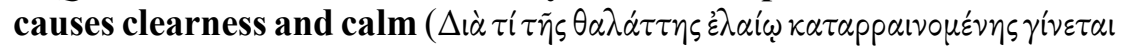
$\kappa \alpha \tau \alpha \phi \dot{\alpha} \nu \varepsilon 1 \alpha \kappa \alpha i \gamma \alpha \lambda \eta \dot{\nu \eta}$;). The problem ties in closely with the general theme of seawater in the previous problems; and on a more minute level, the opposition $\gamma \alpha \lambda \eta^{\prime} \nu \eta-\sigma \alpha \dot{\lambda}$ ov mentioned in the conclusion to the previous problem $(Q . N$. II, 9I4F) will recur in the first causa here. The aetiology at hand contains three explanations that are closely interconnected with each other. The first two explanations alternately deal with the exterior and interior effects of oil on the sea (the first one deals with the aspect of $\gamma \alpha \lambda \eta^{\prime} \nu \eta$, the second with that of $\left.\kappa \alpha \tau \alpha \phi \dot{\alpha} \nu \varepsilon 1 \alpha\right)$, and the final explanation provides an answer for both of these effects together (in doing so, it combines elements from the preceding two explanations).

The first explanation, which Plutarch borrows from Aristotle, is kept fairly brief: he says that the wind, slipping off the smoothness (so caused by the

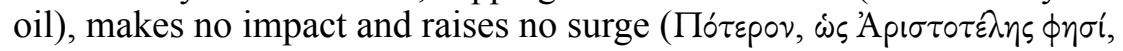

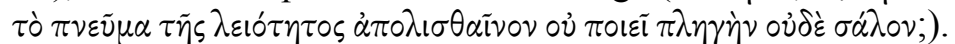

In the second explanation, Plutarch highlights the incompleteness of Aristotle's theory, which he considers to be plausible, but only so

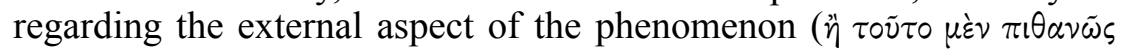

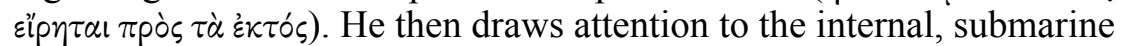
aspect of the phenomenon, by referring to the popular account that divers take oil into their mouth and blow it out in the depths, so that they get

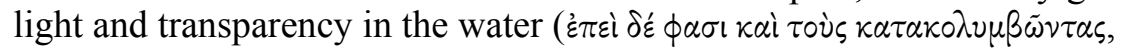

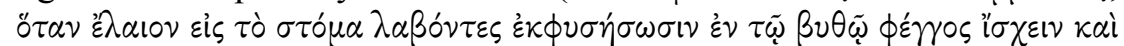
$\delta i(\psi \psi(v)$. As Plutarch notes, it is of course impossible to allege slipping of

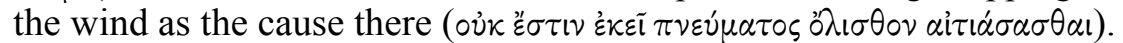
He explains that because of its density, the oil (in its movement out of the divers' mouth) pushes and forces aside the sea, which is earthy and irregular. When the sea flows back to itself and draws together afterward, intermediate passages are left, which provide transparency and clearness 


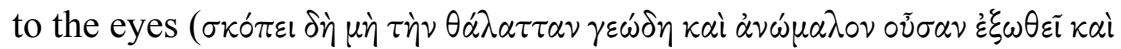

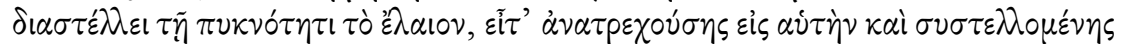

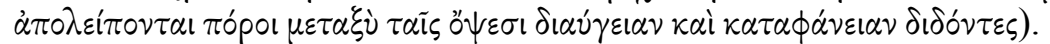

By combining the internal and the external aspect of the problem in the third and final causa, Plutarch tries to explain both the effects of $\kappa \alpha \tau \alpha \phi \alpha \dot{v \varepsilon} \alpha$ and $\gamma \alpha \lambda \eta^{\prime} \eta \eta$ as mentioned in the quaestio. He starts by pointing out that the air that is mixed with the seawater (internally, but probably close to the surface of the sea, where the sunbeams can reach it) is naturally full of light because of its heat (which explains the sea's transparency), but that it becomes irregular ( $\alpha \nu \omega \mu \alpha \lambda \circ \varsigma$, cf. the previous causa) and dark

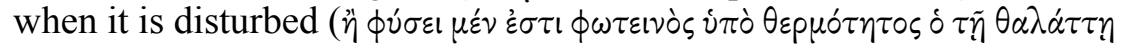

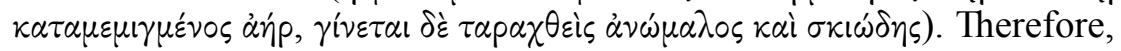
when the oil with its density ( $\pi$ urvó $\tau \eta \tau \iota$, cf. the previous causa) smoothes out the irregularity of the surface (externally, cf. causa one), the air regains

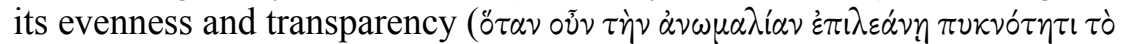

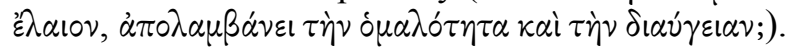

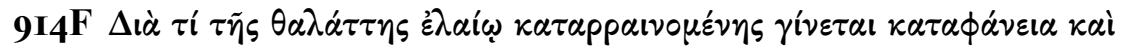
$\gamma \alpha \lambda \eta^{\prime} \nu \eta ;:$ Theophylactus Simocatta raises the same problem (Quaest. phys. 7: J.L. Ideler, I84I, p. I75, 3-24), and the solution he provides is very close to the one Plutarch attributes to Aristotle in the first causa here (for Theophylactus' sources, see M. Marcovich, 1954). The problem also recurs in De prim. frig. 950BC, albeit in an adapted form and somewhat in passing (Aristotle's account is again quoted and criticised). Plutarch there argues that, among other liquids, oil is the most transparent ( $\delta 1 \alpha \phi \alpha \nu \varepsilon s)$, because it contains the most air (and not the sea, as here in the third causa; contrary also to Quaest. conv. 696B and 702BC). This is evidenced by the oil's lightness (kouфó $\eta$ ), which causes it to remain on the surface ( $\dot{\pi} \iota \pi \Delta \lambda \dot{\alpha} \zeta \varepsilon l)$ of all things (c.q. liquids), being carried up by the air. Plutarch

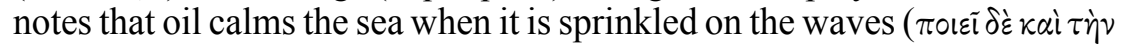

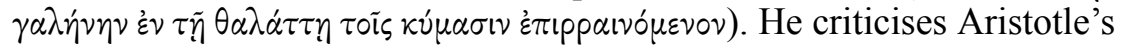
explanation (cf. causa one), according to which the winds slip off the surface of the sea because of the oil's smoothness. In fact, so Plutarch argues, the waves are dissipated when they are hit by any liquid (o $\delta$ di $\alpha$

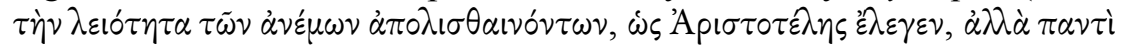

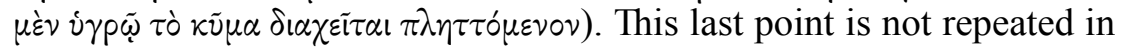
Q.N. I2, but the focus on both the internal and the external aspect of the phenomenon remains. It is a typical feature of oil, so Plutarch continues,

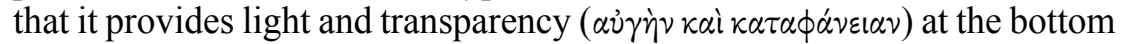
of the sea, because the liquids there are dispersed by the air contained

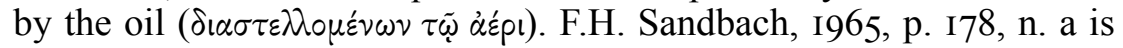
probably correct that Plutarch is implying that "the oil contains much air (hence its lightness), which provides the transparency". Plutarch believes that it literally gives light, not only on the surface for those who pass the 
night at sea, but also below the surface for spongedivers when they blow

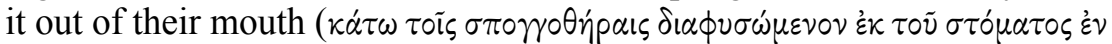
$\tau \tilde{\eta} \theta \alpha \lambda \dot{\alpha} \tau \tau \eta$, cf. the second causa in Q.N. I2). There are clear parallels with the aetiology in Q.N. I2, but also some slight differences. Importantly, the problem of oil poured on the surface of the sea is not central in De prim. frig. 950BC. What is central there is the (Empedoclean and anti-Stoic)

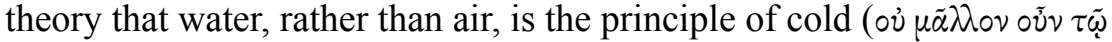
áर् that the phenomenon is mentioned. The fact that oil is most transparent and gives light to divers supports the idea that it contains much air. Water, by contrast, contains darkness, and is, therefore, cold (darkness being related to coldness: cf. De prim. frig. 948E). In Q.N. I2, however, the natural phenomenon is treated separately and on its own terms, so that the aetiology is more elaborated and systematic (the same conclusion can be drawn for the parallel between De prim. frig. 950AB and Q.N. 39 about the darkness of deep water: see the commentary ad loc.).

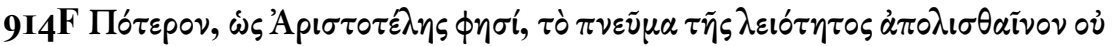

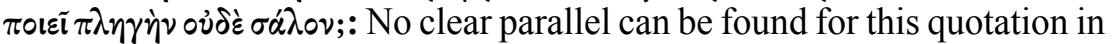
Aristotle's works (nor for the similar one in De prim. frig. 950B). Neither is it included among Aristotle's fragments, but Q.N. I2 and several of its parallel passages are mentioned in V. Rose, I863, p. 2I9. As we will see below, there is, indeed, a large amount of parallel material, in I) Ps.Aristotle's Problems and in 2) the Supplementary problems ascribed to Ps.-Aristotle/Alexander of Aphrodisias. Therefore, we may be dealing in Q.N. I2 with the remains from a lost Ps.-Aristotelian problem (cf. F.H. Sandbach, I965, p. I77, n. a and I982, p. 227). It is not unlikely either, though, that Plutarch is simply reorganising some of this material in Q.N. $\mathrm{I} 2$, rather than that he is inaccurate in reproducing it (pace L. Senzasono, 2006, pp. I85-I86, n. 74). I) A passage similar to the opening problem is found in Probl. 935bi7-27 (concerning the greater transparency of seawater vis-à-vis fresh water; cf. also Probl. 932b8-24). It is argued there, but not further explained, that oil after being poured on the water renders

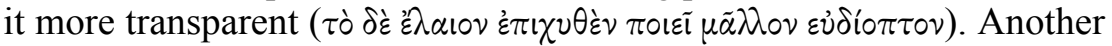
parallel is found in Probl. 96rar8-23 (regarding oil being poured in the ear to clear water from it), where we read that oil lies on the surface of the

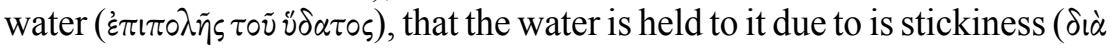

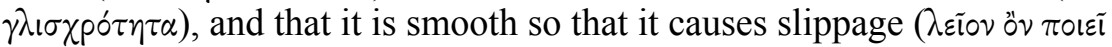
o $\lambda ı \sigma \theta \alpha i v \varepsilon \iota v)$. Similarly, in Probl. 96Ia24-30 (concerning the ears of divers breaking less easily when oil has been poured in them), it is argued, in very similar wording as in Plutarch, that oil causes the seawater in the ears to slip off ( $\dot{\alpha} \pi \circ \lambda$ เ $\sigma \theta \alpha$ í $\nu \varepsilon เ \nu \pi \circ \varepsilon \tilde{)})$, so that it cannot produce a choc in the ears ( $\pi \lambda \eta \gamma \eta \dot{\eta} \nu$ o $\pi \circ เ \varepsilon \tilde{\imath})$. In the Aristotelian causa in Q.N. I2, 9I4F, however, the context is different and the subject of $\dot{\alpha} \pi \circ \lambda\lrcorner \sigma \theta \alpha \tilde{\imath} \nu \nu$ ov $\pi \circ \iota \varepsilon \pi \pi \lambda \eta \gamma \dot{\eta} \nu$ is not the 
seawater but the wind (according to Senzasono, Plutarch may be rendering this account in an inexact way due to the inaccuracy of his memory or personal notes, but perhaps he is just rephrasing it). 2) The topic of the sea's calmness being produced by the oil recurs in Ps.-Arist./Alex. Aphr., Suppl.

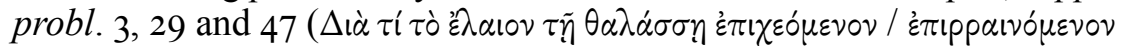

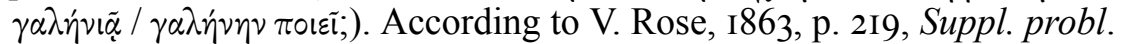
3,47 derives from 3, 29 (he says that the latter is 'used' for the former), but this is questionable (cf. S. Kapetanaki and R.W. Sharples, 2006, p. 277 , n. 563). In any case, two different answers are given: in Suppl. probl. 3, 29, it is argued that the oil, being smooth, causes the wind to slip off the surface

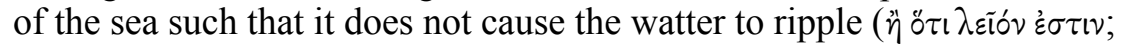

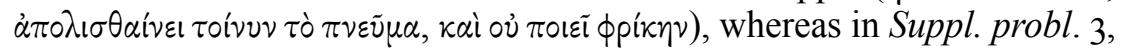
47 it is argued that the oil, which is sticky and moist, causes the waves to slip over each other and lose their rapid motion and impetus ("o $\tau\llcorner\gamma \lambda i \sigma$ xpov

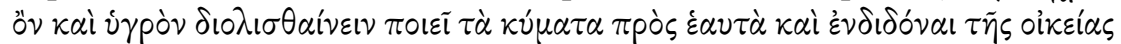
opuñs kai фopãs). The first explanation is closest to the Aristotelian causa in Q.N. I2 and the second to Probl. 96ra24-30 mentioned above. According to H. Flashar, I962, p. 360, n. I and p. 740 (cf. also R. Mayhew, 20IIa, p. 35I, n. I4), Q.N. I2, 9I5A (and, I presume, especially the reference to divers in causa two) probably refers to Ps-Arist., Probl. 96ra24-30 rather than to Ps.-Arist./Alex. Aphr., Suppl. probl. 3, 29 and 47 (he concludes that "in die Probl. ined. im einzelnen Material eingegangen [ist], das Plutarch [...] in einem dem Ar. zugeschrieben Corpus von Probl. gefunden [hat]"). However, S. Kapetanaki and R.W. Sharples, 2006, p. I2 (cf. also R.W. Sharples, 2006, p. 25, n. I7) argue, on the contrary, that Q.N. I2 (and, I presume, especially the quaestio and causa one) probably refers to Suppl. probl. 3, 47. They argue I) that "the question in Plutarch, and the point for which Aristotle is cited, is the general one raised in 3.47 rather than the specific point about divers in the Bekker Problem [= Probl. 96ra24-30]", and 2) that "Plutarch goes on to attack the claim of those (plural) who say that the same explanation applies to divers". I) In regards to the first point, however, it seems that Suppl. probl. 3, 29 is closer (than 3, 47) to Plutarch's formulation of the quaestio and the first causa of Q.N. I2. 2) In regards to the second point, it should be noted that Plutarch does not argue that 'those people' - Kapetanaki and Sharples are clearly referring to the subject in $\phi \alpha \sigma$ - claim that "the same [c.q. Aristotelian, i.e. external] explanation applies to divers"; rather, he adduces this popular account in order to add a new point, which introduces another (c.q. internal) perspective. This is not meant as an attack on 'those people' but is part of Plutarch's criticism of Aristotle (who only provides an external explanation). They also add 3) that the point that Plutarch makes about the oil causing the wind to slip over the waves in De prim. frig. 950B probably refers to Suppl. probl. 3 , 29 , but the same is actually true, as we just saw, for the quaestio and the first causa of Q.N. I2. 
The most problematic aspect of this kind of Quellenforschung, however, is that it downplays Plutarch's exploratory attitude to received knowledge and his own innovative contributions to the problem. It is not unlikely that Plutarch joins together material that he found in, or generally remembers from, a collection of problems that is quite different from the collections we have today [see I.I.3., n. 87]. Moreover, if we compare the argumentative strategies in his other problems, it can only be expected that Plutarch not only rearranged this material afresh, but also added his own original insights and comments (as may be marked by the imperative $\sigma$ kó $\pi \varepsilon l \delta \grave{\eta} \mu \eta^{\prime}$ in the second causa [see I.I.4., n. III]).

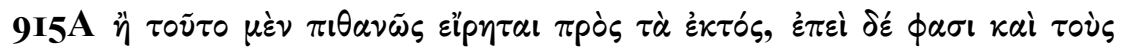

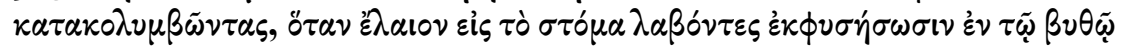
$\phi \varepsilon ́ \gamma \gamma \circ$ ไ the remark about divers, cf. De prim. frig. 950B. Cf. also Pliny, $\mathrm{NH}$ 2, 234 and Opp., Hal. 5, 638-648.

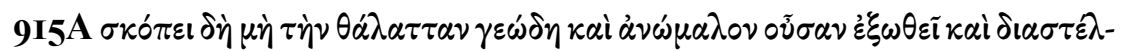

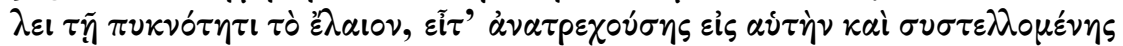

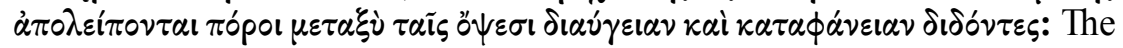

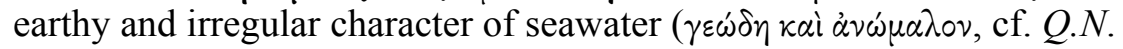
I, 9IID) hinders clear vision into it. The density ( $\pi$ vкvó $\eta_{5}$ ) of the oil, on the other hand, probably refers to its lack of pores (cf. Quaest. conv. $696 \mathrm{AB}, 702 \mathrm{BC}$ ) so that it cannot mingle with water but pushes it aside (cf. F.H. Sandbach, I965, p. I78, n. b). In so doing, it creates pores in the seawater, providing transparency and clearness to our sight. Sandbach is right that " $[t]$ his explanation applies particularly to the submarine phenomenon". The reader may object, therefore, that this second causa is equally deficient as the first one. It only explains the aspect of $\kappa \alpha \tau \alpha \phi \alpha \dot{\alpha \varepsilon 1 \alpha}$ and not also that of $\gamma \alpha \lambda \eta^{\prime} \eta \eta$, as mentioned in the quaestio. Plutarch will make an attempt to explain both of these aspects at the same time in the third causa.

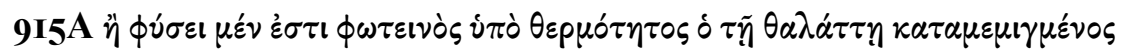
ańp: Cf. Q.N. 39, for the idea that surface water, as opposed to water in the depths, takes on the clearness of the sunbeams, which renders it white in colour.

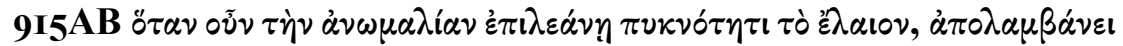

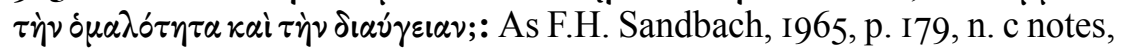
we are primarily dealing with the effects of oil on the surface of the sea in this third causa (cf. $\dot{\varepsilon} \pi \imath \varepsilon \dot{\alpha} \alpha \eta$ ). However, Plutarch also clearly refers to the air mixed with the seawater (cf. $\kappa \alpha \tau \alpha \mu \varepsilon \mu \gamma \mu \varepsilon^{\prime} v o s$, see the previous comment). This is not necessarily incompatible, if we may assume that 
Plutarch is referring to the top-layer of the seawater including the sea surface itself (he thus combines both the external and the internal aspects of the phenomenon at the same time). What Plutarch is basically arguing, then, is that, on account of its density, oil raises no swelling of the waves (cf. causa one), but smoothes out the sea and, thus, the air contained in it, leading it to become calm and, by implication, transparent. The words $\tau \dot{\eta} \nu$

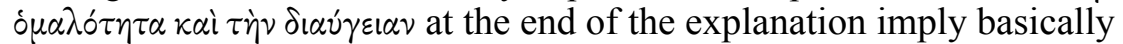
the same thing as $\gamma \alpha \lambda \eta^{\prime} \nu \eta$ and $\kappa \alpha \tau \alpha \phi \alpha v \varepsilon 1 \alpha$ respectively, as mentioned in the quaestio (as such, the aetiology is 'complete' at this point, resulting in an argumentaive ring [see 4.3.3.3.]). Psellus in De omn. doctr. § I69, 7-IO Westerink rewrites this sentence completely. He agrees, however, that oil on the surface is under scrutiny (externally) as well as the seawater

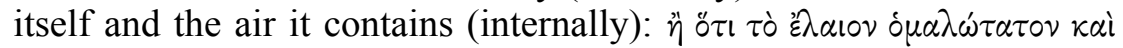

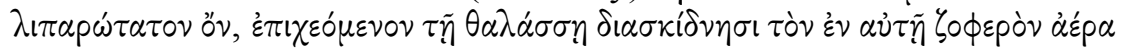

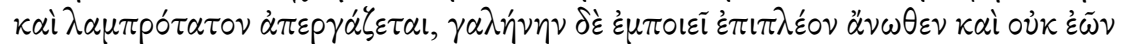
$\kappa \alpha \dot{\tau} \tau \theta \theta \varepsilon \nu \alpha \dot{\tau} \tau \dot{\eta} \nu \dot{\alpha} \nu \alpha \beta p \dot{\alpha} \tau \tau \varepsilon \sigma \theta \alpha$ l. See also M. Meeusen, 20I2b, p. II2, n. 54.

\section{Q.N. 13, 915BC}

In Q.N. I3, Plutarch deals with a last problem concerning seawater. He wonders why fishermen's nets decompose more in the winter than in the summer, whereas the opposite is true of other objects

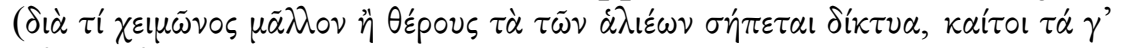

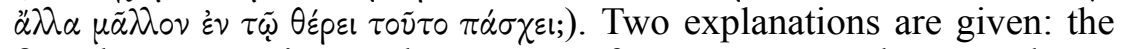
first draws attention to the process of $\alpha \nu \tau i \pi \varepsilon p i \sigma \tau \alpha \sigma i \varsigma$, the second to a process that is said to be similar to, but not to be mistaken for, $\sigma \tilde{\eta} \psi i \varsigma$ (this certainly puts the $\sigma \dot{\eta} \pi \varepsilon \tau \alpha$ from the quaestio into perspective [see 4.3.3.3.]).

The first explanation is based on the idea that the process of putrefaction is triggered by heat being concentrated in the sea. It opens with a quotation from Theophrastus, who believes that heat, withdrawing under the cold, is concentrated and makes the water in the depths of the sea warmer, as

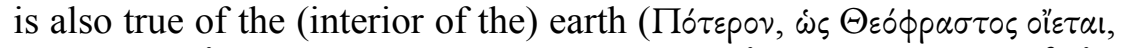

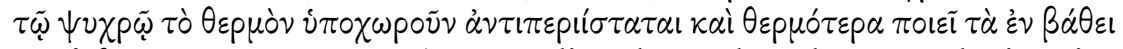
$\tau \tilde{\eta} \varsigma \theta \alpha \lambda \dot{\alpha} \tau \tau \eta \zeta, \ddot{\omega} \sigma \pi \varepsilon \rho \tau \tilde{\eta} \varsigma \gamma \tilde{\eta} \varsigma ;$ ). Regarding the analogy between the interior part of the sea and that of the earth, Plutarch explains that springwaters are also warmer in the winter. He adds that ponds and rivers emit more vapour, because the heat is enclosed in the depths, as it is mastered by

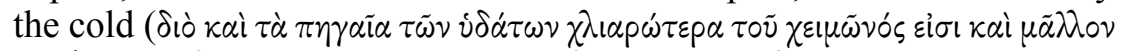

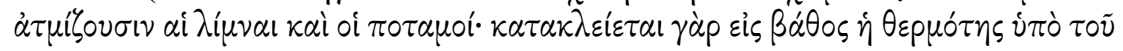

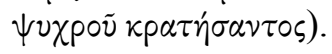


In the second explanation, Plutarch makes a subtle distinction by reinterpreting the process of $\sigma \tilde{\eta} \psi(s$ mentioned in the quaestio. He argues that the nets do not actually rot but undergo some kind of a process that is very similar to rotting and putrefaction when they become rough and frozen, as they are desiccated by the cold and violently frayed by the

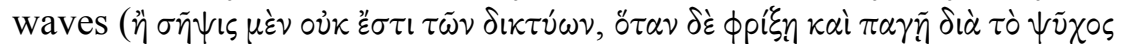

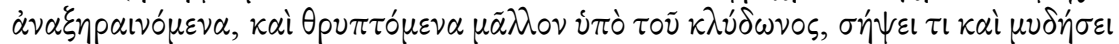
$\left.\pi \dot{\alpha} \sigma \chi \varepsilon เ \pi \alpha p \alpha \pi \lambda \eta^{\prime} \sigma \iota \nu ;\right)$. Plutarch adds that the nets also suffer more damage by the cold, as they are pulled to pieces like overstrained chords. This is due to the fact that the sea is repeatedly agitated by the wintery weather

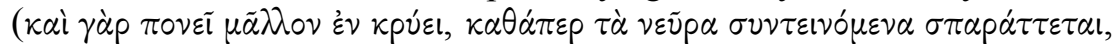

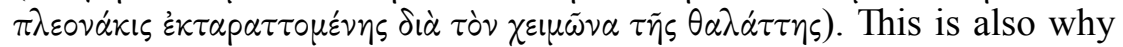
fishermen, out of fear that their nets will come loose, treat them with dyes

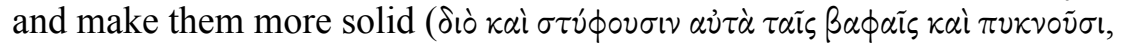
$\phi \circ \beta \circ v^{\mu} \mu \varepsilon v o l \tau \dot{\alpha} \varsigma \dot{\alpha} \nu \alpha \lambda \dot{v} \sigma \varepsilon(\varsigma)$. An additional reason is that fish would not notice them (and, by implication, not be attracted to them) if they were not dyed or tinted, since the normal colour of the net is like that of air and is hardly

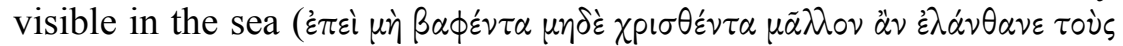

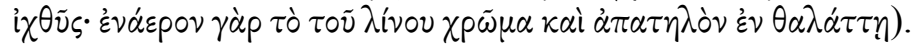

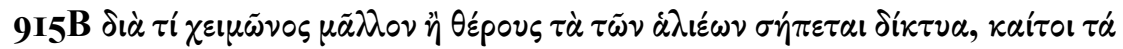

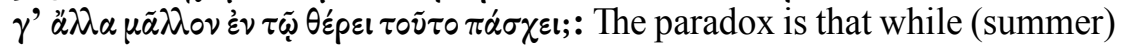
heat normally triggers putrefaction, the reverse seems to be the case for nets in the sea, whereas this is not true in the case of other objects $\left(\tau \dot{\alpha} \gamma^{\prime}\right.$ $\alpha \lambda(\alpha)$. No further mention is made of the other objects in the aetiology, but presumably they are not located in the sea but on land, so that they are directly exposed to atmospheric temperatures.

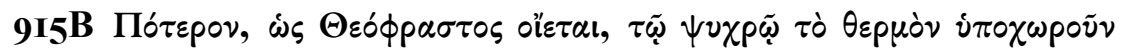

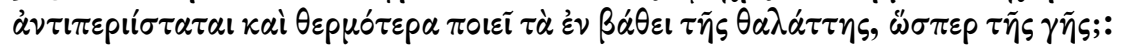
See Theophr., fr. I63 Wimmer (= I73 FHSG). The ensuing argument ( $\delta 10$ кai $\kappa \tau \lambda$.: see the following comment) is interpreted by Wimmer and FHSG as part of the quotation from Theophrastus and correctly so if we may assume that Plutarch did not add the analogy with the earth himself $(\ddot{\omega} \sigma \pi \varepsilon p$ $\tau \tilde{\eta} s \gamma \tilde{\eta} s)$. This remains unclear, though. The quote may very well originate from Theophrastus' lost De aquis (just like the one in Q.N. 7, 9I4A, which also concerns the influence of the seasons on water; see the commentary ad loc.), but it may be known to Plutarch indirectly via a lost Aristotelian problem. Pliny, $\mathrm{NH}_{2}$, 234 also says that the sea is warmer in winter.

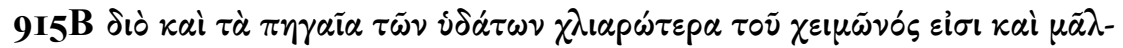

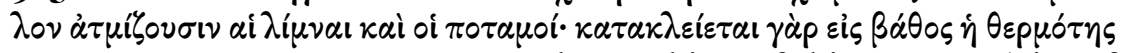

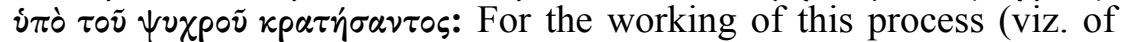
$\left.\dot{\alpha} \nu \tau i \pi \varepsilon \rho^{\prime} \sigma \tau \alpha \sigma \iota \varsigma\right)$ in similar natural contexts, see Arist., Mete. $348 \mathrm{~b} 2-5$, 
Theophr., Ign. I6, Ps.-Alex. Aphr., Probl. I, 56 (J.L. Ideler, I84I, pp. I9, 32-20, 4), Oenopides of Chios, DK4IAII (drawn from Ps.-Aristotle's De Nilo, fr. 248 Rose), Cic., De nat. deor. 2, 25, Sen., NQ 6, I3, 2-3 (= Strato, fr. 89 Wehrli), Lucr., De rer. nat. 6, 840-847, Pliny, $N H$ 3I, 50. For vapours rising from rivers, cf. also De prim. frig. $95 \mathrm{IBC}$ and fr. 75 Sandbach.

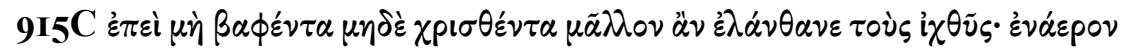

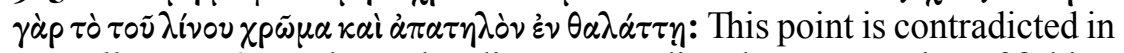
De soll. an. 976EF, where Phaedimus, regarding the construction of fishing lines, points out that fishermen take care that the hairs forming the leader be as white as possible ( $\lambda \varepsilon v \kappa \alpha$, being the colour of seawater: cf. Q.N. 39). In this way, they are less noticeable in the sea due to their similar colour $(\mu \tilde{\alpha} \lambda$ -

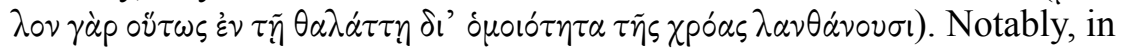
what follows in De soll. an. 976F, there is a clear parallel to Q.N. I7 (on the construction of fishing lines from the hairs of horses; see the commentary ad loc.). Indeed, Q.N. I3 and I7 are closely connected to each other by their shared interest in fishing utensils. Considering the shared link with De soll. an. 976EF, they perhaps even rely on the same hypomnematic material. Arguably, the problems that follow in Q.N. I8-I9 (on sea animals) may also pertain to this hypomnematic cluster (see the commentary ad loc.). The concatenatio of the problems is complicated at this point in the collection, however, by the incorporation of a cluster of three problems (Q.N. I4-I6) regarding the natural properties of wheat and barley.

\section{Wheat and barley (Q.N. I4-I6)}

The cluster of problems in Q.N. I4-I6 deals with three agricultural questions and is concerned, more particularly, with problems related to the constitution, growth, and nourishment of wheat and barley, the Greeks' two main cereal crops. The theme of this cluster ties in with the focus on the physical differences, and especially contrarieties, between wheat and

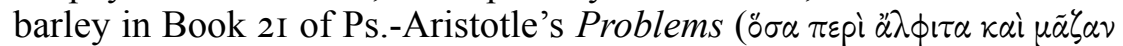

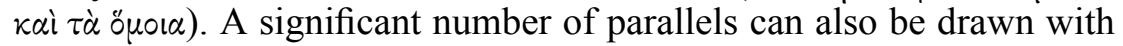
Theophrastus' botanical works, who himself on a number of occasions reflects on the physical differences between wheat and barley (e.g., $H P$ $8,4, \mathrm{I}-6)$. In $C P$ 3, 2I, 5, Theophrastus says that the growth of grain (including wheat and barley: cf. $H P 8, \mathrm{I}, \mathrm{I}$ ) depends on three universal variables: the nature of the land, the strength or weakness of the seeds and the temperature of the air. These three variables recur in the aetiologies of Q.N. I4-I6. This does not necessarily imply, however, that Theophrastus is Plutarch's direct source, since the intermediation of a set of lost problems cannot be excluded. 


\section{Q.N. I4, 915CD}

In Q.N. I4, Plutarch wonders why the people of Doris pray for a

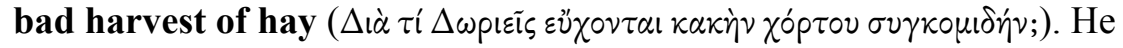
provides one explanation, which boils down to the idea that they actually pray for rainfall before the summer heat.

Plutarch argues that hay is 'badly' harvested if it gets rained on $\left({ }^{3} \mathrm{H}\right.$ kakw

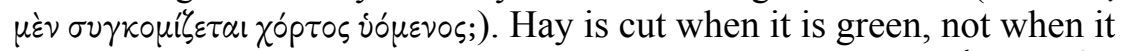

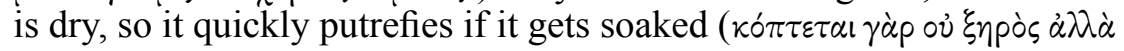

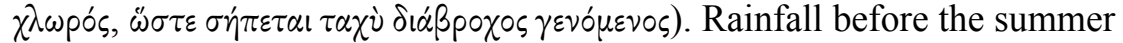
is unfavourable for hay. Grain, however, can use it as protection against

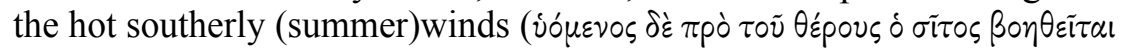

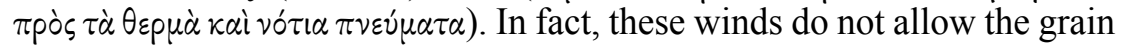
to grow firm as it forms in the ear, but they inhibit or reverse the hardening process by their heat, unless the earth is soaked so that there is lasting

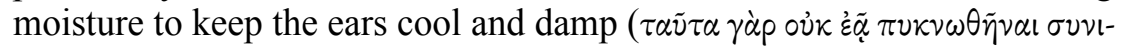

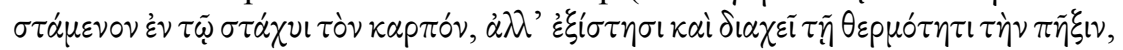

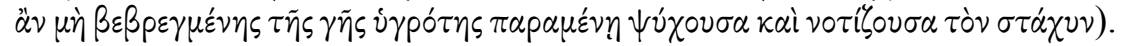

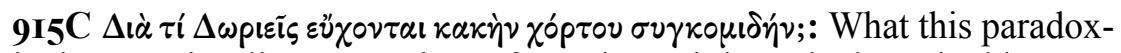
ical prayer implies, so we learn from the aetiology, is that a bad harvest of hay is connected with a good harvest of grain (cf. L. Senzasono, 2006, p. I90, n. 82). This problem reminds the reader of the type of culturalantiquarian inquiry in Plutarch's Quaestiones Graecae (cf. also Q.N. Io, $9 \mathrm{I} 4 \mathrm{D}$ and $23,9 \mathrm{I} F \mathrm{~F}$ [see 2.4.2.]). Presumably, the proper name $\Delta \omega$ pirís does not refer to all the Doric speaking Greeks, but rather to the inhabitants of Doris, a small state located on the border between Thessaly and Boeotia (see F.H. Sandbach, I965, p. I8I n. d). Doris can also refer to the region in Asia Minor, consisting of several Doric settlements and islands.

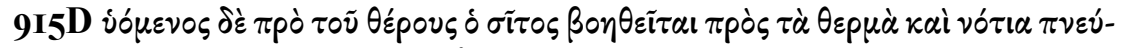

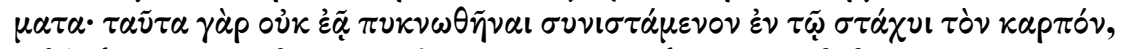

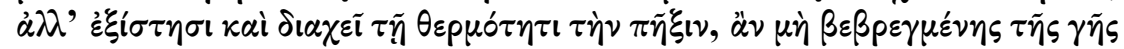

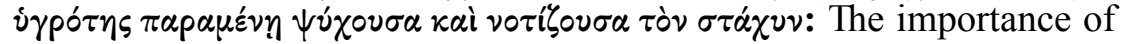

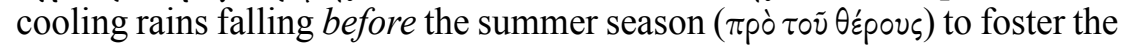
growth of grain is echoed in Q.N. 4, 913A (see the commentary ad loc.). For 'wind-blown' ( $\dot{\xi} \xi \alpha \nu \varepsilon \mu \circ \tilde{\sigma} \sigma \theta \alpha \mathrm{l}$ ) wheat and barley, cf. Theophr., HP 8, IO, 2-3. Theophrastus says, however, that the winds evaporate the moisture in the grains so that they dry and wither, whereas according to Plutarch, the southerly winds reverse the hardening process by their heat. $\mathrm{Cf}$. also $\mathrm{CP}_{4}, \mathrm{I} 3,4$. 


\section{Q.N. 15, 915DE}

In $Q . N$. I5, Plutarch wonders why a rich, deep soil bears wheat, while

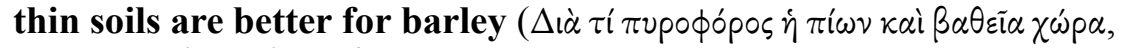

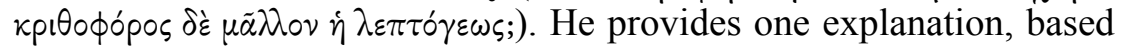
on the distinct physical properties of wheat and barley seeds (esp. their nourishment and strength).

Plutarch argues that strong seeds need more food (which is provided by the soil in which they are planted), whereas weak ones require thin and light nourishment. He also states that barley is weaker and more open in texture, so that it will not bear much or heavy food ( ${ }^{s} \mathrm{H}{ }^{\prime \prime} \tau \iota \tau \tilde{\omega} \nu \sigma \pi \varepsilon p \mu \dot{\alpha} \tau \omega \nu \tau \dot{\alpha}$

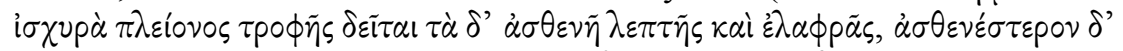

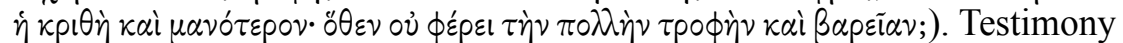
is found in the fact that the three-month variety of wheat, which gives a lower yield and requires less nourishment, grows better in dry places,

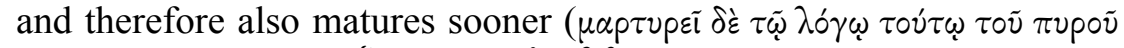

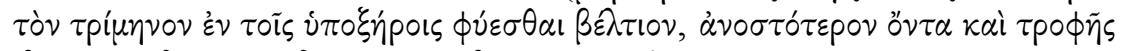

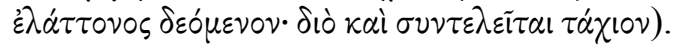

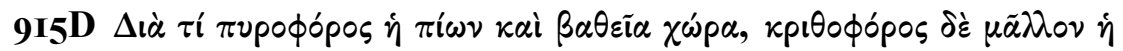

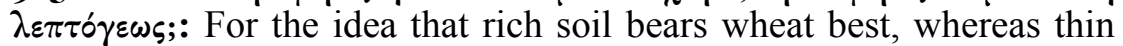

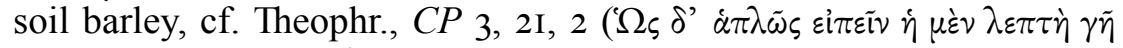

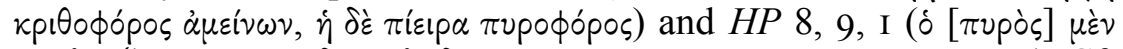

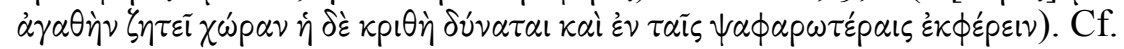
also Varro, De re rust. I, 23-24.

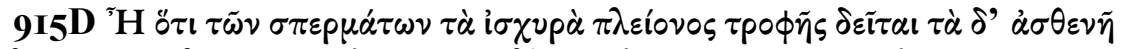

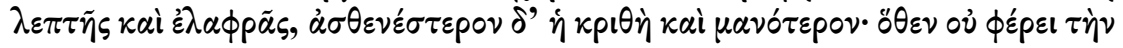

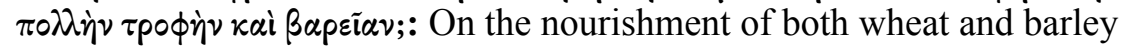

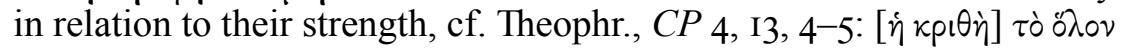

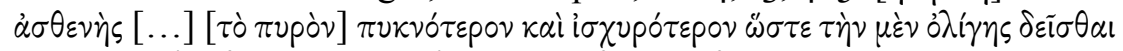

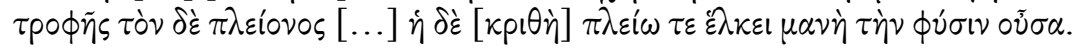

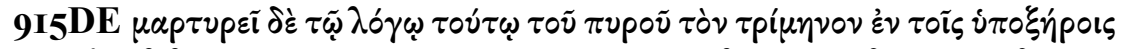

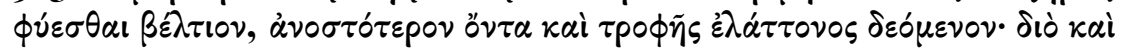
$\sigma \nu \nu \tau \varepsilon \lambda \varepsilon i \tau \alpha \iota$ $\alpha^{\prime} \chi 10 \nu$ : The three-month variety of wheat is sown in spring and is named after the fact that it takes only three months to grow (cf. Theophr., HP 8, I, 4). In his commentary on Hes., Op. 486-489 (= fr. 68 Sandbach), Plutarch reports that this kind of grain owes its growth to the spring rains (cf. Q.N. 4, 9I3A and I4, 9I5D). For the lower nutritive demands of the three-month variety of wheat, cf. Theophr., $C P$ 3, 2I, 2: T $\omega \nu$

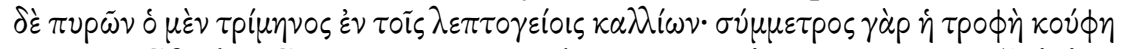

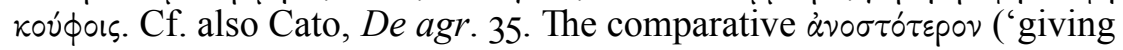


a lower yield') is only found here in $Q . N$. $15,9 \mathrm{I} 5 \mathrm{E}$ and in Theophr., $C P$ 4, I3, 2 (cf. also 3, 2I, I: $\alpha \nu 0 \sigma \tau \iota \mu \omega \tau \alpha \tau \alpha$ ). C. Hubert, I960, p. I4 suggests

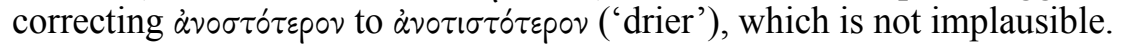
It is perhaps safer, though, to stay with the reading of most manuscripts (cf. also L. Senzasono, 2006, pp. I90-I9I, n. 85), especially because it is closer

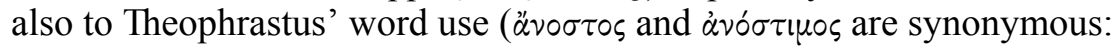

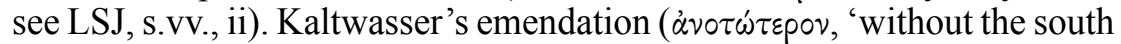
wind') is not very useful.

\section{Q.N. I6, 915EF}

Q.N. I6 is closely related to the previous problem by the topic of planting

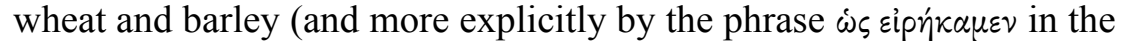
first causa). Plutarch seeks to explain the saying 'plant wheat in mud,

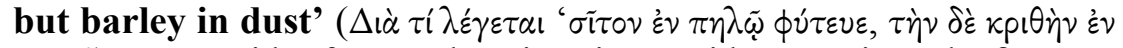

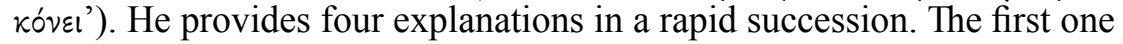
focuses on the amount of food mastered by both types of grain, the second on their composition, the third on the composition of the soil, and the fourth on the damage done to wheat by ants.

In the first explanation, Plutarch cross-refers to what was said in the previous chapter (Q.N. I5, 9I5D). He argues that wheat can master more food, whereas barley cannot stand a great and overwhelming amount

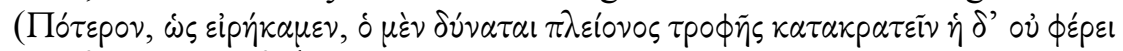

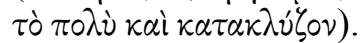

According to the second explanation, wheat, being solid and woody, grows better in damp soil, where it is softened and moistened, whereas a drier soil at the start (i.e. when the seeds are planted?) is suitable for

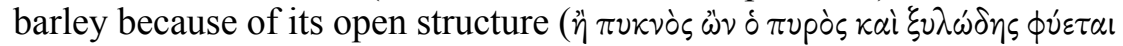

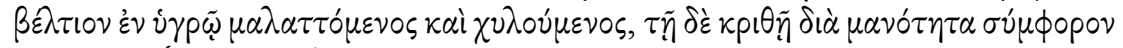

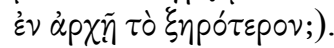

In the third explanation, Plutarch argues that the composition (of the muddy soil) is suitably proportioned and harmless (to the wheat) because

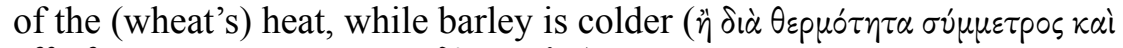

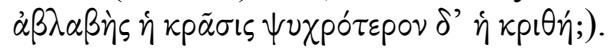

In the fourth and final explanation, Plutarch draws attention to farmers' fear of planting wheat in dry soil because of the damage done to it by

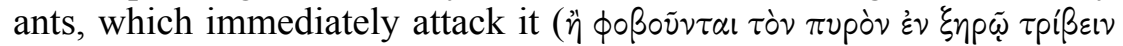

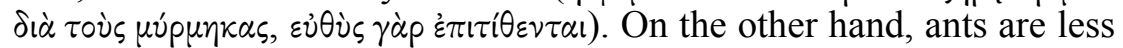
likely to plunder barley, since their grains are difficult to lift and carry

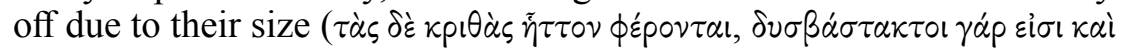
$\delta \nu \sigma \pi \alpha \rho \alpha \kappa o ́ \mu ı \tau \tau ం เ ~ \delta i \dot{\alpha} \mu \varepsilon ́ \gamma \varepsilon \theta \circ$;). 


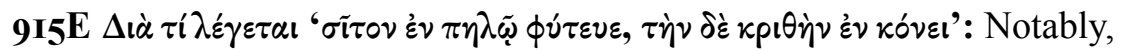
the proverb reads $\sigma i \tau o v$, not $\pi$ upóv, but Plutarch interprets it as wheat in his aetiology (i.e. barley's counterpart). E. Diehl, I925, p. 197, I6 included this verse in his collection of carmina popularia. According to L. Senzasono, 2006 , p. I9I, n. 86, it is an agricultural proverb (rather than a riddle) with a clear instructional meaning. It is perhaps a bit strange, however, to literally plant barley, or anything else, in dust or ashes (kóvis). The same is true for planting wheat in the mud. A similar saying is explained in Ps.-Arist.,

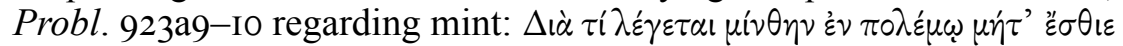

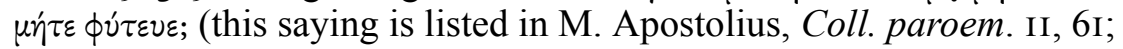
see E.L. Leutsch, I965, pp. 530-53I).

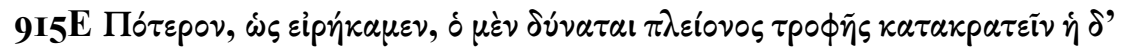

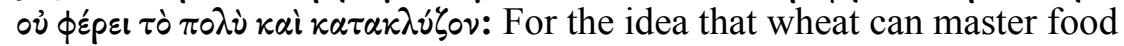

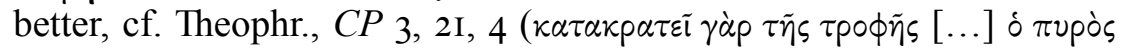

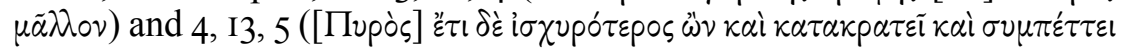
$\mu \tilde{\alpha} \lambda \mathrm{\gamma} \sigma)$.

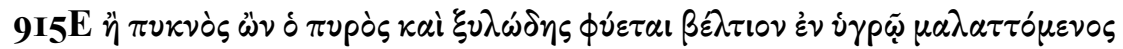

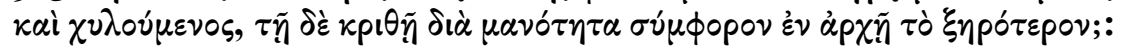
According to Theophr., $C P$ 3, 2I, 4, wheat grows better in rainy regions and is more resistant to rains than barley. Regarding the open texture of

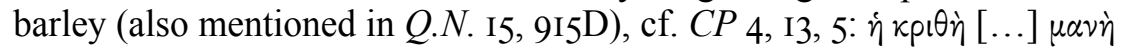
$\tau \grave{\eta} \nu \phi u ́ \sigma เ \nu$ õ $\sigma \alpha$.

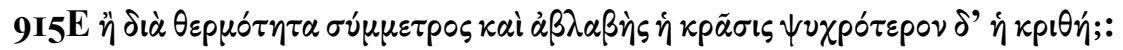
The formulation of this causa is concise. I take $\delta i \dot{\alpha} \theta \varepsilon p \mu o ́ \tau \eta \tau \alpha$ to refer to the natural heat of the wheat and not of the muddy soil in which it is planted, although this is not impossible from a syntactical perspective (cf. F.H. Sandbach, 1965, pp. I84-I85 with n. a and L. Senzasono, 2006, p. I92, n. 88). After all, muddy soil is more likely to be cold as it is drained with cool water (cf. Q.N. I4, 9I5D), as opposed to dusty soil, which is drier and, by implication, hotter. If this is correct, Plutarch implies that a hot plant (c.q. wheat) requires a cold soil (c.q. mud) and a cold plant (c.q. barley) a hot one (c.q. dust). A relevant parallel for this is found in Quaest. conv. 648CD, where Ammonius refers to Harpalus' failure to plant ivy in Babylonian soil: this is ascribed to the natural heat of the plant (cf. Theophr., $C P$ 4, 4, I; cf. also Alex. 35, I5). Ivy, being naturally hot itself, cannot become acclimated to the hot Babylonian soil and withers because of the excessive heat: 'what is cold loves heat, and what is hot

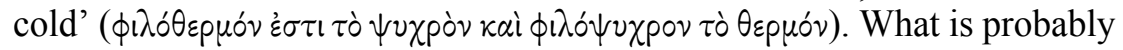
meant in Q.N. I6, then, is that the cold, muddy soil is commensurate ( $\left.\sigma \dot{v} \mu \mu \varepsilon \tau \rho \sigma^{\prime}\right)$ to the wheat, which is hot ( $\left.\delta \dot{\alpha} \theta \varepsilon p \mu o^{\prime} \tau \eta \tau \alpha\right)$, and - vice versa that barley, being colder ( $\psi$ upó́ $\varepsilon p o v)$, requires a warmer, drier, dusty soil. 
For the required commensuration ( $\sigma \nu \mu \mu \varepsilon \tau p i \alpha)$ of the composition (кpã $\sigma ا \varsigma)$ of the soil to the plant growing in it, cf. also Theophr., $C P$ 2, 9, 7: हl $\tau ا \varsigma$

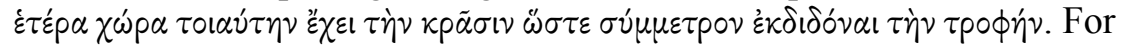
the coldness of barley, cf. Hipp., De victu. 2, 40, and for the heat of wheat, cf. Theophr., CP 3, 2I, 4. In Quaest. conv. 697B, the natural heat of wheat is illustrated by the fact that wine is quickly evaporated when wine jars are placed in the wheat pits.

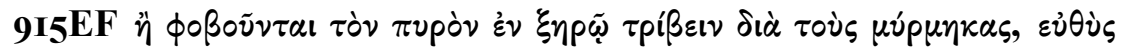

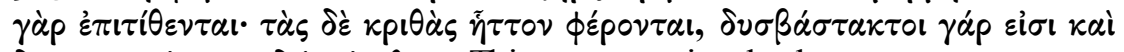

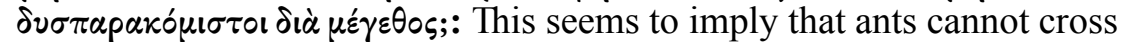
humid soil (c.q. mud); otherwhise they would be able to steal the wheat grains. According to this logic though, one may wonder why barley is not planted in humid soil just as well - the ants cannot carry its grains anyway, so it would not really matter -, but this point was already explained in the previous causae. On the cleverness (and virtuousness) of ants more generally, see De soll. an. $967 \mathrm{D}-968 \mathrm{~B}$ (where allusion is again made to ants' reluctance toward humidity in the quotation from Arat., Phaen. 956). Michael Glycas also refers to ants' reluctance toward barley and

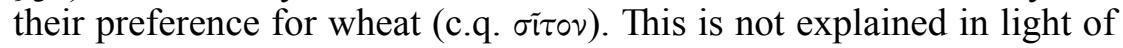
the magnitude of the grains of barley but of the odour given off by their

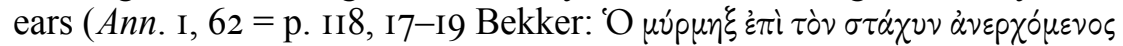

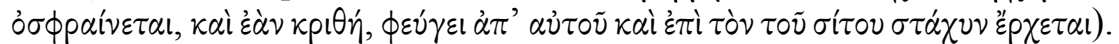
For ants' perception of smells, cf. Arist., De sensu 444bi2. Theophr., $H P$ 8 , IO, 4 is concerned with the damage caused by grubs $(\sigma \kappa \omega \dot{\lambda} \lambda \eta \kappa \varepsilon \varsigma)$ to the roots and ears of wheat. According to L. Senzasono, 2006, pp. 192-193, n. 89 the term $\sigma \kappa \omega \dot{\lambda} \eta \kappa \varepsilon \varsigma$ in that passage may indicate 'larvae of insects', and thus also of ants. This, however, is speculation and Plutarch does not speak of grubs or larvae at all.

\section{Sea animals and fishing (Q.N. 17-I9)}

The three problems that follow in Q.N. I7-I9 deal with the topic of sea animals and fishing. From a thematic perspective Q.N. I3 links up closely with Q.N. I7 (both problems deal with fishermen utensils). Based on several parallel accounts in a relatively short section of De sollertia animalium (viz. 976E-977A, 978EF, 979B; see the commentary below), there may be reason to assume that Q.N. I3 and I7-I9 are modelled on the same or similar hypomnematic material (it is unlikely, therefore, that there is a chronological rupture in composition between Q.N. I8 and I9 [see the prologue, n. 24]). No clear source can be appointed for these chapters, but it can be presumed that Plutarch, at least in part, relies on 
Peripatetic zoology (see, e.g., the quote from Theophrastus' De animalibus colorem mutantibus in Q.N. I9, 9I6B). As always, the intermediation of lost Ps.-Aristotelian problems cannot be excluded.

\section{Q.N. $17,915 \mathrm{~F}-916 \mathrm{~A}$}

In Q.N. I7, Plutarch wonders why people use the hairs of stallions rather than those of mares to manufacture fishing lines $(\Delta \dot{\alpha} \alpha \tau \tau \tilde{\omega} \nu$

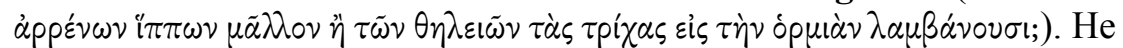
provides two short explanations. According to the first, the properties of the horse's body as a whole are also present in its smaller body parts, even in its smallest ones (c.q. its hairs). In the second, Plutarch makes a more concrete distinction between the male and the female body, where attention (implicitly) goes to their different anatomy.

In the first explanation, Plutarch argues, by analogy with the relative strength in other body parts, that the stallion has stronger hair than the mare

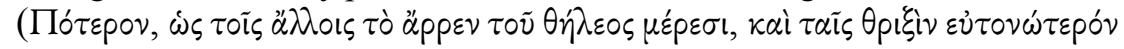
$\dot{\varepsilon} \sigma \tau \tau \nu ;)$.

In the second explanation, he suggests that people rather believe that the mares' hairs become inferior because they are wetted by their urine ( $\eta$

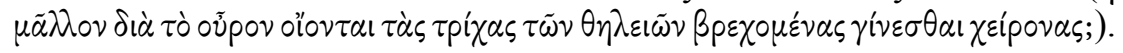

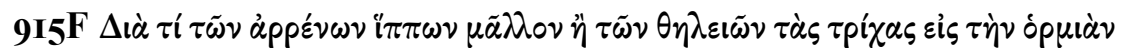
$\lambda \alpha \mu \beta \alpha \alpha^{2} \sigma v \sigma l ;:$ As appears from the second explanation, "[t]he hairs of the tail are in question" (F.H. Sandbach, I965, p. I85, n. c).

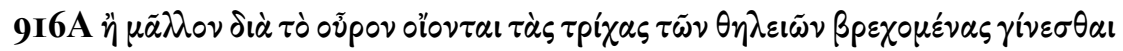
$\chi \varepsilon i$ povas;: The argument is based on the anatomical dissimilarity between the male and the female body. The reported discomfort is strange to stallions, since their tails, as opposed to those of mares, are not located in the vicinity of the urethra. The same explanation is given in a parallel

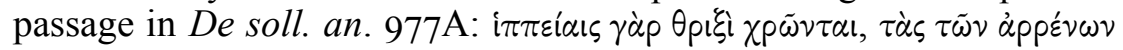

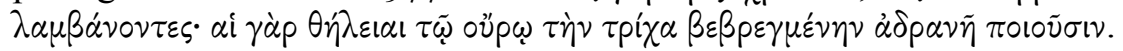
This passage probably originates from the scholia on Hom., Il. 24, 8082 (quoted in De soll. an. 976F, with reference also to Archil., fr. 57

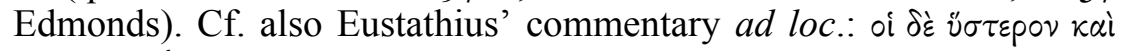
i $\pi \pi \varepsilon i \alpha \iota s \theta p i \xi i ~ \chi p \tilde{\omega} \nu \tau \alpha \iota$. Cf. H. Cherniss and W.C. Helmbold, I957, p. 423, n. f.

\section{Q.N. I8, 9I6AB}

The following problem in Q.N. I8 originates from popular weather lore (cf. also Q.N. 2 and 4). Plutarch wonders why the appearance of the 


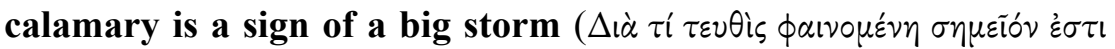
$\mu \varepsilon \gamma \alpha \dot{\lambda} \circ \cup \chi \varepsilon \varepsilon \mu \tilde{\omega} \nu \circ \varsigma ;)$. He gives only one explanation, which draws specific attention to the etymology of the word $\mu \alpha \lambda \alpha \kappa \iota \alpha$ (cephalopods; literally 'soft things', 'molluscs').

Plutarch argues that all cephalopods by nature are sensitive to cold due to their bodily construction. Their flesh is bare and naked, they are not covered with a shell, skin or scales, and their hard and bony parts are located inside, which is why they are called 'soft things' (' $\mathrm{H} \pi \dot{\alpha} v \tau \alpha \phi \dot{v} \sigma \varepsilon$ l

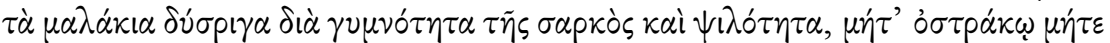

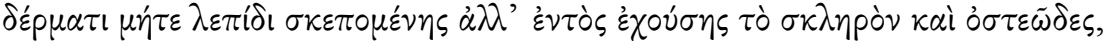

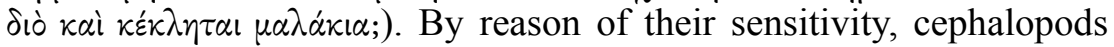
quickly become aware of the impending storm ( $\tau \alpha \chi \dot{\nu} \delta \dot{\eta} \pi p \circ \alpha 1 \sigma \theta \dot{\alpha} \nu \varepsilon \tau \alpha$ l

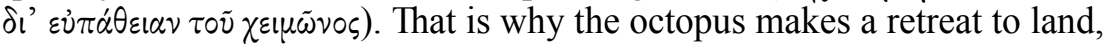
and when it grasps small rocks, it is a sign of imminent winds, whereas the calamary jumps out of the water in an attempt to escape the cold and the

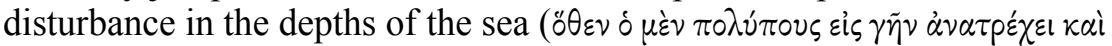

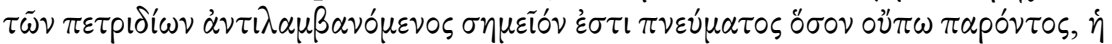

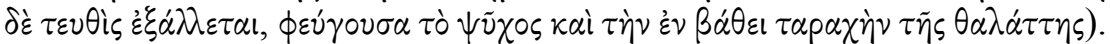
At the end of the explanation, Plutarch adds that the calamary has the most fragile and delicate flesh of all of the cephalopods (this results in an

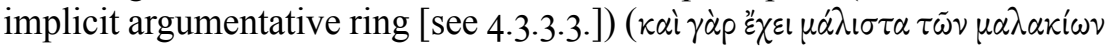

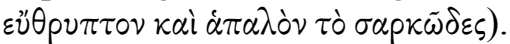

9I6A $\tau \varepsilon v \theta i c:$ See LSJ, s.v.: "calamary or squid, Loligo vulgaris". See also A. Dalby, 2003, p. 3II, s.v. "squid": "When used specifically, Greek teuthis is the name for the small Loligo vulgaris and related species. Greek teuthos is the name for full-grown specimens of the much larger species Todarodes sagittatus and its relatives. This is the squid that can fly, though it does not fly far." According to Varro's Latin etymology (De ling. Lat. 5, 79), the lolligo was originally called volligo because it flies up. It is probably better to speak of 'leaping', though, as Plutarch

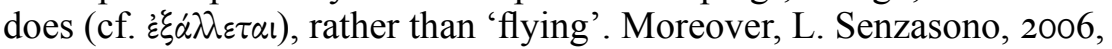
p. 195, n. 94 notes that the loligo vulgaris (the calamary) does not fly out of the water, but that the loligo volitans does (on which, cf. Pliny, $\mathrm{NH}$ I8, 36I and 32, I49: probably to be identified with the flying fish, i.e. the family of exocoetidae). He points out that both animals were probably mistaken for one another in Antiquity. For further references on squids 'flying' in the manner of flying fish, see D'A.W. Thompson, I947, p. 260 .

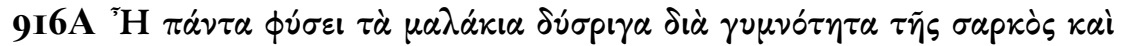

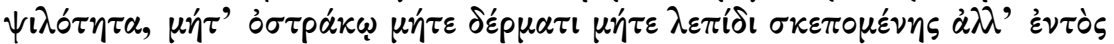

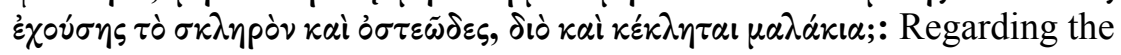


octopus' intolerance of cold (and sweet) water, cf. also Theophylactus Simocatta, Quaest. phys. 9 (J.L. Ideler, I84I, p. I76, I2-34).

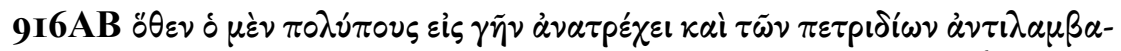

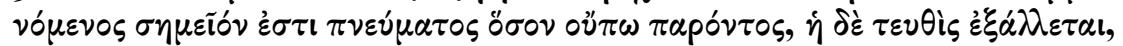

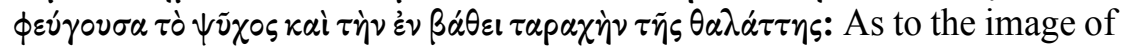
the octopus clinging to small stones in order to remain balanced, a similar remark can be found in De soll. an. 979B, where Plutarch reports that the sea-hedgehog has the same habit: it clings to small rocks $\left(\lambda_{\imath} \theta_{\iota} \delta\right.$ íos$)$ in order not to capsize or be swept away by the swell when it senses a

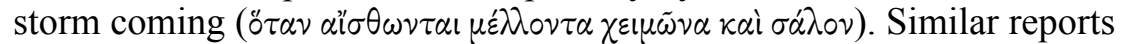
about the octopus, calamary, cuttlefish and the like clinging to (small) rocks in order to remain steady are found, e.g., in Arist., $P A$ 685a3o-b2, HA 523b32-33, Ael., NA 5, 4I, Ath., Deipn. 7, 323d (= Arist., fr. 338 Rose), Pliny, $N H$ 9, 83; I8, 36I. Cf. also Sept. Sap. conv. I63D (a giant octopus carries along a stone) and De soll. an. 967AB (bees ballast themselves with little stones). For the calamary's peculiar ability to leap out (' $\xi^{\xi} \dot{\alpha} \lambda \lambda_{\varepsilon \tau \alpha l)}$ of the sea and 'fly' in the air, cf. Opp., Hal. I, 429-432 (in order to escape its attackers); 3, I66-I67, Ael., NA 9, 52 (out of fear), Cic., De div. 2, I45, I2-I4, Pliny, NH 9, 84; I8, 36r; 32, I5 and I49 (loligo volitans). According to A.F. Scholfield, I958, p. xxii "there can be little doubt that Aelian has paraphrased Oppian". If this is correct, Plutarch and (Aelian via) Oppian possibly rely (either directly or indirectly) on the same or similar source, presumably of Peripatetic origin, perhaps Theophrastus' De signis (cf.

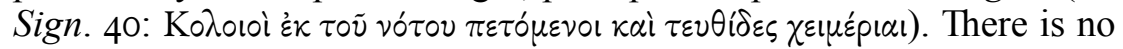
reason to assume, however, that Plutarch relies on personal observation for the differences in explanation with Aelian (pace L. Senzasono, 2006, p. I94, n. 94). Moreover, the idea that the calamary jumps out of the water in an attempt to escape the cold and the disturbance in the depths of the sea is contradicted in Q.N. 8,9I4B, where Plutarch reports that the sea becomes warmer when it grows rough, not colder [see 4.3.3.I.].

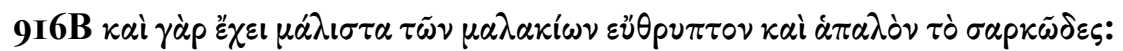
The idea that the calamary has the most fragile and delicate flesh of all cephalopods implies that it is also the most sensitive. Cf. Arist., PA 678b32:

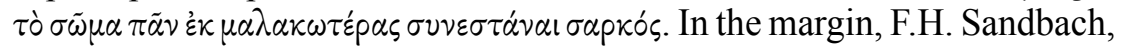
I965, p. I86, n. d remarks that the calamary's "bony processes are smaller than those of the cuttlefish but not than those of the octopus". The main focus here is, of course, on the calamary and less on the octopus (to which Plutarch turns in the next problem). 


\section{Q.N. 19, 9I6BF}

Q.N. I9 is the most extensive problem in the collection and concerns

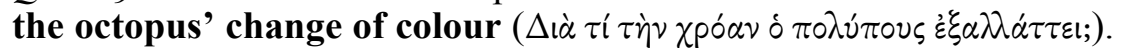

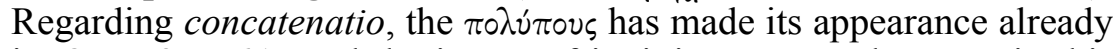
in Q.N. I8, 9I6A, and the image of it sitting on a rock recurs in this problem. There is a relatively large cluster of parallel passages for this phenomenon throughout Plutarch's oeuvre (cf. Alc. 23, 4-5, De ad. et am. 5ID-53D, De am. mult. 96F, De soll. an. 978EF), which I have presented schematically earlier on [see 2.I.2.]. Plutarch provides three explanations for the phenomenon here, which are closely connected to each other. The first one deals with the octopus' change of colour by a physiological process in the animal's body involving its breath $(\pi v \varepsilon \tilde{\nu} \mu \alpha)$, the second draws attention to the fact that the octopus not only changes, but also adapts its colour to its surroundings and the third tries to explain the natural mechanism that lies behind this adaptation (therefore, it is also the most comprehensive of the three, explaining both the change and the adaptation of the octopus' colour).

In the first causa, Plutarch gives Theophrastus' opinion, according to which the octopus is by nature a cowardly animal. Thus, when it is agitated, it undergoes a change by its breath and simultaneously alters its

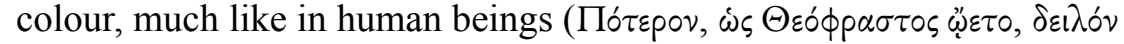

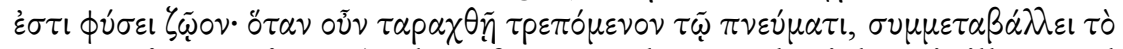
$\chi \rho \tilde{\omega} \mu \alpha \kappa \alpha \theta \dot{\alpha} \pi \varepsilon \rho \ddot{\alpha} \nu \theta \rho \omega \pi \circ \varsigma)$. The reference to human physiology is illustrated with the Homeric saying that 'the coward's complexion alters' ( $\delta_{1} o$ kai

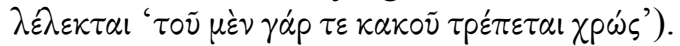

In the second causa, Theophrastus' argument is considered insufficient. Even though it is a plausible explanation for the change of the octopus' colour, it does not account for its assimilation to its surroundings

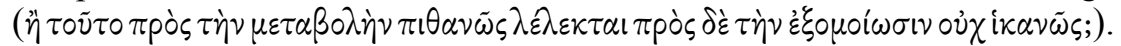
Plutarch further explains that the octopus changes in such a way that it

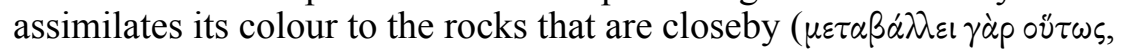

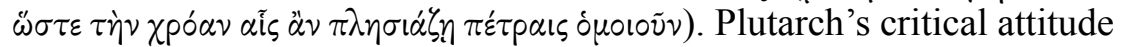
becomes more pronounced when he quotes two poets in order to illustrate the aspect of assimilation. First he gives an excerpt from Pindar, who wrote: 'matching most in mind the sea beast's complexion, take in every

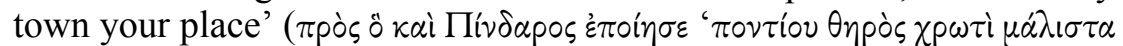

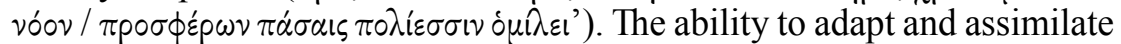
to one's surroundings ( $\delta \mu \lambda \varepsilon \varepsilon)$ is echoed in the distich by Theognis that follows: 'acquire the mind of the many-coloured octopus, that looks to

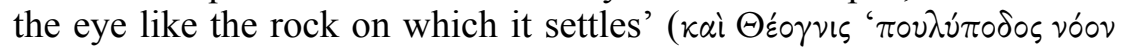

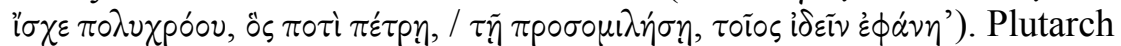
continues that they (viz. the poets) say that people who are very clever 
and cunning also have this habit; they always imitate the octopus in order

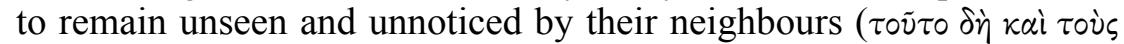

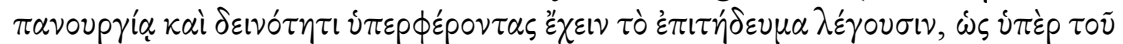

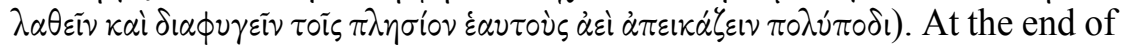
the causa, Plutarch ridicules Pindar and Theognis, wondering ironically whether they believe that the octopus treats its colour like a garment that can be easily changed whenever the animal wishes (

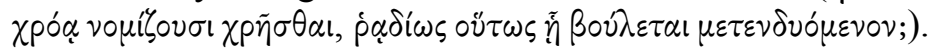

At the beginning of the third causa, Plutarch suggests that the octopus itself initiates the effect by feeling fright, but that the determining factor

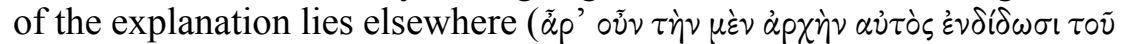

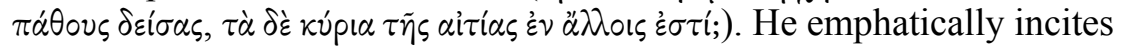
the reader to consider Empedocles' theory of emanations, according to

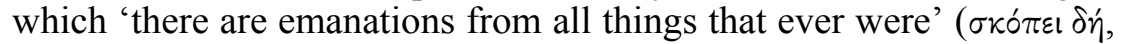

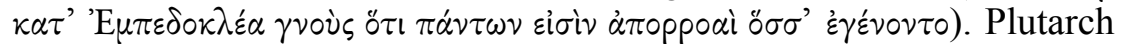
explains that many streams of particles continuously emanate not only from animals, plants, the earth and the sea, but also from stones, bronze

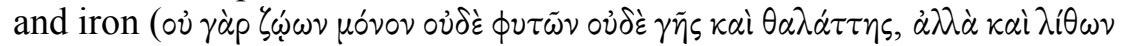

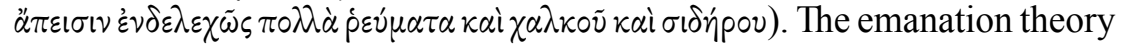

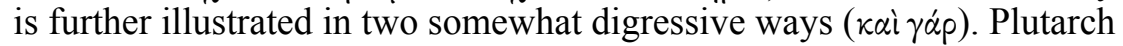
first notes that everything that decays or gives off a smell does so because some part is continuously streaming away and departing from it (kai yà

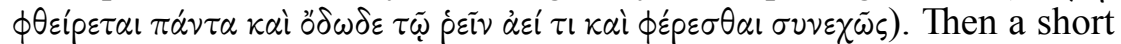
digression into magnetism follows. Plutarch notes that people explain the phenomenon of attraction or jumping (in magnetism) by emanations, some assuming it to be due to entanglements, others to impacts, and

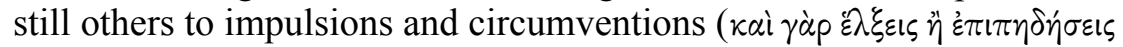

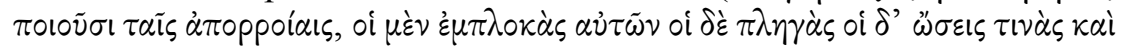
$\pi \varepsilon p เ \varepsilon \lambda \varepsilon \dot{\sigma} \sigma \varepsilon เ \zeta$ i $\pi \circ \tau \imath \theta \varepsilon \varepsilon \varepsilon v 01)$. After these digressive illustrations, the discourse returns to the main line of explanation. Plutarch argues that it is likely that many fine particles are constantly detached from rocks lying by the seashore as they are sprayed and battered by the sea. These particles do not adhere to the body of any animal (except the octopus), and they cannot be seen because they either slip off the skin of animals that have narrower pores or pass through those that have more open ones $(\mu \dot{\alpha} \lambda \mathbf{\lambda} \sigma \tau$

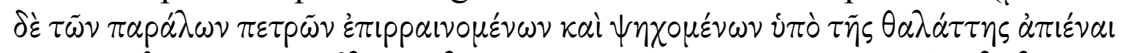

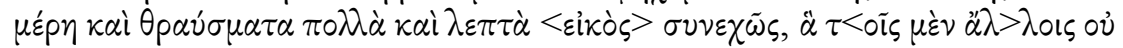

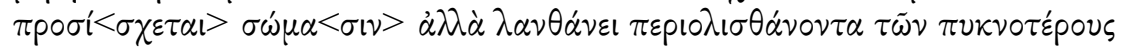

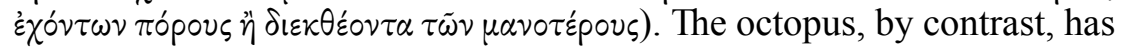
flesh that is obviously honeycombed in appearance and full of pores and

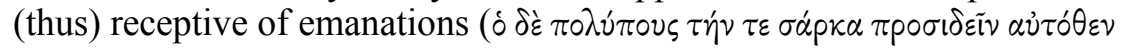

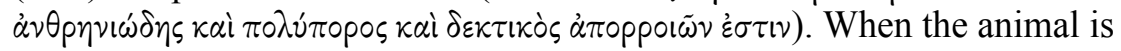
frightened, it undergoes and effects a change by its breath (cf. causa one), by compressing, as it were, and contracting its body, so that it receives and 
shelters the emanations from nearby objects on its surface (

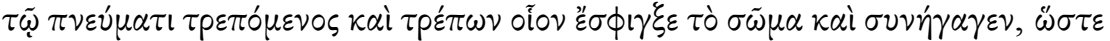

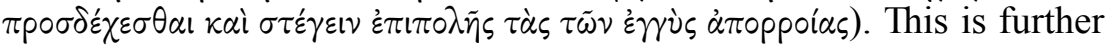
explained by the fact that (the skin's) roughness, in combination with (its) softness, provides places of lodgement for the particles that settle on it and do not disperse but collect and remain in place. As such, the roughness causes the surface (of the skin) to take on the same colour as

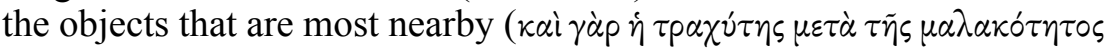

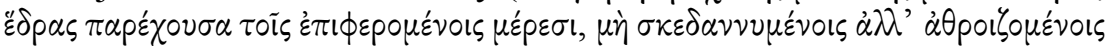

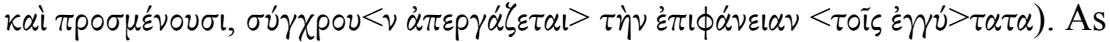
an important piece of evidence, at the end of the explanation, Plutarch refers to the fact that the octopus does not take on a likeness to all of the objects nearby, nor does the chameleon take on a likeness to pale objects. In fact, both animals only take on a likeness to those objects that have emanations to which their pores are commensurate ( $\tau \varepsilon \kappa \mu \eta_{p}$

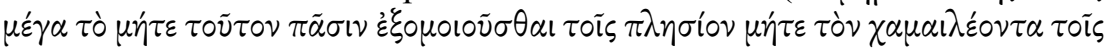

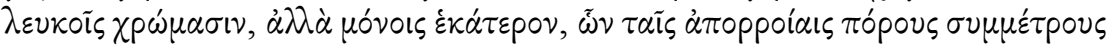

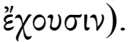

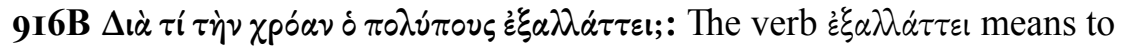
"change utterly" (LSJ, s.v.) and does not imply an element of adaptation. Nevertheless, this aspect of adaptation will play an important role in Plutarch's aetiology (viz. in the second and third causae).

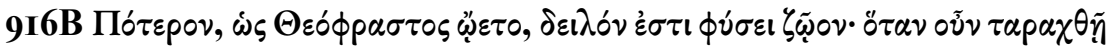

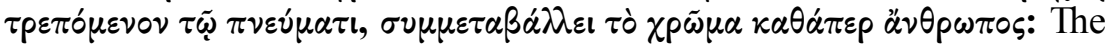
basic idea here ( $=$ fr. I88 Wimmer $=365 \mathrm{C} \mathrm{FHSG}$ ) is that the octopus' passive sensation of fear triggers an active movement and change in the body (c.q. metachrosis) by the intermediation of the $\pi \nu \varepsilon \tilde{u} \mu \alpha$ (cf. F.H. Sandbach, I965, p. I87, n. f). This is reminiscent of Aristotle's $\pi v \varepsilon v \tilde{\mu} \alpha$ theory, where $\pi v \varepsilon \tilde{u} \mu \alpha$ is famously described as an óp $\gamma \alpha \nu \circ \nu$ of the soul, by which movement is imparted to the body ( $D A 433$ bi 8, $G A$ 789b8-9; cf. also esp. $M A$ 703a3-bi). As we learn from Athenaeus, Theophrastus' account originates from his lost De animalibus colorem mutantibus (D.L. 5, 44), where the octopus' metachrosis is attributed to its fear and need for protection (Theophr., fr. I73 Wimmer $=365 \mathrm{~B}$ FHSG $=$ Ath., Deipn. 7 ,

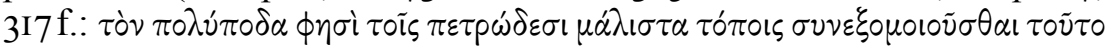

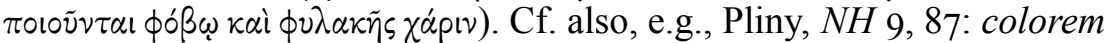
mutat ad similitudinem loci, et maxime in metu. Theophrastus is probably

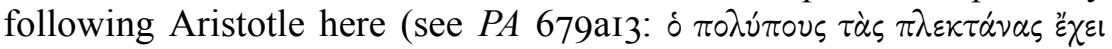

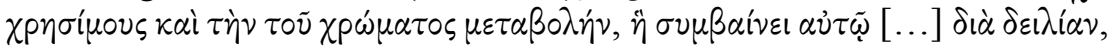
cf. also $H A$ 622aI5). Several parallels for this phenomenon have been collected by V. Rose, I863, pp. 362-365 (to which Clem. Al., Paed. 3, II, 80,2 can be added). 


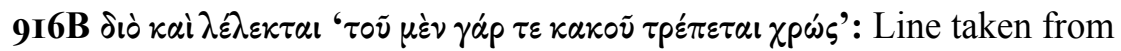
the conversation between Idomeneus and Meriones on heroes and cowards (Il. 13, 279). In De virt. mor. 452A Plutarch quotes from the same Homeric

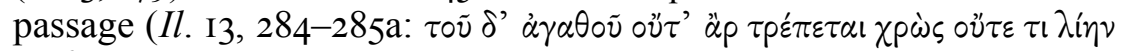
$\tau \alpha \rho \beta \varepsilon i \overline{)}$. In Q.N. I9, however, the focus is on the physical rather than the ethical side of cowardice (which is reminiscent of the general line of

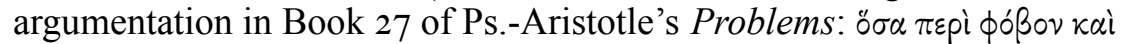
$\alpha \nu \delta \rho \varepsilon i \alpha \nu$ [see I.2.5, n. 226]). Pliny, $N H$ II, 224-225 ascribes the change in colour to the variation of the blood supply.

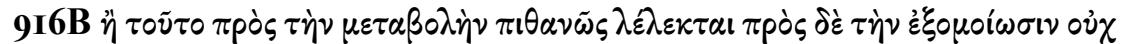

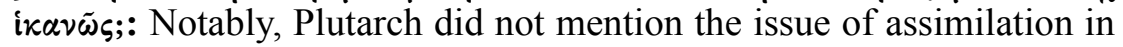
the quaestio, where he only refers to the octopus' change of colour (cf. $\dot{\varepsilon} \xi \alpha \lambda \dot{\alpha} \tau \tau \varepsilon$ : see the commentary ad loc.). For the aspect of assimilation, cf. also, e.g., Ael., VH I, I and Antig. Car., Hist. mir. 25a, I-2; 50, I-2.

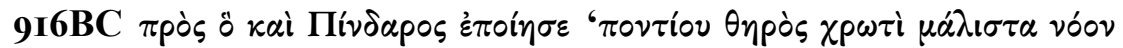

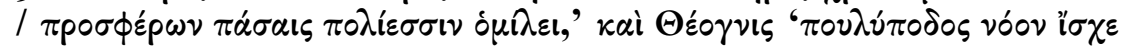

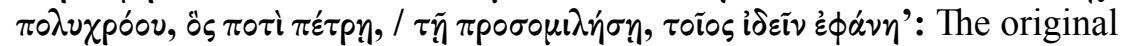
context of Pindar's quote (= fr. 43 Snell) is Amphiaraus' advice to his son Amphilochus, that he has to adapt to the circumstances in which he finds himself. Theognis' lines (2I5-2I6 West) are part of the poet's advice to Cyrnus to adapt his $\tilde{\eta} \theta 0$ s to each one of his friends' characters (alternatively, the poet may also be addressing his own Avuós: cf. 213 West, see B.A. Van Groningen, I966, p. 82). The two quotations may have been taken from one and the same intermediate source where they were already combined. They both recur in De soll. an. $978 \mathrm{E}$ and are also clustered in Ath., Deipn. I2, 5I3cd (see also 7, 317a). The lines from Theognis are also quoted separately in De am. mult. 96F. Plutarch may be relying on a Peripatetic tradition, more precisely on an intermediary derivation from Theophrastus, e.g., via a lost problem (see A. Peretti, I953, p. 96, n. I and F.R. Adrados, 1958, pp. 3-4; see also F.H. Sandbach, I965, p. 136 and L. Senzasono, 2006, pp. 197-198, nn. 99-I00).

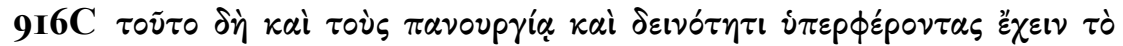

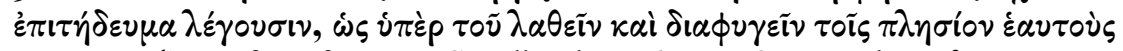

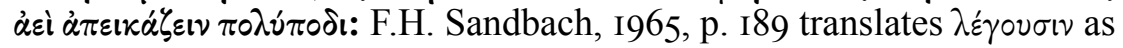

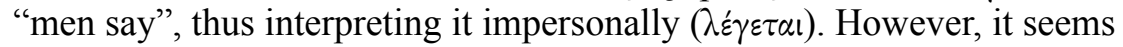
more natural that Pindar and Theognis are the subjects of $\lambda \varepsilon$ '

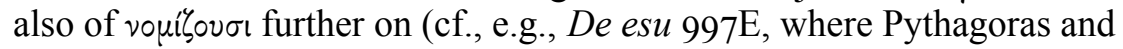
Empedocles are the subjects of $\left.\phi \eta^{\prime} \sigma o v \sigma \iota\right)$. Indeed, what 'they say' according to Plutarch's interpretation is in agreement with the original context of the quotes just recorded (see the previous comment). Sandbach marks

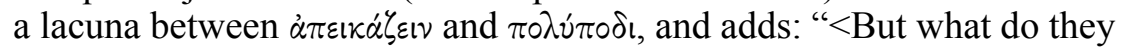


suppose to be the mechanism of change> in the octopus?" (cf. De soll.

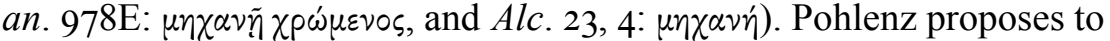
insert onoíws. There is no lacuna in the manuscripts, though, but, even so, Sandbach's interpolation does nicely capture what Plutarch seems to be implying (no modifications should be made to the text to make this more explicit, though). In what follows it is clearly Plutarch's intention to criticise the poets and their moralising interpretation of the natural phenomenon at hand. What Plutarch is probably implying, then, is that the octopus' colour change is not the effect of a deliberate choice: it is

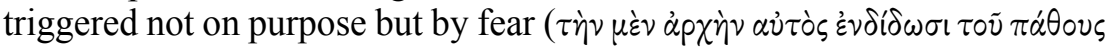
$\delta \varepsilon i \sigma \alpha \varsigma \kappa \tau \lambda$.). According to L. Senzasono, 2006, p. I98, n. IOI, an element of fear rather than friendship is already present in Plutarch's interpretation of the poets, but this seems unlikely (the context of friendship is clear from the parallels in De ad. et am. 5ID and De am. mult. 96F-97A).

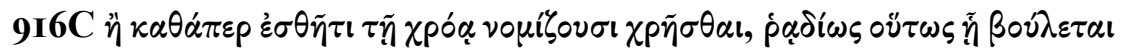
$\mu \varepsilon \tau \varepsilon v \delta$ ชó $\mu \varepsilon v o v ;:$ The irony in Plutarch's literary criticism of the two poets is clear here (the register of which is exceptional to the overall denotative style of the collection [see I.2.4., n. 204]). Cf. also Amatorius 767A: $\ddot{\omega} \sigma \pi \varepsilon p$ i $\mu \alpha \tau i \omega \nu$. At the same time, this phrase raises the question of whether the octopus deliberately changes its colour or not, that is, whether the adaptation is based on a rational decision or on the emotion of fear. In De soll. an. 978EF, Phaedimus argues that the octopus' metachrosis (as opposed to the chameleon's; see further) is not due to an emotional reaction

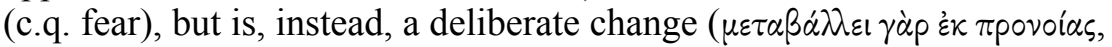

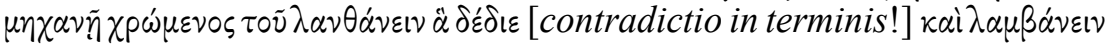

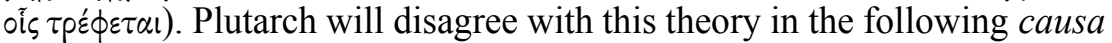
in Q.N. I9, where he argues that the octopus itself initiates the effect by

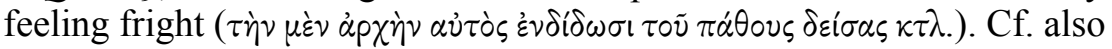
F.H. Sandbach, I965, pp. I36-I37. Additionally, the quotations from Pindar and Theognis (and also from Homer in the first causa) oblige Plutarch to incorporate a certain degree of ethical 'depth' in his explanation (cf. De am. mult. 96F [see I.2.4.]). See L. Senzasono, 2006, p. I98, n. IOI. He complies with this only for the purposes of a refutation, that is, a proof of default thereof. Plutarch knows, after all, that the octopus' change of colour cannot be adequately explained in terms of purely mental or ethical categories, but that it must have a genuine natural cause and a physical and

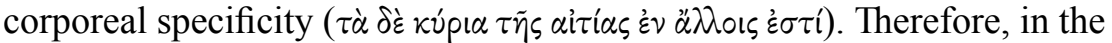
third and final causa, Plutarch - presumably in his personal contribution to the problem - provides an explanation based on Empedocles' theory of emanations.

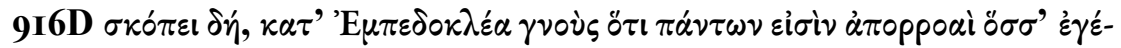

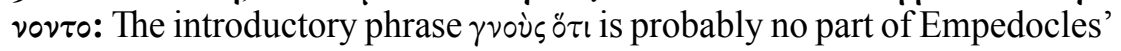


fragment (= DK3IB89) (see F.H. Sandbach, I965, p. I88 and L. Senzasono, 2006 , p. 199, n. I02), although this is not impossible from a metrical viewpoint (see C. Hubert, I960, p. I6). J.P. Hershbell, I97I, p. I8I considers this quote from Empedocles to be an example of Plutarch's polemical and eclectic attitude towards the Peripatetic school in Quaestiones naturales. The least that can be said is that Plutarch is trying to complete - rather than to reject - Theophrastus' theory with it, as formulated in the first causa. Moreover, we have no account of the octopus' change and assimilation of colour by Empedocles - if he actually had an opinion about it. In fact, according to F.H. Sandbach, I965, p. I37, "Plutarch would seem to be summarizing some account of the emanation theory that had no original connexion with the problem of the octopus". There may be reason to assume, therefore, that we are dealing in this third causa with Plutarch's personal contribution to the problem (see M. Meeusen, 20I2a). This may be indicated by the introduction of the explanation with the phrase $\sigma$ ró $\pi \varepsilon$ l $\delta \dot{n}$ [see I.I.4., n. III], and by, what Sandbach calls, a return to a "full style" (he additionally marks the presence of several coupled synonyms: $\mu \varepsilon p \eta$ кai

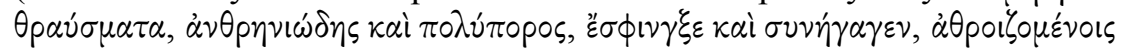

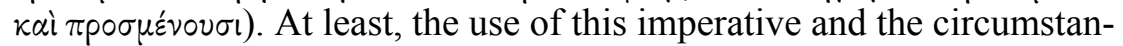
tiality of discourse may hint at Plutarch's enthusiasm for expounding what he believes is the 'determining factor of the explanation' ( $\tau \dot{\alpha} \delta \dot{\varepsilon}$ kv́p $1 \alpha \tau \tilde{\eta} s$ aitias).

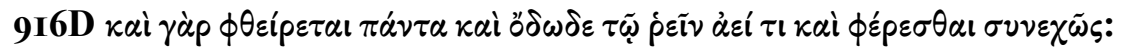
For Empedocles' theory of smells and our perception thereof, see the (critical) doxography of Theophr., Sens. 20 (= DK3IA86): $\varepsilon \dot{\eta} \dot{\eta} \phi \theta i \sigma ı s \delta i \dot{\alpha} \tau \dot{\eta} \nu$

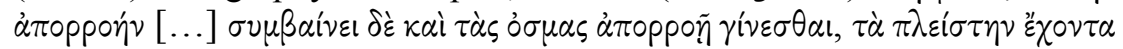

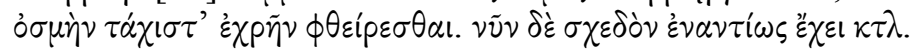

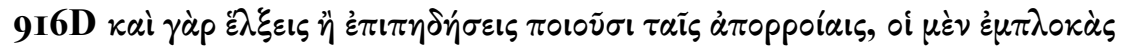

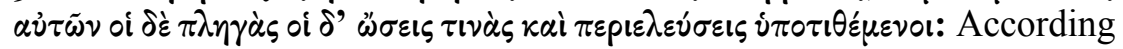
to F.H. Sandbach, 1965, p. I37, this digression into magnetism "contains barely intelligible and certainly irrelevant detail". On closer inspection, however, the passage is relatively clear and is not that irrelevant for the aetiology either. The same is true for the previous account about decay and smell (see the previous comment). By incorporating these two accounts Plutarch does, indeed, postpone the actual point that he aims to make with the quote from Empedocles, but they do still come in handy to illustrate the emanation theory. In fact, the octopus' metachrosis is presented as a third instance of this theory (besides that of smell and magnetism). The enumeration of technical terms does, however, seem to be unsystematic: the passage contains references to Democritus/Epicurus ( $\xi \mu \pi \lambda \circ \alpha \alpha i / \pi \varepsilon p 1 \pi \lambda \circ \alpha \alpha i$ : interlacing of atoms, $\pi \lambda \eta \gamma \alpha i$ :

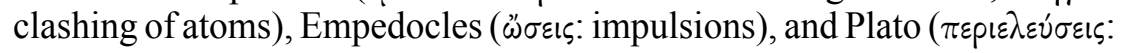


circumventions; see below). An important doxographical source for our understanding of ancient theories on magnetism is Alex. Aphr., Quaest. 2, 23 (= Psellus, De lapid. 26). This passage summarises the magnetic theories of Empedocles (DK3IA89), Democritus (DK68Ai65) and Diogenes of Apollonia (DK64A33). For Epicurus' view on magnetism, see fr. 293 Usener (= Gal., Nat.Fac. I, I4 = 2, 44-56 Kühn). According to L. Senzasono, 2006, p. 200, n. I04, the quotation from Empedocles in Q.N. I9 originates from the same text on which Alex. Aphr., Quaest. 2, 23 relies, but this is uncertain. Perhaps more important is the parallel between the passage at issue in Q.N. 19, 916D and Quaest. Plat. 1005BD, where Plutarch provides an exegesis of Pl., Tim. 79e-8oc (esp. 8oc on magnetism). Plutarch there takes a Platonic position in the debate on magnetism, by rejecting the mechanisms of $\dot{\varepsilon} \lambda \xi i s$ and $\dot{\varepsilon} \pi \iota \pi \dot{\eta} \delta \eta \sigma \iota \zeta$, as mentioned here

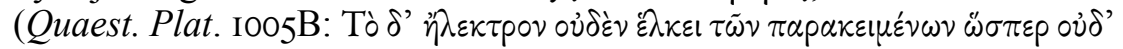

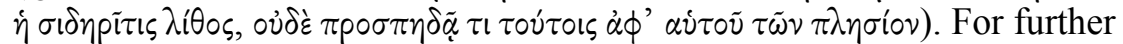
commentary, see A.E. Taylor, I928, pp. $578 \mathrm{ff}$. and J. Opsomer, I994a, pp. 336-337. The correspondence in thought and words between Quaest. Plat. I005D and Q.N. 19, 9I6D is striking, so that it is not unlikely that Plutarch is relying on the same hypomnematic material in both passages. Most notably, the same Platonic position that Plutarch supports in the Platonic question is echoed in the technical terms enumerated here in

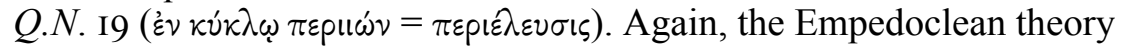
of emanations is very prominent there. Both passages also formulate the same idea of commensuration ( $\sigma \nu \mu \mu \varepsilon \tau p i \alpha$, see further). They also contain more subtle verbal reminiscences, such as the fact that particles do not 'slip

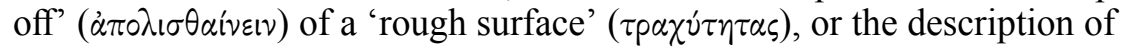

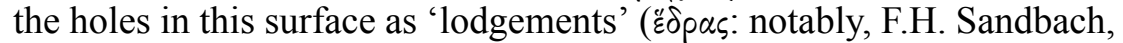
I965, p. I90, n. 7 corrects $\dot{\varepsilon} \lambda 1 \kappa a \varsigma$ in $\varepsilon \delta p a s$ in $Q . N$. 19, 916D precisely on the

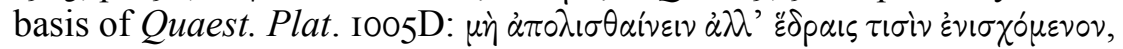
cf. also Tim. 8oc: $\varepsilon \delta \rho \alpha \nu$ ). For further accounts of magnetism in Plutarch, see De Is. et Os. 376B and Quaest. conv. 64IC (with J. Opsomer, I994a, pp. 35I-36I). As to Plutarch's source, it is not unlikely that we should think of a commentary on Plato's Timaeus (see A.E. Taylor, 1928, p. 579: "Plutarch does not mention the source of any of his explanations, but as his various essays show him to have been directly or indirectly acquainted with the explanations of or commentaries on the Timaeus by Xenocrates, Crantor, and Posidonius, probably some of these are responsible for what he says.").

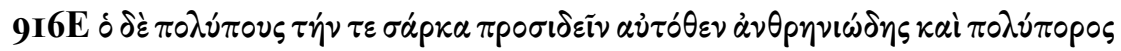

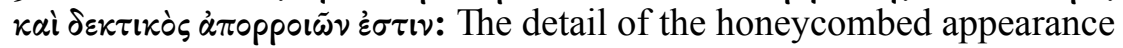

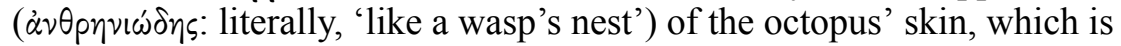

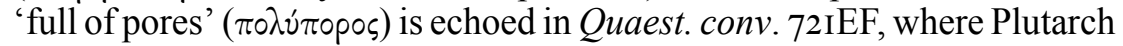

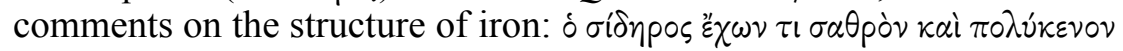




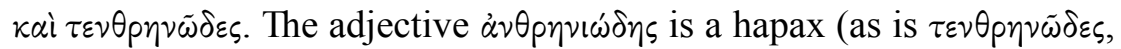
perhaps to be corrected in $\tau \varepsilon \nu \theta p \eta \nu i \tilde{\omega} \delta \varepsilon \varsigma$, which is more, albeit not very, common).

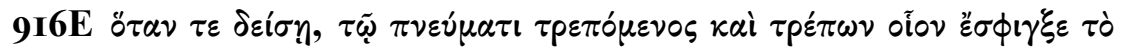

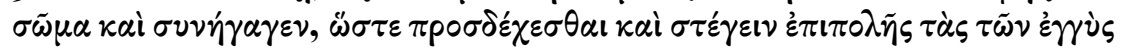

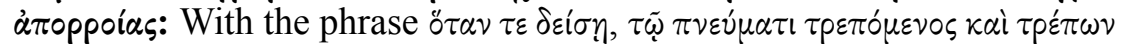
Plutarch implies that the octopus, when afraid, simultaneously undergoes and effects a bodily change by its breath. The shift in verbal diatheses

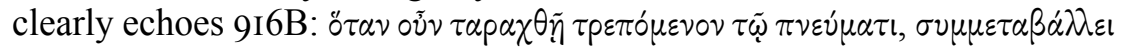
$\tau \dot{~} \chi \rho \tilde{\omega} \mu \alpha$. The same shift recurs in De sera num. $565 \mathrm{C}$ (where the squid's

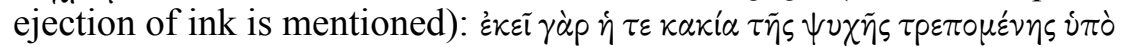

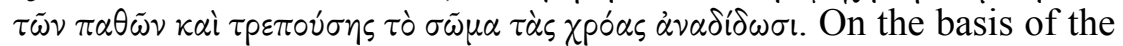

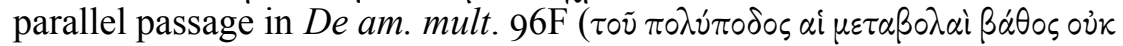

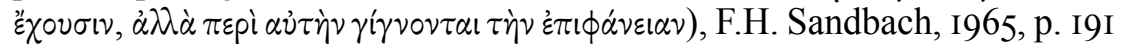
(with $\mathrm{n}$. d) adds the following in his translation: "without allowing them [sc. the emanations] to penetrate it [sc. the surface of the skin]". However, this interpolation is not based on the reading of the manuscripts and seems unnecessary.

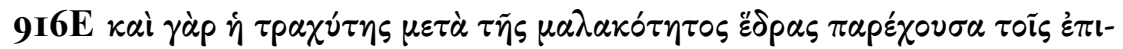

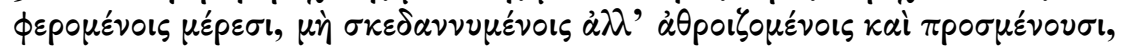

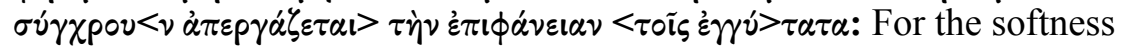
of the octopus' skin and that of the $\mu \alpha \lambda \alpha$ ki $\alpha$ more generally, cf. Q.N. I8, $9 \mathrm{I} 6 \mathrm{AB}$.

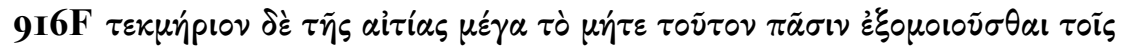

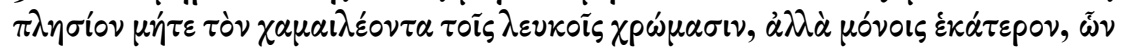

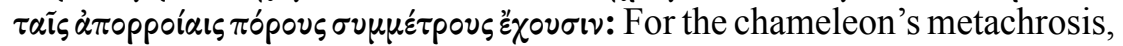
see also Antig. Car., Hist. mir. 25b (and the passages collected by V. Rose, I863, pp. 362-365 more generally). More specifically, for the chameleon's inability to adapt to pale or red colours, see Theophr., fr. I72, I Wimmer

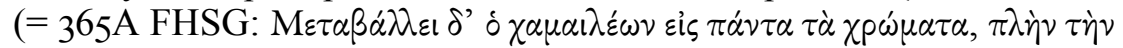

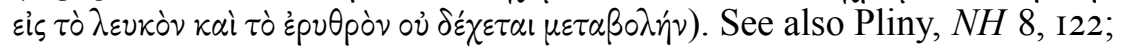
II, 225. Notably, in Q.N. I9, Plutarch only mentions the chameleon's inability to adapt to pale colour, thus leaving out the red one, as he also does in the parallel passages in De ad. et am. $53 \mathrm{D}$ and Alc. 23 , 5. Therefore, Plutarch is presumably relying on an intermediary source that was equally incomplete (cf. L. Senzasono, 2006, p. 202, n. I07: "È probabile che Plutarco attinga a una fonte meno completa per la varietà

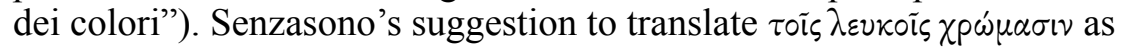
'bright colours' rather than 'pale colours' is not convincing (cf. Q.N. 39: Cur aqua in summa parte alba, in fundo vero nigra spectatur?). In yet another parallel passage, viz. in De soll. an. 978EF, Plutarch again relies 
on Theophrastus ( $=$ fr. I89 Wimmer $=365$ D FHSG) and writes that the chameleon's metachrosis is triggered by fear and is due to the fact that the animal is full of breath since it has very large lungs - this may well be an echo of Theophrastus' $\pi v \varepsilon \tilde{v} \mu \alpha$ theory in the first causa in Q.N. I9

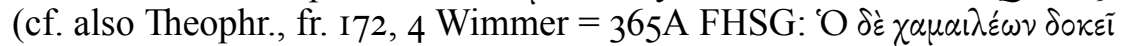

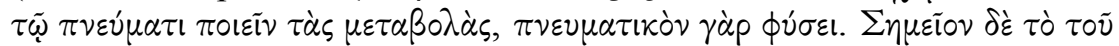

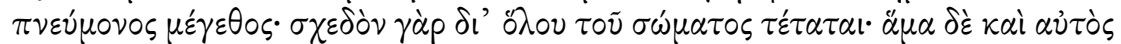

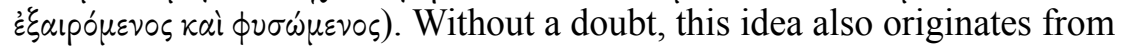
Theophrastus' De animalibus colorem mutantibus (see above).

\section{Land animals and hunting (Q.N. 20-28)}

The following cluster of problems in Q.N. 20-28 centres on the topic of land animals $(Q . N .20-22,26,28)$ and hunting $(Q . N .23-25)$ - with the exception of Q.N. 27, which deals with the production of wine from must and, thus, adheres more naturally to the following cluster of problems on viniculture (Q.N. 30-3I). No clear source can be appointed for these chapters, but it can be presumed that Plutarch, at least in part, draws on Peripatetic zoology (esp. Aristotle, quoted in Q.N. 2I, 9I7CD). Notably, the problems on hunting $\left(Q . N .23^{-25}\right)$ have a very high concentration of parallels in Xenophon, Cyn. 5, I-5 (presented schematically in [4.2.I.2.]).

\section{Q.N. 20, 916F-917B}

In Q.N. 20, Plutarch inquires into the physiology of tears. He examines how it is that the tears of wild boars are sweet, whereas those of deer

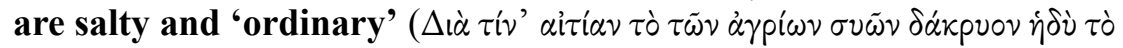

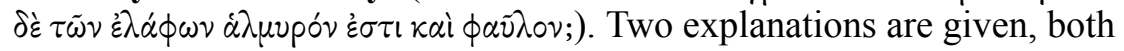
of which are - remarkably enough - formulated dogmatically rather than interrogatively for unclear reasons. The first one focuses on the animals' bodily temperature, the second on the constitution of their blood.

According to the first explanation, heat and cold are the main cause of this

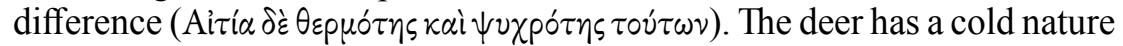

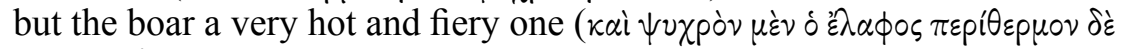
кai $\pi v p \tilde{\omega} \delta \varepsilon \varsigma \delta \sigma \tilde{\delta} \varsigma)$. That is why the former flees and the latter defends itself when chased, and it is then that the boar especially sheds its tears in rage

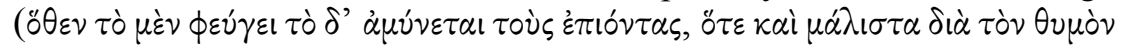

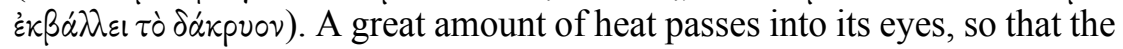

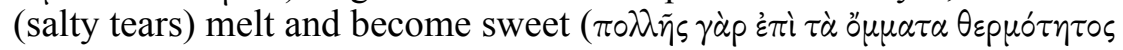

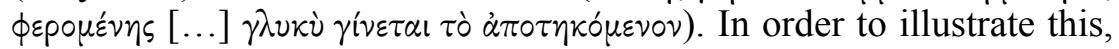
Plutarch quotes a line from Homer: 'Setting up his bristly manes, flashing

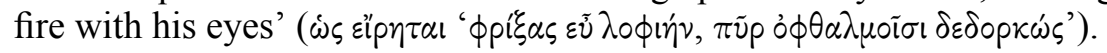


The second explanation connects the quality of tears with that of blood. Plutarch reports that according to some people, like Empedocles, tears are discharged from the blood when it is stirred, just as whey (i.e. milk serum)

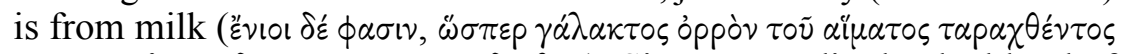

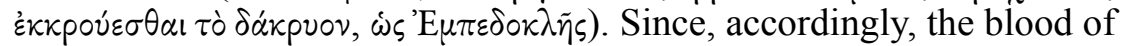
boars is rough and black because of their heat (cf. the previouse causa), while that of deer is thin and watery, it is reasonable that the secretion, in both states of rage and of fear (respectively), is like (the quality of) the

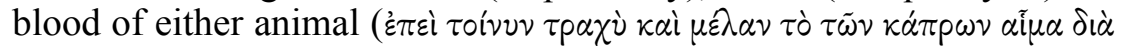

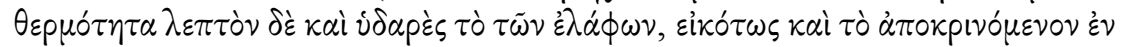

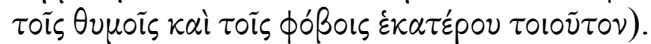

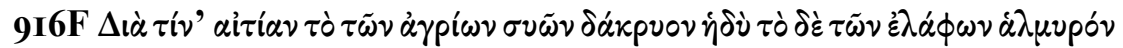

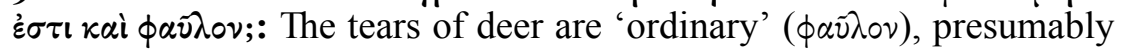
because they are salty (as opposed to those of wild boars) and are, thus, comparable to 'normal', human tears. Therefore, the sweet taste of those of boars is, indeed, 'extraordinary'. The same problem is mentioned in passing in Quaest. conv. 700F, where it remains unsolved. There may be a connection in this problem with Book 27 of Ps.-Aristotle's Problems

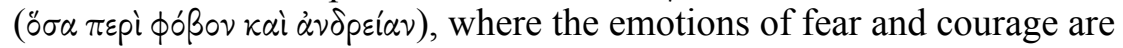
also treated in physiological terms (c.q. bodily cold and heat) [see I.2.5, n. 226].

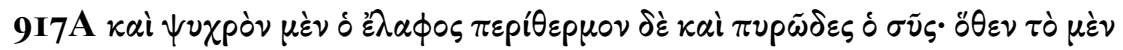

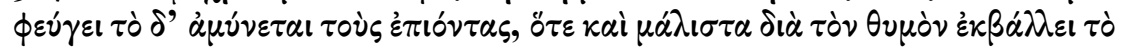
dáxpuov: For the rage and fiery character of boars, cf. fr. I06 Sandbach. Cf. also Arist., PA 65Ia2-3, Xen., Cyn. I0, 8; I5-I7, Pliny, NH 8, 207.

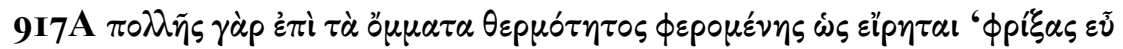

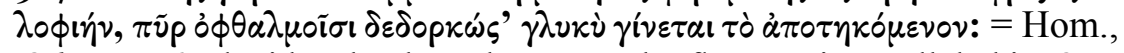
Od. I9, 446. The idea that heat destroys salty flavours is paralleled in Q.N. $5,913 \mathrm{C}$ in the context of ripening fruit. No heating takes place in deer, which explains why their tears remain salty and 'ordinary'.

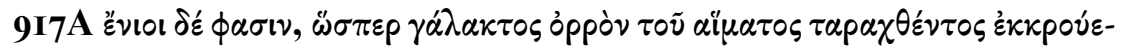

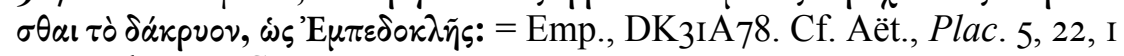
$=$ Ps.-Plut. $909 \mathrm{C}$.

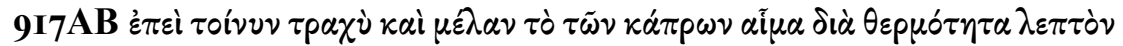

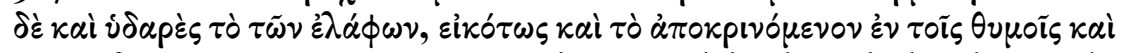

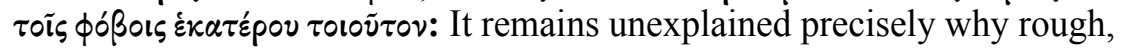
black blood makes for sweet tears and thin, watery blood for salty ones. Nevertheless, there seems to be a connection with Q.N. 3, 912E, where Plutarch argues that the blood of animals (c.q. cattle) that lick salt becomes 
thin $(\lambda \varepsilon \pi \tau \dot{v} v \tau \alpha \iota)$. This may explain the thinness of deer blood, and, by implication, the secretion of salty tears from it. According to Aristotle, the blood of deer is watery and cold (Mete. 384a26-28) and that of boars

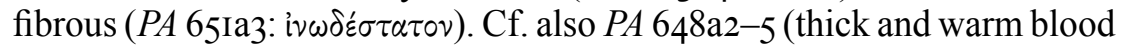
makes for strength, while thin and cold blood is conducive to sensation and intelligence) and $650 \mathrm{~b}_{2} 8$ (animals that have very watery blood are somewhat timorous).

\section{Q.N. 2I, 9I7BD}

Q.N. 2I is closely related to the previous problem by its zoological focus (and especially by its attention to wild boars in the final causa). Plutarch wonders why domesticated sows farrow more than once (perhaps implying twice; see the final comment), and at various moments, while wild sows farrow only once and almost during the same period

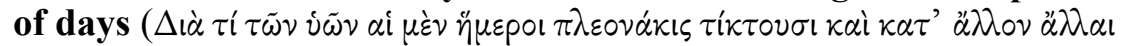

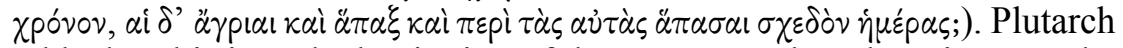
adds that this is at the beginning of the summer, when the rainy months are over. This is illustrated by the proverb: 'It no longer rains the night that

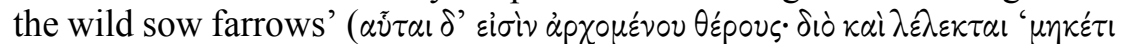

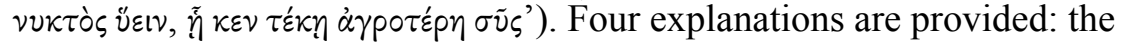
first is based on the theory of generative residues, the second focuses on the effects of leisure and action on the animal's body, the third draws attention to the visual stimulus for animal impulses (opuaí) and the fourth deals with the fertility of wild boars (as implicitly linked to that of sows). Owing to the close structural connections between the separate explanations (by

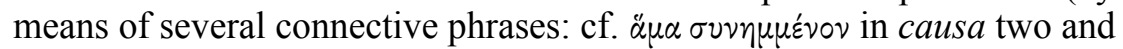
$\ddot{\eta}$ kai in causa three and four [see 4.3.3.I., n. 262]), there is a strong sense of argumentative coherence in the aetiology.

In the first causa, Plutarch explains that domestic sows have a great amount of food to produce the generative residue. He supports this with a

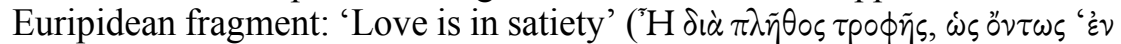
$\pi \lambda \eta \sigma \mu \circ \nu \tilde{\eta}$ Kं́ $\pi$ p 's'). The generative residue is produced by an abundance of

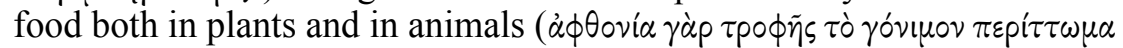

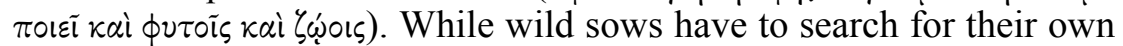
food in the wilderness and in fear, domesticated sows constantly have it

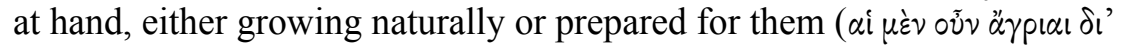

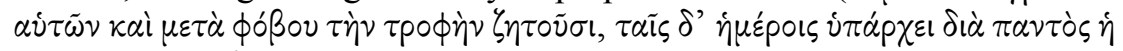

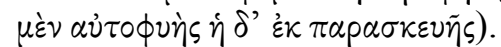

The second explanation focuses on the effects of leisure and action on the animal's body. It is directly connected with the previous one, with 


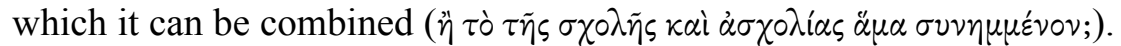
Plutarch argues that while domesticated sows are lazy and unwilling to wander far away from their swineherds, wild ones traverse mountains and run around. Thus, they dissipate their entire nourishment and use it up for

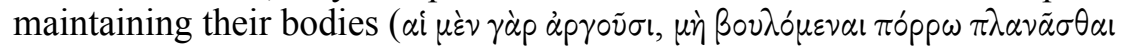

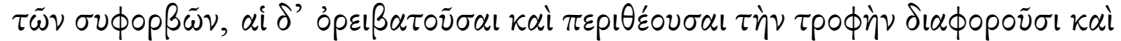
$\kappa \alpha \tau \alpha \nu \alpha \lambda i \sigma \kappa o v \sigma \nu \varepsilon \dot{\zeta} \tau \tau \dot{\delta} \sigma \tilde{\omega} \mu \alpha \pi \tilde{\alpha} \sigma \alpha \nu)$. As a consequence of this permanent

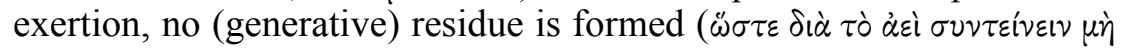
$\gamma^{\prime}\left(\nu \varepsilon \sigma \theta \alpha \iota \pi \varepsilon p^{\prime} \tau \tau \omega \mu \alpha\right)$.

In the third explanation, Plutarch argues that the fact that domesticated sows are fed and herded together with the males reminds them of sex

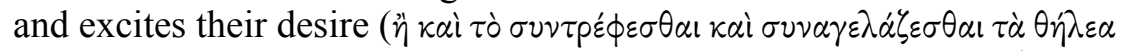

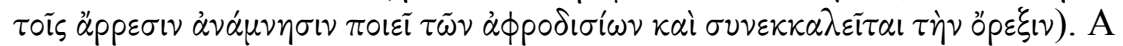
line from Empedocles, originating from the context of human passions, is quoted to illustrate this: 'Desire comes upon him, being reminded by

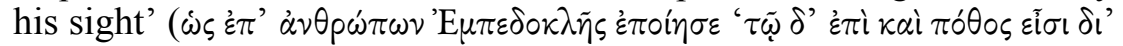

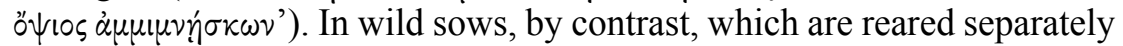
from each other, their lack of natural affection and unsociability blunts

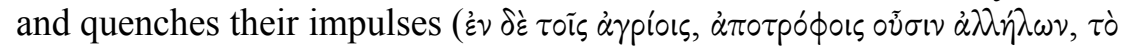

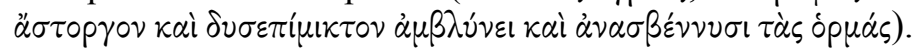

The fourth and final explanation takes into account the fertility of wild boars. Plutarch wonders whether perhaps Aristotle's account is true (

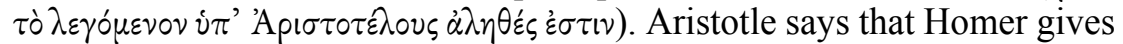
the name $\chi \lambda$ oúvns ('castrated boar') to the boar that has only one testicle, and that the testicles of most boars get crushed by their rubbing themselves

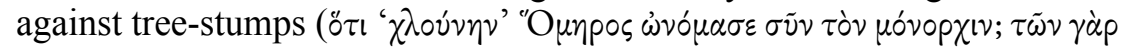

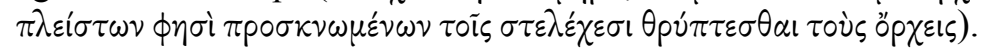

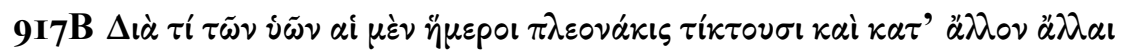

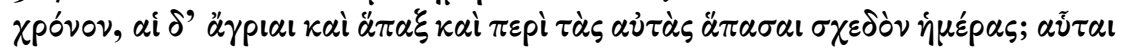

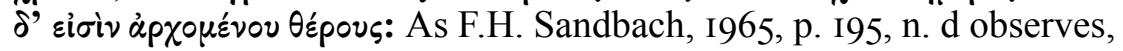
"Plutarch does nothing to answer the second half of his question, namely

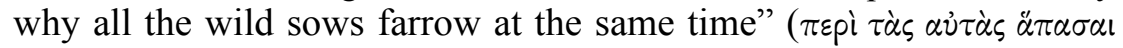
$\sigma \chi \varepsilon \delta \delta \nu ~ \eta \dot{\mu \varepsilon} p a \varsigma)$. Neither does he explain that domesticated sows farrow

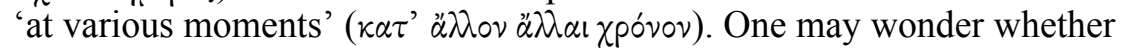
this temporal specification perhaps originally belonged to an introductory $\pi$ ó $\varepsilon$ pov causa that was later rewritten and integrated in the quaestio (note that the first causa opens with ${ }^{*} \mathrm{H}$ ). This remains unclear. Alternatively, L. Senzasono, 2006, pp. 209-2I0, n. I25 speaks of Plutarch's "scrupulo di completezza". In addition, although the formulation of the quaestio is not very clear for these points, it seems unlikely that Plutarch implies I) that wild sows farrow only once in their entire life rather than once a year (cf. F.H. Sandbach, 1965, pp. 194-195, n. c and L. Senzasono, 2006, p. 205, n. II7), and 2) that the domesticated sows farrow on several fixed 
times a year. I) The idea that wild sows farrow once a year is confirmed by Ps.-Arist., Probl. 896a20-29, Ps.-Arist./Alex. Aphr., Suppl. probl. 2, I55 (= Probl. ined. 2, I52), Pliny, $N H$ 8, 2 I2 and M. Glycas, Ann. I, 62 (p. II9, 22-I20, 2 Bekker). As to the season in which they litter, Arist., $H A 578 \mathrm{a} 26$ writes spring, instead of the beginning of summer - on the basis of which H. Flashar, I962, p. 526 prefers to read j̃pos here in Q.N. 2I with manuscript B. 2) Regarding the second point, F.H. Sandbach, I965, pp. I94-I95, n. c notes that "[i]t is unlikely that Plutarch believed that domesticated sows farrow several times a year". However, Plutarch clearly writes that they do this 'at various moments' ( $\kappa \alpha \tau$ ' $\alpha \lambda \lambda_{0 \nu} \alpha \lambda \lambda \alpha \mathrm{l}$ xpóvov). Therefore, I take it that Sandbach means that it is unlikely that domesticated sows farrow several fixed times a year, which may very well be implied, indeed (cf. Ps.-Arist., Probl. 896a2I, regarding the mating of domesticated pigs: ö $\tau \varepsilon$ हैं $\chi \chi \varepsilon \nu)$. Notably, domesticated sows bear twice per year according to Ps.-Arist./Alex. Aphr., Suppl. probl. 2, I55 (=Probl. ined. 2, I52); cf. also Pliny, NH 8, 205 and M. Glycas, Ann. I, 62 (p. II9, 22-I20, 2 Bekker). In Ps.-Arist./Alex. Aphr., Suppl. probl. 2, I44 (=Probl. ined. 2,

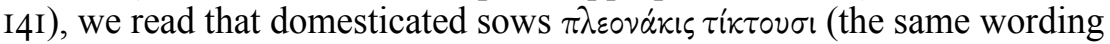
as in Plutarch's quaestio, where it is clearly contrasted with $\alpha \pi \alpha \xi)$. Cf. also Arist., $H A$ 542a27-30, 572a5-8 and Ps.-Arist., Probl. 896a23. Sandbach notes in the margin that "it is only by very early weaning that modern pigkeepers obtain three [litters]". As regards the number of piglets yielded at each farrowing, according to Suppl. probl. 2, I44 (= Probl. ined. 2, I4I), wild pigs bear seven young at the most, whereas domesticated sows bear thirteen.

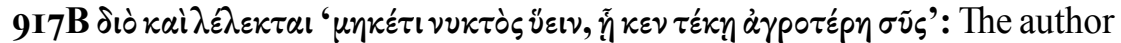
and origin of this hexameter are unknown. According to R. Strömberg, I954, p. 9I, we are dealing with a proverb that may originate from a poem on weather signs or from a comic pastiche of such a weather prognosis (cf. Ar., Pax I083, I086). As such, it may have an ironic connotation, implying that "circumstances must not be unfavourable when a villain makes a coup". Strömberg argues, moreover, that the particle $\kappa \varepsilon v$ does not necessarily imply that the verse has an Aeolic or Tessalian origin, and

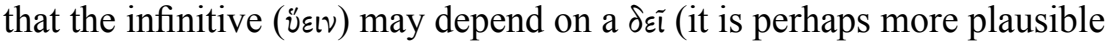
that Plutarch simply adapted the verse to the new syntactical context, depending on $\lambda \varepsilon \lambda \varepsilon \kappa \tau \alpha \iota)$. Erasmus includes the verse in Adag. Chil. 2, 5, 43 (= I443): non iam nocte pluet, sus qua enitetur agrestis, "The wild sow's farrow will bring a fine morrow" (R.A.B. Mynors, I99I, pp. 260-26I). He explains that it has proverbial value: per iocum usurpari poterit si dicamus res fore tranquilliores, posteaquam morosus ac rixosus quispiam animo suo morem gerat (Mynors: "It will be possible to use it in jest, suppose we wish to say that things will be quieter, once some quarrelsome person who is difficult to please has relieved his feelings."). According 
to L. Senzasono, 2006, pp. 205-206, n. II8, however, the proverb should be interpreted literally, like most other agricultural or meteorological proverbs (as a potential source for this proverb, Senzasono thinks of a work similar to Aratus' Phaenomena). Plutarch does, indeed, interpret the verse literally here, but then again, he has a well-known custom of lifting verses from their original context and providing new meanings to them [see 4.2.I.I.]. According to F.H. Sandbach, I965, p. I95, n. d, the verse quoted in De prim. frig. 949B - i.e. Call., fr. 787 Schneider (rejected by

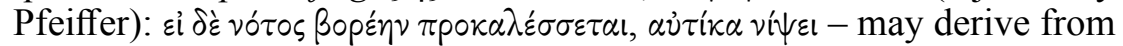
the same source, but this is uncertain. In any case, the same metrum, introductory phrase ( $\delta ı \grave{~} \kappa \alpha \grave{\imath} \lambda \varepsilon \lambda \varepsilon \kappa \tau \alpha \iota)$, and meteorological context do not lend any absolute certainty (cf. also Senzasono).

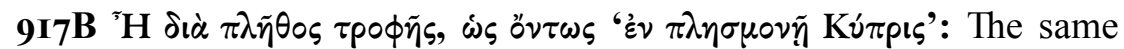
fragment (= Eur., TGF 895; cf. also De tuenda I26C) is cited by Ps.-Arist., Probl. 896a22-24 regarding the fertility of wild vis-à-vis domesticated animals (c.q. boars). The full verse runs as follows: $\dot{\varepsilon} \nu \pi \lambda \eta \sigma \mu \circ v \tilde{\eta} \tau 0$ Kú $\pi p ı$, $\dot{\varepsilon} \nu \pi \varepsilon เ \nu \tilde{\omega} \nu \tau \iota \delta$ ' $\circ v^{\prime}$. For the relation between the fertility of sows and their nourishment, cf. also Arist., HA 542a27-28, Ps.-Arist./Alex. Aphr., Suppl. probl. 2, I44 (=Probl. ined. 2, I4I); 2, I55 (=Probl. ined. 2, I52), M. Glycas, Ann. I, 62 (p. II9, 22-I20, 2 Bekker).

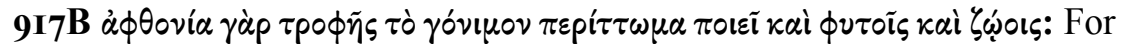
the idea that the generative residue is produced by an abundance of food, cf. also Q.N. 30, 919C [see 4.3.4.I., n. 295].

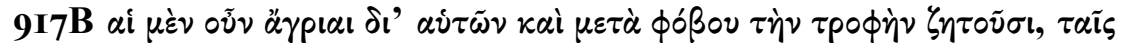

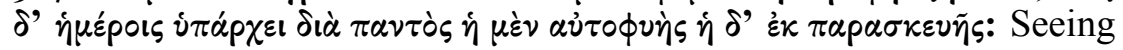
that wild sows do not consume much nourishment (since they have to search for their own food in the wilderness and in fear), they can produce only a small amount of generative residue, rendering them less fertile than domesticated sows. The addition of $\mu \varepsilon \tau \grave{\alpha} \phi o ́ \beta$ (related to wild sows) should perhaps be interpreted in opposition to Kú $\pi$ pı (related to domesticated sows). Where there is fear, there can be no love and, by implication, no satiety or generative residue.

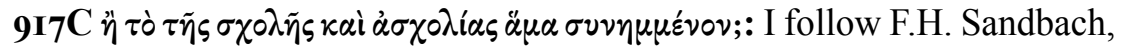

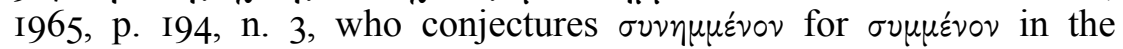
manuscripts (preferred by L. Senzasono, 2006, p. 207, n. I2I; cf. also V. Ramón Palerm, 2005, p. 40I). The former ( $\nu \nu \eta \mu \mu \varepsilon ́ v o v)$ metaphorically denotes a "combination in thought" (LSJ, s.v. $\sigma \nu v \alpha \dot{\alpha} \tau \omega \omega, \mathrm{i}, 2)$, the latter "hold together" (LSJ, s.v. $\sigma \nu \mu \mu \varepsilon \dot{v} \omega)$ ). One late manuscript reads $\sigma \nu \mu \beta \alpha \tilde{\imath} \nu \nu$ (also Hubert). Wyttenbach suggests $\sigma v v \alpha i \tau i o v$, and Bernardakis $\sigma v \mu \beta \alpha i v o v$ $<\alpha i \tau i o v>$. On the assumption that Sandbach's conjecture is correct, note that 
the technical, logical meaning of $\tau \dot{\partial} \sigma v \nu \eta \mu \mu \dot{\varepsilon} v o \nu(\dot{\alpha} \xi \hat{\xi} \omega \mu \alpha)$ as a "hypothetical proposition as premiss in a syllogism" is not at issue here (LSJ, s.v.

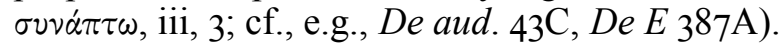

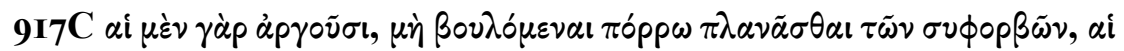

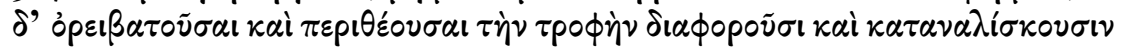

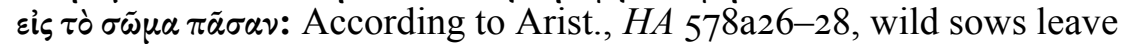
for inaccessible and shady regions with precipices and ravines in order to litter. The aspect of fear ( $\mu \varepsilon \tau \dot{\alpha} \phi o ́ \beta o v)$ from the first causa may be implicit here.

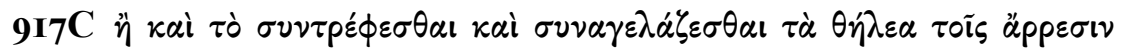

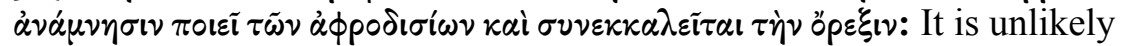
that the first $k \alpha i$ should be read in conjunction with the $k \alpha i$ that follows, because Plutarch does not repeat the article $\tau o$. The first kai (in conjunction with $\eta$ ) may be used adverbially, expressing "emphatic assertion or assent" (see LSJ, s.v.); alternatively, it may connect the causa at hand with the previous one [see 4.3.3.I., n. 262].

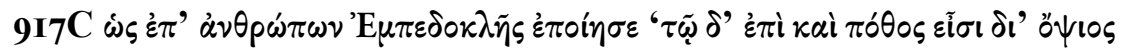
$\dot{\alpha} \mu \mu \mu \nu \eta{ }^{\prime} \sigma \kappa \omega \nu$ ': This fragment is only known from this passage in Plutarch (=Emp., DK3IB64; the soundness of the text is debated). For text critical remarks, see C. Hubert, I960, p. I9, F.H. Sandbach, I965, p. I97, n. a, M.R. Wright, I98I, p. 2I8, B. Inwood, 200I, p. 283, V. Ramón Palerm, 2005, pp. 40I-402, L. Senzasono, 2006, pp. 207-208, n. I22. Wright's position is the most critical one: "The fragment is hopelessly corrupt, and as with other lines having Plutarch as the only source [...], it may be that his memory failed him." However, it is not out of the question that Plutarch deliberately adapted the verse to the new context, as he more often does [see 4.2.I.I.]. The sensory aspect of sight ( $\delta \iota^{\prime}$ oै $\psi 10 \varsigma$, being Wyttenbach's conjecture for $\delta \dot{\alpha} \alpha \dot{\varepsilon} \psi \varepsilon \omega \varsigma$ in the manuscripts) is central to Plutarch's argument. For sight as an impulse to love, cf. also Quaest. conv. 68IA.

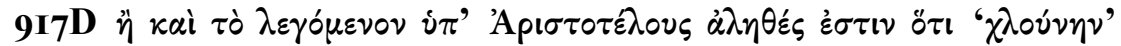

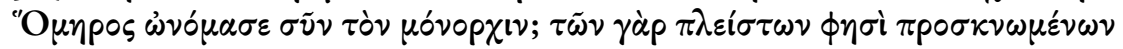

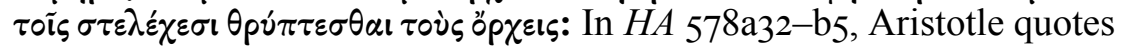
the same Homeric passage $($ Il. 9,539$)$ and writes that young boars catch a disease that causes itching of the testicles. To stop the irritation, they scratch their testicles against trees ( $\pi p o ̀ s \tau \dot{\alpha} \delta \dot{\varepsilon} v \delta \rho \alpha)$ and damage them,

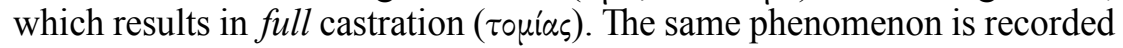
with a similar (but not the same) Homeric reference in Ps.-Arist./Alex. Aphr., Suppl. probl. 2, I45 (= Probl. ined. 2, I42; see S. Kapetanaki and R.W. Sharples, 2006, p. 225, n. 457), where it illustrates another problem, 
viz. why there are many wild boars but few wild swine ( $\Delta \grave{\alpha} \tau \dot{\alpha} \ddot{\alpha} \rho p \varepsilon v \varepsilon \varsigma \mu \dot{\varepsilon} \nu$

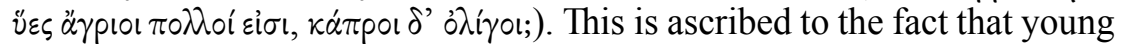
swine catch an itching of the testicles, so that they scratch and destroy them. Xenophon reports that small boars use stones to rub themselves against (Mem. I, 2, 30). The author of Suppl. probl. 2, I45 may rely on Arist., $H A$ 578a32-33, which specifically concerns the relation between castration, savagery and magnitude in wild boars: see F.H. Sandbach, 1965, p. 197, n. b (for the opposite idea that boars become gentle by castration, see however fr. I06 Sandbach). Sandbach also believes that Plutarch perhaps found the passage at hand in Aristotle's Пepi 'Ouńpov (F.H. Sandbach, 1982, pp. 225-226). But Plutarch probably only knew this work indirectly (see J. Bouffartigue, 20I2, p. I08, n. 285). There may still be reason to assume that Plutarch in Q.N. 2I generally draws on one or more lost Aristotelian problems, which, in their turn, probably originate from Aristotle's original text. Notably, the theme of Q.N. 2I ties in closely with that of Book IO

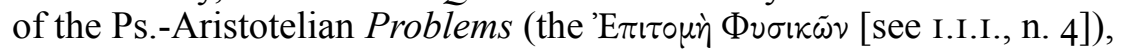
which draws heavily on Aristotle's zoological and biological writings, and often specifically deals with copulation, generation and with the number and nature of offspring in animals. According to U.C. Bussemaker, I857, p. xviii, the reference in the last causa in Q.N. 2I, 9I7CD is to Suppl. probl. 2, I45, but H. Flashar, I962, p. 360 believes that Plutarch is rather referring to Arist., HA 578bi, or perhaps even to a lost problem combining that passage with Probl. 896a20-29 (concerning the number and time of copulation in wild and domesticated animals vis-à-vis humans; with a reference to Eur., TGF 895). Flashar adds (p. 307) that Probl. 896a2029 is probably an abridged version of that lost problem, which in itself must have looked more or less like Plutarch's Q.N. 2I as a whole. Flashar does not, however, pay attention to the adaptation of the Aristotelian material to the new context in Q.N. 2I ("Das echt-arist. Problem muß dann etwa so ausgesehen haben, wie der ganze Abschnitt bei Plut."). Cf. also ibid., pp. 526-527 (with further parallels between Q.N. 2I and Probl. 896a20-29). Three further remarks should be made, though. I) First of all, there is no parallel for Plutarch's third causa in Aristotle (regarding sociability in swine, and the lack of it), unless this is implied - though this is unlikely - in the concept of $\ddot{\alpha} \lambda \dot{\varepsilon} \alpha$ in Probl. 896a23-24 (ì $\delta i \dot{\alpha} \tau \dot{\eta} \nu$

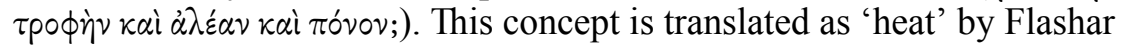
(and probably correctly so: see J. Jouanna, I982 and R. Mayhew, 20IIa, p. 323), rather than as 'escape' or 'shelter' (which is the meaning of the homonymous $\dot{\alpha} \lambda \dot{\varepsilon} \alpha$, cf. LSJ, s.v. A). No reference is made to this 'heat' in the third causa (unless this is implied in the sow's sexual desire). 2) Second, what is supplemented in Probl. 896a24-29 (viz. the reference to sheep in Magnesia and Lybia bearing young twice, and the reason being the long period of gestation) is nowhere to be found in Plutarch. 3) Third and most importantly, Flashar pays no attention to the adaptation of the 
Aristotelian material to the new context in Q.N. 2I - in fact, Plutarch is simply reduced to Aristotle, or even worse, to a lost Aristotelian problem.

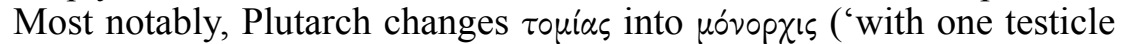
only'). It would, of course, be absurd to claim that all boars become fully castrated during their youth, because in this way, the species of boars would soon be extinct (Plutarch writes $\pi \lambda \varepsilon \tilde{\sigma} \tau \tau$ ol rather than $\pi \dot{\alpha} \nu \tau \varepsilon \varsigma$, whereas Aristotle simply has vह́oเ). The claim of L. Senzasono, 2006, p. 209, n. I23

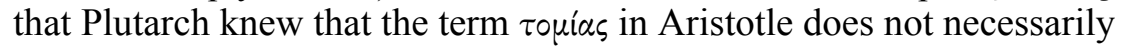
indicate the full castration and privation of both testicles but only one is not convincing, since it does not explain why Plutarch did not simply copy $\tau$ ouías, then (Senzasono also says that the root $\tau \varepsilon \mu$ - indicates a cut and thus implies a mutilation, but in Arist., $H A 575 \mathrm{br}$ it clearly refers to full castration). Bearing in mind the number of litters vaguely referred to in the quaestio - viz. $\pi \lambda \varepsilon o v \dot{\alpha} k ı$ for the domesticated sow and $\ddot{\alpha} \pi \alpha \xi$ for the wild sow - Plutarch's adaptation may perhaps imply that half the number of testicles diminishes the fertility of wild boars and thereby that of wild sows - perhaps, indeed, by a factor of two. The fact that domesticated sows have two litters, while wild sows have only one is confirmed by several ancient authors (see the comments to the quaestio). It seems plausible, then, that we are not dealing with a redundant fait divers in this final explanation, because it not only concerns the fertility of wild boars, but indirectly also that of wild sows. Thus, it links up closely with the quaestio

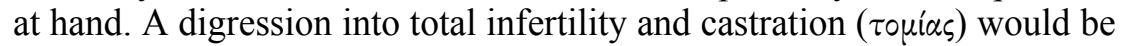
of no use here, and thus an adaptation of Aristotle's text was mandatory

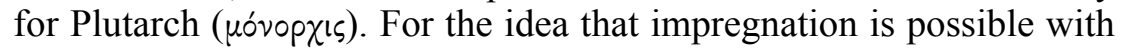
only one testicle, see Arist., GA 765a23-3I. For the opposite idea that horses with only one testicle are infertile or beget such offspring, see Hipp. Berol. I4, I, II-13 (= Corp. Hipp. Graec. I, p. 78, I5-I7 Oder -

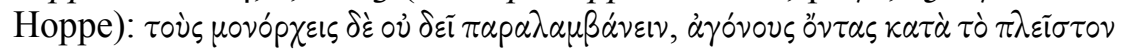

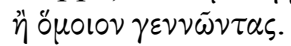

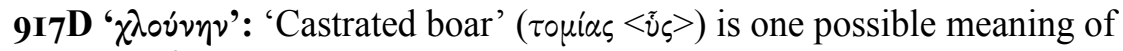
the word $\chi \lambda$ oúvns (cf. LSJ, s.v. and the scholia to the Homeric passage at hand). In his Lexicon Homericum, Apollonius the Sophist analyses the

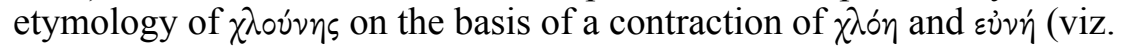

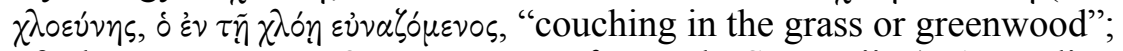
cf. also Etym. magn. 8I2, 44-5I, s.v. $\chi \lambda$ ó and LSJ, s.v. ii, 4). According to P. Louis, I968, p. I65, n. 2, this is the meaning of $\chi \lambda$ oúvn in Arist., $H A$ $578 \mathrm{br}$ : he bases his argument on the phrase $\pi p \dot{s} \tau \tau \dot{\alpha} \delta \dot{\varepsilon} v \delta \rho \alpha$, but it is clear from the broader context that the primary connotation there is rather that

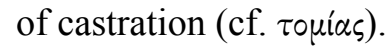




\section{Q.N. 22, 917D}

In Q.N. 22 Plutarch wonders why people say that the she-bear's 'hands' (c.q. fore-paws) have the sweetest flesh and why they are the most

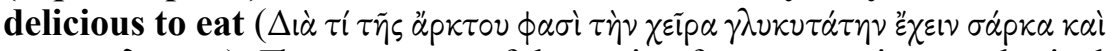
$\phi \alpha \gamma \varepsilon \tau \dot{\eta} \dot{\delta} \delta \sigma \tau \eta \nu ;)$. The treatment of the topic of sweetness in a zoological context recalls the problem in Q.N. 20 (regarding the sweet tears of wild boars). The explanation that is given here may again contain an allusion to the relation between sweetness and heat. Plutarch provides only one explanation drawing attention to the processes of concoction and 'transpiration'.

Plutarch argues that those body parts that most concoct the food provide

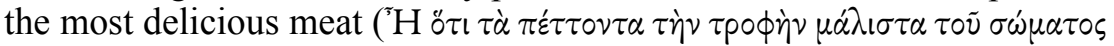

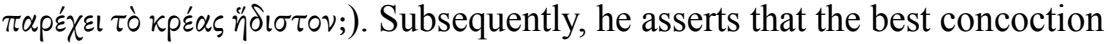
is by what 'transpires', being most in motion and most exercised ( $\pi \dot{\varepsilon} \tau \tau \varepsilon 1 \delta \dot{\varepsilon}$

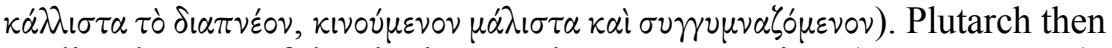
applies the case of the she-bear to these two premises ( $\check{\sigma} \sigma \pi \varepsilon \dot{\eta} \ddot{\alpha} p \kappa \tau \circ \varsigma)$ : the bear makes the most movement with its fore-paws, which it uses as

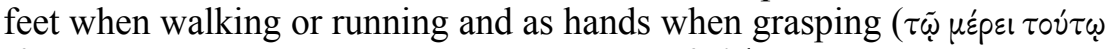

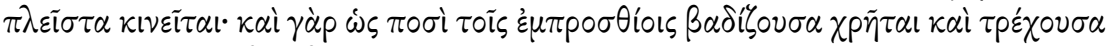

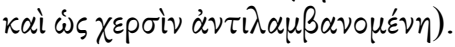

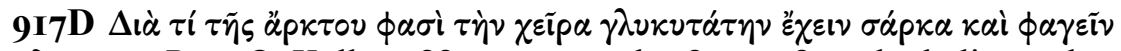

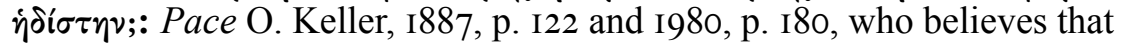
the delicacy of the bear's paws (and frog's legs) was a medieval invention unknown in Antiquity. On boiled bear meat, cf. Pliny, $\mathrm{NH} 8$, I28. In Petr., Sat. 66, 5-6 bear meat is considered disgusting and is compared with that of wild boars. In the Finnish epic Kalevala, the bear has several stock euphemisms, which refer to the sweetness of its paws (as reported by F.H. Sandbach, I965, p. I99, n. a), but the references are mostly to the sweet taste of honey rather than of the flesh itself: mesikämmen (honey palm), mesikäpälä (honey paw), mesiloappa (honey greedy). Thanks are due to Kristiina Näyhö from the Finnish Literature Society (SKS) for providing useful information on this matter.

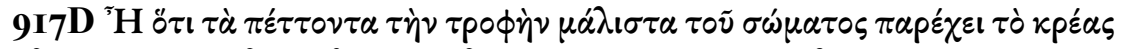

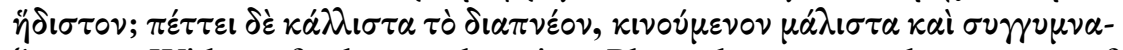

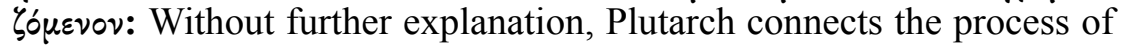

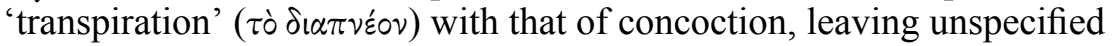
what is their precise relation and what is actually meant with the former. On the basis (presumably) of the phrase $\tau \dot{\alpha} \pi \dot{\varepsilon} \tau \tau o v \tau \alpha \tau \dot{\eta} \nu \tau \rho \circ \phi \eta \dot{\eta} \nu$, C. Hubert,

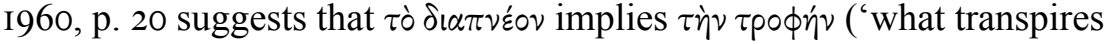
the food'), but he remains uncertain, and rightly so in my belief (in any 
case, concoction is not simply the same as 'transpiration'). According to L. Senzasono, 2006, pp. 2II-2I2, n. I28, it is not the food that is 'transpired', but the residues that it leaves behind (he refers to Ps.-Arist., Probl. 966aI7-25, where no mention is made of 'transpiration' but only of a 'well ventilated body', $\sigma \tilde{\omega} \mu \alpha \tau \dot{\partial} \varepsilon \dot{u} \pi \nu \circ v \nu)$. This does not help us much in clarifying the meaning of $\tau \dot{\partial} \delta 1 \alpha \pi \nu \varepsilon \varepsilon v$ here. F.H. Sandbach, I965, p. 199 (with n. b) translates $\tau \dot{\partial} \delta\llcorner\alpha \pi v \varepsilon$ ov as "what transpires", but he adds that "[t]he meaning is dubious and the text not above suspicion". The text is not suspect, but still I am inclined to side with Sandbach's abstract translation. In any case, $\delta 1 \alpha \pi \nu \varepsilon \tau$, in the sense of 'to transpire', does not simply mean 'to sweat', but has to do with a more general process of evaporation (see LSJ, s.v. iii; the concept of sweat is not found in Q.N. 22, and in Ps.-Arist., Probl. 967a3, the 'transpiration' of the body by air is, in fact, explicitly opposed to sweating, c.q. by an enclosure of heat). It involves an active passage of air through an object or body (cf. LSJ, s.v. i: "blow through"; see, e.g., Quaest. conv. 702 C and Ps.-Arist., Probl. 943 b23 (with Hom., Od. 4, 567)). In the passage at hand, the 'transpiring'

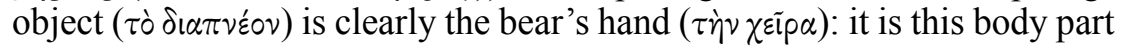
that "admits air" most by moving or exercising (see LSJ, s.v. i, 2 for the intransitive use). Since the bear's hand 'transpires' most, it is this body part that concocts the food most, so that it is sweetest. As to the connection between transpiration and concoction, a link can be drawn with Q.N. 27, 9I8E, where the verb $\delta 1 \alpha \pi \nu \varepsilon i \nu$ is directly related to $\tau$ ò $\theta \varepsilon p \mu o ́ v$, which in turn is related to $\tau \dot{\eta} \nu \gamma \lambda u \kappa \dot{\tau} \tau \eta \tau \alpha$ (cold does not allow 'transpiration', but by shutting in the heat preserves the sweetness of the must). As such, both the processes of 'transpiration' and concoction imply an element of heat (for the connection between 'transpiration' and heat, cf. also, e.g., Ps.-Arist., Probl. 927bi2, 936bi8, 939b37). This heat may be implied in the passage at hand by the frequent motion and exertion of the bear's paws

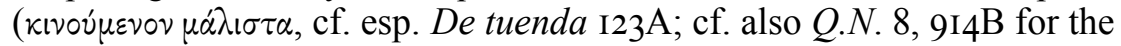
idea that motion fans the heat of the sea). Moreover, in Q.N. 20, 9I7A, heat also causes sweetness (by melting the salty tears of boars). Cf. also esp. Quaest. conv. $642 \mathrm{C}$, for the belief that sheep that are bitten by wolves have the sweetest flesh, because the wolf's breath $(\pi \nu \varepsilon \tilde{v} \mu \alpha)$, which is very hot and fiery, makes it tender.

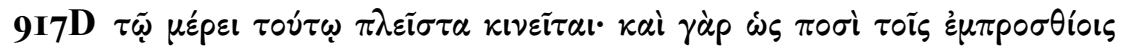

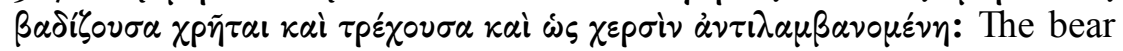
also uses its hands for tearing apart the nets of hunters: cf. Q.N. 28, 919A.

The problems treated in Q.N. $23-25,917 \mathrm{E}-9 \mathrm{I} 8 \mathrm{~B}$ are closely related to each other through the topic of hunting and, more specifically, by the 
influence of meteorological conditions on animal tracks and trails (c.q. spring, winter, dew and full moons). There is a dense cluster of parallels with Xen., Cyn. 5, I-5 (presented schematically in [4.2.I.2.]). As noted earlier on, Q.N. 6 links up with this cluster of problems by its focus on the physical properties of dew probably in the broader context of hunting.

\section{Q.N. 23, 917EF}

In Q.N. 23 Plutarch wonders why the season of spring is unfavourable

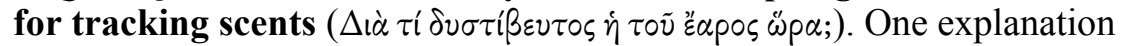
is given, where Plutarch refers to Empedocles' theory of emanations. At the end he incorporates a mythological coda.

In the first part, Plutarch refers to the theory of emanations. He argues that hounds, 'with nostrils tracking fragments of the limbs of wild beasts' as Empedocles says, pick up the emanations left behind by animals in the brushwood, but that these are obscured and confused in the spring

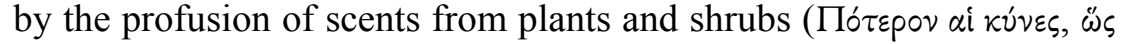

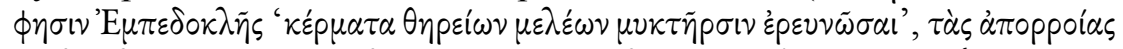

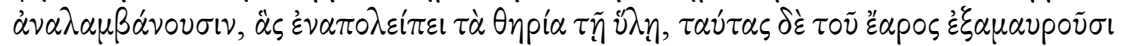

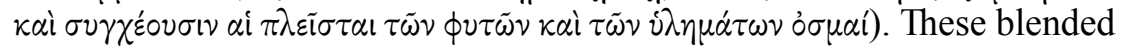
odours that overflow from blooming flowers distract and deceive the hounds so that they cannot pick up the scent of animals ( $\kappa a i$ i $\pi \dot{\varepsilon} \rho \tau \eta \dot{\nu}$

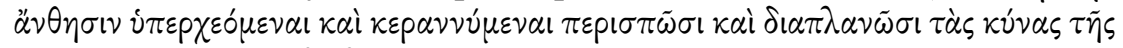
$\tau \tilde{\omega} \nu \theta \eta \rho^{\prime}(\omega \nu \dot{\partial} \sigma \mu \tilde{n} s \dot{\varepsilon} \pi \imath \lambda \alpha \beta \varepsilon \dot{\varepsilon} \sigma \theta \alpha)$. This is further illustrated in a mythological coda: as people say, nobody hunts around Mt. Etna in Sicily, because a great amount of mountain violets grows and flourishes in its meadows throughout the year. The sweet fragrance of this flower always occupies the place and captures the exhalations from the animals ( $\delta$ ì $\pi \varepsilon p i \tau \eta \dot{\nu}$ Ait $\tau \nu \eta \nu^{\prime}$

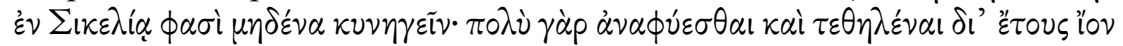
ỏ $\left.\theta \eta p^{\prime} \omega \nu \dot{\alpha} \nu \alpha \pi \nu \circ \alpha \dot{\alpha}\right)$. A myth is told that Korè was abducted by Pluto when

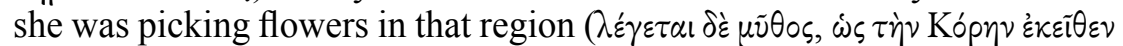

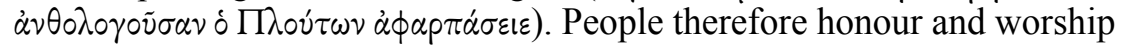
the place as a sanctuary and do not attack the animals that graze there ( $\kappa \alpha i$

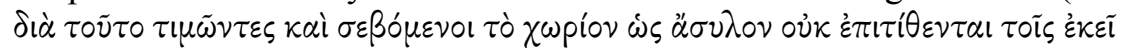

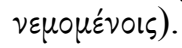

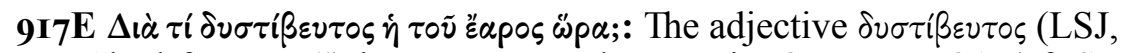
s.v.: "bad for scent") is very rare and recurs in Q.N. 25,9 I8A (cf. S.-

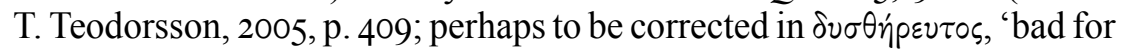
hunting': cf. Pl., Soph. 2I8d and 26ra). For the concept of $\sigma \tau i \beta \varepsilon i \alpha / \sigma \tau 1 \beta \varepsilon \dot{v} \omega$ in Plutarch, cf. Q.N., 25, 918B, De Pyth. or. 399A and De soll. an. 966D. 


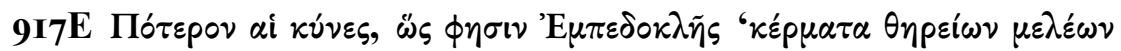

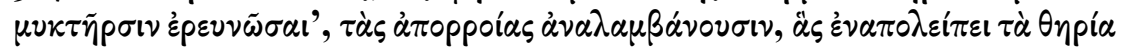

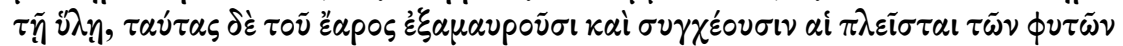

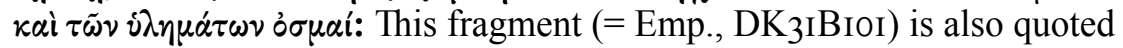
in De cur. 520F. It may originate from the same Plutarchan hypomnema (see H. Martin, I969, p. 70). For more on the fragrance of flowers obscuring the smell of tracks in spring, cf. Xen., Cyn. 5, 5 and Theophr., CP 6, 20, 4 . See also Book 12 of the Ps.-Aristotelian Problems more generally (ö $\sigma \alpha \pi \varepsilon p i$ $\tau \dot{\alpha} \varepsilon \dot{v} \omega \dot{\delta} \eta)$, where the same emanation theory of odour is present throughout.

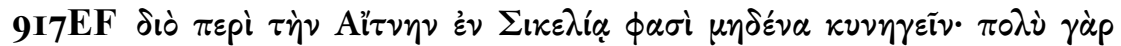

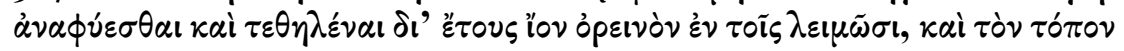

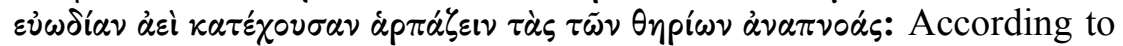
F.H. Sandbach, I965, p. 200, n. a, "[t] his version is perhaps somewhat forced. An emendation may be made, to give the meaning 'the nostrils of the hunters seize on the fragrance ..." ". The emendation is based on a

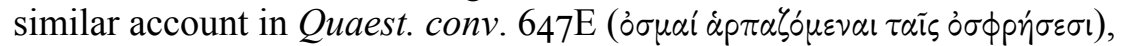
but it is unnecessary in the passage at hand (cf. also L. Senzasono, 2006, p. 2I4, n. I33).

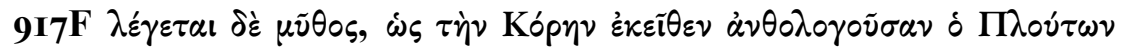

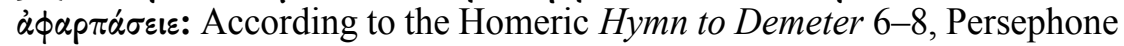
gathers several kinds of flowers, including violets (albeit at the plain of Nysa: I7). For further commentary on 'the flower catalogue' and the actual location of Persephone's abduction (with a list of other locations), see N.J. Richardson, I974, pp. I40-I44 and I48-I50. For Etna as the place of Persephone's abduction, see already Carcinus, TGF p. 799, fr. 5, 6 (cf. also Moschus, Epit. Bionis I2 I and Hyg., Fab. I46). According to Ps.-Arist., Mir. ausc. 836bi3 ff. and Diod. Sic. 5, 3, 2, the abduction took place in the vicinity of Enna. For further references, see F. Bräuninger, I937, cols. 952 and 966.

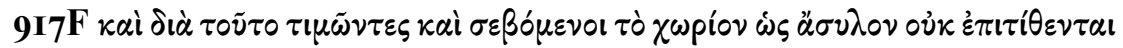

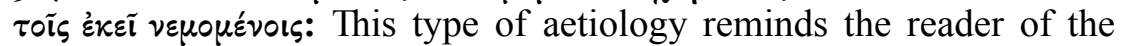
cultural-antiquarian inquiry in Plutarch's Quaestiones Graecae (cf. also Q.N. I0, 9I4D and I4, 9I5C [see 2.4.2.]). From the opening of the aetiology

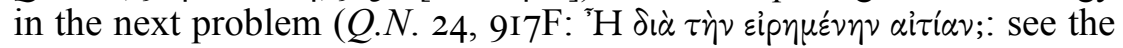
commentary ad loc.), it can be inferred that the ending of this problem is lacunary (see F.H. Sandbach, I965, p. 20I, n. c). Perhaps, Plutarch intervened in the text to obtain a mythological finale here [see 4.I.2.2., n. 82]. 


\section{Q.N. 24, 917F-9I8A}

In Q.N. 24, we find yet another problem from the world of hunting. There is an explicit reference in the aetiology to a preceding explanation that cannot be clearly traced in Q.N. 23, and may therefore be missing $\left({ }^{7} \mathrm{H} \delta \dot{\alpha}\right.$

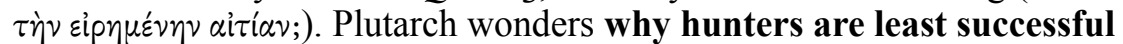

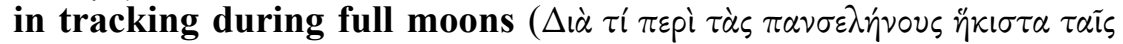

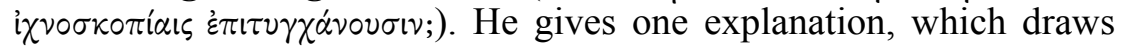
attention to the precipation of dew by the moon. Again, the explanation contains a mythographical part.

As noted, the causa opens with a reference to a preceding explanation

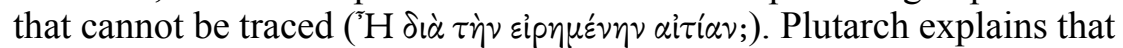
full moons precipitate dew, which he illustrates with a quotation from Alcman, who allegorically calls Dew the daughter of Zeus and Moon:

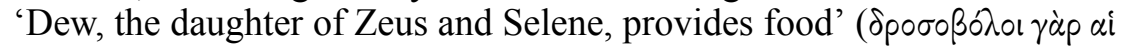

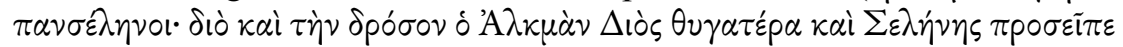

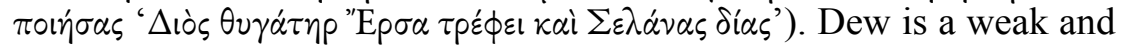
impotent kind of rain, and the heat of the moon is also weak. Therefore, the moon draws it up from the earth like the sun, but being unable to lift

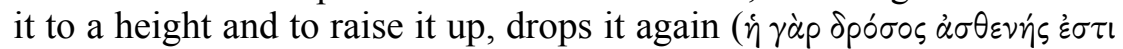

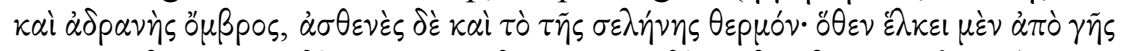

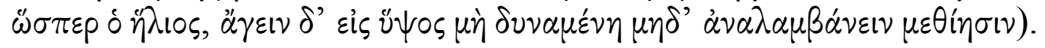

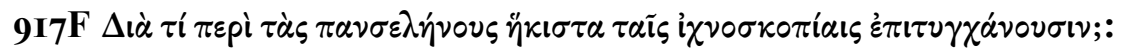

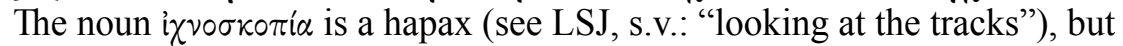
the verb $i \chi v 0 \sigma \kappa \circ \pi \tilde{\omega}$ occurs more often.

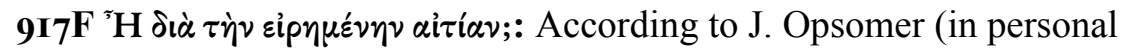
communication), "the back reference is merely to the idea that some physical influences (the flow of water, for instance) may wipe away traces of scents". This is not implausible, but it seems too general (compare

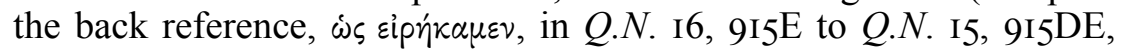
which is much more concrete). By contrast, F.H. Sandbach, I965, p. 20I, n. c believes that the explanation to which Plutarch refers probably drew attention to the fact that "dew is frequent in the spring and spoils the scent" of tracks (for the view that heavy dew obliterates the scent of tracks by carrying it downwards, cf. Xen., Cyn. 5, 3). At the end of Q.N. 23, "an

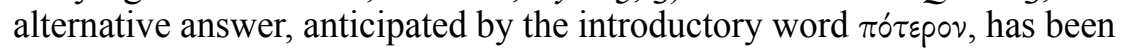
lost". It is, indeed, odd that no second causa follows after the $\pi$ ó $\tau \varepsilon p o v$ causa in Q.N. 23 (for exceptions, see R. Kühner and B. Gehrt, I966, §589, IO). We may be dealing with a case of hypomnematic negligence [see 2.3.2.] or intermittent composition [see the prologue, n. 23]. In either case, it is not impossible that Q.N. 24 is a separate reformulation and elaboration 
of what was originally the now lost second causa in Q.N. 23, which may have run as follows: 'Or is it because dew, which is frequent in springs, obscures the scent of the tracks? Full moons also precipitate dew, which is why hunters are least successful in following tracks during full moons.' Plutarch then felt that further explanation was necessary, thus why he devoted a new, separate chapter to it (c.q. Q.N. 24) with a ghost-reference to what was previously said. This remains hypothetical. One point that may support this theory is that Plutarch may have intended to maintain the mythological conclusion at the end of the (first) causa in Q.N. 23. In any case, Plutarch more often concludes his physical aetiologies with a mythological account [see 4.I.2.2.]. Moreover, if the myth had remained between the two original physical explanations, it would have seemed to be a redundant fait divers, which Plutarch does not, of course, hold it to be (cf. L. Senzasono, 2006, p. 215, n. I35: "Se è cosí, un motivo religioso era calettato entro due motivi naturalistici e quindi in un certo senso soverchiato da essi."). According to J. Schellens, I864, pp. I9-20, however, there can be no doubt ("haud dubie") that Q.N. 25 originally preceded Q.N. 24. At the end of Q.N. 25, he would add: "Quare etiam circa plenilunia minime indagantur e vestigiis ferae. Nam plenilunia rorem

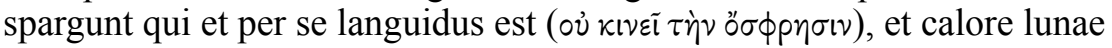
parum valido nequit auferri." There is no problem with the ending of Q.N. 25 , though, as is rather the case with that of Q.N. 23, as we saw.

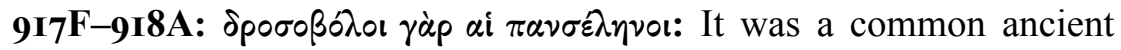
belief that the moon generates dew. Cf., e.g., Macrob., Sat. 7, I6, 3I (with reference to Alcman) and Manilius, Astron. 4, 50I-502 (with A.E. Housman, I920, p. 6I for further references).

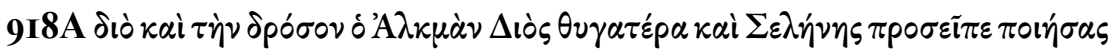

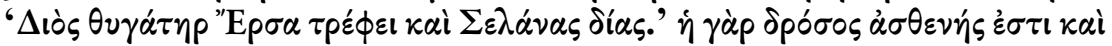

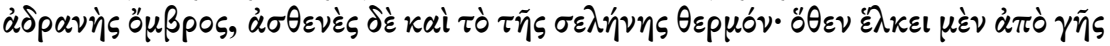

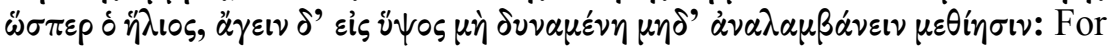
the idea that dew is a kind of rain, cf. also Arist., Mete. 347bI7-22. For the weakness of the moon's heat, cf. Quaest. conv. 658B and De facie 929A. Xenophon reports that the moon obscures the scent directly by its heat $(\tau \tilde{\omega} \theta \varepsilon p \mu \tilde{\omega})$, especially when at full $(C y n .5,4)$. The idea that the moon draws up moisture from the earth ties in closely with Stoic exhalation

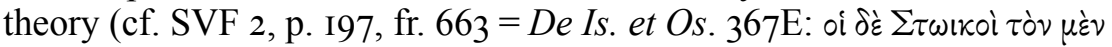

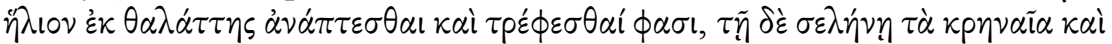

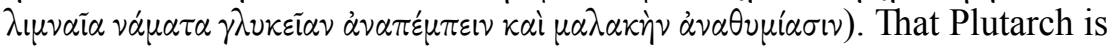
probably drawing from a Stoic source is also supported by the allegorical explanation of Alcman's mythological account (= Alcm., 43 Diehl), this type of exegesis being particularly privileged by the Stoics (cf. P.R. Hardie, I992, p. 4772, with n. II4). The same quote from Alcman and a similar 
allegorical interpretation recurs in the parallel passages in Quaest. conv. 659B and De facie 940A, where a slightly different explanation for the role of the moon in the production of dew is given. Attention is drawn there to a process of $\mu \varepsilon \tau \alpha \beta 0 \lambda \eta$ ' the moon has a liquefying effect, and the air - Zeus in the quotation - is liquefied by the moon into dew), while in Q.N. 24 the explanation is based on the motive force of $\delta \lambda \kappa \eta^{\prime}$, which is of a mechanical kind (the aspect of lunar liquefaction is absent here). Cf. also F.H. Sandbach, 1965, p. 203, n. a. The attempt of L. Senzasono, 2006 , p. 2I 8 , n. I4I to reconcile the differences between both explanations is at the risk of neglecting the different argumentative contexts in this cluster of parallels (cf. B. Van Meirvenne, 200I, pp. 292-293, n. 27) [see 2.I.2.].

\section{Q.N. 25, 918AB}

The topic of hunting continues in Q.N. 25 (cf. L. Senzasono, p. 219, n. I42). Plutarch wonders why a domain that has become dewy due to coldness

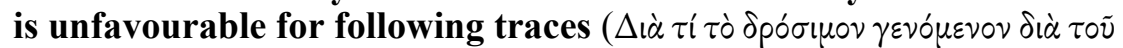
$\psi v$ xous $\delta v \sigma \tau i \beta \varepsilon v \tau o v ;)$. He gives two explanations: the first one refers to the quantity and (implicitly) to the visual aspect of the traces ( $i x \vee \eta)$, and the second to their smell (ö $\sigma \phi p \eta \sigma \varsigma s)$. Both features of vision and smell are closely related to each other by the phrase $\ddot{\eta} \delta \varepsilon \tilde{\mu} \mu \grave{\eta} \mu o ́ v o v \kappa \tau \lambda$. in the second causa.

In the first explanation, Plutarch argues that wild animals hesitate to go far from their lairs because of the frost. Thus, they do not produce many

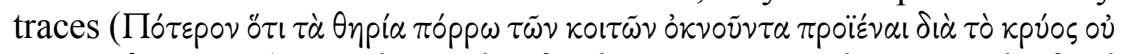

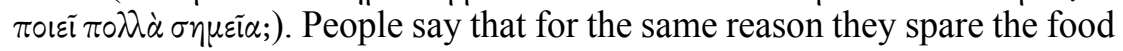
close at home (in other seasons), so that they are not worried to wander

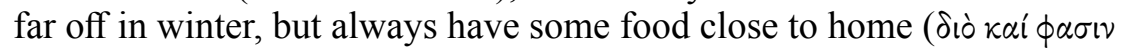

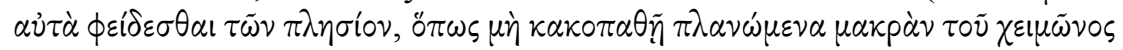

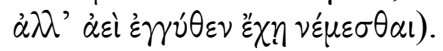

At the beginning of the second explanation, Plutarch makes a subtle distinction. He argues that hunting grounds must not only be marked by (visible) tracks, but must also affect the sense of smell (i $\delta \varepsilon \tilde{\varepsilon} \mu \eta \dot{~ \mu o ́ v o v ~ ह ै \chi ~} \chi \varepsilon \nu$

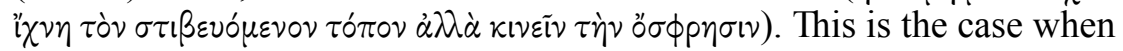
scents are loosened and gently released by heat, whereas excessive cold freezes the odours and does not let them flow or affect sensation ( $\kappa เ v \varepsilon i \tilde{\delta} \delta$

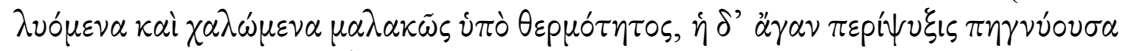

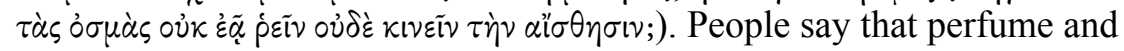
wine give off less smell in cold weather and in the winter. This is the case because the frozen air arrests the scents and does not allow them to 


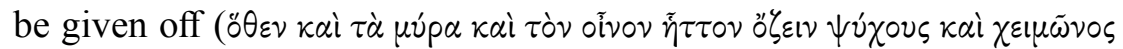

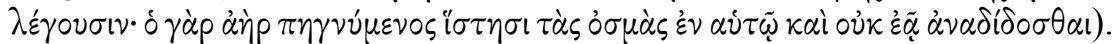

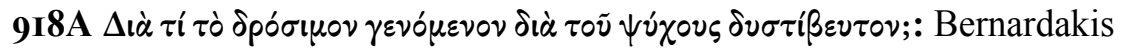
corrects the adjective $\delta$ pó ${ }^{\prime} \mu o v$ (a hapax) into the more, but still not very,

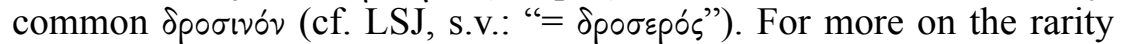
of the adjective $\delta \nu \sigma \tau i ß \varepsilon v \tau \circ \varsigma$, see the comment to Q.N. 23, 9I7E above. F.H. Sandbach, I965, p. 203, n. b doubts the soundness of the text here and notes that "dew has nothing to do with the answer". There is nothing suspicious in the manuscripts, though, and the answer that Plutarch gives is still very pertinent. According to some scholars, it is not unlikely that Plutarch is referring to frozen dew. Longolius summarised the problem as follows: Ros hybernus, hoc est pruina, indagationem difficilem reddit. J. Schellens, I864, p. 20 also speaks of "pruina" (i.e. frost or snow). Cf. also L. Senzasono, 2006, pp. 2I8-2I9, n. I42 ("brina"). Yet, as J. Opsomer notes (in personal correspondence), Plutarch literally speaks of 'dew due to cold' (it is unlikely that $\delta i \dot{\alpha} \tau o \tilde{v} \psi v$ xous relates to $\delta v \sigma \tau i \beta \varepsilon v \tau o v$ ); thus, the reference is not necessarily to hoarfrost.

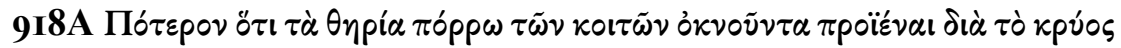

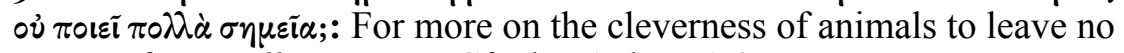
traces, cf. De soll. an. 97ID. Cf. also Ael., NA 6, 3.

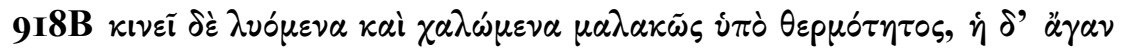

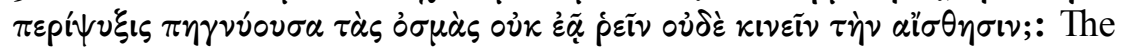
negative effect of wintery cold on smells and on the hounds' perception thereof is also mentioned by Xenophon $(C y n .5, \mathrm{I}-2)$, who notes, in addition, that it is only when the sun loosens ( $\delta\left\llcorner\lambda v_{v} \sigma \eta\right)$ the tracks or as the day advances that the dogs are able to smell and that the scent revives. For the dulling effect of cold on flavours and odours (and on our sensation of them), cf. also Theophr., $C P$ 6, I7, 5 and $O d$. 40 with. Ps.-Arist., Probl. 907a8-I2 and Ps.-Arist./Alex. Aphr., Suppl. probl. 2, IOI.

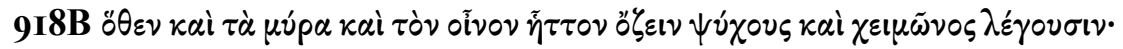

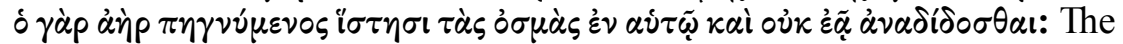
analogy with wine ties in closely with the problems on viniculture in $Q . N$. 30-3I (see also Q.N. Io and 27). F.H. Sandbach, I965, p. 202, n. 3 corrects

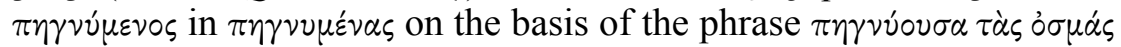
above and with a reference to De prim. frig. 95IA, where the inability of

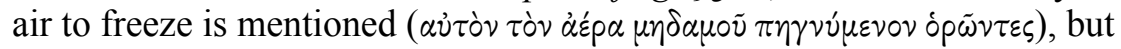
this seems unnecessary (cf. also L. Senzasono, 2006, p. 220, n. I45). 


\section{Q.N. 26, 9I8BE}

Q.N. 26 concerns another zoological problem, viz. why animals seek and pursue substances that have remedying properties when they are ill, and often restore themselves to health by using them $(\Delta i \dot{\alpha} \tau i \tau \dot{\alpha} \zeta \tilde{\omega} \alpha \tau \dot{\alpha} \zeta$

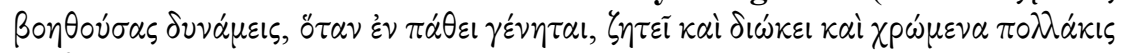
$\dot{\omega} \phi \varepsilon \lambda \varepsilon i \tau \alpha l ;)$. The problem connects with the previous ones by the reference to animal sense perception ( $\alpha$ i $\sigma \theta \eta \sigma \iota)$.

The quaestio is further illustrated in an intermediate section where Plutarch gives several examples drawn from natural history. Bitches eat grass in order to vomit bile, sows capture and eat river crabs to relieve headaches, tortoises feed on marjoram as an antidote for the viper flesh they have eaten, and people say that the she-bear recovers from nausea

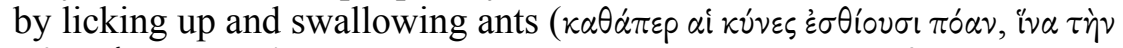

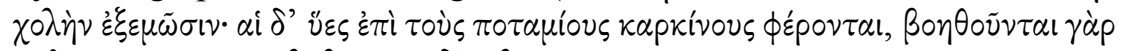

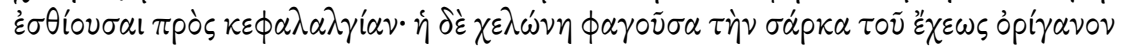

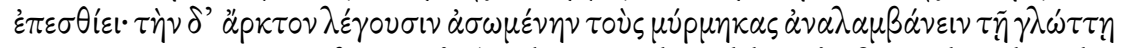

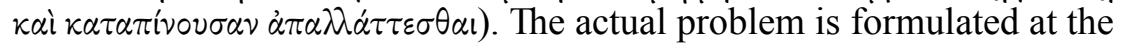
very end of the quaestio, where Plutarch points out that these animals have no previous experience or have never tried these remedies before

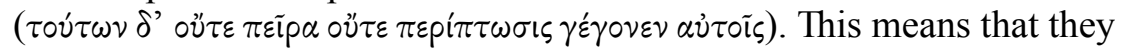
do not act on the basis of knowledge or insight, and that there must be another, more physical, reason for it.

Plutarch gives two explanations that are closely connected to each other. According to the first causa, it is by the attractive qualities of odours that animals find the proper cure for their disease. However, this does not explain why animals are attracted by these odours only when they are ill. Plutarch explains this point in the second causa, where he argues

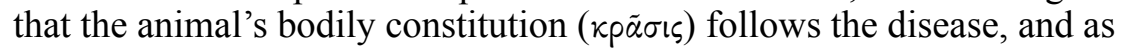
such influences the appetite. The two explanations are complementary to each other and must be read together for a proper understanding of the problem.

In the first explanation, Plutarch adds two new cases: he argues that in the same way as the odour of honeycombs excites and attracts bees from far off and that of carrion vultures, so do crabs attract sows, marjoram

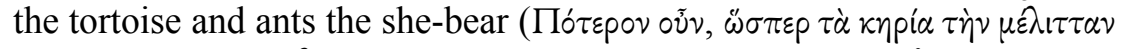

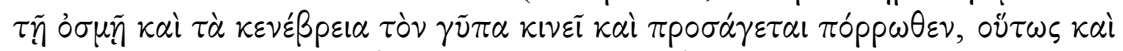

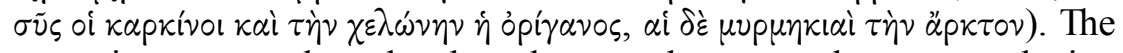
attraction comes about by the odours and streams that are conducive and suitable to the animal's well-being, under the governance of the

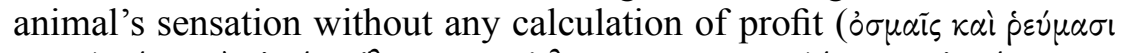

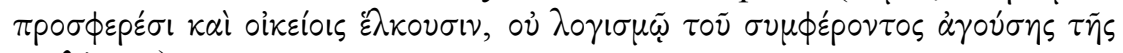
ai $\sigma \dot{\eta} \sigma \varepsilon \omega \varsigma)$. 
The second explanation centres on the animal's кpã $\sigma ı \varsigma$ (i.e. its bodily

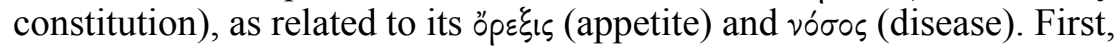
Plutarch generally argues that the animals' appetites are produced by their bodily constitutions, which are brought about by their diseases. These diseases create various pungencies, sweetnesses, or other strange and

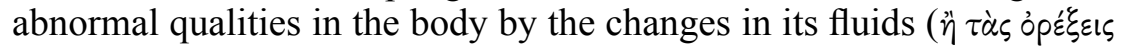

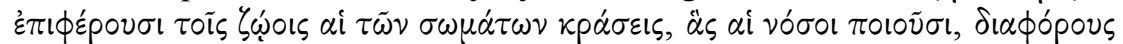

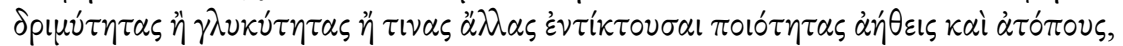
$\tau \tilde{\omega} \nu \dot{\delta} \gamma \rho \tilde{\omega} \nu \tau \rho \varepsilon \pi \tau \mu \varepsilon v \omega \nu ;)$. This point is further illustrated by two cases of abnormal appetites. Plutarch first refers to the fact that pregnant women

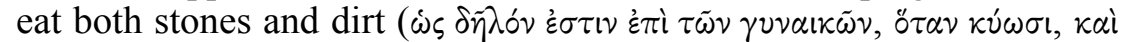
$\lambda i \theta \circ \cup \varsigma$ кai $\gamma \tilde{\eta} \nu \pi \rho \circ \sigma \phi \varepsilon \rho \circ \mu \varepsilon \varepsilon \omega \nu)$. The second example is more circumstantial. Plutarch argues that accomplished physicians know in advance which patients are past recovery and which are capable of recovery on the basis of

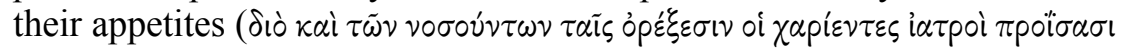
$\left.\tau \circ \dot{s} \varsigma \dot{\alpha} \sigma \dot{\omega} \tau \omega \varsigma \dot{\eta} \sigma \omega \tau \eta p^{\prime} \omega \varsigma \dot{\varepsilon} \chi 0 \nu \tau \alpha \varsigma\right)$. According to the physician Mnesitheus, at least, patients that are in the initial stage of 'pneumonia' recover when they have an appetite for onions but die when they long for figs, because the appetite follows the bodily constitution, which in turn, follows the disease

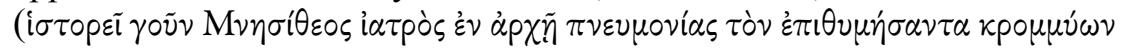

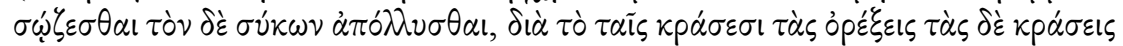
$\tau \circ \tilde{i} \varsigma \pi \dot{\alpha} \theta \varepsilon \sigma \nu$ है $\pi \varepsilon \sigma \theta \alpha$ ). Plutarch concludes (with an argumentative ring [see 4.3.3.3.]) that it is plausible that animals also (i.e. just like human beings) that catch not entirely lethal and destructive diseases acquire precisely that bodily condition and constitution that leads and guides each one of

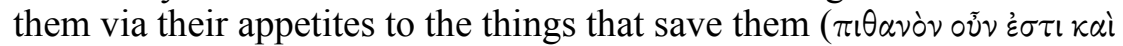

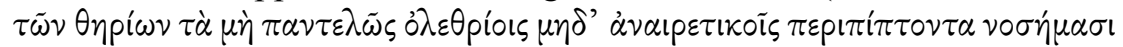

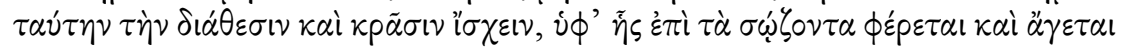

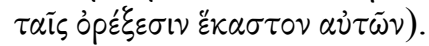

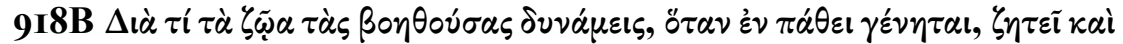

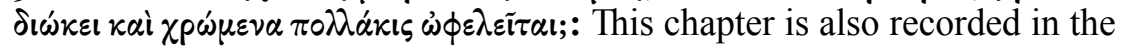
sourcebook of G.L. Irby-Massie and P.T. Keyser, 2002, p. 277 on Greek Science of the Hellenistic Era.

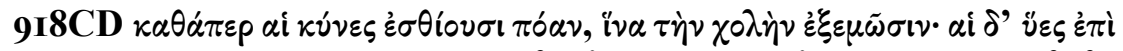

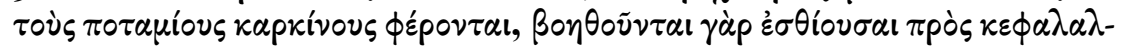

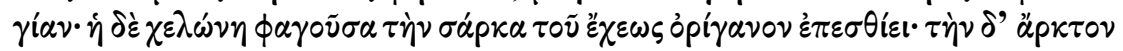

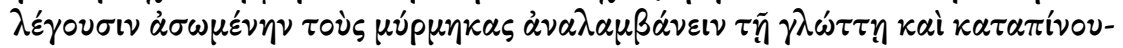
$\sigma \alpha \nu \dot{\alpha} \pi \alpha \lambda \lambda \alpha \tau \tau \varepsilon \sigma \theta \alpha \mathrm{l}$ : This intermediate section is meant to illustrate that such auto-remediation is a relatively common phenomenon in the animal kingdom. There are numerous parallels for these paradoxical accounts, both in the corpus Plutarcheum (for tortoises, dogs, and the she-bear, cf. De soll. an. 974B; for pigs and tortoises, cf. Gryllus 99IEF), and in the 
ancient scientific tradition more generally, sometimes with minor variations. For bitches, cf. Arist., HA 6I2a5-6, 594a28-29, Ael., NA 5, 46; 8, 9, Gal., Ven.Sect.Er. II, I68, 2-3 Kühn, Sext. Emp., HP I, 7I, Pliny, $N H$ 25, 9I, Cic., De nat. deor. 2, I26; for sows, cf. Pliny, $N H$ 8, 98 (boars eat sea-crabs); for tortoises, cf. Arist., HA 6I2a24-25, Ps.-Arist., Mir. ausc. 83ra27-28, Antig. Car., Hist. mir. 34, Ael., $N A$ 3, 5; 6, I2 (they eat marjoram before attacking vipers), Pliny, $N H$ 8, 98 and 20, I69 (they eat cunila bubula); for she-bears, cf. Arist, HA 594b9 (they eat crabs and ants), Ael., $N A$ 6, 3, Sext. Emp., $H P$ I, 57, Pliny, $N H$ 8, IOI (as an antidote against mandragora) and 29, I33 (they eat ants' eggs).

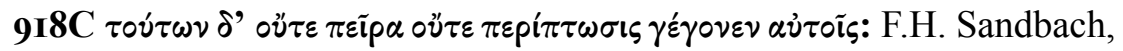
I965, p. 204, n. 3 adds $\delta 1 \delta \alpha \sigma \kappa \alpha \lambda i \alpha \pi \circ \theta \dot{\varepsilon} \nu$ oü $\tau \varepsilon$ ('they did not receive any

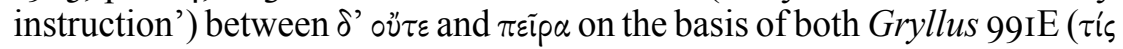
$\delta \dot{\varepsilon} \tau \dot{\alpha} \varsigma \chi \varepsilon \lambda \omega \nu \alpha \varsigma \dot{\varepsilon} \delta \hat{\delta} \delta \alpha \xi \varepsilon \kappa \tau \lambda$.;) and Pliny, NH 27, 7 (feris ratio et usus inter se tradi non possit). This seems unnecessary, though (cf. also L. Senzasono, 2006, p. 223, n. I48).

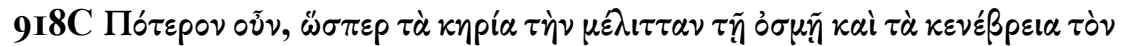

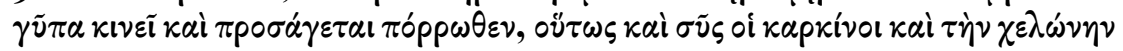

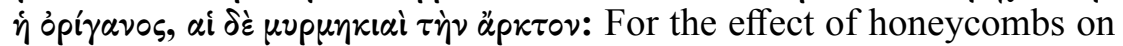
bees and of carrion on vultures, cf. Lucr., De rer. nat. 4, 678-680. For bees, cf. also Col., De re rust. 9, I5, I0. Plutarch will deal with the effect of strong smells on bees in Q.N. $35^{-36}$ in more detail.

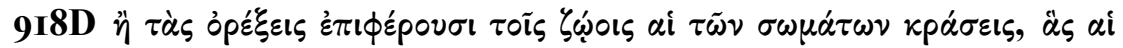

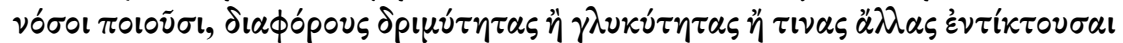

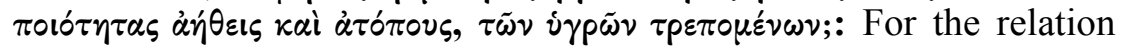

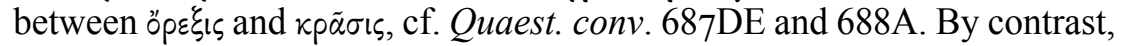

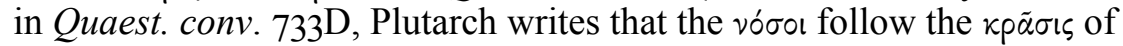
the body and not the other way around. Regarding the change of bodily fluids, cf., e.g., Q.N. I, 9IIE, where Plutarch indicates that fevers turn moisture into bile.

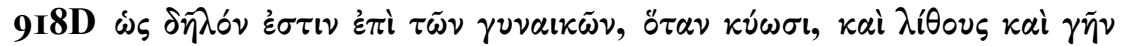
$\pi$ тробфро $\mu \varepsilon v \omega \nu$ : Pregnancy is presented as some kind of a 'disease', which brings about a change in the bodily constitution of women and, by implication, in their appetite. The belief that pregnant women long for stones is repeated in Praec. ger. reip. 8oIA. Plutarch's source is uncertain: he may rely on hearsay or (indirectly) on a medical treatise, perhaps from the kind of Soranus' Gynaecia or the Hippocratic gynaecological writings. He may have found it in the same work from which he draws Mnesitheus' account (in what follows). Notably, the Lamprias catalogue mentions a lost work Пвpi $\gamma \varepsilon \omega \phi \alpha \dot{\gamma} \omega \nu \nu$ (nr. I9I). Cf. also Hipp., De superfetat. I8, Arist., $H A$ 
584aI9, EN II48b24-29, Pliny, $N H$ 28, 247. On geophagy more generally (which is considered rare among Greeks and Romans), see B. Laufer, I930 (p. I64).

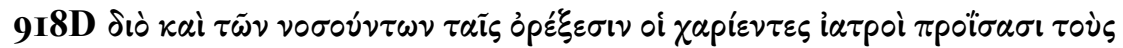

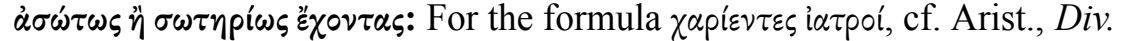
som. 463 a5 and $E N$ IIO2a22.

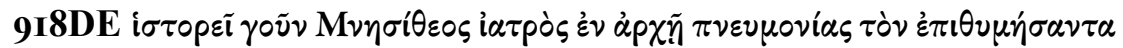

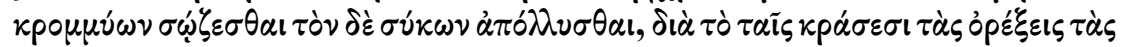

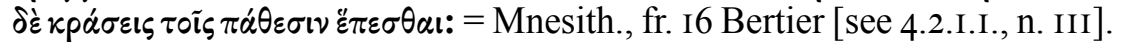
The word $\pi \nu \varepsilon v \mu o v i \alpha$ is rare while $\pi \varepsilon p i \pi \lambda \varepsilon v \mu o v i \alpha$ (also simply $\pi \lambda \varepsilon v \mu \circ v^{\prime} \alpha$ ) or $\pi \varepsilon p i \pi v \varepsilon \nu \mu o v i ́ \alpha$ are more common (see LSJ, s.vv. and J. Bertier, I972, p. I7I). Is Plutarch perhaps relying on an intermediate source or paraphrasing Mnesitheus' account in his own (less technical) words? Or should we, rather, correct the reading of the manuscripts (manuscript $\psi$ has $\pi \varepsilon p i$ $\pi \nu \varepsilon v \mu v^{\prime}(\alpha)$ ?

\section{Q.N. 27, 918EF}

Q.N. 27 concerns a vinicultural problem, and, as such, links up more naturally with $Q . N$. 30-3I (cf. also $Q . N$. I0) than with the problems concerning land animals and hunting in Q.N. 20-28. Plutarch wonders why must (i.e. freshly pressed grape juice, in which the sugar has not yet changed into alcohol) remains sweet for a long time if the vessel is

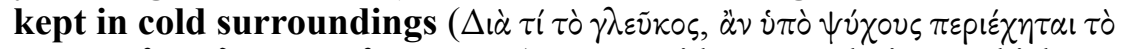

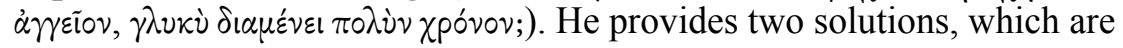

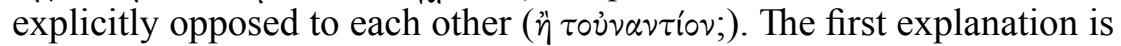
based on the idea that heat destroys the sweetness of the must whereas cold preserves it. According to the second, cold shuts heat in and thus preserves the sweetness of the must.

The first explanation maintains that the change of must into the vinous liquid is a concoction. Cold, on the other hand, hinders concoction, because

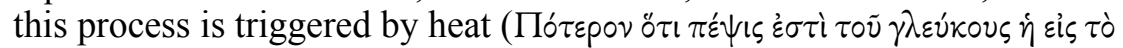

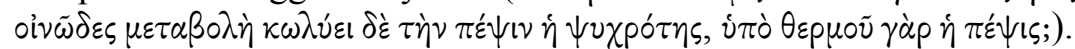

The second explanation is explicitly opposed to the first one by the

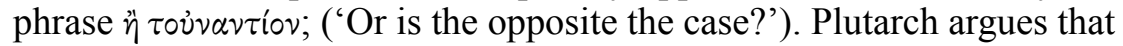
the sweet flavour is proper to the (ripe) grape. Hence it is said that the sweet flavour that becomes mixed (with the unripe, sour grape) 'ripens'

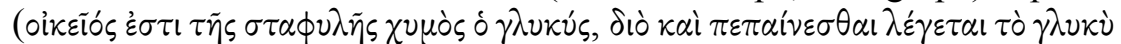

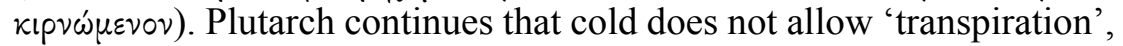


but shuts in the heat and thus conserves the sweetness of the must $(\dot{\eta} \delta \dot{\varepsilon}$

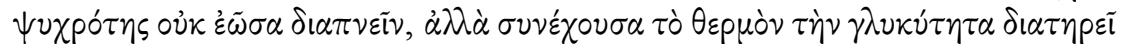
$\tau \circ \tilde{v} \gamma \lambda \varepsilon \dot{\text { kovs}}$ ). That is the same reason as to why the must of grapes that are gathered in the rain ferments less. After all, fermentation is caused by

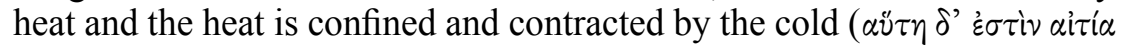

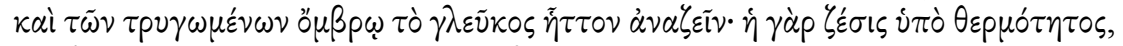

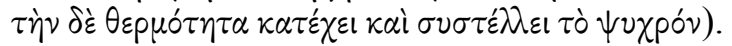

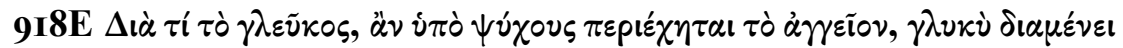
$\pi \circ \lambda \dot{\nu} \nu$ xpóvov;: Plutarch may be implying that the container with must is submerged into fresh water in order to keep it sweet: cf. Pliny, $\mathrm{NH}$ I4, 83 and Col., De re rust. I2, 29.

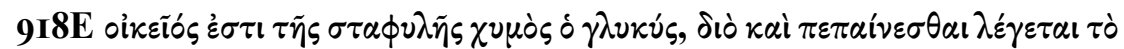

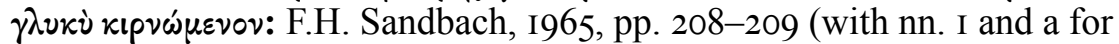
further remarks) marks a lacuna between $\lambda \varepsilon \dot{\varepsilon} \varepsilon \tau \alpha \iota$ and $\tau \dot{\partial} \gamma \lambda \nu \kappa \dot{~} \kappa ı \nu \nu \omega ́ \mu \varepsilon v o v$ (he translates " $<$ when the warmth leaves the must there is also released $>$ "), but there is no lacuna in the manuscripts. Even so the text is rather concise at this point. If we interpret the term $\sigma \tau \alpha \phi \nu \lambda \eta$ as a 'ripe grape', as (implicitly) opposed to an 'unripe grape' ( $\left.{ }^{\prime} \mu \phi \alpha \xi\right)$, the meaning becomes clearer (for the opposition between the ripe and the unripe grape, see LSJ, s.v. $\left.\sigma \tau \alpha \phi \nu \lambda \eta \eta^{\prime}\right)$. Plutarch's argument then amounts to the idea that the admixture of sweetness matures the unripe grape and ripens it (sweetness being proper to a ripe grape). Cf. Gal., SMT II, 657, 2-4 (Kühn): $\dot{\eta} \not \mu \phi \alpha \xi$

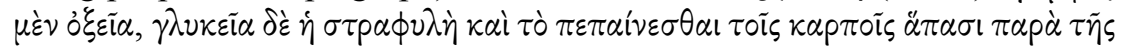

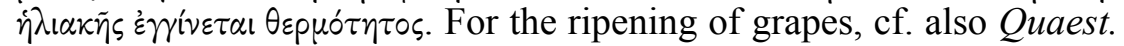

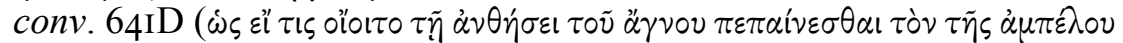

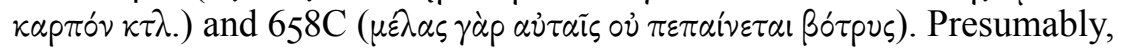
an aspect of heat is implicit in the verb $\pi \varepsilon \pi \alpha i v \varepsilon \sigma \theta \alpha$, since ripening is a process that involves increasing heat (cf. Q.N. 5, 9I3C and LSJ, s.v.; on an etymological basis, F.H. Sandbach, I965, pp. 208-209 n. a even links the concept of $\pi \varepsilon \pi \alpha i v \varepsilon \sigma \theta \alpha \iota$ with that of $\pi \varepsilon \dot{\varepsilon}(\zeta)$. According to Ps.-Arist., Probl. 930b23-25, fruit contains a great deal of fire and moisture, so that because

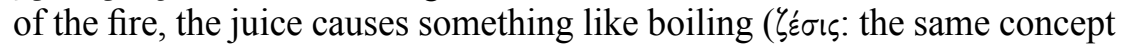
recurs at the end of Q.N. 27). The association between the grape's heat and its sweetness is central to Plutarch's argument. The point seems to be that the sweetness of the ripe grape somehow contains heat owing to the process of maturisation that is triggered by its admixture. This heat is also present in the must itself that is made from the ripe, sweet grapes (as is clear from what follows in the argument). This is, indeed, opposite to

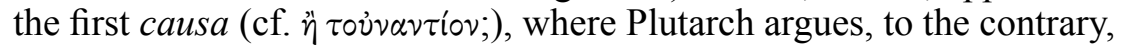
that heat (of concoction) destroys sweetness in the must, turning it into a vinous liquid. For the association between heat and sweetness, cf. also Q.N. 20, 9I7A (and 5, 913C). 


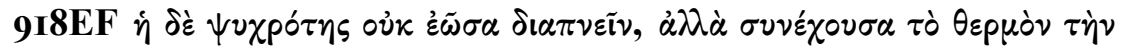

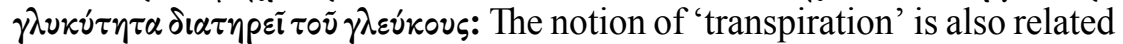

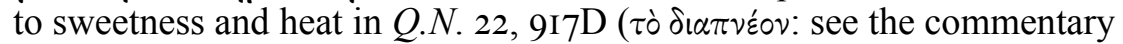
ad loc.). The idea that coldness shuts the heat in is probably an allusion to the process of $\dot{\alpha} v \tau i \pi \varepsilon p i \sigma \tau \alpha \sigma i \varsigma$. Cf. also Theophr., $C P$ 2, 8, 2-3.

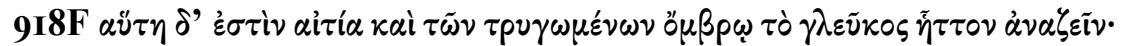

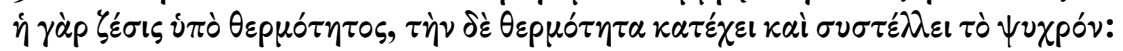
For the opposite idea, viz. that wine made from grapes collected in the rain is sour rather than sweet, see Gal., SMT II, 656, II-I4 (Kühn). According to Arist., Mete. 380b3I-38raI, the production of wine from must is due to a process of boiling ( $\tilde{\varepsilon}^{\psi} \psi \eta{ }^{\prime} \varsigma$, cf. also Pliny, $\mathrm{NH} \mathrm{I} 4,83$ : fervere). This

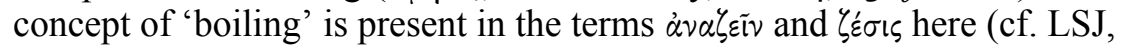
s.vv.).

\section{Q.N. 28, 918F-919A}

In Q.N. 28, Plutarch returns to the theme of land animals and hunting. He wonders why she-bears, least of all animals, gnaw through nets,

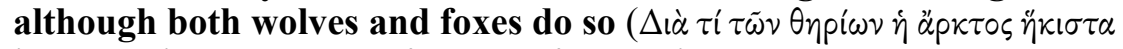

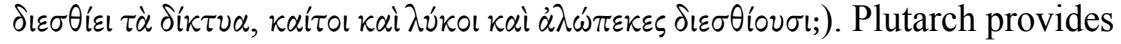
three explanations that follow each other in a rapid succession (the conclusion of the problem is lacunary). The first explanation concerns the anatomy of the bear's mouth, the second, the strength in its forepaws, and the third refers to both the bear's mouth and its fore-paws, but adds a further specification. The second and third causae, which mention the bear's 'hands', will especially remind the reader of Q.N. 22, where Plutarch discusses the sweet taste of the bear's fore-paws in relation to their frequent movement.

In the first explanation, Plutarch argues that the bear's teeth are set at the very back of its open mouth, so that it (sc. the mouth) is least able to reach the cords (of the net). After all, the bear's lips meet them first due to their

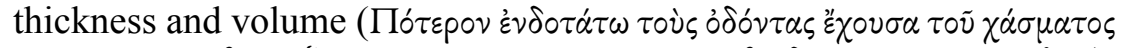

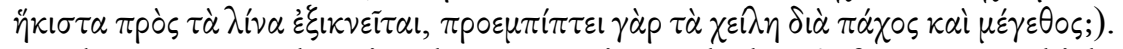

The second explanation draws attention to the bear's fore-paws, which, so Plutarch argues, have greater power to shred and tear apart the mesh of

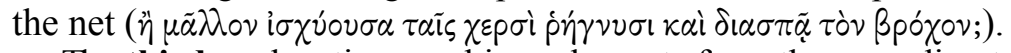

The third explanation combines elements from the preceding two, but the text is lacunary at the end. Plutarch argues that the bear uses both its paws and its mouth at the same time: the former to tear the net apart and

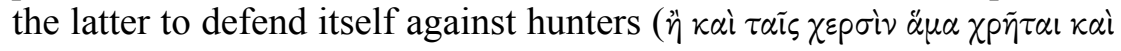




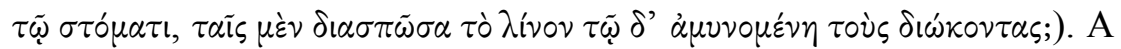
final consideration involves the idea that nothing helps the bear more than rolling around. Rather than trying to tear the cords (of the net) apart, it is in this way that the bear often tumbles out of the nets and escapes, so that

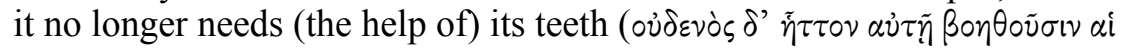

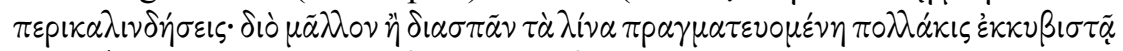

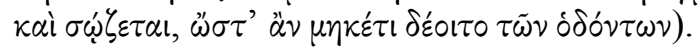

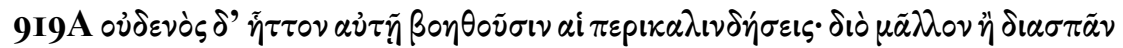

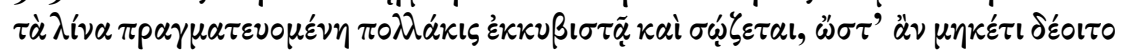

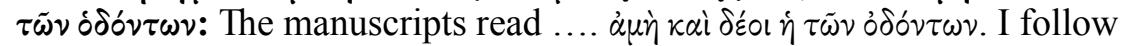
the reading of C. Hubert, I960, p. 24 ('so that the bear no longer needs (the help of) its teeth'), but the alternative reading of F.H. Sandbach, I965, p. $2 \mathrm{IO}, \mathrm{n}$. I is also appealing, as it draws attention to a more subtle and

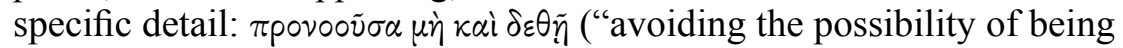
entangled by its teeth"). Alii alia. The noun $\pi \varepsilon p ı<\alpha \lambda \iota \nu \delta \dot{\eta} \sigma \varepsilon ı$ is a hapax (the

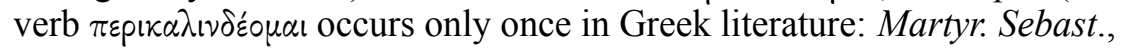

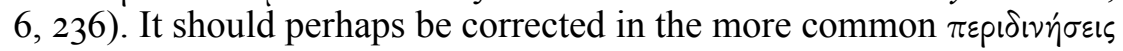
(cf., e.g., De facie 923C, Flam. I0, 6, Lys. I2, 6).

\section{Q.N. 29, 919AB}

In Q.N. 29, we find a problem that stands somewhat on its own in the collection. It is relatively atypical not only from a formal perspective, but its content is also much more reflective and rhetorical than is the case in Plutarch's other natural problems [see I.2.3.]. Initially, the reader might expect Plutarch to simply treat yet another natural problem here, but the tone of the discourse rapidly changes. The problem is why we marvel at hot springs, but not at cold ones (Tis $\dot{\eta} \alpha i \tau i \alpha, \delta \iota^{\prime} \dot{\eta} \nu \tau \dot{\alpha} \psi v x p \dot{\alpha} \tau \tilde{\omega} \nu \dot{v} \delta \dot{\alpha} \tau \omega \nu$ ov $\theta \alpha \nu \mu \dot{\alpha} \zeta o \mu \varepsilon v \dot{\alpha} \lambda \dot{\alpha} \dot{\alpha} \dot{\alpha} \theta \varepsilon p \mu \dot{\alpha} ;)$. Plutarch points out that there is, in fact, not much reason to marvel at this phenomenon, because it is obvious that

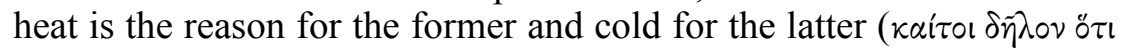

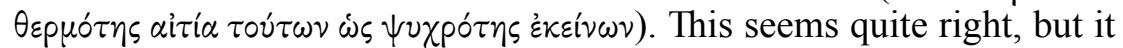
remains unclear where this heat or cold exactly comes from. In fact, we will learn from the aetiology that it is not so much the natural phenomena of hot or cold springs themselves, but people's short-sighted marvelling at them that is the issue here. Unfortunately, the ending of the chapter is lacunary: it breaks off abruptly, but the original argument can be restored from several parallel accounts (see the final comment).

At the beginning of the explanation, Plutarch makes an abstract and sophisticated remark about the essence of cold, pointing out that it is 
not true, as some believe, that heat is an active property, whereas cold is a privation of heat. After all, in this way, the non-existent would appear to be responsible for more phenomena than the existent (Ov $\gamma \alpha \dot{\alpha} \rho$, $\dot{\omega} \varsigma^{\varepsilon} \nu 10 \mathrm{l}$

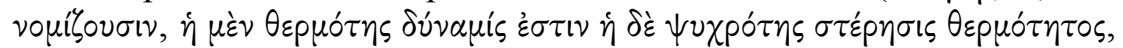

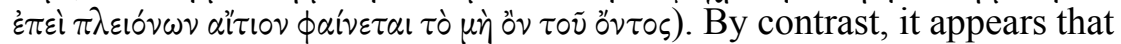
nature attributes marvellousness to rarity and stimulates the research of how a phenomenon comes to be only if it occurs infrequently ( $\dot{\alpha} \lambda \lambda$ '

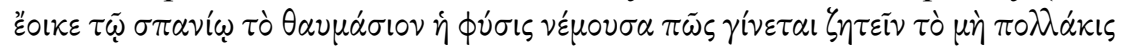
$\gamma(\nu o ́ \mu \varepsilon v o v)$. In what follows, Plutarch describes his own personal marvel for the cosmic spectacles that nature puts on display. He first quotes the following lines from Euripides: 'You see this infinite heaven up high /

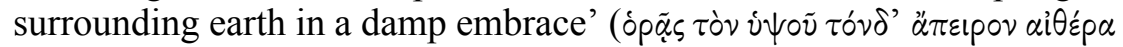

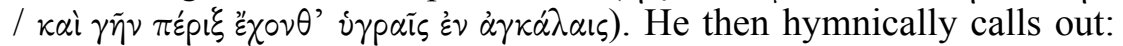
'What a multitude of spectacles does it bring at night, how great is the

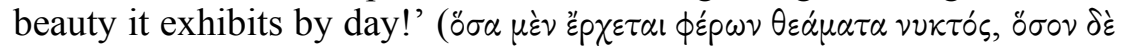

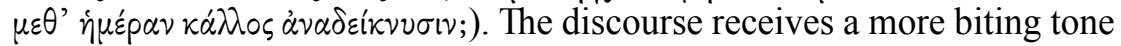
when Plutarch starts to target the common people, whom he accuses of not

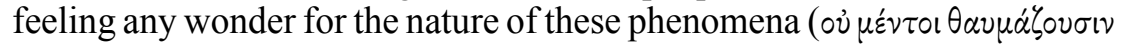
oi $\pi \circ \lambda$ oi $\tau \dot{\eta} \nu \tau \circ \dot{\tau} \tau \omega \nu \phi \dot{v} \sigma(v)$. Their attention only goes to rare phenomena such as rainbows, the variety of clouds by day, meteors bursting like bubbles,

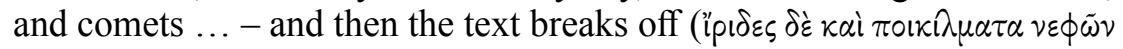

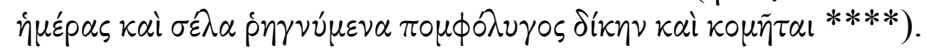

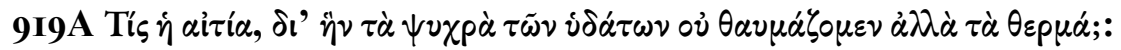
Notably, the formulation of the quaestio with the phrase $\tau i \varsigma \dot{\eta} \alpha i \tau i \alpha \delta i^{\prime} \eta \nu$ is rather exceptional (but cf. also Q.N. 40), and the aetiology is not based on the typical structure of $\pi$ ó $\tau \varepsilon p o \nu[. ..] \ddot{\eta}[\ldots] \ddot{\eta}[\ldots]$. The topic of this chapter falls under the general theme of Book 24 of Ps.-Aristotle's Problems (ö $\sigma \alpha$

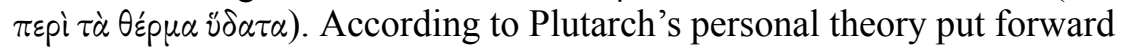
in De prim. frig. $952 \mathrm{C}-955 \mathrm{C}$, it is not water, but earth that is the principle of cold. From this perspective, the problem of Q.N. 29 seems legitimate: if all springs rise from the earth, why are some hot and others cold? As G. Sarton, I965, p. 388, n. 28 notes, "[h] ot and mineral springs were highly appreciated and exploited by the Romans, as they had been before them by the Greeks, Etruscans, Carthaginians, and Gauls. Balneology began in prehistoric times." Plutarch in Ca. Ma. 2I, 5 reports, for instance, that Cato the Elder bought $v \delta \alpha \tau \alpha \theta \varepsilon p \mu \alpha$. On the generation and disappearance of

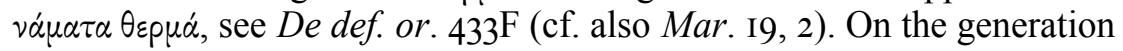
of springs in general, see Aem. Paul. I4.

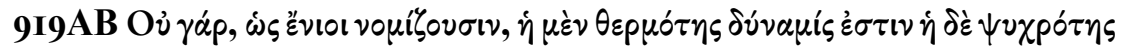

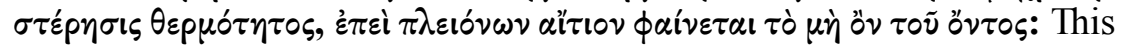
point is not explained any further. What Plutarch probably implies is that cold springs occur more frequently than hot springs, making them 


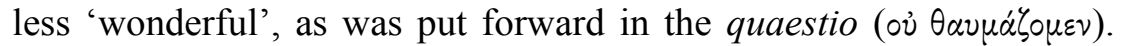
The same theory, according to which cold is a dívaus in itself rather than a $\sigma \tau \dot{\varepsilon} p \eta \sigma i s$ of heat, is elaborated upon in the first part of De primo frigido (945F-948A). The idea that cold is a $\delta$ v́vaus in its own right is

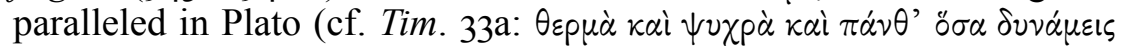

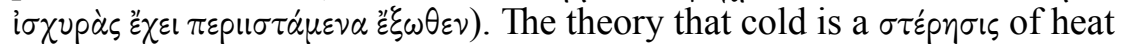
is Aristotelian (cf. Met. I070b9-I3, De caelo 286a25-26, GC 3i8bi4I7; but by contrast, cf. PA 649ai8-I9; see also O. Longo, I992). If Plutarch with हैं $v$ oo implicitly refers to the Peripatetics here, it appears that these are criticised without their name being explicitly mentioned. This procedure is not uncommon in the Moralia (as marked by D. Babut, I994, p. 574, with n. I37 and I969, p. 95 with nn. 5 and 6). Aristotle is anonymously criticised, also in De def. or. $426 \mathrm{D}$. Let it be clear, moreover, that these हैviol should not be identified with oi $\pi \circ \lambda$ oi later on.

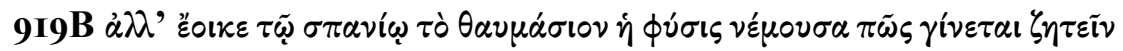

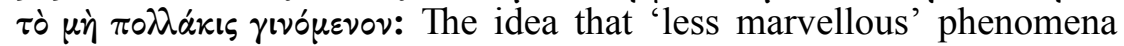
(c.q. cold springs) deserve attention just as much as 'more marvellous' ones (c.q. hot springs) is relatively common (cf. Arist., $P A$ 645al6I7, Sen., NQ 7, I-4, Cic., De nat. deor. 2, 96, Ps.-Cic., Rhet. ad Her. 3, 36, Lucr., De rer. nat. 2, I030-I039, Pliny, Ep. 8, 20, esp. I-2 reference by J.J. Hartman, I9I6, p. 556). Most scholars translate $\phi \dot{\sigma} \sigma \mathrm{s}$ as 'human nature' here, which may well be correct (cf. F.H. Sandbach, I965, p. 2II; L. Senzasono, 2006, p. I2I). But perhaps a more denotative and referential interpretation of the term is worth considering, in line with the general stylistics of the collection (otherwise, one could expect a more

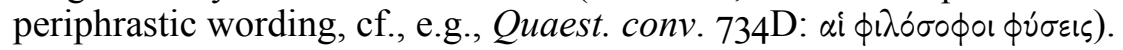
C.F. Schnitzer, I860, p. 2732 combines both options in his translation (my italics: "Aber es scheint in der Natur zu liegen daß man dem Seltenen den Charakter des Wunderbaren beilegt und bei Allem was nicht oft vorkommt nach der Entstehung fragt."). The meaning of $\dot{v} \sigma \mathrm{ks}$ may, indeed, be zeugmatic, in that human nature is strongly related to

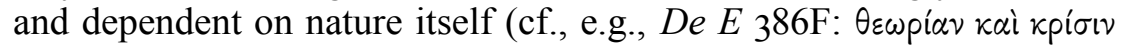
$\left.\dot{\alpha} \nu \theta \rho \omega \dot{\pi} \pi \omega \mu \sigma^{\prime} \omega \omega \pi \alpha \alpha \delta \varepsilon \delta \omega \kappa \varepsilon \nu \dot{\eta} \phi \dot{\sigma} \sigma \varsigma\right)$. In that case, it is perhaps implied that nature itself attributes marvellousness to rarity and stimulates the research of how a phenomenon comes to be only if it occurs infrequently. It

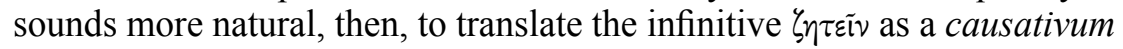
with the ellipse of an object ('nature incites <people> to inquire'). The aspect of wonder ( $\tau \dot{\partial} \theta \alpha \nu \mu \alpha \dot{\sigma} / 0 \nu$ ) is not so much considered a human

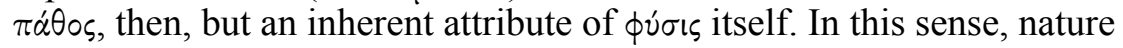
( $\phi \dot{v} \sigma \zeta \varsigma$ ), in presenting its 'wonders' to us, strongly appeals to a proper understanding by researching how these phenomena come to be ( $\pi \tilde{\omega} \varsigma$ $\gamma^{\prime}(\nu \varepsilon \tau \alpha \iota \zeta \eta \tau \varepsilon \tau)$. 


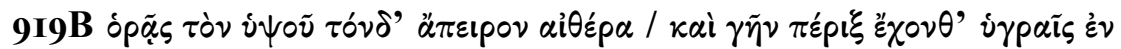

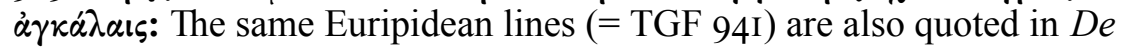
exilio 60IA and $A d$ princ. iner. $780 \mathrm{DD}$. In the third verse, which is not quoted here, the poet identifies the aibnjp with Zeus.

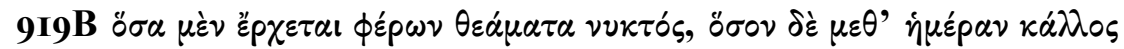
$\dot{\alpha} \nu \alpha \delta \varepsilon i \kappa v v \sigma \iota v ;:$ For similar rhetorical questions and exclamations, cf. Sen., Ben. 4, 23 and Ad Helv. 8, 4. The expressive couple of rhetorical questions further underlines the awesome sights that the $\pi \varepsilon p 1 \varepsilon$ xov puts on display. In combination with the evocative fashion in which Plutarch quotes Euripides' lines (see the previous comment), they lift the discourse to a more rhetorical level (which is exceptional to the collection's general register [see I.2.3.]).

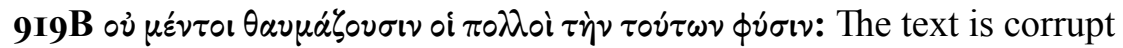

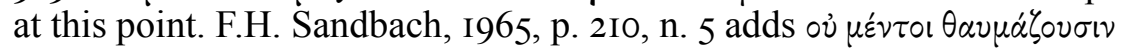
(after Wyttenbach). Cf. also C. Hubert, 1960, p. 25: oi $\langle\delta \dot{\varepsilon}\rangle \pi \circ \lambda$ oi $\tau \dot{\eta} \nu$

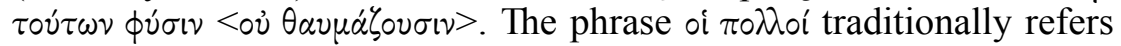
to the un(der)educated plebs (cf., e.g., Q.N. 3, 9I2D and Quaest. conv. $664 \mathrm{BC}$ ). I take this to imply that the wonder of the common people for rare natural phenomena remains superficial and does not lead on to actual

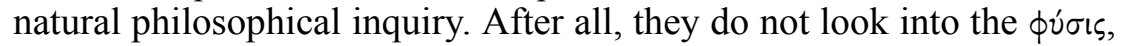
i.e. the natural causes (cf. $\pi \tilde{\omega} \varsigma \gamma^{\prime}(\nu \varepsilon \tau \alpha l \zeta \eta \tau \varepsilon \tilde{\nu})$ ), of natural phenomena. For

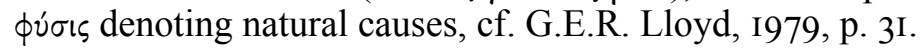

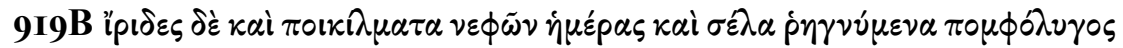

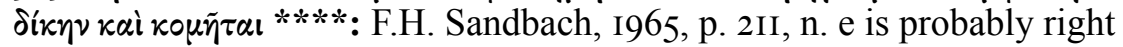
that the $\pi \circ \mathrm{o}^{\prime} \lambda \mu \alpha \tau \alpha \nu \varepsilon \phi \tilde{\omega} \nu$ refer to the "coloration rather than shapes or patterns" of the clouds. As to $\sigma \varepsilon \lambda \alpha \varsigma$, we read in Ps.-Arist., De mund. $395 b_{3}-4$ that the noun refers to the lighting of a column of fire in the air,

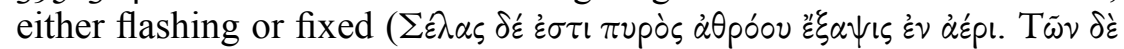
$\sigma \varepsilon \lambda \dot{\alpha} \omega \nu \dot{\alpha} \mu \dot{\varepsilon} \nu \dot{\alpha} \kappa o v \tau i \zeta \xi \tau \alpha l, \ddot{\alpha} \delta \dot{\varepsilon} \sigma \tau \eta i^{\prime}(\xi \tau \alpha l)$. Seneca translates $\sigma \varepsilon \lambda \alpha$ as fulgores (NQ I, I5, I-3, cf. also De fort. Rom. 323C: $\sigma \varepsilon \lambda \alpha \varsigma \alpha \dot{\alpha} \sigma \tau \alpha \pi \tilde{\eta} \pi \alpha \rho \alpha \pi \lambda \dot{\eta} \sigma 10 \nu)$. F. Fuhrmann, 1964, p. 77 marks only one case of literary imagery for Quaestiones naturales, viz. "[1]es météores éclatent comme des bulles". For the bursting of fiery bubbles, cf. also De sera num. 563F-564A and Sen., $N Q$ I, I, 3. For a similar polysyndetic enumeration of 'wonderful' meteorological spectacles, see De Pyth. or. 409CD, where children's amazement for celestial phenomena is particularly reprimanded (kai yà oi

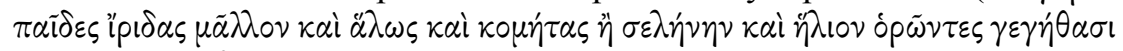
kai $\alpha \gamma \alpha \pi \tilde{\omega} \sigma \iota \kappa \tau \lambda$.). A similar passage is found in Amatorius 766A ( $\tilde{\omega} \sigma \pi \varepsilon p$ oi

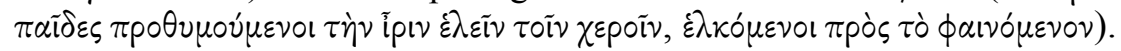
One can expect from these parallels that Plutarch originally concluded his invective against the common people in Q.N. 29 with the same topic, 
namely that the 'childish' astonishment of the ignorant plebs for such wonderful phenomena - and hence also for similar phenomena, such as the hot springs - is motivated on irrational grounds, presumably superstition (cf. Per. 6, I [quoted 3.2.2.], see also, e.g., Alex. 75, I-2, Sen., NQ 7, 2 and Critias, fr. DK88B25, esp. 27-36). I have elaborated this point elsewhere: see M. Meeusen, 20I5b. Ironically enough, though, with all of this, Plutarch does not really provide a detailed solution to the quaestio at hand about hot and cold springs (did it perhaps follow in the lost part?). He does, of course, explain in the quaestio that it is clear that heat is the reason for the hot springs and cold for the cold ones, but this requires further elaboration to be satisfactory. Cf. also C.F. Schnitzer, I860, p. 2732, n. 2: "Die Erklärung der Ursache fehlt, wenn sie nicht darin liegt daß das Seltene als das Wunderbare gelte."

\section{Viniculture (Q.N. 30-3I)}

The two chapters that follow in Q.N. 30-3I are closely connected to each other through the topic of vines and viniculture, which ties in with the subject of wine drinking and drunkenness in Book 3 of the Problems (

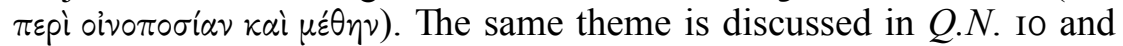
27. The main focus in Q.N. 30-3I is of a mostly botanical kind, though. One may, therefore, presume a Theophrastan source, possibly through the intermediation of lost problems (see esp. Q.N. 30). Unfortunately, the original Greek text breaks off abruptly at the end of Q.N. 3I.

\section{Q.N. 30, 9I9BC}

In Q.N. 30, Plutarch examines the meaning and etymology of the verb $\tau p \alpha \gamma \tilde{\alpha} \nu$ ('to go goatish'), which is said of vines that do not bear fruit, but flourish with branches and shoots $(\Delta i \dot{\alpha} \tau i \tau \tilde{\omega} \nu \dot{\alpha} \mu \pi \dot{\varepsilon} \lambda \omega \nu \tau \dot{\alpha} \zeta \dot{\alpha} \kappa \dot{\alpha} \rho \pi \circ v \varsigma$,

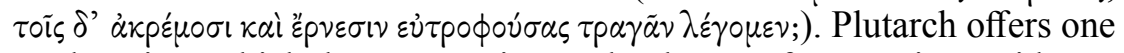
explanation, which draws attention to the theory of generative residues.

By analogy with the vines, Plutarch argues that exceedingly fat male goats

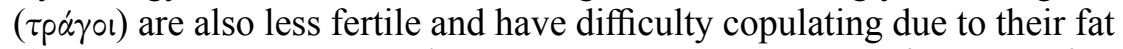

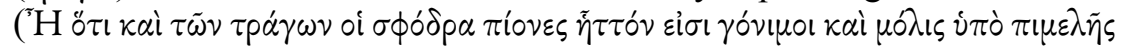

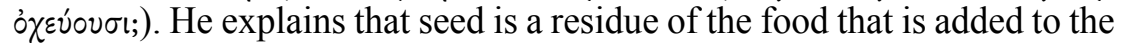

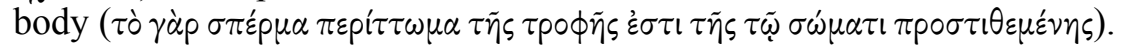
Thus, when either an animal or a tree is in good condition and increases in volume, it is a sign that the food is consumed in the body and either does not produce a residue or produces only a small and modest amount (" $\tau \alpha \nu$

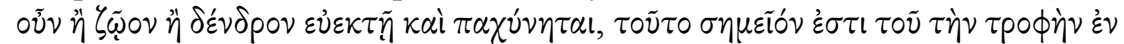

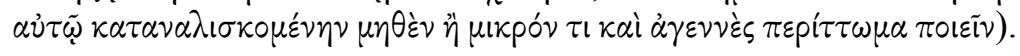




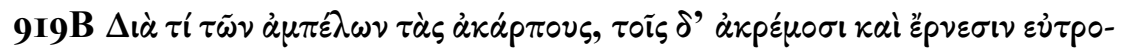

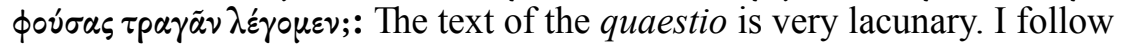
Wyttenbach's reading. The same phenomenon is recorded by Aristotle and Theophrastus, who provide basically the same explanation for it, at times also mentioning the decreased fertility of fat goats (see Arist., $H A$ 546a -4, GA 725b32-726a6, Theophr., CP 5, 9, I0; cf. also HP 2, 7, 6 and 4, I4, 6). There is reason to assume that Plutarch's source was Peripatetic and that he perhaps relies on a lost problem. The concept of $\tau p \alpha \gamma \tilde{\alpha} \nu$ is also used with respect to boys' voices cracking when they reach puberty. Cf. Ps.-Alex. Aphr., Probl. I, I25 (J.L. Ideler, I84I, pp. 42, 36-43, 32): $\dot{\varepsilon} \kappa$

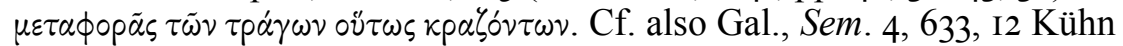
and $U P$ 4, I72, I3 Kühn.

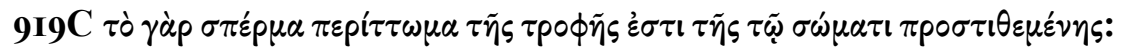
For the idea that seed is formed from a residue of food, cf. Q.N. 2I, 917 B [see 4.3.4.I., n. 295].

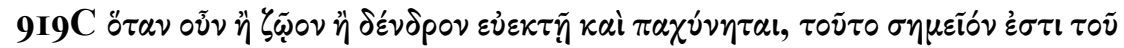

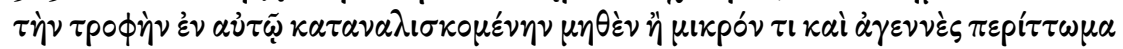
$\pi \circ เ \varepsilon \tau$ : For the same reason, no residue is left in strong palm trees and athletes (cf. Quaest. conv. 724E with Q.N. 32), or in other trees (like fir and cypress) and overweight people (cf. Quaest. conv. 640F-64IA).

\section{Q.N. 3I, 9I9CE}

Q.N. 3I is closely connected with the previous chapter through the topic of vines (cf. also the repetition of the verb $\pi p \circ \sigma \tau i \theta \eta \mu$, which refers to the addition of food to the body). Plutarch wonders why a vine wilts if it is sprinkled with wine, especially with wine made from its own

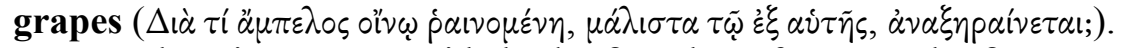
Four explanations are provided. The first three focus on the first part of the quaestio (viz. that a vine wilts if it is sprinkled with wine). The first one refers to the wine's heat, the second to its putrefactive character and the third to its astringent nature. The fourth explanation, by contrast, focuses on the specification of 'wine made from its own grapes' in the quaestio, more precisely by referring to the vine's inability to receive a substance that has left it (the ending of the problem is lacunary).

In the first explanation, Plutarch draws an analogy between the wilting of

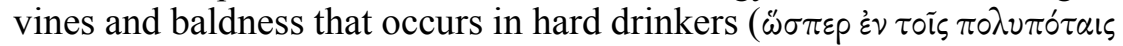
$\gamma(v \varepsilon \tau \alpha l \phi \alpha \lambda \alpha$ k $p \omega \sigma(\zeta)$. Plants and hairs alike grow only if their roots receive 
moisture, but the wine evaporates the moisture due to its heat ( $\dot{v} \pi \grave{\text { o }}$

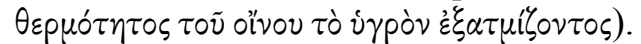

In the second explanation, Plutarch draws attention to the putrefactive nature of vinous liquid by quoting Empedocles, who asserts that 'wine

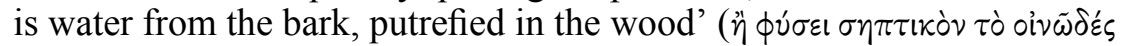

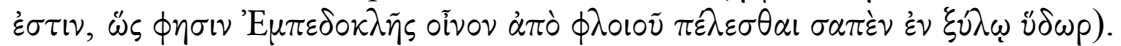
Thus, when the vine is externally moistened by wine, fire is generated for the vine, and the mixture/'temperature' changes the specific property of

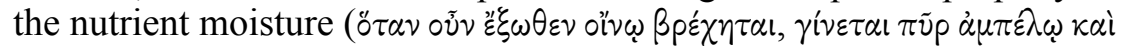

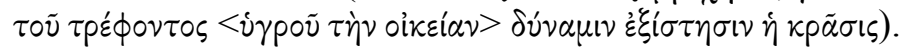

The third explanation draws attention to the clogging effect of wine. Plutarch argues that unmixed wine with its astringent nature enters the roots and there narrows and contracts the pores. In this way, it does not allow water into the plant by which it would naturally flourish and grow ( $\eta$

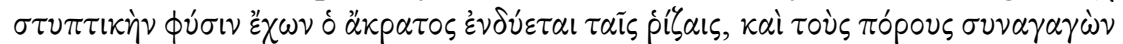

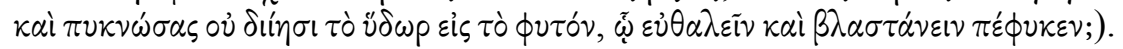

In the fourth and final explanation, Plutarch argues that it is even more unnatural for the vine to receive a substance that leaves and returns back

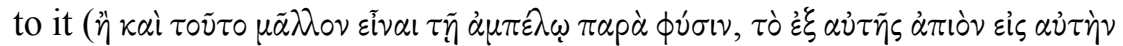
$\dot{\varepsilon} \pi \alpha \nu$ เò $\pi \dot{\alpha} \lambda \iota \nu \delta \varepsilon \dot{\chi} \varepsilon \sigma \theta \alpha \iota ;)$. He explains this by pointing out that the part of the moisture in plants that cannot feed them, or be added, or be part of

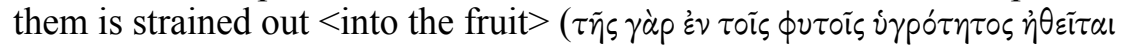

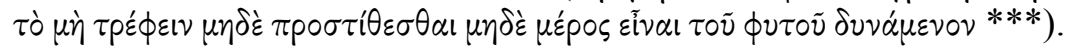

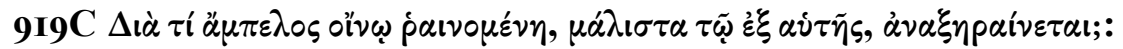
For the related, though contrary, view that wine positively effects seeds, see Theophr., $C P_{3}, 24,4$.

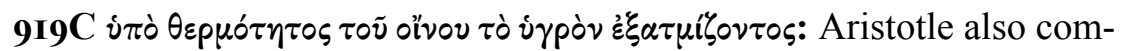
pares the loss of foliage in a plant (and of feathers in a bird) with baldness in men, explaining both phenomena on account of a lack of warm moisture

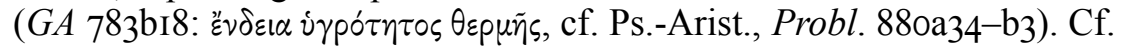
also Quaest. conv. $649 \mathrm{CD}$, where Plutarch argues that loss of foliage is

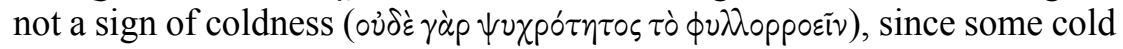
plants, like myrtle and maidenhair, are evergreens. For the idea that dryness causes baldness, cf. also Hipp., De sem., de nat. pu., de morb. 4, 20, 30-33 and Ps.-Alex. Aphr., Probl. I, 2 (J.L. Ideler, I84I, p. 6, 6-29). Galen also believes that baldness is due to a lack of moisture (Comp.Med.Loc.

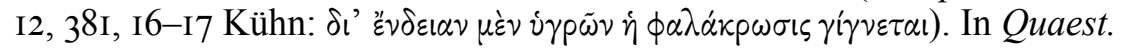
conv. $652 \mathrm{~F}$, we read that drunkards resemble old men, because many get bald or grey at an early age. Plutarch explains this, however, from a defi-

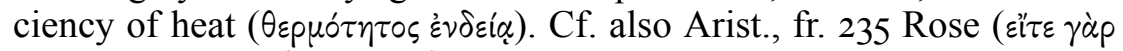

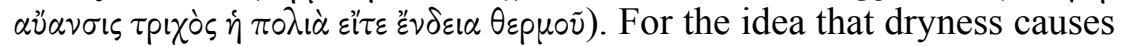
greyness (whereas moisture renders young men's hair black), cf. De Is. 
et $O s .364 \mathrm{~B}$ and Arist., GA $780 \mathrm{ob} 6$ (greyness is a weakness, viz. a nonconcoction, of the moisture in the brain). For the place of such theories in ancient popular medicine, see I. Rodríguez Alfageme, I999a, p. 42I.

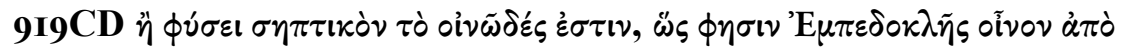

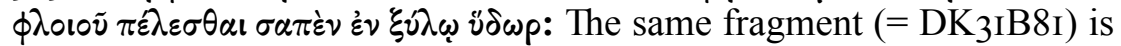
quoted without syntactical adaptations in Q.N. 2, 9I2C, where Plutarch argues that the process of concoction resembles that of putrefaction $(\dot{\eta} \delta \dot{\varepsilon}$

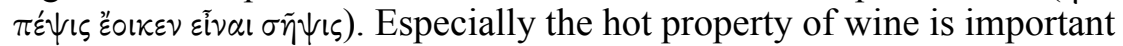
for Plutarch's argument at hand. As Empedocles' quote illustrates, this heat is due to a process of putrefaction, more precisely the putrefaction of water.

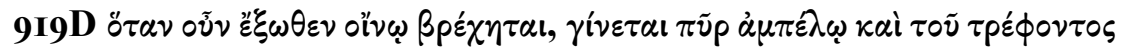

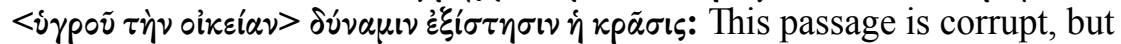
the basic meaning of the second causa is clear: wine is putrefied water, which is harmful for the vine due to its heat and fiery constituent. Some further consideration is required regarding the concepts of I) $\pi \tilde{\nu} \rho$ and

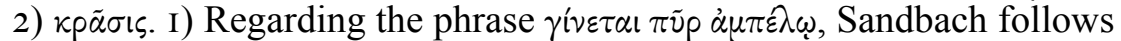
Wyttenbach in adding $\dot{\varepsilon} \pi \mathrm{i} \pi \tilde{\nu} \rho \tau \tilde{\eta}$ between $\pi \tilde{\nu} \rho$ and $\dot{\alpha} \mu \pi \varepsilon \lambda \omega$, thus referring to the theory of adding fire to fire ( $\pi \tilde{v} \rho \dot{\varepsilon} \pi i \mathrm{i} \pi \tilde{\nu})$ ). According to this theory, a smaller amount of fire or heat (c.q. the innate heat of the vine) is extinguished by a larger one (c.q. of the wine). Alternatively, this theory can also imply that a smaller amount of fire or heat merges into a larger one and increases its volume. In this sense, the heat becomes excessive for the vine, by it being moistened with hot wine. For more detail on this theory, see H. Flashar, I962, p. 328. It is frequently seen in the work of Aristotle (e.g., GC 323b8-Io) and also in the Problems (866a26-28 (repeated in a36-bI), 874b6-7, 937a26-27, 96Ib3I-32). Plutarch is well acquainted with this theory (cf. also Pl., Leg. 666a): it has proverbial value in De ad. et am. 6IA, De tuenda I23E, Coni. praec. I43F, Cons. ad ux. 6IoC and Art. 28, I (see J.A. Fernández Delgado, I99I, pp. 202-203). However, even if it is not impossible that Plutarch had this process in mind in the present passage, there is no lacuna in the manuscripts between $\pi \tilde{\nu} \rho$ and $\dot{\alpha} \mu \pi \varepsilon \lambda \omega$, so that there is no need for an editorial intervention. The meaning of the text remains clear with or - preferably - without it (see also V. Ramón Palerm, 2005, p. 403 and L. Senzasono, 2006, p. 52 and pp. 234-235, n. I76: "In realtà il testo tràdito è chiaro"; the same theory

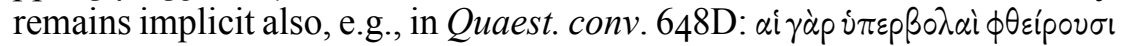
$\tau \dot{\alpha} \varsigma \delta v v \dot{\alpha} \mu \varepsilon ı \kappa \kappa \tau \lambda$.). Therefore, I take it that Plutarch is simply using the term $\pi \tilde{u}$ in reference to the fiery constituent of the wine, the heat of which was indeed commonly approved (see the previous causa; cf. also, e.g., Ps.-Arist., Probl. 871a2 and Arist., fr. 222 Rose). Alternatively, according to V. Ramón Palerm, 2005, p. 403, wine transforms into fire for the vine 
("mediante el riego con vino, éste se convierte en fuego para una vid ( $\gamma(\nu \varepsilon \tau \alpha \mathrm{l} \pi \tilde{\nu} \rho \dot{\alpha} \mu \pi \varepsilon \lambda \omega)$ "), but this is not what Plutarch actually writes ( $\pi \tilde{\nu} \rho$ is the subject, not the predicate, of $\gamma^{\prime}(v \varepsilon \tau \alpha l:$ 'fire is generated for the vine'). The causa at this point amounts to the idea that the fiery constituent of the wine ( $\pi \tilde{v} \rho$ ) dries out the vine. 2) In what follows, the concept of kpã $\sigma / s$

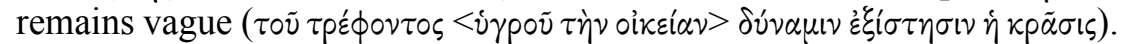

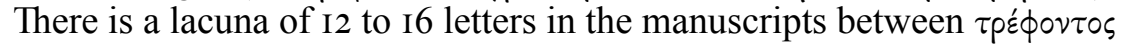

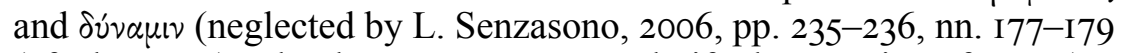
(cf. also p. 52), who does not, moreover, clarify the meaning of кp $\tilde{\alpha} \sigma \varsigma \varsigma$ ). I

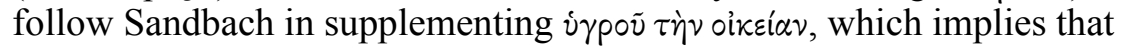

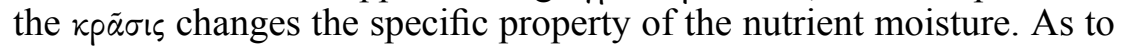
the concept of kpã $\sigma i \varsigma$, then, this may not just be a reference to the fiery 'temperament' of the vine itself, but to the mixed composition of the wine, which is a 'blend' of cold, watery and hot, vinous constituents. In this sense, the wine's 'temperature' is too hot - viz. like $\pi \tilde{v} p$ - for the vine [see 4.3.I.2., n. I7I]. Thus, it destroys the property of the nutrient substance (c.q. the water) in the wine, so that the vine sprinkled with it withers. Alternatively, the nutrient moisture to which Plutarch refers is already

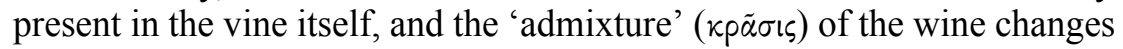
its nutrient property by its fiery constituent.

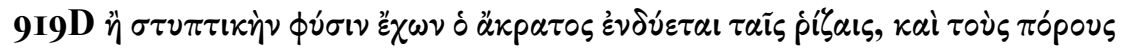

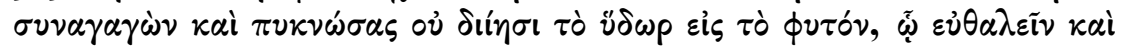
$\beta \lambda \alpha \sigma \tau \alpha \dot{v \varepsilon เ \nu} \pi \varepsilon ́ \phi u \kappa \varepsilon v ;:$ For the (Empedoclean) theory that the narrowness of pores is related to leaf fall in plants, cf. Quaest. conv. 649D (with

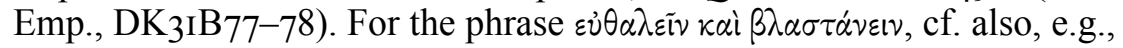

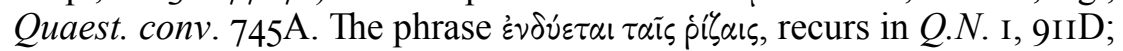

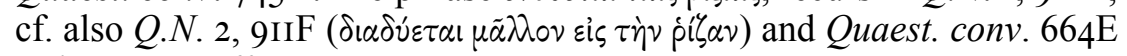

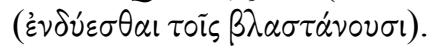

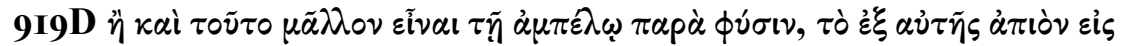

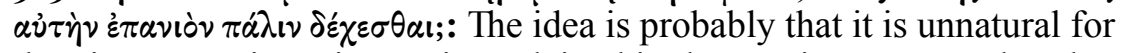
the vine to receive wine, as is explained in the previous causae, but that it is even more unnatural ( $\mu \tilde{\alpha} \lambda$ ov $\pi \alpha \rho \dot{\alpha} \phi \dot{\sigma} \sigma \nu)$ to receive wine made from its own grapes ( $\tau \dot{\partial} \dot{\xi} \xi \alpha \dot{\tau} \tau \tilde{\eta} s$ ), as is implied in the quaestio ( $\mu \dot{\alpha} \lambda \mathrm{\lambda} \sigma \tau \alpha \tau \tilde{\omega} \tilde{\xi} \dot{\xi} \xi$ ai $\tau \tilde{\eta} s)$. See the following comment.

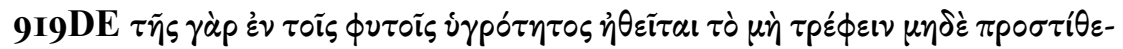

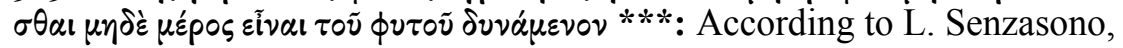
2006, pp. 237-238, n. I84, there is a climax in the tricolon of the verbs

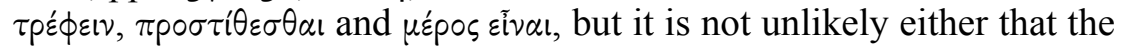
latter two verbs simply specify the first. The verb $\pi \rho \circ \sigma \tau i \theta \eta \mu$ recurs in $Q . N$. $3,912 \mathrm{E}$ and $30,919 \mathrm{C}$, again regarding the assimilation of nourishment. What Plutarch is probably implying, then, is that the grapes contain the 
residual (excremental) part of the vine's nourishment, which is useless and presumably even detrimental for the vine. There seems to be a link with the generative residue, which, as Plutarch argues in Q.N. 30, 919C, is

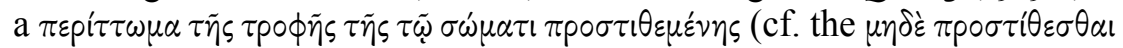
here). Arguably, by discharging the residue via the grapes, the vine purifies itself. Therefore, Sandbach's addition $<$ into the fruit $>$ seems essential (cf.

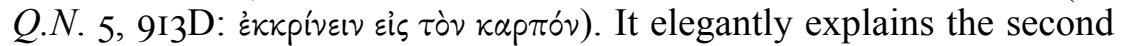
part of the quaestio - viz. why wine is harmful for the vine, especially when it is produced $\dot{\xi} \xi \alpha \dot{\tau} \tau \tilde{\eta} s$, that is, from its own grapes -, which would otherwise have remained unsolved. It is not unlikely, therefore, that the aetiology also originally ended with this fourth explanation. Notably, Psellus completely rewrites the last explanation. In doing so, he actually

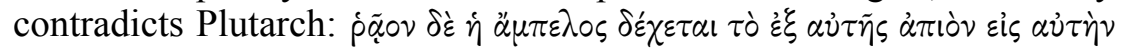
$\dot{\varepsilon} \pi \alpha \nu$ ióv (De. omn. doctr. § I87 Westerink). It is not unlikely that Psellus found Plutarch's argument to be obscure. Perhaps the text was already illegible in the manuscript that he used (see M. Meeusen, 20I2b, p. II5, n. 68).

\section{Longolius (Q.N. 32-39)}

The eight chapters that follow in Q.N. 32-39 were first published by Longolius in his 1542 Latin translation of Quaestiones naturales. Longolius notes in a marginal note that they are extracted from a Milanese manuscript, but this manuscript has been lost ever since, and the Greek text is still missing today. Considering the numerous parallels in Plutarch's other works and the same general style and method of explanation, there can be no doubt that these problems are authentic (for further detail on Longolius' translation, see A. Morales Ortiz, I999 and M. Meeusen, forthcoming a).

\section{Q.N. 32}

It is unclear whether Q.N. 32 followed immediately after Q.N. 3I in Plutarch's original Greek text. In any case, there is a faint thematic link between Q.N. 32 and Q.N. 30-3I, in that they each concern botanical problems (viz. plants and their specific properties). The link with the aetiology in Q.N. 30 becomes more concrete in the shared parallel passage in Quaest. conv. $724 \mathrm{EF}$ (both concerning generative residues). In the problem at hand in Q.N. 32 , Plutarch wonders why the palm tree alone among all trees rises against a weight imposed on it (Cur inter omnes arbores sola palma contra impositum onus adsurgit?). Three explanations are given: the first one focuses on the palm tree's fiery and breathlike property, the second on the compressed air in its branches and the third on 
the slow rising of its twigs, which gives them the impression (speciem) of rising up against the weight. With this final explanation, Plutarch tries to show that the tree raises its twigs only in appearance. He does not, as such, aim to reject the popular belief (as formulated in the quaestio), but he certainly puts it in a broader physical perspective [see 4.3.3.3.].

In the first explanation, Plutarch argues that the palm tree's fiery and breathlike property, which gives it its great strength, exerts itself when tested and vexed, and so raises (the palm) more and more (Utrum quod ignea et spirabilis facultas, qua maxime pollet, cum tentatur et irritatur, sese exercens magis et magis erigit?).

According to the second explanation, the sudden impetus of the weight on the branches pushes back all the air compressed within them (An quoniam pondus ramos subito urgens aerem omnem qui in his est oppressum cedere retro cogat). Afterwards, when the air slightly recovers its strength, it pushes against the weight with greater force (qui deinde resumptis paulo viribus adversum onus acrius rursus instat?).

In the third and final explanation, Plutarch argues that the supple and tender twigs cannot sustain the impetus of the weight. When the weight comes to rest, though, they gradually erect themselves and give the impression of rising up against it (An molles et tenerae virgae impetum non sustinentes, cum onus quiescit, paulatim se erigunt et speciem quasi contra illud adsurgant praebent?).

Cur inter omnes arbores sola palma contra impositum onus adsurgit?: Scholars have found the formulation of Plutarch's problem rather obscure. There is especially discussion as to whether Plutarch is referring to a living palm tree, or to the beams or logs made from its timber. On the basis of several parallel accounts (collected below), F.H. Sandbach, I965, p. $215, \mathrm{n}$. b believes that Plutarch is probably implying that "a log laid horizontally hunches itself in an upward curve against a superimposed weight”. By contrast, L. Senzasono, 2006, p. 238, n. I85 argues that the problem concerns a growing and living palm tree. He refers to the terms ramos and tenerae virgae in the second and third explanation respectively. Sandbach notes that "[i]t is possible that Longolius misunderstood the Greek text here, and wrongly supposing it to refer to a growing tree, introduced the words ramos and virgae, without warrant". Then again, since Longolius uses these two different terms for the palm's 'branches', it seems only logical that these render two different Greek terms. Indeed, ramos is perhaps a poor translation of 'logs' or 'beams', but this is implausible for virgae molles et tenerae. Therefore, Senzasono is probably correct that "non c'è ragione di congetturare la possibilità che il traduttore abbia frainteso il testo qui". The popular belief has a rich tradition and seems to originate from the world of architecture and building. Xenophon 
reports that Cyrus used palm trees for the construction of the foundations of watchtowers (Cyr. 7, 5, II-I2). He notes that this kind of wood is the right material for this purpose, because of the well-known fact that palm trees bend upward under heavy pressure like the backs of pack-asses (oi

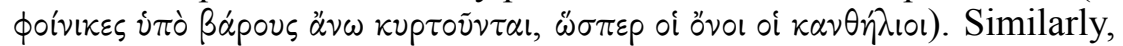
Theophrastus writes that among other kinds of wood, that of palm trees is strong, because it bends the opposite way to other woods. Whereas other kinds of wood bend downwards, palm wood bends upwards (HP 5, 6, I:

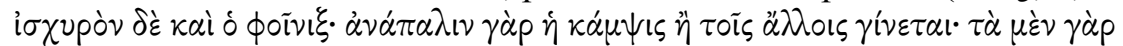

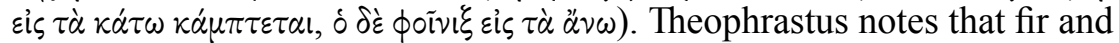
silver fir also have an upward thrust, and that they are strong when set slant-wise $\left(\pi \lambda \alpha^{\prime} \gamma(\alpha \iota \tau \iota \theta \varepsilon \mu \varepsilon \nu \alpha \iota)\right.$; he adds that wood of the chestnut tree is used

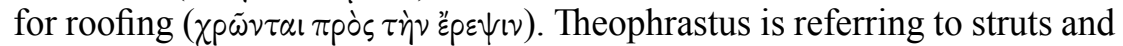
supports for walls and roofs here (cf. the impositum onus in Plutarch's quaestio). Notably, the term $\pi \lambda \alpha^{\prime} \gamma(\alpha \iota$ in Theophrastus' text is an emendation based on Pliny, $N H$ I6, 222: in traversum. Theophrastus was probably Pliny's source. For the palm tree's special bending ability, see $\mathrm{NH}$ I6, 223 (et palmae arbor valida; in diversum enim curvatur, [et populus] cetera omnia in inferiora pandantur, palma ex contrario fornicatim). See L\&S, s.v. fornicatim: "in the form of an arch, archwise". See also S. Amigues, I993, p. 84, n. I. A similar account of the use of palm trees in construction works is found in Strabo (parallel only marked by S. Amigues, I993, p. 84, n. 3). Strabo writes that the palm tree, when aged, does not give way downwards, but curves upwards because of the weight and gives

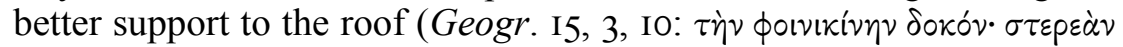

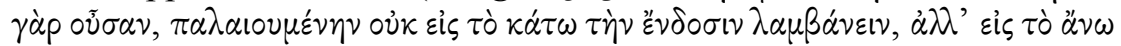

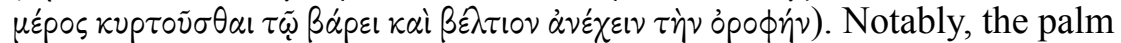
tree's natural resilience remained a popular topic well beyond Antiquity in the form of a moral 'emblem' (see L. Holford-Strevens, 2005). Similar value is ascribed to it in Quaest. conv. $724 \mathrm{EF}$, where the symposiasts discuss the award of the palm frond as a symbol of victory. At the end of the discussion, the palm tree is compared with an athlete: the tertium comparationis is their largeness, shapeliness, sterility, and strength. It is argued that all of the nourishment is used to build up the body, so as not to form any generative residue (cf. Q.N. 2I, 9I7B, 30, 9I9C and Quaest. conv. 640F-64IA; see F. Fuhrmann, I964, p. 8I, with n. 3). The athlete's bodily and mental strength (acquired through heavy training)

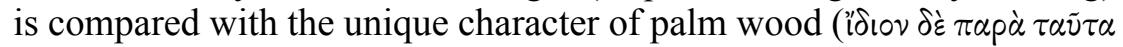

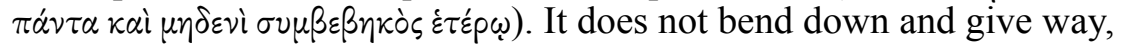
but curves up in the opposite direction when a weight is imposed upon

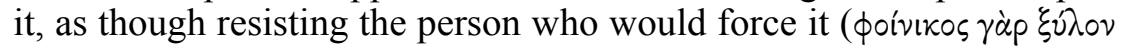

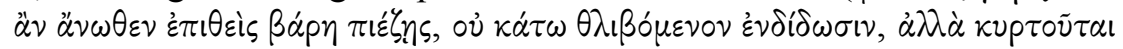

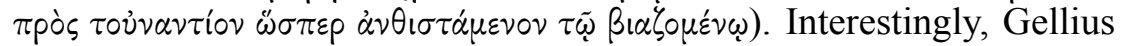
paraphrases this passage with an explicit reference to the eighth Book 
of Plutarch's Symposiacs and also to the seventh of Aristotle's Problems (NA 3, 6 = Arist., fr. 229 Rose: Per hercle rem mirandam Aristoteles in septimo problematorum et Plutarchus in octauo symposiacorum dicit etc.; see F. Klotz and K. Oikonomopoulou, 20II, p. 235). The problem at hand cannot be traced in the extant Ps.-Aristotelian Problems, though, meaning that it is probably lost.

Utrum quod ignea et spirabilis facultas, qua maxime pollet, cum tentatur et irritatur, sese exercens magis et magis erigit?: F.H. Sandbach, I965, p. 2I5 translates the first magis as an adverb modifying sese exercens and the second modifying erigit ("more than before"). The reduplication of magis, though, can also denote an aspect of the gradual rise in erigit only, which seems preferable here ("more and more": L\&S, s.v. b, 2, b; cf. LSJ, s.v. $\mu \tilde{\alpha} \lambda_{\text {Oov: }}$ "denoting a constant increase, more and more, sts. doubled"). Cf. also L. Senzasono, 2006, p. 239, n. I87.

An quoniam pondus ramos subito urgens aerem omnem qui in his est oppressum cedere retro cogat, qui deinde resumptis paulo viribus adversum onus acrius rursus instat?: The argument is of a mechanical

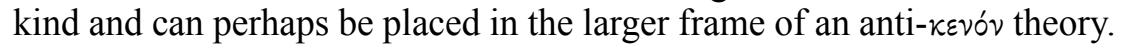
To clarify Plutarch's explanation, one may think of the compression of air in a pump, syringe, or bellows. When one closes off the opening and presses the handle, the compressed air will not allow the handle to be pushed down completely. When the handle is released again, the pressure of the air pushes it backwards. A similar effect occurs in the palm tree's branches when the air that is present in them is compressed by the imposed weight and released again. The fact that the branches raise themselves is because the air in them naturally rises. F.H. Sandbach, I965, p. 215 translates paulo as "slowly", but it is not synonymous with paulatim (see the third causa); thus, 'slightly' seems more apposite here. Cf. also L. Senzasono, 2006, pp. 239-240, n. I88.

An molles et tenerae virgae impetum non sustinentes, cum onus quiescit, paulatim se erigunt et speciem quasi contra illud adsurgant praebent?: Plutarch does not further explain why and how the twigs gradually erect themselves. What is more important for Plutarch's argument, though, is that they only give the impression (speciem) of rising up against the imposed weight, meaning that the reported belief should be nuanced [see 4.3.3.3.]. 


\section{Q.N. 33}

Q.N. 33 connects with the chapters on salt and water in Q.N. I-I3 (esp. Q.N. I, 2 and 4, which also deal with the nutritive properties of water). Plutarch examines why water that is drawn from wells is less nutritious than water that flows from a spring or falls from the sky (Quare aqua de puteis hausta minus alit quam quae de fonte aut caelo manat?). Three explanations are given in a rapid succession: the first takes into account the coldness of the water in the well and its small amount of air, the second its salty constituent and the third its immobility.

Plutarch first argues that water drawn from wells is colder and also contains (only) a small amount of air (An quia frigidior magis sit et parum quoque aeris habeat?).

In the second explanation, he argues that well water contains a large amount of salt from the earth that is mixed with it, and that salt especially causes thinness (An quod salis multum immixta sibi de terra habeat; sal autem maciem, si quid aliud, facit?).

In the third explanation, Plutarch argues that well water, because it is inactive and immobile, acquires a bad quality, which is hostile to plants and animals. This explains why it is not well concocted and cannot nurture anything (An quod pigra nec cursu exercitata qualitatem aliquam malam adquirat, quae stirpibus et animantibus contraria in causa est quod nec bene concoquatur nec nutrire quicquam possit?). Hence, stagnant waters are considered less good, since they cannot disperse the damage they receive from bad qualities that originate either in the air or the earth (Hinc et stagnantes aquae minus probae censentur, quod iniurias quas vel ab aeris mala qualitate vel a terra accipiunt digerere nequeant).

An quia frigidior magis sit et parum quoque aeris habeat?: The comparative frigidior magis seems odd. The opposition between magis and parum was probably clearer in the original Greek text. Plutarch does not clarify this argument any further. It may be implied that coldness slows down concoction of food - concoction being brought about by heat. The greater coldness of water drawn from wells can perhaps be explained by the fact that it does not come into contact with sunlight, as opposed to water from rivers or water that falls from the sky. Moreover, water from rivers stand more in contact with air than that from wells. Rainwater also contains more air because it falls from the sky. They are both more nutritious, probably because airy water is more quickly guided and transmitted into the body (e.g., into a plant: cf. Q.N. 2, 9I2A and 4, 9I2F).

An quod salis multum immixta sibi de terra habeat; sal autem maciem, si quid aliud, facit?: The idea that salt causes thinness is paralleled in 
Q.N. 3, 9I2E ( $\lambda \varepsilon \pi \tau \dot{v} v \varepsilon \tau \alpha \iota)$. It could be objected here that water flowing from springs is also affected by the earth through and over which it flows (cf. Q.N. 2, 912B).

Hinc et stagnantes aquae minus probae censentur, quod iniurias quas vel ab aeris mala qualitate vel a terra accipiunt digerere nequeant: For the idea that pond water is old and stale, while spring and river water is fresh and new-born and therefore more nutritive (albeit still less nutritive than rainwater), see Q.N. 2, 9I2A. For the idea that the admixture of earth makes stagnant waters putrid, while running waters avoid mixture or throw off any earth that enters their course, see Quaest. conv. $725 \mathrm{D}$ (cf. also Aqua an ignis $957 \mathrm{D}$ and De lat. viv. II29D with F. Fuhrmann, I964, p. 60). For the disease inducing properties of stagnant waters, $\mathrm{cf}$. Hipp., Aer. 7 and Ps.-Arist., Probl. 884a32-34. According to L. Senzasono, 2006, pp. 240-24I, n. I92, the phrase stagnantes aquae is a translation of $\sigma \tau \dot{\alpha} \sigma \mu \alpha \tilde{\nu} \delta \alpha \tau \alpha$, or perhaps $\lambda \mu \nu \nu \alpha \tilde{\alpha} \alpha \tilde{v} \delta \alpha \tau \alpha$, but the second seems unlikely, because Longolius in Q.N. 2, 912A translates $\tau \dot{\partial} \lambda \mu \nu \alpha \tilde{o} \nu \nu<i \delta \omega p>$ as $a q u a$ palustris. Additionally, the aqua de puteis (water drawn from wells) in the

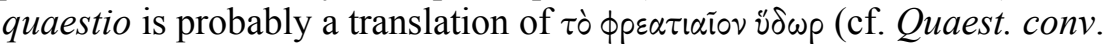
$690 \mathrm{~B}$ ). Senzasono also argues (p. 24I, n. I93) that digerere is a translation of diakpivw in the medical sense of 'dissolve', 'dissociate', 'dissipate', 'destroy' (cf., e.g., Cels., De med. 2, I7, I; see L\&S, s.v. i, b, 2: "In medic. lang., to dissolve, dissipate morbid matter"). Yet, a less technical term is

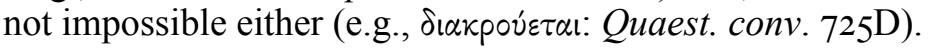

\section{Q.N. 34}

In dealing with winds, the chapter at hand stands relatively isolated in the collection. Plutarch examines why the west wind is commonly considered the swiftest of all, as Homer writes: 'we too could run as fast as the west wind's blast' (Cur Zephyrus ventorum omnium celerrimus vulgo fertur, et Homerus 'nos quoque Zephyri curramus flatibus $\left.u n a^{\prime}\right)$. Two explanations are given that are closely connected to each other. Whereas the first explanation only deals with the atmospheric circumstances when the west wind blows (viz. the cleanness of the sky), the second accounts for the actual cause of the wind and its motive force (viz. the heat of the sun).

The first explanation draws attention to the atmospheric circumstances. Plutach argues that the west wind normally blows when the air is entirely clear and the least clouded. This is because the density and impurity of the air is no mean obstacle for the rapid passage of the winds (An quod 
aere perpurgato et minime nebuloso flare soleat? Aeris enim densitas et impuritas ventorum cursum non mediocriter impedit).

Central to the second explanation is the opposition between heat and cold. Plutarch argues that the sunlight is responsible for this phenomenon, because it strikes the cold wind so that it moves faster (An quod sol radiis suis flatum frigidum perstringens, quo velocius feratur, auctor est?). He finds it credible that anything cold that is contracted by the force of the winds is forced by the heat into prolonged and accelerated flight, as if overcome by an enemy (Quicquid enim frigidi ventorum vi contrahitur, id a calore veluti hoste superatum longius et citius propelli credendum est).

Cur Zephyrus ventorum omnium celerrimus vulgo fertur: The topic of winds falls under the general theme of Book 26 of Ps.-Aristotle's

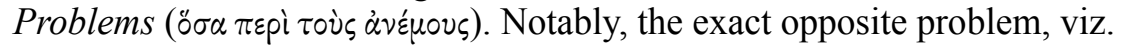
why the west wind is the calmest and most pleasant, is treated in Ps.-Arist., Probl. 943b2 I-23 (with a reference to Hom., Od. 4, 567) and 946b2I-22. According to Theophr., Vent. 38 (with a reference to Hom., Il. 23, 200), this depends on the season.

et Homerus 'nos quoque Zephyri curramus flatibus una': The original Homeric lines (=Il. I9, 4I5-4I6), spoken by the horse Xanthus to Achilles,

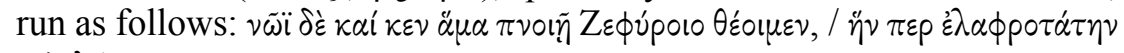

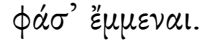

An quod sol radiis suis flatum frigidum perstringens, quo velocius feratur, auctor est? Quicquid enim frigidi ventorum vi contrahitur, id a calore veluti hoste superatum longius et citius propelli credendum est: It seems reasonable to assume that the sun would also strike other winds by its heat, and not only the west wind. Therefore, this second causa should probably be read in combination with the first, concerning the atmospheric circumstances when the west wind blows. Note, moreover, that since the cold is not concentrated by the opposite heat of the sun but by the force of the winds (contrahitur ventorum vi), this is probably not an instance of the process of $\dot{\alpha} \nu \tau i \pi \varepsilon p i \sigma \tau \alpha \sigma \iota \varsigma$ (pace L. Senzasono, 2006, pp. 24I-242, n. I96). The beating of the sunlight (perstringens) can be linked with the rising and setting of the sun, described as the cause of the winds in Ps.-Arist., Probl. 944aII-I2 (where we read, more in specific, that the west wind blows towards the late afternoon but not in the morning). According to F.H. Sandbach, I965, p. 2I8, n. a, "[o]ne would think the rising sun as well able to set the east wind in motion as the setting sun the west. But it may be assumed that the west wind is colder [...] and therefore flees faster." Its coldness is, indeed, commented on in Ps.-Arist., Probl. 946aI7-32, albeit in connection with its mildness (moreover, in the same passage the north

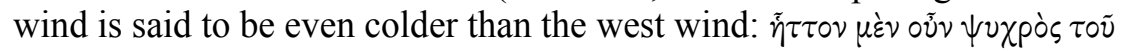


Bopéov). Cf. also Theophr., Vent. 40. The imagery in veluti hoste superatum is exceptional to the general stylistics of the collection. By its obvious military register, it possibly alludes to the Homeric line in the quaestio. Cf. also Coni. praec. I39D, where Plutarch refers to a fable attributed to Aesop (nos. 306-307), according to which the sun earned a victory

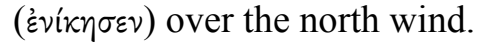

The two chapters of Q.N. 35-36 are closely linked to each other through the focus on the natural and instinctive behaviour of bees towards certain bad odours. The bees' strong perception of smells was already alluded to in Q.N. 26, 9I8C, where Plutarch notes that honeycombs excite bees by their scent and attract them from a distance (cf. Q.N. 36: olfactus sensu valet plurimum). Interest in bees is not unusual among the ancients, because it was the only domesticated insect useful to humans (for further reading on bees and apiculture in Antiquity, see O. Keller, I980, pp. 42I-43I (esp. p. 424)). Flies, by contrast, were considered ungovernable creatures (cf. Quaest. conv. 728A). Despite the frequent references to bees in the Moralia, there is no reason to assume that Plutarch was a bee-keeper himself (cf. also L. Van der Stockt, 2005, p. I3; pace G. Siefert, I908, p. I9, n. I; on bee imagery in Plutarch, see F. Fuhrmann, I964, pp. 58, 94 and E.K. Borthwick, I99I).

\section{Q.N. 35}

In Q.N. 35, Plutarch examines why bees cannot bear smoke (Cur apes fumum ferre nequeunt?). He gives two explanations: the first one focuses on the narrow passages of the bees (it is formulated in an assertoric rather than interrogative fashion for unclear reasons), the second on their aversion towards pungency and bitterness.

According to the first explanation, bees have very narrow passages for their vital breath (Quod meatus spiritus vitalis sane quam angustos habeant). The breath is cut off and clogged by the smoke and suffocates the bees, nearly killing them (At is fumo interceptus et conclusus angit et propemodum ad mortem apes adigit).

In the second explanation, Plutarch argues that the cause can be found in the pungent and bitter constituent of smoke (An acredo amaritudoque fumi in causa est?). He explains that bees find delight in sweet things and have no other form of nourishment (Gaudent enim dulcibus apes neque alio nutrimento aluntur). Thus, they hate smoke as a contrary (to sweetness) and harmful thing for it being bitter (itaque ut contrariam et noxiam rem propter amaritudinem fumum detestantur). This is illustrated 
by the common practice of bee-keepers to make smoke by burning bitter plants like hemlock or centaury in order to drive the bees away (Qua de causa mellarii cum fumum abigendis apibus faciunt, amaras herbas, ut cicutam et centaurium, incendere solent).

Cur apes fumum ferre nequeunt?: For the idea that bees cannot bear

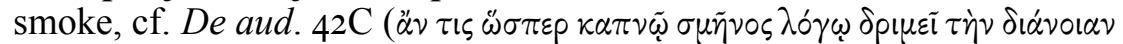

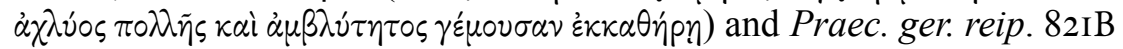

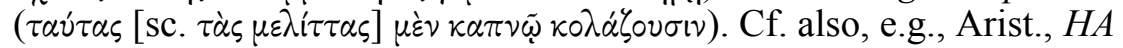
623b20-2I, Pliny, NH II, 45, Col., De re rust. 9, I4, 7, Verg., Georg. 4, 230; 24I-242.

Quod meatus spiritus vitalis sane quam angustos habeant: Longolius probably translates $\pi v \varepsilon \tilde{u} \mu \alpha$ as spiritus vitalis here (cf. F.H. Sandbach, I965, p. 219; L. Senzasono, 2006, pp. 242-243, n. I99). It is unclear why the causa opens with quod rather than an quod and why it is formulated in an assertoric rather than interrogative fashion. F.H. Sandbach, I965, p. 2I8, n. I is correct that "[e]ither Longolius's Greek text had the mistake of omitting $\tilde{\eta}$ (cf. 9I4C, E, 9I7D) or an is omitted from the Latin text".

Gaudent enim dulcibus apes neque alio nutrimento aluntur: For the bee's love of sweet things, cf. Quaest. conv. 673E: $\dot{\eta} \mu \varepsilon \lambda \iota \tau \tau \alpha \tau \tilde{\omega} \phi і \lambda o ́ \gamma \lambda \nu \kappa \nu s$. Cf. also Arist., $H A$ 535a2.

Qua de causa mellarii cum fumum abigendis apibus faciunt, amaras herbas, ut cicutam et centaurium, incendere solent: For the use of smoke in driving off bees, cf., e.g., Pliny, $N H$ II, 45: apes abigi fumo utilissimum (see also the comment on the quaestio). There is no reason to assume, pace L. Senzasono, 2006, p. 243, n. 20I, that "l'umanista [Longolius] avesse presente il testo di Plinio nel tradurre questo passo". It is not impossible, however, that Plutarch and Pliny rely on the same or a similar (Peripatetic?) source.

\section{Q.N. 36}

Q.N. 36 is closely related to the previous problem by its focus on bees. Plutarch examines why bees are quicker to sting people who have just committed adultery (Cur apes citius pungunt qui stuprum dudum fecerunt?). One explanation is given, which draws attention to the bee's perception of smells and their devotion to cleanliness. The explanation closes with two mythological references. 
Plutarch argues that the bee is extremely devoted to neatness and hygiene, and, furthermore, that it has a very powerful sense of smell (An quod animal est munditiae et elegantiae perquam studiosum; praeterea olfactus sensu valet plurimum?). He explains that irregular coition is usually more impure (than regular coition) through unchasteness and unrestrained lust. Bees discover it more quickly and dislike it more violently (Quum itaque impuri congressus propter impudicitiam et immoderatam libidinem soleant esse immundiores, et citius ab apibus deprehenduntur et odium vehementius adversus illos concipiunt). This is further illustrated in a mythological coda. Plutarch writes that Theocritus, in veiled ironic terms, describes how the (dying) herdsman Daphnis sends off Aphrodite to Anchises in order to be stung by bees because of their adultery (Unde apud Theocritum iocose Venus ad Anchisen a pastore ablegatur, uti apum aculeis propter adulterium commissum pungatur): 'So go to Ida, go to Anchises, where oak and galingale grows, and the mellifluous home buzzes loudly by the humming of bees' ('Te confer ad Idam, / confer ad Anchisen, ubi quercus atque cypirus crescit, / apum strepitatque domus melliflua bombis'). Pindar, too, associates the bee-sting with perfidy, when he addresses the bee as follows: 'Tiny builder of honeycombs, who pierced Rhoecus with your sting, taming his perfidy' (et Pindarus: 'Parvula favorum fabricatrix quae Rhoecum pupugisti aculeo domans illius perfidiam').

Cur apes citius pungunt qui stuprum dudum fecerunt?: It is an ancient commonplace that the bee is an honourable and virtuous creature, a true model of diligence and purity, and famous for its chastity, neatness, and abstinence. The priestesses of Delphi, Demeter, Artemis, and Cybele, for instance, were called Melissai (cf. LSJ, s.v. $\mu \varepsilon \lambda \iota \sigma \sigma \alpha$ ii, 2). Likewise, it was a popular ancient belief that bees procreate a-sexually (cf. Pliny, NH II, I6). The locus classicus is provided by Semonides of Amorgos' comparison of the perfect wife to a bee (fr. 7 West, 83-93): the bee-wife manages a thriving household and does not like to sit with her female fellows to gossip about sex. Nevertheless, she makes her husband happy by producing an illustrious and handsome offspring. For the queen bee as a model of oeconomia, cf. also Xen., Oec. 7, 32-35 (with further commentary by S.B. Pomeroy, I995, pp. 276-280).

An quod animal est munditiae et elegantiae perquam studiosum; praeterea olfactus sensu valet plurimum? Quum itaque impuri congressus propter impudicitiam et immoderatam libidinem soleant esse immundiores, et citius ab apibus deprehenduntur et odium vehementius adversus illos concipiunt: The aetiology in Q.N. 36 runs parallel to that in Q.N. 35 in two ways. First of all, the strong emotional category of hate returns in both problems (detestantur - odium vehementius). Notably, 
this aggressive aversity is not morally but physically motivated, since the bee's fundamental dislike and potentially lethal irritation is provoked by natural causes. Second, the idea that something contrary is also harmful to the bee (Q.N. 35: contrariam et noxiam), is paralleled in Q.N. 36 in the causal opposition between cleanliness and dirtiness (the negative prefix in- recurs frequently in Q.N. 36: impuri, impudicitiam, immoderatam, immundiores). The 'dirtiness' of the impuri congressus bears on the material aspect of the impure mixture of body odours and perfumes (for further parallels, see below), meaning that it is not based on the ethical depravity of the act of adultery itself (impudicitiam et immoderatam libidinem). As such, adultery is punished by the bee for physical reasons, without direct ethical motives. Cf. also L. Senzasono, 2006, p. 244, n. 202: "Plutarco non attribuisce alle api un discernimento moralistico, ma si limita a rilevare che il coito impuro è piú sudicio e che quindi l'olfatto delle api ne è piú rapidamente sollecitato per la loro fine sensibilità (elegantia) e per il loro forte senso della pulizia." In Coni. praec. I44D, by contrast, Plutarch incorporates the same natural phenomenon in the moral dynamics of the marital advice that he gives to the groom [see I.2.4.] (I have treated this parallel elsewhere: see M. Meeusen, 2013c). A large amount of other parallels can be found in Plutarch and other authors. On the unpleasant body odour of those who have or are able to have sexual intercourse (as opposed to children), see Ps.-Arist., Probl. 879a23-26. For the evil smell of adulteresses, cf. also, e.g., Cat., Carm. 42 (moecha putida). On the relationship between odours and mating in animals, see, e.g., Gryllus $990 B C$. For the idea that the emanations from the female body defile that

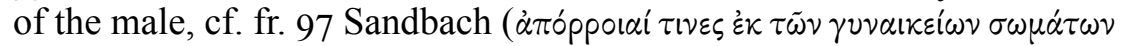

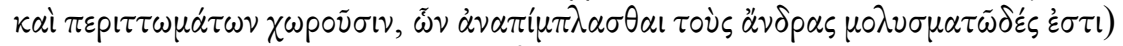

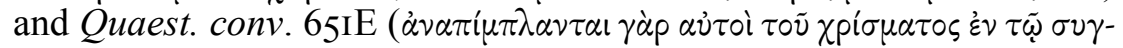

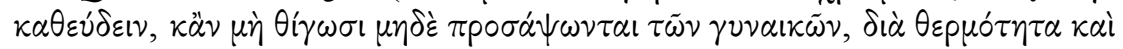

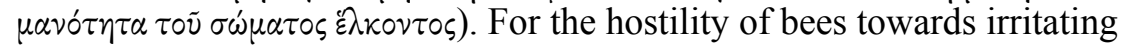
smells, see Arist., $H A$ 626a26-28, where we read that bees are very tidy creatures ( $\kappa \alpha \theta \alpha \rho i \omega \epsilon \alpha \tau \circ \nu \zeta \tilde{\omega} \circ \nu)$ and are annoyed by unpleasant odours or perfumes; in fact, they sting those who wear them (cf. also Ps.-Arist., Mir. ausc. 832a3-4: myrrh). L. Senzasono, 2006, p. 244, n. 202 believes that

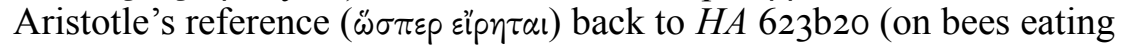
honey in order to build up a reserve when they are confused by smoke) also explains the narrow connection between $Q . N .35-36$, but this is very uncertain (the contexts are different). On the assumption that Aristotle was, indeed, Plutarch's source, the intermediation of a lost Ps.-Aristotelian problem cannot be excluded (however, F.H. Sandbach, I982, pp. 207-232, esp. 230 believes that Plutarch was probably acquainted with Aristotle's Historia animalium directly). For further parallels, see also Theophr., $C P$ 6,5 , I (bees are extremely hostile to persons wearing perfume), Ael., $N A$ I, 58 (bees equally dislike bad smells and perfumes); 5 , II (bees chase 
off men wearing perfume and they also recognise and pursue adulterers, which is considered a sign of their $\sigma \omega \phi p o \sigma u ́ v \eta$ ), Pliny, $N H$ II, 6I (bees hate bad odours and artificial perfumes and attack persons wearing perfume); II, 44 (they hate menstruating women); 7, 64 (beehives wither from the smell of menstrual fluids); 28, 79 (if menstruating women touch a beehive, the bees flee from it), Col., De re rust. 9, I4, 3 (beekeepers are advised not to enjoy veneric pleasures the day before they handle the beehives, nor to be drunk or unwashed; they should also abstain from food with a strong aroma), Varro, De re rust. 3, I6, 6 (bees follow everything that is pure and avoid places that are befouled or have an evil odour; they also cannot bear perfumes or people wearing them), Geop. I5, 2, I9 (bees attack persons more severely if they reek of wine and of perfume, especially women that are of an amorous complexion; according to L. Senzasono, 2006 , pp. $243-244$, n. 202 this has nothing to do with the problem at hand, but I do not see how); I5, 3, 4 (the bee is an extraordinarily clean animal, settling on nothing that has a disagreeable smell or that is impure), Pallad., Op. agr. I, 37, 4-5 and 4, I5, 4 (the bee-keeper has to be pure and chaste).

Unde apud Theocritum iocose Venus ad Anchisen a pastore ablegatur, uti apum aculeis propter adulterium commissum pungatur: The actual pun (iocose) is probably in the fact that Daphnis, in his description of the locus amoenus setting (see the following comment), makes specific mention of bees, which will not, of course, give a very hearty welcome to the goddessadulteress if she is to follow Daphnis' 'good advice' (cf. R. Hunter, I999, p. 97). According to F.H. Sandbach, I965, p. 220, the Latin pungatur can imply that he (Anchises) or she (Venus) was stung, but the second option seems more likely. L. Senzasono, 2006, p. 244, n. 203 doubts Plutarch's understanding of Theocritus' text, but I see no reason why ("Riguardo all'averbio iocose, se pur decodifica fedelmente il messagio del testo originale, non è chiaro se Plutarco, intento a documentare il suo parere sull'istinto delle api, abbia veramente colto il tono del testo teocriteo, tenuto conto che spesso, quando cita, non se ne cura, preoccupato com'è solo d'illustrare con esempi autorevoli la sua tesi o di conferire un certo tono al suo contesto."). Plutarch does, indeed, lift these verses from their original context, but this custom is common in his writings and testifies to his ability to use the available sources in an original way [see 4.2.I.I.].

Te confer ad Idam, / confer ad Anchisen, ubi quercus atque cypirus / crescit, apum strepitatque domus melliflua bombis: These verses (= Theocr., Id. I, I05-I07) are spoken by Daphnis as a taunt of Aphrodite. The original Greek text runs as follows: हैp $\pi \varepsilon \pi \circ \tau$ ' 'I $\delta \alpha \nu$, / हैp $\pi \varepsilon \pi \circ \tau$ ' 'A $\gamma \chi i \sigma \alpha \nu$.

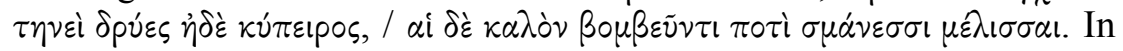
the original story, Anchises was struck by lightning for revealing his secret affair with Aphrodite (see A.S.F. Gow, 1950, pp. 23-24). U. von 
Wilamowitz, I906, p. 234 refers to an otherwise unattested myth according to which Anchises was blinded by bees (cf. the myth of Rhoecus: see the following comment).

Parvula favorum fabricatrix quae Rhoecum pupugisti aculeo domans illius perfidiam: This fragment (= Pind., fr. 252 (= I65) Snell) is only known from Longolius' Latin translation. According to E.K. Borthwick,

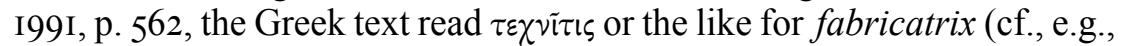
De soll. an. 982F: $\tau \tilde{\omega} \tau \varepsilon \chi \nu i \kappa \tilde{\omega} \pi \alpha \rho \alpha \beta \alpha \lambda \lambda \varepsilon i \nu \mu \varepsilon \lambda i \tau \tau \alpha \varsigma)$. The myth of Rhoecus can be reconstructed from several sources: viz. the version of Charon

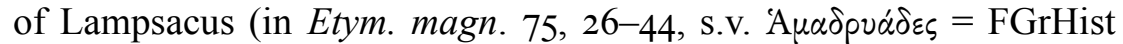
262, I2), the scholia on Apollonius Rhodius (2, 476-477) and those on Theocritus (Id. 3, I3c). The story goes that a Cnidian named Rhoecus, who lived in Nineveh (?), instructed his servants to support a tree that was falling with age. The tree nymph - an 'hamadryad', whose life was connected with that of the tree in which she lived - thanked her saviour by granting him a wish. He chose to lie with her and she agreed. She promised that a bee would summon him to her but also demanded that he avoided intercourse with other women. The bee eventually came to Rhoecus when he was playing draughts, but he spoke impatiently to it. Therefore, the insulted nymph punished him by cursing him with some bodily handicap, perhaps blindness ( $\pi \eta p \omega \theta \tilde{\eta} v \alpha \iota)$. F.H. Sandbach, I965, p. 22I, n. b may be right that "Pindar's story must have been different, Rhoecus suffering for infidelity, as is hinted in the inconsequent ban on other intercourse in Charon's version, and not for lack of tact". This is also what Plutarch is implying. Yet, the variation and confusion of motives is a relatively common feature of ancient mythography in general. See also H.W. Prescott, I9I3, p. I80: "It is probable, therefore, that Rhoecus, like Daphnis, suffered because of his faithlessness toward the nymph." According to L. Senzasono, 2006, p. 245, n. 204, Rhoecus' aggressive reaction towards the bee was perhaps considered an act of perfidia in itself by the nymph, meaning that he did not necessarily commit adultery (Plutarch is clearly thinking otherwise, though). Whether this implies, moreover, as Senzasono adds, that the punishment was reduced to a simple sting of the bee, and that precisely this would be in line with the jesting tone (iocose), seems unlikely. From the opposition between the gentile character of the parvula favorum fabricatrix and the fact that it punishes perfidia with stings, Senzasono suggests that the quotation from Pindar allows an even more ironic interpretation than that from Theocritus. Strictly speaking, though, the adverb iocose depends on ablegatur, so that the humoristic aspect is restricted to the myth told by Theocritus, where a clear ironic effect is, indeed, present (see the commentary ad loc.). 
The following two chapters in Q.N. 37-38 are closely connected to the problems on land animals and hunting in Q.N. 20-28, especially through their focus on animal instincts (cf. Q.N. 26).

\section{Q.N. 37}

Q.N. 37 deals with the intelligence of dogs (or rather, their lack of it). Plutarch wonders why dogs chase and bite a stone, ignoring the person who flung it (Quare canes, relicto homine qui iecit, lapidem morsu insectantur?). For a good understanding of the quaestio, one should note that the stone is thrown at the animal in order to injure it, and not simply thrown away so that the dog should fetch it. Plutarch provides three explanations: the first draws attention to the dog's intellectual inferiority to man, the second to its instinct and false opinion and the third to its emotion of hate. The aspect of hate (odit) in the last causa recalls the strong aversity of bees towards certain odours in Q.N. 35-36 (detestantur - odium vehementius).

In the first explanation, Plutarch argues that the dog cannot understand anything by means of its intellect and that it has no memory, which are virtues proper to human beings (An quia neque cogitatione comprehendere quicquam nec reminisci (quibus solus homo virtutibus valet) potest?). Due to the fact that the dog cannot distinguish in its mind where the injury comes from, it believes that the object alone is its enemy, considering the threatening movement that it makes before its eyes. Therefore, it takes out its revenge on the stone (Itaque quum mente non discernat a quo iniuria fuerit illata, id tantum quod ob oculos minaciter versatur inimicum esse existimat deque eo vindictam sumere parat).

In the second explanation, Plutarch argues that the dog imagines that the stone is some kind of animal, as it rolls over the ground, and that it instinctively tries to catch it at first. Once it realises that it is mistaken by its imagination, though, it returns to attack the man (An lapidem, dum per terram mittitur, feram aliquam esse autumnans, pro ingenio hanc prius capere conatur, deinde cum viderit se opinione sua frustrari, hominem rursus invadit?).

According to the third explanation, the dog hates the projectile just as much as it hates the man who threw it, but that it pursues the closer of the two (An quod et id quod missum fuerit et hominem ipsum aequaliter odit, et id quod proximius est insectatur?).

Quare canes, relicto homine qui iecit, lapidem morsu insectantur?: The same phenomenon is recorded by Plato (Rep. 469e). It also serves as an example in De gar. 514D, where Plutarch explains the nickname of the

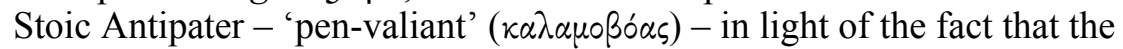


man wrote entire books against Carneades' attacks on the Stoa instead of addressing him personally (SVF 3, p. 244, fr. 5; this Antipater is quoted in the following chapter in $Q . N .38$ ). The link with the phenomenon at hand is clear (cf. F. Fuhrmann, I964, pp. 24 and I48), but only in Q.N. 37 does Plutarch provide an aetiology for it. Cf. also Sept. sap. conv. I47C and De tranq. an ${ }_{467} \mathrm{C}$ for the story of a man who threw a stone at his dog, missed, and hit his stepmother (whereupon he exclaimed: 'Not so bad after all!').

An quia neque cogitatione comprehendere quicquam nec reminisci (quibus solus homo virtutibus valet) potest?: By contrast, in Q.N. 2I, 917C, Plutarch ascribes a certain aspect of $\alpha \nu \alpha \dot{\mu} \mu \nu \eta \sigma \varsigma s$ to animals (c.q. pigs), which implies that they have some rational capability. If we bear in mind Plutarch's writings on animal psychology, in which he defends the rational abilities of animals (cf., e.g., Gryllus 992A), it seems rather unlikely that Plutarch would personally ascribe much credibility to the explanation at hand (cf. also L. Senzasono, 2006, pp. 245-246, n. 206). As to the potentially Stoic background to this argument, cf. Sext. Emp., $H P \mathrm{I}, 64-72$.

Itaque quum mente non discernat a quo iniuria fuerit illata, id tantum quod ob oculos minaciter versatur inimicum esse existimat deque eo vindictam sumere parat: For the idea that rage often dims the sight (cf. $o b$ oculos) of dogs or even blinds them in their struggle with their prey, cf. Quaest. conv. 68IDE (

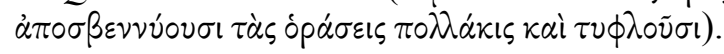

\section{Q.N. 38}

In Q.N. 38 Plutarch examines why she-wolves give birth to their young at a fixed time of the year within twelve days (Cur lupae certo anni tempore omnes intra xii dies pariunt?). The problem is much in line with Q.N. 2I (on the number and time that sows litter). The aetiology contains two explanations: first, a physical one (with an implicit allusion to the Stoic theory of natural sympathy) and then a mythological one. Both are formulated in an assertoric rather than interrogative fashion for unclear reasons. They are also commensurable with each other in that the first explanation tackles the first part of the quaestio (certo anni tempore) and the second explanation the second part (intra xii dies).

The first explanation is borrowed from Antipater, who, in his book $O n$ animals, asserts that she-wolves litter at the same time when trees that 
bear nuts (or acorns) shed their flowers (Antipater in libro de animalibus partum lupas proiicere adserit, cum glandiferae arbores florem abiiciunt). By eating these flowers, their wombs are opened, but when these flowers are not available, the offspring perishes in the mother's very body and cannot see the light of day (quo gustato uteri illarum reserantur: cum eius copia non est, partum in ipso corpore emori nec in lucem venire posse). Plutarch adds that those regions that are not fertile with chestnut-trees or oak-trees are not inhabited by wolves (praeterea regiones illas a lupis non vastari, quae glandium quercuumque feraces non sunt).

In the second explanation, Plutarch paraphrases the story about Leto to which certain people refer (Quidam ad fabulam Latonae referunt). When Leto became pregnant from Zeus, she could not find a safe haven from Hera anywhere. Thus, Zeus transformed her into a wolf for a period of twelve days, during which she travelled to Delos (quae cum uterum ferret nec uspiam tuta prae Innone esse posset, duodecim diebus, quibus in Delum proficiscebatur, in lupum a Iove mutata). In this way, she procured that all wolves should be able to litter in that same period from then on (ut deinceps omnes lupae eo ipso tempore parere possint impetravit).

Cur lupae certo anni tempore omnes intra xii dies pariunt?: The belief that she-wolves (and dogs) mate and litter within I2 days is also found in

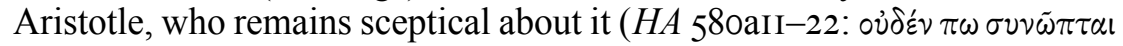

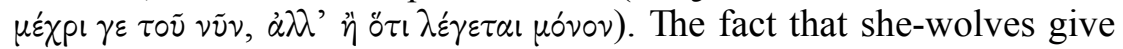
birth to their young at a fixed time of the year probably implies that they litter once a year but presumably more than once in their lifetime, as is

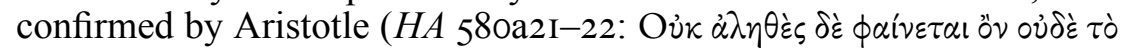

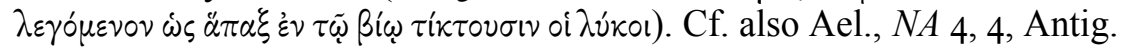
Car., Hist. mir. 56, Pliny, $N H$ 8, 83, Isid., Et. I2, 2, 24, Solinus, Mem. 2, 36 .

Antipater in libro de animalibus partum lupas proiicere adserit, cum glandiferae arbores florem abiiciunt: Presumably a quote from the Stoic of Tarsus (= SVF 3, p. 25I, fr. 48) [see 4.2.I.I., n. II3].

Quidam ad fabulam Latonae referunt, quae cum uterum ferret nec uspiam tuta prae Iunone esse posset, duodecim diebus, quibus in Delum proficiscebatur, in lupum a Iove mutata, ut deinceps omnes lupae eo ipso tempore parere possint impetravit: The story goes that after Leto travelled from the land of the Hyperboreans to Delos in twelve days, she gave birth to Apollo and Artemis. This perhaps accounts for Apollo's title Lykeios (see F.H. Sandbach, 1965, p. 224, n. a). Among the quidam mentioned at the beginning of the explanation, Aristotle comes first, since he records the same mythological account in HA 580aI4-I9 (cf. also Ael., NA 4, 4 and Antig. Car., Hist. mir. 56). According to L. Senzasono, 2006, pp. 246-247, 
n. 207, Plutarch relies directly on Aristotle's account (F.H. Sandbach, 1982, pp. 207-232, esp. 230 argues that Plutarch was probably acquainted with Aristotle's Historia animalium), but the intermediation of a lost problem cannot be excluded. Especially Book to of Ps.-Aristotle's Problems comes to mind (i.e. the 'E $\pi \imath \tau \sim \mu \eta \dot{~} \Phi v \sigma \iota \kappa \tilde{\omega} \nu$ [see I.I.I., n. 4]), which draws heavily on Aristotle's biological and zoological writings and is often concerned with animal copulation and generation (see R. Mayhew, 20IIa, pp. 279-28I).

\section{Q.N. 39}

From a thematic perspective, Q.N. 39 is closely related to the hydrological problems in Q.N. I-I3. In the chapter at hand, Plutarch examines why water is seen as white in its upper layer, but black at the bottom $(\mathrm{Cur}$ aqua in summa parte alba, in fundo vero nigra spectatur?). He provides three explanations: the first focuses on the clarifying effect of sunlight on the water, the second on the water's colour as a reflection of light and the third on the earthy constituent in the water itself.

In the first explanation, Plutarch metaphorically calls the depth 'the mother of blackness', because it dulls and weakens the sunbeams before they can descend to it (An quod profunditas nigredinis mater est, ut quae solis radeos prius quam ad eam descendant obtundat et labefactet?). Due to the fact that the surface, by contrast, is continuously affected by the sun, it must take on the clearness of its light (Superficies autem, quoniam continuo a sole adficitur, candorem luminis recipiat oportet). Empedocles is quoted to support this: "And the black colour at the bottom of the river arises from shadow and is also seen in cavernous hollows' (Quod ipsum et Empedocles approbat 'Et niger in fundo fluvii color exstat ab umbra I atque cavernosis itidem spectatur in antris').

In the second explanation, Plutarch argues that the depths of rivers and of the sea are bursting with mud, and that they (viz. the depths) from themselves produce the same (viz. dark) colour by reflection of the sun, as characterises the mud (An limo plerumque oppletus fluminum marisque fundus talem de se colorem per solis reflexum parit, quali utique is praeditus est?).

In the third explanation, Plutarch argues that it is more plausible that the water of rivers and of the sea is the least pure and clean but that it is stained by an earthy quality, since it continuously carries along an amount of the earth over which the river runs or the sea tosses ( $A n$ probabilius est aquam minime quae illis est puram et sinceram esse, sed terrea qualitate (utpote quae continuo, qua currit vel agitur, aliquid ex ea advehat) imbutam). When the earth sinks to the bottom, the water 
becomes more turbid and less transparent there (cum ad fundum residet, turbidiorem et minus perspicuam effici).

Cur aqua in summa parte alba, in fundo vero nigra spectatur?: The problem is that if water is essentially black, why is it seen as white in its upper layer and black only at the bottom? The idea that water is black was common in Antiquity (cf., e.g., Arist., GA 779b30-33 and 735a32 with b35). On the basis of a few parallels in Homer, where allusion is made to the blackness of water (Il. 2, 825; 9, I4; Od. 4, 359; 20, I58), L. Senzasono, 2006, p. 248, n. 2IO argues that Plutarch is probably interpreting a Homeric passage here but does not quote the poet explicitly as he presupposes the reader to know the lines by heart. This is unlikely, because Plutarch does not refrain from quoting Homer elsewhere (running up to five quotations in total in Quaestiones naturales). A parallel account for the darkness of deep water is found in De prim. frig. $950 \mathrm{AB}$ (cf. also, e.g., De Is. et Os. $364 \mathrm{~B}$ ), but Plutarch does not give a very detailed or systematic explanation of it there (since it is only part of the sub-argument, the main argument being the Empedoclean, anti-Stoic theory that water, rather than air, is the principle of cold). Plutarch there ascribes the darkness to the mass density of the water ( $\dot{v} \pi \dot{0} \pi \lambda \dot{\eta} \theta 0 v \varsigma$ ), whereas the water that comes in contact with

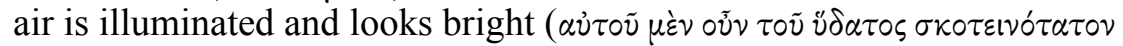

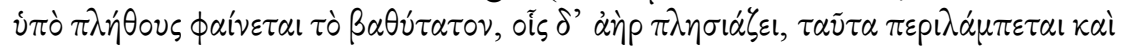
$\delta(\alpha \gamma \varepsilon \lambda \tilde{\alpha})$. The element of $\pi \lambda \tilde{\eta} \theta 0 \varsigma$ is not repeated here in Q.N. 39; the relation between air and light, on the other hand, is relatively common: cf. also Q.N. $12,915 \mathrm{AB}$, De prim. frig. $952 \mathrm{~F}$ (in the sea, lakes and rivers) and $D e$ facie $922 \mathrm{DE}$ (in the hollows of the earth).

An quod profunditas nigredinis mater est, ut quae solis radeos prius quam ad eam descendant obtundat et labefactet?: The imagery in profunditas nigredinis mater is rather exceptional to the general register and style of the collection [see I.2.3.]. One may wonder if this is perhaps Longolius' invention.

Superficies autem, quoniam continuo a sole adficitur, candorem luminis recipiat oportet: F.H. Sandbach, 1965, p. 225 translates continuo as "immediately" here, but a little bit further on as "perpetually", which suits both cases better (as is also seen, e.g., in Quint., Inst. or. 2, 20, 3 and 9, I, II; see L\&S, s.v. b).

Quod ipsum et Empedocles approbat 'Et niger in fundo fluvii color exstat ab umbra / atque cavernosis itidem spectatur in antris': The fragment is only preserved in Longolius' Latin translation (= Emp., DK3IB94). H. Diels, I9OI, p. I4I, 94 tried to restore the original Greek text as follows:

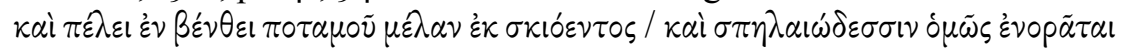


$\dot{\varepsilon} \nu \ddot{\alpha} \nu \tau$ poเs. According to Empedocles, blackness belongs to water and

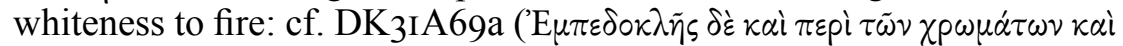

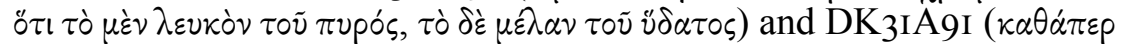

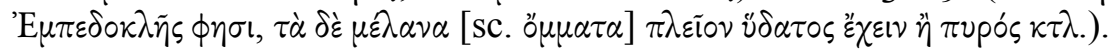

An limo plerumque oppletus fluminum marisque fundus talem de se colorem per solis reflexum parit, quali utique is praeditus est?: For the idea that reflection of light is only possible with respect to solid bodies,

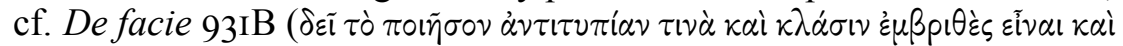

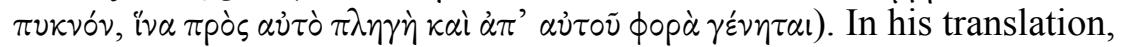
F.H. Sandbach, I965, p. 225 adds between brackets that the (dark) colour that reflects from the mud "may not be that of the water" itself, which is, indeed, what Plutarch seems to be implying here.

An probabilius est aquam minime quae illis est puram et sinceram esse, sed terrea qualitate (utpote quae continuo, qua currit vel agitur, aliquid ex ea advehat) imbutam: For the earthy quality of seawater, cf. Q.N. I, $9 \mathrm{IID}$ and $8,9 \mathrm{I} 4 \mathrm{~B}$, and for that of spring waters, cf. Q.N. 2, 9I2B. By contrast, in Quaest. conv. $725 \mathrm{D}$, Plutarch writes that running water, as opposed to stagnant water, avoids mixture or shakes off any earth that enters its course.

\section{Psellus (Q.N. 40-4I)}

The additional problems in Q.N. 40-4I are part of the $\mathrm{II}^{\text {th }}$ century side tradition of Quaestiones naturales in Michael Psellus' De omnifaria doctrina, where they are numbers $\S \S \mathrm{I} 70$ and I 88 Westerink respectively (= $\S \S \mathrm{I} 34$ and I52 Migne; the latter was copied by M. Glycas, Ann. I, I3 (= pp. 25, 2I-26, 5 Bekker)). The least that can be said is that there is a Plutarchan core to these two problems, so they deserve to be studied here, if only for the parallel material and related physical topics in Plutarch. In spite of the controversy about the authenticity of these two problems, there may be reason to assume - not only on the basis of the parallel material in Plutarch's writings but also of the order of Psellus' sources in the first redaction of De omnifaria doctrina (which only covers natural scientific topics) - that they contain the remains of two lost Quaestiones naturales. If this is true, these chapters are not the result of a mere bric-à-brac by Psellus (though his adaptation of Plutarch's text is obvious). For further discussion, see L.G. Westerink, I948, p. 3, F.H. Sandbach, I965, p. I43 and M. Meeusen, 20I2b, pp. I07-IIO. L. Senzasono, 2006, pp. 50-5I refuses to include both problems in his edition on grounds of the uncertain attribution in comparison to Longolius' problems. 


\section{Q.N. 40 (= Psellus, De omn. doctr. 170 Westerink)}

Q.N. 40 links up with the problems concerning salt and water in Q.N. I-I3. It examines why brine bursts forth from the sea when a thunderbolt

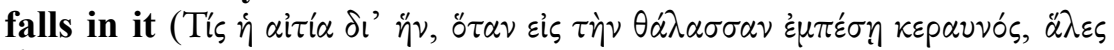
$\left.\dot{\varepsilon} \xi \alpha \nu \theta_{\circ \tilde{v} \sigma \nu} ;\right)$. This phenomenon is explained in one lengthy explanation, where the very first word takes central position, viz. the process of solidification.

The argument goes that the solidification of seawater produces salt, and that it is solidified when a thunderbolt falls in it and draws off the sweet and

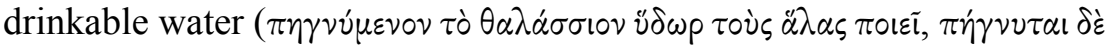

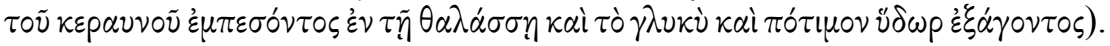
Light and drinkable water, by contrast, is not solidified when scorched by the sun or by a thunderbolt, but both things, and especially the thunderbolt,

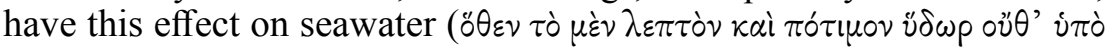

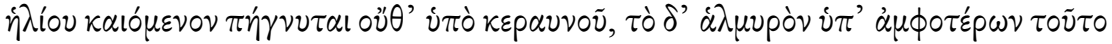
$\pi \dot{\alpha} \sigma \chi \varepsilon l, \kappa \alpha i \mu \dot{\alpha} \lambda ı \sigma \tau \alpha \dot{\nu} \pi \dot{o} \kappa \varepsilon p \alpha \nu v \circ \tilde{u})$. This is explained by the fact that when the lightning fire, which is sulphureous, falls into the sea, it evaporates and dries up the drinkable substance and solidifies the earthy and salty

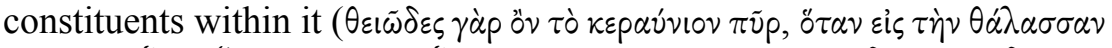

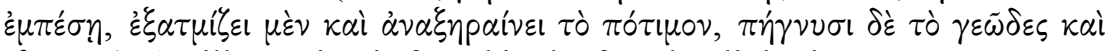
$\dot{\alpha} \lambda \mu \nu \rho o ́ v)$. An illustration is found in the fact that lightning protects corpses against decay and that salt also conserves them undecayed, as they both

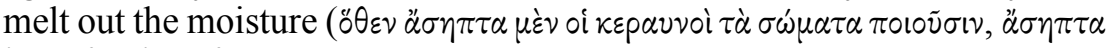

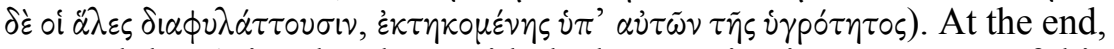
we read that Aristotle, along with the better scientists, approves of this

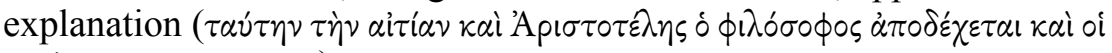

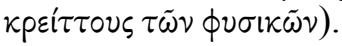

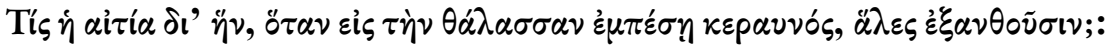
For a similar formulation of the quaestio with the introductory phrase $\tau i s$

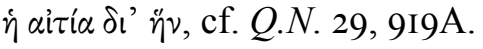

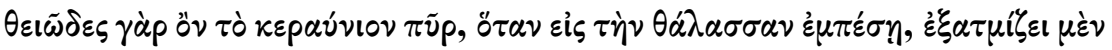

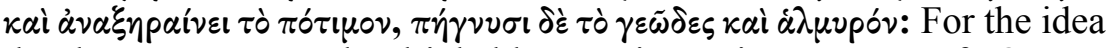
that heat evaporates the drinkable constituent in seawater, cf. Q.N. 9, 9I4C (with the commentary ad loc. for further parallels). For heat (of the sun) evaporating the finest and lightest part of the seawater on the skin of bathers and leaving behind a briny scum ( $\dot{\alpha} \lambda \omega \dot{\delta} \eta \bar{s} \dot{\varepsilon} \pi i \pi \alpha \gamma \circ \varsigma)$, cf. also Quaest. conv. 627EF (with a reference to Ps.-Arist., Probl. 932b25). See also Q.N. I, 9IID (with the commentary ad loc.). In Quaest. conv. 665CD, the orator Dorotheüs ascribes a divine character to sulphur $(\theta \varepsilon \tilde{\imath}$ ○े) on the basis of a dubious etymology. See S.-T. Teodorsson, I990a, p. 57. Ps.-Arist., Probl. 
937 b29 also calls sulphur and lightning sacred (the problem is why hot baths are considered holy: cf. Q.N. 29).

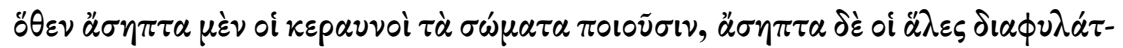

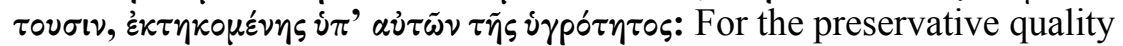
of salt, cf. Q.N. I, 9IID, IO, 9I4DE and Quaest. conv. 685BC. For that of lightning, cf. Quaest. conv. $665 \mathrm{C}$ and $685 \mathrm{C}$ (where it illustrates the divine character of lightning). For the contrary belief that bodies struck by lightning decay in a few days, cf. Sen., $N Q 2$ 2, 3I, 2 (fulmine icta intra paucos dies verminant). According to S.-T. Teodorsson, I990a, p. 23I, the connection between the preservative qualities of lightning and salt was presumably "first made in a Peripatetic work". This may be true, because at the end of Q.N. 40, the authority of Aristotle is adduced (see the following comment).

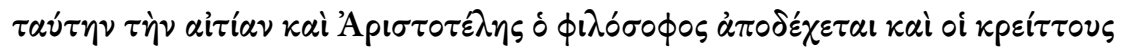

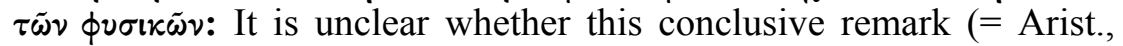
fr. 2 I8 Rose) is original or part of the reformulation of the chapter by Psellus. In any case, the Stagirite's natural scientific acumen is also explicitly praised in Quaest. conv. 656C, where Plutarch's father says that Aristotle is very sharp in solving natural problems ( $\dot{\xi} \xi \dot{v} \tau \alpha \tau \circ \varsigma \dot{\omega} \nu \dot{\varepsilon} \nu$

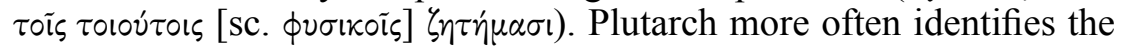
Stagirite as a $\phi \mathbf{l} \sigma^{\prime} \sigma \circ \phi \circ \varsigma$, perhaps to distinguish him from the historian Aristotle of Chalcis (cf. Amatorius 76IA). Therefore, it is probably "neither an epitheton ornans nor a cognomen ex virtute" (G. Roskam, 20IIb, p. 42). Cf. Thes. 3, 2, Lyc. I, I, Sol. 32, 4, Cam. 22, 3, Comp. Arist. et Ca. Ma. 2, 4, Comp. Alc. et Cor. 3, 2, Mul. virt. 254EF, Quaest. Rom. 265B (cf. also fr. I22 Sandbach, De gar. 503A, Alex. I7, 9).

\section{Q.N. 4I (= Psellus, De omn. doctr. I88 Westerink)}

Q.N. 4I concerns a botanical problem, viz. why roses flower better when certain ill-smelling plants have been planted beside them

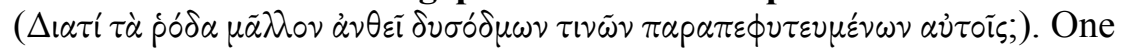
lengthy explanation is given, which is based on the theory of like attracts like, as effected, more specifically, by the processes of attraction and motion of material effluences ( $\dot{\lambda} \lambda \hat{n}$ and $\phi o p \alpha \dot{)}$ ). The (Stoic) concept of natural sympathy and antipathy is not far away (for the antipathetic property of the fig tree, which is mentioned as a parallel case in the explanation, cf. Quaest. conv. 664C: $\dot{\alpha} \lambda \lambda^{\prime}$ ' $\chi \chi \omega \nu ~ \delta \dot{v} v \alpha \mu \nu \nu \dot{\alpha} \nu \tau \imath \pi \alpha \theta \tilde{\eta}, \kappa \alpha \theta \dot{\alpha} \pi \varepsilon p$ $\dot{\eta} \sigma u \kappa \tilde{\eta})$. 
First, the phenomenon at hand is generalised as being commonly observed in the botanical world. Not only roses, but also lilies, violets and all flowers that have a sweet efflux become even sweeter-smelling when (malodorous)

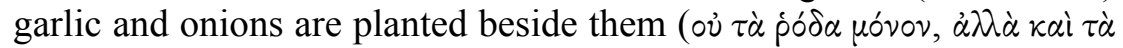

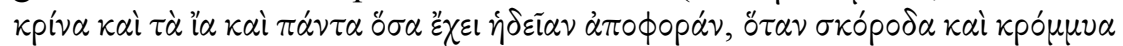

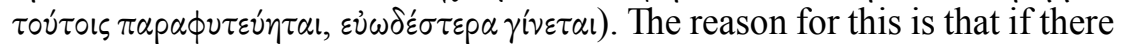
is anything pungent and ill-smelling in them, it naturally emanates to the more pungent plants. What remains becomes very sweet-smelling

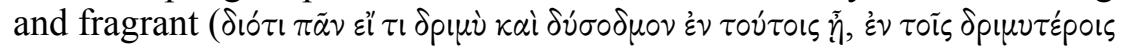

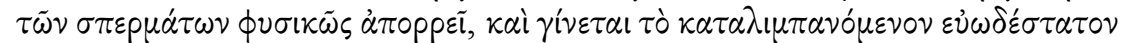

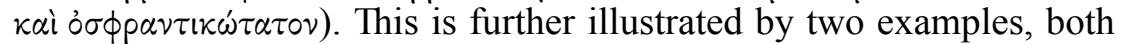
regarding the bad smell of fig trees. Rue also becomes more pungent than normal, when planted under a fig tree, because what is malodorous

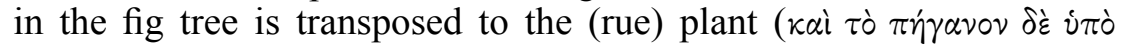

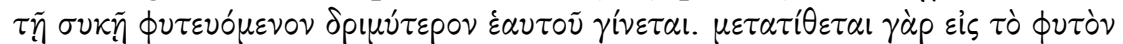

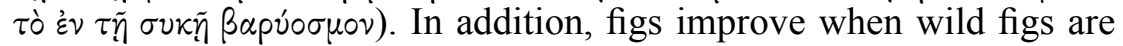

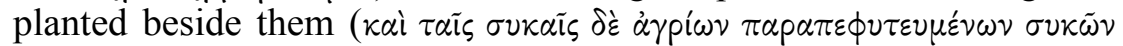
$\beta \varepsilon \lambda \tau^{\prime} \omega \tau \dot{\alpha} \sigma \tilde{v} \kappa \alpha \gamma^{\prime}(v \varepsilon \tau \alpha l)$. This is due to the fact that in each of these plants, there is an attraction and motion towards things congeneric and alike. Thus, all that is pungent in the sweet fig tree passes over to the wild one, preserving the sweetness of its figs undiluted ( $\delta \lambda \kappa \tilde{\eta} \varsigma \gamma \dot{\alpha} \rho \dot{\varepsilon} \kappa \alpha \dot{\sigma} \tau \omega \omega \kappa \alpha i$

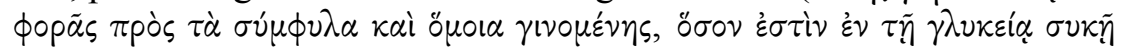

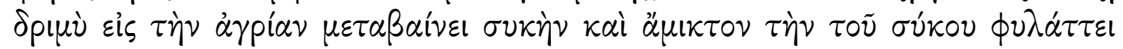
$\left.\gamma \lambda \nu \kappa \tau^{\tau} \eta \tau \tau\right)$.

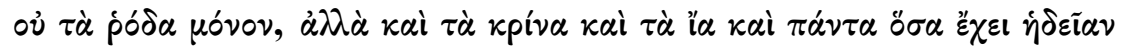

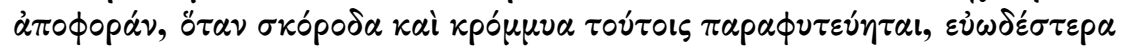

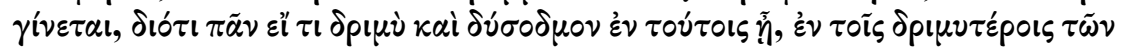

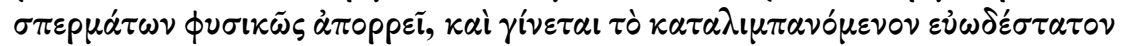

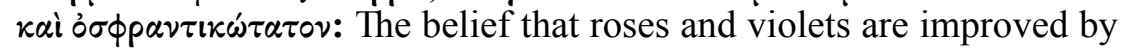
planting garlic and onions beside them is paralleled in De cap. ex inim. $92 \mathrm{~B}$, where the same explanation is given (Plutarch ascribes the belief to

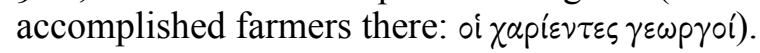

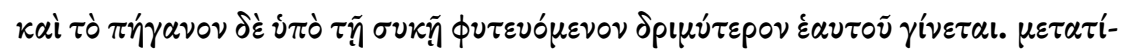

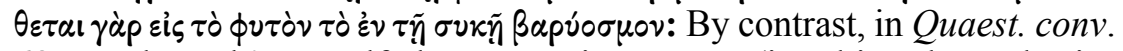
$684 \mathrm{D}$, Plutarch's grandfather Lamprias reports (invoking the authority of gardeners) that rue actually becomes sweeter and milder instead of more pungent ( mat. med. 3, 45, I, Pallad., Op. agr. 4, 9, I4, Pliny, NH I9, I56. Similarly, Ps.-Arist., Probl. 924b35-925a5 examines why rue grows best and most if it is grafted onto a fig tree (cf. Theophr., $C_{5}, 6$, I0). The contradiction may be due to Psellus' rewriting of the chapter, but an adaptation by Plutarch himself cannot be excluded (either way, to bring this example more in line 
with the one that follows). For the pungency of fig trees and the intense vapour that they produce, cf. Quaest. conv. 696EF.

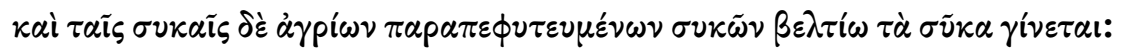
The same phenomenon is mentioned in passing in Quaest. conv. 70oF. In Amatorius $753 \mathrm{~A}$, the artificial pollination of dates and figs is compared to joining a young man to an older woman. Cf. also Arist., $H A$ 557b29, Theophr., $C P$ 2, 9, 5, Pliny, $N H$ I5, 79-8I. 


\section{Synopsis}

By way of conclusion, I here provide a synopsis of the main arguments as elaborated in the four introductory essays that form the first part of this book. I hope to have shown that Plutarch's Quaestiones naturales demonstrate that, among many other intellectual and philosophical predilections, the Chaeronean had numerous particular - and at times rather peculiar - questions about the natural world on his mind and took them to heart. By providing a systematic study and commentary of this generally neglected work in light of Plutarch's natural scientific programme more generally the volume at hand is meant to usefully contribute to our understanding of Plutarch's world view and, thus, to our knowledge of ancient natural science in the Imperial Era more generally.

The first chapter provides a general outline of the Aristotelian genre of natural problems and the place of Plutarch in the wider tradition of the Ps.-Aristotelian Problems. A seminal point that is raised here and serves as a conceptual framework for the study as a whole is that Plutarch's natural problems have an obvious Aristotelian, or more generally Peripatetic, character, which is problematic in light of his philosophical allegiance to Plato and the Academy. A good understanding of Plutarch's natural problems proves to be indispensable for contemporary scholarship not only because it provides precious insight into the reception of Ps.-Aristotle's Problems in the Imperial Era, but also because it sheds an important light on the Stagirite's influence on Plutarch's philosophy, a problem that is settled only at the end of chapter four (see below). Against this backdrop, the first chapter examines the 'problematic' organisation of Quaestiones naturales both on a micro- and on a macrostructural level. As indicated by its original Greek title, the aspect of physical aetiology is central to the collection's scientific set-up, which explains the sub-literary style of discourse and the general avoidance of moralising dynamics. This type of discourse is characteristic of the Aristotelian genre of natural problems more generally, which served as Plutarch's model. It is not strictly representative of the author's scientific intentions, since Plutarch's concept of natural science is by no means reducible to these features. This raises questions about the position of Quaestiones naturales in relation to the corpus Plutarcheum more generally.

The second chapter further elaborates on this topic. Special attention there goes to the incorporation of the same and similar Quaestiones naturales material in Plutarch's other treatises, especially Quaestiones convivales. We have seen that Plutarch's collections of problems should not be mistaken for his personal notes $(i \pi \circ \mu \nu \eta \mu \alpha \tau \alpha)$, as traditional 
scholarship has often done. By contrast, Quaestiones naturales provides an independent aetiological framework for Plutarch to collect his thoughts on particular natural questions and to deal with them in an autonomous fashion (i.e. to a large degree on their own terms and free from any other preoccupations, such as stylistic embellishment or moralising dynamics). Eventually, the possiblity of the collection's publication by Plutarch himself is considered, where the usability of this kind of literature in a philosophical school context is emphasised.

This last point is further elaborated upon in chapter three, which addresses the intended reading and educational value of Quaestiones naturales. I here show that natural problems were a popular subject for discussion in Plutarch's philosophical school and also during convivial gatherings of his intellectual milieu. In a seminal passage from De tuenda I33E, natural problems are described as being $\dot{z} \lambda \alpha \phi \rho \dot{\alpha} \kappa \alpha i ̀ ~ \pi \imath \theta \alpha \nu \dot{\alpha}$ ('easy and persuasive'), a phrase that highlights the low level of complexity of the genre and its general utility as exercises in natural scientific debate. Thus, I elaborate on the idea of intellectual gymnastics promoted by Plutarch's natural problems, while also stressing that the solutions to these problems are not simply meant as forms of sophistic playfulness. On the contrary, the search for physical causes in explaining wonder-inducing natural phenomena can be seen as an intellectual exercise aimed at the eradication of irrational, superstitious beliefs about God and his influence in the natural world around us - an idea that ties in closely with Plutarch's broader philosophical-religious project.

The place of Plutarch's Quaestiones naturales in this broader philosophical-religious project is further elaborated upon in chapter four. Here, I first focus on the collection's aetiological design and its link with the ancient genre of paradoxography and mirabilia literature. Plutarch was not so much concerned - for underlying philosophical and religious motives with the veracity of the natural phenomena but with their physical causes. An explanation is found in Plutarch's Platonic-Academic outlook on the world and his dualistic view on causality, wherein it is accepted that natural phenomena are based on physical causes but also have a higher, divine motivation. In order to support this, I provide an analysis and interpretation of the mythological material that Plutarch incorporates in his physical aetiologies, arguing that these may hint at a higher type of causality and at a 'mystification' of the aetiological discourse. An analysis of the material Plutarch borrows from the poets and from authors of scientific prose then follows. We see that in his attempt to formulate plausible explanations to the problems, Plutarch often relies on received knowledge by 'problematising', that is, reframing in the problem format, a wide array of ancient Greek scientific learning. At the same time, he tries to balance this approach with his own innovative contributions to the problems, thus demonstrating his own argumentative creativity. In 
the remainder of the chapter, I provide a general outline of Plutarch's scientific methodology, focusing successively on the material principles and natural processes mentioned in the physical aetiologies, Plutarch's generally sceptical and anti-empiricist approach to natural phenomena, the logical-rhetorical organisation of the collection and the use of a more or less uniform set of technical terms. At the end of chapter four, I revisit the question of Aristotle's influence on Plutarch's Platonism, arguing that Quaestiones naturales is not the product of his aspirations to be regarded as an Aristotelian scientist. In the end, Plutarch's science of natural problems is, by its inquisitive method and philosophical purpose, framed in a wider Platonic view of the world. 


\section{Bibliography}

A

Abramowiczówna, Z., Komentarz Krytyczny i egzegetyczny do Plutarcha quaestiones convivales Ks. I i II, Toruń, r96o.

—, "Plutarch's 'Tischgespräche'”, Altertum, 8 (I962), pp. 80-88.

Adam, H., Plutarchs Schrift Non posse suaviter vivi secundum Epicurum. Eine Interpretation, Amsterdam, 1974.

Adrados, F.R., "El poema del pulpo y los orígenes de la colección teognídea”, Emerita, 26 (1958), pp. I-IO.

Aguilar, R.M., "Hipócrates en Plutarco", Cuadernos de Filologia Clásica, 4 (1994), pp. 3545.

—, "Plutarco y los médicos helenísticos", in Casanova, A., 2005, pp. 4I7-434.

Amboglio, D., "Fra hypomnemata e storiografia", Athenaeum, 78 (1990), pp. 503-508.

Amigues, S., Théophraste. Recherches sur les plantes, vol. 3, Paris, 1993.

Anderson, G., The Second Sophistic: A Cultural Phenomenon in the Roman Empire, London, I993.

Andò, V., "La ricezione ippocratica in Plutarco", in Gallo, I., 2004, pp. I59-I83.

Anton, J.P. (ed.), Science and the Sciences in Plato, New York, I980.

Armstrong, A.H., The Cambridge history of later Greek and early Medieval Philosophy, Cambridge, 1967.

Arnould, D., Le rire et les larmes dans la littérature grecque: d'Homère à Platon, Paris, I990.

Ashbaugh, A.F., Plato's Theory of Explanation. A Study of the Cosmological Account in the Timaeus, New York, 1988.

Asmis, E., Epicurus’ Scientific Method, New York, 1984.

Asper, M., Kallimachos. Werke. Griechisch und Deutsch, 2004, Darmstadt.

- (ed.), Writing Science. Mathematical and Medical Authorship in Ancient Greece, Berlin, 2013.

B

Babbitt, F.C., Plutarch's Moralia in Sixteen Volumes, vol. 2, Cambridge, Mass. - London, I928.

_, Plutarch's Moralia in Sixteen Volumes, vol. 4, Cambridge, Mass. - London, 1936 [= I936a]. 
_, Plutarch's Moralia in Sixteen Volumes, vol. 5, Cambridge, Mass. - London, 1936 [= 1936b].

Babilas, W., Tradition und Interpretation. Gedanken zur philologischen Methode, München, I96I.

Babut, D., Plutarque et le stoïcisme, Paris, 1969.

—, “Sur l' unité de la pensée d'Empédocle”, Philologus, I20 (I976), pp. I39-I64.

—, "Du scepticisme au dépassement de la raison: philosophie et foi religieuse chez Plutarque", in Babut, D. (ed.), Parerga: choix d'articles de Daniel Babut (1974-I994), Lyon, I994, pp. 549-58I.

—, "Plutarque, Aristote, et l'Aristotélisme", in Van der Stockt, L., I996a, pp. I-28.

—, 'L' unité de l' Académie selon Plutarque. Notes en marge d' un débat ancien et toujours actuel", in Bonazzi, M., Lévy, C. and Steel, C. (eds.), A Platonic Pythagoras: Platonism and Pythagoreanism in the Imperial Age, Turnhout, 2007, pp. 63-98.

Bakker, F., Three Studies in Epicurean Cosmology, Utrecht, 2010.

Baldassari, M. "Osservazioni sulla struttura del periodo e sulla costruzione ritmica del discorso nei Moralia di Plutarco", in Van der Stockt, L., 2000a, pp. I-I3.

Barigazzi, A., "Implicanze morali nella polemica plutarchea sulla psicologia degli animali", in Gallo, I., I992, pp. 297-3I5.

Barrow, R.H., Plutarch and his times, London, 1967.

Barthelmess, J., "Recent Work on the Moralia", in Brenk, F.E. and Gallo, I., I986, pp. 6I-8I.

Barton, T., Power and knowledge: astrology, physiognomics, and medicine under the Roman Empire, Michigan, 1994 [= I994a].

—, Ancient Astrology, London, 1994 [= I994b].

Battegazzore, M., "L'atteggiamento di Plutarco verso le scienze”, in Gallo, I., I992, pp. 19-59.

Beagon, M., "The curious eye of the Elder Pliny”, in Gibson, R.K. and Morello, R., 20II, pp. 7I-88.

Becchi, F., "Aristotelismo ed antistoicismo nel De virtute morali di Plutarco", Prometheus, I (I975), pp. I60-I80.

—, "Aristotelismo funzionale nel De virtute morali di Plutarco", Prometheus, 4 (1978), pp. 26I-275.

—, "Plutarco tra platonismo ed aristotelismo: la filosofia come $\pi \alpha \iota \delta \varepsilon i \alpha$ dell'anima", in Pérez Jiménez, A., Garciá López, J. and Aguilar, R.M., I999, pp. 25-43.

—, "Lignes directrices de la doctrine zoopsychologique de Plutarque", Myrtia, I7 (2002), I59-I74.

—, "Le traduzioni latine dei Moralia di Plutarco tra XIII e XVI secolo", in Volpe Cacciatore, P. (ed.), Plutarco nelle traduzioni latine di età umanistica: Seminario di studi, Fisciano, I2-I3 luglio 2007, Napoli, 2009, pp. 9-52. 
—, "Plutarch, Aristotle, and the Peripatetics", in Beck, M., 20I4, pp. 73-87.

Beck, M., "Plutarch's Hypomnemata, Standard Topoi and Idiosyncratic Composition in the Moralia", in Horster, M. and Reitz, C., 20I0a, pp. 349-367.

- (ed.), A Companion to Plutarch, Oxford, 2014.

Bernard, W., Spätantike Dichtungstheorien: Untersuchungen zu Proklos, Herakleitos und Plutarch, Stuttgart, 1990.

Bertier, J., Mnésithée et Dieuchès, Leiden, 1972.

—, "A propos de quelques resurgences des Épidémies dans les Problemata du Corpus aristotelicien", in Baader, G. and Winau, R. (eds.), Die hippokratischen Epidemien: Theorie, Praxis, Tradition, Stuttgart, 1989, pp. 26I-269.

Beta, S., "Riddling at table: trivial ainigmata vs. philosophical problemata", in Ferreira, J.R., Leão, D., Tröster, M. and Barata Dias, P., 2009, pp. 97-IO2.

Bétolaud, V., Oeuvres complètes de Plutarque. Oeuvres morales et oeuvres diverses traduites en français, vol. 4, Paris, 1870.

Blair, A., "The Problemata as a Natural Philosophical Genre", in Grafton, A. and Siraisi, N.G. (eds.), Natural Particulars. Nature and the Disciplines in Renaissance Europe, Cambridge, 1999, pp. I71-204.

Bolkestein, H., Adversaria critica et exegetica ad Plutarchi quaestionum convivalium librum primum et secundum, Amsterdam, 1946.

Bömer, F., "Der Commentarius. Zur Vorgeschichte und literarischen Form des Schriften des Caesars", Hermes, 8I (1953), pp. 210-250.

Bonazzi, M., "Contro la rappresentazione sensibile: Plutarco tra l'Academia e il platonismo", Elenchos, 25 (2004), pp. 4I-7I.

—, "Plutarch and the Skeptics", in Beck, M., 20I4, pp. I2I-I34.

Bonazzi, M. and Opsomer, J. (eds.), The Origins of the Platonic System. Platonisms of the Early Empire and their Philosophical Context, Louvain - Paris - Namur - Walpole, Mass., 2009.

Bonitz, H., Index Aristotelicus, Berlin, 1870.

Borthwick, E.K., "Bee Imagery in Plutarch", $C Q$, 4I (I99I), pp. 560-562.

Bouffartigue, J., Plutarque. L'intelligence des animaux, vol. I4, I, Paris, 2012.

Boulogne, J., “Les 'Questions Romaines' de Plutarque”, $A N R W$ 2, 33, 6 (1992), pp. 46824708.

-, Plutarque. Un aristocrate grec sous l'occupation romaine, Lille, 1994.

—, "Plutarque et la médecine", $A N R W$ 2, 37, 3 (I996), pp. 2762-2792.

—, “Les 'Étiologies romaines': une herméneutique des moeurs à Rome”, in Payen, P., I998a, pp. 3I-38.

—, Plutarque. Conduites méritoires de femmes, Étiologies romaines, Étiologies grecques, Parallèles mineurs, vol. 4, Paris, 2002. 
—, Plutarque dans le miroir d'Épicure. Analyse d'une critique systématique de l'épicurisme, Villeneuve d' Asq, 2003.

- (ed.), Les Grecs de l'antiquité et les animaux. Le cas remarquable de Plutarque, Lille, $2005[=2005 \mathrm{a}]$.

-, "Le culte égyptien des animaux vu par Plutarque. Une étiologie égyptienne (Isis et Osiris, 7I-76, 379D-382C)", in Boulogne, J., 2005a, pp. 197-205 [= 2005b].

—, "Plutarque lecteur de Théophraste", in Casanova, A., 2005, pp. 287-300 [= 2005c].

_, "Le paradigme de la crase dans la pensée de Plutarque," Ploutarchos, 4 (2006/7), pp. $3^{-17}$.

—, "Les digressions scientifiques dans les Vies de Plutarque", in Nikolaidis, A.G., 2008, pp. 733-749.

Bowersock, G.W.M., "Plutarch and the Sublime Hymn of Ofellius Laetus", GRBS, 23 (I982), pp. 275-279.

—, "Plutarch", in Easterling, P.E. and Knox, B.M.W. (eds.), The Cambridge History of Classical Literature, I: Greek Literature, I985, pp. 665-669.

Bowie, E., "Plutarch's Habits of Citation", in Nikolaidis, A.G., 2008, pp. I43-I57.

Boyancé, P., "Platon et le Vin”, BAGB Lettres d'Hum., Io (I95I), pp. 3-19.

Boys-Stones, G., "Plutarch on the Probable Principle of Cold: Epistemology and the De Primo Frigido", CQ, 47 (1997), pp. 227-238 [= 1997a].

-, "Thyrsus-Bearer of the Academy or Enthusiast for Plato? Plutarch's de Stoicorum repugnantiis", in Mossman, J., I997a, pp. 4I-58 [= I997b].

Bräuninger, F., "Persephone”, RE, I9, I (I937), cols. 944-972.

Bréchet, C., "Vers une Philosophie de la Citation Poétique: Écrit, Oral et Mémoire chez Plutarque", in Castelnérac, B., 2007, pp. IOI-I34.

Brenk, F.E., In Mist Apparelled: religious themes in Plutarch's Moralia and lives, Leiden, I977.

—, "Plutarch's Middle-Platonic God: About to Enter (or Remake) the Academy", in HirschLuipold, R. (ed.), Gott und die Götter bei Plutarch. Götterbilder - Gottesbilder Weldbilder, Berlin - New York, 2005, pp. 27-49.

Brenk, F.E. and Gallo, I. (eds.), Miscellanea Plutarchea. Atti del I convegno di studi su Plutarco (Roma, 23 novembre I985), Ferrara, 1986.

Brisson, L. (transl. C. Tihanyi), How Philosophers Saved Myths: Allegorical Interpretation and Classical Mythology, Chicago, 2004.

—, "Why Is the Timaeus Called an Eikôs Muthos and an Eikôs Logos?", in Collobert, C., Destrée, P., and Gonzalez, F.J. (eds.), Plato and Myth. Studies on the Use and Status of Platonic Myths, Leiden - Boston, 20I2, pp. 369-39I.

Broadie, S., Nature and Divinity in Plato's Timaeus, Cambridge, $20 \mathrm{I} 2$.

Bucher-Isler, B., Norm und Individualität in den Biographien Plutarchs. Untersuchungen zu seiner Charakterdarstellung, Stuttgart, 1972. 
Buckler, J., "Plutarch and Autopsy", in $A N R W$ 2, 33, 6 (1992), pp. 4788-4830.

Bühler, W., "Die Philologie der Griechen und ihre Methoden”, Jahrbuch der Akademie der Wissenschaften in Göttingen (1977), pp. 44-62.

Burnyeat, M.F., "Eikōs muthos", in Partenie, C. (ed.), Plato's myths, Cambridge, 2009, pp. I67-I86.

Bussemaker, U.C., Aristotelis opera omnia graece et latine, vol. 4, Paris, I857.

Butterfield, H., The Whig Interpretation of History, London, I93I.

C

Caballero Sanchez, R., "Excursus geografici nella Vita Alexandri di Plutarco", in Gallo, I., I992, pp. 9I-97.

Cameron, A., Callimachus and His Critics, Princeton, 1995.

Candau Morón, J., González Ponce, F. and Chávez Reino, A. (eds.), Plutarco transmisor. Actas del X simposio internacional de la sociedad española de Plutarquistas (Sevilla, I2-I4 de noviembre de 2009), Sevilla, $201 \mathrm{I}$.

Capelle, W., "Auf Spuren alter Фvбเкоi”, Hermes, 45 (I9I0), pp. 32I-336.

Carrano, A., Questioni greche, Napoli, 2007.

Casanova, A. (ed.), Plutarco e l'età ellenistica, Firenze, 2005.

Castelli, L.M., "Manifestazioni somatiche e fisiologia delle "affezioni dell'anima" nei Problemata aristotelici", in Centrone, B., 2011a, pp. 239-274.

Castelnérac, B. (ed.), Philosophia and Philologia: Plutarch on Oral and Written Language, Hermathena, I82 (2007).

Centrone, B. (ed.), Studi sui Problemata Physica aristotelici, Elenchos, 58 (2011) [= 2011a].

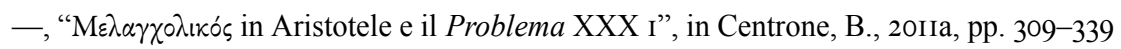
[= 20IIb].

von Christ, W., Geschichte der griechischen Literatur, vol. 2, I, München, I959.

Chassignet, M. (ed.), L'étiologie dans la pensée antique, Turnhout, 2008.

Cherniss, H., Plutarch's Moralia in Sixteen Volumes, vol. I3, I, Cambridge, Mass. - London, I976.

Cherniss, H. and Helmbold, W.C., Plutarch's Moralia in Sixteen Volumes, vol. I2, Cambridge, Mass. - London, 1957.

Claes, P., Concatenatio Catulliana: A New Reading of the Carmina, Amsterdam, 2002.

Clagett, M., Greek Science in Antiquity, New York, 1955.

Clement, P.A. and Hoffleit, H.B., Plutarch's Moralia in Sixteen Volumes, vol. 8, Cambridge, Mass. - London, I969.

Collobert, C., "Aristotle's Review of the Presocratics: Is Aristotle Finally a Historian of Philosophy?", Journal of the History of Philosophy, 40 (2002), pp. 28I-295. 
Conte, G.B., "Empirical and Theoretical Approaches to Literary Genre", in Galinsky, K. (ed.), The Interpretation of Roman Poetry: Empiricism or Hermeneutics?, Frankfurt am Main, I992, pp. I04-I23.

Corcoran, T.H., Seneca, Naturales Quaestiones, vol. I, London - Cambridge, Mass., I97I.

Cornford, F.M., Plato's Cosmology. The Timaeus translated with a running commentary, London, I937.

Cribiore, R., Gymnastics of the Mind. Greek Education in Hellenistic and Roman Egypt, Princeton, 200I.

Croiset, A. and M., Histoire de la littérature grecque, V: Période alexandrine; période romaine, Paris, I899.

Culham, P., "Plutarch on the Roman Siege of Syracuse: the Primacy of Science over Technology", in Gallo, I., 1992, pp. I79-197.

Cunningham, A., "Getting the Game Right: Some Plain Words on the Identity and Invention of Science", Studies in History and Philosophy of Science, I9 (1988), pp. 365-389.

\section{D}

Dalby, A., Food in the ancient world from A-Z, London, 2003.

Darbo-Peschanski, C., "Pourquoi chercher des causes aux coutumes?", in Payen, P., I998a, pp. $2 \mathrm{I}-30$.

D'Arms, J.H., "The Roman Convivium and the Idea of Equality", in Murray, O., I990a, pp. $308-320$.

-, "Heavy Drinking and Drunkenness in the Roman World: Four Questions for Historians", in Murray, O. and Tecuşan, M. (eds.), In vino veritas, London, I995, pp. 304-3I7.

De Lacy, P.H., "Plutarch and the Academic Sceptics", The Classical Journal, 49 (I953), pp. $79-85$.

De Leemans, P. and Goyens, M. (eds.), Aristotle's Problemata in Different Times and Tongues, Leuven, 2006.

Del Re, R., "Il pensiero metafisico di Plutarco: Dio, la natura, il male", Studi Italiani di Filologia Classica, 24 (1950), pp. 33-64.

Denniston, J.D., The Greek Particles, Oxford, 1966.

Démarais, L., "L' animal, les mirabilia et l'étiologie dans les Propos de table. L' exemple du problème sur le rémora (II 7)", in Boulogne, J., 2005a, pp. I57-I7I.

De Rosalia, A., "Il Latino di Plutarco", in D'Ippolito, G. and Gallo, I., I99I, pp. 445-459.

Desideri, P., "Scienza nelle Vite di Plutarco", in Gallo, I., I992, pp. 73-89.

Diehl, E., Anthologia lyrica graeca, vol. 2, Leipzig, I925.

Diels, H., Doxographi Graeci, Berlin, I879.

—, Poetarum Philosophorum Fragmenta, Berlin, I90I. 
—, "Aristotelica", Hermes, 40 (1905), pp. 30I-316.

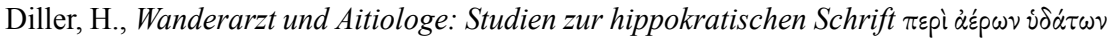

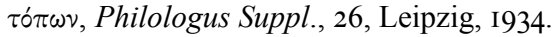

Dillon, J.M., The Middle Platonists: a study of Platonism 80 B.C. to A.D. 220, London, I977.

—, "“Orthodoxy" and "Eclecticism": Middle Platonists and Neo-Pythagoreans", in Dillon, J.M. and Long, A.A., I988, pp. I03-I25.

- , "Plutarch and God: Theodicy and Cosmogony in the Thought of Plutarch", in Frede, D. and Laks, A. (eds.), Traditions of Theology. Studies in Hellenistic Theology, its Background and Aftermath, Leiden, 2002, pp. 223-237.

—, "Plutarch and Platonism", in Beck, M., 20I4, pp. 6I-72.

Dillon, J.M. and Long, A.A. (eds.), The Question of "Eclecticism”: Studies in Later Greek Philosophy, Berkeley, 1988.

D’Ippolito, G. and Gallo, I. (eds.), Strutture formali dei "Moralia" di Plutarco, Napoli, I99I.

D'Ippolito, G. and Nuzzo, G., Plutarco. L'origine del freddo - Se sia piú utile l'acqua o il fuoco. Introduzione, testo critico, traduzione e commento, Napoli, 2012.

Doehner, T., Quaestiones Plutarcheae, vol. 2, Misniae, I858.

—, Vindiciarum Plutarchearum liber, Zwiccaviae, I864.

Donini, P., "Problemi del pensiero scientifico a Roma: il primo e il secondo secolo d.C.", in G. Giannantoni, G. and Vegetti, M. (eds.), La scienza ellenistica : atti delle tre giornate di studio tenutesi a Pavia dal I4 al I6 aprile I982, Napoli, I984, pp. 353-374.

—, "Lo scetticismo academico. Aristotele e l'unità della tradizione platonica secondo Plutarco", in Cambiano, G. (ed.), Storiografia e dossografia nella filosofia antica, Torino, I986, pp. 203-226 [= I986a].

—, "Plutarco, Ammonio e l'Academia", in Brenk, F.E. and Gallo, I., I986, pp. 97-IIo [= I986b].

-, "Science and Metaphysics: Platonism, Aristotelianism, and Stoicism in Plutarch's On the Face in the Moon", in Dillon, J.M. and Long, A.A., I988, pp. I26-I44.

—, "I fondamenti della fisica e la teoria delle cause in Plutarco", in Gallo, I., I992, pp. 99I2O.

—, "Plutarco e la rinascita del platonismo", in Cambiano, G., Canfora, L. and Lanza, D. (eds.), Lo spazio letterario della Grecia antica. I: La produzione e la circolazione del testo. Vol. 3: I Greci e Roma, Roma, 1994, pp. 35-6o [= 1994a].

-, "Testi e commenti, manuali e insegnamento: la forma sistematica e i metodi della filosofia in età postellenistica", ANRW 2, 36, 7 (I994), pp. 5027-5100 [= 1994b].

_, "Platone e Aristotele nella tradizione pitagorica secondo Plutarco", in Pérez Jiménez, A., Garciá López, J. and Aguilar, R.M., I999, pp. 9-24. 
—, "L'eredità academica e i fondamenti del platonismo in Plutarco", in Barbanti, M., Giardina, G.R. and Manganaro, P. (eds.), Henosis kai philia. Unione e amicizia. Omaggio a F. Romano, Catania, 2002, pp. 247-273.

—, "Il silenzio di Epaminonda, i demoni e il mito: il platonismo di Plutarco nel De genio Socratis", in Bonazzi, M. and Opsomer, J., 2009, pp. I87-2I4.

-, Plutarco. Il volto della luna. Introduzione, testo critico, traduzione e commento, Napoli, 20 II.

Dorandi, T., "Den Autoren über die Schulter geschaut: Arbeitsweise und Autographie bei den antiken Schriftstellern", ZPE, 87 (199I), pp. II-33.

—, Le stylet et la tablette: dans le secret des auteurs antiques, Paris, 2000.

Dörrie, H., Porphyrios' "Symmikta Zetemata”. Ihre Stellung in System und Geschichte des Neuplatonismus nebst einem Kommentar zu den Fragmenten, München, 1959.

Dronkers, A.I., De comparationibus et metaphoris apud Plutarchum, Utrecht, I892.

Düring, I., "Aristotle's method in biology. A note on De Part. An. I i, 639b3o-640a2", in Mansion, S., I96I, pp. 2I3-22I.

Duff, T., Plutarch's Lives. Exploring Virtue and Vice, Oxford, I999 [= I999a].

—, "Plutarch, Plato and 'Great Natures'”, in Pérez Jiménez, A., Garciá López, J. and Aguilar, R.M., I999, pp. 313-332 [= I999b].

—, "The Prologues", in Beck, M., 20I4, pp. 333-349.

Dyroff, A., "Zur stoischen Tierpsychologie", Bayerische Blätter für das GymnasialSchulwesen, 33 (I897), pp. 399-404.

$\mathbf{E}$

van der Eijk, P.J., “Aristoteles über die Melancholie”, Mnemosyne, 43 (1990), pp. 33-72.

-, "Towards a Rhetoric of Ancient Scientific Discourse. Some Formal Characteristics of Greek Medical and Philosophical Texts (Hippocratic Corpus, Aristotle)", in Bakker, E.J. (ed.), Grammar as Interpretation. Greek Literature in its Linguistic Contexts, Leiden, 1997, pp. 77-129.

—, "Quelques observations sur la réception d' Aristote dans la médecine gréco-romaine de l'époque impériale", in Lehmann, Y., 2013, pp. I83-193.

Emerson, R.W., The Complete Works of Ralph Waldo Emerson, vol. Io: Lectures and Biographical Sketches, Boston, I89I.

$\mathbf{F}$

Fairbanks, A., "On Plutarch's Quotations from the Early Greek Philosophers", TAPA, 28 (I897), pp. $75^{-87 .}$

Farrington, B., Greek Science. Its Meaning For Us, Harmondsworth, I96I.

Fernández Delgado, J.A., "Los proverbios en los “Moralia” de Plutarco”, in D’Ippolito, G. and Gallo, I., I99I, pp. I95-2I2. 
Ferrari, F., Dio, idee e materia. La struttura del cosmo in Plutarco di Cheronea, Napoli, 1995.

—, "Plutarco e lo scetticismo ellenistico", in Casanova, A., 2005, pp. 369-384.

Ferrari, F. and Baldi, L., Plutarco. La generazione dell'anima nel Timeo. Introduzione, testo critico, traduzione e commento, Napoli, 2002.

Ferreira, A., "The Power of Nature and Its Influence on Statesmen in the Work of Plutarch", in Meeusen, M. and Van der Stockt, L., 2015, pp. I55-165.

Ferreira, J.R., Leão, D., Tröster, M. and Barata Dias, P. (eds.), Symposium and Philantropia in Plutarch, Coimbra, 2009.

Ferreira, J.R., Leão, D. and Martins de Jesus, C.A. (eds.), Nomos, Kosmos \& Dike in Plutarch, Coimbra, 2012.

Filius, L., The Problemata physica attributed to Aristotle: the Arabic version of Hunain ibn Ishāq and the Hebrew version of Moses ibn Tibbon, Leiden, 1999.

Fischer, K.-D., "Beiträge zu den pseudosoranischen Quaestiones medicinales", in Fischer, K.-D., Nickel, D. and Potter, P. (eds.), Text and Tradition. Studies in Ancient Medicine and its Transmission presented to Jutta Kollesch, Leiden, I998, pp. I-54.

Fitzgerald, W., Martial: The World of the Epigram, Chicago, 2007.

Flacelière, R., "Plutarque et les éclipses de lune", Revue des Etudes Anciennes, 53 (I95I), pp. 203-22I.

—, "La lune selon Plutarque", in Ducrey, P., Bérard, C., Dunant, C. and Paschoud, F. (eds.), Mélanges d' histoire ancienne et d'archéologie offerts à Paul Collart, Lausanne, I976, pp. 193-I95.

Flacelière, R., Irigoin, J., Sirinelli, J. and Philippon, A., Plutarque. De l'éducation des enfants; Comment lire les poètes, vol. I, I, Paris, 1987.

Flashar, H., Problemata physica, Berlin, 1962.

Fögen, T., Wissen, Kommunikation und Selbstdarstellung. Zur Struktur und Charakteristik römischer Fachtexte der frühen Kaiserzeit, München, 2009.

Forster, E.S., "The Pseudo-Aristotelian Problems: Their Nature and Composition", CQ, 22 (I928), pp. I63-I65.

Franke, W.A. and Mircea, M., "Plutarch's Report on the Blue Patina of Bronze Statues at Delphi: A Scientific Explanation", Journal of the American Institute for Conservation, 44 (2005), pp. I03-II6.

Frazier, F., "Théorie et pratique de la $\pi \alpha$ idı́ symposiaque dans les Propos de table de Plutarque", in Trédé, M. and Hoffmann, P. (eds.), Le rire des anciens, 1998, Paris, pp. 28I-292.

—, "Philosophie et religion dans la pensée de Plutarque. Quelques réflexions autour des

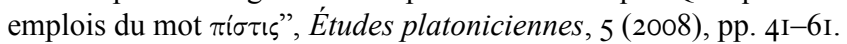

-, "Quand Plutarque actualise le mythe d'Er. Delphes, la Justice et la Providence dans le mythe de Thespésios (De sera 22, 563 B-33, 568 A)", in Van der Stockt, L., Titchener, F., 
Ingenkamp, H.G. and Pérez Jiménez, A. (eds.), Gods, Daimones, Rituals, Myths and History of Religions in Plutarch's Works. Studies Devoted to Professor Frederick E. Brenk by the I.P.S., Málaga - Logan, 20I0, pp. 193-2I0.

—, "Ordre et désordre dans la pensée de Plutarque. Réseaux lexicaux et problématiques

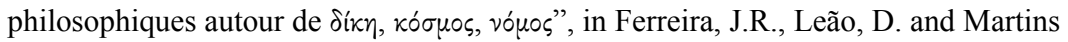
de Jesus, C.A., 20I2, pp. 215-242.

—, "The Perils of Ambition", in Beck, M., 20I4, pp. 488-502.

Frazier, F. and Leão, D.F. (eds.), Tychè et pronoia. La marche du monde selon Plutarque, Coimbra, 2010.

Frazier, F. and Sirinelli, J., Plutarque. Propos de table, vol. 9, 3, Paris, 1996.

French, R., Ancient Natural History, London, 1994.

Frede, M., Essays in Ancient Philosophy, Oxford, 1987.

Froidefond, C., Plutarque. Isis et Osiris, vol. 5, 2, Paris, 1988.

Frost, F.J., Plutarch's Themistocles. A Historical Commentary, Princeton, I980.

Fuhrmann, F., Les images de Plutarque, Paris, 1964.

—, Plutarque. Propos de table, vol. 9, I, Paris, 1972.

—, Plutarque. Propos de table, vol. 9, 2, Paris, 1978.

—, Plutarque. Apophthegmes de rois et de généraux; Apophtegmes laconiens, vol. 3, Paris, 1988.

\section{G}

Gallo, I. (ed.), Plutarco e le scienze. Atti del IV Convegno plutarcheo, Genova-Bocca di magra, 22-25 aprile I99I, Genova, 1992.

-, "Forma letteraria nei 'Moralia' di Plutarco: Aspetti e problemi”, in $A N R W$ 2, 34, 4 (1998), pp. 35II-3540 [reprinted in id. (ed.), Parerga Plutarchea, Napoli, I999, pp. 39-86].

- (ed.), La biblioteca di Plutarco. Atti del IX Convegno plutarcheo, Pavia, I3-I5 giugno 2002, Napoli, 2004.

Gallo, I. and Moreschini, C. (eds.), I generi letterari in Plutarco. Convegno plutarcheo. Pisa, 2-4 Juin I999, Napoli, 2000.

García López, J., "La Naturaleza en las comparaciones de Plutarco", in García López, J. and Calderón Dorda, E. (eds.), Estudios sobre Plutarco: paisaje y naturaleza, Madrid, I99I, pp. 203-220.

Garzya, A. and Masullo, R., I problemi di Cassio Iatrosofista, Napoli, 2004.

Georgiadou, A., "The Corruption of Geometry and the Problem of Two Mean Proportionals", in Gallo, I., I992, pp. I47-I64.

Gianakaris, C.J., Plutarch, New York, 1970. 
Gibson, R.K. and Morello, R. (eds.), Pliny the Elder: Themes and Contexts, Leiden Boston, 20II.

Giesen, K., "Plutarchs Quaestiones graecae und Aristoteles' Politien", Philologus, 60 (I90I), pp. 446-47I.

Gleason, M., Making Men: Sophists and Self-presentation in Ancient Rome, Princeton, I995.

-, "Shock and awe: the performance dimension of Galen's anatomy demonstrations", in Gill, C., Whitmarsh, T. and Wilkins, J. (eds.), Galen and the World of Knowledge, Cambridge, 2009, pp. 85-II4.

Glucker, J., Antiochus and the Late Academy, Göttingen, 1978.

Goldhill, S., "The Anecdote: Exploring the Boundaries between Oral and Literate Performance in the Second Sophistic", in Johnson, W.A. and Parker, H.N. (eds.), Ancient Literacies: The Culture of Reading in Greece and Rome, Oxford, 2009, pp. 96II3.

Göldi, O., Plutarchs sprachliche Interessen, Diss. Zürich, I920.

Goodwin, W.W., Plutarch's Morals, vol. 3, Boston, 1878 .

Görgemanns, H., Das Mondgesicht, Zürich, 1968.

—, Untersuchungen zu Plutarchs Dialog De facie in orbe lunae, Heidelberg, 1970.

—, "Biologie bei Platon", in Wöhrle, G. (ed.), Geschichte der Mathematik und der Naturwissenschaften in der Antike, vol. I, Biologie., Stuttgart, 1999, pp. 74-88.

Gow, A.S.F., Theocritus, vol. 2, Cambridge 1950.

Graf, E., "Plutarchisches. Entstehungsweise der Symposiaca. Keine Excerpte. Chronologische Reihenfolge. 'Ẽaipos. Amatorius", in Commentationes philologae quibus Ottoni Ribbeckio praeceptori inlustri sexagensimum [sic] aetatis magisterii Lipsiensis decimum annum exactum congratulantur discipuli Lipsienses, Leipzig, I888, pp. 57-70.

Grandjean, T., “Le recours à l'étiologie chez Dion de Pruse et chez Plutarque de Chéronée”, in Chassignet, M., 2008, pp. I47-I64.

Grant, E., A History of Natural Philosophy. From the Ancient World to the Nineteenth Century, Cambridge, 2007.

Gregory, A., Plato's Philosophy of Science, London, 2000.

Griffith, M., "Public and Private in Early Greek Institutions of Education", in Too, Y.L. (ed.), Education in Greek and Roman Antiquity, Leiden, 200I, pp. 23-84.

Grimaudo, S., "La medicina ellenistica in Plutarco", in Gallo, I., 2004, pp. 4I7-437.

Guardasole, A., "Les Problemata hippocratiques: un exemple original de catéchisme et commentaire dans la tradition médicale et religieuse", REG, I20 (2007), pp. I42-I60.

Gudeman, A., " $\lambda \dot{\sigma} \sigma \varepsilon ı$ ", $R E, \mathrm{I} 3,2$ (I927), cols. 25II-2529.

Guidorizzi, G., Il mondo letterario greco: storia, civiltà, testi. 3: Dall'età ellenistica all'età cristiana, Milano, 2000. 
Gunderson, E., Nox Philologiae: Aulus Gellius and the Fantasy of the Roman Library, Wisconsin, 2009.

Guthrie, W.K.C., A History of Greek Philosophy, Cambridge, I962 (= vol. I), I965 (= vol. 2).

\section{H}

Hadot, P., What is ancient philosophy?, Cambridge, 2002.

Halliday, W.R., The Greek questions of Plutarch, Oxford, 1928.

Halliwell, S., "On Poets and Homeric Problems", in Kennedy, G. (ed.), The Cambridge History of Literary Criticism, vol. I, Cambridge, I989, pp. I49-I5I.

Hamilton, J.R., Plutarch: Alexander, A Commentary, Oxford, 1969.

Hani, J., La religion égyptienne dans la pensée de Plutarque, Paris, I976.

Hankinson, R.J., "Saying the Phenomena", Phron., 35 (1990), pp. I94-215.

Harder, A., Callimachus. Aetia. Vol. I: Introduction, Text, and Translation, Vol. 2: Commentary, Oxford, 2012.

Hardie, P.R., "Plutarch and the interpretation of myth", $A N R W$ 2, 33, 6 (1992), pp. 47434787.

Harrison, G.W.M., "Problems with the Genre of Problems: Plutarch's Literary Innovations", Class. Phil., 95 (2000), pp. 193-199 [= 2000a].

—, "Tipping his Hand: Plutarch's Preferences in the Quaestiones Naturales", in Van der Stockt, L., 2000a, pp. 237-249 [= 2000b].

Hartman, J.J., De Plutarcho scriptore et philosopho, Lugduni Batavorum, I9I6.

Healy, J.F., Pliny the Elder on Science and Technology, Oxford, 1999.

Hein, G., Quaestiones Plutarcheae. Quo ordine Plutarchus nonnulla scripta moralia composuerit, agitur, Diss. Berlin, I9I6.

Helmbold, W.C., and O’Neil, E.N., Plutarch's Quotations, Baltimore, I959.

Hershbell, J.P., "Plutarch as a Source for Empedocles Re-Examined", AJPh, 92 (I97I), pp. I56-I84.

—, "Empedoclean Influences on the Timaeus", Phoenix, 28 (1974), pp. I45-I66.

—, "Plutarch and Heraclitus", Hermes, I05 (1977), pp. I79-20I.

—, "Plutarch and Anaxagoras", ICS, 7 (I982), pp. I4I-I58 [= I982a].

—, "Plutarch and Democritus", QUCC, Io (I982), pp. 8I-III [= I982b].

Hett, W.S., Aristotle. Problems, vol. I, London - Cambridge, Mass., 1936.

Hillyard, B.P., Plutarch: De audiendo: a text and commentary, New York, I98I.

Hine, H.M., An edition with commentary of Seneca, Natural questions, book two, Salem

(New Hampshire), 1984. 
—, "Subjectivity and Objectivity in Latin Scientific and Technical Literature", in Taub, L. and Doody, A., 2009, pp. 13-30.

Hirsch-Luipold, R., Plutarchs Denken in Bildern: Studien zur literarischen, philosophischen und religiösen Funktion des Bildhaften, Tübingen, 2002.

—, "Religion and Myth", in Beck, M., 20I4, pp. I63-176.

Hirzel, R., Der Dialog. Ein literarhistorischer Versuch, 2 vols., Leipzig, I895.

-, Plutarch, Leipzig, I9I2.

Holford-Strevens, L., "Favorinus: The Man of Paradoxes", in Barnes, J. and Griffin, M. (eds.), Philosophia Togata II. Plato and Aristotle at Rome, Oxford, I997, pp. I88-217.

-, Aulus Gellius: An Antonine Scholar and his Achievement, Oxford, 2003.

—, "Recht as een Palmen-Bohm and Other Facets of Gellius' Medieval and Humanistic Reception", in Holford-Strevens, L. and Vardi, A. (eds.), The Worlds of Aulus Gellius, Oxford, 2005, pp. 249-28I.

Holzberg, N., Martial und das antike Epigramm, Darmstadt, 2002.

Horster, M. and Reitz, C. (eds.), Condensing texts - condensed texts, Stuttgart, 2010 [= 20I0a].

—, " 'Condensation' of literature and the pragmatics of literary production”, in Horster, M. and Reitz, C., 20IOa, pp. 3-I4 [= 20I0b].

Housman, A.E., M. Manilii, Astronomicon, liber quartus, London, 1920.

Hubert, C., "Zur Entstehung der Tischgespräche Plutarchs”, in Xápıєєs, Friedrich Leo zum sechzigsten Geburtstag dargebracht, Berlin, I9II, pp. I70-I87.

—, Plutarchi Moralia, vol. 6, I, Lipsiae, I959.

— (Pohlenz, M. and Drexler, H.), Plutarchi Moralia, vol. 5, 3, Lipsiae, I960 [Hubert edited Quaestiones Naturales].

Huit, C., La philosophie de la nature chez les anciens, Paris, I90I.

Hunter, R., Theocritus. A Selection, Cambridge, 1999.

Huxley, G.L., "Historical Criticism in Aristotle's "Homeric Questions"”, Proceedings of the Royal Irish Academy, 79 (1979), pp. 73-8I.

\section{I}

Ideler, J.L., Physici et medici Graeci minores, vol. I, Berlin, I84I.

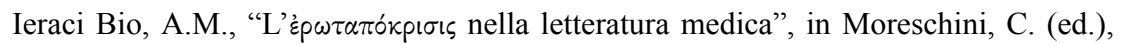
Esegesi, parafrasi e compilazioni in età tardoantica. Atti del terzo convegno dell'associazione di studi tardoantichi, Napoli, 1995, pp. 187-207.

Ierodiakonou, K., "Alexander of Aphrodisias on medicine as a stochastic art", in van der Eijk, P.J., Horstmanshoff, H.F.J. and Schrijvers, P.H. (eds.), Ancient Medicine in its Social-Cultural Context, vol. 2, Amsterdam, 1995, pp. 473-485. 
Ingenkamp, H.G., "Plutarch by D.A. Russell”, Gnomon, 48 (1976), pp. 546-55I.

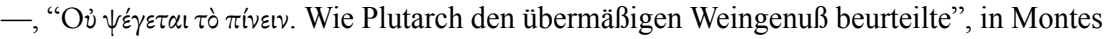
Cala, J.G., Sanchez Ortiz de Landaluce, M. and Gallé Cejudo, R., I999, pp. 277-290.

Inglese, L., Plutarco. La curiosità. Introduzione, testo critico, traduzione e commento, Napoli, 1996.

Inwood, B., The Poem of Empedocles, Phoenix Suppl., 29, London, $200 \mathrm{I}$.

Ioppolo, A.M., "La posizione di Plutarco nei confronti dello scetticismo", in Gallo, I., 2004, pp. 289-310.

Irby-Massie, G.L. and Keyser, P.T., Greek Science of the Hellenistic Era: A Sourcebook, London - New York, 2002.

Irigoin, J., "Le Catalogue de Lamprias: tradition manuscrite et éditions imprimées", $R E G$, 99 (I986), pp. 3I8-33I.

Isnardi Parente, M., "Plutarco et la matematica Platonica", in Gallo, I., I992, pp. I2I-I45.

\section{$\mathbf{J}$}

Jacob, C., "De l' art de compiler à la fabrication du merveilleux. Sur la paradoxographie grecque", Lalies, 2 (I983), pp. I2I-I40.

—, "Questions sur les questions: archéologie d' une pratique intellectuelle et d' une forme discursive", in Volgers, A. and Zamagni, C. (eds.), Erotapokriseis. Early Christian Question-and-Answer Literature in Context. Proceedings of the Utrecht Colloquium, I3-I4 October 2003, Leuven, 2004, pp. 25-54.

Janssen, G., Moralia 9: Biologie En Natuurkunde, Leeuwarden, 2004.

Johansen, T.K., Plato's Natural Philosophy, Cambridge, 2004.

Jones, C.P., “Towards a Chronology of Plutarch's Works", JRS, 56 (I966), pp. 6I-74 [= I966a].

—, "The Teacher of Plutarch", HSCP, 7I (I966), pp. 205-213 [= I966b].

Jones, R.M., The Platonism of Plutarch and selected Papers, New York - London, 1980.

Jones, W.H.S., Hippocrates, vol. I, Cambridge, Mass. - London, I923.

—, Hippocrates, vol. 4, Cambridge, Mass. - London, I93I.

Jouanna, J., "Plutarque et la patine des statues à Delphes (Sur les oracles de la Pythie, 395B-396C)”, Rev. Philol., 49 (1975), pp. 67-7I.

—, "Sens et étymologie de $2 \lambda \lambda \dot{\varepsilon} \alpha$ (i et ii) et de $\dot{\alpha} \lambda \kappa \eta^{\prime}$ ", REG, 95 (I982), pp. I5-36.

-, "Hippocrate et les Problemata d' Aristote: essai de comparaison entre Airs, eaux, lieux, c. I0; Aphorismes iii, II-I4 et Problemata i 8-I2 et 19-20", in Wittern, R. and Pellegrin, P. (eds.), Hippokratische Medizin und antike Philosophie, Hildesheim, 1996, pp. 273-293.

Jeanneret, M. (Whiteley, J. and Hughes, E. transls.), A feast of Words. Banquets and Table Talk in the Renaissance, Cambridge, I99I. 
Jessen, O., "Halieus", $R E$, 7, 2 (I9I2), col. 2252.

Jürss, F., "Wissenschaft und Erklärungspluralismus im Epikureismus", Philologus, I38 (I994), pp. 235-25I.

K

Kahle, C., De Plutarchi ratione dialogorum componendorum, Diss. Gottingae, I9I2.

Kapetanaki, S. and Sharples, R.W., Pseudo-Aristoteles (Pseudo-Alexander). Supplementa problematorum, Berlin, 2006.

Karamanolis, G.E., Plato and Aristotle in Agreement? Platonists on Aristotle from Antiochus to Porphyry, Oxford, 2006.

—, "Plutarch", in Zalta, E.N. (ed.), Stanford Encyclopedia of Philosophy, 20Io, http://plato .stanford.edu/archives/fall20I4/entries/plutarch/ (accessed I3/IO/2OI4).

Kechagia, E., "Philosophy in Plutarch's Table Talk. In Jest or in Earnest?”, in Klotz, F. and Oikonomopoulou, K., 20II, pp. 77-IO4 [= 2011a].

—, Plutarch Against Colotes: A Lesson in History of Philosophy, Oxford, 20II [= 20IIb].

Keller, O., Thiere des classischen Alterthums in culturgeschichtlicher Beziehung, Innsbruck, 1887 .

—, Die antike Tierwelt, Hildesheim, I980 (Leipzig, I909-I9I3).

Keyser, P.T. and Irby-Massie, G.L. (eds.) The Encyclopedia of Ancient Natural Scientists. The Greek Tradition and its Many Heirs, New York, 2008 [= 2008a].

—, "Asklēpiodotos (of Nikaia?) (40 BCE-30 CE)", in Keyser, P.T. and Irby-Massie, G.L., 2008 , p. $\mathrm{I} 72[=2008 \mathrm{~b}]$.

Kirk, G.S., Heraclitus. The Cosmic Fragments, Cambridge, 2010 (= I954).

Klotz, F., "Portraits of the Philosopher: Plutarch's Self-Presentation in the Quaestiones Convivales", CQ, 57 (2007), pp. 650-667.

—, "The Sympotic Works", in Beck, M., 20I4, pp. 207-222.

Klotz, F. and Oikonomopoulou, K. (eds.), The Philosopher's Banquet. Plutarch's Table Talk in the Intellectual Culture of the Roman Empire, Oxford, 20II.

König, J., "Fragmentation and coherence in Plutarch's Sympotic Questions", in König, J. and Whitmarsh, T., 2007, pp. 43-68.

-, "Sympotic dialogue in the first to fifth centuries CE", Goldhill, S. (ed.), The End of Dialogue in Antiquity, Cambridge, 2008, pp. 85-II3.

-, "Conversational and Citational Brevity in Plutarch's Sympotic Questions", in Horster, M. and Reitz, C., 20I0a, pp. 32I-348.

-, "Self-Promotion and Self-Effacement in Plutarch's Table Talk", in Klotz, F. and Oikonomopoulou, K., 20II, pp. I79-203.

König, J. and Whitmarsh, T. (eds.), Ordering Knowledge in the Roman Empire, Cambridge, 2007. 
Kowalski, J., De Plutarchi scriptorum iuvenilium colore rhetorico, Cracoviae, I9I8.

Krafft, F., "XEPNIKA ПРОВ $\Lambda$ HMATA. Vermutungen zum Titel einer Schrift Demokrits", in Manegold, K.-H. (ed.), Wissenschaft, Wirtschaft und Technik. Studien zur Geschichte, Wilhelm Treue zum 6o. Geburtstag, München, 1969, pp. 448-453.

Krauss, F., Die rhetorischen Schriften Plutarchs und ihre Stellung im Plutarchischen Schriftenkorpus, Diss. Nürnberg, I9I2.

Kroll, W., "P. Fabianus", RE, I8, 3 (1949), cols. I056-I059.

Kühner, R. and Gerth, B., Ausführliche Grammatik der griechischen Sprache, Hannover, I966.

\section{$\mathbf{L}$}

Labhardt, A., “Curiositas. Notes sur l' histoire d' un mot et d' une notion”, $M H, 17$ (1960), pp. 206-224.

Lachenaud, G., Scholies à Apollonios de Rhodes, Paris, 2010.

Laes, C., Children in the Roman Empire: Outsiders Within, Cambridge, $201 \mathrm{I}$.

Lakmann, M.L., Der Platoniker Tauros in der Darstellung des Aulus Gellius, Leiden, I995.

Lao, E., Restoring the Treasury of Mind. The practical Knowledge of the Natural History, Diss. Princeton, 2008.

Laufer, B., Geophagy, Chicago, 1930.

Lawn, B., The Salernitan Questions: an Introduction to the History of Medieval and Renaissance Problem Literature, Oxford, 1963.

Leão, D., "Plutarch on Solon's Simplicity Concerning Natural Philosophy: Sol. 3,6-7 and Frs. 9 and I2 West", in Meeusen, M. and Van der Stockt, L., 20I5, pp. 227-238.

Lee, H.D.P., Aristotle. Meteorologica, London - Cambridge, Mass., I952.

Lehmann, Y. (ed.), Aristoteles Romanus. La réception de la science aristotélicienne dans l'Empire gréco-romain, Turnhout, 2013.

Lehoux, D., “Tropes, Facts and Empiricism”, Perspectives on Science, II (2003), pp. 326345 [= 20I2, pp. I33-I54].

—, "Observers, Objects, and the Embedded Eye; or, Seeing and Knowing in Ptolemy and Galen”, Isis, 98 (2007), pp. 447-467 [= 2012, pp. I06-I32].

-, What Did the Romans Know?: an Inquiry into Science and Worldmaking, Chicago London, $20 \mathrm{I} 2$.

Leith, D., "Question-Types in Medical Catechisms on Papyrus", in Taub, L. and Doody, A., 2009, pp. I07-I23.

Lelli, E., "Plutarco", in Radici Colace, P., Medaglia, S.M., Rossetti, L. and Sconocchia, S. (eds.), Dizionario delle scienze e delle techniche di Grecia e Roma, vol. 2, Pisa Roma, 20IO, pp. 848-849. 
Lennox, J.G., Aristotle's Philosophy of Biology: Studies in the Origins of Life Science, Cambridge, 200I.

-, "Aristotle's Posterior Analytics and the Aristotelian Problemata", in Mayhew, R., 20I5c, pp. 36-6o.

Leo, F., De Plutarchi Quaestionum Romanarum auctoribus, Diss. Halis Saxonum, I864.

Lesage Gárriga, L., "The Light of the Moon: An Active Participant on the Battlefield in Plutarch's Parallel Lives", in Meeusen, M. and Van der Stockt, L., 2015, pp. I45-I53.

Leutsch, E.L., Corpus paroemiographorum Graecorum, vol. 2, Hildesheim, 1965.

Levi, P., The Pelican History of Greek Literature, Harmondsworth, I985.

Lewis, M. "Theoretical Hydraulics, Automata, and Water Clocks", in Wikander, O. (ed.), Handbook of Ancient Water Technology, Leiden - Boston - Köln, 2000, pp. 343-369.

Liedmeier, C., Plutarchus' Biographie van Aemilius Paullus: historische commentaar, Utrecht - Nijmegen, 1935 .

Lindberg, D.C., The Beginnings of Western Science. The European Scientific Tradition in Philosophical, Religious and Institutional Context, 60o B.C. to A.D. I45o, Chicago, I992.

Lloyd, G.E.R., "The Hot and the Cold, the Dry and the Wet in Greek Philosophy", JHS, 84 (1964), pp. 92-106.

-, Polarity and Analogy: Two Types of Argumentation in Early Greek Thought, Cambridge, I966.

—, "Plato as a Natural Scientist", JHS, 88 (I968), pp. 78-92.

—, Early Greek Science: Thales to Aristotle, London, 1970.

-, Greek Science after Aristotle, New York, 1973.

-, Magic, Reason and Experience: Studies in the Origin and Development of Greek Science, Cambridge, I979.

-, Science, Folklore and Ideology: Studies in the Life Sciences in Ancient Greece, Cambridge, 1983 .

—, Science and Morality in Greco-Roman Antiquity, Cambridge, I985 [= I99I, pp. 35237I].

-, The Revolutions of Wisdom: Studies in the Claims and Practice of Ancient Greek Science, Berkeley, 1987.

—, Methods and Problems in Greek Science, Cambridge, I99I.

-, Adversaries and Authorities: Investigations into Ancient Greek and Chinese Science, Cambridge, 1996.

-, "Science in Antiquity. The Greek and Chinese Cases and Their Relevance to the Problems of Culture and Cognition", in Biagioli, M. (ed.), The Science Studies Reader, London, I999, pp. 302-3i6. 
-, Ancient Worlds, Modern Reflections. Philosophical Perspectives on Greek and Chinese Science and Culture, Oxford, 2004.

Lobeck, C.A., Aglaophamus sive de theologiae mysticae graecorum causis, libri tres, Regimontii Prussorum, I829.

Longo, O., "La teoria Plutarchea del primum frigidum", in Gallo, I., I992, pp. 225-230.

Lopes, R., "The Omnipresence of Philosophy in Plutarch's Quaestiones Convivales", in Ferreira, J.R., Leão, D., Tröster, M. and Barata Dias, P., 2009, pp. 4I5-424.

Louis, P., Aristote, Histoire des animaux, Paris, 1968.

—, Aristote, Problèmes, vol. I, Paris, I99I.

\section{M}

Maßß, E., Scholia Graeca in Homeri Iliadem Townleyana, Oxford, I887.

Magnelli, E., "Poeti ellenistici in Plutarco: tipologie e preferenze", in Casanova, A., 2005, pp. 215-242.

Mansfeld, J., "Sources”, in Algra, K., Barnes, J., Mansfeld, J. and Schofield, M. (eds.), The Cambridge History of Hellenistic Philosophy, Cambridge, I999, pp. 3-30.

—, "Physikai doxai and problemata physika in Philosophy and Rhetoric: From Aristotle to Aëtius (and Beyond)", in Mansfeld, J. and Runia, D.T. (eds.), Aëtiana. The Method and Intellectual Context of a Doxographer, vol. 3: Studies in the Doxographical Traditions of Ancient Philosophy, Leiden - Boston, 20I0, pp. 33-97.

Mansfeld, J. and Runia, D.T., Aëtiana. The Method and Intellectual Context of a Doxographer, vol. I: the Sources, Leiden - New York - Köln, I997.

Mansion, S. (ed.), Aristote et les problèmes de méthode, Louvain - Paris, I96I.

Marcovich (Markovic), M., "On the sources of Theophylactus Simocatta's Quaestiones physicae", ZAnt., 4 (1954), pp. I20-I35 [in Croatian with English summary].

—, Eraclito, Frammenti, Firenze, 1978.

Marganne, M.-H., La chirurgie dans l'Égypte gréco-romaine d'après les papyrus littéraires grecs, Leiden - Boston - Köln, I998.

Marrou, H.-I., Histoire de l'éducation dans l'Antiquité, Paris, I948,

Martin, H., "Plutarch's Citation of Empedocles at Amatorius 756D”, GRBS, Io (1969), pp. $57-70$.

Martin, J., Symposion: die Geschichte einer literarischen Form, Paderborn, I93I.

Mayhew, R., Aristotle, Problems, Cambridge, Mass. - London, 20II [= 20IIa].

—, "On Problemata XXIX I3: Peripatetic Legal Justice and the Case of Jury Ties", in Centrone, B., 20IIa, pp. 275-307 [= 20Irb].

- (ed.), The Aristotelian Problemata Physica: Philosophical and Scientific Investigations, Leiden - Boston, 2015 [= 20I5a]. 
—, "Aristotle on Fever in Problemata I", Apeiron, 48 (2015), pp. 176-194 [= 2015b].

-, "Aristotle's Biology and his Lost Homeric Puzzles", QC, 65 (20I5), pp. I09-I33 [= 20I5c].

Meeusen, M., "From Reference to Reverence: Five Quotations of Aristotle in Plutarch's Quaestiones Naturales", in Candau Morón, J., González Ponce, F. and Chávez Reino, A., 20II, pp. 347-363.

- "Matching in Mind the Sea Beast's Complexion. On the Pragmatics of Plutarch's Hypomnemata and Scientific Innovation: the Case of Q.N. I9 (9I6BF)", Philologus, I56 (20I2), pp. 234-259 [= 20I2a].

—, "Salt in the Holy Water: Plutarch's Quaestiones Naturales in Michael Psellus' De omnifaria doctrina", in Roig Lanzillotta, L. and Muñoz Gallarte, I., 20I2, pp. IOI-I2I $[=20 \mathrm{I} 2 \mathrm{~b}]$.

-, "Opening up the Heavens over Athens: Plutarch and Laetus Discussing Physical Causes", in Casanova, A. (ed.), Figure d'Atene nelle opere di Plutarco, Firenze, 20I3, pp. 249-262 [=2013a].

—, "Natural Philosophy, Technè and Technicality in Plutarch", in Santana Henríquez, G., 2013 , pp. 157-I67 [= 2013b].

-, "How to Treat a Bee-Sting? On the Higher Cause in Plutarch's Causes of Natural Phenomena: the Case of Q.N. 35-36", QUCC, I05 (2013), pp. I3I-I57 [= 20I3c].

-, "Plutarch and the Wonder of Nature. Preliminaries to Plutarch's Science of Physical Problems", Apeiron, 47 (20I4), pp. 3I0-34I.

—, "A Note on Croaking Frogs: Plu. Q.N. 2.9I2C", Mnemosyne, 68 (20I5), pp. II5-I20 [= 20I5a].

-, "Plutarch Solving Natural Problems: for What Cause? (The Case of Quaest. nat. 29,9I9AB)", in Meeusen, M. and Van der Stockt, L., 20I5, pp. I29-I42 [= 20I5b].

—, "Aristotle's Authority in the Tradition of Natural Problems. The Case of Plutarch of Chaeronea", in Boodts, S., Leemans, J. and Meijns, B. (eds.), Shaping Authority. How Did a Person Become an Authority in Antiquity, the Middle Ages and the Renaissance?, eds. Turnhout, 20I6, pp. 47-85.

—, "Natural Problems Lost and Found: Gisbert Longolius Translating Plutarch's Quaestiones Naturales", forthcoming in Humanistica Lovaniensia [= forthcoming a].

—, "The Shifting Realities of Plutarch's Natural Problems. A Note on the Reception of Quaestiones Naturales", forthcoming in Guerrier, O. and Frazier, F., Plutarque: éditions, traductions, paratextes [= forthcoming b].

—, "Pagan Garlands and Christian Roses: Plutarch's Quaestiones Convivales in Michael Psellus' De Omnifaria Doctrina", forthcoming in Van Deun, P., Van Pee, S. and Demulder, B. (eds.), Building the Kosmos. Greek Patristic and Byzantine Question and Answer Literature [= forthcoming c].

—, "Egyptian Knowledge at Plutarch's Table: Out of the Question?", forthcoming in 
Georgiadou, A. and Oikonomopoulou, K. (eds.), Space, Time and Language in Plutarch [= forthcoming $\mathrm{d}]$.

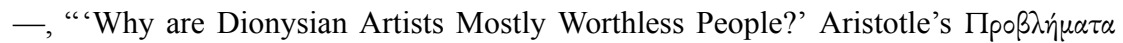
'E $\gamma \kappa u ́ \kappa \lambda \iota \alpha$ in Context", forthcoming in $C Q$ [= forthcoming e].

—, "An interpretation of Ps.-Alexander of Aphrodisias, Medical Puzzles i, Praef. in light of medical-philosophical school practice", forthcoming in Bouras-Vallianatos, P. and Xenophontos, S., Greek Medical Literature and its Readers: From Hippocrates to Islam and Byzantium [= forthcoming $\mathrm{f}]$.

—, "Aristotle's Second Breath: Pneumatic Processes in the Natural Problems (on Sexual Intercourse)", forthcoming in Coughlin, S., Leith, D. and Lewis, O. (eds.), The Concept of Pneuma After Aristotle [= forthcoming g].

Meeusen, M. and Van der Stockt, L. (eds.), Natural Spectaculars. Aspects of Plutarch's Philosophy of Nature, Leuven, 2015.

Menn, S., "Democritus, Aristotle, and the Problemata", in R. Mayhew, 20I5a, pp. Io-35.

Messeri Savorelli, G. and Pintaudi, R., "Frammenti di rotoli letterari Laurenziani”, $Z P E$, II5 (I997), pp. I7I-I77.

Michaëlis, C.T., De ordine vitarum parallelarum Plutarchi, Berlin, I875.

Middleton, W.E.K., A history of the thermometer and its use in meteorology, Baltimore, I966.

Minar, E.L., Sandach, F.H. and Helmbold, W.C., Plutarch's Moralia in Sixteen Volumes, vol. 9, Cambridge, Mass. - London, I96I.

Mittelhaus, K., De Plutarchi Praeceptis gerendae reipublicae, Diss. Berlin, I9II.

Mohr, R.D. and Sattler, B. (eds.), One Book, the Whole Universe: Plato's Timaeus Today, Las Vegas, 2010.

Montes Cala, J.G., Sanchez Ortiz de Landaluce, M. and Gallé Cejudo, R. (eds.), Plutarco, Dioniso y el vino. Actas del VI Simposio espanol sobre Plutarco, Cadiz, I4-I6 de mayo de I998 Sociedad espanola de Plutarquistas, Madrid, I999.

Morales Ortiz, A., "Pedro Juan Núñez, traductor de Plutarco", in Rodríguez Adrados, F. and Martínez Díez, A. (eds.), Literatura griega, Actas del IX Congreso español de Estudios Clásicos: Madrid, 27 al 30 de septiembre de 1995, Vol. 4, Madrid, I998, pp. $253^{-257}$.

—, "Observaciones a la traducción latina de G. Longueil de Aetia Physica de Plutarco", Myrtia, I4 (I999), pp. I43-I5I.

—, Plutarco en España: Traducciones de Moralia en el siglo XVI, Murcia, 2000.

Moraux, P., Les listes anciennes des ouvrages d'Aristote, Louvain, I95I.

Morel, P.-M., Démocrite et la recherche des causes, Paris, 1996.

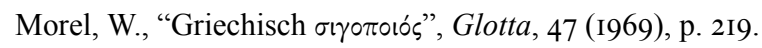

Morgan, T., Literate Education in the Hellenistic and Roman Worlds, Cambridge, 1998. 
—, "The Miscellany and Plutarch", in Klotz, F. and Oikonomopoulou, K., 20II, pp. 49-73

Mossman, J. (ed.), Plutarch and his Intellectual World, London, 1997 [= 1997a].

-, "Plutarch's Dinner of the Seven Wise Men and its place in symposion literature", in Mossman, J., I997a, pp. II9-I40 [= I997b].

—, "Travel Writing, History, and Biography", in McGing, B. and Mossman, J. (eds.), The Limits of Ancient Biography, Swansea, 2006, pp. 28I-303.

Mossman, J. and Titchener, F., "Bitch is Not a Four-Letter Word. Animal Reason and Human Passion in Plutarch", in Roskam, G. and Van der Stockt, L., 20II, pp. 273-296.

Müller, K.K., “Asklepiodotos”, RE, 2, 2 (I896), cols. I637-I64I.

Murphy, T., Pliny the Elder's Natural History. The Empire in the Encyclopedia, Oxford, 2004.

Murray, O. (ed.), Sympotica: a Symposium on the Symposion, Oxford, I990 [= I990a].

—, "The Affair of the Mysteries: Democracy and the Drinking Group", in Murray, O., I990a, pp. I49-I6I [= I990b].

Mynors, R.A.B., Collected works of Erasmus. Adages II i I to II vi Ioo, Toronto, I99I.

\section{$\mathbf{N}$}

Naas, V., "Imperialism, mirabilia and knowledge: some paradoxes in the Naturalis Historia", in Gibson, R.K. and Morello, R., 20II, pp. 57-70.

Nachstädt, W., Sieveking, W., Titchener, J.B., Plutarchi Moralia, vol. 2, Lipsiae, 1935.

Negri, M., "Plutarco lettore (e commentatore) di Arato", in Gallo, I., 2004, pp. 275-288.

Newmyer, S.T., "Plutarch on Justice Toward Animals: Ancient Insights on a Modern Debate", Scholia, I (1992), pp. 38-54.

-, Animals, Rights and Reason in Plutarch and Modern Ethics, New-York, 2006.

-, "Animal Philanthropia in the Convivium Septem Sapientium", in Ferreira, J.R., Leão, D., Tröster, M. and Barata Dias, P., 2009, pp. 496-504.

—, “Animals in Plutarch", in Beck, M., 20I4, pp. 223-234.

Nikolaidis, A.G., "Plutarch's Contradictions", Classica et Mediaevalia, 42 (I99I), pp. I53I86.

—, "Plutarch's Attitude to Wine", in Montes Cala, J.G., Sanchez Ortiz de Landaluce, M. and Gallé Cejudo, R., I999, pp. 337-348.

- (ed.), The unity of Plutarch's work: "Moralia" themes in the "Lives", features of the "Lives" in the "Moralia", Berlin, 2008.

-, "Plutarch's Views on Art and specially on Painting and Sculpture", in Santana Henríquez, G., 20I3, pp. I69-I8I.

Nutton, V., “Galen's Authorial Voice: a Preliminary Enquiry”, in Taub, L. and Doody, A., 2009 , pp. 53-62. 
Nuzzo, G., “"La natura del freddo": struttura e valore nel corpus dei "Moralia"”, in D'Ippolito, G. and Gallo, I., I99I, pp. 409-4I7.

\section{$\mathbf{O}$}

O'Grady, P. and Silvermintz, D., "The Anonymus Iamblichi and the Double Arguments", in O'Grady, P. (ed.), The Sophists: an Introduction, London, 2008, pp. I38-I5I.

Oikonomopoulou, K., "Peripatetic Knowledge in Plutarch's Table Talk", in Klotz, F. and Oikonomopoulou, K., 20II, pp. I05-130.

-, "Plutarch's corpus of quaestiones in the tradition of imperial Greek encyclopaedism", in König, J. and Woolf, G. (eds.), Encyclopaedism from Antiquity to the Renaissance, Cambridge, 20I3, pp. I29-I53 [= 2013a].

- "Ancient question-and-answer literature and its role in the tradition of dialogue", in Föllinger, S. and Müller, G.M. (eds.), Der Dialog in der Antike. Formen und Funktionen einer literarischen Gattung zwischen Philosophie, Wissensvermittlung und dramatischer Inszenierung, Berlin, 2013, pp. 37-64 [= 2013b].

—, "The Problemata's Medical Books: Structural and Methodological Aspects", in Mayhew, R., 20I5a, pp. 6I-78.

Oltramare, P., Sénèque. Questions naturelles, vol. I, Paris, I96I.

O’Neil, E.N., Plutarch, Moralia, vol. I6, Cambridge, Mass. - London, 2004.

Opsomer, J., Geschiedenis van het Platonisme en Plato-exegese in Plutarchus' Quaestiones Platonicae, Diss. Leuven, 1994 [= 1994a].

—, "L'âme du monde et l' âme de l' homme chez Plutarque," in Valdés, M.G. (ed.), Estudios sobre Plutarco: ideas religiosas, Madrid, 1994, pp. 33-49 [= I994b].

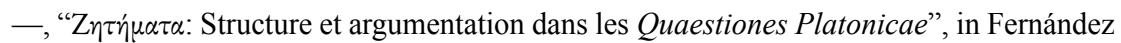
Delgado, J.A. and Pordomingo Pardo, F. (eds.), Estudios sobre Plutarco: aspectos formales. Actas del IV simposio español sobre Plutarco, Salamanca, 26 a 28 de Mayo de 1994, Salamanca, 1996, pp. 7I-83 [= 1996a].

—, "Divination and Academic 'Scepticism' according to Plutarch", in Van der Stockt, L., I996a, pp. I65-I94 [= I996b].

—, "Favorinus versus Epictetus on the Philosophical Heritage of Plutarch. A Debate on Epistemology," in Mossman, J., I997a, pp. I7-40.

—, In Search of the Truth, Academic Tendencies in Middle Platonism, Brussel, 1998.

-, “Antiperistasis: A Platonic Theory”, in Pérez Jiménez, A., Garciá López, J. and Aguilar, R.M., I999, pp. 4I7-429.

—, "Eirôneia in the Corpus Plutarcheum (with an Appendix on Plutarch's Irony)", in Van der Stockt, L., 2000a, pp. 309-329.

—, "Plutarch's Platonism Revisited", in Bonazzi, M. and Celluprica, V. (eds.), L'eredità platonica: Studi sul platonismo da Arcesilao a Proclo, Napoli, 2005, pp. I63-200.

—, “Ofellius Laetus (ca 50-95 CE)”, in Keyser, P.T. and Irby-Massie, G.L., 2008a, pp. 586587. 
—, "M. Annius Ammonius. A philosophical profile", in Bonazzi, M. and Opsomer, J., 2009, pp. I23-I86.

-, "Arguments non-linéaires et pensée en cercles. Forme et argumentation dans les Questions Platoniciennes de Plutarque", in Brouillette, X. and Giavatto, A. (eds.), Les dialogues platoniciens chez Plutarque: stratégies et méthodes exégétiques, Leuven, 20I0, pp. 93-II6.

—, "Plutarch and the Stoics", in Beck, M., 20I4, pp. 88-I03.

—, "Plutarch on the Geometry of the Elements", in Meeusen, M. and Van der Stockt, L., 20I5, pp. 29-55.

O'Sullivan, T.M., Walking in Roman Culture, Cambridge, $201 \mathrm{I}$.

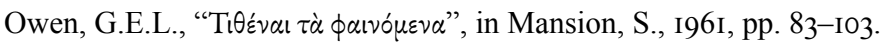

\section{$\mathbf{P}$}

Pailler, J.-M., "Les Questions dans les plus anciennes Vies romaines. Art du récit et rhétorique de la fondation", in Payen, P., I998a, pp. 77-94.

Parke, H.W. and Wormell, D.E.W., The Delphic Oracle, vol. I, Oxford, 1956.

Parroni, P., Seneca, Ricerche sulla natura, Milano, 2002.

Payen, P. (ed.), Plutarque: Grecs et Romains en Questions, Saint-Bertrand-de-Comminges, I998 [= I998a].

—, "Rhétorique et géographie dans les Questions romaines et Questions grecques de Plutarque", in Payen, P., I998a, pp. 39-73 [= I998b].

—, "Les recueils de Questions et la tradition "antiquaire" dans le corpus de Plutarque", Pallas, 90 (2013), pp. 217-233.

—, "Plutarch the Antiquarian", in Beck, M., 20I4, pp. 235-248.

Pease, A.S., “Things without honour”, Class. Phil., 2I (1926), pp. 27-42.

Pecere, O. and Stramaglia, A. (eds.), La Letteratura di Consumo nel Mondo Greco-Latino, Cassino, 1996.

Peck, A.L., Aristotle, Generation of Animals, Cambridge, Mass. - London, 1953.

-, Aristotle, Historia Animalium, vol. I, Cambridge, Mass. - London, 1965.

Pelling, C., "Plutarch's Method of Work in the Roman Lives", JHS, 99 (1979), pp. 74-96 [reprinted in Scardigli, B., I995, pp. 265-318 (with a postscript) and Pelling, C., 2002, pp. I-44].

—, "Plutarch's Adaptation of His Source-Material", JHS, I00 (1980), pp. I27-I40 [reprinted in Scardigli, B., I995, pp. I25-I54 and Pelling, C., 2002, pp. 9I-II5].

—, Plutarch and History: Eighteen Studies, Swansea - London, 2002.

—, "Plutarch", in de Jong, I., Nünlist, R. and Bowie, A. (eds.), Narrators, Narratees, and Narratives in Ancient Greek Literature: Studies in Ancient Greek Narrative, vol. I, Boston, 2004, pp. 403-422. 
—, "Plutarch's Socrates", Hermathena, I75 (2005), pp. I05-I39.

- "Putting the -viv- into 'Convivial': The Table Talk and the Lives", in Klotz, F. and Oikonomopoulou, K., 20II, pp. 207-23I.

Peretti, A., Teognide nella tradizione gnomologica, Pisa, 1953.

Pérez Jiménez, A., “Alle frontiere della scienza: Plutarco e l'astronomia”, in Gallo, I., I992, pp. 27I-286.

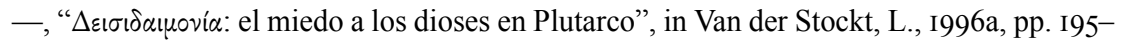
225.

Pérez Jiménez, A., Garciá López, J. and Aguilar, R.M. (eds.), Plutarco, Platón y Aristóteles. Actas del V Congreso Internacional de la I.P.S. (Madrid - Cuenca, 4-7 de Mayo de I999), Madrid, I999.

Pérez Jiménez, A. and Titchener, F. (eds.), Valori letterari delle Opere di Plutarco. Studi offerti al Professore Italo Gallo dall'International Plutarch Society, Málaga - Logan, 2005.

Perrin, B., Plutarch's Lives in eleven volumes, vol. 7: Demosthenes and Cicero, Alexander and Caesar, Cambridge, Mass. - London, I9I9.

Pomeroy, S.B., Xenophon Oeconomicus. A Social and Historical Commentary, Oxford I995.

Pordomingo Pardo, F., "El banquete de Plutarco: ¿Ficción literaria o realidad histórica?”, in Montes Cala, J.G., Sanchez Ortiz de Landaluce, M. and Gallé Cejudo, R., I999, pp. 379-392.

Poschenrieder, F., Die naturwissenschaftlichen Schriften des Aristoteles in ihrem Verhältnis zu den Büchern der hippokratischen Sammlung, Bamberg, I887.

Powell, J.G.F., "Cicero's Translations from Greek”, in Powell, J.G.F. (ed.), Cicero the Philosopher, Oxford, 1995, pp. 273-300.

Prantl, C., Ueber die Probleme des Aristoteles, Abh. Bayr. Akad. d. Wiss. 6, München, I852, pp. 339-377.

von Premerstein, A., “commenarii”, $R E$, 4, I (I900), cols. 726-759.

Prescott, H.W., “EBA POON (Theocritus, Id. I. I39, I40)”, CQ, 7 (I9I3), pp. I76-I87.

Preston, R., "Roman questions, Greek answers: Plutarch and the construction of identity", in Goldhill, S. (ed.), Being Greek Under Rome, Cambridge, 200I, pp. 86-II9.

Puech, B., "Prosopographie des amis de Plutarque", $A N R W$ 2, 33, 6 (I992), pp. 483I-4893.

\section{$\mathbf{R}$}

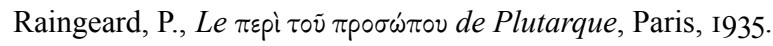

Ramón Palerm, V., “Cuestiones sobre la naturaleza: Notas críticas”, in Pérez Jiménez, A. and Titchener, F., 2005, pp. 397-404.

—, "Plutarco y Juan de Pineda", in Candau Morón, J., González Ponce, F. and Chávez Reino, A., 20II, pp. 62I-632. 
Ramón Palerm, V. and Bergua Cavero, J., Obras Morales y de Costumbres, ix. Sobre la malevolencia de Heródoto; Cuestiones sobre la naturaleza; Sobre la cara visible de la luna; Sobre el principio del frio; Sobre si es más útil el agua o el fuego; Sobre la inteligencia de los animales; 'Los animales son racionales' o 'Grilo'; Sobre comer carne, Madrid, 2002.

Regenbogen, O., "Die Naturwissenschaft der Peripatetiker", Scientia, 50 (193I), pp. 345354 .

Reinhardt, K., Kosmos und Sympathie: neue Untersuchungen über Poseidonios, München, 1926.

Relihan, J.C., "Rethinking the History of the Literary Symposium", ICS, I7 (1992), pp. 213244 .

Rescigno, A., Plutarco. L'eclissi degli oracoli. Introduzione, testo critico, traduzione e commento, Napoli, I995.

Ricard, D., Oeuvres de Plutarque, traduites du grec, vol. 4, Paris, I844.

Richardson, N.J., The Homeric Hymn to Demeter, Oxford, 1974.

—, "Aristotle and Hellenistic Scholarship", in Montanari, F. (ed.), La philologie grecque à l'époque hellénistique et romaine, Entretiens Fondation Hardt, 40 (1994), pp. 738.

Rihll, T.E., Greek Science, Oxford, 1999.

Risselada, R., Imperatives and Other Directive Expressions in Latin: A Study in the Pragmatics of a Dead Language, Amsterdam, 1993.

Roberts, W.R., Dionysius of Hallicarnasus, On Literary Composition, London, I9IO.

Rodríguez Alfageme, I., "Medicina popular en Plutarco", in Montes Cala, J.G., Sanchez Ortiz de Landaluce, M. and Gallé Cejudo, R., I999, pp. 4II-422 [= I999a].

—, "Fisiología en Plutarco: Antecedentes Aristotélicos", in Pérez Jiménez, A., Garciá López, J. and Aguilar, R.M., I999, pp. 613-628 [= I999b].

—, "Aspectos de la medicina helenística en Plutarco", in Casanova, A., 2005, pp. 435-465

Roig Lanzillotta, L., "Plutarch's Anthropology and Its Influence on His Cosmological Framework", in Meeusen, M. and Van der Stockt, L., 20I5, pp. I79-I95.

Roig Lanzillotta, L. and Muñoz Gallarte, I. (eds.), Plutarch in the Religious and Philosophical Discourse of Late Antiquity, Leiden - Boston, 2012.

Rolleston, J.D., "Alcoholism in Classical Antiquity”, British Journal of Inebriety, 24 (I927), pp. IOI-I2O.

Rose, H.J., The Roman Questions of Plutarch, Oxford, 1924.

Rose, V., Aristoteles Pseudepigraphus, Leipzig, I863.

-, Anecdota Graeca et Graecolatina, vol. 2, Berlin, I870.

-, Aristoteles qui ferebantur librorum fragmenta, Leipzig, I886. 
Roskam, G., "From Stick to Reasoning. Plutarch on the Communication between Teacher and Pupil", Wiener Studien, 2004, pp. 93-II4.

-, On the Path to Virtue. The Stoic Doctrine of Moral Progress and its Reception in (Middle-)Platonism, Leuven, 2005.

—, A commentary to Plutarch's De latenter vivendo, Leuven, 2007.

—, "Plutarch on Aristotle as the First Peripatetic", Ploutarchos, 6 (2008/9), pp. 25-44.

—, "Educating the young ... over wine? Plutarch, Calvenus Taurus, and Favorinus as convivial teachers", in Ferreira, J.R., Leão, D., Tröster, M. and Barata Dias, P., 2009, pp. 369-383.

—, "Plutarch's 'Socratic Symposia'. The Symposia of Plato and Xenophon as Literary Models in the Quaestiones convivales", Athenaeum, 98 (2010), pp. 45-70.

-, "Plutarch against Epicurus on Affection for Offspring. A reading of De amore prolis", in Roskam, G. and Van der Stockt, L., 20II, pp. I75-20I [= 20IIa].

-, "Aristotle in Middle Platonism. The Case of Plutarch of Chaeronea", in Bénatouil, T., Maffi, E. and Trabattoni, F. (eds.), Plato, Aristotle, or Both? Dialogues between Platonism and Aristotelianism in Antiquity, Hildesheim - Zürich - New York, 20II, pp. 35-6I [= 20IIb].

—, "Two Quaestiones Socraticae in Plutarch", in Candau Morón, J., González Ponce, F. and Chávez Reino, A., 20II, pp. 4I9-43I [= 20IIc].

Roskam, G. and Van der Stockt, L. (eds.), Virtues for the People. Aspects of Plutarchan Ethics, Leuven, 20II.

Roskam, G. and Verdegem, S., “"This Topic Belongs to Another Kind of Writing”. The Digressions in Plutarch's Life of Coriolanus", in Van der Stockt, L. and Stadter, P.A. (eds.), Weaving Text and Thought. On Composition in Plutarch, forthcoming, Leuven.

Russell, D.A., Plutarch, New York, 1973.

—, "Plutarch, Quaestiones Convivales IV-VI", CR, 30 (I980), pp. I2-I4.

-, "Self-Disclosure in Plutarch and in Horace", in Most, G.W., Petersmann, H. and Ritter, A.M. (eds.), Philanthropia kai Eusebeia: Festschrift für Albrecht Dihle zum 70. Geburtstag, Göttingen, I993, pp. 426-437.

-, "The Rhetoric of the Homeric Problems", in Boys-Stones, G. (ed.), Metaphor, Allegory, and the Classical Tradition: Ancient Thought and Modern Revisions, Oxford, 2003, pp. 217-234.

Russell, D.A. and Konstan, D., Heraclitus: Homeric problems, Atlanta, 2005.

\section{$\mathbf{S}$}

Saïd, S., Trédé, M. and Le Boulluec, A., Histoire de la littérature grecque, Paris, 1997.

Sambursky, S., The physical world of the Greeks, London, 1963.

Sandbach, F.H., "Rhythm and Authenticity in Plutarch's Moralia", CQ, 33 (1939), pp. I94203. 
- (and Pearson, L.), Plutarch's Moralia in Sixteen Volumes, vol. II, Cambridge, Mass. London, 1965 [Sandbach edited Quaestiones Naturales].

—, Plutarch's Moralia in Sixteen Volumes, vol. 15, Cambridge, Mass. - London, 1969.

—, "Plutarch and Aristotle", ICS, 7 (1982), pp. 207-232.

Sansone, D., "Plutarch, Alexander, and the Discovery of Naphtha", GRBS, 2I (I980), pp. $63-74$.

Santana Henríquez, G. (ed.), Plutarco y las artes. XI Simposio Internacional de la Sociedad Española de Plutarquistas. Las Palmas de Gran Canaria, 8-Io November 20I2, Madrid, 2013.

Santaniello, C., "Plutarco e i presocratici", in Gallo, I., 2004, pp. I07-I33.

Sarton, G., A History of Science: Ancient Science through the Golden Age of Greece, New York, 1970.

-, A History of Science: Hellenistic Science and Culture in the Last Three Centuries B.C., New York, 1965.

Sassi, M., "Mirabilia", in Cambiano, G., Canfora, L. and Lanza D. (eds.), Lo spazio letterario della Grecia antica. I: La produzione e la circolazione del testo. Vol. 2: L'ellenismo, Roma, I993, pp. 449-468.

Scarcella, A.M., Conversazioni a tavola. Libro primo. Introduzione, testo critico, traduzione e commento, Napoli, 1998.

Scardigli, B. (ed.), Essays on Plutarch's Lives, Oxford, 1995.

Scheffel, W., Aspekte der Platonischen Kosmologie. Untersuchungen zum Dialog “Timaios", Leiden, 1976.

Scheid, J., À Rome sur les pas de Plutarque, Paris, $20 \mathrm{I} 2$.

Schellens, J., De hiatu in Plutarchi Moralibus, Bonnae, I864.

Schepens, G. and Delcroix, K., "Ancient Paradoxography: Origin, Evolution, Production, and Reception", in Pecere, O. and Stramaglia, A., I996, pp. 375-460.

Schmidt, J., "Paradoxa", RE, I8, 3 (I949), cols. II34-II37.

Schmidt, T.S., Plutarque et les barbares, Leuven, 1999.

—, "Les Questions barbares de Plutarque: un essai de reconstitution", in Chassignet, M., 2008, pp. 165-183.

Schmitt-Pantel, P., La cité au banquet. Histoire des repas publics dans les cités grecques, Rome, 1992.

Schmitz, T., Bildung und Macht. Zur sozialen und politischen Funktion der zweiten Sophistik in der griechischen Welt der Kaiserzeit, München, 1997.

_, "Plutarch and the Second Sophistic", in Beck, M., 20I4, pp. 32-42.

Schnitzer, C.F., Plutarch's Werke. Moralische Schriften, vol. 22, Stuttgart, I860.

Scholfield, A.F., Aelian. On the Characteristics of Animals, vol. I, Cambridge, Mass. London, 1958. 
Schopenhauer, A., Parerga und Paralipomena, vol. 5, Darmstadt, 1976 (I85I).

Schroeter, J., Plutarchs Stellung zur Skepsis, Diss. Königsberg, I9II.

Schuster, M., Untersuchungen zu Plutarchs Dialog De sollertia animalium mit besonderer Berücksichtigung der Lehrtätigkeit Plutarchs, Diss. Augsburg, I9I7.

Sedley, D., "Philosophical Allegiance in the Greco-Roman World", in Griffin, M. and Barnes, J. (eds.), Philosophia Togata I. Essays on Philosophy and Roman Society, Oxford, I989, pp. 97-II9.

Seide, R., Die mathematische Stellen bei Plutarch, Diss. Regensburg, 198I.

Senzasono, L., Plutarco. Precetti igienici. Introduzione, testo critico, traduzione e commento, Napoli, I992.

—, "Il concetto di 'potenza' nelle Nat. Quaest. di Plutarco", in Pérez Jiménez, A., Garciá López, J. and Aguilar, R.M., I999, pp. 657-664.

-, Plutarco. Cause dei fenomeni naturali. Introduzione, testo critico, traduzione e commento, Napoli, 2006.

Setaioli, A., "Truffles and thunderbolts (Plu., Quaest. conv. 4.2, I-2)", in Ferreira, J.R., Leão, D., Tröster, M. and Barata Dias, P., 2009, pp. 439-446.

Sharples, R.W., "Alexander of Aphrodisias: Scholasticism and Innovation", in $A N R W$ 2, 36, 2 (I987), pp. II76-I243.

-, "Science, Philosophy and Human Life in the Ancient World", in Wolff, J. and Stone, M.W.F. (eds.), The Proper Ambition of Science, London, 2000, pp. 7-27.

-, "Introduction: Philosophy and the Sciences in Antiquity", in Sharples, R.W. (ed.), Philosophy and the Sciences in Antiquity, Aldershot, 2005, pp. I-7.

—, "Pseudo-Alexander or Pseudo-Aristotle, Medical Puzzles and Physical Problems", in De Leemans, P. and Goyens, M., 2006, pp. 2I-3I.

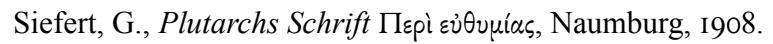

Simonetti, E.G., "Il caso della lampada di Ammone come eikôn dell'universo", forthcoming in Volpe Cacciatore, P. (ed.), Immagini letterarie e iconografia nelle opere di Plutarco, Salerno.

Sirinelli, J., Plutarque de Chéronée: Un philosophe dans le siècle, Paris, 2000.

Slater, W.J., “Aristophanes of Byzantium and Problem-Solving in the Museum”, $C Q, 3^{2}$ (1982), pp. 336-349.

Slotty, F., "Die Stellung des Griechischen und anderer idg. Sprachen zu dem soziativen und affektischen Gebrauch des Plural der ersten Person", Indogermanische Forschungen, 45 (1928), pp. 348-363.

Small, J.P., Wax Tablets of the Mind: Cognitive Studies of Memory and Literacy in the Ancient World, London, 1997.

Smits, J.P.H.M., Plutarchus en de Griekse muziek: de mentaliteit van de intellectueel in de tweede eeuw na Christus, Bilthoven, 1970. 
Snell, B., "The Forging of a Language for Science in Ancient Greece", CJ, 56 (1960), pp. 50-60.

Snyder, H.G., Teachers and Texts in the Ancient World. Philosophers, Jews and Christians, London, 2000.

Soury, G., "Les "Questions de table" et la philosophie religieuse de Plutarque", $R E G, 62$ (I949), pp. 320-327.

von Staden, H., Herophilus: the art of medicine in early Alexandria, Cambridge, 1989.

—, "Author and Authority. Celsus on the Construction of a Scientific Self”, in Vázquez Buján, M.E. (ed.), Tradición e Innovación de la Medicina Latina de la Antigüedad y de la Alta Edad Media, Santiago de Compostela, I994, pp. I03-II7.

Stadter, P.A., "The Proems of Plutarch's Lives", ICS, I3 (1988), pp. 275-295.

—, A Commentary on Plutarch's Pericles, Chapel Hill, 1989.

—, "Pericles Among the Intellectuals", ICS, I6 (I99I), pp. III-I24.

—, "Drinking, Table Talk, and Plutarch's Contemporaries", in Montes Cala, J.G., Sanchez Ortiz de Landaluce, M. and Gallé Cejudo, R., I999, pp. 48I-490.

—, "Notes and Anecdotes: Observations on Cross-Genre Apophthegmata", in A.G. Nikolaidis, 2008, pp. 53-66.

Stahl, G., "Die "Naturales Quaestiones" Senecas: Ein Beitrag zum Spiritualisierungsprozeß der römischen Stoa", Hermes, 92 (1964), pp. 425-454.

Stahl, W.H., Roman Science, Madison, 1962.

Starr, R., "The Circulation of Literary Texts in the Roman World", CQ, 37 (I987), pp. 23I223.

Stoltz, C., Zur relativen Chronologie der Parallelbiographien Plutarchs, Lund, 1929.

Stoyles, B.J., "Material and Teleological Explanations in Problemata Io", in Mayhew, R, 20I5a, pp. I24-I50.

Strömberg, R., Greek Proverbs: A Collection of Proverbs and Proverbial Phrases which are not Listed by the Ancient and Byzantine Paroemiographers, Göteborg, 1954.

Stückelberger, A., "Meerwasserentsalzung Nach Aristoteles (?). Ein Nachtrag", Hermes, I24 (I996), pp. 378-380.

Swain, S., "Plutarch: Chance, Providence, and History", AJPh, IIo (I989), pp. 272-302.

\section{$\mathbf{T}$}

Tanga, F., "Some Notes on Plutarch's Quaestiones naturales", in Meeusen, M. and Van der Stockt, L., 20I5, pp. II3-I28.

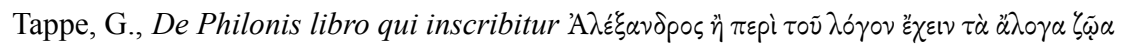
quaestiones selectae, Diss. Gottingae, I912.

Taub, L., Ancient Meteorology, London, 2003. 
—, Aetna and the Moon: Explaining Nature in Ancient Greece and Rome, Oregon, 2008.

—, "Explaining a Volcano Naturally: Aetna and the Choice of Poetry", in Taub, L. and Doody, A., 2009, pp. I25-I4I.

Taub, L. and Doody, A. (eds.), Authorial Voices in Greco-Roman Technical Writing, Trier, 2009.

Taylor, A.E., A commentary on Plato's Timaeus, Oxford, 1928.

Tecuşan, M., "Logos Sympotikos: Patterns of the Irrational in Philosophical Drinking: Plato Outside the Symposium", in Murray, O., I990a, pp. 238-260.

Teixeira, E., 'Remarques sur l' esprit scientifique de Plutarque d' après quelques passages des Propos de table", in Gallo, I., I992, pp. 2II-223.

Teodorsson, S.-T., A commentary on Plutarch's Table Talks, Göteborg, I989 (= vol. I), I990 (= vol. 2 [= I990a]), I996 (= vol. 3).

—, “A Forgotten Anatomical Method Traced?”, Eranos, 88 (I990), pp. 64-66 [= I990b].

—, "Plutarch and Peripatetic Science", in Pérez Jiménez, A., Garciá López, J. and Aguilar, R.M., I999, pp. 665-674 [= 1999a].

-, "Dionysus Moderated and Calmed: Plutarch on the Convivial Wine", in Montes Cala, J.G., Sanchez Ortiz de Landaluce, M. and Gallé Cejudo, R., I999, pp. 57-69 [= I999b].

—, "Plutarch's Use of Synonyms: A Typical Feature of his Style", in Van der Stockt, L., 2000a, pp. 5II-5I8.

—, "Plutarco, innovatore del vocabolario greco", in Pérez Jiménez, A. and Titchener, F., 2005, pp. 405-4I8.

—, "The place of Plutarch in the literary genre of Symposium", in Ferreira, J.R., Leão, D., Tröster, M. and Barata Dias, P., 2009, pp. 3-16.

—, "Plutarch, a main source for the Presocratics and the Sophists", in Candau Morón, J., González Ponce, F. and Chávez Reino, A., 20II, pp. 433-446.

Thévenaz, P., L'Âme du monde. Le devenir et la matière chez Plutarque. Avec une traduction du traité De la Genèse de l'Âme dans le Timée, Neuchâtel, I938.

Thivel, A., "La doctrine des $\pi \varepsilon p \iota \sigma \sigma \omega \mu \alpha \tau \alpha$ et ses parallèles hippocratiques", Revue de philologie, 39 (1965), pp. 266-282.

Thomas, O., "Creating Problemata with the Hippocratic Corpus", in Mayhew, R., 20I5a, pp. 79-99.

Thomas, R., Herodotus in Context. Ethnography, Science and the Art of Persuasion, Cambridge, 2000.

Thompson, D’A.W., A Glossary of Greek Fishes, London, 1947.

Titchener, F., "The role of reality in Plutarch's Quaestiones Convivales", in Ferreira, J.R., Leão, D., Tröster, M. and Barata Dias, P., 2009, pp. 395-40I. 
—, "Plutarch's Table Talk: Sampling a Rich Blend. A Survey of Scholarly Appraisal", in Klotz, F. and Oikonomopoulou, K., 20II, pp. 35-48.

—, "Fate and Fortune", in Beck, M., 20I4, pp. 479-487.

Titchener, J.B., The Manuscript-Tradition of Plutarch's Aetia Graeca and Aetia Romana, Illinois, 1924 .

Torraca, L., "L'astronomia lunare in Plutarco", in Gallo, I., I992, pp. 23I-26I.

_, "Problemi di lingua e stile nei 'Moralia' di Plutarco", ANRW 2, 34, 4 (1998), pp. 348735 IO.

Tsekourakis, D., "Orphic and Pythagorean Views on Vegetarianism in Plutarch", in Brenk, F.E. and Gallo, I., I986, pp. I27-I38.

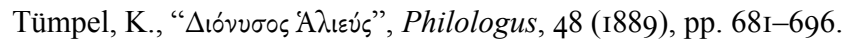

\section{$\mathbf{U}$}

Ulacco, A., "Malattia e alterazione del calore naturale: medicina ippocratica e fisiologia aristotelica negli hosa iatrika e in altri Problemata pseudo-aristotelici", in Centrone, B., 20IIa, pp. 59-88.

Usener, H., Alexandri Aphrodisiensis quae feruntur problematorum libri 3 et 4, Berlin, I859.

\section{V}

Valgiglio, E., Plutarco. Gli oracoli della Pizia. Introduzione, testo critico, traduzione e commento, Napoli, 1992.

Vallance, J.T., “A Second Look: Marshall Clagett's 'Greek Science in Antiquity': ThirtyFive Years Later", Isis, 8I (1990), pp. 713-72I.

Vamvouri Ruffy, M., "Symposium, Physical and Social Health in Plutarch's Table Talk", in Klotz, F. and Oikonomopoulou, K., 20II, pp. I3I-I57.

—, Les Vertus thérapeutiques du banquet: Médecine et idéologie dans les Propos de Table de Plutarque, Paris, 2012.

Van der Stockt, L., "Plutarch's Use of Literature. Sources and Citations in the Quaestiones Romanae", AncSoc, I8 (1987), pp. 28I-292.

—, Twinkling and Twighlight: Plutarch's Reflections on Literature, Brussel, 1992 [= 1992a].

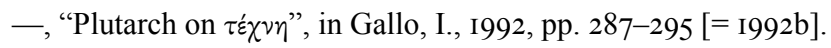

- (ed.), Plutarchea Lovaniensia. A Miscellany of Essays on Plutarch, Lovanii, 1996 [= I996a].

-, "Some remarks on two Plutarchean introductions", in Van der Stockt, L., I996a, pp. $265^{-272}[=\mathrm{I} 996 \mathrm{~b}]$.

—, "A Plutarchan Hypomnema on Self-Love", The American Journal of Philology, I20 (1999), pp. 575-599 [= 1999a]. 
—, "Three Aristotle's Equal but one Plato. On a Cluster of Quotations in Plutarch", in Pérez Jiménez, A., Garciá López, J. and Aguilar, R.M., I999, pp. I27-I40 [= I999b].

- (ed.), Rhetorical Theory and Praxis in Plutarch. Acta of the IVth International congress of the International Plutarch Society, Leuven, July 3-6, I996, Louvain, 2000 [= 2000a].

- "Aspects of the Ethics and Poetics of the Dialogue in the Corpus Plutarcheum", in Gallo, I. and Moreschini, C., 2000, pp. 93-II6 [= 2000b].

—, "Plutarch in Plutarch: the problem of the hypomnemata", in Gallo, I., 2004, pp. 33I-340.

—, "Plutarch and dolphins: love is all You need", in Boulogne, J., 2005a, pp. I3-2I.

—, "Some aspects of Plutarch's view of the physical world. Interpreting Causes of Natural Phenomena", in Candau Morón, J., González Ponce, F. and Chávez Reino, A., 20II, pp. $447-455$.

- "Eunomia in heaven and on earth. Plutarch's nomos between rhetoric and science", in Ferreira, J.R., Leão, D. and Martins de Jesus, C.A., 20I2, pp. 203-213.

-, "Technical terminology in Plutarch's Lives: addressing the layman", in Pace, G. and Volpe Cacciatore, P. (eds.), Gli scritti di Plutarco: tradizione, traduzione, ricezione, commento. Atti del IX Convegno Internazionale della International Plutarch Society Ravello - Auditorium Oscar Niemeyer 29 settembre-I ottobre 20II, Napoli, 20I3, pp. 439-445.

Van Groningen, B.A., "General Literary Tendencies in the Second Century A.D.”, Mnemosyne, I8 (1965), pp. 4I-56.

—, Théognis: le premier livre, Amsterdam, 1966.

Van Hoof, L., Plutarch's Practical Ethics. The Social Dynamics of Philosophy, Oxford, 2010.

Van Kooten, G., “A Non-Fideistic Interpretation of $\pi i \sigma \tau \iota \varsigma$ in Plutarch's Writings: The Harmony between $\pi i \sigma \tau\llcorner\varsigma$ and Knowledge", in Roig Lanzillotta, L. and Muñoz Gallarte, I., 20I2, pp. 215-233.

Van Meirvenne, B., “'Puzzling over Plutarch': Traces of a Plutarchean Plato-study Concerning Lg. 729a-c in Adulat. 32 (Mor. 7IB), Coniug. praec. 46-47 (Mor. $144 \mathrm{~F}$ ) and Aet. Rom 33 (Mor. 272C)", in Montes Cala, J.G., Sanchez Ortiz de Landaluce, M. and Gallé Cejudo, R., 1999, pp. 527-540.

—, "“Earth and Ambrosia” (De facie §§ 24-25): Plutarch on the Habitability of the Moon", in Pérez Jiménez, A. and Casadesús Bordoy, F. (eds.), Estudios sobre Plutarco: misticismo y religiones mistéricas en la obra de Plutarco, Actas del VII Simposio Español sobre Plutarco (Palma de Mallorca, 2-4 de nov. de 200o), Madrid - Malaga, 200I, pp. 283-296.

Van Nuffelen, P., "Words of Truth: Mystical Silence as a Philosophical and Rhetorical Tool in Plutarch", in Castelnérac, B., 2007, pp. 9-39.

Vegetti, M., Il coltello e lo stilo: animali, schiavi, barbari e donne alle origine della razionalità scientifica, Milano, I979. 
Verbeke, G., L'évolution de la doctrine du pneuma: du stoïcisme à S. Augustin, Paris Louvain, 1945.

—, "Plutarch and the development of Aristotle", in Düring, I. and Owen, G.E.L. (eds.), Aristotle and Plato in the mid-fourth century, Göteborg, I960, pp. 236-247.

Verdenius, W.J., "Der Ursprung der Philologie”, Studium Generale, I9 (I966), pp. I03-II4.

Vernière, Y., Symboles et mythes dans la pensée de Plutarque. Essai d'interprétation philosophique et religieuse des Moralia, Paris, 1977.

Vetta, M., "Plutarco e il 'Genere Simposio'”, in Gallo, I. and Moreschini, C., 2000, pp. 217-229.

Veyne, P., Les Grecs ont-ils cru à leurs mythes? Essai sur l'imagination constituante, Paris, 1983.

Vlastos, G., "On Heraclitus", AJP, 76 (1955), pp. 337-368.

—, "The Socratic Elenchus", Oxford Studies in Ancient Philosophy, I (1983), pp. 27-58.

Volkmann, R., Leben, Schriften und Philosophie des Plutarch von Chaeronea, Berlin, I869.

\section{W}

Weidlich, T., Die Sympathie in der antiken Literatur, Stuttgart, I894.

Weiss, D., De nonnullis Plutarchi Moralium locis ab Herwerdeno tractatis, Biponti, I888.

Weissenberger, B., Die Sprache Plutarchs von Chaeronea und die pseudoplutarchischen Schriften, Diss. Würzburg, I895.

Wellmann, M., “Antipatros, 32”, RE, I, 2 (I894), col. 2517.

—, "Bolos, 3", RE, 3, I (I897), cols. 676-677.

—, Die Фuбıќ́ des Bolos Demokritos und der Magier Anaxilaos aus Larissa, Berlin, I928.

Wendel, C., "Späne III", Hermes, 77 (I942), pp. 2I6-2I8.

Westerink, L.G., Michael Psellus, De Omnifaria Doctrina, Nijmegen, 1948.

Whitmarsh, T., Greek Literature and the Roman Empire: The Politics of Imitation, Oxford, 200 .

—, “Alexander's Hellenism and Plutarch's Textualism”, CQ, 52 (2002), pp. 174-192.

—, Ancient Greek Literature, Cambridge, 2004.

-, The Second Sophistic, Oxford, 2005.

Williams, G.D., The cosmic viewpoint: a study of Seneca's Natural questions, Oxford, 2012.

von Wilamowitz, U., Griechisches Lesebuch, vol. 2, Berlin, 1902.

—, Die Textgeschichte der griechischen Bukoliker, Berlin, 1906.

Wright, M.R., Empedocles: the Extant Fragments, London, I98I. 


\section{$\mathbf{X}$}

Xenophontos, S.A., "Plutarch's Compositional Technique in the An Seni Respublica Gerenda Sit: Clusters vs. Patterns", The American Journal of Philology, I33 (2012), pp. 6I-9I.

\section{Y}

Yaginuma, S., "Plutarch's Language and Style", $A N R W$ 2, 33, 6 (1992), pp. 4726-4742.

\section{$\mathbf{Z}$}

Zeyl, D.J., Plato. Timaeus, Indianapolis, 2000.

Ziegler, K., "Plutarchos von Chaironeia", RE, 2I, I (195I), cols. 636-962.

Zucker, A., "Papirius Fabianus ( $c a 35 \mathrm{BCE}-c a$ 30CE)", in Keyser, P.T. and IrbyMassie, G.L., 2008a, pp. 6Io-6II. 
INDEX LOCORUM 



\section{Index Locorum}

\begin{tabular}{|c|c|}
\hline \multicolumn{2}{|l|}{ Aelian } \\
\hline \multicolumn{2}{|l|}{$\mathrm{NA}$} \\
\hline I, 58 & 479 \\
\hline 3,5 & 456 \\
\hline 4,4 & 484 \\
\hline 5, II & I22, 479 \\
\hline $5,4 \mathrm{I}$ & 428 \\
\hline 5,46 & 456 \\
\hline 6,3 & 453,456 \\
\hline $6, \mathrm{I} 2$ & 456 \\
\hline 6,19 & 384 \\
\hline 8,9 & 456 \\
\hline $9, \mathrm{I} 3$ & 384 \\
\hline 9,52 & 428 \\
\hline 9,64 & $37 \mathrm{I}, 400$ \\
\hline Epil. $43-46$ & 99 \\
\hline \multicolumn{2}{|l|}{$V H$} \\
\hline $\mathrm{I}, \mathrm{I}$ & 432 \\
\hline
\end{tabular}

\section{Aeneas Tacticus \\ Pol.}

22,24

405

\section{Aesop}

Fab.

$$
\text { 306-307 }
$$

476

\section{Alcman \\ Fr. Diehl}

43

I4O, 277, 45I

\begin{tabular}{|c|c|}
\hline $\begin{array}{l}\text { Alexander (and F } \\
\text { Aphrodisiensis }\end{array}$ & lexander) \\
\hline In Ar. Met. & \\
\hline $38, \mathrm{I} 6-20$ & 396 \\
\hline In Ar. Top. & \\
\hline $62,30-63,19$ & 84 \\
\hline Probl. & \\
\hline I, 2 & 466 \\
\hline I, 55 & 400,408 \\
\hline I, 56 & 420 \\
\hline I, I25 & 465 \\
\hline
\end{tabular}

2, 46

Quaest.

2, 23

435

Anaxagoras

Fr. DK

59A35 I8

59AII6 28I, 370

59AII7 370

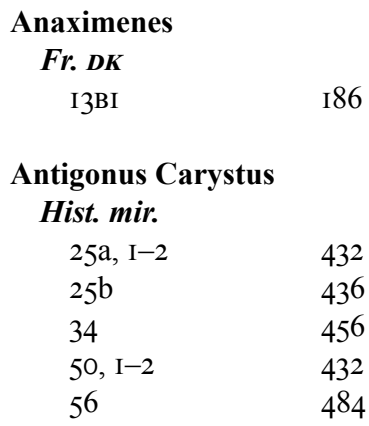

Apollonius Mys

Fr. von Staden

33

28I, 387

Apollonius Rhodius

Arg.
$2,88-89 a$
285
$2,476-477$
$48 \mathrm{I}$

Apostolius, Michael

Coll. paroem.

II, 6I

424

\section{Aratus}

Phaen.

946-947

956

$269,277,385$

269, 425 


\section{Archilochus}

Fr. Edmonds 57

426

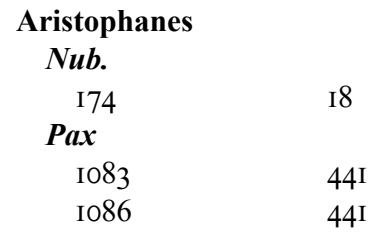

Aristotle (and corpus Aristotelicum)

APr.

$\begin{array}{ll}\begin{array}{l}24 \mathrm{ai} 6-\mathrm{I} 7 \\ \text { APo. }\end{array} & 78 \\ 72 \mathrm{a} 8 & 78 \\ 89 \mathrm{~b} 24-35 & 79 \\ 89 \mathrm{~b} 29-30 & 250\end{array}$

Top.

IOO25-IOIa24 339

IOIb28-37 $\quad 78$

IO4bI-28 $\quad 78$

IO4b3-5 78

I04bi3-I8 $\quad 78$

I05bi3-I9 $\quad 78$

I05bi9-2I $\quad 78$

I27a3-I3 3OI

I27aI9 $\quad 382$

I49b25 $\quad 339$

I62aI7 $\quad 326$

De caelo

286a25-26

GC

3I8bi4-I7 $\quad 462$

3I $8 b_{33}-35 \quad 398$

323b8-I0 $\quad 467$

Mete.

347bi7-22 45I

$348 \mathrm{~b} 2 \quad 309$

348b2-5 4I9

354bi8 399

$354 \mathrm{~b} 33 \quad 373$

355a32 ff. $\quad 408$

$358 \mathrm{a} \quad 28 \mathrm{I}$

358aI4-I7 $\quad 373$

358b6-9 $\quad 302$

$358 \mathrm{~b} 7-9 \quad 372$

358bi6-I8 $\quad 398$ 358bi8-20 $\quad 399$

358b34-359a5 $\quad 400$

359a7-2I $\quad 372$

363a24 I80

369aI2-29 392

379all-b9 $\quad 307$

379bio-38rb23 307

38ob3I-38rai $\quad 459$

38Ibi3 I80

384a26-28 439

De mund.

395b3-4 463

DA

4I $5 \mathrm{~b} 2-3 \quad 266$

4I6a28-35 380

$420 \mathrm{~b} 29 \quad \mathrm{I} 47$

422bio-I4 397

433br $8 \quad 302,43 \mathrm{I}$

De sensu

442aI7 400

442aI7-2I $\quad 397$

444bi2 425

Somn. vig.

$456 a 29 \quad$ I80

Div. som.

$463 a 5$

Juv.

470aI8 I80

De respir.

472b6-473aI4 309

$472 \mathrm{bi} 6 \quad 309$

$\mathrm{HA}$

523b32-33 $\quad 428$

$535 \mathrm{a} 2 \quad 477$

536aII $\quad 384$

542a27-28 442

542a27-30 44I

546aI-4 465

$557 \mathrm{~b} 29 \quad 49 \mathrm{I}$

572a5-8 44I

$574 \mathrm{a} 8 \quad 390$

575 bi $\quad 445$

$578 \mathrm{a} \quad 28 \mathrm{I}$

$578 \mathrm{a} 26 \quad 44 \mathrm{I}$

578a26-28 443

578a32-b5 $\quad 443$

578a32-33 $\quad 444$

$578 \mathrm{bI}$ 


\begin{tabular}{|c|c|c|c|}
\hline $580 a I I-22$ & 484 & $783 \mathrm{bI} 8$ & 466 \\
\hline 580aI4-I9 & $25 \mathrm{I}, 484$ & $789 \mathrm{~b} 8-9$ & $302,43 \mathrm{I}$ \\
\hline $580 a 20-22$ & $25 \mathrm{I}$ & De plant. & \\
\hline $580 a 2 \mathrm{I}-22$ & 484 & $8 \mathrm{~s} 5 \mathrm{bi} 6$ & 370 \\
\hline 58ob3I & 390 & Mir. ausc. & \\
\hline $584 a I 9$ & 457 & 83Іа27-28 & 456 \\
\hline 588bi6-I7 & 370 & $832 a 3-4$ & 479 \\
\hline $590 a 22$ & 333 & $836 b_{3} 3 f f$. & 449 \\
\hline $590 a 22-27$ & 400 & 844 b $20-22$ & 387 \\
\hline $594 a 28-29$ & 456 & Probl. & \\
\hline 594 b9 & 456 & 86ra6-9 & 380 \\
\hline 596ai6-25 & 386 & $866 \mathrm{a} 26-28$ & 467 \\
\hline 6Iob29 & I36 & 866a36-bi & 467 \\
\hline 6 I $2 a 5-6$ & 456 & 87 Ia2 & 305,467 \\
\hline $612 a 24-25$ & 456 & 87ıа8-I6 & 294 \\
\hline $622 \mathrm{aI} 5$ & $43 \mathrm{I}$ & $872 \mathrm{~b} 25-32$ & 295 \\
\hline $623 \mathrm{~b} 20$ & 479 & $872 b_{32}-873 a 4$ & 294 \\
\hline $623 \mathrm{~b} 2 \mathrm{O}-2 \mathrm{I}$ & 477 & $874 \mathrm{~b} 6-7$ & 467 \\
\hline $626 a 26-28$ & 479 & $874 \mathrm{bI} 3-2 \mathrm{I}$ & 295 \\
\hline 4 & & $875 a 29-40$ & 294 \\
\hline $640 a 14-\mathrm{I} 5$ & 249 & $875 a 34-35$ & 82 \\
\hline 645aI6-I7 & 462 & $879 a 23^{-26}$ & 479 \\
\hline $646 a 15$ & 303 & $88 \mathrm{oa}_{34}-\mathrm{b}_{3}$ & 466 \\
\hline $648 \mathrm{a} 2-5$ & 439 & $884 a 32-34$ & 474 \\
\hline 649aI8-I9 & 462 & $886 b 4-9$ & 402 \\
\hline $65 \mathrm{ob} 28$ & 439 & $887 a i ı$ & 65 \\
\hline $65 \mathrm{Ia} 2-3$ & 438 & $887 a 22-40$ & 402 \\
\hline $65 \mathrm{Ia} 3$ & 439 & $887 b_{3} 8-888 a_{23}$ & I 49,295 \\
\hline $676 a 18$ & I80 & 893 а3 I & 388 \\
\hline $678 b_{32}$ & 428 & $893 \mathrm{~b} 7$ & 388 \\
\hline $679 a{ }_{3}$ & $43 \mathrm{I}$ & $896 a 20-29$ & 44I, 444 \\
\hline 68гаI2-I5 & 370 & $896 a 2 I$ & $44 \mathrm{I}$ \\
\hline $685 \mathrm{a} 30-\mathrm{b} 2$ & 428 & $896 a 22-24$ & 442 \\
\hline $\boldsymbol{A}$ & & $896 a 23$ & $44 \mathrm{I}$ \\
\hline $703 a 3-b i$ & $302,43 \mathrm{I}$ & $896 a 23-24$ & 444 \\
\hline $\boldsymbol{A}$ & & $896 a 24-29$ & 444 \\
\hline $725 b_{32}-726 a 6$ & 465 & $907 a 8-12$ & 453 \\
\hline $726 a 26-27$ & 358 & 923a9-Io & 424 \\
\hline $735 \mathrm{a} 32$ & 486 & $924 b_{35}-925 a 5$ & 490 \\
\hline 735 b35 & 486 & $927 \mathrm{bI} 2$ & 447 \\
\hline 736b37-737aI & $30 \mathrm{I}$ & $93 \mathrm{ob} 23-25$ & 458 \\
\hline $743 \mathrm{a} 8-\mathrm{II}$ & 400 & 932a40-b8 & 372 \\
\hline $747 \mathrm{~b}_{5}$ & I80 & $932 b 8$ & 337 \\
\hline $765 \mathrm{a} 23-3 \mathrm{I}$ & 445 & $932 \mathrm{~b} 4-6$ & 373 \\
\hline $772 \mathrm{bII}$ & I80 & $932 \mathrm{~b} 8-\mathrm{I} 6$ & 407 \\
\hline $775 b_{37}$ & I80 & $932 \mathrm{~b} 8-24$ & $4 \mathrm{I} 5$ \\
\hline $779 \mathrm{~b} 30-33$ & 486 & $932 \mathrm{~b} 25$ & 488 \\
\hline $780 b 6$ & 467 & $932 \mathrm{~b} 25-28$ & 372 \\
\hline
\end{tabular}




\begin{tabular}{|c|c|}
\hline \multicolumn{2}{|l|}{ Probl. (cont.) } \\
\hline 933a9-I3 & 372 \\
\hline 933aI8-27 & 373 \\
\hline 933bıi-I6 & 398 \\
\hline 933bı7-20 & 399 \\
\hline $933 \mathrm{~b} 33-4 \mathrm{I}$ & 399 \\
\hline 934b27ff. & 408 \\
\hline $934 b 34-36$ & 373 \\
\hline $935 a 5-8$ & 373 \\
\hline $935 \mathrm{~b}$ & 28I \\
\hline $935 b_{3}-17$ & 399 \\
\hline 935 bI7-27 & 407,415 \\
\hline 935bi8-20 & 373 \\
\hline 936bı18 & 447 \\
\hline $937 \mathrm{a} 26-27$ & 467 \\
\hline $937 \mathrm{~b} 29$ & 489 \\
\hline $939 b_{37}$ & 447 \\
\hline $943 \mathrm{~b} 2 \mathrm{I}-23$ & 475 \\
\hline $943 \mathrm{~b} 23$ & 447 \\
\hline 944aII-I2 & 475 \\
\hline 946aI7-32 & 475 \\
\hline $946 b 2 \mathrm{I}-22$ & 475 \\
\hline $948 b_{35}-949 a 8$ & I89 \\
\hline 953аIo-955a40 & $\mathrm{I} 43,35^{8}$ \\
\hline 935 bi7 & 337 \\
\hline 96гаг8-23 & 415 \\
\hline 96 Ia24-30 & $4 \mathrm{I} 5,4 \mathrm{I} 6$ \\
\hline $96 \mathrm{Ib}_{3} \mathrm{I}-32$ & 467 \\
\hline $966 \mathrm{aI} 7-25$ & 447 \\
\hline $967 a 3$ & 447 \\
\hline \multicolumn{2}{|l|}{ Met. } \\
\hline $980 a 26-27$ & 265 \\
\hline 98гаff. & $3 \mathrm{I} 7$ \\
\hline $982 \mathrm{bII}-\mathrm{I} 5$ & 243 \\
\hline $995 \mathrm{~b} 2-4$ & 78 \\
\hline I055b32 ff. & 85 \\
\hline IO70b9-I3 & 462 \\
\hline \multicolumn{2}{|l|}{$E N$} \\
\hline IIO2a22 & 457 \\
\hline II 48 b24-29 & 457 \\
\hline \multicolumn{2}{|l|}{$R \boldsymbol{R}$. } \\
\hline I355a6-8 & 339 \\
\hline I355b26-27 & 339 \\
\hline \multicolumn{2}{|l|}{ Poet. } \\
\hline I46ob6ff. & 84 \\
\hline I447bi 8 & 275 \\
\hline
\end{tabular}

Fr. Rose
275

84

83

399

489

28I, 378

37I, 374

282

295

4II

374, 4II, 467

$8 \mathrm{I}$

472

I97

466

I90

392

384

420

428

\section{Vita Marciana}

$427,8 \mathrm{R}^{3} \quad 83$

\section{Index Hesychii}

II6

I68

I04

83

Ps.-Aristotle/Alexander Aphrodisiensis Suppl. probl.

I, I7, 32-35 385

$2,22 \quad 380$

$2,34 \quad 400$

2, $5 \mathrm{I} \quad 65$

$2,59 \quad 388$

$2,6 \mathrm{I} \quad 388$

2, $64 \quad 388$

2, IOI 453

2, $106 \quad 4 \mathrm{I} 2$

2, II5-II6 390

2, I37, 2-4 386

2, I44 83, 44I, 442

2, I45 83, 443,444

2, I55 83, 44I, 442

$2, \mathrm{I} 56 \quad \mathrm{I} 8 \mathrm{I}$

3, $17 \quad 83,133$

$3,29 \quad 83,416$

3, $47 \quad 83,416$

Probl. ined.

3, 5I $\quad 83$




\section{Arrian}

Frag. Phys. (Roos)

3, I90, 7-I2

392

$\begin{array}{cl}\begin{array}{c}\text { Athenaeus } \\ \text { Deipn. }\end{array} \\ \text { I, 26b } \\ \text { I, 3I f. } & 409,410 \\ \text { I, 32de } & 409 \\ \text { 2, 42b } & 409 \\ \text { 7, 3I } 7 \mathrm{a} & 3 \mathrm{II}, 405 \\ 7,3 \mathrm{I} 7 \mathrm{f} . & 432 \\ 7,323 \mathrm{~d} & 43 \mathrm{I} \\ \text { II, 33b } & 428 \\ \text { I2, 5I3cd } & 409 \\ & 432\end{array}$

Aurelianus, Caelius

Tard. pass.

5, I39

\section{Callimachus}

Fr. Pfeiffer

$$
\text { I, I-5 }
$$

$43, \mathrm{I} 2-\mathrm{I} 7$

178

465

787 Schneider

\section{Carcinus}

TGF

5,6

449

\section{Cassius Dio}

Hist. Rom.

50, 34

373

\section{Cassius Iatrosophista \\ Probl.}

65

398

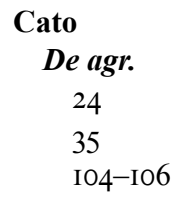

Catullus

\section{Carm.}

42

479

\section{Celsus}

De med.
$2, \mathrm{I} 7, \mathrm{I}$
474
$2, \mathrm{I} 8, \mathrm{I} 2$
379

Charon of Lampsacus

\section{FGrHist}

262, I2

$48 I$

\section{Cicero}

De div.

$\begin{array}{ll}\text { I }, 8, \text { I3 } & 269 \\ \text { I, I5 } & 385 \\ 2,2 \text { I, } 47 & 269 \\ 2,33 & 285 \\ 2, \text { I26 } & 456 \\ \text { 2, I45, I2-I4 } & 428 \\ \text { De nat. deor. } & \end{array}$

$\begin{array}{ll}2,25 & 420 \\ 2,26 & 406 \\ 2,96 & 462\end{array}$

De or.

$\begin{array}{ll}2,5,2 \text { I } & \text { I9I } \\ 2,86-87 & 265\end{array}$

Ep. ad Attic.

7, I, I

I96

Progn.

4, I-3 385

Rhet. ad Her.

$3,36 \quad 462$

\section{Clemens Alexandrinus}

Paed.

3, II, 80, 2

\section{Columella}

De re rust.

$\begin{array}{ll}9, \mathrm{I} 4,3 & 480 \\ 9, \mathrm{I} 4,7 & 477 \\ 9, \mathrm{I} 5, \mathrm{IO} & 456 \\ \mathrm{I} 2,2 \mathrm{I}-22 & 4 \mathrm{IO} \\ \mathrm{I} 2,29 & 458 \\ \mathrm{I} 2,37 & 4 \mathrm{IO}\end{array}$




\section{Critias}

Fr. DK

$88 \mathrm{~B} 25$

Democritus

Fr. $D K$

68AI7a

68A33

68A99a

68AI35

68AI55a

68AI65

68BII8

68BI50

68B299h

68в300

Diodorus Siculus

Bibl. hist.

$5,3,2$

\section{Diogenes of Apollonia}

Fr. DK

64A33

\section{Diogenes Laertius}

Vit. phil.

I, IO

5, 23

5,26

5,44

5,45

5,46

5,48

5,49

$7, \mathrm{I} 32-\mathrm{I} 33$

9, 2I

9, 47

9, 49

IO, 27

IO, 26-28

IO, IO4

Dioscorides

De mat. med.

3,45 , I

490
449

464

244

77

245

397

$37 \mathrm{I}$

309, 435

I04

359

77

77

435

62

84

IO4

43I

79, 37I, 400,

405

6I, 62

6I, 79, 84

79,84

I09

61

I04

77

62

I04

348
Elias (David)

Comm. in Ar. Cat.

II 4,2

172

II 4,8

172

II 4, I2-I3

83

II4, I3-I4

I73

Empedocles

Fr. DK

3IA69a

3IA70

3IA78

3IA9I

3IA92

3IBI7

3Ів64

3IB74

3IB77

3IB77-78

$3 \mathrm{IB} 8 \mathrm{O}$

3IB8I

3IB86

3ІB89

3Iв94

3IBIOI

487

370

277, 438

487

309

30I

277, 443

I55

309

468

II5, 382

277, 278, 38I, 467

434

277, 3IO, 354,

434, 435

278, 486

277, 449

\section{Ephorus}

FGrHist

70,56

410

\section{Epicurus}

Ep. ad Her.

35, 2-5

62

Fr. Usener

I8-2I

57-65

293

524

435

I 22

\section{Erasmus}

Adag. Chil.

$$
\text { 2, 5, } 43 \text { (= I443) 44I }
$$

\section{Etymologicum magnum}

$75,26-44$

$48 \mathrm{I}$

$8 \mathrm{I} 2,44-5 \mathrm{I}$

445 


\section{Euripides}

TGF

895

94I

Eusebius

$P E$

$$
\text { I, 7, I6 }
$$

I5, 20

I54

379

\section{Eustathius}

Comm. ad Hom. Il.

629, 63-64

$87 \mathrm{I}, 36-38$

$4 \mathrm{IO}$

410

\section{Favorinus}

\section{Fr. Barigazzi}

I-2

\section{Flavius Josephus \\ Antiq. Jud. \\ I5, II, 3}

\section{Galen (Kühn) \\ Temp.}

I, 509, I-4 308

Nat.Fac.

$$
\begin{aligned}
& 2,7,2-3 \\
& 2,44-56
\end{aligned}
$$$$
\text { UP }
$$

4, I72, I3 465

Sem.

4, 633, I2 465

$$
\text { мM }
$$

IO, 300, II

SMT

II, 450, I4ff. $\quad 397$

II, 47I, I3-I4 325

II, $474 \quad 8 \mathrm{I}$

II, 630, 2-4 374

II, 656, II-I4 $\quad 459$

II, $657,2-4 \quad 458$

I2, 35, 3-7 $\quad 374$

I2, 222, I5-223, 5374

Ven.Sect.Er.

II, I68, 2-3

Comp.Med.Loc.

I2, 38I, I6-I7 374
374

456

466
277, 442, 444

II8, 277, 463

236

389

357

435

65

65

389 5

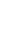
.

Gellius, Aulus

$\begin{array}{ll}\text { NA } & \\ \text { Praef. } 2 & 99 \\ \text { Praef. } 2-4 & \text { I } 7 \mathrm{I} \\ \text { Praef. } 7 & \text { I54 } \\ \text { Praef. } 9 & 96 \\ \text { Praef. } 25 & 97 \\ \text { I, } 26 & \text { I93 } \\ 3,5 & \text { I7I } \\ 3,6 & \text { I7I, } 472 \\ \text { 4, II, I3 } & \text { I7I } \\ 7, \text { I3 } & 200,222 \\ \text { I7, II } & \text { I7I } \\ \text { I9, 4 } & 22, \text { I89, I99 } \\ \text { I9, 6 } & \text { I90 } \\ 20,4 & \text { 190 }\end{array}$

\section{Geminus}

\section{El. astr.}

I7, 48

269

\section{Geoponica}

$\begin{array}{ll}2,47, \text { II } & 398 \\ \text { I5, 2, I9 } & 480 \\ \text { I5, 3, 4 } & 480\end{array}$

Glycas, Michael

Ann. (Bekker)

I, 9 (p. I9, 5-9) 398

I, I3 (pp. 25, 2I-26, 5)

487

I, I6 (p. 3I, I-4) 372

I, I6 (p. 3I, I2-I3) 380

I, 62 (p. II8, I7-I9) 425

I, 62 (p. II9, 22-I2O, 2)

44I, 442

\section{Heraclitus}

Fr. $D K$

22A6, I5 379

22BI2 28I, 379

22B49a 379

22B86 253

22B9I 379

Ps.-Heraclitus

Quaest. Hom.

35

$4 \mathrm{IO}$ 


\section{Herodotus}

Hist.

2,22

325

Herophilus

Fr. von Staden $50 a$ (and b)

249

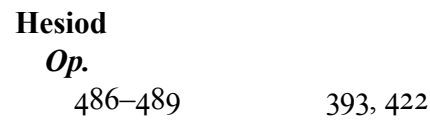

Hippiatrica Berolinensia

I4, I, II-I3 445

Hippocrates (and corpus Hippocraticum)

Aer.

$$
7
$$

$7,68-72 \quad 390$

$7-8 \quad 280$

$8 \quad 379,38 \mathrm{I}, 408$

$8,6 \quad 398$

De diaet. in morb. ac. 7 (3, 5-I4 Littré) 77

De flat.

$7 \quad 382$

De prisc. med. I8-I9 307

De sem., de nat. pu., de morb.

$4,20,30-33 \quad 466$

De superfetat.

I8

De victu

$2,40 \quad 425$

45, 7-IO $\quad 390$

56, Iff. $\quad 390$

Epid.

6, 2, 5 (5, 278-280 Littré)

Prorrh.

77

2, $43 \quad 402$

Hippolytus

Haer.

$5,20,5$

\section{Homer}

Il.

$\begin{array}{ll}2,825 & 486 \\ 6, \mathrm{I} 36 & 4 \mathrm{IO} \\ 9, \mathrm{I} 4 & 486 \\ 9,2 \mathrm{I} 4 & \mathrm{I} 54,372 \\ 9,539 & 277,443 \\ \mathrm{I} 3,279 & \mathrm{II} 9,277,432 \\ \mathrm{I} 3,284-285 \mathrm{a} & 432 \\ \mathrm{I} 9,4 \mathrm{I} 5 & 278 \\ \mathrm{I} 9,4 \mathrm{I} 5-4 \mathrm{I} 6 & 275,475 \\ 23,200 & 475 \\ 24,80-82 & 426\end{array}$

od.

$\begin{array}{ll}4,359 & 486 \\ 4,567 & 447,475 \\ 5,322-323 & 277,400 \\ \text { I9, } 446 & 277,438 \\ \text { 20, I58 } & 486 \\ \text { Hymn. Dem. } & \\ 6-8 & 449 \\ \text { I7 } & 449\end{array}$

Hyginus Mythographus

Fab.

I46 449

\section{Inscriptions}

I.Eph. VII, 2, 390I 286

I.G. $\mathrm{II}^{2}, 38 \mathrm{I} 6 \quad 286$

\section{Isidorus Hispalensis}

Et.

$$
\text { I2, 2, } 24
$$

\section{Isocrates}

Panath.

$\begin{array}{cc}\text { I35 } & 236 \\ \text { Paneg. } & \\ \text { I } 88 & 236 \\ \text { Hel. } & \\ \text { I2 } & 236\end{array}$

\section{Lucretius}

De rer. nat.

$\begin{array}{ll}2,474 & 400 \\ 2, \text { I030-I039 } & 462 \\ 4,678-680 & 456\end{array}$


5,269 ff. $\quad 400$

$5,526-532 \quad 347$

$6,357-378 \quad 392$

$6,635 \mathrm{ff}$.

$6,840-847$

400

420

Macrobius

Sat.

$7,3,23$

200

\section{Manetho}

FGrHist

609, I9-22

62

\section{Martialis}

Spect.

22

33I

\section{Mnesitheus of Athens \\ Fr. Bertier \\ I6}

282,457

\section{Moschus \\ Epit. Bionis}

I2 I

\section{Oenopides of Chios \\ Fr. DK}

4IAII

420

\section{Olympiodorus}

Comm. in Ar. Mete.

I58, $27 \mathrm{ff}$.

400

\section{Oppian}

Hal.

$$
\text { I, 429-432 }
$$

$5,638-648$

428

417

\section{Orpheus \\ Fr. Kern \\ I68}

263

Palladius

Op. agr.

$\begin{array}{ll}\text { I, } 37,4-5 & 480 \\ 4,9, \mathrm{I} 4 & 490 \\ 4, \mathrm{I} 5,4 & 480\end{array}$

II, I4 409

II, I7 409

II, 2I 409

Papyri

P. Antinoopolis 85 I8I

P. Antinoopolis 2I3 I8I

P. Berol. Inv. 9764, I7-I8

PL III 543A I8I

P. Oxy. 2688-2689 I8I

P. Oxy. $2744 \quad$ I8I

PSI inv. 2055 I8I

\section{Pausanias}

Graec. descr.

$\begin{array}{ll}\mathrm{I}, 32, \mathrm{I} & 33 \mathrm{I} \\ 3,20,4 & 33 \mathrm{I} \\ 7, \mathrm{I} 8, \mathrm{I} 2 & 33 \mathrm{I} \\ 8,23,9 & 33 \mathrm{I}\end{array}$

Petronius

Sat.

$66,5-6 \quad 446$

Philochorus

FGrHist

328, I9I 4 IO

\section{Philolaus}

Fr. DK

$$
\text { 44A7a }
$$

\section{Photius}

Bibl.

Cod. I75, II9b 99

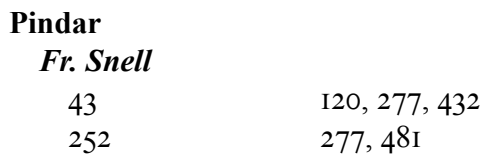

\section{Plato (and corpus Platonicum)} Apo.

$\begin{array}{ll}\text { I9b } & \text { I8 } \\ 26 \mathrm{~d} & \mathrm{I} 8 \\ 27 \mathrm{a} & 90\end{array}$


Charm.

$\begin{array}{cc}\begin{array}{l}\text { I64e-I65a } \\ \text { Crat. }\end{array} & 320 \\ \text { 402a } & \\ \text { Epinom. } & 379 \\ \text { 98Ic } & \\ \text { 98Id } & 30 \mathrm{I} \\ \text { 984a } & 370 \\ \text { Leg. } & 229 \\ 639 \mathrm{~b} & \\ 666 \mathrm{a} & 4 \mathrm{I} 2 \\ \text { Men. } & 467 \\ 76 \mathrm{c} & \\ \text { Ped. } & 309\end{array}$

Phd.

$74 a$
$95 \mathrm{e}-99 d$
$96 \mathrm{a}$
$97 \mathrm{~b}-99 d$
II $2 \mathrm{ac}$

Phdr.

229e

$230 d$

$249 \mathrm{c}$

$250 d$

$270 a$

Philebus

$55 \mathrm{e}$
Pol.

285d

Prot.

334b

Rep.

4oIcd

469e

49Ib-492a

49Id

$495 \mathrm{~b}$

$527 \mathrm{~b}$

$53 \mathrm{ob}$

$53 \mathrm{IC}$

$532 \mathrm{bc}$

$546 \mathrm{a}$

$603 \mathrm{ab}$

607 be

Soph.

2I $8 d$

$245^{b}$

26Ia
320

379

301

370

229

$4 \mathrm{I} 2$

467

309

90

I8

5 , I 28

262

380

320

I8

317

265

II3

3II

77

372

277

482

I43

28I, 370

I43

$3 \mathrm{I} 7$

77

77

$3 \mathrm{I} 7$

28I, 370

277

277

448

77

77,448
Symp.

$\begin{array}{cl}\text { I77b } & 236 \\ \text { Tht. } & \\ \text { I55d } & 243 \\ \text { I62e } & \text { I9, 90 } \\ \text { I80c } & 77\end{array}$

Tim.

27d-28a $\quad 3$ I3

$28 \mathrm{a} \quad 3 \mathrm{I} 3$

$28 \mathrm{c} \quad 262,267$

29a 262

29d $3 \mathrm{I} 3$

29e 262

30a 262

$30 \mathrm{2} \quad 256$

$33 \mathrm{a} \quad 462$

46ce 262

$47 \mathrm{ab} \quad 265$

$47 \mathrm{e} \quad 262$

48a I36, 262

$52 \mathrm{a} \quad 3 \mathrm{I} 3$

$53 \mathrm{~b} \quad 262$

$55 \mathrm{~cd} \quad \mathrm{I} 70$

59e 28I, 304, 399

6ode $\quad 374$

$65 \mathrm{de} \quad 28 \mathrm{I}, 4 \mathrm{OI}$

$67 \mathrm{~b} \quad \mathrm{I} 47$

$68 \mathrm{e} \quad 227,262$

$70 \mathrm{c} 3 \mathrm{I} 3$

$76 \mathrm{~d} \quad 262$

$77 \mathrm{ab} \quad 370$

$79 \mathrm{a}-8 \mathrm{oc} \quad 309$

$79 \mathrm{e}-8 \mathrm{oc} \quad \mathrm{I} 83,355,435$

$80 \mathrm{c} \quad 256,435$

$83 \mathrm{c} \quad 374$

$86 \mathrm{~b} \quad \mathrm{I} 29$

9oa 28I, 370

9Ia 3 I3

$92 \mathrm{c} \quad 229,3 \mathrm{I} 3$

Plautus

Rudens

$588 \quad 410$

\section{Plinius Maior}

NH
2, $\mathrm{I} 35^{-\mathrm{I}} 36$
392
2,222
408 
2, 224

2, 226

2, 234

4, 79

$6,5 \mathrm{I}$

7,64

8,83

8,98

8 , IOI

$8, \mathrm{I} 22$

$8, \mathrm{I} 28$

$8, \mathrm{I} 30$

8,205

8,207

$8,2 \mathrm{I} 2$

9,83

9,84

9,87

IO, I85

II, I6

II, 44

II, 45

II, 6I

II, 224-225

I3, I35

I3, I39-I42

I4, 73-75

I4, 78

I4, 83

I4, I 20

I4, I26

I5, 79-8I

I5, I06 ff.

I6, 222

I6, 223

I7, 234

I7, 225

I8, 9I

I8, I52

I8, 275

I8, 36I

I9, I56

20, I69

25, 9I

27, 7

28, 79

28,247

29, I33
372,400

374

406, 4I7, 4I9

408

408

480

484

456

456

436

446

$33 \mathrm{I}$

44I

438

44I

428

428

43I

390

478

480

477

480

432

374

374

409

409

458, 459

409

409

49I

397

47I

47I

372

403

403

372

403

$385,427,428$

490

456

456

456

480

457

456
3I, 3 I

3I, 33

3I, 34

3I, 48

3I, 50

3I, 52

3I, 56

3I, 70

$32, \mathrm{I} 5$

$32, \mathrm{I} 49$

$36, \mathrm{I} 25$

378,380

403

$38 \mathrm{I}$

400

420

408

406

400

428

427

IO9

\section{Plinius Minor}

Ep.
$3,5,17$
I79
$8,20, \mathrm{I}-2$
462

Plutarch (and corpus Plutarcheum)

MORALIA

De aud. poet.

$\begin{array}{ll}\text { I6A } & 276 \\ \text { I6C } & 274,277,326 \\ \text { I7DE } & 277 \\ \text { I7DF } & 268 \\ 26 \mathrm{~B} & 7 \mathrm{I} \\ 28 \mathrm{~A} & 293 \\ 28 \mathrm{E} & 75 \\ 3 \mathrm{IE} & 206,293\end{array}$

De aud.

$42 \mathrm{~A} \quad$ I9I

$42 \mathrm{C}$ III, 477

42E-44A $\quad$ I93

$42 \mathrm{~F} \quad \mathrm{I} 93$

43A I98, 206

43C I94, 3I2, 443

44BC 243

$44 \mathrm{~F} \quad 236$

47B 206

48BC $\quad$ 194, 298

$48 \mathrm{C} \quad 296$

De ad. et am.

$\begin{array}{ll}49 \mathrm{AB} & 3 \mathrm{I} 9 \\ 5 \mathrm{ID} & 433 \\ 5 \mathrm{ID}-53 \mathrm{D} & \mathrm{I} 38,429 \\ 53 \mathrm{D} & 436 \\ 6 \mathrm{IA} & 467 \\ 65 \mathrm{E} & 3 \mathrm{I} 9\end{array}$




\begin{tabular}{|c|c|c|c|}
\hline De ad. et am. (cont) & & $\mathrm{I} 42 \mathrm{~F}-\mathrm{I} 43 \mathrm{~A}$ & 307 \\
\hline $66 \mathrm{CD}$ & 253 & $\mathrm{I} 43 \mathrm{~F}$ & 467 \\
\hline $7 \mathrm{OE}$ & 29 & I44D & $\mathrm{I} 22, \mathrm{I} 27, \mathrm{I} 38,479$ \\
\hline 7IA & 292 & Sept. sap. conv. & \\
\hline $72 \mathrm{~A}$ & 320 & $\mathrm{I} 46 \mathrm{E}$ & I95 \\
\hline De prof. in virt. & & $\mathrm{I} 47 \mathrm{C}$ & 483 \\
\hline $75 \mathrm{~F}$ & $3 \mathrm{I} 3$ & $\mathrm{I} 47 \mathrm{EF}$ & 222 \\
\hline $78 \mathrm{E}$ & $\mathrm{II} 2, \mathrm{II} 3$ & I $49 \mathrm{CE}$ & 260 \\
\hline De cap. ex inim. & & $\mathrm{I} 53 \mathrm{E}-\mathrm{I} 54 \mathrm{~A}$ & 76 \\
\hline $86 \mathrm{E}$ & $37 \mathrm{I}, 389$ & I54DF & 202 \\
\hline $89 \mathrm{~A}$ & 319 & $156 \mathrm{D}$ & 204 \\
\hline $90 \mathrm{C}$ & $7 \mathrm{I}$ & I63D & $238,319,428$ \\
\hline $92 \mathrm{~B}$ & I2I, 138,490 & I63EF & I26, 268 \\
\hline De am. mult. & & I64B & 319 \\
\hline $96 \mathrm{~F}$ & $\mathrm{I} 2 \mathrm{O}, \mathrm{I} 2 \mathrm{I}, \mathrm{I} 39,429$ & De sup. & \\
\hline & $432,433,436$ & I64E & 253 \\
\hline $96 \mathrm{~F}-97 \mathrm{~A}$ & I38, 433 & I65C & 253 \\
\hline De fortuna & & I69AB & I43 \\
\hline $98 \mathrm{BC}$ & $\mathrm{I} 47,328$ & I69EF & 258 \\
\hline Cons. ad Apoll. & & $\mathrm{I} 69 \mathrm{~F}$ & 253 \\
\hline II6D & 319 & I7IAB & 253 \\
\hline II9D & I 28 & I7IF & 254 \\
\hline I2IE & I68 & Reg. et imp. apophth. & \\
\hline De tuenda & & $\mathrm{I} 72 \mathrm{BE}$ & I67 \\
\hline $\mathrm{I} 22 \mathrm{~F}$ & I96 & Mul. virt. & \\
\hline $\mathrm{I} 23 \mathrm{~A}$ & 447 & $243 \mathrm{~A}$ & I67 \\
\hline $\mathrm{I} 23 \mathrm{E}$ & 467 & $253 \mathrm{E}$ & IOO \\
\hline $\mathrm{I} 26 \mathrm{C}$ & 442 & $254 \mathrm{EF}$ & 489 \\
\hline $\mathrm{I} 29 \mathrm{~F}$ & 357 & Quaest. Rom. & \\
\hline $\mathrm{I} 30 \mathrm{~A}$ & I96, 22I & $263 \mathrm{E}$ & I83 \\
\hline I3OBD & 197 & $264 \mathrm{~B}$ & I83 \\
\hline I3OD & 199 & $265 \mathrm{~B}$ & 489 \\
\hline $\mathrm{I} 3 \mathrm{OF}$ & 197 & $267 \mathrm{E}$ & 343 \\
\hline I3OF-I3IA & 197 & $268 \mathrm{CD}$ & I83 \\
\hline I3IA & I99 & $269 \mathrm{CD}$ & I83 \\
\hline I33B & 220 & $269 \mathrm{~F}$ & I48 \\
\hline $\mathrm{I} 33 \mathrm{BF}$ & 197 & $270 \mathrm{~B}$ & 343 \\
\hline $\mathrm{I} 33 \mathrm{C}$ & I98, I99, 200 & $27 \mathrm{IF}-272 \mathrm{~B}$ & I48 \\
\hline $\mathrm{I} 33 \mathrm{CE}$ & 339 & 27ID & I48 \\
\hline I33DF & 198 & $273 \mathrm{E}$ & I83, 343 \\
\hline I33E & I06, II9, I99, 200, & $275 \mathrm{C}$ & 343 \\
\hline & $206,209,2 \mathrm{II}$ & $275 \mathrm{E}$ & 343 \\
\hline & $232,322,35 \mathrm{I}, 360$ & $276 \mathrm{E}$ & 26 \\
\hline & 493 & 277D & 343 \\
\hline $\mathrm{I} 33 \mathrm{~F}-\mathrm{I} 34 \mathrm{~A}$ & 197 & 279DE & I69 \\
\hline Coni. praec. & & $279 \mathrm{E}$ & 343 \\
\hline $\mathrm{I} 38 \mathrm{C}$ & I68 & $279 \mathrm{~F}$ & 343 \\
\hline I39D & 476 & $28 \mathrm{OE}$ & 343 \\
\hline
\end{tabular}




$\begin{array}{ll}28 \mathrm{IF} & \mathrm{I} 69,343 \\ 282 \mathrm{CD} & \mathrm{I} 83 \\ 282 \mathrm{EF} & \mathrm{I} 83 \\ 283 \mathrm{~A} & 343 \\ 283 \mathrm{C} & 293 \\ 285 \mathrm{BC} & \mathrm{I} 48 \\ 286 \mathrm{~B} & 343 \\ 288 \mathrm{~B} & \mathrm{I} 83,343 \\ 288 \mathrm{C} & \mathrm{I} 83 \\ 289 \mathrm{C} & \mathrm{I} 83 \\ 290 \mathrm{AB} & \mathrm{I} 83 \\ 29 \mathrm{IA} & 343\end{array}$

Quaest. Graec.

$\begin{array}{ll}292 \mathrm{CD} & \text { I83 } \\ 292 \mathrm{E} & \text { I83 } \\ 293 \mathrm{~A} & \mathrm{I} 83\end{array}$

Parall. Graec. et Rom.

\begin{tabular}{|c|c|}
\hline $3 \mathrm{I} 5 \mathrm{CD}$ & 76 \\
\hline \multicolumn{2}{|c|}{ De fort. Rom. } \\
\hline $323 \mathrm{C}$ & 463 \\
\hline $326 \mathrm{~A}$ & I67 \\
\hline \multicolumn{2}{|c|}{ De Al. Magn. fort. } \\
\hline $328 \mathrm{~A}$ & I67, I96 \\
\hline \multicolumn{2}{|c|}{ Bellone an pace } \\
\hline $35 \mathrm{ODE}$ & II 2 \\
\hline \multicolumn{2}{|c|}{ De Is. et Os. } \\
\hline $35 \mathrm{IC}$ & 268 \\
\hline $35 \mathrm{ICD}$ & 266 \\
\hline $352 \mathrm{D}$ & 388 \\
\hline $352 \mathrm{~F}$ & I 49,389 \\
\hline $353 \mathrm{~F}$ & 403 \\
\hline $355 \mathrm{D}$ & 253 \\
\hline $364 B$ & $337,467,486$ \\
\hline $367 \mathrm{E}$ & $45 \mathrm{I}$ \\
\hline $372 \mathrm{~F}$ & 258 \\
\hline $375 \mathrm{C}$ & $7 \mathrm{I}$ \\
\hline $376 \mathrm{~B}$ & 435 \\
\hline $378 \mathrm{~A}$ & 253 \\
\hline $379 \mathrm{E}$ & 253 \\
\hline 38IB & 268 \\
\hline $382 \mathrm{AB}$ & $66, \mathrm{I} 25,268$ \\
\hline $382 \mathrm{D}$ & $7 \mathrm{I}$ \\
\hline
\end{tabular}

De $E$

$\begin{array}{ll}384 \mathrm{E} & \text { I77, I79 } \\ 385 \mathrm{~A} & \text { I9I } \\ 385 \mathrm{AB} & \text { I93 } \\ 385 \mathrm{~B} & 28 \\ 385 \mathrm{C} & 243\end{array}$

$\begin{array}{ll}385 \mathrm{D} & 3 \mathrm{I} 9 \\ 386 \mathrm{~B} & \mathrm{I} 34 \\ 386 \mathrm{E} & 3 \mathrm{I} \\ 386 \mathrm{~F} & 462 \\ 387 \mathrm{~A} & 339,443 \\ 387 \mathrm{~B} & 346 \\ 387 \mathrm{~F} & 3 \mathrm{OO}, 3 \mathrm{I} 9 \\ 389 \mathrm{~F} & 7 \mathrm{I} \\ 389 \mathrm{~F}-39 \mathrm{~A} & 3 \mathrm{I} \\ 39 \mathrm{IE} & 28 \\ 392 \mathrm{~A} & 28,3 \mathrm{I} 9 \\ 392 \mathrm{AE} & 28 \\ 392 \mathrm{~B} & 379 \\ 392 \mathrm{E} & 3 \mathrm{I} 8 \\ 393 \mathrm{~A} & 3 \mathrm{I} 8 \\ 393 \mathrm{D} & 3 \mathrm{I} 7 \\ 394 \mathrm{C} & 3 \mathrm{I} 9\end{array}$

De Pyth. or.

394E I34

395A-396C 50, I33, I34

$395 \mathrm{~F} \quad 83,9 \mathrm{I}$

396AC I34

$396 \mathrm{E} \quad 343$

397DE I34

399A 448

400B $\quad 370$

$400 \mathrm{C} \quad 384$

4OODE I34

4OOF-4OIA I34

4OIE I34

$402 \mathrm{E} 24 \mathrm{O}$

402BC I34

$404 \mathrm{~B}-405 \mathrm{~A} \quad \mathrm{I} 26$

$406 \mathrm{E} \quad$ III

$408 \mathrm{E} \quad 319$

409CD 226, 227, 463

De def. or.

4IOB-4IID I33, I35

4IID 238

4IIEF 67

4I2D $\quad$ I96

4I4A 293

$420 \mathrm{C} \quad 238$

42IE 286

42IE-43IA $\quad$ I7O

424B $\quad \mathrm{BO} 3$

424C $\quad 300,325$

424D 309 
De def. or. (cont.) 426D $426 \mathrm{DE}$

430A-43IA

$43 \mathrm{OE}$

430E-43IA

43 IA

$433 \mathrm{~F}$

$435 \mathrm{~F}$

$435 \mathrm{~F}-436 \mathrm{~A}$

$436 \mathrm{D}$

$436 \mathrm{DE}$

$436 \mathrm{E}$

$437 \mathrm{C}-438 \mathrm{D}$

$438 \mathrm{D}$

$438 \mathrm{CD}$

De virt. mor.

$44 \mathrm{OE}$

$45 \mathrm{IC}$

$452 \mathrm{~A}$

De coh. ira

457D

457DE

$458 \mathrm{~F}-459 \mathrm{~A}$

46IF-462A

De tranq. an.

$464 \mathrm{E}$

$464 \mathrm{E}-465 \mathrm{~A}$

$464 \mathrm{~F}$

$467 \mathrm{C}$

472D

$475 \mathrm{EF}$

$475^{\mathrm{F}}-476 \mathrm{~A}$

$477 \mathrm{CD}$

De am. prol.

493A-495A

493B

De gar.

503A

5 IIB

5I4D

De cur.

$5 \mathrm{I} 5 \mathrm{C}$

$5 \mathrm{I} 7 \mathrm{CE}$

5I7D

$5 \mathrm{I} 8 \mathrm{D}$

$520 \mathrm{~F}$
462

I23, 255

$30 \mathrm{I}$

258

267

319

$46 \mathrm{I}$

IO3

26I, 263

IO3

262, 264

354

I34, 302

$3 \mathrm{I} 5$

302

I93, 292

407

432

I68

I68

82

279

I66, I78

I65, I66, I72

I05, I66, I67, I68,

I69, I70, I78

483

283

$4 \mathrm{I} 3$

I3 8

228, 23I, 266

I24

I24, I25

489

319

I38, 482

274

230

264,268

285

449
De vit. pud.

$534 \mathrm{~F}$

II 2

De se ipsum laud.

544A

29I

De sera num.

$548 \mathrm{AB}$

I95

$55 \mathrm{ODE}$

265

$556 \mathrm{~F}-557 \mathrm{~F} \quad 272$

$558 \mathrm{E} \quad \mathrm{I} 36$

$559 \mathrm{C} \quad 379$

$563 \mathrm{~B}-568 \mathrm{~A} \quad 27 \mathrm{I}$

$563 \mathrm{~F}-564 \mathrm{~A} \quad 463$

$565 \mathrm{C} \quad 436$

De fato

$568 \mathrm{~F}$

I06

De genio Socr.

$588 \mathrm{E}$

I47

59IC

270

59IDE

370

De exilio

$600 \mathrm{~F}$

370

60IA

463

Cons. ad ux.

6IOC

467

Quaest. conv.

6I2D 204

6I2DE

I52, I62, I65

$6 \mathrm{I} 2 \mathrm{E}$

29, I00, I56, I60,

I62, I72, 200, 203

6I3C I9I

6I3D 202

6I3E

$6 \mathrm{I} 3 \mathrm{~F}$

I99, 20I, 202, 359

I9I

I52, 20I, 204, 209,

267

6I4C 20I

6I4CD

339

6I4D

6I4DE

200, 202, 206

$35 \mathrm{I}$

6I4E

$6 \mathrm{I} 4 \mathrm{~F}$

200, 20I, 206, 359

$20 \mathrm{I}$

$6 \mathrm{I} 5 \mathrm{~B}$

20I, 206

$6 \mathrm{I} 5 \mathrm{C}$

I60

$615 \mathrm{CD}$

203

6I6F 202

6I9BF I64

620A I64

620A-622B $\quad 193$ 


\begin{tabular}{|c|c|c|c|}
\hline $620 \mathrm{E}$ & 307 & $643 \mathrm{AB}$ & 202 \\
\hline 62IA & 202 & $643 \mathrm{C}$ & 202 \\
\hline $62 \mathrm{IB}$ & 202 & $644 \mathrm{D}$ & 202 \\
\hline $62 \mathrm{IC}$ & 204 & $645 \mathrm{C}$ & I6o \\
\hline $62 \mathrm{IDE}$ & I95 & $645 \mathrm{D}-646 \mathrm{~A}$ & I92 \\
\hline 623D & 97 & $645^{D}-649 \mathrm{~F}$ & 28 \\
\hline $625 \mathrm{AC}$ & I64 & $646 A$ & $28,22 \mathrm{I}$ \\
\hline $625 \mathrm{C}$ & 293 & $646 \mathrm{~B}$ & 203 \\
\hline $626 \mathrm{D}$ & 307 & $647 \mathrm{E}$ & 449 \\
\hline $626 \mathrm{EF}$ & 285 & $648 \mathrm{CD}$ & I 44,424 \\
\hline $626 \mathrm{E}-627 \mathrm{~F}$ & 360 & $648 \mathrm{D}$ & 307,467 \\
\hline $626 \mathrm{~F}$ & 285,326 & $649 \mathrm{~A}$ & 28 \\
\hline $627 \mathrm{AB}$ & $37 \mathrm{I}$ & $649 \mathrm{CD}$ & 466 \\
\hline $627 \mathrm{AC}$ & 399 & $649 \mathrm{D}$ & $308,309,468$ \\
\hline $627 \mathrm{AD}$ & $25, \mathrm{I} 39,370$ & 649EF & I44 \\
\hline $627 \mathrm{~B}$ & 325 & $650 \mathrm{~A}$ & 82 \\
\hline $627 \mathrm{BC}$ & 374 & $65 \mathrm{IA}$ & 388 \\
\hline $627 \mathrm{C}$ & 373 & $65 \mathrm{IC}$ & 326 \\
\hline $627 \mathrm{D}$ & 372 & $65 \mathrm{IE}$ & 479 \\
\hline $627 \mathrm{E}$ & 275 & $65 \mathrm{IF}$ & 296 \\
\hline $627 \mathrm{EF}$ & $89,372,488$ & $652 B$ & 305 \\
\hline 628BD & 244 & $652 \mathrm{~B}-653 \mathrm{~B}$ & $4 \mathrm{IO}$ \\
\hline $628 \mathrm{D}$ & $22 \mathrm{I}$ & $652 \mathrm{~F}$ & $4 \mathrm{II}, 466$ \\
\hline $629 A$ & 324 & $653 B$ & 296 \\
\hline $629 \mathrm{C}$ & 222 & $654 \mathrm{D}$ & 265 \\
\hline \multirow[t]{2}{*}{ 629D } & 98, I00, I60, I62, & $654 \mathrm{E}$ & 64 \\
\hline & I65 & $655^{D}-656 \mathrm{~B}$ & 294 \\
\hline $629 \mathrm{E}$ & I56 & $656 \mathrm{~A}$ & 293 \\
\hline $629 \mathrm{E}-634 \mathrm{~F}$ & I64 & $656 \mathrm{~B}$ & 326 \\
\hline $629 \mathrm{~F}$ & I95 & $656 \mathrm{C}$ & 72,489 \\
\hline $634 \mathrm{~F}$ & 204 & $656 \mathrm{D}$ & 293 \\
\hline $635 \mathrm{C}$ & 302 & $657 \mathrm{~B}$ & 202 \\
\hline $635 \mathrm{CD}$ & 89 & $657 \mathrm{BE}$ & $33 \mathrm{I}$ \\
\hline 637D & 357 & $657 \mathrm{E}$ & $27 \mathrm{I}$ \\
\hline $640 \mathrm{C}$ & 372 & $657 \mathrm{~F}-659 \mathrm{D}$ & I39 \\
\hline $640 F-64 I A$ & $375,465,47 \mathrm{I}$ & $658 \mathrm{~B}$ & II6, 290, 45I \\
\hline 64IAE & 352 & $658 \mathrm{C}$ & $45^{8}$ \\
\hline $64 \mathrm{IB}$ & 256 & $659 \mathrm{~B}$ & $\mathrm{I} 4 \mathrm{O}, 45^{2}$ \\
\hline \multirow[t]{2}{*}{ 64IC } & 4I, 247, 3I3, 3I4, & $659 \mathrm{C}$ & 403 \\
\hline & 335,435 & $660 \mathrm{AB}$ & 204 \\
\hline 64ICE & 208 & $660 \mathrm{C}$ & 202 \\
\hline 64ID & $45^{8}$ & 660D & I56, I60, I96 \\
\hline $64 \mathrm{IF}-642 \mathrm{~B}$ & 352 & 66IBC & I39 \\
\hline $642 \mathrm{~A}$ & 293 & 66IBD & 380 \\
\hline $642 \mathrm{AB}$ & 208 & $662 \mathrm{D}$ & 326 \\
\hline $642 \mathrm{C}$ & 447 & 663B & 380 \\
\hline $642 \mathrm{BC}$ & I49 & $663 \mathrm{~F}$ & I39 \\
\hline $643 \mathrm{~A}$ & 202 & $664 \mathrm{~A}$ & I73 \\
\hline
\end{tabular}


Quaest. conv. (cont.)

$664 \mathrm{~A}-665 \mathrm{~A}$

$664 \mathrm{~A}-666 \mathrm{D}$

664B

664B-665A

664BC

$664 \mathrm{C}$

664CD

664D

664DE

664D-665A

664D-665C

664E

$665 \mathrm{~A}$

$665 \mathrm{C}$

$665 \mathrm{CD}$

$665 \mathrm{E}$

666A

$667 \mathrm{C}-669 \mathrm{E}$

668D

669 B

$670 \mathrm{~B}$

$670 \mathrm{~F}$

$67 \mathrm{IBC}$

$672 \mathrm{C}$

672D-673A

673A

673D-674C

$673 \mathrm{E}$

674E-675D

$675 \mathrm{~B}$

$675 \mathrm{DC}$

$675 \mathrm{EF}$

$676 \mathrm{~B}$

$677 \mathrm{E}-678$ в

$679 \mathrm{DE}$

$68 \mathrm{OCD}$

680D

680F-68IA

68IA

68IC

68IDE

$682 \mathrm{~A}$

682B

$682 \mathrm{BC}$

683D

$683 \mathrm{E}$

$684 \mathrm{~A}$
206, 228, 257

24I

378, 393

208, 209

463

24I, 247, 489

257

$25,222,324$

36I, 39I, 392, 393

206, 208

I39

37I, 399, 468

207, 209, 267

I58, I59, 24I, 489

488

224

I39

344

222

389

206

403

$27 \mathrm{I}$

$33 \mathrm{I}$

200

203

89

477

89

I77

29I

I34

38I, 392

89

$27 \mathrm{I}$

242,340

237, 245, 249

3 IO

443

I 44

483

222

293

293

382

II5, 274

389
$684 \mathrm{C}$

684D

684E

$684 \mathrm{E}-685 \mathrm{~F}$

$684 \mathrm{~F}$

$684 \mathrm{~F}-685 \mathrm{~A}$

$685 \mathrm{~A}$

$685 \mathrm{AB}$

685B

$685 \mathrm{BC}$

$685 \mathrm{BD}$

$685 \mathrm{C}$

685D

$685 \mathrm{DE}$

685DF

$685 \mathrm{EF}$

686D

$686 \mathrm{E}$

$687 \mathrm{BC}$

687D

$687 \mathrm{DE}$

$687 \mathrm{E}$

$688 \mathrm{~A}$

$689 \mathrm{AB}$

689B

$689 \mathrm{BC}$

$689 \mathrm{C}$

$689 \mathrm{E}-690 \mathrm{~B}$

690A

690в

690DE

$690 \mathrm{~F}$

690F-69IC

69ID-692A

$692 \mathrm{E}$

$693 \mathrm{E}-695 \mathrm{E}$

694B

694D

694DE

$695 \mathrm{E}$

$696 \mathrm{AB}$

696в

696EF

$697 \mathrm{~A}$

697B

697D

697DE
374, 399

490

I39, I58, I73

I56, I57, 267, 372

275

I58

390

I58

388,389

372, 4II, 489

I39

489

$25,2 \mathrm{I} 4$

9I, I54, 205, 390,

398

I54

I56, 27I

I52, I62, I65, I95

I60

309

388

325,456

389

456

309

IO4, 3IO

309

363,388

83

389,390

474

89

82,247

89

89

36I

I4I, I49

222, 4I2

295,326

308

I39

$4 \mathrm{I} 7$

$4 \mathrm{I} 4$

49I

374

389,425

20I, 372

202 


\begin{tabular}{|c|c|c|c|}
\hline $697 \mathrm{E}$ & I56 & $7 \mathrm{I} 8 \mathrm{E}$ & $3 \mathrm{I} 2$ \\
\hline $697 \mathrm{~F}$ & 170 & $7 \mathrm{I} 8 \mathrm{EF}$ & $260,3 \mathrm{I} 7$ \\
\hline $697 \mathrm{~F}-700 \mathrm{~B}$ & I7I, 3 I4 & $7 \mathrm{I} 9 \mathrm{EF}$ & 222 \\
\hline $698 \mathrm{~A}$ & 276 & $720 \mathrm{~B}$ & 262 \\
\hline 698в & 262 & $720 \mathrm{C}$ & $29,27 \mathrm{I}$ \\
\hline 698D & 389 & $720 \mathrm{C}-722 \mathrm{~F}$ & 28 \\
\hline $698 \mathrm{E}$ & 242 & $720 \mathrm{E}$ & $227,300,301$ \\
\hline $698 \mathrm{EF}$ & 275 & $72 \mathrm{IEF}$ & $\mathrm{I} 47,435$ \\
\hline 699A & 275 & $72 \mathrm{IF}$ & 357 \\
\hline 699AB & 388 & $722 \mathrm{E}$ & 350 \\
\hline 699в & $267,274,354,363$ & $723 \mathrm{~A}$ & $\mathrm{I} 73,203$ \\
\hline 699D & $3 \mathrm{I} 3,3 \mathrm{I} 4$ & $723 \mathrm{E}-724 \mathrm{D}$ & I34 \\
\hline $700 \mathrm{~B}$ & $7 \mathrm{I}, 74,314,328$ & $724 \mathrm{E}$ & $\mathrm{I} 35, \mathrm{I} 38,375,465$ \\
\hline $700 \mathrm{BC}$ & $\mathrm{I} 73$ & $724 \mathrm{EF}$ & I7I, I74, 469, 47I \\
\hline $700 \mathrm{C}$ & $85, \mathrm{I} 70$ & $725 \mathrm{C}$ & $3 \mathrm{I} 3$ \\
\hline \multirow[t]{2}{*}{ 700D } & I36, I75, 245, 247, & $725 \mathrm{CD}$ & $38 \mathrm{I}$ \\
\hline & 248 & 725D & 474,487 \\
\hline 700DE & I75 & $725 \mathrm{~F}$ & I73 \\
\hline $700 \mathrm{E}$ & $\mathrm{I} 74, \mathrm{I} 75,293$ & $727 \mathrm{~A}$ & I73 \\
\hline $700 E F$ & 330 & $728 \mathrm{~A}$ & 476 \\
\hline $700 F$ & $\mathrm{I} 74,438,49 \mathrm{I}$ & $728 \mathrm{E}$ & 213 \\
\hline 70IA & $\mathrm{I} 75,242,247$ & $728 \mathrm{~F}$ & 268 \\
\hline $70 I F$ & $305,326,410$ & $73 \mathrm{OB}$ & I7I \\
\hline $702 \mathrm{~A}$ & I9I & 73IA & 206,402 \\
\hline $702 \mathrm{BC}$ & $4 \mathrm{I} 4,4 \mathrm{I} 7$ & 733B & 374 \\
\hline $702 \mathrm{C}$ & 447 & 733D & 456 \\
\hline $702 \mathrm{D}$ & 220 & $734 \mathrm{CD}$ & 79, I60, 190, 196, \\
\hline 702Dff. & I69 & & 219,250 \\
\hline $704 \mathrm{C}-706 \mathrm{E}$ & $33 I$ & 734D & $292,295,462$ \\
\hline $705 \mathrm{~B}$ & I9I & $734 \mathrm{~F}$ & 69 \\
\hline $705 \mathrm{E}$ & I7I & $734 \mathrm{~F}-735 \mathrm{~A}$ & 296 \\
\hline $706 \mathrm{E}$ & I73, 224 & $735 \mathrm{C}$ & 296 \\
\hline 7IOC-7IIA & $33 \mathrm{I}$ & $736 \mathrm{C}$ & $76, \mathrm{I} 56, \mathrm{I} 6 \mathrm{0}, \mathrm{I} 74$ \\
\hline $7 \mathrm{I} 2 \mathrm{~A}$ & I96 & $736 \mathrm{D}$ & 29 \\
\hline $7 \mathrm{I} 3 \mathrm{C}$ & I9I & 737D & 76 \\
\hline $7 \mathrm{I} 3 \mathrm{~F}$ & $35 \mathrm{I}$ & $738 \mathrm{C}$ & 97 \\
\hline $7 \mathrm{I} 4 \mathrm{C}$ & $27 \mathrm{I}$ & 739D & $27 \mathrm{I}$ \\
\hline 7I6BC & 27I & $739 \mathrm{E}$ & $\mathrm{I} 70$ \\
\hline 7I6D & 203 & $740 \mathrm{~F}$ & I73 \\
\hline $7 \mathrm{I} 6 \mathrm{~F}$ & 202 & 74IB & $33 \mathrm{I}$ \\
\hline $7 \mathrm{I} 6 \mathrm{~F}-7 \mathrm{I} 7 \mathrm{~A}$ & $4 \mathrm{IO}$ & 74IC & 324 \\
\hline $7 \mathrm{I} 7 \mathrm{~A}$ & I6o, I73 & 74ID & 97 \\
\hline $7 \mathrm{I} 7 \mathrm{E}$ & $2 \mathrm{I} 3$ & $743 \mathrm{BC}$ & $27 \mathrm{I}$ \\
\hline 7I8AB & 27I & 744D & 300 \\
\hline $7 \mathrm{I} 8 \mathrm{~B}$ & I7O, 2II & $744 \mathrm{~F}$ & 286 \\
\hline $7 \mathrm{I} 8 \mathrm{C}$ & $2 \mathrm{I} 3,287,296$ & $745 \mathrm{~A}$ & 468 \\
\hline $7 \mathrm{I} 8 \mathrm{D}$ & 265 & $747 \mathrm{~A}$ & $27 \mathrm{I}$ \\
\hline 7I8DE & 229,300 & $747 \mathrm{~B}$ & 28 \\
\hline
\end{tabular}


Quaest. conv. (cont.)

$\begin{array}{cc}748 \mathrm{D} & 76, \mathrm{I} 62 \\ \text { Amatorius } & \\ 753 \mathrm{~A} & 49 \mathrm{I} \\ 756 \mathrm{~B} & 240 \\ 757 \mathrm{E} & 370 \\ 76 \mathrm{IA} & 489 \\ 76 \mathrm{IB} & 76,286 \\ 766 \mathrm{~A} & 226,227,463 \\ 767 \mathrm{~A} & 433 \\ \text { Maxime cum principibus } \\ \text { 776F-777A } & 135 \\ \text { Ad princ. iner. } & \\ 78 \mathrm{OD} & 463 \\ \text { 78IA } & 268\end{array}$

Praec. ger. reip.

$\begin{array}{ll}\text { 8OIA } & \text { I } 38,456 \\ 8 \mathrm{I} 6 \mathrm{DE} & 2 \mathrm{I} 7 \\ 82 \mathrm{IB} & 477\end{array}$

De Her. mal.

$$
855 \mathrm{EF}
$$$$
237
$$

Plac.

874D-9IIC

88 ов

900BD

$905 \mathrm{~A}$

909C

9Iов

Q.N.

(the list only includes separate discussions of the problem chapters in the commentary)
I, 9IICF
368-375
2, 9IIF-9I2D
$375-385$
3, 9I2DF
385-390
4, 9I2F-9I3A
390-394
5 , 9I3AE
394-40I
6, 9I3EF
4OI-404
7, 9I3F-9I4B
8 , 9I4B
9, 9I4BD
IO, 9I4DE
II, 9I4EF
I2, 9I4F-9I5B
I3, 9I5BC
I4, 9I5CD
I5, 9I5DE
I6, 9I5EF
404-406
406-407
407-408
409-4II
$4 \mathrm{II}-4 \mathrm{I} 3$
$4 \mathrm{I} 3-4 \mathrm{I} 8$
$4 \mathrm{I} 8-420$
$42 \mathrm{I}$
422-423
423-425

$\begin{array}{ll}\text { I7, 9I5F-9I6A } & 426 \\ \text { I8, 9I6AB } & 426-428 \\ \text { I9, 9I6BF } & 429-437 \\ 20,916 \mathrm{~F}-9 \mathrm{I} 7 \mathrm{~B} & 437-439 \\ \text { 2I, 9I7BD } & 439-445 \\ \text { 22, 9I7D } & 446-447 \\ 23,917 \mathrm{EF} & 448-449 \\ 24,917 \mathrm{~F}-9 \mathrm{I} 8 \mathrm{~A} & 450-452 \\ 25,918 \mathrm{AB} & 452-453 \\ 26,918 \mathrm{BE} & 454-457 \\ 27,9 \mathrm{I} 8 \mathrm{EF} & 457-459 \\ 28,918 \mathrm{~F}-9 \mathrm{I} 9 \mathrm{~A} & 459-460 \\ 29,919 \mathrm{AB} & 460-464 \\ 30,919 \mathrm{BC} & 464-465 \\ 3 \mathrm{I}, 919 \mathrm{CE} & 465-469 \\ 32 & 469-472 \\ 33 & 473-474 \\ 34 & 474-476 \\ 35 & 476-477 \\ 36 & 477-48 \mathrm{I} \\ 37 & 482-483 \\ 38 & 483-485 \\ 39 & 485-487 \\ 40 & 488-489 \\ 4 \mathrm{I} & 489-49 \mathrm{I}\end{array}$

\section{De facie}

920B-945E $6 \mathrm{I}$

922DE 486

$922 \mathrm{E}-923 \mathrm{~A} \quad 2 \mathrm{I} 6$

922 $\mathrm{F}-928 \mathrm{D} \quad 66$

923A $\quad 264$

923C 460

$927 \mathrm{CD} \quad 256$

928AC I43

929A 290, 45I

929B I9I

$930 \mathrm{C} \quad 324$

930F 305

93IB $\quad 487$

932BC $\quad 83$

932D $\quad 340$

933A 3 II3

933CD $\quad 324$

935DE $\quad 300$

937CD $\quad$ I95

938C 2I0, 246

939D 374

940A I39, I40, 452 


\begin{tabular}{|c|c|c|c|}
\hline $940 \mathrm{~F}-945 \mathrm{D}$ & $64,27 \mathrm{I}$ & $960 \mathrm{~B}$ & I95 \\
\hline $942 \mathrm{C}$ & I9I & 96IA & 68 \\
\hline De prim. frig. & & $962 \mathrm{~F}$ & 285 \\
\hline $945^{\mathrm{F}}$ & $66,267,303,357$ & 964D & I9I \\
\hline $945^{\mathrm{F}-948 \mathrm{~A}}$ & $69,357,462$ & $965 \mathrm{C}$ & 286 \\
\hline $946 \mathrm{~A}-948 \mathrm{~A}$ & I4I & $965 \mathrm{DE}$ & I93 \\
\hline $946 \mathrm{C}$ & 64 & $966 \mathrm{~B}$ & $\mathrm{I} 25$ \\
\hline 946DE & 307,308 & $966 \mathrm{D}$ & 448 \\
\hline $946 \mathrm{EF}$ & 266 & $967 \mathrm{AB}$ & 428 \\
\hline $946 \mathrm{~F}$ & 3I8 & $967 \mathrm{D}-968 \mathrm{~B}$ & 425 \\
\hline $947 \mathrm{E}$ & 301,302 & $967 \mathrm{E}$ & 285 \\
\hline $947 \mathrm{~F}$ & $286,306,34 \mathrm{I}$ & $967 \mathrm{~F}$ & 269 \\
\hline $948 B$ & 317 & 97ID & 453 \\
\hline $948 \mathrm{BC}$ & $205,229,3 \mathrm{I} 6,33 \mathrm{I}$ & 974B & 455 \\
\hline $948 \mathrm{C}$ & $283,3 \mathrm{I} 7$ & 974BD & I39 \\
\hline $948 \mathrm{CD}$ & 68,69 & $975 \mathrm{AC}$ & 268 \\
\hline $948 D$ & $64,3 \mathrm{I} 8$ & $975 \mathrm{~B}$ & $66, \mathrm{I} 25$ \\
\hline $948 \mathrm{E}$ & $4 \mathrm{I} 5$ & $975 \mathrm{DE}$ & $3 \mathrm{I} 3$ \\
\hline 949B & 309,442 & $976 \mathrm{C}$ & 268 \\
\hline $949 \mathrm{~F}$ & 69 & $976 \mathrm{E}-977 \mathrm{~A}$ & 27,425 \\
\hline $950 \mathrm{~A}$ & 337 & $976 \mathrm{EF}$ & 420 \\
\hline $950 \mathrm{AB}$ & $4 \mathrm{I} 5,486$ & $976 \mathrm{~F}$ & 420,426 \\
\hline \multirow[t]{2}{*}{$950 \mathrm{~B}$} & 70, I39, 4I5, 4I6, & $977 \mathrm{~A}$ & 426 \\
\hline & $4 \mathrm{I} 7$ & 977D & $33 \mathrm{I}$ \\
\hline $950 \mathrm{BC}$ & $329,4 \mathrm{I} 4,4 \mathrm{I} 5$ & $978 \mathrm{E}$ & 432,433 \\
\hline 95IA & 453 & $978 \mathrm{EF}$ & $27, \mathrm{I} 38, \mathrm{I} 39,425$, \\
\hline 95IBC & 420 & & $429,433,436$ \\
\hline 95ID & 301,306 & 979B & $27,425,428$ \\
\hline $95 \mathrm{IF}$ & 324 & $982 \mathrm{E}$ & 383,384 \\
\hline $952 \mathrm{~A}$ & 3I 8 & $982 \mathrm{~F}$ & $48 \mathrm{I}$ \\
\hline $952 \mathrm{~B}$ & 325 & Gryllus & \\
\hline $952 \mathrm{C}$ & 9I & 989c ff. & $\mathrm{I} 24$ \\
\hline $952 \mathrm{C}-955 \mathrm{C}$ & $293,46 \mathrm{I}$ & 99овС & 479 \\
\hline $952 \mathrm{D}$ & 319 & 99IE & I39, 456 \\
\hline $952 \mathrm{~F}$ & 486 & 99IEF & 455 \\
\hline $954 \mathrm{C}$ & $4 \mathrm{I} 2$ & $992 \mathrm{~A}$ & 483 \\
\hline $955 \mathrm{~A}$ & $30 \mathrm{I}$ & De esu & \\
\hline \multirow[t]{2}{*}{$955 \mathrm{C}$} & $\begin{array}{l}69,9 \mathrm{I}, 3 \mathrm{I} 5,3 \mathrm{I} 8, \\
320,327,328,\end{array}$ & $\begin{array}{c}\text { 997E } \\
\text { Quaest. Plat. }\end{array}$ & 432 \\
\hline & 344,348 & IOOOB & $2 \mathrm{I} 6$ \\
\hline Aqua an ignis & & IOOOE & I94 \\
\hline $957 \mathrm{~A}$ & $30 I$ & IOOOE-IOOIC & 178 \\
\hline $957 \mathrm{~B}$ & 267 & IOOID & 328 \\
\hline 957D & $38 \mathrm{I}, 474$ & IOO2E-IOO3B & 178 \\
\hline $958 \mathrm{E}$ & 64,265 & IOO3A & $\mathrm{I} 77,2 \mathrm{I} 3$ \\
\hline De soll. an. & & $\mathrm{IOO} 3 \mathrm{~B}-\mathrm{IOO} 4 \mathrm{C}$ & $\mathrm{I} 78$ \\
\hline 959в & 290 & I004D & 309,350 \\
\hline $959 \mathrm{C}$ & 23 & I004D-I006B & $\mathrm{I} 78$ \\
\hline
\end{tabular}


Quaest. Plat. (cont.)

$\begin{array}{ll}\text { IOO4DE } & 309 \\ \text { I004D-IO06B } & \text { I } 78, \text { I } 83,309 \\ \text { I004E } & 82,309 \\ \text { I005B } & 435 \\ \text { I005BD } & \text { I } 83,256,355,435 \\ \text { I005D } & 309,435 \\ \text { I005F } & 309 \\ \text { I006B-I007E } & \text { I78 } \\ \text { I006D } & 7 \mathrm{I} \\ \text { I006F } & \text { I05 }\end{array}$

De an. procr.

IOI2B

De Stoic. rep.

I033B

I035D

IO35F-I036A

IO4OA-I04IB

I04IA

I04IE

I045F

IO47CD

De comm. not.

го6ов ff.

I070C

IO7OF

I07ID

I072F

Non posse

I086D

IO86E

I09ID

I095CD

I096BC

I096C

Adv. Col.

$\begin{array}{ll}\text { IIO8B ff. } & \text { I92 } \\ \text { IIO8BC } & 283 \\ \text { III4C } & 328 \\ \text { III5B } & 68, \text { I67, 2I8 } \\ \text { III5C } & 246 \\ \text { III5E } & 3 I 7 \\ \text { III7D } & 320 \\ \text { III8C } & 319 \\ \text { II22F } & 328 \\ \text { II24A } & 344 \\ \text { II24B } & 320 \\ \text { II24C } & 7 I, 283\end{array}$

De lat. viv.

$\begin{array}{ll}\text { II29B } & \text { I22, I23, I24 } \\ \text { II29D } & 38 \text { I, } 474\end{array}$

Pars an fac.

2, I6-I7 $\quad 357$

6, I5-I7 $\quad 357$

\section{Fr. Sandbach}

$\begin{array}{ll}24 & 269 \\ 40 & 269 \\ 42 & 275 \\ 43 & 274 \\ 45 & 344 \\ 5 \mathrm{I} & 62 \\ 62 & \mathrm{I} 54 \\ 63 & 320 \\ 99 & 62 \\ \mathrm{II} 9 & 84,269,383 \\ \mathrm{I} 25 & 85 \\ \mathrm{I} 26 & 84 \\ \mathrm{I} 32 & 3 \mathrm{I} 5 \\ \mathrm{I} 36 & 85 \\ \mathrm{I} 38 & 84, \text { IO2 } \\ \text { I39 } & 84 \\ \text { I49 } & 84 \\ \text { I60 } & 84 \\ \text { I6I } & 84 \\ \text { I66 } & 84, \text { IO2 } \\ \text { I67 } & 84 \\ \text { I70 } & 85\end{array}$

I3-20

24

68

75

97

I06

I22

I22-I27

I27

I36

I56

I57

I79

$2 \mathrm{I} 5 \mathrm{f}$

$216 \mathrm{~g}$

Lampr. cat.

84, I06, I83, 269,

383

274

$392,393,422$

420

479

438, 444

489

$75, \mathrm{I} 84$

I84, 275

384

270

272

I54

357

68

407

293

I97

293

I9I, I95, 2 I3

$7 \mathrm{I}$

214

203

203

290

(1)

I92 


$\begin{array}{ll}\mathrm{I} 77 & 3 \mathrm{I} 9 \\ \mathrm{I} 83 & 6 \mathrm{I}, 62 \\ \mathrm{I} 9 \mathrm{I} & 456 \\ \mathrm{I} 93 & 62,84 \\ \mathrm{I} 96 & 62 \\ 200 & 62 \\ 200 \mathrm{a} & 6 \mathrm{I} \\ 2 \mathrm{I} 2 & 62 \\ 2 \mathrm{I} 8 & 6 \mathrm{I}, 85, \mathrm{IO} 2\end{array}$

6, I

$6,2-4$

6,4

8 , I

$8, \mathrm{I}-2$

I3, 7-8

I6, 7

33,5

35,2

39, 2-3

Fab.

\section{Thes.}

$\begin{array}{ll}\text { I, } 3 & 273 \\ 3,2 & 489\end{array}$

Rom.

\section{3, I}

I5, 7

2I, 8

Lyc.

$$
\text { I, I }
$$

Sol.

$\begin{array}{ll}\text { II, } 2 & \text { I67 } \\ 32,4 & 489\end{array}$

Them.

$$
2
$$

32,6

Cam.

$\begin{array}{ll}6,4 & 254 \\ 6,5-6 & 252,253 \\ 6,6 & 3 \mathrm{I} 9 \\ \mathrm{I} 9,8 & 26, \mathrm{I} 48, \mathrm{I} 79 \\ 22,3 & 489 \\ 33,7 & \mathrm{I} 67\end{array}$

Arist.
$6,2-3$
I9, 7

Ca. Ma.

2I, 5

25, 4

Comp. Arist. et Ca. Ma.

$\begin{array}{cl}\begin{array}{c}\text { 2, } 4 \\ \text { Per. }\end{array} & 76,489 \\ 4-5 & \text { II3 } \\ 4,6 & \text { I9 } \\ \text { 4, 6-5, I } & 43 \\ \text { 5, I } & \text { II3, 23I } \\ 6 & 258\end{array}$

$\begin{array}{cl}\text { I6, 6 } & 245 \\ \text { I46 } & \\ \text { Nic. } & 449 \\ \text { I, 5 } & \\ 23 & \text { I32, I68 } \\ 23,2-4 & \text { I43 } \\ 23,3 & 260 \\ \text { I 3 } & \text { I }\end{array}$

Comp. Nic. et Crass.

$\begin{array}{cl}\begin{array}{l}\text { 5, } 3 \\ \text { Alc. }\end{array} & 254 \\ \text { I, } 5 & \\ 6,2 & 2 \mathrm{I} 4 \\ 23,4 & 2 \mathrm{I} 4 \\ 23,4-5 & 433 \\ 23,5 & \mathrm{I} 38, \mathrm{I} 39,429 \\ \text { Cor } & 436\end{array}$

Cor.

$\begin{array}{ll}\mathrm{I} 5,4 & 2 \mathrm{I} 4 \\ 38 & 252 \\ 38,2 & 260\end{array}$

Comp. Alc. et Cor.

$\begin{array}{cl}\begin{array}{c}\text { 3, } 2 \\ \text { Lys. }\end{array} & 489 \\ 2,3 & \\ \text { I2 } & \text { I43 } \\ \text { I2, 6 } & \text { I } 45, \text { I449, 227 } \\ \text { I2, 7 } & 460 \\ \text { I8, I } & \text { I } 45, \text { I48, I80 } \\ \text { III } & \text { I33 }\end{array}$

Sull.

5, $5 \quad$ I67

Pomp.

$\begin{array}{cc}\text { 25, 6-7 } & \text { I47 } \\ \text { Marc. } & \\ \text { I4 } & 260 \\ \text { I7 } & 260\end{array}$

\section{Dion}

$\begin{array}{ll}2,4-7 & \mathrm{I} 42 \\ 2 \mathrm{I}, 9 & \mathrm{I} 32\end{array}$


Brut.

$25,4^{-6}$

25,6

Timol.

I5, II
Aem. Paul.

I4

I4, II

I5, 9-II

I7, 7-I3

Dem.

$\begin{array}{ll}2,2 & 177 \\ 2,2-4 & 279\end{array}$

Cic.

40, 2

Comp. Dem. et Cic.

3, I

Alex.

I

I, 2

7, 2

7, 4

I7, 9

27, 2

35

35, IO-I2

$35, \mathrm{I} 5$

35 , I6

75, I-2

Caes.

63, 2

Phoc.

2, 3

2, 6-9

3, I-3

Demetr.

$\begin{array}{cc}\begin{array}{c}38,4 \\ \text { Ant. }\end{array} & 139,4 \mathrm{I} 3 \\ \mathrm{I} 5,5 & \\ 66 & \mathrm{I} 67 \\ \text { Mar. } & 373 \\ \mathrm{I} 9,2 & \\ \text { Plam } & 46 \mathrm{I}\end{array}$

Flam.

IO, 6

Arat.

29, 6

Art.

28, I
I4I

I49

I42

I4I, I45, 46I

I46

3 I 2

I43

177

279

355

I67

245

I45

7I, 2 I8

I96

489

380

I44

273

424

I32, I 45

464

I47

I99

I36

I36

I39, $4 \mathrm{I} 3$

I 46,460

I39, I43, I88, 4I2

467

\section{Galba}

2,5

245

2O, I

279

Pollux

On.

$2,69 \quad 387,388$

Porphyry

Quaest. Hom. ad Il.

9, 682

76

Proclus

Hyp.

$$
\text { 4, } 74
$$

405

\section{Psellus, Michael}

De omn. doctr.

$\begin{array}{ll}\text { I } 68,3 & 37 \mathrm{I} \\ \mathrm{I} 69,7-\mathrm{IO} & 4 \mathrm{I} 8 \\ \mathrm{I} 70 & \mathrm{I} 5,487,488 \\ \mathrm{I} 87 & 469 \\ \mathrm{I} 88 & \mathrm{I} 5,487,489 \\ \text { De lap. } & \\ 26 & 435\end{array}$

Quint.

Inst. or.

$\begin{array}{ll}2,20,3 & 486 \\ 8,2, \text { I2-I3 } & 36 \text { I } \\ 9, \text { I, II } & 486\end{array}$

\section{Semonides Amorgensis}

Fr. West

7, 83-93

478

Seneca

Ad Helv.

$8,4 \quad 463$

Ben.

$\begin{array}{ll}4,23 & 463 \\ 7, \mathrm{I}, 5 & \text { I09 } \\ 7, \mathrm{I}, 7 & 109\end{array}$

Brev. vit.

I3, I-3 IIO

De prov.

I, 2-4 255 
Dial.

\begin{tabular}{|c|c|}
\hline \multirow{2}{*}{\multicolumn{2}{|c|}{$\begin{array}{l}\text { 5, 30, I } \\
\text { Ep. }\end{array}$}} \\
\hline & \\
\hline 88,36 & IIO \\
\hline II8, I4 & 19 \\
\hline \multicolumn{2}{|l|}{$N Q$} \\
\hline I, I, 3 & 463 \\
\hline $\mathrm{I}, \mathrm{I} 5, \mathrm{I}-3$ & 463 \\
\hline $2,3 \mathrm{I}, 2$ & I08, 489 \\
\hline $2,57,2$ & I08, 392 \\
\hline 2,58 & I09 \\
\hline 3, Praef. I8 & IIO \\
\hline $3,2 \mathrm{I}, 2$ & 380 \\
\hline 3,25, II & 403 \\
\hline $3,27,3$ & I09 \\
\hline 3,5 & $\mathrm{IO} 8,400$ \\
\hline $3, \mathrm{II}$ & I09 \\
\hline $3, \mathrm{I} 6$ & I09 \\
\hline 3,20 & I09 \\
\hline 3,25 , II & I08 \\
\hline $6, \mathrm{I}_{3}, 2$ & I08 \\
\hline $6,17,3$ & I09 \\
\hline $6,32, \mathrm{I}$ & IIO \\
\hline $7, \mathrm{I}-4$ & 108,462 \\
\hline 7,2 & 464 \\
\hline
\end{tabular}

\section{Sextus Empiricus}

HP

$\begin{array}{ll}\text { I, 3I If. } & 320 \\ \text { I, 57 } & 456 \\ \text { I, 64-72 } & 483 \\ \text { I, 7I } & 456 \\ \text { I, I92-I93 } & 320 \\ \text { I, 200-2OI } & 320 \\ \text { I, 202-206 } & 344\end{array}$

\section{Solinus}

Mem.
2,36
484

\section{Sophocles}

TGF

787

Spartianus Aelius

Hadr.

20,2

\section{Stesimbrotus}

\section{FGrHist}

I07, I

II4

\section{Stobaeus \\ Flor.}

I, 29, $2 \quad 392$

Strabo

Geogr.

$\begin{array}{ll}2,3,8 & \text { I09, 257 } \\ 8,6, \text { I2 } & 4 \text { IO } \\ \text { I5, 3, IO } & 47 \text { I } \\ \text { I6, 3, 6 } & 374\end{array}$

Strato

Fr. Wehrli

89

420

SVF

I, pp. IOO-IOI, frs. $45 \mathrm{I}-453$

I60

I, p. II6, fr. $5 \mathrm{I} 5 \quad 285$

I, p. II6, fr. 5 I6 I59

2, p. I97, fr. 663

2, p. 206 , frs. $722-723$

I59

2, pp. $232-233$, fr. 863

2, p. 233 , fr. $866 \quad 265$

2, p. 333, II54 I59

3, p. I7, fr. 68 IIO

3, p. I46, fr. $546 \quad 285$

3, p. 205, lx IIO

3, p. 244, fr. $5 \quad 483$

3, p. 25I, fr. $47 \quad 285$

3, p. 25I, fr. $48 \quad 28$ I, 285,484

3, p. 255 , fr. $63, \mathrm{I} 5 \quad 307$

\section{Themistius}

Or.

$$
26,329 \mathrm{c}
$$

II3

\section{Theocritus}

Id.

$\begin{array}{ll}\mathrm{I}, \mathrm{IO} 5^{-\mathrm{IO}} 7 & 278,48 \mathrm{O} \\ 3, \mathrm{I} 3 \mathrm{C} & 48 \mathrm{I}\end{array}$




\begin{tabular}{|c|c|c|c|}
\hline \multirow{2}{*}{$\begin{array}{l}\text { Theognis } \\
\text { El. }\end{array}$} & \multicolumn{3}{|c|}{$\boldsymbol{H P}$} \\
\hline & & $2,7,6$ & 465 \\
\hline $2 \mathrm{I} 3$ & 432 & $4,4, \mathrm{I}$ & I 45 \\
\hline \multirow[t]{2}{*}{$215-216$} & $\mathrm{I} 2 \mathrm{O}, 277,432$ & 4,6 & 374 \\
\hline & & $4,7,3$ & 239 \\
\hline \multirow{2}{*}{\multicolumn{2}{|c|}{$\begin{array}{l}\text { Theophylactus Simocatta } \\
\text { Quaest. phys. }\end{array}$}} & $4,7,2$ & 374 \\
\hline & & $4,7,8$ & 377 \\
\hline 7 & $4 \mathrm{I} 4$ & $4, \mathrm{I} 4,6$ & 465 \\
\hline \multirow[t]{2}{*}{9} & 428 & $4,16,5$ & 372 \\
\hline & & $5,6, \mathrm{I}$ & $47 \mathrm{I}$ \\
\hline Theophrastus & & $7,5,2$ & 378 \\
\hline$C P$ & & $8, \mathrm{I}, \mathrm{I}$ & 420 \\
\hline $2,3,3$ & I45 & $8, \mathrm{I}, 4$ & 422 \\
\hline $2,5,3$ & 370 & $8,4, \mathrm{I}-6$ & 420 \\
\hline $2,5,5$ & 377 & $8,4,5$ & 394 \\
\hline $2,7,3$ & I45 & $8,6,6$ & 393 \\
\hline $2,8,2-3$ & 459 & $8,7,3$ & 377 \\
\hline $2,9,5$ & $49 \mathrm{I}$ & $8,8,2$ & 378 \\
\hline $2,9,7$ & 425 & $8,9, \mathrm{I}$ & 422 \\
\hline $3,8,3$ & 377 & 8, IO, $2-3$ & 421 \\
\hline $3,2 \mathrm{I}, \mathrm{I}$ & 423 & 8, Iо, 4 & 425 \\
\hline $3,2 \mathrm{I}, 2$ & 422 & Ign. & \\
\hline $3,2 \mathrm{I}, 4$ & 424,425 & I6 & 420 \\
\hline $3,2 \mathrm{I}, 5$ & 420 & Lap. & \\
\hline $3,22, I-2$ & 403 & 67 & 409 \\
\hline $3,24,4$ & 466 & Mete. & \\
\hline $4,4, \mathrm{I}$ & 424 & I92 FHSG & I83 \\
\hline $4,9,4-5$ & 394 & od. & \\
\hline $4, \mathrm{I} 3,2$ & 423 & 40 & 453 \\
\hline $4, \mathrm{I} 3,4$ & $42 \mathrm{I}$ & Sign. & \\
\hline $4, \mathrm{I} 3,4-5$ & 422 & I5 & 385 \\
\hline $4, \mathrm{I} 3,5$ & 424 & 40 & 385,428 \\
\hline $4, \mathrm{I} 4,3$ & 403 & Sens. & \\
\hline 5,6, IO & 490 & 20 & 434 \\
\hline 5,9, IO & 465 & $65-67$ & 397 \\
\hline $5, \mathrm{I} 5,6$ & 372 & 67,27 & 397 \\
\hline $6, \mathrm{I}, 2$ & 396 & Vent. & \\
\hline $6, \mathrm{I}, 4$ & 397 & 38 & 475 \\
\hline $6, \mathrm{I}, 6$ & 397 & 40 & 476 \\
\hline $6,4, \mathrm{I}$ & $396,397,400$ & Fr. FHSG & \\
\hline $6,4,2$ & 396 & $26 \mathrm{a}$ & 84 \\
\hline $6,4,6$ & 386,398 & I37 & 62 \\
\hline $6,5, \mathrm{I}$ & 479 & $\mathrm{I} 37,26$ & 79 \\
\hline 6, IO, I-2 & $334,396,397$ & 173 & 28I, 308, 4I9 \\
\hline $6, \mathrm{IO}, 2$ & $37 \mathrm{I}, 375$ & 2I4a, I3-I7 & $3 \mathrm{II}, 405$ \\
\hline $6, \mathrm{I} 7,5$ & 453 & $2 \mathrm{I} 4 \mathrm{a}, 26-30$ & 377 \\
\hline $6,20,4$ & 449 & $\begin{array}{l}2 \mathrm{I} 4 \mathrm{c} \\
263\end{array}$ & $\begin{array}{l}28 \mathrm{I}, 3 \mathrm{II}, 405 \\
238\end{array}$ \\
\hline
\end{tabular}




$$
\begin{aligned}
& 362 \mathrm{a} \\
& 365 \mathrm{a} \\
& 365 \mathrm{~b} \\
& 365 \mathrm{c} \\
& 365 \mathrm{~d}
\end{aligned}
$$

\section{Varro}

De ling. Lat.

5, 79

De re rust.

I, 23-24

$3, \mathrm{I} 6,6$

\section{Vergilius}

Georg.

4, 230

4, 24I-242
248

436, 437

$43 \mathrm{I}$

28I, 302, 43I

437

427

422

480

477

477
Xenophon

Cyn.

5, I-2

5, I-5

5,3

5,4

5,5

5, 33

IO, 8

IO, I5-I7

II, I

Cyr.

7,5, II-I2

Mem.

$\begin{array}{ll}\text { I, 2, 30 } & 444 \\ \text { I, 4, 6 } & 387\end{array}$

Oec.

7, 32-35
453

$289,437,448$

450

$45 \mathrm{I}$

449

203, 290

438

438

33I

47I

444

387

478 